\title{
De invoering van wetgeving in het Franse departement Nedermaas gedurende het eerste Directoire : inleiding en regestenlijst van afgekondigde rechtsvoorschriften 1 oktober 1795-19 maart 1797
}

Citation for published version (APA):

Kamphuis, H. A. (1995). De invoering van wetgeving in het Franse departement Nedermaas gedurende het eerste Directoire : inleiding en regestenlijst van afgekondigde rechtsvoorschriften 1 oktober 1795-19 maart 1797. [Doctoral Thesis, Maastricht University]. Rijksarchief Limburg. https://doi.org/10.26481/dis.19950427hk

Document status and date:

Published: 01/01/1995

DOI:

10.26481/dis.19950427hk

Document Version:

Publisher's PDF, also known as Version of record

Please check the document version of this publication:

- A submitted manuscript is the version of the article upon submission and before peer-review. There can be important differences between the submitted version and the official published version of record. People interested in the research are advised to contact the author for the final version of the publication, or visit the DOI to the publisher's website.

- The final author version and the galley proof are versions of the publication after peer review.

- The final published version features the final layout of the paper including the volume, issue and page numbers.

Link to publication

\footnotetext{
General rights rights.

- You may freely distribute the URL identifying the publication in the public portal. please follow below link for the End User Agreement:

www.umlib.nl/taverne-license

Take down policy

If you believe that this document breaches copyright please contact us at:

repository@maastrichtuniversity.nl

providing details and we will investigate your claim.
}

Copyright and moral rights for the publications made accessible in the public portal are retained by the authors and/or other copyright owners and it is a condition of accessing publications that users recognise and abide by the legal requirements associated with these

- Users may download and print one copy of any publication from the public portal for the purpose of private study or research.

- You may not further distribute the material or use it for any profit-making activity or commercial gain

If the publication is distributed under the terms of Article 25fa of the Dutch Copyright Act, indicated by the "Taverne" license above,

Download date: 26 Apr. 2023 
De invoering van wetgeving in het Franse departement Nedermaas gedurende het eerste Directoire 
Publikaties Rijksarchief Limburg nr. 1

(C) H.A. Kamphuis, Maastricht 1995

CIP GEGEVENS KONINKLIJE BIBLIOTHEEK, DEN HAAG

Kamphuis, Hendrik Albert

De invoering van wetgeving in het Franse departement Nedermass gedurende het eerste Directoire : inleiding en regestenlijst van afgekondigde rechtsvoorschriften I oktober 1795-19 mart 1797/ Hendrik Albert Kamphuis. Maastricht : Rijksarchief Limburg. - Ill. - (Publikaties / Rijksarchief Limburg ; nr. 1)

Proefschrift Rijksuniversiteit Limburg Maastricht. - Met lit. opg., reg.

ISBN $90-74407-01-3$

Trefw:: wetgeving; Nedermaas ; geschiedenis ; 1795-1797

Boekproduktia: Datawyse I Universitaire Pers Maastricht

Omslag ontwerp: Bureau Piet Gerards 


\section{De invoering van wetgeving in het Franse departement Nedermaas gedurende het eerste Directoire}

Inleiding en regestenlijst van afgekondigde rechtsvoorschriften 1 oktober 1795 - 19 maart 1797

\section{PROEFSCHRIFT}

ter verkrijging van de graad van doctor aan de Rijksuniversiteit Limburg te Maastricht, op gezag van de Rector Magnificus, Prof.mr. M.J. Cohen, volgens het besluit van het College van Decanen, in het openbaar te verdedigen op donderdag 27 april 1995 om 16.00 uur

door

Hendrik Albert Kamphuis 
Promotor:

Prof.mr. J.E. Spruit (Universiteit Utrecht)

Beoordelingscommissie:

Prof.mr. A.Fl. Gehlen (voorzitter)

Prof.mr. R. Feenstra em. (Rijksuniversiteit Leiden)

Prof.mr. O. Moorman van Kappen (Katholieke Universiteit Nijmegen)

Deze uitgave werd mede mogelijk gemaakt door:

Dr. P.G.M.J. Janssens Stichting te Maastricht

NOT-fonds te 's-Gravenhage 
aan de nagedachtenis van mijn moeder aan mijn vader 

Het is een goed gebruik een boek een woord vooraf mee te geven. Dit geldt misschien wel te meer, wanneer een boek de kwalificatie proefschrift meekrijgt. Het schrijven van een boek echter is en blijft wel een eenzaam avontuur. Toch kan het voltooien van een boek niet geheel op eigen kracht geschieden. Vandaar dat het ook een goed gebruik is om diegenen dank te zeggen, die een wezenlijke bijdrage aan de wording ervan hebben geleverd.

In de eerste plaats wil ik mijn promotor bedanken. Professor Spruit was het die mij een aanstelling als assistent in opleiding bij de vakgroep metajuridica van de Faculteit der Rechtsgeleerdheid van de Rijksuniversiteit Limburg bezorgde. In een gemoedelijke sfeer steeds heeft de gedachtenwisseling over de voortgang van het onderzoek plaatsgevonden. Bij mijn promotor kon ik altijd te rade gaan, wanneer er problemen aan de einder dreigden op te doemen. Zonder zijn voortdurende bemoedigingen al die jaren, zou het onderzoek toch zeker met minder vaart zijn verlopen.

De Rijksuniversiteit Limburg als werkgever, en dan in het bijzonder de vakgroep metajuridica, ben ik evenzeer dank verschuldigd. De informele werksfeer en de omgang met de medewerkers van de vakgroep - en in wijder verband de Faculteit heeft veel bijgedragen aan het welslagen van deze onderneming. Velen van hen hebben door hun blijken van belangstelling bemoedigingen, onbewust wellicht, doen uitgaan om niet te versagen. Ook na het aflopen van mijn aanstelling is men vanuit de vakgroep mij ter wille geweest bij het voltooien van het proefschrift.

Minstens evenveel dank ben ik verschuldigd aan het Rijksarchief in Limburg te Maastricht. De gastvrijheid die ik daar jarenlang genoot en de behulpzaamheid die ik er ondervond bij het onderzoek, heeft de voortgang ervan ten zeerste bevorderd. Ook het feit dat het Rijksarchief dit boek in zijn nieuw opgezette reeks heeft willen opnemen, getuigt van grote betrokkenheid bij en de belangstelling voor mijn onderzoek.

Zonder geld komt men echter in het leven niet bijster ver. De financiële ondersteuning die ik mocht genieten van de Nederlandse Organisatie voor Wetenschappelijk Onderzoek, de Stichting Wetenschappelijk Onderzoek Limburg en het Ministerie van Onderwijs en Wetenschappen (STIR-programma), alsmede de Faculteit heeft mij in staat gesteld in het voorjaar van 1991 een onderzoeksverblijf in Parijs te kunnten bekostigen. Langs deze weg wil hiervoor mijn erkentelijkheid uitspreken.

Het is ten slotte evenzeer een goed gebruik om de vrucht van een dergelijke onderneming van een opdracht vergezeld te doen gaan. Aan wie zou ik het boek anders kunnen opdragen dan aan mijn ouders? Mijn ouders zijn het tenslotte geweest die mij in staat gesteld hebben de weg af te leggen, die heeft kunnen leiden tot het ontstaan van dit boek. Mijn moeder heeft het gereed komen van dit boek echter niet mogen meemaken. Haar leven was met nauwelijks zesenvijftig jaren, na een zeer ernstige ziekte, al te vroeg voldragen. Het is aan mijn moeders nagedachtenis dat ik dit boek bovenal opdraag. 



\section{INHOUD}

\section{INLEIDING}

Hoofdstuk I

1. De territoriale constellatie aan de vooravond van de Franse inval 7

2. De grondslag voor de inlijving 9

3. Het territoir van het departement Nedermaas $\quad 12$

$\begin{array}{ll}\text { 4. Annexatie gesanctioneerd } & 27\end{array}$

$\begin{array}{ll}\text { 5. Slotbeschouwing } & 28\end{array}$

Hoofdstuk II DE AFKONDIGING

1. Het begrip promulgatie

2. Afkondigingsbevoegde autoriteiten 38

3. Periodisering met betrekking tot de afkondiging 45

a. 1 oktober $1795-18$ november $1795 \quad 45$

b. 18 november $1795-2$ december $1795 \quad 46$

c. 2 december $1795-26$ maart $1803 \quad 47$

d. 26 maart 1803 - einde Frans bewind 51

4. Afkondiging in het departement Nedermaas 53

a. "Registre ouvert"

b. Het besluit van 18 pluviôse IV

c. Code Merlin 63

5. Uitvoeringsproblemen voortvloeiend uit de wet van 12 vendémiaire IV 70

a. De wet van 24 brumaire VII $\quad 70$

b. Welke wetgeving, geplaatst in de Bulletins des Lois, in werking getreden?

6. Slotbeschouwing

Hoofdstuk III "VOUS ETES FRANÇAIS"

1. Hoofdlijnen in de afgekondigde wetgeving 83

2. Centrale en decentrale overheden $\quad 84$

a. Grondwet en de wetgevende en centrale bestuursorganen 84

b. De lagere bestuursorganen $\quad 87$

3. Rechterlijke organisatie en rechterlijke macht 92

$\begin{array}{ll}\text { a. Burgerlijke rechtspraak } & 93\end{array}$

b. Correctionele en criminele rechtspraak 95

c. Aanvullende wetgeving op het terrein van de burgerlijke en
de strafrechtspraak

4. Ontmanteling van de maatschappelijke structuur van het ancien régime 106 
5. Wetgeving op het terrein van de Kerk en de geestelijke instellingen

6. Burgerlijke stand

7. Slot

a. Begrenzing van de regestenlijst

b. Opbouw van het regest

c. Afkortingen

d. Slotopmerking 


\section{INLEIDING}

Sedert de zomer van 1789 heersten er in Frankrijk revolutionaire omstandigheden die in de daaropvolgende jaren grote gevolgen zouden hebben voor de traditionele maatschappelijke verhoudingen. De Franse Revolutie markeerde het einde van het ancien régime en de definitieve opkomst van de burgerlijke krachten, die zich vooral in de negentiende ceuw verder zouden verstevigen. Tijdens de bijeenroeping van de Etats généraux in mei 1789 - voor het eerst sinds 1614 - slaagde de derde stand, de in meerdere of mindere mate tot welstand geraakte burgerij, erin de overhand te verkrijgen door de Etats généraux om te vormen tot een Assemblée nationale constituante. Gaandeweg ondermijnde dit de positie van de beide andere standen - de geestelijkheid en de adel - zo sterk, dat zij hun bevoorrechte positie in de samenleving eenvoudigweg kwijtraakten. De Constituante legde het fundament voor een nieuw maatschappelijk bestel. Met het aanvaarden van de eerste Franse grondwet in september 1791 was haar taak beëindigd: de absolute monarchie werd tot constitutionele monarchie; de Constituante werd tot Assemblée nationale législative. De autonome dynamiek die de Revolutie kenmerkte, ontketende echter krachten, nog versterkt door het intreden van de oorlogstoestand in april 1792, die uiteindelijk leidden tot de val van de monarchie, alsmede tot het einde van de Législative. Een nieuwe assemblee, de Convention nationale, zou de revolutionaire krachten tot het uiterste voeren. De periode van de Conventie - van 1 oktober 1792 tot einde oktober 1795 - betekende enerzijds het hoogtepunt van de Revolutie, anderzijds het dieptepunt door het uitoefenen van de macht met behulp van dictatoriale en terreurmaatregelen. Haar beroemdste slachtoffer was natuurlijk koning Lodewijk XVI, dan volgt al gauw Robespierre, die ten onder ging aan de door hem zelf ontketende krachten. Thermidor betekende een geleidelijke kalmering van de revolutionaire opgewondenheid en de weg naar de burgerlijke republiek. De thermidoriaanse Conventie legde daarvoor de basis door het ontwerpen van de grondwet van het jaar III. Met het uiteengaan van de Conventie trad vervolgens de Directoire-periode in. Het Directoire exécutif functioneerde als het orgaan van de uitvoerende macht, naast een nieuwe wetgevende assemblee, die voor het eerst in de Franse geschiedenis uit twee kamers bestond: de Conseil des Cinqcents en de Conseil des Anciens. Deze burgerlijke republiek viel keer op keer ten prooi aan staatsgrepen, totdat op 9 november 1799 Napoleon daaraan definitief een einde maakte. In de geschiedschrijving wordt door sommigen het einde van de Revolutie gesitueerd op de Negende Thermidor, de dag van de val van Robespierre en zijn medestanders. De proclamatie van de Consuls bij gelegenheid van de presentatie van de grondwet van het jaar VIII aan het Franse volk verklaarde het einde van de Revolutie uitdrukkelijk: "La Révolution est fixée aux principes qui l'ont commencée: elle est finie"".

' Aangehaald bij Jacques Godechot, Les constitutions de la France depuis 1789 (Parijs, 1979) 147. 
De Conventie begon met het exporteren van het gedachtengoed van de Revolutie. Door de overwinning van het Franse leger op de troepen van de coalitie in de slag bij Fleurus einde juni 1794 konden de Zuidelijke, Oostenrijkse Nederlanden, het prinsbisdom Luik, de gebieden op de linker Rijnoever en naderhand ook nog de Repubiek der Verenigde Nederlanden worden veroverd. Als eén van de laatste steunpunten viel op 4 november 1794 de vesting Maastricht. Een tweetal door de Fransen ingestelde centrale administraties, onderverdeeld in arrondissementen, te Brussel en Aken ging vervolgens de veroverde gebieden besturen. Op 1 oktober 1795 daaropvolgende annexeerde de Franse staat de bezette Oostenrijkse Nederlanden, het prinsbisdom Luik en de territoria rond Maastricht, waaronder de daar gellegen generaliteitslanden. Er volgde een administratieve indeling naar Frans model, een indeling in departementen derhalve. Eén van die zogenaamde départements réunis, het departement van de Nedermaas (Meuse-Inférieure) besloeg ruwweg gesproken het grondgebied van de huidige provincies Nederlands en Belgisch Limburg. Van het Nedermaas-departement was Maastricht als hoofdstad aangewezen. Deze situatie bestendigde zich een kleine twintig jaar lang, tot de val van Napoleon.

Door de Fransen werden de ingelijfde gebieden beschouwd een integraal bestanddeel uit te maken van het grondgebied van de Franse natie. Dit betekende dat Franse revolutionaire, en dan vooral de bestendige, verworvenheden in de geannexeerde gebieden werden ingevoerd. Deze studie behandelt daarvan de juridische neerslag, de regelgeving zoals deze door de Franse wetgevers en uitvoerende instanties uitgevaardigd werd. In Frankrijk noemt men dat het droit intermédiaire. De vraagstelling die daarbij als leidraad gefungeerd heeft, luidt als volgt: welke wetgeving is er in het arrondissement Maastricht en het departement van de Nedermaas ingevoerd? Aanvankelijk leefde de gedachte nog om de gehele twintig jaar te beschrijven, maar door de overstelpende hoeveellheid aan wetgeving is alleen de periode direct aansluitend aan de inlijving beschreven, de overgangsperiode van het ancien régime naar de moderne tijd. Met het van kracht worden van de zogenaamde Code Merlin - een tweedelige wetsverzameling met alsnog ingevoerde oudere, hoofdzakelijk revolutionaire wetgeving - op 19 maart 1797 eindigt de beschrijving van de wetgeving. De beschrijving heeft de vorm gekregen van een regestenlijst van afgekondigde rechtsvoorschriften, min of meer naar het voorbeeld zoals dat ook is gebeurd voor de rechtsvoorschriften die in het Overkwartier van Gelre zijn afgekondigd ${ }^{2}$. Ofschoon dus maar een relatief korte afkondigingsperiode - een anderhalf jaar - beschreven is, gaat het in de regestenlijst om toch al 582 rechtswoorschriften of delen daarvan. Dit is niet alles: de Code Merlin telt er ook nog eens 424 . Een eventuele vervolgbeschrijving van de wetgeving ten tijde van het Directoire of tot de invoering van de code civil in 1804, misschien zelfs tot het einde van het Franse bewind, zou mijns inziens wel op haar plaats zijn.

Bij een dergelijke regestenlijst behoort een inleidend betoog. Deze inleiding omvat drie hoofdstukken. Het eerste hoofdstuk heeft tot onderwerp de wetgeving op de inlijving en de juridische omschrijving van het grondgebied van het departement $\mathrm{Ne}$ dermaas. Deze circumscriptie is voortgezet tot het einde van het Franse bewind,

\footnotetext{
2 A.M.J.A Berkvens, Plakkatenlijst Overkwartier I665-1794 (2 din; Nijmegen, 1990-1992).
} 
omdat een territoriumwijziging consequenties kon hebben voor het gelden van de wettelijke regels.

Het tweede hoofdstuk behandelt de afkondiging. Dit is een tamelijk ingewikkelde kwestie. Er zijn daarin een aantal periodes te onderscheiden. Daarbij is ook nu weer de Napoleontische tijd beschreven, omdat met de invoering van de titre préliminaire van de code civil er deels een verandering in de afkondiging van wetgeving is opgetreden. Onderzoekers die zich met de periode bezighouden, die niet door de regestenlijst wordt bestreken, kunnen op die wijze zelf het van kracht worden van wetgeving nagaan.

In het derde hoofdstuk tenslotte wordt een beschrijving gegeven van de wetgeving zoals die in de regestenlijst, de Code Merlin, alsmede een deel van de Bulletins des Lois is opgenomen. Een dergelijke schets kan natuurlijk vanwege de grote massa aan wetgeving alleen maar de grotere lijnen aangeven. In de beschrijving zijn de bestuurlijke en rechterlijke pijlers gedurende het Directoire, zoals de grondwet van het jaar III die heeft omschreven, aan de orde gesteld. Daarnaast zijn de grotere afgekondigde corpora behandeld. Waar mogelijk is reeds bestaande literatuur verwerkt.

Het onderzoek voor deze studie is goeddeels verricht in het Franse Archief dat zich bevindt in het Rijksarchief in Limburg en in de collectie van de Stadsbibliotheek, beide te Maastricht. Voorts is tijdens een drie maanden durend bezoek aan Parijs aanvullend onderzoek gedaan in de Archives Nationales, de Bibliothèque Nationale en het Institut d'Histoire de la Révolution Française.

Er bestaan talloos veel historische publicaties over de politiek-maatschappelijke gebeurtenissen van de Revolutie. Al sinds de Revolutie wordt daar onderzoek naar gedaan en wordt erover geschreven. Over de Franse Revolutie wordt ook een speciaal. tijdschrift uitgebracht, de Annales Historiques de la Révolution Française. Enkele recentere algemene historische studies zijn die van Furet en Richet ${ }^{3}$, Soboull ${ }^{4}$ en Lefebvres. Voorts behandelen de eerste vijf delen van de pocketreeks Nouvelle Histoire de la France Contemporaine de tijd van de Revolutie en het Napoleontische tijdperk ${ }^{6}$. Een heel mooie synthese is er verschenen van de hand van Sutherland,

\footnotetext{
${ }^{3}$ François Furet \& Denis Richet, La Révolution française (coll. Plutiel; Parijs, 1973); in Frankrijk verschijnen vaak pocketuitgaves van de oorspronkelijk gebonden uitgave; ter onderscheiding is het aanbevelenswardig de naam van de pocketreeks te vermelden, wanneer men die theeft gebruikt.

* Soboul, La Révolution françarise. Nouvelle édition revue et augmentée du précis d'Histoire de la Révolution française, avec un avant-propos de Claude Mazauric et une bibliographie de l'oeuvre d'Albert Soboul par Françoise Brunel (Parijs, 1982).

${ }^{5}$ Lefebvre, La France sous le Directoire 1795-1799. Avant-propos d'Albert Soboul, présentation de Jean-René Suratteau (nwe. ed.; Parijs, 1984).

"Pocketreeks Points,Histoire: Michel Vovelle, La chute de la monarchie 1787-1792; Mare Bouloiseau. La Rêpubliqwe jacobine 10 aoûs 1792-9 thermidor an II; Denis Woronoff, La République bourgeoise de Thernidor à Brumaire 1794-1799; Louis Bergeron, L' Episode napoléonien I.Aspects intérieures 1799-1815; J. Lovie \& A. Palluel-Guillard, L'Episode napoleonien 2.Aspects entếrieures" $1799-1815$.
} 
France 1789-1815. Revolution and Counterrevolution'. Solé in zijn La Révolution en questions schrijft over Sutherlands boek dat het een "qualité exceptionelle (...) en particulier pour le déroulement des évếnements entre 1790 et 1799 ..." bezit ${ }^{8}$. Solés boek is interessant, doordat hij met behulp van vragen de grote thema's van de Franse Revolutie kritisch beschouwt en daarbij een bespreking geeft van de recente literatuur.

Van de recentere naslagwerken kunnen worden genoemd: twee historische dictionaires $^{9}$ en een bibliografie ${ }^{10}$. Het laatst genoemde werk kent onder andere een classificatie per departement. De dëpartements réunis komen er ook afzonderlijk in voor. In totaal telt deze bibliografie 31.960 referenties, de dubbeltellingen meegerekend. Te zelfder tijd is er voor deze periode ook in België een bibliografie verschenen van de hand van Bruneel ${ }^{11}$.

Een zeer handig hulpmiddel is het Manuel pratique ${ }^{12}$ van Pierre Caron. Daarin vindt men alle oudere bronnenpublicaties vanaf het begin van deze eeuw en de archivalische bronnen. Wat betreft rechtshistorisch bronnenmateriaal kan men tevoren het best eerst Coings Handbuch raadplegen ${ }^{13}$. De bibliografie oogt uitputtend. Verder is literatuur over het droit intermédiaire heel verspreid verschenen. De nadruk ligt dan nog weer op de institutionele geschiedenis, getuige de studies van Godechot en voor het begin van deze eeuw voor België Poullet ${ }^{14}$. Verder zijn er de omvangrijke stuldies van Márcel Garaud over het intermediaire recht, Histoire générale du Droit privé français (de 1789 à 1804) namelijk: La Révolution et l'égalité civile, La Révolution et la Propriété foncière en samen met Szramkiewicz, La Révolution et la Famille. Het colloquium dat in 1986 te Orléans gehouden werd onder de titel La Révolution et l'ordre juridique privé. Rationalité ou scandale? biedt ook veel nieuwe informatie.

7 D.M.G. Sutherland, France 1789-1815. Revolution and Counterrevolution. Fontana History of Modern France (3e dr.; Londen, 1989).

"Jacques Solé, La Révolution en questions (Points/Histoire; 1988) 112; de schrijver neemt hele passages in vertaling over van Sutherland.

"Albert Soboul, Dictionnaire Historique de la Révolution Française, publié sous la direction scientifique de Jean-Rene Suratteau et François Gendron (Parijs, 1989); Jean Tulard, Jean-François Fayard \& Allred Fierro, Histoire et dictionnaire de la Révolution française 1789-1799 (2e herdr; Parijs, 1988).

"Alfred Fierro, Bibliographie de la Róvolution française 1940-1988 (2 din; Parijs, 1989).

$"$ C. Bruneel, ed. Des Rúvolutions à Waterloo. Bibliographie sélective d'historre de Belgique (1789. 1815). Archives et Bübliothèques de Belgique/Archief- en Bibliotheekwezen in België numéro spécial/extranummer XXXVI (Brussel, 1989).

${ }^{12}$ Pierre Caron, Manuel pratique pour l'étude de la Révolution française (2e dr.; Parijs, 1947).

1." Ermst Holthöfer, "Frankreich", in: Helmut Coing, ed., Handhuch der Quellen urd Literatur der neueren europäischen Privatrechrsgeschichte III Das 19. Jahrhundert. Veröffentlichung des MaxPlanck-Instituts für europäische Rechtsgeschichte (5 din; München, 1982-1988) III/1, 863-882.

${ }^{14}$ Jacques Godechot, Les institurions de la France sous la Révolution et l'Empire (3e dr.; Parijs, 1985); Prosper Poullet, Les Institutions Françaises de 1795 a 18/4. Essai sur les origines des institutions Belges contemporaines (Brussel, 1907); aangaande de verspreiding van het Franse gedachtengoed en de instellingen van de Revolutie in vooral Europa kan men raadplegen Jacques Godechot, La Grande Nation. L'expansion révolutionnaire de la France dams le monde de 1789 à 1799 (2e herz. dr.; Parijs, 1983). 
Een aardige introductie op het Franse revolutionaire recht, hoewel beknopt en deels verouderd, vormt nog steeds Viards Histoire générale ${ }^{15}$.

Wat betreft de rechtsgeschiedenis van het departement Nedermaas zijn er niet bijster veel studies verschenen over het door de Fransen ingevoerde recht. Afgezien van de inleidingen bij archiefinventarissen, die doorgaans institutionele aspecten betreffen, moet men daarom veelal te rade gaan bij algemenere studies en bijdragen $^{16}$.

Aan het slot van deze inleiding nog twee opmerkingen. De eerste heeft betrekking op het onderwerp van deze studie. De studie gaat niet over de Bataafse Republiek, behoudens een korte uitweiding in het tweede hoofdstuk. Het departement Nedermaas kan immers niet los worden gezien van de départements réunis, zoals zij op hun beurt niet los kunnen worden gezien van Frankrijk. Een vergelijking van de rechtsontwikkeling in het departement Nedermaas en van die van de Bataafse Republiek zou te ver voeren.

De tweede opmerking betreft de weergave van citaten. Aangehaalde tekstgedeelten uit archivalia zijn in het algemeen overgenomen, zoals die in de archiefbronnen staan. Diacritische tekens ontbreken soms, daar waar men die zou verwachten, soms worden ze anders gehanteerd. Verder zijn ook de afkortingen gehandhatd.

${ }^{15}$ Pierre-Paul Viard, Histoire générale du droit privé français (1789-1830) (Parijs, 1931).

${ }^{16}$ Zie de beschrijwing van $\mathrm{O}$. Mooman van Kappen, "I25 jaar Limburgse rechtsgeschiedenis", Publications de la Société Historique et Archéologique dans le Limbourg, CXXV (11989) 100-125. 


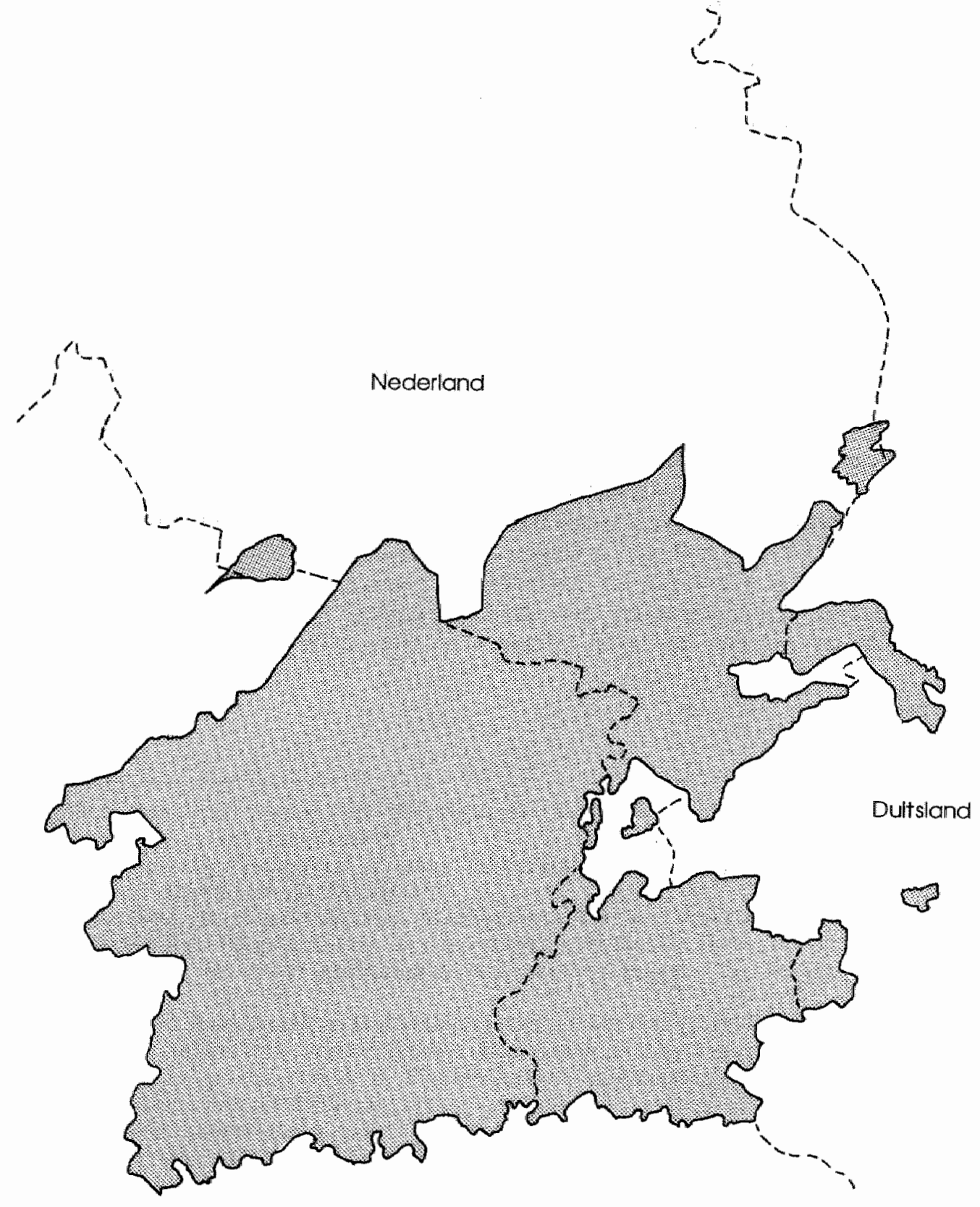

Belglë

copyrignt o Rilksarchief Limburg. Maastrlcht, 1995

De ligging van het departement Nedermaas ten opzichte van de huidige staatkundige verdeling. De dikke grenslijnen geven de omvang van het departement Nedermaas aan ten tijde van het Directoire. De onderbroken grenslijnen zijn de huidige staatsgrenzen tussen Duitsland, Nederland en België. 


\section{VENDEMIAIRE AN IV}

De negende vendểmiaire van het jaar IV - in de christelijke tijdrekening 1 oktober 1795 - betekende voor de Zuildelijke, Oostenrijkse Nederllanden, het Prinsbisdom Luik. en enkele overige territoria een diepgaande breuk in een reeds eeuwenlang bestaand maatschappelijk bestel. De Franse revolutionaire legers die hun veroveringen na de slag bij Valmy (20 september 1792) slechts enkele maanden konden consolideren en de veroverde gebieden in het voorjaar van $\mathbb{1 7 9 3}$ weer moesten ontruimen, keerden definitief terug na de slag bij Fleurus (26 juni 1794) en veroverden achtereenvolgens het gehele gebied links van de Rijn gelegen. De negende vendémiaire betekende de inlijving van een gedeelte der bezette landstreken, welke administratief in een negental departementen werden onderverdeeld. Eén van deze departementen besloeg ruwweg gesproken het huidige Nederlands- en Belgisch-Limburg tot aan Venlo: het departement Meuse-Inférieure (Nedermaas) met als hoofdstad Maastricht'.

\section{De territoriale constellatie aan de vooravond van de Franse inval}

De gebieden links en rechts van de Maas vertoonden sedert eeuwen een grote staatkundige verbrokkeling, deels in soevereine territoria ${ }^{2}$. De laatste herschikking van de

\footnotetext{
'Een algemeen overzicht van de pollitiek-militaire gebeurtenissen in R. Devleeshouwer, "De Zuidelijke Nederlanden tijdens het Franse bewind 1794 - 1814" in: D.P. Blok e.a., ed., Algemene Greschiedenis der Nederlanden (15 dln.; Haarlem/Weesp, 1977-1983) XI, 187-200. L.J. Rogier, m.m.v. M.G. Spiertz, "Limburg in de Franse tijd" in: E.C.M.A. Batta e.a., ed., Limburg"s Verleder. Geschiedenis van Nederlands Limburg tot 1815 (2 dln.: Maastricht, 1960, 1967) II, 668-703, schetst een beeld van het departement van de Nedermaas; zie voorts de lezing van P.J.H. Ubachs, "Een Franse uithoek: Limburg 1794-1814", Bijdragen en Mededelingen betreffende de Geschiedenis der Nederlanden CIV (1989), 654-664, alsmede W. Jappe Alberts, Geschiedenis van de beide Limburgen. Beknopte geschie. denis van het gebied omvattende de tegenwoordige Nederlandse en Belgische provincies Limburg " sedert de vroegste vijden. Maaslandse Monografieën XV en XVII (2 dln; Assen. 1972-1974) II. hoofdlst. v.

${ }^{2}$ J.J. de Wit \& A.J.A. Flament, "De vorming der heerschappujen op het grondgebied in Limburg of die zich daarower hebben uitgestrekt, van de Romeinsche overheersching tot 1814-1817 (ontstaan der prov. Limburg)". Publications de la Société Historique et Archéologique dans le Limbourg XLVII (1911), 1-259, schetst een overzicht van de territoria met de relevante verdragsbepalingen; kaarten: Geschiedkundige allas van Nederland ('s-Gravenhage, 1913-1934) II (1648-1853), kaart 12: A.A. Beekman \& F.L. Ganshof, "De Zuidelijke Nederlanden in de $17 \mathrm{e}$ en 18e eeuw, kaart 14: A.A. Beekman, "De Republiek in 1795", bladen 18 en 19; de begeleidende teksten P.J. Blok e.a. ed, Gesehiedkundige atlas van Nederland. De Republiek in 1795 met de heerlijkheden, ambachten emz. ('s-Gravenhage, 1913); H. Emmer, De Grenzen van Nederland van de Wielingem tot aan den Rijn. (Haarlem, 1937), 53-83; Joseph Ruwet, La principauté de Lì̀ge en 1789. Carte de géographie historique (Brussel, 1958); E.M.Th.W. Nuyens, Historische Atlas van Limburg en aangrevzende gebieden I Serie staatkundige kaarten: de tegenwoordige provincies Limburg en omliggende gebieder
}

(wordt vervolgd...) 
gebieden werd vastgelegd in het Verdrag van Fontainebleau, dat op 8 november 1785 tussen de Staten-Generaal der Republiek der Verenigde Nederlanden en de Habsburgse keizer Jozef II als heer van de Oostenrijkse Nederlanden werd gesloten ${ }^{3}$. Ingevolge dit tractaat werd in zekere mate een ommekeer gebracht in de al maar voortschrijdende desintegratie van de omstreken van Maastricht met een radius van ten hoogste enkele tientallen kilometers. De verbrokkeling vond enerzijds haar hoogtepunt in het Partagetractaat van $1661^{4}$, waarbij de Zuidelijke Nederlanden - toen nog onder hun Spaanse soeverein - en de Republiek der Verenigde Nederlanden overgingen tot de verdeling van de landen van Overmaas (Valkenburg, 's-Hertogenrade en Dalhem) in deels Spaans en Staats gebied deels onverdeeld gebleven gebied, en anderzijds de verdeling van het Overkwartier van Gelre bij de Vrede van Utrecht na beëindiging van de Spaanse Successieoorlog in 1713.

Zoals reeds opgemerkt, de streken links en rechts van de Maas, welke het territoir zouden gaan vormen van het departement van de Nedermaas vertoonden een grote verbrokkeling. Het grootste aaneengesloten territoir werd gevormd door het Prinsbisdom Luik. De vorst-bisschop was tevens zowel graaf van Horn als van Loon, welke twee graafschappen westelijk van de Maas gelegen waren. De tweede soeverein in rang wat uitgestrektheid van territoir betrof, was de Republiek der Verenigde Nederlanden, die samen met de prins-bisschop de stad Maastricht bestuurde, het zogenaamde condominium. Voorts waren aan Staats gezag onderhorig: de Staatse landen van Valkenburg, 's-Hertogenrade en Dalhem, alsmede het Staats Overkwartier van Gelre (Venlo en het ambt Montfort). Aan het Staatse gezag waren verder nog onderworpen de dorpen van redemptie en de banken van het Kapittel van Sint-Servaas. De Oostenrijkse Habsburgers vormden de derde soeverein: Oostenrijks Overkwartier van Gelre (Roermond en Weert met omliggende gebieden) en de Oostenrijkse Landen van Valkenburg, "s-Hertogenrade en Dalhem.

Pruisen strekte zich stroomafwaarts aan beiden zijden langs de Maas uit, het Pruisisch Overkwartier van Gelre. Bij de vredesverdragen van Utrecht na de Spaanse Successieoorlog in 1713, de tractaten van Rastatt en Baden in 1714 en het Derde Barrière Tractaat van 1715 werd aan Pruisen een gedeelte van het Overkwartier

\footnotetext{
${ }^{2}($...vervolg)
}

in de Franse tijd (1802) (Assen/Amsterdam, 1977); zie voorts de recentere kaarten in P.J.M. Aussems e.a. ed., Kleine Atlas voor de geschiedenis wan beide Limburgen (Hasselt/Maastricht, 1989), 10, 12$15,17-19,21-24$.

${ }^{3}$ Tekst van het verdrag in: M. Gachard, Jules de la Court \& Paul Verhaegen ed., Recueil des Ordonnances des Pays-Bas Autrichiens IIIe ser (1700-1794) (14 din.; Brussel, 1860-1942) XII, 458-461; Clive Parry ed., The Consolidated Treaty Series (231 din.; Dobbs Ferry, New York, 1969-1981) XLIX, 355-361 (preliminaire artikelen, 20 sep 1785), 369-380 (definitieve verdrag, 8 nov 1785).

4 Zie hierover: J.A.K. Haas, De verdeling van de Landen van Overmaas 1644 - 1662. Territoriale desintegratie van een betwist grensgebied diss. Nijmegen (Assen, 1978) en idem, "Het verdrag van Fontainebleau 1785. Maastricht en de landen wan Overmaas als internationale conflictstof aan het eind van het ancien régime", Publications de la Société Historique et Archéalogique dans le Limbourg CXXIV (1988), 264-344, i.h.b. 318-344. 
toegewezen. Een groot territoir besloeg eveneens het goeddeels oostelijk van de Maas en Roermond gelegen hertogdom Gulik. Her en der lagen over het gebied al dan niet (semi)-soevereine territoria verspreid, onder meer het vorstendom Thorn, de graafschappen Gronsveld en Wittem en de heerlijkheid Wijlre.

\section{De grondslag voor de inlijving}

Nadat de Franse Republiek haar veroveringen in de Zuidelijke Nederlanden, en de gebieden westelijk van de Rijn gelegen in 1794 en het voorjaar van 1795 had geconsolideerd" , besloot de Convention nationale op 9 vendémiaire IV (1 okt 1795) tot de annexatie van grote delen van "België". De Loi sur la réunion de la Belgique et du pays de Liège à la République française vormde daarvoor de grondslag ${ }^{\not{B}}$.

Gedurende twee dagen, 8 en 9 vendémiaire IV, beraadslaagde de Nationale Conventie over het project tot anhechting van de veroverde Zuidelijke Nederlanden en het Luikerland bij het Franse grondgebied. Het comité de salut public had op 2 vendémiaire IV (24 september 1795) een rapport, opgesteld door Philippe-Antoine Merlin (de Douai), daarover uitgebracht ${ }^{9}$. Merlin verwees daarbij uitdrukkelijk naar het decreet door de Conventie op 13 april 1793 uitgevaardigd ${ }^{10}$. De argumentatie in het rapport is te herleiden tot een tweetal kernpunten. Ten eerste moest Frankrijk zien te voorkomen dat er andermaal een Oostenrijkse restauratie zoals in 1793 zou plaatsvinden, hetgeen voor het voortbestaan van de Franse Republiek een gevaar bleek te zijn. Ten tweede verwachtte Parijs dat de economische rijkdommen, die een geannexeerd België zouden kunnen opleveren, als onderpand voor het op grootscheepse schaal in omloop gebrachte papiergeld (assignaten) zou kunnen dienen, om op deze wijze een

${ }^{5}$ Zie hierover De Wit \& Flament, "Vorming heerschappijen", 104-124; Parry, Consolidated Treaty Series XXVII, 465-474; XXVIII, 37-82, 141-168 (Utrecht); XXIX, 1-33 (Rastatt), 141-194 (Baden), 333-368 (Derde Barrière Tractaat). Een aardig overzicht van de verdeling van het Overkwartier wordt geschetst door Th. Seelen, "De verdeling van Opper-Gelre bij de Vrede van Utrecht". Spiegel der Historie. Maandblad voor de geschiedenis der Nederlanden III (1968), 310-313; recentelijk ook A.M.J.A. Berkwens, Plakkatenlijst Overkwartier 1665-1794. Rechtshistorische reeks van het Gerard Noodt Instituut XIX en XXV (2 dln; Nijmegen, 1990-1992) II, 5-6, 24-25.

${ }^{6} \mathrm{H}$. Hardenberg m.m.v. F. Nuyens, Inventaris der Archieven van het Arrondissement Maastricht en van het Departement van de Nedermaas (1794-1814). Met een inleiding over de vorming van het grondgebied en de geschiedenis der bestuursinstellingen ("s-Gravenhage, 1946), i.

${ }^{7}$ Zie voor de militaire operaties die tot de val van de vestingen Maastricht en Venlo hebben geleid, F.H.A. Sabron, De oorlog wan 1794-95 op her grondgebied van de Republiek der Vereenigde Nederlanden (2 dln; Breda, 1892-1893) 1, 275-326; daarover ook: Peter Wetzler, War and Subsistence. The Sambre and Meuse Army in 1794. American Uniwersity Studies Series IX History IX (New York/Bern/Frankfurt am Main, 1985) 78-81.

${ }^{8}$ Bulletin des Lois de la République française le série no.186 (1137).

${ }^{9}$ Recueil des discowrs sur la question de la réunion de la Belgique à la France, imprimé par ordre de la Convention nationale (Parijs, an V/1797) 1-25.

10 Ibidem, 15; cB IIIe ser IV 81; dêcrę relatif aux pays rếunis à la République française; "La Convention nationale, sur la demande faite par un de ses membres, que la Convention déclare qu"elle n'entend pas nuire aux droits des pays réunis à la République française, et que jamais elle ne les abandonnera aux tyrans avec lesquels elle est en guerre, passe à l'ordre du jour, motivé sur ce que les contrées ré́unis font partie intégrante de la République". 
einde te kunnen brengen aan de voortschrijdende geldontwaarding. Voorts werd er in het rapport gesteld dat de Belgen en de Luikenaren er recht op hadden om Frans staatsburger te worden" zij hadden zich daar immers "en grande majorite" in februari en maart 1793 voor uitgesproken! Het comité vroeg zich daarenboven af of niet ook Limburg en Luxemburg ingelijfd zouden moeten worden. De inwoners van die Oostenrijkse streken waren niet in grondvergaderingen (assemblées primaires) bijeengeweest, maar waren thans wel in de macht van de Republiek. Het zou in het belang van de Republiek zijn dat deze gebieden eveneens ingelijfd zouden worden, maar de inwoners zouden voorlopig niet de volheid der rechten van de Franse staatsburgers genieten, zolang zij zich niet in de grondvergaderingen voor de opneming in de Franse staat hadden uitgesproken". Het "projet de décret" dat aan het rapport van het comité de salut public was toegevoegd, week in zekere mate af van de uiteindelijk aanvaarde wet $^{12}$. Stavelot-Malmédy en Logne werden niet genoemd, en voorts waren er ook artikelen voorzien die in de wet niet zijn teruggekeerd. Weggelaten is een bij voorbeeld niet onbelangrijk art.5: "Celles des lois de la république française qui ne sont pas encore exécutées dans les pays mentionnés aux quatre articles précédens, le seront à compter de la publication du présent décret". Aangezien de nominatieve opsplitsing in negen departementen ontbrak, werd aan de volksrepresentanten en mission in België opgedragen te voorzien in een verdeling in departementen en kantons, terwijl art.8 van de definitieve wet daarentegen hun taak beperkte tot de vaststelling van de circumscripties van de departementen en kantons.

De eerste vier artikelen van de wet van 9 vendémiaire IV specificeerden deze annexatie. Het derde artikel maakte gewag van de wens ("voeu") in 1793 uitgesproken door "la partie ci-devant autrichienne de la Gueldre" inzake aansluiting bij Frankrijk. Soortgelijke "voeux" zijn door de gemeenten Ieper, Grammont en andere gemeenten in Vlaanderen en Brabant naar voren gebracht ${ }^{13}$.

In 1793 reeds, tijdens de eerste Franse bezetting, had de Nationale Conventie een reeks decreten uitgevaardigd die aansluiting van het Luikse, Stavelot-Malmédy en Logne $^{14}$, Henegouwen, het Doornikse, Namen en "la majorité des communes" van Vlaanderen en Brabant beoogde. De wens van de bevolking waar hier sprake van is, duidt op het handjevol revolutionairen en andere Fransgezinden die voorstander waren van de aansluiting bij Frankrijk. De wens hiertoe werd, ofwel door "le peuple souverain" naar voren gebracht in de grondvergaderingen (assemblées primaires), ofwel in

\footnotetext{
${ }^{11}$ Recueil des discours, 18-19, 21-23.

12 Ibidem, 23-25.

${ }^{13}$ Art.3 van de aansiluitingswet van 9 vendémiaire IV: "La Convention nationale accepte le voeu émis en 1793 par les communes d"Ypres, Grammont et autres communes de la Flandre, du Brabant et de la partie ci-devant autrichienne de la Gueldre, non comprises auxdits décrets [zie noot 15], pour leur réunion au territoire français".

14 De vorst-abt van Stavelot-Malmédy was tevens graaf van Logne. Het graafschap vormde het westelijke deel van het vorstendom; Georges Hansotte, La principauté de Stavelor-Malmédy à la fin de l'ancien régime. Carte de la principauté en 1789. Dénombrement des maisons, des chevaur et des bestiaux vers 1750 (Brussel, 1973) 2, 13-14; Gaston Schuind, Stavelot-Malmédy. Une principauté ecclésiastique de l'ancien régime (Stavelot, 1914/herdr. Brussel, 1982) 7.
} 
adressen aan de Nationale Conventie, waar zij aan de "barre" werden overhandigd": Alleen de plaatsen in de regio's Antwerpen, Limburg en Luxemburg ontsnapten aan het houden van de grondvergaderingen, behoudens het westelijk van de Maas gelegen Loonse district Stokkem. In Maaseik schijnt de opwekking aan de bevolking om zich vit te spreken voor aansluiting bij Frankrijk geen enkel effect te hebben gesorteerd ${ }^{16}$.

Het zevende artikel verdeelde de gebieden die voor inlijving bij Frankrijk voorzien waren over negen in te stellen departementen. Deze negen departementen waren de departementen Dijle, met als hoofdstad Brussel, Schelde (Gent), Leie (Brugge),

${ }^{15}$ H. Pirenne, Histoire de Belgique (7 din; Brussel, 1902-1932) VI, 42-43; Devleeshouwer, "Zuidelijke Nederlanden 1794-1814", 188-190; idem, "Le cas de la Belgique" in: Occupants Occupés 17921815. Colloque de Bruxelles, 29 et 30 janvier 1968 (Brussel, 1969), 45-48.

De aansluitingswet van 9 vendémiaire IV noemt in de artt.1 en 2 de data van cle volgende decreten die door de Nationale Conventie uitgevaardigd zijn en door haar "selon leur forme et teneur" zullen worden uitgevoerd:

* I maart 1793 Décret qui déclare que la ville, fauxbourgs \& banlieue de Bruxelles font partie intégrante de la République françoise (cB IIIe ser III 311-312)

* 1 maart 1793 Décret relatif à la demande des députés de la ville de Gand pour la réunion de cetre ville \& de sa banlieue à la Rëpublique (cB IIle ser III 314)

* 2 maart 1793 Décret qui réunit da la République française les communes de Franchimont, Stavelot \& Logne (cB IIIe ser III 319-320)

* 2 maart 1793 Décret qui déclare que le pays de Hainaut fait partie intégrante du territoire de la

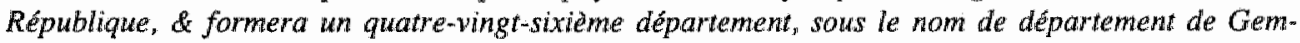
mapp (cB IIIe ser III 321)

* 2 maart 1793 Décret quí réunit la ville libre de Gand à la République (cB IIIe ser III 332)

* 4 maart 1793 Décret pour la réunion de Florennes, \& trente-six villages formant son arrondissement, au territoire de la République (cB IIIe ser III 344)

* 6 mart 1793 Décret portant que la ville de Tournay \& sa banlieue font partie intégrante de la République française (cB. IIIe ser III 356)

* 8 maart 1793 Décret qui déclare que la ville \& banlieue de Lowwain font partie intégrante de la République française (cB Ille ser III 373-374)

* 9 maart 1793 Décret pour la réunion de la ville \& banlieue de Namur a la République française (cB IIIe ser III 380)

* 9 maart 1793 Décret qui déclare que la ville d'Ostende fait partie intégrante de la République française (cB IIIle ser III 380 )

* 11 maart 1793 Décret qui déclare que les villes \& banieues de Namur, Ham-sur-Sambre, Charlessur-Sambre, \&c., font partie integrante du territoire de la République française (cB IIIe ser III 394) * 19 maart 1793 Décret qui réumit à la république Française les communes de Nerel, d'Aëltre, de Thouroult, de Blankenberg, d'Ecloc, de Damne \& de la banlieue de Bruges (cB IIJe ser III 444)

* 23 maart 1793 Décret de réunion du Tournaisis à la République française (cB IIIe ser III 474-475)

* 8 mei 1793 Décret par lequel la Convention déclare qu' elle accepte la ré́union du pays de Liege à la République française (cB Ille ser V 72-73).

${ }^{16}$ Suzanne Tassier, Histoire de la Belgique sous l"occupation frangaise en 1792 et 1793 (Brussel, 1934) 310; J. Bayer-Lothe, "Aspects de l'accupation française dans la principauté de Liège" in: Occupants Occupés 1792-1815. Colloque de Bruxelles, 29 et 30 janvier 1968 (Brussel, 1969), 80-82; kaartje van de Luikse landen in Georges Hansotte, Les institutions politiques et judiciaires de la Principauté de Liege aux temps modernes. Crédit Communal Collection Histoire, série in-8 ${ }^{\circ}, n^{0} 73$ (s.l., 1987$) 37$. 
Jemappes (Bergen), Wouden (Luxemburg), Sambre en Maas (Namen), Ourthe (Luik), Twee Neten (Antwerpen) en Nedermaas (Maastricht).

\section{Het territoir van het departement Nedermaas}

In het departement van de Nedermaas werd het grondgebied van zijn kortstondige voorganger, het arrondissement Maastricht, dat ressorteerde onder de te Aken zetelende Centrale Administratie van de Landen tussen de Maas en de Rijn, opgenomen. Blijkens de inleiding bij Hardenbergs inventaris ${ }^{17}$ heeft de precieze afbakening van de arrondissementsgrenzen - hoofdzakelijk de toewijzing van de Luikse Kempen aan Maastricht - tot wrijvingen met het arrondissementsbestuur te Luik geleid, dat op zijn beurt onder de Centrale Administratie van België te Brussel ressorteerde. De oorzaak van de onenigheid omtrent de grensafbakening moet in tweeërlei grond worden gezocht: enerzijds de feitelijke omstandigheid dat de Luikse Kempen - het graafschap Loon ruwweg - eeuwenlang reeds tot het Prinsbisdom Luik behoorde en anderzijds de haastige arrêtés die de volksrepresentanten bij het Noorder- en het Sambre-en-Maasleger uitvaardigden om het bestuur in de door deze legers bezette gebieden van de grond te krijgen. In een arrêté van 21 fructidor II (7 september 1794) reeds werd er een administratieve indeling gemaakt voor de bezette Belgische en Luikse gebieden. De laatste alinea van art.1 bepaalde zonder omwegen: "Le pays de Liège dont le cheflieu est à Liège, comprend toutes ses dépendances"1". Dit kan niet anders betekenen dan dat alle voormalige prinsbisschoppelijke territoria tot de Luikse administratieve entiteit werden gerekend.

De capitulatie van Maastricht op 4 november 1794, en enkele dagen later ook van Nijmegen, verschafte de Franse veroveraars een aaneengesloten territoir met als natuurlijke grens de Rijn en de Waal. De volksrepresentanten beoogden vervolgens door middel van het uitvaardigen van besluiten tot enige administratieve indeling van het veroverde gebied te komen. Het arrêté des représentans du peuple relatif à l'organisation de l'administration des pays conquis entre la Meuse et le Rhin door Haussmann, Frécine en Joubert te Keulen op 24 brumaire III (14 november 1794) uitgevaardigd $^{19}$, verordonneerde dat er een Centrale Administratie voor de Landen tussen Maas en Rijn te Aken zou worden gevormd, waaronder een zevental administraties ressorteerden. Te Maastricht voor de generaliteit van Maastricht en de landen van Valkenburg, Vaals, Wittem, Wijlre, Dalhem, Maaseik en Heerlen, alsmede de Luikse Kempen (Campine liégeoise), dit terwijl de ingestelde administratie te Spa - in hetzelfde artikel onder $7^{\circ}$ - eveneens de zorg voor het Loonse $(L O o z)$ had toebedeeld

\footnotetext{
${ }^{17}$ Hardenberg \& Nuyens, Inventaris archieven arrondissement Maastricht en departement Nedermaas, xiii-xxiii.

${ }^{18}$ Pasinomie ou collection complète des lois, décrets, arrêtès et réglemens généraux qui peuvent être invoqués en Belgique, mise en ordre et annotée par J.B. Duvergier, complétée pour la Belgique par Isid. Plaisant, première série (16 dlln; Brussel, 1833-1837) VI, xxxii; arrêté qui détermine l'étendue de l'arrondissement de chaque canton de la Belgique.

${ }^{19}$ Pasinomie VI, xli-xliv; rH III 326-336; sectie II art.1 onder $1^{\circ}$.
} 
gekregen $^{20}$. Twee dagen later, 26 brumaire, besloten de volksrepresentanten bij het Noorder- en het Sambre-en-Maasleger en in de departementen Nord en Pas-de-Calais (Berlier, Roger-Ducos, Lacoste, Portiez, Briez en Haussmann) tot de instelling van de Centrale Administratie van België te Brussel. Onder de acht arrondissementsadministraties was ook Luik, dat wederom de linker Maasoever omvatte: "(...) une à Liège, pour la partie liégeoise en-deçà de la Meuse"21. De dag daarop, 27 brumaire III (17 november 1794), maakten de volksrepresentanten een einde aan deze bestuurlijke verwarring. In hun arrêté qui détermine le mode d'après lequel seront administrés la ville et le pays de Liége bepaalden zij dat Overmaas en de Luikse Kempen bestuurd zouden worden, zoals was bepaald in het besluit van 24 brumaire III, dus rangschikking van deze streken onder de arrondissementsadministratie te Maastricht en mitsdien ressorterend onder de Centrale Administratie te $\mathrm{Aken}^{22}$. Overigens liet ook dit onderhavige besluit aan duidelijkheid te wensen over, daar er in art.1 gesproken werd van het Luikerland "en deçà de la Meuse" dat zich diende te conformeren aan datgene wat aan de administraties van België voorgeschreven zou worden.

De volksrepresentanten Joubert en Portiez (de l'Oise) kwamen korte tijd daarna persoonlijk naar Maastricht om bij arrêté van 18 frimaire III (8 december 1794) de circumscriptie van het arrondissement te preciseren ${ }^{23}$. De opsomming in het arrêté was evenwel niet volledig, aangezien de vroegere soevereine territoria Wittem, Wijlre, Slenaken en Gronsveld niet genoemd werden, maar toch tot het arrondissement Maastricht werden gerekend, getuige de kantonnale indeling die gemaakt was en op 29

${ }^{20}$ M.-R. Thielemans, “Deux institutions centrales sous le régime français en Belgique. L'administration centrale et supérieure de la Belgique et le conseil de gouvemement", Revue Belge de Philologie et. d'Histoire/Belgisch Tijdschrift voor Filologie en Geschiedenis, XLI (1963) 1120, vermeldt dat hier gedoeld wordt op Logne.

${ }^{21}$ Pasinomie VI, xliv-xlvi; arrêté des représentans du peuple organisant l'administration centrale de la Belgique et les administrations civiles d'arrondissement ant.1.

${ }^{22}$ Pasinomie VI, xlviii-xlix; an.2: "Le pays d'Outre-Meuse, et la Campine liégeoise seront administrés ainsi qu'il est prescrit par l'arrêté du 24 brumaire, pris à Cologne".

${ }^{23}$ rH III 353-354, Franse versie; Hardenberg \& Nuyens, Inventaris archieven arrondissement Maastricht en departement Nedermaas, $x$; Frans Archief [FA] inv.nr.94 "Register der notulen no. 1 " fol 16vo-17vo; het arrondissement Maastricht werd gevormd door:

" $1^{\circ}$ De stad van Maestricht en hare Generalitijt, daer onder begreepen het Dorp St Pieter.

$2^{\circ}$ Het geheele Land van Valkenborg, hier voren bekend onder de Namen wan Oostenrijcks en Hollandsch Valkenborg.

$3^{\circ}$ Het geheele Land van s"Hertogen-Raade, hier vooren bekend, onder de Namen van Oostenrijks en Hollandsch s'Hertogen-Raade uijtgenomen de twee plaetsen | woorheen Heerlijkheden: | Roerdorp en Wels, dewelke sullen deel maken van de Administratie van Aken.

$4^{\circ}$ De Dorpen | woorheen Heerlijkheeden: I van Elsloo en Steijn.

$5^{\circ}$ Het Land |:voorheen Graafschap: | van Home en de districten van Weerth, Thorn, Wessem en Kessenich.

$6^{\circ}$ De Geheele Luyksche Kempen en het | :hier voren onder den naam van Graafschap bekende:| Land van Loon, bestaande in de steeden en districten van Tongeren, Bilsen. Borgloon, Hasselt en Herck.

$7^{\circ}$ Het Land van Daalhem, zal van de Ronding van Maastricht afgenoomen en onder de Administratie van Limborg gebrogd worden". 

keurd $^{24}$.

Tot aan zijn opneming in het departement van de Nedermaas heeft het arrondissement Maastricht gefunctioneerd onder de Centrale Administratie van de Landen tussen Maas en Rijn te Aken. Niet alleen deden zich wrijvingen voor tussen de arrondissementsadministraties van Maastricht en Luik, aangaande de streken westelijk van de Maas en de toewijzing van Visé aan het arrondissement Maaastricht, maar eveneens tussen Maastricht en de andere aangrenzende arrondissementsadministraties van Gelder en Limburg. Gelder had de Overkwartierse dorpen Obbicht en Papenhoven bij zijn territoir willen trekken. De beide dorpen behoorden sinds het Verdrag van Fontainebleau van 1785 tot het Staats-Overkwartier van Gelre. Het besluit van 18 frimaire III had het Land van Dalhem bij de arrondissementsadministratie van Limburg gevoegd. Berneau, in het spraakgebruik van die tijd tot de Generaliteit van Maastricht gerekend omdat het één der banken van Sint-Servaas was, en de dorpen Oost en Cadier die beiden geheel door het Maastrichtse arrondissement omgeven waren, behoorden evenwel tot het Land van Dalhem, maar ressorteerden desondanks onder het arrondissement Maastricht. De nieuwe kantonnale indeling van het arrondissement van 5 germinall III (25 maart 1795) die door de Centrale Admimistratie te Aken en de volksrepresentant Roberjot werd goedgekeurd, bevestigde dat ${ }^{25}$.

Art.4 van de wet van 9 vendémaire IV inzake de aansluiting van de Zuidelijke Nederlanden en het Prinsbisdom Luik geeft nadere informatie omtrent het territoir van het departement van de Nedermas:

Sont pareillement réunis au territoire français tous les autres pays en-deça du Rhin qui étaient, avant la guerre actuelle, sous la domination de l'Autriche, et ceux quil ont conservés a la Républiqque française par le traité conclu à la Haye, le 27 floréal dernier, entre ses plénipotentiaires et ceux de la République des Provinces-Unies, auquel il n"est dérogé en rien par aucune des dispositions đu présent décret.

De voorheen Oostenrijkse territoria die deel gingen uitmaken van het departement van de Nedermaas waren het Oostenrijks Overkwartier van Gelre en de Oostenrijkse landen van Overmaas, te weten Valkenburg en 's-Hertogenrade. Bij het Haagse Vredesen Alliantieverdrag van 27 floréal III (16 mei 1795) had de Republiek der Verenigde Nederlanden, op wier grondgebied inmiddels ook Franse troepen waren doorgedrongen, toegestemd in onder meer de afstand van haar bezittingen in het Maasdal en aangrenzende gebieden, waarover zij tot voorheen de jurisdictie had. Het Verdrag was onder zware Franse druk - alleen al vanwege het militaire overwicht - tot stand gekomen en werd van Franse zijde te Den Haag getekend door Reubell en Siéyès, beiden

${ }^{24}$ Hardenberg \& Nuyens, Inwentaris archieven arrondissement Maastricht en departement Nedermaas, $\mathrm{x}$-xii.

2s Ibidem, xiii-xxiii; ten onrechte worden Obbicht en Papenhoven door Hardenberg, xv, onder de Landen van Overmaas gerangschikt, zie ook De Wit \& Flament, "Vorming heerschappijen", 106. 
lid van het comité de salut public ${ }^{26}$. Naast de overdracht van Staats-Vlaanderen, "sont réservés par la République Française (...) Maèstricht, Venloo et leurs dépendances, ainsi que les autres enclaves et possessions des Provinces-Unies, situées au sud de Venloo, de l'un et de l'autre côté de la Meuse" (art.12 onder $\left.2^{\circ}\right)^{27}$. Dit betekende dat alle voorheen Staatse gebieden langs de Maas onder Franse soevereiniteit kwamen te staan.

Onderwijl werd er achter de schermen vooruitgelopen op de definitieve inlijving van de bezette gebieden. Het comité de salut public stelde door middel van het arrêté adoptant une nouvelle division du territoire de la Belgique, du pays de Liége, et autres pays adjacens, en neuf arrondissemens ou départemens ${ }^{28}$ van 14 fructidor III (31 augustus 1795) een departementale administratieve indeling vast. Op instigatie van de volksrepresentant Ramel de Nogaret, die tijdelijk op missie was met het Noorderleger in België en Holland, had het lid van de Centrale Administratie te Brussel, de advocaat Doutrepont, een groot deel van de voorbereidende werkzaamheden verricht. Deze kwam aanvankelijk met een indeling in acht departementen, waaronder een zeer lang gerekt departement Nedermaas (van Namen tot Venlo) waarvan Maastricht de hoofdstad zou moeten worden. Ramel de Nogaret gaf Doutrepont toen opdracht de indeling zodanig te wijzigen, dat een departement Nedermaas Luik tot hoofdstad kreeg en een departement van de Ourthe de stad Verviers. Het comité de salut public bepaalde evenwel in zijn besluit van 14 fructidor III dat Luik de hoofdstad van het te vormen departement van de Ourthe zou moeten worden, en Maastricht dat van Nedermaas $^{29}$. Dit departement Meuse-Inférieure was weer in 30 kantons opgedeeld. Deze indeling door het comité de salut public van het territorium bekend onder de naam van "Pays-Bas autrichiens, de Liége et de Maestricht" in departementen en kantons, werd bij wet van 23 ventôse V (13 maart 1797) "provisoirement" gehandhaafd, ondanks tussentijdse kantonnale wijzigingen ${ }^{30}$. Men kan zich afvragen, gelet op de wetstekst, of hier alleen wordt geduid op de Oostenrijkse Nederlanden, of tevens op de gebieden van het vroegere Prinsbisdom Luik en de bezittingen van de Republiek in het Maasdal. Gelet evenwel op de context waarin deze wet tot stand kwam, de aanstaande vernieuwing van de autoriteiten, moet toch worden aangenomen dat het gehele territoir van de départements réunis hieronder moet worden begrepen.

In tegenstelling tot de wet van 23 ventôse $\mathrm{V}$, verwijst de wet van 9 vendémiaire IV slechts impliciet naar het besluit van het comité de salut public van 14 fructidor III

${ }^{26}$ G.W. Vreede, Geschiedenis der diplomatie van de Bataafsche Republiek (3 dln.; Utrecht, 18631865) I, bijlage ix, 56-68; H.T. Colenbrander, ed. Gedenkswkken der algemeene geschiedenis van Nederland van 1795 tot 1840. Rijks Geschiedkundige Publicatièn I ('s-Gravenhage, 1905) I, 646.

${ }^{27}$ Parry, Consolidated Treaty Series, LII, 383-391.

${ }^{23}$ Pasinomie VII, vi-xuii; rH V, 7-26.

${ }^{29}$ Hardenberg \& Nuyens, Inventaris arrondissement Maastricht en departement Nedermaas, xxiiixxiv; Paul Verhaegen, La Belgique sous la domination française 1792-1814 (5 dln; Brussel/Parijs, 1922-1929) I, 596-599; L. de Lanzac de Laborie, La domination française en Belgique. Directoire Consulat - Empire 1795-1814 (2 din.; Parijs, 1895) I, 15.

${ }^{30}$ Pasinomie VII, wi; BL. IIe ser no. 112 (1066); Loi qui maintient la division provisoire de la cidevant Belgique en départemens et cantons; art. 1: "La division en dépantemens et en cantons de la cidevant Belgique, fixée par un arrêté du comité de salut public du 14 fructidor an III, est provisoirement maintenue". 
(31 augustus 1795). Art.8 van de wet laat aan de volksrepresentanten die naar België gezonden waren de grenstrekking en de verdeling in kantons van de onderscheidene departementen over, "à l'instar des autres parties du territoire français".

Vrij spoedig na het uitbreken van de Revolutie was door de Assemblée nationale gezorgd yoor een nieuwe uniforme administratieve verdeling van het Franse grondgebied om een einde te maken aan de heersende grote verscheidenheid aan administratieve entiteiten tijdens het ancien régime. Gedurende de beraadslagingen einde 1789/ begin 1790 werd al gauw besloten om de eerder voorgestelde strikt geometrische verdeling te verlaten en orn zoveel als mogelijk oude grensscheidingen te respecteren. De nieuwe departementen in Frankrijk met benamingen die ontleend waren aan de geografie of de fysische gesteldheid, hadden een ongeveer gelijke oppervlakte, waarbij tevens de oude provinciegrenzen zoveel mogelijk gehandhaafd bleven ${ }^{31}$. Dit stelsel werd tot op zekere hoogte ook voor de negen départements réunis gevolgd. De bewering van Pirenne dat de nieuwe indeling van de geannexeerde streken als een tabula rasa moet worden beschouwd, is in zoverre juist, dat de vroegere lappendeken aan territoria verdween, maar er werd daarnaast wel degelijk rekening gehouden met oude limietscheidingen ${ }^{32}$.

De grondwet van 5 fructidor III (22 augustus 1795) bepaalde in tit.I art.4 dat het Wetgevend Lichaam de grenzen van de departementen kon wijzigen, maar dat de oppervlakte van een departement de $10000 \mathrm{~km}^{2}$ niet te boven mocht gaan. De verst gelegen gemeente mocht niet verder dan $10 \mathrm{~km}$ van de kantonshoofdplaats verwijderd $z_{i j n}{ }^{33}$. De eerdere verdeling door het comité de salut public van het departement in een dertigtal kantons werd dan ook niet gevolgd. Vanaf 1796 kende het departement van de Nedermaas 31 kantons, met deels andere kantonshoofdplaatsen. Het is dan ook geheel onbegrijpelijk dat gouvernementscommissaris Bouteville du Metz, die als opvolger van de volksrepresentanten Pérès en Portiez (de l'Oise) sedert de maand frimaire IV de administratieve organisatie in de départements réunis van de grond moest brengen, in de aan zijn rapport aan het Directoire exécutif van 25 ventôse V (15 maart 1797) toegevoegde overzichtsstaat van de administratieve indeling van de negen départements réunis, als opmerking bij het departement van de Nedermaas als enige - aantekende, dat:

La division de ce département a été conservée comme elle a été formée par l'arrêté du comité de salut public du 14 fructidor ${ }^{34}$.

\footnotetext{
${ }^{3}$ Jacques Godechot, Les institutions de la France sous la Révolution et l'Empire (3e herz. en verm. dr.; Parijs, 1985) 93-98, 102, 470; zie ook Maurice-A. Arnould, "La naissance des départements. De la "représentation", reflet du réel, au découpage réel de la France de 1789 ". Bespreking van $L a$ formation des départements. La représentation du territoire français à la fin du XVIII siecle (Parijs, 1989) door Marie-Vic Ozouf-Marignier. Revue Belge de Philologie et d'HistoirelBelgisch Tijdschrift woor Filologie en Geschiedenis, LXX (1992) 399-409.

12 Pirenne, Histoire de Belgique, VI, 77.

Jacques Godechot, Les constitutions de la France depuis 1789 (Parijs, 1979) 103.

34 Parijs Archives Nationales, inv.nr. D IV bis 39 doss.634 [op stuk zelf; inventaris vermeldt 633 ${ }^{\text {ter] }}$ Compte de la mission du Citoyen Bouteville, Commissaire du Gouvernement dans les neuf Départe-
} (wordt vervolgd...) 
In werkelijkheid was de kantonnale indeling aanzienlijk gewijzigd: andere kantons en andere kantonshoofdplaatsen door gouvernementscommissaris Bouteville zelf gedecreteerd. De administrateur-landmeter Wilmar zette zich aan het moeilijke werk om de kantonnale indeling op papier te krijgen. Twee keer rapporteerde Wilmar over de kantonnale indeling. In zijn tweede rapport hield hij rekening met de afstand van de Gulikse gebieden die aanvankelijk bij het territoir van het departement Nedermaas waren gevoegd door het comité de salut public (onder meer Tegelen en Sittard). De volksrepresentanten Pérès en Portiez (de l'Oise) hadden dit bij besluit van 11 frimaire IV (2 december 1795) bepaald na klachten daaromtrent uit Aken ${ }^{35}$. De kantonnale indeling was goeddeels definitief geworden gedurende het inspectiebezoek van gouvernementscommissaris Bouteville aan Maastricht op 19 nivôse IV (9 januari 1796) en volgende dagen. Wilmars tweede rapportage was op enkele punten bijgesteld wat betreft de aanwijzing van kantonshoofdplaatsen, dan wel wat betreft de kantonslimietscheidingen. Bij besluit van 23 nivôse IV (13 januari 1796) werden daarop door Bouteville de leden van de respectieve kantonsmunicipaliteiten benoemd ${ }^{36}$.

Enige decaden na de vastlegging van de kantons - op 13 ventôse IV (3 maart 1796) - werd alsnog een éénendertigste kanton met als hoofdplaats Heerlen gevormd, dat afgesplitst was van het te groot bevonden kanton Valkenburg ${ }^{37}$. Eveneens werden gedurende de uitoefening van het commissariaat van Bouteville inzake de instelling van de onderscheidene besturen (tot medio februari 1797) enkele andere kantonshoofdplaatsen in plaats van de al bestaande aangewezen ${ }^{38}$. Zo werd bij voorbeeld op 29 fructidor IV (15 september 1796) Stevensweert, dat aan de periferie - op een eiland gevormd door Maasarmen - van het gelijknamige kanton lag en dat 's winters vanwege hoge waterstanden en ijsgang niet meer bereikbaar was voor de inwoners van het kanton, vervangen door het centraler gelegen Echt als kantonshoofdplaats ${ }^{39}$.

\footnotetext{
${ }^{34}$ (...vervolg)
}

mens réunis par la loi du 9 Vendémiaire an 4 (Brussel, an V/1797) 60. Onder FA inv.nr. 1029 bevindt zich een staat met de "Noms des communes composant le Département de la Mieuse Inférieure" van 10 vendémiaire V (1 okt 1796) opgemaakt door Dejardin employé bij de $2^{\circ}$ sectie van het $3^{e}$ bureau; de hierna te bespreken dorpen Anze-sur-Geer, Paifve en Eygelshoven worden daarin niet genoemd.

${ }^{35}$ De Wit \& Flament, "Vorming heerschappijen", 152; Pasinomie VII, xlix; arrêté relatif au ressort de quelques communes du pays de Juliers; R.L.M.M. Camps, "Oude regenten onder een nieuwe vlag. De Venlose magistraat in het begin van de Franse tijd (1794-1796)" in: Fr.J. Hermans e.a., ed., Venlo's Mozaïek. Hoofdsiukken wit zeven eeuwen stadsgeschiedenis. Werken Limburgs Geschied- en Oudheidkundig Genootschap XII (Maastricht, 1990) 211, 215.

${ }^{36}$ Hardenberg \& Nuyens, Inventaris arrondissement Maastricht en departement Nedermaas, xxxviixxxix; FA inv.nr. 296 "lois et arrêtés II" fol 170vo-183ro.

${ }^{37}$ FA inv.nr.134 fol 28; Hardenberg \& Nuyens, Inventaris arrondissement Maastricht en departement Nedermaas, $\mathrm{xl}$.

${ }^{38}$ FA inv.nr.107 fol 255-256; Hardenberg \& Nuyens, Inventaris arrondissement Maastricht en departement Nedermaas, xxxix.

${ }^{39}$ FA inv.nr.4201 onder nº1023R2, arrêté Bouteville; FA inv.nr.251 fol 203vo-204vo; Parijs Arch.Nat. inv.nr. D IV bis 39 dossier nr.634 [volgens inventaris 633"r] Compte de la mission du citoyen Bouteville, 63; Hardenberg \& Nuyens, Inventaris arrondissement Maastricht en departement Nedermaas, xxxix-xl, annotatie niet geheel correct. 


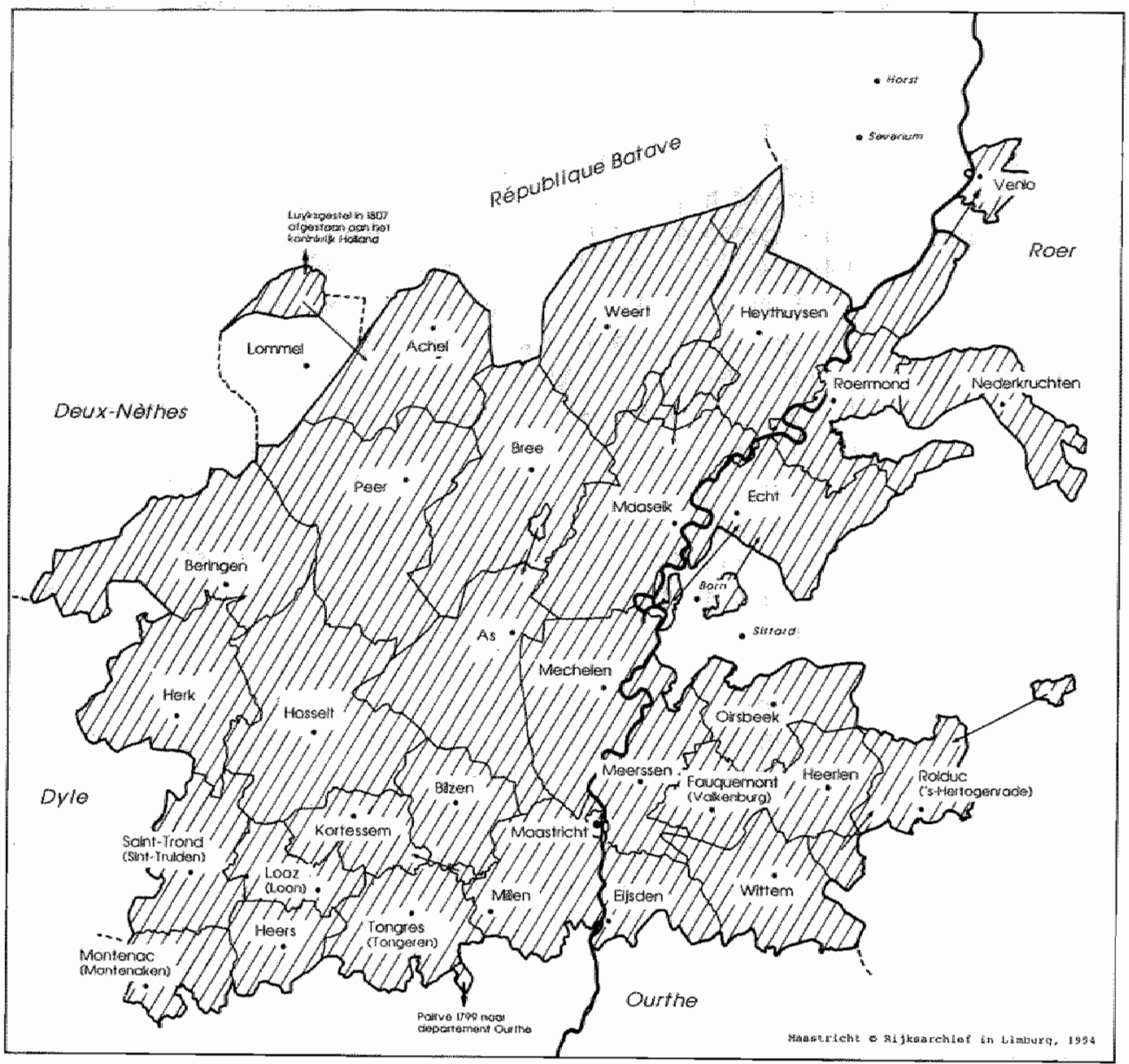

Departement Nedermaas 1795-1814, met de kantonnale indeling van 1796-1800. 
De splitsing van Maastricht en het stadsdeel Wyck in twee kantons - noord en zuid zoals Hardenberg schrijft ${ }^{40}$ - ingevolge het departementale arrêté van 22 vendémiaire V (13 oktober 1796) is niet correct. Bouteville had het departementaal bestuur in kennis gesteld van de benoeming van twee vrederechters in Maastricht; dit op verzoek van de departementale burgerlijke rechtbank, en daartoe het departementale bestuur van de Nedermaas verzocht het kanton Maastricht in twee ressorten ("arrondissements") op te delen ${ }^{41}$. Ook in zijn Compte aan het Directoire exécutif maakte Bouteville slechts gewag van het bestaan van eén kanton Maastricht ${ }^{42}$. In het algemeen was het zo dat in elk kanton één vredegerecht functioneerde, maar dorpen en stadjes met meer dan 2000 inwoners hadden een eigen vrederechter, terwijl in steden met meer dan 8000 inwoners verschillende vrederechters konden worden benoemd ${ }^{43}$.

Bij schrijven van 26 thermidor IV (13 augustus 1796) liet Hennequin, commissaris van de pouvoir exécutif bij het kanton 's-Hertogenrade (Rolduc), aan diens collega Rogier bij het departementaal bestuur weten dat de kleine gemeente Eygelshoven onafhankelijk bleek te zijn van elke hogere bestuursinstelling. De gemeente erkende noch het arrondisssement Aken, noch het departement van de Nedermaas, waarvan zij toch een integraal onderdeel vormde, gezien het feit dat er een douanekantoor gevestigd was. Maar Eygelshoven was niet begrepen onder de gearresteerde departementale indeling, terwijl zij vroeger wel bij het kanton 's-Hertogenrade hoorde. Bij de installatie van de municipale administratie echter, was zij ervan losgemaakt. Enkele dagen later kon Hennequin nog berichten dat Eygelshoven deel uitmaakte van de voormalige heerlijkheid Heiden, welke gerekend werd tot de Gulikse en dus keurvorstelijk-Paltsgrafelijke bezittingen te behoren ${ }^{44}$. De departementale bestuurders verlangden nadere inlichtingen van Hennequin, omdat hun bij eigen onderzoek was gebleken dat bij de eerste verdeling van de negen départements rếunis, het besluit van het comité de salut public van 14 fructidor III ( 31 augustus 1795), Eygelshoven niet afzonderlijk genoemd werd bij het kanton 's-Hertogenrade. Was het niet zo dat Eygelshoven ressorteerde onder de wél genoemde gemeenten? En hoe kon het dat er toch een douane-

${ }^{40}$ Hardenberg \& Nuyens, Inventaris arrondissement Maastricht en departement Nedermaas, $\mathrm{xl} ; \mathrm{H}$. Hardenberg, Inventaris van de archieven der rechtscolleges, alleensprekende rechters en rechterlijke ambtenaren, wan 1794 tor 1841 gefungeerd hebbende op het grandgebled wan de tegenwoordige Nederlandsche provincie Limburg ('s-Gravenhage, 1946) 31.

"FA inv.nr. 255 fol 31 vo "correspondance active et passive $n$ "17" - Bouteville aan departementaal bestuur 17 vendémiaire $\mathrm{V}$ (8 okt 1796); FA unv.nr.137 fol 109 "registre aux arretés nr. $3^{4 \text { " }}-22$ vendémiäre $V$ (13 okt 1796) art. 1: "La Commune de Maestricht sera partagée en deux arrondissements dans l'un desquels un des juges de paix susnommés [de beide benoemde vrederechters] et respectivement ceux qui les remplaceront à l'avenir exerceront particulièrement les fonctions que la loi leur attribues".

42 Parijs Arch.Nat. inv.nr. D IV bis 39 dossier 634 [wolgens inventaris $633^{\text {ter }}$ ] Compte de Bouteville, 60.

${ }^{43}$ Prosper Poullet, Les Institutions Françaises de 1795 a 1814. Essai sur les Origines des Institutions Belges contemporaines (Bussel, 1907) 88; Godechot, Institutions de la France "476-477.

44 FA inv.nr.251 fol 112vo-113ro, 115, "correspondance active et passive $\mathrm{n}^{2} 13^{\prime \prime}$; schrijven Hennequin aan Rogier 26 en 29 thermidor IV (13 en 16 aug 1796). 
kantoor gevestigd was? $?^{45}$. De commissaris van het Directoire exêcutif te 's-Hertogenrade schreef dat Eygelshoven slechts onder het kanton ressorteerde, omdat het hoorde bij de gemeente Horbach. Hennequin legde verder de verklaring van de inspecteur van de douane over, die stelde dat er een douanekantoor in Eygelshoven was, omdat de gemeente beschouwd werd tot het kanton 's-Hertogenrade te behoren. Mocht dit niet het geval zijn dan zou er niettemin een douanekantoor zijn, aangezien de gemeente geheel door het departement Nedermaas omringd was. Hierop wenste het departementaal bestuur nog te weten, of de gemeente Horbach niet voor de inlijving behoorde tot het Gulikse en tot welk kanton deze gemeente op dat moment werd gerekend ${ }^{46}$. Volgens de Rolducse commissaris van het Directoire exécutif maakte de gemeente Horbach voor de inlijving bij Frankrijk deel uit van het Gulikse territoir, en op dat moment behoorde zij tot de gemeente Richterich, dat het Land van Heiden vormde, de vroegere vrije heerlijkheid die onmiddellijk ondergeschikt was aan de Paltsgraaf ${ }^{47}$.

Het departementaal bestuur legde het probleem Eygelshoven voor aan gouvernementscommissaris Bouteville te Brussel om hierover een beslissing te nemen, aangezien er geen enkele authentieke akte voorhanden was en omdat Eygelshoven vroeger deel had uitgemaakt van het kanton "s-Hertogenrade. Gesteld werd dat de kleine gemeente slechts bij vergissing niet genoemd werd bij de opsomming van de gemeenten van het kanton ${ }^{48}$. Bouteville bepaalde daarop dat Eygelshoven onder het departement van de Nedermaas ressorteerde. Hij overwoog daarbij, "qu" il est indispensable que cette commune soit administrée et conséquemment attachée à une administration quelconque". Bovendien was het zo dat Eygelshoven deel had uitgemaakt van het kanton 's-Hertogenrade gedurende de periode van het arrondissement Maastricht en thans werd de gemeente geheel door het kanton omringd. En de bedoeling was immers duidelijk gebleken, gelet op het feit van de vestiging van een douanekantoor te Eygelshoven $^{49}$. Door Eygelshoven toe te voegen aan het kanton 's-Hertogenrade week Bouteville af van het arrêté van zijn voorgangers Pérès en Portiez (de l'Oise) van 11 frimaire IV ( 2 dec 1795), dat stelde dat de gemeenten en streken die niet genoemd werden in het besluit van het comité de salut public van 14 fructidor III (31 augustus 1795) onder de Centrale Administratie van Aken zouden blijven ressorteren, alsmede de overweging dat de aansluitingswet van 9 vendémiaire IV (1 okt 1795) in geen enkel opzicht betrekking had op Guliks territoir. Het was daarom niet verwonderlijk dat de gouvernementscommissaris directeur-generaal van de Administratie van de Veroverde Landen tussen Maas en Rijn, Pruneau, Eygelshoven opeiste, na klachten

\footnotetext{
45 FA inv.nr 254 fol 64v0-65ro "correspondance active en passive $n^{9} 16$ "; departementaal bestuur aan Hennequin 14 vendémiaire $V(5$ okt 1796).

${ }^{46}$ FA inv.nr.255 fol 55vo-56ro, fol 97 "correspondance active et passive $n^{2} 17^{\prime \prime}$; schurijwen Hennequin aan departementaal bestuur 23 vendémiaire $V(14$ okt 1796), departementaal bestuur aan Hennequin 6 brumaire V (27 okt 1796).

47 FA inv.nr.256 fol 75 "correspondance active et passive $n^{9} 18$ "; Hennequin aan departementaal bestuur 12 brumaire $V(2$ nov 1796).

48 FA inv.nr.4201 onder nr.932R3; minuut-schrijven departementaal bestuur aan Bouteville 19 frimaire V ( 9 dec 1796).
}

${ }^{49}$ Ibidem; arrêtế Bouteville 27 frimaire V (27 dec 1796). 
van de onderhavige gemeente en het kanton $\mathrm{Aken}^{50}$. Maar deze demarche bleef zonder gevolg.

Grenskwesties die zich hadden voorgedaan tussen de arrondissementen Maastricht en Luik, traden ook aan het licht tussen de departementen van de Nedermaas en de Ourthe. Ditmaal beperkten ze zich tot de streek zuidwestelijk van Maastricht gelegen, met name rond de dorpen Anze-sur-Geer en Paifve.

Het gehucht Anze-sur-Geer, gelegen op de rechteroever van de Jeker die ter plaatse de grens vormde, werd door de dorpen Roclenge (departement Nedermaas, kanton Millen) en Houtain-Saint-Siméon (departement Ourthe, kanton Milmort, later Herstal) betwist. Inwoners van Anze beklaagden zich erover dat het kanton Millen tellingen liet verrichten voor onder meer de gedwongen geldlening. In een tweetal besluiten liet het departement van de Ourthe dat van de Nedermaas weten dat Anze vroeger tot het dorp Houtain-Saint-Siméon behoorde en thans ondergeschikt was aan het departementaal bestuur van de Ourthe ${ }^{51}$. Het departementaal bestuur van de Nedermaas legde deze grenskwestie bij schrijven van 4 vendémiaire V (25 september 1796) voor aan gouvernementscommissaris Bouteville te Brussel. Beide departementen eisten het gehucht Anze-sur-Geer op, hoewel het departement van de Ourthe erkende dat Anze tot de parochie van Roclenge werd gerekend, maar dat er hier gehandeld diende te worden overeenkomstig een besluit van het Directoire exécutif dat gewaagde van "la dépendance politique". Het departement van de Nedermaas kon daarentegen bewijsstukken tonen, waarin inwoners van Roclenge attesteerden dat Anze voor circa énderde bijdroeg in de lasten. Het departement verdacht sommige inwoners ervan zich op deze wijze te vrijwaren van de afdracht van belastingen ${ }^{52}$. Blijkens een schrijven van het departementaal bestuur van de Ourthe van 29 pluviôse V (17 februari 1797) had Bouteville nog niet over het geschil beslist, aangezien het departement instemde met het voorstel van de Nedermaas om wederzijds commissarissen te benoemen teneinde ter plaatse een onderzoek in te stellen. Luik wees er wel op dat alleen het gouvernement hieromtrent definitief zou kunnen beslissen, tot zo lang bleef Anze-surGeer onder het - thans - kanton Herstal ressorteren, alsmede in de lasten bijdragen $^{53}$. Op 5 floréal V (24 april 1797) schreef het departementaal bestuur naar Luik,

\footnotetext{
${ }^{50}$ FA inv.nr.4202 onder 610R4; Pruneau aan departementaal bestuur 1 pluviôse V (20 jan 1797); De Wit \& Flament, "Vorming heerschappijen", 158-159; Hardenberg \& Nuyens, Inwentaris arrondissement Maastricht en departement Nedermaas, $\mathrm{xl}$.

${ }^{51}$ FA inv.nr.245 fol 48ro-49vo "correspondance active et passive $n^{27}$ ", arrêtés departement Ourthe 18

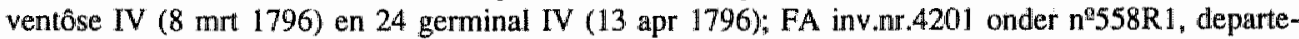
mentaal bestuur Ourthe aan departementaal bestuur Nedermaas 18 ventôse IV.

${ }^{52} \mathrm{FA}$ inv.nr.251 "correspondance active et passive $\mathrm{n}^{\mathrm{Q}} 13$ fol $23 \mathrm{vo}-25 \mathrm{ro}$, departementaal bestur Ourthe aan departementaal bestuur Nedermaas 6 thermidor IV ( 24 jul 1796), met additionele correspondentie: fol 232vo-234ro, departementaal bestuur Nedermaas aan Bouteville 4 vendémiaire V (25 sep 1796): FA inv.nr. 4201 stukken onder $\mathrm{n}^{2} 296 \mathrm{R} 2$.

${ }^{53} \mathrm{FA}$ inv.nr.259 fol 191 vo "correspondance active et passive $\mathrm{n}^{\mathrm{D}} 21$ ", departementaal bestuur Ourthe aan departementaall bestuur Nedermaas 29 pluviôse $V$ (17 feb 1797); FA inv.nr.260 fol 44ro-45ro "correspondance active et passive $n^{\circ} 22^{\text {", }}$, Nedermaas aan Ourthe 15 pluviôse V (3 feb 1797); kort daarvoor reeds had, na een klacht uit Luik, het departementaal bestuur van de Nedermaas de militaire executie die het kantonnale bestuur van Millen jegens Anze wilde ten uitwoer leggen stopgezet tot de
}

(wordt vervolgd...) 
dat uit commissaris Coenegrachts rapportage bleek dat Anze geen deel uitmaakte van Houtain, noch dit kon worden; het nodigde het departementaal bestuur van de Ourthe tevens uit tot intrekking van zijn besluit, waarbij Anze onder Houtain ressorteeerde. Luik persisteerde evenwel bij zijn arrêté op basis van de rapportage van zijn eigen commissaris ${ }^{54}$. In verband met de "différences essentielles" benoemde het departementaal bestuur van de Nedermaas toen de deskundige Cavenne om een kaart te tekenen. Dit vlotte klaarblijkelijk niet zo, want de municipale agent te Roclenge informeerde begin 1799 nogmaals bij het departementale bestuur naar de stand van zaken in het geschil over Anze ${ }^{55}$. Mijns inziens bleef Anze-sur-Geer onder het departement van de Ourthe ressorteren. Dat is ook de opvatting van Hardenberg ${ }^{56}$.

Het redemptiedorp Paifve, dat krachtens art.20 van het Verdrag van Fontainebleau uit 1785 tot de Staatse landen bleef behoren, leidde eveneens tot een touwtrekken tussen de beide aangrenzende départements réunis. In het besluit van 14 fructidor III (31 augustus 1795) van het comité de salut public inzake de kantonnale indeling van de departementen werd Paifve niet met name genoemd. Dit werd ook toegegeven in het schrijven van 2 ventôse IV (21 februari 1796) van het departement van de Ourthe, waarbij de gemeente Paifve er zich over beklaagde dat het Nedermaase kanton Tongeren over haar heerste, terwijl zij geheel door het kanton Milmort omgeven werd. Bouteville vroeg het departement van de Nedermaas hieromtrent ook nadere inlichtingen. Het departementaal bestuur van de Nedermaas was niet van zins zijn claim op Paifve te laten varen, te meer daar men van de zijde van de Ourthe erkende dat Paifve vroeger ressorteerde onder Nerem dat thans tot het kanton Tongeren behoorde. Het departement van de Nedermaas ging zelfs nog verder door het aan de overzijde van de Maas gelegen Berneau ook op te eisen en hoopte hierin tot overeenstemming met het departement van de Ourthe te komen ${ }^{57}$. Bouteville is waarschijnlijk niet tot een beslissing gekomen, want het lijkt er sterk op dat hij Paifve onder beide departementen laat ressorteren ${ }^{58}$.

Hardenberg schrijft dat op het einde van de Directoire-periode het departementale bestuur van de Nedermaas erin berustte dat Paifve voorlopig onder het departement

sia (...vervolg)

beslissing van Bouteville, FA inv.nr. 259 fol $123 \mathrm{wo}$, Nedermaas aan kantonsmunicipaliteit van Millen en aan Ourthe 4 pluviôse V (23 jan 1797).

In Boutevilles Compte, 48 wordt Anze-sur-Geer wel onder het departement Ourthe gerangschikt.

${ }^{34}$ FA inv.nr.260 fol 223 vo-224ro "correspondance active et passive $n^{2} 22$ ", Nedermaas an Ourthe 5 floréal V (24 apr 1797); FA iny.nr.13 "indicateur général" onder $n^{0} 197 R 5$, Ourthe aan Nedermaas 13 floreal V (2 mei 1797).

${ }^{\text {s. }}$ FA inv.nr.140 fol 110 "registre aux arrêtés $n^{93}$ "7"; departementaal arrêté 26 floréal V (15 mei 1797); FA inv.nr.20 "indicateur général" onder n¹372R12, municipale agent Roclenge aan Nedermaas III ventôse VII (1 mrt 1799).

35. Hardenberg \& Nuyens, Inwentaris arrondissement Maastricht en departement Nedermaas, $x 1$.

${ }^{57} \mathrm{FA}$ inv.nr.240 "correspondance active et passive $\mathrm{n} 2$ " fol 11 vo-12vo, Ourthe aan Nedermaas 2 ventôse IV (21 feb 1796), fol 87, Bouteville aan Nedermaas 14 ventôse IV (4 mit 1796); FA inv.nr.244 "correspondance active et passive $n^{2} 6$ " fol $180 \mathrm{vo}-181$ vo, Ourthe aan Nedermaas 8 florkal IV (27 apr 1796), fol 219, Nedermaas aan Ourthe 16 floreal IV (5 mei 1796); FA inv.nr.247 "correspondance active et passive $n^{99^{*}}$ fol 98 ro-99\%o, Bouteville aan Nedermaas 5 prairial IV (24 mei 1796).

${ }^{58}$ Bouteville, Compte, 49, 57 [6|]; Paifvre (kanton Herstal) en Paiff (kanton Tongeren). 
van de Ourthe zou ressorteren ${ }^{59}$. Alvorens het zover kwam, deed zich evenwel het tegenovergestelde voor. Bij departementaal besluit van 23 pluviôse VII (11 februari 1799) werd uitdrukkelijk bepaald, dat het dorpje Paifve een "dépendance" vormde van de gemeente Nerem (Nederheim), kanton Tongeren. Dit besluit was uitgevaardigd naar aanleiding van het requisitoir van de commissaris-agent-generaal voor de belastingen, die stelde dat Paifve op geen enkele wijze in de belastingen bijdroeg, ondanks de "arrêtếs de démarcation" via welke bepaald was dat Paifve onder Nerem ressorteerde. Deze demarcatiebesluiten konden bij het onderzoek niet nader worden getraceerd. Opdracht werd toen gegeven om nieuwe belastingkohieren samen te stellen. Een reactie van de zijde van het departementaal bestuur van de Ourthe liet dan ook niet lang op zich wachten: op 21 ventôse VII (11 maart 1799) vroeg het om intrekking van het Nedermaase besluit, aanvoerende dat sedert de maand floréal IV (april/mei 1796) Paifve door hem als behorende tot het kanton Kemexhe (voorheen Herstal) bestuurd werd. Kennelijk zag het departement van de Nedermaas zich genoodzaakt om zijn laatste besluit inzake Paifve te herroepen. Onder verwijzing naar een besluit van het Directoire exécutif van 29 nivôse VII (18 januari 1799) werd door het departement van de Nedermaas bij arrêté van 21 floréal VII (10 mei 1799) zijn bestuurscompetentie over het gehucht Paifve ongedaan gemaakt, maar dit onder de uitdrukkelijke bepaling, dat (art.3): "Il n'est pas renoncé aux droits de propriété que le canton de Tongres aurait à faire valoir à l'égard de ce hameau, attendu que toute question de division de territoire ne peut être décidée que par le Corps législatif" ${ }^{\circ 60}$. In de considerans gaf het departementale bestuur toe dat nog maar sinds 23 pluviôse Paifve door de Nedermaas bestuurd werd en dat dit voor een veel langere tijd door de Ourthe geschied was en dus "la possesssion de l'administrer est de fait révolu à ce dernier". Of en in hoeverre het Wetgevend Lichaam een uitspraak over Paifve gedaan heeft, kon niet worden nagegaan. In ieder geval ressorteerde het dorp bij de Consulaire kantonnale indeling van 19 pluviôse X (29 januari 1802) onder het departement van de Ourthe (kanton Glons) ${ }^{61}$.

Hardenberg wijdt een hele paragraaf aan de geruchten die de ronde deden, dat er overwogen werd om tot een herschikking van de negen départements réunis te komen en daarbij het departement van de Nedermaas eventueel op te heffen ${ }^{62}$. De eventuele herschikking van de departementen werd actueel door het feit dat het Corps législatif op 1 germinal V (21 maart 1797) gedeeltelijk moest worden vernieuwd. Daartoe

\footnotetext{
${ }^{\$ 9}$ Hardenberg \& Nuyens, Inventaris arrondissement Maastricht en departement Nedermaas, $\left.\mathrm{x}\right]$.

${ }^{60}$ FA inv.nr.149 "régistre aux arrêtés $n^{23^{16 " *}}$ fol 8vo-9vo, arrêté 23 pluviöse VII (11feb 1799); FA inv.nr.20 "indicateur général" 578R 12, Ourthe aan Nedermaas 21 ventôse VII (11 mrt 1799); BL Me ser no.255 (2398) arrêté concernant l'assiette des contributions directes pour les comnunes dont le département ou la situation relative sont contestés art.2: "Les communes contestées par deux départemens, qui n'ont pas été assignées, par une loi, arrêté ou décision, à l'un de cés départemens, ne pourront, pour l"an VII, être imposées que dans le canton qui, par le fait, est en possession de les administrer"; FA inv.nr.150 "régistre aux arrêtés $n^{2037 " \% ~ f o l ~ 199 v o-200 r o, ~ a r r e ̂ t e ́ ~} 21$ floréal vII (10 mei 1799).

6. Nuyens, Historische Atlas Limburg, 16.

${ }^{62}$ Hardenberg \& Nuyens, Inleiding inventaris arrondissement Maastricht en departement Nedermaas, xli-xlv.
} 
moest het aantal afgevaardigden per departement voor de Conseil des Cinq-cents en de Conseil des Anciens worden vastgesteld. Het was de eerste keer dat inwoners van de negen Verenigde Departementen hun vertegenwoordigers konden kiezen. Bij wet van 3 brumaire IV ( 24 november 1795 ) was door de Nationale Conventie bepaald dat in alle gebieden die vielen onder de werking van de aansluitingswet van 9 vendémiaire IV de bestuurlijke autoriteiten vooralsnog benoemd zouden worden door de volksrepresentanten die naar Belglë waren gezonden ${ }^{63}$. Aanvankelijk werd eerst nog een discussie te Parijs gevoerd of wel aan alle ingelijfde streken het kiesrecht zou moeten worden gegund. De aansluitingswet van 9 vendémiaire IV (1 oktober 1795) zelf vormde daartoe de aanleiding. De artt. 5 en 6 maakten namelijk een onderscheid tussen een tweetal categorieën inwoners:

Les habitans des pays de Liége, de Stavelot, de Logne et de Malmedy, et ceux des communes de la Belgique comprises dans les articles II et III du prësent décret [i.e. de aansluitingsdecreten van 1793 en wilsuitingen van zekere gemeenten en streken tot aanhechting bij de Franse Republiek], jouiront dès-à-présent de tous les droits de citoyen français, si d'ailleurs ils ont les qualités requises par la constitution [art.5].

A l'égard des communes comprises dans l'article IV ci-dessus [i.e. de Oostenrijkse Nederlanden en de streken afgestaan aan Frankrijk krachtens het Haagse verdrag van 16 mei 1795], les habitans jouiront, jusqu'à ce qu'il en ait ếté autrement disposé, de tous les droits garantis par la constitution aux étrangers qui résident en France ou y possèdent des propriétés [art.6].

Dit onderscheid trok onmiddellijk na de inlijving bij Frankrijk de aandacht van de departementale bestuurders. In het verslag aan de conseil de gouvernement de la Belgique te Brussel, dat ter gelegenheid van de plechtige bekendmaking van de aansluiting bij Frankrijk te Maastricht was opgemaakt, werd aan de conseil verzocht de Nationale Conventie te informeren inzake "le contentement du peuple de cette réunion provisionnelle, et son ardent désir d'en obtenir une plus parfaite en acquérant le rang et le droit de citoyens actifs" ${ }^{\text {"64 }}$. Deze missive werd bij schrijven van de conseil de gouvernement in afschrift doorgezonden aan de Nationale Conventie. De raad ondersteunde krachtig het Nedermaase verzoek, want: “D'après l'article 9 [lees: 6] de la Loi du 9 vendém ${ }^{\text {re }}$ ce département ne va pas encore jouir de la plénitude de ses droits" $"$.

\footnotetext{
63. Art.9 van wet van 9 vendémiaire IV: "Ils nommeront provisoirement les fonctionnaires qui devront composer les administrations de département, celles de cantons, et les tribunaux des pays de Limbourg, de Luxembourg, de Maëstricht, de Venloo et leurs dépendances, et de la Flandre ci-dewant hollandaise"'; BL Ie ser no.203 (1217), Loi portant que les dispositions de l"article IX de celle du 9 wendémiaire dernier, sont applicables à tous les pays rểuis par cette loi au territoire de la République ant.1.

${ }^{64}$ FA inv.nr.279 onder $n^{2} 16$ "correspondance particullère $n^{2} 1$ ", nationale agent en leden het bestuur vormend van het arrondissement Maastricht aan conseil de gouvernement de la Belguque 23 vendemiaire IV (15 okt 1795).

${ }^{65}$ Parijs Arch. Nat. inv.nr. C 389 dossier 110 "Conseil des 500. Vingt-cinq pièces. Lettres, adresses et délibérations des administrations et des corps constitués, envoyés et lues au Conseil des 500. Du 15 au 17 brumaire an $4^{\mathrm{e} "}$, Conseil du Gouvernement aan Nationale Conventie 29 vendémiaire IV (21 okt 1795).
} 
Voor de volksrepresentanten/gouvernementscommissarissen Pérès en Portież (de l'Oise) was dit wettelijk gefundeerde onderscheid tussen eerste- en tweederangs ingezetenen enige weken later kennelijk al niet meer terzake doende, aangezien zij in hun proclamation aux Français, habitans des pays réunis van 14 brumaire IV (5 november 1795) zich zonder aarzelingen aldus tot de inwoners richtten: "vous êtes Français" ${ }^{" 66}$.

Niettemin werd deze problematiek actueel, aangezien de verkiezingen voor het Corps législatif op 1 germinal V (21 maart 1797) in het verschiet lagen, alsmede omdat de aansluitingswet van 9 vendémiaire IV in art. 10 uitdrukkelijk bepaalde dat het Wetgevend Lichaam het aantal vertegenwoordigers diende vast te stellen "que chacun des départemens (...) devra nommer à l'époque du renouvellement qui aura lieu l'an V de la République". Een speciale commissie uit de Conseil des Cinq-cents stelde het op prijs de mening van het departement van de Nedermaas te weten over de op dat moment bestaande departementale indeling van België. Door sommigen scheen er toentertijd te zijn aangedrongen op een betere demarcatie van de departementsgrenzen. Bouteville echter was voorstander van behoedzaam opereren: "n"oublions jamais cette utile maxime festina lente". Het departement van de Nedermaas dat $\mathrm{zich}$ in zijn bestaan bedreigd voelde, juichte de "sagesse" van Bouteville in dezen toe ${ }^{67}$. Om de Nedermaase zaak te Pari.js te bepleiten, vaardigde het departementaal bestuur twee mensen naar Parijs af, voorzien van twee breedvoerige memoranda ${ }^{68}$. Het tweetal, beiden functionaris bij de departementale criminele rechtbank - Membrède (president) en Michiels aîné (openbaar aanklager) - , kreeg daar een uitbrander van de minister van justitie Philippe-Antoine Merlin (de Douai) te verduren die niet te spreken was over het feit dat twee der belangrijkste functionarissen van de rechtbank zich zonder voorafgaande toestemming naar Parijs hadden begeven ${ }^{69}$. Ook gouvernementscommissaris Bouteville had zich sterk beijverd voor de toekenning van de grondwettelijke rechten aan alle ingezetenen van de départements réunis. In missives aan de minister van binnenlandse zaken en de Conseil des Cinq-cents pleitte hij ervoor geen onder-

\footnotetext{
66 FA inv.nr.291 onder n35; Proclamation, 1.

${ }^{67}$ FA inv.nr.254 fol 60vo-61 ro "correspondance active et passive $n^{\circ} 16^{\prime \prime}$, commissie uit Cinquents an Nedermaas 11 vendémiaire V (2 okt 1796), fol 131 vo-132vo Nedermaas aan Bouteville 28 wendémi“ aire V (19 okt 1796); FA inv.nr.255 fol 32vo-33wo "correspondance active et passive $\mathbf{n}^{17} 7^{* *}$, Bouteville aan Nedermaas 17 vendémiaire V (8 okt 1796).

6. Deze memoranda bevinden zich o.a. in FA inv.nr.4201 onder n"800R3 en FA inv.nr.256 fol 136vo142vo, 146ro-152 vo "correspondance active et passive $\mathrm{n}^{\mathrm{O}} 1 \mathrm{18}^{\text {", }}$, memorandum $\mathrm{A}$ "Considérations sur la necessité de laisser subsister la division de la Belgique et autres pays réunis en neuf Départements par des citoyens des mêmes départements", memorandum B "Quelques observations particulières pour prouver l"utilité de laisser le Département de la Meuse inférieure un département séparé en conservant la Commune de Maestricht pour son chef-lieu"; Hardenberg \& Nuyens, Inventaris arron* dissement Maastricht en departement Nedermaas, xliii-xlv, haalt passages eruit aan.

${ }^{69}$ Parijs Arch.Nat. Archief ministerie van justitie inv.nr. BB ${ }^{30} 166$ (1) Bureau particulier du ministre. Correspondance avec les départemens réunis de la Belgique an IV-an VI, minuut-kantschrijven Merlin aan Michiejs 12 brumaire V ( 2 nov 1796): "je suis étonné, citoyen, que les deux principaux membres d'un tribunal criminel, aient quitté brusquement leur poste, pour se rendre à paris, sans m'en avoir prévenu, sans avoir obtenu l'autorisation préalable qui leur étoit nécessaires d'après le but de leur voyage. c'est avec peine, je vous l'avoue, que je sens cette idée se mêler à celle du plaisir que j"aurail à vous voir".
} 
scheid te maken tussen categorieën burgers ${ }^{70}$. Bovendien diende men de in de wet van 9 vendémiaire IV gedane toezegging gestand te doen, waarin uitdrukkelijk bepaald was dat met ingang van het jaar $\mathrm{V}$ de inwoners van de negen Verenigde Departementen hun vertegenwoordigers zouden kunnen kiezen. Bouteville schreef dienaangaande:

On m'apprend que l'on se prépare à contester le droit de suffrage aux habitants de Maestricht et du Limbourg. (...) Un premier décret avait statué que les assemblées primaires auraient lieu dès l'an IV, disposition qui a été rapportee. Il est possible que l'on ait d'abord trouvé un trop grand danger à laisser exercer alors les diroits de citoyen par des hommes qui $n$ "avaient pas voté la réunion. Quelle qu'ait pu être la cause de cette disposition toujours étonnante, celle de l'article 10 [aansluitingswet 9 vendémiaire IV] me semble lever cette difficulté. Cet article veut que les habitants de tous les Départements-réunis nommeront leurs représentants au $1^{\text {ef }}$ germinal de l'an V. II serait inconcevable que les habitants d'une commune formant le chef-lieu d'un département français pussent être privés de ce droit ${ }^{71}$.

Blijkens de al genoemde wet van 23 ventôse V ( 13 maart 1797), waarin bepaald was de bestaande departementale indeling voorlopig te handhaven, was het gevaar voor opheffing van het departement van de Nedermaas op dat moment in ieder geval tijdelijk geweken. Slechts zeven dagen voor het bijeenroepen van de assemblées primaires werd deze alsmede een tweede wet van dezelfde datum uitgevaardigd, teneinde aan grondwettelijke en wettelijke verplichtingen te kunnen voldoen ${ }^{72}$. De laatste wet

${ }^{70}$ Eugène Hubert \& Camille Tihon, ed, Correspondance de Bouteville (2 dln; Brussel, 1929-1934) II, $118-125,337-342,428-438,524-531$, missives nr.331 (8 brumaire V/29 okt 1796), nr.450 (29 frimaire V/19 dec 1796), nr.496 (17 nivôse V/6 jan 1797), nr.543 (7 pluviôse V/26 jan 1797).

${ }^{71}$ Ibidem II, 529 brief nr.543, Bouteville aan minister van binnenlandse zaken 7 pluviôse V (26 jan 1797); in zijn Compte, 18 aan het Directoire exécutif wees Bouteville er nogmaals op. Onderwijl had de minister van justitie Merlin (de Douai) diens collega van binnenlandse zaken in een schrijven op 1 pluviôse V (20 jan 1797) met de kwalificatie "très urgent" erop gewezen dat ingevolge art. 6 van de aansluitingswet van 9 wendémiaire IV grote delen van départements réunis nog steeds geen stemrecht hadden: "Si cette Disposition était encore en vigueur, il n'y aurait pas une seule partie du Département des forêts dont les habitans eussent droit d'éligibilité et de suffrage dans les prochaines Elections. Il en serait à peu près de même de tout le Departement de la Meuse inférieure et de celui des deux Nethes". Volgens. Merlin vervulde art.16 van de wet van 20 nivôse V (9 jan 1797) de voorwaarde van art.6 wan de wet van 9 vendémiaire IV, "jusqu'à ce qu'll en ait ếté autrement ordonne". In een rondschrijwen diende de minister van binnenlandse zaken op wens van het Directoire exécutif de departementale besturen hiervan in kennis te stellen; Merlin: "Je dis des 9 Dëpartemens réumis, car indépendament de ce que la réunion n'a été votée dans aucune Partie du Département des forêts et dans presqu'aucune des Dép's de la Meuse inférieure et des deux Nethes, il se trouve dans chacune des six autres, beaucoup de communes qui ne l'ont pas votee d'avantage et auxquelles, par conséquent, on pourrait appliquer la disposition de l"art" 6 de la Loi du 9 vendemiaire an 4 , si elle subsistait encore", Parijs Arch.Nat. inv.nr. F" 27 doss.2 "Pays annexés ou dépendants". BL IIe ser no.100 (947), loi concernant le renowvellement prochain du Corps législatif van 20 nivôse V (9 jan 1797) tit.II art. 16: "Au mois de germinal prochain, tous les départemens de la République française, y compris ceux réunis par la loï du 9 vendémiaire, an IV, concourront, chacun en raison de sa population, à l"élection d'un tiers seulement des membres du Corps législatif ...".

${ }^{72}$ De Lanzac de Laborie, Domimation française, $I_{n}$ 101-1.03; BL IIe ser no.112 (1067), loi qui ordonne le renouvellement des autorités constituées, dans les neuf départemens ré̉unis le 9 Vendémiaire an IV. 
is een loi particulière die alle leden van gerechtelijke en bestuurslichamen vernieuwde, omdat zij slechts voorlopig benoemd waren. Van het door de aansluitingswet van 9 vendémiaire IV vastgelegde onderscheid tussen categorieën ingezetenen werd niet langer gerept.

\section{Annexatie gesanctioneerd}

Tijdens de eerste twee coalitieoorlogen met zijn Europese rivalen had de Franse Republiek een aanzienlijk territoir weten te bezetten en te consolideren. Op deze plaats zijn echter alleen de veroveringen van België en de linker Rijnoever van belang. Op 26 vendémiaire VI (17 oktober 1797) sloten de Franse staat en Oostenrijk een vredesverdrag en additionele geheime conventie te Campo-Formio, waarvoor Napoleon Bonaparte te Leoben in een preliminair vredesverdrag op 18 april 1797 reeds de basis had gelegd ${ }^{73}$. De Habsburgse keizer deed toen afstand van zijn bezittingen in de Zuidelijke Nederlanden, te Campo-Formio aldus geformuleerd (art.3):

S.M. l'Empereur, Roi de Hongrie et de Bohème, renonce pour elle et ses successeurs, en faveur de la République Française, à tous ses droits et titres sur le ci-devant provinces Belgiques sous le nom de Pays-Bas Autrichiens. La République Française possédera ces pays en perpétuité, en toute souveraineté et propriété, et avec tous les biens territoriaux qui en dépendent.

$\mathrm{Na}$ heropening van de vijandelijkheden, welke tot een einde kwamen in het door de Keizer, het Duitse Rijk en Frankrijk in het Lotharingse stadje Lunéville gesloten vredesverdrag, werd de inbezitneming van België uitdrukkelijk bevestigd. De passus in art.2 dienaangaande van het vredesverdrag van Lunéville van 20 pluviôse IX ( 9 februari 1801) was vrijwel woordelijk overgenomen uit het verdrag van CampoFormio. Het bewuste derde artikel werd nadrukkelijk hernieuwd: "La cession des cidevant provinces belgiques à la république française stipulée par l'article III du traité de Campo-Formio, est renouvelée ici de la manière la plus formelle (...)"74.

De kleinere (semi)-soevereine territoria - als bij voorbeeld de abdij Thorn en het graafschap Gronsveld, maar eveneens het voormalige prinsbisdom Luik - die gerekend werden tot het Duitse Rijk te behoren, en die stilzwijgend onder de jurisdictie van het departement van de Nedermaas gebracht waren, kwamen bij het verdrag van Lunéville in aanmerking voor enigerlei schadeloosstelling. A rt. 6 stelde eenvoudigweg dat de Franse staat onder algehele soevereiniteit de landen en domeinen gelegen op de linker Rijnoever en die deel uitgemaakt hadden van het Duitse Rijk in eigendom had. Het Duitse Rijk als geheel diende de vorsten en staten, die geheel of gedeeltelijk hun bezittingen waren kwijtgeraakt schadeloos te stellen: "l'empire sera tenu de donner aux princes héréditaires quil se trouvent dépossédés à la rive gauche du Rhin, un dédommagement qui sera pris dans le sein du dit empire (...)" (art.7). De schadeloosstellingen aan de bezitters van de (semi)-soevereine territoria, alsmede aan de Palts-

\footnotetext{
${ }^{73}$ Parry, Consolidated Treaty Series, LIV, 53-58 (Leoben), 157-168 (Campo-Formio).

${ }^{74}$ Ibidem, LV, 475-495.
} 
graaf als Guliks landsheer en de Pruisische koning, werden toegewezen op de zitting van de Rijksdag te Regensburg op 25 februari $1803^{75}$.

Sedert de totstandkoming van het verdrag van Lunéville konden de "vrije Rijksheerlijkheden" internationaalrechtelijk niet meer als enclaves worden beschouwd, zoals De Wit en Flament ze betitelden ${ }^{76}$. De aansluitingswet van 9 vendémiaire IV maakte in het geheel geen gewag van deze territoria. Blijkens hun handelen bekommerden de Franse autoriteiten zich ook niet om dit fijnzinnige onderscheid. Hun wetgewing en bestuursmaatregelen waren, wat het territoir van het departement Nedermaas betrof, gelijkelijk van kracht in de gebieden wel genoemd in de aansluitingswet, als in die gebieden die daar niet werden genoemd.

\section{Slotbeschouwing}

In deze afsluitende paragraaf zal in grote trekken de circumscriptie van het departement van de Nedermaas tijdens zijn functioneren over de periode 1795 tot 1814 worden geschetst.

Het territoir van het departement Nedermaas nam een veelheid aan grotere of kleinere territoria in zich op. De veroveringsoorlog door de Franse legers in 1794 moet achteraf beschouwd - naar een aforisme van de historicus Rogier - weliswaar als een gewelddaad, maar evenzeer als een weldaad worden gezien ${ }^{77}$. De Fransen ruimden de absurde staatkundige versplintering op. Daarvan een exacte en waterdichte opsomming te geven, heeft veel weg van het zoeken naar de kwadratuur van de cirkel. Het traceren van de grotere soevereinen levert uit de aard van de zaak de minste problemen op. Aanzienlijk lastiger wordt het als men tevens tracht de constituerende delen stuk voor stuk op te sommen. Op grond van het voorafgaande kan worden gesteld dat het territoir van het departement gedurende de Directoire-periode opgebouwd was uit:

- de generaliteitslanden van de Republiek der Verenigde Nederlanden, te weten Maastricht (deels) en het graafschap van de Vroenhof, alsmede de banken van het Kapittel van Sint-Servaas (behoudens Berneau) en de redemptiedorpen (behoudens Paifve), de Staatse landen van Valkenburg, 's-Hertogenrade en Dalhem (Cadier en Oost), en het Staats-Overkwartier van Gelre (Venlo en het land van Montfort, alsmede Obbicht en Papenhoven);

- het prinsbisdom Luik, te weten de graafschappen Loon (met deels Lummen ${ }^{78}$, deels

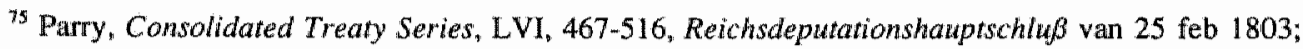
zie ook De Wit \& Flament, "Vorming heerschappijen", 174-175, 177-180; of de bezitters van nietgenoemde heerlijkheden - zo wordt Wijlre niet genoemd in het Reichsdeputationshauptschluß schadeloosgesteld zijn, is onduidelijk.

${ }^{76}$ De Wit \& Flament, "Vorming heerschappijen", 173.

${ }^{77}$ Rogier \& Spiertz, "Franse tijd", 679-680.

${ }^{78}$ Lummen was tweeherig: Loons en Oostenrijks; W.M. van de Boel e.a., Historische Atlas van Limburg en aangrenzende gebieden I Serie staatkundige kaarten: de staatkundige kaart van Limburg en aangrenzende gebieden in de jaren 1543/1548 (Assen/Maastricht, 1990) 22, 78; P.L. Nève, Het
} (wondt vervolgd...) 
Sint-Truiden ${ }^{79}$ en deels Neeroeteren ${ }^{80}$ ) en Horn, Maastricht (deels) en de heerlijkheid Sint-Pieter;

- de Oostenrijkse Nederlanden, te weten de Oostenrijkse landen van Valkenburg, 'sHertogenrade en Dalhem (Mheer en Noorbeek), het Oostenrijkse Overkwartier van Gelre en het Brabantse Halen en deels Lummen (westgrens wan het departement);

- het Gulikse Eygelshoven;

- een reeks (semi)-soevereine territoria, te weten het vorstendom Thorn (met deels Neeroeteren), de graafschappen Gronsveld, Rekem en Wittem, de heerlijkheden Cartils $^{81}$, Slenaken, Breust, Elsloo ${ }^{82}$, Mesch, Pol en Panheel, Rijckholt, Stein, Wijlre, Wijnandsrade, Kessenich, Petersheim, Leut, Sint-Truiden en de landscommanderij van de Duitse Orde te Alden Biesen ${ }^{83}$.

Uit het zogenaamde Reichsdeputationshauptschluß van 25 februari 1803 valt op te maken dat alleen de zoëven genoemde bezitters van de graafschappen Wittem, Gronsveld en Rekem, de heer van Slenaken, de Luikse prinsbisschop, de vorstin-abdis van Thorn en de grootmeester van de Duitse Orde enigerlei schadeloosstelling kregen toegewezen ${ }^{84}$.

In de inleiding bij de Historische Atlas van Limburg wordt geconstateerd dat de begrenzing van het grondgebied van het departement van de Nedermaas "minder revolutionair [was] dan men wel zou denken"85. Dit leidde ertoe dat het grondgebied van het departement geen aaneengesloten gebied vormde. Er waren een viertal exclaves. Geheel door vroeger Guliks territoir omgeven waren de exclave Rurdorf en Welz, gelegen aan de middenloop van de rivier de Roer, naamgeefster van het latere departement van de Roer, en administratief behorende tot het kanton "s-Hertogenrade, alsmede het plaatsje Nieuwstadt, dat administratief ingedeeld was bij het kanton Echt. Het voorheen Staatse Venlo, tevens de kantonshoofdplaats, vormde eveneens een exclave ten opzichte van het departement van de Nedermaas. Venlo was door het vroegere Gulikse en Pruisische territoir omgeven. Deze gelijktijdig met de départements réunis door de Fransen veroverde streken, werden in 1798 omgevormd tot het departement van de Roer. De poging van de zijde van het departementaal bestuur van de Nedermaas in de jaren 1808-1810 om deze enclaves - het departement van de

\footnotetext{
${ }^{\pi 8}$ (....vervolg)

Rijkskamergerecht en de Nederianden. Competentie - territoir - archieven. Maaslandse Monografieën XIV (Assen, 1972) 393-395, 522; Ruwet, Principauté de Liège, 56-57.

79 Sint-Truiden was tweeherig: de Luikse prinsbisschop als graaf van Loon en de abt wan SintTruiden; Hansotte, Institutions politiques, 242-243; Nève, Rijkskamergerecht, 383-392, 520, 522 .

${ }^{80}$ De heerlijkheid Neeroeteren was tweeherig: de Luikse prinsbisschop als graf van Loon en de vorstin-abdis van Thorn; Nève, Rijkskamergerecht, 494-496, 522.

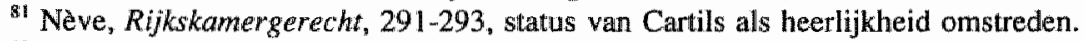

${ }^{82} \mathrm{Ibidem}, 304-305$; de status is eveneens omstreden; Haas, "Verdrag Fontainebleau 1785", 324, 329, 343-344, schrijft dat de Staten-Generaal afgezien hebben van een officiële akte wan inbezitneming.

${ }^{83}$ Nève, Rijkskamergerecht, 450 , schrijt, dat het wellicht geoorloofd zou kunnen zijn de gebouwen en bezittingen als een vrije rijksheerlijkheid te beschouwen, aangezien sedert het einde der middeleeuwen de grootmeester van de Duitse Orde tot de rang van rijksvorst was verheven.

${ }^{84}$ Zie noot 75 .

${ }^{85}$ Nuyens, Historische Atlas Limburg, 3.
} 


\section{"LIMBURG"}

1785 - 1794

met de grenzen van het departement Nedermaas $1795-1814$

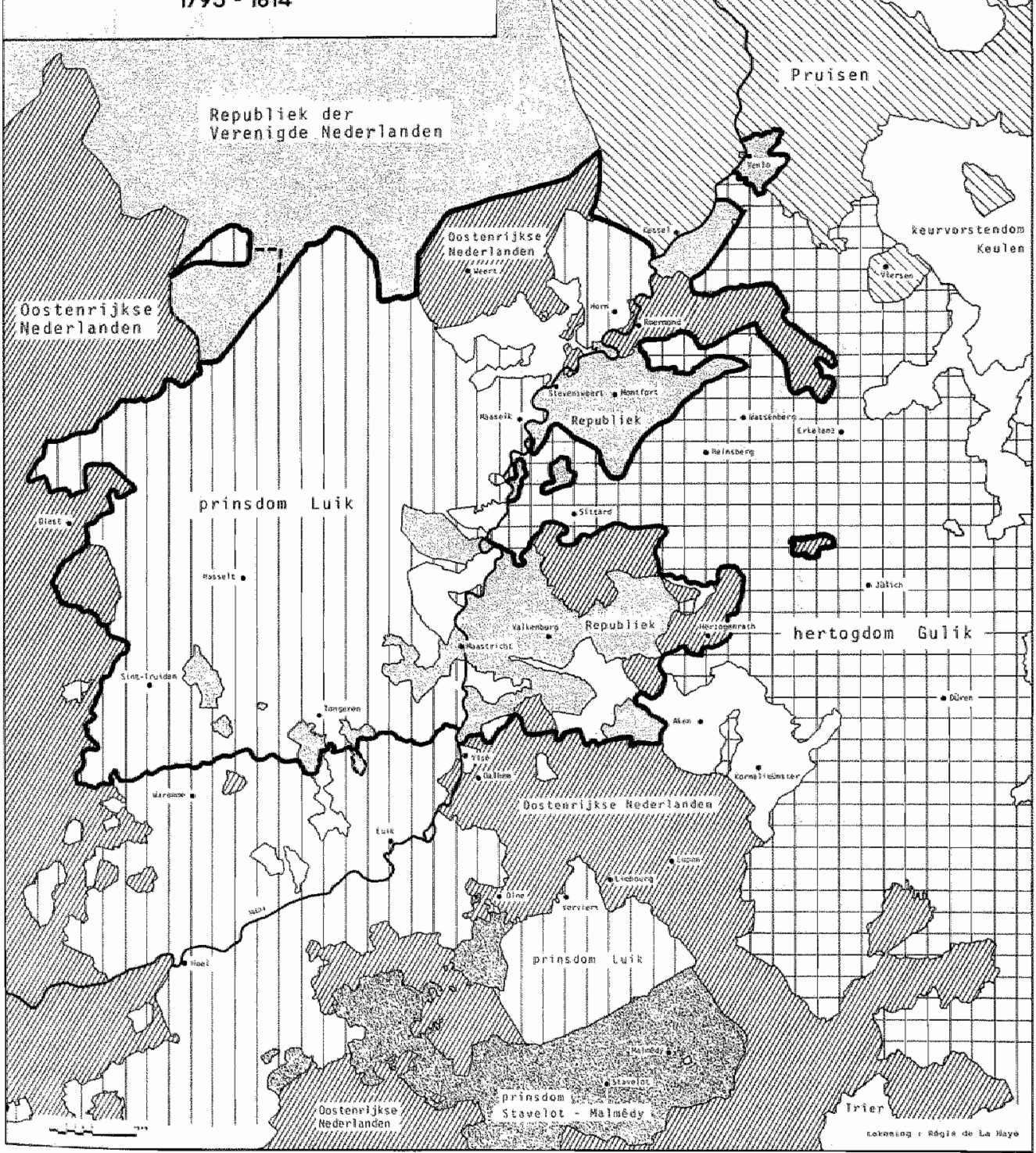

Staatkundige verbrokkeling langs de Maas vóór 1794. De dikke grenslijn geeft de omvang aan van het in 1795 gecreëerde departement Nedermaas. 
Roer strekte zich tussen Sittard en Roermond zelfs tot op de linker Maasoever uit - te beëindigen door de grenzen die het comitê de salut public bij besluit van 14 fructidor III ( 31 augustus 1795) had bepaald weer als grensscheiding met het Roerdepartement te nemen, faalde ${ }^{86}$.

Het goeddeels handhaven van eeuwenoude limietscheidingen ${ }^{87}$ - alleen aan de grens tussen de Ourthe en de Nedermaas tussen Eijsden en Vaals zou een economisch beginsel de grondslag hebben gevormd voor de grenstrekking - betekende ook het voortbestaan van de exclave Luyksgestel, dat voor het grootste deel door het territoir van de Bataafse Republiek omgeven was en administratief onder het kanton Achel ressorteerde. In 1807 kwam er een einde aan de geëxclaveerde positie van Luyksgestel. Bij het verdrag van Fontainebleau van 11 november 1807 tussen het Franse Keizerrijk en het Koninkrijk Holland werd in art.4 besloten het noordelijke gedeelte van het Franse Luyksgestel te ruilen tegen het Hollandse Lommel ${ }^{88}$ :

S.M. le Roi de Hollande cède à la France le territoire de Léemel [Lommel] et la partie méridionale du territoire d'Éertel [Eersel], en échange desquels S.M. l'Empereur Napoléon cède à la Hollande la partie septentrionale du territoire de Gerstel [Luyksgestel]. La limite entre les deux États sera une ligne droite, traversant de l'est à l'ouest les territoires susdits d'Eertel et de Gerstel, et passant à mille mètres de distance au nord du point le plus septentrional du canal du nord.

Napoleon deelde in 1809 het Lommelse territoir administratief in bij het kanton Achel $^{89}$.

Gedurende de Napoleontische episode onderging het departement nog enige geringe grenswijzigingen met de aangrenzende departementen ${ }^{90}$. Met het departement van de Ourthe werd de grens nader bepaald tussen het Nedermaase Mheer (kanton Gulpen) en het tot de Ourthe behorende 's-Gravenvoeren (kanton Dalhem) op 19 frimaire X (10 december 1801$)^{91}$. Bij Consulair besluit van 22 nivôse XI (12 januari 1803) werd de grens tussen Vreren en Diets-Heur (Heure-le-Tixhe, kanton Tongeren, departement Nedermaas) en het tot de Ourthe behorende Wihogne (kanton Glons) opnieuw vastgelegd $d^{92}$.

In een recent verschenen proefschrift over de bestuurlijke geschiedenis van het departement van de Roer vermeldt de schrijfster, dat vooral met het departement van

\footnotetext{
"Zie hiervoor de bescheiden in FA inv.nr.4223.

${ }^{\text {s7 }}$ Nuyens, Historische Atlas Limburg, 3-4.

Parry, Consolidated Treaty Series, LIX, 389-394.

${ }^{89} \mathrm{BL}$ IVe ser no.234 (4318), décret impérial qui réunit le territoire de Lommel au canton d"Achel 11 apr 1809; decreet ook in FA inv.nr.884; E.M.Th.W. Nuyens, De staatkundige geschiedenis der provincie Limburg vanaf haar ontstaan tot aan haar witeenwallen in 1839 (met allas). Werken Limburgs Geschied-en Oudheidkundig Genootschap II (Maastricht, 1956) 13-14.

"Hardenberg \& Nuyens, Inventaris arrondissement Maastricht en departement Nedermaas, 1.

${ }^{91}$ LA VII fol 65, arrêté des Consuls de la République qui fixe les limites des communes de Fouron et de Mheer; ook in FA inv.nr.4205 onder $n^{2} 26 \mathrm{R} 8$.

${ }^{92}$ LA VII fol 95vo-96ro, arrêté qui rëgle les limites des communes de Freren et Heur-le-Trixhe, département de la Meuse-inférieure er Wihogne département de l'Ourthe.
} 
de Nedermaas grenscorrecties tot stand zijn gekomen ${ }^{93}$. Deze vonden plaats op $19 \mathrm{ok}-$ tober 1806 tussen Vaals en het in het departement van de Roer gelegen Laurensberg (kanton Burtscheid) ${ }^{94}$, tussen Venlo en Velden (kanton Wankum) op 22 januari $1808^{95}$, tussen het Nedermaase Echt en Waldfeucht (kanton Heinsberg) op 17 mei $1809^{96}$, alsmede tussen de in het departement Nedermaas gelegen gemeente Meijel (kanton Weert) en de in het departement van de Roer gelegen gemeente Helden (kanton Horst) op 22 april $1812^{97}$.

Kregen deze grenswijzigingen wel haar beslag, de beoogde vastlegging van een nieuwe grens tussen de departementen van de Nedermaas en de Roer door het uit woeste gronden bestaande Meinweggebied, oostelijk van Roermond gelegen, verwierf uiteindelijk geen goedkeuring van Parijs ${ }^{98}$. Eenzelfde uitkomst was de voorgenomen grenscorrectie met het departement van de Ourthe tussen Eijsden en Visé deelachtig $^{99}$.

Nog aan de vooravond van de ineenstorting van het Franse gezag in deze streken op 11 december 1813 - vaardigde Napoleon een decreet uit inzake de vastlegging van de grens tussen de departementen Nedermaas en Roer door het uit woeste gronden bestaande gebied van de Graatheide ${ }^{100}$.

\footnotetext{
93 Sabine Graumann, Französische Verwaltung am Niederrhein. Das Roerdepartement 1798-1814. Dusseldorfer Schriften zur Neueren Landesgeschichte und zur Geschichte Nordrhein-Westfalens XXVII (Essen, 1990) 22.

${ }^{94}$ LA VII fol 250vo-251ro, décret impérial qui fixe les limites des départemens de la Meuseinféricure et de la Roer quant a Vaals et Laurensberg.

9. LA VIII fol 15, décret impérial qui fixe les limites entre les communes de Venlo (Depr de la Meuse-inférieure) \& Velden (Dep' de la Roër); ook in FA inv.nr.4208 onder nª 655R30.

* LA VIII fol 81ro, décret impériale qui fixe les limites d'Echt (Meuse Infe) \& Waldfucht (Roër); ook in FA inv.nr.4205 onder $n^{0} 20 \mathrm{R} 38$.

${ }^{27}$ LA IX fol 34, décret impérial qui fixe les limites entre les communes de Meyel |:Meuse inférieure: | et Helden |:Roër: |; ook in FA inv.nr.4205 onder $\mathbf{n}^{2} 48 \mathrm{R} 47$.

98 G.H.A. Venner, De Meinweg. Onderzoek naar rechten op gemene gronden in her voormalige Gelders - Gulikse grensgebied circa 1400 - 1822. Maaslandse Monografieën XL (Assen/Maastricht, 1985) 341-349.

${ }^{99}$ Régis de la Haye, "De verschuivingen wan de zuidgrens van Eijsden. Een historisch-cartografisch onderzoek", Uit Eijsdens Verleden, LI (1990) 14-15.

${ }^{100} \mathrm{LA} \mathrm{LX}$ fol 110 vo-111.ro, décret impérial qui fixe les limites des départemens de la Meuse Inférieure et de la Roër entre les commumes de Beeck, Elsloo. Stein, Geleen, Obbigt et Papenhoven d"une part et celles de Born, Grevenbeck [Grevenbicht] et Sittard de l'autre; ook in FA inv.nr.4204 onder $n^{2}$ 169R56; Graumann, Französische Verwaltung. 22.
} 


\section{DE AFKONDIGING}

\section{Het begrip promulgatie}

$\mathrm{Nu}$ en dan trekt het probleem van de "afkondiging van wetten" de aandacht van onderzoekers'. Volgens Coopmans in een recente publicatie kan men aan de uitdrukking "afkondiging" een drietal betekenissen toekennen. In de eerste plaats dient men hier onder te verstaan "het geheel van handelingen die na de vaststelling van een wet moeten plaatsvinden om haar in werking te brengen"2. Vervolgens dienen ook als afkondiging te worden beschouwd de specifiekere handelingen van uitvaardiging (promulgatio) en bekendmaking (publicatio). Onder uitvaardiging verstaat Coopmans de handeling waarmee de uitvoerende macht de totstandkoming van de wet en haar inhoud constateert en de verdere bekendmaking ervan beveelt $t^{3}$. Dit laatste dient door een andere autoriteit en op een ander tijdstip mondeling of schriftelijk te geschieden. Door de drieërlei betekenis van het woord "afkondiging", lijkt begripsverwarring welhaast onvermijdelijk. Het lemma dat Van Dale ${ }^{4}$ wijdt aan de term promulgatie, stelt dat deze term van Frans-Latijnse oorsprong is, doch verouderd en de betekenis heeft van afkondiging, openbare bekendmaking, uitvaardiging. Voorts wordt ook nog als verklaring gegeven: "bekrachtiging door het hoofd van de staat van het bevel waarbij een door de wetgevende macht aangenomen wet uitvoerbaar wordt verklaard". Deze laatste omschrijving komt dan overeen met hetgeen Coopmans verstaat onder uitvaardiging. Het Woordenboek der Nederlandsche Taal zegt in genuanceerde bewoordingen: "Soms (wordt) een onderscheiding tusschen promulgatie (uitvaardiging) en publicatie (afkondiging) gemaakt"s. Andere, juridische lexica - als voorbeeld wordt hier de jongste uitgave van Creifelds Rechtswörterbuch aangehaald - verklaren de term promulgatie in min of meer overeenkomstige bewoordingen. Deze luiden dan

\footnotetext{
"Jos P.A. Coopmans, "De afkondiging van wetten in historisch perspectief" in: F. Stevens \& D. van den Auweele, ed. "Houd voet bij stuk". Xenia iwris historiae G. wan Dievoet oblata (Leuven, 1990) 431-453; C.W. Dubbink, "Lasten en bevelen", Nederlands Juristenblad, LXVIII (1992) 164-167.

${ }^{2}$ Coopmans, "Afkondiging wetten". 431.

${ }^{3} \mathrm{C}$.W. van der Pot, Handhoek van het Nederlandse stadsrecht, bewerkt door A.M. Donner (10e dr..; Zwolle. 1977) 336, zegt dat "... de uitvaardiging of promulgatie in plechtige vorm van de wetstekst" als onderscheid met het bevel dat de door het parlement goedgekeurde tekst als wet zal gelden, geen wezenlijke betekenis meer heeft. In latere edities wan het Handhoek wordt de onderhavige problementiek niet meer behandeld. De door Van der Pot zelf nog verzorgde zesde druk (Zwolle, 1957) wermeldt over de promulgatie: "... het plechtige in schrift brengen der wet, gepaard met de verklauring, dat deze op de voorgeschreven wijze is tot stand gekomen, de solemnis editio legis".

"Van Dale Groot Woordenhoek der Nederlandse Taal. G. Geerts \& H. Heestermans m.m.w. C. Kruyskamp ed.(3 din; lle herz.dr.; Utrecht/ Antwerpen, 1984) s.v. "promulgatie"; beknopter nog, is de omschrijuing in de recente $12 \mathrm{e}$ herz.dr. uit 1992.

"Woordenhoek der Nederlandsche Taal (tot nu toe 25 dln. en suppl.; "s-Gravenhage/Leiden, 1882 1990) XII/2, bewerkt door J.H. van Lessen, 44 I7, s.v. "promulgatie" en "promulgeeren".
} 
aldus:" "Bekanntmachung, insbes. Verkündung von Rechtsvorschriften", waarbij onder dit laatste dient te worden verstaan:

deren Bekanntgabe in der durch Verfassung. Gesetz oder sonstige Bestimmungen vorgeschriebenen Form; sie ist Voraussetzung ihrer Wirksamkeit. Die Verkündung von Gesetzen bildet den letzlten Akt des Gesetzgebungsverfahrens'.

Door Wehrhahn, in een uitvoerige verhandeling over de afkondiging van wetgeving in Frankrijk, wordt in dezen de zogenoemde Promulgationszuständigkeit en Publikationszuständigkeit ${ }^{7}$ onderscheiden. In een Frans handboek ${ }^{8}$ wordt promulgatie gedefinieerd als de handeling van het hoofd van de uitvoerende macht, waarbij deze een wet, die op reguliere wijze door het wetgevend lichaam is aanvaard, uitvoerbaar (exécutoire) verklaart. De promulgatie dient niet te worden verward met andere handelingen van de uitvoerende macht, met name de bekendmaking. Zoals in een noot wordt toegelicht, is de promulgatie een rechtshandeling en de bekendmaking het eenvoudige feit van de plaatsing van een wet in een openbare wetsverzameling. In feite evenwel, worden de promulgatie en de bekendmaking versmolten, aangezien door de bekendmaking van de promulgatiehandeling zelve de wet wordt bekendgemaakt".

De door Van Dale geconstateerde veroudering van de term promulgatie voor het Nederlandse taalgebied is echter geenszins toepasselijk voor het Franse. In de titre préliminaire van de nog immer vigerende Code Napoléon, na diens val herdoopt in code civil, wordt in het eerste artikel deze term uitdrukkelijk gebezigd ${ }^{10}$. In de he-

\footnotetext{
"Creifelds Rechtswörferbuch (10e dr.; München, 1990) s.v. "Promulgation" en "Verkündung von Rechtsvorschriften".

${ }^{7}$ Herbert Wehrhahn, "Die Verkündung und das Inkrafttreten der Gesetze in Frankreich 1789 und danach" in: Theodor Eschenburg, Theodor Heuss \& Georg-August Zinn, m.m.v. Wilhelm Hennis, ed., Festgabe für Carlo Schmid zum 65. Geburtstag, dargebracht von Freunden, Schülem und Kollegen (Tubingen, 1962) 213-297, i,h.b. 213-217; gaarne wil de schrijwer hierbij dankzeggen aan de oudrijkstirchivaris in de prowincie Limburg drs. M.K.J. Smeets, die hem op het bestwan van deze publicam tie attendeerde.
}

* A. Esmein, Eléments de droit constiturionnel français en compare, revue par Henry Nêzard (2 diln; 8e dr.; Parijs, 1927-1928) II, 68-69; zie ook Coopmans, "Afkondiging wetten", 452.

"Zo ook C.W. Opzoomer, Aantekening op de wet houdende algemere bepalingen der wetgeving van het koninksijk (4e dr.; "s-Gravenhage, 1884) 42-43, "Als daad valt de publicatie met de promulgatie sarmen, en is de afkondiging de bekendmaking"; voorts schrijft hij: "Promulgatie of publicatie, afkondiging of bekendmaking is de daad der witwoenende macht, waardoor de wet tot het wolk wordt gebracht", ibidem, 48 , welke hij weer onderscheidt van het in werking treden.

" Codes Dalloz, Code Civil, geredigeerd m.m.v. Gilles Goubeaux \& Philippe Bihr $90 \mathrm{dr}$.; Parijs, 1990-1991), art. : "Les lois sont exécutoires dans tout le territoire français en vertu de la promulgation qui en est faite par" le Roi [le Président de la République].

Elles seront exécutées dans chaque partie du Royaume [de la République], du moment où la promulgation en pourra être connue.

La promulgation faite par le Roi lle Président de la Républiquel sera réputée connue dans le département de la résidence royale [dans le département où siège le Gowvernement], un jour après celui de la promulgation; et dans chacun des autres départements, après l'expiration du même délai, augmenté d'antant de jours qu'il y aura de foris 10 myriamètres (environ 20 lieues anciennes) entre la ville où lá promulgation en aura été faite, et le chef-lieu de chaque département". 
dendaagse Franse omschrijving van het begrip komen de zojuist genoemde elementen dan ook duidelijk naar voren:

Déclaration officielle intervenant après l'élaboration d'une loi (ou parfois la signature d'un traité) qui préside â l'insertion de cet acte dans l'ordre juridique et conditionne son entrée en vigueur sous réserve de la publication à intervenir (...) Parfois employé improprement comme syn. de publication ou de édiction"

Men hield dus sterk vast aan het Latijnse maxime non obligat lex, nisi promulgata, of een variant daarop ${ }^{12}$. Portalis sprak in dit verband kort, maar krachtig van "promulgatio, et divulgatio promulgationis"13. Dat de term promulgatie soms oneigenlijk gehanteerd wordt in de betekenis van bekendmaking, draagt vanzelfsprekend wel bij tot de begripsverwarring. Coopmans' uitleg van deze term in de betekenis van uitvaardiging moet dan ook als de aannemelijkste worden aangemerkt. Immers, de term promulgatie ook bezigen in de betekenis van afkondiging impliceert tevens de bekendmaking van een wet.

Hoe werd er met het begrip afkondiging van wetten in het Frankrijk van de Revolutie omgegaan? De vooraanstaande rechtsgeleerde Merlin (de Douai) ${ }^{14}$ die als lid van het comité de salut public ten tijde van de Nationale Conventie, als minister van justitie en van generale politie onder het Directoire, naderhand als lid van dat college, en onder Napoleon als procureur-generaal bij het Hof van Cassatie op de voorgrond trad, heeft in zijn Répertoire universel et raisonnê de jurisprudence ${ }^{\text {t5 }}$ ook aandacht geschonken aan deze problematiek. Merlin zegt dat wat betreft de wetgeving vóór 1789 de woorden "promulgation" en "publication" synoniem waren. Promulgatie betekende toen de bekendmaking van een wet in de vereiste formaliteit. Sedert het uitbreken van de Franse Revolutie werd deze betekenis ontkoppeld, maar zoals Merlin schrijft, nu eens werd er een strikte scheiding, dan weer een minder strikte scheiding in deze

$"$ Vocabulaire juridique, publié sous la direction de Gérard Comu (2e herz. en verm. dr.; Parijs, 1990) s.w. "Promulgation".

${ }^{12}$ Detlef Liebs m.m.v. Hannes Lehmann \& Gallus Strobel, ed. Lateinische Rechtsregeln und Rechtssprichwörter (3e dr.; München, 1983) 110. Het beginsel dat een wet eerst dan verbindend is voor de onderdanen, wanneer zij bekendgemaakt is, dateert reeds uit het Romeinse recht; Codex Justinianus 11,14,9: "Leges sacratissimae, quae constringunt omnium vitas, intellegi ab omnibus debent, ut universi praescripto earum manifestius cognito, vel inhibita declinent vel permissa sectentur".

${ }^{13}$ P.A. Fenet, Recueil complet des travaux préparatoires du Code civil, suivi d'une édition de ce code, à laquelle sont ajoutés les lois, décrets et ordonnances formant le complément de la législation civile de France, et où se trouvent indiqués, sous chaque article séparérnent, tous les passages du recueil qui s"y rattachent (15 dln; 1827, herdir. Osnabrück, 1968) VI, 259.

${ }^{14}$ Albert Soboul, Dictionnaire historique de la Révolution française, publie sous la direction scientifique de Jean-René Suratteau \& François Gendron (Parijs, 1989) 737-741 s.v. "MERLIN Philippe Antoine, dit de Douai", minister van justitie van 3 nov 1795 - 4 jan 1796 en van 3 apr 1796 - 8 sep 1797.

is Merlin, Répertoire universel et raisonné de jurisprudence, corrigée, réduite aux objets dont la connaissance peut encore être utile, et augmentée $1^{2} d^{\prime \prime}$ un grand nombre d'articles, $2^{2}$ de notes indicatives des changemens apportés aux lois anciennes par les lois nowvelles, $3^{\prime 2}$ de dissertations, de plaidoyers et de réquisitoires de l'éditeur sur les unes et les autres (4e dr.; $17 \mathrm{~d}$, Parijs/Brussel, $1812-1825)$ VII, 525-526 s.v. "loi". 
terminologie aangebracht. De Nationale Conventie in haar wet van 14 frimaire II (4 december 1793), "la grande charte du gouvernement révolutionnaire" , bekommerde zich nauwelijks om de exacte hantering van deze begrippen ${ }^{17}$. Wehrhahn gewaagt in dezen van de "unwählerische Vorliebe für den Ausdruck promulgation (...)". Sect.I art.9 van de wet versmelt zelfs de afzonderlijke termen:

Dans chaque lieu, la promulgation de la loi sera faite, dans les vingt-quatre heures de la réception, par une publication à son de trompe ou de tambour; ex la loi deviendra obligatoire à compter du jour de la proclamation [promulgation]".

Onder de vigeur van de grondwet van het jaar III worden de begrippen weer in zekere zin gescheiden opgevat. De onderlinge betrekking die er bestaat tussen de begrippen promulgatie en publicatie laat zich kenschetsen als oorzaak en gevolg. Verderop zal er dieper worden ingegaan op de problematiek wan de afkondiging van wetten, zoals deze heeft plaatsgehad gedurende de werking van de grondwet van het jaar III, dit in het licht van de regestenlijst van afgekondigde rechtsvoorschriften.. In het Napoleontische Frankrijk blijft deze scheiding in de terminologie gehandhaafd, welke in juridische zin definitief geformuleend wordt in art.1 van de titre préliminaire van de code civil. De redactie van het artikel evenwel, heeft in de jaren voorafgaande aan de totstandkoming ervan tot wijdlopige discussies in de besluitvormende organen aanleiding gegeven.

Merlin heeft in zijn additions bij de vierde druk van zijn Répertoire de jurispruden ce gemeend nogmaals een zo nauwkeuring mogelijke omschrijving van de begrippen "promulgation" en "publication" te moeten geven ${ }^{20}$ :

On dit d'un acte qu"il est exécutoire, quand il est dans la forme requise pour que l'exécution puisse en être commandée. Ainsi, une Loi est exécutoire lorsqu"elle est revêtue du caractère d'ou dérive, pour les organes ou agens de l'autorité publique, le pouvoir de les y contraindre; et c'est la promulgation qui lui imprime ce caractère (...) La promulgation differe donc essentiellement de la publication. L'une est à la Loi ce qu"est à un contrat ou ầ un jugement la formule, mandons et ordonnons, qui en termine l'expédition; l'autre est à la Loi ce qu'est au

\footnotetext{
16 Godechot, Institutions, 294.

${ }^{17} \mathrm{cB}$ IIIe ser XII 141-150, décret sur le mode de gouvernement provisoire \& révolutionnaire.

lix Wehrhahn, "Verkindung", 265.
}

"In het door Merlin, Réperroire de jwrisprudence, VII, $526 \mathrm{~s} . \mathrm{v}$. "loi" aangehaalde wetsartikel is sprake van "proclamation", zo ook bij cB IIIe ser XII 142; in cL XVI 592 en P V 589 darantegen, alsmede bij l. Rondonneau, Collection générale des lois, déctets, arrêtês, sénatus-consultess, avis du Consell d'Etat et réglemens d"administration, publiés depuis 1789 jusqu"au ler avril 1814 , et insérés dans la collection du Lowwe in $4^{\prime}$, dans la collection in $8^{\circ}$ de l'lmprimerie nationale, et dans les quatre premic̀res séries du Bulletin des lois (16 din.; Parijs, 1817-1820) IV, 785 en I. Desenne, Code général framçais, contenant les lois et actes du gowvernement publiés depuis l'ourerture des Etats Généraux au 5 mai 1789, jusqu'au 8 juillet 1815. classés par ordre de matières, et amnotés des arvêts et décisions de la Cour de Cassation: swivi de deux tables générales. l' tre par ordre chronologique, et lantre par ondre alphabétique de matières (22 dln.; Parijs, 1818-1825) 1.65 is sprake van "promulgation"; gelet evenwel op het feit dat in lnet claaropwolgende tiende artikel sprake is van "cette proclamation" valt het aan te nemen dat dit laatste bedoeld is; uitsluitend de gearresteerde minuut van het decreet kan hier afdoende opheldering verschaffen.

${ }^{20}$ Merlin, Répertoive de jurisprudence, XVI, 685 s.v. "loi". 
contrat ou au jugement revêtu de cette formule, le commandement qui est fait en vertu de l"un ou de lautre à la partie obligée ou condamnée.

Bij de totstandkoming van de titre préliminaire lag het probleen evenwel niet zozeer bij het leerstuk van de promulgatie zelf, maar ging het veeleer om de problematiek van de bekendmaking, dat wil zeggen op welk tijdstip kunnen de onderdanen geacht worden de wet te kennen, zodat zij ook daadwerkelijk uitvoerbaar is ${ }^{21}$.

De aangestipte begripsverwarring is zeker naspeurbaar in de Frans-Nederlandse uitgave van het Bulletin des Lois, waarin de titre préliminaire als wet wordt bekendgemaakt $^{22}$. Het Franse "promulgation" wordt zowel vertaald met "afkondiginge" als "uytkondiginge" en het woord "publication" eveneens met "afkondiginge" en "uytkondiginge". Het Wetboek Napoleon, ingerigt voor het Koningrijk Holland ${ }^{23}$ daarentegen, is zorgvuldiger in de gehanteerde terminologie. Dit Wetboek Napoleon dat, zoals uit de naamgeving reeds blijkt, goeddeels geënt is op de Franse Code Napoléon. vertaalt "promulgation" als afkondiging en "publication" als bekendmaking 24

De termen promulgatie en afkondiging worden niet gehanteerd in de beide grondwetsontwerpen van de Bataafse Republiek uit de jaren 1796 en 1797. De staatsraad, voorzien als de uitvoerende macht, spreekt in het bijbehorende formulier de last uit "dat deeze [de wet] alömme, daar zulks behoord, zall worden gepubliceerd en geaffigeerd" 25 . Evenmin wordt de term promulgatie gehanteerd in de staatsregelingen van de Bataafse Republiek van 1798 en $1801^{26}$. Deze duikt eerst op in de staatsregeling van 1805 en de Constitutie voor het Koningrijk Holland uit $1806^{27}$.

Tot slot een laatste observatie over de grondwet van 1815. In een artikel in het Nederlands Juristenblad uit 1958 stelt de schrijver dat omstreeks 1813 de term promulgatie in de betekenis van afkondiging gebruikt werd ${ }^{28}$. Ook Coopmans constateert de begripsvermenging: de termen "afkondiging" en "promulgatie" werden in

2" Fenet, Recueil complet, VI, passim.

${ }^{23}$ BL IIIe ser no.254 (2375), loi sur la Promulgation. les Effers et l'Application des Lois wan 14 ventôse XI (5 mrt 1803), vertald als Wet nopens de Afkondiginge, Uywerkzels en de Toepassinge van de wetten.

${ }^{23}$ Wethoek Napoleon, ingerigt voor het Koningrijk Hollond (s.\#., 1809).

${ }^{24}$ Over de relatie tussen deze beide wetboeken: J.H.A. Lokin \& W.J. Zwalve, Hoofdstukken uit de Ewropese Codificatiegeschiedenis (2e dr.; Groningen, 1992) 274-279 i.h.b. 277.

${ }^{25}$ L. de Gou, ed. Hel Plan van Constitutie wan 1796 . Chronologische bewerking van het archicf van de eerste constitutiecommissie ingesteld bij decreet van de Nationale Vergadering van 15 madrt 1796. Met een facsimile witgave vam her Plan van Constitutie. Rijks Geschiedkundige Publicatien kl.ser. $n^{\circ} 40$ ('s-Gravenhage, 1975) 332, ant.355; idem, Het Ontwerp van Constitutie van 1797. De behandeling wan het Plan van Constitutie in de Nationale Vergadering. Mer een facsimile witgave van het Ontwerp wan Constitutie. Rijks Geschiedkundige Publicatiën kl.ser. n"55, 56, 57 (3 dln; "sGravenhage, 1983-1985) III, art.366.

26 Van Hasselt, Verzameling van Nederlandse staatsregetingen en grondwetten (17e dr; Alphen aan den Rijn, 1987) staatsregeling 1798 artt. 103 en 104, juncto reglement letter C art.17; staatsregeling 1801 art.37.

27 Ibidem, staatsregeling 1805 art.27; constitutie 1806 art.58; zie tevens Coopmans, "Afkondiging wetten", 441-445, wiens opmerking dat het promulgatieformulier sedert 1805 op het Franse geënt blijkt te zijn enigszins overbodig lijkl: de Franse invloed nam immers gaandeweg toe.

${ }^{2 *} \mathrm{~J}$. Veldstra, "De wijze van afkondliging van wetten", Nederlands Juristenblad, XXXIII (1958) 226. 
meerdere betekenissen gebruikt en wat betreft de bepaling van het tijdstip van de verbindende kracht van wetten werden deze woorden tevens gehanteerd in de zin van bekendmaking ${ }^{29}$. De "traduction officielle" van de grondwet van $1815^{30}$ hanteerde het Franse "promulgation" voor afkondiging der wetten in de artt.119 en 120. Maar de passus in art. 10: "Gedurende een jaar na de invoering dezer grondwet (...)" evenwel, heeft men ook vertaald met de term promulgatie: "Pendant une année après la promulgation de la présente Loi fondamentale $(\ldots .$.$) ". De zoëven al genoemde schrijver$ van het artikel uit het jaar 1958 stelt in een volgend artikel zonder omwegen, dat "de Franse tekst juister was geformuleerd dan de Nederlandse"31.

Op grond van de bovenstaande uiteenzetting over de afkondigingsproblematiek lijkt het daarom niet te gewaagd zich te verenigen met Wehrhahns opvatting van Begriffspromiskuität, wanneer hij spreekt over de terminologievermenging inzake de afkondiging van wetten ${ }^{32}$. Hij bedient zich uiteraard van deze kwalificatie refererende aan het zogenoemde Franse droit intermédiaire, het Franse recht vigerende in de periode na het uitbreken van de Revolutie in 1789 tot de totstandkoming van de code civil.

\section{Afkondigingsbevoegde autoriteiten}

De afkondiging van rechtswoorschriften, die in de bijvoegde regestenlijst beschreven zijn, heeft plaatsgevonden onder de werking van de grondwet van het jaar III, de tweede constitutie die door de Convention nationale tot stand gebracht is. Deze langste grondwet ${ }^{33}$ uit de Franse geschiedenis tot nu toe kende in de vijfde titel (Pouvoir exécutif) een afzonderlijke paragraaf betreffende de promulgatie (Promulgation des lois), de artt.128-131. Hoewel Merlin in zijn Répertoire de jurisprudence beweert dat de grondwet van 5 fructidor III ( 22 augustus 1795) het onderscheid tussen promulgatie en bekendmaking herstelde, blijkt dit niet overduidelijk uit de desbetreffende grondwetsbepalingen ${ }^{34}$. In art.128 wordt gesteld dat het Directoire exécutif, als het collectieve hoofd van de uitvoerende macht, wetten en andere handelingen van het Wetgevende Lichaam binnen twee dagen na hun aanvaarding van het staatszegel laat voorzien en doet bekendmaken (publier). Het daaropvolgende artikel introduceert de term promulgatie: "Il [=Directoire] fait sceller, promulguer dans le jour, les lois et

\footnotetext{
${ }^{29}$ Coopmans $_{i}$ "Afkondiging wetten", 447.

Man Hasselt, Staatsregelingen en grondwetten, grondwet 1815 , vermeldt als noot bij de Franse tekst "traduction officielle"; de vratag blijf, in hoeverre de Franse vertaling als gelijkelijk authentiek an de Nederlandse grondwetstekst mag worden beschouwd; H.T. Colenbrander, ed. Onstaan der Grondwet. Bromenverzameling Rijks Geschiedkundige Publicatiën kl.ser. $n^{2} 1$ en 7 ( $2 \mathrm{dlm}$; "s-Gravenhage, 1908-1909) II. 620-651, vermeldt alleen de Nederlandse tekst; in het voor de Franstalige onderdanen van het Verenigd Koninkrijk uitgebrachte Jownal officiel du gowemement de la Belgique (Brussel, 1815) He ser V n-29 supplement, is de grondwet tweetalig opgenomen.

3 J. Veldstra, "Het in werking treden der wetten", Nederlands Juristenhlad, XXXIII (1958) 821.

${ }^{32}$ Wehrhahn, "Verkündung", 268.

3 Godechot, Constitutions, 101-141.

${ }^{34}$ Merlin, Répertoire de jurisprudence, VII, 526 s.v. "loi"; Wehrhainn, "Verkiundung", 268-269.
} 
actes du Corps législatif qui sont précêdés d'un décret d'urgence ${ }^{35 "}$. Het bekendmakingsformulier is in art.130 van de grondwet van het jaar III opgenomen ${ }^{36}$. Deze formule is in elk nummer wan het Bulletin des Lois van de tweede serie opgenomen, walarin wetten zijn geïnsereerd. Een uitzondering vormen de Bulletins des Lois no. 1 en 3, welke uitsluitend arrêtés en een proclamatie van het Directoire bevatten. Een ander voorbeeld is het Bulletin des Lois no.76, dat weliswaar hoofdzakelijk besluiten van het Directoire exécutif bevat, maar tevens het intitulé van een wet ${ }^{37}$. Klaarblijkelijk kan het bekendmakingsformulier ook achterwege blijven in geval de inhoud van de wet verder niet bekendgemaakt wordt. Het laatste artikel betreffende de promulgatie komt enigszins als overbodig over, aangezien er wordt gesteld dat het Directoire niet tot promulgatie mag overgaan, wanneer wetten in de aanhef niet doen blijken te voldoen aan het vormvereiste van de totstandkoming ervan.

In aansluiting op hetgeen in de vorige paragraaf is gezegd, wordt door Merlin het onderscheid tussen promulgatie en bekendmaking gekenschetst als oorzaak en gevolg. Promulgatie is derhalve de handeling van het Directoire exécutif, waarmee het de bekendmaking van een wet verordonneert ${ }^{38}$. Een afkondigingsbesluit van het Direc* toire van 23 floréal IV (12 mei 1796) gewaagt hieromtrent eerst van "soient incessamment promulguées" en even later van "pour y être exécutés et obligatoires"3?.

Strikt genomen heeft de afkondiging van de wetgeving in het departement van de Nedermaas vanaf de inlijving op 1 oktober 1795 niet uitsluitend plaatsgehad onder het Directoire, dat pas besluiten begon uit te vaardigen vanaf 12 brumaire IV ( 3 november 1795$)^{40}$, nadat dit college drie dagen tevoren was geïnstalleerd ${ }^{41}$. De afkondiging van rechtsvoorschriften geschiedde tijdens de voorafgaande bezettingsperiode door de volksrepresentanten en mission die door de Convention thermidorienne, dat wil zeggen de assemblee uit de periode na de val van Robespierre, naar de veroverde

\footnotetext{
${ }^{35}$ Léon Duguit \& Henry Monnien, Les constitutions et principates lois politiques de la France depuis 1789. Collationnées sur les textes officiels, précédées de notices historiques et suivies d'une table analytique détaillée, ouvrage continué par Roger Bonnard (5e dr; Parijs, 1932) heeft als tekst woor art.129"... sceller et promulguer ..."; zo ook Rondonneau, Collection générale, V, 500 en Desenne, Code général franģais. I, 84.

36. Art. 130 grondwet jaar III: "La publication de la loi et des actes du Corps législatif est. orclonnee en la forme suiwante: Au nom de la République française (loi) ou (acte du Corps législatiff... Le Direct" toire ondonwe que la loi ou l'acte législanif ci-dessus sera publié, exécuté, et qu' il sera muni da sicéau de la République".

${ }^{37} \mathrm{BL}$ lle ser. no.76 (703), loi qui mer 500,000 liw. valeur métallique, à la disposition da ministre des finances, pour les dépenses cowrantes de son département van 24 fructidor IV (10 sep 1796).

${ }_{3 *}$ Merlin, Répertoire de jurisprudence, VII, 526 s.v. "loi".

${ }^{34} \mathrm{FA}$ inv.nr. 297 LA III fol 102ro.

44. BL Ile ser no.1 (6). déclaration du Directoire exécutif, pontant qu'il est imstallé van 13 brumaire IV (4 nov 1795).

4) $\mathrm{cB}$ IVe ser I 22, décret du conseil des Anciens relatif à la nomination des citoyens Révellièré Lépeaux, Reubell, Barras, Sieyes er Letourneur (de la Manche), pour membres du Directoire exéccutif van 9 brumaire IV (31 okt 1795).
} 
gebieden waren gezonden ${ }^{42}$. Aan de uitgezonden wolksrepresentanten waren vergaande bevoegdheden gedelegeerd uit hoofde van het bepaalde in het decreet van de Nationale Conventie van 30 april 1793 en de Instructie van 7 mei daaraanvolgende ${ }^{43}$. Art.18 wan het decreet kende aan de volksrepresentanten bij de legers onbeperkte macht toe. Zij waren "investis de pouvoirs illimités pour l'exercice des fonctions qui leur sont déléguées (...) [et] leurs arrêtés seront exécutés provisoirement". Het decreet van 14 frimaire II (4 december 1793) dat als de blauwdruk van de revolutionaire bestuursorganisatie wordt beschouwd, beval aan de uitgezonden volksrepresentanten om de tien dagen te corresponderen met het comité de salut public, met inachtneming van het bepaalde in het decreet van 5 frimaire II ( 25 november 1793) daaraan voorafgaande $^{44}$ :

Les représentans du peuple envoyés en commission sont tenus de se conformer exactement aux ariêtés du comité de salut public; les généraux \& autres agens du pouvoir exếcutif ne pourront s'autoriser d'aucun ordre particulier se refuser ì l'exécution desdits arrêtés.

Effectief hebben de volksrepresentanten bij de legers pas na de verovering van de Zuidelijke Nederlanden en aangrenzende gebieden hun bevoegdheden ten volle kunnen uitoefenen. De val van Robespierre en consorten op de Negende Thermidor betekende evenwel ook een zekere inperking van de machtspositie van de volksrepresentanten. Dezelfde maand thermidor nog werd eerst aan de volksrepresentanten en mission en aan de overige geïnstalleerde autoriteiten opgedragen de door hen uitgevaardigde besluiten aan het comité de salut public te communiceren en vervolgens werd hun uitzending tot zes maanden beperkt, voor zover zij toegevoegd waren aan de legers en tot drie maanden wanneer zij toezicht uitoefenden op de civiele autoritei-

\footnotetext{
${ }^{42}$ Een twintigtal volksrepresentanten is onder verschillende titel in de veroverde gebieden van de Oosterinijke Nederlanden en de Landen tussen Rijn en Maas werkzaam geweest, Robert Devleeshouwer, L'arrondissement du Brabant sous l'occupation française 1794-1795. Aspects administratifs et économiques (Brussel, 1964) 166-167.

4.3 Arlente Hennebert, "Les représentants en mission en Belgique après Thermidor", Annales Historiques de la Révolution Franģaise, VIII (1931) 316; Hansgeorg Molitor, Vom Untertan zum Administré. Studien zur französischen Herrschaft und zum Verhalten der Bevölkerung im Rhein-Mosel-Raum von den Revolutionskriegen his zum Ende der napoleonischen Zeit. Veröffentlichungen des Instituts für europaische Geschichte Mainz XCIX Abt. Universalgeschichte (Wiesbaden, 1980) 33-35; cB IIle ser IV 179-186, décret concernantes commissaires de la Convention enoyés dans les départemens pour le recrutement, près les armées, sur les frontieres, etc. van 30 apr 1793, zij voeren de titel van "representans du peuple envoyés près de telle armée" (art.9); cB IIle ser V 54-72, Plan de travail de surveillance et de correspondance, proposé par le Comité de Salut Public aux Représentans du Peuple. députés près des Armées de la République van 7 mei 1793.

${ }^{4} \mathrm{CB}$ IIIe ser XII 76, 141-150, décret portant que les représentans du peuple envoyés en commission \& les généraux, seront tenus de se conformer aux arrêtés du comité de salut public van 5 frimaire II (25 nov 1793), décret sur le mode de gouvernement provisoire \& révolutionaire van 14 frimaire II (4 dec 1793) sect III art 2.
} 
Ien in de departementen ${ }^{45}$. In onnavolgbaar Duits kenschetst Molitor de positie van de volksrepresentanten bij de legers:

Die Verwallung eroberte Gebiete gehörte in ihre [-comité de salut public] Zuständigkeit, so dafi ihre Erfüllungsgebilfen am Ort, nämlich die Volksrepräsentanten bei den erobernden Armeen, als Urheber aller Verwaltungsmaßnahmen und Regelungen anzusehen sind, die über das reine Einziehen von Nahrungsmitteln und Fourage und die Anforderung von Quartier, Tafelkosten und Fuhrdiensten durch die militärischen Kommandanten auf örllicher Ebene hinausgingen. Für letzteres hatten die Repräsentanten die Aufsichts- und Kontrollbefugnis ${ }^{\star 6}$.

Ogenschijnlijk bezaten de volksrepresentanten bij de legers, zolang er sprake was van de "pays conquis", een onbeperkte machtspositie; niettemin erodeerde deze gaandeweg gedurende deze periode. Op 19 prairial UI ( 7 juni 1795) werden alle uitgezonden volksrepresentanten bij de legers die al langer dan zes maanden afwezig waren teruggeroepen, teneinde aan de beraadslagingen over de constitutionele wetten deel te nemen, welke zouden moeten leiden tot de grondwetstekst van het jaar III $^{47}$. Tien dagen daama haalde de Conventie de angel uit de wet van 30 april 1793 door de missie van de volksrepresentanten te beperken tot een welomschreven opdracht. $\mathrm{Zij}$ dienden zich te beperken tot de "fonctions relatives à leurs missions respectives", tevens zou voortaan hun uitzending nog maar bestaan uit een "objet limité"

Wanneer men evenwel de respectieve benoemingen van de onderscheidene volksrepresentanten in ogenschouw neemt - in Devleeshouwers studie staat een overzicht van een twintigtal benoemingen" ${ }^{49}$ - blijken zij onder diverse titels in de "pays conquis" te opereren. Door hun betrekkelijk korte uitzending waren er vele wisselingen van de wacht. Doorgaans kende hun benoemingsomschrijving de clausule dat zij aangesteld waren als representant bij het Noorder- en het Sambre-en-Maasleger. Als représentant en mission, dus als agent en gedelegeerde van de Nationale Conventie dan wel haar regeringscomité - het comité de salut public - in de bezette gebieden, oefenden zij de wetgevende macht uit. Hun arrêtés hadden kracht van wet, zolang deze niet door de genoemde hoogste organen werden herzien ${ }^{50}$.

\footnotetext{
${ }^{4.5} \mathrm{BL}$ Ie ser no.33 (186) en no.38 (209), loi qui ordonne l'onvoi au comité de salut public, des" arrêtés pris par les représentans du peuple en mission wan 18 thermidor II (5 aug 1794), loi qu" fixe la durée des missions des représentans du peuple près des armées et dans les départemens van 26 thermidor II (13 aug 1794) artt. I en 2; Hennebert, "Représentants en mission", 319; Devleeshouwer, Arrondissement du Brabant, 165.

46 Molitor, Untertan, 35.

47 BL le ser no.154 (905), loi qui rappelle les repressentans o leur poste. pour la discassion des lois constitutionnelles art.1.

${ }^{4 *}$ Devleeshouwer, Arrondissement du Braham, 165, "... met à né̉ant l'essentiel de l'économie de la loi..."; BL le ser no.157 (923), loi portant qu"a l"avenir l'objet des missions des Représentans du Peuple sera limité van 29 prairial III (17 jun 1795$)$.

49 Devleeshouwer, Arrondissement du Brabant, 166-167.

${ }^{510}$ Rijksarchief in Limburg Handschriftencollectie nr. 16, Alexander Gordon, "Politieke en Gerechtelijke indeeling van het Hertogdom Limburg", (4 din; s.a., s.1.) III (1794-1814) nr.22; met dank aan prof. mr. A.Fl. Gehlen, alls bijzonder hoogleraar in de rechtsgeschiedenis van de Limburgse territoria verbonden aan de Rijksuniversiteit Limburg te Maastricht, die mij op vriendelijke wijze op het bestaan van dit handschrift heeft geattendeerd; over de negentiende-eeuwse rechter Gordon zie
}

(wordt wervolgd...) 
Een voorbeeld moge verduidelijken, dat besluiten van de volksrepresentanten geacht werden kracht van wet te hebben. Ingevolge een besluit, houdende het opleggen van een belasting aan de bezette gebieden, van het comité de salut public van 15 prairial III ( 3 juni 1795) vaardigde de volksrepresentant Pérès een uitvoeringsbesluit uit op 25 prairial III (13 juni 1795), dat de Centrale Administratie te Aken belastte met de repartitie. Vervolgens werd daarbij uitdrukkelijk door de Centrale Administratie in haar besluit van 8 messidor III ( 26 juni 1795 ) overwogen ${ }^{51}$ :

Que les arrêtés des Représentans du peuple ont force de loi [curs. HK], et que les autorités constituées n'en peuvent différer l'exécution,

en voorts in art.3:

Il est enjoint aux administrations d'arrondissement \& aux municipalités de se conformer aux dispositions de l'arrêté du Représentant du peuple cidessus mentionné́.

De Akense Centrale Administratie moet worden gezien als het uitvoeringsorgaan van de door de volksrepresentanten genomen besluiten ${ }^{52}$. De wetgevende macht van de volksrepresentanten is in de veroverde streken van België en de Landen tussen Maas en Rijn dan ook nimmer betwist, aldus de negentiende-eeuwse Maastrichtse rechter Gordon in zijn niet gepubliceerde vierdelige manuscript "Politieke en Gerechtelijke indeeling van het Hertogdom Limburg" ${ }^{\text {53. }}$.

In het repertorium ${ }^{54}$ waarin het arrondissement Maastricht de toegezonden besluiten van de Centrale Administratie van de Landen tussen Maas en Rijn inschreef, stuit men tevens regelmatig op door de volksrepresentanten uitgevaardigde besluiten. Aangaande de uitvaardiging en het in werking brengen van deze besluiten heeft Gordon een caleidoscoop van afkondigingsformules genoteerd, die door de volksrepresentanten in deze contreien gehanteerd werden. Vrijwel ieder uitgevaardigd arrêté bevatte wel de één of andere afkondigingsclausule ${ }^{5 .}$.

\footnotetext{
sig (...vervolg)

"Variétés et nécrologie. III Alexander Gordon, president der rechtbank te Maastricht", Publications de la Sociéte Hisforique et Archeologique dans le Limbourg, XXIII (1886) 447-453; in de jaren 1859 1884 bekleedde Gordon het voorzitterschap van de arrondissementsrechtbank te Maastricht.

"FA inv.mr.265 "register der arretés n?2; ook in FA inv.nr.221 onder 11 messidor n"1. Deze opwatting wordt ondersteund door wederom de rechtsgeleerde Merlin, Recueil alphabétique des questions de droit qui se prë́sentent le plus fréquemmern dans les tribunanx; ouvrage dans lequel sont fondus et classés la plupart des plaidoyers et réquisitoines de l'aufeur, avec le texte des arrêts de la Cour de Cassation qui s'en sont ensuivis (3e herz. en verm. dr.; 6 dln; Parijs, 1819-1820) IV, 185 s.v. "loi" \& II, waarin hij stelt, dat: "Sans doute, les membres de la conwention nationale pouvaient, dans le cours de leurs missions, prendre des arrêtés qui avaient force de loi tant qu'ils n"avaient pas été réformés, soit par la Convention nationale elle-même. soit par les comités de gouvernement"

52 Molitor, Untertan, 37.

${ }^{53}$ Gordon, "Politieke en Gerechtelijke indeeling", III, $\mathrm{n}^{222}$.

54 FA inv.nr. 309 "Index der Arretées van de Représentanten van het Volck en administratie Centraa:"

ss Gordon, "Politieke en Gerechtelijke indeeling", III, 1029.
} 
Gelet op de regestenlijst van afgekondigde rechtswoorschriften regardeert ons hier alleen de periode vanaf de inlijving bij Frankrijk. In het "registre ouvert", een repertorium $^{56}$, dat is aangelegd door het departementale bestuur ter registratie van de binnengekomen rechtsvoorschriften in de brede zin des woords, komen in de aanvang de namen voor van enkele volksrepresentanten die tot dan toe in de veroverde gebieden werkzaam waren. Alleen Giroust en Lefebvre (de Nantes) vallen nog als représentant en mission aan te merken ${ }^{57}$. Giroust was het die bij arrêté verordonneerde dat de aansluitingswet van 9 vendémiaire IV (1 oktober 1795) naar de onderscheidene besturen werd verzonden, werd herdrukt en werd bekendgemaakt. Eveneens werd door hem de wet op het inwendige toezicht in de gemeenten van 10 vendémiaire IV (2 oktober 1795) afgekondigd. Te zamen vaardigden de twee volksrepresentanten op 21 vendémiaire IV (13 oktober 1795) nog een arrêté uit inzake de vooriopige wijze van de bekendmaking van wetten in de départements réunis ${ }^{58}$.

Ter overbragging van de periode vanaf de inlijving bij Frankrijk tot de installatie van het Directoire exécutif zijn door de Nationale Conventie een tweetal maatregelen genomen om het bestuur in de nieuw gevormde departementen op gang te brengen. De wet van 14 vendémiaire IV (6 oktober 1795) machtigde de beide grote regeringscomités om volksrepresentanten uit te zenden, waar zij zulks nodig oordeelden ${ }^{59}$. Zes dagen later werd bepaald dat reeds uitgezonden volksrepresentanten, die niet op de datum van 5 brumaire IV (27 oktober 1795) geacht werden te zijn teruggekeerd in Parijs, hun missie dienden voort te zetten in de hoedanigheid van commissaire du gouvernement $^{60}$. Op grond hiervan zond het comité de salut public op 24 oktober 1795 de representanten Portiez (de l'Oisse), Pérès (de la Haute-Garonne) en Roberjot naar de sedert de negende vendémiaire bij Frankrijk aangesloten gebieden. "Ils sont

\footnotetext{
${ }^{56}$ FA inv.nr.283 "Registre ouvert en conformité de l'article 12 de la Loi du 12 vendémiaire an 4. Contenant la date de l"enregistrement au chef-lieu de ce Département, des lois et arrêtés qui y sont rendus obligatoires". Aangaande dit repertorium zie $\$ 4$.

${ }^{57}$ Giroust was sedert 27 germinal III (16 apr 1795) naar deze streken uitgezonden, cB IIIe ser XXVII décret qui envoie en mission le représentant du peuple Giroust dans les pays conquis en deça de la Meuse; le représentant du peuple Meynard dans les pays conquis entre Meuse \& Rhin (..). Opmerking: gelet op de redactie zou dit tot een competentiegeschil kunnen leiden met betrekking tot het arrondissement Maastricht, dat zich immers langs beide zijden van de Maas uitstrekte. Bij het décret qui rappelle dans le sein de la convention nationale les représentans du peuple en mission dans les départemens van 4 messisor III (22 jun 1795), art.2 waren o.m. de volksrepresentanten Giroust en Lefebvre (de Nantes) uitgezonderd, cB IIIe ser XXXI 18-19. De laatste was bij decreet van 4 ventôse III (22 feb 1795), $\mathrm{cB}$ IIIe ser XXVII $28-29$, décret qui envoie les représentans du peuple Dubois (du Haut-Rhin), Lefebvre (de la Loüre-Inférieure), \& Talot, près les armées du Nord \& de Sambre \& Meuse benoemd; deze drie representanten vervingen samen met de al eerder gezonden Richard, Cochon en Ramel, hun collega's Bellegarde, Briez, Frécine, Gillet, Haussmann en Jean Baptiste Lacoste, wier ambtstermijn afliep; Lefebvre diende samen met Përẻs en Portiez westelijk van de Maas te opereren; zie ook Dewleeshouwer, Arrondissement du Brabant, 167.

58 Zie regestenlijst onder de datum van 21 vendémiaire $I V$.

${ }^{59} \mathrm{cB}$ IIle ser XXXIV 109, décret qui autorise les comités de salut public \& de sareté générale à envoyer des représentans du peuple où ils le jugeront nëcessaüre.

${ }^{60} \mathrm{CB}$ IIIe ser XXXIV 182, décret portant que les représentans du peuple envoyés dans les départemens ou aux armées qui ne seront pas rappelés à l'époque du 5 brumaire prochain, soit qu' ils aient été élus au corps législatif ou non, continueront leur mission en qualité de conmissaires du gouver. nememt, \&c. van 20 vendémiaire IV (12 okt 1795).
} 
investis đes pouvoirs attribués aux représentants du peuple près les armées et dans les départements ..."; zij oefenden deze functie uit te rekenen vanaf 5 brumaire IV (27 oktober 1795$)^{61}$.

Het Directoire verving hen al vrij spoedig door een bijzondere regeringscommissaris, maar zij functioneerden toch nog een tijdje langer dan eigenlijk in de bedoeling lag, tot de installatie van hun opvolger op 30 frimaire IV (21 december 1795) te Brussel. Van 1 frimaire IV (22 november 1795) tot 1 pluviôse V (20 januari 1797) was Louis-Ghislain de Bouteville du Metz gouvernementscommissaris in de onlangs bij Frankrijk ingelijfde negen départements réunis ${ }^{62}$. Zijn opdracht luidde als volgt:

Le citoyen Bouteville organisera les autorités constituées du département de l'Ourte. Il activera cle tous ses moyens la rentrée des contributions, et complettera dans les huit autres départemens les opêrations que n'aurailent point achevées les commissaires actuells du gouvernement qu' il va remplacer ${ }^{63}$.

Bouteville verwoordde zijn werkzaamheden na de beëindiging van zijn opdracht aldus:

\begin{abstract}
Faire publier successivement les lois dans les départemens réunis, y introduire graduellement, $y$ affermir chaque jour le gouvernement républicain, et chaque jour sur-tout le faire aimer, cherir, respecter d'awantage, y consommer enfin avec le plus de sagesse et le moins de danger possible la révolution et l'établissement du régime constitutionnel; telle était, Citoyens Directeurs, la tâche qui vous était départie et à laquelle vous avez cru pouvoir m'associer ${ }^{64}$.
\end{abstract}

Het is evenwel niet zo dat de afkondiging van wetten via de persoon van Bouteville geschiedde. Zulks geschiedde steeds door het Directoire exécutif zelf door middel van een frase als: "Arrêté du directoire exécutif, qui ordonne la publication, dans les départemens réunis ..." ${ }^{95}$. Bouteville vaardigde overigens wel besluiten uit, betrekking hebbende op plaatselijke circumscripties en op benoemingen van locale autoritei$\operatorname{ten}^{66}$.

${ }^{61}$ F. A. Aulard ed., Recueil des Actes du Comité de Salur public avec la correspondance officielle des représentants en mission et le registre du Conseil exécutif provisoire (28 dln, 3 registerdln en 3 suppl.; Parijs, 1889-...) XXVIII, 672 n557; Hennebert " "Représentants", 329; Roberjot reisde vanwege zijn slechte gezondheid niet meer naar de Verenigde Departementen af, De Lanzac de Laborie, Domination française, $\mathrm{I}, 21$.

${ }^{62}$ Over Bouteville, zie Hubert \& Tihon, Correspondance Bowteville, I, vii-x; Verhaegen, Belgique sous la domination française, $35 \mathrm{nt}$.1; De Lanzac de Laborie, Domination française, I, 21-25;

63 Aangehaald in Bouteville, Compte, 2.

${ }^{64}$ Ibidem, 3; eveneens in Hubert \& Tihon, Correspondance Bouteville, I, viii nt.2. Het besluit van het Directoire exêcutif van 1 pluviôse $V(20$ jan 1797) houdende de beëindiging van Boutevilles werkzaamheden op de dag van de ontvangst van het besluit, staat afgedrukt in ibidem, II, 522-523 nt.1; zie ook A. Debidour, Recueil des actes du Directoire exécutif (procès-verbaua, arrêtés, instructions, letres et actes divers) (4 din; Parijs 1910-1917) IV, 693.

"FA inv.nr.283 "Registre ouvert", passim.

Z6 regestenlijst, bij voorbeeld onder de data van 23 nivôse IV (13 jan 1796), 17 brumaire V (7 nov 1796), 27 frimaire $V(17$ dec 1796$)$ en 28 nivôse $V(17$ jan 1797). 
Waaruit bestond de wettelijke grondslag voor het afkondigen van rechtswoorschriften en wat behelsde de wetgeving op het terrein van de afkondiging? De wetgeving ter zake is tamelijk complex en zal in het hiernavolgende nader worden uiteengezet. Aangezien het "registre ouvert" opent met de aansluitingswet van 9 vendémiaire IV (1 oktober 1795) en op basis van dit repertorium de regestenlijst is samengesteld, wordt uitsluitend de wetgeving behandeld die relevant is geweest voor de periode na 1 oktober 1795. Gordon ${ }^{67}$ onderscheidt vanaf die datum vier verschillende periodes met betrekking tot de afkondiging, te weten:

- van 9 vendémiaire IV ( 1 oktober 1795) tot 27 brumaire IV (18 november 1795);

- van 27 brumaire IV (18 november 1795) tot 11 frimaire IV ( 2 december 1795);

- van 11 frimaire IV (2 december 1795) tot 5 germinal XI (26 maart 1803);

- van 5 germinal XI (26 maart 1803) tot einde Franse bewind.

\section{a. 1 oktober $1795-18$ november 1795}

De wijze van afkondiging in de periode die liep vanaf de aansluiting bij Frankrijk tot 18 november 1795 - de datum van het in werking treden van het arrêté réglant un mode de publication des lois dans les départemens rếunis van 21 vendémiaire IV (13 oktober 1795) - werd nog bepaald door een reeks oudere besluiten van de volksrepresentanten. In het arrêté van 27 thermidor II (14 augustus 1794) was in art. 10 bepaald, dat "les loix et coutumes particulières des pays conquis sont provisoirement maintenues et conservées ...", voor zover daar niet door besluiten van de volksrepresentanten van werd afgeweken ${ }^{68}$. Bij gevolg bleef ook de bestaande wijze van afkondigen gewoonlijk door middel van toezending van gedrukte exemplaren, publicatie door voorlezing in de ter plaatse gebruikte taal, alsmede het aanplakken van een exemplaar in elke gemeente afzonderlijk - van rechtsvoorschriften gehandhaafd. Gordon merkt hierbij op dat men in de praktijk zich hier niet aanhield, want bijna ieder besluit van de volksrepresentanten kende wel het één of andere voorschrift omtrent de wijze van afkondiging ${ }^{69}$. De volksrepresentanten wensten toch een éénduidige afkondigingsre-

\footnotetext{
${ }^{67}$ Gordon. "Politieke en Gerechtelijke indeeling", III, n"84, 85, 86, 152, 53.

${ }^{6 *}$ rH 1 70-86: P VI xxiii-xxviii; arrëtê des représentans: du peuple (Lacombe Saint-Michel, Gillet. Richard, Laurent et Briez), contenan le résumé de tous les arrểés publiés jusqừ à cetre époque. ê plusieurs aumes dispositions générales relarives au pays.

64 Gordon, "Politieke en Gerechtelijke indeeling", $\llbracket 11, n^{2} 26$; Gordons opmerking dat overschrijwing in een register in de Zuidelijke Nederlanden nooit heeft bestaan en dat de voorheen gebruikelijke overschrijving in de Landen tussen Maas en Rijn niet langer gebezigd werd, blijkt onjuist. Bij het Hof wan Oostenrijks Gelre werden plakkaatregisters aangelegd, zie Berkvens, Plakkatenlijst Overkwartier, I en II, passim.
} 


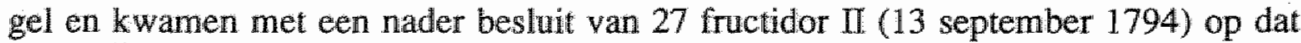
gebied $^{70}$.

De beide organisatiebesluiten die de Centrale Administraties van de Landen tussen Maas en Rijn en van Bellgië instelden, bevestigden deze vorm van afkondiging. In het ressort van de Centrale Administratie te Aken, waartoe ook het arrondissement Maastricht behoorde, dienden de arrondissementsadministraties zorg te dragen voor: " $L$ 'impression, l'affiche et la publication dans toutes les communes des lois et arrêtés qui leur seront adressé $\mathrm{s}^{1071}$. Eenzelfde last tot afkondiging van rechtsvoorschriften is bepaald in het organisatiebesluit van de Centrale Administratie van België te Brussel van 26 brumaire III (16 nov 1794) ${ }^{72}$. De bloemlezing van afkondigingsformuleringen die Gordon in zijn handschrift heeft opgenomen voor het ressort van de Centrale Administratie van België, komt, tot in de essentie herleid, op het volgende neer: tweetalig drukken, soms voorlezing, en voorts bekendmaken en aanplakken in de gemeenten. Beziet men willekeurig enige arrêtés uitgevaardigd door de volksrepresentanten sedert de inlijving bij Frankrijk, dan treft men telkens een dergelijke afkondigingsclausule aan $^{73}$. Men moet ervan uitgaan dat het tijdstip van verbindend worden der rechtsvoorschriften per gemeente verschillend zal zijn geweest ${ }^{74}$.

\section{b. 18 november $1795-2$ december 1795}

Op 21 vendémiaire IV (13 oktober 1795) vaardigden de volksrepresentanten Lefebvre (de Nantes) en Giroust het arrêté réglant un mode provisoire de publication des lois dans les départemens réunis uit, dat ruim een maand later op 27 brumaire IV (18 november 1795) in het departement van de Nedermaas werd geregistreerd ${ }^{75}$. Het voorlopige karakter van de wijze van bekendmaking van rechtsvoorschriften was gelegen in het feit dat in het besluit nog gesproken werd van de arrondissementsadministraties, aangezien op dat moment de departementale besturen als voorzien in de aansluitingswet van 9 vendémiaire IV nog niet in functie waren. Het is verder aannemelijk dat de volksrepresentanten te Brussel al kennis hadden van de hoogstbelangrijke wet inzake

\footnotetext{
${ }^{70} \mathrm{rH}$ I 171-172; P VI xxxv, arrêté des représentans du peuple, relatif à la publication et à l'exécution des arretés rendus par eux, art. 1: "Les arrêtés des représentans du peuple qui ont été ou qui seront envoyés aux magistrats des chef-lieux du pays conquis, devront être envoyés par eux dans toutes les communes de leur arrondissement, publiés et affichés dans la manière accoutumée".

"rH III 326-336; P VI xli-xliv, arrêté des représentans du peuple (Hawssmann, Frécine, Joubert) relatif a l'organisation de ladministration des pays conquis entre la Meuse et le Rhin van 24 brumaire III (14 nov 1794), sect.II art.4 onder 9"; Gordon, "Politieke en Gerechtelijke indeeling", III, $\mathrm{n}^{2} 28$ heeft geen aanwijzingen dat in deze worm wan afkondiging een verandering is opgetreden.

${ }^{72} \mathrm{P}$ VI xlv-xIvi, arrêté des representars du peuple (Berlier, Roger-Ducos. Lacoste, Portiez, Briez et Haussmann) organisant l"administration de la Belgique et les administrations civiles d'arrondissememt, art.12 "Les lois de la république qui pourront concerner la Belgique et les artêtés des représentans du peuple, ainsi que ceux de l'administration centrale, seront par celle-ci transmis aux administrations d"arrondissement, qui veilleront, chacune dans leur ressort, à leur promulgation et exécution" ${ }^{73}$ Zie regestenlijst, bij voorbeeld onder de datum van 21 vendémiaire IV (13 okt 1795), 22 vendémiaire IV (14 okt 1795 ), 12 brumaire IV ( 3 nov 1795).

${ }_{74}$ Gordon, "Politieke en Gierechtelijke indeeling", III, $\mathrm{n}^{\mathrm{a}}$ 29, 30.

${ }^{75}$ Zie regestenlijst onder de datum van 21 vendemiaire IV (13 okt 1795).
} 
de afkondiging en bekendmaking van wetten van 12 vendëmiaire IV ( 4 oktober 1795), die eerst later in het departement geregistreerd werd.

Volgens het arrêté van 21 vendémiaire IV zullen wetten en besluiten aan die arrondissementsadministraties worden toegezonden die het ressort vormden van de negen départements réunis. De officiële verzending geschiedde uitsluitend in het Frans en een exemplaar ervan diende op de griffie van iedere municipaliteit te berusten. In die arrondissementen waar de Franse taal zeer ongebruikelijk was en het bezwaarlijk was af te zien van een vertaling, mochten de arrondissementsbesturen ten behoeve van de instructie van hun ingezetenen een vertaling laten maken en dan laten drukken tot een beloop dat strikt noodzakelijk was. De arrondissementsadministraties dienden de wetten en besluiten naar de plaatsen van hun ressort te zenden volgens de door het comité de salut public gearresteerde territoriale indeling van 14 fructidor III (31 augustus 1795). $\mathrm{Zij}$ dienden zich ervan te vergewissen, dat ter plaatse de wetten en besluiten ontvangen en bekendgemaakt werden (artt.2-4). Aan de arrondissementsadministratie te Maastricht werd in het vijfde artikel opgedragen de verzending op zich te nemen van rechtsvoorschriften naar Roermond en Venlo, plaatsen die voorheen tot het arrondissement Gelder behoorden. Het zesde en laatste artikel kende wederom een typische afkondigingsclausule:

Le présent Arrêté sera traduit en Flamand, et envoyé à la diligence du Conseil de Gouvernement aux onze Administrations d"Arrondissement susdites, et par elles aux Municipalites, pour y être publié; et les Agens Nationaux de ces Administrations en accuseront la réception au Conseil de Gouvernement ${ }^{76}$.

De reeds geschetste wijze van afkondiging die sedert de komsl van de Fransen in 1794 gehanteerd werd, bleef derhalve nog wat langer voortduren ${ }^{77}$.

\section{c. 2 december 1795 - 26 maart 1803}

Op 5 frimaire IV (26 november 1795) vaardigden de volksrepresentanten/gouvernementscommissarissen Pérès en Portiez (de l'Oise) het besluit uit, "qui ordonne la publication dans les départemens réunis" van de loi qui détermine un mode pour l'envoi et la publicarion des lois van 12 vendémiaire IV (4 oktober 1795), waarvan de registratie op 11 frimaire IV (2 december 1795 ) in het departement Nedermaas geschiedde $^{78}$. Het departementaal bestuur besloot om de wet tweetalig bekend te maken en aan te plakken in alle gemeenten "de notre ressort" decreet over de revolutionaire bestuursorganisatie van 14 frimaire II (4 december 1793) het Iweede rechtsvoorschrift inzake de bekendmaking van wetten, dat onder de Nationale Conventie tot stand gekomen is. Zonder considerans worden in een twaalftal artikelen de modaliteiten van de afkondiging van wetgeving vastgelegd. In verband met de vervaardigde regestenlijst zal uitvoerig bij deze wet worden stilgestaan. Tij-

\footnotetext{
${ }^{76}$ FA inv.nr.230 "ingekomen en minuten van uitgaande stukken" onder 27 brumatre [IV] $n^{0} 127$.

${ }^{77}$ Gordon, "Politieke en Gerechtelijke indeeling", III, n"85, 87.

${ }^{7 \mathrm{k}}$ Zie regestenlijst onder de datum van 12 vendémiaire IV (4 okt 1795).

${ }^{74}$ FA nr. 105 "registre des délibérations" sub dato 11 frimaire IV (2 dec 1795).
} 
dens de beraadslagingen over de sitre préliminaire van de te ontwerpen code civil werd deze wet door een lid van het Tribunaat gekenschetst als een organieke wet bij de grondwet van het jaar III ${ }^{\text {so }}$. Zij regeent de wijze van de bekendmaking en het uitvoerbaar worden van rechtsvoorschriften tot haar gedeeltelijke vervanging door art. 1 van de als afzonderlijke wer van kracht geworden titre préliminaire in maart $1803^{81}$. De datum van binnenkomst bij het departementaal bestuur van de Nedermaas van het Bulletin des Lois dat de laatstgenoemde wet bevatte, werd officieel vastgesteld op 5 germinal XI (26 maart 1803).

Het eerste artikel van de wet van 12 vendémiaire IV zegt dat, zodra een wet of een handeling van het Corps législatif aan het vormvereiste van bekendmaking als voorgeschreven door de grondwet voldoet, de minister van justitie op last van het Directoire exécutif de wet of handeling onverwijld zal doen drukken en bekendmaken in een officieel bulletin, tenzij het Corps législatif de handschriftelijke verzending beveelt. In dat geval dient in het bulletin het intitulé te worden opgenomen. De tweede alinea van art. 1 vermeldt dat het bulletin de titel van Bulletin des Lois zal voeren, en dat daarin uitsluitend de wetten en handelingen (actes) van het Wetgevend Lichaam, alsmede proclamaties en besluiten van het Directoire exécutif ter verzekering van de uitvoering van wetten in zullen worden opgenomen. Resoluties van de Conseil des Cinq-cents waarvan het drukken is bevolen, zullen in een het Bulletin des Lois begeleidend Feuilleton des résolutions et des projetśs de résolution worden geplaatst. Zulks geldt ook voor rapporten en opinies waarvan de wet het drukken en verzenden beveelt (art.2). Ieder nummer van het Bulletin des Lois voert uitwendige kenmerken van authenticiteit. De minister van justitie dient zo spoedig mogelijk het Bulletin en Feuilleton naar een veelheid van bestuurlijke, gerechtelijke en militaire autoriteiten te zenden (artt.4-6) ${ }^{82}$. Driemaandelijks zal er een cahier met de in het voorafgaande kwartaal uitgevaardigde wetten naar onder meer de griffie van elke rechtbank en het secretariaat van elk bestuurlijk lichaam worden verzonden om daar te worden gedeponeerd "à perpétuité, pour l'utilité publique" (art.7). Individuele burgers konden door middel van een abonnement of intekening via het hoofdpostkantoor in gemeenten met ten minste 5000 inwoners tegen een gematigde prijs zich van het Bulletin en het Feuilleton voorzien (artt.8-10).

Ogenschijnlijk lijkt het alsof de wet van 12 vendémiaire IV het Bulletin des Lois als nieuw orgaan creëerde. Dit was niet hel geval: ten tijde van de Jacobijnse dictatuur al had de Convention nationale in haar décret sur le mode de gouvernement provisoire \& révolutionnaire van 14 frimaire II (4 december 1793) het Bulletin des Lois gescha-

\footnotetext{
${ }^{30}$ Fenet, Receuil complet, VI, 233: "La loi du 12 vendémiaire an IV (...) a été mise au rang de celles organuques de la Constitution de l'an III".

"BL Ille ser no. 254 (2375), loi stu" la Promulgation, les Effets et "Application des Lois van 14 ventôse XI (5 mrt 1803), in het "registre ouvert" ingeschreven onder n"887; Gordon, "Politieke en Gerechtelijke indeeling", III, $\mathrm{n}^{2} 153$.

"FA inv.nr.292 bevat een Instruction donnée par le Ministre de la Justice aux Directeurs de celui de ses Bureaux quí est chargé de l'Envoi des Lois et Arrêtés du Directoire exécutif van 9 frimaire IV (30 nov 1795) met een opgave aan welke instanties het Bulletin des Lois moet worden toegezonden met bepaling van het precieze aantal exemplaren (art.1).
} 
pen $^{83}$. Ruim zes maanden ${ }^{84}$ na de instelling ervan verscheen het eerste nummer van het Bulletin des Lois van wat achteraf de "première série" zou gaan heten met de beruchte loi concernant le Tribunal révolutionnaire van 22 prairial II (10 juni 1794). Dit Bulletin des Lois echter, was louter als notificatieorgaan te beschouwen en veranderde vooralsnog niets aan het in werking treden van wetten en besluiten. Van ouder datum was het zogenaamde bulletin de correspondance, in eerste instantie bedoeld als informatie- en propagandaorgaan om de handelingen van de revolutionaire assemblees ruimer bekend te doen worden. Aangezien het verschijnen van het Bullerin des Lois op zich liet wachten, ging men ertoe over om belangrijke decreten woordelijk in het bulletin de correspondance te plaatsen en rechtstreeks, zonder tussenkomst van de districtsbesturen, te verzenden aan alle rechtbanken, de kantonshoofdplaatsen, de staven van de legers en de marine, militaire eenheden en bewapende schepen van de Republiek $^{85}$. Een afzonderlijk decreet van de Nationale Conventie bepaalde dat wetten van algemeen belang of generale executie, waarvan om bijzondere redenen de promulgatie via het bulletin de corvespondance geschiedde, niettemin ook in het Bulletin des Lois dienden te worden gedrukt. Daarentegen zou geen enkel decreet met een individuele of locale strekking in het Bulletin des Lois geplaatst worden, tenzij de Conventie anders besliste ${ }^{86}$. Regelmatig is in rechtsvoorschriften uit die periode een afsluitende bepaling opgenomen, luidende: 'L'insertion du présent décret au bulletin de correspondance, tiendra lieu d'envoi et de publication" $" 87$.

Wehrhahn stelt dat de rollen tussen het bulletin de correspondance en het Bulletin de Lois nagenoeg omgedraaid waren. Was het bulletin de correspondance het reguliere en algemeen verspreide notificatieorgaan tot in de gemeenten, het Bulletin des Lois was daarentegen in wezen een bijzonder orgaan voor de gerechten, dat tevens aange-

"3.3 CB IIle ser XII, sect.I art. I: "Les lois qui concernent I"intérêt public, ou qui sont d'une exécution générale, seront imprimées séparément dans un Bulletin numéroté, qui servira désormais à leur notification aux autorités constituées. Ce bulletin sera intitule: Bulletin des Lois de la République". Aanvankelijk was de titel dus Bulletin des Lois de la République [Française], maar deze werd tijdelijk vervangen door de titel Lois de la République [Française], BL Ie sei no.126 (662) loi qui change le titre de Bulletin des Lois van 28 pluviôse III (16 feb 1795). Met het eerste nummer van de tweede serie, het begin van de Directoine-periode, keerde de oude nakm weer terug.

"We Wrhahn, "Verkündung", 251, schrijft dat het eerste exemplaar op 23 prairial II (1I jun 1794) verscheen, terwijl in BL Ie ser no. I (1) het collatiomneren gedagtekend is op 24 prairial II (12 jun 1794).

"Sistem, 253-254; het bullerin de correspondance was bij besluit van $15 * 20$ april 1792 ingesteld; $\mathrm{cB}$ llle ser XV 30, décret qui ordonne l'envoi direct du bulletin de la Convertion à diverses antorités constituées, civiles et militaires van 5 ventôse II (23 feb 1794); cB Ille ser XVII 264, dêrret qui ordonne l"envoi du bulletin aux tribunaux et aur juges-de paix van 27 floréal II (16 mei 1794).

" cB llle ser XX 207-208; BL le ser no.40 (223), loi qui détermine celles sasceptibles d"ểre insérées, soir dans le bulletin des lois, soit dans celui de correspondance van 30 thermidor II (17 aug 1794) arti. 1 en 2.

"27 Zie regestenlijst, bij voorbeeld onder de datum van 7 messidor Il (25 jun 1794$), 14$ fructidor III (31 aug 1795), 10 wendémiaire IV (2 okt 1795); het is opmerkelijk dat in het Souverein Beshuit betrekkerijk de daarstelling wan een Staatshlad der Vereenigde Nederlanden van 18 dec 1813 (Staatsblad 1814 no.1) in art. 3 vrijwel dezelfde bewoordingen worden gebezigd: "De insertie dezer stukken in het Staatsblad wordt beschouwd als derzelver publicatie, en als vervangende de bevorens gebruike. lijke toezending van gedrukte exemplaren ...". 
wend kon worden om wetgeving opnieuw te dnukken in opdracht van de departementalle besturen. De verspreiding van het Bulletin des Lois werd bij wet van 8 pluviôse III (27 januari 1795) beperkt tot de rechtbanken en departements- en districtsbesturen $^{88}$.

Het wezenlijk vernieuwende van de wet van 12 vendémiaire IV is gelegen in de beide laalste artikelen. Het Bulletin des Lois veranderde van notificatieorgaan in afkondigingsorgaan ${ }^{89}$. Art. 11 eerste alinea van de wet stelt dit onomwonden:

En conséquence de la présente loi, il ne sera plus fait de publication de lois par lecture publique, par réimpression ni affiche, ni à son de trompe ou de tambour, en aucun département aux frais de la République, si ce n"est lorsque ces formalités senont expressément ordonnées par un article de la loi.

De formele bekendmaking trad hiermee in de plaats wan de voorheen gebruikelijke materièle bekendmaking. De oude wijze van afkondiging werd daarmede dus in beginsel afgeschaft, ofschoon het Directoire en lagere bestuursorganen nadere afkondigingsformaliteiten konden voorschrijven, indien zij dit gewenst achtten (art.11, $2^{9}$ alinea);

Pourront néanmoins le directoire exécutif et chaque administration départementale ou municipale, ou de bureau central dans les municipalites au-dessus de cent mille habitans, par délibération spéciale, ordonner, soit pour des lois anciennes ou récentes, soit même pour des réglemens, telles de ces formalités particulières qu'ils jugeront convenables.

Een specimen hiervan komt naar voren in een artikel over de introductie van de Franse wetgeving op het gebied van het notariaat in het departement Nedermaas ${ }^{90}$.

Het laatste, twaalfde artikel van de wet van 12 vendémiaire IV schrijft een nieuwe wijze van het in werking treden van wetgeving voor:

Néanmoins, les lois et actes du corps législatif obligeront, darns l"étendue de chaque département, du jour auquel le bulletin officiel où ils seront contenus, sera distribué au chef-lieu du departement.

Ce jour sera constaté par un registre où les administrateurs de cháque département certifieront I"arrivee de chaque numéro.

Rechtswoorschriften zijn derhalve uitvoerbaar over het gehele grondgebied van een departement, zodra zij in de desbetreffende departementale hoofdstad gearriveerd zijn.

\footnotetext{
Wehthahn, "Verkündung", 255, BL Ie ser no.117 (616). loi qui détermine le mode d"impression et d'envoi des lois.

* Het Directoire exécutif staakte het verschijnen wan het bulletin de correspondance; Wehrhahn, "Verkündung", 274; cB IVe ser I 212, arrềté qui supprime le bulletin officiel van 24 frimaire IV (15 dec 1795 ).

"A. Al. Gehlen, "De invoering van het Franse notariaat in het departement van de Nedermaas, "au son de trompe ou de tambour" (1795-1803)" in: A.H. Jenniskens e.a., ed. Campus Liber. Bundel opstellen over de geschiedenis van Maastricht aangebaden aan mr.dr. H.H.E. Wouters, siadsarchiwaris en -bibliothecaris 1947-1977, bij zijn zeventigste verjaardag. Werken Limburgs Geschied- en Oudheidkundig Genootschap VIII (Maastricht, 1982) 384-395, m.n. 389.
} 
Het Bulletin des Lois werd in de woorden van Gordon" van officiële wetten-en verordeningenverzameling tot officieel blad, in de woorden van Wehrhahn van notificatieorgaan tot officieel blad ${ }^{92}$. Deze wijze van het uitvoerbaar worden van rechtsvoorschriften bleef van kracht tot het in werking treden van het promulgatieartikel van de titre préliminaire van de Code Napoléon op 26 maart 1803.

\section{d. 26 maart 1803 - einde Frans bewind}

Art. I van de titre préliminaire bepaalt dat de wetten over het gehele grondgebied van de Franse Republiek uitvoerbaar zijn, "en vertu de la promulgation" door de Eerste Consul en wel "du moment où la promulgation en pourra être connue". De promulgatie zal geacht worden bekend te zijn in het departement alwaar de regering zetelt éen dag na die van de promulgatie; in elk ander departement na verloop van dezelfde termijn vermeerderd met evenzovele dagen als er aantal malen 10 myriameters zijn gelegen tussen de stad waar de promulgatie geschiedde en de departementale hoofdstad. Dit betekende dat nog wel de ontvangst van de Bulletins des Lois in het repertorium geregistreerd werd, maar dat de datum van registratie niet noodzakelijkerwijs hoefde samen te vallen met die van het in werking treden ${ }^{93}$. Deze regeling gold alleen voor de wetten in formele zin; voor andere, imperiale, decreten bleef de wet van 12 vendémiaire IV van kracht, aldus het advies van de Staatsraad van 12 prairial XIII (1 juni 1805) ${ }^{94}$. De conseil d'êtat overwoog daarbij het volgende:

Que les décrets impériaux étant préparés et rendus avec moins de publicité, ils ne peuvent pas être frappés de la même présomption de connaissance, et qu'en effet ils n'ont pas été compris dans la disposition de l'article $1^{\text {er }} \mathrm{du}$ Code,

en adviseerde vervolgens:

que les décrets impériaux insérés au Bulletin des lois sont obligatoires, dans chaque département, du jour auquel le Bulletin a été distribué au chef-lieu, conformément à l'article 12 de la loi du $\$ 2$ wendémiaire an IV;

Et que quant a ceux qui ne sont point insérés au Bulletin, ou qui n y sont indiques que par leur titre, ils sont obligatoires du jour qu"il en est donné connaissance aux personnes qu'ils concernent, par publication, affiche, notification ou signification, ou en wois faits ou ordonnes par les fonctionnaires publics chargés de l'exécution.

Bij arrêté werd formeel de afstand van Parijs tot de departementale hoofdsteden vastgelegd, teneinde tot een goede uitvoering van het bepaalde in art. 1 van de titre

\footnotetext{
$9 !$ Gordon. "Politieke en Gerechtelijk indeeling", III, $\mathrm{n}$ 31, 99.

"Wehthahn, "Verkündung", 273-276.

"Wehrhahn, "Verkündung", 280-285; Gordon "Politieke en Gerechtelijke indeeling", III, $\mathrm{n}^{\mathrm{Q}} 152-156$.

44 Gordon, "Politieke en Gerechtelijke indeeling", III, n¹55; BL IVe ser no.48 (812), exrrait des Minutes de la Secrétairerie d'état van 25 prairal XIII (14 jun 1805); zie ook M. Gillet. Analyse chronologique des circulaires, instructions et décisions, émanées du ministère de la justice, depuis le

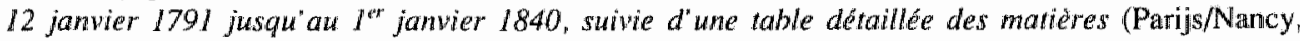
1840) 125 , circulaire van 30 maart 1813 .
} 


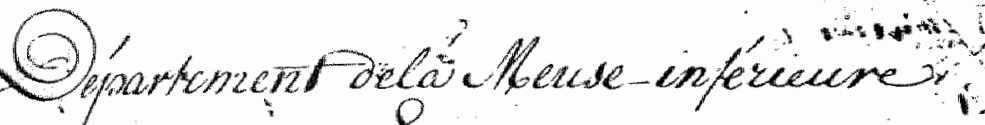

.

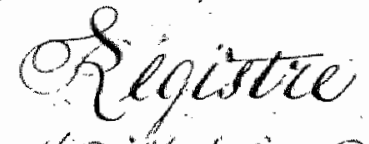

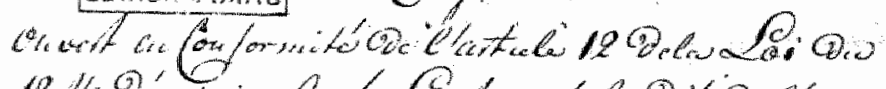

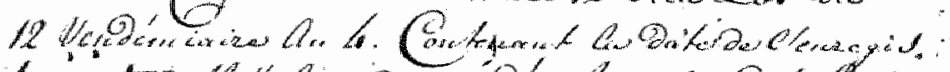

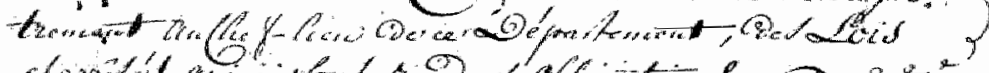

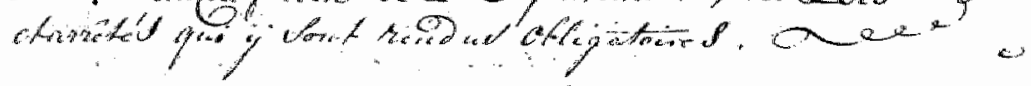

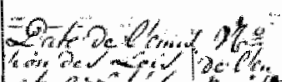

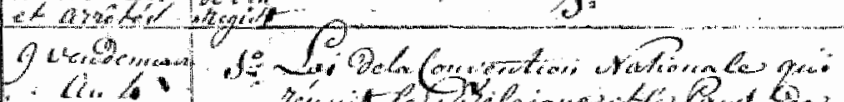

a.

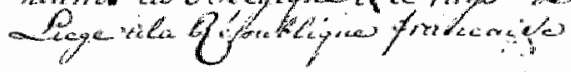

onteraeffine:

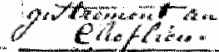

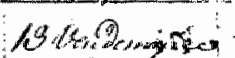
Q.. 2 ace

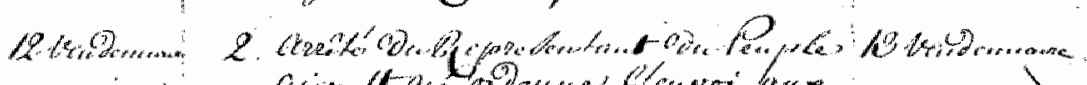

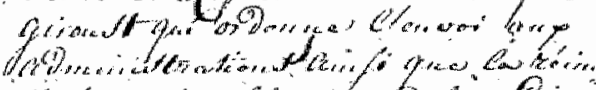

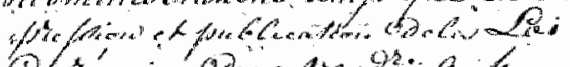

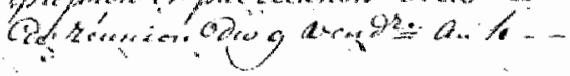

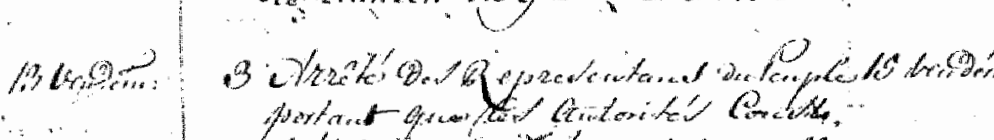

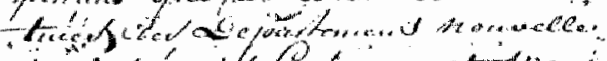

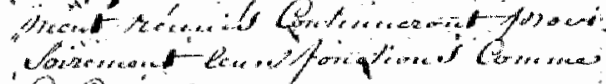
(i-9)ent.

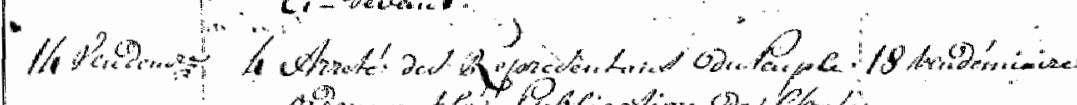
Q⿻一𠃋十

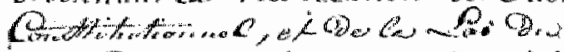

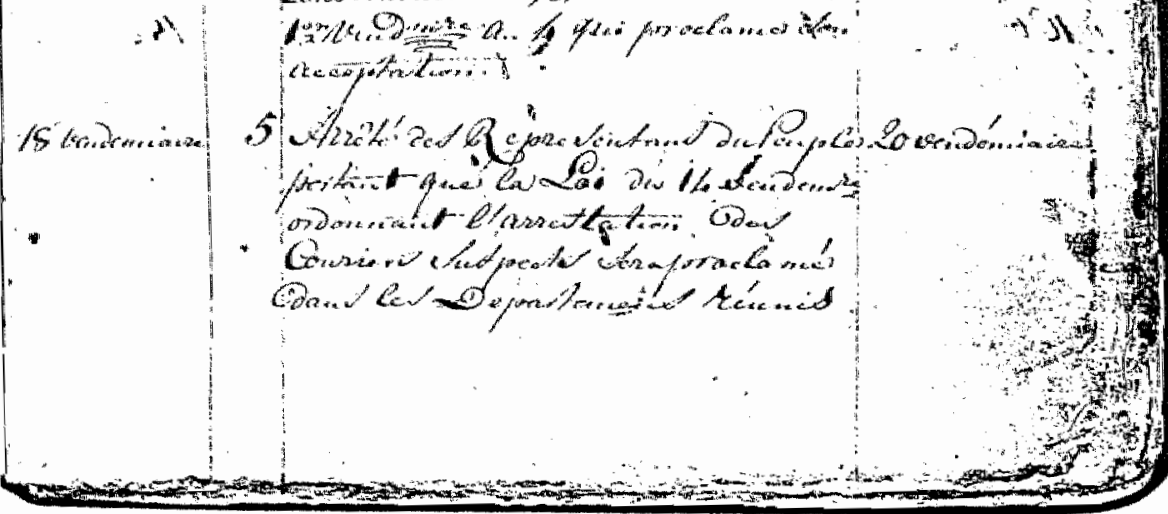

"Registre ouvert", fol 1 recto (Rijksarchief in Limburg, Maastricht; Frans archief inv.nr.283). 
préliminaire inzake het van kracht worden van wetten te geraken. Dataruit blijkt dat vijf dagen na de dag van promulgatie van een wet, deze in de departementale hoofdsteden Maastricht, Luik en Aken van respectievelijk de departementen Nedermaas, Ourthe en Roer van kracht werd ${ }^{95}$.

\section{Afkondiging in het departement Nedermaas}

\section{a. "Registre ouvert"}

Aangezien de laatste alinea van het twaalfde artikel van de wet van 12 vendémiaire IV de aanleg van een repertorium ter vaststelling van de ontvangst der Bulletins des Lois dwingend voorschreef, is er ook door het Nedermaase departementale bestuur een dergelijk repertorium geopend, het "registre ouvert en conformité de l'article 12 de la loi du 12 vendémiaire an 4 contenant la date de l'enregistrement au chef-lieu de ce département, des lois et arrêtés qui y sont rendus obligatoires" ".96. Dit repertorium vormde de grondslag voor de vervaardiging van de regestenlijst met rechtsvoorschriften over de periode 1 oktober 1795 tot medio maart 1797. Deels moet het "registre ouvert" retroactief zijn samengesteld, want het wordt geopend met de aansluitingswet van 9 vendémiaire IV ( 1 oktober 1795), terwijl de wet van 12 vendémiaire IV eerst onder numero 52 staat ingeschreven. Dergelijke repertoria zijn ook in de aangrenzende departementen geopend. Deze lopen evenwel niet synchroon met het door het departementaal bestuur van de Nedermaas aangelegde repertorium". Van het "regis-

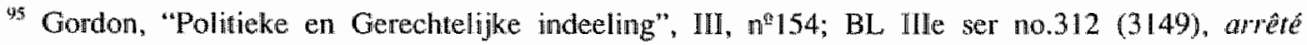
contenant le Tableau des Distances de Paris aux Chefs-lieux de département van 25 thermidor XI (13 aug 1803); Gordon, ibidem, vermeldt, dat bij een senatus-consulte "stilzwijgend beslist" was dat het exedent aan kilomelers niet werd meegeteld, BL IVe ser no.21 (375), sénatis-consulte qui anualle la nomination du S Jean-Baptiste Lacoste au titre de candidat pour le Sénat van 15 brumaire XIII (6 nov 1804). Deze argumentatie is niet in alle opzichten aannemelijk, aangezien de Sénat conservateur zegt dat de constitutie van 28 floreal XII (18 mei 1804) "au plus tard" op 3 praitial XII (23 mei 1804 ) uitvoerbaar werd in het departement Wouden (hoofdstad Luxemburg),

FA inv.n 283.

${ }^{97}$ E. Fairon, "Inventaire analytique du fonds français aux Archives de l'Etat a Liège". Amuaire d"Histoire Liégeoise (Annuaive de la Commission Communale de l"Histoive de l'Ancien Pays de Liëge) III (1943-1947) 215, inv.nr. 187-188 "registre pour l'enregistrement des lois et arrêtés rendus obligatoires au département, dressé au Secrétariat de l'Administration centrale, en conformité de l'art. 12 de la loi du 12 vendémiaire an IV", lopend van $\sharp$ vendémiaire V (22 sep 1796) tot 13 floréal $X$ ( 3 mei 1802); in het departement van de Dijle werd het repertorium - "registre aux expeditions de lois et arrêtés" - door de secretaris wan de centrale administratie van het departement op 5 frimaire IV (26 nov 1795) geopend. Frederic Stevens, "L"introduction de la législation révolutionnaire en Belgique" in: La Révolution et l"ordre juridique privé: rationalité ou scandale? Actes du Colloque d"Oréans 1/-13 septembre 1986 (2 din; Orléans, 1988) 11, 488; Fred Stevens" "De Franse wetgeving over hef notarisambt en het Antwerpse notariaat van 1794 tot 1814. Een institutionele en kwantitatieve studie". Niet uitgegeven proefschrift Katholieke Universiteit Leuven, Faculteit der Rechtsgeleerdheid ( $3 \mathrm{dln}$; 1988) I, 23-24; in hoeverre de Verzeichnisse in het departement varn de Roer, de $n^{6} 328,327$ en 320, "Verzeichnis der von dem (General-)Regierungskommissar in den vier neuen Departements eingegangenen Beschlüisse (arrêtés) und Verordnungen (réglemens)" 1798-1802, (wordt wervolgd...) 
tre ouvert" heeft het departementaal bestuur extracten in druk laten vervaardigen om grotere kennis van afgekondigde wetgeving te geven aan publieke functionarissen:

Considerant combien il importe ì tous les fonctionnaires publics de connâtre la série des lois, arrêtés du directoine execuif et autres actes du gouvernement qui ont été promulgués dans les neuf départemens réunis par la loi du 9 vendémiaire an 4 , et la date exacte de laquelle ils sont obligatoire dans le département de la Meuse-inférieure, par leur transcription sur les registres de l'administration dudit département, conformement à la loi du 12 vendëmiaire an $4^{9 k}$.

Dit geschiedde nadat secretaris J.M. Reintjes tijdens de zitting van 13 nivôse V' ( 2 januari 1797) het departementaal bestuur in kennis stelde van het feit dat er nagenoeg dagelijks vragen van burgers bij de administratie werden ontvangen over met name genoemde wetten en hun verbindbaarheid ${ }^{99}$. Ruim een jaar later verlangde Girard, de commissaris van hel Directoire exécutif buj het departementaal bestuur, dat er zelfs iedere decade (tien dagen) een overzicht van geregistreerde rechtswoorschriften zou worden vervaardigd. Bij besluit van 5 prairial VI ( 24 mei 1798) voldeed het departementaal bestuur aan dit verlangen, overwegende dat het van belang was "que le jour de cet enregistrement soit généralement connu et que sa publication oterait au public tout prétexte d'ignorance". Het overzicht werd aangeplakt op een "table noire" en bevestigd aan de buitengevel van het gebouw waar het departementaal bestuur zitting

\footnotetext{
"(...verwolg)

"Verzeichnis der vom Justizminister übersandten, im Bulletin des lois veröffentlichten Gesetze (lois) und Beschliisse (arrêtés)" 1802-1805, "Verzeichnis der versandten Gesetze (lois), Beschlüsse (arrêtés) und amtl. Zuschriften (dépêches) mit Angabe der Empfänger und Bestimmungsorte" 1798/99, als vermeld in Veröffentichungen der staatlichen Archive des Landes Nordrhein-Westfalen. Reihe A: Inventare staatlicher Archive. Das Hanptstaatsarchiv Dässeldorf und seine Bestände. Band II: die Behörden der Zeit 1794-1815 Teil I: die linksrheinischen Gebiete, bearbeitet von Ingrid Joester (Siegburg, 1987) 128, beantwoorden aan het bepalde in art. 12 van de wet van 12 vendémiaire IV, valt zonder nauwgezette bestudering ervan niet zonder meer met zekerheid aan te geven; Gordon "Politieke en Gerechtelijke indeeling". III, $\mathrm{n}^{121} 12123,124,152$ vermeldt, dat een besluit van 5 brumaire VII (26 okt 1798) van de gouvernementscommissaris Rudler in de vier departementen op de linker Rijnoever inzake de wijze van alkondiging soortgelijke bepalingen bevatte als de wet wan 12 vendémiaire IV; hij heeft niet kunnen ontdekken of de ondlerhavige wet voor deze gebieden executoir verklaard is; de ontvangst vatn rechtsvoorschriften zou dan eveneens door middel van registratie in een repertorium dienen te geschieden; de aantekening bij K.Th.F. Bormann \& A. V. Daniels, ed., Handhuch der fur die Königl. Preup. Rheimprovinzen verkundigten Gesetze, Verordnungen und Regrentwgsbeschlässe aws der Zeit der Fremdherrschaft (8 dln; Keulen, 1833-1845) IIn, 205, vermeldt geen afkondigingsdatum voor de vier departementen op de linker Rijnoever.

sêpertoire on Mémorial chronologique des Lois. Proclamations et Arrêtés publítes dans le départennent de la Mense-unférieure, à dater du 9 Vendémiaire, jour de la réunion à la République frangaise, jusqu'au 29 frimaire an 5 (s.l. [Brussel], an V) 76; FA inv.nr.138 "registre aux arrêtés $\mathrm{n}^{\mathrm{g} 3^{50 "}}$, foll 155 onder $\mathrm{n}^{2} 334 \mathrm{R} 4$, departementaal besluit van 22 nivôse $\mathrm{V}$ (11 jan 1797).

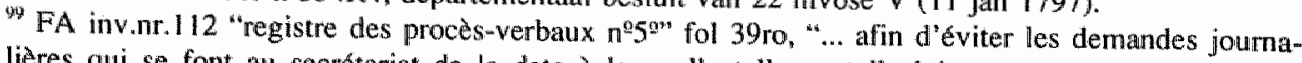
lières qui se font au secrétariat de la date a la quelle telle ou telle loi y est parvenue et y a été consignee dans les registres". Opgemerkt zij, dat het "registre ouvert" geen openbaar register vormde, een "registre public", maar louter een ambtshalve aangelegd repertorium was.
} 
hield. Een afschrift hiervan diende aan de gerechtelijke en bestuurlijke autoriteiten te worden gezonden ${ }^{100}$.

Het eerste gedrukte extract van het "registre ouvert" voerde als titel Repertoire ou Mémorial chronologique des lois, proclamations et arrêtés publiées dans le dêpartement de la Meuse-inférieure en werd, in een oplage van 500 exemplaren, naar alle rechtbanken, vredegerechten en municipale besturen verzonden ${ }^{101}$. In de jaren daarna verschenen er nog een drietal Suites au Répertoire ou Mémorial chronologüque; de Deuxième Suite omvatte tevens nog acht volgnummers, de Troisième Suite slechts één. De oplage werd overigens teruggebracht tot 150 exemplaren, althans volgens het besluit tot het drukken van de Première Suite van 7 prairial VI (26 mei 1798) ${ }^{102}$. De uitgave ervan werd waarschijnlijk beëindigd met het verschijnen van $N^{o} I$ à la Troisième Suite au Répertoire op 2 vendémiaire XI (24 september 1802), afgaande tenminste op het gebundelde Répertoire ou Mémorial chronologique en de "indicateur général"103. Dit houdt vermoedelijk verband met het feit dat korte tijd voordien art. 1 van de loi sur la Promulgation, les Effets et l'Application des Lois van 14 ventôse XI ( 5 maart 1803), de latere titre préliminaire, in werking was getreden en een vastliggend tijdstip van het verbindend worden van wetten introduceerde.

Welke informatie verschaft het "registre ouvert"? Het repertorium duidt in het kort hoofdzakelijk de besluiten van de volksrepresentanten, van her Directoire exécutif, van de Consuls en de keizerlijke decreten aan. Tot en met het in werking treden van de zogenaamde Code Merlin ${ }^{104}$ zijn verreweg de meeste besluiten afkondigingsbesluiten van het Directoire exécutif, besluiten die de bekendmaking bevelen van met name genoemde wetten en besluiten. Na medio maart 1797 en zeker na de staatsgreep van 18 fructidor V (4 september 1797) die een einde maakte aan het zogenoemde eerste Directoire, overheersen de besluiten in de personele sfeer, zoals de benoemingen van plaatselijke autoriteiten, en uitvoeringsbesluiten. Ten tijde van het Keizerrijk neemt het aantal rechtswoorschriften met een algemenere strekking weer wat toe. Elke inschrijving in het "registre ouvert" kent een volgnummer, dat soms uit één of meerdere deelnummers bestaat. Zo is bij voorbeeld het registratienummer 89 opgebouwd uit 48 deelnummers en nummer 134 uit 9 . Van iedere inschrijving wordt voorts de datum van uitvaardiging (date de l'émission) en uiteraard de datum van registratie in het departement van de Nedermaas (date de l'enregistrement) vermeld. Het departementaal bestuur heeft ook de Bulletins des Lois, te beginnen met die van de tweede serie, in het "registre ouvert" ingeschreven. Aanvankelijk nog een tijdlang zonder registra-

\footnotetext{
"(10) FA inv.nr.17 "indicateur général A9", 29 floréal VI (18 mei 1798) onder n"850R9; FA inv.nr.145 "registre aux arrêtés n" $3^{12^{12}}$ fol 84 vo-85ro onder no950R9, 5 prairial VI ( 24 mei 1798 ).

"61 Répertoire ou Mémorial chromologique, 76; FA inv.nr.284 valt hierwan aan te merken als de minuut.

in2 Première Suite au Réperfoire ou Mémorial Chronologique ... (Maastricht, s.a. [an VI]), 181; FA

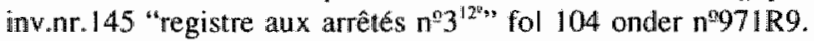

${ }^{1033}$ NeI a la Troisieme Suire au Répertoire (s.I. [Maastricht], s.a. [an XI]) 137; drukw FA inv.nr.127; $\mathbb{F A}$ inv.nr.37 "indicateur général de préfecture $n^{\circ} 13^{*}$, dit laatste extract over het tweede semester van het jaar $X$ op 26 germinal $X I 1$ (16 apr 1803) onder $n^{9} 436 R$ 13 $3^{\text {pft }}$ aan de "maires" verzonden; er zijn geen verdere verwijzingen.

1:44 Zie paragraaf $4 \mathrm{c}$.
} 
tienummer, pas het Bulletin des Lois no. 197 van de tweede serie krijgt als eerste een registratienummer toegekend (numero 387). Het gehele "registre ouvert" telt 1943 registratienummers. De laatste inschrijving behelst een keizerlijk decreet van 12 maart 1814, dat een besluit van de conseil de préfecture van het departement van de Nedermaas wan 30 mei 1812 annuleerde en dat nog op 17 mei 1814 te Maastricht werd geregistreerd.

Het komt voor dat een wet of besluit tweemaal werd afgekondigd. Kennelijk wist de daartoe bevoegde autoriteit het niet meer exact, of had geen kennis van de eerdere afkondiging. Het vaakst is dit gebeurd in de tijd dat de volksrepresentanten/gouvernementscommissarissen nog de opdrachten verstrekten rechtsvoorschriften in de negen Verenigde Departementen bekend te maken. Regelmatig komt het voor dat bepaalde wetgeving op achtereenvolgende tijdstippen gedeeltelijk uitvoerbaar werd verklaard. Een enkel voorbeeld moge dit verduidelijken. Bij besluit van de volksrepresentanten/gouvernementscommissarissen wordt de loi relative aux fonctions des corps administratifs et municipaux, en exécution du titre VII de l'acte constitutionnel van 21

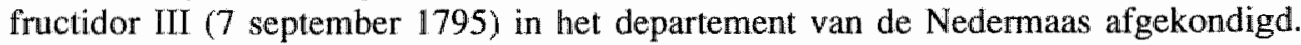
Het Directoire exécutif kondigde bij zijn besluit van 11 fructidor IV (28 augustus 1796) de artt. 22-26 nogmaals af. Zelfs komt het éénmaal voor dat bij één en hetzelfde besluit van de volksrepresentanten/gouvernementscommissarissen een wet - de loi qui ordonne l'établissement des gardes champêtres dans toutes les communes de la République van 20 messidor III ( 8 juli 1795) - tweemaal werd afgekondigd ${ }^{105}$.

\section{b. Het besluit van 18 pluviôse $I V$}

Het zou niet realistisch zijn te verwachien dat sedert het in werking treden van de wet van 12 vendémiaire IV het uitvoerbaar worden van wetten in de negen Verenigde Departementen vlekkeloos zou verlopen. Sinds het uitbreken van de Franse Revolutie in de zomer van 1789 was er een onvoorstelbaar grote hoeveelheid rechtsvoorschriften uitgevaardigd. Er wordt gewag gemaakt van getallen die de 20.000 rechtsvoorschriften te boven gaan ${ }^{106}$. Wat daar ook van moge zijn, vaststaat dat alleen al de 205 nummers van de eerste serie van het Bulletin des Lois, welke het laatste anderhalf jaar van de Nationale Conventie bestrijkt, 1233 wetten telt. Invoering ineens hiervan in de negen Verenigde Departementen was eigenlijk niet mogelijk.

Betrekkelijk spoedig na het in werking treden van de wet van 12 vendémiaire IV inzake het uitvoerbaar worden van rechtsvoorschriften zag het Directoire exécutif zich genoodzaakt om nadere regels te stellen aangaande de afkondiging in de negen Verenigde Departementen. Enkele van die departementen vroegen zich af welke oudere wetgeving nu wel of niet verbindend was en of zij eigener beweging tot de bekend-

\footnotetext{
Ios Zie regestenlijst onder de datum van 20 messidor III (8 jul 1795).

"16h Stevens, "Franse wetgeving notarisambt", I, 14-15.
} 
making ervan konden overgaan ${ }^{107}$. Gouvernementscommissaris Bouteville beschouwde na de afkondiging van de wet van 12 vendémiaire IV wetten die geplaatst waren in het Bulletin des Lois als verbindend in de départements réunis, behoudens die welke consecutief waren aan oudere nog niet formeel bekendgemaakte wetten ${ }^{108}$. On de onzekerheid over al dan niet bekendgemaakte wetten weg te nemen vaardigde het Directoire op 18 pluviôse IV (7 februari 1796) het arrêteé relatif au mode de promulgation des lois dans les neuf départemens qui composaient la ci-devant Belgique uit ${ }^{109}$.

In de considerans van het besluit refereert het Directoire aan de moeilijkheden die minister van justitie Merlin ondervond bij de verzending en de bekendmaking van wetten in de negen Verenigde Departementen. Het Directoire overwoog eveneens, dat "aux dispositions générales de cette loi [van 12 vendémiaire IV] il a été fait une exception relativement aux pays réunis" en dat art. 2 van de wet van 3 brumaire IV ( 25 oktober 1795) de stand van zaken aangaande de bekendmaking en uitwoering van rechtsvoorschriften hersteld had, zoals verwoord in het besluit van het comité de salut public van 20 frimaire III (10 december 1794) ${ }^{10}$. De bewoordingen van art. 1 van het Directoire-besluit continueerden de bijzondere status van de negen Verenigde Departementen:

L'arrêté du comité de salut public, du 20 frimaire, an III, et article II de la loi du 3 brumaire, an IV, seront exécutés suivant leur forme et teneur: en conséquence, jusqu"à ce qu'autrement soit statué par le Corps législatif, il n'y aura de lois françaises obligatoires dans les pays réunis à la République française, ou dont la réunion a été confirmée par le décret du 9 vendémiaire dernier, que celles non abrogées qui y ont été ou y seront envoyées pour y être observées, soit en exécution d'un arrêté spécial du comité de salut public, des représentans du peuple en mission, du Directoire exécutif, ou des commissaires généraux du Gouvernement revêtus de ses pouvoirs, soit en exécution d'une disposition spéciale d'un décret, d'une loì, d'un acte émané de la Représentation nationale.

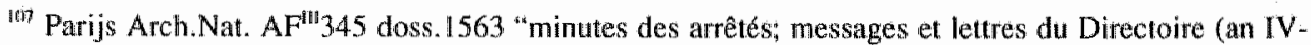
an VIII)" st.69: bestuur departement Schellde aan minister van justitie 12 frimaire IV (3 dec 1795) exh. 26 frimaire IV (17 dec 1795), st.74: concept commissaris Directoire exécuif aan minister van justitie 15 nivôse IV (5 jan 1796), st.76: afschrift bestuur van departement Jemappes aan minister wan justitie 15 nivôse IV, st.77; extract uit missive voorlopige commissaris Directolre exécutif van departement van de Leie aan minister van justitie [?] van 16 nivose IV (6 janulari 1796): BB $^{311} 164$ "envoi et publication des lois françaises dans les pays réunis à la France an IV-1813" departementaal bestuur van de Twee-Neten aan minister van justitie 8 nivôse IV (29 dec 1795).

"hiok Stevens, "Introduction législation révolutionnaire", 488-489.

${ }^{109}$ BL Ile ser no.25 (165); zie ook regestenlijst onder de datum van 18 pluviôse IV (7 feb 1796).

" dernier, sont applicables à tous les pays réunis par cette loi au territoire de la République, ant.2: "Les arrêtés du comité de salut public, et ceux des représentans du peuple en mission auxquels il n"a pas été dérogé jusqu'à ce jour par le comité de salut public, continueront d'être exécutés dans ces pays jusqu'à l'établissement qui $s^{\prime y}$ fera successivement des lois françaises"; P VI Ixi, Arrêté du comitë de salut public maintenam le gouvernement provisoire de Belgique, et déterminent quelles lois péuvent y être exécutées, art.4: "Toutes les autorités administratives de la Belgique ne pourront faire exécuter d'autres lois, arrêtés ou ordres que ceux qui leur seront transmis par les représentans du peuple en mission dans ces contrées, ou les agens autorisées par eux à cet effet". 
Besluiten houdende de bijzondere verzending van een wet aan de autoriteiten in de départements réunis zullen tegelijkertijd de verzending van nog van kracht zijnde wetten of wetsartikelen bevelen waarnaar de wet verwijst, tenzij deze wetten of artikelen voorafgaand reeds op dezelfde manier verzonden waren (art.2). De departementale en gemeentelijke besturen konden van de bevoegdheid hun gegeven krachtens art.2 van de wet van 12 vendémiaire IV gebruikmaken om ruimere bekendheid te geven aan de bij bijzonder besluit afgekondigde wet; nochtans zou de wet verbindend zijn vanaf de dag van binnenkomst en registratie in het departementale "registre ouvert".

Welke waren de redenen van het Directoire exécutif om dit besluit uit te vaardigen? In de overwegingen van het arrêté wordt gesteld dat vooral na het afkondigen van de wet van 12 vendémiaire IV door de volksrepresentanten Pérès en Portiez (de l'Oise) de autoriteiten de minister van justitie consulteerden of de onderhavige wet voor hen wel verbindend was en of zij anterieure, niet-ingetrokken wetten die zich bij de toegezonden verzamelingen bevonden uitvoerbaar moesten verklaren. Voorts hechtte Parijs er groot belang aan dat eerst alle overheden in de Verenigde Departementen zouden zijn geïnstalleerd en naar behoren zouden functioneren, voordat men tot grootscheepse invoering van de nieuwe wetgeving zou kunnen overgaan. Het Directoire huldigde dan ook een tamelijk realistische visie, want:

\begin{abstract}
... on ne pourrait exiger des fonctionnaires publics l'exécution simultanée d'un nombre considérable de lois ils n'auraient pas eu le temps de saisir l'ensemble et les détails, et qu'il serait encore plus injuste d'exiger cette exécution simultanée des habitans qui, ayant eu jusque-là des lois et des usages très-différens, ont besoin de s'instruire successivement des lois qui doivent désormais les régir;

(...) qu'il n'esi pas même possible d'y faire exécuter sur-le-champ, quoique successivement, celles qui interviennent chaque jour, puisque la plupart sont relatives a autres lois qui n'ont pas encore êté publiées dans les pays réunis.
\end{abstract}

Het was derhalve voor het Directoire uitermate urgent om deze onzekerheden weg te nemen. Niettegenstaande de voorlopige uitzonderingspositie voor de départements réunis inzake de afkondiging van rechtswoorschriften, diende de minister van justitie voort te gaan met het verzenden van het Bulletin des Lois, "afin d'en faciliter l'étude et la connaissance, et de préparer les fonctionnaires publics et les citoyens à leur exécution" op het moment dat er een verzending volgde bij bijzondere opdracht (art.4).

Aangezien de verzending van alle nummers van de tweede serie van het Bulletin des Lois op gelijke wijze naar de negen Verenigde Departementen als naar elders in Frankrijk geschiedde, bepaalde het Directoire exécutif in een aanvullend besluit op 20 germinal IV ( 9 april 1796), dat wat betreft de door het Wetgevend Lichaam aanvaarde en in het Bulletin des Lois geplaatste wetten de bijzondere opdracht tot afkondiging 
uitsluitend het nummer van het desbetreffende Bulletin zou vermelden ${ }^{i 1}$. Soms werd een dergelijke afkondigingsopdracht ook in het Bulletin des Lois geplaatst ${ }^{12}$.

De afkondigingsregeling voor de dëpartements réunis als gegeven in het besluit van 18 pluviôse IV was circa tien maanden van kracht. Blijkens een schrijven van het bestuur van het departement van de Dijle was men aldlaar niet onverdeeld gelukkig met de uitzonderingspositie, waarin de negen Verenigde Departementen waren geplaatst. Dit zou funest zijn voor de verdere integratie van deze gebieden in Frankrijk $^{113}$. Uit correspondentie van gouvernementscommissaris Bouteville met de minister van binnenlandse zaken Bénezech ${ }^{114}$ blijkt zelfs dat Lambrechts ${ }^{115}$, de commissaris van hel Directoire exécutif in het Dijle-departement en latere minister van justitie, sterk aandrong op intrekking van het arrêté van 18 pluviôse IV ${ }^{16}$. Het departementaal bestuur van de Nedermaas nam de nieuwe stand van zaken rond de afkondiging min of meer voor kennisgeving aan. Tijdens de zitting van het departementaal bestuur op 3 ventôse IV ( 22 februari 1796) verzocht administrateur Picquery van het tweede bureau tot wiens taken wetgevingszaken behoorden slechts, dat elk van zijn collega"s hem hierover afzonderlijk zou spreken en erover een rapportage zou opstellen $^{117}$.

Klaarblijkelijk conformeerden diverse autoriteiten zich toch niet exact aan de nieuwe wijze van het uitvoerbaar worden van rechtswoorschriften in de départements réunis. In een depêche wees het Directoire exécutif erop dat hem herhaaldelijk klachten bereikten over het ongerief, dat veroorzaakt werd door het feit dat ministers en andere autoriteiten de uitvoering van een wet of besluit bevalen, welke niet bekendgemakt was krachtens een bijzondere opdracht overeenkomstig het bepaalde in het arrêté van 18 pluviôse IV. De fungerend voorzitter van het Directoire, Carnot ${ }^{118}$, wenste dat men zich hier stipt aan zou houden. Wel konden de ministers de noodza-

\footnotetext{
$111 \mathrm{BL}$ Ile ser no.39 (316), arrêté additionnel à celui du 18 Plaviôse, an $W$, sur le mode de promulgation des lois dans les neuf départemens qui composaient la ci-devant Belgique.

${ }_{i \text { ii2 }} \mathrm{Bij}$ voorbeeld: BL Ile ser no.42 (342), no.59 (549), no.69 (639); zie tevens regestenlijst, passim.

11.3 Stevens, "Intuoduction législation révolutionnaire" "489; Parijs Arch.Nat. inv.nr. AF"lili 94 doss.409 st.26 "rapports ministeriells et pièces annexes concernant la Belgique", departementaal bestuur Dijle aan Directoire 5 ventóse IV (24 feb 1796).
}

"Soboul, Dicrionnaire historique, 105, 747-748, s.v. "BENEZECH Pierre François" en "ministres"; minister van 3 nov 1795 tot 16 jul 1797.

115. Jean Tulard, Jean François Fayard \& Alfred Fierro. Histoire et dictionnaire de la Rénolution franģaise 1789-1799 (2e herdr.; Parijs, 1988) 925-926, 985-987 s.w. "TABLEAU DES MINISTRES" en "LAMBRECHTS"; Charles Joseph Mathieu Lambrechts was als minister de opvolger van Merlin, 24 sep 1797 - 20 jul 1799; Lambrechts was afkomstig uit Sint-Truiden (departement Nedermaas).

116 Stevens, "Introduction législation révolutionnaire", 489; Parijs Arch.Nat. inv.nr. F" 30 "renseignements divers" doss.5 "correspondance diverses relative a l'organisation des départements belges mouvellement réunis ans IV॰V", Bouteville aan minister van birnenlandse zaken 17 germinal IV $(6$ apr 1796); missive eveneens opgenomen in Hubert \& Tihon, Correspondance Bouteville, 1, 193-196, maar dan onder de datum van 16 germinal IV (5 apr 1796).

${ }^{117}$ FA inv.nr. 108 "registre des procès-verbaux", 3 ventôse IV (22 feb 1796) onder $n$ "83, " $\mathrm{L}$ 'administrateur Picquery observe qu"il conviendroit que chaque membre me dite en particulier sur la loi [!] sous Na165 dud' Bulletin [des Lois no.25] \& en fasse un rapport a la séance de demain".

"ik Soboull, Dictionnaire historique, 189-191 s.w. "CARNOT Lazare Nicolas Marguerite", directeur tijdens het eerste Directoire tot de staatsgreep van 4 sep 1797, als opvolger van Siéyès die zijn aanwankelijke benoeming niet had aanvaard. 
kelijkheid of nuttigheid van het afkondigen van zekere wetten en besluiten aan het Directöre voorleggen ${ }^{119}$. De minister van generale politie, Cochon de Lapparent ${ }^{120}$, vroeg naar aanleiding hiervan aan zijn collega van justitie om een overzicht van bekendgemaakte wetgeving in de départements réunis "pour mettre fin aux plaintes et aux abus". Volgens een aantekening in margine van de hand van Merlin werd Cochon dit op 3 prairial IV (22 mei 1796) toegezonden ${ }^{121}$.

Ter geruststelling van de departementale besturen in de negen Verenigde Departementen zond de minister van justitie, Génissieu ${ }^{122}$, op 13 ventôse IV ( 3 maart 1796) een rondschrijven waarin hij nogmaals uiteenzette waarom het van wijsheid getuigde het arrêté van 18 pluviôse IV uit te vaardigen. Het Directoire wenste de autoriteiten noch de ingezetenen te overstelpen met wetten "qui n'ont été envoyées aux autres français qu'a de longues intervalles". Alle wetgeving zou worden toegestuurd, maar niet "sans ordre, sans choix et sans discernement". In een post scriptum nodigde hij de departementale besturen uit hem een overzicht te doen toekomen van alle reeds bij uitdrukkelijke opdracht bekendgemaakte wetten, hetzij door het comité de salut de public, hetzij door de uitgezonden volksrepresentanten, hetzij door het Directoire exécutif. In een tweede kolom werd om een overzicht verzocht van de arrêtés, eveneens in chronologische volgorde opgesomd ${ }^{123}$. Blijkens de archivalia te Parijs heeft het bestuur van het departement van de Leie medio juni 1796 een dergelijke staat toegezonden ${ }^{124}$. Stevens daarentegen schrijft abusievelijk dat het departement van de Dijle dit overzicht zou hebben toegezonden ${ }^{125}$. Wel heeft Lambrechts, de commissaris van het Directoire exécutif van hetzelfde departement, op 18 en 19 germinal IV (7 en 8 april 1796) een "Recueil en quatre volumes, de tous les arrêtés pris par les réprésentans du peuple et de toutes les loix publiées par leur ordre avant et depuis la réunion de la Belgique à la République", alsmede een "ébauche" van het chronologi-

${ }^{119}$ Parijs Arch.Nat. inv.nr. F ${ }^{\mathrm{l}} 27$ doss.2, Directoire exécutif aan minister van binnenlandse zaken 16 floréal IV ( 5 mei 1796). De depêche werd kennelijk aan meer ministers verzonden; Charles Delacroix, minister van buitenlandse zaken, maakte er gewag van in een missive aan de minister van binnenlandse zaken, 23 floréal IV (12 mei 1796); inv.nr. BB ${ }^{31} 164$, een interne ministerièle instructie voor het departement van justitie van dezelfde datum beveell de bureaus aan de andacht te verscherpen, terwijl een overzicht wan afgekondigde wetgeving, waarvan men al zeker was, zou worden opgesteld.

"2010 Soboul, Dictionnaire historique, 241-243, 747-748 s.v. "MINISTRES" en "COCHON de Lapparent Charles"; Tulard, Fayard \& Fierro, Histoire ef dictionnai"e "985-987 s.v. "TABLEAU DES MINISTRES"; minister van 3 apr 1796 tot 16 jul 1797.

12.1 Parijs Arch.Nat. inv.nr. BB ${ }^{\text {w1 }} 164$, minister van generale politie aan minister van justitie 21 floréal IV (10 mei 1796); Stevens, "Introduction législation française", 490, zegt dat het hieronder vermelde overzicht samengesteld door Lambrechts aan de ministers werd gezonden.

${ }^{122}$ Soboul, Dictionnaires histonique, 747-748 s.v. "MINISTRES"; Tulard, Fayard \& Fierro, Histoure et dictionnaire, 985-987 s.v. "TABLEAU DES MINISTRES"; minister varn 5 jan 1796 tot 3 apr 1796.

${ }^{12.3}$ FA inw.nr.275 "correspondance ministérielle tégistre n" ${ }^{\circ}$ " fol 69 ro-70ro, schrijven minister van justitie aan departementale besturen van de negen Verenigde Departementem.

${ }^{124}$ Parijs Arch. Nat. inw.nr. BB $^{\mathrm{m} 1} 164$ "Envoi et publication des lois françaises dans les pays réunis à la France an IV-1813", bestuur Leie-departement aan minister van justitie 27 prairial IV (15 juni 1796), de bijgevoegde staat behelst de analyse et de datum van de wetten en besluiten die sedert 23 messidor II (11 juli 1794) tot en met 12 geminal IV (I april 1796) in het departement bekendgemaakt
zijn.

izs Stevens, "Introduction légisłation française", 489; idem, "Franse wetgeving notarisambt", I, 26. 
sche overzicht, waarom de minister van justitie de administratie had verzocht, toegestuurd $^{126}$. Dit chronologische overzicht kan toch ook worden opgevat als gevolg te hebben gegeven aan het verzoek van de minister van justitie, zoals verwoord bij diens schrijven van 13 ventôse IV. Archivalische naspeuringen hebben evenwel geen informatie opgeleverd, dat het departement van de Nedermaas aan bovengemeld verzoek van de minister van justitie heeft voldaan ${ }^{127}$. Het is heel goed mogelijk dat dit voor de Nedermaase bestuurders een te ingewikkelde operatie is geweest ${ }^{128}$.

Voorlopig dienden de centrale administraties van de negen départements réunis die decreten en besluiten als wet te beschouwen, waarvan het Directoire speciaal de bekendmaking had bevolen ${ }^{129}$. Uit Boutevilles briefwisseling blijkt ook dat men te Parijs voornemens was te komen tot de integrale invoering van de nog tot dan toe relevante revolutionaire wetgeving in de negen Verenigde Departementen ${ }^{130}$. Bij schrijven van 23 fructidor IV (9 september 1796) nodigde de minister van justitie de commissarissen van het Directoire exécutif bij de departementale besturen en bij de burgerlijke en criminele rechtbanken uit hem "le plus promptement" te adviseren over de wetten die in Frankrijk sedert de maand augustus 1789 bekendgemaakt waren, die op dat moment vanwege plaatselijke omstandigheden ("à raison des localités") niet meer uitvoerbaar hoefden te worden in de départements réunis ${ }^{131}$. Al wóór 1 vendémiaire V (22 sep 1796) zou men een gemotiveerd overzicht moeten opsturen. De minister was zich wel bewust van het feit dat dit een moeizaam werkje zou zijn.

\footnotetext{
${ }^{126}$ Parijs Arch.Nat. inv.nr. BB ${ }^{30} 164$, commissaris van het powvoir exécutif aan minister van justitie, het zijn twee tableaus, de ene met de arrêtés, de andere met de wetten; ook Stevens, "Introduction législation française", 489; zeer vermoedelijk doelt Lambrechts op het zogenaamde Recueil Hayez in$4^{\circ}$, dat uiteindelijk 25 delen zou omvatten en een wisselende titell voerde: het vierde was getiteld Recueil des lois françaises, publiées dans les départemens réunis par la la Loi du 9 Vendémiaire de l'an 4, et de divers Arrêtés des Autorités constituées: pour servir de suite au Recueil des Arrêttés. etc; zie voor het Recueil Hayez, Charles Delecourt, "Bibliographie des collections de lois depuis 1789 jusqu'en 1814", Archives de droit et de législation, I (1837), 118-120.

${ }^{127}$ Nooch de "indicateur général", noch het inv.nr. BB ${ }^{314} 164$ van de Archives Nationales te Parijs llevert hieromtrent aanwijzingen op.

${ }^{124}$ De inwoners van Eygelshoven, dat bij besluit van gouvernementscommissaris Boutewille van 27 frimaire $\mathrm{V}$ (17 dec 1796) voor het eerst deel ging uitmaken van het kanton 's-Hertogenrade, kregen daarentegen wel alle wetgeving in eén keer over zich uitgestort. Art.2 van het besluit bepaaldle: "L'administration du département prendra de suite les mésures nécessaires pour y faire publier et exécuter toutes les loix promulguées dans les Départemens réunis". Bij de installatie van de municipale agent en zijn adjoint van Eygelshoven werden hun de wetten en besluiten "qui ont êté publiess dans les autres communes du canton pour l'être la leur" ter hand gesteld, FA inv.nr. 4201 onder n⿳932R3, besluit Bouteville en "extrait du régistre aux arrêtés de l'administration municipale du canton du Rolduc" van 14 nivôse V (3 jan 1797).

${ }^{12 y}$ Stevens, "Introduction législation française", 490; Hubert \& Tihon, Correspondance Bouteville " I, 238 missive $\mathrm{n}^{0} 128$, Bouteville aan Leie-departement 25 prairial IV (13 jun 1796).

${ }^{313}$ Hubert \& Tihon. Correspondance Bouteville, II, 331-332, missive $\mathrm{n}^{\circ} 446$, Bouteville aan commissarissen bij de departementale besturen en bij de burgerlijke en criminele rechtbanken 28 frimaire $\mathrm{V}$ (18 dec $\| 796)$.

${ }^{134}$ RAL Nieuwe Rechterlijke Archieven [NRA] inv.nr.273 "correspondance ministerielle ans IV-IX", minister van justitie Merlin aan de commissaris van de pouvoir exécutif bij de departementale burgerlijke en criminele rechtbank 23 fructidor IV (9 sep 1796).
} 
Archivalische naspeuringen te Maastricht hebben geen antwoordschrijven van de beide commissarissen Girard en Roemers opgeleverd. Stevens vermeldt echter - zich baserend op Boutewilles Compte - dat allen zich tot een beknopte beantwoording hadden beperkt, behalve de commissaris van het Directoire exécutif in het Dijle-departement ${ }^{132}$, maar één en ander heeft mijns inziens meer betrekking op de latere missive van Bouteville van 28 frimaire V (18 december 1796). Bouteville schreef toen de commissarissen bij de departementen en de departementale rechtbanken aan met het verzoek hem per ommegaande inlichtingen te verschaffen met betrekking tot het onderzoek dat zij reeds verricht zouden hebben ingevolge het verzoek van de minister van justitie van de maand fructidor. Bouteville zelf moest namelijk de minister van binnenlandse zaken Bénezech adviseren over die wetten waarvan hij vond dat hun afkondiging ("promulgation") noodzakelijk was, alsmede over tot binnenlandse zaken behorende ressorten als de verdeling van gemene goederen, gemeentelijke schulden, voorzorgsmaatregelen ingeval van ongevallen, branden, epidemieën, hagelschade, de plattelandseconomie, bibliotheken enzovoorts ${ }^{133}$. Opnieuw kon het antwoord van de commissaris van het Directoire exécutif bij het departementaal bestuur van de Nedermaas niet meer worden opgespoord. Het antwoord daarentegen van de waarnemend commissaris bij de burgerlijke rechtbank, rechter Hartmann, staat in de marge van Boutevilles missive geschreven ${ }^{134}$. Hartmann schreef dat hij slechts voorlopig en nog maar sinds kort de functie van commissaris vervulde en dat hij onmogelijk aan het oogmerk van de minister kon voldoen, want "le travail qu'il désire exigerait une application de plusieurs mois", alsmede de bestudering van de Bulletins des Lois sinds 1789 (sic), waarvan de verzending naar de commissarissen van de départements rếunis volgens hem niet was geschied.

De Nedermaase autoriteiten hadden in ieder geval geen volledig zicht op de vigerende rechtsvoorschriften. Dit moge blijken uit haar schrijven aan Bouteville op 15 nivôse $\mathrm{V}$ (4 januari 1797). Uit een vergelijking met een extract uit het register met alle in de negen départements réunis verbindende wetten en besluiten van het departement van de Ourthe en het repertorium van de Nedermaas, bleek dat men een aantal wetten en besluiten niet "officiellement" ontvangen had" ${ }^{135}$. Bouteville stuurde hun de "Liste des Loix et arretés qui ne sont pas parvenus officiellement à l'ad ${ }^{\text {on }}$ de la Meuse Inférieure" met enige observaties terug ${ }^{136}$. Hij vond dit onbegrijpelijk, maar was van mening dat hij de bekendmaking, die kennelijk louter beruste op een vergissing, mocht herstellen, voor zover er geen sprake zou zijn van bezwarende omstandigheden. Wel bleef het bezwaar bestaan, dat de verlate bekendmaking geen terugwerkende kracht mocht hebben. Sommige van Boutevilles aantekeningen constateren dat bepaal-

\footnotetext{
192 Stevens, "Introduction législation révolutionnaire", 490; Bouteville, Compte, 19.

${ }^{13}$ Hubert \& Tihon, Correspondance Bouteville, II, 331-332, missive ${ }^{2} 446$; rigineel in NRA inw.m. 265 "Ingekomen brieven en stukken en minuten van uitgaande brieven, an IV ( 1796$)$ - an V
(1796)". 11.34 Ibidem, minuut-schtijven waamemend commissaris Hartman aan Bouteville 7 nivôse V (27 dec
1796). 1.35 FA inw nr. 259 "correspondance active et passive $n^{2} 21$ ", fol 59 vo-60ro, departement Nedermas aan
Bouteville onder $n^{0226 R 4}$.

${ }^{196}$ Ibiden fol $123 \mathrm{vo}-125 \mathrm{vo}$, Bouteville aan Nedermaas 22 nivôse $V(11$ jan 1797) onder ñ226R4.
} 
de besluiten van de volksrepresentanten achterhaald waren, van andere wordt vermeld dat zij bekendgemaakt zijn en overall worden toegepast, zoals gedeeltelijk de wetgeving betreffende de "gendarmerie nationale". Soms vergiste het departementaal bestuur zich en noemde besluiten die gewoon in het "registre ouvert" stonden. Ook gouvernementscommissaris Bouteville vergiste zich: bij de wet op de veeartsenijscholen van 29 germinal III (18 april 1795) ${ }^{137}$ tekende hij aan dat zij bekendgemaakt zou zijn, terwijl het "registre ouvert" onder $n^{2} 286$ vermeldt dat de bekendmaking ervan eerst is geschied bij besluit van het Directoire exécuilf wan 9 fructidor $V$ (26 augustus 1797). Ofschoon Bouteville vond dat het departementaal bestuur kon overgaan tot het herdrukken en bekendmaken van die rechtsvoorschriften, volgde er niet alsnog een inschrijving in het "registre ouvert". Dit impliceert dat er - in ieder geval in de eerste maanden na de inlijving bij Frankrijk - rechtsvoorschriften zijn afgekondigd, die niet in het "registre ouvert" zijn ingeschreven, en derhalve uiterst moeilijk traceerbaar blijven ${ }^{138}$. Voor de besluiten van de volksrepresentanten verwijst Bouteville het departementaal bestuur naar het zogenaamde recueil Hayez. Het valt aan te nemen dat de besluiten van de volksrepresentanten, die niet officieel bij het departementaal bestuur binnengekomen zijn, een gevolg is geweest van de omstandigheid dat het arrondissement Maastricht ressorteerde onder de Centrale Administratie van de Landen tussen Maas en Rijn te Aken. De verwarrende overgangsperiode na de aansluiting bij Frankrijk zal vermoedelijk niet vreemd geweest zijn aan de leemtes in de afkondiging.

\section{c. Code Merlin}

Ingevolge het besluit van het Directoire exécutif van 16 frimaire V (6 december 1796) verscheen gedurende de maand ventôse van het jaar V (februari/maart 1797) bij de "Imprimerie de la République" te Parijs het tweedelige Recueil de Lois et Règlemens pour les neuf Départemens réunis par la Loi du 9 Vendémiaire, an $I V$, en exécution de l'Arrêté du 7 Pluviôse an $V$. In verband met het feit dat het gereedkomen ervan onder verantwoordelijkheid van de minister van justitie Merlin (de Douai) geschiedde, wordt dit "recueil" ook wel als Code Merlin betiteld.

Dit arrêté concernant la publication des lois dans les neuf départemens réunis par celle du 9 Vendémiaire, an $V$ van 16 frimaire $\mathrm{V}^{139}$ betekende in allgemene zin het einde van de bijzondere positie van het uitvoerbaar worden van wetgeving in de negen Verenigde Departementen. Het Directoire overwoog dat het besluit van het comité de salut public van 20 frimaire III (10 december 1794) en art.2 van de wet van

\footnotetext{
${ }^{137}$ BL Ie ser no.139 (774), loi portant qu' il y aura dans la République deux ë́coles d"économie runale vétérinaire.

${ }^{13 \mathrm{k}}$ Het blijkt dat het afkondigingsbesluit van de volksrepresentanten van 27 frimaire IV (18 dec 1795) inzake de wetten van 16 jan * 16 feb 1791,22 jun * 20 jul 1791, $14 * 29$ apr 1792 en 4 frimalre IV (25 nov 1795) aangaande de "gendarmerie nationale" ingeschreven staat in LA VI fol 91 ro-96vo" in de kantlijn [fol 91ro] is aangetekend: "L'arrêté ci-contre et les lois y comprises quoique n' 'etant parvenu aux archives que vers le mois de brumaire an 6 . neanmoins, l'enrégistrement doit dater du 10 ou 11 Niwose an $4^{\text {"w. }}$.

139 Zie regestenlijst onder de datum van 16 frimaire $V(6$ dec 1796).
} 


\section{RECUEIL DE LOIS}

\section{T}

\section{R E G L E M E N $S$}

Pour les neuf Departemens reunis par la Loi du 9 V endemiane, an IV.

En exécuman de li Arete du Direcroine crecuif dut Pluniase, an V.

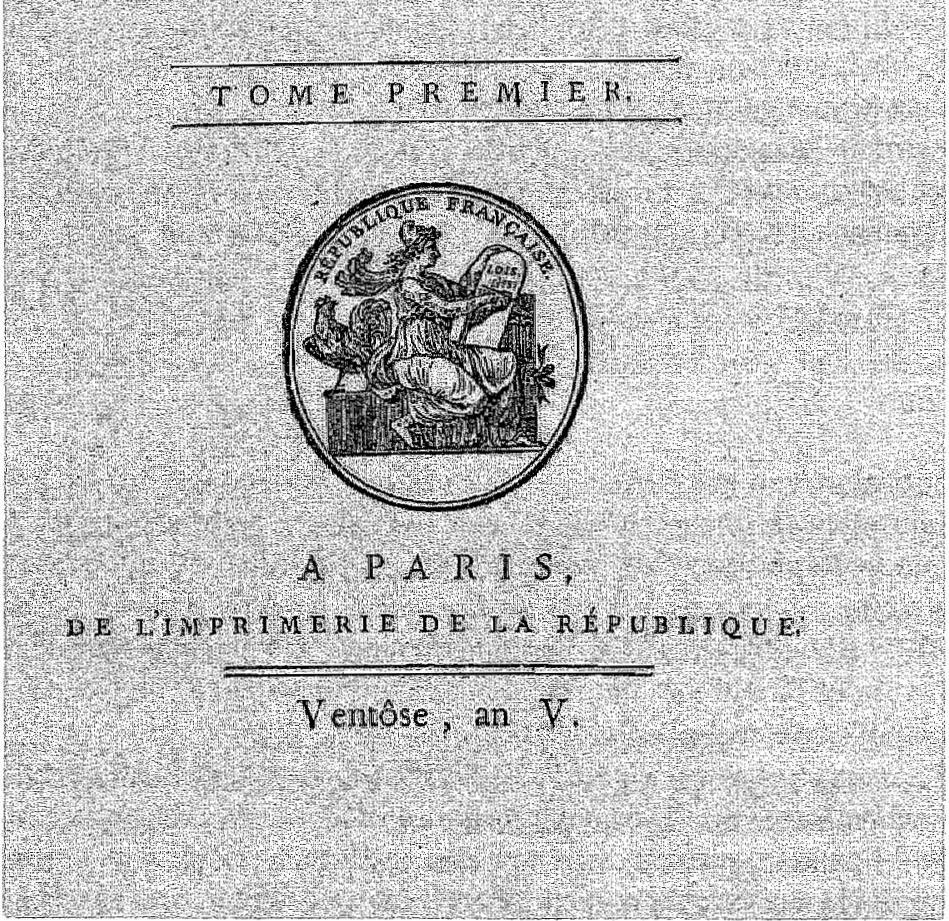

Code Merlin 
3 brumaire IV (25 oktober 1795) slechts ten doel hadden te verhinderen dat in de Verenigde Departementen wetten bekendgemaakt zouden worden die samenhingen met andere nog niet-bekendgemaakte wetten en derhalve niet tenuitvoergelegd zouden kunnen worden. Thans vond het Directoire dat dit op voortvarender manier zou kunnen geschieden dan in zijn besluiten van 18 pluviôse IV ( 7 februari 1796) en 20 germinal IV ( 9 april 1796) was bepaald. De eerste twee artikelen van het besluit vormden de quintessens ervan ${ }^{140}$ :

Les lois et les arrêtés du Directoire exécutif insérés dans les cahiers du bulletin des lois, qui, à compter de ce jour, parviendront aux départemens réunis, seront obligatoires pour ces départémens comme pour les autres départemens de la République, à dater du jour de la distribution de chaque cahier au chef-lieu de département, s'il n'y a exceptions prononcées par des arrêtés spéciaux à l'égard de lois ou d'arrêtés formellement désignées [art.1].

Sont đès-à-présent exceptés les lois ou articles de loi et les arrêtés qui pourraient concerner les mandats territoriaux [art.2].

Het derde en vierde artikel gaven aan de minister van justitie opdracht binnen 24 uur een ontwerp-besluit aan het Directoire voor te stellen om de départements réunis uit te zonderen van de toepassing van een in het Bulletin des Lois te plaatsen wet of besluit, indien dit nodig mocht zijn. Voor de overige ministers gold hetzelfde, maar zij dienden dit via de minister van justitie te regelen. In het laatste artikel kreeg de minister van justitie tevens de opdracht binnen een maand een algemeen overzicht van nog niet in de Verenigde Departementen bekendgemakkte wetten op te stellen, "qui sont susceptibles d'y recevoir dès-à-présent leur exécution". De overige ministers dienden hem binnen twee decaden een staat van wetten te overhandigen aangaande het hun geattribueerde.

Het arrêté van 16 frimaire V bepaalde dus dat voortaan alle cahiers van het Bulletin des Lois onmiddellijk verbindend waren in de negen Verenigde Departementen, zodra zij in de departementshoofdstad ontvangen waren. Voor het departement van de Nedermaas was dit met ingang van het Bulletin no. 95 van de tweede serie, dat op 29 frimaire V (19 december 1796) in het "registre ouvert" geregistreerd werd, twee dagen na de registratie van het besluit van 16 frimaire $\mathrm{V}^{14 !}$. Tijdens zijn zitting van 1 nivôse $V$ (21 december 1796) besloot het departementaal bestuur dat het arrêté van 16 frimaire $\mathrm{V}$ ten getale van 500 exemplaren tweetalig zou worden gedrukt en naar alle gemeentebesturen diende te worden verzonden, teneinde overal waar dat nodig was te worden bekendgemaakt en aangeplakt ${ }^{142}$. Het departementaal bestuur veronderstelde dat de kantonsmunicipaliteiten al wel bijzondere aandacht aan het besluit van 16 frimaire $\mathrm{V}$ zouden hebben geschonken:

\footnotetext{
14tet $F A$ inv.nr.291 "Arrêtés du Directoire Exécutif et lois anciennes 1749 - an XIII".

${ }^{14 !}$ Gordon, "Bestuurlijke en Gerechtelijke indeeling", III, n\$82 noot 165, zich baserend op de Première Suite au Répertoire ou Mémorial Chronologique vermeldt dat dit met de registratie van het Bulletin des Lois van de tweede serie no.96 begint. Onjuist lijkt hetgeen tat door P VII cviii wordt wermeld, dat het eerste cahier van het Bulletin des Lois, dat onder de werking van het besluit wan 16 frimaire $\mathrm{V}$ in Belgie verspreid is, no.93 van de tweede serie zou zijn.

${ }^{142}$ FA inv.nr.112 "régistre des procès verbaux $n^{0}$ 5" $^{\text {" }}$ foll 16 vo onder $n^{2} 20 R 4$; inv.nr. 138 "Régistre aux arrêtés $3^{5 *}$ foll 76vo-77ro onder $\mathrm{n}^{\mathrm{n}} 20 \mathrm{R} 4$.
} 
Vous devez donc dorenavant, Citoyens, à mesure que vous les recevrez farre publier exactement et scrupuleusement dans toutes les communes de votre ressort les loüx et arrễés du Directoure Exécutif et vous y étes d'autant plus obliges que de [lees: si] quelqu"un de vos concitoyens se trouvoient poursuivi pour infraction i quelques unes de ces loix, et qu"il prouvat qu"elles n'ont pas êté publiees, vous serez personnellement punisables de la piece [lees: peine] qu"il aurait encourue ${ }^{43}$.

Twee maanden later al werd de algemene regel, vastgelegd in het besluit van 16 frimaire V, door het Directoire exécuitif herbevestigd. Het Directoire bepaalde dat een wet van 15 pluviôse $V$ ( 3 februari 1797) inzake achterstallige betalingen van zowel altijddurende renten als lijfrenten tussen particuliere personen niet alsnog behoefde te worden bekendgemaakt. De plaatsing ervan in het Bulletin des Lois en de ontvangst ervan in de departementale hoofdstad was voldoende. Een uitzondering op de algemene regel was niet aan de orde ${ }^{144}$.

Het rapport ${ }^{145}$ dat de minister van justitie Merlin aan het Directoire exécutif uitbracht, ingevolge het besluit van 16 frimaire $\mathrm{V}$, was wat later gereed, aangezien de deeloverzichten hem niet tijdig door de overige ministers waren overhandigd. Merlin had een overzicht samengesteld, voortspruitende uit eigen onderzoek en het door Bouteville opgestelde "tableau", dat hij als "projet d'arrêté" aan het Directoire voorlegde ${ }^{146}$. Bouteville had zijn "tableau" op 17 nivôse V (6 januari 1797) naar de ministers van justitie en binnenlandse zaken, alsmede naar een commissie uit de Conseil des Cinq-cents gezonden. Hij schreef dat hij gebruikgemaakt had van de naspeuringen en observaties van de commissarissen van het Directoire exécutif bij de departementen en de rechtbanken, maar het geringe aantal observaties was bij lange na niet genoeg om aan het verzoek om inlichtingen van de minister van binnenlandse zaken Bénezech te voldoen. Daarom had Bouteville alle door de vier nationale vergaderingen tot dan toe uitgevaardigde wetten, alsmede de besluiten van het Directoire, aan een onderzoek onderworpen ${ }^{147}$. Op de achtergrond speelde steeds het punt mee, of de ingezetenen van de negen départements réunis die op 1 germinal $\mathrm{V}$ (21 maart 1797) hun eigen vertegenwoordigers zouden benoenten, tevens de gehele Franse revolutionaire wetgeving van node hadden.

${ }^{14.3}$ FA inv.nr.259 "correspondance active et passive $n^{2} 21$ " fol 1 ro onder $n^{292 R 4}$, departementaal bestuur aan de kantonsmunicipaliteiten 3 nivôse $V(23 \mathrm{dec} 1796)$.

144 Zie regestenlijst onder de datum van 17 pluviôse $V(5$ feb 1797).

${ }^{145}$ Recuell de Lois et Reglemens pour les meuf Départemens réunis par la Loi du 9 Vendémiaire, an IV. en exécution de l"Arrêté du Directoire exécutif du 7 Pluviôse, an V (2 din; Parijs, ventôse V) I, ivi.. "Rapport du ministre de la justice au Directoire Exécutif" 7 pluviôse V (26 jan 1797).

146 Stevens, "Introduction législation révolutionnaire", 490-491; Parijs Arch.Nat. inv.nr. F" 30 "renseignemens divers" doss.5 "correspondance diverses relatives à l'organisation des départemens belges nouvellement réunis (ans IV-V)", Boutevilles "Tableau des Loix d'un intérest général, \& qui ne se trouvent pas entierement abrogées par des Loix postérieures émanées des trois assemblées nationales constituante, legislative, conventionelle et de la $1^{\text {ere }}$ législature constitutionnelle depuis l'établissement de la République et enfin des arrêtés du Directoire Exécutif concernant les departemens réunis par la loi 9 Vendemiaire an $4^{\text {ensen, }}$.

${ }^{147}$ Hubert \& Tihon, Correspondance Bonteville, II, 428-438, missive n²496, i.h.b. 429. 
Boutevilles "Tableau des Loix d"un Intérest général" geeft aan of wetten al dan niet bekendgemaakt zijn. Van de nog niet in de Verenigde Departementen bekendgemaakte wetten wordt vermeld of de bekendmaking alsnog raadzaam is. Merlins "projet d"arrêté" werd op 7 pluviôse V (26 januari 1797) door het Directoire exécutif als besluit gearresteerd. Dit tweedelige Recueil de lois et règlemens of Code Merlin omvat volgens het "registre ouvert" 424 wetten of delen van wetgeving ${ }^{148}$. Daaronder bevinden zich ook extracten uit ordonnanties daterend uit het ancien régime, het oudste uit de ordonnantie van augustus 1539 "sur le fait de la Justice", maar ook enige uit de grote ordonnanties uitgevaardigd ten tijde van Lodewijk XIV. Volgens Merlin was er tot dat moment niet gederogeerd aan die ordonnanties, waarbij hij zich beriep op één der eerste decreten van de Nationale Conventie van 21 september 1792 , welke bepaalde dat niet-herroepen wetten voorlopig van kracht bleven ${ }^{149}$. Het besluit van het Directoire exécutif bestaat uit drie kolommen, die respectievelijk aangeven "lois publiées", "actes qui en ont ordonné la publication" en "lois insérées au recueil" in chronologische volgorde ${ }^{150}$. Art. 1 van het besluit bepaalde:

Les loï, règlemens et arrêtés ci-dessus énoncés, seront, avec le présent arrêté imprimés et publiés dans les départemens véunis par la loi du 9 vendémiaire, an $I V$, pour y être exécutés en ce qui ne sera pas contraire aux dispositions des lois postérieures soient comprises dans la collection ci-dessus, soit qu'elles fassent partie de celles qui y ont été publiées précédemment, ou le seront en vertu de l'article ci-après dans les mêmes départemens.

Ingevolge het tweede artikel moesten alsnog 60 wetten en besluiten uit de Directoireperiode in de negen Verenigde Departementen worden bekendgemaakt en uitgevoerd. Daarvan is alleen het intitulé en de vindplaats in de tweede serie van het Bulletin des Lois aangegeven ${ }^{15 \mid}$. Daaronder bevinden zich nog een vijftal rechtsvoorschriften op het terrein van het bekendmaken en het van kracht worden van wetgeving ${ }^{152}$. De beide besluiten van het Directoire exécutif van 2 germinal IV (22 maart 1796) en 12 prairial IV (31 mei 1796) zijn daarvan de belangrijkste. In het eerstgenoemde besluit was onder meer het volgende bepaald:

${ }^{14 k}$ FA inv.mr. 283 "registre ouvert" no.257; Stevens, "Introduction législation révolutionnaire". 49 ! spreekt van "environ 438 " wetten.

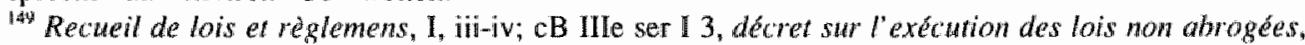
ook in Recueil de lois et reglemens. II, 1.

1 s.91 Ihidem, II, 397-464.

${ }^{151}$ Ibidem, 1., 464-470. Het eerste vormt thet arrêté qui règle provisourement le mode de publication des Lois wan 12 brumaire IV (3 nov 1795) [BL lle ser no.1 (1)] en het laatste merkwaardigerwijs het arrêté qui détermine la manière dont seront acquittés les frets et estuaries résultant de l'arrestation des batmens neutres van 9 frimaire V (29 nov 1796) [BL Ile ser no.95 (895)].

${ }^{152}$ Naast het al in de vorige noot genoemde besluit van 12 brumaire IV ( 3 nov 1795), zijn dit: de loi portam que celle d'un intérết général seront seules imprimées van 15 nivôse IV (5 jan 1796) [BL IIe ser no.17 (100)], het arrêté qui prescrit des mesures pow assurer l'exécution des lois van 20 pluviôse IV (9 feb 1796) [BL Ile ser no.26 (175)], het arrêté contenant des mesures relatives do l'exécution des lois wan 2 germinal IV (22 mrt 1796) [BL Ile ser no.35 (261)] en het arrêté qui détermine le mode à suive pour faire connaîre aux autorités constituées l'époque à compter de laquelle les lois ê actes du gouvernement deviemnent obligatoines dans chaque dêpartement van 12 praïriall IV (31 mei 1796) [BL IIe ser no.5। (436)]. 
Dans chaque administration centrale de département, ill sera ouvert un registre intitulé: Registre d'exécution des Lois et des arrếés du Directoire exécutif [art. I]. Ce registre portera le nom de chacune des administrations municipales du département ${ }_{\text {p }}$ et sera divisé en autant de chapitres qu'ill renfermera de lois ou d'arrêtés [art.2]. Chaque chapitre présentera la date de la réception de la loi ou de l'arrêté, le terme fixé pour son exécution, et le compte des diligences faites à cet effet par l'administration centrale ainsí que par chaque administration municiale de département [art.3]. Après l'expiration du délai prescrit pour l'exécution de la loi ou de l'arrêté, il sera fait un relevé du registre, avec indication des municipalités qui seront en retard, pour être envoye au Directoire exécutif par l'intermédiaire des ministres, chacun en ce qui le concernera [art:4].

Het departement Nedermaas heeft ook een dergellijk register geopend ingevolge het eerste artikel ${ }^{153}$, maar het bestrijkt slechts de periode 7 floréal IV (26 april 1796) tot 11 en 12 messidor IV ( 28 en 29 juni 1796). Bijna een jaar eerder dan de formele afkondiging wan het besluit via de Code Merlin. Verder heeft men alleen van de eerste expeditie een overzicht per kanton vervaardigd. Het besluit van 12 prairial IV droeg aan de commissarissen van het Directoire exécutif bij de departementale besturen op iedere decade aan alle autoriteiten in een departement een overzicht te doen toekomen van de Bulletins des Lois met de precieze dag van binnenkomst in de departementale hoofdstad ${ }^{154}$.

Stevens schrijft ${ }^{155}$ dat al op 25 pluviôse V (13 februari 1797) de Code Merlin in 25 exemplaren naar de commissaris van het Directoire exécutif in het departement van de Twee Neten werd gezonden. Blijkens Nedermaase archivalia evenwel, is het Recueil de Lois et Règlemens daar op 29 ventôse V (19 maart 1797) in de departementale hoofdstad ontvangen en geregistreerd. Daags daarna, op 30 ventôse, werd de Code Merlin naar de kantonsmunicipaliteiten doorgezonden. Eerst op 1 en 2 floréal V (20 en 21 april 1797) volgde de doorzending naar de commissarissen van het Directoire exécutif bij de gerechten en aan de vrederechters, nadat Girard, de commissaris van het Directoire exécutif bij het departementaal bestuur, een nieuwe zending had ontvangen van de minister van justitie ${ }^{156}$.

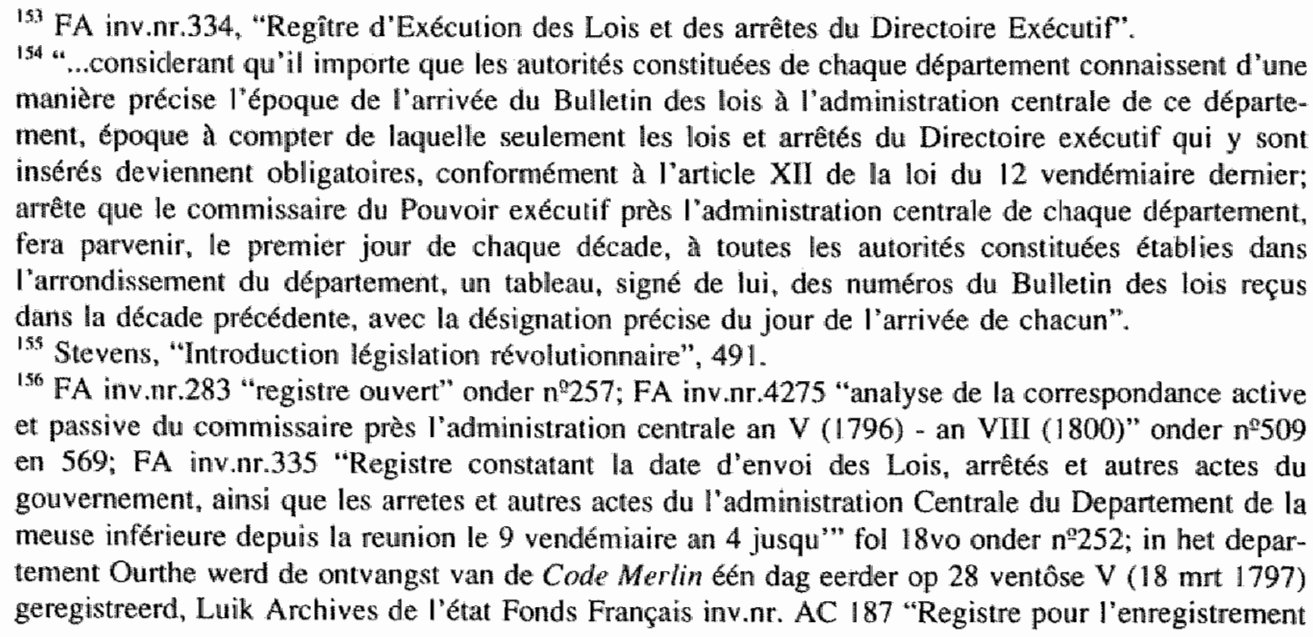

(wordt vervolgd...) 
Volgens Delecourt, schrijver van een artikel ${ }^{157}$ over de bibliografie van Franse wetsverzamelingen, kan men aan het tweedelige Recueul de Lois et Règlemens de officiële en authentieke exemplaren toevoegen van de besluiten van het Directoire houdende de bekendmaking van Franse wetten in de départements réunis, welke van de gestempelde handtekening van de minister van justitie voorzien zijn. Het zou hier dan moeten gaan om de onder het inventarisnummer 291 in het Frans Archief aanwezige collectie. Over de compleetheid ervan valt niets met zekerheid te zeggen. In het artikel wordt gesteld dat deze exemplaren de enige zijn die bewijskracht hebben ("faire foi en justice"), ondat ze de enig officièle zijn. Deze collectie wordt trouwens uiterst zeldzaam geacht.

In het zoëven genoemde artikel wordt eveneens gesteld dat het Recueil de Lois et Règlemens niet gevrijwaard is van vergissingen en lacunes op het gebied van de werkelijke datum van de wetgeving en de aanhaling van de afkondigingsbesluiten. Volgens Gordon ${ }^{158}$ werd ook het officiële karakter ervan in twijfel getrokken, omdat enkel de handtekening van de minister van justitie Merlin afgedrukt staat. Bij arrêté van 22 floréal V (11 mei 1797) heeft het Directoire exécutif deze twijfel weggenomen $^{1.59}$. De uitvaardiging ervan geschiedde naar aanleiding van een missive van de commissaris van de pouvoir exécutif bij de burgerlijke rechtbank in het departement Jemappes aangaande moeilijkheden bij de uitvoering van de wetten opgenomen in de Code Merlin. Enerzijds werd er gesteld dat de uitvoering ervan nog niet door het Directoire exécutif was verordonneerd en dat het besluit van 7 pluviôse $\mathrm{V}$ slechts een voorstel was, aangezien het door geen enkel lid van het Directoire was gesigneerd. Anderzijds werd er gesteld dat het voldoende was dat de toezending officieel was geschied en dat de handtekening van de minister van justitie de echtheid ervan waarmerkte en dat de wetten dus verbindend waren. De burgerlijke rechtbank vroeg slechts of het ontbreken van de ondertekening door het Directoire exécutif een beletsel vormde voor cle toepassing van deze wetten. Het Directoire besliste dat over de voorgelegde kwestie niet hoefde te worden beraadslaagd, zich beroepende op art. 3 van de wet van 10 vendémiaire IV ( 2 oktober 1795) dat de minister van justitie belastte met het drukken en verzenden van besluiten en instructies van het Directoire aan de bestuurlijke en gerechtelijke autoriteiten. Voorts beriep het Directoire zich erop dat het

\footnotetext{
is6o (...vervalg)

des loix et arrêtés rendus obligatoires au Département, dressé au secretariat de l'administration centrale de ce departement, en conformité de l'article 12 de la loi du 12 vendémiaire an $4^{\mathrm{e}}$. Commençant au premier vendémiaire an 5 de la République française une \& indivisible" fol 30 .

De verzending in ventôse komt overeen met een missive van de minister van justitie aan diens collega van binnenlandse zaken op 22 ventôse V (12 mrt 1797), waarin hij schriftt: "le 25 de ce mois jen ferai faire un premier envoi qui sera suffisant pour les administrations centrales et municipales des Départemens rêunis". De minister van binnenlandse zaken wraagt in een klad-schijven om 12 exemplaren op 27 ventôse $V\left(17 \mathrm{mrt}\right.$ 1797), Parijs Arch.Nat. inw.nr. $\mathbb{F}^{\text {le }} 27$ doss 2 "Pays annexes ou dependants".

${ }^{157}$ Delecourt, "Bibliographie", $125-126$.

${ }^{15 \%}$ Gordon, "Politieke en Gerechtelijke indeeling", III, n"83 noot 168.

${ }^{159}$ LA VI fol 27 vo-28vo; P VII clix; FA inv.nr.286 "arrêtés du Directoire exécutif et lois, écrits et imprimés an IV - an VIII", arrểé concernant au Recueil de lois envoyé aux neuf départemens réunïs. Dit besluit is onder n"268 op 1 prairial $V(20$ mei 1797) in het "registre ouvert" ingesehreven.
} 
besluil van 7 pluviôse V voorzien was van het zegel van de Franse Republiek en dat aldus het besluit alle de vereiste karaktertrekken van authenticiteit in zich droeg. Ingevolge hiervan "on ne peut légitimement contester ni l'existence de cet arrêté, ni l'authenticité de la copie qui en est imprimé à la fin du recueil ci-dessus mentionné". Het onderhavige arrêtté van 22 floréal V diende te worden gedrukt en aan alle bestuurlijke en gerechtelijke autoriteiten in de negen Verenigde Departementen te worden verstuurd om aan elke onduidelijkheid een einde te maken.

Blijkens briefwisselingen op de ministeries te Parijs overigens, werd de Code Merlin ook daar voortdurend bij de werkzaamheden geraadpleegd ${ }^{160}$.

\section{Uitvoeringsproblemen voortvloeiend uit de wet van 12 vendémiaire $I V$}

\section{a. De wet van 24 brumaire VII}

De Conseil des Cinq-cents en de Conseil des Anciens aanvaardden op 24 brumaire VII (14 november 1798) de loi relative à l'exécution de celle du 12 Vendémiaire an IV sur la publication des lois ${ }^{161}$. In de zogenoemde "déclaration d'urgence" werd gesteld dat het belangrijk was om een einde te maken aan de twijfels die gerezen waren inzake het effect van de wet van 12 vendémiaire IV (4 oktober 1795). Al geruime tijd daarvoor had het Directoire exécutif in een "message" de Conseil des Cinq-cents in kennisgesteld van de problematiek rond de wet van 12 vendémiaire IV en het van kracht worden van de anterieure wetgeving in de départements réunis en de Conseil verzocht om daarover een uitspraak te doen ${ }^{162}$. Het belang van de wet schuilt in de eerste twee artikelen:

La loi du 12 vendémiaire an IV est obligatoire, conformément à ses dispositions, du jour de son arrivée à l'administration centrale de chaque département (art.1). Les lois envoyées dans les anciens départemens, et celles dont la publication avait été ordonnée dans les départemens réunis par la loi du 9 vendémiaire an IV, et qui n'avaient pas été publiées suivant les formes anciennes lors de l"arrivée officielle de la loi du 12 vendémiaire de la même année au chef-lieu de chaque département. sont devenues obligatoires du jour de ladite arrivée (art.2).

Art.1 laat het verbindend worden van de wet van 12 vendémiaire IV inzake de verzending en de bekendmaking van wetten regeren door hetgeen zij zelf in art. 12 be-

${ }^{161}$ Parijs Arch.Nat. inv.nr. F'e 27 doss. 2 "Pays annexés ou dependants", het hoofd van de tweede divisie ("secours publics") van de bureaus van het ministerie van binnenlandse zaken, Dernieau, vraagt om de Code Merlin aan Champagneux, chef de cabinet, van de eerste divisic van het ministerie, warop deze terugschrijft (concept) op 19 floreal V ( 8 mei 1797): "Je vous envoye, mon cher collegue, le recueil en deux volumes que vous me demandez, mais je vous observe que ce n'est qu"en communication et à titre de prêt; les travaux de ma division me mettent dans le cas d'en avoir souvent besoin. s'il etoit necessaire que vous en eussiez un semblable, je crois que le ministre de la Justice pourroit le procurer. Quant aux lois et arrêtés posterieur publiés dans les départements réunis ils doivent se trouwer en géneral consignes dans le bulletin des loix".

${ }^{16} \mathrm{BL}$.le ser no.240 (2176).

162 MAP III 54-56, "message du directoire exécutif, concernant la publication des lois dans les departemens réunis" van 28 germinal V (17 aprill 1797). 
paalde voor het toekomende. Voor het in werking treden van de wet van 12 vendémiaire IV zelf was dus niet meer de oude wijze van bekendmaken in de vorm van openbare voorlezing, herdrukken en aanplakking onder trompetgeschal of tromgeroffel van toepassing ${ }^{163}$. Die wetten die al naar de departementen van het Frankrijk van vóoór 1792 en naar de negen départements réunis waren verzonden, maar niet bekendgemaakt waren overeenkomstig de oude formaliteiten, werden geacht verbindend te zijn vanaf het moment dat de binnenkomst van de wet van 12 vendémiaire IV zelf officieel geregistreerd werd (art.2). In het departement van de Nedermaas was dat dus op $1 \|$ frimaire IV ( 2 december 1795).

Over deze afkondigingsproblematiek zijn indertijd ook tot in hoogste instantie processen gevoerd. In een ingewikkelde erfrechtelijke kwestie, waarbij aan de orde was of de afwikkeling van de nalatenschap diende te geschieden overeenkomstig het oude recht, dan wel overeenkomstig de nieuwe revolutionaire erfrechtelijke beginselen, was allesbeslissend of het nieuwe Franse recht bij het openvallen van de nalatenschap reeds vigerend was. Het betreft een casus uit het Dijle-departement, die in hoger beroep voor de Nedermaase burgerlijke rechtbank diende. De burgerlijke rechtbank in het Dijle-departement vonniste op 24 thermidor IV (11 augustus 1796) dat het nieuwe Franse recht op de dag van het openvallen van de nalatenschap vigerend was en dat mitsdien de testamentaire bepalingen inzake de goederen die over de departementen Dijle, Leie en Schelde verspreid lagen niet langer toepasselijk waren ${ }^{164}$.

In het hoger beroep dat diende voor de burgerlijke rechtbank in het departement van de Nedermaas, luidde de uitspraak precies tegengesteld. De rechtbank oordeelde dat de wet van 12 vendémiaire IV niet al vanaf 5 frimaire IV (26 november 1795), de dag waarop de volksrepresentanten/gouvernementscommissarissen de bekendmaking ervan bevalen, verbindend was, maar enige dagen later, in ieder geval na het openvallen van de nalatenschap en dus was het oude erfrecht ter zake van deze nalatenschap nog van kracht ${ }^{165}$. Tweemaal werd in een cassatiearrest dit vonnis van het tribunal civil van het departement van de Nedermaas vernietigd, op 9 messidor VII (27 juni 1799) en 2 thermidor IX (21 juli 1801) $)^{\text {t6tit. }}$

que le jugement du tribunal du département de la Meuse inférieure, du 4 [lees:II] vendémiaire an 5, qui a écarté la demande de Deladeuze [één der procespartijen], sous prétexte que la loi du 17 nivôse an 2, sur laquelle elle était fondée, n'avait pas etté publiée, a violé les art. 11 et 12 de la loi du 12 vendémiaire an 4 , interprétés par celle du 24 brumaire an 7 .

${ }^{16.3}$ Gordon, "Politieke en Gerechtelijke indeeling", III, n:86 nt.. 172.

1 tow Merlin, Questions de droix, 675-676, s.v. "pays rếunis".

${ }^{105}$ NRA inv.nr.57 "Régistre des jugements definitifs rendu par le tribunal civil du Département de la Meuse inférieure I $I^{\text {re }}$ section" fol 86vo-93ro; het vonnis van 11 vendémiaire V (2 okt 1796) is ook gedrukt voor de Conseil des Cinq-cents. Parijs Arch.Nat, inv.nr. AD XVI 52 "Villes et provinces II 1789-18.15 Meuse, Meuse-Inférieure, Montblanc, Mont-Terrible, Mont-Tonnerre, Morbihan", "Pièces relatives a la question de savoir à quelle époque la loi du 12 vendémiaire an 4 sur la publication des lois a opéré dans les neuf départemens réunis, par la loi du 9 vendémiaire an 4 ".

"St. Merlin, Questions de droit IV, 676-677 s.v. "pays réunis"; I.B. Sirey, Receuil général des lois et des arrêts, en matière civile, criminelle, commerciale et de droit public depuis l'avènement de Napoleon (12 din; Parijs, s.a.) I, $2^{\circ}$ partie, 390-391. 
De laatste zinsnede is opmerkelijk: een latere wet werd te hulp geroepen om het vonnis van een lagere rechtbank te vernietigen. Toen de burgerlijke rechibank in het departement Nedermaas uitspraak deed, kon zij natuurlijk geen rekening houden met een toen nog niet-bestaande wet. Dit geval staat echter niet op zichzelf. Wehrhahn merkt hierover op: "Trotz ihrer grundsätzlichen Ablehnung von Rückwirkungsbestimmungen folgte die Cour de cassation diesem Gesetze [van 24 brumaire VII] vorbehaltlos" ${ }^{\prime 67}$. Het tribunal de cassation motiveerde dit bij de vernietiging van een andere uitspraak van het tribunal civil in het departement van de Nedermaas op 27 messidor VII (15 juli 1799) als volgt:

Considérant qué cela est ainsi expressément décidé par la loi du 24 brum. an 7 , qui, quoique posterieure au jugement attaqué, n"en doit pas moins, sans effet rétroactif, servir de fondement à l'annulation de ce jugement, puisqu 'elle ne fait que confirmer les dispositions de celle du 12 vend. an 4 , ainsi qu"elle le declare par ces mots, conformément à ses dispositions ${ }^{16 \%}$.

De departementale burgerlijke rechtbank had namelijk op 2 prairial VI (21 mei 1798) de régie de l'enregistrement et des domaines niet-ontvankelijk verklaard in haar conclusies in de zaak tegen de Hasseltse ex-notaris Putzeijs, die bepalingen van de wetten op de registratie en het zegelrecht had overtreden. In zijn verweer stelde Putzeijs dat ten tijde van het passeren van de akten, die wetten nog niet officieel bekendgemaakt waren. De burgerlijke rechtbank was dat ook van oordeel, met een toch opmerkelijke argumentatie. Volgens de rechibank was het eerst voldoende dat wetten ower het gehele departement verbindend waren ná het besluit van 16 frimaire $V$ ( 6 december 1796), en dat het besluit van de volksrepresentanten van 5 frimaire IV (26 november 1795 ) dat de naleving beval van de wet van 12 vendémiaire IV geen kracht van wet had en dus de oude manier van bekendmaking in de gemeenten handhaafde. Voorts oordeelde de rechtbank, dat het afkondigingsbesluit van het Directoire exécurif van 9 nivôse IV (30 december 1795), dat de bekendmaking van de wetten inzake de registratie en het zegelrecht gelastte, volgens de letter van het besluit ook zelf overal waar dat nodig mocht zijn, bekendgemaakt en aangeplakt diende te worden, angezien het besluit zelf ook uitvoerige nadere bepalingen behelsde ${ }^{169}$. Het tribunal de cassation deelde deze opvatting van de Nedermaase burgerlijke rechtbank dus niet.

Wat betreft de regestenlijst dient dus voorzichtigheidshalve rekening te worden gehouden met het feit dat wetgeving die voor het verbindend worden van de wet van 12 vendémiaire IV op 11 frimaire IV ( 2 december 1795 ) is toegezonden, maar niet bekendgemaakt is overeenkomstig de oude vorm, op 11 frimaire IV verbindend is geworden. Dit laatste laat zich zeer moeilijk vaststellen. Het "registre ouvert" constateert formeel de datum van registratie van de ontvangst van toegezonden wetten en

\footnotetext{
167 Wehrhahn, "Verkiindung", 278.

16* Recueil génểral des lois et des arrêts awec notes et commentaires, présentant sur chaque question lé résumé de la jurisprudence et la doctrine des auteurs, rédigé sur l"ancien recueil général des lö́s el des arrêts, fondé par M. Sirey, revu et complété par L.M. Devilleneuve \& A.A. Carette (10 din; Parijs, (840-1843) I, I partie, 224.

16" NRA inv.nr.63 "Regître des jugemens définitifs de la $2^{e}$ section commençant au 2. Prairial et finissant au 27. Thermidor de l'an $6^{\circ}$ de la Republique Francaise", fol 1ro-3vo.
} 
besluiten. Het verstandigst is om deze data van verbindend worden in het departement van de Nedermaas aan te houden. Alleen in geval van een juridisch geschil zou dit preciezer formeel kunnen worden vastgesteld, voor zover er over geprocedeerd werd.

Zelfs besliste het tribunal de cassation, dat wanneer in een afkondigingsbesluit van het Directoire exécutif bepaall was dat het besluit zelve moest worden bekendgemaakt en aangeplakt, dit niet van invloed was op het in werking treden van in dat besluit genoemde wetgeving. In het departement Ourthe vervolgde de régie de l'erregistrement et du domaine national de notaris Dumoulin te Ensival (kanton Hodimont) voor het niet hebben voldaan van registratierechten en het zegelrecht bij het opmaken van een akte. Dumoulin stelde zich onder meer op het standpunt dat ten tijde van het opmaken van de akte de onderhavige wetten nog niet verbindend waren, aangezien zij niet overeenkomstig het bepaalde in het afkondigingsbesluit van het Directoire exécutif in de kantonshoofdplaats waren bekendgemaakt. Het tribunal civil in het departement Ourthe stelde notaris Dumoulin in het gelijk, maar in cassatie werd de zaak verwezen naar het tribunal civil te Maastricht, wegens schending van de artt.11 en 12 van de wet van 12 vendémiaire IV, die immers stelden dat wetgeving over her gehele grondgebied van een departement verbindend was, zodra de binnenkomst in departementale hoofdstad formeel geregistreerd was ${ }^{170}$. Dumoulin voerde als verweer aan, dat het tribunal de cassation niets had gezegd over het afkondigingsbesluit van het Directoire.

De burgerlijke rechtbank in het departement Nedermaas besliste op 22 thermidor VII (9 augustus 1799) opnieuw ten gunste van notaris Dumoulin, gelet op het bepaalde in het afkondigingsbesluit ${ }^{171}$. De régie ging wederom in cassatie. In het arrest van 15 pluviôse IX (4 februari 1801) vernietigde het tribunal de cassation daarop het vonnis van de Nedermaase departementale rechtbank:

... la seconde partie du premier de ces articles [art. ॥ van de wet van 12 vendémiaire IV], en autorisant le directoire exécutif et les administrations centrales et municipales d'ajouter à ce mode de publication telles autres formalités qu'ils croiraient nécessaires, ne fait pas dépendre le caractère obligatoire de la loi de l'observation de ces formalités (...) et qu'au fait, l'art.7 de l'arrêté du directoire exécutif du 9 niv. an 4 ne présent d'affiche que par rapport à lui, et non point quant à la loi sur l'enregistrement, dont il ne parle aucunement ${ }^{172}$.

\section{b. Welke wetgeving, geplaatst in de Bulletins des Lois, in werking getreden?}

Volgens Stevens in zijn Leuvense dissertatie over de Franse wetgeving op het notarisambt en het Antwerpse notariaat waren in werkelijkheid de wetten die vanaf numero 11 in het Bulletin des Lois van de tweede serie opgenomen waren in de départements réunis van kracht ${ }^{173}$. De schrijver heeft zich daarbij hoogstwaarschijnlijk gebaseerd

\footnotetext{
${ }^{17}$ Recueil général des lois et des arrêts, $\mathrm{I}_{\text {" }}{ }^{\text {pe }}$ partie, 183.

171 NRA inv.nr. 49 "minuten van vonnissen en akten" onder $n$ " 838 .

${ }^{172}$ Recueil gêrnéral des lois et des arrêts, I. Ire partie, 422 .

${ }^{17.3}$ Stevens, "Franse wetgeving notarisambt", I, 24; in gelijke bewoordingen ook in idem, "Introduction législation rếvolutionnaire", 488.
} 
op een schrijven van Bouteville, gericht aan het bestuur van het Schelde-departement: In dit schrijven van 16 nivôse IV (6 januari 1796) is Bouteville van mening, dat:

... les lois nouvelles, inserées au Bulletin, à compter du $\mathrm{n}^{9} 11$, sont obligatoires pour les administrations des nouveaux departements, du jour où le Bulletin officiel en est distribué au cheflieu du département, et que l"arrivếe en est constatée sur le regïstre tenu à cet effet. L'article 12 de la loi du 12 vendémiaire est formell sur ce point ${ }^{174}$.

Aan het slot van de paragraaf over de invoering van de Franse wetgeving stelt Stevens dat pas vanaf 16 frimaire $V(6$ december 1796) de Franse wetgeving, zoals zij geplaatst is in het Bulletin des Lois, van kracht werd, behoudens uitdrukkelijke andersluidende bepaling. Men dient volgens hem ook rekening te houden met de omstandigheid, dat wetten die tussen 12 vendémiaire IV ( 4 oktober 1795) en 18 pluviôse IV ( 7 februari 1796$)$ gedurende deze periode als van kracht zijnde werden beschouwd ${ }^{175}$. Volgt men Stevens' zienswijze dan betekent dat voor het departement van de Nedermaas, dat niet alleen alle nummers van het Bulletin des Lois tot en met numero 24 tijdelijk als verbindend werden beschouwd, maar ook nog de laatste nummers $(192$ - 205) uit de eerste serie van het Bulletin des Lois. Volgt men Boutevilles zienswijze dan betekent dit voor het departement dat vanaf 1 nivôse IV (22 december 1795) de Bulletins des Lois van de tweede serie verbindend zijn geworden, indien men daaronder no. 11 mede begrijpt ${ }^{176}$.

Blijkens Parijse archivalia evenwel, werden de Bulletins des Lois van de tweede serie tot en met no.94, onder verwijzing naar het bepaalde in het besluit van 18 pluviôse IV, beschouwd niet bekendgemaakt te zijn in de negen Verenigde Departementen ${ }^{177}$. Van ieder nummer van het Bulletin diende door de departementale besturen de datum van binnenkomst in de departementale hoofdstad te worden aangegeven. De data voor de negen départements réunis zijn steeds blanco gelaten. Deze overzichten zijn door de minister van justitie Lambrechts, de oud-commissaris van het Directoire exécutif in het Dijle-departement en oorspronkelijk afkomstig uit Sint-Truiden, eigenhandig gecertifieerd. De "tableaux" zijn opgemaakt volgens de berichten van ontvangst geleverd door de centrale administraties van de departementen.

Het "Tableau indicatif de l'époque à compter de laquelle les lois et actes du Gouvernement insérés dans le $\mathrm{N}^{2} 1^{\text {er }}$ du Bulletin des lois, sont obligatoires dans chacun des Départemens de la République", door de minister gecertifieerd op 19 pluviôse VIT (7 februari 1799), vermeldt als observatie bij het Dijle-departement:

Voyez dans le $\mathrm{N}^{2} 25$ du Bullletin des lois $2^{\circ}$ série l'arrêté du 18 Pluviôse an 4 d'après lequel les lois ne devaient être obligatoires dans les. Départemens réunis par la loi du 9 Vendémiaire an 4 ,

\footnotetext{
${ }^{174}$ Hubert \& Tihon, Correspondance de Bouteville, I, 39-40, missive $\mathrm{n}^{\mathrm{2}} 23$.

${ }^{175}$ Stevens, "Franse wetgeving notarisambt", 30.

${ }^{176}$ Een complicerende factor is hierbij nog dat BL Ile ser no.5 verlaat, maar gelijktijdig met no. 11 , in het "registre ouvert" is geregistreerd.

${ }^{17}$ Parijs Arch.Nat. AF" 40 doss. 142 "Dates de la publication des lois contenues dans les Bulletims $n^{\text {os }}$ 1 a 50; doss. 143 "Dates de la Publication des lois contenues dans les B $B^{\text {tins }}$ no"s 51 a 100 "; doss. 144 "Dates de la Publication des lois contenues no's 1 à $100 "$ ".
} 
qu'autant qu'elles y avaient été ou y seraient envoyeses pour y être observés en execution d'un arrête spécial \& $\&^{a}$. Ce mode de publication a eté abrogé par un arrêté du 16 frimaine an 5 , et a compter de cette époque toutes les lois insérées dans le Bulletin ont été obligatoires dans les Départemens réunis du jour de leur arrivée aux chef-lieux. La seconde colonne des tableaux restera donc en blanc, pour ces départem", jusqu"au No95 dont l"envoi a survi celui de l'artête du 16 frimaire an $5^{178}$.

Het "Tableau indicatif" voor numero 95 van het Bulletin des Lois, dat door de minister van justitie op 6 ventôse VII (24 februari 1799) gecertifieerd werd, vermeldt als observatie bij het Dijle-departement:

\footnotetext{
Voyez sur le $1^{\text {er }}$ tableau l'observation relative aux Départements réunis par la loi du 9 Vendémiaire an 4. L'arrêté du 16 frimaire an 5 ayant ordonné que toutes les lois insérées dans le Bulletin, seront obligatoires dans ces Departements du jour de leur arrive aux chefs lieux et I'envoi du N\$95 ayant êté fait immédiatement après celui de l'artêtée, les êpoques de la promulgation des lois dans les Départements réunis, sont indiquées àt compter de ce $\mathbb{N}^{\text {at7 }}$.
}

De genoteerde datum van ontvangst te Maastricht van dit Bulletin des Lois, 29 frimaire V (19 december 1796), stemt keurig overeen met de datum van registratie in het "registre ouvert". Gordons veronderstelling dat de Bulletins des Lois van de tweede serie voortaan met ingang van no.96 na ontvangst te Maastricht terstond verbindend waren, wordt door het bovenstaande weerlegd ${ }^{180}$.

Het is aanbevelenswaardig rekening te houden met de mogelijkheid dat delen van wetgeving die tot no.95 in de tweede serie van het Bulletin des Lois zijn geplaatst, en die noch door een bijzonder afkondigingsbesluit van het Directoire exécutif, noch door art. 2 van het besluit van 7 pluviôse $V$ (26 januari 1797), zoals dit ook in de Code Merlin is opgenomen, niet in het departement van de Nedermaas verbindend geworden zijn. Dit laat zich slechts van geval tot geval vaststellen. Met name zal dit het geval zijn met rechtsvoorschriften die niet rechtstreeks het departement regarderen.

Ter afsluiting van deze paragraaf zal nog een drietal concrete problemen met betrekking tot de afkondiging van wetgeving in het departement van de Nedermaas worden aangestipt.

Waarschijnlijk beschouwdle het departementaal bestuur na registratie van de Bulletins des Lois deze als verbindend voor de ingezetenen van het departement. De Nedermaase autoriteiten gaven opdracht tot het herdrukken, bekendmaken en aanplakken van het besluit relatif aux Fuyards de la première réquisition ${ }^{181}$ van 8 pluviôse IV (28 januari 1796). Het departementaal bestuur besliste op eendere wijze over de wet op de vordering van het dertigste paard. Deze wet was geplaatst in het Bulletin des Lois no.24, het voorlaatste nummer waarin het arrêté van 18 pluviôse IV inzake de bijzondere wijze van afkondiging voor de negen Verenigde Departementen was opgenomen. Circa één maand na registratie in het departement van de Nedermaas

\footnotetext{
${ }^{178}$ Parijs Arch.Nat. AF ${ }^{111} 40$ doss. 144.

174 lbidem.

${ }^{1 * 4}$ Zie noot 141 ; dit geldt eveneens voor de opvatting van de samenstellers wan de Pasinomie.

${ }^{18 \|}$ BL he ser no.22 (138): FA inw.nr. 107 fol 229ro onder n"555 "registre des procés-verbaux".
} 
kondigde het Directoire de wet bij bijzonder besluit af ${ }^{182}$. Deze gang van zaken stemde owereen met de opvatting van Bouteville op dat moment, die het Bulletin des Lois variaf $\mathrm{n}^{1} 11$ als verbindend beschouwde.

In hetzelfde nummer 11 van het Bulletin des Lois was geplaatst de wet van 19 frimaire IV (10 december 1795) houdende een beroep op de financiële fondsen van de gegoede burgers in de vorm van een dwanglening, welke op 1 nivôse IV (22 december 1795) te Maastricht geregistreerd werd. Van de zijde van het departementaal bestuur werd opgemerkt dat men er rekening mee zou houden. Niettemin had het departementaal bestuur twijfels over de verbindbaarheid wan deze wet, ondanks dat de minister van financiën Faipoult ${ }^{183}$ heel uitdrukkelijk tevoren reeds een begeleidend schrijven aan het departementaal bestuur van de Nedermaas had gericht. Daarin zei hij dat de wet niet op eendere wijze tenuitvoergelegd kon worden als in de overige Franse departementen, maar dat het departementaal bestuur de invordering aan de plaatselijke omstandigheden diende aan te passen en voor het overige naar bevind van zaken diende te handelen ${ }^{184}$. In een missive aan de volksrepresentanten/gouvernementscommissarissen vroeg de conseil de l'administration of wetten die rechtstreeks door de minister toegezonden waren, zonder door de gouvernementscommissarissen bekendgemaakt te zijn, tenuitvoergelegd dienden te worden. Zij werden eveneens uitgenodigd de tenuitwoerlegging van de gedwongen geldlening te bevelen ${ }^{185}$. Het antwoord hierop van de gouvernementscommissarissen kon niet worden opgespoord. Het departementaal bestuur heeft de wet van 19 frimaire IV gewoon op 29 frimaire IV geregistreerd in het "registre ouvert", zonder melding te maken van een speciaal afkondigingsbesluit. Op dezelfde wijze is de wet opgenomen in het overzicht dat de Code Merlin geeft. Korte tijd later kon er geen misverstand meer over bestaan, aangezien er op 26 frimaire IV (17 december 1795) al een besluit uitgevaardigd was door het Directoire exécutif over de inning van de dwanglening in de negen Verenigde Departementen.

Een derde en laatste opmerkelijke problematiek wordt gevormd door de wel of niet formele invoering van het douaneregime. Bij besluit van 3 ventôse IV (22 februari 1796) beval het Directoire dat het Franse douaneregime over het gehele grondgebied van de negen Verenigde Departementen van kracht zou worden, hetgeen ook betekende dat de vrijhaven van Oostende werd opgeheven. De Pasinomie verwijst bij dit besluit naar een besluit van de volksrepresentanten van 29 frimaire IV ( 20 december 1795), dat de bekendmaking beval van een hele reeks wetten inzake de douanewetge-

\footnotetext{
1\%2 Zie regestenlijst onder de datum van 15 pluviôse IV (4 feb 1796); FA inv.nr.107 fol 292vo onder

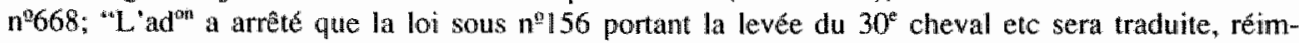
primée, publiée et envoyée dans toutes les communes du département".

183 Tullard, Fayard \& Fierro, Histoire et dictionnaire, 812 s.v. "FAIPOULT (Guillaume Charles)"; minister van 8 nov 1795 tot 13 feb 1796.

"FA inv.nr.233 "ingekomen en minuten van uitgaande stukken" onder n"375 (29 frimaire), minister van financiën aan Nedermaas 24 frimaire IV (15 dec 1795), ook in FA inv.nr.274 "correspondance des ministres an 4 " fol 34vo-35ro.

${ }^{145}$ FA inv.nr.274 "correspondance des ministres an 4" fol 13 onder $n^{\circ 9}$ Nedermaas aan volksrepresentanten 29 frimaire IV (20 december 1795).
} 
ving ${ }^{\sharp 85}$. Verreweg de meeste wetten en besluiten zijn niet opgenomen in het "registre ouvert", terwijl enkele in het overzicht van de Code Merlin als bekendgemuakt staan genoteerd, of wel daarin zijn opgenomen. Dit betekent dat ze ook niet opgenomen zijn in de regestenlijst van afgekondigde wetgeving. Blijkens archivalia hadden de volksrepresentanten al de aanzet gegeven tot de invoering van het nieuwe douanestelsel: bij besluit van 26 brumaire IV (17 november 1795) kon de aanvankelijk al eerder voorziene invoering vanwege administratieve belemmeringen uitgesteld worden tot de datum van 1 nivôse IV (22 december 1795) ${ }^{187}$. Het opmerkelijke nu is, dat het Nedermaase departementale bestuur aan de minister van financiën Ramel $^{188}$ berichtte, dat tot tevredenheid het douanestelsel "en pleine activité sur les frontières de notre département" was ${ }^{189}$. Kort daarvoor evenwel, had het departementaal bestuur aan de directeur van het douanewezen te Roermond nog geschreven, dat het nog niet precies kon zeggen, wanneer de wetgeving ter zake in de hoofdplaatsen van het departement zou worden bekendgemaakt, vanwege het feit dat men te Brussel nog niet gereed was met het drukken en de vertaling ervan ${ }^{190}$.

De commissaris van het Directoire exécutif in het Dijle-departement, Lambrechts, daarentegen schreef een maand later in een brief aan de minister van justitie dat de wetgeving op douanegebied niet gedrukt was volgens een besiuit van de volksrepresentanten. De bekendmaking ervan was volgens Lambrechts noch door de volksrepresentanten, noch door het Directoire bevolen, maar de directeur van het douanewezen had wel de wetgeving ter zake laten drukken. "Il convient, Citoyen Ministre, de réparer très promptement cette irrégularité qui peut animer de très grandes difficultés, puisque ces lois ne sont pas publiées dans la forme voulue"|191. Ondanks de verzekering van het departementaal bestuur dat de douanewetgeving volledig nageleefd werd, signaleerde gouvernementscommissaris Bouteville toch problemen. Van de zijde van de dienst van het douanewezen beklaagde men zich over het niet-bekendmaken van de douanewetgeving in de landstaal in het departement van de Nedermaas. Het departementaal bestuur stelde daarop voor dat de vertaling en het drukken beter via Brussel zou kunnen geschieden ter vermijding van overbodige kosten. De drukkerij te Maastricht kon al het werk ook niet aan. Bovendien kon men de ingezetenen niet dwingen zich te conformeren aan deze wetten, zolang zij er geen kennis van hadden, "faute de promulgation"192.

1*6 P VII Ivi, IXiv-Ixv; wat het afkondigingsbesluit van de volksrepresentanten betreft, wordt er verwezen naar de zogenoemde Collection de Gand, zie hierover Delecourt, "Bibliographie", 125.

1*7 Parijs Arch.Nat. inv.nr.C 2720 "Papiers de Portiez de l'Oise relatifs aux départemens belges an III - an V". Précis des Arrêtés les plus importans adoptés. par les Représentans du Peuple au Conseil du Gouvernement Brumaire an $4^{\text {ex: }}$, niet-gesigneerd besluit.

1* Soboul, Dictionnaire historique, 881-882 s.v. "RAMEL NOGARET Jacques", minister van 14 feb 1796 tot 20 jul 1799.

FA inv.nr.275 "registre $n^{\text {in }} 1$ correspondance ministerielle" fol 59vo-60ro, Nedermaas aan minister van financiën 16 ventôse IV (6 mrt 1796).

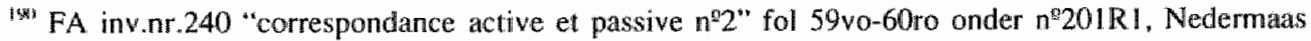
aan Turk, directeur der douane 11 ventôse IV (1 mrt 1796).

${ }^{198}$ Parijs Arch.Nat. inv.nr.BB ${ }^{3 / 1} 164$, Lambrechts aan minister van justitie 18 germinal IV (7 apr 1796). ${ }^{192} \mathrm{FA}$ inv.nr. 248 "correspondance active et passive $\mathrm{n}^{\circ} 10^{\prime}$ " fol $122 \mathrm{vo}-124 \mathrm{ro}$ onder $\mathrm{n}^{2} 2658 \mathrm{R} 1$, Bouteville aan Nedermaas 11 messidor IV (29 jun 1796); inv.nr.249 "correspondance active et passive $\mathrm{n}^{21} 1$ " foll 205vo-206ro onder $n 22658 \mathrm{R}$. , Nedermaas aan Bouteville 25 messidor IV (13 jul 1796). 
De minister van justilie Merlin was in een schrijven op 24 fructidor IV (10 september 1796) aan de commissaris van de pouvoir exécutif bij de burgerlijke en criminele rechtbank in het departement van de Nedermaas heel stellig. Na een speciaal onderzoek wat betreft de bekendmaking van de douanewetten in de départements réunis, had hij “... acquis la certitude qu'elles l'ont étế toutes, à compter de celle du 22 aoust $1791^{\prime *}$. Merlin was verbaasd over het feit dat in weerwil van art.12 van de wet van 12 vendémaire IV het tribunal civil weigerde om deze wetgeving toe te passen, "sous prétexte qu'elles n'ont pas été proclamés". De minister verzocht de commissaris de leden van de rechtbank op hun plicht te wijzen, teneinde te voorkomen dat hij nadere maatregelen zou moeten nemen. Niettemin vond hij het van belang om alsnog de douanewetgeving te proclameren om misbruik tegen te gaan. Te dien einde had hij tevens de commissaris van het Directoire exécutif bij het departementaal bestuur aangeschreven ${ }^{193}$. Op 6 vendémiaire $V(27$ september 1796) stelde het departementaal bestuur de Brusselse drukker bij het leger, Armand Gaboria, in kennis van de goede ontvangst in drie afzonderlijke zendingen van 500 gedrukte exemplaren van de "code des douanes nationales", alsmede van 500 exemplaren ervan in de Vlaamse taal $^{194}$. Voor zover kan worden nagegaan is de douanewetgeving naderhand niet alsnog ingeschreven in het "registre ouvert".

\section{Slotbeschouwing}

Het van kracht worden van de wetgeving in de bij de wet van 9 vendémiaire IV bij Frankrijk ingelijfde gebieden, waaronder het departement Nedermaas, heeft, zoals te verwachten kon zijn, de nodige moeilijkheden opgeleverd. Alleen al de formele afkondiging leverde problemen op, laat staan de implementatie van een zo omvangrijke wetgeving. In het revolutionaire Frankrijk bekommerde men zich nauwelijks om een exacte terminologie. De terminologie ter zake van het afkondigen was onvast: begrippen als "promulgation", "publier" en "rendre obligatoire" werden door elkaar en naast elkaar gebezigd.

Wat betreft de periode die de regestenlijst met afgekondigde rechtsvoorschriften beslaat, zijn er op centraal niveau, twee afkondigingsbevoegde autoriteiten te onderscheiden: de volksrepresentanten en mission, na de regimewisseling in het najaar van 1795 tijdelijk nog als gouvernementscommissarissen actief, en hun opvolger onder de vigeur van de grondwet van het jaar MI, het Directoire exécutif als collectief staatshoofd.

Met betrekking tot de afkondiging van rechtsvoorschriften gedurende het bestaan van het departement Nedermaas zijn vanaf 1 oktober 1795 drie periodes te onderscheiden. Tot de formele registratie van de wet van 12 vendëmiaire IV inzake het bekendmaken

\footnotetext{
${ }^{19.3}$ NRA inv.mr, 273 "correspondance ministerielle ans IV - XI" onder n"349, minister van justitie aan commissaris.

1"4A inv.nr.252 "correspondance active et passive $n^{\circ} 14$ " fol 225 vo onder $n$ "82R3, Nedermaas aan Gaboria; onder drukw FA nr.100 bevindt zich een (Nouveau) Code des Douanes (Brussel, s.a.).
} 
en van kracht worden van uitgevaardigde wetgeving op 2 december 1795 , bleef de oude wijze van openbare voorlezing, herdrukken, aanplakking onder trompetgeschal of tromgeroffel formeel van kracht. Met het verbindend worden van de wet van 12 vendémiaire IV werd wetgeving onmiddellijk van kracht over het gehele grondgebied van het departement, zodra de ontvangst in de departementale hoofdstad in een repertorium was geregistreerd. Deze wijze van verbindend worden van rechtsvoorschriften bleef van kracht tot het verbindend worden van artikel 1 van de titre préliminaire van de code civil op 26 maart 1803 . Vijf dagen na de promulgatie van wetgeving door Napoleon was deze verbindend voor het departement van de Nedermaas. Deze regeling gold alleen voor wetten in formele zin. Andere rechtsvoorschriften, zoals keizerlijke decreten, bleven vallen onder de werking van de wet van 12 vendémiaire IV.

In verband met de overstelpende hoeveelheid in Frankijk reeds bestaande wetgeving werd door het Directoire exécutif tijdelijk besloten om de wetgeving niet onmiddellijk in de départements réunis van kracht te doen laten worden, dan uitsluitend door middel van een bijzonder afkondigingsbesluit. Dit besluit van 18 pluviôse IV werd na circa tien maanden herroepen bij besluit van 16 frimaire $V$, waarbij bepaald was dat voortaan alle wetgeving die geplaatst was in het Bulletin des Lois van de tweede serie - op een enkele uitzondering na - onmiddellijk verbindend was, zodra de ontvangst daarvan in de departementshoofdstad geregistreerd was. Tevens werd toen opdracht gegeven een verzameling met relevante inhaalwetgeving, de zogenoemde Code $\mathrm{Mer}$ lin, te doen samenstellen.

Desondanks bleven er onduidelijkheden bij de ingezetenen bestaan met betrekking tot het tijdstip waarop wetgeving van kracht zou zijn geworden. Daarover werd tot in hoogste instantie geprocedeerd. Het ministerie van justitie te Parijs zelf liet daarover twijfel bestaan: in 1799 stelde het formeel vast dat in de negen départements réunis de Bulletins des Lois van de tweede serie tot numero 95, onder verwijzing naar het beparalde in het besluit van 18 pluviôse IV, niet verbindend waren geworden.

In de praktijk is het het verstandigst in concrete gevallen het departementale "registre ouvert" te raadplegen om te bezien of een bepaalde wet of een bepaald besluit al dan niet als verbindend werd beschouwd in het departement van de Nedermaas. In geval van een juridisch geschil uit die tijd kunnen de gerechtelijke vonnissen wellicht opheldering bieden. 


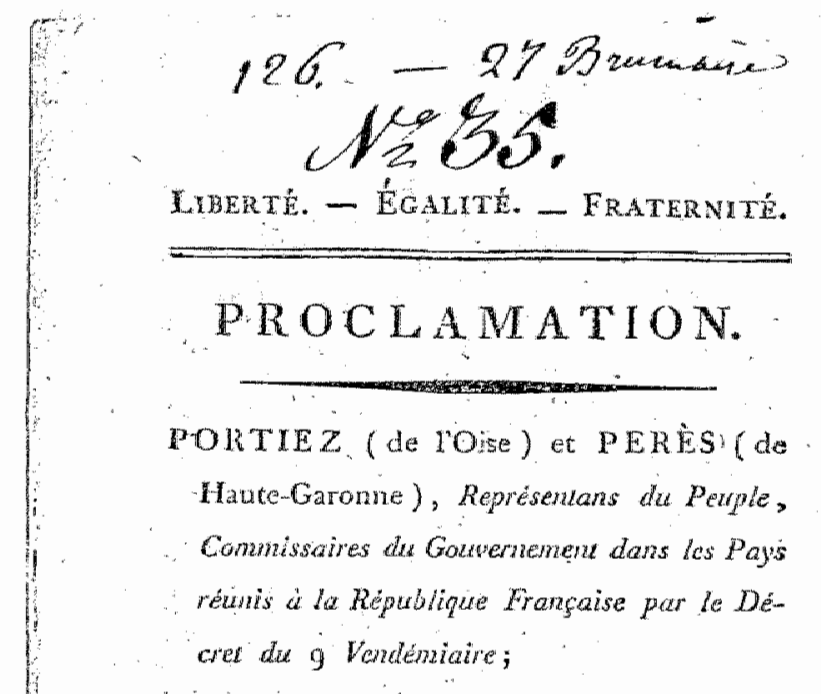

A U X F R A N C A IS,

HABXINS DES PAYS REUNIG.

\begin{abstract}
V
os deftimes, fil long-tenps incertames, fon enfin inrếvocablement fixées : vous êtes Francalis Si ce bea titre yous allure la jouifance des loix fublimes 8 bren-

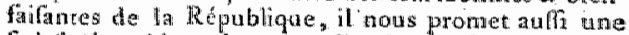
faciantion bian dance, celle de penfer que pous ctes libres pa la force de nos armes, \& que nous ne formons arec vous quine mème famille. Il exifloit difn res décres qui vous rénnifoient a la France. - Wovs havez par cuel concont's d'évememens contratres

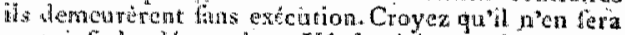
pas sinf du dicret du $g$ Vendentifre, gur, pour la fecombe fois, mous donne la wême patrie.
\end{abstract}

A cette premiùre époque la deforganifation chendoit fes ravages deverans fur notie malheureux fol.

Proclamatie van de volksrepresentanten/gouvernementscommissarissen Pérès en Portiez gericht aan de inwoners van de départements réuwis (Rijksarchief in Limburg, Maastricht: Frans archief inv.nr.291). 


\title{
"VOUS ETES FRANÇAIS"
}

\begin{abstract}
Vos destinees, si lang-temps incertaines, sont enfin irrévocablement fixées: vous ûtes Français. Si ce beau titre vous assure la jouissance des loix sublimes \& bienfaisantes de la République, il nous permet aussi une satisfaction bien douce, celle de penser que vous êtes libires par la force de nos armes, \& que nous ne formons avec vous qu'une même famille!.
\end{abstract}

Aldus luidde de aanhef van de proclamatie van 14 brumaire IV (5 november 1795) waarmee de volksrepresentanten Portiez (de l'Oise) en Pérès (de la Haute-Garonne) in hun hoedanigheid van gouvernementscommissaris in de sedert 1 oktober 1795 bij Frankrijk aangesloten gebieden de weldaad van de Franse revolutionaire wetgeving in het vooruitzicht stelden. De volksrepresentanten kondigden in een de proclamatie begeleidend besluit aan, welke wetgeving volgens hen dadelijk in de negen départements réunis diende te worden bekendgemaakt. Het besluit gaf aan welke rechtsgebieden daarbij als eerste in aanmerking zouden komen voor afkondiging:

Désirant faire jouir promptement les habitans desdits pays des avantages de la réunion, \& leur appliquer a cet effet les loix françaises les plus bienfaisantes, en attendant que les autres puissent être successivement publiées (...). Les loix relatives à l'abolition des dîmes, des droits féodaux, du retrait lignager, des substitutions, de l"action en rescision pour lésion d'outremoitié, de maîtrises \& jurandes, de même que celles qui prescrivent un nouvel ordre de succéder à l'avenir, seront incessamment publiées, pour être exécutées dans toutes l'étendue des pays réunis à la République Française, par le décret du 9 Vendémiaire [art.1]. En attendant ladite publication, il est sursis à toutes contestations, instances \& procédures relatives aux objets énoncés en l'article Ier [art.2]. Le conseil de gouvernement est chargé de faire imprimer, publier \& afficher, tant lesdites loix que le présent arrêté \& la proclamation y jointe, par-tout: où besoin sera, \& d'en certifier les Représentans du Peuple, commissaires du gouvernement, dans le plus court délai [art.3 $]^{2}$.

Deze proclamatie van de volksrepresentanten luidde het begin in van een vloed aan Franse revolutionaire wetgeving, die de maatschappelijke ordening tot in haar wortels zou veranderen. De Belgische historicus Pirenne kenschetste het afscheid van het ancien régime in deze landstreken treffend met een verwijzing naar de gebeurtenissen

"FA inv.nr.291 "Arrêtés du Directoire Exécutif et lois anciennes 1749 - an XIII" onder n³5 "Proclamation des Représentans du Peuple aux Français, habitans des Pays Réunis". De commissaris van het Directoire exécutif bij het departementaal bestuur van de Nedermaas, de Fransman Rogier, deed éen en ander nog eens weer over in zijn "Proclamation aux habitans de ce Département" op 25 frimaire IV (15 dec 1795); gebruikt is de gedrukte proclamatie die berust te Parijs Arch.Nat. inv.nr. AD XVI 52 "Villes et provinces. II 1789-1815: Meuse, Meuse-Inférieure, Montblanc, Mont-Terrible, Mont-Tonnerre, Morbihan".

${ }^{2}$ FA inv.nr.291 onder $n^{935}$ bis "arrêté concernant la publication de certaines loix de la Répubique"; zie ook de regestenlijst sub dato. 
in Frankrijk in 1789: "La Belgique eut sa nuit du 4 août par voie d'arrêtés" , de datum waarop de Assemblée nationale constituante decreteerde dat zij de feodale regeringsvorm in haar geheel had afgeschaft ("... détruit entièrement le régime féodal"). De volksrepresentanten hebben met behulp van een reeks besluiten de introductie van de Franse wetgeving in gang gezet. Zij werden daarbij actief terzijde gestaan door de conseil de gouvernement ${ }^{4}$. Daarmee waren zij door Parijs speciaal belast onder de functiebenaming van gouvernementscommissarissen. Circa twee maanden na zijn installatie, nam het Directoire exécutif de afkondigingswerkzaamheden van hen over.

De regestenlijst geeft een beschrijving van - een deel - van de zoëven genoemde vloed aan afgekondigde wetgeving in het departement Nedermaas. Over de periode 1 oktober 1795 tot en met 19 maart 1797, de dag waarop de ontvangst van de Code Merlin in het departement in het "registre ouvert" werd ingeschreven, is er sprake van ruim elfhonderd rechtsvoorschriften of delen daarvan. Van de veelheid aan wetten en andere rechtsvoorschriften biedt de bijgevoegde regestenlijst een goede indruk. In de regestenlijst zelf worden 582 wetten en besluiten beschreven 5 .

Dit hoofdstuk beoogt een rubricering aan te brengen in deze massa aan wetgeving. De veelheid aan wetgeving legt uiteraard een beperking op aan het aantal te bespreken onderwerpen. Er is sprake van de bekendmaking en het uitvoerbaar verklaren van "corpora" aan wetgeving. Bij het schetsen van de hoofdlijnen zal nu en dan de wetgeving opgenomen in de Code Merlin ook worden besproken. De werkelijke draagwijdte van al deze wetgeving zal, gelet op het bestek van deze studie, eigenlijk alleen maar terloops en zijdelings aan de orde kunnen worden gesteld. Er moet hier worden volstaan met hetgeen de bestaande literatuur biedt. Immers, de bestudering van de concrete toepassing van deze wetgeving zou jarenlang diepgaand onderzoek in de archieven vergen.

De wetgeving die uitging van de volksrepresentanten en mission en van de Centrale Administratie van de Landen tussen Maas en Rijn in de periode van het bestaan van het arrondissement Maastricht (november 1794 tot oktober 1795), voorafgaande aan

\footnotetext{
${ }^{3}$ Pirenne, Histoire de Belgique, VI, 89.

${ }^{4}$ Aangaande de conseil de gowvernement zie M.-R. Thielemans, "Deux institutions centrales sous le régime français en Belgique. $L$ "administration centrale et supérieure de la Belgique et le conseil de gouvernement", Revue Belge de Philologie et d'HistoirelBelgisch Tijdschrift woor Filologie en Geschiedenis, XLI (1963) 1091 11135, XLII (1964) 399-441, XLIII (1965) 1272-1323, XLIV (1966) 500-560, i.h.b. het laatste artikel, 534, 538-541, 544-545, 550-551, 559; zijn voorganger, de admimistration centrale et supérieure de la Belgique, beperkte zich alleen tot het uitwoeren van de besluiten van de volksrepresentanten.

${ }^{5}$ In de korte periode tussen de formele registratie van het besluit van 16 frimaire $\mathrm{V}$ (6 dec 1796) op 17 december 1796 tot die van de Code Merlin op 19 maart 1797 zijn er ook nog vijftien cahiers van het Bulletin des Lois bij het departementaal bestuur van de Nedermaas binnengekomen - de nummers 95 tot en met 110 - met in total 154 rechtsvoorschriften, waarvan én in de Code Merlin apart wordt vermeld, namelijk BL Ie ser no.95(895); zie ook RO nr.257(424); in het "registre ouwert" zelf zijn alleen de nummers 96 tot en met 110 ingeschreven met in total 136 wetten en besluiten; niet ingeschreven zijn besluiten aangaande het koersbeloop van de mandats, die door het besluit van 16 frimaire $\mathrm{V}$ werden uitgezonderd.
} 
de annexatie dus, blijft ook buiten beschouwing. Deze reeksen besluiten zijn niet, op incidenteel een enkele na, in het "registre ouvert" opgenomen en derhalve ook niet in de regestenlijst met afgekondigde rechtsvoorschriften. Het gaat om enige honderden arrêtés. De arrondissementsadministratie heeft daar ook repertoria ${ }^{6}$ van bijgehouden: een "Table des arrêtés de la Centrale et Reprêsentants du peuple" en een "Index der Arrêtées van de Representanten van het Volck en administratie Centraal" Bij het doorzien van al die rechtsvoorschriften krijgt men de indruk dat er veelal sprake is van ad hoc-besluiten. Dit hoeft niet te verbazen, want gedurende de periode van het arrondissement Maastricht werden de door de Franse legers bezette gebieden aanvankelijk beschouwd als veroverd land. Zeker in de eerste maanden na de verovering hebben de Fransen zware schattingen ten behoeve van de bezettingslegers opgelegd. De schattingen betekenden een grote last voor de bevolking, omdat de requisities gewoonlijk de eerste levensbehoeften betroffen". Deze situatie werd nog verergerd door extreem koude weersomstandigheden einde 1794 - begin 1795.

\section{Hoofdlijnen in de afgekondigde wetgeving}

Het is ondoenlijk alle wetgeving te beschrijven die in de relatief korte periode van anderhalf jaar na de inlijving bij Frankrijk in de negen départements réunis in het algemeen en in het departement van de Nedermaas in het bijzonder is afgekondigd. Er moet hier worden volstaan met het bespreken van enige hoofdmomenten ${ }^{8}$. Leidraad daarbij zal zijn de grotere corpora aan wetgeving.

De volksrepresentanten Pérès en Portiez (de l'Oise), die als gouvennementscommissarissen de taak van de introductie van de Franse revolutionaire wetgeving op zich namen, hebben zich niet onbetuigd gelaten. Hetgeen zij in hun proclamatie al aankondigden, hebben zij ook inderdaad in werking gezet. In de korte periode vanaf 9 vendémiaire IV ( 1 oktober 1795) tot 30 frimaire IV ( 21 december 1795) is de essentie aan maatschappijhervormende wetgeving bekendigemaakt en aan de bevolking opgelegd. Wat in het revolutionaire Frankrijk zeker vier jaar kostte, dat kregen de bewoners van de negen Verenigde Departementen in slechts een paar maanden tijds over zich uitgestort. In heel korte tijd werd aan de uiterlijke structuren van het ancien régime een einde gemaakt. De Parijse bestuurders achtten veertien maanden voldoende voor de assimilatie van de bevolking in de geannexeerde gebieden. Vanaf het moment van de formele registratie - op 17 december 1796 - van het besluit van 16 frimaire $V(6$ december 1796$)$ gold in het algemeen gesproken alle nieuwe wetgeving

\footnotetext{
${ }^{6} \mathrm{FA}$ inv.nr.308 en 309; het latste repertorium kent een onderverdeling in "Over het Finantieele en Nat. Domeijnen neffens de aanstellinge der administratie", "Subsistentien" en "Arretees over differente objecten".

${ }^{7}$ Zie hierover: Wetzler, War and subsistence, 196-211, 214-218; L.C.J.H. Jacobs, "C.C. Roemers als agent national van het arrondissement Maastricht (30 november 1794 - 26 september 1795)". Publications de la Société Historique et Archeologique dans le Limbourg, CXXIX (1993) 207-209.

${ }^{2}$ Onderzoekers die alles zouden willen inzien en beoordelen, kunnen betrekkelijk eenwoudig de regestenlijst, alsmede de Code Merlin raadplegen. Bij de bespreking wan de wetgeving zal niet in alle gevallen naar de vindplaatsen in de regestenlijst worden verwezen. Er kan immers gewoon op datum worden gezocht.
} 
met onmiddellijke ingang ook voor de ingezetenen van het departement van de Nedermaas en de rest van België.

Alvorens over te gaan tot het bespreken van de clusters aan wetgeving, wordt eerst de structuur van het Franse grondwettelijke bestel tijdens de Directoire-periode geschetst.

\section{Centrale en decentrale overheden}

\section{a. Grondwet en de wetgevende en centrale bestuursorganen}

In het departement van de Nedermaas werd als één van de eerste stappen, enkele dagen na de bekendmaking van de wet van 9 vendémiaire IV ( 1 oktober 1795), de grondwet van 5 fructidor III (22 augustus 1795) en de wet houdende de proclamatie van de aanvaarding door het Franse volk van de hem voorgelegde constitutie van 1 vendémiaire IV (23 september 1795) afgekondigd ${ }^{9}$. Deze grondwet was al de derde in successie sinds het uitbreken van de Franse Revolutie in 1789. Die uit de jaren 1791 en 1793 hebben geen toepassing gevonden in de départements réunis; in Frankrijk zelf was de werking van de grondwet van 1793 opgeschort tot het herstel van de vrede. Het Franse volk was omtrent de inhoud van deze nieuwe grondwet wel geraadpleegd, maar dit was allerminst het geval ten aanzien van de ingezetenen van de ingelijfde departements réunis. Bij de raadpleging van het Franse volk kan men trouwens ook de nodige vraagtekens plaatsen: er waren maar relatief weinig stemmers opgekomen, zodat de constitutie zeker niet door de meerderheid van de Fransen goedgekeurd was ${ }^{10}$. Deze constitutie omschreef voor het eerst - met een opsomming van de departementen - in de artt.3, 6 en 7 het grondgebied van de Franse Republiek, dat wil zeggen het Frankrijk van vóór 1792 en de overzeese gebiedsdelen. Aan de Europese departementen werden zonder enige aarzeling door de conseil de gouvernement te Brussel ${ }^{11}$ de negen départements réunis toegevoegd, zonder dat de inwoners van deze streken daaromtrent naar werd gevraagd.

Allerwegen wordt de grondwet van het jaar III beschouwd als de grondslag voor de burgerlijke republiek, en die gedurende de jaren 1795-1799 - de periode van het Directoire tot de machtsgreep van Napoleon - de revolutionaire opgewondenheid enigszins kalmeerde ${ }^{12}$. Evenals haar beide voorgangers kende de grondwet van het

\footnotetext{
"Godechot, Constitutions, 101-141, tekst grondwet van het jaar III; BL Ie ser no.180 (1100), loi portant proclantation de lacceptation, par le Peuple français, de la Constiturion qui lui a été présentée par la Convention nationale.

111 Godechot, Institutions, 467-468.

"Ihidem, 460; FA inv.nr.279 "correspondance particulière no.1" onder no.10, conseil de gouvermement aan bestuur arrondissement Maastricht 14 vendémiaire IV (6 okt 1795).

12 Clive Church, "Du nouveau sur les origines de la constitution de 1795", Revue Historique de Droit français et étranger, LII (1974) 594-627, aldaar 594-595, 625, 627; de schrijver stelt, dat deze constitutic voortwloeide uit een langdurige machtsstrijd tussen de regering en de administratie als reactie op de opkomst van een nieuwe tijdens de Terreur ontstane bureaucratie, nodig ter versterking
} 
jaar III een "déclaration des droits de l'homme et du citoyen", maar nu aangevuld met enkele nogal voor de hand liggende "devoirs". In de laatste titel van de grondwet (dispositions générales) zijn ook nog enige rechten omschreven, zoals de vrijheid van gedachten, spreken en drukpers, die voorheen in de "déclaration" zelf waren opgenomen. Van de plichten valt eigenlijk alleen de dienstplicht als zodanig aan te mer$\operatorname{ken}^{13}$.

De politieke status voor de ingezetenen van de départements réunis, zoals in tweede titel van de grondwet werd vastgelegd, alsmede de procedure inzake de assemblées primaires en électorales in de beide daaropvolgende titels, was feitelijk pas voor het eerst aan de orde gedurende het jaar $\mathrm{V}$. Het in de aansluitingswet van 9 vendémiaire IV ( 1 oktober 1795) aangebrachte onderscheid tussen de ingezetenen die zichzelf al als Frans staatsburger mochten beschouwen en zij die voorshands de status van vreemdeling kregen is al eerder aan de orde geweest. Pas toen de verkiezingen voor het Wetgevend Lichaam van $\mathbb{1}$ germinal V (21 maart 1797) in zicht kwamen werd deze materie actueel. In de regestenlijst is nog juist de Instructie voor de uit te schrijven assemblées primaires, communales en électorales opgenomen ${ }^{14}$.

In het kader van deze paragraaf zijn de titels V - VIII van de grondwet van het jaar III de belangrijkste. De vijfde titel heeft tot onderwerp de wetgevende macht. De grondwet van het jaar III introduceerde voor de eerste maal in Frankrijk het tweekamerstelsel: de Conseil des Cinq-cents en de Conseil des Anciens. Het aantal leden van de Conseil des Anciens bedroeg de helft van die van de Cinq-cents. Bij wet was het aantal af te vaardigen vertegenwoordigers per departement vastgelegd. Het departement van de Nedermaas mocht drie afgevaardigden aanwijzen voor de Conseil des Cinq-cents en twee voor de Conseil des Anciens ${ }^{15}$.

De wetgevende bevoegdheid lag uitsluitend bij het Wetgevend Lichaam. Er bestond derhalve een duidelijke scheiding tussen de wetgevende en de uitvoerende macht. De verklaring hiervoor ligt in het argument dat de post-thermidoriaanse Conventie als grondwetgever de situatie wilde vermijden dat de machtenverstrengeling die zich geopenbaard had tijdens de Jacobijnse Republiek, waarbij feitelijk de regeringscomités (comité de salut public; comité de sûreté générale) voortkomende uit de Nationale Conventie zelf, de dienst uitmaakten, zich zou bestendigen. Al gedurende de thermidoriaanse reactie van het jaar III, na de val van Robespierre en consorten dus, werd,

\footnotetext{
${ }^{12}$ (....vervolg)

van het bewind. De hervorming van het ambtenarenapparaat en de grondwetsherziening in 1795 zouden daardoor onderling nauw verstrengeld zijn geraakt.

13. Godechot, Institutions, 458-460.

${ }^{14}$ Zie hierover hoofdstuk 1 ; BL, lle ser no.114bis (1097bis).

${ }^{15} \mathrm{BL}$ Ille ser no.108 (1024), loi qui ordonne lenvai du tableau du nombre des députés du Corps législatif à élire par chaqué département van 27 pluviôse V (15 feb 1797); in hell "tableau" wordt over een periode van tien jaar het jaarlijks aftredende gedeelte vermeld; wettelijk werd op die datum het aantal inwoners van het departement Nedermaas vastgesteld op 216.566.
} 
wooruitlopend op de nieuwe grondwettelijke constellatie, de machtspositie van de regeringscomités aanzienlijk ingeperkt ${ }^{16}$.

De grondwet wan 5 fructidor III (22 augustus 1795) schiep een afzonderlijke uitvoerende macht, het Directoire exécutif. Het Wetgevend Lichaam koos als kiesassemblee namens de natie dit vijf leden tellende collectieve staatshoofd, waarvan Godechot zegt dat er feitelijk sprake was van een verkleind comité de salui public. De leden van dit Directoire werden voor vijf jaar gekozen, waarbij er jaarlijks één diende af te treden die bij loting aangewezen werd. Eén van de leden van het Directoire vervulde steeds gedurende drie maanden de functie van president van het college, zonder dat deze over bijzondere bevoegdheden beschikte. Het Directoire als geheel, in ieder geval de meerderheid van de leden, bestuurde. Het verenigde een groot aantal bevoegdheden in zich. Te noemen vallen: het aangaan en de regeling van de buitenlandse betrekkingen, het beschikken over leger en marine (zonder de uitoefening van de daadwerkelijke bevelvoering overigens), benoeming van bevelvoerende generaals, benoeming en ontslag van ministers, alsmede benoeming van commissarissen van het Directoire exécutif bij de legers, de lagere besturen en de gerechten, en leidende functionarissen van gespecialiseerde diensten als de belastingen en de domeinadministratie. In het geval van het vacant worden van functies bekleed door verkozen functionarissen ten gevolge van overlijden, ontslag, schorsing of afzetting gedurende de ambtstermijn had het Directoire het tussentijdse benoemingsrecht, zelfs van rechters en vrederechters. Het Directoire had geen zeggenschap over de schatkist (Trésorerie). Deze was geattribueerd aan een vijftal commissarissen, die op eendere wijze als de leden van het Directoire gekozen werden; zij waren volkomen onafhankelijk.

Inzake wetgeving miste het Directoire exécutif het recht van initiatief. Het kon alleen met behulp van een "message" de Conseil des Cinq-cents uitnodigen een zaak in overweging te willen nemen en zelfs bepaalde maatregelen voorstellen, zonder echter dat zij als wetsvoorstel geredigeerd waren ${ }^{17}$. Daarentegen maakte het Directoire wel zeer ruim gebruik van de mogelijkheid besluiten uit te vaardigen. Dergelijke besluiten gingen soms verder dan het alleen maar wijzen op de naleving van bestaande wettelijke regelingen, of de bedoeling ervan aan te geven. Het kwam nogal eens voor dat Directoire-besluiten zelfstandige regelingen bevatten ${ }^{18}$.

${ }^{16}$ Godechot, Institutions, 294-316, 462-463; na de negende thermidor werd de machtspositie van de regeringscomités ingeperkt door de loi relative à la réorganisation des comités de la Convention nationale wan 7 tructidor II (24 aug 1794), BL le ser no.46 (243) en de loi qui maintient les atributions des différens comités, et dérermine le mode et les cas de réumion de plusieurs van 21 floréal III (10 mei 1795), BL Ie ser no.143 (807).

"Godechot. Institutions, 464-465; titel VI grondwet van het jaar III.

"Charles Durand, "Les rapports entre la loi et le règlement gouvememental de l'an IV à 1814" in: Charles Durand \& Albert Lanza, Etudes sur les rapports entre la loi ef le règlement gowvernemental an XIX siecle. Travaux et mémoires de la faculté de droit et de science politique d'Aix-Marseille XXVI (Aix-en-Provence/Marseille) 14-30; "En général les arrêtés réglementaires du Directoire ne poussent pas aussi loin l'initiative au-delà des prévisions constitutionnelles même largement interprêtées. Mais ils ne s'en tiennent pas toujours, loin de là, à rappeler d'une règle législative encore en vigueur ou tenue pour telle par eux, et à en préciser éventuellement le sens (...) Les arrêtés du Directoire étendent en plusieurs cas la notion d'exécution de la loi, ils comprennent des règlements autonomes, qui ne sont le prolongement d'aucune loi, même en dehors du régime interne d'un service (wordt vervolgd....) 
Het Directoire exécutif had voorts ministers tot zijn beschikking. Zij werden benoemd en ontslagen door het Directoire zelf. Het Wetgevend Lichaam evenwel bepaalde hun aantal en hun respectieve bevoegdheden. De ministers hadden tot taak om binnen de hun geattribueerde bevoegdheden rechtstreeks met de aan hen ondergeschikte autoriteiten te corresponderen. Zij waren verantwoording verschuldigd aan het Directoire, zowel aangaande de niet-toepassing van wetten, als de niet-toepassing van de door het Directoire uitgevaardigde arrêtés. Godechot zegt dat ze slechts commiezen van het Directoire waren. De ministers vormden dan ook geen raad van ministers $^{19}$.

De grondwet van het jaar III bepaalde in art. 150 dat er ten minste zes en ten hoogste acht ministers zouden zijn. Het aantal werd uiteindelijk zeven. Bij wet van 10 vendémiaire IV ( 2 oktober 1795) werden de ministeries van justitie, binnenlandse zaken, financiën, oorlog, marine en kolomiën, en buitenlandse betrekkingen door de Nationale Conventie ingesteld. In verband met de overmaat aan geattribueerde bevoegdheden voor het ministerie van binnenlandse zaken werd op 12 nivôse IV ( 2 jan 1796) een zevende ministerie van generale politie ingesteld door het Corps législatif. Voor het departement van de Nedermaas, en naar men mag aannemen voor alle départements réunis, doet zich de irrationaliteit voor dat wel vrij spoedig na haar uitvaardiging de wet van 10 vendémiaire IV is afgekondigd, maar de wet van 12 nivôse IV pas via de Code Merlin ${ }^{20}$.

\section{b. De lagere bestuursorganen}

De zevende titel van de grondwet van 5 fructidor III (22 augustus 1795) - corps administratifs et municipaux - regelde de bevoegdheden van en attributies aan de lagere bestuurslichamen, van departement tot gemeente ${ }^{21}$. Ieder departement was onderverdeeld in kantons, de kantons op hun beurt weer in gemeenten. De "administration centrale" van cen departement telde vijf leden, van wie jaarlijks één vervangen werd. Gemeenten met meer dan 5000 inwoners hadden een eigen gemeentebestuuur; was het inwonertal van de gemeente lager, dan was er slechts een municipale agent en een adjunct (adjoint). De vergadering (réunion) van de municipale agenten vormde de kantonsmunicipaliteit. Het gemeentebestuur kende voorts een binnen het kanton gekozen voorzitter. Het getal gemeenteambtenaren varieerde naargelang het inwonertal ${ }^{22}$.

Gelijktijdig met de introductie van de kantonnale bestuursindeling werd het intermediaire bestuurslichaam van de districten afgeschaft. Het district bestond formeel

\footnotetext{
1*...vervolg)

public et de la police de sécurité. Ce pouvoir réglementaire s"exerce soit sur l'autorisation ou sur l"invitation directe, soit avec l'assentiment ou la tolérance des chambres législatives ...", citaat 29-30. ${ }^{14}$ Godechot, Institutions, 466. "... les 'ministres' ne sont que des commis du Directoire"; Poullet, Imstitutions Françaises, 67-78: zie ook de artt.148-152 grondwet wan het jaar III.

${ }^{20} \mathrm{BL}$ le ser no.192 (1153), loi su" lorganisation du ministère; BL IJe ser no.16 (94), loi portant création d"un seprième ministère, sous le nom Police générale de la République.

2 Godechot, Constitutions, 121-124.

${ }^{22}$ Grw artt.174, 177-182.
} 
sedert de grondwet van 3 september 1791 in Frankrijk, waarbij het districtsbestuur ondergeschikt was aan dat van het departement. Toen was ieder district al onderverdeeld in kantons; zij vormden elementaire kieseenheden. De nooit toegepaste grondwet van 24 juni 1793 (of het jaar I) bestendigde deze indeling, maar sprak in plaats van kantons van municipaliteiten. De districten werden eveneens gehandhaafd door het decreet op de revolutionaire bestuursorganisatie van 14 frimaire II ( 4 december 1793) en kregen de bevoegdheden die toen aan de departementale besturen ontnomen waren. $\mathrm{Zij}$ waren het instrument van de revolutionaire regering. Daarom werden zij niet langer door de grondwet van het jaar III voorzien ${ }^{23}$.

Welke waren de taken en bevoegdheden van de departementale besturen en de kantonsmunicipaliteiten? Voor de departementale besturen, aldus Poullet, kan men hun functies tot een viertal hoofdobjecten herleiden: de uitvoering van wetten en het bestuur in de regio ten behoeve van het algemeen belang; het beheer van belangen die eigen aan de departementen zijn; het toezicht op de municipale besturen; en de beslechting van bestuursgeschillen ${ }^{24}$. Art.190 van de grondwet van het jaar III stelde dat zij hoofdzakelijk belast waren met de repartitie van de directe belastingen en het toezicht op de opbrengsten daarvan. Verder bepaalde het Wetgevend Lichaam de regells en de wijze van hun functioneren op dit gebied en het overige binnenlandse bestuur $^{25}$. De organieke wet van 21 fructidor III ( 7 september 1795) was ten aanzien van het geattribueerde aan de departementale besturen nogal summier geredigeerd: "Les administrations de département conserveront les attributions qui leur sont faites par les lois aujourd'hui en vigueur, quels que soient les objets qu'elles embrassent" ${ }^{26}$. Volgens Poullet ging het hier om de reeks wetten en delen van wetgeving die bij besluit van de volksrepresentanten van 19 frimaire IV (10 december 1795) in de départements réunis werden afgekondigd. De attributie aan het departementale bestuur aangaande de uitvoering van wetgeving was omvangrijk: het betrof de wetten op het gebied van de financiën, onderwijs, weldadigheid, landbouw, nijverheid, toezicht op de verbindingen, openbare werken, veiligheid en openbare rust, de nationale garde, de toepassing van de revolutionaire wetten ten aanzien van weerspannige geestelijken en de uitgewekenen en zo meer ${ }^{27}$. De departementale besturen kenden nauwelijks een eigen belangensfeer. Dit werd ten zeerste versterkt doordat zij financieel geheel

${ }^{23}$ Godechot, Institutions, 24, 108, 321-322; idem, Constitutions, 37, 57, 83, grondwet van 1791 tit.II art. 1 en tit.III, hoofdst. IV, sect.II art. I; grondwet van 1793 art.3; P V 589-594, décret sur le mode de gouvernement provisoire et révolutionnaire van 14 frimaire II (4 dec 1793) bij voorbeeld sect.II art.15-16, sect.III art.5.

${ }^{24}$ Poullet. Institurions françaises, 164-170.

25. Art. 190 grondwet jaar III: "Les administrateurs sont essentiellement chargés de la répartition des contributions directes et de la surveillance des deniers provenant des revenus publics dans leur territoire.

Le Corps lëgislatif détermine les règles et le mode de leurs fonctions, tant sur ces objets, que sur les autres parties de l'Administration interieure".

26. BL le ser no. 185 (1128), loi relative aux fonctions des corps administratifs et municipaux du titre VII de l'acte constiturionnel art. 18.

${ }^{27}$ FA nr.283 "registre ouvert" no.84; Poullet, Institutions françaises, 165-168; Godechot, Institutions, $470-471$. 
ondergeschikt waren aan het Parijse centrale gezag. Art.311 van de grondwet was daarover heel stellig: departementale en municipale besturen mochten geen enkele belasting aan de bevolking opleggen bovenop de door het Wetgevend Lichaam vastgestelde, noch beraadslagen over een plaatselijke lening ten laste van de ingezetenen van een departement, kanton of gemeente.

Geheel overeenkomstig de grote centraliserende tendenzen in het Franse staatsdenken waren de municipale besturen onder de voogdij geplaatst van de departementale besturen. Art.193 van de grondwet van het jaar III laat geen misverstand bestaan over het centralistische karakter van de Franse staat:

Les administrations municipales sont subordonnées aux administrations de département et celles-ci aux ministres.

En conséquence, les ministres peuvent annuler ${ }_{*}$ chacun dans sa partie, les actes des administrations de département; et celles-ci, les actes des administrations municipales, lorsque ces actes sont contraires aux lois ou aux ordres des autorités superieures.

Zoals de ministers departementale besturen bij overtreding van wetten of bevelen van hogerhand konden schorsen, zo hadden de departementale besturen hetzelfde recht jegens de hun ondergeschikte municipale besturen. Maar iedere schorsing of vernietiging van bestuurshandelingen werd pas definitief na de formele bevestiging door het Directoire exécutif (artt.194 en 195).

Bestuursgeschillen ter beslechting aan een departementaal bestuur opgedragen, besloegen doorgaans het terrein van de directe belastingen, moeilijkheden gerezen tussen uitvoerders van openbare werken, alsmede de vastlegging van de hoogte van de schadevergoeding voor particulieren die schade ondervonden bij de uitvoering van de openbare werken. Gewoonlijk stond er beroep open op de betrokken minister ten aanzien van de departementale uitspraken ${ }^{28}$.

Departementen kenden ten aanzien van de uitvoering van de hun opgedragen taken verordenende bevoegdheid (pouvoir réglementaire). Deze bevoegdheid kreeg gestalte in de vorm van arrêtés. In de arrêtés konden geen strafbepalingen worden opgenomen. Een departementaal bestuur kon alleen de van kracht zijnde wettelijke strafbepalingen ter zake in herinnering roepen. Departementale arrêtés konden ook de vorm van een beschikking hebben.

De eerder genoemde wet van 21 fructidor III ( 7 september 1795) was veel uitgebreider ten aanzien van de municipaliteiten. Het kanton trad in de plaats van het district en nam diens taken en bevoegdheden over. Ingevolge art.19 namen de kantonsmunicipaliteiten kennis van de zaken die voorheen opgedragen waren aan de municipaliteiten, alsmede die zaken behorende tot het algemeen bestuur die de wet aan de districten gedelegeerd had. In de arrondissementen Maastricht en Gelder hadden echter geen districten gefunctioneerd. Het organisatiebesluit van de volksrepresentanten van 24 brumaire III (14 november 1794) voor de landen tussen Maas en Rijn had over de plaatselijke besturen bepaald: "Les divisions ou les arrondissemens particuliers, tels que bailliages, mairies, cantons, ou municipalites, sont conservés avec

28 Poullet, Institutions françaises, 168-170. 
leurs territoires et juridictions, selon leur composition actuelle"29. Het vierde artikel van de tweede sectie van dit besluit gaf een opsomming van de werkzaamheden die aan de arrondissementsbesturen opgedragen waren ${ }^{30}$.

Op aanwijzing van het departement vergaderden de kantonsmunicipaliteiten periodiek, maar ten minste driemaal per maand. De municipaliteit werd gevormd door de municipale agenten en de gekozen woorzitter. Gemeenten met meer dan 5000 inwoners hadden een eigen municipaal bestuur en tevens een afwijkend vergaderschema. In het departement van de Nedermaas gold dit alleen voor de hoofdstad Maastricht. Het Maastrichtse municipale bestuur bestond overeenkomstig art.182 van de grondwet uit zeven leden. Evenals het departementale bestuur kon de kantonsmunicipaliteit slechts besluiten nemen als het quorum aan de beraadslaging deelnam en dan alleen met meerderheid van stemmen. De uitvoering van de besluiten van de kantonsmunicipaliteiten viel toe aan de municipale agenten, of bij hun afwezigheid aan de adjuncten. Zij vervulden ook de functie van ambtenaar van de burgerlijke stand. In deze kleine plattelandsgemeenten hadden de municipale agenten tevens het gerechtelijke toezicht (police judiciaire) $^{31}$. De kantonsmunicipaliteiten kenden ook een zekere verordenende bevoegdheid. Onder de naam van délibération, en behoudens wijziging door het departementaal bestuur, konden zij besluiten nemen op die gebieden die aan hun zorg toevertrouwd waren, alsmede maatregelen treffen teneinde wetten en politieverordeningen (règlement de police) opnieuw bekend te maken of de burgers aan de naleving ervan te herinneren. Bij ontstentenis van een wet ter zake hadden de municipaliteiten niet generaal het recht hun voorschriften te sanctioneren. De wet van $19 * 22$ juli 1791 sur la police municipale et correctionnelle echter, kende strafbedreiging jegens degenen die municipale arrêtés op het gebied van politie overtraden ${ }^{32}$. De acta van bestuurslichamen werden openbaar gemaakt door het ter inzage leggen van de registers dienaangaande voor de geadministreerden. Om de zes maanden werd een dergelijk register afgesloten, maar de deponering ervan geschiedde pas vanaf het moment dat het was afgesloten ${ }^{33}$.

De centrale overheid had bij de decentrale besturen een toezichthoudende functionaris, de commissaris van het Directoire exécutif, ook wel commissaire du pouvoir exécutif genoemd. Deze functionarissen waren de voortzetting van de Franse koninklijke

${ }^{29} \mathrm{P}$ VI xli-xliv, arrêté des représentans du peuple (Haussmann, Frécine, Joubert) relatif à l"organisation de l'administration des pays conquis entre la Meuse et le Rhin, sect.II art.2; een overeenkomstige regeling was van kracht voor de Belgische arrondissementen, $P$ VI xliv-xlvi, arrêté des représentans du peuple (Berlier. Roger-Ducos, Lacosie, Portiez Briez et Haussmamn) organisam l"administration centrale de la Belgique et les administrations civiles d'arrondissement van 26 brumaire III (16 nov 1794) art.5: "Le magistrat ordinaire du pays est tenu de reconnaitre l"autorité de l'adninistration de son arrondissement, et d'y obéir pour tous ces objets qui lui sont attribuées. Les droits particuliers des citoyens continueront d'être réglés par lesdits magistrats comme par le passé". 3t Opsomming ook in Hardenberg \& Nuyens, Inventaris arrondissemem Maastricht en departemen Nedermaas, lii.

${ }^{31}$ Artt.6, 8 en 16 van de wet van 21 fructidor III (7 sep 1795); Poullet, Institutions françaises, 187189.

32 Poullet, Institutions françaises, 190-191.

33 Art.201 grondwet jaalr III. 
procureur-général-syndic bij de departementen sinds 1791 en de agent national bij de districten uit het jaar II. Zowel de kantonscommissaris als de departementscommissaris bekleedden een machtspositie. Hun taak bestond erin de uitwoering van de wet te vorderen, alsmede toe te zien op de werkzaamheden van de administraties ("... surveille et requiert l'exécution des lois", Grw. jaar III art.191 $2^{2}$ alinea). Vooral de commissarissen bij de departementen speelden een heel belangrijke rol: zij waren bij alle zittingen van het departementaal bestuur aanwezig en konden van alle dossiers kennis nemen. Zij vormden de voorafschaduwing van de Napoleontische prefecten ${ }^{34}$.

De wetgeving die de hiervoor genoemde organieke wet ${ }^{35}$ van 21 fructidor III (7 september 1795) handhaafde ten aanzien van de attributies aan de departementale besturen, behelsde hoofdzakelijk bepalingen op het terrein van de bevoegdheden en de organisatie van departementen, districten en gemeenten. Beheer van de financiële middelen, de grote wegen, het bosareaal, in beslag genomen goederen, de repartitie van de belastingen en de beoordeling van bezwaren van particulieren tegen de hoogte van de belastingaanslagen, behoorden tot de competentie van deze bestuurslichamen. Voorts hadden de districtsbesturen een taak op het gebied van grensscheidingen, vooral als dit te maken had met belastingaanslagen.

Van bestuurslichamen met een vertegenwoordigend karakter werd verwacht dat beraadslagingen werden genotuleerd en dat de namen van degenen die aan de discussie deelgenomen hadden eveneens werdlen genoteerd. Van de binnengekomen verzoekschriften en de beslissing daarop dienden de departementale en districtsbesturen een register bij te houden dat desgewenst aan de belanghebbenden ter hand werd gesteld.

Bestuursfuncties zijn in het algemeen onverenigbaar met functies bij de rechterlijke macht. Ook onderling waren bepaalde bestuursfuncties onverenigbaar met elkaar. Er gold een verbod op de cumulatie van bestuurlijke functies. Publieke functionarissen dienden als er sprake was van incompatibiliteiten een keuze te maken. Niet langer in functie zijnde leden van bestuurslichamen dienden rekenschap af te leggen van het door hen gevoerde beheer bij het bestuurslichaam waar zij voorheen deel van uit-

\footnotetext{
${ }^{34}$ Godechot, Imstitutions, 471, 473; Poullet, Institutions françaises, 175, 194; over de periode vam het zogenaamde tweede Directoire, na de staatsgreep van 18 fructidor $V$ (4 sep 1797), bestaan er bronnenpublicaties die inzicht geven in de controlerende taak van de commissarissen ten behoeve van de centrale overheid, L. Roppe, G.W.A. Panhuysen \& Elis. M. Nuyens, ed., De decadaire, resp. maandelijkse rapporten van de commissarissen van het Directoire exécurif in het departement van de Nedermaas 1797 - 1800. Werken Limburgs Geschied-en Oudheidkundig Genootschap I (Maastricht, 1956); M. Colson, ed., De rapporten van de kantonkommissarissen (1797 - 18001. Deel I Maaseik. Werken Limburgs Geschied- en Oudheidkundig Genootschap V (Maastricht, 1972); Henry Baillien, ed., De rapporten van de kantonkommissarissen (1797 - 1800). Deel II Tongeren. Werken uitgegeven onder auspiciën van de Bestendige Deputatie van de Provincie Limburg XV (Hasselt, 1972); S. Tagage. "Vrijheid, Gelijkheid en Broederschap" in het kanton Venlo, 1794 - 1800", Publications de la Sociêt Hé Historique et Archeologique dans le Limhourg, CX (1974) 7-226; zie over het kanton Millen: Marc Mullens, "De kommissarissen van het kanton Millen tijdens het Directoire (1796 1800y", Het Oude Land wan Loon. XIX (1964) 207-223 en idem, "Politieke strijd, partijvorming en Vlaams-Waalse wrijvingen in het kanton Millen tijdens het Directoire (1796-1800)", Ihidem, XXIII (1968) 103-153; de situatie rond Bree is beschreven door: Henri Peeters, Het kanton Bree tijdens de Franse revolutie, ([Bree], 1985 ).

${ }^{35}$ Zie $\mathbb{R O}$ nr.84.
} 
maakten. Voldeed men hieraan niet, dan kon dit leiden tot vervolging en tijdelijke opschorting van de uitoefening van de burgerrechten.

In dit corpus aan wetgeving was ook gedeeltelijk de tamelijk vroege Instruction concernant les fonctions des assemblées administratives van $12 * 20$ augustus 1790 opgenomen. Aan het begin van de Instructie werden de bestuurslichamen eraan herinnerd dat zij geen enkelle wetgevende of rechterlijke bevoegdheid meer bezaten. Hiermee werd er verwezen naar het beginsel van de machtenscheiding.

In de Code Merlin van 7 pluviôse V (26 januari 1797) zijn nog een reeks wetten ${ }^{36}$ opgenomen aangaande de formaliteiten die bestuurslichamen in acht dienden te nemen ten aanzien van het verwerven van gebouwen ten behoeve van de dienstuitvoering. Verder was het bestuurslichamen verboden zich in te laten met maritieme operaties. Daarnaast was er ook wetgeving opgenomen met betrekking tot eventuele schulden die gemeenten mochten hebben. De loi relative aux portraits des rois placés dans les établissemens des corps administratifs van 2 september 1793 had een duidelijk iconoclastisch karakter: portretten en afbeeldingen van koningen in bestuursgebouwen dienden te worden vernietigd, bustes te worden omgesmolten en marmeren beelden te worden verbrijzeld. Het extract uit de loi relative à la division de la France en départemens van 15 januari, 16 en 24 februari * 4 maart 1790 had betrekking op de grensscheidingen tussen gemeenten: wanneer de grens door een beek of rivier gevormd werd, dan liep de grens in het midden van de bedding. Een wet nog net door de Législative op 28 augustus 1792 uitgevaardigd, voorzag in het herstel van de eigendomsrechten en de rechten van gemeenten en burgers, waarvan zij beroofd waren ten gevolge van de feodale machtsuitoefening.

\section{Rechterlijke organisatie en rechterlijke macht}

De tweede pijler waar het nieuwe Franse staatsbestel op rustte, was de wetgeving op het terrein van de rechterlijke macht en haar organisatie ${ }^{37}$. De grondwet van het jaar III onderscheidde de burgerlijke en de strafrechtspleging, la justice civile en la justice correctionnelle et criminelle. Het ribunal de cassation ${ }^{38}$ en het haute-cour de justice bekroonden de rechterlijke organisatie. De nieuwe grondwet bestendigde de beginselen van de rechterlijke organisatie, zoals die waren vastgelegd in de grondwet van 1791. Theoretisch werd de onafhankelijkheid van de rechterlijke macht gehandhaafd door het benoemen van de zittende magistratuur door kiesgerechtigde burgers ${ }^{39}$. De

\footnotetext{
${ }^{16}$ RO nrs. 257(19), 257(59), 257(61), 257(87), 257(130), 257(148), 257(159), 257(198) en 257(214).

"Maarten Willem van Bowen, De rechterlijke instellingen ter discussie. De geschiedenis wan de wetgeving op de rechterljke organisatie in de periode 1795-181\%, diss. Nijmegen (Nijmegen, 1990) 41-56, biedt een globale beschrijving van de Franse rechterlijke organisatie vanaf 1789 tot 1795 .

"." Jean-Louis Halperin, Le Tribunal de Cassation et les powoirs sous la Révolution (1790-1799), préface de Gérard Sautel. Bibliothèque d'Histoire du Droit et Droit romain XXIII (Parijs, 1987) 205266 (titel III: het tribunal de cassation tussen het Directoire en het Wetgevend Lichaam).

${ }^{34}$ Godechot, Instritations, 476. Zie grondwet van $3^{*} 13$ september 1791 tit.III "Des pouvoirs publics", hfdst.V" "Du pouvoir judiciaire".
} 
grondwet van 1791 verwoordde dit heel elegant in art.5 van de derde titel: "Le Pouvoir judiciaire est délégué à des juges élus à temps par le peuple"wid.

\section{a. Burgerlijke rechtspraak}

De burgerlijke rechtspraak rustte op twee pijlers, namelijk het vredegerecht en de departementale burgerlijke rechtbank (tribunal civil) ${ }^{41}$. Arbitrage door scheidslieden tussen partijen onderling werd niet ontmoedigd. Hoger beroep van hun uitspraken was uitsluitend mogelijk als partijen dit nadrukkelijk hadden afgesproken.

De belangrijkste arbiter bleef de vrederechter. Dit werd door de diverse elkaar opvolgende wetgevende assemblees steeds voorgestaan. De assemblees wensten door middel van de arbitrage ten overstaan van de vrederechter zoveel mogelijk de toename van het aantal processen te voorkomen. Overeenkomstig de kantonnale onderverdeling van het departement van de Nedermaas waren ook de ressorten van de vredegerechten vastgelegd, behoudens het kanton Maastricht dat uit twee ressorten bestond: Maastricht-Noord en Maastricht-Zuid. In civiele kwesties vonniste de vrederechter - bijgestaan door twee assessoren - tot een beloop van 50 lives in muntgeld, of 100 livres in beroepszaken. Kwesties beneden 50 livres werden zonder beroepsmogelijkheid afgehandeld. Het vredegerecht besliste in geschillen van geringe importantie, doorgaans betrof het agrarische kwesties. De vrederechter en diens twee bijzitters vormden een bureau de paix et de conciliation om in geschillen eerst te trachten tot een schikking te komen, zonder welke een civiele actie niet ontvankelijk was bij de departementale burgerlijke rechtbank ${ }^{42}$.

De grondwet bood de mogelijkheid tot het instellen van handelsrechtbanken (tribunaux particuliers pour le commerce de terre et de mer). Een dergelijke handelsrechtbank kende het departement Nedermaas niet. Kwesties die eigenlijk tot de competentie van de handelsrechtbanken werden gerekend, werden in dat geval - na de conciliatie door de vrederechter - door de departementale burgerlijke rechtbanken behandeld.

Vóór het in werking treden van de grondwet van het jaar III viel het ressort van de tribunaux civils samen met het district. Veelal werden de tribunaux civils toen tribunaux de district genoemd. Nadien werd uit economische overwegingen het aantal burgerlijke rechtbanken teruggebracht overeenkomstig het aantal departementen.

\footnotetext{
4" De dispositions génévales van de achtste titel van de grondwet van het jaar III" "Pouvoir judiciaire" art.209, is minder fraai geredigeerd: "Nul citoyen, s'il n'a l'âge de trente ans accomplis, ne peut être élu juge d'un tribunal de département, ni juge de paix, ni assesseur de juge dle paix, ni juge d'un tribunal de commence, ni membre du Tribunal de cassation, ni juré, ni commissaire de Directoire executif près les tribunaux".

${ }^{41}$ Artt.210-221 van de grondwet van het jaar III.

${ }^{42}$ Godlechot, Insritutions, 476-477; Poullet, Institutions franģaises, 87-91; zie ook H. Hardenberg, Inventaris wan de archieven der rechtscolleges, alleensprekende rechters en rechterlike ambtenaren, wan 1794 tor 1841 gefungeerd hebhende op het grondgebied van de tegenwoordige Nederlandsche provincie Limburg ("s-Gravenhage, 1949) 29-31; voorts aangaande het instituut van het vredegerecht Henric-Jan Michiel van Dapperen, De vrederechter in Nederland 181/-1838. Mededelingen van het Juridisch Instituut van de Erasmus Uniwersiteit Rotterdam. Serie proefschriften I (Rotterdam, 1991) i.h.b. hoofdst.i.
} 
Bovendien was het district als lager overheidsorgaan afgeschaft. leder departement kende een burgerlijke rechtbank. De grondwet bepaalde dat er per tribunal civil ten minste twintig rechters dienden te zijn; verder een commissaris van het Directoire exécutif en diens substituut, alsmede een griffier. De zittingsduur van de gekozen rechters was vijf jaar, langer dan de vrederechters die voor twee jaren waren gekozen. In beide gevallen was herverkiezing mogelijk. Tijdens de verkiezing voor de rechters in de burgerlijke rechtbank dienden er tevens vijf plaatsvervangendle rechters te worden gekozen, van wie er drie moesten voortkomen uit burgers woonachtig in de plaats alwaar de rechtbank zetelde. Voor de te kiezen rechters golden geen bijzondere beroepskwalificaties. De vrederechters en assessoren werden gekozen door kantonnale assemblées primaires. Deze assemblees benoemden onder meer ook de kiezers voor de departementale assemblées électorales, welke onder meer tot taak hadden de rechters in de burgerlijke rechtbank en de departementale administrateurs te verkiezen. Voor de kiezers in een assemblée électorale gold een census-vereiste ${ }^{43}$.

De burgerlijke rechtbank vonniste in hoogste aanleg in door de wet bepaalde gevallen, alsmede in hoger beroep van de vonmissen van vrederechters, van scheidslieden of van de eventuele handelsrechtbanken. Het hoger beroep van een vonnis van een burgerlijke rechtbank werd behandeld door een tribunal civil in één van de drie aangrenzende departementen (appel circulaire $^{44}$ ). De volksrepresentanten bepaalden op 26 brumaire IV (17 november 1795) dat de burgerlijke rechtbanken in de departementen Ourthe, Twee Neten en Dijle als appelrechtbank voor die van de Nedermaas fungeerden. Een burgerlijke rechtbank splitste zich in secties; een sectie kon alleen vonnissen als er ten minste vijf rechters waren ${ }^{45}$.

Evenals bij een departementaal bestuur fungeerde er een commissaris van het Directoire exécutif bij de rechtbanken. Zijn taak bestond erin toe te zien op het reguliere karakter van de dienst, de inachtneming van de wet te requireren bij te vellen vonnissen en gewezen vonnissen te doen uitvoeren. Hij vertegenwoordigde in burgerrechtelijke zaken in zekere zin het openbaar ministerie. Het besluit van het Directoire van 10 thermidor IV (28 juli 1796) bij voorbeeld schakelde de commissarissen bij de rechtbanken in bij het opstellen van de verweermiddelen in kwesties waarbij de Franse Republiek partij was ${ }^{46}$.

\footnotetext{
4.3 Zie de titels III en IV van de grondwet van het jaar III; voor het departement van de Nedermaas, en voor de overige departements réunis, waren deze verkiezingen woor het eerst gedurende de maand germinal van het jaar $V$ aan de orde; voor die tijd waren de bestuurlijke en genechtelijke autoriteiten benoemd door de speciale gouwernementscommissarissen; de assemblées primaires kwamen ieder jaar van rechtswege bijeen op de eerste germinal (21 maart), de assemblees electorales op 20 germinal (9 apriil).

${ }^{44}$ Van Boven, Rechterlijke instellingen, 53; Godechot, Institutions, 146.

${ }^{45}$ Hardenberg, Imentaris archieven rechiscolleges, 6-8; Hardenberg verneld dat de rechtbank zich in vier secties verdeelde, maar dat er altijd maar twee gefungeerd hebben in de Nedermaase rechtbank; Godechot, Institutions, 477 datrentegen, vermeldt dat de burgerlijke rechtbanken zich in drie secties verdeelden.
}

${ }^{46}$ Arrêté concenant la poursuite et la direction des actions judiciaives qui intéressent la République van 10 thermidor IV (28 jul 1796). 
De grondwet van het jaar III onderscheidde in de strafrechtspraak correctionele en criminele rechtspraak. Het onderscheid was gelegen in het meer of minder ernstige karakter van de vergrijpen. Delicten die een bestraffing met zich meebrachten van ten hoogste drie clagen hechtenis of de waarde van drie dagwerken, vielen onder de competentie van de vrederechter, die in dat geval correctioneel vonniste ${ }^{47}$. De code des delits et des peines van 3 brumaire IV (25 oktober 1795) hanteerde de term van tribunal de police (politiegerecht). Ieder kanton kende een dergelijk politiegerecht. Het was samengesteld uit de vrederechter en twee van zijn bijzitters, de commissaris van het Directoire exécutif bij de desbetreffende kantonsmunicipaliteit en een griffier. Overtreders werden ofwel door de benadeelde partij, ofwel door de commissaris van de uitvoerende macht gedagvaard. Een verdachte kon zich niet laten bijstaan door een verdediger; hij hoefde evenwel niet persoonlijk te verschijnen en mocht zich door een gemachtigde laten vertegenwoordigen. De grondwet had bepaald dat in dit soort delicten dadelijk in hoogste ressort (en dernier ressort) werd gevonnist. De veroordeelde had, bij vermeende schending der wet, alleen nog recours bij het tribunal de cassation te Parijs. Een politiegerecht oordeelde trouwens ook in civiele acties ter zake van schadevergoedingen ${ }^{48}$.

Hetzelfde grondwetsartikel 233 , dat de vrederechter als politierechter aanwees, introduceerde tevens de correctionele rechtbanken (tribunaux correctionnels). Jeder departement kende ten minste drie en ten hoogste zes van dergelijke rechtbanken. In het departement van de Nedermaas waren er aanvankelijk vier correctionele rechtbanken, namelijk te Maastricht, Roermond, Hasselt en Sint-Truiden. De correctionele rechtbank te Sint-Truiden werd echter weer door gouvernementscommissaris Bouteville op 22 nivôse V (11 januari 1797) opgeheven vanwege de al te excentrische ligging. De opheffing geschiedde op verzoek van het departementaal bestuur ${ }^{49}$.

Correctionele rechtbanken namen kennis van delicten waarop bij bestraffing geen lijf- of onterende straffen (peines afflictives, peines infamantes) stonden. De maximaal op te leggen straf was twee jaar hechtenis. Een correctionele rechtbank was samengesteld uit een president, twee vrederechters of bijzitters van de vrederechter, afkomstig uit de gemeente alwaar de rechtbank zetelde. Voorts waren er een commissaris wan de uilvoerende macht en een griffier. De president werd elk half jaar en om beurten gekozen uit de rechters van de departementale burgerlijke rechtbank, uitgezonderd de president van die rechtbank. De procedure voor de correctionele rechtbank geschiedde in het openbaar, mondeling, en volgens eenvoudige regels. De commissaris van de uitvoerende macht gaf een samenvatting van de zaak, alsmede zijn conclusies. Wanneer er een officieuze verdediger was, werd ook deze gehoord. Staande de zitting werd er doorgaans vonnis gewezen. De commissaris diende vervolgens toe te zien op de tenuitvoerlegging van het vonnis. Hoger beroep van vonnissen van een correctionele rechtbank stond open bij de departementale criminele rechtbank, en wel binnen tien

\footnotetext{
${ }^{47}$ Art. $2333^{\mathrm{e}}$ alinea grondwet van 5 fructidor III (22 aug 1795).

40ullet, Institurions françaises, 116-118; Hardenberg, Inventaris archieven rechtscolleges, 32.

${ }^{49}$ Hardenberg, Inventaris archieven rechtscolleges, 15-16; zie ook regestenlijst sub dato.
} 
dagen voor de veroordeelde, de civiele partij, of de commissaris van de uitvoerende macht, of binnen de termijn van een maand voor de openbare aanklager aan wie de commissaris een uittreksel van alle correctionele vonnissen diende te overleggen. Alleen in geval van wetsschending kon het vonnis in hoger beroep worden voorgelegd aan het tribunal de cassation te Parijs ${ }^{50}$.

Naast de departementale burgerlijke rechtbank functioneerde in ieder departement ook een criminele rechtbank (tribunal criminel) ${ }^{51}$. Zij was samengesteld uit een president, een openbaar aanklager, vier rechters afkomstig van de burgerlijke rechtbank, de commissaris van het Directoire exécutif bij de burgerlijke rechtbank of diens substituut, alsmede een griffier. De voorzitters van de secties van de burgerlijke rechtbank konden geen zitting nemen in de criminele rechtbank; de andere rechters waren gedurende zes maanden rechter in de criminele rechtbank en konden zo lang geen deel uitmaken van de burgerlijke rechtbank. De president, de openbaar aanklager en de griffier werden gekozen door de assemblée électorale van het departement.

Een criminele rechtbank was competent in strafzaken die een lijf- of onterende straf met zich meebrachten. Dergelijke straffen konden evenwel alleen worden opgelegd na het oordeel van een jury. Er was in dit soort gevallen dus sprake van juryrechtspraak. De procedure voor de criminele rechtbank verliep via het oordeel van twee jury's. Allereerst diende een jury d'accusation zich uit te spreken over de toelating of verwerping van de akte van beschuldiging, met name of er voldoende grond was om de vervolging voort te zetten. In een departement waren er evenveel jurys d'accusation als er correctionele rechtbanken waren. De president van de correctionele rechtbank vervulde de functie van directeur du jury d'accusation ${ }^{52}$.

In geval van toelating van de aanklacht ving de definitieve instructie aan. De voorzitter van de criminele rechtbank had de bevoegdheid om de verdachte voor de terechtzitting te ondervragen. Tijdens de zitting geschiedde de procedure in het openbaar en mondeling. Na het horen van de getuigen formuleerde de openbaar aanklager, of eventueel de klagende civiele partij, zijn of haar conclusies ter ondersteuning van de beschuldiging. Daarop moest een tweede jury de jugement, bestaande uit minstens twaalf leden, een aantal vragen beantwoorden die door de president van de criminele rechtbank waren gesteld. Er mochten evenwel geen complexe vragen worden gesteld. Op straffe van nietigheid van het vonnis diende door de jury de jugement in ieder geval de vraag aangaande de opzet van de verdachte te worden beantwoord ${ }^{53}$. De verdachte had het recht een bepaald aantal van de juryleden te wraken. Ook kon hij zich laten bijstaan door een raadsman, hetzij één van eigen keuze, hetzij één hem ambtshalve toegewezen.

\footnotetext{
5nt Artt.233-236 wan de grondwet van het jaar III; Poullet, Institutions françaises, 118-121.

51 Artt.237-253 van de grondwet van het jaar III; Godechot, Institutions, 478-479; Poullet, Institutions frangaises: 12 1-131.

52 Aangaande de opkomst en de ontwikkeling van de juryrechtspraak in Frankrijk: Geert Bossers, "Welk eene natie, die de jurij gehad heeft, en ze weder afschaft"" (Delft, 1987) hoofdst.i i.h.b. 6-12. " Loi portant que la question relative à l'intention sera posée à l"avenir dans toutes les affaires soumises d̀ des jurés de jugement van 14 vendémiaire III ( 5 okt 1794).
} 
Werd door de jury de jugement de verdachte schuldig bevonden, dan sprak de commissaris van de uitvoerende macht zijn eis tot toepassing van de wet uit, waarop de rechtbank vonniste. Van vonnissen van een criminele rechtbank was geen hoger beroep meer mogelijk. De enige weg voor de verdachte en de commissaris van de uitvoerende macht - de laatste alleen in het belang van de wet - bestond dan nog in de mogelijkheid van cassatie. Grondwettelijk was aan de commissaris van de uitvoerende macht bij de criminele rechtbank de tenuitvoerlegging van de vonnissen opgedragen. Eveneens was grondwettelijk vastgelegd dat als een verdachte door een wettige jury vrijgesproken was, hij niet nogmaals wan hetzelfde feit kon worden beschuldigd, noch worden vervolgd.

Naast de criminele zaken die lijf- of onterende straffen met zich konden meebrengen, vonniste een departementale criminele rechtbank ook nog - maar dan zonder jury - over het beroep inzake vonnissen van de correctionele rechtbanken, alsmede correctionele delicten begaan door gerechtelijke en opsporingsambtenaren.

Tot zover de hoofdlijnen van de rechterlijke macht op het terrein van de burgerlijke en de strafrechtspraak zoals die in hoofdstuk VIII van de grondwet van het jaar III staan omschreven. Een aanvullende reeks van wetgeving op dit terrein is beschreven in de regestenlijst met afgekondigde rechtsvoorschriften. Ook in de Code Merlin staat nog wetgeving op het gebied van de burgerlijke en de strafrechtspraak.

\section{c. Aanvullende wetgeving op het terrein van de burgerlijke en de strafrechtspraak}

De volksrepresentanten Pérès en Portiez hebben in een arrêté sur l'organisation de l'ordre judiciaire en matière civile van 2 frimaire IV (23 november 1795) een aanzienlijk gedeelte van de al bestaande wetgeving op het terrein van de rechterlijke organisatie, zoals deze door de Assemblée nationale constituante was ontwikkeld in het departement Nedermaas, afgekondigd. Dit besluit was een compilatie van de in Frankrijk nog vigerende wetgeving. In de regestenlijst is al deze wetgeving afzonderlijk opgenomen. Het besluit van de volksrepresentanten kan echter evengoed als én afzonderlijk rechtsvoorschrift worden beschouwd, te meer daar zij de wetstekst soms sterk hebben gewijzigd en de artikelen hebben herordend ${ }^{54}$.

De Constituante had reeds de hoofdlijnen van de rechterlijke organisatie vastgelegd. De belangrijkste wet in dezen is de loi sur l'organisation judiciaire van $16 * 24$ augustus 1790 . Deze wet al regelde de relatieve competentie van de diverse gerechten en ontwikkelde de in eerste aanleg voorgestane conciliatie en arbitrage, teneinde een overmaat aan gerechtelijke procedures te vermijden. Ook in de grondwet van het jaar III is alle ruimte gelaten voor de zogenaamde arbitrage: "Il ne peut être porté atteinte au droit de faire prononcer sur les différends par des arbitres du choix des parties" (art.210). Van beslissingen van de scheidslieden was geen hoger beroep mogelijk, evenmin een voorziening in cassatie, tenzij partijen dit uitdrukkelijk waren overeengekomen. In de wet van 16 augustus 1790 was dus de opzet van de vredegerechten

${ }^{54} \mathrm{RO}$ nrs.76 en 77 ; in de regestenlijst is nadrukkelijk aangegeven dat de afgekondigde wetgeving deel uitmaakt van het besluit van de volksrepresentanten. 
geregeld, waarin een belangrijke rol toegekend was aan het bureau de paix et de conciliation. De vervolgwetgeving die via het besluit van de volksrepresentanten werd afgekondigd, kan worden beschouwd als ampliatie. Het betreft hier onder meer bepalingen ter zake van de incompatibiliteiten, kledingvoorschriften, bezwaren tegen de hoogte van opgejegde belastingen en zo meer. De wet van 14 en $18 * 26$ oktober 1790 op de procedure bij de vredegerechten werd integraal afgekondigd ${ }^{55}$. In het algemeen kan men zeggen dat aanzienlijke gedeelten van de wetgevingsarbeid van de Constituante op het terrein van de rechterlijke organisatie met het zwaartepunt op de vredegerechten in de départements réunis in werking is gebracht. Het betreft dus hoofdzakelijk de wetgeving uit de jaren 1790 en 1791.

In het besluit van de volksrepresentanten van 2 frimaire IV (23 november 1795) was voorts een afzonderlijk besluit als \& IX opgenomen. Het betreft hier het al eerder genoemde besluit van 26 brumaire TV (17 november 1795) aangaande de aanwijzing van de departementale rechtbanken die over en weer als appelrechtbank fungeerden. In het onderhavige besluit was tevens bepaald dat het pleiten ten overstaan van de departementale rechtbank in de Franse taal diende te geschieden. Op grond van genoemd besluit dienden de vonnissen in het Frans te zijn opgesteld. In dezelfde maand frimaire vaardigden de volksrepresentanten nog een aanvullend besluit uit aangaande de instructie van zaken bij de nieuw gevormde burgerlijke rechtbanken in de departementen. Niet alleen de pleidooien, maar al het geschrevene diende in de Franse taal te zijn gesteld:

Tout document écrit en toute autre langue qu'en français, sera produit en langue française, avec la pièce sur laquelle la traduction aura été faite, à peine de rejection. Ces traductions seront nécessairement faites ou approuvées et signées par des traducteurs admis par le tribunal ${ }^{56}$.

Het laat zich denken dat in de gebieden, zoals in het departement van de Nedermaas, waar het Frans gewoonlijk niet de dagellikse omgangstaal vormde, dit door de justitiabelen als hinderlijk werd ervaren ${ }^{57}$.

Ook op bestuurlijk terrein deden zich hieromtrent moeilijkheden voor. Zo stelde het departementaal bestuur gouvernementscommissaris Bouteville in kennis van het feit dat de voorzitter van de kantonsmunicipaliteit van Heerlen het Frans niet machtig

\footnotetext{
ss Loi contenant réglement sur la procédure en la justice de paix.

56 Art.21 van het arrêté sar l'instruction des causes dans les tribunawe civils des nouveaux départemèns réunis à la République par la loi du 9 vendémiaire dermier van 28 frimaire IV (19 dec 1795).

${ }^{57}$ Dit wordı ook geconstateerd door Herman Van Goethem, "La francisation révolutionnaire, résultat" d'initiatives locales. Le cas des tribunaux en Flandre et en Alsace" in: Roland Mortier \& Herve Hasquin, ed. "Deux aspects contestés de la politique révolutionnaire en Belgique: langue et culte", Etudes sur le XVIII siecle, XVI (1989) 39-52, met name in fine; de schrijver benadrukt de aanvankelijk divergerende ontwikkeling ten aanzien van het Frans in Vlaanderen en in de Elzas; C.Coppens, "Het tribunal civil du département de l'Escaut en de rechtspraak van eerste aanleg te Gent. Een bijdrage tot de studie van de burgerlijke rechtspraak in de periode 1796-1830", Belgisch Tijdschrift woor Nieuwste Geschiedenis/Revue Belge d"Histoire Contemporaine, XIV (1983) 25-26, vermeldt dat de rechtszittingen niet uitsluitend in het Frans verliepen. Zie over deze problematiek bij voorbeeld ook het informatieve artikel van Antonio Grilli, "Sprache und Recht in den französischen Rheinlanden. Die Einführung des Französischen als Gerichtssprache im Saardepartement 1798", Rheimische Vierteljahrsblätter. LVII (1993) 227-252.
} 
was. In zijn antwoord benadrukte Bouteville dat er in de departements rëunis veel kantons waren waar slechts Vlaams, of zelfs alleen maar Duits of Hollands gesproken werd. In die kantons was het uiterst moeilijk mensen te vinden die gewoonlijk Frans spraken. Bouteville was van mening dat het veruit te wensen ware dat een kantonsvoorzitter Frans sprak, maar hij betwijfelde toch of het niet of slechits in geringe mate beheersen van het Frans door een kantonsvoorzitter, gelet op de recruteringsproblemen, voor het Directoire exécutif wel een voldoende reden zou vormen om dergelijke kantonsvoorzitter uit zijn ambt te zetten ${ }^{58}$. De kantonsmunicipaliteit van Nedercruchten (Niederkrüchten), ook in het departement Nedermaas, berichtte aan het departementaal bestuur dat men voor het vertallen van de Franse wetten eigenlijk op kosten van het kanton een vertaler in dienst zou moeten nemen. Het kanton vroeg hieromtrent advies. Het departementaal bestuur ondersteunde de zienswijze van het kanton en was daarom van mening dat het beter zou zijn om een bezoldigde vertaler in dienst te nemen, dan de ingezetenen in de gelegenheid te stellen zich voortdurend aan de wet te onttrekken ${ }^{5 \%}$ :

Puisqu'il n'y a pas d'autre moyen de faire connoitre les loix a vos concitoyens qu"en employant la langue du pays, il est juste que vous les fassiez passer dans l'idiome qu'ils parlent, et il vaut mieux que wous soyez obliger d'employer un traducteur que de mettre vos administrés dans le cas de prévariquer continuellement aux loix.

Alvorens de volksrepresentanten de nieuwe rechterlijke organisatie op gang konden brengen, moesten zij in de départements réunis de bestaande gerechten ontbinden. Bij besluit hielden formeel op 10 frimaire IV ( 1 december 1795) des middags om 12 uur de hogere gerechtshoven (tribunaux supérieurs) in de Zuidelijke Nederlanden op te functioneren. Het reeds kort na de bezetting in december 1794 door de Franse autoriteiten geïnstalleerde Maastrichtse oppertribunaal bleef evenwel nog functioneren tot de

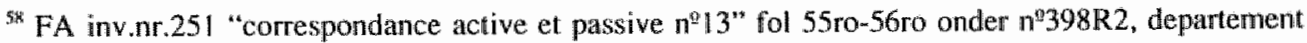
aan Bouteville 16 thermidor IV ( 3 aug 1796), fol 81vo-82 vo onder $n^{0} 347 \mathrm{R} 2$, Bouteville aan departement 21 thermidor IV ( 8 aug 1796): "... il existe dans les neuf Départements rétunis beaucoup des cantons où l'on ne parle que le flamand, quelques uns même où c'est l'allemand d'autres le hollandass. Il doit être, et il est en effet extrêmement difficile de trouver dans ces cantons des citoyens qui parle[nt] surtout famillierement le français (...) sans doute il seroit infiniment a souhaiter que le Président d'une administration de canton parlat le français, mais je doute que le Direct re regarde l'ignorance de cette langue dans l"ordre administratif, comme une raison suffisante d'incapacité, surtout comme je wous l'observe d"après la circonstance que je viens de wous rappeller, au surplus je proposerai la question au Directoire"; dit schrijven gedeeltelijk ook opgenomen in Hubert \& Tihon, Correspondance de Bouteville, 1, 37 1-372 missive $n^{9} 197$; bovenstaande opvatting wordt ook bevestigd door Grammann, Französische Verwaltung, 104 "Bei gehobenen Posten wurde auBerdem die berufliche Qualifikation überprüft, mangelnde französische Sprachkenntnisse freilich standen durch den allgemeinen Personalmangel einer Anstellung nicht im Wege".

59 FA inv.nr. 12 "indicateur général A4" 25 nivốse V (14 jan 1797) onder n"350R4; FA inv.nr.259 "correspondance active et passive $n^{2} 21$ " fol 117 vo onder $n^{2} 350 R 4$, departement aan kanton Nedercruchten 28 nivôse V (17 jan 1797).
} 
benoeming van de rechters en overige leden van de burgerlijke rechtbank door gouvernementscommissaris Bouteville medio januari $1796^{60}$.

In de periode vanaf de inlijving bij Frankrijk tot aan de afkondiging van de Code Merlin werd er tamelijk veel wetgeving op het terrein van de burgerlijke rechtsvordering en de rechterlijke organisatie in de départements réunis ingevoerd. Een deel van de rechtsvoorschriften had betrekking op de organisatie van de rechterlijke macht, dat wil zeggen het aanwerven van rechterlijke ambtenaren en hun benoeming, bezoldiging, fondsen voor de gebouwen en de recesperiodes. De organieke wet van 19 vendémiaire IV ( 11 oktober 1795), uit de nadagen van de Convention nationale dus, omvatte een nadere uitwerking van de rechterlijke organisatie ten aanzien van de burgerlijke, correctionele en handelsrechtbanken, alsmede de vredegerechten. De wet bepaalde ook dat zaken die aanhangig waren bij de door de grondwet opgeheven districtsrechtbanken ter kennisneming kwamen van de departementale burgerlijke rechtbanken. De door de wet (art.41) in het vooruitzicht gestelde bijzondere wet houdende de bestuurlijke en rechterlijke organisatie in de départements réunis is voor zover bekend niet tot stand gekomen ${ }^{61}$.

Minstens even belangrijk als de organisatiewetgeving was de wetgeving op de rechtbankprocedures. De Convention nationale had op 3 brumaire II (24 oktober 1794) bij decreet ${ }^{62}$ een nieuwe rechtbankprocedure uitgevaardigd, die een sterke vereenvoudiging van de instructie van zaken betekende. De voorheen gebruikelijke procedure met verzoekschriften werd afgeschaft en vervangen door middel van het indienen van een eenvoudige memorie. Het instituut van procureur werd ook opgeheven; partijen konden zich alleen nog maar laten vertegenwoordigen door eenvoudige gemachtigden (simple fondé de pouvoir). Het decreet was bedoeld om de vormvereisten en de kosten tot een minimum te reduceren. De rechtbanken dienden zonder kosten te vonnissen na het afleggen van een mondelinge verdediging of na het indienen van een eenvoudige memorie. Deze nieuwe vorm van burgerlijke rechtsvordering had het karakter van gelegenheidswetgeving, maar hield toch stand tot de Napoleontische tijd. Formeel werd de Ordonnance civile van april 1667 op de procedures door het decreet van 3 brumaire II niet herroepen. De eerdere rechtshervorming die in 1791 was doorgevoerd had zich hierop nog gebaseerd. Vandaar dat grote delen van de ordonnantie van Lodewijk XIV nog in de Code Meriin zijn opgenomen.

64) Arrete portant que les anciens ribunax supérieurs de la ci-devant Belgique cesseront leurs fonctions le 10 de ce mois van 6 frimaire (27 nov 1795); zie over het Maastrichtse oppertribunaal A.Fl. Gehlen, "Het Maastrichtse Tribunal Supérieur (einde 1794 - begin 1796)" in: Bernadette C.M. van Hellenberg Hubar e.a., ed., Maaslands Melange. Opstellen over Limburgs verleden Dr. P.J.H. Uhachs aangeboden bij gelegenheid van zijn vijfenzestigste verjaardag. Werken Limburgs Geschieden Oudheidkundig Genootschap XIV (Maastricht, 1990) 107-120.

6) Loi sar la division du territoine de la République. le placement et l'organisation des autorités administratives of judiciaires; de onderhavige wet is ook van belang voor de bestuurlijke organisatie met betrekking tot vaststelling van de spreiding van de besturen.

${ }^{62}$ Décret qui détermine une nouvelle forme powr l'insturtion des affaines devant les tribunaux, et supprime les fontions $d$ 'avonés; zie over deze wet ook Claudine Bloch \& Jean Hilaire" "Nouveauté et modemité du droit révolutionnaire: la procédure civile" in: La Révolution et lardre juridique privé. Rationalité ou scandale? Actes du colloque d"Orléans 11-13 septembre 1986 (2 din; Orléans, 1988) II, 469-482, i.h.b. 470-471, 474, 479-480. 
Voortdurend vaardigde de wetgevende macht te Parijs nieuwe rechtswoorschriften op het terrein van het procesrecht en de rechterlijke organisatie uit. Bij wet van 7 fructidor III ( 24 aug 1795) moesten in civiele kwesties getuigen ten overstaan van de districtsrechtbanken en in aanwezigheid van de belanghebbende partijen in het openbaar worden gehoord. Er was verder een speciale wet inzake het wraken van rechters (23 vendémiaire IV/15 oktober 1795); er was een wet op de inrichting van het tribunal de cassation ( 2 brumaire IV/24 oktober 1795); er was een wet die bepaalde waar de minuten van akten van vrederechters in civiele kwesties dienden te worden gedeponeerd (26 frimaire IV/17 december 1795); er was een wet op de wijze van procederen inzake reclamaties met betrekking tot besluiten van volksrepresentanten en mission (25 ventôse IV/15 maart 1796); er was een wet op de procedure bij conciliaties (26 ventôse IV/16 maart 1796); er was een wet op de te volgen procedure voor personen die niet langer de werking van besluiten van de regeringscomités en van volksrepresentanten en mission genoten, aangezien die besluiten herroepen waren door posterieure wetgeving ( 3 vendémiaire V/24 september 1796). Onnodig te vermelden misschien, dat er daamaast ook nog reeksen besluiten door de gouvernementscommissarissen en vervolgens door het Directoire exécutif uitgevaardigd werden om de rechterlijke organisatie verder op gang te brengen.

Niet alleen werden er voordurend nieuwe wetten en besluiten uitgevaardigd en in het departement Nedermaas afgekondigd die te beschouwen zijn als een verfijning van in het onderhavige geval de rechterlijke organisatie en de burgerlijke rechtsvordering, er werd zo nu en dan bij wet ook wel eens iets afgeschaft. Enige maanden na de invoering van grondwet van het jaar III werden via twee wetten, beide van 9 ventôse IV (28 februari 1796), zowel het familiegerecht als de gedwongen arbitrage afgeschaft, omdat de grondwet niet langer voorzag in dit soort beslechting van geschillen. De kennisneming van de zaken die voorheen bij deze gerechtelijke instanties berustte, was nu opgedragen aan gewone rechters ${ }^{63}$. De mogelijkheid voor partijen om zich te onderwerpen aan vrijwillige arbitrage, en die door de grondwet werd voorgestaan, bleef onverkort van kracht.

Zowel de Code Merlin als de Bulletins des Lois van na 16 frimaire V ( 6 december 1796) hebben nog wetten opgenomen op het gebied van de burgerlijke rechtsvordering en rechtspraak. Zo werd er een interpretatieve wet uitgevaardigd die de gevallen aanduidde waarbij vonnissen in civiele zaken kunnen en moeten worden vernietigd ${ }^{64}$. Het afschaffen van de verplichte arbitrage noodzaakte enige maanden nadien eveneens

${ }^{63}$ Loi qui atribue aux juges ordinaires la connaissance des affaires qui étaient partées devant les vibunaux de famille; loi qui ordonne que les affaires dont la connaissance élait atribuée à des arbitres fortés, seront portếes devant les juges ordinaires; Poullet, Institutions françaises, 86-87; Coppens, "Tribunal civil", 8 , vermeldt dat de familiegerechten al impliciet door de grond wet wan het jaar III afgeschaft waren, maar door de volksrepresentanten toch nog via hum besluit van 2 frimaire IV (23 nov 1795) uitdrukkelijk werdlen ingevoerd.

${ }^{64}$ BL Ile ser no.99 (933), loi interprếtative des dispositions de l'article 4 de celle du 4 germinal, an II. qui détermine les cas où les jugemens peuvent \& doivent être annullés en matière civile van 7 nivơse $\mathrm{V}(27 \mathrm{dec} 1796)$. 
tot een interpretatieve wet ${ }^{65}$. Weer een andere wet kende aan de vrederechters zelf het benoemen en ontslaan van hun griffier toe ${ }^{66}$.

Ook op het gebied van het strafrecht werden er door de volksrepresentanten een groot aantal wetten in de départements réunis van kracht verkllaard en die begin januari 1796 in het departement Nedermaas formeel werden geregistreerd ${ }^{67}$. Bij besluit van 24 frimaire IV (15 december 1795) werd de in de nadagen van de Convention nationale aanvaarde cade des délits et des peines van 3 brumaire IV (25 oktober 1795) afgekondigd. Een Franse rechtshistoricus schreef over dit wetboek dat het feitelijk ging om een "code d'instruction criminelle" ${ }^{\text {"68. }}$. In dit wetboek komen de rechtshandhaving, de rechtspleging door de diverse gerechtelijke instanties en de strafmaat voor de onderscheidene delicten aan de orde. Gelijktijdig met de code des délits et des peines werden nog eens vijftig andere wetten, geheel of gedeeltelijk, op het gebied van het straf-en strafprocesrecht afgekondigd. Dit vloeide voort uit de artt.609 en 610 van de $\operatorname{code}^{69}$ die deze wetten uitdrukkelijk handhaafde, daar hij immers hoofdzakelijk zag op de strafrechtelijke procedure. De belangrijkste hiervan waren het product van de wetgevende arbeid van de Constituante, te weten het décret sur la police municipale et correctionnelle van $19 * 22$ juli 1791 , de code pénal van 25 september * 6 oktober 1791 en de loi concernant les biens et usages ruraux et la police rurale van 28 september * 6 oktober 1791 .

Het décret sur la police municipale et correctionnelle behelsde de handhaving van de openbare orde in de gemeenten. Het toezicht was opgedragen aan gemeentelijke instanties. Logementhouders en herbergiers dienden een register van overnachtingen bij te houden. Verder was de hoogte van de strafmaat bepaald voor een reeks politiemaatregelen op het gebied van gebouwen, onrust op straat, voedsel en dergelijke. De code pénal was een ware verbetering op strafrechtelijk terrein in vergelijking tot het arbitraire karakter van het strafrecht uit het ancien régime. Voor het eerst werd er meer vertrouwen gesteld in de mogelijkheid tot correctie van delinquenten door middel van detentie en het vooruitzicht op invrijheidstelling. Minutieus werden daarom de diverse misdrijven met de bijbehorende strafmaat omschreven. De straffen die opgelegd konden worden, waren de doodstraf (uitsluitend door middel van onthoofding), dwangarbeid in ketenen (fers), eenzame opsluiting op water en brood (gêne),

6.5 BL IIe ser no.51 (435), loi sur les demandes en cassation de jugemens d'arbitrage forcé, rendus avant le $I^{\text {pr }}$ vendémiaire, an IV van 12 prairial IV (31 mei 1796).

66 BL Ile ser no.97 (915), loi qui autorise les juges-de-pax à nommer \& destituev leurs greffiers van 28 frimaire $V(18$ dec 1796$)$.

${ }^{67}$ Zie RO nr.89.

${ }^{6}$ Pierre-Paul Viard, Histoire gênérale du droit privé français" (1789-1830) (Parijs, 1931) 141-142.

69 Art 609: "En attendant que les dispositions de l'ordonnance des eaux et forêts de 1669, les lois des 19 juillet et 28 septembre 1791 , celle du 20 messidor de I'an 3 , et les autres relatives à la police municipale, correctionnelle, rurale et forestière, aient pu être révisées, les tribunaux correctionnels appliqueront aux délits qui sont de leur compétence, les peines qu'elles prononcent"; art.610: "Les tribunaux criminels se conformeront, jusqu’à ce qu'il en ait été autrement ordonné, à toutes les dispositions, tant du code pénal décrété par l'Assemblée constituante le 25 septembre 1791, que les autres lois pénales émanées, soit de l'Assemblée legislative, soit de la Convention nationale, auxquelles il n'a pas été dérogé jusqu"à ce jour". 
opsluiting in een tuchthuis (réclusion), detentie, deportatie, burgerlijke degradatie en de schandpaal (carcan). De Franse revolutionaire wetgevers kenden een veel grotere rol toe aan gevangenissen bij de strafrechtspleging, dan voordien het geval was geweest, maar stuitten daardoor op het feit dat er te weinig van waren en ook niet op korte termijn beschikbaar zouden zijn. De code pénal bleef verder wel gedurende de gehele Revolutie van kracht voor zover het cle misdrijven op het terrein van het gemene recht betrof. De Napoleontische code pénal van 1810 heeft dan ook veel bepalingen van zijn voorganger overgenomen ${ }^{70}$. De loi concernant les biens et usages ruraux et la police rurale behelsde het toezicht op het platteland en het voorkomen van overtredingen die samenhingen met agrarische werkzaamheden. Het toezicht ressorteerde onder de jurisdictie van de vrederechters en gemeenteambtenaren. De vrederechters waren competent ter zake van de beslechting van geschillen en het tegengaan van overtredingen en dergelijke. Deze wet werd ook wel betiteld als code rural. Gedurende de Revolutie evenwel, en verder de gehele negentiende eeuw, hadden de respectieve wetgevers grote moeite om tot een adlequatere codificatie ervan te komen. Al heel gauw immers belandde men op het terrein van het bepaalde in de code civil, die de algemene beginselen betreffende de eigendomsrechten had vastgelegd. De burgerlijke wetgeving omvatte de facto ook reeds het agrarische gemene recht $^{71}$.

Het resterende gedeelte van dit corpus aan strafwetgeving dateerde hoofdzakelijk uit de tijd van de Nationale Conventie. Deels ging het om precisering van al bestaande regelingen of nog niet geregelde zaken (vooral de strafrechtelijke procedure en strafbepalingen), deels ging het om gelegenheidswetgeving. Aangaande dit laatste waren er bij voorbeeld wetten die regelden hoe er moest worden gehandeld bij criminele processen, wanneer bepaalde streken door de vijand of door opstandelingen bezetgehouden werden. Door wetgeving moest men ook de plundering van granen en andere voedingsmiddelen zien te voorkomen. De gelegenheidswetgeving blijkt heel duidelijk uit de wet die vrouwen verplichtte om een driekleurige kokarde te dragen, alsmede de wet die bepaalde dat, als de vrijheidsboom doodgegaan was, er bij het begin van de lente op de eerste germinal een nieuwe geplant diende te worden ${ }^{72}$.

${ }^{3}$ Het al eerder genoemde colloquium te Orléans in 1986 La Revolution ef l'ordre juridique privé. Rationalité ou scandale? heeft aspecten belicht van de code pénal van 1791, hoofdzakelijk wat de totstandkoming erwan betrof: Renée Martinage "Les origines de le pếnologie dans le code pénal de 1791", 15-29; Jacques Godechot, "Les influences étrangères sur le droit pénal de la Révolution française", 47-53; Jean-Jacques Clère, "Les Constituants et l'organisation de la procédure pénule", 44 1-456; de laatstgenoemde bijdrage handelt over de stafrechtsprocedure, zoals deze zich ontwikkelde gedurende de Assemblée constituante: de voorheen schriftelijke en geheime procedure tijdens de fase van instructie werd openbalar en goeddeels mondeling; de schrijver stelt voorts dat de wet van 19 juli 179॥ sur la police mumicipale et correctionnelle een inbreuk betekende op het beginsel van de machtenscheiding, daar de gemeenten belast werden met de ordehandhaving.

"Françoise Fortunet, "Le code rural ou l'impossible codification", Annales Historiques de la Révolution Franchaise, LIV (1982) 95-112; J. Grauwels, "De Code Rural in het departement van de Nedermaas", Het Oude Land van Loon, XXXIV (1979) 127-155, geeft een overzicht van de reeks van 34 vragen en de beantwoording daarvan door de prefect aangaande deze problematiek, ten behoeve van de redactie van een nieuw te ontwerpen code rural.

${ }^{72} \mathrm{RO} \mathrm{nr} .89(40)$, décret qui enjoint aux femmes de porter la cocarde tricolore van 21 september 1793; $\mathbb{R O}$ nr.89(18), décret relatif aux arbres de la liberté wan 3 pluviôse II (22 jan 1794). 
Van wezenlijker belang was de wet van 20 messidor III ( 8 juli 1795) die voorzag in het aanstellen van veldwachters in iedere plattelandsgemeente ${ }^{73}$. Blijkens een artikel over het Leiedepartement hadden de autoriteiten aldaar moeite met de recrutering van personen die voor de functie van de veldwachter geschikt waren. Evenals dit voor andere functionarissen gedurende het Directoire gold, lag dit voor een niet gering deel aan de slechte bezoldiging. De functie van veldwachter werd door de aangestelden vaak als een bijbaan beschouwd. Het leidde er toe dat lang niet altijd betrouwbare personen deze functie uitoefenden. Pas onder het bewind van Napoleon kwam hierin verbetering ${ }^{74}$. De wet op het aanstellen van veldwachters kende ook een opmerkelijke bepaling die voorschreef dat het behoud van de oogst onder het toezicht geplaatst werd van "goede" burgers. Om dit te bevorderen moest er langs de hoofdweg in elke gemeente een bord geplaatst worden met de tekst: "Citoyen, respecte les propriétés et les productions d'autrui; elles sont le fruit de son travail et de son industrie". Het zou wel interessant zijn om te weten of dergelijke bordjes met die tekst, waarschijnlijk dan vertaald, ook langs de wegen in het departement Nedermaas zijn geplaatst.

Het hierboven aangeduide corpus vormde maar een gedeelte van de afgekondigde wetgeving inzake het strafrecht en het strafprocesrecht. De door het Corps législatif uitgevaardigde wetgeving werd successievelijk op last van het Directoire in de départements réunis afgekondigd. Die wetgeving behelsde onder meer de volgende onderwerpen. Bloed- en aanverwanten van één van de medeverdachten inzake hetzelfde strafbare feit en vallende onder dezelfde akte van beschuldiging werden niet als getuige gehoord tegen de overige verdachten ${ }^{75}$. De gelijktijdige terechtstelling van ter dood veroordeelde rechtsopvolgers in de opgaande en de neergaande lijin, zou tot de onmogelijkheid leiden om het vooroverlijden vast te stellen. De jongste van de veroordeelden werd dan verondersteld het langst te hebben geleefd ${ }^{76}$. Door het Corps législatif werd opnieuw een wet op het terugdringen van veld- en bosdelicten uitgevaardigd. Vanwege het feit dat er nog geen nieuwe organisatie van de gendarmerie nationale tot stand gekomen was, ontbrak het de veld- en bospolitie aan een belangrijk middel van toezicht. Kennelijk ging dit ten detrimente van te velde staande gewassen. De processen-verbaal van de veld-en boswachters hoefden daarom niet aan de formaliteit van registratie te worden onderworpen. Noodzakelijk was alleen dat de veld- en boswachters de echtheid van de processen-verbaal ten overstalan van de vrederechter of één van diens assessoren bevestigden ${ }^{77}$.

\footnotetext{
${ }^{7}$ RO nr.89(2) en 89(4I), loi qui ordonne l'établissement des gardes champêtres dans toutes les comwunes rurales de la République.

7 Daniël Vermandere, "De Veldwachters in het Leie Departement (1795-1809)", Standen en LandentAniens Pays et Assemblées d" Etats, XLIV (1968) 145-174.

${ }^{75} \mathrm{RO}$ nr. 134(6), loi portant que les parens el alliés de l'un des co-accusés du même fait, ne peuvent êtré entendus comme témoins contre les autres accusés van 15 ventôse IV (s mrt 1796).

${ }^{76} \mathrm{RO}$ nr.170(5), loi qui érablit un mode pour statuer sur le prédécès de plusieurs individus se succédant de droit, et morts dans la même exécution van 20 priarial IV (8 jun 1796).

${ }^{7} \mathrm{RO}$ nr. $195(8)$, loi relative a la répression des délits ruraux et forestiers wan 23 thermidor IV (10 aug 1796).
} 
De code pénal van 1791 kende geen strafbedreiging tegen poging tot diefstal, brandstichting en andere misdrijven, met uitzondering van moord en vergiftiging. De wetgever stelde alsnog de poging tot een misdrijf strafbaar, wanneer het misdrijf sllechts door toevallige, buiten de wil van de verdachte gelegen, omstandigheden was gestaakt. Een dergelijke poging diende even zwaar te worden bestraft als het misdrijf zelf ${ }^{78}$.

Het juridische handelen van het Directoire exécutif kreeg gestalte in de vorm van arrêtés. Bij een dergelijk besluit herriep het Directoire na ruim acht maanden de afkondiging door de gouvernementscommissarissen van de wet van 14 vendémiaire III (5 okt 1794) inzake het stellen van de formele vraag naar de opzet van de verdachte door de jury. Het Directoire stelde dat deze afkondiging bij vergissing was geschied $^{79}$.

Procesrechtelijk gezien kwamen er ook irrationaliteiten naarvoren. Het Directoire besloot op 8 brumaire V (29 oktober 1796) dat er geen geld uit de staatskas ter beschikking zou worden gesteld ter bestrijding van de drukkosten van de vonnissen van de criminele rechtbanken. Wettelijk was dit alleen toegestaan voor het drukken van de vonnissen van het tribunal de cassation en van de vonnissen van de correctionele rechtbanken als er sprake was van recidive. Nog geen drie maanden later besloot het Directoire weer wel dat van de vonnissen van de criminele rechtbanken elke maand een beknopt overzicht gedrukt diende te worden om als informatie aan de bevolking te worden aangeplakt ${ }^{80}$. Het Directoire bepaalde ook dat vonnissen van de politiegerechten aan de delinquenten dienden te worden overhandigd, om het even of het nu een boete of hechtenis betrof ${ }^{81}$. Het wederrechtelijk kappen van bomen of het stelen van hout en van houtvlotten werd eveneens met behulp van Directoire-besluiten tegengegaan ${ }^{82}$.

In de Code Merlin is vanzelfsprekend ook nog wetgeving op het gebied van de strafrechtelijke procedure opgenomen. De wet van 14 mei 1793 schreef voor op welke wijze geannuleerde strafrechtelijke procedures opnieuw dienden te worden begonnen. De wet van 29 juni 1793 bepaalde dat tot detentie en dwangarbeid in ketenen veroordeelden voor de tenuitvoerlegging ervan eerst enige uren op een schavot te kijk

\footnotetext{
${ }^{7 *}$ RO mr. 170(6), Loi portant des peines contre la tentative du crime van 22 prairial IV (10 jun 1796). ${ }^{7 \%} \mathrm{RO} \mathrm{nr} .89(30), \mathrm{nr} .191$, arrêté qui rapporte cellui du 24 frimaire, an IV, par lequel l'exécution de la loi du 14 vendémiaire, an 11 , a été ordonnée dans les neuf départemens rếunis wan 2 fructidor IV (19 aug 1796).

* RO nr.221(1), arrêté portant qu'il ne sera alloué aucune somme pour l"impression des jugemens des ribunaux criminels van 8 brumaire V (29 okt $\| 796)$; BL IIe ser no.102 (969), arrêté qui ordonne l'impression en placards, à la fin de chaque mois, d'un état sommaire des jugemens rendus par les tribunaux criminels van 2 pluwiôse $V(21$ jan 1797).

${ }^{*} \mathrm{BL}$.lle ser no.101 (957), arrêté concernant les jugemens des tribunaux de police qui, en matière de. délits de leur compérence, seraient remise aux délinquans, soít de l'amende, soit de l'emprisonnement van 27 nivôse $\mathrm{V}$ (16 jan 1797).

*2. BL Ile ser no.98 (923), arrêté concernant les perquisitions de bois coupés en délit ou volés van 4 nivôse V (24 dec 1796); BL Ile ser no.103 (976), arrêté qui déclare applicables à la recherche des bois volés sur les rivières ou ruisseawx flottahles \& navigables. les dispositions de l'arrêté du 4 nivôse présent mois van 26 nivôse V (15 jan 1797).
} 
moesten worden gesteld. Voorts werd ook wettelijk de bezoldiging van de scherprechters en de rechtspositie van de deurwaarders geregeld.

Tot op heden is de activiteit van de criminele rechtbank in het departement Nedermaas nog niet bestudeerd. Over de criminele rechibanken in de departementen Dijle en Sambre-en-Maas zijn al wel studies verschenen ${ }^{8.3}$. Beide studies komen tot de conclusie dat de criminele rechtbanken gematigd in hun veroordelingen waren. Vrijspraak was niet ongebruikelijk door de opstelling van de jury, ten faveure vooral van verdachten van politieke misdrijven. Er was in dat opzicht sprake van een proces van decriminalisatie, invers aan de opstelling van de nieuwe machthebbers. Streng bestraft werden daarentegen vergrijpen die de economische orde verstoorden - vooral bendevorming - en misdrijven gericht tegen personen ${ }^{84}$. Het gevestigde beeld evenwel van een wrede en arbitraire strafrechtspraak blijkt onjuist te zijn. Nauwgezet werden de nieuwe Franse procedureregels dan ook in acht genomen, hetgeen de verdachten meer zekerheid bood dan voordien in het ancien régime het geval was geweest.

\section{Ontmanteling van de maatschappelijke structuur van het ancien régime}

Waarschijnlijk toch schuilt de grootste betekenis van de Franse Revolutie in het ontmantelen van de feodale maatschappelijke structuren. Deze verworvenheid van de Revolutie trof rechtstreeks de kern van een zich sinds eeuwen ontwikkelend maatschappelijk bestel. De Revolutie ontmantelde minstens de uiterlijke structuren van wat wel het complexum feodale werd genoemd. Ofschoon de Constituante in de nacht van de vierde op de vijfde augustus 1789 overhaast decreteerde dat zij het feodale bestel in zijn geheel had afgeschaft (" $L$ 'Assemblée nationale détruit entièrement le régime féodal..."), bleek dit ingrijpen zonder weerga in de tot dan toe heersende bezits- en

*3 Marie-Sylvie Dupont-Bouchat, "La pratique des tribunaux criminels issus de la Révolution en Belgique: continuités et ruptures (an IV - an VIII)" in: La Révolution et rordre juridique privé. Rationalité ou scandale? Actes du colloque d'Orléans 11-13 septembre 1986 (2 din; Orléans, 1988) II 509-526; X. Rousseaux, "Les tribunaux criminels en Brabant sous le Directoire (1795-1800). Acculturation et résistance à la justice républicaine" in: J. Craeybeckx \& F.G. Scheelings m.m.v. M. De Laet ed. De Franse Revolutie en Vlaanderen. De Oostenrijkse Nederlanden tussen oud en nieuw régimelLa Révolution frangaise et la Flandre. Les Pays-Bas autrichiens entre l'ancien et le noweau régime. Handelingen wan het colloquium gehouden op $1-2$ december 1988, te BrussellActes du colloque du / et 2 décembre 1988 à Bruxelles (Brussel, 1990) 277-306; over de verdachten van misdrijven en overtredingen die vanaf de herfst van 1798 tot het einde wan het Franse bewind te Luik in hechtenis waren genomen, is een studie gepubliceerd door Véronique Hansotte " "Les prévenus de crimes et de dellits à Liège sous le régime français", Revue Belge d'Histoire Contemporaine/Belgisch Tijdschrifi voor Nieuwste Geschiedenis, XIV (1983) $115-176$.

* Vanzelfsprekend werd er zeer streng opgetreden tegen opstandige bewegingen, die zich gewapenderhand verzetten tegen het staatsgezag en zijn dienaren. Het leger werd dan te hulp geroepen; na aanhouding van de brigands door het leger, volgde dan militaire berechting. Zie hierover Th. Vandebeeck \& J. Grauwels, De Boerenkrijg in het departement van de Nedermaas, met een voorwoord van Dr. L. Roppe gouwerneur van Limburg en Prof.Dr. L. Rogier. Werken Limburgs Geschied- en Oudheidkundig Genootschap III (Maastricht, 1961) 174-181. 
eigendomsverhoudingen in zijn uitvoering aanzienlijk complexer te zijn dan de representanten van de natie in hun euforie voor ogen hadden. Uiteindelijk beslechtte de Convention nationale het door haar beide voorgangers ingezette ontmantelingsproces. De Constituante en de Législative hadden een hoofdonderscheid gecreëerd tussen zonder meer afgeschafte rechten en afkoopbare rechten. Een dergelijk onderscheid bleek echter in de praktijk heel moeilijk vast te stellen.

De talloze verschijningsvormen in Frankrijk van de feodaliteit, en dienovereenkomstig de verscheidenheid aan benamingen, betekende dat het heel moeilijk was voor de Franse wetgever om tot een sluitende redactie van de wetgeving ter zake te komen. De assemblees hadden de bevrijding van de grond voor ogen. Wie echter had, rechtens of feitelijk, de grond in eigendom? Per landstreek verschilde dat: lang niet altijd werd als zodanig de heer als eigenaar beschouwd. Grosso modo bestond er een onderscheid tussen het propriété éminente of directe van de heer en het propriété utilé van een van de heer "afhankelijke", die zakelijk gerechtigd was. Dit onderscheid werd ook wel, in navolging van de traditie, aangeduid als domaine directe en als domaine utile. Met betrekking tot het laatstgenoemde en als bevestiging van het bovenstaande merkt Godding terloops op: "Aussi voit-on à la fin de 1"Ancien Régime le domaine utile être de plus en plus identifié à la propriété"

In de literatuur wordt de indruk gewekt dat het voldoen van de cijnzen door de betalingsplichtigen als aanvaardbaar werd ervaren. Waarschijnlijk omdat de eens vastgestelde hoogte van de cijns onveranderlijk was en daardoor achterbleef bij de werkelijke waarde van het geld op enig moment. Tiendplichtigen daarentegen, ervoeren hun prestatie - een tiende gedeelte van de opbrengst - als het zwaarst drukkend. Vooral als er sprake was van het kwijten van de zogenaamde gefeodaliseerde tiende (dîme inféodée). Van de gefeodaliseerde tiende werd gesproken wanneer het genot van de oorspronkelijk aan de Kerk verschuldigde prestatie bij leken berustte ${ }^{86}$.

In de départements réunis is de wetgeving die in Frankrijk de ontmanteling van het feodale stelsel doorvoerde door de gouvernementscommissarissen Pérès en Portiez de l'Oise afgekondigd $d^{87}$. Zoals reeds eerder is opgemerkt, werden de op dat moment in Frankrijk vigerende, relevante bepalingen in de ingelijfde gebieden van kracht verklaard. Het verbindend verklaarde corpus aan wetgeving behelsde praktisch gezien het complexum feodale, alles derhalve wat raakvlakken had met het feodale maatschappe-

${ }^{85}$ A.S. de Blécourt, Kort begrip van het oud-vaderlands burgerlijk recht, bewerkt door H.F.W.D. Fischer (6e dr.; Groningen/Djakarta, 1950) nr.129; verdeelde eigendom volgens de middeleeuwse romanistische juristen, verdeeld over de blooteigenaar en andere zakelijk gerechtigden; Philippe Godding. Le droit privé dans les Pays-Bas méridionaux du $12^{\circ}$ au $18^{\circ}$ siecle. Mémoires de la classe des lettres, collection in $4^{\mathrm{E}} 2^{e}$ série XIV (Brussel, 1987) nrs.207 en 208, citaat onder nr. 207.

${ }^{86}$ De talloze verschijningsvormen van de grondeigendom en de overdracht ervan in Frankrijk en de reactie daarop van het revolutionaire recht worden het uitgebreidst behandeld door Marcel Garaud, Histoire générale du droit privé français (de 1789 à 1804). La Révolution et la propriété foncière (Parijs, 1958); voor een kortere oriëntatie: Viard, Histoire géntérale du droit privé français, 46-64; Marcel Garaud, Histoire gévérale du droit privé français (de 1789 à 1804). La Révalution et l'égalité civile (Parijs, 1953) vi (nt.3), vindt echter Viards boek te beknopt: "C"est un bon travail, mais trop succinct sur toutes les questions".

${ }^{87} \mathrm{RO} \mathrm{nr} .60,61$ en 62 , data afkondigingsbesluiten 17 en 21 brumaire IV (8 en 12 nov 1795). 
lijke bestel. Voorop werden de decreten sur la suppression de la féodalité van 4 augustus 1789 en volgende dagen van kracht verklaard. Deze decreten zijn gedeeltelijk ingevoerd en daarbij tevens aan de tijdsomstandigheden van het moment aangepast. De Assemblée construeerde toen al het hoofdonderscheid tussen zonder meer afgeschafte feodale rechten zonder enige schadeloosstelling en afkoopbaar verklaarde rechten. Heerlijke rechten als het recht van duiventil, jachtrechten, heerlijke jurisdicties en cijnsrechten, wanneer deze samenhingen met de mainmorte réelle of personnelke, en tienden waren zonder schadeloosstelling afgeschaft.

De Constituante mocht dan wel in de eerste zinsnede verklaard hebben dat zij het feodale bewind in zijn geheel had afgeschaft, voor de implementatie daarvan was nog zeer veel wetgeving nodig. Via drie grote stappen leidde het uiteindelijk tot de volledige ontmanteling van de feodale eigendoms- en bezitsverhoudingen in de zomer van 1793. Het gecreëerde onderscheid tussen zonder schadeloosstelling afgeschafte rechten en afkoopbare rechten liet zich eenvoudigweg niet vaststellen. De Constituante werkte de beginselen van de vierde augustus en volgende dagen nader uit in de wet van $15^{*}$ 28 maart $1790^{88}$. Ieder onderscheid voortkomende uit superioriteit of macht was ongedaan gemaakt. Zo ook was een zeer groot aantal heerlijke rechten zonder schadeloosstelling als deze samenhingen met horigheid in algemene zin (mainmorte personnelle, réelle en mixte) opgeheven. Afkoopbaar bleven die feodale rechten, verplichtingen en cijnzen, die de prijs en woorwaarde hadden gevormd van een oorspronkelijke bezits- of eigendomstitel ter zake van een stuk grond. Dit laatste werd het kembegrip waar alles omdraaide. Eigendomsrechten konden alleen dan gehandhaafd blijven, wanneer men met behulp van een titre primordial kon aantonen dat er ooit een oorspronkelijke overdracht van de grond had plaatsgevonden. Alle overige gepretendeerde rechten werden als usurpatie beschouwd.

Het hier geschetste beeld van de ontmanteling van de feodale bezits- en eigendomsverhoudingen en de worsteling van de revolutionaire assemblees met betrekking tot deze materie wordt kernachtig beschreven in de studie van Ketelaar over oude zakelijke rechten ${ }^{89}$. De schrijver schetst de gedachtengang binnen het comité de féodalité van de Constituante over het onderscheid tussen af te schaffen en af te kopen rechten. Deze gedachtengang resulteerde in het creëren van een onderscheid tussen hetgeen men noemde droits personnels en droits réels. Door het comité de féodalité werd het onderscheid tussen beide gekenschetst als féodalité dominante (de personele rechten) en als féodalité contractante (de zakelijke rechten). De personele rechten werden dus geacht te zijn afgeschaft en de zakelijke rechten werden afkoopbaar verklaard. Maar dit onderscheid bleek toch niet te handhaven.

De Législative ging daarop kort voor haar uiteengaan zelfs zover dat zij verklaarde het feodale maxime mulle terre sans seigneur te beschouwen als niet te hebben bestaan. Alle grondeigendom was vrij van alle feodale en cijnsrechten. In het algemeen

\footnotetext{
RO nr.60(2), loi concernant les droirs féodaux van $15 * 28$ maart 1790 .

${ }^{89}$ F.C.J. Ketelaar, Oude zakelijke rechten vroeger, nu en in de toekomst. Rechtshistorische Studies III (Zwolle, 1978) 16-19; de schrijver gaat ook kort in op de betekenisverschuiving van de begtippen feodaliteit en feodaal bewind in de beginjaren van de Revolutie; van een strikt juridische betekenis via een economische en sociale betekenis, naar een geheel verwerpelijke betekenis. Vanaf eind 1793 verdwijnt het gebruik van deze begrippen om plaats te maken woor het begrïp ancien régime.
} 
werden alle heerlijke rechten afgeschaft die aanvankelijk nog in de vroegere wetgeving bleven bestaan of afkoopbaar werden verklaard, tenzij bewezen kon worden dat er sprake was van een oorspronkelijke titel ter zake van de overdracht van de grond $^{90}$. De Convention nationale maakte een einde aan deze problematiek ${ }^{91}$. $\mathrm{Zij}$ schafte alle nog overgebleven feodale rechten, vaste en incidentele cijnzen zonder schadeloosstelling af. Het onderscheid tussen zonder meer afgeschafte en afkoopbare rechten bleek niet te handhaven. Alleen prestaties die zuiver betrekking hadden tot de grond, maar niet van feodale oorsprong waren, mochten blijven bestaan. Om elk toekomstig geschil te voorkomen decreteerde zij de verbranding van alle bewijsstukken inzake de gesupprimeerde rechten: vonnissen, arresten, eigendomstitels enzovoorts. Niet lang daarna werd dit voorschrift noodzakelijkerwijs toch wel weer genuanceerd $^{92}$.

Deze ingreep in de eigendoms- en bezitsverhoudingen werd dus ook opgelegd aan de départements réunis. Er zal ongetwijfeld in vele gevallen verre sprake geweest zijn van identieke situaties. Pirenne schreef daar al over: "La nomenclature des droits féodlaux supprimés en comprend quantité dont on n'avait jamais entendu parler en Belgique et n'en mentionne pas d'autres qui y existaient" ${ }^{193}$. Het colloquium dat eind jaren zestig te Toulouse aan de afschaffing van de feodaliteit werd gewijd, biedt tot op zekere hoogte de mogelijkheid de Noordfranse situatie met de Belgische te vergelijken. Devleeshouwers bijdrage concentreert zich op de Henegouwse situatie. Een vergelijking met de sedert het midden van de zeventiende eeuw ingevolge opeenvolgende vredesverdragen bij Frankrijk gekomen noordelijke gebieden langs de grens met de Spaanse Nederlanden, in het bijzonder Frans-Henegouwen, zou men zich kunnen wensen, maar blijft verre van eenvoudig vanwege de verscheidenheid aan feodale rechten $^{94}$. In navolging van Verhaegen stelt Devleeshouwer dat de feodale lasten in

\footnotetext{
"RO nr.6I(4), loi relative à la suppression, sans indemnité, de tous les droits fëodaux ou censuels et de routes redevances seigneuriales van 25 augustus 1792 .

* RO nr.61(6), los qui supprime sans indemnité toutes redevances ci-devant seigneuriales er droits fédaux, même ceux conservés par le décrêt du 25 août dernier van 17 julli 1793.

${ }^{4} 2 \mathrm{RO} \mathrm{nr} .62(6)$, decret relatif aux actes de concession, à titre d'infécodation, et bralement des titres fé̌odaux van 2 oktober 1793; de Code Merlin bevat ook wetgeving op het terrein van de afschaffing van de feodale rechten : RO nr.257(71), loi qui abolit plusiesss droits seigneuriaux et détermine le mode de rachat de ceux précédenment déclarés rachetables (extract) van $13 * 20$ apr 1791, RO nr.257(98), loi relative au rachat des ci-devant droits féodaux (extract) van 14 \& 15 sep * 9 okt 1791, RO nr.257(152), loi relative à l'abolition de toutes servitudes temant do la nature du régime féodal van 7 dec 1792, RO nr.257(155), loi relative aux procédures concernant les délits à l'occasion des droits ci-devant féodaux ou censuels van $30 \mathrm{dec}$ 1792, RO nr.257(163), loi qui éteint et abolit toutes procédures \& jugemens relatifs à des délits commis a la suite d" insurrections ayant pour cause les ci-devant droils féodaux van 12 feb 1793.

93 Pirenne, Histoire de Belgique, VI, 89-90.

${ }^{94}$ R. Devleeshouwer, "L'abolition des droits férodaux en Bellgique" in: L'abolition de la féodalité dans le monde occidental. Toulouse 12-16 novembre 1968 (2 dln; Parijs, 1971) I., 205-219 (rapport), II, 627-641 (discussie); Louis Trénard, "Survivances féodales et rếgime seigneurial dans les provinces septentrionales de la France au XVII" siècle" in: ibidem I, 181-203 (rapport), II, 589-605 (discussie).
} 
de Zuidelijke Nederlanden minder zwaar drukten dan in Frankrijk ${ }^{95}$. Daarnaast kan met behulp van de uitvoerige studies over het droit intermédiaire van de Franse rechtshistoricus Garaud en de recentere studie van Godding over het privaatrecht in de Zuidelijke Nederlanden gedurende het ancien régime het door de Fransen opgelegde revolutionaire recht vergeleken worden met de voorheen bestaande rechtsverhoudingen in de ingelijfde gebieden ${ }^{96}$. Een dergelijke vergelijkende studie zal, zoals zoëven gezegd, tamelijk gecompliceerd zijn. In het algemeen geldt voor de onderwerpen die in dit hoofdstuk aan de orde worden gesteld, dat die kunnen worden vergeleken met de onderwerpen die in de studie van Godding aangedragen worden, tenminste wat betreft de privaatrechtelijke implicaties ervan. Goddings studie vermeldt altijd de zijns inziens relevante literatuur.

Het complexum feodale had vanzelfsprekend een veel grotere draagwijdte dan alleen de hierboven genoemde eigendoms- en bezitswerhoudingen. Het impliceerde ook de standenmaatschappij en ook daar maakte de Revolutie een einde aan. De derde stand, heel algemeen gesproken, de burgerij die in Frankrijk tot zekere welstand was opgeklommen en die in de door Lodewijk XVI bijeengeroepen Staten-Generaal de macht aan zich trok en aldus de vergadering tot Constituante heeft kunnen omvormen, schoof de geestelijkheid en de adel opzij ${ }^{97}$. Ingevolge de Déclaration des droits de l'homme et du citoyen van 26 augustus 1789 was het sedert mensenheugenis bestaande onderscheid naar geboorte uit den boze. De tweede stand - de adlel dus - verloor dan ook zijn voorrechten. De Constituante maakte een einde aan de erfelijke adel; titels en familiewapens mochten niet langer worden gevoerd ${ }^{98}$. Zoals gewoonlijk maakte de Conventie schoon schip door te bepalen dat alle reminiscenties aan het koningschap, de adel en de feodaliteit dienden te worden verwijderd. Decreet na decreet was hieraan gewijd ${ }^{99}$. Onder bedreiging met verbeurdverklaring dienden alle

\footnotetext{
95 Verhaegen, Domination framçaise, II, 486-495 i.h.b. 487, 488, 493; Devleeshouwer, "Abolition", II. $206,215-216,11,628-629,635$.

* Het al eerder genoemde boek van Garaud, Révolution et propriété foncière, in combinatie met diens Révolution er l'Egalité civile en Godding. Droit privé Pays-Bas méridionaux; voor een goed begrip kan ook Ketelaar, Oude zakelike rechten, passim goede diensten bewijzen; over de afschaffing van het feodalle regime ook Godechot, Imstitutions, 192-197.

"7t Over de derde stand: Garaud, Révolution et l'égalité civile, 104-115.

${ }^{9} \mathrm{RO}$ nr.60(4), décret qui abolit la noblesse héréditaire, et porte que les titres de prince, de duc, de comte, marquis et autres titres semblables, ne seront ni pris par qui que ce soit ni donnés à personne van 19*23 jun 1790; zie ook Garaud, Révolution et légolité civile, 80-103; P. Janssens, "De Zuidnederlandse adel tijdens het Ancien Régime (17e-18e eeuw). Problemen en stand vam het onderzoek". Tijdschrift voor Geschiedents. XCIII (1980) 445-465, belicht de positie van de adel in eerst de Spatanse, later de Oostenrijkse Nederlanden.

94 RO nr.62(1), décret qui ordomne la confiscation sous huitaine, au profit de la République, des maisons \& autres édifices portant des armoiries van 1 aug 1793; RO nr.62(2), decret qui ordonne l"enlèvement dès signes de royauté \& de fédalité dans les églises \& et autres monumens publics van 14 sep 1793; RO nr.62(3), décret qui prescrit un terme pour l'entèvement des signes de royauté, \& les formes qui devromt précéder la confiscation des terrains \& édifices sur lesquels on les aura laissé subsister van 18 vendémiaire II (9 okt 1793); RO nr.62(4), décret interpvétatif de celui du dixhuitieme jout du premier mois, qui ordonne l'enlèvement des signes de royauté \& de féodalité van 3 brumaire II (24 okt 1793).
} 
gebouwen, huizen, parken en tuinen ontdaan te worden van wapenborden. Koninklijke kentekenen als de fleur-de-lys dienden dadelijk te worden verwijderd. Klaarblijkelijk ging men hier al te rigoureus mee om, zodat er beschadigingen toegebracht werden aan boeken en kunstvoorwerpen. De Conventie zag toch wel in dat dit moest worden voorkomen en heeft door middel van aanvullende wetgeving de schade zoveel als mogelijk getracht te voorkomen. In de Code Merlin is nog een wet opgenomen die opdracht gaf tot het verbranden van titels van de adel die zich in openbare depots bevonden: "Tous les titres généalogiques qui se trouveront dans un dépôt public, quel qu'il soit, seront brûlés". Deze wet dateerde uit de tijd van de Législative $e^{\text {iton }}$.

In de decreten van 4 augustus 1789 en volgende dagen werd dadelijk ook hetgeen genoemd werd het droit exclusif de la chasse, meestal bij de heer berustend, als afgeschaft beschouwd. Het decreet van $22,23,28 * 30$ april 1790 werkte dit nader uit. Bij extract is het décret sur la chasse in het departement Nedermaas afgekondigd. In grote lijnen was het voortatan verboden op andermans terrein zonder diens goedkeuring te jagen, teneinde schade aan te velde staande gewassen te voorkomen. Gejaagd mocht er wel worden door landeigenaren en pachtboeren op niet-omheinde percelen, maar wederom zonder het veroorzaken van schade aan de gewassen. Veel later maakte het Directoire exécutif een einde aan de jacht in de nationale bossen. Zonder onderscheid was dit voor alle particulieren verboden ${ }^{101}$. Door de Convention nationale waren toen al de visrechten gelijkgesteld aan de jachtrechten. Zij waren dus ook afgeschaft. Deze wet was door de Conventie uitgevaardigd na een vraag haar door het departementaal bestuur van de Charante gesteld of visrechten onder de algehele afschaffing van de feodale rechten dienden te worden begrepen. De Conventie decreteerde in antwoord daarop: "... les droits exclusifs de pêche et de chasse étaient des droits féodaux abolis par des lois précédentes comme toutes les autres"102.

De ontmanteling van de maatschappelijke structuren van het ancien régime leidde ook tot het verbod op de ambachtsgilden. Gesloten beroepsgroepen, zoals de ambachtsgilden, strookten niet met het beginsel van de burgerlijke gelijkheid. Door de gouvernementscommissarissen in de départements réunis werd dan ook al dadelijk na de aanhechting bij Frankrijk de justitiële behandeling van geschillen die gerezen waren tussen ambachtsgilden en de adspiranten bij besluit van 8 brumaire IV (30 okt 1795), in afwachting van het afkondigen van de wetgeving die voorzag in de opheffing van het gildewezen, opgeschort. De opheffing daarvan was niet dadelijk voorzien bij de decreten van de vierde augustus 1789 en volgende dagen. Pas in het jaar 1791 vaar-

\footnotetext{
Ho $\mathrm{RO}$ nr.257(119), loi relative au bralement des titres de noblesse existant dans les dépóts publics van $19 * 24$ jun 1792 .

"na RO nr.60(3), décret sul la chasse; RO nr.220(3), arrêté qui interdit la chasse dans les forêts nationales van 28 vendémiaire $\mathrm{V}$ (19 okt 1796); Janssens, "Zuidnederlandse adel", 4.52 (nt.44) stipt aan dat er van het adellijke jachtwoorrecht gedurende het ancien régime vrijwel niets zou overblijven, behalve in Brabant en Gelre.

${ }^{102}$ Opgenomen in de Code Merlin RO nr.257(203), loi relative a l'abolition des droits exclusifs de pêche et de chasse van 30 jul 1793.
} 


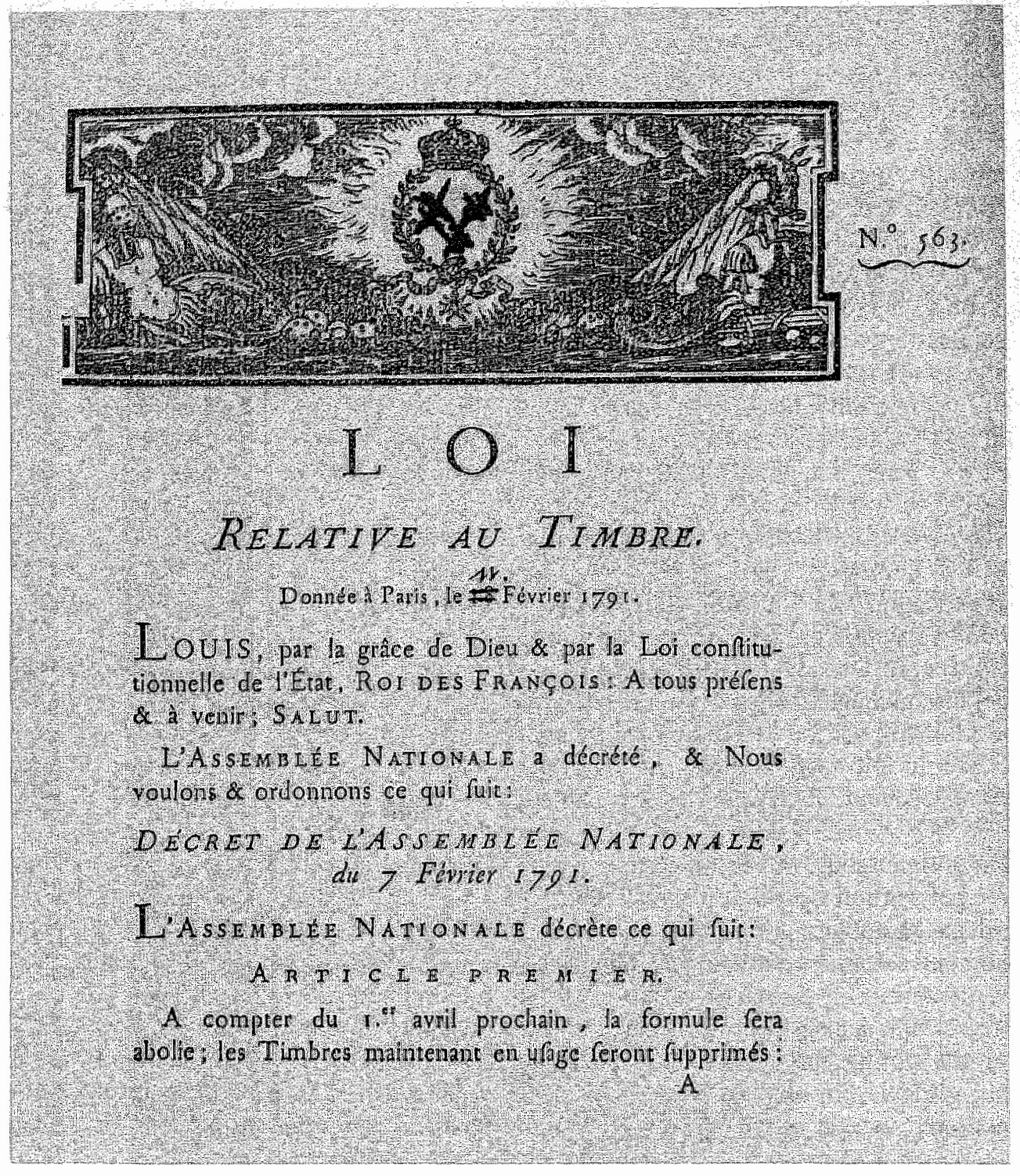

Een ijverige ambtenaar heeft de koninklijke flear-de-lys doorgekrast (Rijksarchief in Limburg, Maastricht; Frans archief inv.nr.291). 
digde de Constituante de wetgeving ter zake uit ${ }^{103}$. Gedeeltelijk werd het decreet van 2 * 17 maart 1791 dat aan de ambachten een einde maakte in het departement Nedermaas bij besluit van de gouvernementscommissarissen van 19 brumaire IV (10 nov 1795) afgekondigd. Voortaan was een ieder vrij in de uitoefening van een beroep naar keuze, wanneer men althans patentrechten had gekweten. In het departement werkten de ambachten uiteraard slechts schoorvoetend mee aan hun eigen opheffing ${ }^{104}$.

In dit kleine wetgevingscorpus aangaande de vrijmaking van de gereglementeerde beroepsbeoefening was ook het coalitieverbod voor werknemers opgenomen. Naar haar rapporteur spreekt men van de wet-Le Chapelier ${ }^{10.5}$. Staande de zitting van de Assemblée werd deze wet toen aanvaard. Werknemers mochten zich niet aaneensluiten om op die wijze betere arbeidsvoorwaarden te kunnen bedingen. Godechot schrijft over deze wet: “.... une des lois les plus hostiles aux ouvriers qui aient jamais promulguées et une des lois les plus durables de l'Assemblée Constituante, puisqu'elle ne fut révoquée qu'en 1864 !". Ruim een maand later werd de werking van deze wet uitgebreid naar werkers in de agrarische sector en huispersoneel. Het sterkst gereglementeerd waren echter arbeiders in de papiernijverheid. Voorkomen moest worden dat de aanmaak van assignaten - het onophoudelijk aan waardevermindering onderhevige papiergeld - zou worden onderbroken. Onder verwijzing naar onder meer de wet-Le Chapelier legde het Directoire bij besluit de arbeiders in de papiernijverheid nog meer restricties op door hen te verbieden zonder voorafgaande kennisgeving hun baas te verlaten om bij een andere in dienst te treden ${ }^{106}$.

\section{Wetgeving op het terrein van de Kerk en geestelijke instellingen}

Het hele complex aan wetgeving dat door de revolutionaire assemblees op het terrein van de Kerk - bedoeld is in het bijzonder de katholieke kerk - en annex daaraan de kerkelijke en geestelijke instellingen is uitgevaardigd, heeft de gemoederen hoogstwaarschijnlijk het meest beroerd. Het raakte rechtstreeks ook de gewone mensen in hun dagelijkse bestaan. De wetgeving op dit terrein maakte feitelijk onderdeel uit van

${ }^{103}$ RO nr. 10, arrêté qui suspend provisoirement toutes les contestations élevées entre les corps de métiers ou jurandes et leur suppôts ou aspirans; RO nr.32(1), décret portant suppression de tous les droits d"aides, de toutes les mâtrises et jurandes, etc van 2 * 17 mit 1791.

${ }^{104}$ A.A.M.N. Dejong, "Zwanezang van het Maastrichtse goud- en zillversmedenambacht" in: Miscellanea Trajectensia. Bijdragen fot de geschiedenis van Maastricht, witgegeven bij gelegenheid wan het 300 jarig bestaan van de stadshibliotheek van Maastricht 1662 * 31 juli * 1962 . Werken Limburgs Geschied-en Oudheidkundig Genootschap IV (Maastricht, 1962) 523-524, 529-531.

${ }^{\text {"Oos }} \mathrm{RO}$ nu.32(3), dêcret aux assemblées des citoyens d'un même état ou profession van 14 * 17 jun 1791.

${ }^{106}$ Godecot, Institutions, 215-218, 522 (citalat 216); in de Code Merlin RO mr.257(83, 84). Loi relative à la police municipale, et au maintien de l'ordre public wan 5,16 * 20 jul 1791, loí relative aux maîtres papetiers et de leurs ouvriers van 26 jul 1791; RO nur.207(12), arrêté̉ contenamt véglement pour la police des papeteries van 16 fructidor IV ( 2 sep 1796); verder over het verbod op ambachtsgilden: Garaud, Révolution et l'égalité civile $128-131$. 
de wetgeving die de ontmanteling van de feodale maatschappelijke structuur bewerkstelligde. De ontmanteling van de standenmaatschappij van het ancien régime betekende zonder meer dat de eerste stand, de geestelijkheid dus, haar bevoorrechte positie kwijtraakte. De Constituante besliste in de herfst van 1789 dat de goederen en de bezittingen van de Kerk aan de natie zouden komen. Van staatswege zou daarop in het onderhoud van de kerkelijke functionarissen worden voorzien. Het ontnemen van de goederen en bezittingen aan de eerste stand lag al besloten in de decreten van de vierde augustus en volgende dagen.

In de départements réunis werd het decreet van $2 * 4$ november 1789 inzake de nationalisatie van de kerkelijke goederen ${ }^{107}$, alsmede de zogenaamde constitution civile du clergé van 12 juli * 24 augustus 1790 , niet afgekondigd - althans niet in de hier onderzochte periode - , maar al hetgeen aan wettelijke voorschriften en uitvoeringsbesluiten daaruit voortvloeide grotendeels wel. De constitution civile du clergé hield in dat de geestelijkheid zich diende te onderwerpen aan de burgerlijke wetgeving en mitsdien praktisch gesproken het overheidsgezag erkende. De voornaamste bepalingen betroffen de nieuwe kerkelijke circumscripties, de benoeming van bisschoppen en pastoors door kiezerscolleges en de salariëring van de geestelijkheid, die immers van zijn inkomstenbronnen van woorheen beroofd was. Als het meest problematische werd de eed van trouw aan de staat ervaren, welke de kerkelijke functionarissen bij hun ambtsaanvaarding dienden uit te spreken ${ }^{108}$.

De wetgeving die de positie van de Kerk als instituut ondermijnde is ook weer in golven in de départements réunis afgekondigd. De volksrepresentanten/gouvernementscommissarissen handelden nog geheel in de sfeer die er heerste ten tijde van de Conventie, de periode waarin de Kerk onder zware druk kwam te staan. Zij begonnen dan ook met het van kracht verklaren van de wetgeving die neerkwam op kerkvervolging ${ }^{109}$. Geestelijken die zich niet wensten te conformeren aan de nieuwe Franse

${ }^{1 m} \mathrm{cB}$ le ser I1 152, décret sin les Biens ecclésiastiques wan $2 * 4$ now 1789 : "L 'Assemblée nationale décrète: 1\%. Que tous les biens ecclésiastiques sont a la disposition de la Nation, a la charge de pourvoir" d"une manière convenablle, aux frais du Culte, à l'entretien de ses Ministres \& au soullagement des pauvres, sous la surveillance $\&$ d"après les instructions de prowinces. $2^{2}$. Que dans les dispositions à faire pour subvenir à l'entretien des Ministres de la Religion, ill ne pourra être assuré a la dotation d'aucune Cure moins de douze cents livres par année, non compris le logement \& les jardins en dépendans"

14* cB le ser IV 63-88, Série des Décrets sur la constitution civile du Clergé wan 12 jul * 24 aug 1790, tit.ll art.21: "Avant que la cérémonie de la consécration [van de verkozen bisschop] commence, l'êlu prêtera, en présence des Officiers municipaux, du peuple \& du Clergé, le serment solemnel de veiller avec soin sur les fidèles du Diocèse qui lui est confie, d'être à la Nation, à la Loi \& au Roi, \& de maintenir de tout son pouvoir la Constitution décrétêe par l"Assemblee Nationale \& acceptée par le Roi" "art.38 "Les Curés élus \& institués, prêteront le même serment que les Evếques dans leur Eglise, un jour de Dimanche, awant la Messe paroissiale, en présence des Officiers Municipaux du lieu, du Peuple \& du Clergé; jusques-là ils ne pourront faire aucunes fonctions curiales"; Godechot, Institutions, 255-266; aan de Amsterdamse universiteit is een proefschrift over deze materie verdedigd: Jan Halk, De discussie over de "constitution civile du clerge" (1790). Opiniegeschiedenis van een conflict. (Groningen, 1964) i.h.b. 135-235.

Iny Zie RO nr.113, afkondigingsbesluit gouvernementscommissarissen d.d. 29 frimaire IV (20 dec 1795), dat op 6 germinal IV ( 26 mrt 1796) in het departement Nedermaas geregistreerd werd. 
arde hing minstens deportatie buiten het Europese continent boven het hoofd. Een uitzondering werd er gemaakt voor geestelijken die ziek waren of met een gebrek. kampten, alsmede de geestelijken die ouder dan zestig jaar waren. Zij dienden in dat geval in de departementshoofdplaats in een hun toegewezen huis onder toezicht van de municipaliteit in afzondering te worden gehouden. Voor zover bekend heeft een dergelijk huis in Maastricht niet bestaan. Degenen die geestelijken die onderworpen waren aan deportatie of opsluiting een schuilplaats boden, zouden als medeplichtige worden beschouwd en werden eveneens met deportatie bestraft ${ }^{110}$.

In dit corpus was ook het besluit van de volksrepresentanten/gouvernementscommissarissen van 29 frimaire IV (20 december 1795) opgenomen, dat bepaalde dat alle overige wetten uit de jaren 1792 en 1793 betreffende priesters die onderworpen waren aan deportatie of afzondering en die nog niet in de op 8 brumaire IV (29 november $1795)$ bekendgemaakte "code des émigrés" waren vervat, ook waren afgekondigd" 11 . Direct in het begin al, na de inlijving op $\mathbb{1}$ oktober 1795, hadden de volksrepresentanten een reeks wetten afgekondigd ter zake van uitgewekenen, gedeporteerden en vreemdelingen $^{\prime \prime 2}$. Geëmigreerden werden als een gevaar beschouwd voor de Franse staat. Onder hen bevonden zich personen van adellijke afkomst en gevluchte geestelijken, alsmede degenen die uitgeweken waren in verband met een voor hen op dat moment ongunstige politieke koerswisseling. Deze laatste categorie onderging nogal eens het lot van buiten de wet geplaatst te zijn ("mise hors la loi"), hetgeen betekende dat men door de Nationale Vergadering vogelvrij verklaard werd en niet langer wettelijke bescherming genoot. De bescherming die de strafrechtelijke procedure aan verdachten bood, was hun ontzegd ${ }^{1 / 3}$. In weerwil van het hooggestemde en ook verkondigde adagium van de gelijkheid voor allen, schiep de Revolutie dus nieuwe ongelijkheden ${ }^{114}$. Slachtoffer daarvan werden zij die zich tegenstander verklaarden van de politieke koers, dus de adel, de geestelijkheid en politiek andersdenkenden. Verdachte werd men automatisch, zodra men het land ontvluchite.

Van de reeks afgekondigde rechtsvoorschriften formuleerde de wet van 25 brumaire III ( 15 november 1794) de criteria wie als uitgewekene diende te worden beschouwd: doorgaans betrof het degenen die voor een bepaalde datum niet in het land terugge-

11" RO nr.113(1), Loi qui ordonme la deportation des prêtres réfractaires van 26 aug 1792; RO $\mathrm{nr} .113(5)$, décret relatif aux ecclésiastiques sujets d la déportarion ou à des peines corporelles van 29 en 30 vendémiaire 11 (20 en 21 okt 1793); $\mathrm{RO}$ or. $113(8)$, décret relatif aux recelears des ecclésiastiques sujets à la départarion wan 22 germinal II (11 apr 1794); RO nr.113(9), décret relatif à la réchusion des ecclésiasriques infirmes ou sexagénaires van 22 floréal II (11 mei 1794); zie voorts Garaud, Réwolution et l'égalité civile, 58-75 over de maatregelen tegen de geestelijkheid; Poullet, Institutions frangaises, 322 [nt.1], vermeldt dat volgens sommige historici de wet wan 29 en 30 vendemiaire III niet toepasbaar was op de Belgische geestelijkheid.

${ }^{111} \mathrm{RO}$ ar. $113(13)$, arrêté ordonnant la publication des lois relatives aux prêtress sujets à la déporration: dit besluit moet in verband gezien worden met $\mathrm{RO} \mathrm{nr} .113(4)$, décret qui déclare les loix relatives aux émigrés applicables aux déportés van 17 september 1793.

112 Zie hierwoor RO nr.21.

113 Paul Savey-Casard, "La mise hors la loi à l'époque révolutionnaire", Revwe Historique de Droit français êt ếtranger, XLVIII (1970) 408-429.

"14 Garaud, Révolution et l'égalité civile, 180-223. 
keerd waren of steun verleenden aan tanden die met Frankrijk in oorlog waren ${ }^{\text {15. }}$. De wet bepaalde dat er door de toen nog fungerende districtsbesturen lijsten van uitgewekenen dienden te worden opgesteld. Degenen die op een dergelijke lijst voorkwamen, konden hiertegen wel in verweer komen. Bij terugkeer riskeerden de uitgewekenen een terechtstelling. De goederen en bezittingen van de uitgewekenen kwamen aan de Franse natie.

Een wet uit de zomer van 1795 gelastte vreemdelingen afkomstig uit landen waarmee Frankrijk in oorlog was, tenzij men er al vóór 1 januari 1792 woonde, binnen drie dagen na de bekendmaking van de wet het land te verlaten. De reisroute diende in het paspoort te worden vermeld. Tevens werd aan iedere buitenlander een identiteitskaart verstrekt ${ }^{116}$. De mate van toezicht door de autoriteiten spreekt ten duidelijkste uit het besluit betreffende vreemdelingen uitgevaardigd door de volksrepresentanten. Dit besluit ${ }^{17}$ valt nog in de periode waarin praktisch gesproken de volksrepresentanten en mission onbeperkte bevoegdheid hadden om regelingen te treffen. Voor zover oude reglementen en ordonnanties betreffende het onderdak verlenen aan vreemdelingen geen inbreuk maakten op de Republikeinse wetgeving bleven zij voorlopig van kracht. Een ieder diende bij de gemeente aangifte te doen van het feit dat er vreemdelingen bij hem of haar in huis verbleven. De personalia van de vreemdelingen diende men dan te overleggen. Van logementshouders werd verwacht dat zij een register bijhielden van de gasten en dit om de veertien dagen aan de autoriteiten ter inzage gaven.

Natuurlijk trachtte men zoveel mogelijk gevrijwaard te blijven van de rigueur van de wetgeving op de uitgewekenen. Gewoonlijk haalde zoiets niet veel uit. Het Directoire exécutif bepaalde uitdrukkelijk dat de volksrepresentanten/gouvernementscommissarissen in de départements réunis voldoende zorgvuldig gehandeld hadden bij de afkondiging van de wetgeving inzake de uitgewekenen en gedeporteerde geestelijken. Dit impliceercle dat uitgewekenen die gearresteerd waren in de départements réunis zich in rechte niet konden verweren met het argument niet onder de termen van de wet van 25 brumaire III (15 november 1794) te vallen, omdat zij daar hun verblijfplaats hadden voor de geproclameerde aanhechting van die gebieden bij Frankrijk ${ }^{\prime 18}$.

Zoals al vaker in dit hoofdstuk naar voren gebracht is, staan er in de Code Merlin en in de Bulletins des Lois nog vele rechtsvoorschriften ter zake van de uitgewekenen, die buiten het bestek van de regestenlijst vallen. De wetten die in de Code Merlin zijn opgenomen, dateren allen uit de periode van de Nationale Conventie ${ }^{119}$. In het $\mathrm{Bul}$ letin des Lois staat bij voorbeeld een rapport opgesteld door de minister van justitie

\footnotetext{
${ }^{11.5} \mathrm{RO}$ nr.2l(10), loi concernant less émigrés van 25 brumaire III (15 nov 1794).

116 RO nr.21(10), loi qui ordonne aux etrangers nés dans les pays avec lesquels la République est en guerre de sortir de France, sils $n^{\prime}$ y sont domicilies avant le premier janvier 1792 van 23 messidor III (11 jul 1795); Garaud, Révolution et l'égalité civile, 193 vermeldt overigens, dat er aan deze wet geen uitwoering is gegeven.

${ }^{117}$ RO nr.9, arrêté concernont les étrangers van 4 brumaire IV (26 okt 1795).

1:18 RO nt.136, arrêté concenant le mode d"application des lois sur les émigrés de France à ceur trowvés dans les départemens réumis le 9 vendémiaire an IV au territoire de la République wan 4 flloreal IV (23 apr 1796).

114 RO mrs.257(150), 257(160), 257(171), 257(172), 257(195), 257(196), 257(293), 257(348), $257(349)$ en $257(353)$.
} 
Merlin voor het Directoire over hoe er gehandeld moest worden ter zake van degenen die op de lijst van uitgewekenen stonden en over wie nog niet definitief was beslist, alsmede over degenen die van het Franse grondgebied verbannen waren en zich gevestigd hadden in de gebieden die naderhand bij Frankrijk ingelijfd waren. Mochten de laatsten in Frankrijk blijven wonen? Mochten beide categorieën hun burgerrechten uitoefenen? In de ogen van de autoriteiten van destijds was zoiets natuurlijk volstrekt uit den boze. Het Directoire besliste dan ook dat het rapport in het Bulletin des Lois zou worden geplaatst ${ }^{120}$, "à l'effet de servir de proclamation pour l'exécution des lois".

Op 15 fructidor IV (1 september 1796) vaardigde het Wetgevend Lichaam een bijzondere wet uit, houdende de opheffing van de religieuze instellingen in de départements réunis. De registratie van deze wet geschiedde op 28 fructidor IV (14 september 1796 ) in het departement Nedermaas ${ }^{121}$. De wet hief in het algemeen alle reguliere religieuze congregaties en instellingen, kloosters, abdijen, priorijen enzovoorts op. Een uitzondering was gemaakt voor instellingen van religieuze zusters die zich wijdden aan openbaar onderwijs en de ziekenzorg, met dien verstande dat dit geschiedde in huizen die buiten de genoemde instellingen gelegen waren. Waarschijnlijk ingevolge deze uitzondering werd later nog bij besluit ${ }^{122}$ van het Directoire bepaald dat voorlopig de communiteiten van de zwarte zusters mochten voortbestaan, daar zij zich wijdden aan de verpleging van lijders aan besmettelijke ziekten. Zij dienden wel het habijt af te leggen, zoals dat ook bepaald was voor de geestelijken die hun communiteit verlieten ten gevolge van de opheffing. Onder de opheffing van de religieuze instellingen vielen vooralsnog niet de seculiere kapittels, voor Maastricht dus die van Sint-Servaas en Onze-Lieve-Vrouw. Ook die opheffing geschiedde weer bij een bijzondere wet, namelijk de wet van 5 frimaire VI ( 25 november 1797) ${ }^{123}$. Toen viel ook het doek voor de kloosterinstellingen die zich aan onderwijs en ziekenzorg wijdden.

De wet van 15 fructidor voorzag in het onmiddellijk opmaken van staten betreffende de activa en passiva van de opgeheven instellingen door ambtenaren van de domeinadministratie. Vanzelfsprekend diende ook al het zilverwerk en het boekenbezit

${ }^{120} \mathrm{BL}$ Ile ser no.108 (1041), Rapport, approuvé par le Directoire exécutif, sur la faculté d'exercer les droits de citoyen, considérée relativement aux individus inscrits sur la liste des émigrés, ou qui, après avoir été bannis de France, se sont retirés dans les pays réunis van 7 ventôse $V$ (25 feb 1797). ${ }^{21}$ RO nr.203, loi qui supprime les établissemens religieux dans les neuf départemens réunis par la loi du 9 vendémiaire, an IV van 15 fructidor IV (1 sep 1796).

${ }^{122} \mathrm{RO}$ nr.254, arrêté qui mainuient et conserve provisoirement les communautés connues sous le nom de soeurs noires dans les neuf départemens réunis van 23 pluviôse V (11 feb 1797).

${ }^{123} \mathrm{BL}$. Ile ser no.161 (1577), lai qui supprime dans les départemens réunis par la loi du 9 Vendémiaire an $N$, les chapitres séculiers, les bénéfices simples, les séminaires, et toules les corporations laĭques des deux sexes; over de opheffing van de Maastrichtse kapittels: br. Sigismund Tagage, "Rond de opheffing van het kapittel van Sint Servaas en de verkoop van zijn goederen" in: Miscellanea Trajectensia. Bijdragen tot de geschiedenis van Maastricht (Maastricht, 1962) 499-512; idem, "De Iaatste jaren van het Onze-Lieve-Vrouwe-Kapittel te Maastricht" in: A.H. Jenniskens e.a., ed. Campus Liber. Bundel opstellen over de geschiedenis van Maastricht aangeboden aan mr.dr. H.H.E. Wouters, stadsarchivaris en -bibliothecaris 1947-1977, bij zijn zeventigste werjaardag. Werken Limburgs Geschied- en Oudheidkundig Genootschap VIII (Maastricht, 1982) 354-369. 
te worden geïnventariseerd. Bij het verlaten van de communiteit kregen de vanaf dat moment ex-religieuzen een bepaald bedrag om in hun levensonderhoud te kunnen voorzien in de vorm van bons. Deze konden evenwel alleen aangewend worden voor het kopen wan nationale domeingoederen gelegen in de départements réunis. Art.19 van de wet bepaalde met betrekking tot de wetgeving op deze nationale domeingoederen dan ook:

Les lois relatives a lladminustration, aux baux et à la vente des biens nationaux de l'ancien territoire, ainsi qu'à la liquidation et au paiement des dettes dont ils étaient grevés, seront publiés, si fait $n^{*}$ a été, dans lesdits départemens réunis, pour y être appliquées aux biens dépendaient desdites maisons ou établissemens, en tout ce qui n'est pas contraire à la présente loi.

Hiermee werd verwezen naar een gigantisch complex aan wetgeving dat allemaal te maken had met het beheer van aan de staat gekomen nationale domeingoederen, alsmede de verkoop daarvan. Tientallen wetten daaromtrent waren al in de départements réunis afgekondigd ${ }^{124}$. De nationale domeinen werden onderscheiden in "biens de première origine", dat wil zeggen goederen oorspronkelijk afkomstig van de Kerk als institutie in de brede zin van het woord, en de "biens de seconde origine", namelijk de in beslag genomen goederen van uitgewekenen, gedeporteerden en veroordeelden. De Franse Republiek ging over tot het te gelde maken van al deze goederen. Niet alleen werd er overgegaan tot de verkoop ervan, verpachtingen kwamen ook voor. Bosareaal bij voorbeeld mocht niet worden verkocht, daar het hout benodigd was voor de bouw en het onderhoud van oorlogsschepen ${ }^{125}$.

Twee dagen na het uitvaardigen van de wet die de instellingen van de reguliere geestelijkheid ophief, vaardigde het Corps législatif nog een wet uit die voorzag in het treffen van maatregelen door het Directoire exécutif, en wel op de kortst mogelijke termijn, ter instandhouding van de inkomsten van de goederen, zowel de lopende als de achterstallige, van de opgeheven religieuze instellingen. Het Directoire was gemachtigd om de goederen te beheren dan wel te vervreemden ${ }^{126}$. Al kort na de inlijving bij Frankrijk trouwens hadden de religieuze instellingen de beschikkingsmacht over hun eigendommen en bezittingen verloren. De volksrepresentanten bij het Noorder- en het Sambre-en-Maasleger vaardigden op 22 vendémiaire IV (14 oktober 1795) een bestuit vit waarbij kerkelijke goederen door de houders niet langer mochten worden verkocht, vervreemd of met een hypotheek bezwaard. Verpachtingen waren

134 Zie RO nrs. 147 (inzake de verwreemding), 210 (beheer goederen witgewekenen), 232; in de Code Merlin zijn ook nog eens een tiental rechtsvoorschriften betreffende de nationale domeingoederen opgenomen, zie RO nrs.257(45), 257(67), 257(93), 257(138), 257(240), 257(251), 257(272), $257(330), 257(331), 257(340)$.

12. Zie over de nationale domeingoederen bij voorbeeld Garaud, Révolution et la propriété fancière, 305-343; Viard, Histoine générale du droit privé, 64-104.

${ }^{126} \mathrm{RO}$ nr.204, loi contenant des moyens pau" accélérer la vente des domaines nationaux et l"exécution de la loi sur la suppression des maisons religieuses dans les neuf départemens réunis le 9 vendemiaire, an $\mathrm{V}$ van 17 fructidor V (3 sep 1796). 
alleen geoorloofd ten overstaan van een overheidsfunctionaris en door de tussenkomst van de directeur der domeinen ${ }^{127}$.

Tot op heden is er nog maar weinig onderzoek gedaan naar de verkopingen van de nationale domeingoederen. In een artikel in de Publications heeft Ubachs daarop gewezen $^{128}$. De schrijver geeft cen overzicht hetgeen daar in Frankrijk en de Nederlanden aan studies over is verschenen. Voor het territoir van het Nedermaas-departement acht hij de oogst nog al mager en hij spoort daarom onderzoekers aan om de gelegenheid te baat te nemen. Maar een dergelijk onderzoek naar de verkopingen en de kopers van nationale domeingoederen is allerminst eenvoudig. De Instructie aangaande de modaliteiten van de verkopingen van nationale domeingoederen opgesteld door het Directoire verwijst naar maar liefst zestig rechtswoorschriften ${ }^{129}$. In de Instructie is ook een afzonderlijke paragraaf opgenomen met bijzondere bepalingen betreffende de te verkopen goederen in de negen départements réunis. De ingewikkeldheid van deze materie moge blijken uit het feit dat de Instructie uitgevaardigd is ingevolge de wet op de begroting voor het lopende jaar $\mathrm{V}^{130}$. Garaud heeft geschreven dat er over de jaren 1790 tot 1802 niet minder dan dertig verschillende wijzen van vervreemdingen voorkwamen ${ }^{131}$. Blijkens recent onderzoek waren er wel degelijk kopers van nationaal domeingoed in het departement Nedermaas. Door de bevolking werden de nationale domeingoederen namelijk aanvankelijk als "zwart goed" beschouwd. Niettegenstaande dit feit zijn de kopers zijn er in iedere geval niet minder van geworden ${ }^{132}$.

De positie van de Kerk als institutie kwam gaandeweg steeds meer onder druk te staan als gevolg van de Franse wetgeving op dit terrein en de daaruit voortvloeiende overheidsmaatregelen. Aanvankelijk werd er van de zijde van de nieuwe machthebbers nog coulant opgetreden. Om de gemoederen niet meer te verontrusten dan strikt noodzakelijk was, werd aanvankelijk de controversiële loi sur l'exercice et la police

\footnotetext{
${ }^{127} \mathrm{RO} \mathrm{nr}$.13, arrêté imterdisant toute vente, aliénation, échange ou hyporhèque des biens ecclésiastiques van 22 vendemiaire IV (14 okt 1795), geregistreerd op 18 brumaire IV (9 nov 1795); M.G. Spiertz, Maastricht in het vierde kwart van de achttiende eeuw. Kerkelijke, politieke en sociale verhoudingen. Maaslandse Monografieën (Assen, 1964) 191 vermeldt, dat daags na de witvaardiging de geestellike instellingen hiervan reeds in kennis waren gesteld.

22* P.J.H. Ubachs, "De werkoop der nationale goederen in de historiografie" "Publications de la Soctêté Historique et Archéologique dans le Limbourg. CXXIII (1987) 185-199 i.h.b.194-199.

129 RO nr.238. Instruction sur le nouveau mode de vente des damaines nationaux aut encheres, ardonné par la loi du 16 brumaire an $V$ wan 2 frimaire $V(22$ nov 1796).

${ }^{30} \mathrm{RO}$ nr.222(3), loi relatíe aux dépenses ondinaises é extraordinaires de l'an $V$ van 16 brumaïre $\mathrm{V}$ (6 nov 1796).

\$t Garaud, Révolution et la propriété foncière, 313: "Très nombreuses sont les lois qui ont réglementé la matière. Depuïs la loi du 14 mai 1790 jusqu'à celles des 15 et 16 floréal an X, on ne rencontre pas moins de trente modes diffêrents d'aliénation des domaines nationaux, instituês par trente lois principales 'modifiées chacune ou rapportée par plusieurs lois postérieures ou secondaires."

${ }^{132}$ N.J.P.M. Bos, "Rijkdom in revolutietijd. Oude en nieuwe rijken te Maastricht, 1795-1814", Economischm en Sociaal-Historisch Jaarboek LII (1989) 148-197, i.h.b. 171-176, 182-183; zie over de verkoop van de goederen en de bezittingen van de landscommanderij Alden Biesen U. Arnold e.a., Ridders en Priesters. Acht eeuwen Duitse Orde in Noordwest-Europa (s.I., 1992) 254-256.
} 
extérieure des cultes van 7 vendémiaire IV (29 sep 1795) niet afgekondigd. Ingevolge de opheffing van de reguliere geestelijke instellingen werd eerst alleen art.19 in de départements' réunis wan kracht verklaard, waarbij het verboden was, op straffe van een boete of langdurige hechtenis, in het openbaar religieuze gewaden en kentekenen van waardigheid te dragen, ook die welke gewoonlijk werden gedragen door een bedienaar van de eredienst ${ }^{133}$.

Aanzienlijk verscherpt raakte de toch al vertroebelde verhouding tussen de Staat en de Kerk toen via de Code Merlin een groot aantal bepalingen van de zoëven genoemde wet van 7 vendémiaire IV in het voorjaar van 1797 van kracht werden ${ }^{134}$. Van alle bedienaren van de eredienst werd vanaf dat moment de "garantie civique" geëist, zoals tit.III art.5 dat bepaalde:

Nul ne pourra remplir le ministère d"aucun culte ${ }_{\text {en }}$ quelque lieu que ce puisse être, s'il ne fait préalablement, devant l'administration municipale ou l'adjointt municipal du lieu où il voudra exercer, une déclaration dont le modèle est dans \'article suivant. Les déclarations déjà faites ne dispenseront pas de celle ordonnée par le présent article. II en sera registre. Deux copies conformes, en gros caractère très-lisible, certifiées par la signature de l'adjoint municipal ou du greffuer de la municipalité, et par celle du déclarant, en seront et resteront constamment affichées dans l'intérieur de l'édifice destiné aux cérémonies, et dans les parties les plus apparentes el plus à portée d'en faciliter la lecture.

Het daaropvolgende art. 6 bevatte het eedsformulier met de uit te spreken eed van trouw jegens de Franse natie:

Je reconnais que l'universalité des citoyens français est le souverain, et je promets soumission et obéissance aux lois de la République.

Zonder deze verklaring was het voortaan verboden de mis op te dragen of in een dienst voor te gaan. Degenen die dit toch deden, riskeerden bestraffing. In geval van recidive was de straf zeer zwaar. Nog zwaarder werden degenen bestraft die de eed braken of herriepen. Er hing hun dan levenslange verbanning boven het hoofd. De wet kende voorts bepalingen ter zake van het tegengaan van delicten tijdens de eredienst (tit.V artt.22-25). Ondanks de formele scheiding van Kerk en Staat vanaf februari 1795 en ondanks het feit dat de Franse Staat de kerkelijke functionarissen niet langer salarieerde - - in de grondwet van het jaar III uitdrukkelijk bevestigd - , bleef de Staat toch zeer nauwlettend het doen en laten van de Kerk volgen, en haar feitelijk door

${ }^{133}$ RO nr.232(1), dit artikel werd door het Directoire verbindend verklaard vanwege het feit dat voorheen reguliere geestelijken beider sexe art.18 van de wet van 15 fructidor IV ( 1 sep 1796), houdende de opheffing van de religieuze instellingen, overtraden.

${ }_{134}$ RO nr.257(351); over de verhouding Kerk en Staat in het departement Nedermaas vooral Spientz, Maastricht vierde kwart achttiende eeuw, hoofdst.vi; op blz. 196 vermeldt de schrijver dat de autoriteiten de bepalingen van de wet al een half jaar eerder zonder uitdrukkelijke opdracht toepasten jegens de geestelijkheid. 
middel van eden enzovoorts aan zich binden. De geformaliseerde scheiding van Kerk en Staat bleef dus feitelijk zonder betekenis ${ }^{135}$.

Om het controversiële karakter van de wet van 7 vendémiaire IV wat nader uiteen te zetten, volgt op deze plaats een korte uitweiding die de begrenzing van de regestenlijst overschrijdt. Het is tevens een voorbeeld van de ingewikkeldheid wat betreft het Franse intermediaire recht. Was de wet van 7 vendémiaire IV in grote lijnen via de Code Merlin in de départements réunis afgekondigd en aldus in het departement Nedermaas formeel geregistreerd op 29 ventôse V (19 maart 1797), bij besluit van het Directoire exécutif van 14 fructidor V (31 augustus 1797) werd opdracht gegeven om deze wet integraal in de départements réunis verbindend te verklaren. De registratie hiervan in het "registre ouvert" geschiedlde op 29 fructidor V (15 september 1797) ${ }^{136}$. Maar, de meest cruciale bepaling ervan - de eed van trouw jegens de Franse natie - werd ingehaald door de politieke gebeurtenissen. De staatsgreep van 18 fructidor V (4 september 1797), die het einde van het eerste Directoire markeerde, betekende een aanzienlijke verharding jegens de Kerk en haar vertegenwoordigers. De beruchte loi contenant des mesures de salut public relativement à la conspiration royale van 19 fructidor $\mathrm{V}$ ( 5 september 1797$)^{137}$ bepaalde in art.25:

La loi du 7 vendémiaire an IV, sur la police des cultes, continuera d'être exécutté à l"égard des ecclésiastiques autorisés à demeurer dans le territoire de la République, sauf qu'au lieu de la déclaration prescrite par l'article VI de ladite loi, ils seront tenus de prêter le serment de haine à la royauté et à l'anarchie, d'attachement et de fidélitê à la République et à la Constitution de I'an III.

De overheid dwong aldus de geestelijkheid zich nog meer te bekennen tot de Franse staat en maatschappelijke werkelijkheid, dan voordien al het geval was geweest. Niet meer was onderwerping en gehoorzaamheid aan de Franse wet voldoende, men diende nu ook de eed van haat jegens het koningschap en, ironisch genoeg, ook jegens de anarchie uit te spreken.

\section{Burgerlijke stand}

Onder de afgekondigde bepalingen van de wet van 7 vendémiaire IV bevond zich ook een tweetal bepalingen, die betrekking hadden op de akten van de burgerlijke stand (tit.IV sect.IV artt.20 en 21). Het was autoriteiten, zowel bestuurlijke als rechterlijke, uitdrukkelijk verboden rekening te houden met attestaties betreffende de burgerlijke stand uitgaande van bedienaren der eredienst. Ambtenaren die belast waren met het

\footnotetext{
${ }^{135}$ Godechot, Institutions, 430-432; art.354 grondwet jaar III: "Nul ne peut être empêché d'exercer, en se conformant aux lois, le culte qu'il a choisi.- Nul ne peut être forcé de contribuer aux dépenses d'un culte. La République n"en salarie aucun".

196 Zie RO nr.289.

${ }^{137}$ BL Ile ser no.142 (1400), geregistreerd in het "registre ouvert" op 25 fructidor V (9 sep 1797); naast het gewone afkondigingsformulier van het Directoire exécutif kende de onderhavige wet een nadere bekendmaking in de gemeenten:" "Ordonne en outre qu'à la diligence des administrations centrales de département, elle sera réimprimée et affichée dans toutes les communes".
} 
houden van de registers van de burgerlijke stand mochten onder strafbedreiging geen gewag maken van religieuze plechtigheden in de akten, noch een bewijs verlangen dat deze hadden plaatsgevonden.

We zijn hiermee op het terrein van het personen- en familierecht aanbeland ${ }^{138}$. Het Directoire heeft bij besluit van 29 prairial IV (17 juni 1796) opdracht gegeven een negental wetten betreffende de burgerlijke stand af te kondigen ${ }^{139}$. Binnen één week na de afkondiging van het onderhavige besluit - voor het departement Nedermaas uiterlijk 19 juli 1796 - dienden de municipale agenten of hun adjuncten in gemeenten met minder dan 5000 inwoners en in grotere gemeenten de daarvoor aangewezen ambtenaren van de burgerlijke stand alle registers, zowel oude als lopende, betreffende geboorte, huwelijk en overlijden die zich in parochiekerken, pastorieën en andere kerkelijke bewaarplaatsen bevonden, over te brengen naar de plaats alwaar het gemeentebestuur zitting hield. Akten van geboorte, huwelijk en overlijden moesten nog tot 1 vendémiaire $V(22$ september 1796$)$ in de lopende registers worden ingeschreven. Pastoors en dominees zagen dit natuurlijk ongaarne. In hun ogen werd hun een wezenlijke taak ontnomen, die zij voorheen steeds hadden vervuld, en die een weerspiegeling vormde van de beslissende momenten in een mensenleven, welke uitdrukking vond in een religieuze consecratie.

Het beeld van de invoering van de burgerlijke stand in het departement in $1796-$ terzijde: vijftien jaar eerder dan in de rest van Nederland, uitgezonderd ZeeuwsVlaanderen - is wisselend. Van het kanton Heerlen is bekend dat de pastoors daar volhardden in hun weigering de registers af te staan. In Maastricht heeft het kennelijk geen problemen gegeven ${ }^{140}$. Het Franse gezag was natuurlijk in de departementale hoofdstad tastbaar aanwezig: het garnizoen lag in de stad. Na ruim een jaar - op 1 vendémiaire VI (22 september 1797) - constateerde de commissaris van het Directoire exéutif bij het departementaal bestuur, Girard, in zijn rapport aan de minister van binnenlandse zaken, dat eigenlijk alleen het houden van de registers van de burgerlijke stand in Maastricht, Hasselt en Sint-Truiden in goede orde geschiedde. Vrijwel overal elders waren de municipale agenten niet in staat om goed register te houden, zelfs niet in hun eigen taal, laat staan in de Franse ${ }^{|4|}$.

\footnotetext{
${ }^{13 *}$ Een overzicht van het geheel biedt: Marcell Garaud \& Romuald Szramkiewicz, Histoire gếnérole du droir privé françäs (de 1789 à 1804). La Révolution Françase et la Famille, préface de Jean Carbonnier (Parijs, 1978).

134 Zie RO nr. 164, arrểté relarif à l'état civil des citoyens dans les départemens réunis, et portant publication des lois relatives à cette matiere.

${ }^{1401}$ L. van Hommerich, "De invoering van de burgerlijke stand te Heerlen, Voerendaal en Nieuwenhagen", Het Land van Herle, XIII (1963), 1-8, met documenten uitgaande van het municipale en het departementale bestuur; Régis de la Hay'e, "De oudste actes van de burgerlijke stand van Maastricht (1794-1796)", Limburgs Tijdschiff voor Genealogie, XII (1984) 25-30; de schrijver merkt op dat het vorderen van de registers voorspoedig verliep; aan de in het afkondigingsbesluit gestelde termijn werd overigens niet voldaan.

1.41 Roppe, Panhuysen \& Nuyens, Decadaire, resp. maandelijkse rapporren, 72-73; "... loin d'avoir des agens qui puissent tenir des registres en français, je suis assure que les sept-huitièmes ne pourraient pas le faire dans leur propre langue".
} 
In de départements réunis werd dus de door de Législative op de valreep voor haar uiteengaan aanvaarde loi qui détermine le mode de constater l'état civil des ciroyens van 20 september 1792 afgekondigd. Voortaan waren de municipaliteiten, in het bijzonder de ambtenaar van de burgerlijke stand, belast met het houden van de registers van de burgerlijke stand. Het kwam er dus in het kort op neer dat men eerst langs het gemeentehuis moest, alvorens er van een kerkelijke consecratie bij geboorte, huwelijk en overlijden sprake mocht zijn $^{142}$. Hiermeer werd er dus een behoorlijke aanzet gegeven tot de scheiding van Kerk en Staat ${ }^{143}$. De wet op de burgerlijke stand was feitelijk een organieke wet ter uitvoering van het bepaalde in de eerste Franse grondwet van $3 * 13$ september 1791 (tit.II art.7):

La loi ne considère le mariage que comme contrat civil.

Le Pouvoir législatif établira pour tous les habitans, sans distinction, le mode par lequel les naissances, mariages et décès seront constatés; et il désignera les officiers publics qui en recevront et conserveront les actes.

Dat het huwelijk door de Franse wetgever als een burgerlijke overeenkomst werd gezien was niet direct een revolutionaire gedachte: in de Oostenrijkse Nederlanden was dit al bij edict vastgelegd in 1784. Enige jaren daarvoor had keizerin Maria Theresia reeds voorschriften uitgevaardigd over het op de juiste wijze houden van burgerlijke standregisters door pastoors en andere geestelijken. Eén exemplaar van de in tweevoud bijgehouden parochieregisters moest door hen aan het provinciale gerechtshof worden overgedragen ${ }^{144}$. De Franse wet op de burgerlijke stand behelsde bepalingen over het houden wan de registers en de vormvereisten van de respectieve

${ }^{142} \mathrm{RO}$ nr. 164(3), in het décret additionnel concernant le mode de constater l'état civil des citoyens par les municipalités van 19 december 1792 was nog bepaald dat de aangifte van geboorte of overlijden binnen drie dagen diende te geschieden op straffe van hechtenis; een aangifte van een overlijden diende plaats te vinden voor de teraardebestelling.

${ }^{143}$ Recentelijk onderzoek heeft geleid tot publicaties op het terrein wan de scheiding tussen Kerk en Stat, en dan in thet bijzonder betreffende de secullarisatie van de burgerlijke staat van mensen. Y. Dockx, "La sécularisation de l'état civil à Bruxelles, 1796-1815" in: J. Craeybeckx \& F.G. Scheelings m.m.v. M. De Laet, ed., De Franse Revolutie en Vlaanderen. De Oostenrijkse Nederlanden ussen oud en nieuw régimelLa Révolution française et la Flandre. Les Pays-Bas autrichiens entre l"ancien et le nowveau régime. Handelingen van het colloqium gehouden op 1.2 december 1988 te Brassel/Actes du colloque du 1 et 2 décembre 1988 a Bruxelles (Brussel, 1990) 231-275; de schrijver constateert in het Brusselse een gehechtheid van de bevolking aan de religieuze plechtigheden bij geboorte, huwellijk en overlijden. Er werd wel voldaan aan hetgeen de burgerlijke overheid oplegde, maar het vormde niet de hoogste prioriteit. Het uitvoerigst wat betreft de invoering van de burgerlijke stand en de aanvaarding ervan in de départements réumis is de synthese van Claude Bruneel, "Laïcisation des institutions et tentatives de mesure de son impact: l'exemple de l'état civil" in: Roland Mortier \& Hervé Hasquin, ed., "Deux aspects contestés de la politique révolutionnaire en Belgique: langue et culte $^{* *}$, Erudes sur le XVII" siecle XVI (1989) 63-77; ook hier wordt geconcludeerd dat de secularisatie van de burgerlijke stand in de eerste jaren eerder weerstand dan begunstiging bij de bevolking en een deel wan haar leidsmannen ondervond, wooral op het plattelland.

144 Berkvens, Plakkatewijst Overkwartier, II, 375, 401-402, edict ter zake van doop-, trouw- en begrafenisregisters van 6 aug 1778; edict ter zake van het huwelijk van 28 sep 1784; Godding, Droit privé Pays-Bas méridionawx, $\mathrm{n}^{2} 126$, kenschetst het laatst genoemde edict als een secularisatie van het huwelijk. 
akten. Het huwelijk diende ten overstaan van de ambtenaar van de burgerlijke stand te worden gesloten en eventueel te worden ontbonden ${ }^{145}$.

Ontbinding van het huwelijk kon voortaan ook plaatshebben. Gelijktijdig met de wet op het vaststellen van de burgerlijke stand werd door de Législative ook een echtscheidingswet uitgevaardigd ${ }^{146}$. Voor de hedendaagse lezer doet deze wet heel modern aan. De eerste paragraaf zegt over de redenen wan scheiding:

Art. 1 Le mariage se dissout par le divorce.

Art. 2 Le divorce a lieu par le consentement mutuel des époux.

Art. 3 L'un des époux peut faire prononcer le diworce, sur la simple allégation d'incompatibilité d'humeur ou de caractère.

Art.4 Chacun des êpoux peut égallement faùre prononcer le diworce sur des motifs déterminés; savoir, $I^{2}$ sur la démence, la folie ou la fureur de l'un des époux; $2^{\text {go }}$ sur la condamnation de I'un d'eux à des peines afflictives ou infamantes; $3^{\circ}$ sur les crimes, sévices ou injures graves de l'un envers l'autre; $4^{2}$ sur le déreglement de moeurs notoire; $5^{2}$ sur l'abandon de la femme par le mari ou du mari par la fermme pendant deux ans au moins; sur l'absence de l'un d'eux, sans nouvelles, au moins pendant cing ans; $7^{0}$ sur l'émigration dans les cas prévus par les loix, notamment par le décret du 8 awril 1792.

De ambtenaar van de burgerlijke stand sprak een echtscheiding uit, nadat een verzoeningspoging door een vergadering van ten minste zes naaste familieleden of vrienden was mislukt. De ambtenaar van de burgerlijke stand nam verder geen kennis van de gronden die tot het verzoek om het ontbinden van een huwelijk hadden geleid. De wet regelde verder de rechtsgevolgen van een echtscheiding.

De Conventie vaardigde vervolgens nog een wet ${ }^{147}$ uit die het minderjarigen, wier ouders waren overleden, uit de ouderlijke macht waren ontzet, of om wettige redenen afwezig waren, toestond om te trouwen na het oordeel van een familieraad. Een dergelijke familieraad werd op verzoek van de minderjarige door de ambtenaar van de burgerlijke stand bijeengeroepen, en was samengesteld uit twee naaste familieleden en twee andere verwanten die niet tot de vermoedelijke erfgenamen zouden behoren. Bij onthouding van de goedkeuring kon uiteindelijk het huwelijk alleen tegengehouden worden op grond van een kennelijk niet-onberispelijke levenswandel van de te huwen partij, of de niet-rehabilitatie na een vonnis waarin een peine infamante uitgesproken werd.

Een merkwaardig decreet ${ }^{148}$ van de Convention nationale was dat waarin zij verklaarde de handelwijze van de ambtenaar van de burgerlijke stand te Parijs goed te keuren, die had geweigerd de aangifte van een geboorte door een burgeres op te

145. A.H. Huussen jr, "Le droit du mariage au cours de la Révolution française", Tijdschrift voor Rechsgeschiedenis/Revue d'Histoire du DroitThe Legal History Review, XLVII (1979) 9-5I en 99127, beschrijft het Franse huwelijksrecht wan de Rewolutie; de schrijver behandell zeer uitvoerig de wetsgeschiedenis en de verdere ontwikkelingsgang, steunend op een uitputtende annotatie.

${ }^{146}$ RO nr. 164(2), toi qui détermine les causes, le mode et les effets du divorce van 20 september 1792.

${ }^{147} \mathrm{RO}$ nr. 164(5), décret portant que provisoirement les mineurs dont les pères ou mères seraient movts, interdits ou absens pour cause légitime. sont autorisés à contracter mariage su" lavis d'un conseil de famille van 7 sep 1793.

${ }^{148} \mathrm{RO}$ nr. 164(8), décret relatif aux déclarations sur l'état coivil van 19 floréal 11 (8 mei 1794). 
nemen, waarbij zij de verklaring aflegde dat het kind niet van haa echtgenoot was. Reden: de wet kende geen andere vader dan die welke aangeduid werd door het huwelijk. Een aangifte die daarmee strijdig was, was immoreel. Aan een vrouw kon het niet worden toegestaan naar goeddunken over de burgerlijke staat van haar kinderen te beschikken. De geboorteakte diende dan ook te worden opgemaakt zonder van deze aangifte melding te maken.

In de Code Merlin zijn ook enkele wetten op het terrein van de echtscheiding opgenomen $^{149}$. Afgezien van een passus in de loi concernant l'administration des biens déclarés à la dispositions de la nation, l'abolition des dîmes \&c van 14 en $20 * 22$ april 1790 gaat het om de twee volgende wetten: de loi qui autorise le conjoint demandeur en divorce à faire apposer les scellés sur les effets mobiliers de la communauté van 22 vendémiaire II (13 okt 1793) en de loi relative au divorce en cas d'émigration van 24 vendémiaire III (15 okt 1794). Deze laatste wet was door de thermidoriaanse Conventie uitgevaardigd vanwege het feit dat de echtgenotes van uitgewekenen een eerder uitgevaardigde wet, houdende de verbreking van de echtelijke band bij afwezigheid langer dan zes maanden, misbruikten om de echtscheiding te vorderen en aldus de verbeurdverklaring van haar goederen en die van hun uitgeweken echtgenoot te voorkomen.

Het was verder een ieder verboden om een andere voor- en achternaam te voeren dan die welke vermeld stond in de geboorteakte ${ }^{150}$. Dit bood namelijk uitgewekenen de mogelijkheid onder een andere naam naar Frankrijk terug te keren. Ambtemaren was het ten strengste verboden burgers anders aan te duiden dan in de geboorteakten stond vermeld. Mochten zij zich hiertoe toch lenen, dan zouden zij worden afgezet en voorts onbekwaam worden verklaard om voortaan nog enig openbare functie uit te oefenen; bovendien hing hun een boete boven het hoofd gelijk alan een kwart van hun inkomen.

Over de burgerlijke staat in de Code Merlin ten sllotte, is er nog een wet opgenomen aangaande de kennisneming van geschillen betreffende de burgerlijke staat van buitenechtelijk geboren kinderen ${ }^{15 !}$.

\section{Slot}

Sous la Révolution, le droit acquiert une souplesse inouie; toujours conforme aux idées et aux passions mobiles de l'époque, il se modifie avec une rapidité surprenante. C"est une lutte perpétuelle de principes et d'intếrêts qui prend un caractère dramatique. C'est une évolution qui dure, non plus dix siècles, mais quinze ans, et qui offre un intérêt juridique semblable, mais plus concentré et plus saississant.

\footnotetext{
1.449 Zie RO nr.257(24), 257(232), 257(290).

${ }^{1549} \mathrm{RO} \mathrm{nr}, 257(280)$, lo i portant qu' aucun citoyen we pourra porter de nom ou prénom autres que ceux exprimés dans son acte de naissance van 6 fructidor II (23 aug 1794).

${ }^{15}$ RO nr.257(300), loi sur la connaissance des contestations relatives d̀ l'éfal civil des enfans nés hors mariage van 25 nivôse III (14 jan 1795).
} 
Aldus Philippe Sagnac in zijn bijna een eeuw oude thèse ${ }^{152}$. Het is inderdaad verbazingwekkend met welk een gemak gedurende de revolutiejaren wetten en decreten werden uitgevaardigd. Zeker onder de Conventie was er sprake van een "surabondance" aan decreten. De snelle wetgevingsarbeid leidde ertoe dat soms al na een week of twee - in de hedendaagse terminologie - reparatiewetgeving noodzakelijk geacht werd $^{153}$. De Franse revolutionaire wetgevers konden ook vrij gemakkelijk op deze wijze opereren, daar ervan werd uitgegaan dat het geregelde toch maar voor tijdelijk was. Tijdelijk omdat de assemblees zich tegelijkertijd bezighielden met het ontwerpen van een burgerlijk wetboek. Vier ontwerpen van de code civil passeerden immers de revue, waarvan de laatste, en dan nog onder druk van Napoleon, "het" wetboek werd. Onder zijn impuls had er een versnelling plaats in de codificatiewerkzaamheden, en niet uitsluitend op het terrein van het burgerlijke recht. Gelijkopgaande met de uitbreiding van de machts- en invloedssfeer van de Franse natie werd haar gedachtengoed, zoals dit in het recht zijn neerslag vond, verder verspreid. Napoleon heeft, in algemene zin gesproken, op diverse gebieden - ook op die van het recht - de verworvenheden uit het decennium voorafgaande aan zijn bewind gehandhaafd en derhalve geconsolideerd $^{1.54}$.

Niettemin valt er wel een onderscheid in karakterisering wat betreft de wetgeving uitgaande van de respectieve elkaar opvolgende assemblees aan te duiden. De wetgeving uitgaande van de Assemblée nationale constituante en de Assemblée nationale législative wekt de indruk gedegener van karakter te zijn, dan die van haar opvolgers. Het zijn in het algemeen uitgebreidere wetten die door haar werden uitgevaardigd. In die eerste jaren na het uitbreken van de Revolutie werd de samenleving omgevormd door representanten van de natie, die nog volledig gevormd waren in het ancien régime ${ }^{155}$. De afgevaardigden in de Convention nationale en daarna in de Conseil des Cinq-cents en de Conseil des Anciens waren dat goeddeels ook, maar zij konden voortbouwen op het door hun voorgangers gelegde fundament. Dat wil niet zeggen dat deze laatsten onbelangrijke wetgeving zouden hebben voortgebracht, getuige bij voorbeeld het nieuwe erfrecht, het hypotheekrecht en de code des délits et des peines uit de tijd van de Conventie. De politiek-maatschappelijke gebeurtenissen dwongen alle assemblees tot snel en adequat reageren, maar onder de Conventie en het Directoire was er vaker sprake van instant-reageren. Afgezien van de laatste maanden van de Législative hadden zij natuurlijk ook te maken met de buitenlandse bedreiging ten gevolge van de oorlogstoestand. Van twee zijden werd de nieuwe Franse maatschappelijke werkelijkheid dus bedreigd: ook binnenslands door het verzet van de zijde van

${ }^{152}$ Ph. Sagnac, La législation civile de la Révolution française (1789-1804). Essai d'histoire sociale (Parijs, 1898) ii, preface.

${ }^{15 i}$ Pierre-Paul Viard, "L"oeuwre juridique de la Convention", Annales Historiques de la Révolution Franģaise, VII (1930) $525-548$ i.h.b. 544.

154 Jacques Godechot, "Sens et importance de la transformation des institutions révolutionnaires a l'époque napoléonienne". Revue d' Histowe Moderne et Contemporaine, XVII (1970) 795-8\3, i.h.b. 798-799, 801-805, 811, 813; zie over Napoleon, de code civil en zijn betekenis ook de schets van Jean Carbonnier, "Le Code civil" in: Pierre Nora, ed., Les Lieux de Mémoive II La Nation (3 din; s.l., 1986) II, 293-315.

155 André Costaldo, Les méthodes de travail de la Constituante: les techniques délibératives de l'Assemblée nationale, 1789-1791 (Parijs, 1989) 21, 371. 
een deel van de bevolking tegen de revolutionaire nieuwigheden. Dit moest noodzakelijkerwijs in de wetgeving wel tot uitdrukking komen.

Voor alle revolutionaire assemblees gold dat de door haar goedgekeurde wetten meestal voorbereid en geredigeerd. waren door uit haar midden afkomstige comités of commissies. Een te regelen materie werd eerst voorgelegd aan een "vast" comité, dat geacht werd een beter zicht te hebben op de technische merites. De revolutionaire assemblees telden dan ook een behoorlijk aantal wan dit soort comités ${ }^{156}$.

Vanwege het grote aantal rechtsvoorschriften dat in zeer korte tijd - zo'n anderhalf jaar - in de départements réunis door de Franse machthebbers van kracht werd verklaard, konden slechts de grote trekken ervan aan de orde worden gesteld. Hoofdzakelijk de grotere corpora zijn in de beschouwing betrokken. Het valt op dat er tussen de afzonderlijke rechtswoorschriften allerlei onderlinge verwevenheden bestaan. Wetten die ogenschijnlijk los van elkaar staan, vertonen vaak raakvlakken met andere.

Een aantal aspecten van de revolutionaire wetgeving zijn zo in dit hoofdstuk aan de orde gesteld; vele echter ook niet. In de regestenlijst is ook wetgeving opgenomen op het gebied van belastingen. Verder komen bij voorbeeld de hypotheekwetgeving (de invoering ervan werd telkenmale bij wet verschoven), het nieuwe erfrecht ${ }^{157}$, contrabande, benoemingsbesluiten van plaatselijke bestuurders in het departement, paspoorten, het notariaat, verdragen met buitenlandse mogendheden enzovoorts aan de orde.

De volksrepresentanten hebben ook een reeks rechtsvoorschriften afgekondigd die het beheer en de verkoop van de goederen en bezittingen van de Maltezer Orde tot onderwerp hadden. De reden daarvoor is waarschijnlijk gelegen in het feit, dat de Orde bezittingen had in het Henegouwse - op dat moment het territoir van het departement Jemappes - alsmede vanwege het feit dat er sprake was van kerkelijk bezit dat, als het overige, tot nationaal domeingoed was verklaard. Voor zover bekend lagen er geen goederen van deze geestelijke ridderorde op het territoir van het departement Nedermaas. Eén van de afgekondigde rechtsvoorschriften, het décret concernant les précautions à prendre pour les conservation des titres et biens du ci-devant ordre de Malte, et des autres ordres de chevalerie van 22 oktober 1792, bepaalde in het laatste artikel dat de bepalingen van het decreet tevens van toepassing waren op de instellingen van andere geestelijke ridderorden, waaronder de Duitse Orde. Zij konden dus

\footnotetext{
${ }^{1366}$ Costaldo, Méthodes de travail, 204-254; C.J. Mitchell. The French Legislative Assembly of 179I (Leiden/New" York/Kopenhagen/Keulen, 1988) 30-39; Viard, "Oeuvre juridique", 538, 544.

${ }^{159} \mathrm{RO}$ nr. 67: bij beslunit van de gouvernementscommissarissen van 28 en 29 brumaire IV (19 en 20 nov 1795 ) werd een reeks wetten betreffende het erfrecht afgekondigd, waaronder grote delen van de befaamde wet wan 17 nivôse II ( 6 jan 1794); de registratie ervan geschiedde op 25 frimaire IV (16 dec 1795). In BL Ile ser no. 105 (1001) staat een lö́ relative aux successions van 18 pluviôse $V(6$ feb 1797); in de Code Merlin staat ook wetgeving op het terrein van de substituties en nalatenschappen, waaronder een extract uit de loi sur diverses questions relatives aux donations, successions et substitutions van 9 fructidor II (26 aug 1794) [RO nr.257(281)].
} 
toepasbaar zijn op de goederen en bezittingen van de landscommanderij Alden Biesen van de Duitse Orde, die gelegen warren in de départements réunis ${ }^{158}$.

In de regestenlijst staan rechtsvoorschriften die men niet dadelijk zou verwachten. Het betreft hier decreten uit de tijd van de Convention nationale die uitgevaardigd werden naar aanleiding van verzoekschriften gericht aan de assemblee door veroordeelden, die aldus een herziening van het vonnis hoopten te bewerkstelligen. Men krijgt ter zake van deze "décrets d'annulation" sterk de indruk, dat hier sprake is van een doorbreking van het beginsel van de scheiding der machten. De Conventie evenwel, stelde zich op het standpunt dat de wet de enige bron van recht was en dat bij haar, de natie vertegenwoordigende, als enige de bevoegdheid tot uitleg van de wet berustte. Ook het tribunal de cassation was in laatste instantie aan haar ondergeschikt. Rechtbanken vroegen dan ook regelmatig advies aan de Conventie over bepaalde juridische vraagstukken, de zogenoemde référés ${ }^{159}$. De wet van 14 vendémiaire III (5 oktober 1794) bij voorbeeld heeft ondubbelzinnig het karakter van een "décret d'annulation". De Conventie vernietigde toen zowel het vonnis van de criminele rechtbank in het departement Marne als het vonnis van het tribunal de cassation, dat het eerdere vonnis bevestigde. Een vrouw had zich tot de Conventie gewend en zich beklaagd over haar veroordeling tot zes jaar eenzame opsluiting ( $g e ̂ n e$ ) wegens een vals getuigenis in eem. burgerlijke zaak. De Conventie bepaalde toen dat de criminele rechtbank in het departement Aube haar zaak opnieuw diende te beoordelen ${ }^{160}$.

Revolutie betekende ook feest. Vooruitlopend op de afkondiging via de Code Merlin van de loi sur l'organisation de l'instruction publique van 3 brumaire IV (25 oktober $1795)^{161}$ verordonneerde het Directoire dat het fëte des époux op 10 floréal IV (29

${ }^{15 x}$ RO nr.97(2); art.8 luidde aldus: "Les dispositions du présent décret sont déclarés communes aux établissemens, soit de l'ordre Teutonique, soit de tous autres ordres de chevalerie qui peuwent exister sur les terres de la république. Elles seront exécutées, à leur égard et à l'égard de leurs agens, receveurs, fermiers et autres, de la mềme manière qu'elles le doivent être à l'égard des établissemens et agens du ci-devant ordre de malthe".

159 RO 96(2), décret qui détermine les cas où les jugemens pewvent et doivent être annullês en matiere civile van 4 germinal II (24 mrt 1794); RO m.89(21), détret relatif au mode de jugement des prévenus de faux assigmars en pays étranger van 22 germinal II (11 apr 1794); RO nr.89(25), loi relative à une question sur la peine infliger à une collecteur des impositions de 1790. convaincu de concussion et de falsification de ses rôles van 28 prairial II (16 jun 1794); RO nr.96(1), loi portant qu"en matière civile les rémoins seront entendus publiquement dans les tribunaux de district van 7 fructidor III (24 aug 1795); Van Boven, Rechterlijke instellingen, $49-49$ onderscheidt een tweetal "référés", het "référé facultatif" en het "rêféré obligatoire"; zie ook Viard, "Oeuvre juridique", 538. "ail RO nr.89(30), loi portant que la question relative a l' intention sera posée à l"aveniz dans toutes les affaires sonmises à des jurés de jugement van 14 vendémiaire 111 ( 5 okt 1794 ); in minder dan een jaar werd deze wet trouwens door het Directoire hemoepen; over deze materie: Jean-Louis Halperin, "Les décrets d'annulation des jugements sous la Convention" in: La Réwolution el l'ordre juridique privé. Rationalité ow scandale? Actes du colloque d"Orléans 11-13 seprembre 1986 (2 din; Orléans. 1988) II, 457-468; Viard, "Oeuvre juridique", 537-538.

${ }^{161}$ BL lle ser no.203 (1216); Code Merlin: RO nr.257(356). 
april 1796) in alle municipaliteiten diende te worden gevierd ${ }^{162}$. Onder toezicht van de municipale besturen dienden de festiviteiten plaats te hebben. Een en ander mocht niet te veel kosten met zich meebrengen, maar diende wel in overeenstemming te zijn met het verheven karakter van het feest. Voorbeeldig gehuwden en gezinnen met kinderen, die ook nog een wees hadden opgenomen, dienden door de municipaliteit aan anderen ten voorbeeld te worden gesteld. Het departementaal bestuur van de Nedermaas liet het Directoire-besluit tweetalig drukken en toezenden aan de municipaliteiten, die zich er nauwgezet aan dienden te conformeren. Het was wel kort dag: het besluit werd formeel op 5 floréal IV (24 april 1796) in het departement geregistreerd en op de tiende al waren de festiviteiten...

Bij wet werd bepaald dat op 1 vendémiaire V (22 september 1796) het feest van de vestiging van de Republiek in alle gemeenten diende te worden gevierd. Het Corps législatif belastte het Directoire met het nemen van de noodzakelijke maatregelen, opdat de feestelijkheden zich waardig voltrokken ${ }^{163}$.

Beide feesten vormden een onderdeel van de hierboven genoemde wet op het publieke onderricht (titel VI, fêtes nationales). Naast de beide genoemde feesten waren er nog vijf andere, te weten: het feest van de jeugd (jeunesse), het feest van de dankbaarheid (reconnaissance), het feest van de landbouw (agriculture), het feest van de vrijheid (liberté) gedurende twee dagen ( 9 en 10 thermidor) en het feest van de ouderen (vieillards). Voor de Convention nationale bestond de viering van de nationale feesten (tit.VI art.2) uit: patriottische liederen, een voordracht over de moraal van de burger (discours sur la morale du citoyen), een verbroederingsbanket, diverse spelen en het toekennen van beloningen. De kantonnale besturen dienden van tevoren de nationale festiviteiten aan te kondigen ${ }^{164}$.

Wanneer men de hele massa aan afgekondigde wetgeving in één woord zou willen kenschetsen, dan dringt het woord police - toezicht - zich op. Dit is vanzelfsprekend een te rigoureuze vereenvoudiging van het complexe stelsel aan regelgeving die de respectieve elkaar opvolgende assemblees hebben ontworpen. Het zou immers afbreuk doen aan talloze waardevolle aspecten, die de wetgeving natuurlijk ook met zich meebracht. Niettegenstaande dit feit blijft de mate van toezicht zich onmiskenbaar aan de hedendaagse beschouwer van de revolutionaire wetgeving opdringen. Aan twee voorbeelden van wetten wordt die mate van toezicht nog wat toegelicht.

In de Code Merlin verwijst de index onder "lettres" naar een wet wan de Conventie van 9 mei $1793^{165}$. Deze loi relative aux lettres à l'adresse des personmes sur la liste des émigrés droeg twee gemeenteambtenaren of twee gemeenteraadsleden op zich naar het postkantoor te begeven om te verifiëren of er al dan niet aangetekende brieven aanwezig waren geadresseerd aan personen die op de lijst van uitgewekenen

\footnotetext{
${ }^{162} \mathrm{RO} \mathrm{nr} .126$, arrêté qui détermine la maniere dont seva célébrée, le 10 floréal, la fête des époux wan 27 germinal IV (16 apr 1796).

${ }^{163 .}$ RO nr.195(9), loi portant que la fondation de la République française sera fêtée le ler vendémiaire, dans toutes les communes van 29 thermidor IV (16 aug 1796).

164 Over het fenomeen revolutionaire feesten en de betekenis ervan: Mona Ozouf, La fête révolutionnaire 1789-1799 (Folio/Histoire; s.1., 1976), over het stelsel van brumaire IV i.h.b. 192-204.

${ }^{165}$ RO ar. $257(181)$.
} 
vermeld stonden. Ten gemeentehuize moesten de brieven en pakjes geopend worden om te bezien of er geld en waardepapieren in zaten. De opbrengst hiervan moest worden gestort bij de ontvanger van de domeinen. Er was hier natuurlijk sprake van de schending van het briefgeheim.

Het tweede voorbeeld: de loi sur la police intérieure des communes de la République van 10 vendémiaire IV ( 2 oktober 1795). Deze wet werd betrekkelijk kort na haar uitvaardiging door de volksrepresentant en mission Giroust in het departement van de Nedermaas afgekondigd. De eerste titel van de wet luidde als volgt:

Tous citoyens habitant la même commune sont garans ciwilement des attentats commis sur le territoire de la commune, soit envers les personnes, soit contre les propriétés.

Om het interne toezicht in de gemeenten te waarborgen moest elke gemeente verder een lijst opstellen met de naam, leeftijd, staat of beroep van alle inwoners boven de twaalf jaar, alsmede hun woonplaats en het tijdstip wan hun komst naar de gemeente. Een dergelijke lijst diende naar de kantonsmunicipaliteit en het departementaal bestuur te worden gezonden. De ambtenaren en municipale agenten die hieraan niet voldeden, werden persoonlijk verantwoordelijk gehouden voor geweldplegingen op het grondgebied van de gemeente. Om te kunnen reizen buiten het grondgebied van het kanton van domicilie diende men houder van een paspoort te zijn. Zonder een paspoort riskeerde men arrestatie en een behandeling als vagebond. Schaden die ontstonden door geweldplegingen of door het uitblijven van geldelijke prestaties werden de gemeente als collectiviteit aangerekend en moesten door haar worden vergoed, tenzij de daders en overige nalatigen konden worden aangewezen ${ }^{166}$.

Al deze wetgeving leidde tot een enorme toename van de bureaucratie. Iedere instantie of bestuurslaag moest aan een hogere rapporteren. Omgekeerd gingen er oneindig veel directieven van hoog naar laag. Op het niveau van de departementen heerste als gevolg daarvan een ware papierwinkel, aangezien zij als spil fungeerden tussen Parijs en de uithoeken van het land. Te Parijs zelf nam daardoor ten tijde van het Directoire de ministeriële bureaucratie ook ontzaglijk toe. Niet in de laatste plaats vanwege het feit dat de centrale overheid over alles geïnformeerd wilde zijn. De basis daarvoor werd al gelegd door de Conventie die zich genoodzaakt voelde nauwlettend toe te zien op het doen en laten van haar onderdanen ${ }^{167}$.

\footnotetext{
${ }^{166}$ In de nasleep van de geweldplegingen tijdens de zogenaamdle Boerenkrijg van 1798/1799, werd deze wet door diverse particulieren ingeroepen, die schade hadden geleden; Vandebeeck \& Grauwels, Boevenkrijg, 307-327; hun opmerking op blz..308, dat de wet van 10 vendémiaire IV eerst op 4 nov 1798 door een besluit van het Directoire zou zijn afgekondigd en toepasselijk verklaard, berust op een misverstand. De volksrepresentanten hadden de wet reeds in het najaar van 1795 afgekondigd, en zij werd ook dadelijk doorgestuurd naar de kantons. Het Directoire riep in zijn arrêté concernant l'indemnité des pillages et excès commis dans plusieurs cantons des départements ré́unis le 9 vendemiaire an $N$ van 14 brumaire VII (4 nov 1798) de onderhavige wet te hulp [BL Ile ser no.235 (2124)].

167 Clive H. Church, Revolution and Red Tape. The French Ministerial Bureaucracy 1770-1850 (Oxford, 1981) hoofdst. $v$-vii, handelen over de bureaucratie in de Divectoire-periode.
} 
Het departement van de Nedermaas draaide, zodra de aanloopperiode na de inlijving op 1 oktober 1795 overwonnen was, mee in het carrousel van de Franse wetgeving en de administratieve handelingen die daaruit voortvloeiden. De inwoners van het departement zullen er ongetwijfeld anders over hebben gedacht en wegen gezocht hebben om zich aan de impact van de wetgeving te kunnen onttrekken. Voor Parijs evenwel, vormden de départements réunis een integraal onderdeel van de Franse staat. Zij waren immers réunis - verenigd - met hem. Zoals het departement van de Nedermaas niet los kan worden gezien van de départements réunis, zo kunnen zij op hun beurt niet los worden gezien van Frankrijk. Dit gold in ieder geval op het terrein van de wetgeving. 


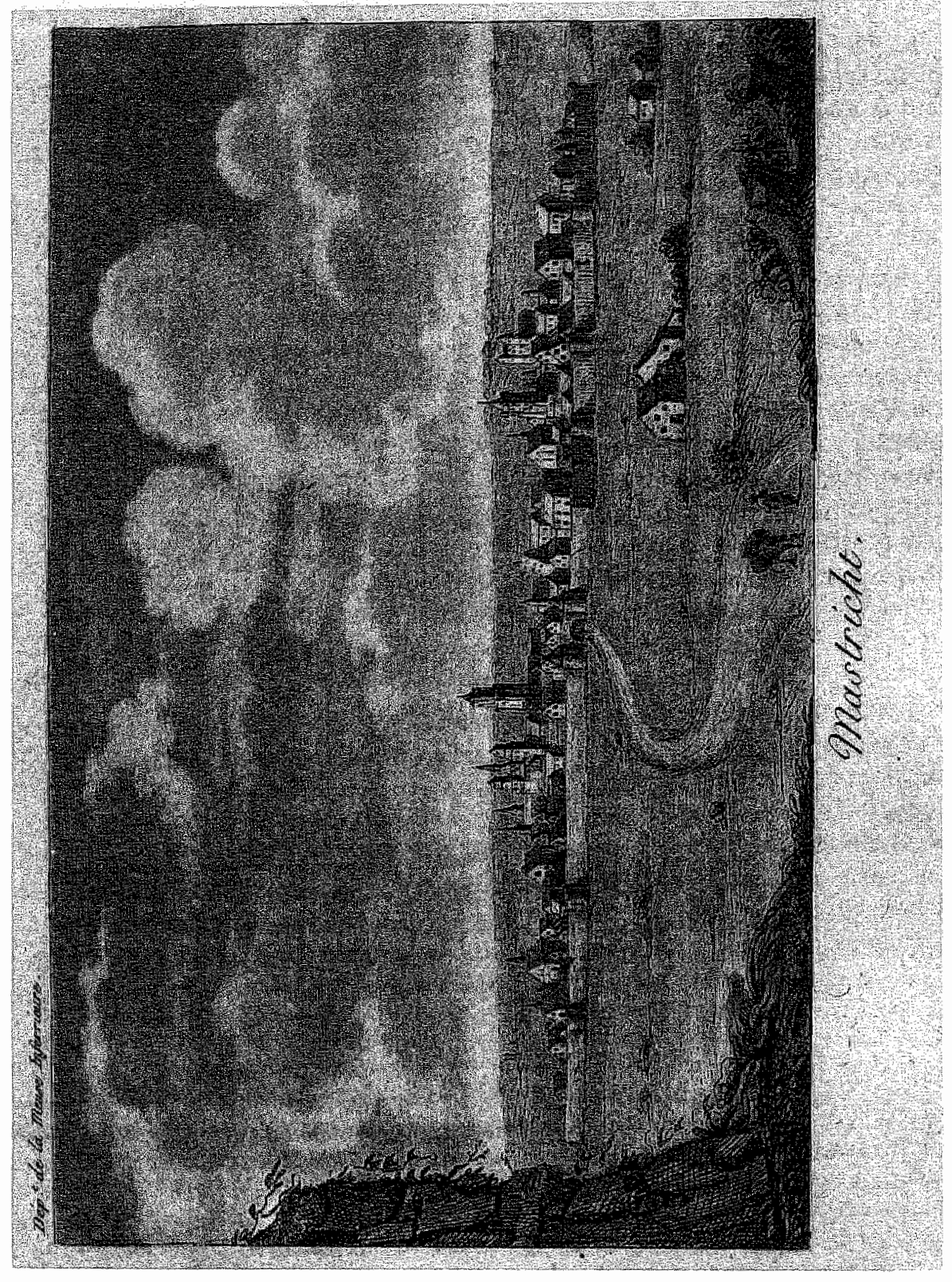

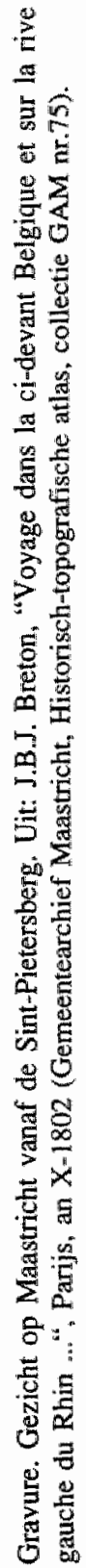


(niet opgenomen zijn de bronnen en publicaties die genoemd worden in de lijst met afkortingen)

Alberts, W. Jappe. Geschiedenis wan de beide Limburgen. Beknopte geschiedenis van het gebied omvattende de tegenwoardige Nederlandse en Belgische provincies Limburg. sedert de vroegsie tijden. Maaslandse Monografieèn XV, XVII (2 dln; Assen, 1972-1974).

Amold, U. e.a. Ridders en Priesters. Acht eerowen Duitse Orde in Noordwest-Europa. Tentoonstelling van de Landcommanderij Alden Biesen en het Vlaams Commissariaat-Generaal voor Toerisme in samenwerking met de Internationale Historische Kommission zur Erforschung des Deutschen Ondens en het Historisch Studiecentrum Alden Biesen (s.l., 1992).

Arnould. Maurice-A. "La naissance des départements. De la 'représentation', reflet du réel, au découpage réel de la France de 1789". Bespreking van La formation des départentents. La représentation du territoire français à la fin du XVIII siècle (Parijs, 1989) door Marie-Vic OzoufMarignier. Revue Belge de Philologie et d'HistoirelBelgisch Tijdschrift woor Filologie en Geschie. dewis, LXX (1992) 399-409.

Aussems, P.J.M. e.a., ed. Kleine Allas voor de geschiedenis van beide Limburgen (Hasselt/Maastricht, 1989).

Baillien, Henry, ed. De rapporten van de kantonkommissarissen (1797 - 1800). Deel II Tongeren. Werken uitgegeven onder auspüciën van de Bestendige Deputatie van de Provincie Limburg XV (Hasselt, 1972).

Bayer-Lothe, I. "Aspects de l'occupation française dans la principauté de Liège" in: Occupants Occupés 1792-1815. Colloque de Bruxelles, 29 et 30 janvier 1968 (Brussel, 1969) 67-119.

Bellefroid, Paul. Dictionnaire fransais-néerlandais des termes de droit (3e dr.; Brussel/Gent, 1930).

Bergeron, Louis. L'Episode napoléonien 1.Aspects intêrieures 1799-1815. Nouvelle histoite de la France contemporaine IV (coll. Points/Histoire, 1972).

Berkwens, A.M.J.A. Plakkatenlijst Overkwartier 1665-1794. Rechtshistorische reeks van het Gerard. Noodt Instituut XIX, XXV (2 dln; Nijmegen, 1990-1992).

Blécourt, A.S. de. Kort begrip van het oud-vaderlands burgerlijk recht, bewerkt door H.F.W.D. Fischer (6e dr.; Groningen/Djakarta, 1950).

Bloch. Claudine \& Jean Hilaire. "Nouveauté et modemité du droit révolutionnaire: la procédure civile" in: La Révolution et l"ordse juridique privé. Rationalité ou scandale? Actes du colloque d"Ortéans 11-13 septembre 1986 (2 din; Orléans, 1988) 11, 469-482.

Blok. P.J. e.a., e.d. Geschiedkundige atlas wan Nederland. De Republiek in 1795 met de heerlijkheden, ambachten enz. ('s-Giravenhage, 1913).

Boel, W.M. van de, e.a. Historische Atlas van Limburg en aamgrenzende gebieden I Serie staatkundige kaarten: de staarkundige kaart van Limburg en aangrenzende gebieden in de jaren 1543/1548 (Assen/Maastricht, 1990).

Bormann, K.Th.F. \& A. W. Daniels, ed. Handbuch der fïr die Königl. Preuß. Rheinprovinzen verkindigren Gesetze, Verordmungen and Regierumgsbeschlüsse aus der Zeit der fremdherrschaft (8. din; Keulen, $1833-1845)$.

Bos, N.P.J.M. "Rijkdom in revolutietijd. Oude en nieuwe rijken te Maastricht, 1795- 1814". Economisch-en Sociaal-Histarisch Jaarboek, LII (1989) 148-197.

Bossers, Geert. "Welk eene natie, die de jurij gehad heeft, en ze weder afschaft!" (Delft, 1987).

Bouloiseau "Marc. La République jacobine 10 août 1792-9 thermidor an II. Nouvelle Histoire de la France contemporaine II (coll. Points/Histoire, 1972).

[Bouteville] Compte de la mission du Citoyen Bouteville, Commissaire du Gowvernement dans les neuf Départemens réunis par la loi du 9 Vendémiaire an 4 (Brussel, an V/1797). 
Boven, Matrten Willem van. De recherlike instellingen ter discussie. De geschiedenis wan de wetgeving op de rechterlijke onganisatie in de periode 1795-181\%. Gerard Noodt Instituut diss. Nijmegen (Nijmegen, 1990).

Bruneel. Claude. "Laïcisation des institutions et tentatives de mesure de son impact: l'exemple de l'étal civil" in: Roland Mortier \& Hervé Hasquin, ed. "Deux aspects contestés de la politique révolutionnaire: langue et culte". Erudes sur le XVIIT siecle, XVI (1989) 63-77.

Bruneel $\mathrm{C}_{4}$ ed. Des rêvolutions à Waterloo. Bibliographie sélective d" histoire de Belgüque (I789. 1815). Archives et Bibliothèquess de Belgique/Archief- en Bibliotheekwezen in Belgiè numểro spécial/exranummer XXXVI (Brussel, 1989).

Camps, R.L.M.M. "Oude regenten onder een nieuwe vlag. De Venlose magistraat in het begin van de Franse tijd (1794-1796)" in: Fr.J. Hermans e.a., ed. Venlo"s Mozaiek. Hoofdstukken wit zeven eewwen stadsgeschiedenis. Werken Limburgs Geschied-en Oudheidkundig Genootschap XII (Maastricht, 1990) 201-222.

Caron, Pierre. Manuel pratique pour l'étude de la Révolution française (2e dr.; Parijs, 1947).

Carbonnier, Jean. "Le Code civil" in: Pierre Nora, ed. Les Lieux de Mémoire II La Nation (3 dln; s.l., 1986) II, 293-315.

Church. Cliwe, "Du nouveau sur les origines de la constitution de 1795". Revue Historique de Droit français et etranger, LII (1974) 594-627.

Church, Clive H. Revolution and Red Tape. The French Ministerial Bureaucracy 1770-1850 (Oxford, 1981).

Clère. Jean-Jacques. "Les Constituants et l"organisation de la procédure pénale" in: La Révolution et l'ordre juridique privé. Rationalité ou scandale? Actes du colloque d"Orléans 11-13 septembre 1986 (2 dln; Orléans, 1988) II, 441-456.

Codes Dalloz. Cade Civil, geredigeerd m.m.w. Gilles Goubeaux \& Philippe Bihr (90e dr.; Parijs, 1990-1991).

Colenbrander, H.T., ed. Gedenkstukken der algemeene geschiedenis wan Nederland wan 1795 tot 1840. Rijks Geschiedkundige Publicatiên gr.ser. I-VI, XI-XIII, XVI-XVII, XXIII, XXV, XXVII, XXX-XXXI, XXXVII, XL, XLII, XLIV, XLVI, L (10 din/22 bdn; "s-Gravenhage, 1905-1922).

Colenbrander, H.T., ed. Ontstaan der Gondwet. Bromnenverzameling. Rijks Geschiedkundige Publicatièn kl.ser. I, VII (2 dln; "s-Gravenhage, 1908-1909).

Colson, M., ed. De rapporten wan de kantonkornmissarissen $(1797-1800)$. Deel I Maaseik. Werken Limburgs Geschied- en Oudheidkundig Genootschap V (Maastricht, 1972).

Concordance des calendriers grégorien et rêpublicain, préface par Albert Soboul (Librairie Historique Clavreuil, 3e dr:: Parijs, 1983).

Coopmans, Jos P.A. "De afkondiging van wetten in historisch perspectief" in: F. Stevens \& D. van den Auweele, ed. "Houd voet bij stuk". Xenia iuris historiae G. van Dievoet oblata (Leuven. 1990) $431-453$.

Coppens, C. "Het tribunal civil du département de l'Escaut en de rechtspraak van eerste aanleg te Gent. Een bijdrage tot de studie van de burgerlijke rechtspraak in de periode 1796-1830". Belgisch Tijdschrift voor Nieuwste Geschiedenis/Revue Belge d"Histoire Contemporaine. XIV (1983) 1-51.

Costaldo, André. Less méthodes de travail de la Constituante: les techniques délibératives de l'Assemblèe nationale, 1789-179/ (Parijs, 1989).

Creifelds Rechtswörterhuch (10e dr., München, 1990).

Dapperen, Henric-Jan Michiel van. De vrederechter in Nederland 1811-1838. Mededelingen van het Juridisch Institutt van de Erasmus Universiteit Rotterdam. Serie proefschriften I (Rotterdam, 1991).

Dejong, A.A.M.N. "Zwanezang van het Maastrichtse goud- en zilversmedenambacht" in: Miscellanea Trajectensia. Bijdragen tot de geschiedenis vam Mastricht, uitgegeven bij gelegenheid van het 300 -jarig bestaan van de stadsbibliotheek van Maastricht $1662 * 31$ juli * 1962. Werken Limburgs Geschied-en Oudheidkundig Genootschap IV (Maastricht, 1962) 523-555.

Delecourt, Charles. "Bibliographie des collections de lois depuis 1789 jusqu"en 1814 ". Archives de droit et de législation, I (1837) 83-138. 
Desenne, J., ed. Code général français, contenant les lois et actes du gowvernement publiés depuis louverture des Elats Généraut au 5 mai 1789, jusqu' au 8 jullet 1815, classés par ordré de matières, et annotés des arrêts et dếcisions de la Coñ de Cassation; suin de deux tables gểnérales, l'une par ordre chronologique, et l'autre par ardre alphabétique de matiêres (22 din. Parijs, 1818-1825).

Devleeshouwer, Robert. L'arrondissement du Brabant sous l"occupation francaise 1794-1795. Aspects administratifs et économiques (Brussel, 1964).

Devleeshouwer, Robert. "Le cas de Belgique" in: Occupants Occupés 1792-1815. Colloque de Brumelles, 29 et 30 janvier 1968 (Brussel, 1969) 43-65.

Devleeshowwer, R. "L'abolition des droits feadaux en Belgique" in: L'abolition de la fëodalite dans le monde occidental. Toulouse 12-16 novembre 1968 (2 dilm; Parijs, 1971) 1, 205-219, II 627-641.

Devleeshouwer, R. "De Zuidelijke Nederlanden tijdens het Franse bewind 1794 - 1814" in: D.P. Blok e.a., ed. Algemene Geschiedenis der Nederlanden (15 din; Haarlem/Weesp, 1977-1983) XI, 187 200.

Dockx, Y. "La sécularisation de l"état civil à Bruxelles, 1796-1815" in: J. Craeybeckx \& F.G. Scheellings m.m.v. M. De Laet, ed. De Franse Revolutie en Vlaanderen. De Oostenrijkse Nederlanden tussen oud en nieuwlLa Révolution française et la Flandre. Les Pays-Bas awirichiens entre l'ancien et le nouveau régime. Handelingen van het colloquium gehouden op $1-2$ december 1988 te BrussellActes du colloque du l et 2 décembre 1988 a Bruxelles (Brussel, 1990) 231 -275.

Duguit, Lên \& Henry Monnier. Les constiturions et principales lois politiques de la France depuis 1789. Collationnées sur les textes officiels, précédées de notices historiques et suivies d'une table analytique détaillée, ouvrage continué par Roger Bonnard (5e dr.; Parijs, 1932).

Dubbink, C.W. "Lasten en bevelen". Nederlands Juristenblad, LXVII (1992) 164-167.

Dupont-Bouchat, Marie-Sylvie. "La pratique des tribunaux criminels issus de la Révolution en Belgique: continuites et ruptures (an IV - an VIII)" in: La Révolution et l"ordre juridique privé. Rationalité ou scandale? Actes du colloque d'Orléans $11-13$ septembre 1986 (2 din; Orléans, 1988) II, $509-526$.

Durand, Charles. "Les rapports entre la loi et le règlement gouvernemental de l'an IV à 1814" in: Charles Durand \& Albert Lanza, ed. Etudes sur les rapports entre la loi et le règlement gouvernemental au XIX siecle. Travaux et mémoires de la faculté de droit et de science politique d'AixMarseille XXVI (Aix-en-Provence/Marseille, 1976) 5-248.

Emmer, H. De Grenzen van Nederland van de Wielingen tot aan den Rijn (Haarlem, 1937).

Essmein, A. Eléments de droit constitutionnel français et comparé, revue par Henry Nézard (2 din; $8 \mathrm{e}$ dr.; Parijs, 1927-1928).

Fairon, E. "Inventaire analytique du fonds français aux Archives de l'Etat a Liège". Annuaire d'Histoire Liégeoise (Annuaire de la Commission Communale de l'Histoire de l"Ancien Pays de Liegel. III (1943-1947) 183-330.

Fenet, P.A., ed. Recueil complet des travaux préparatoires du Code civil, suivi d'uné édition de ce code, à laquelle sont ajoutés les lois, décrets et ordonnances formant le complément de la législation civalle de France, et où se trouvent indiqués, sous chaque article séparément, tous les passages du recueil qui s'y rattachent (15 dln; 1827/herdr. Osnabrück, 1968).

Fierro, Alfred. Bibliographie de la Révolution française 1940-1988 (2 dln; Parijs, 1989).

Fortunet, Françoise. "Le code rural ou l'impossible codification". Annales Historiques de la Révolution Francaise, LIV (1982) 95-1112.

Furet, François \& Denis Richet. La Révolution française (coll. Pluriel; Parijs, 1973).

Gachard, M.; Jules de la Court \& Paul Verhaegen, ed. Recueil des Ordonnances des Pays-Bas Autrichiens Hile ser (1700-1794) (14 din; Brussel, 1860-1942).

Garaud. Marcel. Histoire générale du droit prïvé français (de 1789 à 1804). La Révolution et l'ëgalité civile, avant-propos de Georges Lefebvre (Parijs, 1953).

Garaud, Marcel. Histoire générale du droit privé français (de 1789 à 1804). La Révolution et la propriété foncière (Parijs, 1958).

Garaud, Marcel \& Romuald Szramkiewicz. Histoire gênérale du droit privé français (de 1789 a 1804). La Révolution Française et la Famille, préface de Jean Carbonnier (Parijs, 1978). 
Gehlen, A.FI. "De invoering van het Franse notariaat in her departement wan de Nedermaas, "au son de trompe ou de nambour" (1795-1803)" in: A.H. Jenniskens e.a., ed. Campus Liber. Bundel opsnellen over de geschiedenis van Maastricht aangeboden aan mr.dr. H.H.E. Wouters, stadsarchivaris en -bibliothecaris 1947-1977, bij zijn zeventigste verjaardag. Werken Limburgs Geschied-en Oudheidkundig Genootschap VIII (Maastricht, 1982) 384-395.

Gehlen, A.Fl. "Het Maastrichtse Tribunal Supérieur (einde 1794 - begin 1796)" in: Bernadette C.M. van Hellenberg Hubar e.a., ed. Maaslands Melange. Opstellen over Limburgs verleden Dr. P.J.H. Whachs aangeboden bij gelegenheid wan zijn vijfenzestigste verjaardag. Werken Limburgs Geschied- en Oudheidkundig Genootschap XIV (Maastricht, 1990) 107-120.

Geschiedkundige allas wan Nederland ("s-Gravenhage, 1913-1934).

Gillet. M. Analyse chronologique des circulaires, instructions et décisions, émanées du ministère de

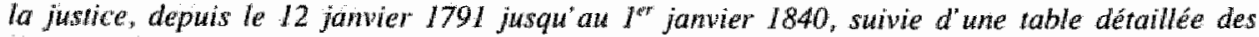
matieres (Parijs/Nancy, 1840).

Godding, Philippe. Le droit privế dans les Pays-Bas méridionaux da $12^{\circ}$ au $18^{\circ}$ siècle. Mémoires de la classe des lettres, collection in- $4^{\circ} 2^{\circ}$ série XIV (Brussel, 1987).

Godechot, Jacques. "Sens et importance de la transformation des institutions révolutionnaires a l'époque napoléonienne". Revue d" Histoire Moderne et Contemporaine, XVII (1970) 795-813.

Godechot, Jacques. Les constitutions de la France depuis 1789 (Parijs, 1979).

Godechot, Jacques. La Grande Nation. L'expansion révolutionnaire de la France dans le monde de 1789 à 1799 (2e herz.dr.; Parijs, 1983).

Godechot, Jacques. Les institutions de la France sous la Révolution et l"Empire (3e herz. en verm. dr.; $_{\text {; }}$ Parijs, 1985).

Godechot, Jacques. "Les influences étrangères sur le droit pénal de la Révolution française" in: La Révolution ef "ordre juridique privé Rationalité ou scandale? Actes du colloque d"Orlétans $11-13$ septembre 1986 ( 2 dln; Orléans, 1988) I, 47-53.

Goethem, Herman van. "La francisation révolutionnaire, résultat d'initiatives locales. Le cas des tribunaux en Flandre en Alsace" in: Roland Mortier \& Hervé Hasquin, ed. "Deux aspects contestés de la politique révolutionnaire en Belgique: langue et culte". Erudes sur le XVIIT siècle, XVI (1989) 39-52.

Gordon, Alexander. "Politieke en Gerechtelijke indeeling van het Hertogdom Limburg". 4 dln; s.I." s.a. (Handschriftencollectie nr.16 Rijksarchief in Limburg).

Gou, L. de, ed. Het Plan van Constitutie van 1796. Chronologische bewerking van het archief wan de eerste constitutiecommissie ingesteld bij decreet van de Nationale Vergadering van 15 maart 1796. Met een facsimile uitgave van her Plan van Constitutie. Rijks Geschiedkundige Publicatien kl.ser. XI. ("s-Gravenhage, 1975).

Gou, L. de, ed. Her Ontwerp van Constitutie van 1797. De behandeling wan het Plan van Constitutie in de Nationale Vergadering. Met een facsimile uitgave van het Ontwerp van Constitutie. Rijks Geschiedkundige Publicatiën kl.ser. LV, LVI, LVII (3 dIn; 's-Gravenhage, 1983-1985).

Graumann, Sabine. Franzësische Verwaltung am Niedermein. Das Roerdepartement 1798-1814. Düsseldorfer Schriften zur Neueren Landesgeschichte und zur Geschichte Nordrhein-Westfalens XXVII (Essen, 1990).

Grauwels, J. "De Code Rural in thet departement van de Nedermaas". Het Oude Land van Loon, XXXIV (1979) 127-155.

Grilli, Antonio. "Sprache und Recht in den französischen Rheinlanden. Die Einführung des Französischen als Gerichtssprache im Saardepartement 1798". Rheinische Vierteliahrsbläter, LVII (1993) 227-252.

Guyot, M. Réperwire universel et raisonné de jurisprudence crivile, criminelle, canonique et bénéficin ale. ourrage de plusieurs jurisconsultes, nouvelle édition corrigée, \& augmentée tant des loix nouvelles que des arrêts rendus en matiere importante pour les parlemens \& les autres cours du royaume, depuis l'édition prếcédente (2e dr.; $17 \mathrm{dln}$; Parijs, 1784-1785).

Haak, Jan. De discussie over de 'constitution civile du clergé' (1790). Opiniegeschiedenis van een confict (Groningen, 1964). 
Haas, J.A.K. De verdeling van de Landen van Overmans 1644 - 1662. Terwitoriale desintegrate wan een betwist grensebied diss. Nijmegen (Assen, 1978).

Haas, J.A.K. "Het verdrag van Fontainebleau 1785. Maastricht en de landen van Overmaas als internationale conflictstof aan het eind van het ancien régime". Publications de la Socúte Historique et Archeologique dans le Limbourg CXXIV (1988) 264-344.

Halperin, Jean-Louis. Le Tribunal de Cassation et les powoirs sous la Revolution (1790.1799). preface de Gérard Sautel. Bibliothèque d'Histoire du Droit et Droit romain XXIII (Parijs, 1987).

Halperim, Jean-Louis. "Les decrets d"annulation des jugements sous la Convention" in: La Révolution el frardre juridique privé. Rationalité on scandale?" Actes du colloque d"Orléans 11-13 septembre 1986 (2 din; Orléans, 1988) 1I, 457-468.

Hansotte, Georges. La principauté de Stavelot-Malmédy à la fin de l'ancien régime. Carte de la principauté en 1789. Dénombrement des maisons, des chevaux et des bestiaux vers 1750 (Brussel. 1973).

Hansotte, Georges. Les institutions politiques et judiciaires de la Principauté de Liège anx temps modernes. Crédit Communal Collection Histoire, série in $8^{\circ}, n^{8} 73$ (s.1., 1987).

Hansotte, Véronique. "Les prévenus de crimes et de délits à Liège sous le régime français". Revue Belge d'Histoire Contemporaine/Belgisch Tijdschrift woor Nieuwste Geschiedenis, XIV (1983) $115-176$.

Hardenberg, H. m.m.v. F. Nuyens. Inventaris der Archieven van het Arrondissement Maastrich en van het Departement wan de Nedermaas (1794-1814). Met een inleiding over de vorming van het grondgebied en de geschiedenis der bestuursinstellingen ('s-Gravenhage, 1946).

Hardenberg. H. Inventaris van de archieven der rechrscolleges, alleensprekende rechters en rechterlijke ambtenaren, wan 1794 tor 1841 gefungeerd hebbende op het grondgebied van de tegenwoordige Nederlandsche provincie Limburg ('s-Gravenhage, 1949).

Hasselt, van. Verzameling van Nederlandse staatsregelingen en grondwetten (17e dr.; Alphen aan den Rijn, 1987 ).

Haye, Régis de la. "De oudste actes van de burgerlijke stand wan Maastricht (1794-1796)". Limburgs Tijdschrift voor Genealogie, XII (1984) 25-30.

Haye. Régis de la. "De verschuivingen van de zuidgrens van Eijsden. Een historisch-cartografisch onderzoek". Uit Eijsdens Verleden, LI (1990) 14-18.

Hennebert, Arlette. "Les représentants en mission en Belgique après Thermidor". Annales Historiques de la Révolution Française, VIII (1931) 315-334.

Holthöfer, Emst. "Frankreich" in: Helmut Coing, ed. Handbuch der Quellen und Literatur der neweren europäischen Privarrechtsgeschichte III Das 19. Jahrhundert. Veröffentlichung des MaxPlanck-Instituts für europäische Rechtsgeschichte (5 dln; München, 1982-1988) III/1, 863-882.

Hommerich, L. van. "De invoering van de burgerlijke stand te Heerlen, Voerendaal en Nieuwenhagen". Her Land wan Herle, XIII (1963) 1-8.

Houtman, Erik. Documenten betreffende het departement wan de Nedermaas (1790-1815) in de "Archives Nationales" te Parijs. Miscellanea Archivistica VI (Brussel, 1974).

Hubert, Eugene \& Camille Tihon, ed. Correspondance de Bouteville (2 dln. Brussel, 1922. 1934).

Huussen jr, A.H. "Le droit du mariage au cours de la Révolution française". Tijdschrift woor" Rechtsgeschiedenis/Revue d' Histoire du Droit/The Legal History Review, XLVII (1979) 9-51 en 99-127.

Jacobs, L.C.J.H. "C.C. Roemers als agent mational wan thet arrondissement Maastricht (30 november 1794 - 26 september (795)". Publications de la Société Historique et Archéologique dans le Limbourg, CXXIX (1993) 195-230.

Janssens, P. "De Zuidnederllandse adel tijdens thet Ancien Régime (17e-18e eeuw). Problemen en stand van onderzoek". Tijdschrift voor Geschiedenis, XCII (1980) 445-465.

Joester, Ingrid. Veröffentlichungen der staatlichen Archive des Landes Nordrhein- Westfalen. Reihe A: Inventare sraatlicher Archive. Das Hauptstaatsarchiv Düsseldorf und seine Bestände. Band III: die Behörden der Zeit 1794-1815 Teil I: die linksrheinischen Gebiete (Siegburg, 1987).

Journal officiel du gouvernement de la Belgique. Ile serie.

Ketelaar, F.C.J. Oude zakelijke rechten, wroeger, nu en in de toekomst (Zwolle. 1978). 
Linzac de Laborie L. de. La domination frangaise en Belgique. Directoire - Consulat - Empire 1795 -1814 (2 dlm; Parijs, 1895).

Leffebvre. La France sous le Directoire 1795-1799. Avant-propos d"Albert Soboul, présentation de Jean-René Suratteau (nwe. ed.; Parijs, 1984).

Lepointe, G. Petil vocabulaire d' Histoure du droit français (nwe.ed.; Mayenne, 1948).

Liebs, Dettew mm.v. Hannes Lehman \& Gallus Strobel, ed. Lateinische Rechtsregeln und Rechissprichwörter (3e dr.; München, 1983).

Lokin, J.H.A. \& W.J. Zwalve. Hoofdstukken uit de Europese Codificatiegeschiedenis (2e dr.; Groningen, 1992).

Lovie, J. A. Palluel-Guillard. L'Episode napoléonien 2.Aspects extérieures 1799-1815. Nouvelle histoire de la France contemporaine $V$ (coll. Points/Histoire; 1972).

Martinage. Renée. "Les origines de la pénologie dans le code pénal de 1791" in: La Révolution et l'ordre juridique privé. Ravionalité on sciandale? Actes du calloque d"Orléans $11-13$ seprembre 1986 (2 din; Orleans, 1988) 1, 15-29.

Merlin, [Ph.-A.], ed. Répertoire universel et raisonné de jurisprudence, corrigée, réduite aux objets dont la connarsance peut encore être utile, et augmentée l" d' un grand nombre d'articles, $2^{\circ}$ de notes indicatives des changemens apportés aux lois anciennes par les lois nouvelles, $3^{\circ}$ de dissertations, de plaidoyers et de réquisitoires de l"editeur sur les unes et les autres $(17 \mathrm{dln} ; 4 \mathrm{e}$ dr.: Parijs/Brussel, 1812-1815).

Merlin, [Ph.-A.], ed. Recueil alphabétique des questions de droit qui sé présentemt le plus fréquemment dans les tribunaux; ouvrage dans lequel sont fondus et classés la plupart des plaidoyers et réquisitoires de l'auteur, avec le texte des arrêts de la Cour de Cassation qui s"en sont ensuivis (6 din; 3 e herz. en verm. dr.; Parijs, 1819-1820).

Mitchell, C.J. The French Legislative Assembly of 1791 (Leiden/NewYork/Kopenhagen/Keulen, 1988).

Molitor, Hansgeorg. Vom Untertan zum Administrê. Studien zur französischen Herrschaft und zum Verhalten der Bevölkerung im Rhein-Mosel-Raum won den Revolutionskriegen bis zum Ende der napoleonischen Zeit. Veröffentlichungen des Instituts für europäische Geschichte Mainz XCIX Abt. Universalgeschichte (Wiesbaden, 1980).

Moorman van Kappen, O. "125 jaar Limburgse rechtsgeschiedenis". Publications de la Société Historique et Archéologique dans le Limbourg, CXXV (1989) 100-125.

Mullens, Marc. "De kommissarissen van het kanton Millen tijdens het Directoire (1796 - 1800)". Het Oude Land van Loon, XIX (1964) 207-223.

Mullens, Marc. "Politieke strijd, partijvorming en Vlaams-Waalse wrijvingen in het kanton Millen tijjdens het Directoire (1796 - I800)". Het Oude Land wan Loon, XXIII ( 1968 ) 103-153.

Neve, P.L. Het Rijkskamergerecht en de Nederlanden. Competentie - territoir - archieven. Maaslandse Monografieèn XIV (Assen, 1972).

Nuyens, E.M.Th.W. De staatkundige geschiedenis der provincie Limburg vanaf haar ontstaan tot aan haar aiteewvallen in 1839 (met atlas). Werken Limburgs Geschied- en Oudheidkundig Genootschap II (Maastricht, 1956).

Nuyens, E.M.Th.W. Historische Atlas van Limburg en aangrenzende gebieden I Serie staatkundige kaarten: de tegenwoordige provincies Limburg en omliggende gebieden in de Franse tijd (1802) (Assen/Amsterdam, 1977).

Opzoomer, C.W. Aantekesing op de wet houdende algemene bepalingen der wetgeving nan het koninkrijk (4e dr:; "s-Gravenhage, 1884).

Ozouf, Mona. La fête révolutionnaire 1789.1799 (Folio/Histoire; s.1., 1976).

Parry "Clive, ed. The Consolidated Treaty Series (231 din; Dobbs Ferry, New York, 1969-1989).

Peeters, Henri. Het kanton Bree tijdens de Franse revolutie ([Bree], 1985).

Pirenne, H. Histoire de Belgique (7 din; Brussel, 1902-1932).

Pot, C.W. van der. Hardhoek van het Nederlandse staatsrecht (6e dr.; Zwolle, 1957), bewerkt door A.M. Donner (10e dr.; Zwolle, 1977).

Poullet, Prosper. Les Institutions Frrangaises de 1795 à 1814. Essai sur les origines des Institutions Belges contemporaines (Brussel, 1907). 
Recueil des discours sur la reunion de la Belgique à la France, imprime par ordre de la Convention nationale (Parijs, an V).

Recueil de Lois et Reglemens pour les neuf Departemens rênis par la Loi dw 9 Vendémiaire, an $W$, en exécution de l'Arrêté du Directoire exéutif du 7 Pluviose, an V (2 din; Parijs, ventôse an V).

Recwell des proclamations, arrêtés, etc. émanés des représentants du peuple et de ladpuinishation centrale et supérieure de la Belgique [voortgezet als] Recuehl ales lois françises, publies dans les départements réunis par la Loi du 9 Vendémiaire de l"an 4, et de divers Arrêtés des Aurorités consritules: pour servir de suite an Recueil des Anettês, erc. (25 din; Brussel, an II-1806).

Recueil général des lois et des arrêtés avec notes et commentaires, présentant sur chaqué question le résumé de la jurisprudence et la doctrine des auteurs, rédigé sur lancien revuél général des lois et des ariêts fondés par $M$. Sirey, revu et complété par L.M. Devilleneuve \& A.A. Carette (10 din; Parijs, 1840-1843).

Répertoire ou Mémorial chronologique des Lois, Proclamarions et Arrêtés publiées dans le département de la Meuse-inférieure, à dater du 9 Vendémiaire, jour de la ré́union a la République française, jusqu' au 29 frimaire an 5 (s.l. [Brussel], an V).

Rogier, L.J. m.m.v. M.G. Spiertz "Limburg in de Franse tijd" in: E.C.M.A. Batta e.a., ed. Limburg's Verleden. Geschiedenis van Nederlands Limburg tot 1815 (2 din; Maastricht, 1960, 1967) II, 668703.

Rondonneau, L., ed. Collection génêrale des lois, décrets, arrêtés, sénatus-conisultes, avis du Conseil d'Etat et réglemens d'administration, publiés depuis 1789 jusqu'au ler avril 1814, et insérés dans la collection du Louwe in $4^{\circ}$, dans la collecrion in $8^{\text {a }}$ de l'Imprimerie nationale, et dans les quatre premieres séries du Bulletin des lois (16 din; Parijs, 1817-1820).

Roppe, L.; G.W.A. Panhuysen \& Elis.M. Nuyens, ed. De decadaire, resp. maandelijkse rapporten van de commissarissen van her Directoire executif in het departement van de Nedermaas 1797. 1800. Werken Limburgs Geschied-en Oudheidkundig Genootschap I (Maastricht, 1956).

Rousseau, X. "Les tribunaux criminels en Brabant sous le Directoire (1795-1800). Acculturation et resistance à la justice républicaine" in: J. Craeybeckx \& F.G. Scheelings m.m.v. M. De Laet, ed. De Franse Revalutie en Vlaanderen. De Oostenrijkse Nederlanden russen oud en nieuw régimelLa Révolution française et la Flandre. Les Pays-Bas autrichiens entre l'ancievt et le nowveau régime. Handelingen van het colloquium gehouden op 1-2 december 1988 te BrussellActes du colloque du 1 et 2 décembre 1988 a Bruxelles (Brussel "1990) 277-306.

Ruwet, Joseph. La principauté de Liege en 1789. Carte de géographie historique. (Brussel, 1958).

Sabron, F.H.A. De oorlog van 1794-95 op het grondgebied van de Republiek der Vereenigde Nederlanden ( 2 din; Breda, 1892-1893).

Sagnac, Ph. La légisiation civile de la Révolution française (1789-1804). Essai d'histoire sociale (Parijs, 1898).

Savey-Casard, Paul. "La mise hors la loi à l'époque révolutionnaire". Revue Historique de Droif franģais et étranger, XLVIII (1970) 408-429.

Schuind, Gaston. Stavelot-Malmédy. Une principauté ecclésiastique de l'ancien régime. (Stavelot, 1914/herdr. Brussel, 1982).

Seelen, Th. "De verdeling van Opper-Gelre bij de Vrede van Utrecht". Spiegel der Historie. Maandblad voor de geschiedenis der Nederlanden III (1968) $310-313$.

Sirey. J.B., ed. Recueil général des lais et des arréts, en matière civile, criminelle, commerciale et de droit public depuis l'avenement de Napoleon (12 din; Parijs, s.a).

Soboull. La Révolution franşaise. Nouvelle édition revue et augmentée du précis d"Histoire de la Révolution française, avec un avant-propos de Claude Mazauric et une bibliographie de l'oeuvre d'Albert Soboul par Françoise Brunel (Parijs, 1982).

Soboul, Albert. Dictionnaire historique de la Révolution française, publié sous la direction scientifique de Jean-Rene Suratteau \& François Gendron (Parijs, 1989).

Solé, Jacques. La Révolution en questions (coll. Points/Histoire: 1988).

Spiertz, M.G. Maastricht in het vierde kwart wan de achttiende eeww. Kerkelijke politieke en sociale verhoudingen 1775-1801. Maaslandse Monografieën I (Assen, 1964). 
Stevens, Frederic. "LL"introduction đẹ la législation révolutionnaire en Belgique" in: La Révolution es l'ordre juridique privé: rationalité ou scandale? Actes du Colloque d'Orléans $11-13$ septembre 1986 (2 din; Orléans, 1988) II, 485-493.

Stevens, Fred. "De Franse wetgeving over het notarisambt en het Antwerpse notariaal van 1794 tot 1814. Een institutionele on $\mathrm{kwantitatieve} \mathrm{studie".} \mathrm{Niet} \mathrm{uitgegeven} \mathrm{proefschrift} \mathrm{Katholieke} \mathrm{Universi-}$ teit Leuven, Faculteit der Rechtsgeleendheid ( 3 dlln; 1988).

Suite (Première, Deuxiène, Troisieme) au Répertoire ou Mémorial Chronologique des Lois, Proclamations et Arrêtés publiées dans le déparcement de la Meuse-Inférieure, ... (Maastricht, s.a.).

Sutherland, D.M.G. France 1789-1815. Revolution and Counterrevolution. Fontana History of Modern France ( 3 e dr.; Londen, 1989).

Tagage, br. Sigismund. "Rond de opheffing wan het kapittel van Sint Servaas en de verkoop van zijn goederen" in: Miscellanea Trajectensia. Bijdragen tot de geschiedenis van Maastricht, uitgegeven bij gelegenheid van het 300-jarig bestaan wan de stadsbibliothe ak van Maastricht $1662 * 31$ juli * 1962. Werken Limburgs Geschied-en Oudheidkundig Genootschap IV (Maastricht, 1962) 496522.

Tagage, S." "Vrijheid, Gelijkheid en Broederschap" in het kanton Venlo, 1794 - 1800". Publications de la Sociêté Historique ef Archéologique dans le Limbourg, CX (1974) 7-226.

Tagage, Sigismund. "De laatste jaren wan het Onze-Lieve-Vrouwe-Kapittel" in: A.H. Jenniskens e.an, ed. Campus Liber. Bundel opstellen over de geschiedenis van Maastricht aangeboden aan mr.dr. H.H.E. Wouters, stadsarchivaris en -bibliothecaris 1947-1977, bij zijn zeventigste verjaardas. Werken Limburgs Geschied- en Oudheidkundig Genootschap VIII (Maastricht, 1982) 354-369.

Tassier, Suzanne. Histoire de la Belgique sous l"occupation française en 1792 et 1793. (Brussell, 1934).

Thiellemans, M.-R. "Deux institutions centrales sous le régime français en Belgique. L"administration centrale et superieure de la Belgique et le conseil de gouwemement". Revue Belge de Philologie et d'Histoire/Belgisch Tijdschrift woor Filologie en Geschiedenis "XLI (1963) 1091-1135, XLLII (1964) 399-441, XLLIII (1965) 1272-1323, XLIV (1966) 500-560.

Trénard, Louis. "Survivances féodales et régime seigneurial dans les provinces septentrionales de la France au XVII" siècle" in: L"abolition de la féodalité dans le monde occidental. Toulouse 12-16 novembre 1968 (2 din; Parijs, 1968) I. 181-203, II, 589-605.

Tulard, Jean; Jean François Fayard \& Alfred Fierro. Histoire et dictionnaire de la Révolution française 1789.1799 (2e herdr.; Parijs, 1988).

Ubachs, P.J.H. "De werkoop der nationale goederen in de historiografie". Publications de la Société Historique et Archéologique dans le Limbourg, CXXIII (1987) 185-199.

Ubachs, P.J.H. "Een Franse uithoek: Limburg 1794-1814". Bijdragen en Mededelingen betreffende de Geschiedenis der Nederlanden, CIV (1989) 654-664.

Vandebeeck, Th. \& J. Grauwels. De Boerenkrigg in het departement van de Nedermaas, met een voorwoord van Dr. L. Roppe gouverneur van Limburg en Prof.Dr. L. Rogier. Werken Limburgs Geschied- en Oudheidkundig Genootschap III (Maastricht, 1961).

"Variétés et nécrologie. III Alexander Gordon, president der rechtbank te Maastricht". Publications de la Société Historique et archéologique dams le Limbourg, XXIII (1886) 447-453.

Veldstra, J. "De wijze van afkondiging van wetten". Nederlands Juristemblad, XXXIII (1958) 225232.

Veldstra, J. "Het in werking treden der wetten". Nederlands Juristenblad, XXXIII (1958) $817-824$

Venner, G.H.A. De Meinweg. Onderzoek naar rechten op gemene gronden in het voormalige Gelders - Gulikse grensgebied circa 1400 - 1822. Maaslandse Monografieën XL (Assen/Maastricht, 1985).

Verhaegen, Paul. La Belgique sous la domination française $1792-1814$ (5 dln; Brussel/Parijs, $1922-$ 1929).

Vermandere, Daniël. "De Veldwachters in het Leie Departement (1795-1809)". Standen en Landen Anciens Pays et Assemblées d'Etats, XLIV (1968) 145-174.

Viard, Pierre-Paul. Histoire génêrale du droit privé français (1789-1830) (Parijs, 1931).

Viard, Pierre-Paul. "L oeuvre juridique de la Convention". Annales Historiques de la Révolution Française, VII (1930) 525-548. 
Vocabulaire juridique, publie sous la direction de Gérard Comu (2e herz en vern. dr.; Parijs, 1990). Vowelle, Michel. La chute de la monarchie 1787-1792. Nouvelle Histoire de la France contemporaine I. (coll. Points/Histoire; 1972).

Vreede, G.W. Geschiedenis der diplomatie van de Bataafsche Republiek (3 din, Utrecht, 1863-1865).

Wehrhahn, Herbert. "Die Verkündung und das Inkraftreten der Gesetze in Frankreich 1789 und danach" in: Theodor Eschenburg. Theodor Heuss Georg-August Zinn m.m.v. Willhelm Hennis, ed. Fesigabe für Carlo Schmid zum 65. Geburtstag, dargebracht von Freunden. Schülern und Kollegen (Tübingen, 1962) 213-297.

Wethoek Napoleon, ingerigt voor het Koningrijk Halland (s.l., 1809).

Wetzler, Peter. War and Subsistence. The Sambre and Meuse Army in I794. American Uniwersity Situdies Series IX History IX (New York/Bern/Frankfurt am Main, 1985).

Wijdeveld, N.I.K.E. m.m.v. M. van Hattum \& R. van Answaarden. Glossarium wan oude Franse rechtstermen. Verzamelen en bewerken van de jurisprudentie van de Grote Raad nwe. reeks VII (Amsterdam, 1983).

Wit, J.J. de \& A.J.A. Flament. "De vorming der heerschappijen op het grondgebied in Limburg of die zich daarover hebben uitgestrekt, van de Romeinsche overheersching tot 1814-1817 (ontstaan der prov. Limburg)". Publications de la Sociêté Historique et Arichéologique dans le Limbourg. XLVII (1911) 1-259.

Woordenboek der Nederlandsche Taal (25 din en suppl - ...; 's-Gravenhage/Leiden, 1882- 1990 - ...).

Woronoff, Denis. La République bougeoise de Thermidor à Brumaire 1794-1799. Nouwelle Histoire de la France contemporaine III (coll. Points/Hïstoire; 1972). 



\section{L'introduction de la législation dans le département français de la Meuse-Inférieure pendant le premier Directoire}

La législation promulguée du $1^{\text {et }}$ octobre 1795 au 19 mars 1797 : introduction et analyses

Cet ouvrage présente les résultats d'une recherche sur la promulgation de la législation dans le département de la Meuse-Inférieure, l'un des territoires occupés par les armées révolutionnaires françaises à partir de l'automne 1794 . Le $1^{\text {er }}$ octobre 1795 , les territoires occupés furent annexés officiellement par la France, et divisés en départements. L'étude se compose de deux parties. La plus grande est constituée par les analyses des lois et décrets promulgués. Une introduction, divisée en trois chapitres, développe certains aspects du département de la Meuse-Inférieure et de la législation qui y fut promulguée. La législation décrite dans les analyses couvre la période de promulgation allant de l'annexion officielle du $1^{\text {er }}$ octobre 1795 a l'entrée en vigueur, le 19 mars 1797, du Code Merlin, une collection de lois en deux tomes contenant la législation ancienne, à majorité révolutionnaire, introduite après-coup.

Le chapitre $\mathbb{I}^{\text {er }}$ analyse la circonscription du département. La Convention nationale décida, par la loi sur la réunion de la Belgique et du pays de Liège à la République française du 9 Vendémiaire an IV ( ${ }^{\mathrm{er}}$ octobre 1795), l'annexion à la France d'une partie des territoires occupés. Dès la fin de 1794, ceux-ci avaient été divisés en arrondissements qui ressortissaient à deux Administrations Centrales, à Bruxelles et à Aixla-Chapelle. L'arrondissement de Maastricht faisait partie de celle d'Aix-la-Chapelle. La nouvelle division administrative rendue nécessaire par l'annexion à la France, prévoyait la formation de neuf départements, appelés habituellement départements réunis. L'un de ces départements réunis était celui de la Meuse-Inférieure, dont le chef-lieu était Maastricht. Le territoire de ce département couvrait grosso modo les provinces du Limbourg belge et du Limbourg néerlandais, exception faite de la partie au nord de Venlo.

La formation par les Français du département de la Meuse-Inférieure mit fin au morcellement politique des deux côtés de la Meuse. Avant la venue des Français, ces pays mosans étaient partagés en une multitude de territoires plus ou moins grands et plus ou moins indépendants. Les grands territoires étaient la principauté de Liège, les Pays-Bas autrichiens et les Pays de la Généralité (les territoires administrés par les Etats-Généraux de la République des Provinces Unies). Çà et là, la région étail parsemée de territoires moins importants, qui jouissaient de divers degrés de souveraineté (comtés, seigneuries, etc.). Pendant la période du Directoire, le département de la Meuse-Inférieure était divisé administrativement en trente-et-un cantons. 
Malgré des informations circulant au début de cette période sur une possible suppression du cépartement de la Meuse-Inférieure, celui-ci a fonctionné jusqu'à la fin du régime français en 1814 . 11 y eut seulement quelques corrections de frontières avec les départements limitrophes de la Roer et de l'Ourthe. Sous le Directoire, celles-ci donnèrent lieu à des frictions avec le département de l'Ourthe. Les problèmes concernaient notamment les villages d'Anze-sur-Geer et de Paifve, situés tous les deux au sud-ouest de Maastricht. Les corrections de frontières pouvaient avoir des consếquences pour l'application de la législation.

Parce qu'il avait été tenu compte dans une large mesure des anciennes limites, le territoire du département de la Meuse-Inférieure ne formait pas un ensemble géographique uni. Quatre enclaves étaient situés hors du territoire proprement dit : Rurdorf et Welz, situé en moyenne Roer ; la petite ville de Nieuwstadt ; Venlo, chef-lieu de canton; et Luyksgestel. En vertu du traité de 1807 entre la France et le royaume de Hollande, la partie septentrionale de la dernière enclave fut échangée avec le territoire hollandais de Lommel.

Le Traité de Lunéville mit fỉn à la deuxième guerre de coalition entre la France napoléonienne et ses rivaux européens. L'Empire Germanique céda ses possessions sur la rive gauche du Rhin. Les seigneurs des territoires cédés à la France eurent droit à une indemnisation, qui fut réglée par le Reichsdeputationshauptschluß en 1803. Dès avant l'annexion, par le Traité de La Haye du 16 mai 1795, la République des Provinces-Unies avait cédé à la France ses territoires dans la vallée de la Meuse.

Le chapitre II traite du problème de la promulgation. Le premier paragraphe de ce chapitre se concentre sur le concept dogmatique de la promulgation. Contrairement à ce qui se pratique en France encore maintenant, la distinction entre promulgation et publication est considérée aujourd'hui comme obsolète. En France, la promulgation est l'acte juridique du pouvoir exécutif, de déclarer exécutoire une loi régulièrement adoptée par le Corps législatif. L'article premier du titre préliminaire du Code civil, toujours en vigueur, accorde le droit de promulgation au chef de l'état. La France révolutionnaire ne s'occupait guère de l'exacte définition des termes. La terminologie dans le domaine de la publication des lois et décrets n'était pas fixée : des termes comme "promulgation", "publier" et "rendre obligatoire" étaient confondus et utilisés indifféremment.

La publication des lois et arrêtés, analysés dans la liste, a eu lieu sous l'effet de la Constitution de l'an III. La compétence de la publication des lois, selon cette Constitution, était du ressort du Directoire exécutif. Antérieurement à l'installation du Directoire sous sa forme collégiale, la publication des lois dans les territoires occupés incombait aux représentants du peuple, venus avec les armées d'occupation. Dans les derniers jours de la Convention nationale, certains d'entre eux furent nommés commissaires du gouvernement. Après sa création, le Directoire exécutif nomma Bouteville comme leur successeur. Comme commissaire du gouvernement dans les départements réunis, il était chargé de faire démarrer l'organisation et l'administration des départements nouvellement créés.

Dans le département de la Meuse-Inférieure, la publication des lois et arrêtés s'est déroulée en trois périodes. Jusqu'au jour de l'enregistrement formel dans le département de la Meuse-Inférieure, le 2 décembre 1795, de la très importante loi du 1.2 
vendémiaire an IV (4 octobre 1795) sur la publication et l'entrée en vigueur des loỉs promulguées, les procédés de publication des lois par lecture publique, impression et affichage, qui existaient auparavant, restèrent en vigueur. Lorsque la loi du 12 vendémiaire an IV devint exécutoire, la législation entra en vigueur immédiatement sur toute l'étendue du département, dès la réception au chef-lieu et l'enregistrement dans un répertoire. Ce procédé de rendre exécutoire les lois s"appliqua jusqu'à l'entrée en vigueur de l'article $1^{\text {er }}$ du titre préliminaire du Cade civil le 26 mars 1803 . Pour le dêpartement de la Meuse-Inférieure, à partir de ce moment-là, un délai de cinq jours après la promulgation des lois par Napoléon, devint nécessaire pour l'entrée en vigueur des lois. Ce procédé ne concernait que les lois au sens formel. D'autres règlements gouvernementaux, comme par exemple les décrets impériaux, restaient sous l'effet de la loi du 12 vendémiaire an IV.

En raison de l'important décalage avec la législation déjà introduite en France, le Directoire exécutif décida à titre provisoire de ne pas introduire immédiatement la législation dans les départements réunis, mais de procéder à une publication spéciale. Cet arrêté du 18 pluviôse an IV (7 février 1796) fut révoqué au bout d'une dizaine de mois par l'arrêté du 16 frimaire an V (6 décembre 1796), qui prévoyait que désormais toute législation - à quelques exceptions près - publiée dans le Bulletin des Lois de la deuxième série serait immédiatement exécutoire, dès l'enregistrement de sa réception au chef-lieu du département. En même temps, il était décidé de faire constituer par le Ministère de la Justice une collection des anciens lois et décrets encore applicables, le dit Code Merlin.

Mais les habitants restaient malgré tout dans l'incertitude quant au moment précis où la législation devenait exécutoire. Des procédures furent menées jusqu'aux plus hautes instances. Le doute ne fut même pas levé par le Ministère de la Justice à Paris: en 1799 , le ministre de la Justice, Lambrechts, renvoyant à l'arrêté du 18 pluviôse an IV, constata formellement que dans les neuf départements réunis, les Bulletins des Lois de la deuxième série jusqu'au numéro 95 n'étaient pas devenus obligatoires.

Le chapitre III décrit la législation promulguée dans les départements réunis en général et dans le département de la Meuse-Inférieure en particulier, durant la période d'un an et demi à partir de l'annexion du $1^{\text {er }}$ octobre 1795 jusqu'à l'entrée en vigueur du Code Merlin le 19 mars 1797 . Il fut véritablement question d'un déluge législatif: plus de onze cents lois et arrêtés furent déclarés exécutoires dans le département par les autorités compétentes, dont 582 ont été analysés dans la liste. En outre, le Code Merlin donne encore 424 lois et décrets, in extenso ou partiellement. Dans la période située entre l'arrêté du Directoire du 16 frimaire an V (6 décembre 1796) et l'enregistrement du Code Merlin plus de cent lois et arrêtés, imprimếs dans le Bulletin des Lois, ont été inscrits dans le répertoire départemental. En raison de la très grande quantité de lois et arrêtés, il $\mathrm{n}^{\prime}$ a été possible de développer que les grandes lignes des plus importants corpus.

Deux des plus importants corpus publiés donnaient la législation dans le domaine des administrations centrales et décentralisées, ainsi que la législation concernant le pouvoir judiciaire et son organisation. La Constitution de l'an III avait institué un Corps législatif, composé de deux chambres, le Conseil des Cinq-Cents et le Conseil des Anciens. Le pouvoir exécutif appartenait au Directoire exécutiff, composé de cinq 
membres. Les départements étaient les administrations intermédiaires par excellence. Dans la France fortement centralisée, ils fonctionnaient comme des pivots entre Paris et tous les coins du pays. Au niveau cantonal, les municipalités étaient composées d'agents municipaux des différentes communes. Un commissaire du pouvoir exécutif, en tant que représentant de l'état, avait comme mission de contrôler les administrations décentralisées. Au niveau du pouvoir judiciaire et de son organisation, la Constitution de 1'an III distinguait la justice civile et pénale, la dernière étant divisée en une justice correctionnelle et une justice criminelle. Les assemblées révolutionnaires françaises attendaient beaucoup de l'échelon judiciaire le plus bas : les justices de paix. Comme chez toutes les administrations décentralisées, un commissaire du pouvoir exécutif était en fonction auprès des tribunaux.

La législation qui, dans la France révolutionnaire, avait conduit au démantèlement des structures sociales de l'Ancien Régime, fut imposée également aux départements réunis. Il s'en suivit une intervention dans les droits de possession et de propriété, du moins en ce qui concerne la structure externe. Le démantèlement de la sociétế féodale signifiait la perte de la position privilégiée du premier état, le clergé. Certaines parties de la législation française, dans ce domaine, furent donc publiées. Ainsi, dans les départements réunis, l'église fut entravée. Les idées révolutionnaires sur l'égalitê pour tous amenaient en réalité de nouvelles inégalités. Ceux qui se déclaraient opposés au nouvel ordre social français, ou ceux qui appartenaient auparavant aux nantis, subissaient désormais les rigueurs de la loi.

La législation publiée dans le département de la Meuse-Inférieure touchait à tous les domaines possibles et imaginables, depuis l'introduction du mariage civil et la possibilité de divorcer, jusqu'aux fêtes révolutionnaires et aux impôts. Beaucoup de lois promulguées se rapportaient à la gestion et la vente de biens appartenant aux domaines nationaux. Ces biens provenaient des institutions dont les propriétés étaient séquestrées par l'état (la noblesse, l'église, les émigrés). Mais l'observateur actuel du droit intermédiaire français de cette époque est surtout frappé par le haut degré de contrôle. L'état essayait de surveiller attentivement les faits et gestes de ses administrés.

La liste des analyses donne, en général, les lois et arrêtés publiés dans le répertoire du département de la Meuse-Inférieure dans la période allant de l'annexion à la France, le $1^{\text {er }}$ octobre 1795, jusqu'à l'enregistrement du Code Merlin le 19 mars 1797. Les séries des arrêtés des représentants du peuple en mission, du temps de l'arrondissement de Maastricht, n'ont pas été retenues, tout comme la législation imprimée dans le Bulletin des Lois depuis l'enregistrement de l'arrêté du 16 frimaire an V (6 décembre 1796). La liste comporte la législation (lois, arrêtés, proclamations) ou des parties de la législation promulguée depuis aont 1789 jusqu'à la fin du mois de février 1797. Chaque analyse est composée selon un schéma. En haut à gauche est portée la date de l'émission. Les dates d'approbation par l'Assemblée et la sanction royale, qui était encore exigée, sont séparées par un astérisque *. Sous la date de l'émission se trouvent les références des sources des lois et arrêtés publiés. Il est à conseiller de consulter également les registres comportant la copie littérale d'une loi etc., puisqu'il arrive qu'un texte législatif ait été adapté aux circonstances du temps. L'intitulé de chaque loi est maintenu en français. L'analyse proprement dite est un court résumé du conte- 
nu d'une loi, dont la fonction est de donner une orientation rapide. Les autres renseignements fournis dans l'analyse sont un ensemble de données venant de diverses sources : l'administration compétente, avec des signatures éventuelles, l'organe consultatif, l'instance expéditrice et le renvoi vers d'autres lois et décrets, mais uniquement sur la partie publiée. Bien entendu, l'analyse donne la référence du répertoire départemental ("registre ouvert", RO), avec la date de l'enregistrement dans le département de la Meuse-Inférieure, date à laquelle une loi devenait exécutoire dans l'ensemble du département. Dans le cas où la date d'expédition d'une loi aux cantons est mentionnée dans le "registre d'envoi" (RE), celle-ci est également indiquée. A la fin de chaque analyse se trouve la mention de l'organe qui donna l'ordre de publication d'une loi, avec la date.

Traduction : Régis de la Haye 


\section{Die Einführung der Gesetzgebung in das französische Niedermaasdepartement während des ersten Directoires} Einführung und Regesten der verkündeten Rechtsvorschriften vom 1. Oktober 1795 bis zum 19. März 1797

Diese Abhandlung befaßt sich mit den Gesetzen, die im Niedermaasdepartement verkündet wurden, also in einem jener Gebiete, die im Herbst 1794 von den französischen Revolutionsarmeen besetzt worden waren. Am 1. Oktober 1795 wurden die besetzten Gebiete formell von Frankreich annektiert und zu französischen Departements umgebildet. Dieses Buch enthält zwei Bestandteile. Der Hauptteil wird von den Regesten der verkündeten Gesetzgebung dargestellt. Drei einführende Kapitel beleuchten vorher einige Aspekte des Niedermaasdepartements und der in diesem Raum verkündeten Gesetze. Die unter den Regesten aufgenommenen Gesetze nehmen Bezug auf den Zeitraum von der formellen Angliederung an 1. Oktober 1795 bis zum in Kraft treten des sogenannten Code Merlin, einer zweibändigen Gesetzessammlung der nachträglich eingeführten älteren, hauptsächlich revolutionären Gesetzgebung.

Das erste Kapitel behandelt den Umriß des Departements. Die Convention nationale verordnete durch die loi sur la réunion de la Belgique et du pays de Liège à la République francaise vom 9. Vendémiaire IV (1. Oktober 1795) die Einverleibung von Teilen der besetzten Gebiete zu Frankreich. Schon Ende 1794 waren diese in Arrondissements eingeteilt und den Zentralverwaltungen zu Brüssel und Aachen unterstellt worden. Das Arrondissement Maastricht gehörte zu dem Aachener Verwaltungsbezirk. Die neue verwaltungsmäßige Zuordnung, die aus der Angliederung hervorging, beinhaltete die Gründung von neun Departements, üblicherweise die départements réunis genannt. Eines dieser Departements war das Niedermaasdepartement, das Maastricht als Hauptort hatte und das Gebiet der heutigen belgischen und niederländischen Provinzen Limburg, abgesehen von Limburg nördlich von Venlo, umfaßte.

Das von den Franzosen gegründete Niedermaasdepartement beendete die große territoriale Zersplitterung, die auf beiden Seiten der Maas vorherrschte. Vor dem französischen Einmarsch kannte das Land am Maas mehrere gröBere und auch kleinere (halb)souveräne Territorialstaaten. Größere Territorien bildeten das Stift Lüttich, die österreichischen Niederlanden und die sogenannten Generalitätsländer, die von den Generalstaaten der Republik der Vereinigten Niederlanden verwaltet wurden. Dazwischen lagen kleinere Territorialstaaten (Grafschaften, Herrschaften usw.). Das Niedermaasdepartement wurde während der Epoche des Directoires in 31 Kantone unterteilt.

Obwohl es zu Anfang Gerüchte gab, wonach das Niedermaasdepartement wieder aufgelöst werden solle, existierte dieses Departement bis zu dem Zusammenbruch der 
französischen Gewalt im Jahre 1814. Mit dem benachbarten Rurdepartement und dem Ourthedepartement wurden Grenzberichtigungen vorgenommen. Während des Directoires führte das zu Spannungen mil dem Ourthedepartement, und zwar in Bezug auf die Zugehörigkeit der sữdwestlich von Maastricht gelegenen Dörfer Anze-sur-Geer und Paifve. Die Grenzkorrekturen konnten die Geltung der Gesetze beeinflussen.

Dier Bezirk des Niedermaasdepartements bildete kein geschlossenes Territorium, weil man doch oft die alten Grenzen berücksichtigt hatte. Deshalb existierten noch vier Exklaven weiter, und zwar Rurdorf und Welz an der Rur, Nieuwstadt, Venlo, Hauptort des gleichnamigen Kantons, und Luyksgestel. 1807 wurde durch einen Vertrag zwischen Frankreich und dem Königreich Holland der nördliche Teil dieser letzteren Exklave gegen das holländische Lommel getauscht.

Der Vertrag von Lunéville aus dem Jahre 1801 beendete den zweiten Koalitionskrieg zwischen dem napoleonischen Frankreich und seinen europäischen Rivalen. Das Deutsche Reich verzichtete auf seinen Besitz am linken Rheinufer. Die Fürsten dieser an Frankreich verlorenen Territorien wurden 1803 mittels des Reichsdeputationshauptschlusses entschädigt. Schon vor der Angliederung hatte die Republik der Vereinigten Niederlanden durch den Haager Vertrag vom 16. Mai 1795 ihre Gebiete im Maastal abgetreten.

Im zweiten Kapitel wird die Problematik der Verkündung erörtert. Zuerst wird auf den dogmatischen Begriff der Promulgation eingegangen. Abgesehen von Frankreich wird heute der Unterschied zwischen Promulgation (oder Erlassung) und Publikation (oder Bekanntmachung) für veraltet angesehen. In Frankreich ist die Promulgation der Rechtsakt des Hauptes der Exekutivgewalt, in dem dieser ein auf regulärer Weise von der Legislative angenommenes Gesetz für vollstreckbar erklärt. Der erste Satz des titre préliminaire des noch immer geltenden Code civil betraut das Staatsoberhaupt mit der Promulgation. Im revolutionären Frankreich kümmerte man sich jedoch kaum um die genaue Wortwahl. Die Terminologie zur Verkündung von Rechtsvorschriften war schwankend. Begriffe wie "promulgation", "publier" und "rendre obligatoire" wurden durch und neben einander verwendet.

Die Verkündung der Rechtsvorschriften, die in den Regesten verzeichnet worden sind, erfolgte unter der Geltung der Konstitution des Jahres III. Die Zuständigkeit zur Verkündung der Gesetzgebung war durch die Verfassung dem Directoire anvertraut worden. Bevor aber das Directoire als Kollegium eingesetzt worden war, wurde die Verkündung der Gesetzgebung in den einverleibten Gebieten von den Volksvertretern, die mit der Besatzungsarmee mitgereist waren, betreut. In der Spätphase der Convention nationale wurden einige von ihnen noch zu Verwaltungskommissaren ernannt. Nach der Einsetzung des Directoires ernannte dieses dann Bouteville zu ihrem Nachfolger. Als Verwaltungskommissar der départements réunis sollte er die Einrichtung und Aufgaben der neugeschaffenen Departerments konkretisieren.

In Hinsicht auf die Verkündung der Rechtsvorschriften im Niedermaasdepartement kann man drei Zeitabschnitte unterscheiden. Bis zur formellen Eintragung des höchstwichtigen Gesetzes vom 12. Vendémiaire IV (4. Oktober 1795) bezüglich der Verkündung und des Inkrafttretens der erlassenen Gesetzgebung am 2. Dezember $1795 \mathrm{im}$ Niedermaasdepartement blieb die bis daher gepflogene Weise der Verkündung durch öffentliche Verlesung, Nachdruck und Anschlag formell in Kraft. Als das Gesetz vom 
12. Vendêmiaire verbindlich wurde, trat die Gesetzgebung im ganzen Departement in Kraft, sobald die Entgegennahme des Gesetzes im Hauptort des Departements in ein Register eingetragen worden war. Diese Art des Inkrafttretens der Rechtsvorschriften wurde beibehalten bis zum 26. März 1803, als der erste Artikel des titre préliminaire des Code civil verbindlich wurde. Für die Verbindlichkeit der Gesetze im Niedermaasdepartement galt nun ein Zeitraum von fünf Tagen ab der Promulgation der Gesetzgebung durch den Kaiser. Diese Regelung galt nur für formelle Gesetze. Andere Rechtsvorschriften, wie zum Beispiel kaiserliche Dekrete, vielen weiterhin unter den Wirkungsbereich des Gesetzes vom 12. Vendémiaire IV.

Wegen der erdrückenden Zahl der schon in Frankreich geltenden Gesetze entschloß sich das Directoire exécutif, diese Gesetzgebung nicht sofort in den départements réunis in Kraft zu setzen, sondern erst mittels eines speziellen Verkündungsbeschlusses. Dieser BeschlaB vom 18. Pluviose IV (7. Februar 1796) wurde nach etwa zehn Monaten wiederrufen durch den Beschluß vom 16. Frimaire V (6. Dezember 1796), der bestimmte, daß künftig, mit wenigen Ausnahmen, alle im Bulletin des lois der zweiten Folge aufgenommenen Gesetze sofort verbindlich seien, sobald der Empfang des bezüglichen Bulletins im Hauptort des Departements registriert worden war. Zugleich wurde der Auftrag erteilt, eine Sammlung der wichtigsten älteren Gesetze, den sogenannten Code Merlin, durch das Justizministerium verfassen zu lassen.

Trotzdem gab es bei den Einwohnern manche Unklarheit daruiber, an welchem Zeitpunkt eine bestimmte Regelung in Kraft getreten war. Bis zur obersten Instanz wurde darüber prozessiert. Auch das Justizministerium in Paris ließ den Zweifel weiterleben. 1799 stellte der damalige Justizminister Lambrechts formell fest, unter Bezugnahme auf den Beschluß vom 18. Pluviôse IV, daß die Bulletins des lois der zweiten Folge bis Nummer 95 in den neun départements réunis nicht in Kraft getreten waren.

Das dritte Kapitel bietet eine Übersicht der Gesetzgebung, die während der anderthalb Jahre seit der Angliederung am 1. Oktober 1795 bis zum in Kraft treten des Code Merlin am 19. März 1797 in den départements réunis im allgemeinen und speziell im Niedermaasdepartement verkündet wurden. In diesem Zeitabschnitt gab es eine richtige Gesetzgebungswelle. Etwa 1100 Rechtsvorschriften wurden im Departement von den Verkündungsbehörden in Kraft gesetzt. In der Regestenliste sind 582 Rechtsvorschriften aufgenommen worden. Der Code Merlin enthält darüber hinaus noch 424 Verordnungen oder Abschnitte von Rechtsvorschriften. Im Zeitabschnitt zwischen dem Beschluß des Directoires vom 16. Frimaire V (6. Dezember 1796) und der Eintragung des Code Merlin sind noch weit über hundert in den Bulletins des lois aufgenommene Gesetze und Beschlüsse in das Departementalrepertorium eingetragen worden. Wegen der riesigen Menge der Vorschriften wurden nur die Hauptzüge der größeren Sammlungen skizziert.

Zwei der größeren Gesetzgebungssammlungen nahmen Bezug auf die zentralen und dezentralen Behörden sowie auf die Gerichtsverfassung. Die Konstitution des Jahres III sah ein Corps législatif vor, das zwei Kammern umfallte: der Conseil des Cinqcents und der Conseil des Anciens. Die Exekutivgewalt wurde vom fünfköpfigen Directoire exécutif wahrgenommen. Die Departements waren die intermediären Verwaltungsbehörden schlechthin. Im sehr zentralistisch geprägten Frankreich waren sie 
die Achse zwischen Paris und den entlegensten Winkeln des Landes. Auf Kantonsebene wurde die Munizipalitätsverwaltung aus Munizipalagenten der verschiedenen Gemeinden zusammengesetzt. GrößBere Orte hatten ihre eigene Munizipalität. Ein Kommissar der Exekutive hatte als Vertreter des Staates die Aufsicht über die dezentralen Behörden. Bezüglich der Gerichtsverfassung unterschied die Konstitution des Jahres III zwischen Zivil- und Strafgerichtsbarkeit, wobei letztere in korrektioneller und krimineller Rechtspflege unterteilt war. Viel erhofften sich die französischen revolutionären Assembleen von den untersten Gerichten, den Friedensgerichten. Wie bei den dezentralen Verwaltungsbehörden fungierte bei den Gerichten ebenfalls ein Kommissar der Exekutive.

Die Gesetzgebung, die im revolutionären Frankreich zur Zerlegung der Gesellschaft des Ancien Régime geführt hatte, wurde auch den départements réunis auferlegt. Sie führte zum Eingriff in die vorherrschenden Besitz- und Eigentumsverhältnisse, wenigstens im Bereich der äußeren Struktur. Der Abbau der feodalen Gesellschaft bedeutete auch, daß der erste Stand, die Geistlichkeit also, seine privilegierte Stellung verlor. Teile der dies bezüglichen revolutionären Gesetzgebung wurden verkündigt, wodurch die Kirche in den dếpartements réunis in Bedrängnis geriet. Es kam soweit, daß das hochgespannte revolutionäre Gedankengut von Gleichheit für Alle zugleich zu neuer Ungleichheit Anlaß gab. Diejenigen, die sich zu Gegnern der neuen französischen Gesellschaft erklärten oder vorher zu den Privilegierten gehörten, bekamen die Strenge des Gesetzes zu spüren.

Die im Niedermaasdepartement verkündete Gesetzgebung erstreckte sich über alle nur denkbare Bereiche. Von der Einführung der Zivilehe und der Möglichkeit der Ehescheidung bis zu den revolutionären Festakten und den Steuern. Viele Gesetze nahmen zum Beispiel Bezug auf die Verwaltung und die Versteigerung der nationalen Domanialgüter. Diese stammten von jenen gesellschaftlichen Gruppen (der Adel, die Kirche, die Emigranten), deren Besitz vom Staat beschlagnahml worden war. Der Eindruck, der sich für den heutigen Betrachter des damaligen droit intermédiaire ergibt, ist der Staat die Aufsicht übt. Der Staat versuchte zu der Zeit sorgfältig das Tun und Lassen seiner Untertanen zu beobachten.

Unter den folgenden Regesten sind im allgemeinen die verkündeten Rechtsvorschriften aufgenommen worden, die in das Repertorium des Niedermaasdepartements eingetragen wurden, und zwar während des Zeitabschnitts von der Angliederung an Frankreich am 1. Oktober 1795 bis zur Eintragung des Code Merlin am 19. März 1797. Nicht aufgenommen wurden die Beschlüsse der Volksvertreter en mission während der Epoche des Arrondissements Maastricht. Ebensowenig wurde die in den Bulletins des lois aufgenommene Gesetzgebung beachtet, die seit der Eintragung des Dekrets vom 16. Frimaire V (6. Dezember 1796) erfolgte. Die Regesten enthalten die Gesetzgebung (Gesetze, Beschlüsse, Proklamationen) oder Abschnitte daraus, die seit August 1789 bis Ende Februar 1797 erlassen worden sind. Jeder Vermerk einer Vorschrift ist wie folgt aufgebaut. Linksoben ist das Datum der Erlassung angegeben. Die Daten der Bewilligung von der Assemblee und die damals noch erforderliche königliche Sanktion sind durch ein Sternchen von einander getrennt. Unter dem Datum der Erlassung sind die Belegstellen der verkündigten Gesetzgebung vermerkt. Es empfiehlt sich, auch die Bände, in den die Gesetze wörtlich abgeschrieben worden 
sind, zu Rate zu ziehen, da manchmal der Text einer Rechtsvorschrift den Zeitumständen angepaßt wurde. Die Überschrift der Verordnung wurde in der französischen Sprache beibehalten. Die eigentliche Beschreibung ist eine Kurzfassung des Inhallts des Gesetzes und will Kurzinformation bieten. Die sonstigen Angaben sind aus verschiedenen Quellen zusammengetragen. Genannt werden die beschlußfassende Behörde, etwaige Signaturen, die Beratungsbehörde, die zuleitende Instanz, wie auch Hinweise auf andere gesetzliche Bestimmungen, sofern sie verkündet wurden. Selbstverständlich ist die Belegstelle im Repertorium des Niedermaasdepartement ("registre ouvert"; RO) vermerkt und das Datum der Eintragung, an dem das Gesetz im ganzen Departement in Kraft trat. Soweit das Datum der Weiterleitung der Vorschriften an die Kantone im "registre d'envoi" (RE) vermerkt wurde, wird dieses ebenfalls mitgeteilt. Am Ende ist die Behörde, die den Befehl zur Verkündung gab, und der Ausstellungstag erwähnt.

Vertaling door Dr. G.H.A. Venner 


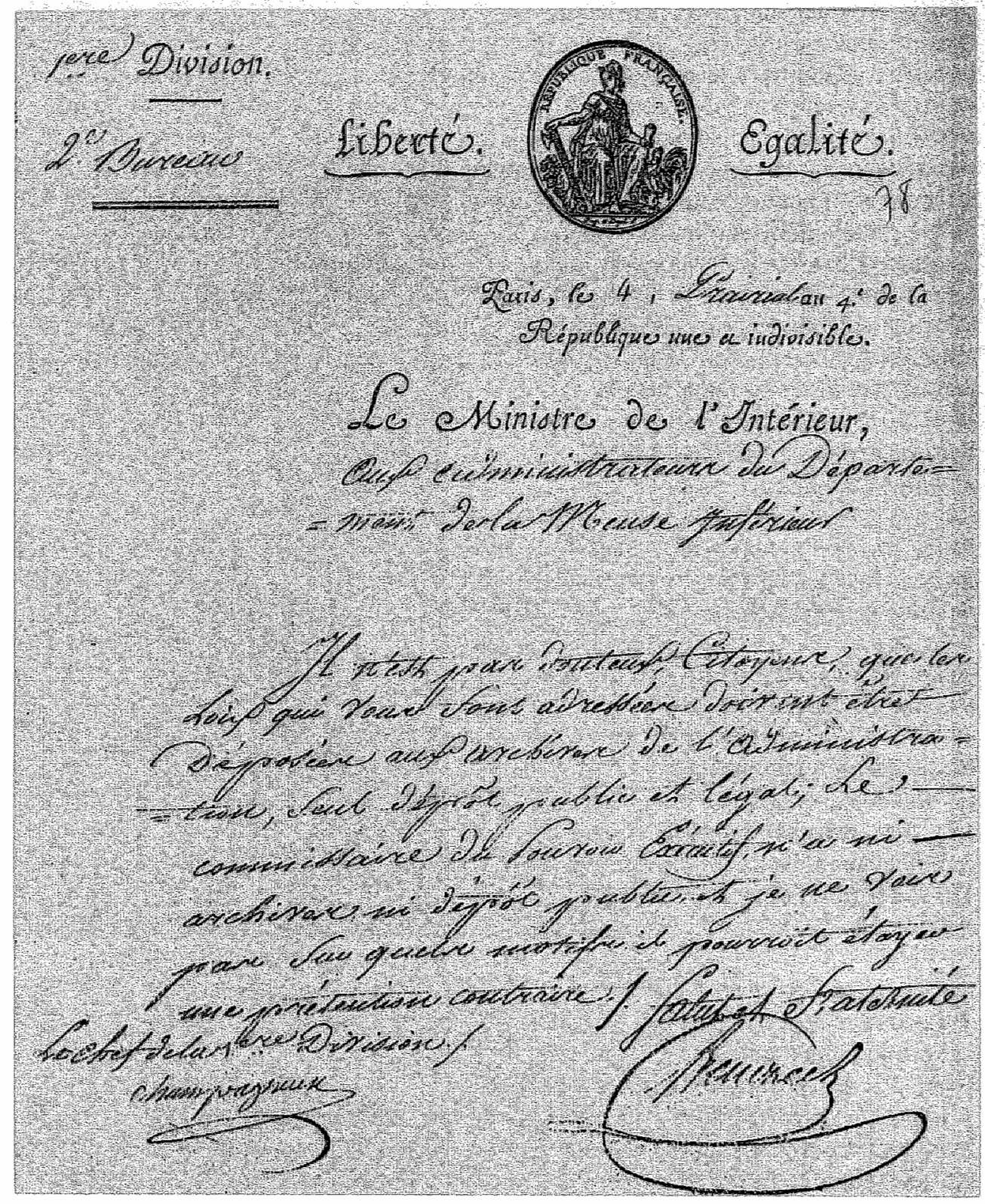

Schrijven van de minister van binnenlandse zaken Benezech aan het departementaal bestuur van de Nedermaas van 4 prairial IV (23 mei 1796), waarin het de commissaris wan het Directoire exécutiff verboden wordt nog langer aan archiefvorming te doen ter zake van onder meer de toegezonden wetgeving ( $\mathbb{R}$ ijksarchief in Limburg, Maastricht; Frans archief inw.nr.870). 


\section{a. Begrenzing van de regestenlijst}

De regestenlijst van afgekondigde rechtsvoorschriften is samengesteld op basis van het door het bestuur van het departement van de Nedermaas aangelegde repertorium - het "registre ouvert" - dat de ontvangst van de rechtsvoorschriften registreerde, overeenkomstig de wet van 12 vendémiaire IV (4 oktober 1795). De lijst omvat de periode vanaf de inlijving bij Frankrijk op 1 oktober 1795 tot de registratie van de Code Merlin medio maart 1797, te weten 256 inschrijvingsnummers. In het algemeen zijn er geen inschrijvingsnummers weggelaten, behoudens de reeks wetten aangaande de marine en het daarbij aangestelde personeel'. In dit geval is er waarschijnlijk sprake van een vergissing: het betreft het laatste cahier van de eerste serie van het Bulletin des Lois, dat zonder afkondigingsbesluit van het Directoire exécutif was toegezonden, en waarover het departementaal bestuur besliste dat het in het archief zou worden gedeponeerd $^{2}$. In een enkel geval zijn verder twee inschrijvingsnummers in één regest samengevoegd, daar waar het gaat om een rectificatie, en als rechtsvoorschriften of delen ervan twee of meerdere keren werden afgekondigd.

De registratie in het departement van de Nedermaas van de uit ruim vierhonderd rechtsvoorschriften of delen ervan bestaande Code Merlin op 29 ventôse V (19 maart 1797 ) is gekozen als begrenzing van de regestenlijst. Deze keuze als einddatum komt als zinvol over, enerzijds om een gigantisch uitdijen van de regestenlijst te voorkomen, anderzijds aangezien de tweedelige Code Merlin relatief eenvoudig valt te raadplegen. Daarenboven geschiedde het opstellen van de Code Merlin ingevolge het besluit van het Directoire exécutif van 16 frimaire V (6 december 1796), dat in algemene zin een einde maakte aan de bijzondere positie van het uitvoerbaar worden van wetgeving in de negen départements réunis. De sedert de registratie van het besluit van 16 frimaire $\mathrm{V}$ bij het departementaal bestuur ontvangen wetgeving, zoals geplatst in de Bullerins des Lois, zijn niet opgenomen in de regestenlijst. Evenmin zijn in de regestenlijst de reeksen besluiten van de volksrepresentanten en mission opgenomen uit de periode van het arrondissement Maastricht (november 1794 oktober 1795), voorafgaande aan de inlijving bij Frankrijk. Deze besluiten zijn in het algemeen niet opgenomen in het departementale "registre ouvert" en vergen een afzonderlijk nader onderzoek.

${ }^{1} \mathrm{RO}$ nir.44(1-12).

2 BL le ser no.205 (1222-1223); bij besluit van het Directoire exécwif van 7 pluviôse V (26 jan 1797) - Cade Merlin - werden alsnog RO nr.44(1), 44(11) en 44(12) afgekondigd, zie RO nr.257(357-359); Pasinomie IX vii-ix vermeldt, dat bij besluit van het Directoire exécutif van 8 frimaire VII ( 28 nov 1798) RO $44(2)$ en $44(12)$ alsnog werden afgekondigd.

${ }^{3}$ Zie hierover ook hoofdstuk II van de ünleiding inzake de afkondiging. 
Aan het regest van een afgekondigd rechisvoorschrift ligt een basisstramien ten grondslag. Een zeker aantal elementen keert steeds terug. De regesten vertonen een grote mate van eenvormigheid. Naast de inhoudelijke kant van een regest, schuilt de grootste variatie in de additionele informatie.

Linksboven staat de datum van uitvaardiging van de wet of het besluit vermeld. De regestenlijst is chronologisch van opbouw. De gebruiker dient er evenwel op bedacht te zijn dat er regellmatig meerdere data worden genoemd. Dit behoeft enige verduidelijking. Met name in de periode van de Assemblée nationale constituante en législative werden veelal alle data genoemd waarop een wetsontwerp in de Assemblée aan de orde was geweest. De laatstgenoemde datum is dan de datum waarop de definitieve redlactie van een wet werd vastgesteld. In contemporaine wetsverzamelingen worden dan ook al die data opgesomd. In dezelfde periode was, alvorens wetgeving uitvoerbaar kon worden, ook de koninklijke sanctie vereist. Ingevolge de grondwet van 3 * 13 september 1791 (tit.III, hoofdst.III, sect.III, artt.1-6) beschikte de koning over het prerogatief van de sanctionering inzake de decreten van de Assemblếe nationale; het koninklijke veto had evenwel slechts een opschortend karakter. De door de koning gesanctioneerde decreten werden als wet betiteld. Feitelijk beschikte de koning al over de sanctie vóór het in werking treden van de grondwet van 1791 door de zogenaamde lettres patentes. De data van aanvaarding en die van de koninklijke sanctie worden door een * gescheiden.

De wetgeving ten tijde van de Convention nationale en het Directoire kent doorgaans ook een tweede datum die de bevestiging van het zegel aanduidt, dan wel de promulgatie door het Directoire exécutif. Deze datum is na de val van de Franse monarchie niet meer overgenomen. Overeenkomstig het advies van de Napoleontische conseil d'état van 5 pluviôse VIII (25 jan 1800), wordt als datum van uitvaardiging de datum van aanvaarding in het parlement aangehouden. Gedurende het Directoire is dat de datum van aanvaarding van een wetsontwerp door de Conseil des Anciens ${ }^{4}$.

Vanaf 6 oktober 1793 ging de Convention nationale de republikeinse kalender hanteren, aanvankelijk nog in Arabische cijfers, vanaf 25 oktober 1793 in de nieuwe republikeinse benaming. De data van uitvaardiging volgens de republikeinse kalender zijn de officiële en zijn derhalve in de regestenlijst gehandhaafd. Tussen haakjes erachter staat de omrekening naar de Gregoriaanse kalender". Het woordje "an" Nederlands "jaar" - in an III, an IV enzovoorts is consequent weggelaten, behoudens in letterlijke aanhalingen.

Onder de datum van uitvaardiging staan enige vindplaatsen van de rechtsvoorschriften genoemd. Het aantal vindplaatsen is niet uitputtend. De keuze ervan is in zekere mate willekeurig. Er is naar gestreefd contemporaine wetsverzamelingen als vindplaats te

\footnotetext{
${ }^{4}$ BL IIIle ser no.6 (37); Merlin, Répertoire de jurisprudence, VII 526-527 s.v. "Ioi".

${ }^{5}$ Bij de omrekening werd gebruik gemaakt van de Concordance des calendriers grégorien et républicain, preface par Albert Soboul (Librairie Historique Clavreuil, 3e dr.; Parijs, 1983). De concordantie geeft met een * aan welke dagen zondagen waren.
} 
noemen. Zoveel mogelijk wordt het Bulletin des Lois en de vindplaats in het Frans Archief te Maastricht genoemd. Wanneer er sprake is van een gedeeltelijke afkondiging is toch de vindplaats van het gehele rechtsvoorschrift in de wetsverzameling aangegeven. Niet elke wetsverzameling overigens geeft het gehele wetsformulier, de Pasinomie bij voorbeeld doet dit niet. Het is verder aanbevelenswaardig om ook de registers (LA; "lois et arrêtés") waarin de wetgeving woordelijk is overgeschreven te raadplegen, daar soms de tekst van een rechtsvoorschrift aan de tijdsomstandigheden werd aangepast.

Het intitulé van de rechtsvoorschriften is in het Frans gehandhaafd: dit vergemakkelijkt het zoeken. Zoveel mogelijk is het intitulé van een contemporaine wetsverzameling, dan wel van het Bulletin de Lois gebruikt. Was dit niet mogelijk dan werd de omschrijving in het "registre ouvert" overgenomen. Mocht in één der contemporaine wetsverzamelingen thet intitulé nogal afwijkend zijn, dan is dat bij de additionele informatie vermeld. Voorts wordt opgemerkt dat de begrippen "loi" en "décret" indertijd door elkaar werden gebruikt.

Uit de aard der zaak vormt het eigenlijke regest, de samenvatting van een rechtsvoorschrift, het "pièce de résistance". De lengte ervan is onder meer afhankelijk van de gecompliceerdheid en de grootte van een rechtsvoorschrift, zonder dat er een rechtlijnig verband bestaat tussen de lengte van een regest en de lengte een rechtsvoorschrift. Een voorbeeld moge dit verduidelijken: de samenvatting van de code des délits et des peines van 3 brumaire IV (25 okt 1795) is kort, terwijl er sprake is van een heel wetboek met honderden artikelen. De tussen rechthoekige teksthaken geplaatste verklarende interpolaties zijn geput uit Merlins Répertoire de jurisprudence en de achttiende-eeuwse voorloper ervan, het Répertoire van Guyot ${ }^{6}$.

Nadrukkelijk wordt gesteld dat een regest de functie heeft van een korte oriëntatie. Een onderzoeker of andere gebruiker dient voor een goed begrip ook de oorspronkelijke tekst van een rechtsvoorschrift te raadplegen.

De overige gegevens genoend bij het regest zijn een bundeling van gegevens uit de diverse bronnen. Genoemd worden het besluitvormend orgaan, met eventueel de signeringen, het adviserend orgaan, de toezendende instantie, de verwijzingen naar andere rechtsvoorschriften maar alleen over het afgekondigde gedeelte. Vrijwel nooit aangegeven is de verwijzing naar de datum van de aansluiting van de départements réunis bij Frankrijk op 9 vendémiaire IV (1 okt 1795). De zinsnede "les départemens réunis à la France par la loi du 9 vendémiaire an IV" wordt voordurend gehanteerd.

\footnotetext{
" M. Guyot, Répertoire universel et raisonné de jurisprudence civile, criminelle, canonique er béneficiale, ouvrage de plusieuss jurisconsultes, nouvelle édition corrigée, \& augmentée tant des loix nowelles que des arrêts rendus en matière importante pour les parlemens \& les autres cours du royaume, depuis l"édirion précédente (2e dr.; $17 \mathrm{dln}$, Parijs, 1784-1785); Merlin, Répertoire universel et raisonmé de jurisprudence, corrigée, réduite aux objets dont la connaissance peut encore être utile. et augmentée $1^{g} d$ 'un grand nombre d'articles, $2^{2}$ de notes indicatives des changemens apportés aux lois anciennes, $3^{\circ}$ de dissertations, de plaidoyers et de réquisitoires de l'éditeur sur les unes et les autres (4e dr.; $17 \mathrm{~d} l n$, Parijs/Brussel, 18:2-1825).
} 
Daarmee voorkwam men om steeds een opsomming te moeten geven welke gebieden daaronder vielen.

Vanzelfsprekend wordt de vindplaats in het "registre ouvert" vermeld met de datum van registratie in het departement van de Nedermaas, de datum waarop een rechtsvoorschrift over de gehele uitgestrektheid van het departement in werking was getreden. Ook voor wetgeving van oudere datum geldt de datum van registratie in het departement als datum van het in werking treden. Wanneer de datum van doorzending van een rechtsvoorschrift naar de kantons vermeld staat in het "registre d'envoi", is dit eveneens aangegeven.

Aan het slot van een regest is het orgaan vermeld dat de opdracht tot afkondiging van een rechtsvoorschrift, met de dagtekening, heeft gegeven.

\section{c. Afkortingen}

ao. adviserend orgaan

Arch.Nat. Archives Nationales te Parijs

Aulard F.A. Aulard, ed. Recueil des Actes du Comité de Salut Public avec la correspondance officielle des representants en mission et le registre du Conseil exécutif provisoire (28 dln, 3 registerdln en 3 suppl.; Parijs, 1889 ...)

BL Bulletin des Lois de la République française (de l'Empire français); eerste serie: Convention nationale, tweede serie: Directoire, derde serie: Consulaat, vierde serie: Keizerrijk

bo. besluitvormend orgaan

$\mathrm{cB} \quad$ collection Baudouin ${ }^{8}=$ eerste serie: Collection générale des décrets rendus par l'assemblée nationale avec la mention des sanctions \& acceptations données par le roi [mei 1789 - september 1791] (18 dln en 3 registerdln; Parijs, s.a. en 1791-1793); tweede serie: Collection générale des décrets rendus par l'assemblée nationale législative avec la mention des sanctions et mandats d'exécution donnés par le roi (avec la mention de la date et de l'apposition du sceau) [oktober 1791 - september 1792] (6 dln; Parijs, s.a.); derde serie: Collection générale des décrets rendus par la convention nationale avec la mention de la date et de l'apposition du sceau (avec la mention de leur date) [september 1792 - brumaire IV] (35 dln; Parijs, s.a.); vierde serie: Collection générale des lois et des actes du corps légisiatif (et du directoire exécutif) faisant suite à la

\footnotetext{
${ }^{7}$ Vanaf 1 vendémiaire VI (22 sep 1797) bestaat er een tweetalige, Frans-Vlaamse, uitgave van het Bulletin des Lois, volgens Charles Delecourt, "Bibliographie des collections de lois depuis 1789 jusqu "en 1814", Archives de droit et de législation, I (1837) 97.

"Verzamelingen met rechtsvoorschriften worden vaak genoemd naar de uitgever; zie hiervoor het overzicht, dat Delecourt, "Bibliographie", 84-138, hiervan heeft gegeven. De collection Bandouin bevind zich in de Stadsbibliotheek te Maastricht. Van de vierde serie ontbreken de delen XVII en XVIII.
} 
collection des dëcrets des assemblees constituante, lésislative et de la convention nationale [brumaire IV - nivose VIII] (18 dln; Parijs, s.a.)

collection du Louvre $=$ Collection générale des lonx, proclamations, instructions, et autres actes du pouvoir exécurif, publiés pendant I'Assemblée Nationale constituante \& législative, depuis la convocation des Etats-généraux jusqu" au 31 décembre 1791: avec tables chronologiques \& de matières (12 dln; Parijs, 1792); voortgezet als Collection générale des loix, proclamations, instructions, et autres actes du pownoir exécutif, avec tables chronologiques \& table méthodique de matières (11 din; Parijs, 1793 - an III)

cols. collationné, signé

cs. contresigné

Debidour A. Debidour, ed. Recueil des actes du Directoire exécutif (procès-verbaux, arrêtés, instructions, lettres et actes divers) (4 dIn; Parijs, 1910 1917)

doss. dossier

drukw FA drukwerken behorende bij het Frans archief (Rijksarchief in Limburg te Maastricht)

F C.J. Fortuijn, Verzameling van wetten, besluiten en andere regtsbronnen wan Franschen oorspiong, in zooverre deze, ook sedert de invoering der nieuwe wetgeving, in Nederland van taepassing zijn (3 din; Amsterdam, 1839-1841)

FA Frans archief = archieven van het arrondissement Maastricht en van het departement van de Nedermaas 1794 - 1814 (Rijksarchief in Limburg te Maastricht)

fol folio

inv.nr. inventarisnummer

Isamb Jourdan, Decrusy \& Isambert, ed. Recueil général des anciennes lois françaises, depuis l'an 420 jusqu'à la révolution de 1789; contenant la notice des principaux monumens des Mérovingiens, des Carlovingiens et des Capétiens, et le texte des ordonnances, édits, déclarations, letrrespatentes, réglemens, arrêts du conseil, etc de la troisième race, qui ne. sont pas abrogés, ou qui peuvent servir, soit à l'interprétation, soit à

\footnotetext{
"De - (volgens Delecourt, "Bibliographie", 94) officiële en authentieke - collection du Louvre bewindt zich in de bibliotheek van de arrondissementsrechtbank te Maastricht. Zij is evenwel niet geheel compleet: de delen II/1, XVII en XVIII ontbreken. Voor zover bekend is dit de enige vindplats in Nederland.

Pierre Caron, Manuel pratique pour l'étude de la Révolution Francaise (2e dr; Parijs, 1947) 208, vermeldt dat de coliection du Lowve onder het Directoire werd voortgezet met nog eens 10 din.; Ernst Holthöfer "Frankreich" in: Helmut Coing ed., Handhuch der Quellen und Literatur der neveren europäisc hen Privatrechrsgeschichte III Das 19. Jahrhundert. Veroffentlichung des Max-PlanckInstituts für europäische Rechtsgeschichte (5 dln; Munchen, 1982-1988) III/1, 878-879 vermeldt tot het jaar VIII nog eens 5 banden. Anders: Delecourt, "Bibliographie", 94, die beweert dat de collection du Loure in prairial II eindigt als het Bulletin des Lois begint te verschijnen; zo ook Jean Tulard, Jean-François Fayard \& Albert Fierro, Histoire et dictionnaire de la Révolution française 1789-1799 (2e dr; Parijs, 1988) 1189.
} 
l'histoire du droit public et privé, avec notes de concordances, tables chronologique et table générale analytique et alphabétique des matières (28 dln; Parijs, [1822]-1827)

LA "lois et arrêtés", 9 dln [FA inv.nr.295-303]

MAP Messages, arrêtés et proclamations du Directoire exécutif, faisant suite à la collection des lois \& actes du Corps législatif [floréal an IV - 29 ventôse an VII ( 6 dln en 1 registerdl; Parijs, s.a. en an VII)

NRA Nieuwe rechterlijke archieven (Rijksarchief in Limburg te Maastricht)

no. numếro

nr. nummer

$\mathrm{P}$

Pasinomie ou callection complète des lois, décrets, arrêtés et réglemens généraux qui peuvent être invoqués en Belgique. Première série, mise en ordre et annotée par J.B. Duvergier, complétée pour la Belgique par Isid. Plaisant (16 dln; Brussel 1833-1837)

pres president

RE

"registre constatant la date d'envoi des lois, arrêtés et autres actes du gouvernement, ainsi que les arrêtés et autres actes de l"administration centrale du département de la Meuse-inférieure depuis la réunion le 9 vendémiaire an 4 jusqu'...", an IV (1795) - an XII (1804) [FA inv.nr.335]

$\mathrm{rH}$

recueil Huyghe eerste serie $=$ Recueil des proclamations et arrêtés des représentans du peuple envoyés près des armées du Nord et de Sambreet-Meuse, etc., ainsi que des ordonnances, réglemens et autres actes du magistrat et autres autorités constituées de la ville et quartier de Bruxelles, émanés à Bruxelles depuis l'entrée victorieuse des troupes de la République Française dans cette ville, le 21 messidor an II de la république (9 juillet 1794, vieux style) [dIn I-IV]; voortgezet als: Recueil des loix de la République française concernant la Belgique réunie et pays adjacens, et des proclamations, arrêtés, ordonnances, réglemens, etc. des autorités constituées, émanés à Bruxelles depuis l'établissement du conseil de gouvernement, servant de suite au recueil des proclamations, arrêtés, etc. émanés depuis l'entrée victorieuse (...) [d\| V]; voortgezet als: Recueil des loix (...) émanés à Bruxelles depuis l'organisation en départements réunis, servant de suite au (...) [dln VI-VII]; voortgezet als: Recueil des loix de la République française et des arrêtés et actes des autorités constituées dans les départemens réunis, servant de suite au (...) [dln VIII-XXV] (25 dln; Brussel, an II - an VIII)

ro recto

RO

s.

"registre ouvert en conformité de l'article 12 de la loi du 12 vendémiaire an 4 contenant la date de l"enregistrement au chef-lieu de ce département, des lois et arrêtés qui y sont rendus obligatoires", an IV (1795) 1814 [FA inv.nr.283]

s.a. sine anno

secr secretarissen (doorgaans)

ser série 

\$. 1.
sine loco
S.V. sub voce
ti. toezendende instantie
vo verso
VS. visé, signé

\section{d. Slotopmerking}

De regestenlijst van afgekondigde rechtsvoorschriften voor het departement van de Nedermaas is als werkinstrument mutatis mutandis ook bruikbaar voor de overige acht départements réunis.

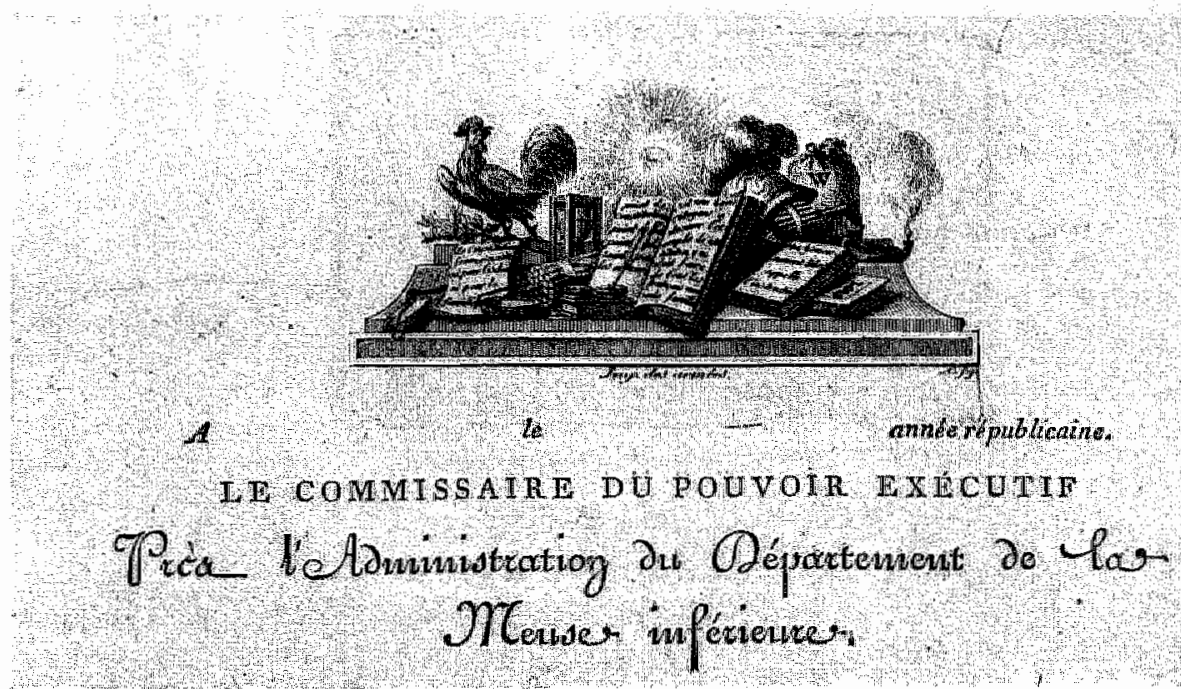

Briefhoofd van de commissaris van het Directoire exécutif bij het departementaal bestuur van de Nedermaas (Rijksarchief in Limburg, Maastricht; prentencollectie inv.nr.643). 


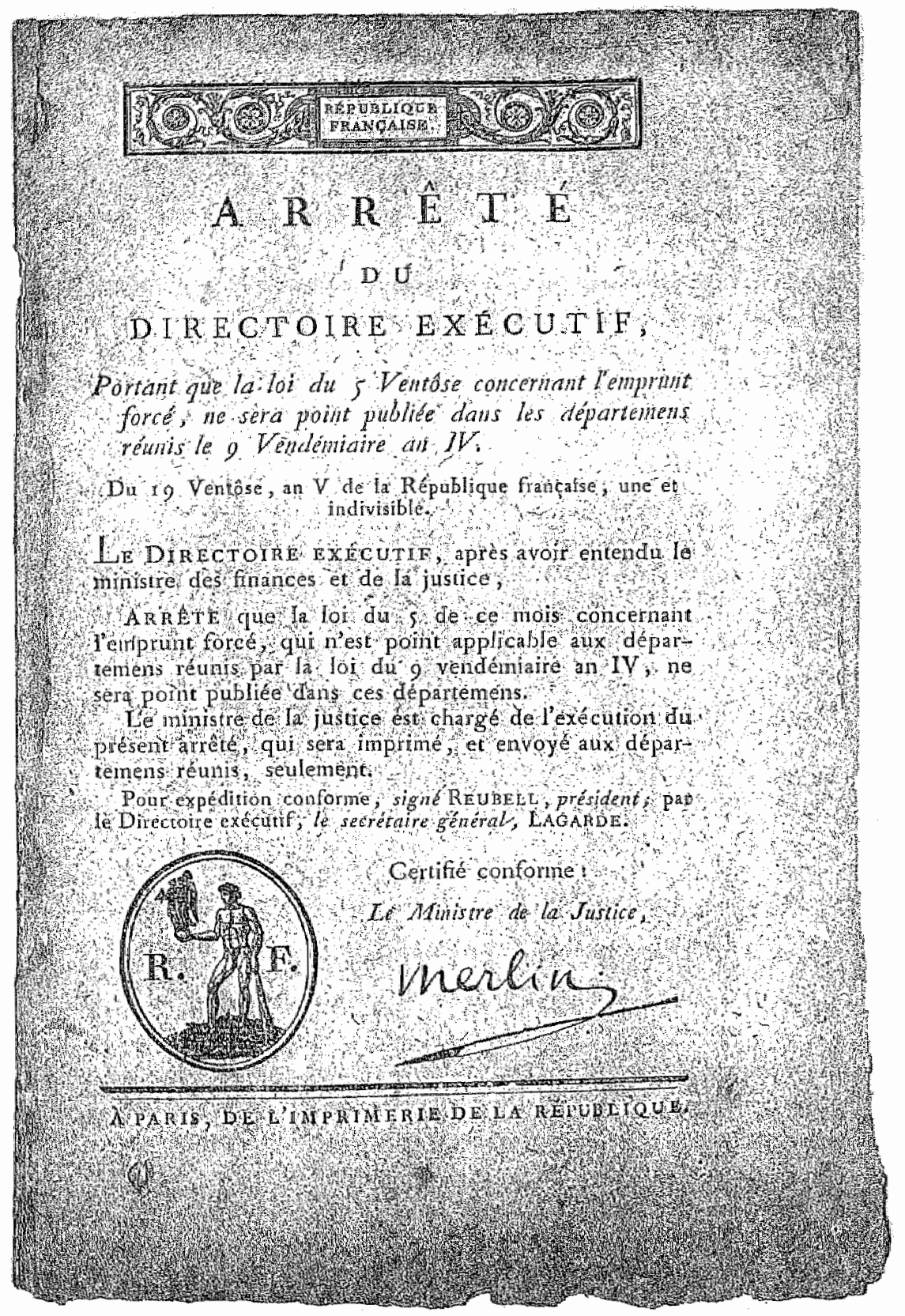

Exen besluit wan het Directoire exécutif, waarbij een wet inzake de dwanglening uitdrukkelijk niet van toepassing is in de départements réunis, en er derhalwe niet zal worden bekendgemaakt (Rijksarchief in Limburg, Maastricht; Frans archief inv.nr.291). 


\section{REGESTENLIJST}

\section{9 augustus}

drukw FA nr.30; F I 84-104; rH VII 189-192; Isamb XVIII n571

[eXtract] L'ORDONNANCE DES EAUX ET FORÊTS (tit.XXXII artt.1-15, 26)

Het kappen van bomen in de bossen door privé-personen wordt door middel van boeten - de hoogte hiervan wordt bepaald door de stamomtrek dichtbij de grond en het aantal keren dat er gekapt wordt - tegengegaan. Men is verder aansprakelijk voor de schade aan de bossen welke door vee of lastdieren wordt aangericht; doorgaans volgt confiscatie en openbare verkoop van de dieren. Ambtenaren is het verboden de hoogte van de opgelegde boeten te verlagen, op straffe van ontzetting uit hun functie.

bo. Lodewijk XIV, kanselier Séguier; gegeven te Saint-Germain-en-Laye (voorbereid door Colbert c.s.)

ti. gouvernementscommissaris Bouteville

RO nr.89(2): 16 nixôse IV (6 jan 1796)

RE nr.13: 14/15 foréal IV (3/4 apr 1796)

- FA en rH spreken van titel XXXIII

- Isamb-intitulé: "Edit portant réglement général pour les eaux et forêts"

- F-intitulê": "Ordonnance du Roi pour les Eaux et Forests de son Royaume"

- verwijzing naar: ordonnantie van 1588 (van Hendrik III) en de arrêts van sep 1601, jun 1602, okt 1623

- afkondiging: besluit volksrepresentanten/gouvernementscommissarissen s. Pérès, Portiez (de l'Oise);

24 frimaire IV (15 dec 1795)

\section{9 augustus $4,6,7,8,11 *$ september 21}

LA I fol 269vo-270vo; FA nr.291; rH V 274-275; P I 33-35; cB le ser I 51-54, 58-65; cL I/1 108113,259

\section{[extract] DÉCRETS SUR LA SUPPRESSION DE LA FÉODALITÉ (artt. 1-6)}

Door de Assemblée nationale wordt het feodale régime in zijn geheel afgeschaft. Zij verordonneert dat zowel de feodale rechten, als de cijnsrechten, in het geval waarin deze samenhangen met de main-morte [="horigheid"] réelle of personnelle, dan wel een persoonlijke dienstbaarheid, zonder schadeloosstelling zijn afgeschaft. Voorts zijn ook afgeschaft het exclusieve recht van duiventil, het jachtrecht, de tienden van welke aard ook, dan well de daarvoor in de plaatsgekomen jaarlijkse pachtsommen die seculiere of religieuze lichamen, houders van beneficies en alle gens de main-morte $[=0 . \mathrm{m}$. leden van religieuze communiteiten, wier goederen niet vererven en mitsdien aan het handelsverkeer ontrokken zijn] genieten. De tienden of cijnzen die zijn overgedragen aan leken ter voorziening in de allernoodzakelijkste middelen voor hun levensonderhoud zijn ook afgeschaft. Overige tienden en andersoortige rechten zijn 
afkoopbaar verklaard, hetgeen eveneens geldt voor altijddurende cijnzen van welke

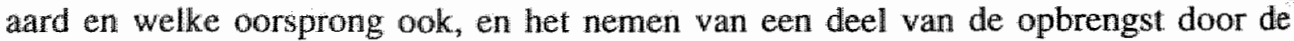
heer alvorens er geoogst is. Zonder schadeloosstelling verder worden de heerlijke jurisdictiën opgeheven.

bo. Assemblée nationale s. Le Chapelier (pres); l"abbé Syeyes, le comte De Lally-Tollendal, Freteau, Petion de Villeneuve, l'abbé De Montesquiou, Emmery (secr)

ti. volksrepresentanten/gouvernementscommissarissen

RO nr.60(I): 19 frimaire IV (10 dec 1795)

RE nr.51: $20 / 21$ frimaire IV (11/12 dec 1795)

- cB-intitulé: "arrêté pour la suppression de plusieurs droits et priviléges"

- artikelen zijn redactioneel aan de tijdsomstandigheden aangepast

- gedrukt en bekendgemaakt op last van de koning 21 sep 1789; toegezonden aan de tribunalen en municipaliteiten (=promulgatie) 3 now 1789 s. Louis, par le roi De Saint Priest

- afkondiging: besluit volksrepresentanten s. Pérès, Portiez (de l'Oise); cs. J.Torfs (secr); 17 brumaire IV (8 nov 1795)

\section{9 oktober $3 * 12$}

FA I fol 213vo-214ro; FA nr.291; rH V 226; P I 44-45; cB Ie ser I 101; cL I// 221-222

\section{DÉCRET PRÊT À INTÉRÊT}

Privé-personen, lichamen, communiteiten en gens de main-morte kunnen tegen rente, waarvan de hoogte bij de wet vastgesteld wordt, geld lenen.

bo. Assemblée nationale

s. Louis, par le roi De Saint Priest

ti. conseil de gouvernement

RO nr.33: 5 frimaire IV (26 nov 1795)

RE nr.34: 13 frimaire IV (4 dec 1795)

- cL-imitulé: "lettres-patentes du Roi portant sanction du décret de l'Assemblée nationale, concemant le prêt à intérêt"

- cB spreekt van 2 okt 1789

- afkondiging: besluit volksrepresentanten s. Pérès, Portiez (de l'Oise); cs. Dellcambe (secr); 14 brumaire IV (5 nov 1795)

\section{9 december $14 * 18$}

LA II fol 92vo-94ro; FA nr.234; rH VI 75-77; P I 63-7!; cB Ie ser I 196-224; cL I/I 354-367

[extract] DÉCRET RELATIF À LA CONSTITUTION des MUNICIPALITÉS (artt.1, 14-15, $50-51,59-61)$

De nog bestaande municipaliteiten in elke stad, marktplaats, parochie onder de benaming van hôtel-de-ville, mairie, échevinat enzovoorts zijn opgeheven. De municipale ambtenaren dienen hun functie, totdat ze worden vervangen, te blijven vervullen. Burgers die een rechterlijk ambt bekleden of belast zijn met de inning der directe belastingen kunnen niet tegelijkertijd ook municipale functies vervullen. Het beheer 
van de goederen en de inkomsten en uitgaven behoort tot de gemeentelijke bevoegdheden. Aan de municipale lichamen kan de omslag van de directe heffingen, de overdracht van geïnde gelden, de uitvoering van openbare werken enzovoorts worden gedelegeerd. Burgers hebben het recht de rekeningen en overige relevante bescheiden in te zien, alsmede klachten in te dienen, wanneer zij menen persoonlijk schade te ondervinden. Ook mogen zij ambtenaren aangeven bij vermeende bestuurlijke overtredingen.

bo. Assemblèe nationale

s. Louis , par le roi De Saint Priest; visa: l'archevêque de Bordeaux

ti. volksrepresentanten/gouvernementscommissarissen

RO nr.84(1): 7 nivôse IV (28 dec 1795)

RE nr.72: $21 / 22$ nivôse IV (11/12 jan 1796)

- de afgekondigde artikelen deels aangepast

- cL-intitulé: "lettres patentes du Roi sur un décret de l'Assemblée nationale, pour la Constitution des Municipalités": cL spreekt van "mois de Décembre 1789"

- cB-intirulë: "décret pour présenter à l'acceptation Royale les articles sur les Municipalités"

- afkondiging: besluit volksrepresentanten s. Pérès, Portiez (de l'Oise); 19 frimaire IV (10 dec 1795)

\section{9 december $22 *$ januari 1790}

LA II fol 94ro-95vo; FA nr.234; rH VI 77-79; P I 73-89; cB Ie ser I 232-251; cL I/I 405-423

[extract] DÉCRET CONTENANT CONSTITUTION DES ASSEMBLÉES PRIMAIRES ET DES ASSEMBLÉES ADMINISTRATIVES (sectie III, artt.1, 2, 6, 7 en enkele andere artt.)

In het decreet worden de bevoegdheden van de departementale besturen inzake de omslag der directe belastingen, het opstellen van de lijsten van contribuabelen en de regeling der inning en afdracht van de opbrengst aangeduid. De departementsbesturen zijn voorts belast met tal van zaken: van onderstand aan armen tot het onderhoud aan kerken en wegen, het bevorderen van de landbouw en nijverheid en de handhaving van de gezondheid. Zonder toestemming van het corps législatif evenwel, mogen de departementale besturen geen enkele belasting opleggen, behalve voor het bestrijden van locale onkosten en onvoorziene omstandigheden. Toezicht wordt uitgeoefend door de procureurs-(généraux)-syndics [vervangen door de commissaires du pouvoir exécutif]

\section{bo. Assemblée nationale}

ao. comité de constitution

s. Louis, par le roi De Saint Priest; visa: l'archevêque de Bordeaux

ti. volksrepresentanten/gouvernementscommissarissen

RO nr.84(2): 7 nivôse IV (28 dec 1795)

RE nr.72: 21/22 nivôse IV (11/12 jan 1796)

- LA, FA en $\mathrm{rH}$ vermelden als datum van uitvaardiging 22 okt 1789

- decreet deels aangepast; verwijzing naar: wet van 21 fructidor III (7 sep 1795)

- cL-intinulé:" "lettres patentes du Roi, sur un décret de l'Assemblée nationale, pour la constitutions des Assemblées primaires \& des Assemblées administratives

- afkondiging: besluit volksrepresentanten s. Pérès, Portiez (de l'Oise); 19 frimaire IV (10 dec 1795) 


\section{DÉCRET RELATIF AUX DÉLIBERATIONS DES ASSEMBLÉES REPRÉSENTATTVES, MUNI- CIPALES ET ADMINISTRATIVES}

De beraadslagingen wan vertegenwoordigende municipale en bestuurlijke assemblées zullen worden genotuleerd en ondertekend. In de notulen worden de namen van alle deliberanten opgenomen.

\section{bo. Assemblée nationale}

s. Louis, par le roi De Saint Priest

ii. volksrepresentanten/gouvernementscommissarissen

RO nr.84(3): 7 nivôse IV (28 dec 1795)

RE nr.72: $21 / 22$ nivose IV (11/12 jan 1796)

- cB-imitulé: "décret concemant la rédaction et la signature des déliberations des assemblées représentatives"

- cL-intitulê": "lettres patentes du Roï, sur un décret de l'Assemblée nationale du 11 Février, relatif ..."

- af fkondiging: besluit volksrepresentanten s. Pérès, Portiez (de l'Oise); 19 frimaire IV (10 dec 1795)

\section{0 maart $15 * 28$}

LA If fol 271 ro-278vo; FA nr.291; rH V 275-283; P I 114-121; cB Ie ser II 182-199; cL I/1 624-642

[extract] LOI CONCERNANT LES DROITS FÉODAUX (tit.I artt.1-3, 11; tit.II artt.1, 8-10, $12-16,19,21-28,36-39$; tit.III art.1)

De wet bepaalt eerst in algemene zin de opheffing van het feodale bewind: onderscheid voortkomend uit superioriteit of macht, alsmede de persoonlijke hommage waaraan vazallen en cijnsplichtigen onderworpen zijn, is afgeschaft. Dit geldt ook voor voorrechten als het eerstgeboorterecht of de voorrang van mannen boven vrouwen. Bij gevolg worden opengevallen nalatenschappen geregeld volgens de wetten die voor alle burgers gelden. Voorts zijn een zeer groot aantal heerlijke rechten zonder schadeloosstelling afgeschaft, als bij voorbeeld de main-morte personnelle, réelle of mixte, horigheid en persoonlijke dienstbaarheden, corvees, haardstedengelden, tolgelden en soortgelijke heffingen, uitgezonderd die geheven worden ten profijte van de schatkist, steden, provincies en dergelijke. Afkoopbaar blijven alle feodale rechten en verplichtingen of cijnzen [censuels utiles], die de prijs en voorwaarde hebben gevormd van een oorspronkelijke bezits- of eigendomstitel ter zake van een stuk land [concession primitive de fonds].

\section{bo. Assemblée natronale}

s. Louis, par le roi De Saint Priest; vu au conseil Lambert

ti. volksrepresentanten/gouwernementscommissarissen

RO nr.60(2): 19 frimaire IV (10 dec 1795)

RE m.5I: $20 / 21$ frimaire IV ( $1 \| / / 2$ dec 1795)

- verwijzing naar: decreten van 4,6,7,8 en 11 aug 1789

- cL-intiules: "lettres patentes du Roi, sur le décret de l'Assemblée nationale, du 15 du présent mois, concernant les Droits féodaux" 
- afkondiging: besluit volksrepresentanten s. Perès, Portiez (de l'Oise); cs. J: Torfs (secr): 17 brumailre IV (8 now 1795$)$

\section{0 april $16,17 * 22$}

LA III fol 102; FA nr.291; rH VIII 201; P I 147-148; cB le ser II 281-285; cL 1/2 726-730

[extract] LOI CONCERNANT LES DETTES DU CLERGË, LES ASSIGNATS, ET LES REVENUS DES DOMAINES NATIONAUX (art.2)

Kerkelijke goederen die verkocht en vervreemd zullen worden uit hoofde van de decreten van 19 december 1789 en 17 maart 1790, zijn bevrijd van elke hypotheek van de wettelijke schuld [dette légale] der geestelijkheid, waarmee deze goederen voorheen bezwaard waren. Geen enkel verzet van de zijde der schuldeisers tegen de verkoop van deze goederen kan worden toegelaten.

bo. Assemblée nationale

s. Louis, par le roi De Saint Priest; va au conseil Lambert

ti. minister van justitie Merlin

RO nr.147(1): 11 prairial IV (30 mei 1796)

- verwijzing naar: decreten van 19 dec 1789, 17 mort 1790

- cB-intitulé: "décret concernant le nombre, la forme et la fabrication des assignats"

- cL-intitulé: "lettres patentes du Roi sur les décrets de l'Assemblée nationale, des 16 \& 17 de ce mois"

- afkondiging: besluit Directoire exécuaff s. Carnot (pres), Lagarde (secr-gen); 23 floréal IV (12 mei 1796); volgens P zou de bekendmaking zijn: 7 pluwiôse $V(26$ jan 1797)

\section{0 (maart 20 en 23 ) april $19 * 20$}

LA II fol 95vo-96ro; FA nr.234; rH VI 80-81; P I 131, 150-151; cB le ser II 212-215, 233, 291; cL $\mathbb{1} / 2715-718$

[extract] DÉCRET CONTENANT DIVERSES DISPOSITIONS RELATIVES AUX ADMINISTRATIONS DE DÉPARTEMENT ET DE DISTRICT, ET A L'EXERCICE DE LA POLICE (artt.8-10)

De districtsbesturen nemen een beslissing over de grensscheidingen die door gemeenschappen worden betwist. Worden bepaalde erven hierdoor diverse keren in de belastingen aangeslagen, dan treffen de districtsbesturen ook hiervoor een voorziening. Voorlopig zal het bestuurlijke en contentieuze toezicht tot op het moment van de organisatie van de rechterlijke macht door municipale lichamen worden uitgeoefend. Beroep dat wordt ingesteld tegen de beschikkingen van municipale lichamen, wordt voorlopig afgehandeld met behulp van bestaande reglementen. Dit beroep wordt voorlopig ten overstaan van koninklijke bailliages en sénéchaussées in streken waar dezen als zodanig dienen, door ten minste drie rechters in laatste ressort behandeld.

bo. Assemblée nationale

s. Louis, par le roi De Saint Priest; visa: I"archevêque de Bordeaux.

ti. volksrepresentanten/gouvernementscommissarissen 
RO nar.84(4): 7 nivöse IV (28 dec 1795)

RE nr.72: $21 / 22$ nivôse IV (11/12 jan 1796)

- cB-intitulés: "décret concernant l"éligibilité aux assemblées administratives de département et de district. les marques distinctives des officiers municipaux, leur rang et séance, et leur autorité" [20 mrt 1790]: "décret sur lappel des jugemens de police rendus par les municipalités [23 mrt 1790]: "correction de la rédaction du décret du 10 [lees: 20] mars, sur l'éligibilité des administrateurs" trésoriers, etc" [19 apr 1790]

- cL-intitulé:" "lettres patentes du Rói sur un décret de l'Assemblée nationale"

- art. 10 overgenomen uit het decreet van $23 \mathrm{mrt} 1790$

- afkondiging: besluit wolksrepresentanten s. Pérès, Portiez (de l'Oise); 19 frimaire IV (10 dec 1795)

\section{0 april $22,23,28 * 30$}

LA I fol 278vo-282ro; FA nr.291; rH V 283-287; P I 156-160; cB le ser II 304-307; cL I/2 759-763.

[eXtract] DECRET SUR LA CHASSE (artt. 1-15)

Teneinde schade aan de gewassen te velde te voorkomen, is het verboden te jagen op andermans terrein zonder diens goedkeuring, op straffe van een boete, welke verhoogd wordt bij herhalling van de overtreding. Wapens en dergelijke worden geconfisqueerd. De municipaliteit dient hierop toe te zien, na ontvangst van een rapport van een speciale ambtenaar hieromtrent. Wel staat het landeigenaren of -bezitters en pachtboeren vrij om wild te vangen, te doden of te verjagen in niet-omheinde percelen zonder daarbij schade aan de gewassen te veroorzaken.

bo. Assemblée nationale

s. Louis, par le roi De Saint Priest

ti. volksrepresentanten/gouwemementscommissarissen

RO nr.60(3): 19 frimaire IV (10 dec 1795)

RE nr.51: 20/21 frimaire IV (11/12 dec 1795)

- verwijzing naar: decreten van 4, 5, 7 en 11 aug 1789 en 23 mrt 1790

- cL-intimulé: "lettres patentes du Roi, sur un décret de l'Assemblée nationale, concernant la chasse"

- decreet aan de tijdsomstandigheden aangepast

- afkondiging: besluit volksrepresentanten s. Pérès, Portiez (de l'Oise); cs. J. Torfs (secr); 17 brumaire IV (8 nov 1795$)$

\section{0 mei $14 * 17$}

LA III fol 102vo-103ro, V fol 152vo; FA nr. 291; rH VIII 202-203, XI 324; P I 173-176; cB le ser II $381-391 ; \mathrm{cL} \mathrm{I} / 2828-838,1124$

[extract] LOI CONCERNANT LA VENTE DE QUATRE CENTS MILLIONS DE DOMAINES NATIONAUX (tit.I artt.7,8,9; tit.III art.6)

Verkochte goederen zijn vrij van alle grondrenten en overige verplichtingen, alsmede van alle heerlijke overdrachts- en grondrechten, welke door decreten afkoopbaar zijn verklaard. Eveneens zijn deze goederen bevrijd van alle schulden en hypotheekrenten. Het verzoeken om een rechterlijke uitspraak door verkrijgers ter zake is niet langer nodig, aangezien het opwerpen van verzet voortaan nietig en niet-bestaande is. Ver- 
pachtingen en verhuringen daterend van vóór 2 november 1789 zullen naar vorm en inhoud worden uitgevoerd. De verkrijgers kunnen de pachters niet uitzetten, ook niet door het aanbieden van een schadeloosstelling. Objecten kunnen zowel als geheel of in gedeelten bij opbod worden verkocht. Wanneer bij de definitieve toewijzing de diverse opbrengsten gelijk zijn aan het bod op het gehele object, geschiedt de toewijzing bij voorkeur gedeeltelijk.

\section{bo. Assemblée nationale}

s. Louis, par le roi De Saint Priest; vu au conseil Lambert

ti. minister van justitie Merlin

RO nr. 147(2) en 248: 11 prairial IV ( 30 mei 1796) en 23 pluviôse V (11 feb 1797)

- verwijzing naar: decreten van 4 aug $1789 ; 15$ mrt 1790; 3 mei 1790; 14 apr 1790; 16 apr 1790

- cB-intitulé: "décret concemant l'aliénation des domaines nationaux, leur vente aux municipalités et leur revente aux particuliers"; [tit.III art.5 op 25 juli 1790 nogmaals gesanctioneerd na correctie]

- cL-intirulé: "lettres patentes du Roi, sur le décret de l'Assemblée nationale pour ..."

- LA V en FA nr.291 als noot; de datum van 2 november 1789 is voor de départements réunis 1 januari 1794, bepaald bij besluit van de volksrepresentanten bij het Noorder- en het Sambre-enMaasleger van 9 frimaire Ill (29 nov 1794)

- afkondiging: besluit Directoire exécutif s. Carnot (pres), Lagarde (secr-gen); 23 floreal IV (12 mei 1796) [tit.I artt.7,8; tit.III art.6] en beslluit Directoire exëcwtif s. P. Barras (pres), Lagarde (secr-gen); 1 pluviôse V (20 jan 1797) [tit.l art.9; te proclameren in elke gemeente "à son de caisse ou de trompe"]

1790 juni $19 * 23$

LA I fol 282; FA nr.291; rH V 287-288; P I 217-218; cB Te ser III 103-104; cL I/2 950-951

[extract] DÉCRET QUI ABOLIT LA NOBLESSE HÉRÉdTAIRE, ET PORTE QUE LES TITRES DE PRINCE, DE DUC, DE COMTE, MARQUIS ET AUTRES TITRES SEMBLABLES, NE SERONT NI PRIS PAR QUI QUE CE SOIT NI DONNÉS À PERSONNE (art.3, niet volledig overgenomen)

De erfelijke adel is woor altijd afgeschaft; de bijbehorende titelatuur en familiewapens mogen niet langer gevoerd worden. Alleen de eigen familienaam dient men te gebruiken. Personen van buitenlandse adel vallen hier niet onder.

\section{bo. Assemblée nationale}

s. Louis, par le roi Guignard

ti. wolksrepresentanten/gouvernementscommissarissen

RO nr.60(4): 19 frimaire IV (10 dec 1795)

RE nr.51: 20/21 frimaire IV (11/12 dec 1795)

- cL-intitulé: "lettres patentes du roi, sur un décret de l"Assemblée nationale ..."

- afkondiging: besluit volksrepresentanten s. Pérès, Portiez (de l'Oise); cs. J. Torfs (secr); 17 brumaire IV ( 8 nov 1795 ) 
DECRET QUY AUTORISE LES VILLES, HOURGS, VILLAGES ET PAROISSES, AUXQUELS LES CI-DEVANT SEIGNEURS ONT DONNE LEURS NOMS DE FAMILLES, A PRENDRE LEURS NOMS ANCIENS

Stadjes, dorpen en parochies waaraan de vroegere heren hun naam gegeven hebben, zijn gereehtigd hun oude naam weer te gebruiken.

bo. Assemblé mationale

s. Louis, par le roi Guignard

i. volksrepresentanten/gouvernementscommissarissen

RO nu. 60 (5): 19 frimaire IV $(10$ dec 1795$)$

RE nr.51: 20/21 frimaire IV (11/12 dec 1795)

- cL-invirulé: "lettres patentes du roi sur le décret de l"Assemblée nationale, ..."

- afkondiging: besluit volksrepresentanten s. Pérès, Portiez (de l'Oise); cs. J. Torfs (secr); 17 brumaire IV (8 nov 1795)

1790 juni 26,29 , juli $9 * 25$

LA III fol 103; FA nr.291; rH VIII 203-204; P I 235-238; cB le ser IV 40-51; cL I/2 1105-1125

[extract] LOI CONCERNANT L'ALIÉNATION DE TOUS LES DOMAINES NATIONAUX (artt.16, 17, 20)

De schatting van de hoogte der opbrengsten wordt bepaald door de pachtsom, waarbij rekening gehouden wordt met de onderpachten. Mitsdien wordt de hoogte van de opbrengst van een verpacht goed slechts bepaald door die van de onderpachtsom. Wanneer de pachters de eed ten overstaan van het districtsbestuur niet afleggen, wordt de hoogte van de pachtsom toch als basis voor de schatting genomen; de pachters worden in dat geval door de gewone rechter van hun (onder)pachten vervallen verklaard. ledere notaris, openbare depositaris, houder van een beneficie, administrateur of pachter die weigert de pacht van in zijn bezit of onder zijn hoede zijnde nationale goederen mede te delen, wordt door de gewone rechter veroordeeld tot een boete.

bo. Assemblée nationale

s. Louis, par le roi Guignard; vu au conseill Lambert.

i. minister van justitie Merlin

RO nr. 147(3): II prairial IV (30 mei 1796)

- verwijzing naar: decreet van 14 mei 1790

- annex aan deze artikelen is afgekondigd: "titre III de I"instruction du 31 Mai 1790" houdende bepalingen hoe de toewijzingen tijdens de verkoping bij opbod - met het uitdoven van waskaarsen dienen te geschieden.

- cB-intimle: "decret sur la vente des domaines nationaux aux particuliers"

- cL-intitule: "lettres patentes du roi, sur les décrets de l'Assemblée nationale, des 25, 26, 29 Juin \& 9 Juillet $1790, \ldots "$

- afkondiging: besluit Directoire executif s. Carnot (pres), Lagarde (secr-gen); 23 floréal IV (12 mei 1796) 
[extract] LOI QUI SUPPRIME LES RETRATTS LIGNAGER, \& DE MI-DENIER \& PLUSIEURS DROITS DE MÊME NATURE (artt.1 en 2)

De oude rechten onder de benaming van retrait lignager $[=$ het recht dat de wet aan de verwanten van de verkoper van een onroerend goed toekent om het verkochte goed terug te kopen, onder volledige vergoeding van de verwervingskosten aan de koper; deze is verplicht dit te gedogen] en retrait de mi-denier [= het recht van de verkoper van een goed aan twee echtgenoten om bij ontbinding van het huwelijk, als hij in rechte lijn verwant is aan één der beide echtgenoten, het goed voor de helft terug te kopen bij scheiding en deling van de nalatenschap] zijn afgeschaft. Vorderingen krachtens deze rechten zijn alleen bestaand, wanneer zij vóór de publicatie van het onderhavige decreet in laatste ressort zijn goedgekeurd en toegewezen.

bo. Assemblée nationale

s. Louis, par le roi Guignard

ti. conseil de gouvernement

RO nr.34: 5 frimaire IV (26 nov 1795)

RE nr.35: 13 frimaire IV (4 dec 1795)

- cL-intitulé: "Uettres patentes du Roi, sur un décret de l'Assemblée nationale, qui abolit le Retrait lignager, le Retrait de mi-denier, les droits d'Ecart $\&$ autres de pareille nature"

- afkondiging: besluit volksrepresentanten s. Giroust; cs. J.Torfs (secr-prov); 19 vendémiaire IV (11 okt 1795)

\section{0 juli $9,21 * 26$}

LA IV 42vo-43ro; FA nr.291; rH IX 295-296; P I 255; cB Ie ser IV 123-124; cL I/2 $\| 128-1130$

LOI QUI SUPPRIME LES OFFICES DE JURÉS-PRISEURS, CRÉÉS PAR ÉDIT DU MOIS DE FÉVRIER 1771, OU AUTRES; ET QUI AUTORISE LES NOTAIRES, GREFFIERS, HUISSIERS ET SERGENS À PROCÉDER AUX VENTES

De wet schaft de ambtsbediening van beëdigd schatter (juré-priseur), welke onder meer gecreèerd is door het edict van 1771, af. Deze ambtsbediening zal voortaan alleen door notarissen, griffiers, deurwaarders en gerechtsbodes geschieden. Zij zijn bevoegd om de verkoop van roerende goederen tegen een zeker bedrag aan vacatiegeld te verrichten. Het recht - vier deniers per pond van de verkoopsprijs - blijft ambtshalve geheven worden, maar de opbrengst vloeit thans in de schatkist. De rekeningen van de kantoren van de beëdigde schatters zullen worden afgesloten en zullen op zijn laatst twee maanden na publicatie van het decreet ter hand gesteld worden van het comité de liquidation.

\section{bo. Assemblée nationale}

s. Louts, par le roi Guignard; vu au conseil Lambert

RO nr.200(1): 24 fructidor IV (10 sep 1796)

RE nr. 189: 15/16 vendémiaire $W(6 / 7$ okt 1796) 
- verwijzing naar edict van 1771 , ou autres

- $\mathrm{cB}$-intitulë: "décret concemant les fonctions des ci-devant Jurés-Priseurs, \& leur liquidation"

- cL-intitule: "lettres patentes du roi sur les décrets de l"Assemblée nationale, des 9 \& 21 Juillet 1790 ; qui supprime les offices de Jurếs-Priseurs crés par édit du mois de Février 1771 ou autres; ordonnant que le droít de Quatre deniers pour liwre du prix de la vente qui leur avoit été attribué, continuera d"âtre perçu au profit du Trésor public; \& qui autorisent les Notaires, Greffiers, Huissiers \& Sergens à procéder auxdites ventes"

- afkondiging: besluit Directoire exécunif s. L.M. Revellière-Lépeaux (pres), Lagarde (secr-gen); 12 fructidor IV (29 aug 1796) [BL lle ser no.72 (666)]

\section{0 juli 26 augustus 15}

LA I fol 283ro-285ro; FA nr.291; rH V 288-290; P I 260-261; cB le ser IV 147-150; cL I/2 11681171

DÉCRET RELATIF AUX DROITS DE PROPRIÉTÉ ET DE VOIERIE SUR LES CHEMINS PUBLICS, RUES ET PLACES DE VILLAGES, BOURGS OU VILLES ET ARBRES EN DÉPENDANS

Ten gevolge van de afschaffing van het feodale régime en de heerlijke rechtspraak bestaat er geen enkel eigendomsrecht, noch toezicht en regelgeving meer op de openbare wegen en de straten en pleinen van steden en dorpen. Mitsdien is het recht om bomen te planten langs de wegen of deze zich toe te eigenen afgeschaft. De nu bestaande beplanting blijft ter beschikking van de heer, aangrenzende eigenaren kunnen deze beplanting vrijkopen; zo ook kunnen dorpsbewoners de bomen op het marktplein enzovoorts kopen. De door de voormalige heren geplante bomen op het land van aangrenzende eigenaren behoren aan de laatsten toe. De departementale besturen dienen passende maatregelen voor te stellen voor de instandhouding van de bomen die het publieke belang dienen.

\section{bo. Assemblée nationale}

s. Louis, par le roi Guignard; vu au conseill Lambert

ti. volksrepresentanten/gouvernementscommissarissen

RO nr.60(6): 19 frimaire IV (10 dec 1795)

RE nr.51: $20 / 2$ I frimaire IV (11/12 dec 1795)

- verwijzing naar: generale arresten wan het Parlement van Douai van 12 mei en 31 juli 1789; aan deze arresten mag in geen geval gevolg worden gegeven

- CL-intinulé: "lettres patentes du roi, sur un décret de 1"Assemblée nationale, du 26 Juillet $1790, \ldots$..." - afkondiging: besluit volksrepresentanten s. Pérès, Portiez (de l'Oise); cs. J. Torfs (secr); 17 brumaire IV ( 8 nov 1795)

\section{0 augustus $6,11 * 24$}

LA III fol 104ro, V fol 149vo-152ro; FA nr.291; $\mathrm{rH}$ VIII 205, XI 319-322; P I 278-281; cB le ser II 63-72; cL I/2 1314-1360

[extract] DÉCRET FAISANT PARTIE DE LA LOI DU 24 DU MÊME MOIS, RELATIVE AU CI-DEVANT CLERGE ET A LA FIXATION DE SON TRAITEMENT (artt.27-29, 31-38) 
Pachtsommen en huren betreffende voorheen kerkelijke goederen die door de staat verworven dan wel in beslag genomen zijn, dienen door de debiteuren als gewoonlijk te worden voldaan. Storting dient te geschieden in de kas van de districtsontvanger. Onderpachters kunnen naar gelang hun pachtovereenkomst de pachtsom voldoen aan de hoofdpachter of de verpachter zelf, nadat van de onderpacht kennis is gegeven aan de districtsontvanger. Pachters en huurders dienen hun gebruiksrecht van nationale goederen door middel van een verklaring op het districtssecretariaat kenbaar te maken. Overigen die rechten kunnen doen gelden op nationale goederen, moeten deze kenbaar maken op het districtssecretariaat waar de hoofdvestiging van een kerkelijk lichaam of waar de beneficies van afhankelijk zijn zich bevindt. Men dient voorts opgave te doen van de bedragen aan handgeld (pot-de-vin), die bovenop de pacht of vergunning komen. Wanneer men zijn verklaring weigert af te geven, een valse verkiaring afgeeft, of de belofte van een handgeld achterhoudt, is men van alle desbetreffende rechten vervallen verklaard.

bo. Assemble nationale

ao. comite ecclesiastique

s. Louis; plus bas l'Archevêque de Bordeaux

ti. minister van justitie Merlin

RO $\mathrm{nr} .147(4)$ en 248: II prairial IV (30 mei 1796) en 23 pluviôse $V(11$ feb 1797)

- verwijzing naar: wet van $14,20 * 22$ apr 1790

- cBi-intitulé: "décret pour accélérer la liquidation et le paiement du traitement du clergé actuel"

- cL-intitulé: "decret de l'Assemblée nationale, pour accélérer la liquidation \& le payement du Clergé actuel, des 6 \& 11 Août 1790", deel uitmakende van de "loi sur la Constitution civile du Clerge, \& lat fixation de son Traitement" van 12 jul * 24 aug 1790

- afkondiging: besluit Directoire exếcutif s. Carnot (pres), Lagarde (secr-gen); 23 floréal IV (12 mei 1796) [artt.37,38]; besluil Directaire exécutif s. P. Barras (pres), Lagarde (secr-gen); I pluviôse V (20 jan 1797) 『artt.27-29, 31-36, met instructieve noten (LA en FA nr.291), te proclameren in elke gemeente van de départements réunis "à son de caisse ou de trompe"]

\section{0 augustus $12 * 20$}

LA II fol 95ro-106ro; FA nr.234; rH VI 81-97; P I 281-303; cB Ie ser V 76 143; cL I/2 1197-1258

[extract] INSTRUCTION CONCERNANT LES FONCTIONS DES ASSEMBLEES ADMINISTRATIVES (hfdst.I gedeelten uit $\$ 1,2,3,8$; deels de hfdst.II, III, V, VI, VII)

De instructie behelst naast algemene opmerkingen over de taken der bestuurlijke assemblees met voorop de aanwijzing dat zij geen enkele wetgevende of rechterlijke bevoegdheid bezitten, de inhoudelijke aspecten in algemenere zin van de taakuitoefening der onderscheidene locale en hogere overheden. In deze instructie worden aanwijzingen gegeven aangaande het wijzigen van de grenzen van de departementen, districten en kantons, alsmede op welke wijze er door bestuurlijke assemblees dient te worden gecorrespondeerd. Verder zijn er regels gegeven die de bestuurslichamen in acht moeten nemen bij hun controlerende taak jegens de municipaliteiten; inzake financiële aangelegenheden, zoals de inning der belastingen; inzake de vervreemding der nationale domeinen; inzake de bevordering van landbouw en nijverheid en het welzijn der bevolking, bedelarij, hospitalen en gevangenissen. 
bo. Assemblée nationale

8. Lours, par le roi Guignard

ii. volksrepresentanten/gouvernementscommissarissen

RO nr.84(5): 7 nivôse IV ( $28 \mathrm{dec} 1795$ )

RE nr. $72: 21 / 22$ nivôse IV (11/12 jan 1796)

- verwijzing naar decreten van 4 aug $1789 ; 22$ dec $1789 ; 21 / 22$ april $1790 ; 2$ jun 1790; 29[?] jun $1790 ; 6$ ang 1790

- eB-imitulé: "décret relatif à l"instruction aux départemens"

- cL-intitule: "proclamation du roi, sur une Instruction de I'Assemblée nationale, concernant les fonctions des Assemblees administratives"

- afkondiging: besiuit volksrepresentanten s. Pérès, Portiez (de l"Oise); 19 frimaire IV (10 dec 1795)

\section{0 augustus $16 * 24$}

BL IIe ser no.59 (549); LA II fol 50ro-55ro, 64vo-71vo, LA III fol 207ro-209ro; FA nr. 234; rH VI 3-10, 26-38, IX 8-9; P I 310-333, VII Ixxxiv-Ixxxv; cB Ie ser V 170-194; cL I/2 \362-1389

[extract] LOI SUR L'ORGANISATION JUDICIAIRE (tit.I artt.5, 6; tit.II artt.8, 10-14, 16, 18, 20; tit.III artt.1, 2, 5, 6, 9-12; tit.IV artt.4-6; tit.V artt.2, 8-11, 13-15; tit.VIII; tit.IX art.5; tit.X artt. 1-3, 10, 12-17; tit.XII artt.2-5, 13-14)

De wet behelst bepalingen inzake de taken en bevoegdheden van rechters en de rechtspraak in het algemeen, zoals die betreffende vorm waaraan een vonnis moet voldoen. Voorts welke zaken tot de competentie van de vredegerechten behoren: de vrederechter en zijn bijzitters vormen onder meer een bureau de paix et de conciliation. Eveneens wordt de competentie der burgerlijke rechtbanken in de departementen geregeld. Sommige departementen kennen speciale handelsrechtbanken, zo niet dan zijn geschillen inzake de handel ter beslissing opgedragen aan de burgerlijke rechtbanken. Het tribunal de famille - gevormd door familieleden - doet uitspraak in geschillen gerezen tussen familieleden (man en vrouw, gedrag van kinderen); een besluit van de familie echter mag eerst worden uitgevoerd, nadat dit ter kennis is gebracht van de president van de burgerlijke rechtbank. Deze kan de tenuitvoerlegging van de uitspraak verbieden of opschorten, alsmede het oordeel van de familieraad verlichten. De leden van het openbaar ministerie bij de rechtbanken dragen de naam van commissaires du pouvoir exécutif. Vastgelegd wordt verder dat de burgerlijke procesorde voortdurend kan worden veranderd, wanneer dat nodig is.

bo. Assemblée nationale

s. Louis; plus bas l'archevêque de Bondeaux

ti. volksrepresentanten bij het Noorder- en het Sambre-en-Maasleger/gouvernementscommissarissen RO nr.76 en 170(1): I nivôse IV (22 dec 1795) en 12 thermidor IV (30 jul 1796)

RE nr.99: $11 / 12$ ventôse IV (1/2 mrt 1796)

- N.B. de afgekondigde wetsartikelen maken deel uit van het in paragrafen onderverdeelde besluit van de volksrepresentanten van 2 frimaire IV (23 nov 1795) sur l'organisation de l'ordre judiciaire en matière civile [LA II fol 50ro-76ro; FA nr.234; rH VI 3-45; P VII xli-xlviii]

- lekst van de wetsartikelen soms ingrijpend gewijzigd en herordend door de volksrepresentanten

- verwijzing naar: grondwet van 5 fructidor III (22 aug 1795)

- afkondiging: besluit volksrepresentanten s. Pérès, Portiez (de l"Oise); 2 frimaire IV (23 nov 1795);

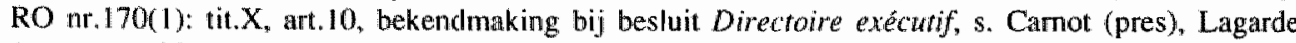
(secr-gen); 30 messidor IV (18 jul 1796) [BL IIe ser no.59 (549)] 


\section{0 augustus $29 *$ september 12}

LA I fol 285vo-286ro; FA nr.291; rH V 291; P I 261; cB le ser V 286; cL III1 59-60

\section{DÉCRET QUI RECTIFIE UNE ERREUR FAITE À L'ARTICLE X DU DÉCRET DU 26 JUIL- LET, SUR LES DROITS DE VOIERIE ET PLANTATIONS D'ARBRES}

In art. 10 van het decreet van 26 juli $* 15$ aug 1790 wordt een vergissing hersteld: bij de instandhouding van de bomen met een publiek belang mogen de municipaliteiten niets ondernemen, dan alleen na uitdrukkelijke goedkeuring van de leiding van het departement. De verwijzing naar de generale arresten van het parlement van Douai van 12 mei en 31 juli 1789 vervalt.

bo. Assemblée nationale

s. Louis " par le roi Guignard

ti. volksrepresentanten/gouvemementscommissarissen

RO nr.60(7): 19 frimaire IV (10 dec 1795)

RE nr.51: $20 / 21$ frimaire IV (11/12 dec 1795)

- verwijzing naar: decreet van 26 jul * 15 aug 1790

- cL-intitule: "lettres patentes du Roi, sur le décret de l'Assemblée nationale, du 29 Aoút dernier, en réformation de l'Article $X$ de celles du 15 dudit mois d'Août, sur le décret du 26 Juillet précédlent relatif aux droits de propriété \& voirie sur les chemins publics"

- afkondiging: besluit wolksrepresentanten s. Perès, Portiez (de l'Oise); cs. J. Torfs (secr); 17 brumaire IV ( 8 nov 1795)

1790 (augustus 25) september $2 * 11$

LA II fol 52vo, 67, 74vo-75ro; FA nr.234; rH VI 6, 30,42-43; P I 354-355; cB Ie ser VI 13-16; cL II/ $25-27$

[extract] LOI SUR L'ORGANISATION JUDICIAIRE (artt.2, 3, 9, 10)

Om verkiesbaar te zijn tot vrederechter, of rechter in een rechtbank hoeft men niet in het kanton of departement zelf woonachtig te zijn, na aanvaarding van de benoeming wel. Bloed- en aanverwanten tot de graad wan volle neef kunnen niet tegelijkertijd rechter in dezelfde rechtbank zijn. Rechters, commissarissen van de pouvoir exécutif, griffiers en de gerechtsdeurwaarders zijn in het zwart gekleed. Advocaten dragen geen speciale kleding en mogen geen orde vormen.

\section{bo. Assemblée nationale}

s. Louis, par le roi Guignard

ii. volksrepresentanten bij het Noorder- en het Sambre-en-Maasleger/gouvernementscommissarissen RO nr.76: « nivôse IV (22 dec 1795)

RE nr.99: 11/12 ventôse IV (1/2 mrt 1796)

- N.B. de afgekondigde wetsartikelen maken deel uit van het in paragrafien onderverdeelde besluit van de valksrepresentanten van 2 frimaire IV (23 nov 1795) sur l'organisation de l'ondre judiciaire en matière civile [LA II fol 50ro-76ro; FA nr.234; rH VI 3.45; P VII xli-xivilii]

- rH art.6 lees: artt. 2 en 3

- cB-intinfê" "décret faisant suite au dếcret du 16 août, concernant l'organisation de l'ordre judiciaire, et l"éligibilité aux fonctions judiciaires" 
- cL invinle: "proclamation du Roi, sur un décret de l'Assemblée nationale, faisant suite au décret. concernam l'organisation judiciaire"

" afkondiging: besluit volksrepresentanten s. Pérès, Portiez (de l'Oise)" 2 frimaire IV (23 nov 1795)

\section{0 (aug 31, sep 1) september $2 * 11$}

LA IV fol 58vo-59vo; FA nr.291; rH IX 273-274; P I 352-354; cB le ser VI 7-13; cL IL/1 27-33

[extract] LOI SUR LA FIXATION DES TRAITEMENS DES JUGES, DES ADMINISTRATEURS ET DES FRAIS DE SERVICE DES TRIBUNAUX (art.5)

Van de salarissen van rechters, commissarissen van de pouvoir exécutif, procureurs(généraux)-syndics en andere leden van de administratie wordt, gedifferentieerd naar de respectieve salarissen, een zeker bedrag ingehouden. Het aldus gevormde fonds wordt als droit d" assistance [ = term oorspronkelijk gehanteerd door juristen verbonden aan de chatelet - de gewone koninklijke justitie in de hoofdstad - in de betekenis van presentiegeld; het recht werd geheven, wanneer één der beide procespartijen tot de proceskosten veroordeeld was en uitbetaald aan de procureurs] verdeeld over de aanwezige functionarissen volgens het door de griffier of de secretaris bijgehouden registre de pointe.

bo. Assemblée nationale

ao. comité de constitution

s. Louis, par le roi Guignard

RO nr.207(1): 2 vendemiaire $V(23$ sep 1796)

- het artikel moet worden uitgevoerd als is bepaald in de wet van 16 prairial IV (4 jun 1796); artikel aan de tijdsomstandigheden aangepast

- Code Merlin vermeldt dat dit artikel reeds bij besluit van de volksrepresentanten van 2 frimaire IV (23 nov 1795) zou zijn bekendgemaakt

- cB-intifulé: "décret sur la fixation des traitemens des juges de paix, des tribunaux de district, des membres des directoires de départemens \& de districts, \& des frais de service"

- cL-intitulé: "proclamation du Roi, sur un décret de l'Assemblée nationale ..."

- afkondiging: besluit Directoire exécutif s. L.M. Revellière-Lépeaux (pres), Lagarde (secr-gen); 23 fructidor IV (9 sep 1796)

\section{0 september 6 en $7 * 11$}

LA III fol 75ro-76ro, fol 105; FA nr.234; tH VI 43-45, 97-98; P I 359-361; cB Ie ser VII 28, 30-36; cL. II/1 33-39

[extract] LOI ADDITIONNELLE SUR L'ORGANISATION DE L'ORDRE JUDICIAIRE (artt.1$7,14,17)$

Belastingplichtigen kunnen over de hoogte van hun aanslag in de directe belastingen bij het departementaal bestuur een bezwaarschrift indienen. Burgerlijke rechtsvorderingen met betrekking tol de hoogte van de indirecte belastingen worden in eerste en hoogste aanleg beslist door de departementale rechtbanken. Geschillen omtrent schadeloosstellingen in verband met uit te voeren werken moeten eerst via minnelijke schikking opgelost worden voor de plaatselijke municipaliteit, ofwel in hoogste ressort 
door het departementaal bestuur na het door de vrederechter en assessoren uitgebrachte advies. Departementale rechters houden ook toezicht op zowel de grote als de zijwegen. Voorts blijven alle oude tribunalen onder welke benaming dan ook opgeheven.

bo. Assemblée nationale

s. Louis, par le roi Guignard

ti. volksrepresentanten bij het Noorder- en het Sambre-en-Maasleger/gouvernementscommissarissen RO nr.76 en 84(6): 1 nivôse IV (22 dec 1795) en 7 nivôse IV (28 dec 1795)

RE nt.99 en 72: $11 / 12$ ventôse IV (1/2 mrt 1796) en 21/22 nivôse IV (11/12 jan 1796)

- N.B. de afgekondigde wetsartikelen maken deel uit van het in paragrafen onderverdeelde besluit van de volksrepresentanten van 2 frimaire IV (23 nov 1795) sur l'organisation de l'ordre judiciaire en matière civile [LA II fol 50ro-76ro; FA nr.234; rH VI 3-45; P VII xli-xlviii]

- wetsartikelen aanzienlijk door de volksrepresentanten aan de tijdsomstandigheden aangepast

- cB-intitule: "décret additionnel à celui du 16 Août, sur l'organisation de l'ordre judiciaire"

- cL-intitulé: "proclamation du Roi, sur un décret de l'Assemblée nationale ..."

- afkondiging: besluit volksrepresentanten s. Pérès, Portiez (de l'Oise); 2 frimaire IV (23 nov 1795) en 19 frimaire IV (10 dec 1795); artt.1, 3 en 4 zijn tweemaal bekendgemaakt [RO nr.84(6)]

\section{0 september $20 * 27$}

LA III 159vo-160ro; FA nr.291; rH VIII 291; P I 375-376; cB le ser VI 110-113; cL II/1 131-134

[extract] LOI RELATIVE AUX FRAIS DE POURSUTTES CRIMINELLES, AUX STATUTS QUI DOIVENT RÉGIR LES BIENS CI-DEVANT FEODAUX OU CENSUELS, ET AUX FORMALITÉS QUI TIENNENT AU NANTISSEMENT FÉODAL OU CENSUEL (artt.3-5)

Vanaf de dag der installatie van de districtsrechtbanken in de pays de nantissement [=landstreken in Noord-Frankrijk; nantissement is de feodale rechtshandeling door middel waarvan men in burgerrechtelijke zin het bezit verwerft van een goed, teneinde ervan de eigendom, het vruchtgebruik, de hypotheek enz. te genieten] zijn alle (plechtige) formaliteiten met betrekking tot feodale of cijnsoverdrachten afgeschaft. De transcriptie van de grossen van vervreemdingen of hypotheekovereenkomsten vervangt voorlopig deze vroegere formaliteiten en strekt tot het effectueren ervan. Dit onverminderd het bepaalde in art.35 van het edict [sur les hypothèques] van juni 1771 en de déclaration van 23 juni 1772 [afschaffing van de formaliteiten van nantissement m.b.t. het verkrijgen van een hypotheek op onroerende goederen], daar waar deze wetten zijn bekendgemaakt. De transcriptie van de grossen van de overeenkomsten in een bijzonder register geschiedt door de griffiers der districtsrechtbanken. Het register wordt zonder kosten ter inzage gegeven.

\section{bo. Assemblée nationale}

s. Louis"; plus bas l'archevêque de Bordeaux

ti. minister van justitie Merlin

RO nu.152: 19 prairial IV (7 jun 1796)

- verwijzing naar: edict van juni 1771; déclaration van 23 juni 1772

- N.B.: in het toegezonden arrêté met het extract van de tekst van de wet van $20 * 27$ sep 1790 is de redactionele verwijzing naar het edict en de déclaration onjuist 


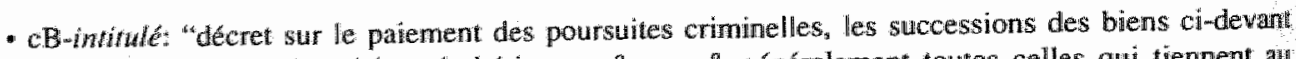
féodaux ou censuels de saisine, deshéritance, \&c .... \& généralement toutes celles qui tiennent au nantissement fédal ou censuel: la forme le prix de la transcription des grosses des contrats d"alienation ou d"hypotheque, \& $c^{\text {" }}$

- afkondiging: besiluit Directoire céćcutif s. Camot (pres), Lagarde (secr-gen); 5 prairial IV (24 mei 1796); intitule afkondigingsbesluit:" "arrêté qui ondonne la publication, dans les neuf départemens réunis le 9 Vendémiaire, an $\mathrm{IV}$, de trois articles de la loi du 27 Septembre 1790 , relative aux formalites a observer pour alienation et l'hypothèque des immeubles dans les pays dits de nantissement"; het besluit bepaalt dat er thans sprake is wan burgerlijke rechtbanken in de departementen in plaats van de vroegere districtsrechubanken voortwloeiend wit de wet van 19 vendémiaire IV (11 okt 1795)

\section{0 oktober $7 * 14$}

LA II fol 106wo; FA nr.234; nH VI 98; P I 394-395; cB le ser VII 14-15; cL IL/1 163-164

\section{[eXtract] DÉCRET QUII RẼGLE DIFFÉRENS POINTS DE COMPÉTENCE DES CORPS ADMI- NISTRATIFS EN MATIERE DE GRANDE VOIRIE (art.1)}

Het beheer van de grote wegen, geattribueerd aan bestuurslichamen, omvat ook het vastleggen van de rooilijn van straten in steden en dorpen die als grote wegen dienst doen.

\section{bo. Assemblée nationale}

ao. comité de constitution

s. Louis; plus bas par le roi Gügnard

ti. volksrepresentanten/gouvernementscommissarissen

RO nr.84(7): 7 nivôse IV (28 dec 1795)

RE nr.72: $21 / 22$ nivôse IV (11/12 jan 1796)

- verwijzing naar: decreet van 6 en 7 sep 1790

- decreet uitgevaardigd n.a.v. geschillen o.m. tussen het departement Haute-Saône en de municipaliteït van Gray

- decreet aangepast aan tijdsomstandigheden

- cB-imitulé: "décret qui détermine les attributions de I"administration de grande voierie, et défend de traduäre les administrateurs devant les tribunaux pour raison de leurs fonctions, mềme sous prétexte d'incompétence"

- cL-intitulé: "proclamation du Roi sur un décret de l'Assemblée nationale ..."

- afkondiging: besluit wolksrepresentanten s. Perès, Portiez (de l'Oise); 19 frimaire IV (10 dec 1795)

\section{0 oktober 14 en $18 * 26$}

LA II fol 56ro-64vo; FA nr.234; rH VI 11-26; P I 415-419; cB Ie ser VII 75-89, 101; cL. II/1 257273

\section{LOI CONTENANT RÉGLeMENT SUR LA PROCÉDURE EN LA JUSTICE DE PAIX}

De wet behelst de bepalingen inzake de procedure bij de vredegerechten: dagvaardingen, verzoeken om een uitspraak door partijen in gerezen geschillen, wraken van de vrederechter, de comparitie, het getuigenverhoor, gerechtelijke plaatsopneming, (voorlopige) vonnissen, de minuten en de uitgifte daarvan, de gerechtskosten. Ten aanzien van de vrederechter in de steden zijn er enige bijzondere bepalingen getroffen. 
bo. Assemblée nationale

s. Louis; l'archeveque de Bordeaux.

ti. wolksrepresentanten bij het Noorder- en het Sambre-en-Maasleger/gouvemementscommissarissen $\mathbb{R O}$ nr.76: 1 nivôse IV (22 dec 1795)

RE nr.99: $11 / 12$ ventôse IV (1/2 mrt 1796)

- N.B.: de wet maakt als \& $\mathrm{V}$ deell uit yan het in paragrafen onderverdeelde besluit van de volksrepresentanten wan 2 frimaire IV (23 nov 1795) sur l'organisation de l'ordre judiciaire en matière civile [LA II fol 50ro-76ro; FA nr.234; rH VI 3-45; P VII xli-xlviii]]

- titel II op 18 okt 1790 gedecreteerd

- met behulp van voetnoten verwezen naar latere wetswijzigingen

- cB-imtitulé: "décret sur la jurisdiction et la compétence des juges de paix"

- afkondiging: besluit volksrepresentanten s. Peres, Portiez (de l'Oise); 2 frimaire IV (23 nov 1795)

\section{0 oktober 23 en 28 november 5}

LA III fol 104, IV fol 24vo-26ro, V fol 1.52ro-154ro; FA mr.291; rH VIII 206, XI 323-328; P I 427440; cB Ie ser VII 120-152; cL II/1 392-427

[extract] LOI RELATIVE À LA dÉSIGNATION DES BIENS NATIONAUX À VENDRE, ETC. (tit.I art.19; tit.II artt.1-11, 13-21; tit.III artt.13-16)

De goederen van opgeheven Franse lichamen, communiteiten en huizen of bezittingen waaraan het bestuur is onttrokken, die gelegen zijn op het grondgebied van vreemde mogendheden, worden door de bestuursassemblëes van het departement en het district, waar de hoofdvestiging (manoir) van de beneficies of de hoofdzetel van de instellingen zich bevindt, bestuurd.

Rechtsvorderingen die door bestuurslichamen worden ingesteld, zijn in naam van de procureur-général-syndic van het departement, op vervolging en ten verzoeke van de districtsprocureur-syndic. De procureur-général-syndic kan geen enkele rechtsvordering instellen dan alleen ingevolge cen besluit van het departementaal bestuur, genomen op advies van het districtsbestuur, op straffe van nietigheid, behoudens eenvoudige invorderingszaken. Degenen die een rechtsvordering tegen een bestuurslichaam willen instellen, dienen de vordering in te stellen tegen de procureur-général-syndic, maar eerst dan als men zich tevoren per eenvoudige memorie tot het desbetreffende bestuwr had gewend en het departementaal bestuur niet binnen één maand uitspraak had gedaan; dit alles eveneens op straffe van nietigheid.

Bestuurslichamen kunnen zelf geen nationale goederen beheren. Zij zijn gehouden deze goederen, ook de onlichamelijke rechten, te verpachten, uitgezonderd gevestigde renten en grondrenten in geld ten bedrage van twintig pond of hoger, welke geïnd worden door de districtsontvanger. De afgekondigde artikelen behelzen voorts bepalingen over de aard en duur der verpachtingen en verhuringen en de toewijzing ervan bij opbod aan gegadigden.

\section{bo. Assemblée nationale}

\$... Louis; l'archevêque de Bordeaux

ti. minister van justitie Merlin

RO nr. 147(5), 195(1) en 248: 11 prairial IV (30 mei 1796), 21 fructidor IV (7 sep 1796) en 23 pluviliose V(11 feb 1797) 
- CB-intitulté: "décret sur la désignation des biens mationaux à vendre dès-à-présent; sur leur adminustration jusqu da la vente; sur les créanciers particuliers des différentes maisons; et sur l'indemnité de la dime infétodée"

- afkondiging: besluit Directoine exécutif s. Camot (pres), Lagarde (secr-gen); 23 floréal IV (12 meil 1796) [rit.I art. 19]; besluit Directoire exếcutif s. L.M. Revellìre-LÉpeaux (pres), Lagarde (secr-gen); 6 fructidor IV (23 aug 1796) [tit.II artt.13-16]: N.B.: het besluit bepaalt dat de afgekondigde artt. van tit.III uitgevoerd worden volgens de modificaties van de wet van 19 nivôse IV (9 jan 1796); en besluat Directoire exécuif s. P. Barras (pres), Lagarde (secr-gen); 1 pluviôse V (20 jan 1797) (tituII artt.1-11, 13-21 met instructieve, werklarende noten (LA en FA nr.291) en te proclameren in elke gemiente "à son de caisse ou de trompe"

1790 november $3 * 17$

LA III fol 104ro; FA nr.291; rH VIII 206-207; P II 4-8; cB Ie ser VIII 13-26; cL II/1 521-535

[extract] LOI RELATIVE À LA VENTE DES DOMAINES NATIONAUX (artt.15, 16, 18)

Zodra er door één persoon of meerdere personen op een kavel ingezet is, maakt het districtsbestuur door publicatie en aanplakking de dag waarop het kavel bij opbod wordt verkocht bekend. Bepaald is verder op welke wijze de veiling dient plaats te vinden.

bo. Assemble nationale

s. Louis; I'archevêque de Bordeaux

ti. minister wan justitie Merlin

RO nr. 147(6): 11 prairial IV (30 mei 1796)

- verwijzing naar: decreten van 14 mei 1790; 25, 26, 29 jun 1790; instructie van 31 mei 1790

- $\mathbf{c B}$ drukt tevens diverse eerdere decreten en instructies af

- $\mathrm{CL}$ en cB: sanctionering op 18 nov 1790

- afkondiging: besluit Directoire exécutif s. Camot (pres), Lagarde (secr-gen); 23 floréal IV (12 mei 1796)

1790 november $20,22,23 *$ december 1

LA IV fol 170ro-207vo; rH IX 328-355; P II 34-53; cB Ie ser VIII 135-208; cL II/2 657-669

\section{LOI CONCERNANT LA CONTRIBUTION FONCIËRE}

De grondbelasting (contribution foncière; belasting op onroerende goederen, grond en gebouwen) zal zonder uitzondering en naar evenredigheid worden geheven op al de eigendom ter zake van de netto-opbrengst, behoudens de belangen de landbouw betreffende. De belastbare opbrengst bestaat uit de gemiddelde netto-opbrengst van een stuk grond, berekend over een reeks van jaren. De grondbelasting is steeds een vast bedrag, jaarlijks door de wetgevende macht te bepalen. De heffing en invordering geschiedt in maandelijkse termijnen in geld. De municipaliteitsbesturen stellen het overzicht van het aantal belastingplichtigen vast, waarbij rekening dient te worden gehouden met de ligging en de aard van de gronden en de eventuele opstallen. In een gering aantal gevallen is vermindering op de hoogte van de aanslag mogelijk, hoofdzakelijk als het recent ontgonnen woeste gronden betreft. Voorts zijn er bepalingen 
die betrekking hebben op het indienen van bezwaren tegen de hoogte van de aanslag, de heffing en invordering ervan. Beslaglegging op de opbrengsten is mogelijk in het geval van het in gebreke blijven van het kwijten van de grondbelasting. Pachters moeten grondbelasting betalen over de door hen gepachte gronden. Deze wet gaat van een uitgebreide instructie opgesteld door de Assemblée nationale vergezeld.

bo. Assemblêe nationale

s. Louis; pllus bas M.L.F. Duport

RO nr. 160(1): 9 messidor IV (27 jun 1796)

- verwijzing naar: edict van 1664 en autres inzake drooglegging en ontginning

- ingevolge art.18 van het arrêté van het Directoire exécutiff van 28 prairial IV (16 jun 1796) zendt de minister van financiën een instructie d.d. 15 fructidor IV (1 sep 1796) aangaande het stelsel van de grondbelasting, welke onder meer bestaat uit een extract van de grondwet van 5 fructidor III (22 augustus 1795), de wet van 23 nov * 1 dec 1790 en het arrêté van het Directoire exécutif van 29 frimaire IV (20 dec 1795) [FA nr.276 fol 106vo-129ro]

- cL geeft ook de Instructie 669-7॥8

- afkondiging: besluit Directoire exécutif s. Carnot (pres), Lagarde (secr-gen); 28 prairial IV (16 jun 1796); de wet verbindend verklaard "en toutes les dispositions qui n"ont pas été abrogées par les lois subséquentes"

\section{0 november $27 *$ december 1}

LA II fol 54wo-55ro; FA nr.234; rH VI 9; P II 56-59; cB le ser VIII 228-236; cL II/2 623-631

[extract] LOI SUR L'ORGANISATION DU TRIBUNAL DE CASSATION (art.4)

Men kan geen eis tot cassatie indienen tegen uitspraken in laatste ressort van vrederechters.

bo. Assemblée nationale

s. Louis; plus bas M.L.F. Duport

ti. volksrepresentanten bij het Noorder- en het Sambre-en-Maasleger/gouvernementscommissarissen RO nr.76: I niwôse IV (22 dec 1795)

RE nr.99: 11/12 ventôse IV (1/2 mrt 1796)

- N.B.: het afgekondigde wetsartikel maakt deel uit van het in paragrafen onderverdeelde besluut van de volksrepresentanten wan 2 frimaire IV (23 nov 1795) sur l'onganisation de l'ordre judiciaire en matière civile [LA II fol 50ro-76ro; FA nr.234; rH VI 3-45; P VII xli-xlviil]]

- cL-intitulé: "loi pour la formation d"un Tribunal de Cassation"

- afkondiging: besluit volksrepresentanten s. Pérès, Portiez (de l'Oise); 2 frimaire IV (23 nov 1795)

\section{0 december $5 * 19$}

LA II fol 134wo-157ro; rH V1 180-215; P II 69-81; cB Ie ser LX 38-7I; cL. II/2 953-984

\section{LOI RELATIVE AU DROIT D'ENREGISTREMENT DES ACTES CIVILS ET JUDICIAIRES, ET DES TITRES DE PROPRIÉTÉ; SUIVI DU TARIF DES MÊMES DROITS}

De wet schaft een groot aantal rechten geheven inzake de registratie af. In de plaats daarvan komt er een uniforme regeling ten aanzien van de kosten (droit d'enregistre- 
ment) die verbonden zijn aan de registratie van door notarissen verleden akten, handelingen van gerechtelijke autoriteiten, onderhandse akten enz. Eveneens geldt dit voor de registratie van de eigendomsoverdracht of het vruchtgebruik van (on)roerende goederen. Bij gebreke van registratie van akten kan men zich daarop in rechte niet beroepen; in dat geval moeten de registratiekosten alsnog worden voldaan, doorgaans tegen een verhoogd tarief. Notarissen, deurwaarders, griffiers enz. hebben jegens hun cliënten ter zake ook verplichtingen. Bureaus voor registratie van akten en aangiftes en voor de inning van de rechten worden in alle steden gevestigd waar het bestuur of de districtsrechtbank zetelt, en voor het overige in de kantons, wanneer zulks nodig wordt geoordeeld. Bij de wet is een tarieflijst gevoegd met de kosten voor de onderscheidene handelingen.

bo. Assemblee nationale

s. Louis; plus bas M.L.F. Duport

ti. minister wan justitie Faipoult

RO nr.91(3): $₫ 9$ nivose IV (9 jan 1796)

RE nr.81: 10/11 pluviôse IV (30/3! jan 1796)

- verwijzing naar: decreten van 3 mei 1790; 14 mei 1790; 25, 26 en 29 jun 1790; 6 en 7 sep 1790

- afkondiging: besluit Directoire exécutif s. Reubell (pres), Lagarde (secr-gen); 9 nivôse IV (30 dec 1795); [P en Code Merlin vermelden ook de afkondiging op 3 fructidor III (20 aug 1795) door de comités de salut public et des finances]

\section{0 december $12 * 1791$ februari 18}

LA II fol 161vo-170vo; FA nr.291; rH VI 222-233; P II 96-99; cB le ser XI 146-156; cL III/1 528538

\section{LOI RELATIVE AU TIMBRE}

De dienst der indirecte belastingen (régie) is belast met de regeling van het zegelrecht en de uitgifte van gezegeld papier. Vrijwel alle authentieke akten en overige officiële en gewaarmerkte bescheiden dienen op gezegeld papier te worden geschreven om rechtskracht te kunnen bezitten. De akten en expedities van het Corps législatif zijn hiervan exempt. De gewone zegelstempels dragen in het randschrift de prijs van het papier en de naam van het departement waarvoor het bestemd is.

bo. Assemble nationale

s. Louis; plus bas M.L.F. Duport

RO nt.91(1): 19 nivôse IV (9 jan 1796)

RE nr.81: $2 / 3$ pluviôse IV (22/23 jan 1796)

- verwijzing naar: decreten wan 5 dec $1790 ; 8$ en 9 okt 1790

- rH, LA, en FA nr.291: publicatie onder de datum van $7 * 11$ feb 1791

- afkondiging: besluit Directoire exécutif s. Reubell (pres), Lagarde (secr-gen); 9 nivôse IV (30 dec 1795) 


\section{LOI QUI REGLE LA FORME DANS LAQUELLE LES DISTRICTS ET LES DEPARTEMENS DONNERONT LEURS AVIS SUR LES PETTTIONS ET REQUETES QUI LEUR SERONT PRESENTÉES}

De districts- en departementsbesturen dienen een register bij te houden dat een samenvatting van de verzoekschriften en het afschrift van de adviezen van de districtsbesturen en de beslissingen van de departementale besturen bevat. De originele bescheiden kunnen aan belanghebbenden overhandigd worden, nadat de adviezen en beslissingen in het bedoelde register zijn ingeschreven.

\section{bo. Assemblée nationale}

s. Louis; plus bas M.L.F. Duport

ti. volksrepresentanten/gouvernementscommissarissen

RO nr.84(8): 7 nivôse IV (28 dec 1795)

RE nr.72: $21 / 22$ nivôse IV (11/12 jan 1796)

- decreet uitgevaardigd n.a.v. geschillen tussen de assemblée van het departement Gard en enige districtsbesturen

- cB-intitule: "décrett sur la forme dans laquelle les Directoires de Districts doivent donner leur avis sur les Requêtes ou Pétitions qui leur sont adressées"

- afkondiging: besluit volksrepresentanten s. Pérès, Portiez (de l"Oise); 19 frimaire IV (10 dec 1795)

\section{1 januari $13 * 19$}

LA II fol 32vo-33vo; FA nr.233; rH VI 69-70; P II 151; cB le ser X 142-143; cL III/1 175-177

\section{LOI RELATIVE AUX SPECTACLES}

Elke burger mag een theater openen en er stukken van diverse aard laten uitvoeren. De opening van het theater moet hij aan de municipaliteit kenbaar maken. Werken van auteurs die reeds vijf jaar of langer zijn overleden, zijn publiek eigendom en mogen in alle theaters worden opgevoerd. De opvoering van werken van levende auteurs mag alleen met hun toestemming gebeuren. Theaterexploitanten en leden van gezelschappen staan onder toezicht van de municipaliteit; municipale ambtenaren kunnen de opvoering van een stuk niet bevelen of verbieden. Bij elke uitvoering is een bewaker, en in de zaal is in ieder geval één burgerambtenaar aanwezig.

\section{bo. Assemble nationale}

ao. comite de constitution

5. Louis; plus bas M.L.F. Duport

ti. volksrepresentanten/gouvernementscommissarissen; minister van binnenlandse zaken Bénézech

RO nr.75 en 101: 30 frimaire IV (21 dec 1795); I ventôse IV (20 feb 1796)

- verwijzing naar: anciens réglemens

- besluit departemental bestuur: exemplaren gezonden aan de municipaliteit "de certe ville"

- cB-intitulé: "decret concernant la liberté des théatres"

- afkondiging: besluit volksrepresentanten s. Pérès, Portiez (de l'Oise); 17 frimaire IV (8 dec 1795); tweede toezending zonder arrêté wan het Directoire exếcturif: 25 pluviôse IV (14 feb 1796) 
LA III fol 206ro-207ro; FA nr.29\|; tH IX 7; P II 184-185, VII Ixxxii-Ixxxiii; cB Ie ser XII vii-ix; cL III/2 978-981

[eXtract] LOI CONCERNANT LA SUPPRESSION DES OFFICES MINISTÉRIELS ET L'ÉTABLISSEMENT DES AVOUÉS (art.13)

Deurwaarders en koninklijke gerechtsdienaren, zelfs die van de vroegere heerlijke rechtspleging, die rechtstreeks ressorteren onder de opgeheven hoge gerechtshoven, zullen uit hoofde van hun vroegere immatriculatie hun functie kunnen blijven vervullen in hetzelfde ressort van ambtsbediening van de daarvoor in de plaats gekomen districtsrechtbanken.

bo. Assemble nationale

s. Louis; plus bas M.L.F. Duport

RO nr.169: 8 thermidor IV (26 jul 1796)

- redactie van het artikel enigszins gewijzigd

- afkondiging: besluit Directoire exécutif s. Carnot (pres), Lagarde (secr-gen); 22 messidor IV (10 jull 1796)

\section{1 februari 11 en $12 * 18$}

LA II fol 76vo-77ro; FA nr.234; rH VI 45-46; P II 200-201; cB Ie ser XI 175-176; cL III/1 557-558

\section{LOI CONCERNANT' LES REQUETES CIVILES}

Requesten-civiel worden, evenals beroepszaken, bij één der drie appelrechtbanken aangebracht. Bovenaan het exploot van de eiser in request-civiel wordt het advies van drie juristen betekend. Voor het overige blijven voorlopig de bepalingen van de ordonnantie van 1667 inzake het request-civiel van kracht. De departementsbesturen moeten een rechtbank toevoegen om tot het getal van drie rechtbanken te komen, wanneer de partijen geen overeenstemming bereiken over de rechtbank die zich over de gronden van het request-civiel moet buigen. In het geval van requesten-civiel aanhangig bij opgeheven rechtbanken, dienen partijen zich te wenden tot de griffie van de departementale rechtbank, die in eerste aanleg van de zaak kennisneemt. Arrondissementsrechtbanken worden aangewezen die inzake een request-civiel uitspraak doen.

\section{bo. Assembléc nationale}

s. Louis; plus bas M.L.F. Duport

ii. volksrepresentanten/gouwemementscommissarissen

RO nr.78(1): 1 nivôse IV (22 dec 1795)

RE nr.99: 11/12 ventôse IV (1/2 mrt 1796)

- verwijzing naar: ordonnantie van april 1667 [ordonnance civile]; wet van 16 aug 1790

- decreet aan tijdsomstandigheden aangepast

- afkondiging: besluit volksrepresentanten s. Pérès; 14 frimaire IV (5 dec 1795) 


\section{INSTRUCTION SUR LA PROCÉDURE PAR REQUÊTE CIVILE}

Het wordt nodig geoordeeld de ingezetenen van de negen départements réunis nader te informeren over het request-civiel, dat in de oude rechtspleging als een laatste rechtsmiddel kon worden aangewend tegen het vonnis en ten overstaan van de rechter die het vonnis heeft gewezen. Thans wordt het als een buitengewoon rechtsmiddel tegen een uitspraak in hoogste aanleg beschouwd. Pothier heeft de beginselen hiervan in zijn verhandeling over de burgerlijke rechtspleging uiteengezet [Robert-Joseph Pothier, Traité de la procédure civile (opus postumum, 1778)]. In de instructie worden deze nader behandeld door middel van de vraagpunten: wat is het request-civiel?; wanneer dit als middel te hanteren?; de rechtbankprocedure te dien aanzien enzovoorts.

ti. gouvernementscommissaris Bouteville

RO nr.96(4): 11 pluviôse IV (31 jan 1796)

- verwijzing naar; Codex Justinianus 2,9,3,7,57,2,7,57,4; Digesten 10,3,18; ordonnantie van Moulins van feb 1566; ordonnantie van april 1667; arresten van 27 nov 1703 en 14 jul 1767 ; wetten van $12 *$ 18 feb $1791 ; 3$ brumaire II ( 24 okt 1793); besluit van 28 frimaire IV (19 dec 1795)

- de wet van 3 brumaire II (24 okt 1793) schaft het request-civiel af

- afkondiging: besluit volksrepresentanten/gouvernementscommissarissen s. Pérès, Portiez (de 1'Oise); 28 frimaire IV (19 dec 1795)

1791 februari $21 * 25$

LA IV fol 208ro-209ro; P II 208-209; cB Ie ser XI 242-243; cL III/I 782-784

LOI QUI ASSUJETTIT À LA CONTRIBUTION FONCIËRE LES DROITS DE PÉAGES ET AUTRES NON SUPPRIMÉS PAR LE DÉCRET DU 24 MARS 1790, LES REVENUS DES CANAUX \&C

Tolrechten en rechten van soortgelijke aard, voor zover niet als heerlijke rechten afgeschaft, vallen onder de grondbelasting ter zake van hun netto-opbrengst. Dit laatste geldt eveneens voor scheepvaartkanalen. De schatting van de opbrengst geschiedt, afhankelijk van de lengte der kanalen, door het districts- dan wel het departementale bestuur. Onder de schatting van de netto-opbrengst dient die van oevers, jaagpaden en kunstwerken te worden begrepen, evenwell niet die van molens en andere bedrijven welke aan een kanaal gelegen zijn. De eigenaren van kanalen dienen een gedetailleerd overzicht van het totaal der opbrengsten en lasten ervan aan het district of het departement te verstrekken.

bo. Assemblée nationale

$\mathrm{S}_{n}$ Louis; plus bas M.L.F. Duport

RO nr. 160(2): 9 messidor IV (27 jun 1796)

- verwijizing naar: decreet van 24 mrt 1790 
- cB-intitulé: "décret qui assujètit à la contribution foncière plusieurs droits non-supprimés, les canaux, droits de péage, \&c."

- afkondiging: besluit Directoire exécutif s. Camot (pres), Lagarde (secr-gen); 28 prairial IV (16 jun 1796); de wet verbindend werklaard "en toutes les dispositions qui n"ont pas été abrogées par les lois subséquentes"

\section{1 februari $24 *$ maart 30}

LA III fol 105ro; FA nr.291; rH VIII 207-208; P II 210-211; cB le ser XI 254-256; cL III/2 11751178

\section{[eXtract] LOI RELATIVE $\lambda$ LA VENTE DES BIENS NATIONAUX (artt.4, 6)}

Op het tijdstip dat verkrijgers van nationale goederen hun eerste betaling verrichten, dragen de districtsbesturen hun de akten van de pachtovereenkomsten en de bijzondere cijnsregisters over, waarbij de verkrijgers hen dechargeren en zich verplichten om de pachtovereenkomsten te tonen telkens als dit wordt gevraagd. Andere bijzondere titels met betrekking tot de verkochte goederen blijven bij het district berusten als deze aan meerdere kopers tegelijk zijn toegewezen. Men kan er een uittreksel van verkrijgen. De huur- en pachtsommen van nationale domeinen en de vruchtopbrengsten dienen in hun geheel aan de verkrijgers te worden voldaan, maar kunnen pas geïnd worden na de bezitsverkrijging, dus na de eerste betaling.

\section{bo. Assemblée nationale}

s. Louis; plus bas M.L.F. Duport

ti. minister van justitie Merlin

RO nr.147(7): 11 prairial IV (30 mei 1796)

- cB-intitulë: "décret relatif aux annuités qui doivent être fournies par les acquéreurs des domaines nationaux"

- afkondiging: besluit Directoire exécutif s. Carnot (pres), Lagarde (secr-gen); 23 floréal IV (12 mei 1796)

\section{1 maart $2 * 17$}

LA If fol 206vo-208vo; FA nr.291; rH V 265-267; P II 230-234; cB Ie ser XII 52-69; cL III/2 918936

[eXtract] DÉCRET PORTANT SUPPRESSION DE TOUS LES DROITS D'AIDES, DE TOUTES LES MAÎTRISES ET JURANDES, ETC. (artt.2, 5-7)

De ambten van pruikenmaker, kapper, badmeester van stoombaden en wisselagent zijn afgeschaft. Tevens zijn de ambten ten behoeve van inspectie, handels- en nijverheidsambachten, meestersbrevetten, rechten geheven voor de verwerving van het meesterschap, alsmede die van colleges van de pharmacie en voorts alle beroepsvoorrechten onder welke benaming afgeschaft. De bestuurders van handwerks- of koopliedengilden zijn gehouden om de bescheiden betreffende het door hen gevoerde beheer over de desbetreffende gelden aan de municipaliteiten over te leggen, die ervan een algemene staat van de activa en passiva opmaken en doorzenden naar de departementsadmini- 
stratie, teneinde de nationale schuld te kunnen vaststellen. Bestaande fondsen bij de verschillende corporaties die later dan twee maanden na afkondiging van dit besluit worden overgelegd, zullen in de districtskas worden gestort, terwijl hun bezittingen als nationale goederen worden verkocht. Een ieder is verder vrij in de uitoefening van een beroep naar keuze, wanneer men tevoren patent heeft verkregen en de hiervoor verschuldigde rechten heeft voldaan.

\section{bo. Assemblée nationale}

s. Louis; plus bas M.L.F. Duport

ti. conseil de gouvernement

RO nr.32(1): 1 frimaire IV (22 nov 1795)

RE nr.31: I frimaire IV (22 nov 1795)

- verwijzing naar: wet van 4 thermidor III (22 jul 1795)

- LA, FA en rH in toegevoegd N.B. verwijzing naar wetten inzake de wijze en de hoogte van de vereffening van door gilden en gezworenen aangegane schulden, alsmede de aflossing van de in deze wet genoemde zaken worden onmiddellijk bekendgemaakt.

- cL-intiulé: "loi portant suppression de tous les droits d'Aides, suppression de toutes les Maîtrises \& Jurandes, \& établissement de Patentes"

- afkondiging: besluit volksrepresentanten s. Pérès, Portiez (de l'Oise); cs. J. Torfs (secr) 19 brumaire IV (10 nov 1795)

\section{1 maart $6 * 27$}

LA II fol 52vo-53vo, 54vo-55vo, 65ro-66vo, 72ro-74vo; FA nr.234; rH VI 7-11, 38-42; P II 240-244; cB le ser XII 94-104; cL III/2 1078-1089

[extract] LOI RELATIVE AU NOUVEL ORDRE JUDICIAIRE (artt.1, 2, 4, 5, 7-10, 13-20; 22-40)

De wet omschrijft de competentie, de taken en bevoegdheden der vrederechters, onder meer aangaande de afwikkeling van opengevallen nalatenschappen. Verder zijn er bepalingen aangaande de procedure die gevolgd wordt voor het bureau de paix omtrent het treffen van een minnelijke schikking bij gerezen geschillen. Daarnaast zijn er bepalingen opgenomen inzake de rechters bij de burgerlijke rechtbanken, de rechtersplaatsvervanger, de griffiers, de burgerlijke rechtspleging, de kosten en de heffingen ter zake.

\section{bo. Assemblée nationale}

s. Louis; plus bas M.L.F. Duport

ti. volksrepresentanten bij het Noorder- en het Sambre-en-Maasleger/gouvernementscommissarissen RO nr. 76: 1 nivôse IV (22 dec 1795)

RE nr.99: 11//12 ventôse (1/2 mrt 1796)

- N.B.: de afgekondigde wetsartikelen maken deel uit van het in paragrafen onderverdeelde besluit van de volksrepresentanten van 2 frimaire IV (23 nov 1795) sur l'organisation de l'ordre judiciaire en matière civile [LA II fol 50ro-76ro; FA nr.234; rH VI 3-45; P VII xli-xIviii]

- verwijzing naar: ordonnantie van 1667, wetten van 16 aug 1790; 2 sep 1790

- bij art.1 wordt ook genoemd de wet van 30 jan 1794 [?]

- wetsartikelen soms ingrijpend gewijzigd en aan de tijdsomstandigheden aangepast

- afkondiging: besluit volksrepresentanten s. Pérès, Portiez (de l'Oise); 2 frimaire IV (23 nov 1795) 
LOI QUI REGLE LES OBLIGATIONS DES FERMIERS ENVERS LES PROPRIETAIRES, RELATIVEMENT A LA DIME, AUX VINGTIEMES, CAPITATION, TAILLE ET AUTRES CONTRIBUTIONS DONT ILS POUVAIENT ETRE TENUS

De wet behelst de betalingsverplichtingen, onder welke benaming ook, die rust op (onder)pachters jegens de verpachters uit hoofde van de pachtovereenkomst. Tot aan het aflopen van de pachtovereenkomst moet de pachter jaarlijks op enigerlei wijze betalen. Eigenaars kunnen de tiende van hun pachters niet meer opeisen krachtens pachtovereenkomsten die na de promulgatie van het decreet inzake de afschaffing van de tiende zijn afgesloten, tenzij dit in het contract uitdrukkelijk bepaald is. Evenmin behoeven de pachters een bijdrage te leveren in de door de verpachter verschuldigde grondbelasting, tenzij ook dil uitdrukkelijk bepaald is in pachtcontracten die zijn afgesloten na de bekendmaking van het decreet inzake de grondbelasting. $\mathrm{Bij}$ een geschil over de hoogte van de pachtsom tussen de eigenarar en de pachter, kan de eigenaar een vordering instellen en een deskundige benoemen om een schatting te maken. Wordt er door de verpachter geen vordering ingesteld, dan kan de pachter door middel van een buitengerechtelijke akte (acte extrajudiciaire) een aanbod inzake de hoogte van de pachtsom doen, onder gelijktijdige benoeming van een deskundige.

\section{bo. Assemblée nationale}

s. Louis; plus bas M.L.F. Duport

RO nr.232(11): 1 nivôse V (21 dec 1796)

- werwijzing naar: decreten van $14,20 * 22$ apr 1790; 20, 22, 23 nov * 1 dec 1790

- cB-intitulé: Décret relatif aux Fermiers des Dimes"

- afkondiging. besluit Directoire exécutif s. P. Barras (pres), Lagarde (secr-gen); 16 frimaire V (6 dec 1796 )

\section{1 maart $15(3,4,5,6,14$ en $) * 27$}

LA II fol 107; FA nr.234; rH VI 99-100; P II 257-260; cB Ie ser XII 170-181; cL III/2 1065-1077

[extract] DÉCRET RELATIF À L'ORGANISATION DES CORPS ADMINISTRATIFS (artt.1, $2,13,14,22,23$ )

Handelingen van de besturen en raden van de districten en van de departementen worden arrêtés genoemd. De minuut van elk arrêté vermeldt het aantal personen, dat aan de beraadslagingen deelgenomen heeft. Rechtsvorderingen betrekkelijk de nationale domeinen of publieke eigendommen kunnen niet zonder machtiging van het departementaal bestuur worden ingesteld; deze worden ingesteld in naam van de procureurgénéral-syndic van het departement. Wanneer departementale besturen geen voldoende inlichtingen van de municipaliteiten of de districtsbesturen verkrijgen, kunnen zij op kosten van de lagere overheden twee commissarissen ter zake benoemen. De departementale besturen moeten voorts elke maand een beredeneerd overzicht van de departementale aangelegenheden aan de minister van binnenlandse zaken sturen. 
bo. Assemblëe nationale

ao. comité de constitution

s. Louis; plus bas M.L.F. Duport

ti. volksrepresentanten/gouvemementscommissarissen

RO nr.84(9): 7 nivôse IV (28 dec 1795)

RE nr.72: 21/22/nivôse IV (11/12 jan 1796)

- art.2 gedeeltelijk afgekondigd

- cL-intizulë: "Ioi contenant des dispositions relatives à l'organisation des corps administratifs".

- afkondiging: besluit volksrepresentanten s. Péres, Portiez (de l'Oise); 19 frimaire IV (10 dec 1795)

\section{1 maart 16,17 * april 10}

LA IV fol 209ro-210vo; P II 262-263; cB Ie ser XII 187-188; cL IV/1 145-147

\section{LOI RELATIVE AUX CONTRIBUTIONS FONCIÈRE ET MOBILIAIRE}

De opbrengst van de grondbelasting voor het jaar 1791 wordt in haar geheel in de nationale schatkist gestort, de belasting op roerende goederen grotendeels. De restsom staat ter beschikking van de wetgevende macht en de departementale besturen. Belastingbetalers die kunnen aantonen een som te hebben bijgedragen groter dan éénzesde gedeelte van hun netto-opbrengst, gerekend naar de hoofdsom van de grondbelasting hebben recht op reductie. Ten behoeve van de vorming van een fonds voor nietinvorderbare posten wordt er over de hoofdsom van de grondbelasting een opgeld van een stuiver per pond geheven, dat deels ter beschikking staat van de wetgevende macht en deels bestemd is voor de departementale besturen. Door middel van opcenten geheven op zowel de belasting op roerende goederen als de grondbelasting dienen de departementen, districten en de municipaliteiten in de heffings- en invorderingskosten te voorzien. De opcenten worden in een aparte kolom op het kohier pondspondsgewijze vermeld.

\section{bo. Assemblée nationale}

s. Louis; plus bas M.L.F. Duport

RO nr. I60(3): 9 messidor IV (27 jun 1796)

- werwijzing naar: decreet van 13 jan 1791

- cB-intitulé: "décret relatif à la fixation des contribution foncière et mobiliaire"

- afkondiging: besluit Directoire exécutif s. Carnot (pres), Lagarde (secr-gen); 28 prairial IV (16 jun 1796); de wet verbindend verklaard "en toutes les dispositions qui n'ont pas été abrogées par les lois subséquentes"

\section{1 maart 27 , juni 15 , juli $12 * 28$}

LA II fol 15vo-23ro; FA nr.233; rH V 397-409; P III 105-109; cB Ie ser XII 342-343, XVI 155-167; cL V/1 493-506

\section{LOI RELATIVE AUX MINES}

Mijnen en groeven voor de winning van ertsen en dergelijke staan ter beschikking van de staat, in die zin dat de exploitatie kan plaatshebben met vergunning an de staat onder gelijktijdige schadeloosstelling van de grondeigenaar. De winning van zand, 
klei, steen, mergel enzovoorts kan daarentegen zonder vergunning door de eigenaren geschieden. Wanneer zij de exploitatie niet zelf ter hand nemen, mogen anderen in het geval het openbare belang ermee gediend is (wegen, bruggen, kanalen) tot exploitatie overgaan, wederom onder schadeloosstelling van de eigenaren. De laatsten hebben altijd voorrang en de vrijheid om tot exploitatie over te gaan; de vergunning hiervoor kan hun niet geweigerd worden. Mijnbouw- en ontginningsconcessies mogen niet de termijn van vijftig jaar overschrijden. Bij de winning dient men steeds te waken voor het toebrengen van schade aan andermans eigendommen, dan wel te voorzien in een schadeloosstelling. De departementale besturen hebben in dezen een toezichthoudende taak. Geschillen inzake de exploitatie en dergelijke worden ter beslissing opgedragen aan de vrederechter of de districtsrechtbank. Voor ijzermijnen gelden afwijkende en aanvullende bepalingen. Het inrichten van ijzersmelterijen kan alleen geschieden met een vergunning afgegeven door het Corps législatif, op advies van het departement. Met een dergelijke vergunning is de houder gerechtigd exploraties te verrichten, behalve op ingezaaide akkers of op akkers met nog te velde staande gewassen.

\section{bo. Assemblee nationale}

ao. comités réunis, des finances, d'agriculture \& de commerce, des domaines \& des impositions

s. En vertu des décrets des 21 \& 25 juin 1791: pour le roi signé M.L.F. Duport

ti. volksrepresentanten/gouvernementscommissarissen

RO nur.68: 25 frimaire IV (16 dec 1795)

RE nr.63: $13 / 14$ nivôse IV (3/4 jan 1796)

- verwijzing naar: decreet van 22 dec 1789 en niet nader angeduide ordonnanties.

- afkondiging: besluit volksfepresentanten s. Portiez (de l'Oise), cs. Delcambe (secr); 29 brumaire IV (20 nov 1795)

\section{1 maart $28 *$ april 1}

LA I fol 208vo-209vo; FA nr.291; rH V 267; P II 276-277; cB le ser XII 348-351; cL IV/1 34-37

\section{[extract] LOI RELATIVE AUX COMMUNAUTÉS D'ARTS ET MÉTIERS (art.7)}

Alle huurovereenkomsten met gilden en communiteiten van na 1 april [1791] zullen worden ontbonden. Aan eigenaren of hoofdhuurders zal als schadeloosstelling door de districtspenningmeester zes maanden huur worden uitgekeerd op vertoon van de gewaarmerkte grosse of expeditie van het huurcontract. In geval van teruggave van de goederen in de oorspronkelijke staat, geschiedt de liquidatie door de municipaliteiten onder toezicht van de departementale besturen. Bestaat er geen huurcontract dan bedraagt de schadeloosstelling slechts drie maanden huur.

\section{bo. Assemblée nationale}

s. Louis; plus bas M.L.F. Duport

ti. conseil de gouvermement

RO nr.32(2): I frimaire IV (22 nov 1795)

RE nr.31: I frimaire IV (22 nov 1795)

- LA, EA en rH in noot van na 1 germinal IV (21 mrt 1796)

- cl-intifulé: "loi relative aux particuliers reçus dans les Maîtrises \& Jurandes des Süx Corps de marchands ou communautés d'arts \& métiers de la ville de Paris" 
- afkondiging: besluit volksrepresentanten s. Pérès. Portiez (de l'Oise); cs. J.Torfs (secr); 19 brumaire IV (10 nov 1795)

1791 april $8,12,14 * 27$

LA V 81vo; FA nr.291; rH X 256; P II 302-305; cB Ie ser XIII 118-127; cL IV/1 367-377

[eXtract] LOI RELATIVE AUX CRÉANCIERS DES MAISONS, CORPS, COMMUNAUTÉS ET ÉTABLISSEMENS SUPPRIMÉS (tit.I art.1)

Alle schuldeisers die een vordering hebben op opgeheven communiteiten en instellingen, zijn gehouden de vereffening van hun schuldvorderingen aan de koninklijke commissaris, directeur-generaal van de verevening van schuldvorderingen op de staat, voor te leggen in de voorgeschreven vorm, met inachtneming van de uitzonderingen en modificaties.

bo. Assemblëe nationale

ao. comité central de liquidation

s. Louis; plus bas M.L.F. Duport

RO nr.232(2): I nivôse V (21 dec 1796)

- verwijzing naar: wet van 23,28 okt * 5 nov 1790

- cB-intitulé: "Décret relatif a la liquidation des dettes contractées par les Corps, Communautés \& établissemens supprimés"

- afkondiging: besluit Directoire exécurif s. P. Barras (pres), Lagarde (secr-gen); 16 frimaire V (6 dec 1796): opmerking: dit artikel afgekondigd ter uitwoering van het bepalde in art. 19 van de wet van 15 fructidor IV (1 sep 1796), houdende de opheffing van de religieuze instellingen in het voormalige België

1791 april $28 *$ mei 8

LA II fol 77vo-78ro; FA nr.234; rH VI 47; P II 339; cB le ser XIII 194-195; cL IV/1 501

DÉCRET RELATIF AUX TRIBUNAUX ÉTABLIS DANS LES VILLES OỦ L'ORDONNANCE DE 1667 N'A ÉTÉ NI PUBliée, NI EXÉCUTÉE; ET QUI PORTE QUE L'ARTICLE 3 dU DÉCRET DU 12 FÉVRIER 1791, RELATIF AUX REQUÊTES CIVILES, SERA OBSERVÉ POUR LES ARRÊTS DU CI-DEVANT PARLEMENT DE DOUAY

De rechters en procureurs bij de rechtbanken, gevestigd in steden waar de ordonnantie van 1667 niet is afgekondigd en in werking gebracht, houden zich aan de procedurereglementen die gebruikelijk zijn, voor zover deze niet strijdig zijn met de bepalingen van het decreet van 6 maart 1790. Pleidooien van partijen dienen in ieder geval te worden aangehoord. Voorts dient het decreet van 11 en 12 februari 1790 in acht genomen te worden voor wat betreft revisies ingesteld tegen de arresten van het vroegere parlement van Douai.

bo. Assemblée nationale

s. Louis; plus bas M.L.F. Duport

ti. volksrepresentanten/gouvernementscommissarissen

RO nr.78(2): I nivôse IV (22 dec 1795) 
RE nr.99: 11/12 wentớse IV (1/2 mrt 1796)

- verwijzing naar: ordonnantie wain 1667; decreten van 11/12 feb 1791;6 mrt 1791

- LA, FA, rH vermelden als datum van uitvaardiging 17 mei 1791

- art.2 dient zo te worden uitgelegd dat dit gelditen aanzien van de arresten van de vroegere soevereine howen die hier tle lande bestonden wór de aansluiting bij de Franse Republiek

- afkondiging: besluit volksrepregentanten s. Pérès; 14 frimaire IV (5 dec 1795)

1791 mei $16,18 * 27$

P II 366-37I; cB le ser XIV 204-219; cL IV/1 873-890

\section{LOI RELATIVE A'ORGANISATION DE LA REGIE DES DROITS D'ENREGISTREMENT ET AUTRES Y REUNIS}

Het decreet behelst de organisatie van de dienst der inning der registratierechten, van het zegelrecht, het hypotheekrecht, van de domeinrechten enzovoorts. In het bijzonder behelst het decreet bepalingen ten aanzien van het bij de dienst werkzame personeel en zijn bezoldiging, alsmede de na te leven bepalingen aangaande de generale discipline inzake de inning.

bo. Assemblée nationale

s. Louis; plus bas M.L.F. Duport

ti. minister van financiën Faipoult

RO nr.[91]: 19 nivôse IV (9 jan 1796)

- verwijzing naar: decreten van 5 dec 1790; 8 mrt 1791

- cB-imtitulê:" "décret relatif à l"organisation de la Régie des droits d"enregistrement, timbre, hypothèques et de Domaines nationaux corporels elt incorporels"

- afkondiging: besluit Directoive exécutiff s. Reubell (pres), Lagarde (secr-gen); 9 nivôse IV (30 dec 1795); van afkondiging in het departement Nedermaas blijkt niet met zekerheid: RO noch LA noemen het decreet, evenmin wordt in de brief van de minister van financiën Faipoult aan het departementale bestuur d.d. 13 nivôse IV (3 jan 1796) [exh 19 nivôse IV] [FA nr.325] uitdrukkellijk gewag gemaakt van afkondiging; daarentegen vermelden P II x, VII cxvii en de Code Merlim II 409 wel de arkondiging, de laatste bij beslunit van het Directoire exếcutif van 29 nivôse IV (19 jan 1796)

1791 mei 24 , juni $25,27,30$, juli $2,4,5,8 * 10$

LA III fol 133vo-159ro; P III 82-98; cB le ser XVI 79-134; cL V/\| 38-92

\section{LOI CONCERNANT LA CONSERVATION ET LE CLASSEMENT DES PLACES DE GUERRE ET POSTES MILITAIRES, LA POLICE DES FORTIFICATIONS ET AUTRES OBJETS Y RELATIFS}

De wet onderscheidt vestingsteden en militaire posten in drie gradaties, naar gelang hun belangrijkheid. Er worden voorts drie omstandigheden onderscheiden: "staat van vrede", "staat van oorlog" en "staat van beleg". Alleen in het laatste geval gaan alle civiele bevoegdheden inzake de openbare orde en het bestuur over op de garnizoenscommandant. De wet behelst voorts een groot aantal bepalingen inzake het militaire personeel, de betrekkingen met de burgerlijke autoriteiten, de militaire objecten, de kazernering van de soldaten en het beheer van de militaire gebouwen. 
bo. Assemblée nationale

bo. comitë militaire

s. en vertu des décrets des 21 \& 25 juin dernier: pour le Roi signé ML.F Duport

ti. minister van oorlog

RO nr. 105: 7 ventôse IV (26 feb 1796)

- verwijzing naar: ordonnantie van $18 \mathrm{mrt} 1776$

- afkondiging onzeker: geen arrêté van het Directoire exécutiff; op 7 pluwiôse V (26 jan 1797) $[=$ Code $\mathrm{Merin}]$ wordt de wet gedeeltelijk afgekondigd

\section{1 juni $7 * 10$}

LA IV fol 210vo-2IIvo; P III 5; cB le ser XV 96-97; cL IV/2 1086-1087

\section{LOI RELATIVE AUX RETENUES A FAIRE SUR LES RENTES CI-DEVANT SEIGNEURIA- LES, FONCIÈRES, PERPÉTUELLES OU VIAGÈRS}

Debiteuren van de vroegere heerlijke renten of cijnzen, grondrenten en altijddurende en liffrenten, hetzij in geld, hetzij in natura, hetzij door prestatie in een gedeelte van de vruchten, zijn bevoegd ter zake van de grondbelasting tot éénvijfde van het bedrag of een andere prestatie in te houden voor het jaar 1791 en volgende, onverminderd de nakoming van pachtcontracten en andere overeenkomsten opgesteld onder de voorwaarde van niet-inhouding van de koninklijke belastingen. Wanneer zulks niet bedongen is, kunnen de debiteuren gelden tot éénvijfde inhouden over de opbrengst van een kapitaal dat tegen $5 \%$ rente is uitgezet. Is het kapitaal niet bekend dan kan de inhouding niet meer bedragen dan ééntiende van de rente of lijfrente. De inhouding geschiedt op het moment van kwijting van de rente, of nakoming van de verplichting in geld of in natura.

\section{bo. Assemblée nationale}

s. Louis; plus bas M.L.F. Duport

RO nr.160(4): 9 messidor IV (27 jun 1796)

- verwijzing naar: wet van 23 nov * I dec 1790

- cB-intitulé: "décret relatif à la retenue que les débiteurs de tentes sont autorisés a faire"

- afkondiging: besluit Directoire exécutif s. Carnot (pres), Lagarde (secr-gen); 28 prairial IV (16 jun 1796); wet verbindend verklaard "en toutes les dispositions qui $n$ "ont pas étế abrogées par les lois subséquentes"

\section{1 juni $10 * 17$}

LA III fol 1ro-3ro; FA nr.291; rH VI 234-236; P III 12-13; cB le ser XV 129-131; cL IV/2 12181221

LOI ADDITIONNELLE À CELLE DU TIMBRE, ET QUI EXEMPTE DE CETTE FORMALITÉ LES REGISTRES DES TRIBUNAUX, MINUTES DE JUGEMENS ET AUTRES $Y$ DESIGNES

De wet geeft aanvullende regels inzake het zegelrecht. Niet langer zijn alle handelingen van overheden of gerechtelijke autoriteiten aan het zegelrecht onderworpen, bij voorbeeld de registers en minuten van rechtbanken en vredegerechten, alsmede de registers en handelingen van bestuurslichamen, wanneer zij althans geen particuliere 
belangen behelzen. In bepaalde gevallen vallen dergelijke handelingen wel onder het zegelrecht, doch moet de belanghebbende dit bedrag kwijten.

bo. Assembléte nationale

s. Louis; phus bas M.L.F. du Port RO nr.91(2): 19 nivôse IV (9 jan 1796)

RE nr.81: 2/3 pluviôse IV (22/23 jan 1796)

- verwijzing naar: wet van 7 * 18 feb 1791

- cB-intitulé: "décret additionnel à la loi du timbre"

- afkondiging: besluit Directoire exécutif s. Reubell (pres), La Garde (secr-gen); 9 nivôse IV (30 dec 1795)

1791 juni $14 * 17$

LA I fol 209vo-212vo; FA ar.291; rH V 268-270; P III 22; cB Ie ser XV 167-169; cL IV/2 12101213

\section{DÉCRET AUX ASSEMBLÉES DES CITOYENS D'UN MÊME ÉTAT OU PROFESSION}

De opheffing van alle standen en gilden is vastgelegd in de Franse grondwet: heroprichting in welke vorm dan ook is verboden. Burgers van eenzelfde stand of beroepsgroep mogen zich niet aaneensluiten, noch regelingen en dergelijke treffen. Eventuele beraadslagingen hieromtrent worden nietigverklaard door bestuurlijke of municipale instanties. Indien burgers toch dergelijke handelingen verrichten, krijgen de aanstichters een boete opgelegd tot 500 pond elk en verliezen zij gedurende één jaar hun burgerlijke rechten. Als er sprake is van bedreigingen of geweld tegen arbeiders wordt er vervolging ingesteld.

\section{bo. Assemblée nationale}

s. Louis; plus bas M.L.F. Duport

ti. conseil de gouvernement

RO nr.32(3): I frimaire IV (22 nov 1795)

RE nr.31: 1 frimaire IV (22 nov 1795)

- tekst d.m.v. N.B. aan de tijdsomstandigheden aangepast

- cL-inimulé: "loi relative aux Assemblées d"Ouvriers \& Artisans de même état \& profession"

- afkondiging: besluit volksrepresentanten s. Pérès, Portiez (de l'Oise); cs. J.Torfs (secr); 19 brumaire IV (10 nov 1795)

\section{1 juli $3 * 10$}

LA III fol 105ro-112vo; FA nr.29!; rH VIII 208-224; P III 71-77; cB le ser XVI 15-30; cL V/I 13 127

\section{LOI EN FORME D'INSTRUCTION SUR DIVERS OBJETS CONCERNANT L'ALIÉNATION DES DOMAINES NATIONAUX}

De instructie van de Assemblée nationale gericht aan de lagere bestuurslichamen behelst een nadere uitleg over de wijze van handelen bij de verkoop van de nationale domeingoederen en de toewijzing ervan aan particulieren. Onregelmatigheden en 
onduidelijkheden hebben zich met name voorgedaan bij: onvermogende bieders en daarmee samenhangend de teruggave van gekocht onroerend goed door de koper aan medestanders (élection d"ami) en het benoemen van lastgevers (nomination de commiand); perceelsgewijs bieden in plaats van bieden op het object in zijn geheel; de verkoop of verpachting voor het leven aan titularissen door hun kapittels; en de oogst en de verdeling der vruchten van aan municipaliteiten en privé-personen verkochte nationale domeinen.

bo. Assemblée nationale

s. en vertu des décrets des 21 \& 25 juin 1791: pour le roi signé M.L.F. Duport

ti. minister van justitie Merlin

RO nr. 147(8): 11 prairial IV (30 mei 1796)

- verwijzing naar: wetten van 26 mrt 1790; 17 mei 1790; 25 jul 1790; (17?) 18 nov 1790; 15 dec 1790; 27 apr 1791; decreten van 24 jul 1790; 24 feb 1791; 28 feb 1791; dispositions des loix anciennes

- cB-intitulé: "décret et instruction sur l'adjudication et vente des biens nationaux"

- afkondiging: besluit Directoire exécutiff s. Carnot (pres), Lagarde (secr-gen); 23 floreal IV (12 mei 1796)

1791 juli $12,13 * 20$

LA IV fol 211vo-212vo; P III 110; cB Ie ser XVI 167-169; cL V/1 396-397

\section{LOI RELATIVE À L'ÉVALUATION DES BOIS ET FORÊTS ET DES TOURBIÈRES}

De schatting voor de aanslag in de grondbelasting van bosgebieden is afhankelijk van de ouderdom van de bossen en of er al dan niet geregeld houtkap plaatsheeft. Bos jonger dan dertig jaar wordt als kreupelhout beschouwd. Het districtsbestuur voorziet in de schatting van de opbrengst van houtopstanden als deze zich uitstrekken over het grondgebied van meerdere dorpsgemeenschappen; deze wordt op het kohier van iedere dorpsgemeenschap ingeschreven. Op soortgelijke wijze voorziet het departementale bestuur hierin als het bosareaal zich over meerdere districten uitstrekt. De opbrengst van gronden in gebruik voor de turfwinning wordt tien jaar lang dubbel zo hoog geschat. $\mathrm{Na}$ afloop van deze termijn worden deze gronden aangeslagen als de overige grondeigendom.

\section{bo. Assemblée nationale}

s. en vertu des décrets des 21 \& 25 juin 1791: pour le roi signé M.L.F. Duport

RO nr. 160(5): 9 messidor IV (27 jun 1796)

- verwijzing naar: wet van 23 nov * 1 dec 1790; decreten van 21 jun 1791; 25 jun 1791

- cB-intizulé: "décret concernant l'évaluation et la cotisation à la contribution foncière des bois et forêts, et des terreins exploités en tourbières"

- afkondiging: besluit Directoire exécutif s. Carnot (pres); Lagarde (secr-gen); 28 prairial IV (16 jun 1796); de wet verbindend werklaard "en toutes les dispositions qui n'ont pas été abrogées par les lois subséquentes" 
[extract] DECRET SUR LA POLICE MUNICIPALE ET CORRECTIONNELLE (tit.I artt.1-41, 44-47; tit.II artt.1-42)

In de algemene bepalingen betreffende de openbare orde wordt aan de municipale lichamen opgedragen jaarlijks een staat van de hoedanigheid der inwoners op te stellen. Logementhouders en herbergiers dienen een register van overnachtingen bij te houden. Het houden van kansspelen is verboden. Voorts zijn er bepalingen die door municipale ambtenaren in acht genomen behoren te worden bij het constateren van overtredingen. In het decreet wordt de hoogte van de straf of boete vermeld voor een reeks politiemaatregelen op het gebied van gebouwen, opstootjes, voedsel, medicamenten en dergelijke. Eveneens worden een reeks delicten en straffen van correctioneel toezicht omschreven, alsmede het regime in de gevangenissen (maison de correction). De correctionele straffen bestaan uit boetes, verbeurdverklaring en gevangenisstraf.

\section{bo. Assemblée nationale}

ao. comité de conssitution

s. en vertu des décrets des 21 \& 25 juin 1791: pour le roi signé M.L.F. Duport

ti. gouvernementscommissaris Bouteville

Ro nr.89(2): 16 nivôse IV (6 jan 1795)

RE nr. 136: 14/15 floréal IV (3/4 mei 1796)

- verwijzing naar: reeds bestaande règlemens de police op diverse terreinen; décret sur l'organisation judiciaire; code pénal [van 1791]

- afkondliging: besluit volksrepresentanten/gouvernementscommissarissen s. Pérès, Portiez (de l'Oise); 24 frimaire IV (15 dec 1795)

\section{1 juli $19 *$ augustus 6}

LA. II fol 33wo-34ro; FA nr.233; rH VI 71-72; P III 126-127; cB le ser XVI 2411-242; cL V/2 813814

\section{DÉCRET RELATIF AUX SPECTACLES}

Geen enkel werk van levende auteurs mag worden opgevoerd zonder hun formele en schriftelijke toestemming of die van hun erfgenamen binnen vijf jaar na overlijden van de auteur, op straffe van verbeurdverklaring van de opbrengst van de opvoeringen. Overeenkomsten gesloten tussen auteurs en schouwburgexploitanten zijn volledig vrij. Op de honoraria die auteurs, of hun rechtverkrijgenden, met de schouwburgexploitanten zijn overeengekomen, kan door de schuldeisers van de schouwburgexploitanten geen beslag worden gelegd.

bo. Assemblée nationale

ao. comite de constitution

cols. J.A. Creusé Latouche, Chateauneuf Randon, Vadier, Delavigne (secr)

s. en vertu des décrets des 21 \& 25 juin 1791: pour le roi signé M.L.F. Duport

ti. volksrepresentanten/gouvernementscommissarissen 
RO nr.75: 30 frimaire IV (21 dec 1795)

- FA en rH: "extrait du procès-verbal de l'Assemblée nationale"

- besluit departementaal bestuur: exemplaren aan de municipaliteit "de cette ville" gezonden

- verwijzing naar: wetten van 16 aug 1790 ; 13 jan 1791

- afkondiging: besluit volksrepresentanten s. Pérès, Portiez (de l'Oise); 17 frimaire TV (8 dec 1795)

\section{1 juli $30 *$ augustus 6}

LA I fol 286ro-287ro; FA nr.291; rH V 292; P III 172-173; cB le ser XVI 385-386; cL V/2 816-817

[extract] DÉCRET PORTANT SUPPRESSION DES ORDRES DE CHEVALERIE (artt. 1, 3, 4)

Alle ridderorden, en bijgevolg alle onderscheidingen naar geboorte, zijn afgeschaft. Niemand in Frankrijk mag een dergelijke waardigheid verlenen of aanvaarden. Wanneer men zulks toch vraagt of verkrijgt, ook van buitenlandse orden, verliest men de waardigheid van en het recht om Frans staatsburger te zijn.

bo. Assemblée nationale

s. en vertu des décrets des 21 \& 25 juin 1791: pour le roi signé M.L.F. Duport

ti. wolksrepresentanten/gouvernementscommissarissen

RO nr.61(1): 19 frimaire IV (10 dec 1795)

RE nr.52: 20/21 frimaire IV (11/12 dec 1795)

- verwijzing natar: decreet van 19 juni 1790

- cL-imitulé: "loi relative à la suppression des ordres de Chevalerie"

- afkondiging: besluit volksrepresentanten s. Pérès, Portiez (de l"Oise); 17 brumaire IV (8 nov 1795)

\section{1 augustus $19 *$ september 12}

LA V 4vo; FA nr.291; rH X 172; P III 222-224; cB Ie ser XVII 187-294; cL V/2 1171-1178

\section{[extract] LOI RELATIVE À LA RÉGIE DES DOMAINES NATIONAUX CORPORELS ET INCORPORELS, NON ALIÉNÉS NI SUPPRIMÉS (art.4)}

De opbrengsten uit nationale domeingoederen, alsmede de afkoop van onlichamelijke rechten, kunnen alleen worden betaald aan ambtenaren van de régie. Zij zijn gehouden de betaling van de opbrengsten en vervallen rechten, alsmede de prijs van de toewijzing van bossen, te vervolgen. Bij achterstalligheid der debiteurs wordt door middel van de afgifte van dwangbevelen tot de invordering overgegaan.

\section{bo. Assemblé nationale}

ao. comités réunis des contributions publiques, des douanes, d'aliénation, ecclésiastique \& des finances

s. en vertu des décrets des 21 \& 25 juin 1791: pour le roi signé M.L.F. Duport

RO nr. 214: 7 brumaire $V$ (28 okt 1796)

RE nr.203: $17 / 18$ brumaire $V(7 / 8$ now 1796$)$

- cB-iminulé: "décret qui fixe l'époque à laquelle les régisseurs nationaux de l'enregistrement, domaines \& droits y réunis, commenceront la régie de tous les domaines nationaux, corporels ou incorporels"

- afkondiging: besluit Directoire exécunif S. L.M. Revellière-Lépeaux (pres), Lagarde (secr-gen); 30 vendémiaire V (2l okt 1796) 
[eXtract] DÉCRET RELATIF AUX MARQUES DISTINCTIVES DES ORDRES SUPPRIMÉS

Geen enkel Frans staatsburger mag langer onderscheidingstekenen van opgeheven orden dragen.

bo. Assemblée nationale

s. Louis; plus bas M.L.F. Duport

ti. volksrepresentanten/gouvernementscommissarissem

RO nr.6I(2): 19 frimaire IV ( 10 dec 1795)

RE nr.52: $20 / 21$ frimaire IV (11/12 dec 1795)

- decreet gedeeltelijk afgekondigd en aan de tijdsomstandigheden aangepast

- afkondiging: besluit volksrepresentanten s. Pérès, Portiez (de l'Oise); 17 brumaire IV (8 nov 1795)

1791 september 15 (augustus 20, en 2, 3, 4) * 29

LA II fol 107vo-108vo; FA nr.234; rH VI 100-102; P III 271-286; cB Ie ser XVIII/1 160-192; cL $V / 2$ 1391-1433; F\॥89-212

[extract] DÉCRET SUR L'ADMINISTRATION FORESTIÈRE (tit.VIII)

De corps administratifs en municipaliteiten zijn, elk in hun eigen ressort, belast met de zorg voor het behoud van het bosareaal, eventueel met dwang wanneer de bosbeambten daarom verzoeken. Inspectie ter plaatse is toegestaan. De districtsbesturen hebben de taak aanbestedingen tot verkoop van bosareaal te doen, alsmede de aanbestedingen van werken tot het onderhoud en de verbetering van het bos. Zij kunnen de municipaliteiten daarmee belasten. Bij aanbestedingen dienen de gegadigden een borg te stellen.

bo. Assemble nationale

ao. comités réunis des domaines, de la marine, des finances, de l"aliênation des biens nationaux et d"agriculture

s. Louis; plus bas M.L.F. Duport

ti. volksrepresentanten/gouvernementscommissarissen

RO nr.84(10): 7 nivôse IV (28 dec 179.5)

RE nr.72: $21 / 22$ nivôse IV (11/12 jan 1796)

- afkondiging: besluit wolksrepresentanten s. Pérès. Portiez (dle l'Oise); 19 frimaire IV (10 dec 1795)

\section{1 september $17 *$ oktober 16}

LA I fol 212vo-213ro; FA nr.291; rH V 270-271; P III 304; cB Ie ser XVIII/1 363-364; cL VI 403404

DECRET RELATIF À LA RESTITUTION DES MARCHANDISES ET EFFETS SAISIS PAR LES ANCIENS GARDES OU SYNDICS DES CI-DEVANTS CORPS ET COMMUNAUTÉS D'ARTS ET MÉTIERS, DONT LA CONFISCATION N'AURA PAS ÉTÉ JUGÉE 
Handelswaar en goederen waarop door gildemeesters beslag is gelegd en waarover geen verbeurdverklaring is uitgesproken, wordt aan de rechthebbenden teruggegeven. Alle rechtsgedingen ten gevolge van het beslag op de goederen, alsmede de processen tussen de gilden hieromtrent zijn en blijven tenietgedaan.

\section{bo. Assemblè nationale}

s. Louis; plus bas M.L.F. Duport

ii. conseil de gouvernement

RO nr.32(4): I frimaire IV (22 nov 1795)

RE nr.31: 1 frimaire IV (22 nov 1795)

- cL-intitulé: "loi relative aux Saisies faites à la requête des ci-devant Corps \& Communautés d"Arts \& Métiers"

- afkondiging: besluit volksrepresentanten s. Pérès, Portiez (de l'Oise); cs. J. Torfs (secr); 19 brumaire IV (10 now 1795)

\section{1 september $17 * 23$}

LA II fol 80ro; FA nr.234; rH VI 51; P III 305; cB Ie ser XVIII/1 362-363; cL V/2 1280-1281

\section{[extract] DECRET SUR LES VACANCES DES TRIBUNAUX}

De rechtbanken genieten gedurende twee maanden (van medio september tot medio november) vacantie. Rechters evenwel die de functie van directeur $d u$ juré vervullen, blijven hun taak uitoefenen, in die hoedanigheid of om te beslissen over zaken van korte behandeling. Gedurende de vacantie blijven eveneens tien leden van het tribunal de cassation werkzaam om te beslissen over de toelating van verzoekschriften.

\section{bo. Assemblée nationale}

s. Louis; plus bas M.L.F. Duport

ti. volksrepresentanten/gouvernementscommissarissen

RO nr.79(2): 1 nivöse IV (22 dec 1795)

RE nr.99: 11/12 ventôse IV (1/2 mrt 1796)

- decreet aan de tijdsomstandigheden angepast

- LA, FA, rH vermelden de datum van de koninklijke sanctie op 19 september 1791

- afkondiging: beslluit volksrepresentanten s. Pérès, Portiez (de l'Oise); 18 frimaire IV (9 dec 1795) [herroepen bij besluit Directoire exéctuif van 30 messidor IV (18 jul 1796); BL He ser no.60 (553)]

\section{1 september $25 *$ oktober 6}

drukw FA nr.30; rH VII 121-160; P III 352-366; cB Ie ser XVIII/2 571-616; cL VI 110-158

[extract] CODE PÉNAL (Ie partie; IIe partie tit.I sect.1, 4-6; tit.II-III)

Het wetboek bestaat uit twee gedeelten, namelijk aangaande de veroordelingen en aangaande de misdrijven en hun bestraffing. De straffen die kunnen worden opgelegd zijn: de doodstraf, dwangarbeid in ketenen (fers), eenzame opsluiting op water en brood (gêne), opsluiting in een tuchthuis (réclusion), detentie, deportatie, burgerlijke degradatie en de schandpaal (carcan). Daarnaast zijn er bepalingen ten aanzien van de tenuitvoerlegging van de straffen, de gevolgen van de veroordelingen, de invloed van 
de leeftijd en de eventuele rehabilitatie der gestraften. Het tweede gedeelte van het wetboek behelst een opsomming van de onderscheidene delicten - van misdrijven tegen en aanslagen op de publieke zaak tot misdrijven begaan tegen particulieren - en de daarbij behorende strafmaat.

\section{bo. Assemblée nationale}

s. Louts; plus bas M.L.F. Duport

ti. gouvernementscommissaris Bouteville

RO nr.89(3): 16 nivôse IV (6 jan 1796)

RE nr.136: 14/15 floreal IV (3/4 mei 1796)

- verwijzing naar: wetten wan 3 aug 1791; 9 messidor $\mathbb{I}$ (27 jun 1794), aanpassing aan de tijdsomstandigheden

- cB-initule: "décret concernant le code pénal"

- cl-intitulé: "Loi. Code Pénal"

- afkondiging: besl tuit volksrepresentanten/gouvernementscommissarissen s. Pérès, Portiez (de l'Oise)" 24 frimaire IV (15 dec 1795 )

\section{1 september $26 *$ oktober 2}

LA IV fol 213vo-222ro; P III 368-372; cB Ie ser XVIII/2 632-648; cL VI 19-34

\section{LOI RELATIVE A LA PERCEPTION DES CONTRIBUTIONS FONCIËE ET MOBILIAIRE ET DU DROIT DE PATENTES}

De inning van de grondbelasting, de belasting op roerende goederen en het patentrecht geschiedt in elke gemeente door één of meerdere ontvangers. De ontvangers worden door de gemeenten aangesteld, waarvoor zij een zekere vergoeding ontvangen. Degene die voor het bedrag inschrijft zo dicht mogelijk bij de minimum-vergoeding wordt de inning van de belastingen gegund, maar alleen dan wanneer hij solvent is en tegen een borg. Wordt er niemand bereid gevonden zich met de inning van de belastingen te belasten, dan wordt een lid van de conseil général van de gemeente daarmee belast. $\mathrm{Bij}$ achterstalligheid in de afdracht van de belastingen van de zijde der contribuabelen kan worden overgegaan tot beslaglegging, echter niet op eerste levensbehoeften en benodigdheden voor het werk, zoals gereedschappen, zaaikoren, een melkkoe enzovoorts. Houders van dwangbevelen - deurwaarders - mogen zich niet te buiten gaan bij de voltrekking van de beslaglegging. De ontvangers moeten maandelijks afdracht doen van de door hen geïnde gelden. Bij gebreke hierin wordt er ook jegens hen dwang toegepast. De leden van de conseil général van de gemeente zijn verantwoording schuldig jegens de districtsontvangers in geval van insolventie van de gemeenteontvangers. Indien door bijzondere omstandigheden de oogst ten achter blijft bij voorgaande jaren, dan wordt de aanslag in de desbetreffende gemeente nader bekeken.

bo. Assemble mationale

no. comire des commibutrons publiques

s. Louis; plus bas M.L.F. Duport

RO nr. 160(7): 9 messidor IV (27 jun 1796)

- verwijzing naar: wet van 18 feb 1791; decreet van 20 sep 1791; decreten "sur les biens et usages ruraux"

- $\mathrm{cL}$ vermeldt als datum van uitvaardiging 6 sep * 2 okt 1791 
- cB-intitulé: "décret sur la penception, le recouvrement et le versement dans les caisses de district, du produit des contributions foncière et mobiliaire, et des patentes"

- afkondiging: besluit Directoire exécutif s. Camot (pres), Lagarde (secr-gen); 28 prairial IV (16 jun 1796); de wefi verbindend verklaard "en toutes les dispositions qui n"ont pas été abrogées par les lois subséquentes"

\section{1 september $27 *$ oktober 16}

LA I foll 287ro-289ro; FA nr.291; rH V 293-294; P III 373-374; cB Ie ser XVIII/2 662-664; cL VI $466-468$

\section{DÉCRET PORTANT DÉFENSE À TOUT CITOYEN FRANÇAIS DE PRENDRE, DANS AUCUN ACTE, LES TITRES ET QUALIFICATIONS SUPPRIMÉS PAR LA CONSTITUTION}

Ieder Frans burger die op kwijtingsbewijzen, verbintenissen en in het algemeen op akten de door de constitutie opgeheven kwalificaties schrijft, wordt onder lijfsdwang (contrainte par corps) veroordeeld tot een boete van zes keer de waarde van zijn bijdrage in de belasting op onroerend goed. Bovendien wordt men doorgehaald op het tableau civique en incapabel verklaard enig civiele of militaire functie te kunnen vervullen. Dezelfde straf geldt voor alle Franse burgers die afgeschafte onderscheidingstekens dragen. Notarissen en dergelijke mogen geen akten ontvangen waarop dergelijke afgeschafte waardigheden staan vermeld, op straffe van algehele ontzegging van de uitoefening van hun functie.

bo. Assemblée nationale

s. Louis; plus bas M.L.F. Duport

ti. volksrepresentanten/gouvernementscommissarissen

RO nr.61(3): 19 frimaire IV (10 dec 1795)

RE nr.52: $20 / 21$ frimaire IV (11/12 dec 1795)

- decreet aangepast aan de tijdsomstandigheden m.b.v interpolaties

- verwujzing naar: grondwet van 1791

- afkondiging: besluit volksrepresentanten s. Pérès, Portiez (de I"Oise); 17 brumaire IV (8 nov 1795)

\section{1 september $28 *$ oktober 6}

drukw FA 30; rH VII 180-189; P III 376-392; cB le ser XVIII/2 697-719; F I 212-229; cL VI 60-84

[extract] LOI CONCERNANT LES BIENS ET USAGES RURAUX ET LA POLICE RURALE (tit.I, sectie $1,2,3,4$ (behalve artt.3, 18), 5, 6; tit.II (behalve art.45)

Het toezicht (police) op het platteland valt onder de jurisdictie van de vrederechters en municipale ambtenaren; veldwachters en de gendarmerie nationale zijn belast met de surveillance. Delicten die op het platteland begaan worden en samenhangen met agrarische werkzaamheden of de veeteelt, en de boeten en schadeloosstellingen daaruit voortvloeiend, vallen onder de competentie van de vrederechters. De wet behelst voorts bepalingen inzake het gebruik van de grond, afrasteringen, beweidingen, wegen, pachten en dergelijke. 
bo. Assemblée nationale

s. Louis; pulus bas M.L.F. Duport

i. gouvenementscommissaris Bouteville

RO nr.892): 16 niwôse IV (6 jan 1796)

RE nr. 136: 14/15 floréal IV (3/4 mei 1796)

- tit.II annex aan art.605 van de code des delits et des peines van 3 brumaire IV (25 okt 1795)

- werwijzing naar: wet van 17,19 en 20 sep 1790; wet op het functioneren van de gendarmerie nationale

- rH geefit tit.II niet

- cL vermeldt als datum van uitvaardiging 2 sep * 6 okt 1791

- afkondiging: besluit volksrepresentanten/gouvernementscommissarissen s. Pérès, Portiez (de l'Oise); 24 frimaire IV (15 dec 1795)

\section{1 september $29 *$ oktober 12}

LA IV fol 212vo-213vo; P III 420; cB le ser XVIII/2 798-799; cL. VI $231-232$

\section{LOI RELATIVE AU MODE D'IMPOSITION POUR LES PROPRIÉTAIRES DE CHAMPARTS, AGRIERS, TERRAGES, CENS ET RENTES ET AUTRES REDEVANCES ANNUELLES}

Ter voorkoming van dubbel boeken van de grondbelasting zijn eigenaren (rechthebbenden) van jaarlijkse pachtsommen, die onderworpen zijn aan de inhouding van een vijfde gedeelte ervan door de pachters, gemachtigd in een verklaring aan de municipaliteit opgave te doen van de oppervlakte en de opbrengst van hun gronden, onder bijwoeging van het bewijs de helft van de grondbelasting te hebben voldaan. $\mathrm{Na}$ verificatie zijn de eigenaren door het departementale bestuur ontheven van de verplichting tot betaling op afrekening van de helft van de directe belasting op de opbrengst van de door pachters verschuldigde renten en pachtsommen, waarop de laatsten éénvijfde gedeelte mogen inhouden.

bo. Assemblée nationale

s. Louis; plus bas M.L.F. Duport

RO nr. 160(6): 9 messidor IV (27 jun 1796)

- verwijzing naar: wet van 17 jul 1791

- cB-intitulé: "décret relatif aux propriétaires de redevances annueiles soumis a la retenu de cin. quième"

- afkondiging: besluit Directorre exécutif s. Carnot (pres), Lagarde (secr-gen); 28 prairial IV (16 jun 1796); de wet verbindend verklaard "en toutes les dispositions qui n"ont pas êté abrogées par les lois subsequentes"

\section{1 september $29 *$ oktober 9}

LA II fol 157ro-161vo; FA nr.291; rH VI 215-221; P III 418-419; cB Ie ser XVIII/2 783-790

LOI ADUITIONNELLE À CELLE DU 19 DÉCEMBRE 1790, SUR LE DROIT D'ENREGISTREMENT

De wet behelst enige aanvullende bepalingen inzake de heffing der registratierechten, alsmede aanvullingen op de organisatie van de dienst der registratie en het zegelrecht. 
bo. Assemblée nationale

s. Louis; plus bas M.L.F. Duport

ti. minister van financiërn Faipoult

RO nr.91(4): 19 nivôse IV (9 jan 1796)

RE nr.81: 10/11 pluwiôse IV (30/31 jan 1796)

- verwijzing maar: wetten van $5 * 19$ dec $1790 ; 3$ apr $1791 ; 16(18) * 27$ mei $1791 ; 10$ jun 1791

- $\mathrm{cB}$-intitulé: "décret additionnel aux lois des 19 décembre 1790,27 mai et 17 juin 1791 , sur le droit d'enregistrement"

- afkondiging: besluit Directoire exécutif $s$. Reubell (pres), Lagarde (secr-gen); 9 nivôse IV ( 30 dec 1795)

\section{1 september $29 *$ oktober 14}

LA II fol 184; FA nr.275 fol 190; FA nr.737; rH VIII 134; P III 403-410; cB Ie ser XVIII/2 809830; cL VI $341-364$

[extract] LOI RELATIVE À L'ORGANiSATION DE LA GARDE NATIONALE (sectie II, art.28)

De oude burgermilities, compagnieën van arquebusiers, boogschutters en dergelijke onder welke benaming ook zijn ontbonden.

bo. Assemblếe nationale

s. Louis; plus bas M.L.F. Duport

ti. gouvemementscommissaris Bouteville

RO nr. 143: 3 prairial IV (22 mei 1796)

- cL wermeldt als datum van uitvaandiging 5 sep * 12 okt 1791

- afkondiging: besluit Directoine exécutif s. Le Tourneur (pres), Lagarde (secr-gen); 9 floréal IV (28 apr 1796); N.B.: in het besluit van het Directoire exécutif is sprake van de wet van 29 sep 1791 , terwijl bij de letterlijke aanhaling van de tekst van art.28, sectie II gesproken wordt van de wet van $5 \operatorname{sep} 1791$

1792 januari $13(10,12 \mathrm{en}) * 18$

BL Ile ser no.59 (549); LA III fol 207ro-209ro; rH IX 9; P IV 6-7, VII Ixxxiv-lxxxv; cB IIe ser II $68-71$; cL. VIII $58-60$

[extract] LOI RELATIVE À L'INSTALLATION DES TRIBUNAUX CRIMINELS (artt.7, 8)

Alle klachten en beschuldigingen die voortvloeien uit informatie voorafgaande aan het tijdstip van de installatie der criminele rechtbanken moeten in eerste instantie of in hoger beroep worden beoordeeld door die rechtbanken bij welke zij zijn aangebracht. Het aanhangig maken van die zaken moet geschieden overeenkomstig de wetten die anterieur zijn aan die van de instelling van de gezworenen. De openbare aanklagers mogen in geen enkel geval de vonnissen van criminele rechtbanken in hoger beroep bestrijden, behoudens in het belang van beschuldigden of burgerlijke partijen. Districtsrechters zijn gehouden slechts die straffen op te leggen, welke genoemd zijn in de code pénal. De criminele rechtbanken dienen al die zaken terug te verwijzen naar 
de rechters van correctionele politie, welke tot de competentie van deze rechters behoren.

bo. Asśemblée nationale

ao. comite de législation

8. Louis; plus bas M.L.F. Duport

RO nr. $170(2): 12$ thermidor IV ( 30 jul 1796)

- verwijzing naar: cade pénal van 25 sep * 6 okt 1791

- cL-intitule: "loi relative aux Tribunaux criminels"; datum van titvaardiging: "10.12 \& 13 janvier 1792, l'an quatrième de la liberté"

- afkondiging: besluit Directoire exëcutif s. Carnot (pres), Lagarde (secr-gen); 30 messidor IV (18 jul 1796) [BL. Ile ser no.59 (549)]

\section{2 maart $20 * 25$}

drukw FA nr.30; rH VII 193-195; P IV 47-48; cB Ile ser III 76-77; cL VIII 337-340

\section{DÉCRET RELATIF AU TRAITEMENT ET À LA PEINE dE MORT}

De doodstraf dient, als bepaald in de code pënal, te worden voltrokken door middel van onthoofding. De menswaardigheid gebiedt dat zulks zo effectief en pijnloos mogelijk geschiedt, en wel op de wijze als in het advies d.d. 7 maart 1792 van Louis, secretaris van de académie de chirurgie, staat vermeld.

\section{bo. Assemblee mationale}

ao. académie de chirwrgie

s. Louis; plus bas Roland

ti. gouvernementscommissaris Bouteville

RO nr.89(4): 16 nivôse IV (6 jan 1796)

RE nr.136: 14/15 floréal IV (3/4 mei 1796)

- verwijzing naar: code pénal van 25 sep 1791

- bijgevoegd het "avis motivé sur le mode de la décolation"

- clu-intifule: "ló relative a la peine de mort, \& au mode d"exécution qui sera suivi à l'avenir"

- cBintitulé: "décret qui fixe le mode de la décolation des condamnés à mort"

- afkondiging: besluit volksrepresentanten/gouvemementscommissarissen s. Pérès, Portiez (de l'Oise)"

24 frimaire IV ( 15 dec 1795$)$

\section{2 augustus 25}

LA 1 fol 289ro-294ro; FA nr.291; rH V 295-300; P IV 315-318; cB Ile ser VI/1 218-221; cL X 611616

\section{LOI RELATIVE À LA SUPPRESSION, SANS INDEMNITÉ, DE TOUS LES DROITS FÉODAUX OU CENSUELS ET DE TOUTES REDEVANCES SEIGNEURIALES}

Het feodale maxime nulle terre sans seigneur wordt beschouwd als niet te hebben bestaan. Dientengevolge is alle grondeigendom vrij van alle feodale en cijnsrechten. De dimes of soortgelijke prestaties ter vervanging van de mainmorte worden zonder schadeloosstelling opgeheven. In het algemeen zijn alle heerlijke rechten afgeschaft 
die aanvankelijk nog in vroegere wetgeving bleven bestaan of afkoopbaar werden, tenzij bewezen kan worden dat het gaat om een oorspronkelijke bezits- of eigendomstitel ter zake van een stuk grond. Zulks geldt eveneens voor tolrechten en dergelijke. Processen die over dit soort zaken gevoerd worden en nog niet in hoogste instantie geoordeeld zijn, blijven stopgezet. Andersoortige geldelijke verplichtingen voortvloeiende uit de verpachtingen moeten de pachters wel aan de eigenaars voldoen.

\title{
bo. Assemblée nationale
}

s. Servan

cs. Danton

ti. wolksrepresentanten/gouvernementscommissarissen

RO nr.61(4): 19 frimaire IV (10 dec 1795)

RE nr.52: 20/21 frimaire IV (11/12 dec 1795)

- verwijzing naar: wetten en decreten van 4 aug 1789; 15 mrt en 23 okt 1790; 10 en 13 apr 1791; 18 jun 1792

- wet aan de tijdsomstandigheden aangepast

- cL-initulé: "loi relative aux Droits féodaux"

- afkondiging: besluit volksrepresentanten s. Pérès, Portiez (de I’Oise); 17 brumaire IV (8 nov 1795)

\section{2 augustus 26}

LA III fol 58vo-60ro; rH VIII 10-12; P IV 321-322; cB Ile ser VI/1 237-238; cL X 626-629

\section{LOI QUI ORDONNE LA DÉPORTATION DES PRÊTRES RÉFRACTAIRES}

Geestelijken die weigeren de eed, voorgeschreven door de wet van 27 nov * 26 dec 1790 , af te leggen, of deze hebben herroepen en hierin volharden, worden gedwongen binnen acht dagen te vertrekken uit het departement waar zij wonen en verder binnen veertien dagen het land te verlaten. Daartoe wordt hun terstond een paspoort verstrekt. Houdt men zich niet aan deze bepalingen, dan volgt arrestatie op last van het districtsbestuur, gevolgd door overbrenging naar een zeehaven en deportatie naar FransGuyana. Geestelijken die aldus het land vrijwillig verlaten of worden gedeporteerd, ontvangen geen inkomsten of een pensioen meer. Bij terugkeer naar Frankrijk of in het geval dat men niet is vertrokken, wordt men veroordeeld tot tien jaar hechtenis. Geestelijken die niet aan de voorgeschreven eed onderworpen zijn, vallen onder dezelfde bepalingen wanneer zij moeilijkheden veroorzaken of als hun verwijdering door zes burgers, in hetzelfde departement woonachtig, wordt gevorderd. Hiervan vitgezonderd zijn gebrekkige geestelijken en zestigjarigen; zij worden in een gemeenschappelijk huis in de hoofdstad van het departement ondergebracht, onder toezicht van de municipaliteit. De autoriteiten moeten omtrent de uitvoering van de wet rapporteren. De districtsbesturen zenden om de veertien dagen naamlijsten van vertrokken of gedeporteerde geestelijken aan de minister van binnenlandse zaken, die hierover bericht aan de Assemblée nationale.

\author{
bo. Assemblèe nationale \\ s. Servan \\ cs. Danton \\ ii. departement van de Dijle
}


RE ar. II 8: 9/10 germinal IV (29/30 mrt 1796$)$

- verwijzing riaar: wetten wan 27 nov 26 dec $1790 ; 15$ * 17 apr 1791; code pénal van 25 sep 1791

- $\mathrm{HH}$ wermeldt abusievelijk als daturn van uitwaardiging 16 aug 1792

- cL-intitulé: "loi relative aux Eccléastiques qui n"ont pas prêté leur serment, ou qui l'avoir prêtế, l'ont retracté, \& ont persiste dans leur Rétractation"

- cB-intimule: "décret sur la deportation des prêtres insermentés"

- afkondiging: besluit wolksrepresentanten/gouvemementscommissarissen s. Pérès, Portiez (de l'Oise); 29 frumaire IV (20 dec 1795 )

\section{2 augustus/september 3}

LA I fol 307ro-309vo; rH V 316-319; P IV 372-373; cB IIe ser VI/2 610-613; cL XI 125-129, 131

\section{DÉCRET SUR LA FRANCHISE ET LE CONTRE-SEING DES LETTRES PAR LA POSTE}

Het decreet behelst - vergezeld van een staat d.d. 6 juni 1792 - welke personen en instanties portvrijdom en het recht van medeondertekening van door de post te verzenden missiven en pakketten genieten. Besturen genieten de franchise alleen collectief, niet in persoon. De medeondertekening geschiedt door middel van een stempel; geen enkele openbare functionaris mag onder zijn naam en eigenhandig contrasigneren. Voor elk bestuur en iedere functonaris is er maar één stempel, waarvan het gebruik aan slechts een enkele persoon is toevertrouwd.

\section{bo. Assemblée nationale}

ao. comite de l"ordinaire des finances

s. Monge

cs. Dantton

ti. volksrepresentanten/gouvernementscommissarissen

RO nr.64: 19 frimaire IV ( 10 dec 1795)

RE nr.49: 20/21 frimaire IV (11/12 dec 1795)

- verwijzing naar: wetten en decreten van 12 okt 1790; 14 okt 1791; 6 jun 1792

- LA, rH en P vermelden als datum van uitvaardiging 3 * 20 sep 1792

- cL-intitulé: "Loix 1 "Contreseing \& franchises des Lettres"

- afkondiging: besluilt volksrepresentanten $s$. Portiez (de l'Oise), Pérès, Delcambe (secr); 26 brumaire IV (17 nov 1795)

\section{2 september 3}

drukw FA nr.30; rH VIII 195-197; P IV 367-368; cB Ile ser VI/2 619-621; cL XI 90-92

\section{DÉCRET RELATIF AUX DEMANDES EN ABOLITION OU COMMUTATION DE PEINES AFFLICTIVES OU INFAMANTES}

Gestraften kunnen verzoeken om opheffing of vermindering van tegen hen uitgesproken lijfstraffen of onterende straffen. Hun zaak wordt behandeld door de criminele rechtbanken van de departementen volgens de bepalingen neergelegd in de code pénal. De straffen van dwangarbeid in ketenen (fers), opsluiting in een tuchthuis (réclusion) en eenzame opsluiting op water en brood (gêne), kunnen in geen enkel 
geval levenslang zijn. Degenen die voorheen veroordeeld waren tot levenslange galeistraf en de tijdsduur genoemd in de code pénal volbracht of overschreden hebben, worden in vrijheid gesteld.

bo. Assewblée nationale

no. comité de legislation

s. Clavière

cs. Danton

ti. gouvemementscommissaris Bouteville

RO nr.89(5): 16 nivôse IV (6 jan 1796)

RE nr.136: 14/15 flloréal IV (3/4 mei 1796)

- verwijzing naar: code pénal van 25 sep 1791

- afkondiging: besluit volksrepresentanten/gouvernementscommissarissen s. Pérès. Portiez (de l'Oise); 24 frimaire IV (15 dec 1795)

\section{2 september 9}

LA I fol 294; FA nr.291; rH V 301; P IV 394; cB IIe ser VI/2 773; cL XI 262

LOI QUI ANÉANTIT TOUS PROCES ENTRE NOTAIRES ET FEUDISTES OU COMMISSAIRES A TERRIERS, POUR LA RECONNOISSANCE OU RECOUVREMENT DE LEURS DROITS

De processen bij de rechtbanken aanhangig als gevolg van geschillen tussen notarissen en feudistes commissaires - zaakgelastigden van de vroegere (feodale) heren - inzake de erkenning en het herstel in hun voorgewende rechten zijn beëindigd. Eveneens is de verdere uitvoering van vonnissen, die nog niet inkracht van gewijsde zijn gegaan, stopgezet. De uitvoerende macht dient onverwijld dit decreet aan alle bestuurslichamen en departementsbesturen te doen toekomen.

bo. Assemblée navionale

s. Danton, président du conseil executif provisoire

cs. Danton

ti. volksrepresentanten/gouvernementscommissarissen

RO nt.61(5): 19 frimaire IV (10 dec 1795)

RE nr.52: 20/21 frimaire IV (11/12 dec 1795)

- cL-intitule: "loi relative a l"extinction de tous les Procès relatifs aux Droits féodaux"

- afkondiging: besluit volksrepresentanten s. Pérès, Portiez (de l'Oise); 17 brumaire IV (8 nov 1795)

\section{2 september 19}

LA III fol I8ro-20vo; FA nr.237. FA nr.291; rH VI 349-352; P IV 433; cB Ile ser VI/2 1013-1015; cL XI $470-472,475$

\section{LOI RELATIVE À LA VENTE DES BIENS DE L'ORDRE DE MALTE}

De goederen van de Maltezer Orde worden bestuurd, en de onroerende goederen verkocht, onder dezelfde voorwaarden als de overige nationale domeingoederen. De vruchtgebruikers van deze goederen zullen gedurende hun leven door de schatkist 
betaald worden, in de vorm van een driemaandelijks pensioen, uit de netto-opbrengst der Maltezer beneficies, dan wel in de vorm van een pacht onder aftrek van de dimes en de afgeschafte feodale rechten. Wanneer men ook een bezoldiging geniet uit hoofde van een staatsbetrekking, kan het pensioen met de helft verminderd worden, als het tractement hoger is dan het pensioen. Deze toelages worden uitbetaald door de ontwanger van het district alwaar men zijn domicilie heeft. Het is verboden de Maltezer decoratie (kruis) te dragen op straffe van verlies van het pensioen. De uitvoerende macht neemt maatregelen tot het behoud van de titels, papieren en documenten inzake de eigendommen van de Maltezer Orde in Frankrijk.

bo. Assemblée nationale

s. Monge

cs. Danton

ti. gouvernementscommissaris Bouteville

RO nr.97(1), 207(3,4): 11 pluviôse IV (31 jan 1796) en 2 vendémiaire V (23 sep 1796)

RE nr.116: $2 / 3$ germinal IV (22/23 $\mathrm{mrt} 1796)$

- verwijzing naar: wet van 24 jul 1790; decreet van 11 aug 1790

- RO nr.207(3,4) betreft de artt. I en 8; het laatste gedeeltelijk aangehaald

- afkondiging." besluit volksrepresentanten/gouvernementscommissarissen s. Pérès, Portiez (de 1'Oise); 29 frumaire IV (20 dec 1795); besluit Directoive exécutif s. L.M. Revellière-Lépeaux (pres), Lagarde (secr-gen); 23 fructidor IV (9 sep 1796)

\section{2 september 20}

LA III fol 181ro-188ro, 192ro-198ro; drukw FA nr.34; rH VIII 343-360, 372-383; P IV 442-448; cB Ile ser VI/2 1059-1075; cL XI 501-534

\section{LOI QUI DÉTERMINE LE MODE DE CONSTATER L'ÉTAT CIVIL DES CITOYENS}

De municipaliteiten - in het bijzonder de daartoe aangewezen ambtenaar - zijn belast met het houden van de registers van de burgerlijke stand. Het drietal registers inzake geboorte, huwelijk en overlijden moet in dubbel worden opgemaakt, waarvan het dubbel moet worden bewaard in het departementale archief. De jaarlijks opgemaakte tafels van de registers moeten voor het eerst in 1800 omgevormd zijn tot een tienjaarlijkse tafel. De geboorteakten worden 24 uur na de aangifte in aanwezigheid van twee getuigen opgemaakt. De aangifte geschiedt door de vader en bij diens ontstentenis door de chirurgijn of de vroedvrouw. Vondelingen worden aan de ambtenaar van de burgerlijke stand getoond. Binnen 24 uur na een overlijden dienen twee van de naaste verwanten of naaste buren van de overledene hiervan aangifte te doen bij de ambtenaar van de burgerlijke stand. Ten overstaan van de ambtenaar van de burgerlijke stand worden huwelijken gesloten en ontbonden. In de wet worden de vereisten als de minimumhuwelijksleeftijd, de termijn van de afkondiging, de eventuele stuiting van een huwelijk omschreven. Voorts zijn de vormvereisten van de op te maken onderscheidene akten vastgelegd. Het wettelijk vastleggen van de burgerlijke stand vormt geenszins een belemmering voor een gewenste kerkelijke viering bij een geboorte, een huwelijk of een overlijden. 
bo. Assemblểe nationale

ao. comité de législation

s. Lebrun

cs. Danton

RO nr. $164(1)$ : 24 messidor IV (12 jul 1796)

RE nr.161: 19/20 thermidor IV (6/7 aug 1796); N.B.: "extrait des lois sur l'état civil des citoyens" [FA nr.136 fol 126ro-131vo; 8 thermidor IV (26 jul 1796)]

RE nr.193: $1 / 3$ brumaire $V(22 / 24$ okt 1796); Vlaamse vertaling [drukw FA nr. 143]

- verwijzing naar, in de vorm van instructie: code pénol van 25 sep * 6 okt 1791: echtscheidingswet wan 20 sep 1792; wetten van 25 vendémiaire II (16 okt 1793); 7 frimaire II (27 nov 1793); 22 germinal II (11 apr 1794); 21 fructidor III ( 7 sep 1795); 19 vendemiaire IV (11 okt 1795); code des détits et des peines van 3 brumaire IV (25 okt 1795)

- drukw FA nr.34 en LA voorzien van formulieren wan de op te maken akten

- drukw FA nr.34 is tevens uitgebreide instructie

- afkondiging: besluit Directoire exécutif s. Camot (pres), Lagarde (secr-gen); 29 prairial IV (17 jun 1796)

\section{2 september 20}

LA III fol 188ro-192ro, 196vo-197ro; drukw FA nr.34; rH VIII 361-371, 380-381; P IV 436-442; cB Ile ser VI/2 1081-1091; cL XI 489-500

\section{LOI QUI DETERMINE LES CAUSES, LE MODE ET LES EFFETS DU DIVORCE}

Echtscheiding heeft plaats met wederzijdse instemming; zij kan voorts worden uitgesproken op grond van de eenvoudige bewering van onverenigbaarheid van karakter door één der echtgenoten en op grond van een reeks van bijzondere motieven, zoals krankzinnigheid, de veroordeling tot lijf- of schandstraffen, de verlating of de afwezigheid zonder enig bericht langer dan vijf jaar. De echtscheiding wordt uitgesproken door de ambtenaar van de burgerlijke stand, zonder dat deze kennisneemt van de oorzaken, en nadat een verzoening door de vergadering van ten minste zes naaste familieleden of vrienden, één of meerdere keren te houden, mislukt is. In de wet worden tevens de rechtsgevolgen van een echtscheiding vermeld, zowel ten aanzien van de voormalige echtelieden zelf (verdeling van hun goederen, levenslang pensioen, alimentatie), als ten aanzien van hun eventuele kinderen (toewijzing aan wie, erfrechtelijke positie).

\section{bo. Assemblée nationale}

s. Lebrun

cs. Danton

RO nr. 164(2): 24 messidor IV (12 jul 1796)

RE nr. 193: 1/3 brumaire V (22/24 ok» 1796); Vlaamse vertaling [drukw FA nr. 143]

- verwijzing naar "deels in de vorm wan instructie: decreet van 8 apr 1792; "Voi sur les actes de naissance, mariage et décès" van 20 sep 1792; wetten van 9 ventốse II (27 feb 1794); 14 messidor II (2 jull 1794)

- formulier van de echtscheidingsakte

- cB-intitulé: "décret sur le divorce"

- afkondiging: besluit Divectoire exécutif s. Camot (pres), Lagarde (secr-gen); 29 prairial IV (17 jun 1796) 


\section{2 oktober 6}

drukw FA nir.30; rH VII 198; P IV 463; cB IITe ser I 53; cL XII 30

DÉCRET SUR LE REMPLACEMENT PROVISOIRE DE LA PEINE DES FERS PAR CELLE DES GALERES

De straf van dwangarbeid in ketenen wordt voorlopig vervangen door galeistraf. Te dien einde worderi de veroordeelden naar de havens overgebracht.

bo. Convention narionale

ao. minister van marine

s. Lebrun

cs. Danton

ti. gouvemementscommissaris Bouteville

RO nr.89(6): 16 niwôse IV (6 jan 1796)

RE nr.136: 14/15 floréal IV (3/4 mei 1796)

- decreet uitgevaardigd op verzoek van een Conwentielid

- afkondiging: besluit volksrepresentanten/gouvemementscommissarissen s. Pérès. Portiez (de l'Oise);

24 frimaire IV ( 15 dec 1795)

\section{2 oktober 10}

LA II fol 108vo; FA nr.234; rH VI 102; P IV xvi; 466 ; cB IIIe ser I 68; cL XII 48

[extract] DÉCRET QUI DÉFEND D'ACCORDER DES GRATIFICATIONS AUX COMMIS EMPLOYÉS DANS LES ADMINISTRATIONS (le alinea)

Commiezen werkzaam bij de besturen krijgen geen gratificaties meer toegekend. De administrateurs zijn verantwoordelijk, indien hiermee in strijd wordt gehandeld.

bo. Convention nationale

s. Monge

cs. Garat

i. volksrepresentanten/gouvernementscommissarissen

RO nr.84(11); 7 nivôse IV (28 dec 1795)

RE nr.72: $21 / 22$ nivose IV (11/12 jan 1796)

- tekst van het decreet annzienlijk gewijzigd

- cL-intinule: "Suppression de toute espèce de gratifications en favear des Commis \& Employés qui ont un traitement de la République"

- afkondiging: besluit volksrepresentanten s. Pérès, Portiez (de l'Oise); 19 frimaire IV (10 dec 1795)

\section{2 oktober 22}

LA III fol 20vo-22vo; FA nr.237, FA nr.291; rH VI 352-355; P IV 474-475; cB IIle ser I 101-103; aL XII 92-94 
De departementale besturen dienen in aanwezigheid van een procureur en twee leden van de gemeente alle eigendomstitels, registers, papieren, bewijsstukken en goederen van de vroegere Maltezer Orde, die zich in priorijen, commanderijen, balijes, enzovoorts bevinden, alsmede bij anderen die deze stukken onder zich hebben, te verzegelen. $\mathrm{Na}$ de opheffing van de verzegeling en het opstellen van een inventaris kan men tot de verkoop van de roerende goederen overgaan. De pensioenen toegekend aan de vruchtgebruikers van de goederen van de opgeheven Maltezer Orde kunnen alleen uitgekeerd worden, indien men geen titels enzovoorts achterhoudt en voldoef aan de termen van de wetten inzake verblijf in Frankrijk. Depositarissen die dergelijke stukken onder zich hebben, dienen deze eveneens over te dragen. De bepalingen van dit decreet zijn tevens van toepassing op de instellingen van de Duitse Orde en op andere ridderorden op het Franse grondgebied.

bo. Convention nationale

ao. comité d'aliériation des biens nationaux

s. Lebrun

cs. Garat

ti. gouvernementscommissaris Bouteville

RO nr.97(2): 11 pluviôse IV (31 jan 1796)

RE nr. 116: $2 / 3$ germinal IV (22/23 mrt 1796)

- verwijzing naar: wetten van 5 nov $1790 ; 8$ nov $1790 ; 19$ sep 1792; 10 okt 1792

- cL-intitulé: "décret qui fixe le mode d'exécution de la loi du 19 septembre dernier, concernant la disposition des biens dont jouissoit le ci-devant Ordre de Malte"

- afkondiging: besluit volksrepresentanten/gouvernementscommissarissen s. Pérès, Portiez (de l'Oise); 29 frimaire IV (20 dec 1795$)$

\section{2 oktober $25 \&$ november 14}

LA II fol 4; FA nr.233; rH V 349; P IV 492-493; cB IIle ser I 115, 186; cL XII 111

\section{LOI SUR L'ABOLITION DES SUBSTITUTIONS}

Substituties (substitution fidéicommissaire) bij erfenissen zijn verboden. De substituties die nog niet opengevallen zijn, blijven zonder enig rechtsgevolg, terwijl reeds opengevallen substituties alleen rechtsgevolgen hebben voor diegenen die de gesubstitueerde goederen hebben ontvangen, of het recht hebben deze op te eisen.

bo. Convention mationale

ao. comité de législarion

s. Roland

cs. Garat

ti. volksrepresentantem/gouwernementscommissarissen

RO nr.67(1): 25 frimaire IV (16 dec 1795)

RE nr.62: $13 / 14$ nivôse IV (3/4 jan 1796)

- artt. 1 en 2 op 25 oct, ant. 3 op 14 nov 1792 gedecreteerd

- cL-intïrulé: "Décret. Abolition des Substitutions"

- afkondiging: besluit volksrepresentanten s. Pérès, Portiez (de 1'Oise); 29 brumaire IV (20 nov 1795) 


\section{2 november 12}

LA III fol 22wo; FA nr.237, FA ni. 291; rH VI 355; P IV 491; cB Ille ser I 178; cL XII 186

\section{DÉCRET CONCERNANT LA VENTE DU MOBLLIER DES ÉTABLISSEMENS DU CI-DEVANT ORDRE DE MALTE}

De verkoop wan de roerende goederen van de opgeheven Maltezer Orde omvat niet de persoonlijke roerende goederen van de vroegere commandeurs, baillis, priors, en andere houders van een beneficie van de Orde, maar slechts de roerende goederen behorende tot de commanderijen, priorijen en overige beneficia, waarvan de lijst zal worden bepaald door middel van pachtakten, visitatieprocessen-verbaal en dergelijke. De roerende goederen die uitgezonderd zijn van de verkoop worden alleen dan aan de eigenaren overhandigd, wanneer door middel van een certificaat van verblijfplaats is vastgesteld, dat zij niet zijn uitgeweken.

bo. Convemiton nationale

s. Roland

cs. Garat

ti. gouvernementscommissaris Bouteville

RO nr. 97(3): I I pluviôse IV (31 jan 1796)

RE nr.116: $2 / 3$ germinal IV (22/23 mrt 1796)

- verwijzing naar: wet van 22 okt 1792

- cL-intitulé: "décret qui excepte de la vente des effets mobiliers appartenant aux commanderies, prieurés, \&c. de l'ordre de Malte, les meubles personnels des ci-devant commandeurs, baillis, prieurs ou autres bénéficiers"

- afkondiging: besluit volksrepresentanten/gouvemementscommissarissen s. Pérès, Portiez (de l'Oise); 29 frimaire IV (20 dec 1795)

\section{2 december 2}

LA III fol 23ro; FA nr.237, FA nr.291; rH VI 356; P IV xvïi; cB IIle ser II 6

\section{DÉCReT RELATIF À DES FAITS ÉNONCÉES DANS UNE ADRESSE DES CAPITAINES FRANÇAIS QUI ONT MOUILLÉ AU PORT DE MALTE}

De uitwoerende macht moet de feiten, aangevoerd in het verzoekschrift van Franse kapiteins die in de haven van Malta voor anker zijn gegaan, verifiëren en na vaststelling hiervan, een schadeloosstelling de Franse Republiek waardig eisen.

bo. Comvention nationale

ao. comité diplonatique

ti. gouvernementscommissaris Bouteville

RO nr.97(4): 11 pluviôse IV (31 jan 1796)

RE nr.1 16: 2/3 germinal IV (22/23 mrt 1796)

- afkondiging: besluit volksrepresentanten/gouvemementscommissarissen s. Pérès, Portiez (de l'Oise);

29 frimaire IV (20 dec 1795) 


\section{DÉCRET CONCERNANT LES PENSIONS DES MEMRRES DE L'ORDRE DE MALTE NON- EMPLOYÉS}

De pensioenen uitgekeerd aan niet-werkende leden van de Maltezer Orde, worden zodanig verminderd, dat ze het bedrag van 1000 liwes niet te boven gaan. De pensioenen worden niet langer bij vooruitbetaling uitgekeerd.

\section{bo. Comention nationale}

ao. comités diplomatique, de surveillance

s. Lebrun

cs. Garat.

ti. gouvemementscommissaris Bouteville

RO nr. 97(5): 11 pluviôse IV ( $3 \|$ jan 1796)

RE nr.l 16: $2 / 3$ germinal IV (22/23 mrt 1796)

- werwijzing naar: wet van 27 sep 1792

- cL-intitulé: "Décret. Pensions accordées aux membres non employés de l'ordre de Malte"

- afkondiging: besluit volksrepresentanten/gouvernementscommissarissen s. Pérès. Portiez (de l'Oise); 29 frimaire IV (20 dec 1795)

\section{2 december 19}

LA III fol 198ro-199vo; drukw FA nr.34; rH VIII 384-387; P IV 533-534; cB IIIe ser II 90-92; cL XII 397-400

\section{DÉCRET ADDITIONNEL CONCERNANT LE MODE DE CONSTATER L'ÉTAT CIVIL DES CITOYENS PAR LES MUNICIPALITÉS}

De aangifte van geboorte of overlijden moet binnen drie dagen geschieden, op straffe van gevangenisstraf. Een aangifte van overlijden dient voor de teraardebestelling verricht te zijn. Voor een uittreksel uit een huwelijks- of echtscheidingsakte moet, evenals voor een uittreksel uit het bijzondere register houdende de huwelijksafkondigingen en een uittreksel van de preliminaire echtscheidingsakte, worden betaald. Echtscheidingsakten worden niet geregistreerd op het register van huwelijksakten, maar op het authentieke afschrift ervan, nadat de verschuldigde registratierechten zijn voldaan. De registers van de preliminaire echtscheidingsakten en die van de huwelijksafkondigingen moeten worden vervaardigd op gezegeld papier. In gemeenten met 50000 inwoners of meer moeten de aangiftes van geboorte en overlijden eerst bij de commissaris van politie van de sectie of de wijk worden gedaan. Deze maakt van de aangifte een proces-verbaal op, waarmee degene die aangifte doet, binnen 24 uur naar het gemeentehuis moet gaan.

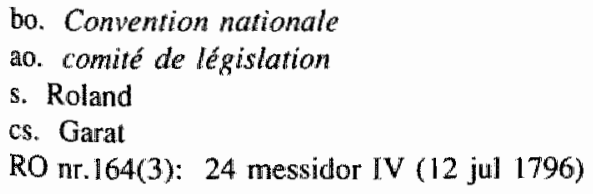


RE nr.161: 19/20 thermidor IV (6/7 aug 1796)

RE nr. 193: 1/3 brumaire $V(22 / 24$ okt 1796); Vlaamse werlaling [drukw FA nr.143]

- verwijzing naar, in de vorm van instructie: wet van 20 sep 1792; code des délits el des peines wan

3 brumaire IV (25 okt 1795)

- drukw FA nr.34 is tevens cen instructie

- LA, $\mathrm{TH}$ en $\mathrm{cL}$ datum van uitvaardiging: "19 décembre 1792. l'an premier de la République françai$s e^{*}$

- afkondiging: besluit Directohre exécutif s. Carnot (pres), Lagarde (secr-gen); 29 prairial IV (17 jun $1796)$

\section{3 januari 2}

LA IV fol 73; drukw FA nr.II1; rH X 7-8; P V 2-3; cB IIle ser III 9; cL XIII 8-9

\section{LOI RELATIVe a la vente des meubles provenant de la liste civile, des ÉMIGRÉS, ET AUTRES MEUBLES NATIONAUX}

Degenen die belast zijn met de verkoop van roerende goederen afkomstig van de uitgewekenen, van de liste civile [ =het bedrag dat de natie aan haar souverein ter beschikking stelt, alsmede de domeingoederen die de natie te zijner beschikking stelt teneinde de uitgaven van het koninklijk huis te bekostigen] en overige nationale roerende goederen, mogen zich als particuliere personen noch direct noch indirect inlaten met de aankoop of de wederoverdracht (rétrocession) van bedoelde roerende goederen. $\mathrm{Zij}$ worden in dat geval vervolgd voor de criminele rechtbank ter zake van diefstal van publieke goederen. Een soortgelijke vervolging staat degene te wachten die op enigerlei wijze het goede verloop van de veiling tracht te beïnvloeden. De openbare verkoping wordt opgeschort, wanneer er onvoldoende bieders komen opdagen, of wanneer het bod beneden de waarde van de goederen blijft.

bo. Convention nationale

s. Clavière

cs. Garat

RO nr.210(1): 23 vendémiaire V (14 okt 1796$)$

- LA en drukw FA vermelden als datum van uitvaardiging: "2 Janvier 1793, an II de la République française, ture et indivisible"

- cB-imitulé:" "décret qui défend aux préposés pour la vente du mobilier des émigrés, de la liste civile \& autres meubles nationaux, \& aux commissaires choisis pour assister aux dites ventes, de s"immiscer dans l'achat des dits meubles, \&c."

- afkondiging: besiuit Directoire exécutif s. L.M. Revellière-Lépeaux (pres), Lagarde (secr-gen); 10 fructidor IV (27 aug 1796)

\section{3 januari 11}

LA III fol 23vo-25vo; FA nr.237, FA ar.291; rH VI 357-360; P V 13-14; cB IIIe ser III 56-57; cl. XIII $59-62$

DÉCRET CONCERNANT LES FERMIERS, RENTIERS ET DÉBITEURS DE TOUS LES DOMAINES NATIONAUX 
Pachters, cijnsbetalers en debiteuren van goederen wan uitgewekenen, van de Maltezer Orde, van vorstelijke bezittingen, en in het algemeen van alle niet-verkochte nationale domeinen, dienen hun contractsverplichtingen en pachten in granen op dezelfde manier te voldoen als zij voorheen jegens hun verpachters verplicht waren te doen. De leveranties geschieden aan de magazijnen aangewezen door het district en bij voorkeur aan militaire magazijnen tegen de afgifte van een ontvangstbewijs " dat door de arrondissementsontvanger van de opbrengsten van de nationale domeingoederen omgezet wordt in een kwijtingsbewijs, dat alleen tot decharge kan strekken. De beambten van de nationale domeinen zien erop toe dat de pachten tijdig worden gekweten. Kennisgeving van de opbrengsten geschiedt aan hogere instanties. Hernieuwing van de pachtovereenkomsten van deze goederen, waarvan de pachtsom in natura wordt gekweten, kan alleen dan plaatshebben als de pachtsom wederom in natura wordt betaald.

bo. Convention nationale

ao. comité des finances

s. Lebrun

cs. Garat

ti. gouvernementscommissaris Bouteville

RO nr.97(6): 11 pluviôse IV (31 jan 1796)

RE nr.116: $2 / 3$ germinal IV (22/23 mrt 1796$)$

- verwijzing naar: wet van 9 sep 1791

- $P$ vermeldt in art.13 een afwijkende tekst

- cL-intitulé: "décret relatif aux Fermiers. Rentiers \& Débiteurs des biens des Emigrés, de l'ordre de Malte, des Princes possessionnés, \& généralement de tous les Domaines nationaux invendus"

- afkondiging: besluit volksrepresentanten/gouvernementscommissarissen s. Pérès, Portiez (de l'Oise); 29 frimaire IV (20 dec 1795)

\section{3 februari 14}

LA III fol 60ro; rH VIII 13; P V 58; cB IIIle ser III 220; cL XIII 306

décret concernant les Personnes Rangées par la loI dans la Classe des ÉMIGRÉs, ET DANS La ClASSE dES PRÊTRES QUI DOIVENT ÊTRE DÉPORTÉS

Eenieder die een uitgewekene of een geestelijke die had moeten worden gedeporteerd ontdekt en laat arresteren, ontvangt 100 livres als schadeloosstelling en beloning. De commissarissen die naar de departementen zijn gezonden, zijn gemachtigd om publieke functionarissen, nalatig in de uitvoering van de wetten dienaangaande, te schorsen.

bo. Convention nationale

cols. Bréard (pres); Thuriot, Cambacérès, Prieur de la Marne, F. Lamarque (secr)

s. Monge

cs. Garat

ti. departement van de Dijle

RO nr.113(2): 6 germinal IV (26 mrt 1796)

RE nr. 118: 9/10 germinal IV (29/30 mrt 1796)

- afkondiging: besluit volksrepresentanten/gouvernementscommissarissen s. Pérès, Portiez (de l'Oise);

29 frimaire IV (20 dec 1795) 


\section{3 maart 1}

LA $V$ fol Iwo-2ro; drukw FA nr.100; rH X 165-166; PV 80; cB IIIe ser III 310-311; cL XIII 459. 461

[extract] LOI QUI ANNULLE TOUS TRATTES D'ALLIANCE ET DE COMMERCE PASSES ENTRE LA FRANCE IT LES PUISSANCES AVEC LESQUELLES ELLE EST EN GUERRE, ET DEFEND L'INTRODUCTION EN FRANCE DE DIVERSES MARCHANDISES ÉTRAN. GLRES (artt.1-6)

Alle bestaande bondgenootschappelijke en handelsverdragen, gesloten tussen de vroegere Franse regering en de mogendheden, waarmee de Republiek in oorlog is, zijn geannulleerd. Op het territoir van de Republiek mogen geen uit Engeland afkomstige katoenen en wollen stoffen, metalen en aardewerk worden ingevoerd, op straffe van verbeurdverklaring binnen drie dagen na de inbeslagneming. Ook mogen geen voorwerpen of handelswaar geïmporteerd worden en aan de douaneautoriteiten worden aangegeven, tenzij kan worden aangetoond dat ze niet afkomstig zijn uit landen waarmee Frankrijk in oorlog is; de Franse consuls in het buitenland dienen ter zake certificaten te verstrekken. Een uitzondering wordt gemaakt voor goederen die op de vijand buitgemaakt zijn en enkele basisproducten ten dienste van de oorlogsvoering.

bo. Convention nationale

ao. comités de commerce, de défense générale et de la guerre

cols. Dubois-Crancé (pres); Mallarmé, Lecointe-Puyraveau, L.J. Charlier, J.Julien de Toulouse, Pierre Choudieu (secr)

s. Beurnonville

cs. Garat

RO nr.211: 27 vendémiaire $V(18$ okt 1796)

- verwijzing naar: wetten van $6 * 22$ atg $1791 ; 9$ februari 1793; tarief van $2 * 15$ mrt 1791

- Code Merlin vermeldt als datum van afkondiging 12 vendémiaire V (3 okt 1796)

- P V vii vermeldt dat de gehele wet afgekondigd is ingevolge het arrêtét van de vołksrepresentanten van 29 frimaire IV (20 dec 1796)

- cB-intirulé: "décret qui fait défenses d"introduire dans le territoire de la République des vélours \& étoffes de coton, des étoffes de laine \&c., venant de l'étranger"

- afkondiging: besluit Directoire exécutif s. L.M. Revellière-Lepeaux (pres), Lagarde (secr-gen); 15 vendémiaire V (6 okt 1796) [BL IIe ser no.81 (751)]

\section{3 maart 8}

LA IIII fol 200ro; drukw FA ir.34; rH VIII 388; P V 90-91; cB IIIe ser III 370; cL XIII 560

\section{DÉCRET Qui PERMET À TOUs MILITAIREs de CONTRACTER MARIAGE SANS L'AGRÉMENT DE LEURS SUPÉRIEURS}

Militairen behoeven, wanneer zij in het huwelijk wensen te treden, niet langer de toestemming daarvoor van hun superieuren.

bo. Convention nationale

cols. Bréard (ex-pres); Mallarmé, J. Julien de Toulouse, Max. Isnard (secr)

s. Beurnonville 
cs. Garat

RO nr.164(4): 24 messidor IV (12 jul 1796)

RE nr. 193: 1/3 brumaire V (22/24 okt 1796); Vlaamse vertaling [drukw FA nr. 143]

- verwijzing naar: reglement van 1 jul 1788

- decreet uitgevaardigd n.a.v. een motie van een Conventielid

- drukw FA nr.34 is tevens een instructie

- datum van uitvaardiging: "8 mars 1793, I" an II de la République française"

- afkondiging: besluit Directaire exécutif s. Carnot (pres), Lagarde (secr-gen); 29 prairial IV (17 jun 1796)

\section{3 maart 11 en 12}

LA IV fol 73wo-76ro; drukw FA nr.111; rH. X 8-12; P V 98-99; cB IIIe ser III 398-400; cL XIII 599633

\section{LOI RELATIVE À L'ADMINISTRATION DES BIENS DES EMIGRÉs, ET À LA VENTE DE LEUR MOBILIER}

De administrateur der nationale domeinen heeft het toezicht op de roerende en onroerende goederen van de uitgewekenen, alsmede de verkoop ervan. Daartoe correspondeert hij met de bevoegde autoriteiten, zoals ministers, andere bestuurslichamen en agenten van de Republiek in de bezette gebieden. Er dient een lijst van personen en de goederen van de geëmigreerden te worden opgesteld. De districtsbesturen begroten de kosten van de personen die bij de bewaking, de boedelbeschrijving, het transport en de verkoop van de roerende goederen aanwezig zijn. De wet behelst verder voorschriften inzake de afdracht van de opbrengst van de verkopingen en het opmaken van de processen-verbaal. De departementale besturen dienen de uitbetaling aan huisgenoten, werkers, leveranciers en houders van authentieke titels van vóór 9 februari 1792 , uit de opbrengst van de goederen van de uitgewekenen te continueren, mits de vordering het bedrag van 800 livres niet te boven gaat. Bij voorrang moeten de lijfrenten worden uitbetaald.

\section{bo. Convention nationale}

ao. comité d"alienation

cols. Brếard (pres); J. Julien de Toulouse, Mallarmé, L.J. Charlier (secr)

s. Clavière

cs. Garat

RO nr.210(2): 23 vendémiaire $V$ (14 okt 1796)

-verwijzing naar: wetten van $9 * 12$ feb 1792; 30 mrt* 8 apr 1792;23 aug 1792;25 nov 1792;26 jan 1793

- cB-intinulé: "décret concernant l"administration des biens provenant des émignés"

- afkondiging: besluit Directoire exécutif s. L.M. Revellière-Lépeaux (pres), Lagarde (secr-gen); 10 fructidor IV (27 aug $\$ 796)$

\section{3 maart 18}

LA III fol 60ro; rH VIII 13; P V 105-106; cB IIle ser III 434; cL. XIII 657 
Acht dagen na bekendmaking van het decreet is elke burger gehouden uitgewekenen of priesters onderworpen aan deportatie aan te geven, te arresteren of te laten arresteren, als hij weet dat zij zich op Frans grondgebied bevinden. Aldus gearresteerde uitgewekenen en priesters worden overgebracht naar een districtsgevangenis en door een militaire jury binnen 24 uur ter dood veroordeeld.

bo. Convention nationale

cols. Jean de Bry (pres); L.B. Guyton, J.B. Boyer-Fonfrède, L.M. Revellière-Lépeaux (secr)

s. Monge

cs. Gohier

ti. departement van de Dijle

RO nr. 113(3): 6 germinal IV (26 mrt 1796)

RE nr.118: 9/l0 germinall IV (29/30 mrt 1796)

- afkondiging: besluit volksrepresentanten/gouvernementscommissarissen s. Pérès, Portiez (dle l'Oise);

29 frimaire IV (20 dec 1795)

\section{3 maart 29}

drukw FA nr.30; rH VII 198; P V 134; cB IIle ser III 142-143; cL XIII 815-816

DÉCRET RELATIF AUX ECRITS TENDANT À PROVOQUER LE MEURTRE ET LA VIOLA* TION DES PROPRIÊTES

Degenen die door hun geschriften moord of beschadiging van eigendommen uitlokken, worden tot de doodstraf veroordeeld als deze delicten rechtstreeks het gevolg zijn van de uitlokking. Wanneer er geen sprake is van een rechtstreeks gevolg, dan wordt men voor zes jaar tot dwangarbeid in ketenen veroordeeld.

bo. Convention nationale

cols. Jean de Bry (pres): J.B. Fonfrède, L.M. Revellière-Lếpeaux (secr)

s. Garal

cs. Gohier

ti. gouvernementscommissaris Bouteville

RO nr.89(7): 16 nivôse IV (6 jan 1796)

RE nr.136: 14/15 floréal IV (3/4 mei 1796)

- FA, rH en $\mathrm{cB}$-intimulé: "décret relatif aux provocateurs au meurtre, etc."

- afkondiging: besluit volksrepresentanten/gouvernementscommissarissen s. Pérès, Portiez (de l'Oise);

24 frimaire IV (15 dec 1795)

\section{3 april 24}

LA II fol 109ro-112vo, III fol 112vo-115ro, IV fol 76vo-80ro; FA nr.234, nr.291; rH VI 102-108, X 13-19; P V 161-163; cB IIle ser IV 137-141; cL XIV 172-178

DÉCRET RELATIF À LA VENTE DES MEUBLES ET IMMEUBLES PROVENANT DES EMIGRES ET AUTRES EFFETS NATIONAUX 
Onder toezicht van de municipaliteiten dragen de door de departementale en districtsbesturen benoemde commissarissen en bewaarders zorg voor het instandhouden van de goederen van uitgewekenen en overige nationale goederen. Deze zijn verzegeld. Alvorens de openbare verkoping bij opbod van waardevolle goederen geschiedt, wordt dit door middel van aanplakking bekendgemaakt. Eén en ander geschiedt onder verantwoordelijkheid van de commissarissen, die ook de zorg hebben voor de goede orde tijdens de verkoping. Er staan boeten en straffen op het hinderen, dan wel onmogelijk maken van de verkoping, of het onttrekken van goederen aan de verkoop. Gemeenten en municipaliteiten is het uitdrukkelijk verboden onroerend goed aan te kopen, zonder voorafgaande goedkeuring van de Convention nationale. Wanneer de inwoners van een gemeente of een groot deel van hen de ten verkoop gebrachte goederen aankopen en de kosten omslaan over de bevolking, wordt dat als een frauduleuze handeling beschouwd.

bo. Convention nationale

vs. Joseplu Becker

cols. Lasource (pres); Mellinet, Chambon (secr)

s. Clavière

cs. Gohier

ti. volksrepresentanten/gouvemementscommissarissen; minister van justitie Merlin

RO nr.84(12), 147(9), $210(3)$ : 7 nivôse IV (28 dec 1795), $1 \rrbracket$ prairial IV (30 mei 1796), 23 vendémiaire $\mathrm{V}$ (14 okt 1796)

RE nr.72: $21 / 22$ nivôse IV (11/12 jan 1796)

- decreet uitgevaardigd n.a.v. petities van de 48 secties van Parijs en van verscheidene districten en departementen, i.w.m. malversaties

- verwijzing naar: decreten van 11 mrt 1792; 24 mirt 1793

- $\mathrm{rH}$ vermeldt abusievelijk als datum van uitvaardiging 24 april 1792

- cB-intitulé: "décret concemant la vente des meubles et immeubles appartenant à la République"

- afkondiging: besluit volksrepresentanten s. Pérès, Portiez (de l'Oise); 19 frimaire IV (10 dec 1795), de artt.1-5, 7-23; besluit Directoire exécutif s. Camot (pres), Lagarde (secr-gen); 23 floréal IV (12 meil 1796) en s. L.M. Revellière-Lépeaux (pres), Lagarde (secr-gen); 10 fructidor IV (27 aug 1796), integraal

\section{3 mei 10}

LA III fol 25vo-26ro; FA nr.237, FA nr.291; rH VI 360; P V 183; cB IIle ser V 86; cL XIV 309

DÉcret QUi DÉClaRe NULS TOUS les BAUX PASSÉs PAR ANTICIPATION, PAR LES MEMBRES OU AGENS DE L'ORDRE DE MALTE, ET DES AUTRES CI-DEVANT ORDRES ET CORPORATIONS

Alle bij voorbaat door leden of vertegenwoordigers van de Maltezer Orde, andere voormalige ridderorden, wereldlijke en religieuze gemeenschappen, colleges en universiteiten opgemaakte pachtakten, daterend van na 2 november 1789 zijn nietig en van generlei waarde. Deze pachtovereenkomsten kunnen niet als basis voor de schatting van de waarde van de goederen dienen. Eveneens nietig en van generlei waarde zijn de verkopingen van goederen op basis van dergelijke pachtovereenkomsten. 
bo. Convention nationale

ws. P.A. Laloy

cols. J.B. Boyer-Fonfrede (pres); Lehardy, J.A. Pénières (secr)

g. Lebrun

cs. Gohier

th. gouvenementscommisisaris Bowtewille

RO mir 97(7): 11 pluviose IV ( 31 jan 1796)

RE nr. 116:2/3 germinal IV (22/23 mrt 1796)

- verwijzing naair" wetten betreffende niet-verpachte goederen; betreffende perceelsgewijze verkoop van nationale domeingoederen

- cL-intitulé "décret qui déclare nuls tous les Baux passés par anticipation, par les membres ou agens des ci-devant ordres de Chevalerie, Corporations séculières \& régulières, Collèges \& Universités, posterieurement au 2 Novembre 1789"

- afkondiging: besluit wolksrepresentanten/gouwernementscommissarissen s. Pérès, Portiez (de l'Oise);

29 frimaire IV (20 dec 1795)

\section{3 mei 15}

drukw FA nr.30; rH VII 198-199; P V 196; cB IIIe ser V 148-149; cL XIV 384-385

DÉCRET RELATIF AUX ACCUSÉS CONDAMNÉS COMME AUTEURS DU MÊME DÉLIT, ET DONT LES CONDAMNATIONS NE PEUVENT SE CONCILIER, ET FONT PREUVE DE L'INNOCENCE DE L'UNE OU DE L'AUTRE PARTIE

Wanneer twee beschuldigden als plegers van éen en hetzelfde delict worden veroordeeld, zodanig dat de beide vonnissen niet kunnen worden verenigd, en het blijkt dat één van beide partijen onschuldig is, dan wordt de voltrekking van het vonnis opgeschort. Betreft het twee vonnissen van één en dezelfde rechtbank dan is deze bevoegd herziening van het vonnis te gelasten en de zaak te verwijzen naar een naburige criminele rechtbank. Zijn er meerdere rechtbanken bij betrokken, dan verloopt de procedure via het tribunal de cassation.

bo. Convention nationale

ao. comité de législation

vs. Delecloy

cols. Max. Isnard cader (pres); Poullain-Grandprez, Claude Fauchet (secr)

s. Garat

cs. Gohier

ti. gouvernementscommissaris Bouteville

RO nr.89(8): 16 nivôse IV (6 dec 1796)

RE nr. 136: 14/15 floréal IV (3/4 mei 1796)

- afkondiging: besluit volksrepresentanten/gouvernementscommissarissen s. Pérès, Portiez (de l'Oise); 24 frimaire IV ( 15 dec 1795 )

\section{3 juni 3}

LA III fol 115; FA nr.291; rH VIII 225-226; P V 315-326; cB IIIe ser ser VI 11-12; cL XIV 563-57!

[extract] LOI RELATIVE À LA VENTE DES IMMEUBLES DES EMIGRÉs (sect.IV artt.5-7, 9) 
Kastelen, parken en bezittingen in de steden toebehorend aan de uitgewekenen zullen worden verkocht. Het resterend gedeelte van hun goederen wordt in percelen of kavels verdeeld, onder handhaving van de bestaande pachtovereenkomsten. De verdelingen worden uitgevoerd door de door het districtsbestuur benoemde commissarissendeskundigen, in samenwerking met municipale ambtenaren. Er wordt een schatting gemaakt op basis van de doorsnee prijzen voor onroerend goed in de gemeente en voor zover mogelijk worden de goederen in gedeelten verkocht.

bo. Comvention nationale

a0. comité d'aliênarion

vs. Joseph Becker

cols. Mallarmé (pres); Méaulle, Durand-Maillane (secr)

s. Dalbarade

cs. Gohier

i. minister van justitie Merlin

RO nr. 147(10): 11 prairial IV (30 mei 1796)

- verwijzing naar: wet van 1 jun 1793

- P vermeldt dat deze wet deel uitmaakt wan het "décret concernant l'administration et la vente des biens des émigrés et la liquidation de leurs dette" van 25 julii 1793

- afkondiging: besluit Directoire erécurif s. Carnot (pres), Lagarde (secr-gen); 23 floréal IV (12 mei 1796)

\section{3 juni 6}

LA III fol 115vo-116ro; FA nr.291; rH VIII 226-227; P V 221-222; cB IIIe ser VI 45; cL XIV 607608

\section{LOI RELATIVE AUX TAXES DUES AUX EXPERTS POUR L'ESTIMATION DES BIENS NATIONAUX, ET AUX SALAIRES DUS POUR FRAIS RELATIFS À LA VENTE DESDITS BIENS}

De vergoedingen aan deskundigen voor de schatting van de nationale domeinen, evenals de salarissen verschuldigd voor de verkoop van deze goederen, worden afgehandeld door departementale besturen op advies van het districtsbestuur, rekening houdend met de omvang en de aard van de werkzaamheden. De districtsontvangers zijn gemachtigd in hun financiële overzichten deze kosten te boeken.

bo. Convention mationale

ao. comité des finances

vs. Joseph Becker

cols. Mallarmé (pres); Durand-Maillane, Méaulle (secr)

s. Dalbarade

cs. Gohier

ti. minister wan justitie Merlin

RO nr.147(11): 11 prairial IV (30 mei 1796)

- verwijzing naar: decreet van || aug 1792 en "à tous autres décrets contraïres"

- afkondiging: besluit Directoire exécutif s. Carnot (pres), Lagarde (secr-gen); 23 floréal IV (12 mei 1796) 


\section{3 juni 15}

LA III fol 26; FA nr 237. FA wr.291; rH VI 361-362; P V 248; cB IITe ser VI 130; cL XIV 726-727

DECRET QUI ACCORDE POUR 1793, AUX CITOYENS TITULAIRES DE L'ORDRE DE MALTE, LA JOUISSANCE DES REVENUS DES BIENS QU'ILS POSSÉdOIENT EN FRANCE

Vroegere titularissen van de Maltezer Orde genieten over het jaar 1793 [lees: 1792] de opbrengsten van de goederen die zij in Frankrijk bezaten, waarbij wel de lasten voor hun rekening komen. De revenuen die voor 1 januari 1793 door de ontvangers der registratie-rechten zijn geïnd, worden door de schatkist gerestitueerd. De pensioenen die aan de titularissen toegekend zijn, worden vanaf 1 januari 1793 driemaandelijks (par quartier) uitbetaald onder dezelfde voorwaarden als aan anderen die een staatspensioen genieten.

bo. Convention mationate

ao. comité d'aliénation

vs. Deleclay

cols. Collot-d"Herbois (pres); Durand-Maillane, Ch. Delacroix, Gossuin, P.A. Laloy (secr)

s. Gohier

cs. Gohier

ti. gouvernementscommissaris Boutevitle

RO nr.97(8): 11 pluviôse IV (31 jan 1796)

RE nr. I16: $2 / 3$ germinal IV (22/23 mrt 1796)

- verwijzing naar: wetten inzake de openbare geldmiddelen; wetten van 19 sep 1792; 2 dec 1792

- afkondiging. besluit volksrepresentanten/gouvernementscommissarissen s. Pérès, Portiez (de l'Oise);

29 frimaire IV (20 dec 1795)

\section{3 juli 8}

drukw FA nr.30; rH VII 199; P V 281; cB IIle ser VII 54; cL XV 49

[extract] DÉCRET QUI DISPENSE LES INDIGENS DE LA CONSIGNATION DE L'AMENDE DE CENT CINQUANTE LIVRES, POUR SE POURVOIR EN CASSATION (art.1)

Onvermogende burgers behoeven niet vooraf de door de wet vereiste 150 livres te storten, wanneer zij in beroep willen komen bij het tribunal de cassation. Zij dienen daartoe een certificaat van onvermogendheid over te leggen van de conseil général van hun gemeente, geviseerd door het districts- en departementaal bestuur.

bo. Convention nationale

s. Deforgues

cs. Gohier

ti. gouvernementscommissaris Bouteville

RO nr.89(9): 16 nivôse IV' (6 jan 1796)

RE nr. 136: 14/15 floreal IV (3/4 mei 1796)

- decreet uitgevaardigd n.a.v. een verzoekschrift van de molenaar Marconet te Saint-Prix en de boer

Parize te Lachaux (departement Saône-et-Loire)

- afkondiging: besluit volksrepresentanten/gouvernementscommissarissen s. Pérès, Portiez (de l'Oise);

24 frimaire IV (15 dec 1795) 


\section{DÉCRET QUI RECTIFIE UNE ERREUR DANS LA LOI DU 15 JUIN, RELATIVE AUX BIENS DE L'ORDRE DE MALTE}

Het bij vergissing genoemde jaartal 1793 in art.1 van de wet van 15 juni 1793 inzake het genot van de opbrengsten der goederen die de Maltezer Orde in Frankrijk bezat, moet worden vervangen doordat van het jaar 1792 . Het genot blijft beperkt tot dit ene jaar.

\section{bo. Convention nationale}

5. Destournelles

cs. Gohier

ti. gouvemementscommissairs Bouteville

RO nr.97(9): 11 pluviôse IV (31 jan 1796)

RE ar. I16: 2/3 germinal IV (22/23 mrt 1796)

- P noemt abusievelijk de wet van 15 juli 1793

- afkondiging: besluit volksrepresentanten/gouvernementscommissarissen s. Pérès, Portiez (de l'Oise); 29 frimaire IV ( $20 \mathrm{dec} 1795$ )

\section{3 juli 12}

LA III fol 27ro-28ro; FA nr.237, FA nr.291; rH VI 362-363; P V 285-286; F II 242; cB Ille ser VIII $82-83$

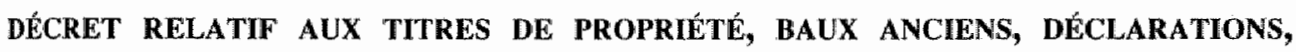
FOURNIS PAR LES FERMIERS DES DOMAINES NATIONAUX ALIÉNÉS

Alle eigendomstitels, oude pachtovereenkomsten, verklaringen afgegeven door pachters van vervreemde nationale domeinen zullen worden teruggeven aan de kopers van deze goederen, onder overlegging van het bewijs van betaling van de koopsom. Partiële verkrijgers van de nationale domeinen mogen, onder inzage van hun ontvangstbewijs, afschriften of extracten op gezegeld papier laten maken, welke als oorspronkelijke titel kunnen gelden, tegen de eventuele betichting van valsheid. De voornaamste partiële verkrijger aan wie de oorspronkelijke titels zijn overgedragen, is gehouden de overige partiële verkrijgers bij te staan, wanneer hun gecollationeerde extracten van valsheid beticht worden.

bo. Comvention nationale

ao. comité d" aliénation

s. Deforgues

cs. Gohier

ti. gouvernementscommissaris Bouteville

RO nr.97(10): 11 pluviôse IV (31 jan 1796)

RE nr.I16: $2 / 3$ germinal IV (22/23 mrt 1796)

- verwijzing naar: wet van $28 \mathrm{mrt} 1793$ 
- cL-initulế: "dêcret relatif à la Remise des Titres de proprietế \& de jouissance des Domaines nationaux aliéness"

- afkondiging: besl lit volksrepresentanten/gouvemementscommissarissen s. Pérès, Portiez (de I"Oise); 29 frimaire IV (20 dec 1795)

\section{3 juli 16}

LA III fol 116ro-118vo; FA nr.291; rH VIII 227-233; P V 289-291; cB IIIe ser VII 110-114; cL XW 98-108

\section{LOI QUI FIXE LES DROITS ET TAXATIONS À PERCEVOIR PAR LES RECEVEURS DU DISTRICT SUR LES CONTRIBUTIONS ET AUTRES RECETTES}

De districtsontvangers hebben de bevoegdheid een zeker bedrag, benodigd voor de vervulling van hun ambt, te heffen op de grondbelasting en de belasting op roerend goed, alsmede op de vruchten en inkomsten van de nationale domeinen over de jaren 1790-1792 (een staat daarvan is bijgevoegd). Zij moeten rekening en verantwoording afleggen over hun inkomsten en uitgaven aan de administrateur van de nationale domeinen en aan de departementale ontvanger. Bepaald wordt ook wanneer en op welke wijze een ontvanger is gedechargeerd. Een speciale staat van de inkomsten en uitgaven dient te worden opgesteld voor de kosten van de eredienst en andere doeleinden, waarvoor de schatkist speciale fondsen beschikbaar stelt.

bo. Convention mationale

ao. comité des finances

s. Deforgues

cs. Gohier

ti. minister van justitie Merlin

RO nr. 147(12): I1 prairial IV (30 mei 1796)

- verwijzing naar: decreten wan 15 sep 1791; 6 jun 1793

- afkondiging: besluit Directoire exécutif s. Carnot (pres); Lagarde (secr-gen); 23 floréal IV (12 mei 1796)

\section{3 juli 17}

LA I foll 295ro-296vo; FA nr.291; rH V 302-304; P V 291-296; cB IIIe ser VII 126-127; cL XV 109.112

LOI QUI SUPPRIME SANS INDEMNITÉ TOUTES REDEVANCES CI-DEVANT SEIGNEURIALES ET DROITS FÉODAUX, MÊME CEUX CONSERVÉS PAR LE DÉCRET DU 25 AOÜT DERNIER

Alle heerlijke pachtsommen, feodale rechten, vaste of incidentele cijnzen die nog zijn overgebleven, zijn zonder schadeloosstelling afgeschaft. Hiervan uitgezonderd zijn die prestaties die zuiver betrekking hebben op de grond en niet van feodale oorsprong zijn. In geval men national domeingoed heeft toegewezen gekregen, waarop nog afgeschafte rechten rusten kan men evenwel geen aanspraak maken op schadeloosstelling. Al degenen die bewijsstukken - daaronder ook begrepen vonnissen en arresten- 
en eigendomstitels inzake de gesupprimeerde rechten onder zich hebben, moeten deze overdragen aan de griffie van de municipaliteiten. In aanwezigheid van de conseil général van de gemeente zullen deze worden verbrand. Zij die bewijsstukken achterhouden worden veroordeeld tot vijf jaar dwangarbeid in ketenen. Kadastrale gegevens moeten wel op het secretariaat van de districten worden bewaard.

bo. Convention nationale

ao. comité de législation

s. Deforgues

cs. Gohier

ti. volksrepresentanten/gouvernementscommissarissen

RO nr.61(6): 19 frimaire IV (10 dec 1795)

RE nr.52: $20 / 21$ frimaire IV (11/12 dec 1795)

- verwijzing naar: decreet van 25 aug 1792

- P vermeldt $12 \mathrm{e}$ art

- afkondiging: besluit volksrepresentanten s. Pérès, Portiez (de l'Oise); 17 brumaire IV (8 nov 1795)

\section{3 juli 19}

LA II fol 34vo-35vo; FA nr.233; rH VI 72-73; P V 301-304; cB IIIe ser VII 147-148; cL XV 139 141

DÉCRET RELATIF AUX DROITS DE PROPRIÉTÉS DES AUTEURS D'ÉCRITS EN TOUT GENRE, DES COMPOSITEURS DE MUSIQUE, DES PEINTRES ET DESSINATEURS

Schrijvers, componisten, schilders en tekenaars genieten gedurende hun hele leven de exclusieve rechten van hun geestesproducten ter zake van koop, verkoop en verspreiding. Hun erfgenamen en overige rechtverkrijgenden genieten dit recht tot tien jaar na het overlijden van de auteur. Ambtenaren van vredegerechten moeten wederrechtelijk in omloop gebrachte voortbrengselen van de geest ten profijte van de auteurs in beslag nemen. De laatsten moeten in elk geval twee exemplaren in de nationale bibliotheek of het kabinet der gravures deponeren. Plegers van plagiaat moeten aan de werkelijke eigenaar een som geld betalen die overeenkomt met de prijs van 3000 exemplaren van de oorspronkelijke editie.

\section{bo. Convention mationale}

ao. comité d'instruction publique

vs. S.E. Monnel

cols. Jean Bon-Saint-Andrê (pres); Billaud-Varenne, R.T. Lindet (secr)

\$. Garat

cs. Gohier

ti. volksrepresentanten/gouvernementscommissarissen; minister van binnenlandse zaken Bénézech

RO nr.75 en 101: 30 frimaire IV (21 dec 1795); I ventôse IV (20 feb 1796)

- dient te worden ingeschreven in de registers, gelezen, gepubliceerd en atangeplakt

" besluit departementaal bestuur: exemplaren gezonden aan de municipaliteit "de cette ville"

- afkondiging: besluit volksrepresentanten s. Pérès, Portiez (de l'Oise); 17 frimaire IV (8 dec 1795);

tweede toezending zonder arrêté van het Directoire exécutif; 25 pluviôse IV (14 feb 1796) 
1793 julli 25 (1792 okt 31 , nov $1,3,10,25$, jun 3$)$

LA IV fol 80ro-100ro; drukw FA nr. 111; rH X 19-54; P V 315-327; cB IIle ser VII 223-248; cL XV 205-245

\section{LOI CONCERNANT L'ADMINISTRATION ET LA VENTE DES BIENS DES ÉMIGRÉS ET LA LIQUIDATION DE LEURS DETTES}

De wet behelst de voorschriften inzake de inbeslagneming van de goederen van uitgewekenen, de middelen tot instandhouding ervan, de kennisneming van het geheel van de goederen en rechten en het eventuele verhaal van hetgene aan de inbeslagneming onttrokken is. In de wet worden voorts de modaliteiten van de verkoop van de (on)roerende goederen aan de meestbiedende omschreven. In die gemeenten waar geen gemene gronden te verdelen zijn, wordt van de onroerende goederen van uitgewekenen een voldoende groot stuk afgesplitst om ieder gezinshoofd, die nog geen eigenaar is van een dergelijk stuk land, een stuk grond ter grootte van één morgen onder de titel van verpachting te geven. Daarnaast zijn er bepalingen omtrent de verevening van de activa en passiva van de geëmigreerden. De (gezamenlijke) schuldeisers zijn gerechtigd hun verklaringen en schuldvorderingstitels te deponeren, teneinde een vereffening te bewerkstelligen, rekening houdende met hun onderlinge rangschikking. Bij het beheer en de verkoop van de goederen van de uitgewekenen zijn de administrateurs van de nationale domeinen en de districtsbesturen ten nauwste betrokken.

bo. Convention nationale

ao. comité d'aliénation

s. Gohier

cs. Gohier

RO nr.210(4): 23 vendemiaire V (14 okt 1796)

- verwijzing naar: instructie en decreten van $5 * 8$ nov 1790; 10 okt 1792 ; wetten van 30 mrt * 8 apr 1792; 23 aug 1792; 2 sep 1792; 12 sep 1792; 13 sep 1792; 13 jan 1793; 1 feb 1793; 11 en 12 mrt 1793; $28 \mathrm{mrt} 1793$; I en 4 apr 1793; lois relatives à l'administration, l'aliénation et vente des bois nationaux

- drukw FA vermeldt als datum van uitvaardiging 31 jul 1793

- wet is een compilatie van eerder uitgevaardigde decreten: titel I; tit.I, het strafrechtelijke gedeelte, is van 28 mrt 1793 [cL-intitulé: "décrets contre les émigrés", cL XIII 777-804 s. Bouchotte, cis. Gohier]

- bepalingen van anterieure wetten waaraan deze wet niet derogeert blijven van kracht

- ale ook RO nr.147(10)

- afkondiging: besluit Directoire exécutif s. L.M. Revellière-Lépeaux (pres), Lagarde (secr-gen); 10 fructidor IV (27 aug 1796)

\section{3 augustus 1}

LA I fol 296vo-297ro; FA nr.291; rH V 304; P V 339; cB IIIe ser VIII 11; cL XV 319

DÉCRET QUI ORDONNE LA CONFISCATION SOUS HUITAINE, AU PROFIT DE LA RÉPUBLIQUE, DES MAISONS \& AUTRES ÉDIFICES PORTANT DES ARMOIRIES

Binnen één week zullen alle gebouwen, huizen, parken, tuinen enzovoorts die een wapenbord voeren ten profijte van de natie worden verbeurdverklaard. 
bo. Convention nationate

s. Gohier

cs. Gohier

ti. wolksrepresentanten/gouvernemeritscommissarissen

RO nr.62(1): 19 frimaire IV (10 dec 1795)

RE nr.53: $20 / 21$ frimaire IV (11/12 dec 1795)

- cB-intitules: "décret relatif aux parcs, maisons, etc portant des armoiries"

- afkondiging: besluit volksrepresentanten s. Pérès, Portiez (de l'Oise), cs. Delcambe (secr); 21 brumaire IV (12 nov 1795)

\section{3 augustus 14}

LA II fol 112vo; FA nr.234; rH VI 108; P V xvi; cB IIle ser VIII 127 ; $\mathrm{cL}$ XV 440

\section{DÉCRET QUI ORDONNE AUX AUTORITÉS CONSTITUÉES D'ENVOYER LEURS PÉTTTIONS} PAR LA POSTE

Bestuurders en andere autoriteiten moeten hun verzoekschriften en dergelijke per post verzenden, in plaats van deze zelf in persoon aan de balie van de Convention nationale te komen overhandigen. Van hen wordt verwacht dat zij op hun post blijven.

bo. Convention nationale

s. Deforgues

cs. Gohier

ti. volksrepresentanten/gouvernementscommissarissen

RO nr.84(13): 7 nivôse IV (28 dec 1795)

RE nr.72: $21 / 22$ nivôse IV (11/12/jan 1796)

- cB-intitulé: "décret portant que les fonctionnaires publics enverront leurs pétitions par la poste"

- afkondiging: besluit volksrepresentanten s. Pérès, Portiez (de l'Oise); 19 frimaire IV (10 dec 1795)

\section{3 augustus 16}

drukw FA nr.30; rH VII 200; P V 366; cB IIle ser VIII 148-149; cL XV 461

DÉCRET RELATIF AUX JUGEMENS CRIMINELS DANS LES PAYS OCCUPÉS PAR LES ENNEMIS OU LES REBELLES

In geval de vijand dan wel opstandelingen gebied van de Republiek bezethouden, geschiedt de uitvoering van vonnissen van de criminele rechtbanken daar waar zij zitting houden.

bo. Comention nationale

ao. comité de législation

s. Dalbarade

cs. Gohier

ti. gouvernementscommissaris Bouteville

$\mathbb{R O}$ nr.89(10): 16 nivôse IV (6 jan 1796)

RE nr. 136: 14/15 floréal IV (3/4 mei 1796)

- verwijzing naar: code pénal van 25 sep 1791 
- afkondiging: besluil wolksrepresentanten/gouwernementscommissarissen s. Pérès, Portiez (de I"Oise):

24 frimaire IV (15 dec 1795)

\section{3 augustus 24}

LA V fol 81vo-87ro; FA nr.291; $\pi$ H X 257-269; P V 384-402; cB IIlle ser VIII 230-272; cL XV 525$582,583-644$

[extract] LOI QUI ORDONNE LA FORMATION D'UN GRAND LIVRE, POUR INSCRIRE ET CONSOLIDER LA DETTE PUBLIQUE NON VIAGËRE, ETC. (artt.1-9, 56, 60, 66-72, 79, $81,111-116,121,130-134,137,142,175-184,205-206,223)$

De totale altijddurende (non viager) publieke schuld zal alfabetisch op naam van de schuldeisers in een grootboek worden ingeschreven. Het grootboek der nationale schuld vormt de enige titel voor alle schuldeisers van de staat, gearresteerd en getekend door onder meer drie commissarissen van de Nationale Conventie of het Wetgevend Lichaam. Er worden twee afschriften van vervaardigd. ledere schuldeiser zal aldus worden gecrediteerd, zowel voor wat betreft de netto-opbrengst van de altijddurende renten, als voor wat betreft de interest op de kapitalen die zijn eigendom zijn. Bedragen lager dan 50 lives worden niet in het grootboek ingeschreven. $\mathrm{Bij}$ het grootboek van de publieke schuld zal een rekening van de staat geopend worden, op welke rekening alle delgingen voortkomende uit beslagleggingen, confiscaties, terugbetalingen en dergelijke zullen worden gebracht, teneinde de vermindering van de nationale schuld te kunnen vaststellen. De wet behelst voorts bepalingen inzake de vereffening van de opeisbare schuldvorderingen, te onderscheiden in vorderingen groter of kleiner dan 3000 livres, en de termijn waarbinnen men zulks kan verzoeken ( 1 juli $\mathrm{t} / \mathrm{m} 30$ september). De schuldeisers dienen jaarlijks in hun districtshoofdplaats daarvoor formulieren, geviseerd door het districtsbestuur, te overleggen. De uitbetaling geschiedt ook in de districtshoofdplaats. Gedurende de maanden oktober, november en december kunnen er geen inschrijvingen in het grootboek plaatshebben. Deze periode is gereserveerd voor de transcripties van de mutaties in de loop van het jaar en de gereedmaking van de jaarlijkse betalingsbladen. Schuldeisers van de staat die tevens debiteur aan de staat zijn, kunnen met hun inschrijvingen op het grootboek kwijten.

bo. Convention nationale

ao. commission des finances

s. Gohier

cs. Gohier

RO nr.232(3): I nivôse V (2| dec 1796)

- art. 121 ook als afzonderlijk decreet uitgevaardigd

- $\mathrm{cB}$ - en cL-datum van uitvaardiging: $15,16,17 \& 24$ aug 1793

- cB-en cL-intitule: "Décret qui ordonne la formation d'un grand livre, pour inscrire \& consolider la dette publique non viagère; la remise \& annulation des anciens titres de créances, sous peines de déchéance; l'accélération de la liquidátion; la suppression des rentes dues aux fabriques; la reconnoissance des dettes des communes, départemens \& districts, comme dettes nationales; la liquidation des annuités \& des effets au porteur; le remboursement ou l'inscription de la dette publique dans les districts; la faculté de conwertir les assignats en une inscription sur le grand livre, à raison de cing pour cent du capital; l'admission de la dette consolidée en paiement des domaines nationaux à vendre, \& l'assujétissement de la dette consolidée au principal de la contribution foncière" 
- afkondiging: besluit Directoire exécutif s. P. Barras (pres), Lagarde (secr-gen); 16 frimaire V (6 dec 1796); opmerking: deze artikelen afgekondigd ter uitwoering wan het bepaalde in art.19 van de wet van 15 fructidor IV (1 sep 1796), houdende de opheffing van de religieuze instellingen in het voormalige Belgiẽ

\section{3 september 1}

LA II fol 35vo-36vo; FA nr.233; rH VI 74; P V 412; cB Ille ser IX 4; cL XV 694-695

\section{DECRET RELATIF AUX DROITS DE PROPRIÉTÉ DES AUTEURS D'OUVRAGES DRAMATI- QUES ET A LA POLICE DES SPECTACLES}

Teneinde aan schrijvers van toneelwerken volledig het hun toekomende auteursrecht te garanderen, wordt de wet van 30 augustus 1792 ingetrokken en moeten die van 13 januari 1791 en 19 juli 1793 worden uitgevoerd. Het toezicht op de theatervoorstellingen blijft uitsluitend bij de municipaliteiten berusten. Well moeten de schouwburgexploitanten een register bijhouden van het aantal opvoeringen.

\section{bo. Convention nationale}

us. Blaux

cols. Robespierre (pres); Merlin (de Douai), Lakanal, P.J. Duhem (secr)

ti. volksrepresentanten/gouvernementscommissarissen; minister van binnenlandse zaken Bénézech RO nr.75 en 101: 30 frimaine IV (21 dec 1795); 1 ventôse IV (20 feb 1796)

- FA-, rH- en cL-intitulé: "décret quỉ rapporte la loi du 30 Août 1792, relative aux ouvrages dramatiques, et ordonne l"exécution de celles des 13 janvier 1791 et 19 juillet dernier"

- dient te worden geregistreerd, gelezen, bekendgemaakt en aangeplaki

- besluit departementaal bestuur: exemplaren gezonden aan de municipaliteit "de cette ville"

- afkondiging: besluir volksrepresentanten s. Pérès, Portiez (de l"Oise); 17 frimaire IV (8 dec 1795); tweede toezending zonder arrêté van het Directoire exécutif; 25 pluwiôse IV (14 feb 1796)

\section{3 september 7}

LA I fol 301; FA nr.291; rH V 309; P V 423; cB IIle ser IX 75; cL XV 780

\section{DECRET QUI DEFEND À TOUS FRANCAIS DE RECEVOIR DES DROITS FEODAUX \& DES REDEVANCES DE SERVITUDES}

Geen enkele Fransman kan feodale rechten of cijnzen, waar ook op aarde, innen op straffe van burgerlijke degradatie.

bo. Convention nationale

s. Bouchotte

cs. Gohier

ti. volksrepresentanten/gouvemementscommissarissen

RO nr.62(5): 19 frimaire IV (10 dec 1795)

RE nr.53: 20/21 frimaire IV (1 1/12 dec 1795)

- afkondiging: besluit volksrepresentanten s. Pérès, Portiez (de l'Oise), cs. I. Torfs (secr); 21 brumaire IV (12 nov 1795) 
DECRET PORTANT QUE PROVISOIREMENT LES MINEURS DONT LES PÈRES OU MERES SERAIENT MORTS, INTERDITS OU ABSENS POUR CAUSE LEGITIME, SONT AUTORISES A CONTRACTER MARIAGE SUR L'AVIS D*UN CONSEIL DE FAMILLE

Minderjarigen wier ouders overleden zijn, dan wel uit de ouderlijke macht zijn ontzet, of om wettige redenen afwezig zijn, mogen trouwen na het oordeel van een familieraad te hebben ingewonnen, welke is samengesteld uit twee naaste familieleden en twee andere verwanten die niet tot de vermoedelijke erfgenamen behoren. Op verzoek van de minderjarige wordt de familieraad door de ambtenaar van de burgerlijke stand bijeengeroepen. Deze is eveneens stemgerechtigd. Bij onthouding van goedkeuring kan uiteindelijk alleen het huwelijk tegengehouden worden op grond van de kennelijk niet-onberispelijke levenswandel van de te huwen partij, of niet-rehabilitatie na een vonnis waarin een onterende straf (peine infamante) is uitgesproken.

bo. Convention mationale

s. Gohier

CS. Gohier

RO nr.164(5): 24 messidor IV (12 jull 1796)

RE nr.193: 1/3 brumaire V (22/24 okt 1796); Vlaamse vertaling [drukw FA nr. 143]

- decreet uitgevaardigd n.a.v. verzoekschrift van Trippier-Lagrange

- drukw FA nr.34 is tevens instructie

- cB vermeldi niet de passus van de twee andere verwanten

- datum van uitwaardiging: "7 septembre 1793, an II de la République française, une et indivisible"

- afkondiging: besluit Direcroire exécutif s. Carnot (pres), Lagarde (secr-gen); 29 prairial IV (17 jun 1796)

\section{3 september 11}

LA V fol 87; FA nr.291; rH X 270; P V 427-430; cB IIIe ser IX 134-143; cL XV 804-815

[extract] LOU QUI DEFEND LA VENTE, CESSION, NÉGOCIATION OU TRANSPORT DES TTRES ACTUELS CONSTATANT LES CREANCES NON VIAGERES SUR LA NATION, ETC. (art. 1 en 2)

De huidige titels die de altijddurende schuldvorderingen op de staat vastleggen, kumnen vanaf 1 oktober 1793 niet langer worden verhandeld, verkocht, afgestaan of overgedragen, op straffe van nietigheid van de akte ter zake en een boete voor de koper, de notaris of de makelaar. Tevens is het ambtenaren van de registratierechten verboden een dergelijke akte te registreren.

bo. Convention nationale

ao. commission des finances

s. Gohier

cs. Gohier

RO nr.232(4): 1 mivôse V (21 dec 1796) 
- cB- en cL-imtihulé: "Décret qui défend la vente, cession, négotiation, ou transport des titres actuels constatant les créances non-viagères sur la nation, à compter du premier octobre prochain, qui règle l'echange de ces titres contre un extrait provisoire d"inscription, et autorise les porteurs des extraits provisoires d'inscriptions à les échanger contre un bon admissible, pendant l'annee 1794, en paiement de domaines nationaux, adjugés depuis le 24 août dernier, à la charge de foumir en neme temps pareille somme en assignats"

- afkondiging: besluit Directoire exécutif s. P. Barras (pres), Lagarde (secr-gen); 16 frimaire V (6, dec 1796): opmerking: deze artikelen afgekondigd ter uitwoering van het bepaalde in art. 19 van de wet van 15 fructidor IV (1 sep 1796), houdende de opheffing van de religieuze instellingen in het voormalige België

\section{3 september 14}

LA I fol 297; FA nr.291; rH V 304; P V 440; cB Ille ser IX 161; cL XV 858

\section{DÉCRET QUI ORDONNE L'ENLÈVEMENT DES SIGNES DE ROYAUTÉ \& DE FÉODALITÉ DANS LES ÉGLISES \& AUTRES MONUMENS PUBliCS}

Gemeentelijke ambtenaren dienen, op straffe van afzetting, het decreet aangaande de koninklijke wapens en kentekenen aangebracht in kerken en op andere openbare monumenten van 4 juli 1793 te laten uitvoeren.

bo. Convertion nationale

s. Paré

$\mathrm{cs}$ Gollier

ti. volksrepresentanten/gouvernementscommissarissen

RO nr.62(2): 19 frimaire IV (10 dec 1795)

RE nr.53: 20/21 frimatire IV (11/12 dec 1795)

- verwijzing naar: decreet van 4 jul 1793

- afkondiging: besluit volksrepresentanten s. Pérès, Portiez (de l'Oise), cs. Delcambe (secr); 21 brumaire IV (12 nov 1795)

\section{3 september 14}

LA III fol 200vo-20lro; drukw FA nr.34; rH VIII 388-389; P V 440; cB IIIe ser IX 159-160; cL XV $850-851$

DÉCRET QUI PRESCRIT LES FORMALITÉS À OBSERVER POUR ETRE ADMIS À SE MARIER LORSQU'ON NE PEUT REPRÉSENTER D'ACTE DE NAISSANCE

Degenen die geboren zijn in streken van de Republiek die door vijandelijke mogendheden of opstandelingen bezet zijn en mitsdien hun geboorteakte niet kunnen tonen, mogen trouwen als er een akte van bekendheid is opgemakt. Eveneens geldt dit voor degenen die zich niet van een geboorteakte kunnen voorzien. De akte van bekendheid wordt afgegeven door de vrederechter in de huidige verblijfplaats op verklaring van drie verwanten dan wel buren of vrienden. Wanneer de huwelijksafkondiging in de woonplaats niet mogelijk is, volstaat de afkondiging in de huidige verblijfplaats. 
bo. Convention nationale

ao. comité de légistation

s. Gohier

cs. Gohier

RO nr. 164(6): 24 messidor IV (12 jul 1796)

RE nir. 193: 1/3 brumaire $V(22 / 24$ okt 1796); Vlaamse vertaling [drukw FA nr.143]

- verwijzing naar: wet van 20 sep 1792

- drukw FA nr.34 is tevens instructie

- datum van tuitvaardiging:" "/4 septembre 1793. l'an 2 de la République française, une et indivisible"

- afkondiging: besluil Directoire exécurif s. Carnot (pres), Lagarde (secr-gen); 29 prairial IV (17 jun 1796)

\section{3 september 17}

LA III fol 60wo; rH VIII 14; P V 445; cB IIle ser IV 192; cL XV 895

DÉCRET QUI DECLARE LES LOIX RELATIVES AUX ÉMIGRÉS APPLICABLES AUX DÉPORTES

De bepalingen van de wetten aangaande de uitgewekenen zijn in alle opzichten toepasselijk op gedeporteerden.

\section{bo. Comvention nationale}

s. Deforgues

cs. Gohier

ti. departement wan de Dijle

RO nr.113(4): 6 germinal IV (26 mrt 1796)

RE nr.118: $9 / 10$ germinal IV (29/30 mrt 1796)

- in verband hiermee zie ook het besluit van de volksrepresentanten/gouvernementscommissarissen van 29 frimaire IV ( 20 dec 1795)

- afkondiging: besluit volksrepresentanten/gouvernementscommissarissen s. Pérès, Portiez (de l"Oise); 29 frimaire IV (20 dec 1795)

\section{3 september 17}

LA IV fol 43ro-44ro; FA nr.291; rH IX 296-297; P V 445; cB IIJe ser IX 184; cL XV 894-895

\section{LOI QUI AUTORISE LES NOTAIRES, GREFFIERS ET HUISSIERS À FAIRE LES PRISEES ET VENTES DES MEUBLES, ET FIXE LE PRIX DE VACATIONS}

Notarissen, griffiers en deurwaarders zijn bevoegd in de gehele Republiek taxaties en verkopingen van roerende goederen te verrichten. Bijgevolg dienen de deurwaardersschatters van Parijs, alsmede de deurwaarders van het vroegere Hôtel [=jurisdictie van het koninklijk huis], hun ambtsbediening te beëindigen. Wanneer zij bevoegd zijn de overige functies van een deurwaarder uit te oefenen, kunnen zij als schatter werkzaam zijn tegen een zeker bedrag aan vacatiegeld, uit te betalen voor hetgeen zij ambtshalve verrichten. Ambtenaren die dezelfde werkzaamheden in de departementen verrichten, hebben gelijkelijk recht op deze vacatiegelden. Art.8 van de wet van $21 * 26$ juli 1790 wordt herroepen, voor zover het de schatters is toegestaan een zeker bedrag te 
heffen op de grosserol van de processen-verbaal. De Convention nationale geeft voorts aan haar comité de liquidation opdracht de mogelijkheid van afschaffing van de deurwaarders te onderzoeken.

\section{bo. Convention nationale}

ao. comités de législation et de liquidation réunis

s. Bouchotte

cs. Gohier

RO nr.200(2): 24 fructidor IV (10 sep 1796)

RE nr.189: $15 / 16$ vendémiaire IV (6/7 okt 1796)

- werwijzing naar: wet van $21 * 26$ jul 1790

- LA en FA nr.291 vermelden als datum van uitwaardiging: "17 Septembre 1793, an II de la République française"

- wet uitgevaardigd n.a.v. verzoekschrift van de deurwaarders-schatters te Parijs

- afkondiging: besluit Directoire exécutif s. L.M. Revellière-Lépeaux (pres), Lagarde (secr-gen); 12 fructidor IV (29 aug 1796) [BL Ile ser no.72 (666)]

\section{3 september 20}

LA III fol 213ro-214ro; FA nr.291; rH IX 17-18; P V 449, VII Ixxxvi; cB IIle ser IX 202-203; cL XV $911-912$

DÉCRET QUI ACCORDE LE DELAI DE TROIS MOIS POUR SE POURVOIR, PAR LA YOIE DE L'APPEL, CONTRE DES CONDAMNATIONS EN VERTU DE LETTRES PATENTES, DES ARRÊTS DE PROPRE MOUVEMENT, ET AUTRES DU CI-DEVANT CONSEIL [DU ROI]

De lettres patentes [=handelingen van vóór 1789 uitgaande van het koninklijk gezag die alleen dan rechtsgevolgen hebben, wanneer ze geregistreerd zijn door het hof waaraan zij zijn gericht] die zonder opgeworpen verzet en voorafgaande discussie geregistreerd zijn bij de vroegere parlementen en andere hoge gerechtshoven, alsmede de arresten van de vroegere Conseil $[d u$ Roi] vastgesteld buiten de aanwezigheid van partijen of zonder dat zij zijn opgeroepen en zonder het noemen van de oorspronkelijke stukken en procesbescheiden, kunnen in geen enkel geval met succes worden tegengeworpen aan degenen ten nadele van wie ze zijn verkregen. De لaatsten die ingevolge lettres patentes zijn veroordeeld, zijn gerechtigd in beroep te komen tegen deze vonnissen. Nog onbesliste rechtszaken aanhangig bij de vroegere parlementen en andere hoven in eerste aanleg uit hoofde van committimus [het (voor)recht dat de koning aan bepaalde personen toekent om in eerste aanleg te pleiten, zowel als eiser als gedaagde, ten overstaan van bepaalde rechters], bevoegdheidstoekenning (attribution) en -ontneming (évocation), kennis van het verzet tegen de registratie van de verkregen lettres patentes in bijzondere gevallen en bijkomende geschilpunten, ofwel uit hoofde van enig privilege kunnen alleen dan in hoogste aanleg door de daarvoor in de plaats gekomen rechtbanken geoordeeld worden als partijen daarin toestemmen. Tegen hiermee in strijd zijnde vonnissen staat hoger beroep open, zelfs als het verzoek tot cassatie is verworpen.

bo. Comvention nationale

ao. comité de législation 
3. Dabarade

cs. Gohier

RO nr. 172: 15 thermidor IV (2 aug 1796)

RE ni.185: 8/9/10 vendémiaire $V(29 / 30$ sep/ll okt 1796)

- datum van uitwaardiging: "20 septembre 1793, l"an II de la République française, une et indivisible"

- afkondiging: besluit Direcroire exécutif s. Camot (pres), Lagarde (secr-gen); 7 thermidor IV (25 jul 1796); argumentatite woor de afkondiging van de wet van 20 september 1793: de vroegere mogendheden in het gebied wan de départements réumis hebben zich verscheidene arbitraire handelingen veroorlloofd; hiun despotische misbruiken dienen te worden beteugeld

\section{3 september 21}

drukw FA nr.30; rH VII 200; P V xx; cB IIIe ser IX 210-211; cL XVI 2-3

\section{[extract] DÉCRET QUI ENJOINT AUX FEMMES DE PORTER LA COCARDE TRICOLORE}

Vrouwen wordt bevolen de driekleurige kokarde te dragen op straffe van acht dagen gevangenisstraf voor de eerste keer dat zij in overtreding zijn. Zij die bij iemand anders de kokarde afscheuren of deze anderszins onteren, worden bestraft met zes jaar opsluiting.

bo. Convention nationale

s. Bouchotte

cs. Gohier

ti. gouvernementscommissaris Bouteville

RO nr.89(40): 16 nivose IV (6 jan 1796)

RE nr.136: 14/15 floréal IV (3/4 mei 1796)

- decreet uitgevaardigd op voorstel van een lid van de Conventie

- drukw FA vermeldt als datum van uitvaardiging: 21 sep II

- afkondiging: besluit volksrepresentanten/gouvernementscommissarissen s. Pérès, Portiez (de l'Oise);

24 frimaire IV (1.5 dec 1795)

\section{3 september 30}

drukw FA nr. 30; rH VII 201; P V 469; cB Ille ser X 65-66; cL XVI 73

DÉCRET RELATIF AUX PROCÈS DANS LESQUELS L'ENVAHISSEMENT DU TERRITOIRE FRANÇOIS EMPECHERA DE PRODUIRE LES PREUVES NÉCESSAIRES À LA MANIFESTATION DE LA VÉRITÉ

Wanneer het voor de criminele rechtbanken vanwege een vijandelijke invasie niet mogelijk is om het nodige bewijsmateriaal te verwerven, kunnen zij, op verzoek van de openbare aanklagers, het onderzoek tijdelijk uitstellen.

bo. Convention mationale

ao. comité de législation

s. Destournelles

cs. Gohier

ti. gouvernenentscommissaris Bouteville

RO nr.89(11): 16 nivôse IV (6 jan 1796) 
RE nt.136: 14/15 floréal IV (3/4 mei 1796)

- drukw FA vermeldt als datum wan uitvaardiging 30 sep I

- verwijzing naar: wet van 29 sep 1792 (N.B.: cL. 1791)

- afkondiging: beslluit volksrepresentanten/gouvemementscommissarissen s. Pérès, Portiez (de l'Oise);

24 frimaire IV (15 dec 1795)

\section{3 oktober 2}

LA I fol 301 vo-302ro; rH V 309-310; P V 475-476; cB IIIe ser X 90; cL XVI 96

DÉCRET RELATIF AUX ACTES DE CONCESSION, À TITRE D'INFÉODATION, ET BRÛLEMENT DES TITRES FÉODAUX

Akten, houdende de oorspronkelijke overdracht onder de titel van belening of verpachting en die zuiver tot de grond beperkt is, dienen te worden onderscheiden van de overige cijnsrechten, welke doen herinneren aan het tirannieke bewind. De termijn waarbinnen gemengde feodale titels moeten worden verbrand, is tot zes maanden verlengd.

bo. Convention nationale

ao. comitế de législation

ti. volksrepresentanten/gouvernementscommissarissen

RO nr.62(6): 19 frimaire IV (10 dec 1795)

RE nr.53: 20/21 frimaire IV (11/12 dec 1795)

- verwijzing naar: wetten van 4 aug $1789 ; 17$ jul 1793

- afkondiging: besluit volksrepresentanten s. Pérès, Portiez (de l"Oise), cs. J. Torfs (secr); 21 brumaire IV (12 nov 1795)

\section{3 oktober 5}

drukw FA nr.30; rH VII 201-202; P V 480; cB IIle ser X 112; cL XVI 123

\section{DÉCRET RELATIF À LA DURÉE de LA dÉTENTION, POUR AMENDES PRONONCÉES PAR}

\section{LA POLICE CORRECTIONELLE}

Onvermogenden die boetes, opgelegd door het correctionele toezicht (police correctionnelle), niet voldoen, kunnen daarvoor slechts één maand in hechtenis worden gehouden.

bo. Convention nationale

ao. comité de législation

s. Deforgues

cs. Gohier

ti. gouvernementscommissaris Bouteville

RO nr.89(12): 16 nivôse IV (6 jan 1796)

RE nr.136: 14/15 floréal IV (3/4 mei 1796)

- drukw FA vermeldt als datum van uitvaardiging 5 okt II

- verwijzing maar: des lois pénales

- afkondiging: besluit volksrepresentanten/gouvernementscommissarisser s. Pérès, Portiez (de l'Oise):

24 frimaire IV (15 dec 1795) 
DECRET QUI PRESCRIT UN TERME POUR L'ENLÈVEMENT DES SIGNES DE ROYAUTÉ, \& LES FORMES QUi DEVRONT PRÉCÉder LA CONFISCATION DES TERRAINS \& EDIFICES SUR LESQUELS ON LES AURA LAISSÉ SUBSISTER

Binnen één week dienen eigenaren of vruchtgebruikers van parken, tuinen, gebouwen enzovoorts de koninklijke kentekenen, zoals de fleur de lys, te verwijderen. Dit moet geschieden in aanwezigheid van de hiertoe bijeengeroepen gemeente. Wanneer men niet tot verwijdering van de kentekenen overgaat, volgt de verbeurdverklaring ten profijte van de Republiek, welke zal worden geproclameerd door het departementaal bestuur, naar aanleiding van het door de gemeente opgemaakte proces-verbaal, en waarin tevens de uitdrukkelijke vermelding van de bekendmaking van dit decreet in die gemeente is vastgesteld.

bo. Comvention nationale

ao. comité de législation

s. Deforgues

cs. Gohier

ti. volksrepresentanten/gouvernementscommissarissen

RO nr.62(3): 19 frimaire IV (10 dec 1795)

RE nr.53: 20/21 frimaire IV (11/12 dec 1795)

- verwijzing naar: decreet van 1 aug 1793

- decreet uitgevaardigd n.a.v. de petitie van de burger Vaudeuil te Saint-Germain (departement Loiret)

- afkondiging: besluit volkstrepresentanten s. Pérès, Portiez (de l'Oise), cs. Delcambe (secr); 21 brumaire IV (12 nov 1795)

\section{II vendémiaire 18 (1793 okt 9)}

LA V fol 2; rH X 167; P V 488; cB IIIe ser X 167-168; cL XVI 162-163

[extract] LOI QUT PROSCRIT DU SOL DE LA RÉPUBLIQUE TOUTES MARCHANDISES FABRIQUées oU MANUFACTURÉES DANS LES PaYS SOUMIS AU GOUVERNEMENT BRITANNIQUE (artt.1-3, 6)

Handelswaar afkomstig van Engeland, Schotland, Ierland en verder van alle gebieden die aan de Britse regering onderhorig zijn, wordt van het grondgebied van de Franse Republiek verbannen. De douaneadministratie dient er streng op toe te zien dat deze goederen niet geïmporteerd worden. Het douanepersoneel is daarvoor persoonlijk verantwoordelijk en wordt bij overtreding tot twintig jaar dwangarbeid in ketenen veroordeeld. Degenen die acht dagen na de bekendmaking van deze wet hiermede nog in strijd handelen, doordat zij handeldrijven in Engelse waren, riskeren dezelfde straf. Eigenaars van Britse handelswaar dienen binnen vijftien dagen een verklaring aan de municipaliteit, alwaar zij verblijven, te overleggen om de factuur te laten vaststellen. 
bo. Convention nationale

ao. comité de salut public

s. Deforgues

cs. Gohier

RO $\mathrm{nr} .211: 27$ vendëmiaire $\mathrm{V}$ (18 okt 1796)

- afkondiging: besluit Directoire exécutif s. L.M. Revelliere-Lépeaux (pres), Lagarde (secr-gen); 15 vendémiaire $\mathrm{V}$ (6 okt 1796) [BL Ile ser no.81 (751)]

\section{II vendémiaire 29 en 30 (1793 okt 20 en 21$)$}

LA III fol 60vo-62ro; rH VIII 14-18; P V 513-514; cB IIle ser X 267-270; cL XVI 275-279

\section{DÉCRET RELATIF AUX ECCLÉSIASTIQUES SUJETS À LA DÉPORTATION OU À DES PEINES CORPORELLES}

Priesters die deportatie opgelegd kregen, verzetten zich gewapenderhand langs de grenzen en op vijandelijk gebied. Degenen die geleidebrieven of paspoorten bij zich dragen van de leiders van de Franse uitgewekenen, van opstandelingen of van bevelhebbers van vijandelijke legers, worden binnen 24 uur ter dood veroordeeld door een krijgsraad na vaststelling van de feiten door middel van twee schriftelijke of mondelinge getuigenissen. De beschuldigden mogen onder bepaalde omstandigheden het proces-verbaal van hun eedsaflegging op de vrijheid en de gelijkheid tonen. De openbare aanklager is dan gemachtigd aan te tonen dat zij zijn gedeporteerd wegens herroeping van de eed of wegens incivisme. In dat geval volgt alsnog veroordeling. Deportatie naar de westkust van Afrika tussen de $23^{\mathrm{e}}$ en de $28^{\mathrm{c}}$ graad zuiderbreedte krijgen al die kerkelijke functionarissen - van (aarts)bisschop tot pastoor en leraren aan seminaries - opgelegd, die weigeren de eed af te leggen, of deze hebben herroepen en sinds de wet van 5 februari 1791 hebben gepreekt. Jegens zieken en geestelijken ouder dan 60 jaar wordt milder opgetreden. Geestelijken die zich in Frankrijk verborgen houden en niet ingescheept zijn richting Frans-Guyana moeten zichzelf bij de autoriteiten voor deportatie aanmelden, anders volgt terechtstelling. Deportatie, opsluiting en de doodstraf brengen de confiscatie van de goederen met zich mee. Geestelijken die kiezen voor vrijwillige deportatie worden als uitgewekenen beschouwd. Een burger die een aan deportatie onderworpen geestelijke een schuilplaats biedt, wordt gelijkelijk bestraft.

bo. Convention nationale

ao. comité de législation

8. Paré

es. Gohier

ti. departement van de Dijle

RO nr.113(5): 6 germinal IV (26 mrt 1796)

RE nr.118: $9 / 10$ germinal IV (29/30 mrt 1796)

* verwijzing naar: wetten en decreten van 12 juli $1790 ; 24$ juli $1790 ; 27$ nov $1790 ; 2$ feb $1791 ; 14$ aug 1792; 21 apr 1793

- FA, rH en cL vermelden als datum van uitvaardiging: "29 et $30^{\text {max }}$ jours du $1^{\text {er }}$. mois de l'an $2^{\text {mer"; }}$ cB vermeldt als datum van uitvaardiging 29 vendémiaire II

- afkondiging: besluit volksrepresentanten/gouvernementscommissarissen s. Pérès, Portiez (de l'Oise); 29 frimaire IV (20 dec 1795 ) 
DÉCRET QUI DÉFEND D'EMPLOYER, DANS LES FABRICATIONS DES PAPIERS, DES FORMES OU TRANSPARENS PORTANT DES ATTRIBUTS DE ROYAUTÉ

Het gebruik van vormen of watermerken met de fleurs-de-lys of andere koninklijke attributen door papierfabrikanten en -handelaren is op straffe van verbeurdverklaring verboden. Zij dienen te worden vervangen door de woorden liberté, égalité, République française, whe et indivisible.

bo. Convention nationale

ao. comité de salut public

s. Paré

cs. Gohier

ti. gouvernementscommissaris Bouteville

RO nr.89(13): 16 nivôse IV (6 jan 1796)

RE nr.136: 14/15 floréal IV (3/4 mei 1796)

- drukw FA en cL vermelden als datum van uitvaardiging: " $\rrbracket^{\text {er }}$ jour du $2^{\mathfrak{E}}$ mois de l'an second"

- afkondiging: besluit volksrepresentanten/gouvernementscommissarissen s. Pérès " Portiez (de l'Oise);

24 frimaire IV (15 dec 1795 )

\section{II brumaire 1 (1793 okt 22)}

drukw FA nr.30; rH VII 203-204; P V 518; cB IIIe ser XI 7-8; cL XVI 301-302

DÉCRET PORTANT QUE LA CONDAMNATION POUR CRIME DE FABRICATION DE FAUX ASSIGNATS ET DE FAUSSES MONNOIES, EMPORTERA CONFISCATION DES BIENS

De goederen van degenen die veroordeell zijn wegens valsemunterij, worden door de staat geconfisqueerd. Te dien einde dienen de bevoegde autoriteiten de noodzakelijke voorzieningen te treffen, zoals verzegeling van de goederen en de publieke verkoping ervan.

bo. Comvernion nationale

ao. comités des finances ef de légistation

s. Paré

cs. Gohier

ti. gouvernementscommissaris Bouteville

RO nr.89(14): 16 niwôse IV (6 jan 1796)

RE nr. 136: 14/15 floréal IV (3/4 mei 1796)

"drukw FA en $\mathrm{cL}$ vermelden als datum van uitvaardiging: " $1^{\text {er }}$ jour du $2^{\circ}$ mois de l'an second"

- verwijzing naar: decreet wan 25 jun 1793 (herroepen)

- afkondliging: besluit volksrepresentanten/gouverrementscommissarissen s. Pérès, Portiez (de l'Oise);

24 frimaire IV (15 dec 1795) 
Het is eigenaren en pachters die de grond niet zelf bewerken, en wier pachtboeren de grond zonder pachtovereenkomst bewerken of krachtens een contract daterend van na de uitvaardiging van de decreten die de heerlijke rechten ophieven, verboden, van hen in geldswaarde of in natura, tienden of heerlijke renten, kerkelijke of feodale pachten of cijnzen te vorderen. Bepalingen dienaangaande zijn nietig. Terugbetaling van reeds betaalde bedragen vóór de bekendmaking van dit decreet is evenwel niet mogelijk. Rechtszaken en nog niet ten uitvoer gelegde vonnissen ter zake zijn tenietgedaan en zijn niet-bestaand. Eigenaren en pachters hebben evenwel de bevoegdheid om onderling afspraken te maken ten aanzien van de verdeling van de opbrengsten en de kwijting van belastingen, zolang zij niets van doen hebben met de afgeschafte rechten. De wet is uitgevaardigd in verband met misbruiken in verscheidene departementen.

bo. Convention nationale

ao. comité de salut public

s. Paré

Cs. Gohier

RO nr.232(12): I nivôse V (21 dec 1796)

- verwijzing nar: wetten van 11 mrt * 10 apr 1791; 25 aug 1792

- cL vermeldt als datum van uitvaardiging: "1 1 er jour du 2 mois de l'an second"

- afkondiging: besluit Directoire exécutiff s. P. Barras (pres), Lagarde (secr-gen); $\| 6$ frimaire V (6 dec 1796)

\section{II brumaire 3 (1793 okt 24)}

LA II fol 299ro-301ro; FA nr.291; rH V 306-309; P V xxv-xxvii; cB IIle ser XI 28-29; cL XVI 308311

DÉCRET INTERPRÉTATIF DE CELUI DU DIX-HUITIÈME JOUR DU PREMIER MOIS, QUI ORDONNE L'ENLEVEMENT DES SIGNES DE ROYAUTÉ \& DE FÉODALITÉ

Ter voorkoming van schade aan waardevolle voorwerpen in bibliotheken en musea, alsmede aan voorwerpen in particulier bezit, is het verboden dat de kentekenen van de feodaliteit en de monarchie worden verwijderd. Transportabele voorwerpen met de verboden kentekenen die zonder schade toe te brengen niet verwijderd kunnen worden, moeten naar een museum worden overgebracht. Bij het herdrukken van boeken enzovoorts mogen het koninklijk privilege en de opdrachten aan vorsten en heren niet opnieuw worden opgenomen. De bibliotheken moeten voortaan de letters $\mathbb{R}$.F. (République Française) in hun boeken stempelen, alsmede de emblemen van vrijheid en gelijkheid. Het volk wordt opgeroepen om het behoud van voorwerpen van bellang voor de geschiedenis en de kunst te bevorderen.

bo. Convention nationale

ao. comité d'instruction publique

s. Paré

cs. Gohier 
1. volksrepresentanten/gouvernementscommissarissen

RO mr.62(4): 19 frimaire IV (10 dec 1795)

RE nr. 53: 20/2 frimaire IV (11/12 dec 1795)

- verwijzing naar: decreet van 18 wendemiaire II (9 okt 1793)

- cL vermeldt als datum van uitvaardiging: " 3 jour du $2^{\mathrm{e}}$ mois de l'an second"

- afkondiging: besluit volksrepresentanten s. Perès, Portiez (de 1'Oise), cs. Delcambe (secr); 21 brumatre IV (12 nov 1795); $P$ vermeldt als datum van afkondiging 24 frimaire IV (15 dec 1795) (P Vxxvi]

\section{II brumaire 3 (1793 okt 24)}

LA III fol 78ro-80ro; FA nr.234; rH VI 48-50; P V 522-524; cB IIIe ser XI 25-27; cL XVI $312-315$

DÉCRET QUI DÉTERMINE UNE NOUVELLE FORME POUR L'INSTRUCTION DES AFFAIRES DEVANT LES TRIBUNAUX, ET SUPPRIME LES FONCTIONS D'AVOUÉS

Het decreet behelst een nieuwe procedure voor de behandeling van zaken aanhangig bij de rechtbanken. Dagvaardingen worden door middel van een eenvoudig exploot het onderwerp en de gronden van de eis, alsmede de tijd en de plaats van behandeling bevattende - uitgebracht. Het gebruik van verzoekschriften is afgeschaft en vervangen door een eenvoudige memorie. Wanneer partijen verschijnen zal op het proces alleen kennisgegeven worden van het exploot van eis en het definitieve vonnis. Verschijnt eến der partijen niet, dan wordt haar ook kennisgegeven van de voorbereidende vonnissen. Uitspraak wordt ter terechtzitting gedaan. Wanneer hoger beroep tegen een vonnis wordt aangetekend, wordt daarvan eveneens door middel van een eenvoudig exploot kennisgegeven. De functie van procureur (pleitbezorger) is opgeheven. Wel mogen partijen zich doen vertegenwoordigen door middel van eenvoudige gemachtigden. De rechtbanken stellen de hoogte van de voorschotten en honoraria van de procureurs vast op het tijdstip van de bekendmaking van het onderhavige decreet.

bo. Convention nationale

ao. comité de legislation

s. Pare

cs. Gohier

ti. volksrepresentanten/gouvemementscommissarissen

RO nr.79(1): I nivôse IV (22 dec 1795)

RE nr.99: $11 / 12$ ventốse IV (1/2 mrt 1796)

- LA, FA en fH laten in de considerans een verwijzing naar art.94 van de grondwet van 1793 weg

- cL vermeldt als datum van uitvaardiging: " $3^{\circ}$ jour du 2 mois de l'an second"

- afkondiging; besluit volksrepresentanten s. Perès, Portiez (de l'Oise); 18 frimaire IV (9 dec 1795)

\section{II brumaire 9 (1793 okt 30)}

LA Ifol 302; rH V 310; P V 535-536; cB IIIe ser XI 87-88; cL XVI 356

LOI QUI DÉCLARE NULS LES JUGEMENS RENDUS ET LES POURSUITES FAITES RELA-

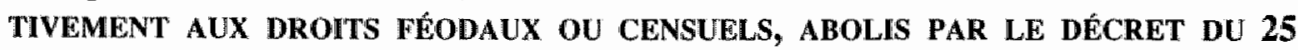
AOOTT 1792 
Vonnissen inzake processen over feodale of cijnsrechten die zonder schadeloosstelling zijn afgeschaft, zijn nietig. Rechters is het, op straffe van het plegen van een ambtsmisdrijf, verboden, uitspraak te doen in nog onbesliste geschillen, wanneer deze uitdrukkelijk bij de wet zijn vernietigd.

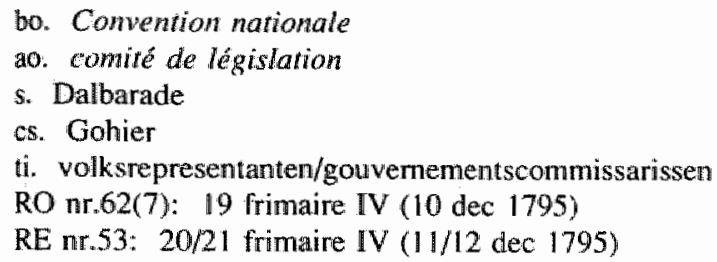

- afkondiging: besluit volksrepresentanten s. Pérès, Portiez (de I"Oise), cs. J. "Torfs (secr); 21 brumaire IV (12 nov 1795)

\title{
II brumaire 9 (1793 okt 30)
}

LA V fol 88; FA nr.291; rH X 271-272; P V 536-538; cB IIIe ser XI 88-92; cL XVI 357-363

[extract] LOI RELATIVE À LA REMISE DES TITRES DE CRÉANCES (\$II artt.10, 14, 16$20,23)$

De directeur-generaal der liquidatie en bestuurslichamen vereffenen niet langer schuldvorderingstitels na overlegging van gecollationeerde afschriften, dan wel de incomplete overlegging van stukken. Alleen degenen die hun oorspronkelijke titels en de stukken compleet hebben overgelegd, hebben recht op verevening. Wanneer men binnen drie maanden na de verzending van een aangetekende brief van de directeurgeneraal der liquidatie zijn naam en adres niet heeft opgegeven of anderszins geen inlichtingen verstrekt, is men definitief van iedere terugvordering op de staat vervallenverklaard. Schuldeisers die niet tijdig hun titels hebben overgelegd, worden daartoe door het districtsbestuur gedwongen; bij weigering van de zijde van de schuldeisers wordt men als verdacht gearresteerd. Vervallenverklaarde schuldvorderingstitels worden ten profijte van de Republiek verkocht.

\author{
bo. Convention nationale \\ ao. comité des finances \\ s. Gohier \\ cs. Gohier
}

RO nr.232(5): 1 nivôse $\mathrm{V}$ (2l dec 1796)

- $\mathrm{cL}$ vermeldt als datum van uitvaardiging: "9e jour du $2^{\circ}$ mois de l"an second"

- afkondiging: besluit Directoire exécutiff s. P. Barras (pres), Lagarde (secr-gen); 16 frimaire V (6 dec 1796); opmerking: deze artikelen afgekondigd ter uitvoering van bet bepaalde in art. 19 van de wet van 15 fructidor IV (I sep 1796), houdende de opheffing van de religieuze instellingen in het voormalige België 


\section{II brumaire 13 (1793 nov 3)}

drukw FA nr.30; rH VII 204-205; P V 544-545; cB IIle ser XI 117; cL XVI 393-394

DÉCRET QUI PRONONCE LA PEINE DE MORT CONTRE LES GEOLIERS \& GARDIENS CONVAINCUS D'A YOIR FAVORISE L'ÉVASION DES PERSONNES DÉTENUES

Bewakers, cipiers en dergelijke die het mogelijk maken dat gevangenen ontsnappen, worden terstond gearresteerd en tegen hen wordt een aanklacht opgesteld. Wanneer de laatsten uit eigen vrije wil de ontsnapping bewerkstelligden, wordt tegen hen de doodstraf uitgesproken. In andere gevallen volgt ontzetting uit hun functie en twee jaar gevangenisstraf.

bo. Convention nationale

ao. comité de législation

s. Gohier

cs. Gohier

ti. gouvernementscommissaris Bouteville

RO nr.89(15): 16 nivôse IV (6 jan 1796)

RE nr. 136: 14/15 floréal IV (3/4) mei 1796)

- afkondiging: besluit volksrepresentanten/gouvernementscommissarissen s. Pérès, Portiez (de l'Oise);

24 frimaire IV (15 dec 1796)

II frimaire 2 (1793 nov 22)

LA III fol 118vo-119ro; FA nr.291; rH VIII 234; P V 565; cB IIle ser XII 9; cL XVI 492

LOI QUI DÉCLARE COMMUNES À TOUS LES BIENS NATIONAUX LES DISPOSITIONS DE LA LOI DU 3 JUIN SUR LE MODE DE VENTE DES BIENS DES EMIGRÉS

Het bepaalde in de artt.5-7 van de wet van 3 juni 1793 aangaande de verdeling en de wijze van verkoop van de nationale goederen, afkomstig van uitgewekenen, is van toepassing op alle nationale goederen. Mitsdien wordt in dezen afgeweken van de wet van 3 november 1790 en andere wetten die hiermee strijdig zijn.

bo. Convention nationale

s. Dalbarade

cs. Gohier

ti. minister van justitie Merlin

RO 147(13): II prairial IV (30 mei 1796)

- verwijzing naar: wetten wan 3 nov 1790; 3 jun 1793; andere niet nader aangeduide wetten

- afkondiging: besluit Directorire exécurif s. Camot (pres), Lagande (secr-gen); 23 floréal IV (1.2 mei 1796)

\section{II frimaire 5 (1793 nov 25)}

LA III foll 62vo-63ro; rH VIII 18-19; P V 574-575; cB IIIe ser XII 74; cL XVI $551-552$ 
Voortaan kan alleen de straf van levenslange deportatie worden uitgesproken, hetzij door het revolutionaire tribunaal, hetzij door de gewone criminele rechtbanken. In dezen wordt er deels gederogeerd aan de wet van 7 juni 1793. De goederen van degenen die tijdelijke deportatie ondergaan, behoren zolang toe aan de staat en worden beheerd door de régisseurs des droits d'enregistrement et domaines nationaux. Heeft de tijdelijk gedeporteerde de zorg voor een vrouw of kinderen of de ouders, dan zal hun jaarlijks steun worden gegeven uit de opbrengsten van zijn goederen.

bo. Convention nationale

ao comité de législation

s. Dalbarade

cs. Gohier

ii. departement van de Dijle

RO nr.l13(6): 6 germinal II (26 mrt 1796)

RE nr.118: 9/10 germinal II (29/30 mrt 1796)

- verwijzing naar: wetten van $19 \mathrm{mrt} 1793 ; 7$ apr 1793; 19 apr 1793; 7 jun 1793 ; decreet van 17 sep 1793

- decreet uitgevaardigd n.a.v. een verzoekschrift van de openbare aanklager bij de criminele rechtbank van het departement Nord

- afkondiging: besluit volksrepresentanten/gouvermementscommissarissen s. Pérès, Portiez (de l'Oise);

29 frimaire IV ( $20 \mathrm{dec} 1795)$

\section{II frimaire 7 (1793 nov 27)}

drukw FA nr.30; rH VII 205; P V 576; cB Thle ser XII 82; cL XVI 556

[extract] DÉCRET RELATIF À LA POURSUITE dES DÉlits d'ESCROQUERIE ET D'ABUS DE LA CRÉDULITÉ (art.1)

Degenen die door middel van oplichting of misbruik van vertrouwen iemand geheel of gedeeltelijk zijn fortuin afhandig maken, zullen in eerste aanleg worden voorgeleid bij de rechtbanken van correctionele politie.

bo. Convention nationale

ao. comité de législation

s. Dalbarade

es. Gohier

ti. gouvernementscommissaris Bouteville

RO nr.89(16): 16 nivôse IV (6 jan 1796)

RE nr.136: 14/15 floréal IV (3/4 mei 1796)

- afkondiging: besluit volksrepresentanten/gouvernementscommissarissen s. Pérès, Portiez (die l'Oise);

24. frimaire IV (15 dec 1796)

II frimaire 9 (1793 nov 29)

LA I fol 302vo-303ro; rH V 310-311; P V 580; cB IIIJe ser XII 102-103; cL XVI 570-571 
Hoofdelijke medeschuldenaren van feodale en cijnsrechten hoeven geen schade te lijden, daar zij zich kunnen laten terugbetalen voor het gedeelte dat zij hebben betaald. De vordering tot terugbetaling is alleen mogelijk voor degene die op justitieel gezag heeft moeten betalen.

bo. Convention nationale

ao. comité de législarion

8. Destournelles

cs. Gohier

ti. volksrepresentanten/gouvernementscommissarissen

RO nr.62(8): 19 frimaire IV (10 dec 1795)

RE nr.53: 20/2) frimaire IV (11/12 dec 1795)

- verwijzing naar: wetten van 25 aug 1792; 17 jul 1793

- decreet uitgevaardigd n.a.v. wragen van de districtsrechtbank te Saint-Flour [departement Cantal]

- afkondiging: besluit volksrepresentanten s. Pérès. Portiez (de l'Oise), cs. J.Torfs (secr); 21 brumaire

IV (12 now 1795)

\section{II frimaire 14 (1793 dec 4)}

drukw FA nr.30; rH VII 205; P V xxix-xxx; cB Ille ser XII 140-141; cL XVI 611-612

DÉCRET QUI DÉFEND AUX AUTORITÉS CONSTITUÉES, AUTRES QUE LES REPRÉSENTANS DU PEUPLE ET LES TRIBUNAUX, D'INTTTULER LEURS ACTES AU NOM DU PEUPLE FRANÇAIS

Slechts de volksrepresentanten en de rechtbanken mogen hun arrêtés, proclamaties, en andere akten voorzien van het opschrift au nom du peuple français, op straffe van schuldig te worden bevonden van het plegen van een aanslag op de een- en ondeelbaarheid van de Republiek.

bo. Convenuion nationale

ao. comité de salut public

s. Destoumelles

Cs. Gohier

ti. gouvernementscommissaris Bouteville

RO nr.89(17): 16 nivôse IV (6 jan 1796)

RE nr.136: 14/15 floréal IV (3/4 nei 1796)

- afkondiging: besluit volksrepresentanten/gouvernementscommissarissen s. Pérès, Portiez (de l'Oise);

24 frimaire IV (15 dec 1796)

\section{II frimaire 15 (1793 dec 5)}

LA III fol 119ro-121vo; FA nr.29l; rH VIII 234-239; P V 596-598; cB IIIe ser VII 156-159; cL XVI 613-618 
LOI QUT ACCORDE LA FACULTE DE RESLLIER LES BAUX AUX ACQUEREURS DES BUENS RETIRES PAR LA NATION DES MAINS DU CI-DEVANT CLERGE, DES CORPORATIONS LAIQUES SUPPRIMÉES ET DU TYRAN, OU CONFISQUÉS EN VERTU DE CONDAMNATIONS

De bevoegdheid, toegekend aan verkrijgers van nationale goederen atkomstig van uitgewekenen, om pachtovereenkomsten te verbreken, wordt tevens toegekend aan verkrijgers van goederen die de staat heeft afgenomen van de vroegere geestelijkheid, van opgeheven lekengemeenschappen en van het koningshuis. Hetzelfde geldt voor verkrijgers van de verbeurdverklaarde goederen, afkomstig van buiten de wet geplaatsten of wegens contrarevolutionaire activiteiten veroordeelden, maar waarvan de toewijzing na de bekendmaking van de onderhavige wet valt. Pachters en huurders hebben recht op de overeengekomen schadeloosstelling ingeval van ontbinding van de pachtovereenkomsten. Bij ontstentenis hiervan ontvangen zij een vastgestelde schadeloostelling, afhankelijk van de duur van de pacht. De schadeloosstelling komt altijd in haar geheel aan de onderpachter toe. Ook dient rekening te worden gehouden met kosten die door de pachter gemaakt zijn voor het bewerken van het land, voordat er geoogst kan worden. Pachtovereenkomsten zijn nietig en niet-bestaand, wanneer de pachters hun pachtcontracten niet hebben aangegeven en overgelegd bij de districtssecretariaten. De districtsbesturen dienen de verpachtingen van nog niet verkochte nationale goederen, waar nog niet op is ingeschreven, te hernieuwen. Maar ingeval het grondpachten betreft, mogen deze pas ingaan na de eerstkomende oogst. Pachters en huurders die op welke wijze ook niet meer in het genot van het verpachte zijn en hieromtrent de goede gang van zaken verstoren, worden zwaar gestraft. Voorts zijn de artt.26, 29 en 30 van de wet van 24 juli 1790 inzake huizen van beneficianten, verkregen door koop of levenslange pacht, herroepen.

bo. Comention nationale

ao. comités de législation, d'aliénation des domaines nationaux et d'agriculture

s. Destoumelles

Cs. Gohier

ti. minister van justitie Merlin

RO nr.147(14): 11 prairial IV (30 mei 1796)

- verwijzing naar: wetten wan 14 mei 1790; 25 jul 1793; decreten van 24 jul 1790; 6, 11 aug 1790; $31 \mathrm{dec} 1790$

- afkondiging: besluit Direc'oire exécutif s. Carnot (pres), Lagarde (secr-gen), 23 floréal IV ( 12 mei (796)

\section{II frimaire 17 (1.793 dec 7)}

LA IV fol 100ro; drukw FA nr.111; rH X 55; P V 602; cB Ille ser XII 172; cL XVI 635

\section{LOI QUI ORDONNE LE SEQUESTRE DES BIENS DES PËRS ET MËRES DONT LES EN- FANS SONT ÉMIGRES}

In beginsel worden de goederen, behorend aan de ouders van uitgeweken minderjarige kinderen, in beslag genomen en in handen van de staat gebracht. In het geval er sprake is van uitgeweken meerderjarige kinderen, dan vindt eveneens inbeslagneming 
plaats, totdat de ouders aangetoond hebben dat zij alles in het werk hebben gesteld on de emigratie te verhinderen.

bo. Convention mationale

s. Destournelles

cs. Gohier

RO nr.210(5): 23 vendémiaire $\mathrm{V}$ (14 okt 1796)

- LA, rH en drukw FA vermelden abusievelijk als datum van uitvaardiging 27 frimaire II (17 dec 1793)

- afkondiging: besluit Directoire exécutif s. L.M. Revellière-Lépeaux (pres), Lagarde (secr-gen); 10 fructidor IV (27 aug 1796)

\section{II frimaire $21(1793 \mathrm{dec} 11)$}

LA V fol 89ro-90ro; FA nr.291; rH X 273-275; P V 607-609; cB IIIe ser XII 188-193; cL XVI 651658

[extract] LOI SUR LA REMISE DES TITRES DE CREANCES (tit.III artt.6-8, 11-12, 14-15, tit.IV artt.17-20)

Degenen die hetzij hun grosse of de ampliatie van de gevestigde of herbevestigde overeenkomst, hetzij hun nieuwe titel kwijt zijn, en degenen wier titels verbrand zijn of zich in door de vijand of opstandelingen bezet gebied bevinden, kunnen van de notaris of de bewaarder de gedeponeerde grosse of de minuut opvragen, onder afgifte van een decharge, welke de grosse of de minuut vervangt. Het overdragen van de titel geschiedt ook aan deelgerechtigden. Wanneer de verloren gewaande titel weer tevoorschijn komt, dient de eigenaar deze te overleggen, op straffe van vervallenverklaring van de terugvordering op de staat. Eigenaren van renten, wier titels verzegeld zijn, kunnen aan onder meer de vrederechter verzoeken de verzegeling op te heffen. De aanwezigheid van gedetineerden is bij de ontzegeling niet noodzakelijk; zij kunnen zich laten vertegenwoordigen door een gemachtigde. De gedetineerden zullen van deze bepalingen in kennis worden gesteld.

bo. Convention nationale

ao conitë des finances

RO nr.232(6): 1 nivôse $V(21$ dec 1796)

- RO nr.232(6) vermeldt abusievelijk de afkondiging van art.9 i.p.v. art.11

- cB-intitulé: "decret sur la remise des titres de créance sur l"état \& sur la consolidation de la dette publique"

- afkondiging: besluit Directoine executif s. P. Barras (pres), Lagarde (secr-gen); 16 frimaire V (6 dec 1796); opmerking: deze artikelen afgekondigd ter uitvoering van het bepaalde in art.19 van de wet van 15 fructidor IV ( 1 sep 1796), houdende de opheffing van de religieuze instellingen in het voormalige België

\section{II nivôse 17 (1794 jan 6)}

LA II fol 4vo-12vo; FA nr.233; rH V 349-363; P V 645-656; cB III e ser XIII 141-153; cL XVII 96112 
De wet regelt de schenkingen en de erfopvolging. Zowel bij schenkingen (donation entre vifs) als bij opengevallen nalatenschappen wordt onderscheid gemaakt tussen schenkingen en nalatenschappen van vóor of van na 14 juli 1789 . Nietig zijn afspraken omtrent schenkingen, nalatenschappen of andersoortige regelingen op of vanaf de veertiende juli. Uitzondering hierop wordt gemaakt voor de voordelen die gehuwden elkaar toekennen, hetzij via een huwelijkscontract, hetzij volgens oude coutumes enzovoorts, hoewel de kinderen niet geheel onterfd kunnen worden. Vroegere religieuzen zijn, gerekend vanaf de $14 \mathrm{e}$ juli 1789 , voortaan ook geroepen tot erfenissen. Op eventuele door hen genoten toelages wordt dan naar rato een korting toegepast. Voorts behelst de wet bepalingen aangaande wie geroepen zijn tot de opengevallen nalatenschappen in de opgaande, neergaande en zijwaartse lijn.

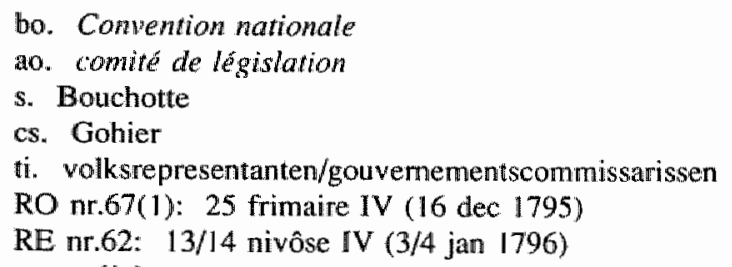

- afkondiging: besluit volksrepresentanten s. Pérès, Portiez (de ل'Oise); 28 brumaire IV (19 nov 1795)

\section{II nivôse 26 (1794 jan 15$)$}

LA IV fol 100vo; drukw FA nr. III; rH X 55-56; P V 668; cB IIIe ser XIIl 264; cL XVII 205

\section{LOI QUI PROROGE LES dÉlAIS ACCORdÉS AUX CRÉANCIERS DES ÉMIGRÉS, POUR FAIRE LEURS DÉCLARATIONS ET LE DÉPÔT DE LEURS TITRES}

De termijn waarbinnen schuldeisers van uitgewekenen hun verklaringen en schuldvorderingstitels op het districtssecretariaat van de laatste woonplaats van de uitgewekenen kunnen deponeren, is, op straffe van verval, verlengd tot 1 germinal II (21 mrt 1794).

ba. Convention wationale

ao. comitếs des finantes "d"aliénation et domaines réumis

s. Dalbarade

cs. Gohier

RO nr.210(6): 23 wendémiaire V' (14 okt 1796)

- verwijzing naar: wetten van 2 sep 1792; 30 okt 1792; 13 jan 1793

- wet uitgevaardigd n.a.v. verzoekschriften wan schuldeisers van uitgewekenen

- afkondiging: besluit Directoire exécutif s. L.M. Revellière-Lépeaux (pres), Lagarde (secr-gen); 10 fructidor IV (27 aug 1796)

\section{II nivôse 28 (1794 jan 17)}

LA I fol 303ro-304vo; rH V 311-313; P V 670-671; cB IIle ser XIII 285-286; cL XVII 21.4-216 
Alle nalatenschappen die door communiteiten of particulieren zijn afgestaan om te dienen als vrijmaking van feodale en cijnslasten en die zich nog in handen van de voormalige heren of hun erfopvolgers bevinden, moeten worden teruggegeven. Nog niet betaalde geldbedragen ter zake kunnen niet worden opgeëist. Vóór 14 juli 1789 opengevallen nalatenschappen kunnen, ongeacht rechtsgedingen hieromtrent, allen worden toegewezen aan volgens de wet niet-horige personen. Na die datum opengevallen nalatenschappen van voorheen horige mensen worden toegewezen overeenkomstig het bepaalde van de wet van 17 nivôse II (6 januari 1794). Vroegere vazallen en cijnsplichtigen kunnen wel procederen over de teruggave van de van hen gevorderde rechten, welke strijdig waren met de in Frankrijk van kracht zijnde wetten en maximen voor de uitvaardiging van de decreten van 4 augustus 1789. Pachters kunnen hun vooruitbetaalde gelden terugvorderen voor de door hen niet genoten gepachte rechten, in afwachting van de afschaffing ervan.

\section{bo. Convention nationale}

no. comité de législation

s. Dalbarade

cs. Gohier

ti. volksrepresentanten/gouvernementscommissarissen

RO nr.62(9): 19 frimaire IV (10 dec 1795)

RE nr.53: 20/2. frimaire IV (11/12 dec 1795)

- verwijzing naar: wetten en decreten van 4 aug $1789 ; 25$ aug $1792 ; 9$ brumaire II (30 okt 1793); 17 nivôse II ( 6 jan 1794)

- afkondiging: besluit volksrepresentanten s. Pérès, Portiez (de l'Oise), cs. Delcambe (secr); 21 brumaire IV (12 now 1795)

\section{II nivôse 28 (1794 jan 17)}

LA III fol 20Iro; drukw FA nr.34; rH VIII 390; P V 671; cB IIIe ser XIII 282; cL. XVII 217

\section{DÉCRET INTERPRETATIF DE LA LOI DU 20 SEPTEMBRE 1792, SUR LE MODE DE CONSTATER L'ETAT CIVIL DES CITOYENS}

De Convention nationale besluit niet te beraadslagen over het feit dat districtsrechtbanken echtelieden die willen scheiden heengezonden hebben om de documenten aangaande hun burgerlijke staat te kunnen overleggen.

\section{bo. Convention nationale}

ao. comité de législation

RO nr. 164(7): 24 messidor IV (12 jul 1796)

RE nr. 193: 1/3 brumaire V (22/24 okt 1796); Vlaamse vertaling 【drukw FA nr. 143]

- verwijzing naar: wet wan 20 sep 1792 [sur le mode de constater l"état civil des citoyens]]

- decreet uitgevaardigd n.a.v verzoekschrift van de burgeres Heuzey van 17 frimaire II (7 dec 1793)

- drukw FA nr.34 is tevens instructie

- afkondiging: besluit Directoive exécutif s. Carnot (pres), Lagarde (secr-gen); 29 prairial IV (17 jun 1796) 


\section{II pluviôse 3 (1794 jan 22)}

drukw FA nr.30; rH VII 206; cB IIIe ser XIV 8; cL XVII 230

\section{DÉCRET RELATIF AUX ARBRES DE LA LIBERTÉ}

In alle gemeenten waar de vrijheidsboom doodgegaan is, moet op de eerste germinal - voor de départements réunis op 1 germinal IV (21 mrt 1796) - een nieuwe worden geplant. Het planten en de verzorging van de boom is toevertrouwd aan goede burgers.

bo. Convention nationale

s. Dalbarade

cs. Gohier

ti. gouvernementscommissaris Bouteville

RO nr.89(18): 16 nivôse IV (6 jan 1796)

RE nr.136: 14/15 floréal IV (3/4 mei 1796)

- decreet aan de tijdsomstandigheden aangepast

- afkondiging: besluit volksrepresentanten/gouvernementscommissarissen s. Pérès, Portiez (de l"Oise); 24 frimaire IV (15 dec 1795)

\section{II pluviôse 5 (1794 jan 24)}

drukw FA nr.30; rH VII 206-207; P VI 14; cB IIIe ser XIV 42; cL XVII 267-268

\section{DÉCRET RELATIF AUX FAUX TÉMOINS}

De doodstraf zal worden uitgesproken tegen hen die als getuige à charge een valse getuigenis afleggen in strafzaken waarop de doodstraf staat, zelfs als de beschuldigde wordt vrijgesproken. In het geval er een valse getuigenis wordt afgelegd door een getuige à decharge, dan wordt deze tot 20 jaar dwangarbeid in ketenen veroordeeld. Betreft het evenwel een contrarevolutionair misdrijf dan wordt eveneens de doodstraf uitgesproken.

bo. Convention nationale

ao. comité de légisiation

s. Dalbarade

cs. Gohier

ti. gouvernementscommissaris Bouteville

RO nr. 89(19): 16 nivôse IV (6 jan 1796)

RE nr.136: 14/15 floréal IV (3/4 mei 1796)

- werwijzing naar: cade pénal van 25 sep 1791

- afkondiging: besluit volksrepresentanten/gouvernementscommissarissen s. Pérès, Portiez (de l'Oise); 24 frimaire IV (15 dec 1795)

\section{II pluviôse 6 (1794 jan 25)}

LA III fol 39; FA nr.237; rH VI 25I-252; P VI 14; cB IIIe ser XIV 49-50; cL XVII 269-270 
Burgers wier titels, sententies; of procesakten, toevertrouwd aan notarissen, vroegere pleitbezorgers, deurwaarders; gemachtigden en dergelijke, zich onder verzegeling bevinden, kunnen de vrederechter of enig ander daartoe bevoegd persoon verzoeken deze op te heffen, en een proces-verbaal van ontzegeling op te maken. Indien zij zich in hechtenis bevinden, is de aanwezigheid van de depositarissen daarbij niet vereist. De vrederechters zijn verantwoordelijk voor de schadeloosstellingen, wanneer zij nalatig of weigerachtig zijn de verzegeling op te heffen. Houders of depositarissen van titels enzovoorts die zich niet onder verzegeling bevinden, dienen deze bij het eerste verzoek van de eigenaar of de gemachtigde terstond over te dragen, op straffe van dagvaarding door de vrederechter en het voldoen van een boete.

bo. Convention nationale

ao. comité de législation

s. Dalbarade

cs. Gohier

vs. S.E.Monnel

cols. Vadier (pres); P.C.A. Goupilleau, Eschasseriaux aîné (secr)

ti. gouvernementscommisaris Bouteville

RO nr.96(3): 11 pluviôse IV (31 jan 1796)

- afkondiging: besluit volkstepresentanten/gouvemementscommissarissen s. Pérès, Portiez (de l'Oise);

28 frimaire IV (19 $\mathrm{dec} 1795)$

\section{II pluviôse 6 (1794 jan 25)}

LA IV fol 101ro; drukw FA nr.111; rH X 56; P VI 14-15; cB IIle ser XIV 47; cL XVII 272

\section{LOI RELATIVE AUX DÉlAIS FIXÉS AUX CRÉANCIERS DES ÉMIGRÉS, POUR LA REMISE DE LEURS TITRES}

De termijn, vastgesteld in de wet van 26 nivôse II (15 jan 1794) voor schuldeisers van uitgewekenen om hun schuldvorderingstitels te deponeren, is alleen van toepassing voor degenen die hun schuldvorderingstitels niet gedeponeerd hebben voor de termijnen genoemd in andere wetten ter zake. De termijnen genoemd in bepalingen van de decreten van 25 juli 1793 en 27 brumaire II (17 nov 1793) inzake het deponeren van de titels en het formeren van een belangengroepering, blijven van kracht.

bo. Convention nationale

ao. comité d'aliénation et des domaines réunis

s. Dalbarade

cs. Gohier

RO nr.210(6): 23 vendemiaire $V(14$ okt 1796)

- verwijzing naar: wetten van 2 sep 1792; 31 okt 1792; 13 jan 1793; decreten van 25 jul 1793; 27 brumaire II (17 nov 1793); 26 nivôse II (15 jan 1794)

- afkondiging: besluit Directoire exécutif s. L.M. Revellière-Lépeaux (pres), Lagarde (secr-gen); 10 fructidor IV (27 aug 1796) 
DÉCRET QUI ORDONNE UN RAPPORT SUR LA CONFECTION D'UN GRAND LIVRE DES PROPRIÉTÉS TERRITORIALES, ET FAIT DÉFENSE D' INSÉRER DANS LES ACTES AUCUNES CLAUSES OU EXPRESSIONS, TENDANT A RAPPELLER LE REGIME FÉDAL OU NOBILIAIRE

De comités des finances, de législation et d"agriculture zijn belast met het vervaardigen van een rapport inzake het aanleggen van een grootboek betreffende de grondeigendom in verband met de verbranding van de feodale titels. De eigendomstitels die aan de municipaliteiten overgedragen zijn, blijven vooralsnog in depot. Het is verder notarissen, griffiers en andere depotbewaarders in hun stukken verboden enige mededeling te doen die doet herinneren aan het feodale bewind, de adel of de monarchie.

bo. Convention nationale

ao. comité de législation

ti. volksrepresentanten/gouvemementscommissarissen

RO nr.63(1): 19 frimaire IV (10 dec 1795)

RE nr.54: 20/21 frimaire IV (11/12 dec 1795)

- verwijzing naar: wet van 17 jul 1793

- afkondiging: besluit volksrepresentanten s. Pérès, Portiez (de l'Oise), cs. J. Torfs (secr); 22 brumaire IV (13 nov 1795$)$

\section{II pluviôse 27 (1794 feb 15)}

LA III fol 63ro; rH VIII 19; P VI 56; cB IIle ser XIV 239; cL XVII 428

DÉCRET RELATIF AUX JUGEMENS RENDUS OU Ȧ RENDRE CONTRE LES ECCLESIASTIQUES, EN EXÉCUTION DE LA LOI DU 30 VENDÉMIAIRE

Reeds gewezen vonnissen en nog uit te spreken vonnissen tegen geestelijken ter uitvoering van de wet van 30 vendémiaire II (21 okt 1793), worden zonder de mogelijkheid tot beroep bij het tribunal de cassation ten uitvoer gelegd.

bo. Comvention nationale

ao. comite de légistation

\$. Paré

cs. Gohier

ti. departement van de Dijle

RO nr.113(7): 6 germinal IV (26 mrt 1796)

RE nr.118: $9 / 10$ germinal IV (29/30 mrt 1796)

- verwijzing naar" wet van 30 vendémiaire II (21 okt 1793)

- Code Merlin vermeldt abusievelijk als datum wan uitvaardiging 22 pluviôse II (10 feb 1794)

- afkondiging: besluit volksrepresentanten/gouvernementscommissarissen s. Pérès, Portiez (de l'Oise);

29 frimaire IV (20 dec 1795) 


\section{II ventose 9 (1794 feb 27)}

LA IV fol 101ro-102vo; drukw FA nr.11॥; rH X 57-59; P VI 85; cB IIle ser XV 109-110; cL XVII $524-526$

LOI RELATIVE AUX CRÉANCES SUR LES ENNEMIS DE LA RÉPUBLIQUE, LES EMIGRÉS, LES DÉPORTES, LES PRÊTRES RECLUS ET LES PERSONNES MISES HORS DE LA LOI, OU CONDAMNES PAR JUGEMENS EMPORTANT CONFISCATION DE BIENS

De naamlijsten van personen wier goederen ten profijte van de staat verbeurdverklaard zijn, moeten, evenals de genierale lijst met de namen van de uitgewekenen, worden geproclameerd in iedere districtshoofdplaats en worden aangeplakt. Tien dagen na de bekendmaking van deze wet moet er door de municipaliteiten een lijst van (on)roerende goederen en schuldvorderingen van Engelsen en Spanjaarden, alsmede van buitenlandse vorsten die in oorlog met de Republiek zijn en die binnen Frankrijk bezittingen hebben, worden opgesteld. De schuldeisers van gedeporteerden, in afzondering gehouden priesters, Engelsen, Spanjaarden, buitenlandse vorsten en buiten de wet geplaatsten dienen hun vorderingen binnen vier maanden na aanplakking van de naamlijsten, op straffe van verval, kenbaar te maken.

bo. Convention nationale

ao. comités de législation, des domaines et d"aliénation

s. Gohier

cs. Gohier

RO nr.2l0(6): 23 vendémiaire $V(14$ okt 1796)

- verwijzing naar: wetten van 25 nov $1792 ; 25$ jul 1793; 27 brumaire II (17 nov 1793); 26 frimaire III (16 dec 1793)

- bepalingen in de wetten van 2 sep 1792, 25 nov 1792, 13 jan 1793 en 26 frimaire II (16 dec 1793) strijdig met de onderhavige wet zijn herroepen

- afkondiging: besluit Directoire exécutif s. L.M. Revellière-Lépeaux (pres), Lagarde (secr-gen); 10 fructidor IV (27 aug 1796)

\section{II ventốse 11 (1794 mrt 1)}

LAA III fol 12/vo-J22ro; FA nr.291; rH VIII 240; P VI iii; cB Ille ser XV 124

\section{LOI RELATIVE AUX BAUX EMPHITÉOTIQUES DES BIENS Cl-DEVANT ECCLÉSIASTI- QUES}

De Convention nationale verklaart dat er niet hoeft te worden beraadslaagd over de haar door het departement Meuse voorgelegde kwestie of men erfpachten kan doen substitueren, welke de vroegere abdij La Challade op 21 oktober 1770 heeft afgesloten met verscheidene inwoners van de gemeente van dezelfde naam en die van Claon, en die op 5 augustus 1771 door het vroegere Parlement van Parijs bekrachtigd zijn. Pachtovereenkomsten van deze aard, aangaande vroegere kerkelijke goederen, zijn door de wet van 27 april 1791 gehandhaafd en vallen niet onder die van 10 frimaire II ( 30 nov 1793) en 15 frimaire II ( 5 dec 1793), welke alleen betrekking hebben op de verhuring van huizen en verpachting van landelijke goederen voor een bepaalde duur. 
bo. Comvention nationale

ao. comité de législation

ti. minister van justitie Merlin

RO nr. 147(15): 11 prairial IV (30 mei 1796)

- verwijzing naar: wetten wan 27 apr 1791; 10 frimaire II (30 nov 1793); 15 frimaire II (5 dec 1793);

"lois antérieures"

- cB-intitulé: "décret portant qu'il n'y a pas lieu à délibérer sur la question proposée par l"administration du département de la Meuse, relative à des baux emphytéotiques passếs le 21 octobre 1770 , par la cij-devant abbaye de la Challade"

- afkondiging: besluit Directoire exécutif s. Carnot (pres), Lagarde (secr-gen); 23 floréal IV (12 mei 1796)

\section{II ventôse 17 (1794 mrt 7)}

drukw FA nr.30; rH VII 207; P VI 91; cB IIIe ser XV 172-173; cL XVII 556-557

\section{DÉCRET INTERPRÉTATIF DU CELUI DU 13 BRUMAIRE, SUR LES PERSONNES PRÉPOSÉES À LA GaRde DES DÉTENUS ÉVADÉS}

Criminele rechtbanken kunnen de straf opgelegd aan bewakers van ontsnapte gevangenen verminderen tot twee maanden hechtenis, als voor de uitspraak van het vonnis blijkt dat de ontsnapten weer gearresteerd zijn.

bo. Convention nationale

ao. comité de législation

s. Gohier

cs. Gohier

ti. gouvernementscommissaris Bouteville

RO nr.89(20): 16 nivôse IV (6 jan 1796)

RE nr.136: 14/15 floréal IV (3/4 mei 1796)

- verwijzing naar: decreet van 13 brumaire II (3 now 1793)

- drukw FA en rH vermelden abusievelijk als datum van uitwaardiging 19 ventôse II ( 9 mrt 1794)

- afkondiging: besluil volksrepresentanten/gouvernementscommissarissen s. Pérès, Portiez (de l'Oise);

24 frimaire IV (15 dec 1795)

\section{II ventôse 19 (1794 mrt 9)}

LA I fol 305vo-306vo; rH V 314-315; P VI 94-95; cB IIle ser XV 192; cL XVII 570-571

DÉCRET RELATIF AUX ACQUÉREURS DES DOMAINES NATIONAUX QUI, EN VERTU DE L'ARTICLE XVI DE LA LOI DU 25 AOÛT 1792, S'ÉTAIT POURVUS EN RÉDUCTION À RAISON DES DROITS SUPPRIMÉS

De bevoegdheid toegekend aan hen die nationale goederen hebben verworven om van de toewijzing af te zien in verband met het feit dat daaronder rechten zijn begrepen die afgeschaft zijn, wordt uitgebreid naar degenen die reeds eerder nationale goederen hebben verworven. Daartoe dient men een verklaring [aan het districtsbestuur] over te leggen. 
bo. Convention nationale

ab. comitế de le gistation

s. Bouchotte

cs. Gotvier

ti. volksrepuresentanten/gouvernementscommissarissen

RO nr.63(2): 19 frimaire IV (10 dec 1795)

RE nr.54: $20 / 21$ frimaire IV (11/12 dec 1795 )

- werwijzing naar: wetten van 6 jull $1792 ; 25$ aug $1792 ; 17$ jull 1793

- afkondiging: besluit volksrepresentanten s. Pérès, Portiez (de l'Oise), cs. J. Torfs (secr); 22 brumaire

IV (13 now 1795) [rH, P en LA vermelden als datum van afkondiging 21 brumaire IV (12 nov 1795]

\section{II germinal 4 (1794 mrt 24)}

LA III fol 37vo-39ro; FA nr.237; rH VI 248-251; P VI 113-114; cB Ille ser XVI 39-41; cL XVII 614-616

DÉCRET QUI DETERMINE LES CAS OÙ LES JUGEMENS PEUVENT ET DOIVENT ÊTRE ANNULLES EN MATTERRE CIVILE

Als er sprake is van wetten uitgevaardigd sedert 1789 geeft schending of verzuim van vormvoorschriften in civiele kwesties de mogelijkheid tot beroep in cassatie, en niet uitsluitend als dit betrekking heeft op schending van een vormvoorschrift dat nietigheid met zich meebrengt. Het laatste geldt alleen ten aanzien van wetten anterieur aan 1789. Cassatie is alleen dan mogelijk wanneer de schending of het verzuim door één der partijen is aangevoerd bij het gerecht en zonder dat daaraan aandacht is besteed. Cassatie kan evenmin worden gevraagd in het geval zulks ten nadele is van minderjarigen, onder curatele gestelden, gehuwde vrouwen, gemeenten en de staat onder het voorwendsel dat de nationale commissaris omtrent de kwestie niet is gehoord. Alle vonnissen welke verzoeken in cassatie verwerpen, zullen worden gemotiveerd.

bo. Convention nationale

ao. comité de législation

vs. Auger

cols. Tallien (pres); Bezardu, M.A. Baudot (secr)

s. Destournelles

cs. Gohier

i. gouvernementscommissaris Bouteville

RO nr.96(2): II pluvióse IV (31 jan 1796)

- verwijzing naar: niet-herroepen wetten anterieur aan 1789 ; wetten van 27 nov 1790 ; 8 brumaire II (29 okt 1793)

- decreet uitgevaardigd n.a.w. verzoekschrift van Jean-Jacques Ducrété om het vonnis wan het tribunal de cassation, clat het vonnis van de districtsrechtbank te Metz bevestigde, te vemietigen

- afkondiging; besluit volksrepresentanten/gouvemementscommissarissen s. Pérès, Portiez (de l'Oise); 28 frimaire IV (19 dec 1795); [P vermeldt als datum van afkondiging 18 frimaire IV (9 dec 1795)]

\section{II germinal 4 (1794 mrt 24)}

LA III fol 83ro-88ro; FA nr.291; rH VII 366-374; P VI $114-119$; cB IIle ser XVI 30-38; cL XVII $618-630$ 
Buitenlandse schepen en Franse schepen komende uit het buttenland hebben geen toegang tot de havens van de eilanden voor de Franse kust, behoudens in het geval van overmacht door weersomstandigheden of opgelopen averij. Alle handelswaar is verder onderworpen aan in- en uitvoerrechten. De scheepskapiteins dienen de vrachtbrieven met de specificatie van de lading aan de douaneambtenaren te overleggen. Goederen die niet in overeensternming met het douaneregime worden in- of uitgevoerd, worden in beslag genomen. Uit hoofde van het droit de préemption hebben de douaneambtenaren de bevoegdheid om een gedeelte van de goederen voor rekening van de staat achter te houden. De inbeslagneming van in- of uitgevoerde handelswaar wordt door de vrederechter beoordeeld, waarna al dan niet tot de verbeurdwerklaring kan worden overgegaan. Douaneambtenaren zijn persoonlijk verantwoordelijk voor de door hen - al dan niet opzettelijk - begane vergissingen bij de inbeslagnemingen. Voorts zijn alle wetten die strijdig zijn met de bepalingen van de onderhavige wet herroepen.

bo. Convention nationale

ao. commission des douanes; comités de législation, de marime, de salut public

vs. Pérard

colls. Tallien (pres); Bézard, Ch. Pottier (secr)

s. Destournelles

cs. Gohier

RO nr.127(1): 5 floréal IV (24 apr 1796); opmerking: in indicateur général ingeschreven onder de datum van 6 floréal IV (25 apr 1796)

- verwijzing naar" code pénal van 25 sep 1791; code général des douanes; "Iois sur la navigation et le commerce; "lois sur la justice criminelle"

- afkondiging: besluit Directoire exécutif s. Le Tourneur (pres), Lagarde (secr-gen) „23 germinal IV (12 apr 1796)

\section{II germinal 21 (1794 apr 10)}

LA II fol 65vo-66ro; FA nr.234; rH VI 28; P VI v; cB Ille ser XVI 153

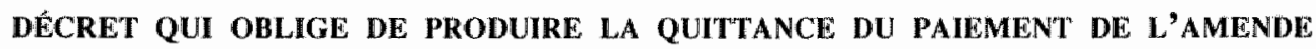

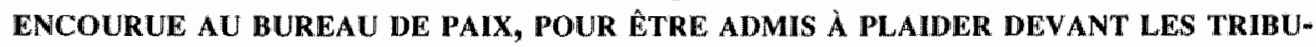
NAUX

Slechts wanneer men de boete wegens het niet-verschijnen voor het bureau de paix heeft betaald, kan men worden toegelaten tot de rechtbank om zijn zaak in tweede instantie aldaar te bepleiten.

\section{bo. Convention nationale}

ao. comité de législation

ti. volksrepresentanten bij het Noorder- en het Sambre-en-Maasleger/gouvemementscommissarissen RO nr.76: I nivôse IV (22 dec 1795)

RE nr.99: $11 / 12$ ventôse IV (1/2 mrt 1796) 
- W.

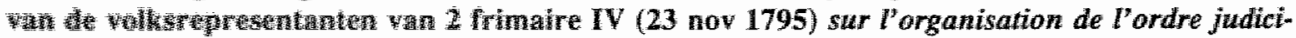

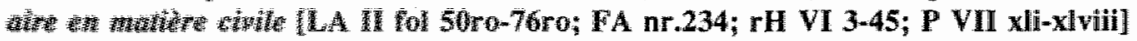

* 管-

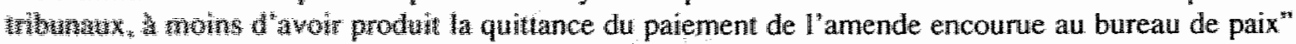

* a

\section{II germinal 22 (1794 apr 11)}

Arwh FA nr.30; rH VII 207; P VI 138; cB IIIe ser XVI 163-164; cL XVII 702-704

\section{RCRET RLLATF AU MODE DE JUGEMENT DES PREVENUS DE FABRICATION DE FAUX ASSIGNATS EN PAYS ÉTRANGER}

Degenen die assignaten vervalst hebben op vijandelijk gebied en deze in omloop brengen in Frankrijk, zullen eventueel aldaar worden gearresteerd en naar Frankrijk worden overgebracht om door de dichtstbijzijnde criminele rechtbank te worden berecht. Vervaardigers van valse assignaten op het territoir van bondgenoten of neutrale landen die naar Frankrijk komen, worden eveneens aangehouden en dienovereenkomstig berecht.

bo. Convention nationale

ao. comités de salut public, de législation

cols. Voulland (ex pres); M.A. Baudot., Leyris (secr)

ti. gouvernementscommissaris Bouteville

RO nr.89(21): 16 nivôse IV (6 jan 1796)

RE nr.136: 14/15 floréal IV (3/4 mei 1796)

- verwijzing naar: code pénal van 25 sep 1791; wet van 2 frimaire II (22 nov 1793)

- decreet uitgevaardigd n.a.v. de vraag gestell door de criminele rechtbank van het departement Ardennes

- decreet gezonden naar de staatsdienaren van de Republiek bij de geallieerde en neutrale mogendheden

- afkondiging: besluit volksrepresentanten/gouvernementscommissarissen s. Pérès "Portiez (de l'Oise); 24 frimaire IV (15 dec 1795)

\section{II germinal 22 (1794 apr 11)}

LA III Fol 63; rH VIII 20; P VI 138; cB IIIe ser XVI 258

\section{[extract] DÉCRET RELATIF AUX RECELEURS D'ECCLÉSIASTIQUES SUJETS À LA DÉPORTATION (artt.1, 2)}

Gerekend vanaf de afkondiging van de wet van 30 vendémiaire II (21 okt 1793) zullen degenen die geestelijken die onderworpen zijn aan deportatie en opsluiting, of die de doodstraf hebben gekregen, een schuilplaats bieden, bestraft worden met deportatie. Zij zullen als medeplichtige worden bestraft.

bo. Convention mationale

ao. comité de législation 
i. departement van de Dijle

RO nr.113(8): 6 germinal IV (26 mrt 1796)

RE nr.1 I18: 9/10 germinal IV (29/30 mrt 1796)

- verwijzing naar: wet van 30 vendémiaire II ( 21 okt 1793)

- decreet uitgevaardigd n.a.v. een brief van de minister wan justitie, alsmede verscheidene verzoekschriften en memories

- afkondiging: besluit volksrepresentanten/gouvernementscommissarissen s. Pérès, Portiez (de I"Oise); 29 frimalire IV (20 dec 1795)

\section{II germinal 28 (1794 apr 17)}

LA III fol 122ro-123vo; FA nr.29!; rH VIII 24】-244; P VI v-vi; cB IIle ser XVI 219-221

LoI portant qu'Il N'y a PAS lieu À délibérer sur plusieurs questions RELATIVEs à LA LOI du 15 Frimaire, CONCERNANT LES BAUX À FERME ET $\grave{A}$ LOYER DES BIENS NATIONAUX

De wet behandelt een zestal vragen aangaande de interpretatie van de wet van 15 frimaire II ( 5 dec 1793) betreffende de verpachtingen van landerijen en overige verhuringen van nationale goederen, alsmede betreffende de verkrijgers van deze goederen.

\section{bo. Convention nationale}

ao. comitế de lếgislation, des domaines et a" aliếnation

ti. minister van justitie Merlin

RO nr.147(16): 11 prairial IV (30 mei 1796)

- verwijzing naar: wetten van 14 mei 1790; 6, 11 aug $1790 ; 5$ nov $1790 ; 25$ jul 1793; 15 frimaire II (5 dec 1793)

- wet uitgevaardigd n.a.v. diverse petities inzake de wet van 15 frimaire II

- cB-intirulé: "décret sur diverses questions à la loi du 15 frimaire concernant les baux des biens nationaux"

- afkondiging: besluit Directoire exécutif s. Camot (pres), Lagarde (secr-gen); 23 floréal IV (12 mei 1796)

\section{II floréal 19 (1794 mei 8)}

LA III fol 20I; drukw FA nr.34; rH VIII 391; P VII 160; cB IIIe ser XVII 124; cL XVII 775-776

\section{DÉCRET RELATIF AUX DÉCLARATIONS SUR L'ÉTAT CIVIL DES ENFANS}

De weigering van de ambtenaar van de burgerlijke stand van de gemeente Parijs om de aangifte van een geboorte door een burgeres te aanvaarden, waarbij zij verklaarde dat het kind niet van haar echtgenoot is, wordt goedgekeurd. De wet erkent geen andere vader dan die welke aangeduid is door het huwelijk. Een aangifte die daarmee strijdig is, is immoreel. Een vrouw kan niet worden toegestaan om naar goeddunken over de burgerlijke staat van de kinderen van haar man te beschikken. De geboorteakte moet worden opgemaakt zonder van deze aangifte melding te maken. 
bo. Convention nationale

aio. comité de lëgislation

cols. Voulland (ex-pres); Pocholle, N. Haussmann (secr)

RO nr.164(8): 24 messidor IV (12 jul 1796$)$

RE nr.193: 1/3 brumaire $V$ (22/24 okt 1796); Vlaamse vertaling [drukw FA nr.143]

- drukw FA nr.34 tevens instructie

- afkondiging: besluit Directoire exécutif s. Camot (pres), Lagarde (secr-gen); 29 prairial IV (17 jun 1796)

\section{II floréal 21 (1794 mei 10)}

LA III foll 123vo-124ro; FA nr.291; rH VIII 244-245; P VI vii; cB IIle ser XVII 141

LOI PORTANT QUE LES DISPOSITIONS DE LA LOI DU 15 FRIMAIRE SUR LA DÉCHÉANCE DES BAUX DE BIENS ECCLESIASTIQUES, NE FRAPPENT PAS SUR LES BAUX EMPHYTÉOTIQUES

De artt.9-13 van de wet van 15 frimaire II ( 5 dec 1793) maken nergens gewag van erfpacht. Mitsdien is het vervallen verklaren van pachtovereenkomsten van voorheen kerkelijke goederen, die niet aangegeven zijn bij en overgelegd aan de districtssecretariaten, alleen op de gewone pachtovereenkomsten van toepassing.

bo. Convention nationale

ao. comités de législation, des domaines et d'aliênation

ti. minister van justitie Merlin

RO nr.147(17); 11 prairial IV (30 mei 1796)

- verwijzing naar: wetten van 6,11 aug $1790 ; 15$ frimaire II (5 dec 1793)

- wet uitgevaardigd n.a.v. een vraag gesteld door de districtsrechtbank te Blois [departement Loir-etCher]

- cB-intitulé: "décret portant que les articles IX, X, XI, XII et XIII de la loi du 15 frimaire ne parle nullement des baux emphytéotiques; que la peine de déchéance prononcée par l'article XXXVIII de la loi des 6 et 11 août 1790 ne frappe que sur les fermiers, et qu'elle est limitée aux preneurs de baux ordinaires"

- afkondiging: besluit Directoire exécutif si Carnot (pres), Lagarde (secr-gen); 23 floreal IV (12 mei 1796)

\section{II floréal 21 (1794 mei 10)}

LA III foll 124ro; FA wr.291; rH VIII 245-246; P VI vii; cB IIIe ser XVII 142

LOI RELATIVE AU TERME QUI OPÈRE LA DÉCHÉANCE D'UN BAIL DE BIENS CI-DEVANT NATIONAUX

De termijn die de vervallenverklaring van een pachtovereenkomst van voorheen nationale goederen met zich meebrengt, is bepaald op twee decaden (twintig dagen). Deze termijn gaat in op de dag van de sommatie door de verkrijger van de nationale goederen aan de pachter om zijn pachtcontract ter inzage te geven.

bo. Convention nationale

ao. comité de législation 
4.. minister van justitie Merlin

RO nr. $147(18)$ : 11 prairial IV (30 mei 1796)

* verwijzing naar: wet van 15 frimaire II ( 5 dec 1793)

- wet uitgevaardigd n.a.v. een vraag opgeworpen door het vonnis wan de districtsfechtbank te Beziers [departement Hérault] op 12 germinal II (1 apr 1794)

- cB-intitule:" "décret portant qu"il n"y a pas lieu à délibérer sur la question proposée par le tribunal du district de Béziers, si, d'après l'article XVII du décret du 15 frimaire, un fermier de biens nationaux est déchu de son bail pour n'en avoir pas donné communication a l'acquéreur dans les vingt jours de la sommation qui lui en a été faite*

- afkondiging: besluit Directoire exécutif s. Carnot (pres), Lagarde (secr-gen); 23 florél IV (12 mei 1796)

\section{II floréal 22 (1794 mei 11)}

drukw FA nr.30; rH VII 209-210; P VI 163-164; cB IIIe ser XVII 151; cL XVII 785-786

\section{DÉCRET PORTANT QU'UN CITOYEN SERA DÉTENU JUSQU'À LA PAIX, POUR DÉSOBÉIS-} SANCE À LA LOI

De nationale agent in het district Montagne du Bon-Air zal een individu van het kanton Triel laten arresteren en opsluiten in een gevangenis tot het herstel van de vredestoestand. Voortaan zullen de straffen ter zake van het niet-gehoorzamen, genoemd in de code pénal van 25 september 1791, worden opgelegd aan hen die op enigerlei wijze de verrichtingen van autoriteiten onmogelijk maken of het effect ervan tenietdoen.

\section{bo. Convention nationale}

ao. comité de législation

cols. Bréand (ex-pres); Paganel, Dornier (secr)

ti. gouvernementscommissaris. Bouteville

RO nr.89(22): 16 nivôse IV (6 jan 1796)

RE nr.136: 14/15 floréal IV (3/4 mei 1796)

- decreet uitgevaardigd n.a.v. een brief van de vroegere minister van justitie inzake een burger van het kanton Triel in het district Montagne du Bon-Air [departement Seine-et-Oise]

- verwijzing naar: code pénal van 25 sep 1791

- decreet alleen aan de rechtbanken gezonden; plaatsing in het bulletin / de correspondance/ strekt tot bekendmaking

- afkondiging: besluĭt volksrepresentanten/gouvernementscommissarissen s. Pérès, Portiez (de l"Oise); 24 frimaire IV (15 dec 1795)

\section{II floréal 22 (1794 mei 11)}

LA III fol 63vo-64ro; rH VIII 20-21; P VI 164; cB IIle ser XVII 149; cL XVII 786-787

\section{DÉCRET RELATIF A LA RÉCLUSION DES ECCLESIASTIQUES INFIRMES OU SEXAGÉNAI- RES}

Alle geestelijken die gebrekkig zijn of ouder dan zestig jaar en die aan de afzondering onderworpen zijn, dienen zich binnen twee decaden naar de hoofdstad van het departement te begeven om in de daarvoor bestemde huizen te worden opgesloten. Bij het 
niet-voldoen hieraan, staat men bloot aan vervolging. De attestaties waaruit gebrekkigheid blijkt, worden door het departement gecontroleerd; zijn deze niet exact genoeg of vervalst, dan volgt deportatie.

bo. Conventian nationale

ao. comité de législation

cols. Bréard (ex-pres); Paganel, N. Haussmann (secr)

ti. departement van de Dijle

RO nr.113(9): 6 germinal IV (26 mrt 1796)

RE nr.118: $9 / 10$ germinal IV (29/30 mrt 1796)

- verwijzing naar: wet van 30 vendémiaire II ( 21 okt 1793)

- plaatsing in het bulletin [de correspondance] strekt tot bekendmaking

- afkondiging; besluit volksrepresentanten/gouvernementscommissarissen s. Pérè̀s, Portiez (de l'Oise); 29 frimaire IV (20 dec 1795); opmerking: dit decreet van 22 floréal II (11 mei 1794) wordt niet uitdrukkelijk in het afkondigingsbesluit genoemd

\section{II floréal 23 (1794 mei 12)}

BL le ser no. I4 (64); LA V fol 90vo; FA nr.291; rH X 276; P VI 168-174; cB IIIe ser XVII 166183; cL XVIII 49-69

[extract] LOI SUR LES RENTES VIAGÈRES DÉCLARÉES DETTES NATIONALES (§I artt.1, 3)

Eigenaars van lijfrenten, voortkomend uit een lening verstrekt door het vroegere bestuur, de voormalige provinciale staten, kapittels en andere opgeheven religieuze instellingen, rechterlijke corporaties, gilden, steden en gemeenten die tot nationale schuld verklaard zijn, zijn gehouden deze overeenkomsten en lijfrentetitels over te leggen aan de nationale schatkist, onder bijvoeging van attestaties de vita van degenen aan wie deze lijfrenten verschuldigd zijn, zowel voor de lopende als die ingevolge het recht van de langstlevende (droit de survie). Soms dient ook de geboorteakte van degenen die tot bedoelde lijfrenten gerechtigd zijn te worden overgelegd. Indien aan deze voorwaarden niet is voldaan, is men van terugvordering op de staat vervallen verklaard.

bo. Convention nationale

ao. comite des finances

vs. Bouillerot

cols. Voulland (ex-pres): Paganel, Francastel (secr)

RO nr.232(7): I nivôse V (2| dec 1796)

- $c B$ vermeldt annex aan deze wet een "Rapport fait par Cambon au nom du comité des finances" ter zake van de openbare lijfschuld [p.183-227]

- afkondliging: besluit Directoire exécutif s. P. Barras (pres), Lagarde (secr-gen); 16 frimaire V (6 dec 1796); opmerking: deze artikelen afgekondigd ter uitvoering van het bepaalde in art. 19 van de wet van 15 fructidor IV (1 sep 1796), houdende de opheffing van de religieuze instellingen in het voormalige België 
DÉCRET RELATIF À LA MANIÈRE de PROCÉder AU CAS de DESTRUCTION OU ENLEVEMENT DE MINUTES DE JUGEMENT NON-EXÉCUTÉS, OU DE PROCÉDURES CRIMINELLES ENCORE INDÉCISES

Het decreet bepaalt hoe te handelen wanneer door een vijandelijke invasie of door rebellen de minuten van vonnissen en andere stukken verloren zijn gegaan of anderszins in het ongerede zijn geraakt. Indien er een verzonden stuk of authentiek afschrift voorhanden is, dan zal dit als minuut worden beschouwd. Eenieder die dergelijke stukken onder zich heeft, moet deze afstaan. Eventueel kan het proces opnieuw plaatshebben met in achtneming van alle gerechtelijke procedures. Vonnissen die niet tenuitvoergelegd zijn en die niet op enigerlei wijze gereproduceerd kunnen worden, worden geacht niet te bestaan en kunnen mitsdien niet dienen als basis voor dle straffen die staan op recidive.

bo. Convention nationale

ao. comitè de législation

cols. Breard (ex-pres); Carrier, Francastel (secr)

ti. gouvernementscommissaris Bouteville

RO nr.89(23): 16 nivôse IV (6 jan 1796)

RE nr.136: 14/15 floréal IV (3/4 mei 1796)

* verwijzing naar: code pénal wan 25 sep 1791

- decreet slechts aan de rechtbanken toegezonden; plaatsing in het bulletin [de correspondance] strekt tot bekendmaking

- cB-intitulé: "décret qui détermine le mode de procéder au rétablissement dans les dépôts, des minutes des jugemens non exécutés et des procédures criminelles encore indécises dont la perte a été occasionnee par force majeure"

- afkondiging: besluit volksrepresentanten/gouvernementscommissarissen s. Pérès, Portiez (de l'Oise);

24 frimaire IV (15 dec 1795)

\section{II prairial 12 (1794 mei 31)}

drukw FA nr. 30; rH VII 212; P VI 182-183; cB IIIe ser XVIII 55; cL XVII 825

DÉCRET RELATIF À LA LIQUIDATION DES FRAIS DE TRANSPORT DE LA GUILLOTINE

De vereffening van de kosten van het transport van de guillotine omvat tevens de gemaakte kosten voor het transport van de veroordeelden, alsmede die voor de benodigdheden bij de terechtstelling.

bo. Convention nationale

ao. comité des finances

cols. Voulland (ex-pres); Briez, Carrier (secr)

ti. gouvernementscommissaris Bouteville

RO nr.89(24): 16 nivôse IV (6 jan 1796)

RE nr. 136: 14/15 floréal IV (3/4 mei 1796)

- verwijzing naar: decreet van 3 frimaire II (23 nov 1793) 
- afkondiging: besluit volksrepresentanten/gouvernementscommissarissen s. Pérès, Portiez (de l'Oise); 24 frimaire IV (15 dec 1796$)$

\section{II prairial 21 (1794 jun 9)}

BL le ser no.5 (19); LA III foll 28ro-29ro; FA nr.237, FA nr.29I; rH VI 364-365; P VI 190; cB IIle ser XVIII 27

\section{LOI RELATIVE À LA REPRESENTATION ET AU PARAPHE DES BAUX DES FERMIERS DU CI-DEVANT ORDRE DE MALTE}

Pachters van goederen van de Maltezer Orde zijn gehouden, op straffe van verval, hun pachtcontracten te tonen en te laten paraferen bimnen veertien dagen na de bekendmaking van de wet van 19 september 1792 .

bo. Convention nationale

à. comité de législation

ws. S.E. Monnel

cols. Thuriot (ex-pres); Carrier, Francastel (secr)

ti. gouvernementscommissaris Bouteville

RO nr.97(11) en 207(5): 11 pluviôse IV (31 jan 1796) en 2 vendémiaire V (23 sep 1796)

RE nr.1 16: 2/3 germinal IV (22/23 mrt 1796)

" verwijzing naar." wetten van 6,11 aug 1790 ; 19 sep 1792; 28 germinal II (17 apr 1794)

- wet uitgevaardigd n.a.v. een kort geding aangespannen bij de districtsrechtbank te Béziers [departement Hérault]

- geschreven versie van de wet gezonden naar de rechtbank; werdere bekendmaking via bulletin [de correspondance]

- afkondiging: besluit volksrepresentanten/gouvernementscommissarissen s. Pérès, Portiez (dle l'Oise); 29 frimaire IV (20 dec 1795\%; besluit Directoire exécutif s. L.M. Revellière-Lépeaux (pres), Lagarde (secr-gen); 23 fructidor IV (9 sep 1796)

\section{II prairial 28 (1794 jun 16)}

BL Ie ser no.5 (23); drukw FA nr;30; rH VII 213; P VI 195; cB IIle ser XVIII 138

\section{LOI RELATIVE À UNE QUESTION SUR LA PEINE À INFLIGER À UN COLLECTEUR DES IMPOSITIONS DE 1790, CONVAINCU DE CONCUSSION ET DE FALSIFICATION DE SES RÔLES}

De Convention nationale is van mening dat de code pénal precies aangeeft, welke straf staat op afpersing van belastingplichtigen en vervalsing van belastingkohieren door publieke functionarissen.

bo. Convention mationale

ao. comité de législation

vs. S.E. Monnel

cols. Thuriot (ex-pres); Francastel, Carrier (secr)

ti. gouvernementscommissaris Bouteville

RO nr.89(25): 16 nivôse IV (6 jan 1796)

RE nr.136; 14/15 loréall IV (3/4 mei 1796) 
- verwijzing naar: code pênal van 25 sep 1791

- wet uitgevaardigd n.a.v. een vraag gesteld door de criminele rechtbank in het departement Manche * afkondiging: besluit volksrepresentanten/gouvernementsconamissarissen s. Pérès, Portiez (de l'Oise); 24 frimaire IV (15 dec 1795)

\section{II prairial 28 (1794 jun 16)}

BL Ie ser no.6 (27); drukw FA nr.30; rH VII 213-214; P VI 195; cB IIJe ser XVIII 137-138

LOI RELATIVE AUX PROCÉdURES QUI, APRÈS AVOIR ÉTÉ DÉTRUITES OU ÉGARÉE, ONT ETTÉ RÉPARÉES EN VERTU DE JUGEMENS EXÉCUTÉS AVANT LA PUBLICATION DE LA LOI DU 29 FLORÉAL

Indien procedures (procesakten), na aanvankelijk te zijn vernietigd of anderszins te zijn weggemaakt, zijn hersteld krachtens vonnissen tenuitvoergelegd voor de uitvaardiging van de wet van 29 floréal II (18 mei 1794), moeten zij worden geacht niet te zijn vernietigd of weggemaakt als bedoeld in bovenvermelde wet.

bo. Convention nationale

ao. comitể de législariont

vs. S.E. Monnel

cols. Thuriot (ex-pres); Carrier, Francastel (secr)

ti. gouvernementscommissaris Bouteville

RO nr.89(26): 16 nivôse IV (6 jan 1796)

RE nr.136: 14/15 floreal IV (3/4 mei 1796)

- werwijzing naar: wet van 29 floreal II (18 mei 1794)

- afkondiging: besluit volksrepresentanten/gouvemementscommissarissen s. Pérès, Portiez (de l'Oise);

24 frimaire IV (15 dec 1795)

\section{II messidor 1 (1794 jun 19)}

BL le ser no.7 (35); LA III fol 124vo; FA nr.291; rH VIII 246-247; P VI 196; cB Ille ser XIX 7-8

\section{LOI QUI ANNULLE DES JUGEMENS ET ACTES EN VERTU DESQUELS DES FERMIERS SERAIENT PRIVÉS DE LA RÉCOLTE PROCHAINE}

Vonnissen waarbij aan pachters de hun toekomende eerstvolgende oogst - uit hoofde van de bepalingen van de wet van 15 frimaire II ( 5 dec 1793) - ontnomen is, anterieur aan de bekendmaking van het decreet van 28 germinal II (17 apr 1794), zijn nietig en worden als niet-bestaand verklaard, onder compensatie van kosten. Dit geldt eveneens voor die akten, waarbij pachters ten onrechte van mening zijn dat hun de eerstkomende oogst is ontnomen, doordat hun de pacht werd opgezegd of doordat zij zijn afgekocht door de verkrijgers. Mochten dezen hun akkers hebben ingezaaid, terwijl de oogst nog toebehoort aan de pachters, dan worden hun door de laatsten de arbeids- en zaaikosten terugbetaald. In geval van geschillen over de hoogte van de vergoeding kiezen de partijen onderling scheidslieden of worden dezen door de vrederechter benoemd. 
bo. Conwewtion nationale

ao. comité de législation

W. S.E. Monnel

cols. Voulland (ex-pres); Bordas, Turreau (secr)

ti. minister van justitie Merlín

RO nr.147(19): 111 pramial IV (30 mei 1796)

- werwijzing natar: wet wan 15 frimaire II (5 dec 1793); decreet van 28 germinal II (17 apr 1794)

- afkondiging besluit Directoire exécutif s. Camot (pres), Lagarde (secr-gen); 23 floreal IV (12 mei 1796)

II messidor 2 (1794 jun 20)

BL Ie ser no.8 (39); LA III fol 29; FA nr.237, FA nr.291; rH VI 365; P VI 198; cB IIle ser XIX 16

LOI SUR UNE QUESTION RELATIVE AUX BAUX DES BIENS CI-DEVANT DÉPENDANS DE L"ORDRE DE MALTE

De pachtovereenkomsten inzake goederen die voorheen onderhorig waren aan de Maltezer Orde, zijn onderworpen aan de formaliteiten [=het opmaken van een pachtakte in aanwezigheid van een lid van het districtsbestuur, dan wel een lid van het corps municipal] die in de wet van $5 * 11$ februari 1791 betreffende religieuze dan wel lekencommuniteiten worden genoemd.

bo. Convention nationale

ao. comité de législation

vs. S.E. Monnel

cols. Vaclier (ex-pres); Michaud, Briez (secr)

ti. gouvernementscommissaris Bouteville

RO nr.97(12) en 207(5): 11 pluviốse IV (3.1 jan 1796) en 2 vendémiaire V (23 sep 1796)

RE nr.116* 2/3 germinal IV $(22 / 23$ mrt 1796)

- verwijzing naar: wetten van $14,16,20$ apr $1790 ; 23,28$ okt $1790 ; 5 * 11$ feb 1791

- wet uitgevaardigd n.a.v. een vraag gesteld door de districtsrechtbank te Beaugency 【departement Loiret]

- cB-intitulë: "décret sur la question tendante à savoir si les baux des biens ci-devant dépendans de l'ordre de Malte, ont etế assujétis aux formalités imposées par la loi du 11 février 1791, aux corps, maisons, communautés et établissemens publics, tant ecclésiastiques que lä̈ques, alors conservés"

- afkondiging: besltuit volksrepresentanten/gouvernementscommissarissen s. Pérès, Portiez (de l'Oise); 29 frimaire IV (20 dec 1795); besluit Directoire exécutif s. L.M. Revellière-Lépeaux (pres), Lagarde (secrugen); 23 fructidor IV (9 sep 1796)

\section{II messidor 7 (1794 jun 25)}

BI Ie ser no.11 (51); drukw FA nr.30; rH VII 214; P VI 202; cB IIle ser XIX 51-52

LOI QUI DETERMINE LA PEINE À INFLIGER AUX FONCTIONNAIRES PUBLICS ET AUTRES, QUI AURAIENT COMMIS LES DÉLITS PRÉVUS PAR L'ARTICLE XXVII DU TITRE II DE LA LOI CONCERNANT LA POLICE MUNICIPALE, ETC.

Publieke functionarissen, bewakers enzovoorts die zich schuldigmaken aan het plegen van obstructie tijdens de verkoop van goederen toebehorende aan de staat door middel 
van omkoping of anderszins, worden door de criminele rechtbanken berecht en tot twaalf jaar dwangarbeid in ketenen veroordeeld.

\section{bo. Convention nationale}

ao. comite de législation

ws. S.E. Monnel

cols. Elie Lacoste (pres); Bordas, Turreau (secr)

ti. gouvernementscommissaris Bouteville

RO nr.89(27): 16 nivôse IV (6 jan 1796)

RE nr. 136: 14/15 floréal IV (3/4 mei 1796)

* verwijzing naar: wetten van 19 jul 1791; 24 apr 1793; 7 frimaire II (27 nov 1793); 14 germinal II (3 apr 1794)

- plaatsing in het bulletin de correspondance strekt tot verzending en bekendmaking

- afkondiging." besluit volksrepresentanten/gouvernementscommissarissen s. Pérès, Portiez (de l'Oise);

24 frimaire IV (15 dec 1795)

\section{II messidor 7 (1794 jun 25)}

BL Ie ser no.12 (58); LA III fol 69ro-73vo; rH VIII 167-177; P VI 202-205; cB IIIe ser XIX 52-60

\section{LOI CONCERNANT L'ORGANISATION DES ARCHIVES ÉTABLIES AUPRES DE LA REPRESENTATION NATIONALE}

De archieven die ingericht worden bij de Nationale Vertegenwoordiging vormen een centraal depot voor de gehele Republiek, waar de bescheiden van de staat, processenverbaal, verdragen, staat der financiën, de bevolkingsstatistieken enzovoorts worden bewaard. Uitsluitend aan het Wetgevend Lichaam behoort de lastgeving tot deponeren in de archieven toe, onder inspectie van het comité des archives. Alle domeintitels worden gesorteerd en deels vernietigd, waaronder de zuiver feodale titels. De stukken behorende tot de griffies van de opgeheven rechtbanken worden eveneens gesorteerd. Het comité des archives laat voorts alle depots van domaniale en bestuurlijke instanties, alsmede collecties en kabinetten inventariseren om te bezien waar zij bewaard moeten worden; één en ander zal geschieden door deskundigen. Boeken die zich thans in archieven bevinden, zullen worden overgebracht naar de Bibliotheque nationale. In ieder departement wordt onder toezicht van de nationale agenten in de districten de sortering verricht door drie tot maximaal negen ter zake kundige burgers, de préposés au triage. Alle depots met de titels en andere stukken zijn voor hen toegankelijk. Houders van op schrift gestelde titels en de overige stukken moeten deze aanmelden. De préposés au triage verdelen alles in twee klassen: bewaren, dan wel vernietigen. De wet kent voorts bepalingen met betrekking tot het vormen van depots te Parijs en algemene bepalingen ten aanzien van de toegankelijkheid van de depots en de inzage van de stukken. Burgers die tijdens processen titels hebben ingediend, andere dan feodale en procedurele, kunnen deze voor beëindiging van de inventarisatie, onder voldoende staving, opeisen.

bo. Convention nationale

ao. comités de salut public, des domaines, de légistation, d'instruction publique et des finances

vs. S.E. Monnel 
cols. Elie Lacoste (pres); Turreau, Bordas (secr)

RO nr.120: 23 germinal IV (12 apr 1796)

- werwijzing naar: wetten en decreten van 4, 7 sep 1790; 5 nov 1790; 27 dec 1791; 10 okt 1792; 12 brumaire II ( 2 nov 1793); 10 frimaire II (30 now 1793); 12 germinal II (I apr 1794)

- decreten van 12 brumaire II ( 2 nov 1793) en 10 frimaire II (30 nov 1793) zijn herroepen voor zover deze strijdig zijn met de onderhavige wet

- RO spreekt abusievelijk van de wet van 7 messidor dernier (25 jun 1795)

- $\mathrm{cB}$-intinté: "décret concernant l"organisation des archives de la République, le triage, le classement et la destination des titres, chartes et pièces manuscrites, et les relations des divers dépôts qui les. renferment avec les archives"

- afkondiging: besluit Directoire exécutif s. Le Toumeur (pres); Lagarde (secr-gen); 10 germinal rV (30 $\mathrm{mrt} \Perp 796)$

\section{II messidor 8 (1794 jun 26)}

BL le ser no.1I (52); LA III fol 64ro; rH VIII 22; P VI 206; cB IIIe ser XIX 62

\section{LOI RELATIVE AUX USUFRUITS QUI REPOSAIENT SUR LES TETES DES ECCLESIASTI- QUES DÉCEDES LN ETAT DE RECLUSION}

Het overlijden van geestelijken in staat van afzondering doet het vruchtgebruik dat bij hen berust ophouden.

\section{bo. Convention mationale}

ao. comité des finances

vs. S.E. Monnel

cols. Elie Lacoste (pres); Cambacerès, Michaud (secr)

ti. departement van de Dijle

RO nr.113(10): 6 germinal IV (26 mrt 1796)

RE nr.118: 9/10 germinal IV (29/30 mrt 1796)

- cB-intitulé: "décret portant que la mort naturelle des ecclésiastiques décédés en état de réclusion fait cesser les usufruits qui reposaient sur leurs têtes"

- afkondiging besluit wolksrepresentanten/gouvernementscommissarissen s. Pérès, Portiez (de l'Oise);

29 frimatre IV (20 dec 1795)

\section{II messidor 11 (1794 jun 29)}

LA I fol 306vo-307ro; rH V 315-316; P VI xv; cB IIle ser XIX 99

DECRET SUR UNE LETTRE DU MINISTRE DE LA JUSTICE, TENDANTE À SAVOIR SI LA LOI QUI DEFEND À TOUS LES TRIBUNAUX DE PRONONCER SUR LES CONTESTATIONS RELATIVEs à la FÉODALTTE, PEUT S'APPLIQUer À UN PROCÈS QUI S'EST ÉLEVÉ. ENTRE DES ASSOCIÉS, À RAISON DU COMPTE D'UNE SOCIÉTÉ QU'ILS AVOIENT ANCIENNEMENT FORMÉE POUR UNE FERME DE CENS, RENTES, LODS ET VENTES

De rechtshandeling waar hier sprake van is, behoort tot de gewone rechtshandelingen van een vennootschap. [Zij valt mitsdien niet onder de wet die verbiedt te procederen inzake geschillen de feodaliteit betreffende]. 
bo. Convention Mationale

ao. comité de légíslation

ti. volksrepresentanten/gotwemementscommissarissen

RO nr.63(3): 19 frimaire IV (10 dec 1795)

RE nr.54: $20 / 21$ frimaire IV (11/12 dec 1795)

- decreet uitgevaardigd n.a.w. een brief van de minister van justitie

- dit decreet wordt niet gedrukt; een authentiek afschrift zal wan de rechters van de districtsrechtbank te Bergerac [departement Dordogne] worden gezonden

- afkondiging: besluit volksrepresentanten s. Portiez (de I'Oise), cs. J. Torfs (secr); 22 bramaire IV (13 nov 1795)

\section{II messidor 23 (1794 jul 11)}

BL Ie ser no.20 (93); LA $\vee$ fol 91ro-93ro; rH X 277-281; P VI 217-220; cB IIle ser XIX 169-177

[extract] LOI SUR LA RÉUNION DE L'ACTIF ET PASSIF DES HÔPITAUX, MAISONS DE SECOURS, DE PAUVRES, ETC. AU DOMAINE NATIONAL; LA LIQUIDATION DU PASSIF de Ces établissemens; la prorogation du délai pour la Remise des titres DE CRÉANCE SUR LES COMMUNES; LE RAPPORT DE LA DÉCHÉANCE DE SIX MOIS D'INTÉRÊTS; ET AUTRES DISPOSITIONS GÉNÉRALES SUR LA LIQUIDATION DE LA DETTE PUBLIQUE (artt.7, 11, 13-23, 25, 27-29)

Degenen die hun schuldvorderingstitels zijn kwijtgeraakt en niet hebben kunnen profiteren van de wet van 21 frimaire II (11 dec 1793) om ze te vervangen, daar de minuten in een register zijn overgeschreven, kunnen zich door de depothouder een gewaarmerkt uittreksel laten verschaffen, en dat laten viseren door het districtsbestuur. Aan het bureau de liquidation dienen de oorspronkelijke of onderhandse schuldvorderingstitels, de authentieke afschriften of uittreksels van authentieke titels vervaardigd van de gedeponeerde minuten of grossen van vóót 24 augustus 1793, de uittreksels van registers van debiteuren-instellingen en overige bewijsstukken te worden overgelegd. De afgekondigde artikelen behelzen verder de procedure van terugbetaling aan schuldeisers van de opgeheven instellingen voor liefdadigheid, zieken- en armenzorg welke nationaal domeingoed zijn geworden en wier activa en passiva overgegaan zijn op de staat. Bestuurslichamen mogen alleen nog schuldvorderingen vereffenen tot 800 livres; daarboven valt deze bevoegdheid toe aan de directeur général de la liquidation.

\section{bo. Convention nationale}

ao. comité des finances

vs. Bouillerot

cols. Louis (du Bas-Rhin) (pres); Bordas, Brival, A. Dumont, A. Besson (secr)

RO nr.232(8): 1 nivôse $V(21$ dec 1796)

- verwijzing naar: wetten van $14 * 27 \mathrm{apr} 1791 ; 24$ aug 1793; 25 sep 1793; 21 frimaire II (11 dec 1793); 17 nivôse II ( 6 jan 1794)

- afkondiging: besluit Directoire exécutuf s. P. Barras (pres), Lagarde (secr.gen); 16 frimaire V (6 dec 1796); opmerking: deze artikelen afgekondigd ter uitvoering van het bepaalde in art. 19 van de wet van 15 fructidor IV ( 1 sep 1796), houdende de opheffing van de religieuze instellingen in het voormalige België 
BL le ser no.23 (109); LA II fol 113 ro, IV fol 102vo; FA nr.234; drukw FA nr.111; rH VI 109; P VI 223; cB IIIe ser XIX 213

\section{LOI QUI AUTORISE LES ADMINISTRATIONS DE DÉPARTEMENT À ORDONNANCER JUSQU'À CONCURRENCE DE LA SOMME DE 800 LIVRES, AU PROFIT DES CRÉANCIERS DE CEUX DONT LES BIENS SONT SEQQUESTRÉS}

De departementsbesturen mogen tot een bedrag van 800 livres machtigen tot betaling, ten bate van de schuldeisers van degenen wier goederen in beslag genomen zijn, in die zin dat het bedrag genomen wordt uit de opbrengst van de gesequestreerde goederen.

bo. Convention nationale

ao. comite des finances

vs. S.E. Monnel

cols. Louis (du Bas-Rhin) (pres); Bordas, A. Besson (secr)

ti. volksrepresentanten/gouvernementscommissarissen

RO nr.84(14) en 210(6): 7 nivôse IV (28 dec 1795) en 23 vendémiaire V (14 okt 1796)

RE nr.72: 21/22 nivôse IV (11/12 jan 1796)

- verwijzing naar: "des lois précédentes"

- afkondliging: besluit volksrepresentanten s. Pérès, Portiez (de I'Oise); 19 frimaire IV (10 dec 1795); besluit Directoire exccutif s. L.M. Revellière-Lépeaux (pres), Lagarde (secr-gen); 10 fructidor IV (27 aug 1796)

\section{II thermidor 6 (1794 jul 24)}

BL le ser no.27 (126); drukw FA mr.30; rH VII 215; P VI 235; cB IIle ser XX 57

\section{LOI SUR LES DIFFICULTÉS ÉLEVÉES DANS L'EXÉCUTION DE L'ARTICLE VII DE LA LOI DU 9 VENTÔSE, RELATIF AUX CONDAMNÉS POUR CRIMES EMPORTANT CONFIS- CATION}

Veroordeelden wier bezittingen verbeurdverklaard zijn en wier laatste woonplaats niet in het vonnis vermeld staat, worden geacht in hun geboorteplaats gedomicilieerd te zijn. Is dit laatste evenmin in het vonnis vermeld, dan wordt als laatste woonplaats aangemerkt de hoofdstad van het departement alwaar de rechtbank zetelt.

bo. Comention nationale

no. comité de législation

vs. S.E. Monnel

cols. Collot-d"Herbois (pres); A. Dumont, Brival (secr)

ti. gouvernementscommissaris Bouteville

RO nr.89(28): 16 nivôse IV (6 dec 1795)

RE nr.136: 14/15 floréal IV (3/4 mei 1796)

- verwijzing naar: wet vam 9 ventôse II ( 27 feb 1794)

- afkondiging: besluit volksrepresentanten/gouvernementscommissarissen s. Pérès, Portiez (de l'Oisse);

24 frimaire IV (15 dec 1795) 
II fructidor 14 (1794 aug 31)

BL le ser no.50 (270); drukw FA nr.30; rH VII 216; P VI 263-264; cB Hite ser XXI 109-110

LOI QUI RECOMMANDE À LA SURVELLANCE DE TOUS LES BONS CITOYENS LES BIBLIOTHÈQUES ET TOUS LES AUTRES MONUMENS NATIONAUX DE SCIENCES ET D*ARTS

Alle goede burgers wordt op het hart gedrukt om toezicht te houden op bibliotheken, alsmede overige voorwerpen van wetenschappelijke of kunstzinnige waarde, toebehorend aan de staat. Men wordt verzocht om degenen die hier onachtzaam mee omspringen, of zelfs beschadigingen aanbrengen, aan te geven bij de autoriteiten, opdat dezen kunnen worden bestraft met twee jaar hechtenis. Op diverse plaatsen zal één en ander worden aangeplakt. Ook is uitdrukkelijk bepaald dat de onderhavige wet in het Bulletin des Lois moet worden geplaatst. Degenen die manuscripten, charters en andere waardevolle oude voorwerpen, afkomstig van voorheen nationale gebouwen, onder zich hebben, dienen deze binnen één maand aan het districtsbestuur van hun woonplaats over te dragen.

bo. Convention nationale

ao. comité d'instruction publique

vs. S.E. Monnel

cols. Merlin (de Thionville) (pres); Lecointre, Guffroy (secr)

ii. gouvernementscommissaris Bouteville

RO nr.89(29): 16 niwôse IV (6 jan 1796)

RE nr.136: 14/15 floréal IV (3/4 mei 1796)

- verwijzing naar: decreet van 13 apr 1793

" wet aan de tijdsomstandigheden aangepast in het "article additionnel"

- afkondiging: besluit volksrepresentanten/gouvernementscommissarissen s. Pérès, Portiez (de l'Oise);

24 frimaire IV (15 dec 1796)

\section{II fructidor 19 (1794 sep 5)}

BL le ser no.55 (289); LA II fol 113; FA nr.234; rH VI 109-110; P VI 269; cB IIle ser XXI 15I

LOI PORTANT QUe La SOlde FIXÉE PAR JOUR de SERVICE, SERA PAyÉE LES SANSCULOTIDES; ET QUE LE TRAITEMENT PAR MOIS OU PAR ANNÉE, N'ÉPROUVERA AUCUN CHANGEMENT POUR LES MÊMES JOURS

Daglonen worden ook op de sansculotides (jours complémentaires) uitbetaald aan degenen die op die dagen werkzaamheden verrichten. Maandelijks of jaarlijks vastgestelde bezoldigingen ondergaan geen enkele verhoging of wijziging op deze dagen.

bo. Convention nationale

ao. comité des finances

vs. Bouillerot

cols. Bermard (pres); Cordier, Reymaud (secr)

ii. volksrepresentanten/gouvernementscommissarissen

RO nr.84(15): 7 nivôse IV (28 dec 1795)

RE nr.72; $21 / 22$ ni̛ôse IV (11/12 jan 1796) 
- LA, FA en $\mathrm{rH}$ spreken van de jours complémentaires

- decreet zal worden geplatitsi in het bulletin de correspondance en het Bulletin des Lois

- cB-intitule: "décre portant que la solde et les traitemens qui sont fixés à raison d"un prix déterminé par jour, seront payes les Sans-Culotides à ceux qui auront fait leur service pendant lesdits jours"

- afkondiging: besluit volksrepresemtanten s. Pérès, Portiez (de l'Oise); 19 frimaire IV (10 dec 1795)

\section{III vendémiaire 14 (1794 okt 5)}

BL. le ser no.68 (364); drukw FA nr. 30; rH VII 217; P VI 290-291; cB IIle ser XXII 78-79

\section{LOI PORTANT QUE LA QUESTION RELATIVE À L'INTENTION SERA POSÉE À L'AVENIR DANS TOUTES LES AFTAIRES SOUMISES À DES JURES DE JUGEMENT}

Voortaan dienen in alle zaken die onderworpen zijn aan het oordeel van de jury (jurés de jugement) door de presidenten van de criminele rechtbanken de vraag aangaande de opzet van de verdachte te worden gesteld, waarover de jury zich, op straffe van nietigheid, formeel moet uitspreken.

bo. Comvention nationale

ao. comité de législation

vs. Leblanc

cols. A. Dumont (pres); Pelet, Laporte (secr)

ti. gouvernementscommissaris Bouteville

RO nr.89(30): 16 miwôse IV (6 jan 1796)

RE nr.136: 14/15 floreal IV (3/4 mei 1796)

- verwijzing naar: wet van 16 sep 1791; code pénal van 25 sep 1791

- wet uitgevaardigd n.a.w. een verzoekschrift van Marie-Anne-Geneviève Leduy, waarin zij beklag doet over het vonnis wan de criminele rechtbank in het departement Marne, die haar veroordeeld heeft tot zes jaar eenzame opsluiting (gêne) wegens vals getügenis in een burgerlijke zaak, hetgeen het tribunal de cassation heeft bevestigd. Beide vonnissen worden door de Convention nationale vernietigd. De criminele rechtbank in het departement Aube moet haar zaak opnieuw beoordelen.

- afkondiging: besluit volksrepresentanten/gouvernementscommissarissen s. Pérès, Portiez (de l'Oise); 24 frimaire IV (15 dec 1795); N.B.: Directoire exécutif herroept deze wet 2 fructidor IV (19 aug 1796); BL. Ife ser no.69 (637)

\section{III vendémiaire 24 (1794 okt 15)}

BL Ie ser no.73 (388); LA II fol 114ro-116ro; FA nr.234; rH VI 110-113; P VI 296-297; cB IIIe ser XXII $|49-15|$

[extract] LOI SUR L'INCOMPATIBILITÉ DES FONCTIONS ADMINISTRATIVES ET JUDICIAIRES (tit.l arti.1-3; tit.II, III, IV)

Voor functies bij de rechterlijke macht geldt in het algemeen dat zij onverenigbaar zijn met een bestuursfunctie, uitgezondlerd die van bijzitters bij de vrederechter voor zover het de uitoefening van een ambtelijke functie bij een gemeente met minder dan 4000 inwoners betreft. De wet behelst voorts de incompatibiliteiten van bestuurs- en rechterlijke functies onderling en het verbod op cumulatie van dergelijke functies. 
Publieke functionarissen moeten in geval van onverenigbaarheid van functies een keuze maken.

bo. Comention nationale

ao. comité de législation

vs. S.E. Monnel

cols. Cambacérès (pres); Boissy, Eschasseriaux jeune (secr)

ti. volksrepresentanten/gouvemementscommissarissen

RO nr.84(16): 7 nivôse IV (28 dec 1795 )

RE nr.72: $21 / 22$ nivôse IV (11/12 jan 1796)

- het onderhavige decreet derogeert aan hiermee strijdige bepalingen in voorgaande wetten aangaande incompatibiliteiten

- afkondiging: beshuit volksrepresentanten s. Pérès, Portiez (de I"Oise); 19 frimaire IV (10 dec 1795)

\section{III brumaire 8 (1794 okt 29)}

BL le ser no.78 (4I5); LA II fol 116; FA nr.234; rH VI 113-114; P VI 307; cB IIIe ser XXIII 44

LOI QUI DÉCLARE LES AGENS NATIONAUX ET ADMINISTRATEURS DE DISTRICT RESPONSABLES DES DESTRUCTIONS ET DÉGRADATIONS COMMISES DANS LEUR ARRONDISSEMENT, SUR LES MONUMENS DE SCIENCES ET ARTS

De nationale agenten en districtsbestuurders zijn zowel individueel als collectief verantwoordelijk voor de vernietiging dan wel de beschadiging van voorwerpen van kunstzinnige of wetenschappelijke waarde, tenzij zij die onmogelijk konden verhinderen. Binnen één decade (tien dagen) na ontvangst van dit decreet moeten zij een staat van de toestand waarin deze goederen zich bevinden en van de bibliotheken aan de commission d'instruction publique doen toekomen. Deze commissie neemt alle noodzakelijke maatregelen ter uitvoering van dit decreet, onder toezicht van het comité d'instruction publique, en geeft bij de Convention nationale die besturen aan die veronachtzamen zich hieraan te conformeren.

bo. Convention nationale

ao. comité d'instraction pablique

vs. Joseph Becker

cols. Prieur (de la Mame) (pres); Goujon, Guimberteau, A. Crassous (secr)

ti. volksrepresentanten/gouvernementscommissarissen

RO nr.84(17): 7 nivôse IV (28 dec 1795)

RE nr.72: $21 / 22$ nivôse IV (11/12 jan 1796)

- afkondiging: besluit volksrepresentanten s. Pérès, Portiez (de l'Oise); 19 frimaire IV (10 dec 1795)

\section{III brumaire 22 (1794 nov 12)}

FA nr.244 fol 43vo-44ro, FA nr.270; Aulard XVIII 87 no.10; Arch.Nat. AF 11221 doss. 1903/40

ARRÊtÉ RELATIF À L'EXÉCUTION DES LOIS [LEES: DE LA LOI] DU 10 JUILLET 1791, [ET DES RĖGLEMENTS] DU 30 THERMIDOR, AN 2 ET 25 VENDÉMIAIRE DE L'AN 3 RELATIFS À LA POLICE DES FORTIFICATIONS 
De bepalingen van de wet van 10 juli 1791 aangaande de dienst der fortificatiën en militaire gebouwen, alsmede de reglementen van 30 thermidor II (17 aug 1794) en 25 vendémiaire III ( 16 okt 1794) betreffende het toezicht op de gebouwen en goederen bestemd voor de kazemering van de troepen, hebben hun volledige werking in de platsen gelegen in de veroverde gebieden. Eveneens zullen de maatregelen, zowe] wat betreft de uitwoering van de werkzaamheden ten dienste van de fortificaties en militaire gebouwen, als wat betreft de comptabiliteit plaatshebben. De commission des travaux publics wordt belast met het doen van voorstellen aan het comité de salut public inzake speciale wijzigingen die de plaatselijke omstandigheden vereisen, en die door de commandanten ter plaatse, de commissarissen van oorlog of de officieren van de genie worden verzocht.

bo. conité de salut public"

ao. commission des travaux publics

s. (sur l'extrait) Carnot, Cambacérès, Pelet, Richard, Ch. Cochon, Bréard, Merlin (de Douai)

ti. brigade-generaal Milet-Mureau, directeur des fortifications, chef de la $3^{p}$ division, in opdracht van de minister van oorlog

RO nr.150: 15 prairial IV ( 3 jun 1796)

- verwijzing naar: wet van 10 juli 1791; reglementen wan 30 thermidor II (17 aug 1794); 25 vendémiaire III ( 16 okt 1794)

- afkondiging onzeker: geen arrêté van het Directoire exécutif; $\mathrm{P}$ en Code Merlin noemen het besluit van het comité de salut public niet

\section{III brumaire 25 (1794 nov 15)}

BL Ie ser no.89 (464); LA I fol I13ro-142ro; FA nr.291; P VI 318-327; rH V 170-200; cB IIle ser XXIII $146-170$

\section{LOI CONCERNANT LES ÉMIGRÉS}

De wet geeft criteria wie als uitgewekene moet worden beschouwd. Doorgaans betreft het mensen die voor een bepaalde datum niet zijn teruggekeerd of steun hebben verleend aan landen die met de Franse Republiek in oorlog zijn. Certificaten van verblijfplaats worden afgegeven door de conseil général van de gemeenten op attestatie van drie dan wel acht getuigen, woonachtig in die gemeente, welk onderscheid te maken heeft met het al dan niet verdacht worden van uitgewekene te zijn. Om de drie maanden moeten burgers hun verblijfscertificaat naar het districtsbestuur van hun domicilie opzenden. Het districtsbestuur is belast met het opstellen van een lijst van uitgewekenen. Door de commission des revenus nationaux wordt een algemene lijst opgesteld van alle uitgewekenen. Degenen die op de lijst voorkomen, kunnen hiertegen in verweer komen. De goederen van de uitgewekenen worden in handen van de staat gesteld. Uitgewekenen en hun medestanders zijn verder voorgoed van het Franse grondgebied verbannen. De doodstraf wordt opgelegd aan hen die de verbanning verbreken; zodra een rechtbank hieromtrent uitspraak heeft gedaan, wordt de straf binnen 24 uur voltrokken. Degenen die gewapenderhand tegen de staat optreden worden door een krijgsraad berecht.

bo. Convention nationale

no. commission chargè̃e de la révision des lois sur les émigrés 
vis. Joseph Becker

cols. Legendre (pres); Duval (de l'Aube), Merlino (secr)

ti. conseil de gowvernement

RO nr.21(1): 26 brumaire IV (17 nov 1795)

RE nr.29: 1 frimaire IV (22 nov 1795)

- verwijzing naar: wetten van 9 feb $1792 ; 28 \mathrm{mrt} \mathrm{1793;19} \mathrm{floreal} \mathrm{II} \mathrm{(8} \mathrm{mei} \mathrm{1794);} \mathrm{bepalingen} \mathrm{van}$ anterieure wetten inzake het onderwerp van de onderhavige wet zijn herroepen; de wetten van 18 fructidor II (4 sep 1794) en van 4 brumaire $\mathbb{1 I I}$ (25 okt 1794) blijven van kracht

- afkondiging: besluit volksrepresentanten s. Pérès, Portiez (de l'Oise); cs. Torfs (secr-prov); 8 brumaire IV ( 30 okt 1795); tien dagen na bekendmaking wordt de wet van kracht

\section{III frimaire 9 (1794 nov 29)}

LA V fol 155ro-158ro; FA wr.291; rH II 295-308, XI 190; P VI lv-lx

\section{[extract] ARRÊTÉ RELATIF À L'ADMINISTRATION DES DOMAINES NATIONAUX ET DES BIENS SÉQUESTRÉS DANS LES PAYS CONQUIS (tit.V)}

Degenen die beweren rechten te genieten op goederen die deel uitmaken van goederen die aan de natie gekomen dan wel gesequestreerd zijn, dienen een omstandige verklaring - houdende de hoedanigheid, de ligging en de opbrengst - ten burele van de ontvanger der domeinen waar die goederen gelegen zijn te overleggen. Deze verklaring dient zo mogelijk door titels of andere documenten te worden ondersteund. Publieke of particuliere depositarissen dienen hun medewerking aan het overleggen van de verklaring te verlenen, wanneer hun zulks wordt gevraagd. Hoofdzakelijk rentmeesters, (onder)pachters, vruchtgebruikers, vennoten worden geacht de verklaring ten kantore van de ontvanger der domeinen te overhandigen.

bo. volksrepresentanten bij het Noorder- en het Sambre-en-Maasleger

s. N. Haussmann, Portiez (de 1"Oise), Briez

RO nr. 252: 5 ventôse $V(23$ feb 1797)

- afkondiging: besluit Directoire exécutif s. Reubell (pres), Lagarde (secr-gen); 16 pluviôse V (4 feb 1797); LA en FA nr.29\|: instructieve noot; bekendmaking "ż son de trompe ou de caisse dans chaque commune des départemens"

\section{III frimaire 17 (1794 dec 7)}

BL Ie ser no.97 (497); LA IV fol 102vo-106vo; drukw FA nr.111; rH X 60-64; P VI 342-344; cB IIIe ser XXIV 180-182

LOI SUR LES ÉTABLISSEMENS DE COMMERCE OU MANUFACTURES DANS LESQUELS ÉTAIENT INTÉRESSÉS DES INDIVIDUS DONT LES BIENS ONT ÉTÉ CONFISQUÉS AU PROFIT DE LA RÉPUBLIQUE, ETC.

Vennoten in een handels- of nijverheidsonderneming dienen de vennootschapsakte en overige relevante stukken aan het districtsbestuur over te dragen, ingeval van de verbeurdverklaring van de goederen van één of meerdere vennoten. De overige vennoten en de weduwe en kinderen van de persoon wiens goederen verbeurdverklaard zijn, verklaren vervolgens schriftelijk zich met de voortzetting van de onderneming te 
belasten. Vier deskundigen-arbiters beoordelen de activa en passiva van de onderneming teneinde te bezien welk gedeelte hiervan ten profijte van de staat komt. Het districtsbestuur dratagt dan door middel wan een akte van cessie alle eigendommen van de vennootschap aan de vennoten en overige contractanten over, onder de last dat zij aansprakelijk zijn voor de schuldvorderingen. In geval degene wiens goederen geconfisqueerd zijn, enig eigenaar is van de onderneming, belasten de weduwe en de kinderen, of eventueel anderen, zich met de voortzetting ervan. Bij ontstentenis van genoemde personen worden er gegadigden door middel van aanplakking opgeroepen het beheer van de onderneming op zich te nemen. Zijn er evenwel geen reacties, dan wordt tot liquidatie ervan overgegaan. Het bepaalde in deze wet is van toepassing op alle soorten handelsactiviteiten, het bankwezen en alle soorten fabrieken en werkplaatsen.

\section{bo. Convention nationale}

ao. comités de commerce, de législation et des finances, réunis

vs. Joseph Becker

cols. Reubell (pres); J.S. Rovere, Boudin (secr)

RO nr.2J0(7): 23 vendérniaire V (14 okt 1796)

- wet van 21 messidor II (9 jul 1794) inzake cle terugvordering van de activa van bankiers en handelslieden door veroordeling toebehorend aan de Republiek, wordt ingetrokken

- cB-intitulé: "décret sur les établissemens de commerce ou manufactures dont les entrepreneurs sont tombés sous la glaive de la loi, ou dans lesquels étoient intéressés des individus dont les biens ont été confisqués au profit de la République"

- afkondiging: besluit Directoire exécutif s. L.M. Revellière-Lépeaux (pres), Lagarde (secr-gen); 10 fructidor IV (27 aug 1796)

\section{III nivôse 22 (1795 jan 11)}

BL le ser no.110 (577); LA I fol 142ra-144ro; rH V 201-203; FA nr.291; P VI 371-372; cB IIIe ser XXV 145-147

LOI RELATIVE À LA RENTRÉE EN FRANCE DES OUVRIERS ET LABOUREURS NON EXNOBLES OU PRÊTRES, SORTIS DU TERRITOIRE DE LA RÉPUBLIQUE DEPUIS LE $1^{\text {E. }}$ MAI 1793

Handwerkslieden, alsmede hun echtgenotes en kinderen beneden achttien jaar, worden niet geacht uitgewekene te zijn, wanneer zij dagelijks hun werk in de nijverheid of op het land verrichten. Dit geldt alleen voor zover zij voorheen niet tot de adel of de geestelijkheid behoorden. Zij mogen de Franse Republiek dan niet hebben verlaten sinds de datum van 1 mei 1793 en moeten vóór de datum van 1 germinal III (21 mrt 1795) zijn teruggekeerd. Voorts moeten zij een attestatie inzake hun beroep aan de autoriteiten overhandigen; valse attestaties worden zwaar bestraft. Hun niet verkochte bezittingen worden teruggegeven onder betaling van de kosten van de inbewaringstelling.

bo. Convention nationale

ao. comités de salut pwblic, de sâreté générale, de législation

vs. Viquy

cols. Clauzel (ex-pres); Daunou, Auguis (secr) 
ti. conseil de gowvernement

RO nr.21(2): 26 brumaire IV (17 nov 1795)

RE nr.29: 1 frimaire TV (22 nov 1795)

- verwijzing naar: wet van 14 frimaire II (4 dec 1793); decreten van 28 frimaire III (18 dec 1794) Therroepen]; 29 frimaine III (19 dec 1794)

- het onderhavige decreet wordt geplaatst in het bulletin de correspondance, vertaald in alle talen en gezonden naar de departementen, legers en agenten van de Republiek bij de geallieerde of neutrale regeringen

- afkondiging: besluit volksrepresentanten s. Péres; Portiez (de l'Oise); 8 brumaire IV (30 okt 1795)

\section{III ventôse 13 (1795 mrt 3)}

BL le ser no.128 (678); LA IV fol 106vo-108ro; drukw FA nr.111; rH X 65-67; P VI 423-424; cB IIIe ser XXVII $100-102$

LOI QUI ORDONNE LA REMISE DES LINGES, BIJOUX ET EFFETS APPARTENANT AUX EPOUX SURVIVANS OU AUX ENFANS DES CONDAMNES; ET LA LEVÉE DES SÉQUESTRES OU SCELLÉ MIS SUR LEURS BIENS MEUBLES ET IMMEUBLES

Linnengoed, kledingstukken, sieraden en andere roerende goederen, nodig voor het dagelijks gebruik aan de nabestaande echtgeno(o)t(e) en de kinderen van een veroordeelde, dient zonder vertraging en kosten te worden teruggeven. De inbeslagneming en verzegeling van de hun eveneens toebehorende (on)roerende goederen wordt terstond opgeheven. Mochten de inbeslaggenomen goederen reeds verkocht zijn, dan vindt vergoeding plaats op de voet van de verkoop. Op soortgelijke wijze wordt er gehandeld inzake de aan de staat vervallen nalatenschap van veroordeelden. De nabestaande echtgeno(o)t(e) en de kinderen hebben de bevoegdheid om een gedeelte van het vee en het landbouwgereedschap te kopen om de hun verpachte grond te kunnen bewerken. $\mathrm{Zij}$ kunnen voorts in de rechten van de veroordeelde treden inzake de verpachting. De bepalingen van de onderhavige wet zijn ook van toepassing voor wat betreft de voortzetting van de activiteiten van ondernemingen.

\section{bo. Convention nationale}

ao. comités de législation ê des finances

vs. S.E. Monnel

cols. A. Dumont (ex-pres); Pémartin, Dupuis (secr)

RO nr.200(8): 23 vendémiaire $V(14$ okt 1796)

- verwijzing naar: wet van 17 frimaire $\mathbb{I I I}(7 \mathrm{dec} 1794)$

- cB-intitulë: "décret portant que les linges, hardes, bijoux, meubles \& effets appartenant aux époux \& aux enfans des condamnés, ou à leur usage journalier, leur seront remis sur un simple état, sans délai \& sans frais; que tous séquestres ou scellés mis sur les biens meubles ou immeubles appartenant par la loi, la coutume ou statut, \&c. aux époux des condamnés, seront levés sans déllai"

- afkondiging: besluit Directoire exéctutif s. L.M. Revellière-Lépeaux (pres), Lagarde (secr-gen); 10 fructidor IV (27 aug 1796)

\section{III ventôse 21 (1795 mrt 11)}

BL Ie ser no.130 (701); LA III fol 125ro; FA nr.291; rH VIII 247; P VI 432; cB IIIe ser XXVII 162 
LOH QUI RAPPORTE L'ARTICLE II DU DECRET DU 6 DE CE MOIS, RELATIF AU NOU. VEAU MODE D'ADJUDICATION DES DOMAINES NATIONAUX A VENDRE; ET QUI DECLARE COMMUN A TOUS LES BIENS NATIONAUX LARTICLE IX DE LA LOI DU 3 JUIN 1793, SUR LA DIVISION ET LE MODE DES VENTES DES BIENS NATIONAUX PROVENANT DES EMIGRTS

Onder intrekking van art.2 van hel decreet van 6 ventôse III (24 feb 1794) inzake de wijze van toewijzing van de ten verkoop aangeboden nationale domeingoederen, wordt de verdeling en de wijze van verkoop onder de werking van art.9 van de wet van 3 juni 1793 gebracht. Mitsdien wordt er gederogeerd aan de wet van $9 * 25$ juli 1790 , als gevolg waarvan de inschrijving op te verkopen nationale domeinen louter facultatief is.

bo. Convention nationale

ao. comité des fimances (section des domaines)

ws. Viquy

cols. A.C. Thibaudeau (pres); Dupuis, Rabaut (secr)

ti. minister van justitie Merlin

RO nr.147(20): II prairial IV (30 mei 1796)

- verwijzing naar: werten van 25 jull 1790; 3 jun 1793; decreet van 6 ventôse III (24 feb 1795)

- afkondiging: besluit Directoire exécutif s. Camot (pres), Lagarde (secr-gen); 23 floréal IV (12 mei 1796)

\section{III ventôse 26 (1795 mrt 16)}

BL le ser no.130 (704); drukw FA nr.30; rH VII 218; P VI 434; cB Me ser XXVII 183-184

\section{LOI PENALE CONTRE CEUX QUI REFUSENT D'OBÉR AUX RÉQUISITIONS DE VOITU- RES}

De straf die staat op de weigering om graan te leveren, is eveneens van toepassing op de weigering te voldoen aan de requisitie van wagens. Wanneer het koren niet in beslag genomen wordt, dan volgt het opleggen van een boete gelijk aan de waarde van de voedingsmiddelen die door deze weigering verloren gegaan zijn.

bo. Convention nationale

ao. comite de salut public

vs, S.E. Monnel

ti. gouvernementscommissaris Bouteville

cols. A.C.Thibaudeau (pres); Pémartin, Dupuis (secr)

RO nr.89(31): 16 nivôse IV (6 jan 1796)

RE nr.136: 14/15 florél IV (3/4 mei 1796)

"verwijzing naar: wet van 3 pluviôse IIIr (22 jan 1795)

- afkondiging: besluit wolksrepresentanten/gouvernementscommissarissen s. Pérès, Portiez (de l'Oise); 24 frimaire IV (15 dec 1795)

\section{III germinal 1 (1795 mrt 21)}

BL le ser no.131 (712); drukw FA nr.30; rH VII 218-222; P VI 438-439; cB IIIe ser XXVII 3-6 
LOI(S) CONTENANT DES MESURES REPRESIVES DES RASSEMBLEMENS SËDITIEUX ET DES ATTEINTES QUI SEROIENT PORTÉ AUX PERSONNES, AUX PROPRIETES, AU GOUVERNEMENT REPUBLICAIN ET A LA REPRESENTATION NATIONALE

Het uitlokken van plundering van particuliere of publieke eigendommen of geweldpleging jegens personen, het oproepen tot het herstel van de monarchie dan wel het in opstand komen tegen de autoriteiten, de regering of de Nationale Vertegenwoordiging, het uiten van oproerige kreten op straat wordt als een misdrijf beschouwd en dienovereenkomstig door de criminele rechtbanken berecht en bestraft met deportatie. Samenscholingen dienen te worden tegengegaan en na sommatie eventueel gewapenderhand uiteengejaagd te worden. De wet geeft voorts voorschriften hoe er moet worden gehandeld als de Nationale Vertegenwoordiging wordt aangevallen, of als er sprake is van bellaging van individuele volksrepresentanten.

bo. Convention nationale

ao. comités de salut public, de sâreté gémérale, de légisharion, militaire

ws. Viquy

cols. Merlin (de Douai) (ex-pres); C.A.A. Blad, Pémartin (secr)

ti. gouvernementscommissaris Bouteville

RO nr.89(32): 16 nivôse IV (6 jan 1796)

RE nr.136: 14/15 floréal IV (3/4 mei 1796)

- werwijzing naar: grondwet van 1793; wet van 7 fructidor II (24 aug 1794)

- n.a.v. een motie van én van haar leden vaardigt de Convention nationale additioneel als decreet uit dat de onderhavige wet aangaande de grande police zal worden toegezonden aan de departementen en de legers en geproclameerd en aangeplakt zal worden in Parijs, alsmede geplaatst zal worden in het Bulletin des Lois

- cB-intitulés: "décret de grande police pour assurer la garantie de la sûreté publique, du gouvernement et de la représentation nationale", "décret portant que le décret de grande police sera envoyé aux départemens et aux armées, proclamé et affiché dans Paris"*

- afkondiging: besluit volksrepresentanten/gouvernementscommissarissen s. Pérès, Portiez (de l'Oise); 24 frimaire IV (15 dec 1795)

\section{III germinal 8 (1795 mrt 28)}

BL le ser no.132 (723); LA II fol 116wo-117vo; FA nr.234; rH VI 114-115; P VI 443; cB IIIe ser $\mathrm{XXVIII} 26$

LOI RELATIVE AUX COMPTES À RENDRE PAR LES MEMBRES DES ADMINISTRATIONS DE DÉPARTEMENS, DE DISTRICT, ET DES MUNICIPALITES, QUI AURONT CESSE D'EXERCER LEURS FONCTIONS

Leden van de departements-, districts- en municipaliteitsbesturen die om welke reden ook hun functie niet langer vervullen, dienen collectief of individueel aan de bestuurslichamen waarvan zij deel uitmaakten rekenschap af te leggen van het door hen gevoerde beheer. Het hieraan niet-voldoen leidt tot vervolging en de tijdelijke opschorting van de uitoefening van de burgerrechten. Indien men gedetineerd is, kan men zich van alle noodzakelijke stukken voorzien en ter zake corresponderen om aan deze verplichting te voldoen. 
bo. Convention nationale

ao. comité de légisiarion

vs. Viquly

cols. Pelet (pres); Bodin, Laignelot (secr)

ti. volksrepresentanten/gouvernementsconmissarissen

RO nir.84(18): 7 nivổse IV (28 dec 1795 )

RE nr. 72: $2 \rrbracket / 22$ nivôse IV ( $1 / / 12$ jain 1796)

- verwijzing nalar: wet van 19 floréal II ( 8 mei 1794); LA en rH gewagen van art.11, lees: art.10

- afkondiging: besluit volksrepresentanten 8. Pérès, Portiez (de I'Oise); 19 frimaire IV (10 dec 1795)

\section{III germinal $22(1795$ apr 11)}

BL Ie ger no. 136 (755); LA I fol 144ro-145ro; FA nr.291; rH V 203; cB Ille ser XXVIII 138

\section{LOI QUI RAPPORTE CELLES QUI METTENT DES CITOYENS HORS DE LA LOI PAR

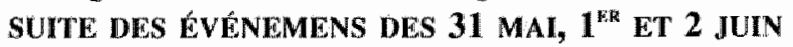

De decreten waarbij burgers buiten de wet zijn geplaatst als gevolg van de gebeurtenissen [te Parijs: val van de Girondijnen] van 311 mei tot 2 juni 1793 worden ingetrokken. Deze burgers worden in al hun rechten hersteld en mogen naar hun haardsteden terugkeren. Tevens zijn de beslagleggingen op hun goederen opgeheven.

bo. Convention nationale

ao. comitể de législation

vs. S.E. Monvel

cols. Boissy (pres); F. Lanthenas, Balmain (secr)

ti. conseil de gouvernement

RO nn.21(3): 26 brumaire IV (17 nov 1795)

RE nr.29: 1 frimaire IV (22 nov 1795)

- decreet wordt ook geplaatst in het bulletin de correspondance

- afkondiging: besluit volksrepresentanten s. Pérès, Portiez (de I'Oise); 8 brumaire IV (30 okt 1795)

\section{III germinal 22 (1795 apr 11)}

BL le ser no.135 (751); drukw FA nr.30; rH VII 227-229; cB Ille ser XXVIII $138-140$

LOI QUI RAPPORTE CELLE DU 27 MARS 1793, PAR LAQUELLE LES ENNEMIS DE LA RÉ VOLUTION SONT MIS HORS DE LA LOI; ET CELLE DU 23 VENTÔSE, AN DEUXIÈME, QUI ORDONNE DE REGARDER ET PUNIR COMME LEURS COMPLICES CEUX QUI LES ONT RECÉLÉS

Het decreet van 27 maart 1793 dat alle vijanden van de revolutie buiten de wet plaatst, alsmede het decreet van 23 ventôse II (13 mrt 1794) gelastende degenen die hun een schuilplaats bieden als medeplichtigen te beschouwen en als zodanig te bestraffen, worden op grond van hun vage en geenszins precieze formulering herroepen. Degenen die op grond van bedoelde decreten zijn vervolgd, worden in hun rechten hersteld. In een afzonderlijke bepaling wordt de enige overlevende van de familie van de volksrepresentant Guadet in al zijn rechten hersteld. De commission des revenus nationaux is hiermee belast. 
bo. Convention nationale

ao. comité de législation

vs. S.E. Monnel

cols. Boissy (pres); Balmain, F. Lanthenas (secr)

ti. gouvemementscommissaris Bouteville

RO nr.89(37): 16 nivôse IV (6 jan 1796)

RE nr.136: 14/15 floréal IV (3/4 mei 1796)

- verwijzing naar: decreet van 27 mrt 1793; 23 ventôse II (13 mrt 1794); code pénal van 25 sep 1791; "autres lois existantes"

- wet uitgevaardigd n.a.v. een petitie van de burger Guadet; enig overlevende wan de vonnissen van de militaire commissie te Bordeaux van 27 messidor II (15 jul 1794) en 3 thermidor II (21 jul 1794) - BL vermeldit ook het "rapport fait au nom du comité de législaton, sur la pétition du citoyen Guadet; par Saladin dans la séance du 22 Germinal, an Ile [?]"

- afkondiging: besluit volksrepresentanten/gouvernementscommissarissen s. Pérès, Portiez (de l'Oise); 24 frimaire IV (15 dec 1795 )

\section{III germinal 23 (1795 apr 12)}

BL Ie ser no.136 (756); drukw FA nr.30; rH VII 229; P VI 465; cB IIIe ser XXVIII 143-144

\section{LOI PORTANT QU'A L'AVENIR AUCUNE FEMME PRÉVENUE DE CRIME EMPORTANT PEINE DE MORT, NE POURRA ÊTRE MISE EN JUGEMENT, QU'IL N'AIT ÉTE VERIFIÉ QU'ELLE N'EST PAS ENCEINTE}

Vrouwen, veroordeeld voor misdrijven waarop de doodstraf staat, mogen alleen terechtgesteld worden als is komen vast te staan dat zij niet zwanger zijn. De comités de législation en de sûreté générale zijn gemachtigd om definitief uitspraak te doen over de vrijlating of latere gevangenschap van de veroordeelden. Te dien einde zenden de openbare aanklagers bij de (buiten)gewone criminele rechtbanken de vonnissen en overige gegevens dienaangaande naar het comité de législation.

bo. Convention nationale

ao. comité de législation

w. S.E. Monnel

cols. Boissy (pres); L.M. Revellière-Lépeaux, Ballmain (secr)

ti. gouvernementscommissaris Bouteville

RO nr.89(38): 16 nivôse IV (6 jan 1796)

RE nr. 136: 14/15 floréal IV (3/4 mei 1796)

- plaatsing in het Bulletin des Lois strekt tot promulgatie

- afkondiging: besluit volksrepresentanten/gouvernementscommissarissen s. Pérès, Portiez (de l'Oise); 24 frimaire IV (15 dec 1795)

\section{III germinal 26 (1795 apr 15)}

BL le ser no.137 (763); LA IV fol 108ro; drukw FA nr.111; rH X 67-68; P VI 467; cB IIle ser XXVIII 161-162

LOI PORTANT QUE CELLE DU 13 VENTÓSE RELATIVE À LA REMISE DES EFFETS PROVENANT DES CONDAMNES, NE SERA SUSCEPTIBLES D'AUCUNE EXCEPTION; ET CONTENANT UNE RECTIFICATION DE L'ARTICLE XIV DE CETTE LOI 
De wet van 13 ventôse III ( 3 mrt 1795) aangaande de overdracht van goederen afkomstig van veroordeelden is voor geen enkele uitzondering vatbaar onder het voorwendsel van contraire anterieure decreten. Verder wordt er een rectificatie aangebracht in art. 14 van bovengenoemde wet.

bo. Convemion mationale

ao. comité des funances, section des domaines et contributions

vs. S.E. Monnel

cols. Boissy (pres); Bailleul, C.A.A. Blad (secr)

RO nr.210(8): 23 vendémiaire $V(14$ okt 1796)

- cB-invitulé" "décret portant que la loi du 13 ventôse, contenant des dispositions générales en faveur de ceux qui y sont désignés, ne sera susceptibles d'aucune exception, sous prétexte de décrets antérieurs contraires, \&c."

- afkondiging: besluit Directoire exécutif s. L.M. Revellière-Lépeaux (pres), Lagarde (secr-gen); 10 fructidor IV (27 aug 1796)

\section{III floréal 1 (1795 apr 20)}

BL. le ser no.141 (792); LA IV fol 108ro-124ro; drukw FA nr.111; rH X 68-94; P VI 471-480; cB Ille ser XXIX 3-22

\section{LOI RELATIVE AUX CREANCES ET DROITS SUR LES BIENS NATIONAUX PROVENANT DES EMMIGRES}

Schuldeisers van uitgewekenen zijn tot rechtstreekse schuldeisers van de Republiek verklaard, behoudens degenen die een vordering hebben op gefailleerde of notoir insolvente geëmigreerden. Men heeft een schuldvordering op uitgewekenen uit hoofde van een titel daterend van vóór de promulgatie van de wet van 9 februari 1792 , dan wel als gevolg van de emigratie van de debiteur na genoemde datum. De schuldvorderingstitels op uitgewekenen zijn ook authentiek verklaard voor de bij Frankrijk aangesloten gebieden, vanaf het moment van de promulgatie van het aansluitingsdecreet. Het deponeren van de schuldvorderingstitels dient, samen met de bewijsstukken, op het secretariaat van het districtsbestuur alwaar de uitgeweken debiteur zijn domicilie had, te geschieden. Het districtsbestuur opent daartoe een speciaal register. De wet geeft verder bepalingen inzake de wijze van vereffening van de schuldvorderingen, de daartoe benoemde functionarissen, de vereffening van de rechten van echtgenotes en de kinderen van geëmigreerden. Voorts zijn er bepalingen aangaande de solventie van de debiteuren. Goederen en rechten die ongedleeld genoten worden samen met uitgewekenen, worden voorlopig eerst gesequestreerd. Pas na de verdeling van de goederen en de vereffening van de ongedeelde rechten kan tot de verkoop der in beslag genomen goederen worden overgegaan. De vereffening van een vordering geschiedt tot een beloop van 2000 livres in assignaten; hogere bedragen zijn toelaatbaar in de vorm van betaling in nationale domeingoederen, dan wel als inschrijving op het grootboek der nationale schuld. Art. 130 ten slotte bepaalt dat alle bepalingen in anterieure wetten "relatives à l'objet de la présente" zijn herroepen.

bo. Convention nationale

ao. comités de législation et des finances 
vs. S.E. Monnel

cols. Treilhard (ex-pres); Himbert, J.B. Louvet (secr)

RO nr.210(9): 23 vendemiaire $\mathrm{V}(14 \mathrm{okt} 1796)$

- werwijzing naar: wetten van 9 feb $1792 ; 2$ sep $1792 ; 20$ sep 1792 ; 11 en 12 mrt 1793; 17 jul 1793 ; 17 nivôse II (6 jan 1794); 23 floréall II (12 mei 1794); 3 prairial II (22 mei 1794); 25 brumaire III (15 nov 1794); 17 frimaire III ( 7 dec 1794$) ; 4$ pluviôse III $(23$ jan 1795); 13 ventôse III (3 mrt 1795): "19 ventôse III (9 mrt 1795); 26 ventôse III (16 mrt 1795); "lois antérieures"; "lois precédentes"

- aanvullend decreet wan 1 floréal III (20 apr 1795) vermeldt dat de artikelen die tijdens de zittingen van 24 en 28 germinal III (13 en 17 apr 1795) gedecreteerd zijn, gevoegd worden bij die van 1. floréal III en te zamen eén wet vormen

- afkondiging: besluit Directoire exécutif s. L.M. Revellière-Lépeaux (pres), Lagarde (secr-gen); 10 fructidor IV (27 aug 1796)

\section{III floréal 2 (1795 apr 21)}

BL le ser no.139 (780); LA III fol 201vo-203ro; drukw FA nr.134; rH VIII 392-395; P VI 48॥-482; cB IIIe ser XXIX 25-27

\section{LOI QUI DÉTERMINE UN MODE POUR SUPPLÉER AUX REGISTRES DE L'ÉTAT CIVIL DETRUITS OU PERDUS PENDANT LA REVOLUTION}

De registers van de burgerlijke stand daterend vanaf 14 juli 1789 die verloren gegaan of vernietigd zijn, zullen worden vervangen. Het departement zal genummerde en geparafeerde copieën laten vervaardigen van de dubbelen die zich in één der depots bevinden. In geval beide originelen verloren gegaan zijn, moeten zij worden gereconstrueerd in de vorm van een drietal lijsten, van de geboorten, van huwelijken en echtscheidingen en van overlijden. Dit dient in chronologische volgorde en met de grootst mogelijke zorgvuldigheid, met behulp van verklaringen van de betreffende personen, familieleden, documenten enzovoorts, door daarvoor aangestelde commissarissen te geschieden. Personen die reeds langer dan 30 jaar zijn overleden, worden niet opgenomen, tenzij daarom door geïnteresseerden uitdrukkelijk wordt gevraagd. De lijsten liggen gedurende twee maanden ter inzage bij de gemeenten, zodat belanghebbenden kunnen reclameren en rectificaties kunnen laten aanbrengen, welke beoordeeld worden door de districtsrechtbank. De commissaris van het district en een gemeenteambtenaar tekenen de lijsten voor authentiek. De processen-verbaal van terechtstellingen dienen voorlopig ook als overlijdensakten voor de burgerlijke stand.

\section{bo. Convention nationale}

ao. comité de législation

vs. S.E. Monnel

cols. Boissy (ex-pres); Bernard (de Saint-Afrique), Himbert (secr)

RO nr.164(9): 24 messidor IV (12 jul 1796)

RE nr. 193: 1/3 brumaire V (22/24 okt 1796); Vlaamse vertaling [drukw FA nr. 143]

- drukw FA nr.34 is tevens instructie

- afkondiging: besluit Directoire exécutif s. Carnot (pres), Lagarde (secr-gen); 29 prairial IV (17 jun 1796) 
LOI PORTANT QU'À L'AVENIR LES FERMAGES DES PROPRIÉTÉS RURALES SERONT ACQUIS AUX ADJUDICATAIRES PROPORTIONNELLEMENT ET À COMPTER DU JOUR DE L'ADJUDICATION

Voortaan moeten de verschuldigde pachtgelden van landelijke eigendommen in evenredigheid worden voldaan aan degenen aan wie deze zijn toegewezen, gerekend vanaf de dag van de loewijzing, zoals gebruikelijk is bij de huur van huizen en bij overige renten. Dit in afwijking van hetgeen bepaald is in de instructie van 3 juli 1791 die de pachtsom aan de verkrijger toekent evenredig aan de voortgang van de houtkap en de oogst.

bo. Convention nationale

ao. comité des finantes

vs. S.E. Monnel

cols. Boissy (ex-pres); Bernard (de Saint-Afrique), Himbert (secr)

ti. minister van justitue Merlin

RO nr.147(21): 11 prairial IV (30 mei 1796)

- verwijzing naar: instructie van 3 jul 1791

- afkondiging: besluit Directoire exécutif s. Camot (pres), Lagarde (secr-gen); 23 floréal IV (12 mei 1796)

\section{III floréal 5 (1795 apr 24)}

BL le ser no. 140 (786); LA II fol 12vo-13ro; FA nr.233; rH V 364; P VI 483; cB IIIe ser XXIX 4243

\section{LOI QUI SUSPEND TOUTE ACTION INTENTÉE À L'OCCASION DE L'EFFET RÉTROACTIF RÉSULTANT DE LA LOI DU 17 NIVÔSE SUR LES SUCCESSIONS}

Alle ingestelde rechtsvorderingen ter zake van de terugwerkende kracht die voortvloeien uit de wet van 17 nivôse II ( 6 jan 1794) betreffende de nalatenschappen, zijn opgeschort.

bo. Convention mationale

vs. S.E. Monnel

cols. Boissy (ex-pres); F. Lanthenas, Pierret (secr)

ti. volksrepresentanten/gouvemementscommissarissen

RO nr.67(2): 25 frimaine IV (16 dec 1795)

RE nr.62: 13/14 nivôse IV (3/4 jan 1796)

- verwijzing naar: wet van 17 nivôse II (6 jan 1794)

- afkondiging: besluit volksrepresentanten s. Pérès, Portiez (de l'Oise); 28 brumaire IV (19 now 1795)

\section{III floréal 8 (1795 apr 27)}

BL le ser no. 140 (788); L.A V fol 93ro-95vo; FA nr.291; rH X 28I-285; P VI 485-486; cB IIle ser $55-58$ 
De schuldeisers van nationaal verklaarde lijfrenten welke nog niet vereffend zijn, worden alsnog ingeschreven in het grootboek van de lijfschuld (dette viagere), aangelegd ingevolge de wet van 23 floréal II (12 mei 1794). De vereffening kan plaatsvinden overeenkomstig deze wet, na de indiening door henzelf of door hun algemene volmachthebber van een verklaring van voorkeur. Degenen die willen worden terugbetaald overeenkomstig hun contracten behoeven een dergelijke verklaring niet in te dienen. De artikelen behelzen voorts de modaliteiten inzake de vereffening van de nationaal geworden lijfrenten. De liquidatie van financieringsmaatschappijen bekend onder de naam van caisse d'escompte, en van brand- en levensverzekeringen geschiedt overeenkomstig de wet van 29 fructidor II (15 sep 1794).

\section{bo. Conventiont nationale}

aor. comité des finances

vs. J.M. Hubert

colls. Boissy (ex-pres); Hümbert, Pierret (secr)

RO nr.232(9): I nivôse V (21 dec 1796)

- verwijzing naar: wetten van 23 floréal II (12 mei 1796); 8 messidor II (26 jun 1794); II fructidor II (28 aug 1794); 29 fructidor II (15 sep 1794); 13 brumaire III ( 3 nov 1794)

- afkondiging: besluit Directoire exécutif s. P. Barras (pres), Lagarde (secr-gen); 16 frimaire V (6 dec 1796); opmerking: deze wet afgekondigd ter uitvoering van het bepaalde in art. 19 van de wet van 15 fructidor IV (1 sep 1796), houdende de opheffing van de religieuze instellingen in het voormalige België

\section{III floréal 9 (1795 apr 28)}

BL Ie ser no.140 (789); LA IV fol 124vo-127vo; drukw FA nr.111; rH X 95-100; P VI 488-490; cB IIIe ser XXIX 63-67

\section{LOI RELATIVE À LA LEVÉE DU SÉQUESTRE MIS SUR LES BIENS DES PÈrES ET MÈRES D'EMIGRES, ETC.}

Iedere (groot)ouder wiens vermoedelijke en rechtstreekse erfgenaam uitgewekene is, dient binnen twee maanden na de bekendmaking van deze wet aan het districtsbestuur zijn goederen, roerende en onroerende, alsmede zijn schulden en vorderingen aan te geven. Daaronder behoort ook hetgeen hij na 14 juli 1789 aan zijn (klein)kinderen heeft gegeven. Bij weigeren van het verstrekken van de opgave wordt men bestraft met verval van de voorrechten die in de wet vervat zijn; beboet wordt men ingeval van bedriegelijke wegneming of schatting. Autoriteiten en burgers kunnen ter zake een aanklacht indienen. Zodra de verklaring door de ascendenten van de geëmigreerde is afgegeven, komt het voltallige districtsbestuur in het openbaar bijeen, teneinde over te gaan tot de liquidatie van het opgegeven erfgoed. De staat doet afstand van het erfgoed tot een beloop van 20000 livres ten gunste van de bloedverwant in de opgaande lijn; het eventuele resterende gedeelte gaat naar de staat. De erfdelen van de uitgewekenen worden bij de nationale domeingoederen gevoegd. Voorts vindt opheffing van de inbeslagneming plaats, alsmede de definitieve vrijlating van de vanwege de emigratie van zijn kind in hechtenis genomen ouder. $\mathrm{Na}$ de uitvoering van dit 
decreet worden er in Frankrijk geen (groot)ouders en verwanten van uitgewekenen meer erkend.

\section{bo. Convention nationale}

ao. comités de légishation et des finances réunis

พs. J.M. Hubert

cols. Boissy (ex-pres); J.B. Lowvet, Himbert, Bernard (de Saint-Afrique) (secr)

RO nr.210(10): 23 vendérniaire $V(14$ okt 1796$)$

- verwijzing naar: wetten van $27 \operatorname{sep~1792;28~mrt~1793;~} 23$ floréal II (12 mei 1794); 3 prairial III (22 meil 1794); 23 nivổe III (12 jan 1795)

- afkondiging: besluit Directoire exếcutif s. L.M. Revellière-Lépeaux (pres), Lagarde (secr-gen); 10 fructidor IV (27 aug 1796)

\section{III floréal 12 (1795 mei 1)}

BL le ser nr.140 (79I); LA I fol 145ro-146vo; FA nr.291; rH V 204-205; P VI 493; cB IIle ser XXIX 84-85

LOI QUI ORDONNE LE PROMPT JUGEMENT DES ÉMIGRÉS TROUVÉS SUR LE TERRITOIRE DE LA RÉPUBLIQUE; L'EXPULSION DES INDIVIDUS RENTRÉS APRES DÉPORTATION; ET CONTIENT DES MESURES RÉPRESSIVES DE TOUTE PROVOCATION À L'AVILISSEMENT DE LA REPRESENTATION NATIONALE OU AU RETOUR DE LA ROYAUTE, ETC.

Iedere uitgewekene die aangetroffen wordt op het grondgebied van de Franse Republiek wordt dadelijk voorgeleid bij een rechtbank. Teruggekeerde gedeporteerden dienen het Franse grondgebied binnen éen maand na bekendmaking van de onderhavige wet te hebben verlaten. Zij die in geschrifte de Nationale Vergadering belasteren of oproepen tot het herstel van het koningschap moeten worden gearresteerd en voor een criminele rechtbank worden gebracht. Verder dienen er maatregelen te worden genomen teneinde te bevorderen dat scholen, theaters enzovoorts de werkzaamheden van de Convention nationale ondersteunen.

bo. Convention mationale

ao. comirés de salut public, de sâteté générale, de législation

vs. S.E. Monnel, J.M. Hubert

cols. Boissy (ex-pres); J.B. Louvet, Himbert, Bernard (de Saint-Afrique) (secr)

ii. conseil de gowernement

RO nr.21(4): 26 brumaire IV (17 now 1795)

RE mr.29: 1 frimaire IV (22 now 1795)

- verwijzing natr. wetten van 25 brumaire III (15 nov 1794); I germinal III (21 mrt 1795); 21 germinal III (10 apr 1795)

- cB-intitulé: "décret relatif aux émigrés qui seront trouvês sur le territoire de la népublique, aux prêtres qui ayant été déportés seront rentrés sur le même territoire, etc."

- afkondiging: besluit volksrepresentanten s. Pérès, Portiez (de I'Oise); 8 brumaire IV (30 okt 1795)

\section{III floréal 14 (1795 mei 3)}

BL le ser no. 142 (800); drukw FA nr.30; rH VII 230; p VI 494; cB IIIe ser XXIX 94 
LOI QUI ORDONNE LA RESTITUTION DES BIENS CONFISQUES PAR SUITE DE JUGEMENS RENDUS PAR LES TRIBUNAUX REVOLUTIONNAIRES DEPUIS LE 10 MARS 1793, AUX PARENS DES CONDAMNÉS AUTRES QUE LES CONSPIRATEURS, ÉMIGRES, ETC.

Het beginsel van de verbeurdverklaring van goederen blijft gehandhaafd ten aanzien van samenzweerders, uitgewekenen en hun medeplichtigen; valsemunters en verkwisters van openbare gelden, alsmede ten aanzien van de familie Bourbon-Capet [de Franse koninklijke familie]. De goederen van de sinds 10 maart 1793 overige veroordeelden evenwel, worden aan hun famillie terugggeven, zonder dat daarvoor herziening van de rechtsgang noodzakelijk is.

bo. Convention nationale

ws. S.E. Monnel

cols. Cambacérès (ex-pres); J.B. Louvet, Bernard (de Saint-Afrique) (secr)

ti. gouvernementscommissaris Bouteville

RO mr.89(39): 16 nivôse IV (6 jan 1796)

RE nr.136: 14/15 floréal IV (3/4 mei 1796)

- cB-intitulé: "décret relatif à la confiscation des biens des condamnés"

- afkondiging: besluit volksrepresentanten/gouvemementscommisarissen s. Pérès, Portiez (de l'Oise); 24 frimaire IV (15 dec 1795 )

\section{III floréal 20 (1795 mei 9)}

BL le ser no. 143 (805); drukw FA nr.30; rH VII 222-223; cB IIIe ser XXIX 124-125

loi qui charge le comité de législation de provoquer l'action des TRIBUNAUX CRIMINELS CONTRE TOUS INDIVIDUS PRÉVENUS DE CRIMES ET D'ACTES D'OPPRESSION, ETC.

De volksrepresentanten en mission te Lyon moeten terstond rapporteren over de gebeurtenissen, die aldaar op 16 floréal III ( 5 mei 1795) plaatshadden [witte terreur: bloedbad aangericht onder gevangengezette Jacobijnse revolutionairen]. Het comité de législation is belast met de taak de criminele rechtbanken aan te sporen de verdachten van ondermijning van het gezag, machtsusurpatie, plundering enzovoorts te vervolgen. Municipaliteiten en andere bestuurslichamen dienen de aanstichters van deze vergrijpen en hun medeplichtigen aan te geven bij de openbare aanklagers. Niemand mag zich in dezen aan zijn taak onttrekken.

bo. Convention mationale

ao. comités réunis de salut public et de süreté générale

vs. S.E. Monnel

cols. Vernier (pres); Peyre, Saint-Martin (secr)

ti. gouvernementscommissaris Bouteville

RO nr.89(33): 16 nivôse IV (6 jan 1796)

RE nr. 136: 14/15 floréal IV (3/4 mei $\| 796$ )

- cB-intitulé: "décret relatif aux événemens qui ont eu lieu à Lyon, le 16 floréal présent mois"

- afkondiging: besluit volksrepresentanten/gouvernementscommissarissen s. Pérès, Portiez (de l'Oise);

24 frimaire IV ( $15 \operatorname{dec} 1795)$ 


\section{III floreall 24 (1795 mei 13)}

BL Ie ser no.144 (810); LA III fol 125vo-126ro; rH VIII 248-250; P VI 502-503; cB IIIe ser XXIX 135-136

\section{LOI QUI PRONONCE LA DÉCHÉANCE CONTRE LES ADJUDICATAIRES DE BIENS NATIO- NAUX QUI N'AURONT PAS PAYÉ LES TERMES ÉCHUS DANS LES DÉlAIS PRESCRITS}

De vervallenverklaring van de toewijzingen aan de kopers van nationale domeingoederen is afhankelijk van het tijdstip van de verwerving ervan en het niet tijdig voldoen van de eerste betaling. De verkrijgers moeten rekenschap afleggen van de vruchtopbrengst en de overige inkomsten aan het districtsbestuur. Blijft verdere tijdige betaling uit, dan volgt de vervallenverklaring van de verworven nationale goederen. De procureur-syndic in het district gaat dan over tot het opnieuw veilen wegens het verzuim van de eerste koper. Met dit decreet wordt afgeweken van alle bepalingen van voorgaande wetten die met de onderhavige strijdig zijn.

bo. Convention mationale

ao. comité des finances, section des domaines

vs. J.M. Hubert

cols. Thibault (ex-pres); Saint-Martin, Peyre (secr)

ti. minister van justitie Merlin

RO nr.147(22): 11 prairial IV (30 mei 1796)

- verwijzing naar: wet van 3 nov 1790

- plaatsing in het bullerin de correspondance en Bulletin des Lois strekt tot bekendmaking

- cB-imitulé: "dlécret relatif aux acquéreurs de domaines nationaux"

- afkondiging: besluit Directoire exécurif" s. Carnot (pres), Lagarde (secr-gen); 23 floréal IV (12 mei 1796)

\section{III floréal 26 (1795 mei 15)}

BL Ie ser 144 (81 I); LA If fol 1.47; FA nr.291; rH V 206; P VI 503; cB IIIe ser XXIX 140-141.

\section{LOI RELATIVE AUX DEMANDES EN RADIATION DE LISTES D'ÉMIGRÉS}

Door het comité de législation zal aan alle leden van de Convention nationale een lijst met de namen van de uitgewekenen worden gezonden, alvorens rapport uit te brengen over de verzoeken om doorhaling op de lijst. Ingetrokken wordt de wet van 18 pluviôse III ( $6 \mathrm{feb}$ 1795), die toestemming gaf tot verlenging van de termijn on met bewijzen van verblijfplaals te komen. Zij die niet hebben geklaagd over hun vermelding op de lijst, worden definitief als uitgewekene beschouwd.

bo. Convention nationale

ao. comité de législation

vs. J.M. Hubert.

cols. Vernier (pres); Peyre, Saint-Martin (secr)

ti. conseil de gouvernement

RO nr.21(5): 26 brumaire IV (17 now 1795)

RE nr.29: 1 frimaire IV (22 now 1795) 
- werwijzing naar: wetten van 25 brumaire III (15 nov 1794); 18 pluviôse III (6 feb 1795)

- afkondiging: besluit volksrepresentanten s. Pêrès, Portiez (de l'Oise); 8 brumaire IV (30 okt 1795)

\section{III floréal 28 (1795 mei 17)}

BL. le ser no. 149 (861); LA IV fol 127vo-128ro, $V$ fol 154ro-115vo; FA nr.291; drukw FA nr.111; rH X 100-10I; P VI 504-505; cB IIIe ser XXIX 147-148; F I 27 ]

\section{LOI RELATIVE AUX dÉClaRATIONS À FAIRE PAR LES DÉBITEURS dES CORPORATI- ONS ECCLÉSIASTIQUES OU LAÏQUES SUPPRIMÉES, DES ÉMIGRÉS, ETC.}

De districtsbesturen vorderen van iedere burger die debiteur van de staat is - als vertegenwoordiger van de opgeheven religieuze gemeenschappen, de uitgewekenen en andere door verbeurdverklaring getroffen personen - een verklaring van de hoogte van de schuldbedragen. Valse declaraties worden zwaar beboet. Een aangifte wordt als vals beoordeeld, wanneer de onjuistheid blijkt hetzij uit openbare akten, hetzij door middel van een getuigenbewijs.

\section{bo. Convention nationale}

ao. contité des finances, section des domaines

vs. S.E. Monnel

cols. Boissy (ex-pres); Mollevaut, Peyre (secr)

RO nr.210(11) en 252: 23 vendémiaire $V(14$ okt 1796) en 5 ventôse $V(23$ feb 1797)

- afkondiging: besluit Directoire exécutif s. L.M. Revellière-Lépeaux (pres), Lagarde (secr-gen); 10 fructidor IV (27 aug 1796); besluit Directoire exécurif s. Reubell (pres), Lagarde (secr-gen); 16 pluviôse V (4 feb 1797), "à son de trompe ou de caisse dans chaque commune des départemens réunis" [LA V en FA nr.291: bijgevoegd instructieve noten]

\section{III prairial 16 (1795 jun 4$)$}

BL Ie ser no.153 (896); LA I fol 177ro-179vo; drukw FA nr.30; rH V 126-128; P VI 519-520; cB IIle ser XXX 109-110

\section{LOI CONTENANT DES MESURES RÉPRESSIVES dE TOUS PILLAGES DE GRAINS, FARI- NES OU SUBSISTANCES}

Gemeenten dienen de plundering van koren, meel en levensmiddelen door het uiteenjagen van samenscholingen van plunderaars te voorkomen. Heeft een gemeente dit nagelaten, dan worden alle inwoners van die gemeente gelijkelijk verantwoordelijk gehouden voor de geleden schade en dienen zij te zorgen voor de restitutie van de geplunderde goederen, alsmede het betalen van een schadevergoeding aan de eigenaren en een boete aan de Republiek. Granen, meel en levensmiddelen dienen binnen drie dagen in natura te worden gerestitueerd. Wanneer er geen restitutie plaatsvindt, worden de twaalf hoogstaangeslagenen in de gemeente gedwongen tegen het dubbele van de prijs de geleden schade te vergoeden. De delinquenten worden bovendien verplicht een boete aan de Republiek te voldoen. In geval van insolventie van verdachten van plundering zijn alle inwoners gelijkelijk verantwoordelijk voor de restitutie van het geplunderde. Een municipaliteit die niet binnen 24 uur de plegers, aan- 
stichters of medeplichtigen van de plundering aanwijst, wordt veroordeeld tot het voldoen van een boete aan de staat die ten minste de dubbele waarde van de geplunderde goederen bedraagt.

bo. Convention nationale

vs. S.E. Monnel

cols. Merlin (de Douai) (ex-pres); Bailly (secr); Balmain (ex-secr)

ti. conseil de gowvernement; gouvemementscommissaris Bouteville

RO nr. 26 (1) en $89(34) ; 27$ brumaire IV (18 nov 1795) en 16 nivôse IV (6 jan 1796)

RE nr.19 en 136: 28 brumaire IV (19 nov 1795) en 14/15 floréal IV ( $3 / 4$ mei 1796)

- afkondiging: besluit volksrepresentanten s. J. le Febvre (de Nantes), Giroust, cs. J. Torfs (secrprov); 21 vendémiaire IV ( 13 okt 1795 ); besluit volksrepresentanten/gouvernementscommissarissen s. Pérès, Portiez (de l'Oise); 24 frimaire IV (15 dec 1795)

\section{III prairial 17 (1795 jun 5)}

BL le ser no.153 (897); LA I foll 179vo-180ro; drukw FA nr.30; rH V I28; P VI 520; cB IIle ser $\mathrm{XXX} \mid 10-111$

\section{LOI AdDitionNelle À Celle du 16 PRAirial, sur les pillages des gRains, FARINES ET SUBSISTANCES}

De daders, aanstichters en medeplichtigen van plunderingen worden bestraft met één jaar gevangenisstraf in het geval er geen sprake is van een gewapende samenscholing. Is dit laatste wel het geval, dan krijgt men de doodstraf.

bo. Convention nationale

ao. comité de salut public

ws. J.M. Hubert

cols. Bréard (ex-pres); Bailly, Marragon (secr)

ti. conseil de gouvermement; gouvemementscommissaris Bouteville

RO nr.26(2) en 89(35): 27 brumaire IV (18 nov 1795) en 16 nivôse IV (6 jan 1796)

RE nr.19 en 136: 28 brumaire IV (19 nov 1795) en 14/1.5 floréal IV (3/4 mei 1796)

- verwijzing naar: decreet van 16 prairial III (4 jun 1795)

- afkondiging: besluit volksrepresentanten s. J. le Febvre (de Nantes), Giroust, cs. J. Torfs (secrprov); 21 vendémiaire IV (13 okt 1795); besluit volksrepresentanten/gouvernementscommissarissen s. Pérès, Portiez (de l'Oise); 24 frimaire IV (15 dec 1795)

\section{III prairial 18 (1795 jun 6)}

BL le ser no.154 (902); LA IV fol 128ro; drukw FA nr.111; rH X 101; P VI 521; cB IIIe ser XXX $119-120$

LOI PORTANT QUE CELLES SUR LES PÈRES ET MÈRES D'ÉMIGRÉS NE SONT POINT APPLICABLES AUX PÈrES ET MÈRES D'ENFANS NÉS HORS MARIAGE

De wetten aangaande de ouders van uitgewekenen zijn niet van toepassing op de ouders van buitenechtelijk geboren kinderen. 
bo. Convention nationale

ao. comité de légisilation

vs. S.E. Monnel

cols. Vermier (ex-pres); Sänt-Martin, Valogne, Marragon (secr)

RO nr.210(12): 23 vendémiaire $V(14$ okt 1796$)$

- afkondiging: besluit Directoire exécutif s. L.M. Revellière-Lépeaux (pres), Lagarde (secr-gen); 10 fructidor IV (27 aug 1796)

\section{III prairial 18 (1795 jun 6)}

BL Ie ser no. 153 (899); LA IV foll 128 vo; drukw FA nr. 11 ; rH X 102; P VI 521; cB IIIe ser XXX $118-119$

LOI PORTANT QUE LES DISPOSITIONS DE L'ARRÊTÉ DU COMITÉ DE LÉGISLATION, DU 12 FLORÉAL, SUR LES BAUX DES BIENS DES DÉTENUS, ETC., SONT APPLICABLES $\grave{A}$ CEUX des BIENS des PRÉVENUS D'ÉMIGRATION ET RÉINTÉGRÉS, ETC.

Het besluit van het comité de législation van 12 floréal III (1 mei 1795) ter zake van de verpachtingen van de goederen van vrijgelaten gevangenen en vrijgesproken beschuldigden is in zijn geheel van toepassing op de verpachtingen van goederen van hen die verdacht worden van emigratie en die door de definitieve doorhaling op de lijst van uitgewekenen in het bezit van hun goederen zijn hersteld. Eveneens is dit besluit van toepassing op de verpachting van de goederen van hen die krachtens veroordeling een vrijheidsstraf hebben ondergaan.

bo. Convention nationale

ao. comiré dé législation

vs. S.E. Monnel

cols. Vernier (ex-pres); Saint-Martin, Valogne, Marragon (secr)

RO nr.210(13): 23 vendémiaire $V$ (14 okt 1796)

- cB vermeldt ook de streklking van het besluit van het comiré de législation

- afkondiging: besluit Directoire exécutif s. L.M. Revellière-Lépeaux (pres), Lagarde (secr-gen); 10 fructidor IV (27 aug. 1796)

\section{III prairial 21 (1795 jun 9)}

BL le ser no.154 (908); LA IV fol 128vo-132ro; drukw FA nr.111; rH X 102-108; P VI 523-525; cB IITe ser XXX 124-128

\section{LOI QUI DÉTERMINE LE MODE DE RESTITUTION DES BIENS DES CONDAMNTSS}

De verbeurdverklaringen van goederen sinds 10 maart 1793 uitgesproken door revolutionaire, militaire of volksrechtbanken en door gewone rechtbanken, revolutionair vonnissend, tot de installatie van het gereorganiseerde revolutionaire tribunaal, ingevolge de wet van 8 nivôse IIII ( 28 dec 1794), worden als niet-bestaande beschouwd. De inbeslagnemingen worden opgeheven; de nabestaande echtgenoten en de erfgenamen krijgen wederom het genot van de goederen. Niettemin blijven een aantal confiscaties gehandhaafd, waaronder die van de goederen, rechten en vorderingen van de voormalige Franse koninklijke familie, die van degenen die buiten de wet geplaatst 
zijn vanwege de samenzwering van 9 thermidor II (27 jul 1794) [val van Robespierre c.s.] en de vonnissen van verbeurdverklaringen uitgesproken na 8 nivôse III (28 de 1794) enzovoorts. De wet regelt voorts de modaliteiten van de restitutie aan de onderscheidene rechthebbenden. De terugbetaling door de Republiek geschiedt in bons aan toonder, welke uitsluitend toelaatbaar zijn als betaling voor de goederen van uitgewekenen.

bo. Comvention mationale

ao. comité de législation

vs. S.E. Monnel

cols. Cambacérès (ex-pres); Marragon, Bailly (secr)

RO nr.210(14): 23 wendémiaire $V(14$ okt 1796)

- verwijzing naar: wetten van 16 sep 1791 "et autres interprétatives ou additionnelles"; "lois précédentes"; 10 mrt 1793; 23 frìmaire III ( $\$ 3$ dec 1794); 8 nivôse III (28 dec 1794); decreten van 30 ventôse III (20 mrt 1795); 14 floréal III (3 meil 1795)

- $\mathrm{cB}$ vermeldt als datum van uitvaardiging 18 prairial III ( 6 jun 1795)

- afkondiging: besluit Directoire exéc(utif s. L.M. Revellière-Lépeaux (pres), Lagarde (secr-gen); 10 fructidior IV (27 aug 1796)

\section{III prairial 22 (1795 jun 10)}

BL le ser no.155 (912); LA I fol 147vo-150vo; FA nr.291; rH V 207-209; cB IIle ser XXX $154-156$

LOI QUI ETEND AUX INDIVIDUS QUi, PAR SUITE DES ÉVÉNEMENS DES 31 MAI, $1^{\text {FR }}$ ET 2 JUIN AURAIENT DISPARU POUR SE SOUSTRAIRE À L'OPPRESSION, LES DISPOSITIONS DE CELLE DU 22 GERMINAL DERNIER

Uitgewekenen die als gevolg van de gebeurtenissen van 31 mei tot 2 juni 1793 [te Parijs: val van de Girondijnen] er onder meer van beschuldigd waren aanhanger van het federalisme te zijn, genieten alsnog de voorrechten van de wet van 22 germinal III (11 apr 1795). Zij zullen op de lijst van uitgewekenen worden doorgehaald, wanneer zij erop vermeld stonden na de datum van 31 mei 1793 en kunnen aantonen dat er een vervolging tegen hen was ingesteld. Binnen de termijn van vijf decaden dient men te hebben gereclameerd, anders wordt men als uitgewekene beschouwd.

bo. Convention nationale

ao. comité de législarion

vs. Enjubault:

cols. Bréard (ex-pres); Bailly, Marragon (secr)

ti. conseil de gownernomem

RO nr.21(6): 26 brumaire IV (17 now 1795$)$

RE nr.29: I frimaire IV (22 nov 1795$)$

- verwijzing naar: decreet van 23 ventôse 11 (13 mrt 1794); wetten van 25 brumaire III (15 nov 1794); 22 germinal 11I (11 apr 1795); "lois générales sur l'émigration"

- cB-intitulk: "décret portant que les individus qui par suite ou a l"occasion des évènemens des 31 mai, premier et 2 juin, auront été obligés de fuir ou de se cacher etc. jouitont du bénéfice de la loi du 22 germinal demier, relative a ceux qui par suite ou à l'occasion des mêmes évènemens avoient êté mis hors la loi"

- afkondiging: besluif volksrepresentanten s. Pérès, Portiez (de l'Oise) 8 brumaire IV (30 okt 1795) 


\section{HI prairial 23 (1795 jun 11)}

BL le ser no.156 (915); LA V fol 95wo; FA nr.291; rH X 285; P VI 525-527; cB IIIe ser XXX 170172

[extract] LOI QUI PRONONCE LA DÉCHÉANCE CONTRE TOUS CREANCIERS DE LA REPUBLIQUE, AUTRES QUE CEUX COMPRIS DANS LES EXCEPTIONS DETERMINEES, QUI N'ONT POINT ENCORE FORMÉ DE RÉCLAMATION (art.8)

De directeur de la liquidation gaat voort met het verwittigen per angetekende brief van de schuldeisers wier vorderingen afgehandeld zijn. Bedoelde schuldeisers dienen hem binnen zes maanden titels te overleggen, waaruit hun eigendomsrecht ter zake van het vereffende object blijkt. Voor het overleggen van de nodige stukken ten behoeve van de vereffeningen en ten aanzien van de echtheid van de schuldvorderingen, dan wel van een aanvullend bewijs van eigendom heeft men slechts drie maanden de tijd.

ba. Convertion nationale

vs. Enjubault

cols. Breard (ex-pres); Boursault. Gamon (secr)

RO nr.232(10): 1 nivôse $V(21$ dec 1796)

- cB-intitulé: "décret pour la production des titres de créance sur la république \& concernant les déchéances"

- afkondiging: besluit Directoine exécutif s. P. Barras (pres), Lagarde (secr-gen); 16 frimaire V (6 dec 1796); opmerking: dit artikel afgekondigd ter uitwoering van het bepaalde in art.19 van de wet van 15 fructidor IV (1 sep 1796), houdende de opheffing van de religieuze instellingen in het woormalige België

\section{III prairial 30 (1795 jun 18)}

BL le ser no. 157 (924); LA I fol 250vo-251vo; FA nr.291; drukw FA nr.30; rH V 331-332; P VI 533 ; cB llle ser XXX 215-216

[extract] LOI QUI ORDONNE LA DISTRIBUTION DES SECOURS PROMIS AUX HABITANS DES DÉPARTEMENS PACIFIÉS, ET DETERMINE LES PEINES À INFLIGER A TOUS LES INDIVIDUS QUI, APRÉS AVOIR PRÊTÉ SERMENT À LA RÉPUBLIQUE, AURAIENT CONSPIRE CONTRE ELLE (arti.2-9)

Degenen die gezworen hebben zich aan de wetten van de Republiek te zullen onderwerpen en desondanks toch samenzweren of gewapend optreden tegen de staat, worden vervolgd als opstandelingen. Verdachten worden voorgeleid aan de militaire rechtbank van een divisie, of - na de pacificatie van het gebied - aan de criminele rechtbank van het departement. De doodstraf wordt opgelegd aan de leiders, ronselaars en aanstichters van gewapende groepen Chouans of anderen. Plattelandsbewoners die in dergelijke groepen verzeild geraakt zijn en niet verdacht worden van moord gaan enige maanden naar de gevangenis en krijgen een zware boete opgelegd. De administratieve en militaire lichamen zijn belast met de uitvoering van deze wet; de volksrepresentanten zien op de naleving ervan toe. 
bó. Comvention nationale

ao. comite de salut public

"s. Enjubault

cols. Bréard (ex-pres); Marragon, Saint-Martin Valogne (secr)

ti. volksrepresentanten/gouvernementscommissarissen; gouvernementscommissaris Bouteville

RO ni. $47(3)$ en $89(45)$ : 9 frimaire IV (30 nov 1795); 16 nivôse IV (6 jan 1796)

RE nr.46 en 136: 14 frimaire IV ( 5 dec 1795 ); 14/15 floréal IV (3/4 mei 1796)

- drukw FA nr.30 vermeldt abusievelijk als datum van uitvaardiging 30 prairial IV (18 jun 1796)

- afkondiging; besluit volksrepresentanten s. Pérès, Portiez (de I"Oise); cs. Delcambe; 26 brumaire IV

(17 now 1795) en 24 frimaire IV (15 dec 1795)

\section{III messidor 4 (1795 jun 22)}

BL Ie ser no. 158 (927); drukw FA nr.30; rH VII 226-227; P VI 537; cB IIIe ser XXXI 19-20

\section{LOI QUI ATTRIBUE AUX TRIBUNAUX DE DÉPARTEMENT LA CONNOISSANCE IMMÉDI- ATE DES CRIMES DE MEURTRES ET D'ASSASSINATS COMMIS DEPUIS LE PREMIER SEPTEMBRE 1792}

De criminele rechtbanken in de departementen nemen onmiddellijk kennis van elke moord en elke doodslag, welke gepleegd is vanaf 1 september 1792. Daartoe dienen rechterlijke functionarissen die hieromtrent stukken onder zich hebben deze binnen acht dagen over te dragen aan de griffies van de rechtbanken. De behandeling van de zaken geschiedt overeenkomstig het bepaalde in de wet van 16 september 1791, voor zover de onderhavige daaraan niet derogeert. Rechters dienen de straffen genoemd in de code pénal uit te spreken. Van de vonnissen in deze categorie delicten uitgesproken is geen cassatie mogelijk, hetgeen in de akte van beschuldiging wordt vermeld. Door de openbare aanklagers wordt een afschrift van het vonnis aan het comité de législation gezonden, drie dagen na de uitspraak.

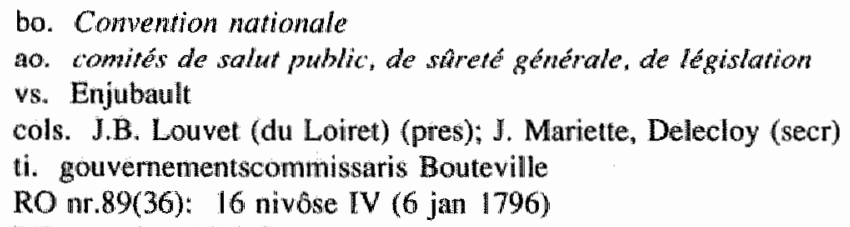

- afkondiging: besluit volksrepresentanten/gouvemementscommissarissen s. Pérè̀s, Portiez (de l'Oise); 24 frimaire IV (15 dec 1795)

\section{III messidor 9 (1795 jun 27)}

BL le ser no.164 (963); drukw FA nr.112; rH IX 179-238; P VI 540-562; cB IIIe ser XXXI 71-114

\section{LOI CONCERNANT LE CODE HYPOTHÉCAIRE}

De code behelst de modaliteiten inzake het vestigen van hypotheken. Naast de hypothecaire beginselen worden de vestiging en het tenietgaan van hypotheken, de rechten 
en verplichtingen van de onderscheidene betrokkenen, de inschrijving in het hypo theekregister, het kantoor van de hypotheekbewaarder, de vrijwillige of gerechtelijke onteigening wegens insolventie en de inschrijvingen hierop, de afschaffing van de oude costumen betreffende hypotheken en de tarieflijst van de hypotheekbewaarder hierin omschreven. Vanaf 1 ventôse IV *) (20 feb 1796) geldt het nieuwe hypotheekregime.

\section{bo. Convention nationale}

ao. comités de salut public, des finances et de législation, rếunis

vs. Enjubault

cols. Doulcet (pres); Villar, Sallengros (secr)

ti. minister van justitie Génissieu

RO nr.115: 6 germinal IV (26 mrt 1796)

RE nr.164: $26 / 27$ thermidor IV (13/14 aug 1796); tweetalig

- verwijzing naar: edict van juni 1771 ; verklaring van 24 nov 1771

- *) moet zijn 1 nivôse IV (22 dec 1795) [BL le ser no.198 (1189): loi qui ordonne une rectification dans celle du 9 messidor, relative au code hypothécaire]

- afkondiging: besluit Directoire exécutif $\mathrm{s}$. Le Toumeur (pres), Lagarde (secr-gen); 2 ventôse IV (21 feb 1796); met dien verstande dat de code hypothécaire in de negen Verenigde Departementen van kracht wordt op 1 floréal IV (20 apr 1796)

\section{III messidor 9 (1795 jun 27)}

BL Ie ser no. 164 (963); drukw FA nr. 112; rH IX 239-249; P VI 562-567; cB IIle ser XXXI I 14-122

\section{LOI SUR LES DÉCLARATIONS FONCIÈRES}

De aangiftes van grondeigendom in de gevallen voorgeschreven in de code hypothécaire moeten worden gedaan door de eigenaar of diens gemachtigde. De nationale domeingoederen worden aangegeven door ambtenaren der registratie, die van gemeentelijke grondeigendom door een gemeenteambtenaar of door de leden van de conseil général. Wegen, wateren en overige publieke eigendommen moeten door de nationale agent ter plaatse worden aangegeven. De aangifte dient aan zekere in- en uitwendige vormvereisten - o.a. de exacte omschrijving van ligging en grootte van de percelen - te voldoen en onder meer te worden gedeponeerd ten kantore van de hypotheekbewaarder. Inzage van de aangifte is mogelijk. Als aanhangsel bij de wet is het formulier van de declaration foncière gevoegd.

bo. Convention nationale

ao. comitếs de salut public, des finances et de légisiation réunis

vs. Enjubault

cols. Lanjuinais (ex-pres); Villar, J.T.L. Lemoine (du Calvados) (secr)

ti. minister van justitie Génissieu

RO nr. III5: 6 germinal IV (26 mrt 1796)

RE nr.164: $26 / 27$ thermidor IV (13/14 aug 1796); tweetalig

- verwijzing naar: decreet van 7 feb 1791; code byporhécaire van 9 messidor III (27 jun 1795)

- afkondiging: besluit Dinectoire exéc wtif s. Le Toumeur (pres), Lagarde (secr-gen); 2 ventôse IV (2l

feb 1796); met dien verstande dat deze wet van kracht wordt op 1. floréal IV (20 apr 1796) 


\section{LOI QUI SUSPEND LA VENTE DES BIENS DES ECCLÉSIASTIQUES RECLUS, DÉPORTÉS OU SUJETS A LA DEEPORTATION}

In verband met drie ontwerp-decreten van het comité de législation decreteert de Convention nationale tot verdaging van de beraadslaging over het eerste voorstel met drie dagen en de opschorting van de verkoping van de goederen van in afzondering gehouden, gedeporteerde of aan deportatie onderworpen geestelijken en voorts tot de verdaging van de beide andere voorstellen tot de aanvaarding van een nieuw voorgestelde grondwet.

\section{bo. Convention nationale \\ ao. comité de légistation \\ vs. Enjubault}

cols. J.B. Louvet (pres); J. Mariette, Delecloy (secr)

ti. departement van de Dijle

RO nr. $113(\| 1) ; 6$ germinal IV (26 mrt 1796$)$

RE nr. 118: 9/10 germinal IV (29/30 mrt 1796)

- verwijzing naar: grondwet [van 5 fructidor III (22 aug 1795)]

- Code Merlin vermeldt abusievelijk als datum van uitvaardiging 13 messidor II (1 jul 1794)

- afkondiging: besluit volksrepresentanten/gouvernementscommissarissen s. Pérès, Portiez (de l'Oise);

29 frimaire IV (20 dec 1795 )

\section{III messidor 20 (1795 jul 8)}

BL. le ser no.161 (941); drukw FA nr.30; rH VIl 230-232; P VI 572-573; cB Ille ser XXXI 169-170

\section{LOI QUI ORDONNE L'ÉTABLISSEMENT DES GARDES CHAMPE'TRES DANS TOUTES LES COMMUNES RURALES DE LA RÉPUBLIQUE}

In alle plattelandsgemeenten dienen veldwachters te worden aangesteld. Deze worden gekozen uit loyale burgers en benoemd door de districtsbesturen op voordracht van de conseils généraux der gemeenten. Elke gemeente heeft minstens één veldwachter. Grondeigenaren hebben het recht voor hun domeinen een veldwachter aan te stellen. Het toezicht op het platteland wordt voorlopig door de vrederechters uitgeoefend en zij vellen ter zake van overtredingen vonnissen. Het behoud van de oogst is onder het toezicht van alle goede burgers geplaatst, te dien einde wordt langs de hoofdweg van elke gemeente een bord geplaatst met de tekst: "Citoyen, respecte les propriétés et les productions d"autrui; elles sont le fruit de son travail et de son industrie"

bo. Convention nationale

ao. comité d'agriculnure et des arts

vs. Enjubault

cols. Doulcet (ex-pres); Villar, Sallengrot (secr)

ti. gouvemementscommissaris Bouteville

RO nr.89(2) en 89(41): "6 nivôse IV (6 jan 1796)

RE nr.136: 14/15 floreal IV (3/4 mei 1796) 
- werwijzing naar; wet van 28 sep 1791; titel II van deze wet moet opnieuw worden gedrukt en in alle gemeenten worden aangeplakt

- deze wet in aanwezigheid van het volk door municipale ambtenaren voorgelezen

- afkondiging: besluit volksrepresentanten/gouvernementscommissarissen \$. Péres, Portiez (de l'Oise);

24 frimaire IV (15 dec 1795)

\section{III messidor 23 (1795 jul 11)}

BL Ie ser no. 162 (947); LA I fol 155vo-157vo; FA nr.291; rH V 215-216; P VI 574; cB IIle ser XXXI $176-177$

LOI QUI ORDONNE AUX ÉTRANGERS NÉS DANS LES PAYS AVEC LESQUELS LA RËPUBLIQUE EST EN GUERRE, DE SORTIR DE FRANCE, S'ILS N'Y SONT DOMICILIÉS AVANT LE PREMIER JANVIER 1792

Vreemdelingen geboortig uit landen waarmee Frankrijk in oorlog is en die na 1 januari 1792 naar Frankrijk zijn gekomen, dienen drie dagen na bekendmaking van deze wet het land te verlaten onder opgave van de reisroute vermeld in hun paspoort. Bij afwijken van de reisroute wordt men gearresteerd. Buitenlanders uit neutrale of geallieerde landen moeten ook vertrekken, wanneer zij niet door hun ambassadeur worden erkend. Vreemdelingen uit met in Frankrijk in oorlog zijnde landen mogen blijven, wanneer zij er vóór 1 januari 1792 woonden en van hun integriteit hebben blijk gegeven. Elke buitenlander krijgt een identiteitskaart. Buitenlanders die in een zeehaven of een grensgemeente arriveren, dienen zich te melden bij de municipaliteit en daar vooralsnog te verblijven. De conseils généraux kunnen evenwel een voorlopige machtiging geven tot verder reizen aan handelaren afkomstig uit geallicerde of neutrale landen.

bo. Convention nationale

ao. comités de salut public, de sûreté générale

vs. Lehault

cols. Lanjuinais (ex-pres); Villar, Sallengrot (secr)

ti. conseil de gouvermement

RO nr.2 I(10): 26 brumaire IV (17 nov 1795)

RE nr.29: 1 frimaire IV (22 nov 1795)

- plaatsing in het Bulletin strekt tot bekendmaking

- afkondiging: besluit volksrepresentanten/gouvernementscommissarissen s. Pérès, Portiez. (de l'Oise); 8 brumaire IV (30 okt 1795)

\section{III thermidor 15 (1795 aug 2)}

BL Ie ser no. 169 (992); LA I fol 157vo-158ro; rH V 217; P VI 595; cB Hlle ser XXXII 88

LOI PORTANT DES PEINES CONTRE TOUT ETRANGER QUI NE SE SERAIT POINT CONFORMÉ A CELLE DU 23 MESSIDOR, ET CEUX QUI EN AURAIENT RECELE

Iedere buitenlander die zich niet houdt aan de bepalingen van de wet van 23 messidor III (11 jul 1795) wordt beschouwd als spion en dienovereenkomstig vervolgd. Burgers 
die schuldig bevonden worden van het verbergen van die buitenlanders zullen met zes maanden gevangenisstraf worden bestraft.

bo. Convention nationale

ao. comité de sureté gếnếrale

ws. Enjubault

cols. Daunou (pres); G.F. Dentzel, Laurenceot (secr)

ti. consell de gowernement

RO nr.21(11): 26 brumaire IV (17 nov 1795$)$

RE nr.29: 1 frimaire IV (22 now 1795)

- RO spreekt van de wet van 25 messidor III (13 jul 1795)

- afkondiging: besluit volksrepresentanten/gouwernementscommissarissen s. Pérès "Portiez (de I"Oise);

8 brumaire IV ( 30 okt 1795)

\section{III fructidor 1 (1795 aug 18)}

BL Je ser no.171 (1026); LA. I fol 150vo-153ro; FA nr.291; rH V 210-212; P VI 608; cB IIIe ser XXXIII $4-6$

\section{LOI RELATIVE AUX INDIVIDUS QUI, PORTÉS SUR LA LISTE DES ÉMIGRÉ, N'ONT POINT ENCORE OBTENU LEUR RADIATION DEFINITIVE}

Een ieder die op de lijst van uitgewekenen vermeld staat en binnen de vastgestelde termijn in beroep is gegaan, maar nog geen definitieve doorhaling van de lijst heeft verkregen, dient zich naar de gemeente waar hij onmiddellijk voorafgaande aan zijn inschrijving gevestigd was te begeven en moet daar onder toezicht van de municipaliteit verblijven. Degenen die in Parijs vertoeven moeten de stad verlaten. Niemand die op de lijst van uitgewekenen staat, mag zich naar Parijs begeven om zijn zaak bij de autoriteiten aldaar te bepleiten. Wanneer men hiermee in strijd handelt, riskeert men ten minste zes maanden gevangenisstraf, ook als men binnen het verstrijken van de tijd van de lijst wordt afgevoerd.

bo. Convention nationale

ao. comités de salut public, de süreté générale, de législation

Ws. Enjubault

colls. Daunou (ex-pres); Garrou, Poisson (secr)

ti. conseil de gouvernoment

RO nr.21(7): 26 brumaire IV (17 now 1795$)$

RE nr.29: 1 frimaire IV (22 nov 1795)

- plaatsing in het bulletin strekt tot bekendmaking

- afkondiging: besluit volksrepresentanten/gouvemementscommissarissen s. Pérès, Portiez (de l"Oise);

8 brumaire IV (30 okt 1795 )

\section{III fructidor 3 (1795 aug 20)}

BL le ser no.174 (1043); drukw FA nr.30; rH VII 232-233; P VI 611-612; cB IIIe ser XXXIII 16

LOI QUI PRONONCE DES PEINES CONTRE TOUT DÉPOSITAIRE QUI, AYANT DISPOSË́ D'UN DEPÔT, NE LE RETABLIRAIT EN EFFETS DE LA MÊME NATURE 
Tedere depositaris die in bewaring gegeven goederen onder zich heeft, is gehouden deze in dezelfde hoedanigheid en tegen dezelfde waarde terug te geven. Indien de bewaarnemer in gebreke blijft, wordt deze veroordeeld tot een geldbedrag overeenkomstig het vervangingsbedrag van de goederen, alsmede tot een boete, de ene helf ten voordele van de staat, de andere ten voordele van de eligenaar van het in bewaring gegevene. Hiervan uitgezonderd zijn de publieke depositarissen die ingevolge de wet van 11 april 1793 het in bewaring gegevene in de nationale schatkist hebben gestort.

bo. Convention nationale

ao. comités de législation et des finances, réunis

vs. Enjubault

cols. Marie-Joseph Chênier (pres); Soulignac, Derazet (secr)

ti. gouvernementscommissaris Bouteville

RO nr.89(42): 16 nivôse IV (6 jan 1796)

RE nr.136: 14/15 floréal IV (3/4 mei 1796)

- verwijzing naar: wetten van 11 apr 1793; 13 thermidor III (31 jul 1795)

- RO vermeldt abusievelijk als datum van uitvaardiging 20 messidor III (8 jull 1795)

- afkondiging: besluit volksrepresentanten/gouvernementscommissarissen s. Pérès, Portiez (de l"Oise);

24 frimaire IV (15 dec 1795 )

\section{III fructidor 5 (1795 aug 22)}

LA I fol 9ro-65vo; drukw FA nr.41, drukw FA nr.43; rH V 65-107; P VII I-20; cB IIIe ser XXXII $31-176$

\section{CONSTITUTION DE LA RÉPUBLIQUE FRANCAISE}

De grondwet wordt voorafgegaan door de Déclaration des Droits et des Devoirs de l'Homme et du Citoyen. De 377 artikelen tellende grondwet is in veertien titels onderverdeeld, namelijk: indeling van het grondgebied; politieke staat der burgers; assemblées primaires; assemblées électorales; wetgevende macht; uitvoerende macht; administratieve en gemeentelijke lichamen; rechterlijke macht; van de gewapende macht; openbaar onderwijs; financiën; buitenlandse betrekkingen; herziening van de grondwet; algemene bepalingen.

bo. Franse wolk

ao. Convention nationale

ws. Lehault, Enjubault:

cols. M.J. Chénier (pres); Derusey, Soulignac, Bernier, Laurenceot, Dentzel, Quirot (secr)

ti. conseil du gouvernemem des représentans du peuple

RO nr.4: 18 vendémiaire IV (10 okt 1795)

RE nr.4: 25 vendémiaire IV (17 okt 1795)

- afkondiging: besluit volksrepresentanten bij het Noorder-en Sambre-en-Maasleger s. Giroust, es. Delcambe; 14 vendémiaire IV $(6$ okt 1795); in de geleidebrief van de conseil du gowvernement des représentans du peuple wordl de arrondissementsadministratie te Maastricht opgedragen om bij de opsomming van de. Franse departementen in tit.l art. 3 van de grondwet de negen Belgische departementen toe te voegen; voorts zal spoedig een Vlaamse vertaling worden toegezonden IFA nr.228; FA nr. 279 "correspondance particulier $n^{\mathrm{g}} \|^{\mathrm{m}} \mathrm{j}$; de arrondissementsadministratie dient de constitutie dadelijk te herdrukken en bekend te maken in de gemeenten 


\title{
III fructidor 7 (1795 aug 24)
}

BL le ser no.174 (1048); LA III fol 36ro-37ro; FA nir.237; rH VI 247-248; P VII 23 ; cB IIle ser XXXIII $83-84$

\section{LOI PORTANT QU'EN MATIERE CIVILE LES TÉMOINS SERONT ENTENDUS PUBLIQUE- MENT DANS LES TRIBUNAUX DE DISTRICT}

Voortaan zullen in alle burgerlijke zaken die tot de competentie van de districtsrechtbanken behoren, de getuigen in het openbaar en in aanwezigheid van de belanghebbende partijen worden gehoord. De griffier houdt notitie van hun namen, leeftijd, hoedanigheid en woonplaats, alsmede de door hen afgelegde eed en getuigenis. Dadelijk na het horen wordt, indien mogelijk, gevonnist.

\author{
bo. Connention nationale \\ ao. comité de légisiation \\ vs. Enjubault \\ cols. Marie-Joseph Chénier (pres); Derazey, Soulignac (secr)
}

RO nr.96(1): 11 pluviôse IV (31 jan 1796)

- verwijzing naar: wet van 3 brumaire II (24 okt 1793)

- wet uitgevaardigd n.a.v. een verzoekschrift van Philippe-Martin Thomas en zijn vrouw MarieMarguerite Leroy en een zekere Lucas en Cocagne aangaande de validiteit van een tegen hen uitgesproken wonnis door de districtsrechtbank te Goumay [departement Seine-Inférieure] tijdens een openbaar getuigenverhoor

- cB-intitulé: "décret relatif à une pétition de Philippe-Martin 'Thomas et Marie-Marguerite Leroy, sa femme, portant qu'à l'avenir en toutes matières civilles dont la connoissance appartient aux tribunaux. civils et sans aucune distinction, les témoins seront entendus a l'audience publique"

- afkondiging: besluit volksrepresentanten/gouvernementscommissarissen s. Pérès, Portiez (de l"Oise); 28 frimaire IV ( 19 dec 1795 )

\section{III fructidor 9 (1795 aug 26)}

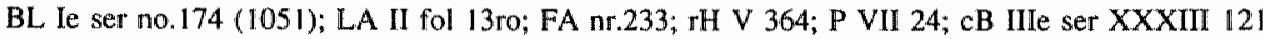

LOI PORTANT QUE LES DISPOSITIONS DE CELles DES 5 BRUMAIRE ET 17 NIVÓSE, SUR LES SUCCESSIONS, N'AURONT D'EFFET QUE DU JOUR DE LEUR PROMULGATION

De wetten betreffende diverse wijzen van overgang van goederen binnen de familie hebben eerst dan werking vanaf het tijdstip van hun promulgatie.

bo. Comvention nationale

ao. comite de législation

vs. Enjubault

cols. Lanjuinais (ex-pres); Soulignac, Derazey (secr)

ti. volksrepresentanten/gouvernementscommissarissen

RO nr.67(3): 25 frimaire IV (16 dec 1795)

RE nr.62: $13 / 14$ nivôse IV (3/4 jan: 1796)

- verwijzing naar: wetten van 5 brumaire II (26 okt 1793); 17 nivôse II (6 jan 1794)

- afkondiging: besluit volksrepresentanten s. Pérès, Portiez (de l'Oise); 28 brumaire IV (19 nov 1795) 


\section{III fructidor 13 (1795 aug 30$)$}

LA I fol 180ro-182vo; rH V 129-131; P VII v; Aulard XXVII 7-8 no.24

\section{ARRETÉ SUR LES ACHATS ET LA POLICE DE GRAINS}

De ambtenaren van de commissie ter bevoorrading van het leger hebben de bevoegdheid om graan voor het leger aan te kopen buiten de bestaande markten om. Het districtsbestuur, alwaar deze beambten hun taak uitoefenen, moet hiervan op de hoogte zijn gesteld. Municipaliteiten dienen de aangekochte hoeveelheden te noteren. Voor het overige mag niemand graan kopen buiten de markt om. Indien er geen juiste geleidecertificaten kunnen worden getoond, mogen de bevoegde autoriteiten de partijen graan in beslag nemen. De besturen dienen dit besluit bekend te maken en aan te plakken ten verzoeke van de procureurs-syndics, op straffe van afzetting.

bo. comité de salut public

ao. commission des approwisionnemens

s. (à la minute) Merlin (de Douai), Doulcet, Henry-Larivière, Rabaut, Marec

ti. conseil de gonvernement

RO nr.26(3): 27 brumaire IV (18 now 1795)

RE nr. 19: 28 brumaire IV (19 nov 1795)

- verwijzing naar: wet van 4 thermidor III ( 22 jul 1795)

- afkondiging: besluit volksrepresentanten s. J. le Febvre (de Nantes), Giroust; cs. J.Torfs (secr-prov);

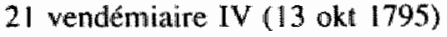

\section{III fructidor 14 (1795 aug 31)}

BL le ser no. 175 (1061); LA II fol 214vo-215ro; FA nr.291; rH V 227; P VII 31; cB IIIe ser XXXIII 160

LOI QUI ABOLIT L'ACTION EN RESCISION DES CONTRATS DE VENTE OU GQUIPOLLANT À VENTE ENTRE MAJEURS POUR CAUSE dE LÉSION d'OUTRE-MOITIÉ

De vordering tot vernietiging van koopovereenkomsten, gesloten tussen meerderjarige personen, dan well contracten gelijkwaardig hiemee, wegens benadeling voor de ene partij voor meer dan de helft (lésion d'outre-moitié) is afgeschaft. ledere vordering en elk rechtsgeding ter zake blijft voorlopig geschorst.

bo. Convention nationale

aco. comité de législation

vs. Enjubault

cols. Bréard (ex-pres); Gourdan, Poisson (secr)

ti. conseil de gowernement

RO nr.35: 5 frimaire IV (26 nov 1795)

RE nr.36: 13 frimaire IV (4 dec 1795)

- plaatsing in het bulletin de correspondance strekt tot bekendmaking

- afkondiging: besluit wolksrepresentanten s. Giroust; $\mathrm{CS}_{\text {. }}$ J. Torfs (secr-prow); 19 vendémiaire IV (11 okt 1795) 


\section{III fructidor 14 (1795 aug 31)}

BL le ser no.175 (1060); LA III fol 88vo-90ro; FA nr.291; rH VII 381-383; P VII 29-31; cB IIIe ser XXXIII $151-153$

\section{LOI QUI MODIFIE PLUSIEURS DISPOSITIONS DE CELLE DU 4 GERMINAL AN DEUXIEME, RELATIVE AUX DOUANES}

Diverse bepalingen in titel VI van de wet van 4 germinal II ( 24 maart 1794) worden door de onderhavige wet vervangen; bepalingen hiermee strijdig zijn herroepen. Het betreft hoofdzakelijk de procedure bij het vredegerecht in het geval van inbeslagneming van handelswaar door of het niet-betalen van de verschuldigde in- en uitvoerrechten aan de douane, alsmede de verbeurdverklaring van de in beslag genomen goederen.

\section{bo. Convention nationale}

ao. comité de commerce

ws. Enjubault

cols. L.M. Revelliêre-Lépeaux (ex-pres); Soulignac, Quirot (secr)

RO nr. 127(2): 5 floréal IV (24 apr 1796); in indicateur général ingeschreven onder 6 floréal IV (25 apr 1796)

- verwijzing naar: wet van 4 germinal II (24 mrt 1794)

- afkondiging: besluit Directoire exécutif s. Le Toumeur (pres), Lagarde (secr-gen); 23 germinal IV (12 apr 1796)

\section{III fructidor 16 (1795 sep 2)}

BL Ie ser no.175 (1064); LA II fol 117vo-118ro; FA nr.234; rH VI 116; P VII 33; cB IIIe ser XXXIII 175

\section{LOI QUI DÉFEND AUX TRIBUNAUX DE CONNAÎTRE DES ACTES D'ADMINISTRATION, ET ANNULLE TOUTES PROCÉDURES ET JUGEMENS INTERVENUS À CET ÉGARD}

Alle gerechtelijke procedures en door rechtbanken gewezen vonnissen tegen leden van bestuurslichamen inzake reclamaties betreffende in beslag genomen voorwerpen, andere bestuurshandelingen ter uitvoering van wetten en besluiten van uitgezonden volksrepresentanten, alsmede inzake de terugvordering van in de schatkist gestorte geldbedragen, zijn vernietigd. Rechtbanken is het eveneens verboden kennis te nemen van overige bestuurshandelingen.

bo. Comention narionale

ao. camite des finances

vs. Enjubault

cols. Breard (ex-pres); Gourdan, Poisson (secr)

ti. volksfepresentanten/gouvernementscommissarissen

RO nr.84(19): 7 nivôse IV (28 dec 1795)

RE nr.72: $21 / 22$ nivôse IV (11/12 jan 1796)

- verwijzing naar: wet van 13 frimaire III ( 3 dec 1794); niet nader aangeduide wetten

- afkondiging: besluit volksrepresentanten s. Pérès, Portiez (de l'Oise); 19 frimaire IV (10 dec 1795) 
BL le ser no.176 (1072); LA I fol 153ro-154ro; FA nr.291; rH V 212-213; P Vil 43; cB llle ser XXXIII $199-200$

[extract] LOI QUI ORDONNE LE BANNISSEMENT À PERPÉTUITÉ DES PRÉTRES DÉPORTÉS ET RENTRÉS SUR LE TERRTTOIRE FRANÇAIS, ET PRONONCE DES PEINES CONTRE TOUS MINISTRES DES CULTES QUI NE SE CONFORMERAIT PAS AUX LOIS DE LA RÉPUBLIQUE (artt.1, 5)

De comités de gouvernement van de Convention nationale zijn belast om met alle ten dienste staande middelen de eerder uitgevaardigde wetten ter zake van gedeporteerde en teruggekeerde priesters te doen naleven. Zij worden voor altijd verbannen en bij terugkeer als uitgewekene behandeld. Vrederechters stellen een gerechtelijk onderzoek in tegen de bedienaren van de eredienst, die zich handelingen, onder meer in geschrifte, veroorloven tegen de wetten van de Republiek; zij worden dienovereenkomstig gestraft.

bo. Convertion nationale

ao. comirés de sûreté générale; de législation

vs. Enjubault

cols. Daunou (ex-pres); Garrou, Poisson (secr)

ti. conseil de gouvernement

RO nr.21(8): 26 brumaire IV (17 nov 1795)

RE nr.29: 1 frimaire IV (22 nov 1795)

- afkondiging: besluit volksrepresentanten/gouvernementscommissarissen s. Pérès, Portiez (de l'Oise);

8 brumaire IV (30 okt 1795)

\section{III fructidor $21(1795$ sep 7)}

BL le ser no.185 (1128); LA I fol 215vo-222ro, IV fol 23ro; FA nr.291; rH V 228-234, IX 270-271; P VII 44-46; cB IIIe ser XXXIII 209-214

LOI RELATIVE AUX FONCTIONS DES CORPS ADMINISTRATIFS ET MUNICIPAUX, EN EXÉCUTION DU TITRE VII DE L'ACTE CONSTITUTIONNEL

Bij de inrichting van de municipale besturen wordt onderscheid gemaakt tussen de municipaliteiten van gemeenten onder dan well boven de 5000 inwoners. In een gemeente met minder dan 5000 inwoners oefent de municipale agent toezicht uit op het bestuur in de gemeente; dit gaat buiten de werkzaamheden om waaraan hij deelneemt als bestuurder van de municipaliteit van het kanton. Kantonsmunicipaliteiten houden periodieke vergaderingen, die uitgeschreven worden door het departementale bestuur. De municipaliteiten van gemeenten met meer dan 20000 inwoners houden zitting minstens eens in de vijf dagen, eens in de tien dagen in de overige. De commissarissen van het Directoire exécutif bij de municipale en departementale besturen houden verblijf in de plaats waar door deze besturen zitting wordt gehouden. $\mathrm{Zij}$ assisteren bij alle beraadslagingen. Er kan geen enkele beslissing worden genomen, dan nadat zij zijn gehoord; zij zijn echter in geen geval stemgerechtigd. Er wordt beslist bij meerderheid van stemmen van de aanwezige leden, wanneer althans het 
quorum atanwezig is. Municipale besturen dienen kennis te nemen van de bestuurszaken, die voorheen door de nationale agenten bij de districten werden behartigd. De bezoldiging van de diverse bestuurders geschiedt [in de tegenwaarde in geld] van verschillende hoeveelheden tarwe. Niet alle bestuursfunctionarissen genieten een dergelijk tractement, daar de nationale schatkist dit niet toestaat. In geval van attributieconflicten tussen gerechtelijke en bestuurlijke autoriteiten, wordt de beslissing aan de minister opgedragen in overleg met het Corps législatif. Bestuurslichamen kunnen zich rechtstreeks tot het Corps législarif wenden. In overgangsbepalingen wordt onder meer aangegeven hoe de archieven moeten worden verdeeld: archieven de algemene administratie betreffende moeten worden overgedragen aan het departement. Verder zijn er nog regelingen inzake de kantonnale en municipale indeling. Opgeheven besturen dienen hun boekhouding over te dragen.

bo. Convention mationale

ao. commission des onze

vs. Enjubault

cols. Marie-Joseph Chénier (pres); Soulignac, Poisson (secr)

ti. conseil de gowernement

RO nr.36 en 196(1): 5 frimaire IV (26 now 1795) en 21 fructidor IV (7 sep 1796)

RE nr.37: 13 frimaire IV (4 dec 1795)

* verwijzing naar: grondwet van 5 fructidor III (22 aug 1795); wet van 17 messidor II (5 jul 1794); "lois aujourd"hui en vigueur"

- afkondiging: besluit volksrepresentanten s. Pérès, Portiez (de l"Oise); cs. Delcambe (secr); 14 brumaire IV (5 nov 1795); besluit Directoire exécuif s. L.M. Revellière-Lépeaux (pres), Lagarde (secr-gen); 11 fructidor IV (28 aug 1796); betreft de artt. 22-26

\section{III fructidor 22 (1795 sep 8 )}

BL Ie ser no. 178 (1084); LA III fol 64vo-65vo; rH VIII 23-24; P VII 47-48; cB IIIJ ser 219-220

\section{LOI QUI DÉTERMINE UN MODE POUR LA REMISE DES BIENS DES PRÈTRES DÉPORTÉS}

De decreten die gedeporteerde of in afzondering gehouden geestelijken, wegens het niet-afleggen van de eed, gelijkstellen met uitgewekenen, zijn wat betreft de verbeurdverklaring van hun goederen herroepen, tenzij de geestelijken vallen onder de termen van de wet van 21 prairial III ( 9 juni 1795) met betrekking tot de teruggave van goederen van veroordeelden. De goederen of de geldswaarde ervan worden ofwel teruggegeven aan de geestelijken die zich niet langer in de staat van deportatie, afzondering of mort civile [toestand van een persoon die van elke deelneming aan de burgerlijke rechten is verstoken ingevolge een gerechtelijke veroordeling ter zake van een misdrijf of ingevolge een verbanning] bevinden en hersteld zijn in hun burgerlijke rechten, ofwel aan hun vermoedelijke erfgenamen - in geval van de natuurlijke dood - wanneer zij levenslang gedeporteerd zijn of levenslang in afzondering worden gehouden. De restitutie geschiedt volgens de bepalingen van de wet van 21 prairial III. De bepalingen van de huidige wet gelden niet voor vroegere bisschoppen, pastoors, vicarissen enzovoorts dan wel hun erfgenamen, wanneer zij het grondgebied van de Republiek of de pays rểunis zonder daartoe te zijn geautoriseerd of gedwongen 
door enige maatregel van Franse autoriteiten, hebben verlaten. Bij terugkeer worden zij vervolgd als teruggekeerde uitgewekenen.

bo. Convention nationale

ao. comité de législation

vs. Lehault

cols. A.C. Thibaudeau (ex-pres); Garran, Derazey (secr)

ti. departement van de Dijle

RO nr.113(12): 6 germinal IV (26 mrt 1796)

RE nr.118: $9 / 10$ germinal IV (29/30 mrt 1796)

- verwijzing maar: wet van 21 prairial III ( 9 jun 1795)

- cB-intinalé: "décret concernant les biens des prêtres déportes"

- afkondiging: besluit volksrepresentanten/gouvernementscommissarissen s. Pérès, Portiez (de l'Oise);

29 frimaire IV (20 dec 1795)

\section{III fructidor 24 (1795 sep 10)}

BL Ie ser no.178 (1085); drukw FA nr.30; rH VIII 233; P VII 49; cB HIe ser XXXIII 231

[extract] LOI QUI DÉFEND À TOUS JUGES ET TRIBUNAUX DE CONNOÎTRE D'AUCUNE PLAINTE OU INSTANCE RELATIVE AUX RAPPORTS FAITS PAR LLS AGENS DE LA RÉPUBLIQUE AUX COMITÉS DE LA CONVENTION NATIONALE

De rapporten die ambtenaren van de Republiek naar de comitës van de Convention nationale zenden, moeten als vertrouwelijke stukken worden beschouwd, die niet bekend mogen worden aan de belanghebbende partijen. Mitsdien is het rechters en rechtbanken verboden kennis te nemen van klachten of gedingen met betrekking tot deze rapportages.

bo. Convention nationale

ao. comité de salut public

ws. Enjubault

cols. A.Dumont (ex-pres); Soulignac, Derazey (secr)

ti. gouvemementscommisaris Bouteville

RO nr. 89(43): 16 niwồse IV (6 jan 1796)

RE nr. 136: 14/15 floréal IV (3/4 mei 1796)

- wet uitgevaardigd n.a.v. de handelwijze van de vrederechter van de sectie Ouest (departement Seine)

- drukw FA vermeldt abusievelijk als datum van uitvaardiging 21 fructidor III (7 sep 1795)

- afkondiging: besluit volksrepresentanten/gouvernementscommissarissen s. Pérès, Portiez (de l"Oise); 24 frimaire IV (15 dec 1795)

\section{III fructidor 27 (1795 sep 13)}

LA I fol 182vo-183vo; rH V 131; FA nr.291; Aulard XXVII 368-369 no.9

ARRÊTÉ QUI ORDONNE LA CONFISCATION ET LA VENTE DES GRAINS SAISIS EN CONTRAVENTION À L'ARRÊTÉ DU 8 FRUCTIDOR 
Graan dat in overtreding met het besluit van het comité dé salut public van 8 fructidor III (25 aug 1795) uitgevoerd wordt naar de veroverde gebieden, wordt in beslag genomen en werkocht, evenals paarden en wagens. De ene helft van het geconfisqueerde is voor degenen die de goederen in beslag namen, de andere helft voor de gemeente alwaar de aanhouding plaatshad.

bo. comité de salut public

s. (à la minute) Cambacêrès (pres); Marec, Merlin (de Douai), Daunou, T. Berlier

ti. conseil de gouvernement

RO nr.26(4): 27 brumaire IV (18 nov 1795)

RE nr. 19: 28 brumaire IV (19 nov 1795)

- verwijzing naar: wet van 11 sep 1793; besluit van 8 fructidor III (25 aug 1795)

- afkondiging: besluit volksrepresentanten s. J. le Febvre (de Nantes), Giroust; cs. J. Torfs (secrprov); $2 \|$ vendémiaire IV (13 okt 1795)

\section{III fructidor 28 (1795 sep 14)}

LA If fol 183vo-184vo; rH V 132; Aulard XXVII 390-391 no.3

\section{ARRẾTÉ SUR L'APPROVISIONNEMENT DE LA COMMUNE DE PARIS}

Van een ieder en van elke autoriteit wordt geëist, onder hun persoonlijke verantwoordelijkheid, dat zij met alle mogelijke middelen het transport van koren en andere levensmiddelen naar Parijs en de magazijnen van het leger zullen vergemakkelijken. Onder geen enkel voorwendsel mogen deze transporten, die blijkens verklaring van de wagenvoerders of begeleiders bestemd zijn voor de bevoorrading van het leger, worden aangehouden.

bo. comitt de salut public

s. (à la minute) Cambacérès (pres); Marec, Le Tourneur (de la Manche), J. Boissy, T. Berlier, L.M. Revellière-Lépeaux, Henry la Rivière.

ti. conseil de gowvernement

RO nr.26(5): 27 brumaire IV (18 now 1795)

RE nr. 19: 28 brumaire IV (19 nov 1795)

- afkondiging: besluit volksrepresentanten s. J. le Febvre (de Nantes), Giroust; cs. J.Torfs (secr-prow); 21 vendémiaire IV (13 okt 1795)

\section{III fructidor 28 (1795 sep 14)}

BL le ser no.178 (1087); LA IV fol 132vo; drukw FA nr.111; rH X 108-109; P VII 53; cB IIIe ser XXXIII 259

\section{LOI RELATIVE AUX RÉClaMations À FAIRE PAR Les PROPRIÉTAIRES de CRÉANCES SUR LES ÉMIGRÉS D'UN MËME DÉPARTEMENT}

De departementale besturen verlangen van degenen die een schuldvordering hebben op uitgewekenen welke de 2000 livres niet te boven gaat, of als de vastgestelde schuldvordering lager is dan 1000 livres, een verklaring over eventuele andere schuldvorderingen op andere uitgewekenen in hetzelfde departement, hetzij uit eigen hoofde, 
hetzij door cessie of overdracht. De verklaring dient de precieze hoogte van de schuldvorderingen te vermelden.

bo, Conwention nationale

ao. comités de lëgislation, des finances et de liquidation

ws. Enjubault

cols. A. Dumont (ex-pres); Derazey, Poisson (secr)

RO nr.210(15): 23 vendémiaire $V(14$ okt 1796)

- verwijzing naar: wet van I floréal III (20 apr 1795)

- afkondiging: besluit Directoire exécutif s. L.M. Revellière-Lépeaux (pres), Lagarde (secr-gen); 10 fructidor IV (27 aug 1796)

\section{III fructidor 28 (1795 sep 14)}

BL Ie ser no.179 (1091); LA IV fol 133ro-134vo; drukw FA nr.111; rH X 109-111; P VII 53-54; cB IIIle ser XXXIII 259-261

\section{LOI QUI DÉTERMINE LE MODE DE LIQUIDATION DES CRÉANCES SUR LES BIENS INDIVIS AVEC LES ÉMIGRÉS}

Voor de vereffening van de schuldvorderingen op de onverdeelde goederen van de uitgewekenen worden de mede-eigenaren en mede-debiteuren door het departementaal bestuur bijeengeroepen om hun titels, stukken en vorderingen mede te delen. Te dien einde wordt er een commissaris benoemd, die met hen vergadert om de rechten van de staat te bedingen. De mede-eigenaren en mede-debiteuren dienen, ofwel in eigen persoon te verschijnen, ofwel zich door een gemachtigde te laten vertegenwoordigen. $\mathrm{Zij}$ die afwezig zijn, omdat ze buitenslands woonachtig zijn, hun woonplaats onvoldoende bekend is, zich in het leger bevinden of om welke andere oorzaak ook, worden door de commissaris bij de burgerlijke rechtbank, dan wel door de vrederechter vertegenwoordigd. In geval van enig geschil omtrent de schuldvordering oordelen twee scheidsmannen over de kwestie, de ene benoemd door de schuldeiser, de andere door de mede-eigenaren, mede-debiteuren en de aanwezige commissaris. Soms is het nodig een opperscheidsman te benoemen.

\section{bo. Convention nationale}

ao. comitếs de législation, des finances et de liquidation

vs. Enjubault

cols. L.M. Revellière-Lépeaux (ex-pres); Poisson, Gourdan (secr)

RO nr.2 I0(16): 23 vendémiaire $V$ (14 okt 1796)

- verwijzing naar: wet van \floréal III (20 apr 1795)

- afkondiging: besluit Direçoire exécutif s. L.M. Revellière-Lépeaux (pres); Lagarde (secr-gen); 10 fructidor IV (27 aug 1796)

\section{III fructidor 29 (1795 sep 15)}

BL. Ie ser no. 178 (1090); LA IV fol 134vo-135ro; drukw FA nr.l11; rH X 112; P VII 54-55; cB IIIe ser XXXIII $269-270$ 
De vereffening van schuldvorderingen op de ouders van uitgewekenen, wier nalatenschappen opengevallen zijn ten gunste van de natie, wordt afgehandeld door het departementale bestuur alwaar de ouders hun domicilie hebben. Het deponeren van schuldvorderingstitels geschiedt in het district van domicilie van de ouders van de uitgewekene. Het districtsbestuur zendt deze terstond aan het departementaal bestuur.

bo. Convention nationale

ao. comités de législation, des finances et de liquidation

Ws. Enjubault

cols. L.M. Revellière-Lếpeaux (ex-press); Poisson, Gourdan (secr)

RO nr.210(17): 23 vendémiaire $V(1.4$ okt 1796)

- verwijzing naar. wet van I floréal III (20 apr 1795)

- afkondiging: besluit Direcroine exécutif s. L.M. Revellière-Lépeaux (pres), Lagarde (secr-gen); 10 fructidor IV (27 aug 1796)

\section{III jour complémentaire 2 (1795 sep 18)}

BL le ser no. 179 (1099); LA I fol 240ro-245vo; FA nr.232; rH V 321-326; P VII 57-59; cB IIle ser XXXIII 284-287

\section{LOI QUI ETABLIT UN NOUVEAU MODE POUR LE JUGEMENT DES DÉLITS MILITAIRES}

leder strafbaar feit door een militair of door andere aan het leger verbonden personen begaan, wordt door een krijgsraad berecht. Deze wordt gevormd door drie officieren, drie onder-officieren en drie soldaten. De vonnissen moeten door alle leden ondertekend worden, mitsdien moeten zij kunnen schrijven. De administratieve raad van een legerkorps benoemt per bataljon een kapitein als rapporteur om op kosten van de verdachte hem onder anderen te informeren inzake de procedure. Hij geeft zijn conclusie, zijn stem telt echter niet mee. De verdachte wordt bij meerderheid van stemmen vrijgesproken dan wel veroordeeld, behalve wanneer het de doodstraf betreft, dan is er een tweederde meerderheid nodig; bij gebreke hiervan zal de lichtste straf worden opgelegd. De doodstraf wordt opgelegd voor de vergrijpen: moord, verkrachting, brandstichting, diefstal met inbraak, met geweld of door samenscholingen. In geval van deze delicten wordt de krijgsraad verdubbeld en mag de verdachte eenzelfde aantal met dezelfde rangen aan de krijgsraad toevoegen. De verdachte dient de procedure zolang voort te zetten, totdat het vereiste aantal krijgsraadsleden is bereikt komen; in geval van weigering door de verdachte hieraan te voldoen, dan worden de oudsten van de diverse rangen benoemd. Overige strafbare feiten worden bestraft volgens de code pénal militaire. De verdachte mag zich van een officieuze verdediger voorzien. Zittingen van de krijgsraad zijn openbaar. Vonnissen worden zonder beroepsmogelijkheid dadelijk na de uitspraak voltrokken.

bo. Convention nationale

ws. Enjubault

cols. T. Berlier (pres); Garrau, Gourdan (secr) 
ti. wolksrepresentanten/gouvernementscommissarissen

RO nr.47(1): 9 frimaire IV (30 nov 1795)

RE mr.46: 14 frimaire IV (5 dec 1795)

- LA, rH en FA nr 232 voegen zonder datum "décret additionnel", "articles additionnels" toe

- plaatsing in het bulletin [de correspondance?] strekt tot promulgatie

- afkondiging: besluit volksrepresentanten s. Pérès, Portiez (de l'Oise); cs. Delcambe (secr-gen); 26 brumaire IV (17 nov 1795)

\section{III jour complémentaire 4 (1795 sep 20)}

BL le ser nr.181 (1109); LA I fol 154ro-155ro; FA nr.291; rH V 213-214; P VII 60; cB IIle ser XXXIII 303-304

\section{LOI QUI DÉSIGNE LES PRÉVENUS D'ÉMIGRATION AUXQUELS NE SERA POINT OPPOSÉS

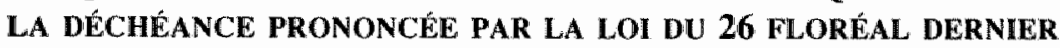

De vervallenverklaring vastgesteld door de wet van 26 floréal III (15 mei 1795) vindt niet plaats tegen degenen die niet tijdig in beroep $k$ wamen en sindsdien de bewijsstukken van hun verblijfplaats hebben overhandigd. De arbeiders die na het verstrijken van de termijn genoemd in de wet van 22 nivôse III (11 jan 1795) naar Frankrijk terugkeerden, kunnen alsnog twee decaden (twintig dagen) na bekendmaking van dit decreet in beroep gaan. Dit geldt alleen maar voor hen met een bewijsstuk daterend van vóór 15 juli 1789 , waarin zij genoteerd staan als handwerkslieden. De districtsbesturen zijn gemachtigd om de sequestratie van hun goederen op te heffen tegen een gegoede borg voor de roerende goederen en de niet-vervreemding van hun onroerende goederen.

bo. Convention nationale

ao. comités de salut public, de sureté générale, de législation, réunis

vs. Enjubault

cols. Lanjuinais (ex-pres); Garrau, Poisson (secr)

ti conseil de gouvernement

RO nr.2I(9): 26 brumaire IV (17 nov 1795)

RE nr.29: 1 frimaire IV (22 nov 1795)

- verwijzing naar: wetten wan 26 floréal III (15 mei 1795); 22 nivôse III (1I jan 1795); "lois existantes"

- afkondiging: besluit volksrepresentanten/gouvernementscommissarissen \&. Pérès, Portiez (de l'Oise); 8 brumaire IV (30 okt 1795)

\section{III jour complémentaire 4 (1795 sep 20)}

BL le ser no. 181 (1110); LA IV fol 135; drukw FA nr.111; rH X 113; P VII 60; cB IIle ser XXXIII 302-303

\section{LOI QUI DÉTERMINE LE CAS DANS LEQUEL LES CRÉANCIERS D'ÉMIGRÉS QUI AURAI- ENT FORMÉS DES ACTES D'UNION SERONT ADMIS À LA LIQUIDATION}

Wanneer er sprake is van gezamenlijk optredende schuldeisers, wordt dit niet als het faillissement van de debiteur beschouwd. De vereffening voor de schuldeisers wordt 
afgehandeld conform de wet van 1 floréal III (20 apr 1795), mits er evenwel van de zijde der schuldeisers geen verklaring of erkenning bestaat, waaruit de insolventie van de debiteurs kan worden afgeleid.

bo. Convention nationale

ao. comités de législation, des finances el de liquidation, réumis

vs. Enjubault

cols. Lanjuinais (ex-pres); Garrau, Poisson (secr)

RO ni.210(18): 23 vendemiaire V (14 okt 1796)

- verwijzing naar; wetten van 25 jul 1793; I floréal III (20 apr 1795)

- afkondiging: besluit Directoire exécurif s. L.M. Revellière-Lépeaux (pres), Lagarde (secr-gen); 10 fructidor IV (27 aug 1796)

\section{IV vendémiaire 1 (1795 sep 23)}

BL Ie ser no. 180 (I100); LA I fol 68ro-69vo; FA nr.228; rH V 64; cB IIIe ser XXXIV 3

\section{LOI PORTANT PROCLAMATION DE L'ACCEPTATION PAR LE PEUPLE FRANCAIS DE LA CONSTITUTION QUI LUI A ÉTÉ PRÉSENTÉE PAR LA CONVENTION NATIONALE}

Het Franse volk heeft de constitutie aanvaard, en deze zal de grondwet van de Republiek zijn. De verzending van de proclamatie geschiedt per speciale koerier naar de departementen en de legers om in alle gemeenten te worden bekendgemaakt.

bo. Convention nationale

ao. comité des decrets, procès-verbaux et archives

vs. Lehaullt, Enjubatult

cols. T. Berlier (ex-pres); Garrau, Gourdan, J. Poisson, Derazey, Bernier (secr)

ii. conseil du gouvernement des représentans do peuple

RO nr.4: 18 vendémiaire IV (10 okt 1795)

- verwijzing naar: grondwet van 5 fructidor III (22 aug 1795)

- afkondiging: besluit volksrepresentanten s. Giroust, cs. Delcambe; 14 vendémiaire IV (6 okt 1795)

IV vendémiaire 1 (1795 sep 23$)$

BL le ser no. 183 (1119); LA I fol 249ro-25I vo; FA nr.291; drukw FA nr.30; rH V 330-332; P VII 65-66; cB IIIe ser XXXIV I-2

loI PORTANT que les Rebelles, CeUX CONNUS SOUS le NOM de Chouans, ETC. DONT LE JUGEMENT ÉTAIT ATTRIBUÉ AUX TRIBUNAUX MILITAIRES, SERONT JUGÉS PAR LES CONSEILS MILITAIRES ÉTABLIS PAR LA LOI DU $2^{K}$ JOUR COMPLÉMENTAIRE

Chouans of andere rebellen worden door krijgsraden, ingesteld bij de wet van 2 jour complémentaire III (18 sep 1795), berecht in plaats van door militaire rechtbanken. De straffen worden opgelegd als bepaald in de wet van 30 prairial III (18 jun 1795). Het dichtstbijzijnde legeronderdeel voorziet in de vorming van de krijgsraad. Deze benoemt de officieuze verdediger, indien de verdachte niet zelf een verdediger benoemt. 
bo. Comention nationale

ao. comités de salut public, militaire

vs. Enjubault

cols. P.C.L. Baudin (des Ardennes) (pres); Auger, P.M. Delauney (secr)

ti. volksrepresentanten/gouvemementscommissarissen; gouvemementscommissaris Bouteville

RO nr.47(2) en 89(44): 9 frimaire IV (30 nov 1795) en 16 nivôse IV (6 jan 1796)

RE nr.46 en 136: 14 frimaire IV ( 5 dec 1795) en 14/15 floreal IV ( $3 / 4$ mei 1796)

- verwijzing naar: wetten van 2 jour complémentaire III (18 sep 1795); 30 prairial III (18 jun 1795); de onderhavige wet haalt de artt.2-9 in extenso van de wet van 30 prairial III inzake de Chouannerie aan; $\mathrm{P}$ doet dit niet

- plaatsing in het Bulletin strekt tot promulgatie

- afkondiging: besluit wolksrepresentanten s. Pérès, Portiez (de l'Oise); cs. Delcambe (secr-gen); 26 brumaire IV (17 nov 1795) en 24 frimaire IV (15 dec 1795)

\section{IV vendémiaire 3 (1795 sep 25)}

BL Ie ser no.185 (1130); LA II fol 13vo-15vo; FA nr.233; rH V 365-368; P VII 67-68; cB IIIe ser XXXIV 19-21

\section{LOI RELATIVE À L'ABOLITION DE L'EFFET RÉTROACTIF DES LOIS DE 5 ET 12 BRUMAIRE ET DU 17 NIYOSE, AN II, CONCERNANT LES SUCCESSIONS, DONATIONS, ETC.}

Rechten die te goeder trouw verworven zijn door derde-bezitters, hypothecaire schuldeisers en anderen daterend van een datum gelegen na de afkondiging van de wetten van 5 brumaire II ( 26 okt 1793) en 17 nivôse II ( 6 jan 1794), maar vóór die van 5 floréal III ( 24 apr 1795), blijven hun toebehoren. Alle vervreemdingen, hypotheken en bepalingen van genoemde goederen onder bezwarende titel of om niet van na laatstgenoemde datum zijn nietig. Nieuwe gevallen van verdelingen, vereffeningen, inbrengen of restricties uit hoofde van deze onderhavige wet kunnen niet plaatshebben op grond van het verzuim van vruchten of belangen van vóór de afkondiging van de wet van 5 floréal III, behalve in een aantal nader omschreven gevallen. Zij die ingevolge deze wet in hun rechten hersteld zijn, krijgen hun goederen terug in de staat waarin zij zich bevinden, of eventueel de waarde ervan in geld. De bepalingen van wetten ter interpretatie van retroactieve bepalingen, ingetrokken door de wet van 9 fructidor 11 (II (26 aug 1795), zijn voor wat betreft hun terugwerkende kracht herroepen.

\section{bo. Convention nationale \\ ao. comité de législation \\ vs. Enjubault}

cols. P.C.L. Baudin (des Ardennes) (pres); Auger, Garrau, Philippe Delleville (secr)

ti. volksrepresentanten/gouvernementscommissarissen

RO nr.67(4): 25 frimaire IV (16 dec 1795)

RE nr.62: 13/14 nivôse IV (3/4 jan 1796)

- verwijzing naar: wetten van $7 \mathrm{mrt} 1793 ; 5$ brumaire II (26 okt 1793); 12 brumaire II ( 2 nov 1793): 17 nivôse II (6 jan 1794); 5 floréal III (24 apr 1795); 9 fructidor III (26 aug 1795)

- wet van 5 floréal III (24 apr 1795) is herroepen

- afkondiging: besluit volksrepresentanten s. Pérès, Portiez (de l'Oise), Delcambe (secr); 28 brumaire IV (19 nov 1795) 


\section{IV vendémiaire 5 (1795 sep 27)}

BL Ie ser no. 183 (1124); drukw FA nr.30; rH VII 236-237; P VII 79; cB IIle ser XXXIV $40-42$

LOI PORTANT DES PEINES CONTRE LES PRESIDENS ET SECRETAIRES DES ASSEMBLECS PRIMAIRES OU ELECTORALES QUI METTRAIENT AUX VOIX OU SIGNERAIENT DES ARRETES ETRANGERS AUX ELECTIONS, ET CEUX QUI LES IMPRIMERAIENT, AFFICHERAJENT, EXECUTERAIENT OU CRIERAIENT

De voorzitters en secretarissen van de assemblées primaires of électorales worden verantwoordelijk gehouden voor het in stemming brengen en signeren van besluiten of andersoortige bestuurshandelingen, die vreemd zijn aan de verkiezingen of de inwendige orde van de zittingen. Eveneens worden verantwoordelijk gehouden degenen die dergelijke besluiten drukken, bekendmaken of ten uitvoer leggen. $\mathrm{Er}$ is sprake van een aanslag op de binnenlandse veiligheid als deze besluiten oproepen tot revolte of verzet tegen de wet, en zal dienovereenkomstig worden bestraft.

bo. Convention nationale

vs. Enjubault, Lehault

cols. P.C.L. Baudin (des Ardennes) (pres); Auger, Garrau (secr)

ti. gouvernementscommissaris Bouteville

RO nr.89(46): 16 niwôse IV (6 jan 1796)

RE nr. 136: 14/15 noréal IV (3/4 mei 1796)

- enkele artikelen wan de grondwet van het jaar III (1795) zijn aangehaald

- wet toegezonden aan alle aurorités constituées on the worden geproclameerd, bekendgemaakt en aangeplakt in alle gemeenten

- afkondiging: besluit wolksrepresentanten/gouvemementscommissarissen s. Pérès, Portiez (de l"Oise):

24 frimaire IV (15 dec 1795$)$

\section{IV vendémiaire 7 (1795 sep 29)}

BL Ie ser no. 186 (1136); LA I fol 184vo-191 ro; rH V 133-139; P VII 75-77; cB IIIe ser XXXIV 6165

\section{LOI SUR LA POLICE DU COMMERCE DES GRAINS ET L'APPROVISIONNEMENT DES} MARCHES ETT DES ARMÉES

Granen en meel kunnen alleen maar worden verhandeld op jaarmarkten en openbare markten, op straffe van drie maanden detentie en confiscatie, en een boete gelijk aan de waarde ervan, door de verkoper en koper elk voor de helft te voldoen. Hiervan uitgezonderd zijn de aan- en verkoop van graan en meel voor de instandhouding van de diensten van openbare instanties, voor de bevoorrading van het leger en de marine, alsmede voor de gemeente Parijs en fabrieken en ateliers die voor de staat werken. Plattelandsbewoners die onvoldoende korenopbrengst voor hun levensonderhoud hebben en die plaatsen bewonen waar geen markt gehouden wordt, mogen zich zelfzelf bevoorraden bij de boeren, wanneer zij van de nodige papieren van de municipaliteil zijn voorzien. Het laatste geldt eveneens voor handelaren, commissionairs en dergelijke. Municipaliteiten en bestuurslichamen zijn bevoegd om boeren en graanhandelaren te op te dragen om de benodigde hoeveelheden aan de markt te leveren. Van 
elke boer wordt afzonderlijk de te leveren hoeveelheid bepaald. Weigering van de leverantie wordt bestraft, terwijl de municipaliteit zelf ook verantwoordelijk wordt gehouden om de requisities uit te voeren. Iedere uityoer van granen en meelsoorten is verboden. Bij gevolg worden alle onderschepte transporten op een afstand binnen twee mijl van de grens of de kust zonder kwijtingsbewijs van de douanerechten met een borgstelling (acquit à caution) van de municipaliteit van de eigenaar in beslag genomen en de overtreders tot twee jaar dwangarbeid in ketenen veroordeeld. De transporteurs gaan vrijuit wanneer er granen naar een kustplaats met 10.000 of meer inwoners worden vervoerd.

\section{bo. Convention nationale \\ ao. comité de salut public \\ vs. Enjubault}

cols. Le Tourneur (de la Manche) (ex-pres); P.M. Delauney, J.F. Philippe Delleville (secr)

ti. conseil de gouvernement

RO nr.26(6): 27 brumaire IV (18 nov 1795)

RE nr.19: 28 brumaire IV (19 nov 1795)

- verwijzing naar: wet van 4 thermidor III (22 jul 1795); "lois anterieures sur la libre circulation des subsistances"; besluiten van het contité de salut public van I fructidor III (18 aug 1795); 7 fructidor III (24 aug 1795), 13 fructidor III (30 aug 1795); 28 fructidor III (14 sep 1795)

- afkondiging: besluit volksrepresentanten s. J. le Febvre (de Nantes), Giroust; cs. J. Torfs (secrprov); 21 vendémiaire IV (13 okt 1795)

\section{IV vendémiaire 7 (1795 sep 29)}

BL. le ser no.186 (1135); LA III fol 126ro; rH VIII 250-251; P VII 74-75; cB IIIe ser XXXIV 60

\section{LOI QUI DÉTERMINE LES CAS DANS LESQUELS LES FERMIERS DE BIENS NATIONAUX, DONT LES BAUX ONT ÉTÉ ANNULLÉS, JOUIRONT DE LA RÉCOLTE DE L'AN TROI- SIÈME}

Een pachter wiens pachtovereenkomst is vervallen uit hoofde van het bepaalde van art.38 van de wet van 6,11 aug 1790 en art.17 van de wet van 15 frimaire II ( 5 dec 1793), heeft alleen dan recht op de oogst van het jaar III voor zover hij de grond had ingezaaid, voordat hem werd opgedragen zijn pachtcontract ter inzage te geven, hetzij omdat hij er niet langer het genot van heeft hem meegedeeld door een openbaar ambtenaar, hetzij doordat er een rechtsvordering tegen hem was ingesteld. Voorts zijn alle vonnissen nietig en niet-bestaand die contrair beschikten aan de hierboven geinterpreteerde wetten.

bo. Convention nationale

ao. comités de législation, des finances (section des domaines)

vs. Enjubault

cols. Le Tourneur (de la Manche) (ex-pres); J.F. Philippe Delleville, P.M. Delaunay (secr)

RO nr.147(23): II prairial IV (30 mei 1796)

- verwijzing naar: wetten van 6,11 aug 1790; 15 frimaire II (5 dec 1793); "lois postérieures"

- LA, FA, rH en RO vermelden abusievelijk als datum van uitvaardiging 7 vendémiaire III (28 sep 1794) 
- cB-intitulé:" "décret sur la question si les fermiers de biens nationaux, dont les baux ont été annullés en vertu de l'article XXXVII de la loi des 6 et 11 août 1790 , et de l'article XVII de la loi du 15 frimaire, an II, par suite de poursuites judiciaires commencées avant que les semences fussent en terre, ont droit à la recolte de l"an III"

- afkondiging: besluit Directoire exécutif s. Camot (pres), Lagarde (secr-gen); 23 floréal IV (12 mei 1796)

IV vendémiaire 7 (1795 sep 29)

BL Ie ser no.186 (1134); LA V fol 95vo-96ro; FA nr.291; rH X 256; P VII 71-74; cB IIIe ser XXXIV $44-52$

\section{[extract] LOI SUR L'EXERCICE ET LA POLICE EXTÉRIEURE DES CULTES (art. 19)}

Niemand mag in het openbaar, op straffe van een boete of hechtenis, in gewaden met versierselen verschijnen, die voor religieuze plechtigheden dan wel voor een bedienaar der eredienst bestemd zijn.

bo. Convention mationale

ao. comité de législation

vs. Enjubault

cols. P.C.L. Baudin (des Ardennes); Auger, Gourdan (secr)

RO nr.232(1): 1 nivôse $V(21$ dec 1796)

- afkondiging: besluit Directoire exécutif s. P. Barras (pres); Lagarde (secr-gen); 16 frimaire V (6 dec 1796); opmerking: dit artikel moet worden uitgevoerd ten aanzien van voorheen reguliere geestelijken beider sexe die art.18 van de wet van 15 fructidor IV (1 sep 1796), houdende de opheffing van de religieuze instellingen in het vroegere België, overtreden

\section{IV vendẻmiaire 9 (1795 okt 1$)$}

BL le ser 186 (1137); LA I fol 5vo-8ro; rH V 35-37; cB IIle ser XXXIV 71-73; P VII 78-79

\section{LOI SUR LA RÉUNION DE LA BELGIQUE ET DU PAYS DE LIÈGE À LA RÉPUBLIQUE FRANÇAISE}

De aansluiting bij Frankrijk van de landen van Luik, Stavelot, Logne en Malmédy, zoals voorzien in de decreten van de Convention nationale van 2 en 4 maart en 8 mei 1793, wordt geëffectueerd. Eveneens wordt uitvoering gegeven aan de decreten van 1 , $2,6,8,9,11,19$ en 23 maart 1793 inzake de aansluiting van Henegouwen, het Doornikse, het land van Namen en het merendeel der gemeenten van Vlaanderen en Brabant bij Frankrijk. Voorts worden met het Franse grondgebied verenigd de gebieden westelijk van de Rijn gelegen, welke onder Oostenrijkse heerschappij stonden, aslmede die gebieden welke door de Bataafse Republiek bij het Haagse verdrag van 27 floréal III (16 mei 1795) aan Frankrijk afgestaan zijn. Inwoners van de voorheen Oostenrijkse - behoudens de gemeenten die in 1793 reeds de wens tot aansluiting bij Frankrijk hadden geuit - en Staatse gebieden genieten voorlopig de rechten door de grondwet gegarandeerd aan vreemdelingen die in Frankrijk wonen of er bezittingen hebben. De inwoners van de overige streken genieten dadelijk alle rechten als Frans burger. De bij Frankrijk aangesloten gebieden worden in negen departementen ver- 
deeld: Dijle (hoofdstad Brussel), Schelde (Gent), Leie (Brugge), Jemappes (Bergen), Wouden (Luxemburg), Sambre-en-Maas (Namen), Ourthe (Luik), Nedermaas (Maastricht) en Twee Neten (Antwerpen). De volksrepresentanten, gedetacheerd in België, zijn belast met het installeren van de diverse besturen.

\section{bo. Convention mationale \\ ao. comité de salut public: \\ ws. Enjubauit}

cols. P.C.L. Baudin (des Ardennes) (pres); J.F. Philippe Delleville, Poisson (secr)

ti. Giroust

RO nr. I: 13 vendémiaire IV ( 5 okt 1795)

RE nr.l: 14 vendémiaire IV ( 6 okt 1795)

- gelezen en bekendgemaakt 19 vendémiaire IV (11 okt 1795); plechtig geproclameerd 20 vendémiaire IV (12 okt 1795)

- verwijzing naar: decreten van $1 \mathrm{mrt} 1793 ; 2 \mathrm{mrt} 1793 ; 4 \mathrm{mrt} 1793 ; 6 \mathrm{mrt} 1793 ; 8 \mathrm{mrt} 1793 ; 9 \mathrm{mrt}$ 1793; 11 mrt 1793; 19 mrt 1793; 23 mrt 1793, 8 mei 1793 ; Hags verdrag van 27 floreal III (16 mei 1795)

- afkondiging: besluit volksrepresentanten bij het Noorder-en het Sambre-en-Maasleger s. Giroust; 12 wendémiaire IV (4 okt 1795)

\section{IV vendémiaire 10 (1795 okt 2$)$}

BL Ile ser no. 188 ( 142 ); LA I fol 191ro-200ro; FA nr.29I; nH V 47-55; P VII 79-83; cB IIIe ser 7378

\section{LOI SUR LA POLICE INTÉRIEURE dES COMMUNES dE LA RÉPUBLIQUE}

Alle inwoners van eenzelfde gemeente zijn in burgerrechtelijke zin aansprakelijk (être garant civilement) voor aanslagen gepleegd op het grondgebied van de gemeente zowel jegens personen als eigendommen. Teneinde het inwendige toezicht (police) van gemeenten te waarborgen, moet elke gemeente een lijst bijhouden met de naam, leeftijd, staat of het beroep van elke burger boven de twaalf jaar, alsmede hun woonadres; een copie hiervan dient te worden gezonden aan het departementaal bestuur en aan de municipale administratie van het kanton. Voorts mag niemand zijn kanton verlaten zonder een paspoort getekend door een gemeenteambtenaar. Van de afgifte van paspoorten dient een register te worden bijgehouden, en het paspoort dient ten minste eens per jaar te worden vernieuwd. Reizigers die buiten het kanton van domicillie zonder paspoort worden aangetroffen, worden terstond gearresteerd. Elke gemeente is collectief aansprakelijk voor delicten met geweld gepleegd door al dan niet gewapende samenscholingen, zowel jegens personen als publieke of private eigendommen, alsmede voor de schadeloosstellingen, tenzij de gemeente al het nodige heeft gedaan om de wandaden te voorkomen. Men staat ook garant voor het niet-voldoen van de leveranties betreffende de pacht aan de eigenaren, tenzij men de mogelijkheid van verhaal heeft op de nalatige pachters. In geval van diefstal of plundering zijn alle inwoners gehouden in de restitutie ervan te voorzien. De commissaris van de uitvoerende macht bij het departementaal bestuur dient eisen tot schadevergoedingen in bij de burgerlijke rechtbank. De vastgestelde schadevergoeding kan gewapenderhand van de gemeente ingevorderd worden. 
bo. Convertion nationale

ao. comirés de salut public, sûneté générale, et législation, réunis

ws. Enjubault

cols. P.C.L. Baudin (des Ardermes) (pres); J.F. Philippe Delleville (secr), Delecloy (ex-secr)

ti. conseil de gouvernement

RO nr.27: 27 brumaire IV (18 now 1795)

RE nr.20: 28 brumaire IV (19 nov 1795)

- verwijzing naar: wet van 16 prairial III (4 jun 1795), blijft van kracht voor zover niet strijdig met de onderhavige

- LA, rH en FA nr.291 vermelden het formulier wan de lijst en van het paspoort

- platatsing in het bulletin de correspondance strekt tot bekendmaking

- afkondiging: besluit volksrepreseritant s. Giroust, cs. Delcambe (secr-prov); 27 vendémiaire IV (19 oki 1795)

\section{IV vendémiaire $10(1795$ okt 2$)$}

BL Ie ser no. 192 (1153); LA I fol 222ro-227ro; FA nr.291; rH V 234-239; P VII 83-84; cB IIle ser XXXIV $80-84$

\section{LOI SUR L'ORGANISATION DU MINISTEERE}

De wet wijst zes ministers aan, namelijk: die van justitie, van binnenlandse zaken, van financiën, van oorlog, van marine en koloniën, en van buitenlandse betrekkingen. De aan hen geattribueerde bevoegdheden, hoewel zij ondergeschikt zijn aan het Directoire exécutif, staan nader omschreven. Ministers worden verantwoordelijk gehouden voor door hen begane strafbare feiten tegen de nationale veiligheid, de grondwet, de vrijheid en het particuliere eigendom, en voor de door hen begane verkwisting van publieke gelden. De commissarissen van de uitvoerende macht bij de rechtbanken en لlagere overheden corresponderen met de ministers. Aan de minister van justitie is speciaal het drukken en verzenden van wetten en besluiten enzovoorts van het Directoire exécutif opgedragen.

bo. Convention nationale

ws. Enjubault

cols. P.C.L. Baudin (des Ardennes) (pres); J.F. Philippe Delleville (secr), Delecloy (ex-secr)

ti. conseil de gowvernemewn

RO nr.37: 5 frimaire IV (26 nov 1795)

RE nr.38: 13 frimaire IV ( 4 dec 1795)

- afkondiging: besluit volksrepresentanten s. Perès, Portiez (de l'Oise); cs. J. Torfs (secr-prov); 13 brumaire IV (4 nov 1795)

\section{IV vendémiaire 12 (1795 okt 4$)$}

LA I fol 5ro; FA nr.227; P VII xxiii

ARRETE QUI ORDONNE L'ENVOI AUX ADMINISTRATIONS AINSI QUE LA RÉIMPRESSION ET PUBLICATION DE LA LOI DE RÉUNION DU 9 VENDÉMIAIRE AN IV 
De onmiddellijke verzending per speciale koerier van de aansluitingswet bij Frankrijk aan elke arrondissementsadministratie en aan de municipaliteiten van Brugge en Antwerpen wordt bevolen. Deze autoriteiten zijn belast met het drukken, publiceren en plechtig proclameren ervan.

bo. volksrepresentant bij het Noorder- en Sambre-en-Maasleger

s. Giroust

ti. volksrepresentant Giroust

RO nr.2: 13 vendémiaire IV ( 5 okt 1795)

RE nr.2: 14 vendémiaire IV (6 okt 1795)

- verwijzing naar: wett van 9 vendémiaire IV (1 okt 1795)

\section{IV vendémiaire $12(1795$ okt 4$)$}

BL Ie ser no.192 (1154); LA I fol 258vo-26I vo; rH V 373-376; P VII 85-86; cB llle ser XXXIV 98 100

\section{LOI QUI dÉTERMINE UN MODE POUR L'ENVOI ET LA PUblCATION DES LOIS}

Zodra een wet of andere handeling van het Corps légisiatif de in de grondwet omschreven vereiste vorm heeft verkregen, laat de minister van justitie op last van het Directoire exécutif deze drukken en bekendmaken door middel van het Bulletin des Lois. In het Bulletin des Lois - voorzien van uiterlijke kenmerken van authenticiteit -worden uitsluitend de wetten en handelingen van het Wetgevend Lichaam, alsmede de proclamaties en besluiten van het Directoire exécutif teneinde de uitvoering van de wetten te verzekeren, opgenomen. Resoluties en ontwerp-resoluties van de Conseil des Cinq-cents worden in her Feuilleton des résolutions et des projets de résolution geplaatst. Het Bulletin des Lois en het Feuilleton worden aan de voorzitters van de departementale en municipale besturen, de presidenten van de rechtbanken, de vrederechters, ambassadeurs en diverse andere autoriteiten verzonden. Burgers kunnen tegen een gematigde prijs een abonnement nemen. Ingevolge deze wet zal er geen publicatie van wetten meer platshebben op statskosten door middel van openbare voorlezing, door herdrukken, door aanplakking, al dan niet onder begeleiding van trompetgeschal of tromgeroffel, tenzij de wet dit uitdrukkelijk voorschrijft. Het Directoire exécutif en verder ieder departementaal- of municipaliteitsbestuur kunnen evenwel bijzondere afkondigingsformaliteiten voorschrijven, wanneer zij dit nodig achten. De wetten en handelingen van het Corps législatif zijn verbindend op het grondgebied van een departement vanaf de dag dat het Bulletin des Lois in de hoofdstad van een departement is verspreid. Te dien einde dient men per departement cen register aan te leggen dat de binnenkomst wan het Bulletin des Lois constateert.

bo. Convention narionale

vs. Enjubautt

cols. P.C.L. Baudin (des Ardennes) (pres); Auger, J.F. Philippe Delleville (secr)

ti. volksrepresentanten

RO nr.52: 11 frimaire IV (2 dec 1795)

RE nr.45: $13 / 14$ frimaire IV (4/5 dec 1795) 
- afkondiging: besluit volksrepresentanten/gouvemementscommissarissen s. Pérès, Portiez (de l"Oise);

5 frimaire IV (26 nov 1795$) ;$ [N.B. toegezonden arrêté is gedateend op 8 frimaire IV (29 nov 1795)]

\section{IV vendémiaire 13 (1795 okt 5)}

LA I fol 8ro-9ro; FA nr.227; rH V 59-60; P VII xxiv

\section{ARRETE RELATIF A L'ADMINISTRATION PROVISOIRE DE LA BELGIQUE}

Alle zittende autoriteiten blijven voorlopig hun functies als voorheen uitoefenen. In het bijzonder de besluiten van de volksrepresentanten inzake de inning van belastingen blijven uitgevoerd naar vorm en strekking. Toezending van dit besluit geschiedt aan de arrondissementsadministraties van de Centrale Administratie van België, alsmede aan de arrondissementsadministraties te Maastricht, Limbourg en Spa, en door hen aan de onder hen ressorterende municipaliteiten.

bo. volksrepresentanten bij het Noorder- en het Sambre-en-Maasleger

ao. conseil du gownernement provisoire (de l'administration centrale de la Belgique)

s. Giroust

cs. Delcambe

ti. volksrepresentant Giroust

RO nr.3: 15 vendémiaire IV (7 okt 1795)

RE nr.3: 15 vendèmiaire IV (7 okt 1795)

\section{IV vendémiaire $14(1795$ okt 6$)$}

BL Ie ser 187 (1140); FA nr.228; LA I 68vo-69ro; rH V 121-122; cB IIle ser XXXIV 109-110

\section{LOI QUI ORDONNE L'ARRESTATION DES COURRIERS ET EMISSAIRES ENVOYÉS DANS LES DÉPARTEMENS PAR LES ASSEMBLÉES PRIMAIRES OU ASSEMBLÉES DE SECTION DE PARIS}

Koeriers en geheime boden die door de assemblées primaires of de assemblées van de sectie Parijs naar de departementen zijn gezonden, moeten met spoed worden aangehouden. Autoriteiten dienen het proces-verbaal van aanhouding en de papieren van de gearresteerden naar het comité de sûreté générale op te sturen. Dit decreet wordt per speciale koerier naar de departementen en de legers overgebracht.

bo. Convertion nationale

ao. comités de salut public, de sîreté générale

vs. Enjubault

cols. P.C.L. Baudin (des Ardennes) (pres); J.F. Phillippe Delleville, Poisson (secr)

ti. conseil de gowvernement de la Belgique

RO nr.5: 20 vendémiaire IV (12 okt 1795)

- plaatsing in het Bullesin strekt tot bekendmaking

- afkonduging: besluit volksrepresentanten bij het Noorder- en het Sambre-en-Maasleger s. Giroust, cs. Delcambe; 18 vendémiaire an IV (10 okt 1795) 


\section{IV vendémiaire 15 (1795 okt 7)}

BL le ser no. 188 (1145); LA I fol 227ro-230ro; FA nr.291; rH V 239-242; cB Ine ser XXXIV 128130

\section{LOI QUI PRONONCE DES PEINES CONTRE LES AUTEURS ET PRINCIPAUX INSTIGA- TEURS DE LA CONSPIRATION ET REBELLION DES 12, 13 ET 14 VENDËMIAIRE, ET ORDONNE LA FORMATION DE TROIS CONSEILS MILITAIRES POUR LES JUGER}

De berechting van de plegers, de aanstichters en de medestanders van de samenzwering van royalisten en uitgewekenen tegen de Convention nationale te Parijs van 12 tot 14 vendémiaire IV (4 tot 6 okt 1795) geschiedt door hiervoor tijdelijk ingestelde krijgsraden. Het comité de sûreté générale zal de vervolging instellen en de verdachten voor de krijgsraad brengen. De op te leggen straffen variëren van 8 tot 25 jaar dwangarbeid in ketenen tot de doodstraf.

\section{bo. Convention nationale}

ao. comités de salut public, de sâreté générale

vs. Enjubault

cols. P.C.L. Baudin (des Ardennes) (pres); J.F. Philippe Delleville, Poisson (secr)

ti. conseil de gowvernement

RO nr.38; 5 frimaire IV (26 nov 1795)

RE nr.39: 13 frimaire IV (4 dec 1795)

- verwijzing naar: code pénal wan 25 sep 1791; wetten van 30 prairial III (18 jun 1795); 2 jour complémentaire III (18 sep 1795); I vendémiaire IV (23 sep 1795); 11 vendémiaire IV ( 3 okt 1795)

- RO vermeldt abusievelijk als datum van uitvaardiging 20 vendemiaire IV (12 okt 1795)

- afkondiging: besluit volkrepresentanten s. Pérès, Portiez (de l'Oise); cs. J. Torfs (secr-prov); 13 brumaire IV (4 nov 1795)

\section{IV vendémiaire 19 (1795 okt 11)}

BL Ie ser no.194 (1160); LA II fol 80vo-87vo; FA nr.234; rH VI 51-62; P VII 90-96; cB IIIe ser XXXIV 150-181

\section{LOI SUR LA DIVISION DU TERRTTOIRE DE LA RÉPUBLIQUE, LE PLACEMENT ET L'ORGANISATION DES AUTORITÉS ADMINISTRATIVES ET JUDICIAIRES}

De Franse departementen zijn voor de uitoefening van de politieke rechten - stemrecht voor de burgers - opgedeeld in assemblées primaires. Deze indeling is gebaseerd op de gemiddelde bevolkingsdichtheid gedurende de laatste drie jaren. Met behulp van tableaus worden de plaatsen aangeduid alwaar de departementale besturen zetelen en waar de rechtbanken gevestigd zijn. De administratieve organisatie en die van de politie is zodanig ingericht, dat in elke gemeente van meer dan 5000 inwoners een commissaris van politie functioneert, wiens benoeming toekomt aan het municipaliteitsbestuur. In gemeenten kleiner dan 5000 inwoners vervult de municipale agent of zijn adjunct de functie van ambtenaar van de burgerlijke stand. De wet behelst voorts een nadere uitwerking van de rechterlijke organisatie: de burgerlijke en correctionele rechtbanken, handelsrechtbanken en vredegerechten en het daarbij werkzame personeel. In de overgangsbepalingen wordt onder meer bepaald, dat zaken aanhangig bij 
de opgeheven districtsrechtbanken verder behandeld zullen worden door de burgerlijke rechtbanken in de departementen, dat de assemblées primaires bijeengeroepen zullen worden woor het verrichten van benoemingen, en dat er een speciale wet zal worden uitgevaardigd voor de bestuurlijke en rechterlijke organisatie in de départements réunis en de koloniën.

bo. Convention nationale

ws. Enjubault

cols. Génissieu (pres); Pons (de Verdun), Auger (secr)

ti. volksrepresentanten/gouvernementscommissarissen

RO nr.80: 1 nivổse IV (22 dec 1795)

RE nr.99: 11/12 ventöse IV (1/2 mrt 1796)

- verwijzing naar: wetten van 16*24 aug $1790 ; 4$ feb 1791; 29 sep 1791; 21 fructidor III (7 sep 1795); 25 fructidor III (II sep 1795); grondwet van 5 fructidor III (22 aug 1795)

- wet toegezonden aan alle assemblées électorales; plaatsing in het Bulletin strekt tot bekendmaking

- afkondiging: besluit wolksrepresentanten s. Pérès, Portiez (de I'Oise); 13 frimaire IV (4 dec 1795)

\section{IV vendémiaire 20 (1795 okt 12)}

BL le ser no.195 (1164); LA I fol 230ro-231ro; FA nr.291; rH V 242; P VII 96; cB IIIe ser XXXIV 185

LOI QUI DEFEND TOUTES NGGOCIATIONS EN BLANC DE LETTRES DE CHANGE OU AUTRES EFFETS DE COMMERCE

De wet verbiedt de handel in blanco-wisselbrieven - dat wil zeggen wisselbrieven waarop de naam van de geëndosseerde niet is ingevuld - , orderbiljetten of andere niet op naam gestelde handelspapieren. Aldus verhandelde waardepapieren worden geconfisqueerd: de helft van de waarde ervan is voor de aanbrenger, de andere helft wordt in de openbare schatkist gestort. Wisselagenten die zich in dergelijke handel begeven worden uit hun functie ontheven en tot een forse boete veroordeeld.

bo. Convervion nationale

ao. comites de salut public, des finances

vs. Enjubault

cols. Gernissieu (pres); Pons (de Verdum), Alex. Villetard (secr)

ti. conseil de gowernement

RO nr. 39: 5 frimaire IV (26 now 1795)

RE nr: $40: 13$ frimaire IV (4 dec 1795)

- plaatsing in het Bulletin strekt tot promulgatie

- afkondiging: besluit volksrepresentanten s. Pérès, Portiez (de l'Oise), cs. J. Torfs (secr-prov); 13 brumaire IV (4 nov 1795 )

\section{IV vendémiaire 20 (1795 okt 12)}

BL. Ie ser no.192 (1157); LA I fol 231; FA nr.291; rH V 243; P VII 96; cB IIIe ser XXXIV 183

LOI QUI ENJOINT AUX INDIVIDUS PREVENUS D'ÉMIGRATION ET NON RAYÉS DÉFINITIVEMENT, DE CESSER TOUTES FONCTIONS PUBLIQUES 
Degenen die verdacht worden van het feit uitgewekene te zijn en niet zijn doorgehaald op de lijst van uitgewekenen, wordt bevolen ogenblikkelijk hun openbare functies neer te leggen. In hun vervanging zal dadelijk worden voorzien door, ofwel de volksrepresentanten en mission, ofwel het comité de législation.

bo. Convention nationale

ao. comités de salut public, de sâreté générale

vs. J.M. Hubert

cols. Génissieur (pres); Alex. Villetard, J.F. Phillippe Delleville (secr)

ti. conseil de gouvernement

RO nr.40: 5 frimaire IV (26 nov 1795)

RE nr.41: 13 frimaire IV (4 dec 1795)

- decreet onmiddellijk aan alle autoriteiten in de Republiek, de assemblées électorales en de volksrepresentanten en mission gezonden

- afkondiging: besluit volksrepresentanten s. Pérès, Portiez (de l'Oise). Giroust; cs. Torfs (secr-prov); 13 brumaire IV (4 nov 1795)

\section{IV vendémiaire 21 (1795 okt 13)}

LA I fol 70; FA nr.228; $\mathrm{rH} \vee 123$

\section{ARRÊTÉ QUI RÉUNIT EN UN SEUL CORPS L'ADMINISTRATION DE LA BELGIQUE ET LE CONSEIL DE GOUVERNEMENT}

De conseil de gouvernement en de Centrale Administratie van België zijn in één bestuurslichaam verenigd onder de benaming van conseil de gouvernement, waarmee ondergeschikte autoriteiten dienen te corresponderen.

bo. volksrepresentanten bij het Noorder-en het Sambre-en-Maasleger

s. Giroust, J. Lefebvre (de Nantes); cs. Delcambe (secr-prov)

ti. volksrepresentanten

RO nr.6: 25 vendemiaire IV (17 okt 1795)

\section{IV vendémiaire 21 (1795 okt 13)}

LA I fol 173vo-175\%o; FA nr.230; rH V 124-125; P VII xxvi-xxvii

\section{ARRÊtÉ RÉGLANT UN MODE PROVISOIRE DE PUIBLICATION DES LOIS DANS LES DÉPARTEMENS RÉUNIS}

Inzake de bekendmaking van wetten geschiedt de officiële verzending uitsluitend in het Frans. Eén exemplaar moet worden gedeponeerd op de griffie van elke municipaliteit. In die arrondissementsadministratie waar een andere voertaal gebruikelijk is, kan in beperkte mate een vertaling worden gemaakt. De elf arrondissementsadministraties dienen te zorgen dat wetten en besluiten de plaatsen van hun ressort, volgens de territoriale indeling van het comité de salut public van 14 fructidor III (31 aug 1795), bereiken en zich ervan te vergewissen dat de ontvangst en bekendmaking plaatsvindt. De plaatsen die hier niet onder vallen, krijgen de wetgeving volgens de nieuwe depar- 
tementale indeling toegezonden. Aldus dient de administratie te Maastricht zorg te dragen voor de verzending naar Roermond en Venlo.

bo. volksrepresentanten bij het Noorder- en het Sambre-en-Maasleger

ao. conseil de gouvemement

s. J. Lefebure (de Nantes), Giroust; cs. J. Torfs (secr-prov)

RO nr.25: 27 brumaire IV (18 nov 1795)

RE nr.18: 28 brumaire IV (19 nov 1795)

- verwijzing naar: besluit comité de salut public van 14 fructidor III (31 aug 1795)

- besluit wordt vertaald in het Vlaams en naar de elf arrondissementsadministraties verstuurd en door hen naar de municipalitieiten; de nationale agenten bij de administraties dienen de goede ontwangst aan de conseil de gouvernement te berichten

\section{IV vendémiaire 22 (1795 okt 14)}

LA I fol 85vo-87vo; 175vo-177ro; FA nr.230; rH V 140-141; P VII xxvii-xxviii

\section{ARRÊTÉ INTERDISANT TOUTE VENTE, ALIÉNATION, ÉCHANGE OU HYPOTHĖQUE DES BIENS ECCLÉSIASTIQUES}

Kerkelijke goederen kunnen niet door de houders worden verkocht, vervreemd, geruild of met een hypotheek bezwaard, en kunnen voortaan slechts ten overstaan van een overheidsfunctionaris (personne publique) en door tussenkomst van de directeur der domeinen worden verpacht. Alle aflossingen aan leken- of kerkelijke instellingen zijn voorlopig opgeschort. Iedere seculiere of reguliere kerkelijke instelling moet binnen tien dagen een gedetailleerd overzicht van haar goederen en inkomsten ter hand stellen van de directeur der domeinen; in geval van nalatigheid worden die inkomsten in beslag genomen en voorlopig gesequestreerd. Aan de arrondissementsadministraties moeten zij een catalogus van hun boeken en manuscripten overhandigen; in geval van nalatigheid worden de bibliotheken verzegeld.

bo. volksrepresentanten bij het Noorder- en het Sambre-en-Maasleger

no. conseil de gonvernement

s. Giroust; cs. Delcambe (secr-prow)

ti. conseil de gowernement

RO nr. 13: 18 brumaire IV (9 nov 1795)

RE nr.7: 21 brumaire IV (12 nov 1795)

- het beslluit bekendgemankt overal waar dit nodig is

- geconsigneerd in de registers te Maastricht met de last tot wertalen en tweetalig drukken en naar alle gemeenten in het departement te verzenden

\section{IV vendémiaire 22 (1795 okt 14$)$}

BL Ie ser no. 193 (1159); drukw FA nr.30; rH VII 236-237; P VII 98; cB IIIe ser XXXIV 196-197

LOI PORTANT DÉFENSE À TOUS JUGES de PAIX ET OFFICIERS DE POLICE DE SURETÉ DE TRAdutre PARdevant un dIRECTEUR dE JURÉ AUCUN CITOYEN, SI CE N'EST DANS LES CAS Y ÉNONCÉS, ETC. 
Op straffe van een boete is het vrederechters en veiligheidsbeambten verboden burgers aan de directeur de juré voor te geleiden, tenzij zij zijn aangeklaagd wegens moord, doodslag, diefstal, aanslagen op de vrijheid en de openbare veiligheid ${ }_{\text {, }}$ en overige vergrijpen in de strafwetten omschreven. Mitsdien moeten verdachten binnen vierentwintig uur na bekendmaking van de onderhavige wet in vrijheid worden gesteld als het arrestatiebevel niet gemotiveerd is als boven is aangegeven. Alle akten van beschuldiging zijn dan ook nietig, wanneer zij niet stoelen op de aangeduide delicten als zodanig gespecificeerd in de strafwetten. De onderhavige wet derogeert niet aan eerdere wetten inzake de Chouans en andere opstandelingen in de westelijke departementen en het binnenland, alsmede die betrekkelijk de prêtres réfractaires en de samenzweerders van 13 vendémiaire IV (5 okt 1795).

\section{bo. Comvention nationale}

ao. comité de législation

vs. Lehault, Enjubault

cols. Génissieu (pres); Pons (de Verdun), Gleizal, Alex. Villetard, Auger (secr)

ti. gouvernementscommissaris Bouteville

RO nr.89(47): 16 nivôse JV (6 jan 1796)

RE nr.136: 14/15 floréal IV (3/4 mei 1796)

- verwijzing naar: "lois pénales"

- plaatsing in het bulletin de correspondance strekt tot bekendmaking

- wet per speciale koerier naar de departementen verzonden

- afkondiging: besluit volksrepresentanten/gouvemementscommissarissen s. Pérès, Portiez (de l'Oise);

24 frimaire IV (15 dec 1795)

\section{IV vendémiaire 23 (1795 okt 15)}

BL le ser no.197 (1176); LA I fol 231vo-233vo; FA nr.291; rH V 243-245; P VII 106-107; cB IIle ser XXXIV 215-217

\section{LOI SUR LES RÉCUSATIONS DES JUGES}

Een rechter of diens plaatsvervanger kan ongemotiveerd worden gewraakt door elke burgerlijke partij, elke beschuldigde, hetzij door hem- of hatarzelf, hetzij door zijn of haar gemachtigden (fondé de pouvoir). Een dergelijke wraking wordt een peremptoire wraking (récusation péremptoire) genoemd. In civiele zaken kan de wraking worden ingesteld tegen de rechters in hoogste aanleg van rechtbanken voor de koophandel en koopvaardij, die daarop zullen worden vervangen door rechters-plaatsvervanger of bij hun ontstentenis door kooplieden of reders, benoemd door niet-gewraakte rechters. Rechters van de departementale burgerlijke rechtbanken kunnen eveneens worden gewraakt. Wraking kan door één der partijen worden ingesteld tegen een rechter(plaatsvervanger) of gedelegeerd commissaris ter zake van het instellen van een onderzoek, ter zake van het opstellen van een proces-verbaal enzovoorts in het geval waarin er slechts sprake is van eerste aanleg, ofwel in laatste ressort. De andere partij kan de plaatsvervangende rechters wraken. In geen geval kunnen de ambtenaren van het openbaar ministerie worden gewraakt. De akte van wraking wordt door de griffier in persoon opgetekend, onder afgifte van een ontvangstbewijs. 
bo. Convention mationale

as. comité de législation

v8. Enjubault

colss. Génissiteu (pres). Pons (de Verdun). Gleizal (secr)

ti. ronseil de gowernement

RO nr.41: 5 frimaire IV (26 nov 1795)

RE nr.42: 13 frimaire IV (4 dee 1795)

- RO. RE en $\mathrm{HH}$ vermelden als datum wan uitwatrdiging 13 vendémiaire IV (5 okt 1795); $\mathrm{P}$ verwijst van 13 naar 23 vendérniaire IV (15 okt 1795)

- afkondiging: besluit volksrepresentanten s. Përès. Portiez (de I"Oise); cs. Torfs (secr-prov); 13 brumatire IV (4 nov 1795)

\section{IV vendémiaire 23 (1795 okt 15)}

BL le ser no. 195 (1170): LA IV fol 135 vo-136ro; drukw FA nr.111; rH X $\| 13-114$; P VII 105-106; cB llle ser XXXIV 217

LOI RELATIVE AU PAIEMENT DES ARRÉRAGES DES PENSIONS DUES AUX CREANCIERS DES PARENS DES GMIGRÉS DONT LA SUCCESSION EST OUVERTE AU PROFTT DE LA NATION

De uitbetaling van pensioenen - altijddurende dan wel levenslange - , verschuldigd aan de schuldeisers van de ouders van uitgewekenen wier nalatenschappen opengevallen zijn ten profijte van de staat, blijven uitgekeerd worden tot de definitieve vereffening van deze schuldvorderingen.

bo. Comention nationale

ao. comités de liquidation et de legislation

vs. Enjubault

cols. Génissieu (pres); Glcizal, Pons (de Verdun) (secr)

RO nr.210)(19): 23 vendémiaire $V(14$ okt 1796)

- verwijzing natar: wet van I floréal III (20 apr 1795)

- afkondiging: bestuit Dire'toire crécurf's. L.M. Revelliere-Lepeaux (pres), Lagarde (secr-gen); 10 fructidor IV (27 aug 1796)

\section{IV vendémiaire 23 (1795 okt 15)}

BL le ser no. 195 (1171); LA IV fol 136; drukw FA nr.111; $\mathrm{rH} \times 114-115$; $\mathrm{P}$ VII 106; cB IIle ser XXXIV 219

LOI QUI DETERMINE LES CAS DANS LESQUELS ON POURRA LIQUIDER SUR UN HERITIER EMIGRE LES CRÉANCES D'UNE SUCCESSION ACCEPTEE PAR CET HÉRITIER AVANT SON EMIGRATION

In geval een uitgewekene vóór zijn emigratie als erfgenaam een nalatenschap zonder meer heeft aanvaard, kan de vereffening met de schuldeisers ter zake van de nalatenschap rechtstreeks platatsvinden, aangenomen dat de debiteur solvent is. Wanneer er sprake is van aanvaarding van de nalatenschap onder voorrecht van boedelbeschrijving worden de schuldvorderingen ter zake van de nalatenschap vereffend als bepaald in de 
wet van I floréal III (20 apr 1795). De schuldeisers van de geèmigreerde zijn gerechtigd de vereffening der schuldvorderingen ter zake van de nalatenschap geheel of gedeeltelijk te vorderen. Zij zijn voorts gehouden met oorspronkelijke stukken te bewijzen dat de erfgenaam recht had op de nalatenschap.

bo. Convention mationale

ao. comités de liquidation et de législation

vs. Enjubault

cols. Génissieu (pres); Gleizall, Pons (de Verdun) (secr)

RO nr.210(20): 23 vendémiaire $V(14$ okt 1796)

- verwijzing naar: wet van I floréal III (20 apr 1795)

- afkondiging: besluit Directoire execurif s. L.M. Revellière-Lépeaux (pres), Lagarde (secr-gen); 10 fructidor IV (27 aug 1796)

\section{IV vendémiaire 25 (1795 okt 17)}

BL le ser no.197 (1179); LA I fol 234; FA nr.291; rH V 246; P VII 108; cB IIle ser XXXIV 216

\section{LOI QUI SUSPEND TOUTE CONTESTATION AYANT POUR OBJET LA RÉSILIATION D'UNE YENTE JUDICIELLE, ETC.}

Alle rechtszaken in hoger beroep tegen vonnissen inzake de verkoop of toewijzing bij decreet, waarin nog geen nadere uitspraak is gedaan, blijven voorlopig opgeschort. Dit geldt eveneens met betrekking tot geschillen aangaande de ontbinding van een gerechtelijke verkoop, waartegen men niet vóór de inwerkingtreding van het decreet van 4 nivôse III ( 24 dec 1794), welke de wet inzake het maximum van de prijzen van levensmiddelen en koopwaar herroept, in beroep is gekomen.

bo. Convention nationale

ao. comité de législation

vs. Enjubault

cols. Génissieu (pres): Pons (de Verdun), Alex. Villetard (secr)

ii. conseil de gouvernement

RO nr.42: 5 frimaire IV (26 nov 1795)

RE nr.43: 13 frimaire IV (4 dec 1795)

- verwijzing naar: decreet van 4 nivôse III (24 dec 1794); besluit volksrepresentanten van 16 thermidor III (3 aug 1795)

- wet uitgevaardigd n.a.w. een petitie van de burger Bonnegens

- plaatsing in het bulletin de correspondance strekt tot promulgatie

- afkondiging: besluit volksrepresentanten s. Pérès, Portiez (de l'Oise); $\mathrm{cs}$. Torfs (secr-prov): 13 brumaire IV (4 nov 1795)

IV vendémiaire 26 (1795 okt 18$)$

LA I fol 200ro-202ro; FA nr.291; rH V 144-145

ARRÊTÉ CONCERNANT LES INDEMNITÉS À ACCORDER AUX CORPORATIONS DONT LES DÎMES ONT ÉTÉ MISES EN PRÉEMPTION 
Religieuze instellingen die niet meer het genot hebben van de opbrengst van de dimes (tienden) voor hun levensonderhoud als gevolg van het recht van voorkoop (droit de préemption) voor de Franse staat, kunnen zich tot de arrondissementsadministraties wenden voor een schadeloosstelling. Een dergelijke vergoeding is er eveneens voor pastoors, maar mag het jaarlijkse bedrag van 2000 livres per geval, uitgekeerd in muntgeld, niet overschrijden.

bo. volksrepresentanten bij het Noorder- en het Sambre-en-Maasleger

ao. consell de gowvernement

s. Giroust; cs. Delcambe (secr-prov)

ti. conseil de gouvernement

RO nr.28: 27 brumaire IV (18 nov 1795)

RE nr.21: 28 brumaire IV (19 nov 1795)

- verwijzing naar: besluit volkstepresentanten van 16 thermidor III ( 3 aug 1795)

\section{IV vendémiaire 26 (1795 okt 18)}

LA I fol 202ro-203vo; FA nr.29l; rH V 146-147

\section{ARRÊTÉ QUI INTERDIT AUX CORPORATIONS RELIGIEUSES TOUTES COUPES, ABATIS OU ENLEVEMENT DANS LEURS BOIS SANS AUTORISATION PREALABLE}

Kerkelijke en overige religieuze gemeenschappen is het verboden om hout te kappen in hun bossen en aanplant, zonder voorafgaande speciale toestemming van de volksrepresentanten. De municipaliteiten dienen op de naleving van dit verbod toe te zien. In geval van overtreding volgt de verbeurdverklaring van de opbrengst en de verdeling en verkoop van het desbetreffende bosareaal.

bo. volksrepresentanten bij het Noorder-en het Sambre-en-Maasleger

ao. conseil de gouvernement

s. Giroust; cs. Delcambe (secr-prov)

ti. conseil de gouvernement

RO nr.29: 27 brumaire IV (18 nov 1795)

RE nr.22; 28 brumaire IV (19 nov 1795)

- verwijzing naar: beshuiten volksrepresentanten van 4 jour complémentaire II (20 sep 1794); 8 frimaire III (28 nov 1794); 13 germinal III (2 april 1795)

- besluit gezonden aan de arrondissementsadministraties en door hen naar de municipaliteiten on te worden bekendgemakt

\section{IV vendémiaire 27 (1795 okt 19)}

BL le ser no.197 (1181); LA I fol 234vo-235vo; FA nr.291; rH V 246-247; P VII 109; cB IIle ser XXXIV 233

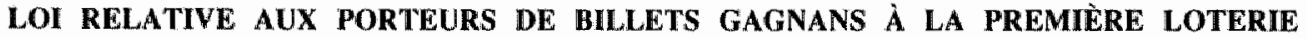 NATIONALE, DE MAISONS, MEUBLES ET EFFETS}

Houders van winnende loten van de eerste nationale loterij - huizen, roerende goederen en dergelijke omvattende - dienen binnen zes maanden na publicatie van deze wet 
te reclameren. Na die datum vervallen alle aanspraken en vervalt het object van het lot aan de staat. De termijn van zes maanden geldt verder voor iedere trekking van de loterij.

bo. Convention nationale

ao. comité des finances, section des domaines

ws. Lehault

cols. Génissieu (pres); Pons (de Verdun), Alex. Villetard (secr)

ti. conseil de gouvernement

RO nr.43: 5 frimaire IV (26 nov 1795)

RE nr.44: 13 frimaire IV ( 4 dec 1795 )

- verwijzing naar: wet van 29 germinal III (18 apr 1795)

- plaatsing in het bulletin de correspondance strekt tot promulgatie

- afkondiging: besluit volksrepresentanten s. Pérès, Portiez (de l'Oise); cs. Torfs (secr-prov); 13 brumaire IV (4 nov 1795)

IV vendémiaire 28 (1795 okt 20)

LA I foll 203vo-204vo; FA nr.291; $\mathrm{rH}$ V 148-149

\section{ARRÉTÉ PORTANT QUE LES VENTES DES bOIS NATIONAUX SE FERONT DORENAVANT EN NUMÉRAIRE MÉTALLIQUE}

De verkoping van de nationale bossen geschiedt voortaan in muntgeld. De kopers voldoen een derde deel contant aan de ontvanger van de nationale domeinen ter verkrijging van een kapvergunning. Indien een koper wat de verdere betaling betreft in gebreke blijft, heeft er opnieuw een veiling van het totale bosareaal plaats.

bo. volksrepresentanten bij het Noorder-en het Sambre-en-Maasleger

ao. conseil de gowvernement

s. II. le Febvre (de Nantes), Giroust; cs. Delcambe

ti. conseil de gouvernement

RO nr.30: 27 brumaire IV (18 nov 1795)

$\mathbb{R E}$ nr.23: 28 brumaire IV (19 nov 1795)

- verwijzing naar: besluit wan de comités de salut public en des finances van I fructidor III (18 aug 1795)

IV vendémiaire 29 (1795 okt 21)

LA I fol 71; FA nr.228; rH V 149-150

ARRÊTTÉ ORDONNANT AUX ADMINISTRATIONS D'ARRONDISSEMENT D'ASSIGNER À CHACUN DES MARCHÉS PUBLICS DE LEUR RESSORT UN ARRONDISSEMENT QUI SERA TENU DE L'APPROVISIONNER AU BESOIN

De arrondissementsadministraties bepalen het ressort waarbinnen bij onvoldoende bevoorrading van de bestaande markten de municipaliteiten kunnen vorderen. 
bo. volkstepresentanten dans les départemens nowvellement rếunis

ao. conseil de gouvernement

8. Giroust; cs. J. Torfs (secr-prow)

ti. volkstepresentanten

RO nr. 7: 30 vendérmiaire an IV (22 okt 1795)

- verwijzing naar: wet van 7 vendémiaire IV (29 sep 1795)

\section{IV vendémiaire 30 (1795 okt 22)}

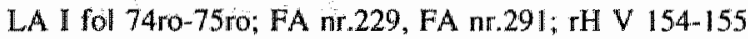

\section{ARRETE SUR LES PANS D'ABBAYE}

De lijfrente (pension viagère), bekend onder de naam pain d'abbaye (abtsbrood), die door het voormalige Oostenrijkse bewind aan diverse personen toegekend is, zal voorlopig blijven worden uitgekeerd. De abdijen kunnen zich niet aan hun verplichtingen in dezen ontrekken onder het voorwendsel dat de Republiek hun tiende (dixme) op de laatste oogst heeft genoten krachtens het recht van voorkoop (droit de préemption). Tegenwerking van de zijde der abdijen zal gerechtelijk worden beoordeeld. Reclamanten van een dergelijke toelage dienen binnen Frankrijk woonachtig te zijn.

bo. volksrepresentanten bij het Noorder-en het Sambre-en-Maasleger

ao. consell de gouvernement

s. Giroust; cs. J. Torfs (secr-prov)

ti. volksrepresentant

RO nr.8: 14 brumaire IV (5 now 1795)

RE nr.5: 4 brumaire IV (26 okt 1795)

\section{IV vendémiaire 30 (1795 okt 22$)$}

LA I fol 205ro-206vo; FA nr.291; rH V 152-153; P VII xxix

\section{ARRẾté SUR LE MODE D'APPEL des CAUSES DÉCIDÉES PAR LES ANCIENS TRIBU- NAUX DES DÉPARTEMENTS RÉUNIS}

Hoger beroep staat open bij de binnenkort in te stellen nieuwe rechtbanken aangaande de vonnissen van de vroegere lagere rechtbanken die nog niet in kracht van gewijsde zijn gegaan, aangaande de vonnissen van hogere rechtbanken waarvan de in het ongelijk gestelde partij algehele revisie verlangt, vooropgesteld dat de voorgeschreven termijnen niet zijn verstreken, aangaande de vonnissen die na de dagtekening van dit besluit zijn uitgesproken, en aangaande de vonnissen die kracht van gewijsde hebben, maar waartegen men wettig de opheffing van het verstrijken van termijnen heeft verkregen. Krachtens het onderhavige besluit zijn alle rechters verplicht, op straffe van nietigheid, hun uitspraken te motiveren. Hoger beroep of herziening heeft geen opschortende werking. Kerkelijke en academische jurisdicties zijn opgeheven en aanhangige geschillen worden ter kennisneming gebracht van de nieuwe rechtbanken. Geen enkel vonnis van deze oude jurisdicties kan worden uitgevoerd, tenzij de nieuwe rechtbanken het vonnis hebben bevestigd. 
bo. volksrepresentanten en mission dans les noweaux départemens réunis

ao. consell de gouvernement

s. Giroust; cs.J. Torfs (secr-prov)

ti. consell de gouvernement

RO nr. 31: 27 brumaire IV (18 nov 1795)

RE nr.24: 30 brumaire IV (21 nov 1795)

- onderhavig besluit aan de arrondissementsadministraties gezonden, door hen atan de rechtbanken en de mumicipaliteiten teneinde te worden bekendgemaakt

\section{IV brumaire 2 (1795 okt 24)}

BL le ser no.20» (1198); LA II fol 87vo-90vo; FA nr.234; rH VI 63-68; P VII $\| 22-126$; cB IIIe sr XXXV $7-12$

\section{LOI CONCERNANT L'ORGANISATION DU TRIBUNAL DE CASSATION}

Het tribunal de cassation wordt door 50 rechters gevormd, die zich in drie secties opdelen. De eerste sectie oordeelt over de toelating dan wel de afwijzing van de cassatieverzoeken, over prise à partie [=het dagvaarden door de veroordeelde van de verantwoordelijke rechter onder bepaalde omstandigheden, die slecht of foutief zou hebben gevonnist], over de relatieve competentie en over de terugverwijzing naar een andere rechtbank. De lweede en derde sectie doen na toelating van een cassatieverzoek uitspraak in eis tot cassatie, terwijl de derde sectie alleen oordeelt over de eisen tot cassatie in criminele, correctionele en politiezaken. De wet geeft verder de bepalingen over de procedure en hetgeen moet gebeuren na de uitspraak tot cassatie in civiele zaken. Voorts wordt het overige bij het tribunal de cassation werkzame personeel nader aangeduid. Het tribunal de cassation dient zich te houden aan het reglement van 28 juni 1738 en anterieure wetten betrekkelijk het tribunal, voor zover deze niet derogeren aan de onderhavige.

bo. Convention nationale

Ws. Enjubault

cols. Génissieu (pres): Pons (de Verdun), Alex. Villetard (secr)

ti. volksrepresentanten/gouvernementscormmissarissen

RO nr.81(1): I nivôse IV (22 dec 1795)

RE nr.99: $11 / 12$ ventôse IV (1/2 mrt 1796)

* verwijzing naar: reglement van 28 juni 1738; "lois antérieures" inzake het wibunal de cassation

- afkondiging: besluit volksrepresentanten s. Pérès; 16 frimaire IV (7 dec 1795)

\section{IV brumaire 2 (1795 okt 24$)$}

BL Ie ser no.201 (1200); drukw FA nr.1I2; rH IX 250-25I; P VII 126; cB IIIe ser XXXV 12-13

\section{LOI ADDITIONNELLE À CELLE dU 9 MESSIDOR SUR LE CODE HYPOTHÉCAIRE}

De opheffing van de districtsbesturen en -rechtbanken als gevolg van de nieuwe grondwet is niet van invloed op het aantal en de vestiging van de hypotheekbewaarders (conservateurs particuliers des hypothèques). Het Directoire exécutif, en tot zijn installatie de regeringscomités, bepaalt/bepalen de plaats en vestiging van de kantoren 
der hypotheekbewaarders. De registratie en betaling van de kohierrechten moet op het dichtstbijzijnde kantoor van de inning der registratierechten geschieden. In geval van plotselinge en onvoorziene waardevermindering van geceduleerde onroerende goederen is de hypotheekbewaarder na opeising van de celen slechts aansprakelijk tot het beloop van de waardevermindering.

bo. Comvention nationale

ao. comités de salut public et des finances, réunis

vs. Enjubault

cols. Doulcet (ex-pres); Pons (de Verdun) (secr), Boudin (ex-secr)

ti. minister van justitie Genissieu

RO nr.1 15: 6 germinal IV (26 mrt 1796)

RE nr.164: 26/27 thermidor IV (13/14 aug 1796); tweetalig

- werwijzzing naar: code hypothécaire van 9 messidor III (27 jun 1795); grondwet van 5 fructidor III (22 aug 1795)

- afkondiging: besluit Directoire exécutif s. Le Tourneur (pres), Lagarde (secr-gen); 2 ventôse IV (21 feb 1796); met dien verstande dat deze wet van kracht wordt op 1 floréal IV (20 apr 1796)

\section{IV brumaire 3 (1795 okt 25)}

BL Ie ser no.203 (1217); LA I fol 90vo-9Ivo; P VII 138 -139; rH V 249-250; cB IIle ser XXXV 111

LOI PORTANT QUE LES DISPOSITIONS DE L'ARTICLE IX DE CELLE DU 9 VENDÉMLAIRE SONT APPLICABLES À TOUS lES PAYS RÉUNIS PAR CETTE LOI AU TERRITOIRE DE LA FRANCE

De volksrepresentanten benoemen voorlopig de functionarissen van de arrondissementsadministratie, van de kantons en van de rechtbanken in de départements réunis. De besluiten van het comité de salut public en de volksrepresentanten, voor zover er door hen niet is van afgeweken, blijven van kracht, tot het in werking treden van de Franse wetgeving. Zij zorgen ook voor de inning van de gewone belastingen en de buitengewone heffingen.

bo. Convention nationale

ao. comire de salut public

vs. Enjubault

cols. Génissieu (pres); Pons (de Verdun), Alex. Villetard, Auger (secr)

ti. conseil de gouvernement.

RO nr. 17: 22 brumaire IV (13 nov 1795)

RE nr. 14: 23 brumaire IV (14 nov 1795)

- afkondiging: besluit volksrepresentanten s. Pérès, Portiez (de 1'Oise); 17 brumaire IV ( 8 nov 1795)

\section{IV brumaire 3 (1795 okt 25 )}

BL Ie ser no.199 (1193); LA I fol 158ro-162ro; FA nr.291; rH V 217-220; P VII 132-133; cB IIle XXXV 104-107 
Degenen die in de assemblées primaires of assemblées électorales ondermijnende maatregelen hebben uitgelokt of ondertekend, kunnen tot het herstel van de algehele vrede geen openbare functies vervullen. Een ieder die op de lijst van uitgewekenen staat en daarvan niet is afgevoerd, evenals hun familieleden, is (zijn) ook uitgesloten van openbare ambten. Wanneer men toch een publieke functie op zich neemt en die niet terstond neerlegt, wordt men bestraft met levenslange verbanning. Elke verrichte handeling wordt nietig verklaard. Functionarissen dienen schriftelijk te verklaren dat zij zich niet met bovengenoemde ondermijnende maatregelen hebben ingelaten, noch dat zij verwanten hebben onder de uitgewekenen. Als men niet onder de heerschappij van de Franse wetten wil leven en zich daaraan niet wenst te conformeren, dient men Frankrijk binnen drie maanden te verlaten zonder er ooit te mogen terugkeren.

bo. Convention nationale

ao. commission des cinq

vs. Enjubault

cols. Génissieu (pres); J.F. Philippe Delleville, Auger (secr)

ti. conseil de gouvernement

RO nr.21(12): 26 brumaire IV (17 nov 1795)

RE nr.29: \# frimaire IV (22 nov 1795)

- werwijzing naar: wet van 22 fructidor III ( 8 sep 1795)

- wetten uit 1792 en 1793 inzake gedeporteerde of afgezonderde priesters moeten binnen 24 uur na afkondiging (promulgatie) van dit decreet worden ten uitvoer gelegd; de besluiten van de comités van de Convention nationale en van uitgezonden volksrepresentanten hiermee strijdig zijn vernietigd

- plaatsing van het decreet in het bulletin strekt tot bekendmaking; het decreet, alsmede het rapport van de commission des cinq, wordt met buitengewone koeriers naar de departementen en de legers overgebracht

- afkondiging: besluit volksrepresentanten/gouvernementscommissarissen s. Pérès, Portiez (de l'Oise); 8 brumaire IV (30 okt 1795)

\section{IV brumaire 3 (1795 okt 25)}

BL Te ser no.202 (1208); LA II fol 23vo-26ro; FA nr.233; rH V 410-414; cB IIIle ser XXXV 107-110

\section{LOI SUR LES COSTUMES DES LÉGISLATEURS ET DES AUTRES FONCTIONNAIRES PUBLICS}

De ambtskostuums van de diverse autoriteiten dienen van in Frankrijk vervaardigde stoffen te zijn gemaakt en daarbij tevens van Franse makelij te zijn. Voor de onderscheidene bestuurlijke en gerechtelijke autoriteiten is een apart kledingsvoorschrift opgesteld. Vrederechters dragen geen ambtskleding, maar alleen enige onderscheidingstekenen, zoals een manshoge staf. Municipale bestuurders dragen alleen een driekleurige sjerp.

bo. Convention nationale

ao. comité d'instruction publique

vs. Enjubault

cols. Baudin (des Ardennes) (ex-pres); Bouret, J.B.D. Mazade (ex-secr)

ti. volksrepresentanten/gouvernementscommissarissen

RO nr.69: 25 frimaire IV (16 dec 1795) 
RE n.64: $13 / 14$ nivôse IV (3/4 jan 1796)

* afkondiging: besluit volksrepresentanten s. Pérès. Portiez (de l'Oise); 8 frimaire IV (29 nov 1795)

\section{IV brumaire 3 (1795 okt 25)}

BL le ser no.204 (1221); drukw FA nr.29, nr.30; rH VII 4-120; P VII 164-217; cB IIIe ser XXXV: $111-219$

\section{CODE DES DELLTS ET DES PEINES}

De code omvat, naast een vifftiental preliminaire bepalingen met algemenere beginselen, drie boeken onderverdeeld in titels. De gehele scala van straf- en strafprocesrechtelijke phenomena wordt hierin behandeld: de rechtshandhaving, de rechtspleging door de diverse gerechtelijke instanties en de strafmaat voor de onderscheidene delicten. De code eindigt met de bij de rechtspleging gehanteerde formulieren (modèles).

\section{bo. Comemion nationale}

vs. Enjubault

cols. Genissieu (pres); Gleizal, Auger (secr)

ti. gouvernementscommissaris Bouteville

RO nr.89(1): 16 nivôse IV (6 jan 1796)

RE nr.136: $\| 4 / 15$ floréal IV (3/4 mei 1796)

- verwijzing naar: ordonnantie van 1669 ; wetten van 19 jul 1791, 16 sep 1791, 28 sep 1791, 29 sep 1791, 30 prairial III (18 jun 1795), 20 messidor III (8 jul 1795); wetten inzake militaire delicten en rebellen; code pénal van 25 sep 1791; grondwet van 5 fructidor III (22 aug 1795)

- afkondiging: besluit volksrepresentanten/gouvernementscommissarissen s. Pérès. Portiez (de l'Oise);

24 frimaire IV (15 dec 1795)

\section{IV brumaire 3 (1795 okt 25)}

BL Ie ser no.201 (1202); LA IV fol 136vo-138ro; drukw FA nr.111; rH X 115-117; P VII 133-134; cB Ille ser XXXV $90-92$

\section{LOI PORTANT QUE LA LIQUIDATION DE LA DETTE PUBLIQUE, ET CELLE PARTICU- LIERE DE LA DETTE DES EMIGRÉS, CONTINUERONT À ETTRE ORGANISEES EN ADMI- NISTRATION SÉPARÉE}

De vereffening van de openbare schuld en de bijzondere vereffening van de schuld der uitgewekenen blijft afzonderlijk georganiseerd, onafhankelijk van het ministerie; de liquidateurs zijn wel afhankelijk van het ministerie van financiën. Met betrekking tot de vereffeningen worden er twee staten opgesteld, de ene van zodanige vereffeningen af te handelen als inschrijvingen op het grootboek der nationale schuld, de andere die slechts aanleiding geeft tot de erkenning van de vereffening. Het Corps législarif voteert jaarlijks het budget van het vereveningsfonds, na daartoe te zijn geïnformeerd door het Directoire exécutif. De minister van financièn is belast met de uitspraak inzake klachten van schuldeisers tegen de beide administraties ingebracht ter zake van de vereffeningen. Bovendien viseert hij de reconnaissances de liquidation of de certificats de propriété, ofschoon de beide administraties de vereveningen op eigen 
verantwoordelijkheid afhandelen. De bepalingen van deze wet zijn verbindend voor de departementale besturen, voor zover zij belast zijn met de vereffening van de schulden van de uitgewekenen in hun ressort.

bo. Comvention nationale

vs. Enjubault

colls. Merlin (de Douai) (ex-pres); Pons (de Verdun) (secr), F. Lanthenas (ex-secr)

RO nr.210(21): 23 vendémiaine $V$ (14 okt 1796)

- verwijzing naar: wet van \& floréall 111 (20 apr 1795); "lois existantes"

- afkondiging: besluit Directoire exécuiff s. L.M. Revelliere-Lépeaux (pres), Lagarde (secr); 10 fructidor IV (27 aug 1796)

\section{IV brumaire 4 (1795 okt 26$)$}

LA If fol 75ro-77ro; FA nr.229; rH V 157-159

\section{ARRÊTÉ CONCERNANT LES ÉTRANGERS}

De oude reglementen en ordonnanties betreffende het onderdak verlenen aan vreemdelingen blijven van kracht, voor zover zij geen inbreuk maken op wetten van de Republiek. Binnen 24 uur na publicatie van dit besluit moeten alle inwoners die onderdak verlenen aan vreemdelingen op het bureau van de nationale agent bij de municipaliteit en aan de plaatselijke commandant een verklaring overhandigen, aangevende straat en huisnummer, en die verder de (voor)namen, leeftijd, geboorteplaats, gewone verblijfplaats, beroep en de hoedanigheid van de bij hen verblijvende vreemdelingen bevat. Eveneens moet worden aangegeven of zij voorzien zijn van een paspoort en sinds wanneer zij aldaar verblijven. Het hieraan niet-voldoen wordt beboet. Degenen die helemaal geen verklaring overleggen, worden verantwoordelijk gehouden voor alle delicten door bij hen logerende vreemdelingen gepleegd en vervolgd als medeplichtige. Voortaan dient een ieder die één of meer gasten heeft, al is het maar voor eén nacht, vóór tien uur 's avonds de hierbovenbedoelde verklaring op het bureau van de nationale agent te overhandigen. Logementshouders moeten voorts een register van de gasten bijhouden en dit om de veertien dagen aan de autoriteiten tonen.

bo. volksrepresentanten

ac. conseil de gouvernenent

s. Lefebvre (de Nantes); cs. J. Torfs (secr-prov)

ti. conseil de gourernement

RO nr.9: 14 brumaire IV (5 nov 1795)

$\mathbb{R E}$ nr.6: 15 brumaire IV (6 nov 1795 )

- verwijzing naar: wet van 10 vendemiaire IV ( 2 okt 1795)

- besluit toegezonden aan de arrondissementsadministrat les teneinde bekendgemaakt te worden overal waar ditt nodig is

\section{IV brumaire 4 (1795 okt 26)}

BL, le ser no.202 (1215); LA I fol 246ro-249ro; FA nr.291; rH V 326-329; P VII 222-223; cB liIJe ser XXXV 244-246 
Hogere officieren vanaf de rang van bataljons- of escadronscommandant zijn niet langer onderworpen aan tuchtraden. Hun krijgstuchtelijke vergrijpen worden bestraft door officieren hoger in rang. De opgelegde straffen moeten worden gerapporteerd aan de bevelvoerend commandant. De minister van oorlog kan van rechtswege klachten van veroordeelden hieromtrent nader beoordelen. Door opperofficieren gepleegde delicten worden door krijgsraden, in wisselende samenstelling , afhankelijk van de rang van de verdachte, berecht.

bo. Convention nationale

ao. comités de salut public; et militaire

ws. Enjubaulit

cols. Brtard (ex-pres); Gleizal (secr), Roger-Ducos (ex-secr)

ti. volksrepresentanten/gouvernementscommissarissen

RO nr.47(1): 9 frimaire IV (30 nov 1795)

RE nr.46: 14 frimaire IV ( 5 dec 1795)

- verwijzing naar: wet van 2 jour complémentaire III (18 sep 1795), de bepalingen van deze wet blijven van kracht, yoor zover de onderhavige daaraan niet derogeert

- platsing in Bulletin strekt tot promulgatie

- afkondiging: besluit volksrepresentanten s. Pérès, Portiez (de l'Oise); cs. Delcambe (secr-gen); 26 brumaire IV (17 nov 1795); als additionele artikelen, zonder datum van uitvaardiging, bij de wet van 2 jour complementaire III (18 sep 1795 )

\section{IV brumaire 4 (1795 okt 26$)$}

BL Ie ser no.202 (12\|1); LA II fol 26vo-27vo; FA nr.233; rH V 414-416; P VII 221; cB IIIe ser XXXV 232-233

LOI QUI COMPREND DANS LES DISPOSITIONS DE CELLE DU 7 VENDEMIAIRE LES ACHATS DE FOIN, DE PAILLE ET AVOINE POUR LA SUBSISTANCE DES CHEVAUX DES ARMÉES

Directeuren der bevoorrading van legerdivisies, onder controle van de commission de l'organisation et du mouvement des armées de terre, kunnen beambten belasten met het verrichten van aankopen voor het leger in één of meerdere departementen. De bevoegdheden en commissies dienen door de departementen te worden geregistreerd. Bij de aankoop van stro, hooi en haver bestaan er geen limieten en zij hebben een looptijd van oogst tot oogst. Dit in tegenstelling tot de door particulieren - postmees-

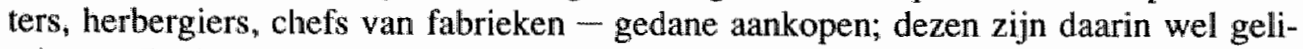
miteerd. De bevoegdheden ter zake van de vroegere commission d'approvisionnement en de voor haar werkzame agenten zijn opgeheven. De commission de l'organisation et du mouvement des armées de terre is speciaal met de uitvoering van de onderhavige wet belast.

bo. Convention nationale

vs. Enjubault

cols. Breard (ex-pres); Gleizal (secr), Roger-Ducos (ex-secr) 
ti. volksfepresentanten/gouvemementscommissarissen

RO nr.70, 1): [25 frimaire IV (16 dec 1795)]

RE nr.65: $13 / 14$ nivôse IV (3/4 jan 1796)

- verwijzing naar: wet van 7 vendémiaire IV (29 sep 1795)

- afkondiging: besluit volksrepresentanten s. Portiez (de l'Oise) 5 frimaire IV (26 nov 1795)

\section{IV brumaire 4 (1795 okt 26)}

BL. Ie ser no.202 (1214); LA II fol 28; FA nr.233; rH V 416-417; P VII 221-222; cB IIle ser XXXV $233-234$

\section{LOI QUI AUTORISE LES CULTIVATEURS À SE POURVOIR DE GRAINS POUR LE RE- NOUVELLEMENT DES SEMENCES}

Boeren is het toegestaan om zich van zaaikoren te voorzien, daar waar het hun goeddunkt. Daartoe dienen zij zich van een vergunning te voorzien, afgegeven door het departementale bestuur, nadat de noodzaak ervan is vastgesteld. De vergunning vermeldt de hoeveelheid aan te kopen koren. De municipaliteit waar de aankoop plaatsheeft, controleert één en ander. In de plaats van bestemming geeft de municipaliteit aldaar een kwijting af, welke weer opgevraagd kan worden door de municipaliteit waar het graan is aangekocht. Burgerlijke gasthuizen hebben ook de bevoegdheid om buiten de markt om graan te kopen.

bo. Convention mationale

vs. Enjubault

cols. Bréard (ex-pres); Gleizal (secr), Roger-Ducos (ex-secr)

ti. volksrepresentanten/gouvernementscommissarissen

RO nr.70(2): [25 frimaire IV (16 dec 1795)]

RE nr.65: $13 / 14$ nivôse IV (3/4 jan 1796)

- werwijzing naar: wet van 7 vendémiaire IV (29 sep 1795)

- platatsing in het bulletin de correspondance strekt tot bekendmaking

- afkondiging: besluit volksrepresentanten s. Portiez (de l'Oise); 5 frimaire IV (26 nov 1795)

\section{IV brumaire 4 (1795 okt 26)}

BL Ie ser no.202 (1210); LA II fol 29; FA nr.233; rH V 417-418; P VII 220-221; cB IIle ser XXXV 238-239

LOI RELATIVE AU TRAITEMENT DES HAUTS-JURES, DES MEMBRES DU TRIBUNAL DE CASSATION, DES JUGES DES TRIBUNAUX CIVILS, DES COMMISSAIRES DU DIRECTOIRE EXÉCUTIF, ETC.

De bezoldiging van rechters en van de commissarissen van het Directoire exécutif bij de diverse gerechtshoven en rechtbanken ligt in het algemeen op hetzelfde niveau als die van de onderscheidene bestuursfunctionarissen. Vrederechters worden gesalarieerd in de vorm van een zekere hoeveelheid tarwe. De bezoldiging van publieke functionarissen, vastgesteld in een hoeveelheid tarwe, wordt niet in natura uitbetaald, maar in het equivalent daarvan in geld. 
bo. Convemion nationale

vs. Enjubault.

cols. Bréard (ex-pres); Gleizal (secr), Roger-Ducos (ex-secr)

ti. volksrepresentanten/gowwernementscommissarissen

RO nr.71: 25 frimaire IV (16 dec 1795)

RE nr.66: 13/14 nivôse IV (3/4 jan 1796)

- afkondiging: besluit volksrepresentanten s. Pérès, Portiez (de l'Oise); 8 frimaire IV (29 nov 1795)

\section{IV brumaire 4 (1795 okt 26)}

BL Ie ser no.201 (1206; LA II fol 90vo-91 ro; FA nr.234; rH VI 68; P VII 220; cB IIIe ser XXXV 246

LOI RELATIVE AU MODE D'ELECTION DES PRÉSIDENS DES TRIBUNAUX CIVILS DES DEPARTEMENS, ET A LA DUREE DE LEURS FONCTIONS

De departementale burgerlijke rechtbanken zijn onderverdeeld in secties. Elke sectie kiest zijn eigen voorzitter, die als zodanig blijft fungeren toldat de sectie wordt vernieuwd.

\section{bo. Convention nafionale}

ao. commission des onze

vs. Enjubault

cols. Merlin (de Douai) (ex-pres); Pons (de Verdun) (secr), F. Lanthenas (ex-secr)

ti. volk.srepresentanten/gouvernementscommissarissen

RO nr.81(2): 1 nivôse IV (22 dec 1795)

RE nr.99: 11/12 ventôse IV (1/2 mrt 1796)

- de onderhavige wet herroepen bij de wet van 27 ventôse [V (17 mrt 1796) [RO nr.148(4)]

- afkondiging: besluit volksrepresentanten s. Pérès; 16 frimaire IV ( 7 dec 1795)

\section{IV brumaire 4 (1795 okt 26)}

drukw FA nr.30; rH VII 239-240; P VII 223-224; cB. IIIe ser 236-238

LOI CONCERNANT L'ABOLITION DES PROCEDDURES POUR FAITS PUREMENT RELATIFS À LA REVOLUTION, ET DE PEINE DE MORT, A DATER DU JOUR DE LA PAIX GENERALE

Op de dag der bekendmaking van de algehele vrede wordt de doodstraf in de Franse Republiek afgeschaft. Tevens worden alle gerechtelijke procedures beëindigd inzake strafbare handelingen in verband met de revolutie begaan. De straffen evenwel, genoemd in de code pénal zullen wel worden opgelegd, ook als er sprake is van meerdere strafbare feiten in één aanklacht. Het Directoire exécutif kan de bekendmaking van deze wet in opstandige departementen uitstellen. Voorts zijn enkele categorieën delinquenten formeel van de amnestie uitgezonderd, zoals de samenzweerders van vendémiaire IV, gedeporteerde priesters, valsemunters en uitgewekenen.

bo. Cowrention nationale

ao. commission des onze" 
ti. gouwemementscommissaris Bouteville

RO nr.89(48): 16 nivôse IV (6 jan 1796)

RE nr.136: 14/15 floréal IV (3/4 mei 1796)

- verwijzing naar: code pénal van 25 sep 1791; wet van 3 brumaire IV (25 okt 1795)

- $P$ vermeldt uitdrukkelijk dat deze wet niet geplaatst is in bet Bullerin

- afkondiging: besluit volksrepresentanten/gouvernementscommissarissen s. Perès, Portiez (de l'Oise);

24 frimaire IV (15 dec 1795 )

IV brumaire 8 (1795 okt 30$)$

LA I fol 80; FA nr.230; $\mathrm{rH}$ V 166

\section{ARRÊTÉ QUI SUSPEND PROVISOIREMENT TOUTES LES CONTESTATIONS ÉLEVÉES ENTRE LES CORPS DE MÉTIERS OU JURANDES ET LEURS SUPPÔTS OU ASPIRANS}

De behandeling van de geschillen welke gerezen zijn tussen ambachtsgilden en de gezellen bij die gilden wordt voorlopig opgeschort. Rechters is het verboden dergelijke aanhangige zaken af te handelen.

bo. volksrepresentanten/gouvernementscommissarissen

ao. conseil de gouvernement

5. Pérès, Portiez (de l'Oise); cs. J. Torfs (secr-prov)

RO nr. 10: 18 brumaire IV (9 nov 1795)

RE nr.9: 21 brumaire IV ( 12 now 1795)

- besluit uitgevaardigd n.a.v een groot aantal dagelijkse reclamaties

\section{IV brumaire 8 (1795 okt 30)}

LA I fol 87 vo-88vo; FA nr.230; rH V 222-223

\section{[extract] ARRÊTÉ PORTANT QUE LES BRIGANDS SAISIS SERONT JUGÉS PAR DES CONSEILS MILITAIRES}

Gewapende bendes bandieten die roven en moorden en zich ophouden in de bossen, met name in het Forêt de Soigne[s] [het Zoniënbos, zuidoostelijk van Brussel], en her en der medestanders recruteren, zullen voor krijgsraden worden gebracht. Deze zullen waar dit nodig is, worden ingesteld.

bo. comitế de salut public

s. (à la minute) Merlin (de Douai), Marec, T. Berlier, Le Tourneur (de la Manche), J. de Bry

ti. conseil de gouvernement

RO nr. 14: 21 brumaire IV (112 nov 1795)

RE nr.11: 21 brumaire IV (12 nov 1795)

- verwijzing naar: wet van I vendémiaire IN (23 sep 1795)

- besluit unigevaardigd n.a.v. cen brief van 3 brumaire IV (25 okt 1795) door de conseil de gouvernement provisoire te Brussel inzake gewapende rebellen

- toegezonden stuk: 21 brumaire IV (12 nov 1795) werandert in 23 brumañte IV (14 nov 1795)

- wolksrepresentanten dienen dit besluit te laten drukken, bekendmaken en aanplakken in de negen départements réunis en exemplaren te zenden aan de bevelhebber van het Noorderleger en de onder commandanten 
- afkondiging: beslun volksrepresentanten s. Pérês, Portiez (de l'Oise); cs. J. Tarfs; zonder dagtekening

\section{IV brumaire 11 (1795 nov 2)}

LA I fol 162ro-163ro; FA nr.291; rH V 221

\section{ARRETE ENONCANT LES DISPOSITIONS À OBSERVER AU SUJET DES PASSEPORTS DES BELGES QUI ONT ETÉ ABSENS}

Voor het verkrijgen van het visum van de volksrepresentanten ten behoeve van teruggekeerde Belgen dienen de paspoorten te worden opgezonden door de municipale ambtenaren, alwaar de afwezige toentertijd woonachtig was, onder vermelding van de verblijfsperiode. De paspoorten moeten getekend worden door de voorzitter van de gemeente en de secretaris-griffier, en de afdruk van het zegel van de gemeente dragen.

bo. volksrepresentanten

ao. conseil de gouvernement

s. Pérès, Portiez (de l"Oise); cs. Delcambe (secr)

ti. conseil de gouvernement

RO nr.22: 27 brumaire IV (18 nov 1795)

\section{IV brumaire 11 (1795 nov 2)}

LA I fol 310; rH V 320; P VII xxxvii-xx.xwii

\section{ARRÊTÉ QUi dÉFEND LE PORT DES CANNES À ÉPÉES, SABRES, \&C.}

Handelaren mogen niet langer degenstokken, dolken, sabels en met lood of ijzer verzwaarde stokken ten verkoop aanbieden, op straffe van verbeurdverklaring en een boete. Personen die dergelijke wapens bij zich dragen worden eveneens beboet, volgens de oude politiereglementen. De wapens worden verbeurdverklaard.

bo. comité de süreté générale

s. Colombel (de la Meurthe) (pres); Pémartin, Calez, C. Alex.. Ysabeau, P.M. Delaunay, Monmayou, Kervelegan, Bordas, Pons (de Verdun), Pierre Guyomar, Roger-Ducos, Bar, Bailly

RO nr.65: 19 frimaire IV (10 dec 1795)

RE nr.50: $20 / 21$ frimaire IV (11/12 dec 1795)

- verwijzing naar: "anciens règiemens de police sur la matière"

- de commission administrative de police ef des tribunaux is met de promulgatie en de uitvoering van het onderhavige decreet belast

- afkondiging: beslluit volksrepresentanten s. Pérès, Portiez (de l'Oise), cs. Delcambe; 26 brumaire IV (17 nov 1795)

\section{IV brumaire 12 (1795 nov 3 )}

LA I fol 89ro-90ro; FA nr.291; rH V 223-224 


\section{ARRETÉ CONCERNANT LA CIRCULATION DES PIECES DE 6, 12 ET 24 SOLS}

De muntstukken van 6, 12 en 24 sals ["stuivers"], die krachtens de ordonnantie van 17 juli 1763 in de Oostenrijkse Nederlanden niet meer in omloop waren, kunnen opnieuw in circulatie worden gebracht tegen de huidige intrinsieke waarde, hetgean neerkomt op de helft van de oorspronkelijke waarde. Iedere ontvanger van geldmiddelen dient dit geld te accepteren.

bo. volksrepresentanten/gouvernementscommissarissen in de negen dêpartemens réswis

ao. conseil de gowernement

s. Pérès, Portiez (de l'Oise); cs. J. Torfs (secr-prov)

ti. consell de gowernement

RO nr. $15: 22$ brumaire IV (13 nov 1795)

RE Mr.12: 23 brumaine IV (14 nov 1795)

- werwijzing naar: ordonnantie van 17 jul 1763; grondwet van 5 fructidor III (22 aug 1795)

- besluit gellezen en bekendgemaakt overal waar dit nodig is tot ieders informatie

\section{IV brumaire 13 (1795 nov 4)}

LA 1 fol 90; FA nr.291; rH V 225; P VII xxxwiii

\section{ARRẼ TÉ INTERPRÉTATIF DE CELUI DU 12 THERMIDOR AN II}

De verbintenissen aangegaan vóór de tweede komst van de Franse troepen naar België, waarvan in art.1 van het arrêté van 12 thermidor III (30 jul 1795) sprake is, zijn niet slechts die aangegaan vóor de inname van Kortrijk, maar ook de verbintenissen aangegaan vóór het in omloop komen van de assignaten.

bo. volksrepresentanten/gouvernementscommissarissen

ao. conseil de gowvernement

s. Pérès, Portiez (de l'Oise); cs. J. Torfs (secr-prov)

ti. conseil de gouvermement

RO nr.76: 22 brumaire IV (13 now 1705)

RE nr.13: 23 brumaire IV (14 nov 1795)

- verwijzing naar: besluit volksrepresentanten van 12 thermidor III (30 jul 1795)

\section{IV brumaire 14 (1795 nov 5)}

LA fol 165vo-172vo; FA nr.29I; rH IV 322-325

PROClaMATION DES REPRESENTANS DU PEUPLE, COMMISSAIRES DU GOUVERNEMENT, AUX FRANÇAIS, HABITANS DES PAYS REUNIS

In de proclamatie worden de inwoners van de negen départements réunis tot Frans ingezetene uitgeroepen. Zij zullen voortaan onder de welldadige Franse wetten leven. Alle heerlijke rechten en diensten, alsmede de ambachtsgilden en andere rechtspraktijken uit het ancien régime, zijn afgeschaft. 
bo. volksrepresentanten/gouvemementscommissarissen

s. Peres (de Haute-Garonne), Portiez (de l'Oise)

t. conseil de gowernement

RO nr.23: 27 brumaure IV ( 18 nov 1795)

- verwijzing naar: decreet van 3 brumaire IV (25 okt 1795); besluit volksrepresentanten wan 14 brumaire IV (5 nov 1795)

\section{IV brumaire 14 (1795 nov 5$)$}

LA If fol 172wo-173wo; FA nir.291; rH V 248-249; P VII xxxviii

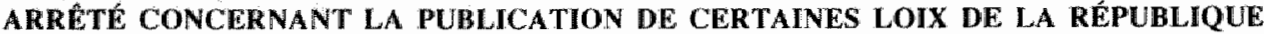

Teneinde dadelijk de voordelen te genieten van de meest weldadige Franse wetten, worden de wetten aangaande de afschaffing van de dîmes, de heerlijke rechten, het retrait lignager, fideïcommissaire substituties, de vordering tot vernietiging van overeenkomsten wegens benadeling voor meer dan de helft, de ambachtsgilden en gezworenen, alsmede die voor de nieuwe orde van erfopvolging onmiddellijk bekendgemaakt. In afwachting van deze bekendmaking zijn alle juridische procedures en geschillen inzake deze onderwerpen opgeschort. De conseil de gouvernement is belast met het laten drukken, bekendmaken en aanplakken van deze wetten, het onderhavige besluit en de bijgevoegde proclamatie, overal waar dit nodig is.

bo. volksrepresentanten/gouvernementscommissarissen

ao. conseil de gouvermement

s. Pérès, Portiez (de l'Oïse); cs. Delcambe (secr)

RO nr.24: 27 brumaire IV (18 nov 1795)

RE nr.28: 30 brumaire IV (21 nov 1795)

- verwijzing naar: proclamatie volksrepresentanten van 14 brumaire IV (5 nov 1795)

\section{IV brumaire 15 (1795 nov 6)}

LA If fol 91 vo-93ro; rH V 250-251; FA nr.291

\section{ARRETE RELATIF AUX PENSIONS DES RELIGIEUX SUPPRIMES OU SORTIS DE LEURS COUVENTS}

De pensioenen of lijfrenten, vervallen op 1 messidor III (19 jun 1795), toegekend aan de leden van de opgeheven religieuze corporaties, worden in assignaten uitgekeerd. De pensioenen of lijfrenten vanaf 1 messidor III worden voorlopig in muntgeld per kwartaal door de kas van de nationale domeinen vooruitbetaald, onder overlegging van attestaties de vita, van verblijfplaats en andere door de wet vereiste bewijsstukken.

bo. volksrepresentanten/gouvernementscommisarissen

ao. conseil de gowernoment

s. Pérès, Portiez (de l'Oise); cs. Delcambe (secr)

ti. conseil de gowernement

RO nr. 18: 22 brumaire IV (13 nov 1795) 
RE nr. 15: 23 brumaire IV (14 nov 1795)

- werwijzing naar: besluiten volksrepresentanten van 19 gerninal 111 (8 apr 1795); 6 prairial III (25 mei 1795)

\section{IV brumaire 16 (1795 nov 7)}

LA I fol 80vo-84ro; FA nr.230; rH VI 145-147

\section{ARRÊTÉ FRAPPANT UNE RÉQUISITION DE VOITURES SUR LES DÉPARTEMENS RÊUUNIS ET DÉTERMINANT LE NOMBRE À FOURNIR PAR CHACUN D'EUX}

De arrondissementsadministraties moeten onmiddellijk 1260 wagens, bespannen met vier paarden, leveren en naar het Sambre-en-Maasleger sturen. Het arrondissement Maastricht wordt voor 200 wagens aangeslagen, 100 te zenden naar Keulen en 100 naar Neuß. Niemand is van deze gedwongen levering vrijgesteld, ook niet wanneer hij al aan de Republiek levert. De arrondissementsadministraties kunnen gewapenderhand de requisitie afdwingen. Weigerachtigen worden bedreigd met inbeslagneming ten profijte van de Republiek. Nalatigheid in de uitvoering van de gedwongen levering van de zijde van de autoriteiten wordt beboet en bestraft met ontslag. De municipaliteiten voorzien vooraf in de betaling van de wagens, onder evenredige vermindering van hun gewone contributie. Iedere eigenaar of leverancier van een wagen ontvangt een vergoeding.

bo. volksrepresentanten/gouvernementsconmissarissen

ao. conseil de gouvernement

s. Péres, Portiez (de l'Oise); cs. J. Torfs (secr-prov)

ti. conseil de gouvernement

RO nr. 11: 18 brumaire IV ( 9 nov 1795)

RE nr.17: 23 brumaire IV (14 nov 1795)

\section{IV brumaire 17 (1795 nov 8 )}

LA I 84vo-85vo; FA nr.230; rH V 258

ARRETÉ PORTANT QUE LES DROITS, IMPOSITIONS ET TOUS AUTRES REVENUS PUBLICS SERONT PERÇS À L'AVENIR EN NUMÉRAIRE MÉTALLIQUE DANS LES DEPARTEMENS REUNIS

Belastingen, rechten, pachtsommen, (schuld)vorderingen, huursommen of aanbestedingen, verschuldigd aan de Republiek, dan wel aan de voorheen provinciale en municipale besturen kunnen slechts worden voldaan in muntgeld, totdat de wijze van inning als gebruikelijk in Frankrijk van kracht wordt. Hiervan uitgezonderd zijn de geldelijke verplichtingen, aangegaan sinds de tweede komst van de Franse troepen naar België, waarvan de betaling in Republikeins geld of in assignaten is bepaald.

bo. volksrepresentanten/gouvernementscommissarissen

ao. conseil de gowermement

s. Pérès, Portiez (de l'Oise); cs. J.Torfs (secr) 
ti. conseil de gouvernement

RO nr. 12. 18 brumaire IV (9 now 1795)

RE nr. 16: 23 brumaire IV (14 now 1795)

- verwijzing naar: besluiten volksrepresentanten bij het Noorder-en het Sambre-en-Maasleger van 25 prairial III (13 jun 1795); 12 thermidor III (30 jut 1795); deze blijven wooralsnog van kracht, voor zover het onderhawige besluit hier niet van afwijkt

- de redactie wan art.3 in rH wijkt enigszins af wan het toegezonden besluit

\section{IV brumaire 17 (1795 nov 8)}

LA 1 fol 109 ro-110vo; FA nr.230; rH VI $148-149$

\section{ARRETE PORTANT QUE LES ADMINISTRATIONS D'ARRONDISSEMENTS DE LIMBOURG, SPA ET MAESTRICHT CESSENT D'ÊTRE SUBORDONNÉES À L'ADMINISTRATION CEN- TRALE DU PAYS D'ENTRE MEUSE ET RHIN}

De arrondissementsadministraties van Limbourg, Spa en Maastricht ressorteren voortaan niet meer onder de Centrale Administratie van de Landen tussen Maas en Rijn zetelend te Aken. Men moet in het vervolg met de conseil de gouvernement te Brussel corresponderen. Dit geldt eveneens voor de directeuren van de brievenpost en de leidinggevende ambtenaren van de nationale domeinen. De overige financiële takken van dienst dienen te worden uitgevoerd, zoals in de desbetreffende besluiten is geregeld. Het onderhavige besluit wijkt in niets af van dat van het comité de salut public van 25 vendémiaire IV (17 okt 1795) inzake de inning van tien miljoen aan belasting in de Landen tussen Maas en Rijn.

bo. volksrepresentanten/gouvernementscommissarissen

ao. conseil de gouvernement

s. Pérès, Portiez (de l'Oise); cs. Delcambe (secr)

ti. conseil de gouvernement

RO nr. 19: 25 brumaire IV (16 nov 1795)

RE nr. 25: 30 brumaire IV (21 now 1795)

- verwijzing naar: besluit volksrepresentanten van 13 vendémiaire IV (5 okt 1795); 11 fructidor III (28 aug 1795); besluit Centrale Administratie van België van 3 prairial III (22 mei 1795); besluit comité de salut public van 25 vendlémiaire IV (17 okt 1795)

- het toegezonden arrêté en het afschrift daarvan vermeldt in art. 5 (=art.4 in rH) een toevoeging, inhoudende dat de arrondissementsadministratie van Maastricht een afschrift moet zenden naar de administratie van het kanton Roermond

\section{IV brumaire 17 (1795 nov 8$)$}

L.A I fol IIIro-112vo; FA nr.230

[extract] ARRÊté FIXANT LE TRAITEMENT des FONCTIONNAIRES PUBLICS ET AUTRES EMPLOYÉS DANS LES DÉPARTEMENS RÉUNIS

De hoogte van de voorlopige maandelijkse bezoldiging van functionarissen werkzaam in de départements réunis is afhankelijk van de grootte der gemeenten. De scheidslijn ligt bij het inwonertal van 50000 . Eveneens wordt er onderscheid gemaakt in de 
bezoldiging van de functionarissen bij de criminele en de burgerlijke rechtbanken en de vredegerechten. De conseil de gouvernement stelt het aantal personeelsleden bij de arrondissementsadministraties vast. De kosten komen ten laste van de arrondissementskas, die deze omslaan over de bestuurden.

bo. volksrepresentanten bij het Noorder- en het Sambre-en-Maasleger

s. Pérès, Portiez (de l'Oise); cs. J. Torfs (secr-prov)

ti. conseil de gouvernement

RO nr.20: 25 brumaire IV (16 nov 1795)

- $P$ VII $x \times x i x$ vermeldt alleen: "enregistrement aux administrations départementales"

\section{IV brumaire 19 (1795 nov 10)}

BL IIfe ser no.4 (19); LA IV 167vo-169ro; rH VIII 285-287; P VII 231; cB IV ser I 54-56

\section{LOI PORTANT QUE LE NOTARIAT ET LES OBJETS QUI LUI SONT RELATIFS SONT COMPRIS DANS LES ATTRIBUTIONS AU MINISTÈRE DE LA JUSTICE}

Het notariaat en de daarop betrekkelijke zaken vallen onder de bevoegdheid van het ministerie van justitie.

bo. Conseil des Cinq-cents cols. Daunou (pres); Cambacérès, Thibaudeau, Boissy (secr); Conseil des Anciens colls. P.C.L. Baudin (des Ardennes) (pres); Lanjuinais, Bréard (secr)

ao. Directoive exécutif

RO nr.151(1): 19 prairial IV (7 jun 1796)

- verwijzing naar: wet van 10 vendémiaire IV ( 2 okt 1795)

- afkondiging: besluit Directoire exécutif s. Carnot (pres), Lagarde (secr-gen); 3 prairial IV (22 meil 1796)

\section{IV brumaire 26 (1795 nov 17)}

LA II fol 68ro-69ro; FA nr.234; rH VI 32-33; P VII xlvi

\section{ARRETÉ DÉTERMINANT LES TRIBUNAUX D'APPEL DES JUGEMENS PAR LES TRIBU- NAUX DE DÉPARTEMENS RÉUNIS}

De volksrepresentanten/gouvernementscommissarissen hebben voorlopig bepaald welke rechtbanken het hoger beroep behandelen van de vonnissen door de burgerlijke rechtbanken in de departementen. De burgerlijke rechtbank in het departement van de Nedermaas fungeert naast andere als beroepsinstantie in uitspraken gedaan door de burgerlijke rechtbanken van de departementen Dijle, Twee Neten en Ourthe. Hoger beroep van uitspraken van de burgerlijke rechtbank van het departement van de Nedermaas staat open bij die van Ourthe, Dijle en Twee Neten. Het pleiten bij de departementale rechtbanken dient in het Frans te geschieden; evenzo worden vonnissen in de Franse taal gesteld.

bo. volksrepresentanten/gouvernementscommissarissen

ao. conseil de gouvernement 
s. Perès, Portiez (de l'Oise)

i. wolkstepresentanten

RO nr.77: 1 nivose IV $(22$ dec 1795$)$

RE nr.99: $11 / 12$ ventôse IV (1/2 mrt 1796)

- N.B.: het arrêté makt als $\$$ IX deel uit van hel in paragrafen onderverdeelde besluit van de volksrepresentanten wan 2 frimaire IV (23 nov 1795) sur l'organisation de l'ordre judiciaire en matière civile [LA II fol 50ro-76ro; FA nr.234; rH VI 3-45; P VII xli-xiviii]

\section{IV brumaire 27 (1795 nov 18)}

LA I fol 235vo-237ro; FA nr.231, FA nr.4277; rH V 333-336

\section{ARRÊTÉ PORTANT NOMINATION DES ADMINISTRATEURS DU DÉPARTEMENT DE LA MEUSE-INFERIEURE ET DU COMMISSAIRE DU DIRECTOIRE EXÉCUTIF PRÈS D'EUX}

Tot administrateurs van het departement Nedermaas zijn benoemd: Rogier (chef de bureau van de conseil de gouvernement), Coenegracht (lid der administratie van het arrondissement Maastricht), Petit (jurist te Roermond), Corneli (jurist te Rimburg) en Cox (uit Hasselt). Membrède, voorheen agent-nationaal bij de arrondissementsadministratie, is nu tot commissaris van de uitvoerende macht benoemd. De uitvoering van dit besluit, alsmede de installatie van de nieuw-benoemden, is opgedragen aan de voormalige agent-nationaal, thans commissaris van de uitvoerende macht, Membrède.

ba. volksrepresentanten/gouvernementscommissarissen

ao. conseil de gouvernement

s. Pérès, Portiez (de l'Oise); Delcambe (secr)

ti. agent-nationat A.C. Membrède

RO nir.45: 7 frimaire IV (28 nov 1795)

- verwijzing naar: wet wan 3 brumaire IV (25 okt 1795); proclamatie volksrepresentanten van 14 brumaire IV (5 nov 1795 )

- rH en $\mathrm{P}$ vermelden als datum van uitvaardiging 26 brumaire IV (17 nov 1795)

\section{IV brumaire 28 (1795 nov 19)}

LA I fol 252ro-256ro; FA nr.232; rH V 369-372; P VII xl-xli

\section{ARRÊTÉ RELATIF $\lambda$ L'ÉTABLISSEMENT DE LA GENDARMERIE NATIONALE DANS LES DÉPARTEMENS RÉUNIS}

De wetten en reglementen betreffende de organisatie en dienst der gendarmerie nationale zullen spoedig in de negen départements réunis worden afgekondigd. In afwachting van de definitieve regeling hiervan worden er drie divisies van de nationale gendarmerie onder leiding van brigadegeneraal Wirion, daartoe gelast door het comité de salut public, geformeerd. De eerste divisie zal de departementen Ourthe, Nedermaas en Wouden omvatten. Ingevolge het besluit van het comité de salut public zal de omslag van de kosten geschieden op basis van de territoriale indeling van België. Burgers die tot de nationale gendarmerie wensen toe te treden, moeten zich laten registreren en hun papieren van de militaire dienst op een centraal bureau te 
Brussel overhandigen. De kandidaten worden door een jury aan een nader onderzoek onderworpen. De naamlijst van (onder)officieren en gendarmes van de nieuwe korpsen wordt aan de minister van oorlog gezonden. In streken waar dit nodig is, kunnen meer gendarmes gestationeerd worden. Van de huidige in functie zijnde detachementen dienen voldoende manschappen bij de bestuurslichamen en rechtbanken te worden geplaatst.

bo. volksrepresentanten/gouvernementscommissarissen

s. Peres, Portiez (de l'Oise)

cc. brigadegeneral Wirion

ti. agent-nationaal A.C. Membrede

RO nr.48: 9 frimaire IV (30 nov 1795)

- werwijzing naar: besluiten comité de salut public wan 14 fructidor III (3॥ aug 1795$) ; 8$ brumaire IV (30 okt 1795)

\section{IV brumaire 29 (1795 nov 20)}

LA I fol 256vo-257ro; FA nr.232

ARRETÉ QUI PRESCRIT LE RENOUVELLEMENT DES BAUX EXPIRES OU QUI EXPIRERONT, EN NUMÉRAIRE MÉTALLIQUE, ET DECLARE QUE LESDITS BAUX N'ONT PU A VOIR LIEU QUE POUR UNE ANNÉE SEULEMENT, ET SANS TACITE RÉCONDUCTION

De verpachtingen van nationale domeingoederen op het grondgebied van het vroegere België die op het punt staan af te lopen, worden in muntgeld hernieuwd. Nieuwe toewijzingen geschieden overeenkomstig de wetgeving ter zake.

bo. volksrepresentanten/gouvemementscommissarissen

ao. conseil de gouvernement

s. Portiez (de l'Oise); cs. Dellcambe (secr)

ti. volksrepresentaniten

RO nr 50 : 11 frimaire IV (2 dec 1795)

- besluit uitgevaardigd n.a.v. een missive van de agent-nationasl bij de arrondissementsadministratie te Luik

\section{IV frimaire 6 (1795 nov 27)}

LA I fol 238vo-240ro; FA nr.232; rH V 378-379

\section{ARRETÉ PORTANT QUE LES ANCIENS TRIBUNAUX SUPÉRIEURS DE LA CI-DEVANT BELGIQUE CESSERONT LEURS FONCTIONS LE 10 DE CE MOIS}

Met ingang van 10 frimaire IV ( $1 \operatorname{dec} 1795$ ) houden de vroegere hogere gerechtshoven (tribunaux supérieurs) in de Zuidelijke Nederlanden op te functioneren. Die dag zullen de plaatselijke municipale ambtenaren gezamenlijk 's middags om 12 uur de gerechtszalen, de griffies en de archieven door hun secretaris-griffier laten verzegelen. Deze verzegeling zal door de municipaliteit, op verzoek van de commissaris van de 
uitvoerende macht bij de nieuw in te stellen rechtbank, worden opgeheven. Allen die stukken van de oude gerechten onder zich hebben, dienen die dadelijk over te dragen. Griffiers van de oude rechtbanken in hun hoedanigheid van bewaarder van consignatiegelden moeten deze verantwoorden.

bo. volksiepresentanten/gouvernementscommissarissen

\$. Pérès, Portiez (de l'Oise)

ti. volksrepresentanten

RO nr.46: 9 frimaire IV (30 nov 1795)

- verwijzing naar: decreet van $6 \& 7 * 11$ september 1790

\section{IV frimaire 7 (1795 nov 28)}

LA I fol 256; FA nr.232; rH V 418

ARRÊTÉ QUI DÉCLARE QUE TOUTES LES AFFAIRES ADMINISTRATIVES QUI ÉTAIENT RÉSERVÉES À LA DÉCISION DU CONSEIL DE GOUVERNEMENT ET À L'ADMINISTRATION CENTRALE de la BELgiQUe, SERONT dORÉNAVANT dÉCIDÉES PAR LES ADMINISTRATIONS DÉPARTEMENTALES

Het nemen van beschikkingen aangaande bestuurszaken, voorheen opgedragen aan de conseil de gouvernement of de Centrale Administratie van België, dient voortaan door de respectieve departementale besturen te geschieden.

bo. volksrepresentanten/gouvernementscommissarissen

s. Pérès, Portiez (de l'Oise)

ti. volksrepresentanten

RO nr.49: II frimaire IV ( 2 dec 1795)

- indicateur universel vermeldt: copieren en op 12 en 13 frimaire [IV] ( 3 en 4 dec 1795) doorgezonden naar de kantonshoofdplaatsen

IV frimaire 7 (1795 nov 28)

LA I fol 257ro-258vo; FA nr.232; rH V 384-385

ARRÊTÉ QUI FLXE LES ATTTRIBUTIONS DES JUGES, ET LEUR DEMANDE DES LISTES DES CITOYENS PROPRES À REMPLIR LES FONCTIONS DE JUGES DE PAIX, PRUD'HOMMES-ASSESSEURS ET COMMISSAIRES PRÈS LES TRIBUNAUX CORRECTIONNELS

Aan rechters is opgedragen een dubbele lijst van personen op te stellen, die geschikt zijn de functies van vrederechter, assessor bij de vrederechter (prud' homme-assesseur) en commissaris bij de correctionele rechtbank (tribunal correctionnel) te vervullen. De departementale besturen zorgen ervoor dat de localiteiten waar de zittingen van de burgerlijke en de criminele rechtbank worden gehouden zo snel mogelijk in gereedheid worden gebracht. Zolang die niet gereed zijn doen de rechters in de burgerlijke rechtbank van ieder departement uitspraak achter gesloten deuren in de dringendste geschillen. Zowel de burgerlijke als de criminele rechtbank zetelt in het departement van de Nedermaas te Maastricht. Het departementaal bestuur geeft aan de volksrepre- 
sentanten te kennen in welke gemeenten het beste de correctionele rechtbanken kunnen worden gevestigd. Hun aantal is afhankelijk van het aantal rechters bij de departementale burgerlijke rechtbank.

bo. volksrepresentanten/gouvernementscommissarissen

s. Pérès, Portiez (de l'Oise)

ti. volksrepresentanten

RO nr.51: 11 frimaire IV (2 dec 1795)

- rH vermeldt als datum van uitvaardiging 7 brumaire IV (29 okt 1795)

IV frimaire 8 (1795 nov 29)

LA I fol 262ro; FA nr.232

\section{ARRÊTÉ QUI FIXE LE TRAITEMENT DES COMMISSAIRES PRES LES NOUVEAUX TRIBU- NAUX À UN TIERS EN SUS DE CELUI DES JUGES}

De maandelijkse bezoldiging van de commissarissen van het Directoire exécutif bij de nieuw ingestelde rechtbanken is éen derde hoger dan die van de rechters, gerekend vanaf 1 vendémiaire IV (23 sep 1795).

bo. volksrepresentanten/gouvernementscommissarissen bij het Noorder- en het Sambre-en-Maasleger s. Pérès, Portiez (de l'Oise)

ii. volksrepresentanten

RO nr.53: 11 frimaire IV (2 dec 1795)

- verwijzing naar: besluit volksrepresentanten van 17 brumaire IV ( 8 nov 1795)

- besluit departementaal bestuur: "sera enregistré au département"

\section{IV frimaire 8 (1795 nov 29)}

LA I foll 262ro-263ro; FA nr.232; rH VI 153

ARRẾtË PORTANT QUE LES FERMIERS ET ADJUDICATAIRES DES DROITS ET REVENUS PUBLICS, DEVRONT ACQUTTTER LEURS REDEVANCES EN NUMERAIRES OU EN ASSIGNATS AU COURS

De pachters van de rechten en publieke geldmiddelen kunnen er niet mee volstaan, overeenkomstig de eerder uitgevaardigde besluiten inzake de inning en de afdracht van de opbrengsten ervan, deze uitsluitend met de in omloop zijnde assignaten te voldoen, maar dienen dit ook in muntgeld doen.

bo. volksrepresentanten bij het Noorder- en het Sambre-en-Maasleger/gouvernementscommissarissen s. Pérès "Portiez (de l'Oise)

ti. volksrepresentanten

RO nr.54: 14 frimaire IV (5 dec 1795)

- verwijzing naar: besluiten volksrepresentanten van 25 prairial III (13 jun 1795); 17 brumaire IV (8 nov 1795)

- besluit departementaal bestuur: "tenu pour notice" 


\section{ARRETE QUI AUTORISE LES ADMINISTRATIONS DÉPARTEMENTALES À REGLER LEURS DÉPENSES ET A EN MANDATER L'ACQUITTEMENT}

Tot de invoering van het republikeinse financiële regime verlenen de departementsadministraties machtigingen tot het afgeven van betalingsopdrachten door de municipaliteiten. De departementale besturen regelen verder zelf hun bestuurlijke uitgaven en geven onder eigen verantwoordelijkheid hun betalingsopdrachten af.

bo. volksrepresentanten bij het Noorder-en het Sambre-en-Maasleger/gouvemementscommissarissen

s. Pérès, Portiez (de l'Oise)

ti. volksrepresentanten

RO nr.56: 14 frimaire IV ( 5 dec 1795)

- verwijzing maar: besluiten volksrepresentanten van 3 prairial III (22 mei 1795); 11 fructidor III ( 28 aug 1795); deze beshltiten blijven van kracht voor zover het onderhavige besluit er niet van afwijkt

\section{IV frimaire $11(1795 \mathrm{dec} 2)$}

LA I fol 263ro-264ro; FA nr.232; rH VI 154; P VII xlix

ARRETE QUI DECLARE QUE TOUS LES COMMUNES, BAILLIAGES ET AUTRES PAYS QUI NE SONT POINT COMPRIS DANS LE DÉCRET DE RÉUNION DU 9 VENDÉMIAIRE, NE FONT POINT PARTIE DU DÉPARTEMENT DE LA MEUSE-INFÉRIEURE, MAIS RESTENT DU RESSORT DE L'ADMINISTRATION CENTRALE D'AIX-LA-CHAPELLE

De gemeenten, jurisdicties en overige streken in het Gulikse, die niet onder de inlijvingswet van 9 vendémiaire IV ( 1 okt 1795) vallen, ofschoon zij wel genoemd worden in het besluit van het comité de salut public van 14 fructidor III (31 aug 1795) inzake de territoriale verdeling, maken geen deel uit van het departement van de Nedermaas. Deze landstreken blijven onder de Centrale Administratie van de Landen tussen Maas en Rijn te Aken ressorteren.

bo. volksrepresentanten bij het Noorder- en het Sambre-en-Maasleger/gouvemementscommissarissen

s. Peres, Portiez (de l'Olise)

ti. volksrepresentanten

RO nit.55: 14 frimaire IV (5 dec 1795)

- verwijzing naar: besluit comité de salur public van 14 fructidor III (31 aug 1795)

- besluit uitgevaardigd n.a.v. missiven van collega-volksrepresentant Meynard en Effertz, lid en afgevaardigde van de administratie te Aken en Gulik

\section{IV frimaire 11 (1795 dec 2)}

LA If fol 265; FA nr.232; rH V 419; P VIl xlix 


\begin{abstract}
ARRETE AUTORISANT LES PROPRIÉTAIRES DE BOIS A EXPLOTTER, SOUS LA SEULE. CONDITION D'EN FAIRE LEUR DECLARATION AU SECRETARIAT GENERTAL DES DEPARTEMENS
\end{abstract}

Onder gelliktijdige intrekking van art.9 van het besluit wan de volksrepresentanten van 8 frimaire III ( 28 nov 1794), mogen particuliere eigenaren van bosareaal voortaan overgaan tot het kappen en het verkopen van hout, op voorwaarde dat zij vijftien dagen van tevoren aan het secretariaat van het departementaal bestuur opgave doen van de te kappen oppervlakte en hoeveelheden hoogopgaand hout. Bij het ontbreken van een dergelijke opgave volgt confiscatie.

bo. volksrepresentanten bij het Noorder- en het Sambre-en-Maasleger/gouvemementscommissarissen s. Pérès, Portiez (de l'Oise)

ti. volksrepresentanten

RO nr.57: 15 frimaire IV (6 dec. 1795)

RE nr.48: 19 frimaire IV (10 dec 1795)

- verwijzing naar: besluit volksrepresentanten van 8 frimaire III (28 nov 1794)

IV frimaire $12(1795 \operatorname{dec} 3)$

LA I fol 267wo-268ro; FA nr.232; rH VI 155

ARRÊTÉ CONCERNANT LE PAIEMENT DES PENSIONS DES RELIGIEUX ET RELIGIEUSES SORTIES QUI CHANGENT DE DOMICILE

De uitbetaling van de toelage aan uitgetreden kloosterlingen, of aan hen wier klooster is opgeheven, geschiedt in het departement alwaar men woonachtig is. De kloosterlingen dienen daartoe op een lijst te zijn ingeschreven. Wanneer zij naar een ander departement verhuizen, moeten zij in het nieuwe departement een certificaat tekenen, waarbij zij afstand doen van uitbetaling van hun toelage in het vorige departement.

bo. volksrepresentanten bij het Noorder- en het Sambre-en-Maasleger/gouvernementscommissarissen s. Përès

ti. volksrepresentanten

RO nr.59: 16 frimaire IV ( 7 dec 1795)

- verwijzing naar: besluit volksrepresentanten van 15 brumaire IV (6 nov 1795)

- het onderhavige besluit heeft de vorm van een déclaration

IV frimaire $13(1795$ dec 4$)$

LA I fol 266ro-267vo, II fol Iro-2ro; FA nr.232, FA mr.4277

ARRÊTÉ PORTANT NOMINATION D'UNE NOUVELLE ADMINISTRATION DU DÉPARTEMENT DE LA MEUSE-INFÉRIEURE ET DU COMMISSAIRE DU DIRECTOIRE EXÉCUTIF

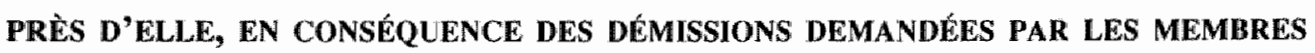
PRIMITIVEMENT NOMMÉS 
In werband met het niet-aanvaarden van hun benoeming - bij het besluit van de volksrepresentanten van 27 brumaire IV (18 nov 1795) - door de beoogde administrateurs van het departement van de Nedermaas, zijn thans tot administrateur benoemd: Carion, jurist en oud-president van het district en van de rechtbank te Bapaume [departement Pas-de-Calais]; Tarte, chef de bureau bij de conseil de gouvernement; Pi[c]query, jurist te Maubeuge [departement Nord]; Van de Wardt, kantonsadministrateur in het departement Nedermaas; d'Henin [De Haynin], voorheen chef de bureau bij het district Valenciennes [departement Nord]. Als commissaris van de uitvoerende macht is benoemd Rogier, chef de bureau bij de conseil de gouvernement en voordien ambtenaar bij de administratie der financiën tussen de Maas en de Rijn. De agentnationaal dient voor de installatie van de nieuw-benoemden zorg te dragen en hiervan de gouvernementscommissarissen te Brussel bericht te zenden.

bo. volksrepresentanten bij het Noorder- en het Sambre-en-Maasleger/gouvernementscommissarissen \$. Perè̀s

ti. agent-nationaal A.C. Membrède

RO nr.58: 15 frimaire IV (6 dec 1795)

- verwijzing naar: decreet van 3 brumaire IV (25 okt 1795)

- het Répertoire ou mémorial chronologique vermeldt abusievelijk als datum van uitvaardiging 13 brumaire IV (4 nov 1795)

\section{IV frimaire 17 (1795 dec 8$)$}

LA I fol 310vo-312ro; FA nr.233; rH V 420-421

\section{ARRETE RELATIF AU VERSEMENT DES GRAINS ET DENRÉES DANS LES MAGASINS DE LA RÉPUBLIQUE, ET PRESCRIVANT DES MESURES CONTRE LES DÉBITEURS DE LA RÉPUBLIQUE EN RETARD}

Debiteuren aan de staat dienen hun pachtsommen, hetzij in natura, hetzij in muntgeld te voldoen. De ontvangers bij de nationale domeinen gaan volgens de gewone weg, maar eventueel met dwangmiddelen, tot invordering over. Bij voortgaande weigering wordt de pachtsom met een kwart verhoogd en zal de debiteur voor een half jaar worden gevangengezet; tevens zal diens oogstopbrengst voor de helft worden verbeurdverklaard.

bo. volksrepresentanten bij het Noorder- en het Sambre-en-Maasleger/gouvernementscommissanissen

s. Pérès, Portiez (de l'Oise)

ti. volksrepresentanten

RO nr.66: 22 frimaire IV (13 dec 1795)

RE nr.55: 24 frimaire IV (15 dec 1795)

- verwijzing naar: wet van 22 brumaire IV (13 now 1795)

- besluit uitgevaardigd n.a.v. missive van de commissaire-ordonnateur

- besluit moet in de departementen worden gedrukt, bekendgemaakt, aangeplakt en uitgevoerd

\section{IV frimaire 17 (1795 dec 8)} BL Ile ser no. 10 (5I); LA II fol 122vo-123vo; FA nr.234; rH X 360 ; P VII 240; cB IVe ser I 174-
175 


\section{ARRETE EN INTERPRÉTATION DE CELUI DU 7 FRIMAIRE, CONCERNANT LE TRAITE- MENT DES EMPLOYÉS}

Het Directoire exécutif bepaalt voorlopig ter uitvoering van zijn besluit van 7 frimaire IV (28 nov 1795) dat de hoogstaangestelden in vier salarisklassen worden onderverdeeld. Voorts mogen onder meer de tractementen van de departementsambtenaren voorlopig niet het minimum van hun klasse overschrijden.

bo. Directoire exécutif

s. Reubell (pres); Lagarde (secr-gen)

ti. Directotre exécutif

RO nr.85: 9 nivôse IV (30 dec 1795)

- verwijzing naar: besluit Directoire exécutif van 7 frimaire IV (28 nov 1795)

- besluit departementaall bestuur: "il en sera tenu notice"

\section{IV frimaire 19 (1795 dec 10)}

BL Ile ser no.\|1 (53); LA If fol 312ro-314ro; FA nr.233; P VII 241-242; cB IVe ser I 183-186

LOI PORTANT QU'IL SERA FAIT UN APPEL DE FONDS, PAR FORME D'EMPRUNT, SUR LES CITOYENS AISÉS

De Franse staat doet een beroep op de fondsen van de gegoede burgers in de vorm van een dwanglening (emprunt forcé). Deze lening wordt opgelegd aan het kwart van de hoogstaangeslagenen in elk departement. De departementale besturen moeten deze dwanglening uitvoeren. Men wordt aangeslagen naar rato van het vermogen, onder afgifte van een kwijtingsbewijs. De lening moet worden voldaan in muntgeld, of in goud en zilver; bij gebreke hiervan mag dit ook in assignaten of granen. Een derde gedeelte van de lening is al opeisbaar in de laatste decade van de maand nivôse van het jaar IV, het resterende gedeelte in de maand daarop, pluviôse. Weigerachtigen wordt een boete van één tiende van de te kwijten som opgelegd voor elke decade vertraging. De wet van 4 brumaire IV (26 okt 1795)*, houdende een oorlogsbelasting, wordt ingetrokken. Degenen die niet aangeslagen worden, mogen toch naar eigen goeddunken een bijdrage leveren aan de lening.

bo. Conseil des Cinq-cents s. Marie-Joseph Chénier (pres), Boissy, Defermont, J.B. Louvet, Crassous (de I'Hérault) (secr); Conseil des Anciens s. Goupilleau (de Fontenay), Portalis, Regnier, Legrand (secr)

ti.. minister van financiën Faipoult

RO nr.74: 29 frimaire IV (20 dec 1795)

RE nr.68: $16 / 17$ nivôse IV (6/7 jan 1796)

- verwijzing naar." wet van 3 brumaire IV (25 okt 1795), lees: 4 brumaire IV (26 okt 1795)

- afkondiging: [opdracht Directoire exécutif s. Reubell (pres), Lagarde (secr-gen); 19 frimaire IV (10 dec 1795)]; er is geen speciaal besluit van de volksrepresentanten of de gouvernementscommissaris Bouteville die deze wet uitdrukkelijk afkondigt; een begeleidende instructie en missiven van de minister van financiën doen blijken van afkondiging (FA nr.233); de Code Merlin vermeldt ook dat deze wet is afgekondigd 
ARRETté QUI ASSIGNE SUR LA CAISSE DES DOMAINES NATIONAUX, LE PAYEMENT DES TRAVAUX QU'EXIGENT LES RÉPARATIONS DES LIEUX DESTINES AUX SÉANCES PUBLIQUES DES TRIBUNAUX CIVILS ET CRIMINELS

De noodzakelijke veranderingen en reparaties aan de gebouwen die bestemd zijn voor de openbare zittingen van de departementale burgerlijke en criminele rechtbanken, worden bekostigd uit de kas van de nationale domeinen in de gemeenten waar deze rechtbanken gevestigd zullen worden. Wanneer één van de kassen niet voldoende geld heeft, moeten de andere kassen in het departement gelijkelijk hieraan meebetalen. De departementale besturen moeten de werkzaamheden en dergelijke regelen.

bo. volksrepresentanten bij het Noorder- en het Sambre-en-Maasleger/gouvemementscommissarissen s. Pérès , Portiez (de l'Oise)

ti. volksrepresentanten

RO nr.73: 29 frimaire IV (20 dec 1795)

- verwijzing naar: besluit volksrepresentanten van 7 frimaire IV (28 nov 1795)

\section{IV frimaire 24 (1795 dec 15)}

LA II fol 30ro-31ro; FA nr.233; rH VI 283-284

\section{ARRETË QUI FIXE LE TRAITEMENT DES INSPECTEURS ET EMPLOYES DES BOIS ET FORÊTS}

Vanwege het nationale belang zal er, teneinde het behoud van de bossen te waarborgen, een bezoldigd toezicht worden ingesteld, gerekend vanaf 1 vendémiaire IV ( 23 sep 1795). De hoogte van de bezoldiging is afhankellijk van de functie die men binnen de bosinspectie bekleedt.

bo. volksrepresentanten bij het Noorder- en het Sambre-en-Maasleger/gouvernementscommissarissen s. Peres, Portiez (de l'Oise)

ti. volksrepresentanten

RO nr.72: 29 frimaire IV (20 dec 1795)

\section{IV frimaire 26 (1795 dec 17)}

LA III fol 91; FA nr.234; rH VI 427

ARRETE QUI DIVISE ENTRE LES DEPARTEMENS RÉUNIS LA SOMME DE 191,165 LIV. 15 SOUS 5 DEN. EN ASSIGNATS, RESTANT D'UN CREDIT OUVERT CHEZ LE PAYEURGENERAL DE L'ARMÉ DU NORD, À L'ADMINISTRATION CENTRALE DE LA BELGIQUE, POUR SECOURS ET INDEMNITES

Een bedrag van 191.165 liwes 15 sols en 2 deniers is nog beschikbaar bij de betaalmeester-generaal, betalalbar gesteld aan de vroegere conseil de gouvernement om 
financiële hulp aan daartoe gerechtigde Belgen te kumnen verlenen. Dit bedrag zal evenredig over de negen departementen worden verdeeld.

bo. volksrepresentanten bij het Noorder- en het Sambre-en-Maasleger/gouvernementscommissarissen

s. Pérès, Portiez (de l"Oise)

ti. volksrepresentanten/gouvernementscommissarissen

RO nr.82: I nivôse IV (22 dec 1795)

- verwijzing naar: besluit volksrepresentanten van I germinal III (21 mrt 1795)

- besluit uitgevaardigd na observaties gemaakt door de centrale administratie van het Dijle-departement

\section{IV frimaire 26 (1795 dec 17)}

LA II fol 130; FA nr.235, FA nr.274 fol 54ro-55ro; rH VI $127-128$

ARRÊté PORTANT QUE L'EMPRUNT FORCÉ NE POURRA ÊTRE EFFECTUÉ, QU'EN NUMÉRAIRE MÉTALLIQUE DANS LES DÉPARTEMENS RÉUNIS

De dwanglening opgelegd bij de wet van 19 frimaire IV (10 dec 1795) kan in de negen départements réunis slechts in muntgeld, dan wel in goud of zilver worden ingevorderd.

bo. Direcroine exécuif

s. Reubel\| (pres); Lagarde (secr-gen)

ti. minister van financiën Faipoult

RO nr.87: 13 nivôse IV (3 jan 1796)

RE nr.69: $16 / 17$ nüồse IV (6/7 jan 1796)

- verwijzing naar: besluit volksrepresentanten van 17 brumaire IV ( 8 nov 1795); wetten van 2 thermidor III (20 jul 1795); 24 fructidor III (10 sep 1795); 19 frimaire IV (10 dec 1795)

\section{IV frimaire 26 (1795 dec 17)}

BL Ile ser no. 13 (66); drukw FA nr.I12; rH IX 251-252; P VII 244; cB IVe ser I 215-216

\section{LOI QUI PROROGE LE TERME INDIQUÉ PAR CELLE DU 9 MESSIDOR AN III POUR L'INTRODUCTION D'UN NOUVEAU RÉGIME HYPOTHÉCAIRE.}

In verband met de te korte termijn die vastgesteld is voor het in werking treden [1] nivôse IV ( $22 \mathrm{dec} 1795)$ ] van het nieuwe hypothecaire regime, wordt deze verschoven naar 1 germinal IV (21 mrt 1796). De datum van 30 ventôse IV (20 mrt 1796) genoemd in art.267 van de code hypothécaire zal na rapportage door een commissie opnieuw worden vastgesteld.

bo. Conseil des Cinq-cents \&. Marie-Joseph Chénier (pres); J.B. Louvet, Defermont (secr); Conseil des Anciens s. Tronchet (pres); Goupilleau (de Fontenai), Legrand, Regnier (secr)

ti. minuster van justitie Génissieu

RO nr. I15: 6 germinal IV (26 mrt \|796)

RE nr.164: 26/27 thermidor IV (13/14 aug 1796): tweetalig

- verwijzing naar: code hypohécaire van 9 messidor III (27 jun 1795) 
- afkondiging: besluit Directoire exếcutif s. Le Toumeur (pres), Lagarde (secr-gen); 2 ventôse IV (21) feb 1796); met dien verstande dat de wet van kracht wordl op I floréal IV (20 apr 1796)

\section{IV frimaire 26 (1795 dec 17)}

BL Ille ser no.13 (63); LA III fol 174ro-175ro; rH VIII 188-189; P VII 244; cB IVe ser I 216-217

\section{LOI QUI DÉTERMINE LE LIEU OÜ SERONT DÉPOSÉES LES MINUTES DES ACTES DE JUGES DE PAIX}

De minuten van akten, processen-verbaal en vonnissen van de vrederechters worden door de griffies der districtsrechtbanken aan de griffiers van de vredegerechten teruggegeven, behalve in de departementen die door opstandelingen onveilig gemaakt worden. De griffiers van de vredegerechten houden dagelijks repertoria aangaande de aard der akten van de vrederechters bij, alsmede van de processen-verbaal en de vonnissen. Jaarlijks worden de minuten van de akten van vrederechters in burgerlijke zaken ten kantore van het municipale bestuur gedeponeerd.

bo. Conseil des Cinq-cents's. Marie-Joseph Chênier (pres); Boissy, J.B. Jolivet, Defermont, Crassous (de l'Hérault) (secr); Conseil des Anciens s. Tronchet (pres); Legrand, Regnier, Goupilleau (de Fontenai) (secr)

RO nr.134(1): 19 floréal IV ( 8 mei 1796)

- afkondiging: besluit Directoire exécutif s. Le Tourneur (pres), Lagarde (secr-gen); 6 floréal IV (25 apr 1796) [BL Ile ser no.42 (342)]

\section{IV frimaire 28 (1795 dec 19)}

LA III 29vo-36ro; FA nr.237; rH VI 237-246; P VII liii-Iwi

\section{ARRETÉ SUR L'INSTRUCTION DES CAUSES DANS LES TRIBUNAUX CIVILS DES NOU- VEAUX DÉPARTEMENS RÉUNIS À LA RÉPUBLIQUE PAR LA LOI DU 9 VENDÉMIAIRE: DERNIER}

Het arrêté behelst - voorlopig totdat het Corps législatif anders heeft bepaald - de bepalingen inzake het aanspannen van rechtszaken bij de nieuw ingestelde rechtbanken en de te dien aanzien gevolgde procedure. In het buitenland woonachtige personen die een rechtszaak beginnen, moeten borg stellen ten aanzien van de kosten van het proces. Rechtbanken mogen niemand ontslaan van de plicht om gezegeld papier te gebruiken. Rechtsgedingen aangespannen bij de oude rechtbanken en die nog niet beëindigd zijn, worden ter zitting gebracht op vordering van de meest gerede partij. Hiervoor wordt eveneens de procedure nader omschreven. Voorts is bepaald op wellke dagen van de revolutionaire kalender welke soort zaken worden behandeld.

bo. volksrepresentanten/gouvernementscommisarissen

s. Pêrès, Portiez (de l'Oise)

ti. gouvernementscommissaris Boutewille (via het bureau d"envoi van het Dijle-departement)

RO nr:96: 11 pluviôse IV (31 jan 1796) 
- verwijzing naar: wetten van $27 \mathrm{mrt} 1791 ; 3$ brumaire II (24 okt 1793); 7 fructidor III (24 aug 1794); wetren "sur l'ordre judiciaire"; code des délits et des peines van 3 brumaire IV (25 okt 1795) - besluit tweetalig bekendgemaakt en aangeplakt overal waar het nodig is

IV frimaire $29(1795$ dec 20$)$

LA II fol 91vo-92vo; FA nr.234; rH VI 176

ARRÊTÉ QUI SUSPEND PLUSIEURS ARTICLES DE L'ARRÊTÉ DU 11 FRUCTIDOR, SUR LE RÉGIME FINANCIER DES PAYS RÉUNIS, ET QUI AUTORISE LES MUNICIPALITÉS À ORDONNANCER LEURS DÉPENSES, À CHARGE D'EN RÉFÉRER À L'ADMINISTRATION CENTRALE

De artt.11, 12, 14, 15 en 18 van het arrêté van 11 fructidor III (28 aug 1795) worden voorlopig opgeschort, voor zover deze afwijken van hetgeen tot nog toe gebruikelijk was wat betreft het machtigen tot betaling door de municipaliteiten. Dezen hebben voorlopig betalingsmachtiging inzake de gewone administratieve kosten en voor nieuwe uitgaven, onder de verplichting het departementale bestuur hiervan in kennis te stellen.

bo. volksrepresentanten/gouvermementscommissarissen

s. Pérès, Portiez (de l'Oise)

ti. volksrepresentanten

RO nr.83: 4 nivôse IV (25 dec 1795)

RE nr.58: $6 / 7$ nivôse IV (27/28 dec 1795)

- verwijzing naar: besluiten volksrepresentanten van 11 fructidor III (28 aug 1795); andere niet gespecificeerde besluiten inzake betalingen

- besluit departementaal bestuur: "consigné dans les registres et arrêté de le faire traduire et imprimer pour être envoié à toutes les municipalités du département"

IV frimaire 29 (1795 dec 20)

LA II fol 129vo; FA nr.234

ARRÉTÉ ASSIGNANT LE PAYEMENT DES HONORAIRES DES MEMBRES ET EMPLOYÉS DES TRIBUNAUX ET DES AUTRES FRAIS DE L'ORDRE JUDICIAIRE SUR LA CAISSE DES DOMAINES NATIONAUX

Voorlopig worden de salarissen van rechters en de overige gerechtelijke uitgaven bekostigd uit de kas der nationale domeinen, behoudens latere terugstorting door de daarvoor definitief vastgestelde kas.

bo. volksrepresentanten/gouvernementscommissarissen

s. Pérès

ti. volksrepresentanten

RO nr.86: $\| 1$ nivôse IV (1 jan 1796) 


\section{ARRETTÉ QUI DÉTERMINE LES ATTRIBUTIONS DES MUNICIPALITÉS RELATIVEMENT AUX CONTRIBUTIONS DIRECTES}

De kantonsmunicipaliteiten, daartoe geïnformeerd door het departementale bestuur, zijn belast met de repartitie van de directe belastingen over de gemeenten. De omslag over de belastingplichtigen en het aanleggen van de kohieren geschiedt door daarvoor aangestelde commissarissen-repartiteur. De inning wordt gegund aan degene die tegen de laagste kosten zich hiermee belast. Zijn die evenwel te hoog dan moet de ontvanger zich ermee zelf belasten. Tegen de hoogte van de aanslag kan men bij de kantonsmunicipaliteit bezwaar maken; het departementale bestuur spreekt zich hier in laatste ressort over uit.

\section{bo. Dinectoire exécutif}

s. Carnot (pres) [FA en LA Reubell]; Lagarde (secr-gen)

ti. minister van financièn Fatipoult

RO nr.88 en nr. 167: 15 nivôse IV (5 jan 1796); 30 messidor IV (18 jull 1796)

- verwijzing naar: wetten van 26 sep*2 okt 1791; 2 now 1791;21 fructidor III (7 sep 1795)

- in FA in de marge aantekening inzake de last tot publicatie

- afkondiging: beshuit Directoire exécutif s. Carnot (pres), Lagarde (secr-gen); 17 messidor IV (5 jul 1796) [BL IIe ser no.57 (508)]

IV frimaire $29(1795$ dec 20$)$

LA III fol 58; rH VIII 9; P VII Ivi

\section{ARRÊTÉ ORDONNANT LA PUBLICATION DES LOIS RELATIVES AUX PRÊTRES SUJETS À LA DÉPORTATION}

Naast de in dit overzicht opgenomen afzonderlijke rechtsvoorschriften inzake geestelijken onderworpen aan deportatie of afzondering, worden tevens afgekondigd: alle overige wetten uit 1792 en 1793 betreffende priesters onderworpen aan deportatie of afzondering die niet in de op 8 brumaire IV (29 nov 1795) bekendgemaakte "code des émigrés" zijn opgenomen.

bo. wolkstepresentanten/gouvernementscommissarissen

s. Pérès, Portiez (de l'Oise)

ti. departement van de Dijle

RO nr.113(13): 6 germinal IV (26 mit 1796)

RE nr. 118: $9 / 10$ geminal IV (29/30 mrt 1796)

- in de Code Merlin en in P worten de bedoelde wetten niet als zodanig nader aangeduid; alleen het decreet van 22 foréal II (I I mei 1794) bekendgemaakt 


\section{LOI QUT DETERMINE LES PEINES A INFLIGER AUX EMBAUCHEURS ET AUX PROVOCA- TEURS A LA DESERTION}

Een ieder die voor de vijand, voor het buitenland, dan wel voor opstandelingen ronselt, zal ter dood worden veroordeeld. Diens goederen zullen worden verbeurdverklaard. Art.11 van de code pénal militaire ter zake van ronselaars is herroepen. Degene die oproept tot desertie wordt met negen jaar hechtenis bestraft en degene die aan een deserteur onderdak verschaft om hem aan vervolging te onttrekken, wordt met gevangenisstraf tussen de zes maanden en twee jaar bestraft. De berechting van verdachten van deze delicten geschiedt door militaire rechtbanken.

bo. Conseil des Cinq-cents s. Marie-Joseph Chénier (pres); Boissy, I.B. Louvet, Defermont (secr); Conseil des Anciens s. Vernier (pres); B. Paradis . Roger-Ducos, Goupil-Préfein (secr)

RO nr.214: 7 brumaire $V(28$ okt 1796)

RE nr.203: $17 / 18$ brumaire $V(7 / 8$ nov 1796)

- verwijzing naar: code penal militaire van 12 mei 1793

- afkondiging: besluit Directoire exécutif s. L.M. Revellière-Lépeaux (pres), Lagarde (secr-gen); 30 vendémiaire V (2l okt 1796); N.B.: "Elle sera de plus proclamée à son de trompe ou de caisse et af"fichée dans chaque commune de ces départemens"

\section{IV nivôse 9 (1795 dec 30)}

LA II fol 132vo-134vo; FA nr.291, FA nr.235; rH VI 177-179; P VII Ivii

\section{ARRETTÉ RELATIF AUX DROITS DE TIMBRE ET D'ENREGISTREMENT, ET ORDONNANT LA PUBLICATION DES LOIS Y RELATIVES}

Het Directoire exécutif van mening zijnde dat de negen Verenigde Departementen door dezelfde wetten als de Franse moeten worden bestuurd en aan dezelfde heffingen onderworpen moeten zijn, bepaalt dat zonder bezwaar de indirecte belastingen kunnen worden geheven en dat de invoering van de wetten inzake de registratie misbruiken zullen voorkomen. Vanaf de dag van de bekendmaking van dit besluit zullen een aantal wetten betreffende de registratie van civiele en gerechtelijke handelingen, eigendomstitels, alsmede het zegelrecht met de daarbij behorende tarieven van kracht worden. Deze rechten dienen bij voorkeur in muntgeld te worden voldaan. De zegelrechten die in een gedeeite van de Belgische departementen geheven worden, alsmede de rechten bij eigendomsovergang van onroerende goederen ingevolge verkoop of vererving, zijn afgeschaft. Overeenkomstig de besluiten van de volksrepresentanten doen de departementale besturen voorlopig uitspraak in geschillen. Het bestuur der registratie en van de nationale diomeinen is belast met de uitvaardiging van de noodzakelijke beschikkingen ter verzekering van de uitvoering van dit arrêtée.

\section{bo. Directoine exécutif}

s. Reubell (pres); Lagarde (secr-gen)

ti. minister van financiën Faipoult

RO nr.91: 19 nivôse IV (9 jan 1796)

RE nr.8॥: $2 / 3$ pluviồse IV (22/23 jan 1796)

- verwijzing naar: wetten van 19 dec $1790 ; 1$ il feb 1791; besluiten wan de volksrepresentanten 
- besluit departementaal bestuur: " „... consigner aux régistres, traduire, imprimer et envoyer dans toutes les communes du Departement"

IV nivôse 14 (1796 jan 4)

BL IIe ser no.53 (458); LA. III fol 172ro; rH VIII 305; P VII 252-253; cB IVe ser II 78-79

ARRETE CONCERNANT L'EMPLOI DE LA MONNAIE DE CUIVRE DANS LES PAIEMENS À FAIRE AUX DIFFÉRENTS CAISSES PUBLIQUES

De belastingen en rechten die in muntgeld kunnen worden betaald, mogen hoogstens tot een veertigste deel van het te betalen bedrag in kopergeld worden voldaan. Betaling van het resterende bedrag moet in goud- of zilvergeld geschieden. In geval van een te grote afdracht van de belastingen in kopergeld, zijn de ontvangers ter zake persoonlijk rekenplichtig in goud- of zilvergeld .

bo. Directoire exécutif

s. Carnot (pres); Lagarde (secr-gen)

RO nr. 161: 11 messidor IV (29 jun 1796)

- cB-intirulë: "arrêté portant qu'il ne sera admis en paiement de tous les droits et contributions payables en numeraire, que le quarantième en monnoie de cuivre de somme à payer"

- afkondiging: besluit Directoire exécurif s. Carnot (pres), Lagarde (secr-gen); 26 prairial IV (14 jum 1796) [BL Ile ser no.53 (459)]

\section{IV nivôse 17 (1796 jan 7)}

LA II foll I32vo; FA nr.235

ARRÊTÉ QUI NOMME LE CITOYEN PRISSE ADMINISTRATEUR DU DÉPARTEMENT DE la MEUSE-INFÉrieure À LA PLACE dU CITOYEN TARTE QUI N'A PAS ACCEPTÉ

Prisse, homme de loi te Brussel, is benoemd tot lid van de centrale administratie van het departement van de Nedermaas in de plaats van Tarte, die zijn benoeming niet aanvaard heeft.

bo. gouvernementscommissaris Bouteville

ti. commissaris van thet Divectoire exécutif Rogier

RO nr.90: 18 nivôse IV (8 jan 1796)

IV nivôse 19 (1796 jan 9)

BL Ile ser no.18 (104); LA III foll 175; rH VIII 190-191; P VII 253-254; cB IVe ser II 97-98; F I 278

LOI QUI DÉTERMINE LA MANIÈRE DONT LES ACTIONS, AU NOM DE LA RÉPUBLIQUE, DEVRONT ÊTRE INTENTÉES OU REPRISES 
Alle rechtsvorderingen die door bestuurslichamen zijn ingesteld, worden in naam van de Republiek door de commissaris van het Directoire exécurif bij het departementaal bestuur gedaan, op vervolging en ten verzoeke van de commissaris van het Directoire exécutif bij het municipaal bestuur in wiens ressort de betwiste objecten zich bevinden. Zijn de vervolgingen ingesteld bij de departementale rechtbank, dan worden zij gevolgd en gedirigeerd door de commissaris van het Directoire exécutif bij het departementaal bestuur in wiens naam de rechtsvervolgingen zijn ingesteld.

bo. Conseil des Cinq-cents s. Treilhard (pres); Quirot, Bézard, J.B. Louvet (de la Haute-Vienne) (secr); Conseil des Anciens s. Vemier (pres); Comilleau, Roger-Ducos, B. Paradis (secr)

RO nr. 134(2): 19 floreal IV (8 mei 1796)

- afkondiging: besluit Direcroire exéccuiff s. Le Toumeur (pres), Lagarde (secr-gen); 6 floreal IV (25 apr 1796) [BL. IIe ser no.42 (342)]

\section{IV nivôse 21 (1796 jan 11)}

BL Ile ser no.18 (106); drukw FA nr.112; rH IX 252-254; P VII 254-255; cB IVe ser II 107-109

\section{LOI ADDITIONNELLE AU CODE HYPOTHÉCAIRE}

Vóór 1 germinal IV (21 mrt 1796) verworven goederen dienen te worden bekrachtigd door de burgerlijke rechtbank van het departement naar de vorm als voorheen door de districtsrechtbank geschiedde. Registers, minuten en overige akten van de griffies der districtsrechtbanken en die ten kantore van de hypotheekbewaarders moeten, onder toezicht van de commissaris van het Directoire exécutif bij de kantonnale besturen, worden geïnventariseerd en overgebracht naar de burgerlijke rechtbanken en de vroegere bewaarders. De wet bepaalt voorts de verdere procedure ten aanzien van hypotheken tot de invoering van het nieuwe hypotheekregime.

bo. Conseil des Cinq-cents s. Treilhard (pres); Quirot, Bézard. J.B. Louvet (secr); Conseil des Anciens s. Vernier (pres); Goupil-Préfeln, Cornilleatu, B. Paradis, Roger-Ducos

ao. commission chargée de l' examen et révision du code hypothécaire

ti. minister van justitie Génissieu

RO nr.115: 6 germinal IV (26 mrt 1796)

RE nr. $164: 26 / 27$ thermidor IV (13/14 aug 1796); tweetalig

- verwijzing naar: code hypothécaire van 9 messidor III. (27 jun 1795)

- afkondiging: besluit Directoire exécurif s. Le Toumeur (pres), Lagarde (secr-gen); 2 ventôse IV (21 feb 1796); met dien verstande dat de wet van kracht wordt op 1 floréal IV (20 apr 1796)

\section{IV nivose 22 (1796 jan 12)}

LA III fol 15vo-16vo; FA nr.236, FA nr.291; rH VI 331-332; cB IVe ser II 118-119

\section{ARRETE QUI FIXE LE JOUR POUR LA CÉLÉBRATION DE LA JUSTE PUNITION DU DERNIER ROI DES FRANÇAIS AU $1^{\text {ER }}$ PLUVIÓse}

Door alle gemeenten van Frankrijk en het leger en de marine dient de gerechte bestraffing van de laatste koning der Fransen op 1 pluviôse IV (21 jan 1796) in de 
hoofdplaats van het kanton in aanwezigheid van het volk te worden gevierd. Allen die door de Franse stalat gesalarieerd worden dienen hierbij aanwezig te zijn en de eed van trouw aan Frankrijk en de eeuwige haat jegens het koningschap uit te spreken. Hiervan wordt proces-verbaal opgemaakt, dat door de commissaris van de uitvoerende macht aan de minister van binnenlandse zaken wordt gezonden.

bo. Directoine exécutif

5. Reubell (pres); Lagarde (secr-gen)

ti. minister van justitie Génissieu

RO nr 94: 3 pluviôse IV (23 jan 1796)

- verwijzing naar" wet wan 21 nivôse III (10 jan 1795)

- besluit departementaal bestuur: "... consigner aux registres et d'en donner toute la publicite"

\section{IV nivôse 22 (1796 jan 12)}

BL Ile ser no. 18 (108); LA III 17ro-18ro, V 203vo-204vo; rH VI 314-316; P VII 255; cB IVe ser II $115-116$

\section{LOI PORTANT QUE LES COTISABLES EN RETARD DE PAYER LES DEUX PREMIERS TIERS DE L'EMPRUNT FORCE, Y SERONT CONTRAINTS}

De contribuabelen van de dwanglening die het eerste derde gedeelte niet op 30 nivôse IV (20 jan 1796) gekweten hebben, worden gedwongen de totale aanslag ineens te voldoen, hetgeen eveneens geldt voor degenen die op 15 pluviôse IV (4 feb 1796) nog niet het tweede derde gedeelte hebben voldaan. Deze dwangmaatregelen worden uitgevaardigd door het departementaal bestuur. Blijft betaling binnen 24 uur uit, dan volgt de inbeslagneming en de verkoop van de goederen en bezittingen van de aangeslagenen.

bo. Conseil des Cinq-cents s. Treilhard (pres); Bezard, J. Voussen, J.B. Louvet (secr); Conseil des Anciens s. Vernier (pres); Cornilleau, Goupil-Préfeln, B. Paradis, Roger-Ducos (secr)

RO nr.95: 5 pluwiôse IV (25 jan 1796); formeel reeds geschiedt door de registratie van het Bulletin des Lots no. 18 op 3 pluviôse IV (23 jan 1796)

RE nr.82: 10/11 pluviôse IV (30/31 jan 1796)

- afkondiging: [opdraciut Directoire exécutif s. Reubell (pres); Lagarde (secr-gen); 22 nivốse IV (12 jan 1796)]; er is geen speciaal afkondigingsbesluit; op verzoek van de commissaris van her Directoire exécutif besluit het departementaal bestuur op 7 pluviôse IV (27 jan 1796) tot het doen vertalen, drukken en publiceren van de wet in alle gemeenten van het departement; daags tevoren had de minister van financiën Faipoult hier ook op aangedrongen in een schrijven d.d. 27 nivôse IV (17) jan 1796) [FA nr.237, FA nr.274 fol 91]; P en Code Merlin vermelden als datum van afkondiging 7 pluviôse $V(26$ jan 1797) |RO nr.257(373)]

IV nivôse 22 (1796 jan 12)

BL Ile ser no. 18 (107); LA III fol 175vo-176ro; rH VIII 191-192; P VII 255; cB IVe ser II 114

LOI QUT DÉTERMINE UN MODE POUR ACCÉLÉRER L'EXPÉDITION DES PROCÈS CRIMINELS DANS LES COMMUNES OÙ IL Y A PLUSIEURS DIRECTEURS DE JURY 
In gemeenten met meerdere directeuren van de jury d'accusation kunnen op elke willekeurige dag lijsten van gezworenen worden gevormd. ledere jury kan vier dagen na het opstellen van de lijst worden bijeengeroepen.

bo. Conseil des Cinq-cents s. Treilhard (pres); Bézard, Quirot, J.B. Louvet (secr); Conseil des Ancions s. Vernier (pres); Goupil-Préfeln, B. Paradis, Cornilleau, Roger-Ducos (secr)

RO nr. 134(3): 19 floréal JV ( 8 mei 1796)

- verwijzing naar: code dess délits et des peines yan 3 brumaire IV (25 okt 1795)

- alkondiging: besluit Direcroire exécutif s. Le Tourneur (pres), Lagarde (secr-gen); 6 florếal IV (25 apr 1796) [BL IIe ser no.42 (342)]

\section{IV nivôse 23 (1796 jan 13)}

LA III fol 13vo-14ro; FA nr.235

\section{ARRETTE PORTANT NOMINATION DES MEMBRES DU TRIBUNAL CRIMINEL}

Als gevolg van de ontslagaanvrage van Gelders, Pelerin en Van Panhuys, respectievelijk president van, openbare aanklager bij en griffier van de criminele rechtbank in het departement van de Nedermaas, zijn in hun plaats benoemd de vroegere agent-nationaal van het arrondissement Maastricht A.C. Membrède als president, de oud-ambtenaar van de gemeente Brussel Michei[iells aîné als openbaar aanklager en de oudadministrateur $\mathrm{C}$. Cole]negracht als griffier. De commissaris van de uitvoerende macht bij de rechtbank is belast met de installatie van de benoemden.

bo. gouvernementscommissaris Bouteville

ii. commissaris van het Directoire exécurif Rogier

RO mr.92: 23 nivôse IV (13 jan 1796)

- verwijzing naar: besluit volksrepresentanien van 7 frimaire IV (28 nov 1795)

\section{IV nivôse 23 (1.796 jan 13)}

LA III fol 14ro-15ro; FA nr.235

\section{ARRÊTÉ PORTANT NOMINATION DES JUGES ET AUTRES MEMBRES DU TRIBUNAL CIVIL DE DÉPARTEMENT DE LA MEUSE-INFERIEURE}

Van de reeds eerder bij besluit van de volksrepresentanten d.d. 7 frimaire IV ( 28 nov 1795) benoemde 25 rechters(-plaatsvervanger) in de burgerlijke rechtbank van het departement van de Nedermaas heeft slechts een zestal hun benoeming aanvaard. Ter vervanging van hen die hun benoeming niet aanvaardden, worden negentien anderen benoemd. De commissaris van de uitvoerende macht bij de rechtbank is belast met hun installatie.

bo. gouvemementscommissaris Bouteville

ti. commissaris van het Directorine execurif Rogier

RO nr.92: 23 nivôse IV (13 jan 1796)

- verwijzing naar: besluit volksrepresentanten van 7 frimaire IV (28 nov 1795) 
IV nivôse 23 (1796 jan 13)

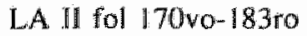

ARRETE PORTANT NOMINATION DES MEMBRES DES ADMINISTRATIONS MUNICIPALES DES CANTONS DU DEPARTEMENT DE LA MEUSE-INFERIEURE

In het besluit worden de benoemingen bekendgemaakt van de leden van de municipaliteitsbesturen van de kantons in het departement Nedermaas. De commissaris van de uitvoerende macht bij het departement is belast met de installatie.

bo. gouvemementscommissaris pour l'organisation des autorités constitutionnelles Bouteville RO nar.93: 23 nivôse IV (13 jan 1796)

- verwijzing naar: [decreet?] van 3 brumaire IV (25 okt 1795)

IV nivôse 30 (1796 jan 20)

BL Ile ser no.24 (151); LA III fol 52vo-53ro, fol 172vo-173ro; FA nr.2836; rH VIII 322-323; P VII 258; cB IVe ser II 166-167

ARRETE QUI DÉTERMINE LE MODE D'ACQUITTEMENT DES DÉPENSES LOCALES ET AUTRES POUR LESQUELLES LES ADMINISTRATIONS DE DEPARTEMENT ET DE DISTRICT DELIVRAIRENT DES MANDATS SUR LES CAISSES NATIONALES

Uitsluitend departementale besturen kunnen betalingsopdrachten ten laste van de nationale kassen afgeven. De ministers openen daartoe bij elk departementaal bestuur en voor elke soort uitgave een vastgesteld krediet bij de departementale kas, ten laste waarvan de betalingsopdrachten van de departementen worden voldaan. De departementale besturen kunnen over geen andere gelden beschikken of betalingsopdrachten afgeven, dan voor uitgaven waartoe zij door de ministers zijn gemachtigd.

bo. Directoine exécunif

s. Le Toumeur (pres); Lagarde (secr-gen)

RO nr.100 en nr.163: 27 pluviôse IV (16 feb 1796); 15 messidor IV (3 jul 1796)

- afkondiging: besluit Directoire exécutif s. Carnot (pres), Lagarde (secr-gen); 18 floréal IV (7 mei 1796); N.B.: registratie van de datum wan afkondiging onder RO nr.100, of schoon het besluit toegezonden was door de minister van justitie Genissieu, is twijfellachtig; het besluit komt niet aan de orde in het proces-verbaal van de zittingen war het departemental bestuur; $\mathrm{P}$ en Cade Merlin vermelden ook als datum van afkondiging 18 floréal JV (7 mei 1796)

\section{IV pluviôse 4 (1796 jan 24)}

BL Ile ser no.21 (134); LA III fol 47vo-48vo; FA nr.291, FA nr.1110; rH VI 333; P VII 259; cB IVe ser II 197-198:

LOI QUI AUTORISE LA VENTE DES DOMAINES NATIONAUX SITUÉS DANS LES NEUF DÉPARTEMENS RÉUNIS PAR LA LOI DU 9 VENDÉMIAIRE 
Het gedeelte der nationale domeingoederen afkomstig van voormalige Franse kerkelijke lichamen als houders van de beneficièn gelegen in de negen départements réumis, wordt ten verkoop aangeboden. Hiermede is het Directoire exécutif belast, dat de opbrengst in de schatkist stort. Het dubbel van de akte van de verkoping of de ruil wordt in het desbetreffende departementale archief bewaard.

bo. Conseil des Cinq-cents s. Camus (pres); F. Lamarque, Droulet, N. Quinette (secr); Conseil des Anciens s. Goupill-Préfeln (pres); Muraire, Lebrun, Lecouteulx-Canteleu, Clauzel (secr)

ti. Corps lëgislatif

RO nr.98: 14 pluviôse IW (3 feb 1796)

RE nr. 110: 25/26 ventôse IV (15/16 mrt 1796)

- FA nr.291: Vlaamse vertaling

- besluit departementaal bestuur: "sera traduite, imprimée dans les deux langues, publié et affiche dans toutes les communes de notre ressort"

- afkondiging: [opdracht Directoire exécutif s. Reubell (pres), Lagarde (secr-gen); 4 pluviòse IV (24 jan 1796)]; er is geen speciaal afkondigingsbesluit

\section{IV pluviôse 5 (1796 jan 25)}

LA III fol 48vo-49ro; FA nr.3358; rH VI 342-343

\section{ARRÊTÉ QUI ORDONNE L'IMPRESSION DE LA LISTE DES RECLAMANS CONTRE LEURS TAXES DANS L'EMPRUNT FORCÉ}

De namen van degenen die een bezwaarschrift indienen tegen de hoogte van de aanslag in de gedwongen geldlening worden gedrukt en over het gehele gebied van het arrondissement van een departement bekendgemaakt, alsmede het bedrag waar het bezwaar zich tegen richt.

\section{bo. Directoire exêcutif}

s. Le Tourneur (pres a.i.); Lagarde (secr-gen)

ti. minister van financiën Faipoult

RO nr.99: 21 pluviôse IV (10 feb 1796)

\section{IV pluviôse 9 (1796 jan 29)}

BL Ile ser no.22 (140); LA III foll 55vo-57vo; FA nr.291; rH VI 388-391; P VII 261-262

\section{LOI RELATIVE À LA PERCEPTION DES DROITS D'ENREGISTREMENT}

De tarieven der registratierechten, vastgesteld in de tarieflijst behorende bij de wet van $5 * 19$ december 1790 , worden verhoogd, variërend van verdubbeling tot vertienvoudiging. De rechten verschuldigd over akten en mutaties betreffende roerende en onroerende goederen, behalve in het geval van overlijden, worden verdubbeld. De kwijting van de registratierechten kan geschieden in muntgeld of in assignaten.

bo. Conseil des Cinq-cents s. Treilhard (pres); Bezard, J.B. Louvet (secr); Conseil des Anciens s. Goupil-Préfeln (pres); Muraire, Lebrun, Lecouteulx-Canteleu, Clauzel (secr)

ti. minister van justitie Génissieu 
RO nir. 111: 13 ventớse IV (3 mrt 1796)

RE nir.112; $25 / 26$ ventose IV (15/16 $\mathrm{mrt} 1796)$

- verwijzing naar: wetten van 5 * 19 dec $1790 ; 25$ vendémiaire IV (17 okt 1795)

- de onderhavige wet wordt herroepen bij de whet wan 14 thermidor IV (1 aug 1796) [RO nr. 179$]$

- afkondiging: besluit Directoire exécutif s. Le Toumeur (pres); Lagarde (secr-gen); 3 ventôse IV (22) feb 1796), met dien verstande dat de wet van kracht zal zijn vanaf 1 germinal IV (21 mrt 1796): eveneens wordt in dit besluit een kleine wijziging aangebracht ten aanzien van de tarieven

\section{IV pluviôse 11 (1796 jan 31)}

LA III fol 49vo-52ro; FA nr.291, FA nr.1110; rH VI 335-339; P VIl lix-1x

\section{ARRETÉ DÉTERMINANT LE MODE ET LES CONDITIONS DE LA VENTE DES DOMAINES NATIONAUX DES DEPARTEMENS REUNIS PROVENANT DES CORPORATIONS RELIGIEU- SES FRANÇAISES, ORDONNEE PAR LA LOI DU 4 PLUVIÓSE}

De verkoop van de nationale domeingoederen in de Belgische departementen, afkomstig van vroegere Franse kerkelijke lichamen, geschiedt door de departementale besturen, hetzij bij opbod, hetzij onderhands met behulp van een schatting (estimation contradictoire). In het besluit worden de modaliteiten van de verkoop en de betalingswijze bepaald. De burger Bochet, één der administrateurs van de régie de l'enregistrement et des domaines, wordt benoemd als bijzonder commissaris voor geheel België ter zake van de verkoping van de nationale domeingoederen.

bo. Directoire exécutif

s. Le Tourneur (pres); Lagarde (secr-gen)

ti. minister van financièn Ramel

RO nr. 106: 7 ventôse IV (26 feb 1796)

RE nr.11!: 25/26 ventôse IV (15/16 mrt 1796)

- verwijzing naar: wetten sur l'aliénation; wet van 4 plưiôse IV (24 jan 1796)

\section{IV pluviôse 15 (1796 feb 4)}

BL Ile ser no.24 (156); LA III fol 205ro-206ro; rH VI 376-378; P VII 263; cB IVe ser II 293-294

LOI QUI ORDONNE UNE LEVÉ DE CHEVAUX, JUMENS, MULES ET MULETS POUR LE SERVICE

Alle paarden en muilezels die op het tijdstip van 1 pluviôse IV (21 jan 1796) gewoonlijk niet gebruikt worden bij landarbeid of de handel staan ter beschikking van het Directoire exécutif voor gebruik bij het leger. Daarnaast wordt het dertigste paard of de muilezel gevorderd, welke minstens vier jaar oud moet zijn. Eigenaren, houders en verzorgers moeten deze dieren bij het kantonnale bestuur aanmelden, op straffe van verbeurdverklaring. Als men een paard of een muilezel verbergt, wordt men beboet tot de hoogte van de verkoopprijs van het dier. Degene wiens paard of muilezel gevorderd is, ontvangt een reçu met de vastgestelde verkoopprijs, die door de betaalmeester van het departement wordt gekweten. 
bo. Consel des Cinq-cents s. Camus (pres); N. Quinette, Drouet (secr); Conseal des Anchens s. Goupil-Préfeln (pres); Muraire, Lebrun, Clauzel (secr)

[RO nr. 117: 11 germinal IV (31 mrt 1796)]

RE nr.96: $3 / 4$ ventôse IV $(22 / 23$ feb 1796)

- Code Merlin noemt de wet niet

- afkondiging: [besluit Directoire exécurif s. Le Toumeur (pres), Lagarde (secr.gen), 29 ventôse IV (19 mrt 1796)]; de afkondiging blijkt miet met zekerheid, alleen bij implicatie; na ontvangst van het desbetreffende Bulletin des Lois besluit het departementaal bestuur: "L"ad" a arrêtée que la loi sous $n^{\circ} 156$ portant la levé du $30^{\circ}$ cheval etc sera traduite, rémprimée, publiêe et envoyée dans toutes les communes du département"

\section{IV pluviôse 18 (1796 feb 7)}

BL IIe ser no.25 (165); LA $\| 61$ ro-164vo; rH VIII 3-8; P VII 264-266; cB IVe ser II 313-316

\section{ARRÊTÉ RELATIF AU MODE DE PROMULGATION DES LOIS DANS LES NEUF DÉPARTE- MENS QUT COMPOSAIENT LA CI-DEVANT BELGIQUE}

Het besluit van het comite de salut public van 20 frimaire III (10 dec 1794) en art.2 van de wet van 3 brumaire IV ( 25 okt 1795) zullen naar vorm en inhoud ten uitvoer worden gelegd, zolang door het Wetgevend Lichaam niet anders wordt bepaald. Mitsdien zijn en zullen er geen wetten verbindend zijn dan die welke niet zijn herroepen en reeds zijn of zullen worden toegestuurd, hetzij ter uitvoering van een bijzonder besluit van het comité de salut public, de volksrepresentanten, het Directoire exécutif, of de generale gouvernementscommissarissen, hetzij ter uitvoering van een bijzondere bepaling van een decreet, een wet enzovoorts uitgevaardigd door de Nationale Vertegenwoordiging. Elk besluit houdende een speciale opdracht tot verzending van een wet aan de autoriteiten, beveelt tegelijkertijd de verzending van niet-herroepen wetten of wetsartikelen waarnaar zij verwijzen, tenzij deze vooraf op dezelfde manier waren verzonden. Wetten, toegezonden bij speciaal besluit zijn verbindend vanaf dag dat ze ingeschreven worden in het departementale repertorium dat daartoe wordt aangelegd. De minister van justitie zal voortgaan met het verrichten van de officiële verzending van het Bulletin des Lois naar de negen départements réunis, teneinde de bestudering en kennisneming ervan door openbare functionarissen en burgers en de voorbereiding op het moment dat de verzending per bijzondere opdracht zal geschieden te vergemakkelijken. Wanneer er zich een probleem bij het verzenden van het Bulletin naar de Belgische departementen voordoet, dan zal het Directoire de minister van justitie speciaal - opdragen dit probleem op te heffen.

\section{bo. Directoire exécutif}

s. Le Tourneur (pres); Lagarde (secr-gen)

ao. minister van justitie

RO nr. 102: 3 ventî̂se IV (22 feb 1796)

- verwijzing naar: besluit comité de salut public van 20 frimaire III (10 dec 1794); wetten van 9 vendémiaire IV ( 1 okt 1795); 12 vendémiaire IV (4 okt 1795); 3 brumaire IV (25 okt 1795) 


\section{IV pluviôse 18 (1796 feb 7)}

BL Ile ser no.25 (166); LA I fol 318ro; FA nr.275 fol 20, FA nr.3358; P VII 266; cB IVe ser II 312313

ARRETE QUI AFFECTE AU REMBOURSEMENT DES RESCRIPTIONS LES RENTREES DE L'EMPRUNT FORCE DANS TOUS LES DÉPARTEMENS DE LA BELGIQUE

De inning van de gedwongen geldlening in de Belgische departementen is in het bijzonder bestemd voor de aflossing van de betalingsopdrachten van de schatkist (rescription). Derhalve moeten door de ontvangers in de departementen elke decade de geïnde gelden naar de schatkist overgemaakt worden, zonder dat de gelden anders aangewend kunnen worden. Deze fondsen blijven in reserve bij de nationale schatkist.

bo. Directoire exécutif

s. Le Tourneur (pres); Lagarde (secr-gen)

ti. minister van financièn Ramel

RO nr. 104: 5 ventôse IV (24 feb 1796)

- onjuiste datum van registratie in RO: 1 ventôse IV (20 feb 1796) gelet op inschrijving in de indicateur gênéral en de registratuur op de stukken

IV pluviôse 19 (1796 feb 8)

LA III fol 53vo-54ro; FA nr.275 fol 9vo-11ro, FA nr.2586; rH VI 394-395

\section{ARRETÉ QUI CASSE CELUI dU REPRÉSENTANT DU PEUPLE MEYNARD dU 10 NIVÔSE QUI PERMETTAIT L'EXPLOITATION DES CUIRS HORS DES PAYS RÉUNIS}

Het Directoire exécutif vernietigt het besluit van 10 nivôse IV (31 dec 1795) van de volksrepresentant Meynard, gouvernementscommissaris in de Landen tussen Maas en Rijn, als zijnde strijdig met de wetten die de uitvoer van voedsel en overige eerste levensbehoeften verbieden, alsmede wegens strijdigheid is met het douaneregime. Voorts is de toestemming vernietigd tot het transporteren van 10000 huiden naar de overzijde van de Rijn, gegeven bij het besluit van 3 jour complémentaire III (19 sep 1795) van dezelfde volksrepresentant.

bo. Directoire exécutif

s. Le Tourneur (pres)

ti. minister van fünanciên Ramel

RO nr. 103: 3 ventôse IV (22 feb 1796)

RE nr.97: $5 / 6$ ventôse IV (24/25 feb 1796)

- verwijzing naar: besluiten volksrepresentant van 3 jour complémentaire III (19 sep 1795); 10 nivôse IV (31 dec 1795); wetten inzake verbod op uitvoer van eerste levensbehoeften

- de minister van financièn is belast met de uitvoering van het arrêté, dat zal worden bekendgemaakt en aangeplakt in de negen départements réunis

\section{IV pluviôse 19 (1796 feb 8)}

BL Ile ser no.26 (172); LA IV fol 70vo-71vo; FA nr.291; rH X 131; P VII 266; cB IVe ser II 320 
Zolang de staatscommissie voor de gewone uitgaven het rapport inzake de wijze van plaatsing en verplaatsing van de diensten van openbare instellingen in gebouwen of nationale domeingoederen, alsmede de regeling hiervan niet gereed heeft, zijn alle (ver)plaatsingen van deze instellingen opgeschort, tenzij daarvoor machtiging bestaat van het Wetgevend Lichaam.

bo. Conseil des Cinq-cents s. Camus (pres); N. Quinette, Bezard (secr); Conseil des Anciens s. Goupil-Prefeln (pres); Muraire, Clauzel, Lecouteulx-Canteleu (secr)

RO nr.209(I): 23 vendémiaire V (14 okt 1796)

RE nr. 196: 9/10 brumaire $V$ (30/31 okt 1796)

- afkondiging: besluit Directoire exécutif s. L.M. Revellière-Lepeaux (pres), Lagarde (secr); 9 vendémiaire V (30 sep 1796); “... seront, dans le plus court délai possible, affichées, publiées et proclamées dans les neuf départemens réunis"

IV pluviôse 21 (1796 feb 10)

LA III fol 54ro; FA nr.275 fol 34, FA nr.2443

\section{ARRÊTÉ QUI MET LES POSTILLONS EN REQUISTTION}

Van postmeesters en postiljons die postkoetsen en diligences begeleiden, die in actieve dienst waren tijdens de bekendmaking van de wet van 23 augustus 1793, wordt gevorderd om hun taak voort te zetten of die weer op te vatten, wanneer zij als gevolg van bedoelde wet gedwongen waren de dienst te verlaten.

bo. Directoire exécutif

s. Le Tourneur (pres); Lagarde (secr-gen)

ti. minister van financiën Ramel

RO nr. 107: 9 ventôse IV (28 feb 1796)

- verwijzing naar: wet van 23 ang 1793

\section{IV pluviôse 23 (1796 feb 12)}

LA III fol 54vo; FA nr.275 fol 39vo-40vo

\section{ARRÊTÉ PORTANT QUE LES PORTS DE LETTRES OU PAQUETS QUE LES COMMISSAI- RES DU POUVOIR EXÉCUTIF PRÈS LES DÉPARTEMENS ET LES TRIBUNAUX RECE- VRONT POUR RAISON DE LEURS FONCTIONS LEUR SERONT REMBOURSÉS}

De commissarissen van de uitvoerende macht bij de departementen en de rechtbanken krijgen de portokosten van brieven en pakketten, ambtshalve door hen verzonden, terugbetaald door de ontvanger-generaal der belastingen van het departement, op vertoon van een gewaarmerkte lijst.

bo. Directoire exécutif

s. Le Toumeur (pres); Lagarde (secr-gen) 


\section{IV pluviôse 25 (1796 feb 14)}

FA ar.664 (gewaarmarkt afschrift); rH VIII 55-61; cB IVe ser II 362-367

\section{ARRETE SUR LE MODE D'EXECUTION DE LA LOI DU 14 PLUVIOSE, QUI ORDONNE UNE LEVEE DE CHEVAUX}

De vordering van paarden en muilezels als voorgeschreven in de wet van 15 pluviôse IV (4 feb 1796) moet plaatshebben vóor 10 germinal IV (30 mrt 1796). Het besluit is de nadere uitwerking van bovengenoemde wet en behelst de vorderingsprocedure. De municipale besturen van de kantons benoemen daartoe speciale commissarissen die zich naar iedere gemeente begeven, teneinde het aantal aanwezige paarden vast te stellen. Alle eigenaren wan paarden dienen in de hoofdplaats van het kanton samen te komen om onderling te bepalen wie een paard of muilezel zal afstaan, anders wordt dit door het kanton bepaald. In het besluit worden verder bepalingen gegeven ten aanzien van de schadeloosstelling, het transport van de paarden naar de departementale hoofdstad en de geschiktheidskeuring van de paarden voor dienst in het leger. Paarden die ongeschikt zijn worden teruggestuurd. Van alle handelingen wordt een proces-verbaal opgemaakt.

\section{bo. Directoine exécurif}

s. Le Toumeur (pres); Lagarde (secr-gen)

RO nr.117: 11 germinal IV (31 $\mathrm{mrt} 1796$ )

RE nr.124: $19 / 20$ germinal IV (8/9 apr 1796)

- verwijzing naar: wet van 15 pluviôse IV (4 feb 1796)

- N.B.: de diverse vindplaatsen plaatsen de onderhavige wet of wel onder 14 , ofwel onder 15 pluviôse IV; idem het besluit onder 25 , of 26 pluviôse IV; $c B$ daarentegen spreekt van besluit van 26 pluviôse IV en wet van 14 pluviôse IV

- afkondiging: besluit Direcroire exécutif s. Le Tourneur (pres), Lagarde (secr-gen); 29 ventôse IV (19 $\mathrm{mrt} 1796)$

\section{IV pluviôse 26 (1796 feb 15)}

drukw FA nr.112; rH IX 255-259; P VII Ixii-1xiii

\section{ARRETE QUI DETERMINE LE NOMBRE ET LE PLACEMENT DES BUREAUX DE LA CONSERVATION DES HYPOTHEQQUES DANS L'ÉTENDUE DES NEUF DÉPARTEMENS DE LA CI-DEVANT BELGIQUE}

In de negen départements réunis zullen 23 kantoren voor de bewaring van hypotheken worden gevestigd, waarvan twee in het departement van de Nedermaas, te weten in Maastricht en Roermond. Hun respectieve ressort omvat de gemeenten waar de kantoren voor de inning der registratierechten zijn gevestigd. Voor het ressort Maastricht zijn dit de gemeenten Maastricht, Hasselt, Sint-Truiden en Tongeren; voor het ressort Roermond de gemeenten Roermond, Maaseik en Peer. 
bo. Dinectowite exécutif

s. Le Tourneur (pres); Lagarde (secr-gen)

ao. algemeen hypotheekbewaarder

tii. minister van justitie Génissieu

RO nr. 114: 6 germinal IV (26 mrt 1796)

- verwijzing naar: code hyporhécaire van 9 messidor III ( 27 jul 1795); wet wan 2 brumaire IV (24 okt 1795)

- afkondiging: besluit Divectoine cxécutf"s. Le Toumeur (pres), Lagarde (secr-gen): 2 ventóse IV (2I feb 1796)

\section{IV pluviôse 26 (1796 feb 15)}

BL Ille ser no.27 (181): LA III fol 65vo-66vo; FA nr.291; rH VIII 162-164; P VII 269; cB IVe ser II 359-360

\section{LOI ADDITIONNELLE À CELLE SUR L'EMPRUNT FORCÉ}

De departementale besturen zijn gemachtigd de omslag met betrekking tot de dwanglening te herschikken ten gunste van hen die te hoog belast zijn. Welgestelde burgers die niet op de kohieren voorkomen, worden alsnog aangeslagen en degenen onder hen die gezien hun mogelijkheden te weinig aan de staat lenen, dienen naar evenredigheid meer op te brengen. Zij die te hoog aangeslagen zijn, krijgen het teveel terugbetaald. Niettemin blijft de totale op te brengen som ongewijzigd en mag de herschikking de afdracht niet verhinderen of vertragen.

bo. Conseil des Cinq-rents s. Camus (pres); Bézard, F. Lamarque (secr); Conseil des Anciens s. Goupil-Préfeln (pres); Lebrun, Muraire, Clauzel, Lecouteulx-Canteleu (secr)

ti. minister van justitie Génissieu

RO nr.116: 6 germinal IV (26 mrl 1796)

- verwijzing naar: wet van 19 frimaire IV (10 dec 1795)

- afkondiging; besluit Directoire exécutif s. Le Toumeur (pres), Carnot (secr-gen, bij opdracht); 21 ventôse IV (11 mrt 1796)

\section{IV pluviôse 28 (1796 feb 17)}

BL lle ser no.28 (188); LA IV fol 140; rH X 118-119; P VII 270-271; cB IVe ser II $372-373$

\section{LOI QUI CHARGE LE DIRECTOIRE EXÉCUTIF DE STATUER DEFINITIYEMENT SUR LES DEMANDES EN RADIATION DE LA LISTE DES ÉMIGRÉS}

Het Directoire exécutif doet definitief uitspraak inzake verzoeken om doorhaling op de lijst van uitgewekenen. Uit de verzoekschriften moeten blijk dat zij binnen de door de wet gestelde termijnen zijn ingediend. Tevens moeten zij voldoen aan de vormvoorschriften ter zake.

bo. Consell des Cinq-cents s. Camus (pres); J.H. Bancal, N. Quinette (secr); Conseil des Arciens s. Goupil-Préfeln (pres); Muraire, Clauzel, Lebrun, Lecouteulx-Canteleu (secr)

RO nr.210(22): 23 vendémiaire V (14 okt 1796) 
- afkondiging: besluat Directoire exécutif s. L.M. Revellière-Lépeaux (pres), Lagarde (sect-gen); 10 fructidor IV (27 aug 1796)

\title{
IV pluviôse 29 (1796 feb 18)
}

LA V 72vo-73ro; FA nr.243 fol 33, FA nr.3378

\section{ARRETTE QUI NOMME LE CITOYEN NIVAR RECEVEUR DES IMPOSITIONS DIRECTES DU DEPARTEMENT DE LA MEUSE-INFERIEURE}

Tot ontvanger der directe belastingen in het departement van de Nedermaas is benoemd Nivar. Hij dient zich onverwijld naar zijn standplaats te begeven.

bo. Directoire exécutif

s. Le Tourneur (pres); Lagarde (secr-gen)

ti. minister van financiën Ramel

RO nr. 109: 11 ventôse IV (1 mrt 1796)

- verwijzing naar: grondwet van 5 fructidor III (22 aug 1795)

\section{IV ventôse 2 (1796 feb 21)}

LA IV fol 164vo-165vo; FA nr.242 fol 37vo-38ro; rH VIII 33-34

\section{ARRETTÉ PORTANT FIXATION DES APPOINTEMENS DES DIRECTEURS ET EMPLOYÉS DE L'ENREGISTREMENT}

Het besluit stelt de maandelijkse bezoldiging in muntgeld vast die vanaf $\mathbb{1}$ pluviôse IV (21 jan 1796) aan de ambtenaren der régie de l'enregistrement et des domaines nationaux zal worden toegekend. De ontvangers van de registratie en de nationale domeinen krijgen daarenboven een courtage naar rato van hun ontvangsten in de plaats van de gelden voor commissie- en bureaukosten. Het personeel zal niet langer het militaire rantsoen brood en vlees ontvangen dat voorheen werd toegekend.

\author{
bo. Directoire exécurif \\ ao. minister van financiën \\ s. Le Tourneur (pres) \\ ti. régisseurs nationaux de l'emegistrement et des domaines \\ RO nr.112: 16 ventôse IV (6 mrt 1796) \\ - verwijzing naar: wet van 14 aug 1793
}

\section{IV ventôse 2 (1796 feb 21 )}

FA nr.242 fol $38 v 0 ;$ rH VIII 34

ARRÉTÉ PORTANT FIXATION DES APPOINTEMENS DES DIRECTEURS DE L'ENREGISTREMENT 
De directeuren der régie de l'enregistrement et des domaines nationaux in de négen Verenigge Departementen ontvangen vanaf 1 pluviôse IV (21 jan 1796) een bedrag in muntgeld voor de huur-, commissie- en bureaukosten ter grootte van hun vaste salaris.

bo. Directoire exécututif

ao. minister wan financiën

s. Le Tourneur (pres)

ti. régisseurs nationaux de l'enregistrement et des domaines

RO nr.112: 16 ventôse IV (6 mrt 1796)

IV ventôse 3 (1796 feb 22)

LA III fol 55; FA mr.275 fol 50vo-52ro, FA nr.2586; rH VIII 26-27; P VII lxiv-lxv

\section{ARRÊté QUi INTRODUIT LE RÉGIME DES DOUANES FRANÇAISES DANS LeS PAYS RÉUNIS ET ABOLIT LA FRANCHISE DU PORT D'OSTENDE}

Het Franse douaneregime zal van kracht worden over het gehele gebied van de negen départements réunis. Ten gevolge hiervan is de vrijhaven van Oostende opgeheven. Vanaf 15 ventôse IV ( 5 mrt 1796) zullen de vastgestelde douanerechten geheven worden op de handel met het achterland, evenwel alleen op handelswaar bestemd voor het buitenland.

bo. Directoire exécurif

ao. minister yan financiën Ramel

s. Le Tourneur (pres); Lagarde (secr-gen)

ti. minister wan financiën

RO nr. 1 10: 13 ventôse IV ( $3 \mathrm{mrt}$ 1796)

RE nr.104: 20/21 ventôse IV (10/11 mrt 1796)

- verwijzing naar: wet van 11 nivôse $1 \mathrm{II}(31 \mathrm{dec} 1794)$

- P-intitulé: "arrêté du directoire exécutif qui introduit dans les départemens réunis le système des douanes françaises, et y ordonne la publication de plusieurs lois"; de laatsten worden niet nader aangeduid, behoudens een verwijzing naar een besluit van de volksrepresentanten van 29 frimaire $\mathrm{IV}$ (20 dec 1795), dat aankondigt dat het Franse douaneregime van kracht zal worden en dat de desbetreffende wetten nog nader bekend zullen worden gemaakt; Code Merlin noemt de beide onderhavige besluiten niet

\section{IV ventôse 4 (1796 feb 23)}

LA IV fol 23vo-24vo; FA nr.291; rH IX 271-272; cB IVe ser III 17-18

\section{LOI PORTANT QUE LES TRATTEMENS ET DEPENSES NON FIXÉS EN MYRIAGRAMMES DE FROMENT, SERONT PORTÉS DANS LES ÉTATS ET CALCULÉS EN FRANCS}

Bezoldigingen en overige uitgaven welke door de grondwet niet in hoeveelheden van tien kilo tarwe zijn vastgesteld, moeten op de uitgavenstaat, die aan de Conseil des Cing-cents gepresenteerd wordt, in francs worden opgevoerd. De hoeveelheid van tien kilo tarwe in andere wetten dan de grondwet als bezoldiging aangekondigd, wordt voorlopig door de somma van twee francs vervangen. 
bo. Consell des Cinquens s. Camus (pres); J.H. Bancal, Bezard, F. Lamarque (secr); Conseil des Anclens s. Regnier (pres); Merlino. Bonnesoenr (secr)

ăo. commissie uit de Cinq-cents "nommếe pour lui présenter l'état des dépenses ordinaires"

RO nr. 196(2): 21 fructidor IV (7 sep 1796)

- verwijzing naar: grondwet van 5 fructidor III (22 aug 1795)

- BL [lle ser no.31(210)] en P vermelden alleen het intitulé

- LA, FA nr.291 en $\mathrm{rH}$ vermelden als intule: "Loi relative aux traitemens et dépenses non fixés en myriagrammes par la Constitution"

- afkondiging: besluit Direcroire execurif s. L.M. Revellière-Lepeaux (pres), Lagarde (secr-gen); 11 fructidor IV (28 aug 1796)

\section{IV ventôse 4 (1796 feb 23)}

LA IV fol 7I vo-72vo; FA nr.291; rH X 132-133; cB IVe ser III 15-16

LOI QUI ORDONNE LA FORMATION D'UN TABLEAU DES EDIFICES NATIONAUX OCCUPES PAR DES ETABLISSEMENS PUBLICS, ET PORTE QU'IL NE SERA A L'AVENIR DISPOSÉ D'AUCUN DE CES ÉDIFICES, SANS L'AUTORISATION DU CORPS LEGISLATIF

Het Directoire exécutif dient een staat van alle gebouwen en terreinen in bezit als national domeingoed dan wel gehuurd en bestemd voor de overheidsdienst te overleggen. Aangegeven moet worden welke bouwgronden als zodanig gehandhaafd kunnen worden; de overige zullen weer onder het beheer van de administratie der nationale domeinen worden geplaatst. Voortaan kan de inrichting van een gebouw, een terrein of de verplaatsing van de ene naar een andere locatie alleen plaatsvinden dan met machtiging van het Wetgevend Lichaam, onder overlegging van een daartoe strekkend gemotiveerd verzoek en vergezeld van de opgemaakte bestekken.

bo. Conseil des Cinquents s. Camus (pres); J.H. Bancal, Bézard, F. Lamarque (seer); Conseill des Anciens s. Regnier (pres); Bonnesoeur, Merlino (secr)

RO nr.209(2): 23 vendémiaíre $V$ (14 okt 1796)

RE nr.196: $9 / 10$ brumaire V (30/31 okt 1796)

- BL [IIe ser no.30 203)] en P vermelden alleen het intitulé

- afkondiging: besluit Directoire exécutif s. L.M. Revellière-Lepeaux (pres), Lagarde (secr-gen); 9 vendémiaire V (30 sep 1796): "... seront, dans le plus court délai possible, affichées. publiées et proclamées dans les neuf départemens réunis ..."

\section{IV ventôse 5 (1796 féb 24)}

BL. Ile ser no.28 (196); LA IV fol 140vo-141vo; rH X 119-121; P VII 275; cB IVe ser III 29-30

\section{LOI QUI DETERMINE LA MANIERE DONT IL SERA STATUÉ SUR LES DEMANDES EN RADIATION DE LA LISTE DES GMIGRES, FORMÉES PAR CEUX QUI ONT ETÉ EXCLUS DU CORPS LEGISLATIF}

Degenen die uitgesloten zijn van het lidmaatschap van het Wetgevend Lichaam, aangezien zij staan op de lijst van uitgewekenen, overhandigen hun memorie met bewijsstukken aan de Conseil des Cinq-cents, die bij stemming een commissie van vijf leden zal benoemen om rapport wit te brengen. Doorhaling op de lijst van uitge- 
wekenen betekent opheffing van de uitsluiting. De verwerping van het verzoek om doorhaling betekent terzelfder tijd de nietigheid van de benoeming in de wetgevende macht.

bo. Conseil des Cinq-cents s. Camus (pres); Bézard, F. Lamarque (secr); Conseil des Anciens s. Regnier (pres); Bernard (de Saint-Afrique) , Rossée, Merlino, Bonnesoeur (secr)

RO nr.210(23): 23 vendémiaire $V(14$ okt 1796)

- verwijzing naar: wet van 3 brumaire IV (25 okt 1795)

- afkondiging: besluit Directoire exécutif s. L.M. Revellière-Lépeaux (pres), Lagarde (secr-gen); 10 finctidor IV (27 aug 1796)

\section{IV ventôse 9 (1796 feb 28 )}

BL Ile ser no.29 (198); LA III fol 176; rH VIII 193-194; P VII 276; cB IVe ser III 50-5I

\section{LOI QUI ATTRIBUE AUX JUGES ORDINAIRES LA CONNAISSANCE DES AFFAIRES QUI ÉTAIENT PORTÉES DEVANT LES TRIBUNAUX DE FAMILLE}

Geschillen die voorheen beoordeeld werden door de familiegerechten, worden nu voorgelegd aan de gewone rechters. Reeds gewezen vonnissen en tot aan bekendmaking van de onderhavige wet nog uit te spreken vonnissen blijven gehandhaafd volgens de vormen en de termijnen in de wetten bepaald, behoudens hoger beroep bij de burgerlijke departementale rechtbank.

bo. Conseil des Cinqucents s. Thibaudeau (pres); Dauchy (de l'Oise), P.J. Audouin, Gibert-Desmolières (secr); Conseil des Anciens s. Regnier (pres); Bonnesoeur, Merlino, Bernard (de SaintAfrique) (secr)

RO nr.134(4): 19 floréal IV (8 mei 1796)

- verwijzing naar: grondwet van 5 fructidor III (22 aug 1795) en wetten daaraan anterieur

- afkondiging: besluit Directoire exécurif s. Le Tourneur (pres), Lagarde (secr-gen); 6 floréal IV (25 apr 1796) [BL Ile ser no.42 (342)]

\section{IV ventôse 9 (1796 feb 28)}

BL IIe ser no.29 (199); LA III fol 177ro; rH VIII 194-195; P VII 276; cB IVe ser III $51-52$

\section{LOI QUI ORDONNE QUE LES AFFAIRLS DONT LA CONNAISSANCE ETAIT ATTRIBUEE $\ddot{A}$ DES ARBITRES FORCÉS, SERONT PORTÉES DEVANT LES JUGES ORDINAIRES}

Geschillen die voorheen ter beslissing aan scheidslieden (arbitres forcés) waren opgedragen, worden voortaan beoordeeld door de gewone rechters. Vonnissen die door scheidslieden sinds 1 vendémiaire IV (23 sep 1795) zijn uitgesproken, worden geacht in eerste aanleg gewezen te zijn. Beroep tegen dergelijke vonnissen staat open bij de burgerlijke rechtbank van het departement tot drie maanden na de bekendmaking van de onderhavige wet.

bo. Conseil des Cinq-cents s. A.C. Thibaudeau (pres); P.J. Audoun, Dauchy (de l'Oise) (secr); Conseil des Anciens s. Regnier (pres); Bernard (de Saint-Afrique), Merlino, Bonnesoeur (secr) RO $n r_{.}$. 344(5): 19 floréal IV ( 8 mei 1796) 
- verwijzing waar. grondwet van 5 fructidor III (22 aug 1795) en wetten daaraan anterieur

- afkondiging: besluit Directoine exécutif s. Le Toumeur (pres), Lagarde (secr-gen); 6 floréal IV (25 apr 1796) [BL lle ser no.42 (342)]

\section{IV ventôse 14 (1796 mrt 4)}

BL Ile ser no.29 (200): LA III 94ro-95ro; rH VIII 121-122; P VII 277; cB IVe ser III 66-67

\section{LOI QUI DETERMINE LE MODE DE DÉLIVRANCE DES PASSE-PORTS À L'ÉTRANGER}

Paspoorten voor het buitenland worden door de departementale besturen verstrekt op het gemotiveerde advies van de municipaliteiten overeenkomstig de vorm en de voorwaarden als bepaald in de wet van 7 december 1792, welke gehandhatafd blijft voor zover niet strijdig met de bepalingen van de onderhavige wet. De commissarissen van de uitvoerende macht bij de departementale besturen zenden iedere decade een omstandig en gewaarmerkt rapport over de afgegeven paspoorten aan de minister voor buitenlandse betrekkingen.

bo. Consell des Cinq-cents s. A.C. Thibaudeau (pres); J.B. Louvet, P.J. Audouin, Gibert-Desmolières, Dauchy (de l'Oise) (secr); Conseil des Anciens s. Regnier (pres); Bernard (de Saint-Afrique), Merlino, Rossée, Bonnesoeur (secr)

RO nr. 140: 27 floréal IV (16 mei 1796)

RE nr. 143: $12 / 13$ prairial IV (3I mei/1 jun 1796)

- verwijzing naar: wet van $7 \mathrm{dec} 1792$

- afkondiging: besluit Directoire exécutif s. Carnot (pres), Lagarde (secr-gen); 9 floréal IV (28 apr 1796) ['BL lle ser no.44 (374)]; Code Merlin vermeldt als datum van afkondiging 2 floreal IV (2.1 apr 1796), die echter door het afkondigingsbesluit van 9 floreal IV is herroepen

\section{IV ventôse 15 (1796 mrt 5)}

BL Ille ser no.31 (219); LA III fol 177vo-178ro; rH VIII 195-196; P VII 277; cB IVe ser III 75-76

LOI PORTANT QUE LES PARENS ET ALLIES DE L'UN DES CO-ACCUSÉS DU MÉmE FAIT, NE PEUVENT ETRE ENTENDUS COMME TÉMOINS CONTRE LES AUTRES ACCuStes

Bloed- en aanverwanten van één der medebeschuldigden inzake hetzelfde strafbare feit en vallend onder dezelfde akte van beschuldiging zullen niet als getuigen tegen de overige beschuldigden worden gehoord.

bo. Conseil des Cinq-ients s. A.C. Thibaudeau (pres); P.J. Audouin, Gibert-Desmolières (secr); Consell des Amciens s. Regnier (pres); Bernard (de Saint-Afrique), Merlino, Bionnesoeur, Rossée (secr)

RO nr. 134(6): 19 floréal IV (8 mei 1796)

- verwijzing naar: code des délits et des peines van 3 brumaire IV (25 okt 1795)

- wet uitgevaardigd n.a.v, moeilijkheden gerezen in het proces tegen Chaudron, Casmann en Humbert voor de criminele rechtbank van het departement Vosges

- afkondiging: besluit Directoire exécutif s. Le Tourneur (pres), Lagarde (secr-gen); 6 floreal IV (25 apr 1796) [BL lle ser no.42 (342)] 


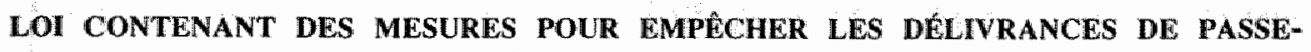
PORTS SOUS DES NOMS SUPPOSÉS

Autoriteiten die belast zijn met het verstrekken van paspoorten mogen deze slechts aan hen afgeven die zij persoonlijk kennen. Kennen zij de persoon niet, dan mogen paspoorten alleen verstrekt worden op attestatie van twee bekende burgers, wier namen in het paspoort worden vermeld en door hen worden ondertekend. Ambtenaren die deze bepaling overtreden, worden van hun functie ontheven en bestraft met drie tot twaalf maanden gevangenisstraf. Getuigen die een valse naam bevestigen en logementshouders die met opzet een valse naam in de registers inschrijven, worden overeenkomstig bestraft.

bo. Conseil des Cinq-cents s. A.C. Thibaudeau (pres); Dauchy (de l'Oise), P.J. Audouin, GibertDesmolières (secr); Conseil des Anciens s. Regnier (pres); Rossée, Bonnesoeur, Merlino (secr)

RO nr. 140: 27 floréall IV (16 mei 1796)

RE nr.143: $12 / 13$ prairial IV (31 mei/1 jun 1796)

- afkondiging: besluit Directoire exéculif s. Carnot (pres), Lagarde (secr-gen); 9 floréall IV (28 apr 1796); Code Merlin vermeldt als datum van afkondiging 2 floréal IV (21 apr 1796), die echter door het afkondigingsbesluit van 9 floréal IV is herroepen [BL Ile ser no.44 (374)]

\section{IV ventôse 18 (1796 mrt 8)}

BL IIe ser no.31 (221); LA III fol 127; rH VIII 254-255; P VII 278; cB IVe ser III 90-9l

\section{LOI QUi DÉClARE ADMISSIBLES EN CASSATION TOUS LES ACTES EN RECOURS ADRESSÉS EN TEMPS UTILE À LA CONVENTION NATIONALE, ET MENTIONNÉS SUR LES REGISTRES DES COMITÉS}

De bezwaren tegen de vonnissen van de criminele rechtbanken, gericht aan de Convention nationale en aldaar door de comités geregistreerd, worden geacht tijdig ingediend te zijn en geven de mogelijkheid tot voorziening in cassatie bij het tribunal de cassation. Eisen van dien aard waarover de Convention nationale nog niet heeft beslist, worden aan het tribunal de cassation gezonden. Soortgelijke bezwaarschriften kunnen niet langer aan het Corps législatif gericht worden en gelden als niet-bestaand.

bo. Conseil des Cinq-cents s. A.C. Thibaudeau (pres); P.J. Audouin, Gibert-Desmolières (secr); Conseil des Anciens s. Regnier (pres); Merlino, Bonnesoeur, Rossée (secr)

ao. commissie uit de Cinq-cents

RO nr 148(1): 13 prairial IV ( 1 jun 1796)

- verwijzing naar: wetten van 16 sep 1791; 27 sep 1792; 14 thermidor III (1 aug 1795)

- wet uitgevaardigd n.a.v. een verzoekschrift van François Paquet

" afkondiging: besluit Directoire exécutif s. Camot (pres), Lagarde (secr-gen); 25 floréal IV (14 mei 1796) 


\section{IV ventose 19 (1796 mrt 9)}

BL IIe ser no.30 (207); P VII 279; cB IVe ser III 93-94

\section{LOI RELATIVE AU PAIEMENT DE L'EMPRUNT FORCÉ DE LA PART DES EMPLOYÉS CIVILS À LA SUITE DES ARMEES}

De bij de legers gestationeerde commissarissen van oorlog moeten een lijst van al het burgerpersoneel opstellen dat bij de legertros werkzaam is, met bijgevoegd de eventuele kwijtingen van hun bijdrage, alsmede die van de commissarissen van oorlog zelf, in de gedwongen geldlening. Deze staat wordt ter beoordeling aan het departementaal bestuur gezonden, teneinde de juistheid van de hoogte van de afdracht vast te stellen.

bo. Conseil des Cinquents s. A.C. Thibaudeau (pres); Dauchy (de l'Oise), Gibert-Desmolières, P.J. Audouin (secr); Conseil des Anciens s. Regnier (pres); Rossée, Merlino, Bonnesoeur (secr) RO nr.130: 7 floréal IV (26 apr 1796)

- afkondiging: besluit Directoive exécutif s. Le Toumeur (pres); Lagarde (secr-gen); 23 germinal IV (12 apr 1796); zonder te derogeren aan eerdere besluiten inzake de wijze van kwijting van de $\mathrm{mm}$ prum forre in de negen Verenigde Departementen

IV ventôse 19 (1796 $\mathrm{mrt}$ 9)

BL IIe ser no.30 (209); LA III fol 178; rH VIII 197-198; P VII 279; cB IVe ser III 97-98

LOI QUI PROROGE JUSQU'AU PREMIER MESSIDOR LE TERME INDIQUÉ POUR L'INTRODUCTION DU NOUVEAU RÉGIME HYPOTHÉCAIRE

De datum van 1 germinal IV (21 mrt 1796) van het in werking treden van het nieuwe hypothecaire regime, zoals genoemd in de wet van 26 frimaire IV (17 dec 1795), is verschoven naar 1 messidor IV (19 jun 1796). Het rapport van de bijzondere commissie inzake het nieuwe hypothecaire regime moet op 1 germinal IV worden uitgebracht.

bo. Consell des Cinq-cents s. A.C. Thibaudeau (pres); Dauchy (de l'Oise), Gibert-Desmolières, P.J. Audouin; Conseil des Ancienss. Regnier (pres); Merlino, Bonnesoeur, Rossée (secr)

RO nr. 134(7): 19 floréal IV (8 mei 1796)

- verwijzing naar; code hypothécaire van 9 messidor III (27 jun 1795); wet van 26 frimaire IV (17) dec 1795)

- afkondiging: besluit Directoire exécurif s. Le Toumeur (pres); lagarde (secr-gen); 6 floréal IV (25 apr 1796) BL lle ser no.42 (342)]

\section{IV ventôse 19 (1796 mrt 9)}

BL Ile ser no.30 (208); LA III fol 100vo-101 ro; $\mathrm{rH}$ VIII 127-128; cB IVe ser lll 96-97

LOI RELATIVE AU SERMEN'I' DE HAINE A LA ROYAUTÉ DE LA PART DES FONCTIONNAIRES PUBLICS

Alvorens in functie te treden, dienen leden van een met overheidsgezag bekleed lichaam de eed van haat jegens het koningschap af te leggen. Degenen die hun over- 
heidsfunctie uitoefenen zonder deze eed te hebben afgelegd, worden bestraft met deportatie. Rechters die nog niet aan de eedsaflegging hebben voldaan, dienen dit binnen drie dagen na de bekendmaking van de onderhavige wet te doen.

bo. Consell des Cinq-cents s. A.C. Thibaudeau (pres); Dauchy (de l'Oüse), Gibert-Desmolières, P... Audouin (secr); Conseil des Anciens s. Regnier (pres); Merlino, Bonnesoeur, Rossee (secr)

ao. Directoire exécurif

RO mr. 139: 27 floréal IV (16 mei 1796)

RE nr.149: 19/20 prairial IV (7/8 jun 1796)

- verwijzing naar: wet van 22 frimaire IV (13 dec 1795)

- wet uitgevaardigd n.a.v. het feit dat enige leden van rechtbanken in de Republiek weigerden de eed van haat jegens. het koningschap af te leggen

- afkondiging: besluit Directoire exécutif $\mathrm{s}$. Camot (pres), Latgande (secr-gen); 17 floreal TV (6 mei 1796)

\section{IV ventôse 19 (1796 mrt 9)}

BL IIe ser no.30 (206); LA III fol 93; FA nr.275 fol 186; rH VIII 149; P VII lx*i, 278-279; cB IVe ser III 94-95

[extract] LOI QUI DÉTERMINE L'ÉPOQUE JUSQU'À LAQUELLE L'EMPRUNT FORCÉ

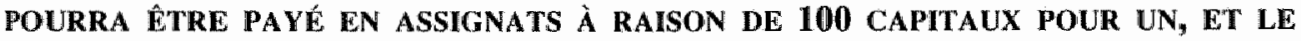
MODE DE REMBOURSEMENT DES PAIEMENS À UN TAUX SUPERIEUR (art.6)

Degenen die geheel of gedeeltelijk roerende goederen wegmaken om aldus aan vervolging wegens het te laat kwijten van de dwanglening te ontkomen, worden in hechtenis genomen tot aan de betaling van de verschuldigde som.

bo. Conseil des Cing-cents s. A.C. Thibaudeau (pres); Gibert-Desmolières, J.B. Louvet, P.J. Audouin (secr); Conseil des Anciens s. Regnier (pres); Bonnesoeur, Merlino, Rossée (secr)

ti. minister van financièn Ramel

RO nr. 142: 3 prairial IV (22 mei 1796)

- afkondiging: besluit Directoire exécurif s. Carnot (pres), Lagarde (secr-gen); 18 floréal IV (7 mei 1796); vermeldt wordt: "Sera oblligatoire et exécuté dans les neuf́ départemens de la ci-devant Belgique. Déclare que les autres articles de cette loi ne sont point applicables à ces mêmes départemens"

\section{IV ventôse 20 (1796 mrt 10)}

BL Ile ser no.31 (225); LA III fol 128; rH VIII 256-257; P VII 279-280; cB IVe ser III 105-106

\section{LOI PORTANT DES PEINES CONTRE CEUX QUI DECRIERAIENT OU REFUSERAIENT LES MONNAIES MÉTALLIQUES FRAPPÉES AU COIN DE LA RÉPUBLIQUE}

Degenen die in woord en in geschrifte het muntgell van de Franse staat in discrediet brengen, alsmede degenen die de aangegeven waarde van het gemunte geld niet aanvaarden, riskeren een zware bestraffing. Elk vonnis ter zake zal op kosten van de veroordeelde in de kantonshoofdplaatsen van een departementsarrondissement worden aangeplakt. 
bo. Conseil des Cinq-cents s. A.C. Thibaudeau (pres); Dauchy (de l'Oise), Gibert-Desmolières, PJ. Audouin (secr); Conseil des Anciens s. Regnier (pres); Merlino, Bonnesoeur, Rossée (secr)

RO nr. 148(2): 13 prairial IV (1 jun 1796)

- afkondiging: besluit Directoire exécutif s. Carnot (pres), Lagarde (secr-gen); 25 floréal IV (14 meî 1796)

IV ventôse 21 (1796 mrt 11)

BL IIe ser no.31 (227); LA. III fol 68; FA. nr.291; rH VIII 178-179; P VII 280; cB IVe ser III 110

\section{LOI QUI RËGLE L'ORDRE DU SERVICE DES JUGES DES TRIBUNAUX AUPRES DES TRI- BUNAUX CRIMINELS}

Voor het gehele grondgebied van de Republiek wordt bepaald dat de rechters in de burgerlijke rechtbanken dienst doen bij de criminele rechtbanken vanaf 1 floréal tot en met 30 vendémiaire en vanaf 1 brumaire tot en met 30 germinal.

bo. Conseil des Cinq-cents s. A.C. Thibaudeau (pres); P.J. Audouin, Gibert-Desmolières, Dauchy (de l"Oise) (secr); Conseil des Anciens s. Regnier (pres); Merlino, Bonnesoeur, Rossée (secr)

ti. minister van justitie

RO nr.119: 23 germinal IV (12 apr 1796)

- afkondiging: besluit Directoire exécutif s. Le Tourneur (pres), Lagarde (secr-gen); 10 germinal IV (30 mrt 1796)

\section{IV ventôse 25 (1796 mrt 15)}

LA I fol 319ro-320ro; FA nr.275 fol 123wo-124wo, FA. nr.679

\section{ARRÊtTÉ CONCERNANT LES CITOYENS DE LA PREMIÈRE RÉQUISITION QUI ONT FOURNIS DES CHEVAUX ET VOITURES POUR ÊTRE EXEMPT DE SERVICE MILITAIRE}

Iedere burger vallende onder de eerste wordering wit hoofde waarvan zijn ouders paarden en wagens hebben geleverd en die thans geen actieve dienst doet in het leger als begeleider van die paarden en wagens, dient zich te conformeren aan de wetten inzake de eerste vordering. Deze begeleiders moeten met hun paarden en wagens op hun post blijven. Voorts zal er geen enkele uitzondering meer worden gemaakt voor dienst bij de bataljons vanwege leveranties van paarden en wagens.

bo. Directoire exécutif s. Le Tourneur (pres); Lagarde (secr-gen)

ao. minister van corlog Petiet

ti. minister van oorlog

RO nr. 121: 27 germinal IV (16 apr 1796)

- verwijzing naar: besluiten comite de salut public van 13 fructidor II (30 aug 1794), 27 vendérniaine III (18 okt 1794); besluit Dinecroire exêcutif van 4 ventôse IV (23 feb 1796); wetten inzake "la première réquisition"

\section{IV ventôse 25 (1796 mrt 15)}

BL IIe ser no.33 (238); LA III fol 128vo-129ro; $\pi$ H VIII 257-258; P VII 284; cB IVe ser III 148-149 


\section{LOI QUI DÉTERMINE LA MANIERE DONT IL SERA PROCEDE SUR LES RECLAMATIONS RELATIVES AUX ARRÊTTES DES REPRESENTANS DU PEUPLE EN MISSION}

Bezwaren met betrekking tot besluiten van de volksrepresentanten en mission dienen rechtstreeks aan het Corps législatif te worden gezonden, dat hieromtrent zelf uitspraak doet in het geval het wetgevingshandelingen betreft. In de overige gevallen, na eventuele wijzigingen van de besluiten, worden de bezwaren ter afdoening aan de bevoegde autoriteiten teruggestuurd. Besluiten van de volksrepresentanten die strijdig met de strekking en inhoud van wetsbepalingen zijn vanaf het tijdstip tot wanneer men in beroep kan komen - zes maanden na de bekendmaking van de onderhavige wet - nietig.

bo. Consell des Cinq-cents s. A.C. Thibaudeau (pres); P.J. Audouin, Gibert-Desmolieres (secr); Conseil des Anciens s. Regnier (pres); Merlino, Bonnesoeur, Rossee, Bernard (de Saint-Afrique) (secr)

ao. commission sur les réclamations relatives aux arrêtés des représentans du penple en mission RO nr. 148(3): 13 prairial IV (1 jun 1796)

- afkondiging" besluit Directoire exécurif s. Carnot (pres), Lagarde (secr-gen); 25 floreal IV (14 mei 1796)

\section{IV ventôse 26 (1796 mrt 16)}

BL Ile ser no.33 (243); LA III fol 179ro-180ro; rH VIII 129-131; P VII 285-286; cB IVe ser UI 151153

\section{LOI CONTENANT RÉGLEMENT SUR LA MANIÊRE DE PROCÉdER EN CONCILIATION}

In geschillen van zuiver persoonlijke aard of roerende goederen betreffende wordt het bureau de conciliation gevormd door de vrederechter en twee assessoren in het kanton waar de gedaagde zijn domicilie heeft. Zijn er verschillende hoofdelijk medeverbonden gedaagden (défendeurs coobligés solidaires) dan houdt het bureau de conciliation zitting in het kanton dat de eiser prefereert. In erfrechtelijke geschillen wordt de dagvaarding tot verzoening uitgebracht in het kanton alwaar de nalatenschap is opengevallen. De wet behelst voorts bepalingen aangaande de procedurele gang van zaken bij het uitbrengen van de dagvaardingen en het in hoger beroep komen bij de burgerlijke rechtbank, waarbij men een boete van 30 livres moet voldoen, wanneer men de gedaagde niet tot verzoening heeft gedlagvaard, of als de laatste niet ter zitting is verschenen.

bo. Conseil des Cinq-cents s. A.C. Thibaudeau (pres); P.J. Audouin, Gibert-Desmolières, Dauchy (de l'Oise) (secr); Consenl des Anciens s. Regnier (pres); Bernard (de Saint-Afrique), Bonnesoeur, Merlino, Rossée (secr)

RO nr. 134(8): 19 flonéal IV (8 mei 1796)

- werwijzing naar: grondwet van 5 fructidor III (22 aug 1795); wetten van 16 aug 1790, 6 mrt 1791 , 21 germinal II (10 apr 1794), 19 vendémiaire IV (11 okt 1795)

- wetten van 16 aug 1790 en 6 mrt 1791 blijwen van kracht voor zover deze niet strijdig zijn met de onderhavige wet

- afkondiging: besluit Direcioire exécurif s. Le Toumeur (pres), Lagarde (secr-gen); 6 floréal IV (25 apr 1796) [BL Ile ser no.42 (342)] 


\section{LOI QUII DÉTERMINE LE MODE DE REMPLACEMENT PROVISOIRE DES COMMISSAIRES PRES LES TRIBUNAUX CORRECTIONNELS}

Bij het overlijden of de wettige verhindering van de commissaris bij de correctionele rechtbank kiezen de leden van dat gerecht door middel van stemming één van de vrederechters of assessoren, in de plaats waar het gerecht zetelt, als tijdelijk vervanger. Valt de keuze evenwel op een vrederechter of assessor die lid is van de correctionele rechtbank, dan wordt deze vervangen door de volgende op de lijst.

bo. Consell des Cinq-cents s. A.C. Thibaudeau (pres); Dauchy (de l"Oise), P.J. Audouin, GibertDesmoliêres, J.B. Louvet (secr); Conseil des Anciens s. Regnier (pres); Merlino, Bemard (de SaintAfrique), Rossée (secr)

RO nr.134(9): 19 floréal IV (8 mei 1796)

- afkondiging: besluit Directoire exécurif s. Le Tourneur (pres), Lagarde (secr-gen); 6 floréal IV (25 apr 1796) [BL IIe ser no.42 (342)]

\section{IV ventôse 27 (1796 mrt 17)}

BL. IIe ser no.33 (244); LA III fol 129; rH VIII 259; P VII 286; cB IVe ser III 1.57-158

\section{LOI RELATIVE À LA NOMINATION des PRÉSIDENS DES TRIBUNAUX CIVILS DE DÉPARTEMENT}

De benoeming van de presidenten van de secties van de departementale burgerlijke rechtbanken dient te geschieden overeenkomstig het bepaalde in de grondwet. De wet van 4 brumaire IV (26 okt 1795) ter zake is ingetrokken en de benoemingen die verricht zijn overeenkomstig die wet, worden geacht niet te zijn gedaan.

bo. Conseil des Cinq-cents s. A.C. Thibaudeau (pres); Dauchy (de 1'Oise), P.J. Audouin, GibertDesmolières, J.B. Louvet (secr); Conseil des Anciens s. Regnier (pres); Merlino, Rossée, Bemard (de Saint-Afrique) (secr)

RO nr. 148(4): 13 prairial IV (1 jun 1796)

- verwijzing naar: grondwet van 5 fructidor III (22 aug 1795); wet van 4 brumaire IV (26 okt 1795) [zie RO nr.81(2)]

- afkondiging: besluit Directoire exéccutif s. Camot (pres); Lagarde (secr-gen); 25 floréal IV (14 mei 1796)

\section{IV ventôse 29 (1796 mrt 19)}

BL Ile ser no.45 (383); LA III fol 67; P VII 289; cB IVe ser III 189-190

ARRETÉ QUI RËGLE LE MODE SUIVANT LEQUEL LES MINISTRES ORDONNANCERONT SUR LA TRESORERIE NATIONALE 
De ministers machtigen tot betaling door de schatkist, niet langer in de nominale waarde der assignaten, maar uitsluitend in baar geld. De bedragen worden ofwel door middel van promesses in mandats territoriaux, ofwel in assignaten tegen een zekere koers uitbetaald. De in omloop zijnde rescripties worden voorlopig omgezet in promesses in mandats territoriaux en naderhand vervangen. De achterstallige betalingen van lijfrenten, pensioenen en dergelijke die nog niet door de schatkist zijn uitbetaald voor het laatste semester van het jaar III of de voorafgaande jaren blijven in de nominale waarde van de assignaten staan. Daarvoor wordt een speciaal fonds gevormd voor het geval deze uitkeringen worden opgeëist.

bo. Directoire exécutif

ao. minister van financiën

s. Le Toumeur (pres); Lagarde (secr-gen)

ti. minister van justitie

RO nr. 118: 15 germinal IV (4 apr 1796)

- verwijzing naar: wet van 28 ventôse IV (18 mrt 1796)

- cB-intitulé: "arrêté concernant les mandats territoriaux"

\section{IV germinal 3 (1796 mrt 23)}

BL IIe ser no.35 (264); LA II fol 186; rH VIII 165-166; cB IVe ser III 226-227

\section{LOI QUI ORDONNE UNE VÉRIFICATION DE TOUTES LES CAISSES PUBLIQUES}

Ten behoeve van de verificatie van de burgerlijke kassen in het gehele departement worden deze kassen door het departementale bestuur, in aanwezigheid van de commissaris van het Directoire exécutif, verzegeld. De municipale besturen kunnen hierbij betrokken worden. Voor de lopende zaken houdt de kassier enig geld. Op soortgelijke wijze dienen de kassen van de legers door de commissarissen van oorlog, in aanwezigheid van een lid van het departementale bestuur, te worden gecontroleerd. Voortaan moeten alle kassen maandelijks worden geverifieerd.

bo. Conseil des Cinq-cents s. Doulcet (pres); R.G. Lemerer, Savary, J. Debry (secr); Conseil des Anciens s. J.A. Creuze-Latouche (pres); d'Alphonse, De Torcy (secr)

RO nr. 144: 3 prairial IV (22 mei 1796)

- afkondiging: besluit Directaire exécutif s. Le Tourneur (pres); Lagarde (secr-gen); 2 floréal IV (21 apr 1796) [BL Ille ser no.46 (389)]

\section{IV germinal 8 (1796 mrt 28)}

LA III foll 205vo; FA nr.275 foll 136vo, FA nr.2245

ARRETÉ QUI NOMME LE CITOYEN HENRY-GEORGE LE JOLIVET, ANCIEN INGENIEUR, INSPECTEUR DES TRAVAUX PUBLICS DES DÉPARTEMENS RÉUNIS

De oud-hoofdingenieur der bruggen en wegen, Henry-George le Jolivet, is tot voorlopig inspecteur-generaal der bruggen en wegen in de negen Verenigde Departementen benoemd. 
bo. Directoire exécutif

ao. minister van binnenlandse zaken Bénezech

\$. Le Touneur (pres); Lagarde (secr-gen)

ti. minister van binnenlandise zaken

RO nr.125: 5 floréal IV (24 apr 1796)

\section{IV germinal 8 (1796 mrt 28)}

BL Ile ser no.36 (275); LA III foll 129vo-130ro; rH VIII 260-261; P VIII 292-293; cB IVe ser III 255256

\section{LOI QUI DETERMINE LA MANIERE DONT IL SERA PROCÉDÉ SUR LES RECLAMATIONS RELATIVES AUX ARRÊTTES DES COMITÉS DE LA CONVENTION NATIONALE}

Bezwaren met betrekking tot besluiten van de comités van de Convention nationale dienen rechtstreeks tot het Corps législatif te worden gericht, dat zelf uitspraak zal doen over de moeilijkheden, wanneer de besluiten wetgevingshandelingen betreffen. In overige gevallen worden de bezwaarschriften aan de bevoegde autoriteiten teruggezonden. Men kan binnen zes maanden in beroep komen tegen de besluiten van de comitếs van de Convention nationale, gerekend vanaf de bekendmaking.

bo. Conseil des Cinq-cents s. Doullcet (pres); J. Debry, R.G. Lemerer, Savary (secr); Conseil des Ancienss s. J.A. Creuzé-Latouche (pres); De Torcy, Meillan (secr), Bonnesceur (ex-secr)

ao. commission sur les réclamations relatives aux arrêtés des divers comités de la Convention nationale

RO nr. 148(5): 13 prairial IV (1 jun 1796)

- afkondiging: besluit Directoire exếcutif s. Carnot (pres), Lagarde (secr-gen); 25 floréal IV (14 mei 1796)

\section{IV germinal 12 (1796 apr 1)}

LA I fol 320; FA nr.275 foll 126\%o-127ro, FA nr.722; rH VIII 92

\section{ARRÊTÉ PORTANT QU'IL SERA DÉLIVRÉ DES PASSEPORTS AUX MARINS BELGES POUR SERVIR LA RÉPUBLIQUE BATAVE}

Het Directoire exécutif machtigt de ministers van marine en koloniën en van buitenlandse betrekkingen om paspoorten af te geven aan matrozen van de vaart op de Maas en haar zijrivieren - vanaf Luik tot de grens met de Bataafse Republiek - die op schepen van de Bataafse Republiek willen gaan varen.

bo. Direcroire exécutif

ao. ministers vain marine en koloniën en van buitenlandse betrekkingen

s. Le Toumeur (pres); Lagarde (secr-gen)

ti. minister van buitenlandse betrekkingen Ch. Delacroix

RO nr.|22: 29 germinal IV (18 apr 1796)

- besluit uitgevaardigd n.a.v. een officièle nota overhandigd door de gevolmachtigde ministers van de Bataafse Republiek

- het besluit zal niet worden gedrukt 


\section{W germinal 18 (1796 apr 7)}

BL IIf ser no.39 (312); LA III fol 80; FA nr.275 fol 139; rH VIII 65-66; P VII 301; cB IVe ser III 331

ARRÊTÉ QUI FIXE L'ÉPOQUE À LAQUELLE IL NE POURRA PLUS ETRE FAIT USAGE DE PAPIER TIMBRÉ EN NOIR DANS LES DÉPARTEMENS RÉUNIS PAR LA LOI DU 9 VENDÉMLAIRE DERNIER

Vanaf 15 floréal IV (4 mei 1796) kan er in de negen départements réunis geen gebruilk meer worden gemaakt van in zwart gezegeld papier, maar uitsluitend van in rood gezegeld papier, teneinde te voorkomen dat kwijting wordt geweigerd van wisselbrieven enzovoorts.

bo. Directoine exécutif

s. Le Toumeur (pres); Lagarde (secr-gen)

ti. minister van financiën Ramel

RO nr.129: 5 floréal IV (24 apr 1796); N.B.: inschrijwing in indicateur génếral onder de datum van 6 floréal IV (23 apr 1796)

- verwijzing naar: wet van $1 /$ pluviôse IV (3\# jan 1796)

\section{IV germinal $18(1796$ apr 7$)$}

BL IIe ser no.39 (309); LA III fol 130vo-131 ro; rH VIII 261-262; P VII 300-301; cB IVe ser III 328

LOI QUI PRESCRIT LES FORMALITÉS À SUIVRE DANS LE JUGEMENT D'UN DÉLIT POUR LEQUEL IL AURAIT ÉtÉ FORMÉ PLUSIEURS ACTES D'ACCUSATIONS CONTRE DIFFERENS ACCUSÉS

Wanneer in het geval van één en hetzelfde misdrijf verscheidene aktes van beschuldiging tegen meerdere beschuldigden zijn opgesteld, zijn de openbare aanklagers gehouden samenvoeging ervan te vorderen. De commissaris van het Directoire exécutif bij de rechtbank moet hierover een gemotiveerd advies geven. De criminele rechtbank beveelt voorgeleiding van alle beschuldigden van hetzelfde misdrijf tijdens eén en dezelfde zitting; zij velt binnen vierentwintig uur het vonnis. De geformeerde jury kan worden gewraakt, wanneer diverse medebeschuldigden onder één en dezelfde akte van beschuldiging vallen.

bo. Conseil des Cinq-cents s. Dowlcet (pres); J. Debry, R.G. Lemerer, Savary (secr); Conseil des Anciens s. J.A. Creuzé-Latouche (pres); De Torcy, Meillan (secr)

ao. commission ad hoc

RO nr. 148(6): 13 prairial IV (1 jun 1796)

- afkondüging: besluit Directoire exécurif s. Carnot (pres), Lagarde (secr-gen); 25 flloréal IV (14 mei 1796)

\section{IV germinal 19 (1796 apr 8)}

LA II fol 183vo-184vo; FA nr.275 fol 175vo-176vo 
Ten behoeve van de heffing van de belastingen wordt het departement van de Nedermaas in een drietal arrondissementen opgedeeld: het eerste arrondissement met als hoofdplaats Maastricht; het tweede arrondissement met als hoofdplaats Hasselt en het derde arrondissement met als hoofdplaats Roermond. Het departementaal bestuur dient zelfstandig een beslissing te nemen over het tijdstip van de invoering van de nieuwe indeling.

\section{bo. Direcroire exécutif}

s. Le Toumeur (pres); Lagarde (secr-gen)

ti. minister van financièn Ramel

RO nr.141: 27 floréal IV (16 mei 1796); N.B. inschrijving indicateur général onder de danum van 23 ventôse IV (13 feb 1796)

RE nr.173: 12/13 fructidor IV (29/30 aug 1796)

- verwijzing naar". grondwet van 5 fructidor III (22 aug 1795); besluit van 10 pluviồse IV (30 jan 1796)

IV germinal $20(1796$ apr 9)

BL Ile ser no.39 (316); LA V fol 69; rH VIII 68-69; P VII 301; eB IVe ser III 345-346

ARRÊTÉ ADDITIONNEL À CELUI dU 18 PLUVIÔSE, AN IV, SUR LE MOdE DE PROMULGATION DES LOIS DANS LES NEUF DÉPARTEMENS QUI COMPOSAIENT LA CI-DEVANT BELGIQUE

De bijzondere opdracht tot het bekendmaken in de negen Verenigde Departementen van de wetten van het Wetgevend Lichaam, geplaatst in de tweede serie van het Bulletin des Lois, vermeldt voortaan alleen het nummer van het Bulletin en het volgnummer. Voor het overige blijven de bepalingen van het besluit van 18 pluviôse IV (7 feb 1796) van kracht.

bo. Directoire exécutif

s. Le Tourneur (pres); Lagarde (secr-gen)

RO nr.128: 5 floreal IV (24 apr 1796)

- verwijzing naar: wet van 12 vendémiaire IV (4 okt 1795); beslułt van 18 pluviôse IV (7 feb 1796)

\section{IV germinal 21 (1796 apr 10)}

LA II fol 18.5vo-186ro; FA nr.246 fol 24vo-26ro, FA nr.870, FA nr. 4282

ARRETTÉ QUI CONSERVE À SON POSTE LE CITOYEN PICQUERY, ADMINISTRATEUR DU DÉPARTEMENT DE LA MEUSE-INFÉRIEURE

Gelet op zijn toewijding aan de Franse staat, is administrateur Picquery in zijn functie bij het departementaal bestuur gehandhaaf, ondanks dat hij valt onder de termen van de wet van 3 brumaire IV (25 okt 1795). Deze wet bepaalt tot het herstel van de 
vrede, dat openbare functionarissen, wier familieleden uitgewekene zijn, uitgesloten zijn.

bo. Directoire exécutif

ao. gouvemementscommissaris Bouteville

s. Le Toumeur (pres); Lagarde (secr-gen)

ti. commissaris van het Directoire exécutif Rogier

RO nr.124: 3 floréal IV (22 apr 1796)

- verwijzing naar: wet van 3 brumaire IV (25 okt 1795)

- besluit uitgevaardigd n.a.w. een verzoekschrift wan het bestuur van het departement Nedermaas

\section{IV germinal 22 (1796 apr 11)}

BL IIe ser no.39 (319); LA III foll 131; rH VIII 263; P VII 302; cB IVe ser III 352

\section{LOI QUI AUTORISE LA RÉQUISITION DES OUVRIERS POUR LES TRAVAUX NËCESSAI- RES À L'EXÉCUTION DES JUGEMENS}

De commissarissen van het Directoire exécutif bij de rechtbanken kunnen tegen de normale vergoeding werklieden vorderen ten behoeve van het verrichten van werkzaamheden noodzakelijk voor de tenuitvoerlegging van vonnissen. Arbeiders die weigeren aan een dergelijke vordering te voldoen, worden met hechtenis bestraft.

bo. Conseil des Cinq-cents s. Doulcet (pres); J. Debry, Savary (secr); Conseil des Anciens s. J.A. Creuzé-Latouche (pres); d'Alphonse, De Torcy, Meillan, Alquier (secr)

RO nr. 148(7): 13 prairial IV (1 jun 1796)

- afkondiging: besluit Directoire exécutif s. Carnot (pres), Lagarde (secr-gen); 25 floréal IV (14 mei 1796)

\section{IV germinal 23 (1796 apr 12)}

BL IIe ser no.39 (323); LA III fol 81ro, fol 90, FA nr.275 fol 138, FA nr.291, FA nr. 2587; rH VIII 66-67, 132-133; P VII 302-303; cB IVe ser III 356

\section{ARRETÉ CONCERNANT LE JUGEMENT DES INSTANCES RELATIVES AUX DOUANES DANS LES DÉPARTEMENS RÉUNIS PAR LA LOI DU 9 VENDEMIAIRE, AN IV}

In verband met moeilijkheden die gerezen waren in de behandeling van en over de vonnissen in rechtsgedingen inzake douanekwesties, en welke voorlopig ter afdoening opgedragen waren aan de departementale besturen, is bepaald dat de wetten van 4 germinal II (24 mrt 1794) en 14 fructidor III (31 aug 1795) in de negen Verenigde Departementen van kracht worden. Mitsdien moeten dergelijke gedingen aanhangig worden gemaakt bij de vrederechters en in hoger beroep bij de burgerlijke rechtbanken in de departementen.

\section{bo. Directoire exécurif}

s. Le Toumeur (pres); Lagarde (secr-gen)

ti. minister van financiën Ramel 
RO nr. 127: 5 floréal IV (24 apr 1796); N.B.: inschrijuing in indicateur génếral onder de dátum van 6 floréal IV ( 25 apr 1796$)$

- verwijzing naar: wetten van 4 germinal II (24 mrt 1794); 14 fructidor III (31 aug 1795); besluit van

9 nivôse IV ( $30 \mathrm{dec} 1795$ )

\section{IV germinal 26 (1796 apr 15)}

LA II fol 186; FA nr.244 fol 103ro-105ro, FA nr.624, FA nr.4282

\section{ARRETTE QUI FRAPPE SUR LE DÉPARTEMENT DE LA MEUSE-INFERIEURE UNE RÉQUI- SITION POUR LA SUESISTANCE DES ARMÉES}

Door het Sambre-en-Maasleger te Keulen wordt van het departement van de Nedermaas een grote leverantie van granen, vlees, hooi en stro gevorderd. Uiterlijk 30 floréal IV (19 mei 1796) moet aan deze requisitie worden voldaan, onder de persoonllijke verantwoordelijkheid van het departementale bestuur. De betaling van het aangevoerde vee en van de levensmiddelen zal tegen de marktprijs geschieden, ofwel door de generalle aannemers der fourage, ofwel door het bestuur onder inhouding van de vergoeding voor de generale aannemers. De commissaris van de uitvoerende macht bij het departement van de Nedermaas is persoonlijk verantwoordelijk voor de afdracht van deze requisitie. Alle overige partiële vorderingen blijven opgeschort.

bo. commissaire-ordonnateur en chef de l'Armée de Sambre \& Meuse Blanchard

ws. général en chef Jourdan; gouvernementscommissaris Joubert

ti. commissaris van het Directoire exécutif Rogier

RO nr. 123: 29 germinal IV (18 apr 1796)

RE nr. 140: 29/30 floréal IV (18/19 mei 1796)

\section{IV germinal 27 (1796 apr 16)}

BL Ile ser no.40 (326); LA III fol 82vo-83ro; FA nr.135 fol 14vo-15vo, FA nr.2474; rH VIII II4$115 ;$ cB IVe ser III 391

ARRETÉ QUI DÉTERMINE LA MANIÈRE DONT SERA CÉLEBRÉ, LE 10 FLORÉAL, LA FETE DES ÉPOUX

In alle municipaliteiten wordt op 10 floréal IV (29 apr 1796) het feest der gehuwden (fête des époux) gevierd. op zodanige wijze dat dit niet te veel kosten met zich meebrengt, maar toch in overeenstemming is met het verheven karakter van het feest. De municipale besturen zijn met de uitvoering ervan belast. $\mathrm{Zij}$ stellen voorbeeldig getrouwden en gezinnen met kinderen die ook nog éen of meer wezen hebben opgenomen ten voorbeeld. Hun namen worden voorgelezen en zij ontvangen een couronne civique. Pasgetrouwden vormen een stoet, waarbij de jonge bruidjes in het wit gekleed gaan en verder een versiering met bloemen en een driekleurig lint dragen. De alleroudsten onder de gehuwden nemen een ereplaats in.

bo. Directoire exécutif

s. Le Tourneur (pres); Lagarde (secr-gen) 
tii. minister van binnenlandse zaken Bénézech

RO nr. 126: 5 floréal IV (24 apr 1796)

RE nr.131: $6 / 7$ floréal IV (25/26 apr 1796)

- besluit departementaal bestuur: “... sera le présent arrêté traduit, imprimé dans les deux langues et envoyé a toutes les municipalités de ce département, pour qu'elles $s^{2} y$ conforment ponctuellement"

\section{IV germinal $27(1796$ apr 16)}

LA III fol 82vo-83ro; FA nr.291; rH VIII 180; P VII lxix

ARRÊTÉ QUI RECTIFIE UNE ERREUR DE RÉDACTION DANS DEUX PRÉCÉDENS ARRÊTẾS DU 10 DE CE MOIS, RELATIFS À LA PUBLICATION DANS LES DÉPARTEMENS RÉUNIS PAR LA LOI DU 9 VENDÉMIAIRE DERNIER, DES LOIS SUR LE SEMESTRE DES TRIBUNAUX, ET SUR L'ORGANISATION DES ARCHIVES DE LA RÉPUBLIQUE

In twee afkondigingsbesluiten van het Directoire exécutif van 10 germinal IV (30 mrt 1796) moeten de woorden "la Belgique" worden vervangen door "les neuf départemens réunis par la loi du 9 vendémiaire dernier", hetgeen in de marge van de beide rechtsvoorschriften dient te worden aangetekend.

bo. Directoire exếcutif

s. Le Toumeur (pres); Lagarde (secr-gen)

ti. minister van justitie Merlin

RO nr.131: 9 floréal IV (28 apr 1796)

- verwijzing naar: besluiten van $\| 0$ germinal IV (30 mrt 1796)

\section{IV germinal 27 (1796 apr 16)}

LA I fol 320vo; FA nr.275 fol 155, FA nr.664

\section{ARRÊTÉ RELATIF À LA LEVÉE dU 30" CHEVAL}

Rij- en trekpaarden van beambten van de militaire konvooien en benodigd voor de dagelijkse werkzaamheden, vallen wel onder het aantal waaruit het dertigste paard wordt genomen, maar zij kunnen niet als zodanig worden gevorderd.

bo. Directoire exécutif

s. Le Toumeur (pres); Lagarde (secr-gen)

ti. minister van oorlog Petiet

RO nr.132: 15 floréal IV (4 mei 1796); N.B.: inschrijving in indicateur général onder de datum van 15 ventôse IV (5 mrt 1796)

IV germinal 27 (1796 apr 16)

LA III fol 92; FA nr.275 fol 158vo-159vo, FA nr.405

ARRÊTÉ RELATIF AUX OUVRIERS EMPLOYÉS AUX MINES, FORGES ETC. DE L'ÂGE DE LA PREMIÈRE RÉQUISITION 
Arbeiders werkzaam bij mijnen met een legale concessie die vallen onder de eerste vordering en die er vóór 1 vendémiaire III ( 22 sep 1794) werkten en er nog werken, en wier maandelijkse productie 150000 kilo bedraagt, hoeven niet te voldoen aan de requisitie. Degenen die na deze datum zijn gaan werken bij mijnen zonder een legale concessie en die niet de genoemde productie halen, moeten zich bij het leger vervoegen. Voor degenen die in zoutmijnen en dergelijke werken, gelden soortgelijke bepalingen.

\section{bo. Directoire exécutifif}

ao. minister van binnenlandse zaken Bénézech

s. Le Tourneur (pres); Lagarde (secr-gen)

ti. minister van binnenlandse zaken

RO nr.133: 19 floréal IV (8 mei 1796)

\section{IV germinal 27 (1796 apr 16)}

BL. IIe ser no.40 (325); LA III 97ro-98vo; rH VIII 136-138; P VII 303-304; cB IVe ser III 388-390

\section{LOI PORTANT des PEINES CONTRE TOUTE ESPËCE dE PROVOCATION À LA DISSOLU- TION DU GOUVERNEMENT RÉPUBLICAIN, ET TOUT CRIME ATTENTATOIRE $\grave{A}$ LA SÛRETÉ PUBLIQUE ET INDIVIDUELLE}

Degenen die door middel van redevoeringen of de verspreiding van gedrukte geschriften oproepen tot de ontbinding van de Nationale Vergadering of het Directoire exécutif, dan wel tot de moord op één of meerdere leden ervan, worden geacht een misdrijf jegens de binnenlandse veiligheid en de persoonlijke vrijheid van de burgers te hebben begaan. Deze personen zullen ter dood worden veroordeeld. Dit geldt eveneens voor hen die het herstel van het koningschap, of het opnieuw in werking laten treden van de grondwetten van 1791 en 1793 nastreven, alsmede voor then die publieke en private eigendommen verwoesten of verdelen. In geval van verzachtende omstandigheden kan de doodstraf omgezet worden in deportatie. De genoemde delicten worden terstond door de directeur du jury, die de functie van opsporingsambtenaar (officier de police) bij de criminele rechtbank uitoefent, vervolgd. Oplopen waar bovengenoemde provocaties plaatshebben, vertonen het karakter van een oproerige samenscholing en de hierbij aanwezigen dienen, eventueel gewapenderhand, te worden gearresteerd. Naargelang de omstandigheden wordt de strafmaat bepaald.

bo. Conseil des Cinq-cents s. Doulcet (pres); J. Debry, Defermon , Sawary (secr); Conseñl des Anciens s. J.A. Creuze-Latouche (pres); d'Alphonse, De Torcy, Meillan (secr)

RO nr. 145(1): 5 prairial IV (24 mei 1796)

RE nr. 147: $16 / 17$ prairial IV (4/5 jun 1796)

- verwijzing naar: grondwetten van $3 * 14$ sep 1791; 24 jun 1793; 5 fructidor III (22 aug 1795); code des defits et des peines van 3 brumaire IV (25 okt 1795)

- afkondiging: besluit Directoire exécutif s. Carnot (pres), Lagarde (secr-gen); 22 florêal IV (11 mei 1796) 


\section{IV germinal 28 (1796 apr 17)}

BL II no.40 (328); LA III fol 99ro-100vo; rH VIII 139-141) P VII 304-305; cB Ve ser IV 393-394

\section{LOI CONTENANT DES MESURES REPRESSIVES DES DELTS QUI PEUVENT ETRE COM- MIS PAR LA VOIE dE LA PRESSE}

Er mogen geen kranten, periodieken enzovoorts gedrukt en aangeplakt worden die niet voorzien zijn van de na(a)m(en) van de auteur(s) en de naam en het adres van de drukker. Overtreding van deze bepaling, hetzij door de weglating van de namen, hetzij door het opgeven van een valse naam, wordt vervolgd door opsporingsambtenaren (officier de police) en bestraft met hechtenis, voor de eerste keer met zes maanden. Wanneer er niet-ondertekende artikelen of uittreksels uit buitenlandse bladen opgenomen zijn, dan is degene die de publicatie verzorgd heeft verantwoordelijk. Gelijkelijk bestraft worden degenen die dergelijke geschriften in welke vorm dan ook verspreiden. Gaat het om misdadig verklaarde provocaties dan worden aanzienlijk zwaardere straffen opgelegd en vindt voorgeleiding plaats aan de directeur du jury d'accusation. Drukkers en verspreiders kunnen zo lang in hechtenis worden gehouden, totdat de naam van de auteur bekend is en deze is veroordeeld.

bo. Conseil des Cinq-cents s. Doulcet (pres); Defermon, Savary (secr); Conseil des Anciens s. Regnier (ex-pres); Alquier, Meillan, d"Alphonse (secr)

ao. commissie uit de Cinq-cents

RO nr. 145(2): 5 prairial IV (24 mei 1796)

RE nr. 148: $16 / 17$ prairial IV (4/5 jun 1796)

- verwijzing naar: wet van 27 germinal IV (16 apr 1796)

- wet uitgevaardigd n.a.v. berichtgeving door het Directoire exécurif

- afkondiging: besluit Directoire exécutif s. Carnot (pres); Lagarde (secr-gen); 22 floréal IV (11 mei 1796)

\section{IV floréal 2 (1796 apr 21)}

LA III fol 90vo-9Ivo; rH IX 29-30; cB IVe ser IV $1 /-12$

LOI QUI ADMET A LA CONSOMMATION DANS L'INTÉRIEUR LES TABACS FABRIQUES, EAUX-DE-VIE DE GENIËVRE ET OUVRAGES DE VERRE REÇUS DANS LES ENTREPOTS DE LA CI-DEVAN' BELgIQUe AVANT LE $1^{\text {Kk }}$ VENTÓSE, AN IV, ET LES SELS REGUS DANS LES MÊMES ENTREPÔTS AVANT LE 15 PLUVIÔSE PRÉCÉdENT

Bewerkte tabak, jenever en glaswerk dat in Belgische pakhuizen ligt opgeslagen van vóór de datum van 1 ventôse IV (20 feb 1796), mag voor binnenlandse consumptie worden aangewend tot de datum van 15 prairial IV (3 jun 1796), onder de voorwaarde dat de verschuldigde rechten die geheven worden op in beslag genomen handelswaar betaald zijn. Na deze datum worden deze goederen weer naar het buitenland geëxporteerd. Ongeraffineerd buitenlands zout dat ook in pakhuizen ligt opgeslagen van vóór de datum van 15 pluviôse IV (4 feb 1796), mag eveneens voor consumptie worden gebruikt. Zoutsoorten die in het buitenland reeds geraffineerd zijn, worden opnieuw geëxporteerd. 
bo. Conseil des Cinquents s. Doulcet (pres); Savary, Defermont. (secr); Corseil des Ancierss s. Lecouteulx-Canteleu (pres); Muraire, Larmagnac (secr)

ao. commissie uit de Cing-cents

ti. commissaris van het Directoire exécurif Rogier

RO nr. 135: 21 floreal IV (10 mei 1796)

RE nr.138: 23/24 floréal IV (12/13 mei 1796)

- wet uitgevaardigd n.atw. een boodschap door hell Directoire exécutif van 19 pluviôse IV (8 feb 1796)

- BL Ile ser no.44 (355) vermeldt alleen het intitulế

- art.4: de resolutie [=de wet] wordt niet gedrukt

- afkondiging: lopdracht Directoire exécutif s. Le Tourneur (pres), Lagarde (secr-gen); 2 floréal IV (21 apr 1796)]

\section{IV floréal 4 (1796 apr 23)}

BL Ille ser no.43 (345); rH VIII 181-185; cB IVe ser IV $41-44$

\section{ARRÊTÉ CONCERNANT LE MODE D'APPLICATION DES LOIS SUR LES ÉMIGRÉS DE FRANCE À CEUX TROUYÉS DANS LES DÉPARTEMENS RÉUNIS LE 9 VENDÉMIAIRE AN IV AU TERRITOIRE DE LA RÉPUBLIQUE}

Het arrêté bepaalt dat door de volksrepresentanten/gouvernementscommissarissen in de negen Verenigde Departementen voldoende zorgvuldig is gehandeld bij de afkondiging van de wetten inzake de uitgewekenen en gedeporteerde geestelijken en dat Franse uitgewekenen die aldaar gearresteerd zijn zich niet kunnen verweren met het argument dat zij niet onder de termen vallen van de wet van 25 brumaire III (15 nov 1794), omdat zij in de periode vóór de geproclameerde aanhechting bij Frankrijk hun verblijfplaats in de negen Verenigde Departementen hadden.

\section{bo. Directoire exécutif}

ao. minister van justitie Merlin

s. Le Tourneur (pres); Lagarde (secr-gen)

RO nr. 136: 21 floréal IV (10 mei 1796)

- verwijzing naar: wetten van 25 brumaire III (15 nov 1794); 22 nivôse III (11 jan 1795); 22 germinal UII (1 I apr 1795); 12 floréal III (I mei 1795); 26 floréal III (15 mei 1795); 22 prairial III (10 jun 1795); \|fructidor III (18 aug 1795); 20 fructidor III (6 sep 1795); 4 jour complementaire III (20 sep 1795); 10 vendémiaire IV ( 2 okt 1795); 3 brumaire IV (25 okt 1795); besluit volksrepresentanten van 8 brumaire IV ( 30 okt 1795)

- besluit uitgevaardigd n.a.v. het vonmis van de criminele rechtbank van het departement Pas-deCalais van 22 germinal IV (11 apr 1796) houdende het voorleggen aan het Wetgevend Lichaam van de moeilijkheden gerezen in de berechting van Paul-Joseph Duhamel-Bellenglise, uitgewekene, die door de criminele rechtbank in het departement van de Twee Neten aan die van de Pas-de-Calais is overgedragen

- besluit wordt geplaatst in het Bulletin des Lois en naar de criminele rechtbanken en de departementale besturen van de negen departements réunis gezonden

\section{IV floréal 8 (1796 apr 27)}

LA III fol 91vo-92ro; FA nr.275 165vo, FA nr.823; rH IX 31 
ARRÊTÉ QUI SUSPEND PROVISOIREMENT LA DÉLIVRANCE DE PASSEPORTS POUR LES COLONIES FRANÇAISES DANS LES DEUX HEMISPHERES SANS L'AUTORISATION SPÉCIALE DU DIRECTOIRE

Tot nader order worden er geen paspoorten voor de Franse koloniën op het noordelijk en zuidelijk halfrond verstrekt, dan alleen met een bijzondere machtiging van het Directoire exécutif.

bo. Directoire exécutif

ao. minister van buitenlandse betrekkingen Cl. Delacroix

s. Le Toumeur (pres); Lagarde (secr-gen)

ti. minister van buitenlandse betrekkingen

RO nr.137: 21 floréal IV (10 mei 1796)

\section{IV floréal 10 (1796 apr 29)}

LA $V$ fol 73 ; FA nr.243 fol 60 vo-61ro

ARRÊTÉ QUI NOMME LE CITOYEN CHARLES-ALEXIS ALEXANDRE COMMISSAIREORDONNATEUR EN CHEF DES ARMÉES, COMMISSAIRE DU GOUVERNEMENT PRÈS LES ARMÉES DU NORD ET DE SAMBRE ET MEUSE ET PAYS ENVIRONNANTS, CHARGÉ SPÉCIALEMENT DES SUBSISTANCES MILITAIRES

Charles-Alexis Alexandre, commissaire-ordonnateur des guerres, is benoemd tot commissaris van het Directoire exécutif bij het Noorderleger. Daarenboven is hij in het bijzonder belast met de bevoorrading van het Sambre-en-Maasleger en de vestingen in Luxemburg en langs de Benedenmaas. Daartoe dient hij te overleggen met de commissaris van het Directoire exécutif bij het Sambre-en-Maasleger, Joubert.

bo. Directoire exécutif

s. Le Toumeur (pres); Lagarde (secr-gen)

RO nr. 138: 24 floréal IV (13 mei 1796)

\section{IV floréal 15 (1796 mei 4)}

LA II foll 185ro; FA nr.276 fol 3

ARRETTÉ QUI EXEMPTE DE LA LEVEE DU $30^{\mathbb{E}}$ LES CHEVAUX EMPLOYÉS AU SERVICE DES FOURNEAUX, FONDERIES, FORGES ET D'ATTELIERS D'ARMES

Paarden die worden gebruikt bij het werk in ijzergieterijen en staalfabrieken, bij hoogovens en in wapenfabrieken vallen weliswaar onder de massa paarden waaruit het dertigste paard ten behoeve van het leger moet worden genomen, maar de keuze dient niet op die paarden te vallen.

bo. Directoire exécutif

ao. minister yan binnenlandse zaken

s. Camot (pres); Lagarde (secr-gen) 
ti. divecteur des fortificanions, chef de la troisidme division, brigadegeneraal Milet-Mureau RO nr. 156: 27 prairial IV (15 jun 1796)

\section{IV foréal 16 (1796 meil 5)}

BL lle ser no.45 (384); LA IV fol 169; rH VIII 286-287; P VII 318; cB IVe ser IV 99; F I 286-287

\section{LOI QUI DÉTERMINE LE LIEU OÙ DOIT ÊTRE DÉPOSÉ, CHAQUE ANNÉE, LE DOUBLE DU RÉPERTOIRE DES ACTES REÇUS PAR LES NOTAIRES PUBLICS}

De notaires publics zijn gehouden jaarlijks een gewaarmerkt dubbel exemplaar van het repertorium van door hen gedurende de loop van het voorgaande jaar verleden akten, en tevens door hen gewaarmerkt, ter griffie van de departementale burgerlijke rechtbank te deponeren. De commissaris van het Directoire exécutif bij deze rechtbank is belast met de vervolging van hierin nalatige notarissen.

bo. Conseil des Cinq-cents s. Crassous (de I'Hërault) (pres); Duprat, Laplaigne, Bion (secr); Conseil des Anciens s. Lecouteulx-Canteleu (pres); Marragon, Larmagnac, C. Alex. Ysabeau, Delacoste (secr) ao. commissie uit de Cinq-cents

RO nr. 15/(2): 19 prairial IV (7 jun 1796y

- verwijzing naar: wet van 29 sep * 6 okt 179 !

- afkondiging: besluit Difectoire exécurif s. Carnot (pres), Lagarde (secr-gen); 3 prairial IV (22 mei 1796)

\section{IV floréal 20 (1796 mei 9)}

BL Ile ser no.48 (404); LA IV fol 142vo-143vo; rH X 121-122; P VII 320; cB IVe ser IV 106

\section{LOI QUI ADMET AU PARTAGe CEUX DONT les biens ONT ÉtÉ SÉquestrés EN VERTU DE LA LOI DU 17 FRIMAIRE, AN II}

Ouders en ascendenten van uitgewekenen, wier goederen gesequestreerd zijn ujt hoofde van de wet van 17 frimaire II ( 7 dec 1793), wordt toegestaan een verzoek tot boedelscheiding in te dienen als bepaald in de wet van 9 floréal III (28 apr 1795). De inbeslagneming blijft van kracht ten aanzien van die goederen, waarvan niet de schelding wordt verzocht.

bo. Conseil des Cinq-cents s. Doulcet (pres); J. Debry, Sawary, R.G. Lemerer (secr); Conseil des Anciens s. Lecouteulx-Canteleu (pres); Larmagnac, Marragon, C. Alex. Ysabeau, Delacoste (secr) RO nr.210(24): 23 vendemiaire V (14 okt 1796)

- verwijzing naar: wetten van 17 frimaire II 77 dec 1793); 9 floreal III (28 apr 1795)

- afkondiging: besluit Direcroire exćcwiff s. L.M. Revellière-Lépeaux (pres), Lagarde (secr-gen); 10 fructidor IV (27 aug 1796)

\section{IV floréal 25 (1796 mei 14)}

BL Ile ser no.48 (405); LA IV fol 143; rH X 123-124; P VII 323; cB IVe ser IV 122-123 
De vereffening van alle wettige schuldvorderingen op geëmigreerde rekenplichtigen is toegestaan, wanneer de schuldeiser tijdig de stukken op het bureau de liquidation van de schuld der uitgewekenen heeft overgelegd.

bo. Conseil des Cinq-cents s. Crassous (de l'Hérault) (pres); L.E. Beffroy, Bion (secr); Consell ales Anciens s. Lecoutetulx-Canteleu (pres); Marragon, Larmagnac, C. Alex. Ysabeau, Delacoste (secr)

aro. commissie uit de Cinq-cents

RO nr.210(25: 23 vendémiaire V (14 okt 1796)

- verwijzing naar: wet van 23 prairial [III] (11 jun 1795)

- wet uitgevaardigd n.a.v. een klacht van de weduwe Mariette ter zake van de vereffening van haar schuldvordering op Augeard, geëmigreerd rekenplichtige

- afkondiging: besluit Directoire exécutif s. L.M. Rewellière-Lépeaux (pres), Lagarde (secr-gen); 10 fructidor IV (27 aug 1796)

\section{IV floréal 28 (1796 mei 17)}

BL Ile ser no.48 (407); LA IV fol 166ro-167ro; rH IX 57-58; P VII 323; MAP I 73-74

\section{ARRËTÉ QUi INTERPRÈTE CELUI DU 23 GERMINAL, RELATIF AUX INSTANCES EN MATIERE DE DOUANES}

De bepaling van het besluit van 23 germinal IV (12 apr 1796) dat de vrederechter kennisneemt van douanekwesties in eerste instantie en in hoger beroep de burgerlijke rechtbank, wordt in zoverre beperkt dat er die gevallen onder worden verstaan, waarin deze geen boete of een andere straf met zich meebrengen. In douanekwesties waar sprake is van een tenlastelegging of de aangifte van een delict dat een boete of andere straf met zich meebrengt, wordt zowel door de opsporingsambtenaar (officier de police judiciaire) als de correctionele en criminele rechtbanken te werk gegaan overeenkomstig de bepalingen van de code des délits et des peines.

\section{bo. Directoire exécutif}

s. Carnot (pres); Lagarde (secr-gen)

RO nr. 146: II prairial IV (30 mei 1796)

- verwijzing naar: wetten van 4 germinal III (24 mrt 1794), 14 fructidor III (31 aug 1795); grondwet wan 5 fructidor III (22 aug 1795); code des délits et des peines van 3 brumaire IV (25 okt 1795); besluit van 23 germinal IV (12 apr 1796)

- het onderhawige besluit herroepen bij besluit van het Directoire exécutif van 27 thermidor IV (14 aug 1796), BL Ile ser no.68 (616) [RO nr. 189]

\section{IV floréal 28 (1796 mei 17)}

LA III fol 169; FA nr.276 fol 24vo; rH VIII 273

\section{ARRETTÉ QUI AUTORISE LES COMMUNAUTÉS RELIGIEUSES DES DÉPARTEMENS RÉUNIS À FAIRE DES EMPRUNTS HYPOTHÉQUÉS SUR LES BIENS}

De religieuze communiteiten in de negen Verenigde Departementen die niet in staat zijn hun belastingen en aanslagen in de gedwongen geldlening (emprunt forcé) uit hun inkomsten te voldoen, blijven gemachtigd hypothecaire leningen aan te gaan onder 
verband van hun goederen tot een zodanig beloop dat de aanslagen alsnog kunnen worden gekweten. Het geleende geld kan slechts worden afgedragen aan de ontvangers der directe belastingen in de departementen.

\section{bo. Directoire exéculitif}

s. Carnot (pres); Lagarde (secr-gen)

ti. minister van financiën Ramel

RO nr. 159: 7 messidor IV (25 jun 1796)

RE nr.157: 11/12 messidor (29/30 jun 1796)

\section{IV prairial 3 (1796 mei 22)}

LA III foll 160ro-165ro; FA nr.29I; rH VIII 274-285; P VII Ixxiii-lxxvii

\section{ARRÉTÉ CONCERNANT L'ORGANISATION DU NOTARIAT DANS LES DÉPARTEMENS RÉUNIS PAR LA LOI DU 9 VENDÉMIAIRE, AN IV}

Alle ambtsbedieningen van notarissen, tabellioenen, hommes de fief [leden van een leenhof] en anderen onder welke benaming verder ook bekend, zijn hiermede vacant verklaard en opgeheven. Zij zullen worden vervangen door notaires publics; voorlopig echter kunnen de gesupprimeerde ambtsbedieningen nog worden voortgezet. De uitoefening van het ambt van notaire public is onverenigbaar met een veelheid van functies, gelegen in de justitiële en bestuurlijke sfeer. Het Wetgevend Lichaam bepaalt het aantal notarissen en hun respectieve standplaatsen, vooralsnog evenwel zijn de departementale besturen gemachtigd het aantal notarissen met hun standplaatsen te bepalen. Het besluit behelst voorts bepalingen over de vormvereisten van door notarissen op te maken akten, het authentieke karakter en de executoriale kracht ervan, alsmede de overbrenging en bewaring van akten. Het ressort van ambtsbediening van een notaire public is beperkt tot het grondgebied van het departement, waarbinnen hij geadmitteerd is.

bo. Directoire exécurif

ao. minister van justitie Merlin

s. Carnot (pres); Lagarde (secr-gen)

RO nr. 151 : 19 prairial IV (7 jun 1796)

- verwijzing naar: "anciennes lois et réglemens"; "lois et coutumes dûment homologuées"; "autres lois relatives au notariat"; wetten van 16*29 sep 1791; 29 sep * 6 okt 1791; 7 pluviôse II (26 jan 1794); code des délits et des peines van 3 brumaire IV (25 okt 1795); 19 brumaire IV (14 nov 1795); 16 floréal IV (5 mei 1796)

- arrêté goeddeels samengesteld uit de gehele of gedeeltelijklke overname van bepalingen uit de wetten van $29 * 6$ okt 1791; 17 mei 1793; 18 brumaire II (8 nov 1793); 7 pluviôse II (26 jan 1794); 24 vendémiaire: III (15 okt 1794)

\section{IV prairial 4 (1796 mei 23 )}

BL Ile ser no.49 (417); LA III fol 167vo-168\%o; rH VIII 400-402; P VII 326-327; cB IVe ser IV 145-147 
De omwisseling van de assignaten - tegen een koers van én op dertig (à trente capitaux pour un) - in mandats [territoriaux] of in promesses uitgeschreven in mandats blijft voortgang vinden tot 10 messidor IV ( 28 jun 1796). Na die datum zijn de assignaten van meer dan 100 livres geen betaalmiddel meer en kunmen niet langer tegen een koers van één op honderd (à cent capitaux pour un) in mandats of in promesses uitgeschreven in mandats gewisseld worden. Het Directoire exécutif dient met alle middelen de omwisseling van assignaten in mandats te bevorderen. Eén en ander dient te geschieden bij de ontvangers der publieke gelden in de gemeenten. De omwisseling van assignaten die de nominale waarde van 100 livres niet te boven gaan, zal bij wet worden geregeld tegen een omwisselkoers van één op dertig, onverminderd nochtans de omwisseling van assignaten tot 50 stuivers in muntgeld.

bo. Conseil des Cinq-cents s. Defermon (pres); Pelet (de la Losère) "Echasseriaux ainé, Mailhe (secr); Conseil des Anciens s. Lebrun (pres); J.G. Lacuée, Maleville, Olivier-Gerente, Picault (secr)

RO nr.157: 27 prairial IV (15 jun 1796)

RE nr. 156: $3 / 4$ messidor IV (21/22 jun 1796)

- verwijzing naar: wet van 28 ventôse IV (18 mrt 1796)

- RO vermeldt abusievelijk als datum van uitvaardiging 14 prairial IV (2 jun 1796)

- indicarew général: besluit tot vertaling 1 messidor IV (19 jun 1796)

- afkondiging: besluit Directoire exécutif s. Carnot, Lagarde (secr-gen); 14 prairial IV (2 jun 1796); het besluit wijzigt niets ten aanzien van de wijze van betaling die in de negen Verenigde Departementen wordt gevolgd

\section{IV prairial 5 (1796 mei 24)}

LA IV fol 167; FA nr.246 fol $227 \mathrm{vo}-228$ ro

\section{ARRETE PORTANT QUE LA COMMUNE DE HEX FAISANT CI-DEVANT PARTIE DU CANTON DE HERS SERA RÉUNIE À CELUI DE TONGRES}

Het kanton Tongeren wordt vergroot met de gemeente Heks, die voorbeen onder het kanton Heers ressorteerde.

bo. gouvemementscommissaris Bouteville

ao. bestuur van het departement van de Nedermaas

ti. commissaris van het Directoire exécutif bij het departement van de Nedermaas Rogier

RO nr. 149." 13 prairial IV (1 jun 1796); N.B.: in de indicateur général ingescheven onder de datum 12 prairial IV (30 mei 1796)

- besluit uitgevaardigd n.a.v. een verzoekschrift van de commissaris van het Directoire exécutif bij het kanton Tongeren, Sermoise, en de wens geuit door inwoners van de gemeente Heks

\section{IV prairial 5 (1796 mei 24)}

BL Ile ser no.50 (423); LA III fol 219; rH IX 26-27; P VII 327; MAP I 102-103 
De verschuldigde portokosten voor aan hen - uit hoofde van hun functie - geadresseerde missives en pakketten zullen aan de openbare aanklagers, de directeuren van de jury, de commissarissen van de uitvoerende macht bij de rechtbanken en de vrederechters, alsmede aan andere leden van de rechterlijke organisatie, worden terugbetaald. Deze restitutie geschiedt iedere maand op grond van voor echt verklaarde staten, houdende de naam van de persoon, de aard van het verzonden stuk en de hoogte van het porto. De betaling geschiedt, op last van het departementaal bestuur, door de ontvangers der registratierechten.

bo. Directoire exécutif

s. Camot (pres); Lagarde (secr-gen)

RO nr.174(3): 21 thermidor IV (8 aug 1796)

- verwijzing naar: wet van 27 sep 1790; besluiten comité de salut public van 14 messidor II (2 jul 1794); 4 fructidor II (21 aug 1794); besluit Directoire exécutif van 23 pluviôse IV (12 feb 1796)

" afkondiging: besluit Directoire exécutif s. L.M. Revellière-Lépeaux (pres), Lagarde (secr-gen); 10 thermidor IV (28 jul 1796); P vermeldt als datum van afkondiging 20 thermidor IV (7 aug 1796)

\section{IV prairial 9 (1796 mei 28)}

BL IIe ser no.50 (426); LA III fol 165in; FA nr.275 fol 227vo-228ro, FA nr.2522; MAP I 112

\section{ARRETE QUI AUTORISE LA CONTINUATION DU TRANSIT PAR VENLO DES MARCHAN- DISES EXPEDIÉS DE HOLLANDE POUR LE PAYS DE JULIERS}

Doorvoer van handelswaar die vanuit Holland naar Gulikse - en vice versa - via het grondgebied van de gemeente Venlo wordt geëxporteerd, blijft geoorloofd, onder de voorwaarde dat het kwijtingsbewijs tot zekerheidstelling (acquit-à-caution) van de bestemming is verworven en het verschuldigde bijzondere tarief van de in- en uitgaande rechten is voldaan.

bo. Directoire exécurif

40. minister van financién Ramel

s. Camot (pres); Lagarde (secr-gen)

ti. minister van financiën

RO nr. 153: 24 prairial IV (12 jun 1796); N.B.: inschrijving in indicateur gếnéral onder de datum van 17 floreal IV (6 mei 1796)

\section{IV prairial 9 (1796 mei 28)}

BL IIe ser no.50 (427); LA III fol 165vo; FA nr.275 fol 228; rH VIII 292-293; P VII 329; MAP I $112-113$

ARRETÉ PORTANT QUE LA SORTIE DE LA HOULLE, DE LA CHAUX, DE LA TERRE $\grave{\lambda}$ PIPE ET DES CLOUS, CONTINUERA PROVISOIREMENT D'AVOIR LIEU DES NEUF DEPARTEMENS REUNIS PAR LA LOI DU 9 VENDÉMIAIRE, AN IV 
Om te voorkomen dat in de negen Verenigde Departementen een zeer groot aantal arbeiders zonder middelen van bestaan zou komen te zitten, blijft de uitvoer - tegen de kwijting van een bijzonder tarief voor de onderscheidene producten - van de delfstoffen steenkool, kalk en pijpaarde, alsmede van gefabriceerde spijkers, naar Holland en het Gulikse voorlopig toegestaan.

bo. Directoire exécutif

ao. minister van financiën Ramel

s. Carnot (pres); Lagarde (secr-gen)

tî. minister van financiën

RO nr.154: 24 prairial IV (12 jun 1796); N.B.: in indicateur général ingeschreven onder de datum van 22 prairial IV (10 jun 1796 )

\section{IV prairial 11 (1796 mei 30)}

BL IIe ser no.51 (428); LA III fol 209ro-210ro; rH VIII 323-325; P VII 329; cB IVe ser IV 156-157

LOI PORTANT DES PEINES CONTRE LES TÉMOINS QUI NE COMPARAISSENT PAS SUR LES CITATIONS À EUX DONNÉES

Degene die na een dagvaarding zonder wettige redenen niet verschijnt voor de directeur du jury of voor de jury d'accusation, wordt door middel van een bevel tot medebrenging (mandat d'amener) voorgeleid. Blijken er geen geldige redenen voor het niet-verschijnen te bestaan, dan wordt hij op grond van een bevel tot aanhouding in hechtenis genomen en door de correctionele rechtbank tot een gevangenisstraf van acht dagen tot één maand veroordeeld. In geval de vrederechter constateert dat een gedagvaarde getuige wel kon verschijnen, maar de ambtenaar van gezondheid een valse attestatie heeft afgegeven, volgt een veroordeling tot twee à drie maanden hechtenis.

bo. Conseil des Cinq-cents s. Defermon (pres); Pelet (de la Losère). P.M. Delaunay, Mailhe (secr); Conseil des Anciens s. Lebrun (pres), Picault, Olivier-Gérente, Maleville (secr)

ao. commissie uit de Cinq-ients

RO nr. $170(3)$ : 12 thermidor IV (30 ju॥ 1796)

- verwijzing naar: code des dellits et des peines van 3 brumaire IV (25 okt 1795)

* afkondiging: besluit Directoire exécunif s. Camot (pres), Lagarde (secr-gen); 30 messidor IV (18 jul 1796) [BL He ser mo.59 (549)]

\section{IV prairial 16 (1796 jun 4)}

LA III 168vo-169ro; FA nr.29!; rH VIII 289; P VII Ixxwiii

ARRÊTÉ CONTENANT RECTIFICATION D'UNE ERREUR DANS CELUI DU 3 PRAIRIAL, RELATIF À L'ORGANISATION DU NOTARIAT DANS LES DÉPARTEMENS RÉUNIS PAR LA LOI DU 9 VENDÉMIAIRE, AN IV

Het besluit herstelt de vergissing van de copiist, waaruit zou blijken dat de functie van notaris onverenigbaar is met die van kantonsadministrateur en secretaris van het 
gemeentebestuur. De wet van 24 vendëmiaire III (15 okt 1794) acht de verenigbaarheid van de functies van gemeenteambtenaar en municipaliteitssecretaris met die van notaris toelaatbaar.

bo. Directoire exécutif

ao. minister van justitje Merlin

s. Carnot (pres); Lagarde (secr-gen)

RO nr.158: 27 prairual IV (15 jun 1796)

- verwijzing naar: wet van 24 vendémiaire III (15 okt 1794); besluit Directoire exécutif van 3 prairial IV (22 mei 796 )

\section{IV prairial 16 (1796 jun 4)}

BL IIe ser no.65 (593); LA IV 26; rH IX 127-128; P VII 331-332; MAP I 133-134

\section{ARRÊTÉ CONCERNANT LES FRANÇAIS VOYAGEANT DANS LES PAYS ÉTRANGERS}

In het buitenland reizende Fransen die zich willen laten inschrijven in een register (registre d"immatricule), die om een attestatie de vita verzoeken, of die de autoriteit van consuls van de Republiek inroepen, dienen een paspoort van hun departementaal bestuur, geviseerd door de minister van buitenlandse betrekkingen te overleggen, teneindle te bewijzen dat ze in Frankrijk in de charges politiques delen. Deze visa zijn slechts nodig voor paspoorten afgegeven vóór de bekendmaking van de wet van 14 ventôse IV ( 4 mrt 1796), welke de municipale en departementale besturen belast met de afgifte van de paspoorten. Houders van paspoorten afgegeven na die datum behoeven alleen het certificaat van hun departement te tonen. Degenen die in neutrale landen reizen, dienen tevens de verklaring van hun departement te overleggen, waaruit blijkt dat zij niet op de lijst van uitgewekenen staan.

bo. Directoire exécurif

s. L.M. Revellière-Lépeaux (pres); Lagarde (secr-gen)

RO nr.195(2): 21 fructidor IV (7 sep 1796)

RE nr. 190: $15 / 16$ vendémiaire $V(6 / 7$ okt 1796)

- verwijzing naar: wet van 14 ventôse IV (4 mrt 1796)

- het onderhavige besluit wordt aan alle politieke agenten van de Republiek in het buitenland gezonden

- afkondiging: besluit Directoire exécurif s. L.M. Revellière-Lépeaux (pres), Lagarde (secr-gen); 6 fructidor IV (23 aug 1796)

\section{IV prairial 16 (1796 jun 4)}

BL Ile ser no.52 (441); LA IV fol 60; rH IX 275-276; P VII 331; cB IVe ser IV 168-169

\section{LOI QUI DÉSIGNE LES FONDS DONT SERONT COMPOSÉS LES DROITS D'ASSISTANCE DANS LES TRIBUNAUX}

Het fonds gevormd uit het ingehouden gedeelte van de salarissen van de rechters en commissarissen van de pouvoir exécutif om te worden aangewend als droit d'assis- 
tance [presentiegeld] ten gunste van de aanwezige functionarissen, zal worden gevormd uit het totaal der inhoudingen van de respectieve salarissen, of nu de plaatsen waar deze salarissen voor zijn bestemd bekleed worden dan wel vacant zijn. Het totale beloop van het fonds zal worden verdeeld over de aanwezige rechters en commissarissen volgens het bijgehouden register.

bo. Conseil des Cinq-cents s. Defermon (pres); Pelet (de la Losère), Echasseriaux aîné (secr); Conseil des Anciens s. Lebrun (pres); J.Q. Lacuée, Maleville, Picault, Olivier-Gérente (secr)

ao. commissie uit de Cinq-cents inzake de boodschap van het Directoire exécutif

RO nr. 207(2): 2 vendérniaire V (23 sep 1796)

- verwijzing naar: wet van $2 * 1 \|$ sep 1790

- cB-intitulé: "loi relative aux droits d'assistance des juges"

- afkondiging: besluit Directoire exécututif s. L.M. Revellière-Lépeaux (pres), Lagarde (secr-gen); 23 fructidor IV ( 9 sep 1796)

\section{IV prairial 17 (1796 jun 5)}

BL Ile ser no.52 (442); LA IV fol 144; rH X 124-125; P VII 332; cB IVe ser IV 170

\section{LOI Relative à la pUblication ET AU dépôt des listes des ḱMIGRés, \&C.}

De departementale besturen zijn belast met de bekendmaking van de lijsten van uitgewekenen, welke zij zenden aan de municipale besturen om te worden gepubliceerd en aangeplakt in de gemeenten. De generale lijst met de supplementen zal alleen ter secretarie van de municipale besturen van de vroegere districtshoofdplaatsen worden gedeponeerd. De schuldeisers dienen hun titels te deponeren op het departementssecretariaat, alwaar de debiteuren volgens de generale lijsten hun domicilie hadden. De termijn voor deponering van de schuldvorderingstitels loopt vanaf de dag van de eerste bekendmaking van de lijst in de kantonshoofdplaats.

bo. Conseil des Cinq-cents s. Defermon (pres); P.M. Delaunay, Pelet (de la Losère), Eschasseriaux aîné (secr); Conseil des Anciens s. Lebrun (pres); J.Q. Lacuée, Maleville, Olivier-Gérente, Picault (secr)

RO nr.210(26): 23 vendémiaire V (14 okt 1796)

* verwijzing naar: wet van 25 brumaire IV (16 nov 1795)

- cB-intitule: "loi concernant la publication des listes des émigres"

- afkondiging: besluit Directoire exécutif s. L.M. Revellière-Lépeaux (pres), Lagarde (secr-gen); 10 fructidor IV (27 aug 1796)

\section{IV prairial 19 (1796 jun 7)}

BL Ile ser no.52 (450); LA III fol 210ro-211ro; rH VIII 326-327; P VII 332-333; cB IVe ser IV 179180

\section{LOI QUI PROROGE JUSQU'AU $1^{\text {RR }}$ FRUCTIDOR LE TERME FIXÉ POUR L'INTRODUC- TION DU NOUVEAU RÉGIME HYPOTHÉCAIRE}

De invoering van het nieuwe hypothecaire regime is verschoven van 1 messidor IV (19 jun 1796) naar 1 fructidor IV (18 aug 1796). Bij gevolg blijft de additionele wet 
van 21 nivôse IV (11 jan 1796) inzake de code hypothécaire langer van kracht. In streken waar het edict van juni 1771 aangaande vereenvoudiging van aflossing van hypotheken van kracht is geworden, mogen niet langer lettres de ratification worden gezegeld, dan alleen onder last van aantekening van verzet of de inschrijving, hetzij bij de oude hypotheekbewaarders, hetzij bij de nieuwe, ingesteld door de wet van 9 messidor III ( 27 jun 1795). In plaatsen waar deze lettres de ratification niet ingesteld zijn, hebben de verkrijgers van onroerend goed de bevoegdheid de hierop rustende hypotheken af te lossen, hetzij overeenkomstig tot nog toe in zwang zijnde wetten en gebruiken, hetzij door te voldoen aan de verplichtingen betreffende deponering van het contract, op grond waarvan het onroerend goed verworven is, en het voldoen van de koopprijs.

bo. Conseil des Cinq-cents s. Defermon (prews); Pelet (de la Losere), Eschasseriaux âné (secr)" Conseil des Anciens s. Lebrun (pres); Olivier-Gérente, Picault, J.Q. Lacuee, Maleville (secr)

$\mathrm{RO}$ nr. $170(4): 12$ thermidor IV (30 jul 1796)

RE nr. 167: 29/30 thermidor IV (16/17 aug 1796)

- verwijzing mar: edict ["sur les hypotheques"] van jun 1771; code hypothecaire van 9 messidor III (27 jun 1795); wetten wan 9 messidor III (27 jun 1795); 21 nuvôse IV (11 jan 1796); 19 ventôse IV (9 mrt 1796$)$

- cB-intitulé: "loi qui proroge le delai de l'introduction du régime hypothécaire"

- afkondiging: besluit Directoire exécutif s. Carnot (pres), Lugarde (secr-gen); 30 messidor $1 \mathrm{~V}$ (18 jull 1796) [BL Jie ser no.59 (549)]

\section{IV prairial 20 (1796 jun 8$)$}

BL IIe ser no.52 (453); LA III fol 211; rH IX 10-11; P VII 333; cB IVe ser IV 182-183

\section{LOI QUi ÉTABLIT UN MOde POUR STATUER SUR Le PRÉdéCÈs DE PLUSIEURS INDIVI- DUS SE SUCCÉdANT DE DROIT, ET MORTS DANS LA MÊME EXÉCUTION}

Gelijktijdige terechtstelling van ter dood veroordeelde rechtsopvolgers in de opgaande en de neergaande lijn, alsmede van overige opvolgers in rechte, leidt tot de onmogelijkheid het vooroverlijden vast te stellen. De jongste der veroordeelden wordt dan geacht het langst te hebben geleefd.

bo. Conseil des Cinq-cens s. Defermon (pres); Eschasseriaux aimé, Mailhe, Pelet (de la Losëra) (secr); Conseil des Anciens s. Lebrun (pres); Olivier-Gerente, Picault, Maleville, J.Q. Lacuee (secr) RO mi. I70(5): 12 thermidor IV (30 jul 1796)

- afkondiging: besluit Direcroire exécutf s. Carnot (pres), Lagarde (secr-gen); 30 messidor IV (18 jul 1796) [BL Ile ser no.59 (549)]

IV prairial $22(1796$ jun 10)

BL Ile ser no.53 (466); LA III fol 21 I vo-2/2ro; rH IX 12; P VII 335; cB IVe ser IV 201-202

\section{LOI PORTANT DES PEINES CONTRE LA TENTATIVE DU CRIME}


De code pénal kent - met uitzondering van moord en vergiftuging - geen strafbedreiging tegen poging tot diefstal, brandstichting en andere misdrijven. Mitsdien wordt elke poging tot misdrijf, kenbaar door uitwendige handelingen en gevolgd door een begin van uitvoering, gestraft als het misdrijf zelve, wanneer de poging tot het mis drijf slechts door toevallige, buiten de wil van de verdachte gelegen, omstandigheden is gestaakt.

bo. Conseil des Cinq-cients s. Defermon (pres); Mailhe, P.M. Delaunay, Echasseriaux amé, Pelet (de Ja Losère) (secr); Conseil des Anciens s. Lebrun (pres); Maleville, J.Q Lacuée, Picault (secr)

RO nr. 170(6): 12 thermidor IV (30 jul 1795)

- verwijzing naar: code pénal van 25 sep * 6 okt 1791

- afkondiging: besluit Directoire exécutif s. Carnot (pres), Lagarde (secr-gen); 30 messidor IV (18 jul 1796) [BL Ile ser no.59 (549)]

\section{IV prairial 24 (1796 jun 12)}

LA III fol 166ro-167ro; FA nr.249 foll 51 wo-52vo, FA nr.626

ARRÊTÉ QUI RÉDUIT À DIX MILLE LA RÉQUISITION DE QUINZE MILLE QUINTAUX DE GRAINS, FRAPPÉE SUR LE DÉPARTEMENT DE LA MEUSE-INFÉRIEURE, PAR L'ORDONNATEUR DES GUERRES BLANCHARD

De vordering van 26 germinal IV (15 apr 1796) van een hoeveelheid graan ten behoeve van het Sambre-en-Maasleger wordt met een derde verminderd. Deze reductie heeft alleen dan plaats als de benodigde hoeveelheid koren daadwerkelijk in de legermagazijnen te Maastricht binnen één maand na 24 prairial IV (12 jun 1796) wordt aangevoerd. Degenen die dan achterstallig in de leverantie zijn, moeten de helft meer leveren dan oorspronkelijk van hen gevorderd werd. De invordering wordt met gewone dwang ten uitvoer gelegd, zonodig gewapenderhand.

bo. commissaire-ordonnateur en chef des armées de la République \& commissaire du gouvernement près l"armée du Nord, celle de Sambre et Meuse et pays enwironnonts

5. Charles-Alexis Alexandre; cs. Thomas

RO nr.155: 25 prairial IV (13 jun 1796)

RE nr. 154: $28 / 29$ prairial IV (16/17 jun 1796)

- verwijzing naar: besluiten van 26 germinal IV (15 apr 1796); 10 floreal IV (29 apr 1796)

- besluit departementaal bestuur: "l'arrêté sera consigné dans les registres, imprimé et affiché dans les deux langues"

\section{IV prairial 25 (1796 jun 13)}

BL Ile ser no.53 (472); LA V fol 141vo-142ro; rH VIII 329-330; P VII 335-337; MAP I 15I-152

ARRETE QUI EXEMPTE DES DROITS DE DOUANES LES TOLLES DE COTON BLANCHES TIREES DE L'ÉTRANGER POUR ÊTRE PEINTES DANS LES MANUFACTURES DES DEPARTEMENS DE LA LYS, DE L'ESCAUT, DES DEUX-NETHES, DF LA DYLE, ET ETRE REEXPORTEES 
De fabrikanten van bedrukte katoen in de departementen van de Leie, de Schelde, de Twee Neten en de Dijle behoeven geen tolrechten te betalen voor, via de kantoren van Oostende en Antwerpen, ingevoerde onbedrukte katoen, indien het katoendoek weer wordt uitgevoerd. Het doek moet worden aangegeven, onder opgave van de bestemming ervan. De begeleiders van het transport moeten een derde gedeelte van de invoerrechten ten kantore van de douane consigneren en verklaren borg te staan voor het resterende bedrag in het geval de uitvoer niet komt vast te staan. Teruggave van de geconsigneerde gelden vindt alleen dan plaats als er binnen het jaar van invoer sprake is van het weer uitvoeren van bedoelde goederen.

bo. Directoire exécutiff

ao. minister van financiën

S. Carnot (pres), Lagarde (secr-gen)

RO nr. 162: 11 messidor IV (29 jun 1796)

- besluit uitgevaardigd n.a.y. een klacht van bedrukkers wan katoen over de hoogte van de tolrechten

\section{IV prairial 28 (1796 jun 16)}

LA III fol 169\%o-171vo; FA nr.291, FA nr.3378; rH VIII. 337-341; P VII Ixxix-1xxx

\section{ARRÊTÉ QUI ÉTABLIT UN MODE POUR LE RECOUVREMENT DES IMPOSITIONS DANS LES NEUF DÉPARTEMENS RÉUNIS PAR LA LOI DU 9 VENDÉMIAIRE, AN IV}

Het besluit behelst bepalingen ter verbetering van de invordering van oude belastingen, alsmede instructies voor de ontvangers in de departementen en de betaalmeestersgeneraal. De geïnde gelden staan in beginsel ter beschikking van de nationale schatkist. De ministers kunnen daarover alleen beschikken dan na kennisgeving aan de nationale schatkist. Wat betreft de departementale uitgaven bepaalt de minister van binnenlandse zaken de hoogte ervan en na kennisgeving aan de trésorerie informeert deze de betaalmeester-generaal, die tot betaalbaarstelling overgaat na de ontvangst van de mandaten van het departementale bestuur. Op soortgelijke wijze worden de uitgaven van de rechterlijke organisatie door de minister van justitie bepaald. De departementale besturen hebben de taak op de kortst mogelijke termijn alle belastingen anterieur aan het jaar 1796 - corresponderend met het jaar IV - in te vorderen en over te gaan tot het samenstellen van de leggers der kohieren. Voorts wordt er een begin gemaakt met de invoering van het Franse belastingstelsel, met name de grondbelasting. De minister van financiën zal daartoe een extract van de niet-herroepen bepalingen van wetten ter zake samenstellen. Zodra de departementen deze hebben ontvangen, zullen zij die ter hand stellen van de municipale besturen, teneinde een legger van de kohieren der grondbelasting in de gemeenten samen te stellen. Elke municipaliteit dient iedere decade de voortgang hiervan te melden aan het departementaal bestuur.

\section{bo. Directoire exécutif}

s. Carnot (pres); Lagarde (secr-gen)

ti. minister van financiën Ramel

RO nr. 160: 9 messidor IV (27 jun 1796)

- verwijzing naar: besluit van 10 pluviôse IV (30 jan 1796); "lois existantes" 
- wetten van 1 dec 1790,25 febr 1791, 10 apr 1791, 10 jun 1791, 20 jul 1791 en 12 okt 1791 inzake de grondbelasting en die van 2 okt $1791 \mathrm{~m} . \mathrm{b} . \mathrm{t}$ de invordering zijn verbindend verklaard voor de megen Verenigde Departementen, behoudens de door latere wetten herroepen bepalingen

\section{IV prairial 29 (1796 jun 17)}

LA III fol 181ro, 203; drukw FA nr.34; rH VIII 342, 395-396; P VII lxxx-lxxxi

\section{ARRÊTÉ RELATIF À L'ÉTAT CIVIL DES CITOYENS DANS LES DÉPARTEMENS RÉUNIS, ET PORTANT PUbliCATION des loIs RELATIVES À CETTE MATIÈRE}

Binnen een week na afkondiging van dit besluit moeten de municipale agenten of hun adjunct in gemeenten met minder dan 5000 inwoners en in grotere gemeenten de aangewezen ambtenaren van de burgerlijke stand alle registers, zowel de oude als de lopende betreffende geboorte, huwelijk en overlijden die zich in parochiekerken, pastorieën en andere kerkelijke bewaarplaatsen bevinden, doen overbrengen naar de plaats alwaar het gemeentebestuur zitting houdt. De lopende registers moeten worden afgesloten door de voorzitter van het gemeentebestuur en teruggegeven aan de municipale agent of de ambtenaar van de burgerlijke stand. De akten van geboorte, huwelijk: en overlijden moeten nog in de lopende registers worden ingeschreven tot 1 vendémiaire V (22 sep 1796). De gemeentebesturen zijn verder gehouden een inventaris te vervaardigen van de gedeponeerde registers en het afschrift ervan in het departementale archief te deponeren.

bo. Directoire exécutif

ao. ministers van justitie en van bimnenlandse zaken

s. Carnot (pres); Lagarde (secr-gen)

RO nr. 164: 24 messidor IV (12 jul 1796)

RE nr.193: I/3 brumaire V (22/24 okt 1796); Vlaamse vertaling [drukw FA nr. 143]

- verwijzing naar: wet van 20 sep 1792

- N.B.: drukw FA nr.34 heeft uit hoofde van instructie een aanpassing ondergaan

IV messidor 6 (1796 jun 24)

BL Ile ser no.55 (487); LA. IV 148ro-150vo; P VII 337-338; cB IVe ser V 15-18

\section{LOI CONTENANT UN NOUVEAU TARIF POUR LA POSTE ET LES MESSAGERIES}

De wet behelst de tarieven naar gewichtsklasse voor het verzenden van brieven binnen Frankrijk, van en naar het buitenland en binnen eenzelfde stad en de buitenwijken. Speciale tarieven gelden voor het verzenden van periodieken en drukwerken. Via aangetekende brieven mogen geen hoeveelheden papiergeld, goud en zilver, of juwelen worden verzonden; bij verlies is er geen verhaal mogelijk. Ook vermeldt de wet de tarieven voor verzendingen via de paardenposterij en het vervoer per diligence.

bo. Conseil des Cinq-cents s. Pelet (de la Losère) (pres); Leclerc (de Loir-et-Cher), J.C. PhilippeDelleville (secr); Conseil des Anciens s. Portalis (pres); Mathieu Dumas, Rabaut, Moysset (secr) ao. commissie uit de Cinq-cents "pour l"organisation des posters et messageries" 
RO nr.221: Ifrimaite $V(21$ nov 1796$)$

RE nr.213: $21 / 22$ frimaire $V(11 / 12$ dec 1796)

- werwijzing naar: wetten van 22 apr 1791:17*22 aug 1791 (volgens $P$; BL en cB maken gewag van de wet 12 aug 1791); tarieven van 1790; 6 nivôse IV (27 dec 1795)

- afkondiging: besluit Directoire exéc utif s. L.M. Revellière-Lepeaux (ex-pres), Lagarde (secr-gen); 11 brumaire $V$ (I nov 1796); N.B.: afgekondigd is alleen het bepaalde wat betreft de brievenpost; het bepaalde ter zake van de besteldienst is tenietgedaan door de wet wan 26 thermidor IV (13 aug 1796) [BL IIe ser no.87 (835)]

IV messidor 9 (1796 jun 27)

BL. Ile ser no.56 (496); LA III fol 203vo-204ro; P VII 340

\section{ARRETÉ RELATIF AU TRANSIT PAR LA COMMUNE DE MEYEL, DES MARCHANDISES EXPEDIÉS DE LA HOLLANDE PAR LA PRUSSE}

Om te voorkomen dat de opbrengsten van de uit Holland door Pruisen geimporteerde handelswaar niet langer ten goede komen aan de inwoners van de gemeente Meijel, worden de bepalingen aangaande de doorvoer via Venlo van handelswaar vanuit Holland naar het Gulikse eveneens van kracht verklaard voor de doorvoer via Meijel.

bo. Directoire exécutif

ao. minister van financièn

s. Carnot (pres); Lagarde (secr-gen)

RO nr.165: 26 messidor IV (14 jul 1796)

- verwijzing naar: besluit van 9 prairial IV (28 mei 1796)

\section{IV messidor 11 (1796 jun 29)}

BL IIe ser no.56 (499); LA IV fol 145ro-146ro; rH X 126-127; P VII 340; cB IVe ser V 32-34

LOI RELATIVE AUX REVENTES FAITES SANS FOLLE ENCHËE, DE DOMAINES NATIONAUX DONT LES ADJUDICATAIRES PRIMITIFS SONT EMIGRÉS, ET SE SONT TROUVES EN RETARD DANS LE PAIEMENT DU PRIX DE LEUR ADJUDICATION

De wederverkopingen van nationale domeingoederen, waarvan de oorspronkelijke kopers zijn geëmigreerd en achterstallig zijn in de betaling van het hun toegewezene, zullen niet, ten gevolge van een leemte in de wet, vernietigd kunnen worden op grond van het ontbreken van het vormvereiste van de rouwkoop.

bo. Conseil des Cinq-cents s. Pelet (de lla Losère) (pres); J.V. Dumolard, Soulignac (secr); Conseil des Anciens s. Portalis (pres); Moysset, Mathieu Dumas, Cretet, Rabaut (secr)

ao. commissie uit de Cinq-cents ter zake van de boodschap van het Directotre exécutif

RO m. 210(27): 23 vendémiatre V (14 okt 1796)

- verwijzing naar: wetten van $14 * 17$ mei $1790 ; 3 * 17$ nov 1790

- afkondiging: besluit Directoire exécutif s. L.M. Revellière-Lêpeaux (pres), Lagarde (secr-gen); 10 fructidor IV (27 aug 1796) 
ARRÊTÉ CONCERNANT LE MODE DE JUGEMENT DES ACTIONS RELATIVES À LA PERCEPTION DES IMPÔTS INDIRECTS, DANS LES NEUF DÉPARTEMENS RÉUNIS PAR LA LOI DU 9 VENDÉMIAIRE DERNIER

Art.5 van het besluit van het Directoire exécutif van 9 nivôse IV (30 dec 1795) houdende de bepaling dat, overeenkomstig de arrêtés van de volksrepresentanten, de departementale besturen voorlopig definitief uitspraak doen in geschillen met betrekking tot alle belastingen in de negen Verenigde Departementen, wordt herroepen voor zover het de indirecte belastingen betreft. Bij gevolg kunnen burgerlijke rechtsvorderingen inzake de heffingen der indirecte belastingen, evenals in de overige departementen van de Republiek, die van belang zijn voor de natie rechtstreeks gebracht worden voor de rechtbanken, zonder dat de voorafgaande verschijning voor het $b u$ reau de conciliation noodzakelijk is. Het besluit van 2 frimaire IV (23 nov 1795) van de volksrepresentanten/gouvernementscommissarissen Pérès en Portiez (de l'Oise) is herroepen voor wat betreft het bepaalde dat de departementale burgerlijke rechtbanken in de Verenigde Departementen, met drie rechters, in eerste en laatste instantie uitspraak doen in burgerlijke rechtsvorderingen aangaande de heffing der indirecte belastingen.

bo. Directoire exécunif

ao. minister van justitie

s. Carnot (pres); Lagarde (secr-gen)

RO nr. 166: 26 messidor IV (14 jul 1796)

- verwijzing naar: wetten van $7 * 11$ sep 1790; 6 mrt 1791; grondwet van 5 fructidor III (22 aug 1795); besluit volksrepresentanten van 2 frimaire IV (23 nov 1795); besluit Directoire excécutif van 9 nivôse IV (30 dec 1795); wet van 26 ventôse IV (16 mrt 1796)

- het onderhavige besluit door het Directoire exécurif gerectificeerd bij besluit van 24 thermidor IV (11) aug 1796) [RO nr.182]

IV messidor 22 (1796 jul 10$)$

LA III fol 232vo-233ro; FA nr.249 fol 234ro-235ro, FA nr.895

ARRETÉ PORTANT DESTITUTION DE QUELQUES COMMISSAIRES DU DIRECTOIRE PRÈS LES MUNICIPALITÉS DES CANTONS DU DÉPARTEMENT DE LA MEUSE-INFÉRIEURE ET LEUR REMPLACEMENT PAR D'AUTRES CITOYENS

De navolgende personen zijn benoemd tot commissaris van de uitvoerende macht bij de kantonsmunicipaliteiten; zij dienen terstond hun werkzaamheden aan te vangen:

- Montenaken: Grégoire le Jeune, kwartiermeester verblijvend te Sedan, ter vervanging van de ontslagen Cousturier;

- Kortessem: Clairfayt, chef de bureau bij het bestuur van het departement van de Nedermaas, ter vervanging van de ontslagen Stephens;

- Loon: Bailly, commissaris voor de requisities, ter vervanging van de ontslagen Groenendaels; 
- Heerlen: Lambert, oud-secretaris van het district Verdun thans in Maastricht, ter vervanging van de ontslagen Roebruck;

- Achel: Pointe, employé bij het departementaal bestuur van Nedermaas, ter vervanging van de ontslagen Vanderhoven;

- Sint-Truiden: Serrurier, huidig commissaris van de uitvoerende macht bij de kantonsmunicipaliteit van Venlo, ter vervanging van de ontslagen Strens;

- Venlo: D'assier [Dassier], employé bij het bestuur van het departement van de Nedermaks, ter vervanging van de tot een andere functie geroepen Serrurier [LA toevoeging: vervangen door Petit]

bo. Directoire exécutif

s. Caumot (pres); Lagarde (secr-gen)

ti. gouvernementscommissaris Bouteville

RO nr. 168: 3 thermidor IV (2\| jul 1796)

IV messidor 22 (1796 jul 10)

LA III fol 206ro-207ro; FA nr.291; rH IX 7-8; P VII Ixxxïi-Ixxxiii

ARRETE CONCERNANT LE SERVICE DES HUISSIERS DANS LES DÉPARTEMENS RÉUNIS PAR LA LOI DU 9 VENDÉMIAIRE, AN IV

Deurwaarders, vroegere koninklijke of heerlijke gerechtsdienaren, kunnen hun functie blijven vervullen in het ressort van de respectieve departementale burgerlijke rechtbanken. Dit geldt niet voor hen die boventallig zijn, ofwel die door hun gedrag, hun gebrek aan kennis, hun incivisme, hun weigering de eed van haat jegens het koningschap uit te spreken of de onverbrekelijke verknochtheid an de Republiek ten toon te spreiden, onwaardig zijn de functie te mogen uitoefenen.

bo. Directoire exéccutif

s. Camot (pres); Lagarde (secr-gen)

RO nr.169: 8 thermidor IV (26 jul 1796)

- verwijzing naar: wetten van 29 jan * $20 \mathrm{mrt} 179 \sharp$; 19 vendemiaire IV (11 okt 1795)

\section{IV messidor $22(1796$ jul 10$)$}

BL IIe ser no.57 (524); LA III fol 212; rH IX 13-14; P VII 343; cB IVe ser V 68

\section{LOI QUI FIXE LA COMPÉTENCE DES CONSEILS MILITAIRES}

Een militair delict kan slechts begaan worden door een persoon, die deel uitmaakt van het leger. Niet-militairen kunnen nimmer als verdachte aan militaire rechters worden overgedragen. Wanneer zich onder twee of meerdere verdachten één of meerdere nietmilitairen bevindt (bevinden), behoort de kennisneming van de zaak aan de gewone rechter. Mitsdien moeten zodanige reeds bij krijgsraden aanhangige procedures doorverwezen worden naar de gewone rechter. 
bo. Conseil des Cinq-cents s. Pelet (de la Losère) (pres); J.V. Dumolard, Soulignac, J.C. PhilippeDelleville, Leclerc (de Loir-et-Cher) (secr); Conseil des Anciens s. Portalis (pres); Creter, Rabaut, Moysset (secr)

RO nr. 170(7): 12 thermidor IV (30 jul 1796)

- verwijzing naar: grondwet van 5 fructidor III (22 aug 1795)

- afkondiging: besluit Dinectoire exécurif s. Camot (pres), Lagarde (secr-gen); 30 messidor IV (18 jul 1796) [BL Ile ser no.59(549)]

IV messidor 22 (1796 jul 10)

LA IV 4ro-5ro; FA nr.737; rH X 368-370; P VII Ixxxiii-lxxxiv

ARRÊTÉ QUI PRESCRTT L'ÉTABLISSEMENT, L'ORGANISATION ET LA SOLDE DE LA GENDARMERIE NATIONALE DANS LES DÉPARTEMENS RÉUNIS

De gendarmerie nationale in de negen Verenigde Departementen bestaat uit 200 brigades, te zamen een divisie vormend. Iedere brigade heeft een sterkte van vijf man, daaronder hun commanderende wachtmeester of brigadier begrepen. Een eskadronscommandant heeft doorgaans twee departementen onder zijn bevell. Gendarmes die tot nog toe als zodanig werkzaam waren, gaan over naar de nieuw ingestelde gendarmerie nationale, aangevuld met cavaleristen, kunnende lezen en schrijven. Een derde van het aantal gendarmefuncties zal gerecruteerd worden uit behoeftigen, voor zover zij aan de vereiste kwaliteiten voldoen. De departementale besturen voorzien in natura in de kazernering van de brigades, terwijl de municipale besturen in de inkwartiering van de detachementen voorzien. Uit de maandelijkse wedde dienen de uitgaven voor het persoonlijk levensonderhoud en de verzorging van het paard te worden bekostigd. Dit geldt eveneens voor het onderhoud van kleding en uitrusting, alsmede de vervanging en de uitrusting van het paard.

bo. Directoine exécutif

ao. minister van oorlog

s. Camot (pres); Lagarde (secr-gen)

ti. goukernementscommissaris Bouteville

RO nr.190: 9 fructidor IV (26 aug 1796)

- verwijzing naar: besluit comité de salut public wan ... [datum niet nader aangeduid], "qui prescrit l'organisation de la gendarmerie nationale dans les neuf départemens réunis à la république par la loi du 9 vendémiaire an IV"

\section{IV messidor 24 (1796 jul 12)}

BL lle ser no.58 (532); LA III fol 216; rH IX 20-21; P VII 344; cB IVe ser V 81

LOI QUI DÉTERMINE LA MANIËRE DE PROCÉDER AU JUGEMENT DES INDIVIDUS PRÉVENUS DE COMPLICITÉ AVEC UN ACCUSÉ TRADUIT DEVANT LA HAUTE-COUR DE JUSTICE

Alle verdachten die in staat van beschuldiging zijn gesteld wegens medeplichtigheid aan een misdrijf waarbij een volksrepresentant of een lid van het Directoire exécutif 
betrokken is, en die door het Wetgevend Lichaam in staat van beschuldiging is gesteld, moeten worden overgedragen aan het hooggerechtshof (haute-cour de justice) om te zamen met hern te worden berecht.

bo. Conseil des Cinq-cents s. Pelet (de la Losêre) (pres); J.V. Dumolard, Soulignac, Leclerc (de Loir-et-Cher) (secr); Consell des Anciens s. Portalis (pres); Mathieu Dumas, Cretet, Moysset (secr) RO nr.174(1): 21 thermidor IV (8 aug 1796)

- verwijzing naar: brief Directoire exécutif van 2 1 floréal IV (10 mei 1796) inzake de samenzwering van de volksrepresentant Drouet

- afkondiging: besluit Directoire exécutif s. L.M. Revellière-Lépeaux (pres), Lagarde (secr-gen); 10 thermidtor IV (28 jul 1796) [P vermeldt als datum afkondigingsbesluit 20 thermidor IV (7 aug 1796)]

\section{IV messidor 24 (1796 jul 12)}

BL IIe ser no.58 (533); LA III fol 216vo-2]8vo; rH IX 22-26; P VII 344-345; cB IVe ser V 77-80

\section{LOI RELATIVE À LA COMPOSITION DU TRIBUNAL DE CASSATION}

Het tribunal de cassation wordt gevormd door vijftig rechters(-plaatsvervanger), waarvan jaarlijks een vijfde gedeelte aftreedt. Het aftreden geschiedt naar mate de nieuwbenoemden worden geïnstalleerd. De rechter en diens plaatsvervanger worden door de departementale assemblée électorale benoemd; zij worden als één persoon beschouwd. Departementen die nog geen rechters in het tribunal de cassation benoemd hebben, zullen het eerst aan de beurt komen. Het ambt van de rechter in het tribunal de cassation is onverenigbaar met een andere wetgevende, bestuurlijke of rechterlijke openbare functie. Dit geldt niet voor de rechters-plaatsvervanger, behoudens in het geval dat zij tot de vervulling van het rechtersambt worden geroepen. Indien men niet binnen een zekere termijn de keuze maakt, betekent dit ontslag als rechter.

bo. Conseil des Cinq-cents s. Defermon (pres); P.M. Delaunay, Pelet (de la Losère), Mailhe (secr); Consell des Anciens s. Portalis (pres); Cretet, Mathieu Dumas, Moysset (secr)

RO nr.174(2): 21 thermidor IV (8 aug 1796)

- verwijzing naar: wet van 28 jan 1791; grondwet van 5 fructidor III (22 aug 1795); wetten van 5 vendémiaire IV (27 sep 1795); 2 brumaire IV (24 okt 1795)

- afkondiging: besluit Directoire exécurif s. L.M. Revellière-Lépeaux (pres), Lagarde (secr-gen); 10 thermidor IV (28 jul 1796) |P vermeldt als datum afkondigingsbesluit 20 thermidor IV (7 aug 1796)

\section{IV messidor 25 (1796 jul 13)}

BL Ile ser no.59 (537); LA III fol 220ro; rH IX 28; P VII 345-346; MAP I 227

\section{ARRÊTÉ QUi PRESCRIT UN ORDRE DE COMPTABILITÉ POUR UNE BRANCHE DE LA RECETTE DES PORTS DE LETTRES ET PAQUETS}

Rechterlijke functionarissen zullen een rekening openen bij de directeur van het postkantoor voor het voldoen van de verschuidigde portokosten, die zij moeten maken uit 
hoofde van hun functie. Het saldo van die rekening zall worden voldaan door de functionarissen, aan wie zij ondergeschikt zijn.

bo. Directoive exécutif

ao. minister van financiën

s. Camot (pres); Lagarde (secr-gen)

RO nr.174(3): 21 thermidor IV (8 aug 1796)

- verwijzing naar: besluit comité de salut pubilc van 4 fructidor II (21 aug 1794); besluiten van 23 pluviôse IV (12 feb 1796); 5 prairial IV ( 24 meï 1796)

- afkondiging: besluit Directoire exécutif s. L.M. Revellière-Lépeaux (pres), Lagarde (secr-gen); 10 thermidor IV (28 jul 1796) [P vermeldt als datum afkondigingsbesluit 20 thermidor IV (7 aug 1796)]

\section{IV messidor 30 (1796 jul 18)}

BL IIe ser no.60 (553); LA III fol 214ro-215ro; rH IX 14- 16 ; P VII $\| x x x y$

\section{ARRETÉ RELATIF AUX VACANCES DES TRIBUNAUX DANS LES DÉPARTEMENS RÉUNIS PAR LA LOI DU 9 VENDÉMIAIRE, AN IV}

De tenuitvoerlegging van de wet die jaarlijks twee maanden vacantie toekent aan de rechtbanken is niet verenigbaar met de huidige stand van de nationale wetgeving. Mitsdien wordt het afkondigingsbesluit van de gouvernementscommissarissen van 18 frimaire IV ( 9 dec 1795), dat de tenuitvoerlegging van de wet van 17 september 1791 beveelt, herroepen. De minister van binnenlandse zaken dient terstond een instructie bestemd voor de negen Verenigde Departementen aan het Directoire exécutif voor te leggen, houdende de bepalingen van in werking zijnde wetten betreffende de Republikeinse kalender.

bo. Directoire exécutif

ao. minister van justitie Merlin

s. Camot (pres); Lagarde (secr-gen)

RO nr.173: 19 thermidor IV (6 aug 1796)

- verwijzing naar: wetten van $17 * 23$ sep 1791; 8 jul 1792; 22 aug 1793; 5 okt 1793; decreet van 14 sep 1793; grondwet van 5 fructidor III (22 aug 1795); code des délits et des peinnes van 3 brumaire TV (25 okt 1795); besluit gouvemementscommissarissen yan 18 frimaire IV ( 9 dec 1795)

- zie RO nr.79(2)

\section{IV thermidor 1 (1796 jul 19)}

LA VI fol 44ro-48ro; FA nr.250 fol 205vo-2IIro, FA nr.2600

\section{ARRÊTÉ QUI MET EN RÉQUISITION LES HOUILLÈRES DE L'ABBAYE DE ROLDUC}

De steenkoolmijnen die gelegen zijn op het grondgebied van en toebehoren aan de geestelijkheid van de abdij Kloosterrade (Rolduc) zijn vanaf 1 thermidor IV (19 jul 1796) in handen gegeven van de staat, onverminderd de eventuele schadeloosstelling van de geestelijkheid door de Franse staat waarop wordt vooruitgelopen. De bevoorrading van het garnizoen en de militaire hospitalen te Maastricht met brandstof is onvoldoende als gevolg van de inertie van het departementaal bestuur van Nedermaas - 
bij de tenuitvoerlegging van de requisitie van twee miljoen eenheden steenkool uit de mijnen van Kloosterrade, alsmede ook vanwege het feit dat de Maas voor onvoldoende bevoorrading kan zorgen. Door het gouvemement wordt, vanwege diens revolutionaire ijver en betoond civisme, Pierre Delbée benoemd tot hoofdadministrateur, belast met de exploitatie en het beheer van de steenkoolmijnen. Het reeds bij de steenkoolwinning werkzame personeel blijft in zijn onderscheidene functies met de bijbehorende bezoldiging gehandhaafd. Een vijfde tot een kwart van de steenkoolopbrengst zal voor de verwarming van Maastricht en het Sambre-en-Maasleger worden aangewend; het resterend gedeelte zal tegen de marktprijs worden verkocht.

bo. commissaire-ordonnateur en chef des armées de la République et commissaire du gouvernement près les armée du Nord et de Sambre \& Meuse et pays environnants Charles-Alexis Alexandre ti. commissaris van het Directoire excutif bij het kanton 's-Hertogenrade (Rolduc) Hennequin RO nr.171: 12 thermidor IV (30 jul 1796); N.B.: in indicateur général ingeschreven onder de datum van 11 thermidor IV (29 jul 1796)

- verwijzing naar: besluit Directoire exécutif van 10 floréal IV (29 apr 1796); requisitie van commissaire-ordonnateur en chef de l"armée de Sambre \& Meuse Blanchard; missive Directoire exëcutif van 7 messidor IV (25 jun 1796)

- het besluit ter goedkeuring voorgelegd aan het Directoire exécutif

- het arrêté stelt dat het besluit van het Directoire exécutifí van 10 floréal IV (29 apr 1796) op 23 prairial IV (II jun 1796) in het departement is geregistreerd, RO nr.138: datum van registratie 24 floréal IV (13 mei 1796)

\section{IV thermidor 4 (1796 jul 22)}

LA IV fol 8vo-9vo; FA nr.25I fol 105vo-106vo; rH X 351-352

\section{ARRÊTÉ RELATIF À LA CIRCULATION DES GRAINS DANS LES DÉPARTEMENS RÉUNIS}

De graanopbrengst van Staats-Vlaanderen (Flandre hollandaise) kan vrijelijk met een kwijtingsbewijs van de zekerheidstelling via alle Scheldehavens waar zich een douanekantoor bevindt getransporteerd worden in de Verenigde Departementen. De douaneadministratie dient nauwgezet toe te zien op de verscheepte hoeveelheden graan. De uitvaardiging van het besluit geschiedt met het oog op een betere bevoorrading van de departementen.

bo. Direcroire exécutif

ao. gouvernementscommissaris in België; bestuur van het departement Schelde

s. Le Tourneur (pres); Lagarde (secr-gen)

ti. gouvernementscommissaris Bouteville

RO nr.180: 30 thermidor IV (i7 aug 1796)

- verwijzing naar: besluit volksrepresentanten/gouvernementscommissarissen van 30 frimaire IV (21 dec 1795); de bepalingen van dit besluit welke strijdig zijn met het onderhavige besluit zijn herroepen

\section{IV thermidor 8 (1796 jul 26)}

LA III fol 221vo-222ro; FA nr.291; rH IX 67 
ARRETÉ PORTANT QU"IL NE SERA PLUS ACCORDE DE PASSEPORTS AUX MARINS BELGES ET LIÉgEOIS, POUR NAVIGUER SUR LES VAISSEAUX DE LA REPUBLIOUE BATAVE

De marine van de Franse Republiek ziet zich genoodzaakt matrozen te werven in het voormalige België. Vanwege dit feit wordt het besluit van 12 germinal IV (1 apr 1796), dat schepelingen op de Maas en haar zijrivieren vanaf Luik toestaat aan te monsteren op schepen van de Bataafse Republiek, herroepen en zullen er niet langer paspoorten aan de Belgische en Luikse matrozen worden verstrekt.

bo. Directoire exécurif

ao. minister van marine

s. L.M. Revellière-Lépeaux (pres); Lagarde (secr-gen)

RO nr. 176: 23 thermidor IV (10 aug 1796)

- werwijzing naar: besluit wan 12 germinal IV (1 apr 1796)

\section{IV thermidor 10 (1796 jul 28)}

BL IIe ser no.62 (572); LA V fol 65; rH IX 68-69; P VII 351; MAP I 252-253; F I 289

\section{ARRETÉ CONCERNANT LA POURSUITE ET LA DIRECTION DES ACTIONS JUDICIAIRES QUI INTÉRESSENT LA RÉPUBLIQUE}

In alle zaken waarbij de Franse Republiek partij is, en die aanhangig gemaakt worden bij de rechtbanken, zijn de commissarissen van het Directoire exécutif bij de besturen gehouden memories, houdende de verweermiddelen van de natie, te zenden aan de commissarissen van het Directoire exécurif bij de rechtbanken. De laatsten kunnen deze ter terechtzitting voorlezen. In ieder geval stellen zij zodanige middelen voor en nemen zodanige conclusies, welke de aard van het geding, naar het hun voorkomt, vereist.

bo. Directoire exéccutif

s. L.M. Revellière-Lépeaux (pres); Lagarde (secr-gen)

RO nr. 177: 24 thermidor IV (11 aug 1796)

- verwijzing naar: wet van 19 nivôse IV (9 jan 1796)

- MAP-intitiulé: "Arrêté relatif à la conduite à tenir par ses commissaires dans toutes les affaires portées devant les tribunaux dans lesquelles la république sera partie"

- RO vermeldt: "Arrêté du Directoire Exécutif rendu obligatoire aux Départemens réunis ...", dit i.v.m. de clausule: "Il sera exécuté dans les départemens réunis par la loi du 9 vendémiaire dernier, comme dans les autres parties de la République"

IV thermidor 12 (1796 jul 30)

LA III fol 220ro-221ro; FA nr.276 foll 81vo-82vo, FA nr.291; rH IX 71-76, X 354-356

ARRÊTÉ CONCERNANT LE PAIEMENT DES DÉPENSES JUDICIAIRES DANS LES DÉPARTEMENS RÉUNIS PAR LA LOI DU 9 VENDÉMIAIRE, AN IV 
De krachtens de arrêttés en reglementen van de volksrepresentanten en gouvernementscommissarissen verrichte betalingen en afgegeven mandaten tot betaling aan de onderscheidene openbare functionarissen en employés bij de rechterlijke organisatie worden gehandhaafd en bevestigd voor wat betreft de bezoldigingen en uitgaven, die reeds zijn verricht tot en met 1 prairial IV (20 mei 1796). Vanaf dit tijdstip zijn de departementale besturen gehouden zich aan de door de minister van justitie vastgelegde rechterlijke uitgaven te houden. $\mathrm{Zij}$ zijn verantwoordelijk voor de betalingsmachtigingen die een overschrijding inhouden.

\section{bo. Directoire exécutif}

ao. minister van justitie

s. L.M. Revellière-Lépeaux (pres); Lagarde (secr-gen)

ti. minister van justitie Merlin

RO nr.175: 23 thermidor IV (10 aug 1796); N.B.: in indicateur général ingeschreven onder de datum van 22 thermidor IV (9 aug 1796)

- verwijzing naar: "lois principales sur l'organisation judiciaire" i.h.b. wetten van 19 vendémiaire IV (11 okt 1795); 4 brumaire IV ( 26 okt 1795); wetten van 20 pluviôse IV ( 9 feb 1796); 4 ventôse IV (23 feb 1796); arrêtés provisoires van 7 frimaire IV (28 nov 1795); 17 frimaire IV (8 dec 1795); 16 pluviôse IV (5 feb 1796); 18 floréal IV (7 mei 1796); besluiten van 30 nivôse IV (20 jan 1796); besluiten en reglementen van de volksrepresentanten en gouvernementscommissarissen; reglement minister van justitie van 29 pluviôse IV (18 feb 1796)

\section{IV thermidor $12(1796$ jul 30$)$}

BL. IIe ser no.63 (577); LA III fol 227\%o-278ro; rH X 362-363

\section{ARRÊTÉ QUI RÈGLE LE MODE DE REMBOURSEMENT DU PORT DES LETTRES ET PAQUETS ADRESSÉS AUX FONCTIONNAIRES PUBLICS DÉNOMMẾS DANS LES ARRÊTÉS DES 23 Pluviôse, 5 PRAIRIAL ET 25 MESSIDOR DERNIERS}

De door de departementale besturen af te geven betalingsmandaten voor de maandelijkse kwijting van de terugbetaling van het porto op brieven en pakketten, die gericht zijn aan openbare functionarissen, zijn op naam van de directeur van het postkantoor bij wie de rekeningen zullen worden geopend. De ontvangers-generaal der belastingen en registratierechten die voor de betaling moeten zorg dragen, zijn gehouden zulks te uitvoeren overeenkomstig de aard van de uitgaven en de hoedanigheid van de functionarissen en volgens het tarief voorgeschreven in de wet van 6 messidor IV (24 jun 1796).

\section{bo. Directoire exécurtif}

s. L.M. Revellière-Lépeaux (pres); Lagarde (secr-gen)

RO nr. 178: 29 thermidor IV (16 aug 1796)

- verwijzing naar: besluiten van 23 pluviôse IV (12 feb 1796); 5 prairial IV (24 mei 1796); 25 messidor IV (13 jul 1796); wet van 6 messidor IV (24 jun 1796)

- "Les ministres de la justice, de l'intérieur, et des finances, sont chargés, chacun en ce qui le concerne, de l'exécution du présent arrêté, qui sera commun aux départemens réunis par la loi du 9 vendémiaire, an IV, et imprimé au Bulletin des lois" 


\section{IV thermidor 14 (1796 aug 1$)$}

BL Ile ser no.62 (575); LA III fol 222ro-224ro; rH IX 78-82; P VII 353; cB IVe ser V 149-152

\section{LOI QUI ETABLIT UN NOUVEAU TARIF POUR LE PAIEMENT DES DROITS DE TIMBRE}

Vanwege het feit dat het koersbeloop voor het zegelrecht als genoemd in de wet van 11 nivôse IV (1 jan 1796) niet langer bestaat, in verband met de assignaten, worden er met ingang van 1 vendémiaire $V$ (22 sep 1796) nieuwe tarieven voor gezegeld papier en zegelrechten vastgesteld. De régie zal nieuwe zegelstempels doen vervaardigen, welke geen onderscheid naar departement kennen. De stempels moeten de hoogte van de leges aangeven en de woorden République française dragen. De zegels met een vaste waarde en maat moeten in zwart worden gestempeld; zij dienen voor papier dat door de régie wordt geleverd en voor papier dat door particulieren zelf wordt gestempeld. Na 1 vendémiaire V (22 sep 1796) kan in rood gezegeld papier niet langer worden gebruikt, tenzij voorzien van het nieuwe zwarte stempel. Dit is slechts mogelijk tot 1 brumaire $\mathrm{V}$ (22 okt 1796). Het opstellen van een akte - al dan niet onderhands - na 1 vendémiaire V (22 sep 1796) op slechts in rood gezegeld papier, wordt als een wetsovertreding beschouwd. Op de laatste aanvullende dag van het jaar IV wordt door de commissarissen van het Directoire exécutif bij de municipale besturen - of bij hun ontstentenis door de vrederechters - een inventaris opgemaakt van de hoeveelheden gezegeld papier. De bepalingen van wetten "sur le timbre", waaraan de onderhavige wet niet derogeert, blijven van kracht.

bo. Conseil des Cinq-cents s. Boissy (pres); Barailon, Bornes (secr); Conseil des Anciens s. Dusátulx (pres); Himbert, G. Desgraves, Durand-Maillane, Dupont (de Nemours) (secr)

ao. commission des finances du Conseil des Cing-cents

RO nr.179: 29 thermidor IV (16 aug 1796)

RE nr.178: $23 / 24$ fructidor IV (9/10 sep 1796)

* werwijzing naar: wetten van 12 dec $1790 * 11$ feb 1791; 11 mivôse IV (1 jan 1796); wetten "sur le timbre"

- $\mathrm{cB}$ vermeldt als datum van uitvaardiging 14 messidor IV (2 jul 1796)

- afkondiging: besluit Directoire exécutif s. L.M. Revellière-Lépeaux (pres); Lagarde (secr-gen); 19 thermidor IV (6 aug 1796) [BL Ile ser no.64 (589)]

\section{IV thermidor 14 (1796 aug 1$)$}

BL Ile ser no.62 (576); LA III fol 224ro-227vo; rH IX 83-88; P VII 354-356; cB IVe ser V 153-157

\section{LOI CONTENANT UNE NOUVELLE FIXATION DES DROITS D'ENREGISTREMENT}

Het feit dat de in omloop zijnde assignaten vervangen zijn door de mandats territoriaux noodzaakt tot wijziging van de tarieven van de registratierechten. De hoogte van deze rechten zal, behoudens enkele wijzigingen, weer worden vastgesteld op voet van het tarief behorende bij de wet van $5 * 19$ dec 1790 . De registratierechten hebben hoofdzakelijk betrekking op: akten van eigendomsoverdracht;, vestiging, afstand of overschrijving van (lijf)renten in het grootboek; schenkingen en mutaties bij overlijden; (ver)koop van nationale goederen enzovoorts. De registratierechten kunnen 
worden betald in de nominale waarde van de mandats, in mandaten met de tegenwaarde van tien ponden koren voor iedere franc zoals bij de grondbelasting, dan wel in muntgeld, naar wens der partijen. De wet van 9 pluviôse IV (29 jan 1796) ter zake van de inning der registratierechten is herroepen; de bepalingen van wetten inzake de enregistrement, welke niet zijn herroepen, blijven van kracht.

bo. Conseil des Cing-cents s. Boissy (pres); Barailon, Emm. Pastoret, Bornes (secr); Conseil des Anciens: s. Dusaulx (pres); Himbert, G. Desgraves, Durand-Maillane, Dupont (de Nemours (secr)

ao. commission des finances du Consell des Cinq-cents

RO nur.179: 29 thermidor IV (16 aug 1796)

RE nr. 178: $23 / 24$ fructidor IV (9/10 sep 1796$)$

- verwijzing naar: wetten wan $5 * 19$ dec $1790 ; 8$ jan $1793 ; 9$ pluviôse IV (29 jan 1796) [zie RO nr: 1111$]$

- "la présente aura son exécution, à compter du jour de sa publication"

- afkondiging: besluit Direcroire exếcutif s. L.M. Revellière-Lépeaux (pres); Lagarde (secr-gen); 19 thermidor IV (6 aug 1796) [BL Ile ser no.64 (589)]

\section{IV thermidor 16 (1796 aug 3)}

BL Ile ser no.63 (581); LA IV fol 27vo-28ro; rH IX 129-130; P VII 357; cB lVe ser V 163-164; F I $289-290$

LOI RELATIVE À LA PRESTATION DE SERMENT DES EMPLOYÉS DE LA RÉGIE DE L'ENREGISTREMENT, DES GARDES FORESTIERS, DES EXPER'TS, ETC

In verband met het feit dat de districtsrechtbanken zijn opgeheven, kunnen de ambtenaren van de régie der registratie, boswachters, deskundigen en anderen de voor de uitoefening van hun functie vereiste eed niet meer afleggen. Wanneer men resideert buiten de gemeente alwaar de departementale burgerlijke rechtbank zetelt, mag men de eed ook afleggen ten overstaan van de vrederechter. Een uittreksel van de akte van eedsaflegging dient terstond aan de departementale burgerlijke rechtbank te worden gezonden.

bo. Conseil des Cinquatents s. Boissy (pres); Ruelle, Bornes, Barailon, Emm. Pastoret (secr); Conseil des Anciens s. Dusaulx (pres): G. Desgraves, Himbert, Dupont (de Nemours) (secr)

RO nr. 195(4): 21 fructidor IV (7 sep 1796)

RE nr.165: 26/27 thermidor IV (13/14 aug 1796) [!]

- afkondiging: besluit Direcroire exócutif s. L.M. Revellière-Lépeaux, Lagarde (secr-gen); 6 fructidor IV (23 aug 1796)

\section{IV thermidor 19 (1796 aug 6)}

BL Ile ser no.66 (598); LA IV 228ro-232vo; rH IX 95-102; P VII 358-360; cB IVe ser V 173-181

\section{LOI CONCERNANT L'EXPORTATION DES MARCHANDISES}

De wet beoogt de uitvoer en de afzet van landbouw- en nijverheidsproducten zo weinig mogelijk te belemmeren. Voor de départements réunis dient tevens de afzet van producten te worden bevorderd, die niet met Franse producten kunnen concurre- 
ren. Er worden drie categorieën producten onderscheiden: die welke voorheen niet mochten worden uitgevoerd, maar thans wel, onder betaling van de uitvoerrechten; die welke aan het uitvoerverbod onderworpen blijven; en die welke uit het buitenland geimporteerd worden, met name gezaagd hout dat via de departementen van de Leie, de Schelde en de Twee-Neten aangevoerd wordt. De uitvoerrechten dienen in muntgeld of de tegenwaarde ervan te worden voldaan.

bo. Consell des Cinq-cents s. Boissy (pres); Barailon, Emm. Pastoret, Ruelle (secr); Conseil des Anciens s. Dusaulx (pres); Himbert, Durand-Maillane (secr)

RO nr. 192: 16 fructidor IV (2 sep 1796)

RE nr.183: $2 / 3$ jour complémentaire (18/19 sep 1796)

- verwijzing naar: tarief voor uitvoerrechten van $2 * 15$ mrt $179 \rrbracket$ wetten van 28 jul * $\|$ aug $1792 ; 12$ pluviôse III ( 31 jan 1795)

- afkondiging: besluit Directoire exécutif s. L.M. Revellière-Lépeaux (pres), Lagarde (secr-gen); 2 fructidor IV (19 aug 1796)

\section{IV thermidor 19 (1796 aug 6)}

BL Ile ser no.65 (594); LA IV fol 27ro; rH IX 128; P VII 358

\section{ARRÊTÉ ADDITIONNEL À CELUI DU 16 PRAIRIAL, CONCERNANT LES FRANÇAIS VOYA- GEANT DANS LES PAYS NEUTRES}

Fransen die reizen in neutrale landen en die willen worden ingeschreven in een register, die om een attestatie de vita verzoeken, of die de autoriteit inroepen van de consuls van de Republiek zijn gehouden - naast het overleggen van de verklaringen en papieren genoemd in het besluit van 16 prairial IV ( 4 jun 1796) - tevens een attestatie van hun departement te overleggen met de bevestiging dat zij niet aan enigerlei vordering zijn onderworpen.

\section{bo. Dinectoire exëcutif}

s. L.M. Revellière-Lépeaux (pres); Lagarde (secr-gen)

RO nr. 195(3): 21 fructidor IV (7 sep 1796)

RE nr.191: $15 / 16$ vendémiaire V (6/7 okt 1796)

- verwijzing naar: besluit wan 16 prairial IV (4 jun 1796)

- RO vermeldt abusievelijk als datum van uitvaardiging 9 thermidor IV (27 jul 1796)

" afkondiging: besluit Directoire exéc,utif s. L.M. Revellière-Lépeaux (pres), Lagarde (secr-gen); 6 fructidor IV (23 aug 1796)

\section{IV thermidor 19 (1796 aug 6)}

BL Ile ser no.64 (588); LA IV fol 28; rH IX 130-131; P VII 358; cB IVe ser V 171

LOI PORTANT QUE LES DÉCISIONS ET JUGEMENS DE LA HAUTE-COUR DE JUSTICE, NE SONT PAS SOUMIS AU RECOURS DEVANT LE TRIBUNAL DE CASSATION

Op de beslissingen en vonnissen van het in te stellen hooggerechtshof staat geen beroep open bij het tribunal de cassation. 
bo. Conweil des Cinq-cents s. Boissy (pres); Barailon, Bomes (sect); Conseil des Anciens s. Dusaull (pres); Himbert, G. Desgraves, Dupont (de Nemours), Durand-Maillane (secr)

RO nr.195(5): 21: fructidor IV (7 sep 1796)

- alkondiging: besluit Directoire exécutif \$. L.M. Revellière-Lépeaux (pres), Lagarde (secr-gen); 6 fructidor IV (23 aug 1796); Code Merrin vermeldt als datum van het afkondigingsbesluit 9 vendémi-

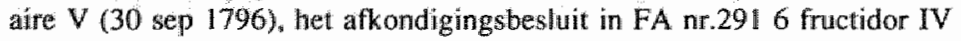

\section{IV thermidor 20 (1796 aug 7 )}

BL. Ile ser no:64 (591); LA IV fol 28vo-29vo; rH IX 132-133; P VII 361; cB IVe ser V 188-189; F I 290-291:

LOI QUI DÉTERMINE LA MANIËRE DONT SERONT REÇUES LES DEPOSITIONS DES MEMBRES DU CORPS LEGISLATIF, DU DIRECTOIRE EXÉCUTIF, ETC. CITÉS EN TEMOIGNAGE DEVANT DES TRIBUNAUX AUTRES QUE CEUX SÉANT DANS LA COMMUNE OÜ ILS EXERCENT LEURS FONCTIONS

Leden van het Wetgevend Lichaam, het Directoire exécutif, ministers, zaakgelastigden in het buitenland worden in een burgerlijke of criminele rechtszaak als getuige gedagvaard door de rechter in de plaats waar zij hun functie uitoefenen, ten verzoeke van een rechtbank elders. Daartoe zendt de president van de criminele rechtbank, de burgerlijke rechter, de directeur van de jury of de opsporingsambtenaar (officier de police) een overzicht van de feiten, de vorderingen en vragen aan de rechter die de functionarissen als getuige dient te dagvaarden. De gedaagden dienen hun verklaringen schriftelijk te overleggen, welke aan het requirerende gerecht zullen worden toegezonden en bekendgemaakt aan de partijen, dan wel aan de openbare aanklager en de beschuldigde.

bo. Conseil des Cinq-cents s. Boissy (pres); Ruelle, Emm. Pastoret, Barailon, Bornes (secr); Conseil des Anciens s. Dusaulx; (pres); G. Desgraves, Himbert, Durand-Maillane, Dupont (de Nemours) (secr) RO nr.195(6): 21 fructidor IV (7 sep 1796)

- verwijzing naar; code des delits et des peines van 3 brumaire IV (25 okt 1795)

- afkondiging: besiuit Directoire exécutif s. L.M. Revellière-Lépeaux (pres), Lagarde (secr-gen); 6 fructidor IV (23 aug 1796)

\section{IV thermidor 20 (1796 aug 7 )}

BL Ile ser no.65 (595); LA IV fol 29vo-34ro; rH IX 134-140; P VII 361-363; cB IVe ser V 182-188

\section{LOI SUR L'ORGANISATION DE LA HAUTE-COUR DE JUSTICE}

Het hooggerechtshof (haute-cour de justice) wordt gevormd door zestien hooggezworenen (haut-jurés), benevens vier toegevoegde gezworenen en vier gezworenen-plaatsvervanger. Juryleden kunnen zich, onder het aanvoeren van wettige redenen, laten excuseren om zitting te nemen in de jury, zodra het Wetgevend Lichaam de vorming van het hooggerechtshof heeft geproclameerd. De proclamatie van het Wetgevend Lichaam wordt overgebracht naar het tribunal de cassation voor de bijeenroeping van het hooggerechtshof, overeenkomstig de artt.269 en 270 van de grondwet. De procla- 
matie wordt tevens aan de departementale besturen gezonden, welke deze laten bekendmaken en aanplakken. De voorzitter en de secretarissen van de Conseil des Cinqcents zenden de akte van beschuldiging en de stukken aan het hooggerechtshof. De beschuldigde kan dertig maal de gezworenen wraken, maar de eenendertigste maal wordt de wrakingsgrond door de rechters van het hof beoordeeld. De nationale aanklagers kunnen uitsluitend gemotiveerd wraken; de aangevoerde gronden worden eveneens door het hooggerechtshof beoordeeld. De rechters van het hooggerechtshof roepen de geformeerde haut-jury in een aangewezen departement bijeen. Beschuldigden hebben het recht getuigen te laten horen. Bij het hooggerechtshof functioneren geen commissarissen van het Directoire exécutif, hun functie wordt door de nationale aanklagers vervuld. De mening van vier hooggezworenen ten gunste van de beschuldigde is voldoende, tenzij de rechters van oordeel zijn dat de jury zich ten gronde vergist. De jury dient dan een nieuwe uitspraak te doen met viervijfde van de stemmen. Het hooggerechtshof bewaakt de procesorde. De openbare aanklagers bij de criminele rechtbanken dienen alle stukken te verzamelen. Nadat het hooggerechtshof vonnis heeft gewezen, wordt het hof ontbonden. Nadien gearresteerden tegen wie verstek uitgesproken was (accusés contumax), anderen dan volksvertegenwoordigers of leden van het Directoire exécutif, worden door de criminele rechtbanken in de departementen berecht.

bo. Conseil des Cinq-cents s. Boissy (pres); Ruelle, Emm. Pastoret, Bones, Barailon (secr); Conseil des Anciens s. Dusaulx (pres); Himbert, G. Desgraves, Durand-Maillane, Dupont (de Nemours) (secr) ao. commissie uit de Conseil des Cinq-cents

- RO nr.195(7): 21 fructidor IV (7 sep 1796)

- verwijzing naar: "lois sur les jurés"; "lois sur la composition du jury de jugement"; grondwet van 5 fructidor III (22 aug 1795); code des délits et des peines van 3 brumaire IV (25 okt 1795)

- afkondiging: besluit Directoire exécutif s. L.M. Revellière-Lépeaux (pres), Lagarde (secr-gen); 6 fructidor IV (23 aug 1796)

\section{IV thermidor 21 (1796 aug 8)}

BL Ile ser no.66 (599); LA V 65vo-66ro; rH X 367; P VII 363; MAP I 277-278

\section{ARRETE QUI AUTORISE LE TRANSIT PAR BULGEMBACH, BOURG-FELDEN ET BOURG- LIBRE, DES RUBANS DE FIL ET LAINE, ET DES ETOFFES DE FIL ET COTON, DU DUCHE DE BERG, EXPÉDIÉ POUR LA SUISSE}

De bepalingen van de besluiten aangaande de doorvoer via Venlo en Meijel zijn eveneens van toepassing op band, wollen garens en katoenen stoffen, die van het hertogdom Berg naar Zwitserland worden vervoerd. De vrachten dienen van een certificaat van herkomst, ondertekend door de voorzitter van de handelskamer (corps de commerce) van de stad Elberfeld, te zijn voorzien. De partijen moeten met het kwijtingsbewijs tot zekerheidstelling via het douanekantoor van Bulgembach [vermoedelijk Bütgenbach, departement Ourthe] worden ingevoerd, en uitgevoerd via de kantoren van Bourg-Felden [Burgfelden, departement Haut-Rhin] of Bourg-Libre [Saint-Louis/Sankt Ludwig, departement Haut-Rhin; nabij Basel] 
bo. Directoire exécutif

ao. minister van financièn

8. L.M. Revellière-Lépeaux (pres); Lagarde (secr-gen)

RO nr.181: 2 fructidor IV (19 aug 1796)

- verwijzing naar: besluiten van 9 prairial IV ( 28 mei 1796); 9 messidor IV ( 27 jun 1796)

- besluit uitgevaardigd n.a.v. her verzoek van de handelskamer te Elberfeld van het aan de overzijde van de Rijn gelegen hertogdom Berg

\section{IV thermidor 23 (1796 aug 10)}

BL Ile ser no.66 (601); LA IV fol 34ro-35ro; rH IX 141-142; P VII 364-365; cB IVe ser V 195-196

\section{LOI RELATIVE À LA RÉtPRESSION DES DÉLITS RURAUX ET FORESTIERS}

Het ontbreken van de nieuwe organisatie inzake de gendarmerie nationale ontneemt de veld- en bospolitie een belangrijk middel van toezicht, dit ten detrimente van de te velde staande gewassen. Derhalve zijn de proces-verbalen van de veld- en boswachters niet onderworpen aan de formaliteit van registratie. Zij hoeven alleen de echtheid ervan ten overstaan van de vrederechter of één van diens assessoren te bevestigen. Er kan geen hogere straf voor een veld- of bosdelict worden opgelegd dan een boete ter hoogte van het loon van drie werkdagen, dan wel drie dagen hechtenis.

bo. Conseil des Cinq-cents s. Boissy (pres); Ruelle, Barailon (secr); Conseil des Anciens s. Dusaulx (pres); Himbert, G. Desgraves, Durand-Maillane, Dupont (de Nemours (secr)

ao. commissie uit de Conseil des Cing-cents

RO nr. 195(8): 21 fructidor IV (7 sep 1796)

RE nr. 198: 11/12 brumaire $V(1 / 2$ nov 1796)

- verwijzing naar: "lois relatives à la police rurale et forestière", code des délits et des peines van 3 brumaire IV ( 25 okt 1795)

- afkondiging: besluit Direcroire exécutif s. L.M. Revellière-Lépeaux (pres), Lagarde (secr-gen); 6 fructidor IV (23 aug 1796)

\section{IV thermidor 24 (1796 aug 11)}

BL Ile ser no.66 (602); LA IV fol 1; rH IX 108-109; P VII 365

\section{ARRÊTÉ QUI RECTIFIE CELUI DU 12 MESSIDOR DERNIER, CONCERNANT LE MODE DE JUGEMENT DES ACTIONS RELATIVES A LA PERCEPTION DES IMPÔTS INDIRECTS DANS LES DÉPARTEMENS RÉUNIS PAR LA LOI DU 9 VENDÉMIAIRE, AN IV}

Teneinde enkele onduidelijkheden in de redactie van het besluit van 12 messidor IV (30 jun 1796) betreffende de wijze van beoordeling van rechtsvorderingen ter zake van de heffing der indirecte belastingen weg te nemen, wordt zowel de tweede considerans als art. 3 van het besluit van 12 messidor opnieuw geredigeerd.

bo. Directoine exécutif

ao. minister van justitie

s. L.M. Revellière-Lépeaux (pres); Lagarde (secr-gen)

RO nr. 182: 2 fructidor IV (19 aug 1796) 
- verwijzing naar: wetten val $16 * 24$ aug $1790 ; 7 * 11$ sep 1790 , grondwet van 5 fructidor fil (22 aug 1795); besluit volksrepresentanten/gouvernementscommissarissen van 2 frimaire IV ( 23 nov 1795); besluit Directoire exếcutif van 12 messidor IV (30 jun 1796) [zie RO nr.166]

\section{IV thermidor 24 (1796 aug 11)}

BL IIe ser no.68 (612); LA IV fol 5vo-6ro; rH IX 113-114; P VII 365; cB IVe ser V 200-201

LOI QUI PROROGE JUSQU'AU PREMIER BRUMAIRE PROCHAIN, LE TERME DU PREMIER FRUCTIDOR, INDIQUÉ PAR LA LOI DU 19 PRAIRIAL DERNIER, RELATIVE AU CODE HYPOTHÉCAIRE

De datum van het in werking treden van de code hypothécaire is verschoven van 1 fructidor IV (18 aug 1796) naar 1 brumaire V (22 okt 1796). Tot die datum blijft de wet van 19 prairial IV (7 jun 1796) van kracht.

bo. Conseil des Cinq-cents s. Boissy (pres); Ruelle, Barailon, Bomes (secr); Conseil des Anciens s. Dusaulx (pres); Himbert, Dupont (de Nemours) (secr)

RO nr.207(6): 2 vendémiaire V (23 sep 1796)

RE nr. I79: 30 fructidor/1 jour complémentaire IV (16/17 sep 1796) [!]

- verwijzing naar: code hypothécaire van 9 messidor III (27 jan 1795); wet van 19 prairial IV (7 jun 1796)

- RO en afkondigingsbesluit vermelden abusievelijk als datum van uitvaardiging 28 thermidor IV (15 aug 1796)

- cB-intitulé: "loi qui proroge لle terme pour la mise en activité du rếgime hypothécaire"

- afkondiging: besluit Direcroire exécutif s. L.M. Revellière-Lépeaux (pres), Lagarde (secr-gen); 23 fructidor IV (9 sep 1796)

\section{IV thermidor 26 (1796 aug 13)}

LA. IV fol 2ro; FA nr.253 fol 58 vo-59ro

ARRETÉ PORTANT QU'IL N'Y A PAS LIEU DE CONFIRMER LA NOMINATION PROVISOIRE DU CITOYEN ROGIER A LA PLACE DE COMMISSAIRE DU DIRECTOIRE EXECUTIF PRES L'ADMINISTRATION CENTRALE DU DÉPARTEMENT DE LA MEUSEINFERIEURE

De voorlopige benoeming van Rogier tot commissaris van het Directoire exécutif bij het bestuur van het departement van de Nedermaas door de volksrepresentanten/gouvernementscommissarissen wordt niet bekrachtigd; mitsdien blijft deze benoeming zonder gevolg en wordt zij geacht niet te zijn gedaan. De gouvernementscommissaris in de départements réunis Bouteville dient te voorzien in de voorlopige vervanging van Rogier.

bo. Directoire exécurif

s. L.M. Revellière-lLếpeaux (pres); Lagarde (secr-gen)

ti. gouvernementscommissaris Bouteville

RO nr. 183: 4 fructidor IV (21 aug 1796); N.B.: in indicateur génêral ingeschreven onder de daum van 5 fructidor IV (22 aug 1796) 
ARRÊTÉ PORTANT QU'LL N'Y A PAS LIEU DE CONFIRMER LA NOMINATION PROVISOIRE DU CITOYEN PICQUERY À LA PLACE D'ADMINISTRATEUR DU DÉPARTEMENT DE LA MEUSE-INFERIEURE

De voorlopige benoeming van Picquery tot administrateur van het departement van de Nedermaas door de volksrepresentanten/gouvernementscommissarissen wordt niet bekrachtigd; mitsdien blijft deze benoeming zonder gevolg en wordt zij geacht niet te zijn gedaan. Overeenkomstig art. 188 van de acte constitutionnel dient onverwijld in zijn vervanging te worden voorzien.

bo. Directoire exécutif

s. L.M. Revellière-Lépeaux (pres); Lagarde (secr-gen)

ti. gouvernementscommissaris Bouteville

RO nr. 184: 4 fructidor IV (2I aug 1796); N.B.: in indicateur général ingeschreven onder de datum van 5 fructidor IV (22 aug 1796)

- verwijzing naar: grondwet van 5 fructidor III (22 aug 1795)

\section{IV thermidor 26 (1796 aug 13)}

LA IV fol 3vo-4vo; FA nr.870

ARRÊTÉ PORTANT QU'IL N'Y A PAS LIEU DE CONFIRMER LA NOMINATION PROVISOIRE DU CITOYEN SERMOISE COMMISSAIRE DU DIRECTOIRE EXÉCUTIF PRES LA MUNICIPALITÉ DU CANTON DE TONGRES

De voorlopige benoeming van Sermoise tot commissaris van het Directoire exécutif bij de municipaliteit van het kanton Tongeren wordt niet bekrachtigd; mitsdien blijft deze benoeming zonder gevolg en wordt zij geacht niet te zijn gedaan. De gouvernementscommissaris in de départements rếunis is belast met te voorzien in de voorlopige vervanging van Sermoise.

bo. Directoire exécutif

s. L.M. Revellière-Lépeaux (pres); Lagarde (secr-gen)

RO nr. 185: 6 fructidor IV (23 aug 1796)

- RO vermeldt abusievelijk als datum van uitvaardiging 26 fructidor IV (12 sep 1796)

\section{IV thermidor 27 (1796 aug 14)}

BL lle ser no.68 (616): LA IV 6ro-8ro; rH IX 120-124; P VII 378-370; MAP I 291-293

ARRÊTÉ QUI RAPPORT CELUI DU 28 FLORÉAL, AN IV, CONCERNANT LES INSTANCES EN MATIÈRE DE DOUANES DANS LES NEUF DÉPARTEMENS RÉUNIS

De uitvoering van het besluit van het Directoire exécutif van 28 floréal IV (17 mei 1796) ontregelt het douanestelsel en geeft aanleiding tot fraude en brengt de onder- 
gang van de handel en van fabrieken met zich mee. Mitsdien wordt dit besluit aangaande de rechtsgedingen in douanekwesties in de départements réumis herroepen. Het besluit van 23 germinal IV (12 apr 1796), dat de uitvoering van de wetten van 4 germinal II (24 mrt 1794) en 14 fructidor III (31 aug 1795) gelast, blijft uitgevoerd worden naar zijn vorm en inhoud.

\section{bo. Directoine exécutif}

ao. minister van justitie

s. L.M. Revellière-Lépeaux (pres); Lagarde (secr-gen)

RO nr.189: 8 fructidor IV (25 aug 1796)

- verwijzing nar: ordonnance des eaux ef forêts van 1669; wetten van 19 jul $1791 ; 28$ sep $1791 ; 4$ germinal II (24 mrt 1796); 20 messidor III (8 jul 1795); grondwet van 5 fructidor III (22 aug 1795); wet van 14 fructidor III (31 aug 1795); code des delits et des peines van 3 brumaire IV (25 okt 1795); besluiten van 28 floréal IV (17 mei 1796); 23 germinal IV (12 apr 1796); "lois qui ont pour objet le maintien de l'ordre social et de la tranquillité publique"; "lois sur I"enregistrement le timbre et toutes les contributions directes et indirectes"; "lois concernant la police municipale, correctionnelle, rurale et forestière"

- [zie RO nr.127, nr.127(1), nr. 127(2), nr. 146]

\section{IV thermidor 28 (1796 aug 15)}

BL Ile ser no.80 (738); LA V fol 17vo-21 vo; rH X 345-351; P VII 370-371; cB IVe ser V 225-230

\section{LOI CONTENANT RATIFICATION DU TRAITÉ DE PAIX CONCLU LE 20 THERMIDOR, AN IV, ENTRE LA RÉPUBLIQUE FRANÇAISE ET LE DUC DE WÜTEMBERG ET TECK}

De wet behelst de ratificatie van het vredes- en vriendschapsverdrag dat op 20 thermidor IV (7 aug 1796) tussen de Franse Republiek en Frédéric Eugène, hertog van Württemberg en Teck, is gesloten. De hertog van Württemberg verplicht zich zijn daadwerkelijke en morele steun aan de coalitielegers in te trekken en voortaan af te zien van welke steun ook, zelfs als dit van hem als lid van het Duitse Rijk wordt verlangd, terwijl Franse troepen vrijelijk op het grondgebied van het hertogdom kunnen worden gelegerd, wanneer dat militair gezien noodzakelijk is. Hij doet tevens afstand van zijn bezittingen gelegen op de linker Rijnoever en de inkomsten daaruit. Württemberg zal uitgewekenen en gedeporteerde priesters niet toestaan op zijn grondgebied te verblijwen. Het verdrag voorziet in de afsluiting van een handelsverdrag met wederzijds voordeel. De beslagleggingen over en weer zullen worden opgeheven en de gevangenen worden uitgewisseld. Overeenkomstig art.6 van het Haagse Verdrag van 27 floréal III (16 mei 1795) is dit vredes- en vriendschapsverdrag verbindend verklaard voor de Bataafse Republiek.

bo. Conseil des Cinq-cents en comité gênéral s. Boissy (pres); Ruelle, Barailon, Bomes (secr); Conseil des Anciens s. Dusaulx (pres); Durand-Maillane, G. Desgraves, Dupont (de Nemours) (secr) ao. Directoine exécutif

RO nr.215(14): 7 brumaire V (28 okt 1796)

* verwijzing naar: grondwet van 5 fructidor III (22 aug 1795); besluit van 11 thermidor IV (29 jul 1796); Haags Verdrag van 27 floréal III (16 mei 1795)

- afkondiging: besluit Directoine exécutif s. L.M. Revellière-Lépeaux (pres), Lagarde (secr-gen); 24 vendẻmiaire $\mathrm{V}$ (15 okt 1796) 
BL Ile ser no.68 (617): LA IV fol 35 ; $\mathrm{rH}$ IX 142-143; cB IVe ser V 232-233

\section{LOI PORTANT QUE LA FONDATION DE LA RÉPUBLIQUE FRANÇAISE SERA FÊTÉE LE $1^{\text {ER }}$ VENDEMIAIRE, DANS TOUTES LES COMMUNES}

De vestiging van de Franse Republiek zal op 1 vendémiaire [V (22 sep 1796)] in alle gemeenten worden gevierd. Het Directoire exécutif is belast met het nemen van de noodzakelijke maatregelen, opdat deze grootse plechtigheid alle luister moge ontvangen.

bo. Conseil des Cing-cents \&. Boissy (pres); Barailon, Bornes (secr); Conseil des Anciens s. Dusaulx (pres); Dupont (de Nemours), Durand-Maillane, G. Desgraves (secr)

RO mr.195(9): 21 fructidor IV (7 sep 1796)

- verwijzing naar" loi sur l'organisation de l'instruction publique van 3 brumaire IV (25 okt 1795)

- afkondligíng: besluit Directoire exécutif s. L.M. Revellière-Lépeaux (pres), Lagarde (secr-gen); 6 fructidor IV (23 aug 1796); Code Merlin vermeldt als datum van het afkondigingsbesluit 9 vendemiaire $V(30$ sep 1796$)$

\section{IV thermidor 29 (1796 aug 16)}

BL Ile ser no.68 (618); LA IV foll 35vo-36vo; rH IX 144-145; P VII 371-372; cB IVe ser V 231-232

LOI QUI DETERMINE LE MODE SUIVANT LEQUEL AURA LIEU LE CAUTIONNEMENT PRESCRIT PAR L'ARTICLE 222 DE LA LOI DU 3 BRUMAIRE, AN IV, SUR LES DÉLITS ET DES PEINES

De wet behelst een nadere omschrijving van de hoogte van de borgstelling voor de onderscheidene vergrijpen, zoals voorgeschreven in art.222 van de code des délits et des peines. Vrijlating op borgtocht is alleen mogelijk als de strafmaat lager is dan die van lijfstraf. De directeur van de jury mag in geen enkel geval vagebonden en landlopers op borgtocht vrijlaten.

bo. Conseil des Cinq-cents s. Crassous (de l'Hérault) (pres); Duprat, Laplaingne (secr); Conseil des Anciens s. Dusaulx (pres); G. Desgraves, Dupont (de Nemours), Durand-Maillane (secr)

RO nr. 195(10): 21 fructidor IV (7 sep 1796)

- verwijzing naar: code des détits el des peines van 3 brumaire IV (25 okt 1795)

- RO vermeldt abusievelijk als datum van uitvaardiging 19 thermidor IV (6 aug 1796)

- afkondiging: besluit Disectoire exécutif s. L.M. Revellière-Lépeaux (pres), Lagarde (secr-gen); 6 fructidor IV (23 aug 1796); Code Merlin vermeldt als datum van het afkondingingsbesluit 9 vendémiaire $V(30 \operatorname{sep} 1796)$

\section{IV thermidor 30 (1796 aug 17)}

BL IIle ser no.68 (619); LA IV fol 44ro-45vo; rH IX 381-382; P VII 372; cB IVe ser V 234-235

[extract] LOI CONTENANT DES MESURES POUR TERMINER LA LIQUIDATION ET LE RECOUVREMENT DE L'EMPRUNT FORCÉ (artt.1, 2, 9, 10) 
De departementale besturen zullen binnen twee decades uitspratak doen over alle verzoeken om ontheffing en vermindering van de aanslag in de gedwongen geldlening. $\mathrm{Na}$ de bekendmaking van de onderhavige wet zullen er geen bezwaarschriften meer in behandeling worden genomen. Het beloop op de kohieren mag met niet meer dan een $k$ wart worden verminderd. Elke ontvanger die op 15 vendémiaire $V(6$ okt 1796) de invordering van vijfzesde der kohieren van zijn gemeente heeft geëffectueerd, krijgt een reductie van één procent op de opbrengst van de dwanglening. De departementsontvanger die op 1 brumaire V ( 22 okt 1796) de invordering van vijfzesde der kohieren van het departement heeft geëffectueerd, geniet een reductie van een half procent.

bo. Conseil des Cinq-cents s. Boissy (pres); Bornes, Barailon (secr); Conseil des Anciens s. Dusaulx (pres); Himbert, G. Desgraves, Durand-Maillane, Dupont (de Nemours) (secr)

ti. minister van financiën Ramel

RO nr.202: 26 fructidor IV (12 sep 1796); N.B.: in indicateur général ingeschreven onder de datum van 29 fructidor IV (15 sep 1796)

* verwijzing naar: wetten van 13 frimaire IV (4 dec 1795); 17 germinall IV (6 apr 1796), N.B. de laatste in de considerans

- afkondiging; bestuit Directoire exécutif s. L.M. Revellière-Lépeaux (pres), Lagarde (secr-gen); 19 fructidor IV (5 sep 1796) [BL. LLe ser no.74 (685)]

\section{IV thermidor 30 (1796 aug 17)}

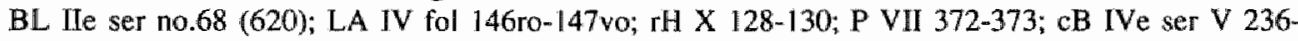
237

\section{LOI RELATIVE AU PARTAGE EN NATURE, DES BIENS INDIVIS AVEC DES EMIGRÉS}

Het bepaalde in art.96 van de wet van 1 floréal III (20 apr 1795) is niet van toepassing op degenen die met uitgewekenen goederen in ongedeelde eigendom hebben en die reeds voor de bekendmaking van bovengenoemde wet hun bewijsstukken ter zake aan de departementale of districtsbesturen hebben overgelegd, alwaar de nalatenschappen, waarop zij recht hebben, zijn opengevallen. Wanneer de rechthebbenden hun hoedanigheid voldoende hebben gestaafd en de eigendomstitels hebben overgelegd, kunnen zij de scheiding in natura van de nog niet verkochte goederen vorderen. De mede-eigenaren van deze ongedeelde goederen dienen zich binnen de termijn van één maand na de bekendmaking van de onderhavige wet met de eigendomstitels en de ligging der goederen bij de departementale besturen te melden.

bo. Conseil des Cinq-cents s. Boissy (pres); Ruelle, Barailon (secr); Comseil des Anciens s. Dusaulx (pres); Himbert. G. Desgraves, Durand-Maillane, Dupont (de Nemours) (secr)

ao. commissie uit de Conseil des Cinq-cents

RO nr.210(27): 23 vendémiaire V (14 okt 1796)

- verwijzing naar: wet van 1 floréal III (20 apr 1795); "loiss précédentes"

- wet uitgevaardigd n.a.v. een verzoekschrift van de burger Lasterye-Dusaillant en zijn echtgenote Elisabeth-Charlotte Riquetti-Mirabeau

- afkondiging: besluit Directoire exécutif s. L.M. Revellière-Lépeaux (pres), Lagarde (secr-gen); 10 fructidor IV (27 aug 1796) 


\section{ARRETÉ QUI RAPPORTE CELUI DU 24 FRIMAIRE, AN IV, PAR LEQUEL L'EXÉCUTION DE LA LOI DU 14 VENDEMIAIRE, AN III, A ÉTÉ ORDONNÉE DANS LES NEUF DÉPARTE- MENS RÉUNIS}

Het besluit van de volksrepresentanten/gouvernementscommissarissen van 24 frimaire IV (15 dec 1795) dat, naast de code des délits et des peines, bij vergissing tevens de wet van 14 vendémiaire III ( 5 okt 1794) inzake de te stellen vraag naar de opzet van de verdachte in de départements réunis afkondigt, wordt herroepen, voor zover het de wet van 14 vendémiaire III betreft.

bo. Directoine exécutif

ao. minister wan justitie

s. L.M. Revellière-Lépeaux (pres); Lagarde (secr-gen)

RO ni.191: 16 fructidor IV (2 sep 1796)

- verwijzing niaar: wet wan 14 vendémiaire III (5 okt 1794) [RO nr.89(30)]; code des délits er des peines van 3 brumaire IV (25 okt 1795); besluit volksrepresentanten van 24 frimaire IV (15 dec 1795)

\section{IV fructidor 2 (1796 aug 19)}

BL IIe ser no.69 (636): LA IV fol 61; rH IX 277-278; P VII 374; cB IVe ser V 239

\section{LOI CONCERNANT LA VISITE DES CAISSES DES PERCEPTEURS DES CONTRIBUTIONS}

Het Directoire exécutif dient alle noodzakelijke maatregelen te nemen, opdat de kassen van de ontvangers der belastingen minstens één keer per decade worden gecontroleerd. De afdracht aan de nationale schatkist dient op zo kort mogelijk termijn te geschieden.

bo. Conseil des Cinq-cents s. Emm. Pastoret (pres); Ozun, Bourdon, Peyre, Noaille (secr); Conseil des Anciens s. Muraire (pres); Fourcade, Ferroux, Pecheur, Johannot (secr)

RO nr.207(7): 2 vendémiaire $V(23$ sep 1796)

- alkondiging: besluit Directoire exécuiff s. L.M. Revellière-Lépeaux (pres), Lagarde (secr-gen); 23 fructidor IV (9 sep 1796)

\section{IV fructidor 2 (1796 aug 19)}

BL lle ser no.69 (638); LA IV fol 6I vo; rH IX 278; P VII 374; MAP I 303

\section{ARRETTÉ CONCERNANT LES PIECES DE BILLON DE LA VALEUR DE VINGT-QUATRE DENIERS}

Geldstukken van billon [koperen muntstukken met een geringe legering aan zilver] met een waarde van 24 deniers [1 denier $=1 / 12$ stuiver] mogen niet worden geweigerd, wanneer er sporen van de muntslag op één der beide zijden aanwezig zijn. 
bo. Directoire exécutif

ao. minister van financiën

s. L.M. Revellière-Lépeaux (pres); Lagarde (secr-gen)

RO nr.207(8): 2 vendémiaire V (23 sep 1796)

- afkondiging: besluit Directoire exécutif s. L.M. Revellière-Lépeaux (pres), Lagarde (secr-gen); 23 fructidor IV (9 sep 1796)

\title{
IV fructidor 4 (1796 aug 21)
}

LA IV fol 10vo-12vo; FA nr.291; rH IX 266-269; MAP I 315-317

ARRÊTE QUI DÉCLARE NULLES LA VENTE DU PARC DE DIEST ET AUTRES, FAITES, DANS LES NEUF DÉPARTEMENS RÉUNIS, SOUS PRÉTEXTE DE DÉFAUT DE PAIEMENT DE LA CONTRIBUTION MILITAIRE

De verkoop van het park te Diest [departement Dijle] aan Constantin-Joseph Vanden Nieuwenhuysen is nietig en van gener waarde en wordt geacht niet te zijn gedaan. Alle overige verkopingen in de negen Verenigde Departementen van onroerende goederen die toebehoren aan de prins van Oranje of aan een andere vorst die met de Franse Republiek in oorlog is, en door het recht van de veroveraar vervallen zijn aan de Franse staat, zijn eveneens nietig en van gener waarde. De Franse natie dient terstond in het bezit van de goederen te worden hersteld. Aan de verkrijgers of hun rechtsopvolgers wordt de koopprijs van die goederen terugbetaald, zoals elders aan verkrijgers van nationale domeingoederen geschiedt, indien de koop ongedaan wordt gemaakt vanwege vormfouten of om andere wettelijke redenen.

bo. Directoire exécutif

s. L.M. Revellière-Lépeaux (pres); Lagarde (secr-gen)

RO nr.193: 18. fructidor IV (4 sep 1796)

- verwijzing naar: Haags Verdrag van 27 floréal III (16 mei 1795); diverse decreten van de Convention nationale inzake "le séquestre et la confiscation des biens appartenant aux princes armés contre la République"; besluit volksrepresentanten bij het Noorder- en het Sambre-en-Maasleger van 9 frimaire III (29 nov 1794)

- besluit uitgevaardigd na.v. het verzoekschrift van Constantin-Joseph Vanden Nieuwenhuysen te Mechelem (departement Twee Neten), verkrijger van het park te Diest

\section{IV fructidor 4 (1796 aug 21)}

BL Ille ser no.71 (648); LA IV fol 37ro-41ro; rH IX 163-170; MAP I 310-314

\begin{abstract}
ARRÊTÉ CONCERNANT L'APPLICATION À FAIRE DES LOIS SUR LES ÉMIGRES, AUX HABITANS DES DÉPARTEMENS RÉUNIS QUI ONT PASSÉ EN PAYS ÉTRANGER PENDANT LE COURS DE L'AN II, ET NE SONT PAS RENTRES DANS LES TROIS MOIS DE LA PUBLICATION DE LA LOI DE VENDÉMIAIRE, AN IV
\end{abstract}

De memorie van I messidor IV (19 jun 1796) door gevolmachtigden van verwanten van verscheidene afwezigen voorgelegd, met het oogmerk de inwoners van de negen Verenigde Departementen te onttrekken aan de werking van de wetten inzake naar het 
buitenland uitgewekenen gedurende het jaar $\mathrm{II}$, en die niet binnen drie maanden na de bekendmaking van de wet van 9 vendémiaire IV (1 okt 1795) zijn teruggekeerd, vormt geen onderwerp van beraadslaging. Voorts is gedeeltelijk de preambule van het arrêté van 4 floréal IV (23 apr 1796) herroepen. Binnen één maand dient de minister van police générale een overzicht van de staat van werkzaamheden van de bestuurslichamen in de Verenigde Departementen inzake de uitgewekenen aan het Directoire exécutif te overleggen.

\section{bo. Directoire exécutif}

s. L.M. Rewelliêre-Lépeaux (pres); Lagarde (secr-gen)

RO nr. 197: 22 fructidor IV ( 8 sep 1796)

RE nr.195: 7/8 brumaire V (28/29 okt 1796)

- verwijzing naar: wetten van 25 brumaire III (15 nov 1794); 22 nivôse III (11 jan 1795); 22 germimal III (11 apr 1795); 12 floréal III (1 mei 1795); 26 floréal III (15 mei 1795); 22 prairial III (10 jun 1795); I fructidor III (18 aug 1795); 20 fructidor III (6 sep 1795); 4 jour complémentaire III (20 sep 1795); 20 vendémiaire IV (12 okt 1795); besluiten voiksrepresentanten bij het Noorder- en het Sambre-en-Maasleger van 27 thermidor II (14 aug 1794); 8 frimaire III (28 nov 1794); 9 frimaire III (29 nov 1794); 8 germinal III (28 mrt 1795); 9 germinal III (29 mrt 1795); 8 brumaire IV (30 okt 1795); 11 brumaire IV (2 nov 1795); 5 frimaire IV (26 nov 1795); 25 frimaire IV (16 dec 1795); besluit comité de salut public van 20 frimaire III (10 dec 1794); besluit Directoire exécutif van 4 floréal IV (23 apr 1796)

- besluit uitgevaardigd n.a.v. de aan het Directoire exécututif overhandigde memorie van Willens en Dotrenge, gevolmachtigden van verwanten van verscheidene afwezigen, woonachtig in de gemeente Brussel (departement Dijle)

\section{IV fructidor 4 (1796 aug 21)}

BL Ile ser no.69 (640); LA IV fol 62ro-64ro; rH IX 279-282; P VII 374-375; cB IVe ser V 245-247

\section{LOI CONCERNANT LES dÉfENSEURS DE LA PATRIE INSCRITS SUR LA LISTE DES ÉMIGRES}

Degenen die van hun rechten vervallen verklaard zijn ten gevolge van de inschrijving op de lijst van uitgewekenen, terwijl zij actief waren ter verdediging van het vaderland, worden in hun rechten hersteld, wanneer zij kunnen aantonen dat zij onder de wapenen waren, dan wel zich van of naar hun legeronderdeel begaven. Eveneens worden in hun rechten hersteld zij die zijn gesneuveld of in handen van de vijand zijn gevallen, op voorwaarde dat de verwanten kunnen aantonen dat zij ten tijde van de inschrijving op de lijst van uitgewekenen in actieve dienst waren. Deze verklaringen dienen binnen twee maanden te worden overgelegd na de bekendmaking van de onderhavige wet. In sommige gevallen volstaat de attestatie van zes burgers, die gelijktijdig in actieve dienst waren. Voorlopig zijn de verkopingen van goederen van de landsverdedigers ingeschreven op de lijst van uitgewekenen opgeschort, wier verwanten binnen twintig dagen na de bekendmaking van de onderhavige wet de noodzakelijke bewijsstukken overleggen. Bij ontstentenis van familieleden kunnen municipale ambtenaren of vrederechters ambtshalve om deze opschorting verzoeken.

bo. Conseil des Cinq-cents s. Boissy (pres); Ruelle, Baraillon, Emm. Pastoret (secr); Conseil des Anciens s. Muraire (pres); Pecheur, Ferroux, Johannot, Fourcade (secr) 
an. commissie uit de Conseil des Cinq-cents

RO nr.207(9): 2 wendémiaire V (23 sep 1796)

- afkondiging: besluit Direcroire exécutif s. L.M. Revellière-Lepeaux (pres), Lagarde (seor-gen); 23 fructidor IV (9 sep 1796)

\title{
IV fructidor 6 (1796 aug 23$)$
}

LA IV fol 2vo-3ro; FA nr.253 fol 67, FA nr.870

\begin{abstract}
ARRÊTÉ PORTANT NOMINATION DU CITOYEN GIRARD À LA PLACE DE COMMISSAIRE DU DIRECTOIRE EXÉCUTIF PRÈS L'ADMINISTRATION CENTRALE DU DEPARTEMENT DE LA MEUSE-INFERIEURE EN REMPLACEMENT DU CITOYEN ROGIER
\end{abstract}

Ter vervanging van Rogier wordt de administrateur van het departement van de Nedermaas Girard benoemd tot commissaris van de uitvoerende macht in het departement.

bo. gouvernementscommissaris Bouteville

RO nr. 186: 7 fructidor IV (24 aug 1796); N.B.: in indicateur gênếral ingeschreven onder de datum wan 6 fructidor IV (23 aug 1796)

- verwijzing naar: beslluit Directoire exécutif van 26 thermidor IV (13 aug 1796)

- RO vermeldt abusievelijk als datum van uitvaardiging 7 fructidor IV (24 aug 1796)

IV fructidor 6 (1796 aug 23)

BL Ile ser no.70 (642); LA IV 13ro-22ro; rH IX 148-162; P VII 376-382; cB IVe ser V 252-267

\section{LOI PORTANT ÉTABLISSEMENT d'UN DROIT DE PATENTE POUR L'AN V}

Teneinde niet alleen de landbouw te belasten, wordt het patentrecht met ingang van het jaar $\mathrm{V}$ geheven op het uitoefenen van de handel, een bedrijf of een beroep. Het patent wordt afgegeven door het bestuur van de kantonsmunicipaliteit, onder overlegging van de verklaring van het bureau van de registratie dat het patentrecht voldaan is. De patenten staan op naam; elke vennoot dient zich afzonderlijk van een patent te voorzien. Een ieder die is voorzien van een patent kan overal in Frankrijk zijn beroep of bedrijf uitoefenen, enkel door overlegging van zijn patent aan de kantonsinunicipaliteit. Degenen die zonder verkregen patent een beroep of bedrijf uitoefenen, worden, ten verzoeke van de commissaris van het Directoire exécutif bij de kantonsmunicipaliteit, vervolgd voor de vrederechter. Zonder verkregen patent kan men niet in rechte handelen ter zake van zijn beroep of bedrijf. Vrijgesteld van het patentrecht zijn: publieke functionarissen en werknemers door de staat bezoldigd; arbeiders en bewerkers wan de grond voor wat betreft de verkoop van hun oogstopbrengst en van hun vee; bedienden en dagloners die voor anderen werken; voor het jaar $\mathrm{V}$ alleen fabrikanten die niet en détail verkopen en reders ter kaapvaart. Het patentrecht kan zowel in munt- als papiergeld worden voldaan. Bij de wet is een lijst gevoegd, houdende de tarieven voor de onderscheidene categorieën van beroepsuitoefeningen. 
bo. Consell des Cunquents s. Emm. Pastoret (pres); Ozun., Bourdon, Peyre, Noaille (secr); Conseill des Anciens \&. Muraire (pres); Fourcade Johannot, Ferroux. Pecheur (secr)

RO nr. 194: 18 fructidor IV (4 sep 1796)

RE nr. 182: $2 / 3$ jour complémentaire IV (18/19 sep 1796)

- afkondiging: besluit Directoire exécutif \$. L.M. Revellière-Lépeaux (pres), Lagarde (secr-gen); 8 fructidor IV (25 aug 1796) [BL Ile ser no.70 (643)]

\section{IV fructidor 7 (1796 aug 24)}

LA IV fol 3; FA mr.253 fol 67vo, FA nr.870

ARRETE QUI NOMME LE CITOYEN VEUGEN À LA PLACE D'ADMINISTRATEUR DU DÉPARTEMENT DE LA MEUSE-INFÉRIEURE EN REMPLACEMENT DU CITOYEN PICQUERY

Veugen - rechter bij de burgerlijke rechtbank van het departement van de Nedermaas - wordt benoemd tot administrateur bij het departement, ter vervanging van de ontslagen Picquery. De commissaris van de uitvoerende macht is belast met de uitvoering van dit besluit.

bo. gouvernementscommissaris Bouteville

RO nr.187: 7 fructidor IV (24 aug 1796); N.B.: in indicateur général ingeschreven onder de datum van 6 fructidor IV (23 aug 1796)

- verwijzing naar: besluit Directoire exécutif van 26 thermidor IV (13 aug 1796)

- LA en FA vermelden abusievelijk 27 thermidor IV (14 aug 1796) in hun verwijzing

\section{IV fructidor 7 (1796 aug 24)}

LA IV fol 3ro; FA nr.253 fol 68ro, FA nr.870

\section{ARRETÉ PORTANT NOMINATION DES CITOYENS NYPELS ET COENEGRACHT EN QUALITE D'ADMINISTRATEURS DU DÉPARTEMENT DE LA MEUSE-INFÉRIEURE EN PLACE DES CITOYENS VAN DE WARDT ET DE HAYNIN DÉMISSIONNÉS}

Nypels en Coenegracht, respectievelijk rechter bij de burgerlijke rechtbank van het departement van de Nedermaas en griffier bij criminele rechtbank, worden tot administrateurs van het departement benoemd, ter vervanging van Van de Wardt en De Haynin die ontslag hebben genomen. De commissaris van het Directoire exécutif is belast met de uitvoering van dit besluit.

bo. gouvernementscommissaris Bouteville

RO nr. 188: 7 fructidor IV (24 aug 1796); N.B.: in indicateur général ingeschreven onder de datum van 6 fructidor IV (23 aug 1796)

\section{IV fructidor 8 (1796 aug 25)}

BL He ser no.71 (651); LA V fol 66ro-67ro; rH X 372-373; P VII 383; MAP I 326 


\section{ARRÊTÉ QUI DETERMINE LE MODE ET LES TERMES DE PAIEMENT DU PRIX DES COUPES DE BOIS DE L'AN $V$}

Degenen aan wie de houtkap voor het jaar $\mathrm{V}$ is toegewezen, dienen het hun toegewezen hout in muntgeld dan wel in papiergeld tegen de dagwaarde te voldoen. De betalingstermijn is vastgelegd op één jaar, te weten: de helft zes maanden na de dag van toewijzing, de resterende helft zes maanden daarna, zonder enig uitzicht op verlenging van deze termijn. In het geval van achterstalligheid in de betaling dient men contant twee stuivers per livre van de aanbestedingsprijs extra te betalen. Voor de negen départements réunis is de betalingstermijn teruggebracht tot zes maanden, dat wil zeggen in twee termijnen van drie maanden.

bo. Directoire exécutif

ao. minister van financièn

S. L.M. Revellière-Lépeaux (pres); Lagarde (secr-gen)

RO nr. 198: 22 fructidor IV (8 sep 1796)

- verwijzing naar: besluit comités de salut public et des finances van 6 vendémiaire IV (28 sep 1795); besluit volksrepresentant Giroust van 30 vendémiaire IV (22 okt 1795): "les ordonnances et réglemens contre les adjudicataires en retard"

\section{IV fructidor 8 (1796 aug 25)}

BL Ille ser no.71 (652); LA IV fol 36wo-37ro; rH X 374; P VII 383; MAP I 326-327

\section{ARRETE QUI ORDONNE LA VENTE DES ARBRES DEPERISSANS ET NUISIBLES DANS LES COUPES ORDINAIRES DE BOIS APPARTENANT AUX ETABLISSEMENS ECCLESIASTI- QUES DANS LES DÉPARTEMENS RÉUNIS LE 9 VENDÉMIAIRE, AN IV}

Kwijnende en schadelijke bomen behorende tot bospercelen van kerkelijke instellingen dienen, naarmate de reguliere houtkap voortgang vindt, op de gebruikelijke manier te worden verkocht, met dien verstande dat op elke morgen (arpent), naast het jongere hout, zes oude bomen en tien nog niet-kaprijpe bomen op aanwijzing van houtvesters moeten blijven staan. De geldelijke opbrengst van het verkochte hout zal in de kas van de régie de l'enregistrement worden gestort.

bo. Dinectoire exécutiff

ao. minister van financiën

s. L.M. Revellière-Lépeaux (pres); Lagarde (secr-gen)

RO nr. 199: 22 fructidor IV (8 sep 1796)

\section{IV fructidor 10 (1796 aug 27)}

BL Ile ser no.72 (660); LA IV fol 64; rH IX 283-284; P VII 384; cB IVe ser V 276-277

LOI CONCERNANT L'IMPRESSION DES OUVRAGES ADOPTÉS COMME LIVRES ELEMENTAIRES 
Schrijvers van leerboeken - dan wel hun erfgenamen of rechtverkrijgenden - blijven in het exclusieve recht gehandhaafd om hun geschriften te doen drukken, verkopen en verspreiden. Het Directoire exécutif is gemachtigd om over 1000 exemplaren ervan te onderhandelen. De basiswerken van auteurs of hun rechtverkrijgenden die niet tot publicatie genegen zijn, zullen op staatskosten worden gedrukt.

bo. Conseil des Cinq-ients s. Emm. Pastoret (pres); Ozun, Bourdon, Noaille, Peyre (secr); Conseil des Anciens s. Muraire (pres); Pecheur, Fourcade, Ferroux (secr)

RO nr. 207(10): 2 vendêtmiaire $V(23$ sep 1796)

- verwijzing naar: wetten van 19 jul 1793; 11 germinal IV (31 mr 1796)

- afkondiging: besluit Directoire exécutif s. L.M. Revellière-Lépeaux (pres); Lagarde (secr-gen); 23 fructidor IV (9) sep 1796)

\section{IV fructidor 12 (1796 aug 29)}

BL Ile ser no.72 (666); LA IV fol 41ro-42ro; FA nr.291; rH IX 293-295; P VII 585; MAP I 331332; Fi. 292-293

\section{ARRETE PORTANT DEFENSES A TOUS AUTRES QUE LE NOTAIRES, GREFFIERS ET HUISSIERS, DE S'IMMISCER DANS LES PRISÉES, ESTIMATIONS ET VENTES PUBLIQUES DE MEUBLES ET EFFETS MOBILIERS}

Uitsluitend notarissen, griffiers en deurwaarders mogen zich inlaten met schattingen en publieke verkopingen van roerende goederen en bezittingen, zowel in het geval van vrijwillige openbare verkoop na boedelbeschrijving, als in het geval van gedwongen rechterlijke verkoop. Overtreders zullen gerechtelijk worden vervolgd ten verzoeke van de commissarissen van het Directoire exécutif bij de besturen en bestraft met een boete, onverminderd de eventuele schadeloosstelling aan de notarissen, griffiers en deurwaarders.

bo. Directoire exécutif

ao. minister van justitie

s. L.M. Revellière-Lépeaux (pres); Lagarde (secr-gen)

RO nr.200: 24 fructidor IV (10 sep 1796)

RE nr.189: 15/16 vendémiaire V (6/7 okt 1796)

- verwijzing naar: "foule de réglemens, el notamment l'edit de février 1771"; "réglemens nonabrogés"; decreet wan 21 sep 1792 ; wetten van $21 * 26$ jul $1790 ; 17$ sep 1793

\section{IV fructidor 12 (1796 aug 29)}

LA V fol 67ro-69ro; FA nr.291; rH IX 298-301

PROClamation auX Citoyens des départemens réunis par la loI dU 9 VENDÉMIAIRE, AN IV

In de proclamatie wordt de bevolking van de negen départements réunis opgeroepen zich verre te houden van de agitatie in bepaalde kantons gericht tegen de assignaten, welke na de tweede, tevens definitieve, binnenkomst van de Franse troepen in het 
voormalige België in omloop zijn gebracht. De assignaten die tot de datum van 9 prairial III ( 28 mei 1795 ) in omloop gebracht zijn, zouden volgens de aanstichters van de onrust door gouden of zilveren muntsoorten moeten worden vervangen. Autoriteiten die zich tot dergelijke contrarevolutionaire handelingen lenen, ook als het slechts een gebrek aan waakzaamheid betreft, hoeven niet op consideratie te rekenen. Zij dienen met het respect aan onherroepbare wetten verschuldigd, de besluiten, die de vrije circulatie van de assignaten verzekeren, ten volle uit te voeren.

bo. Directoine exécutif

s. L.M. Revellière-Lépeaux (pres); Lagande (secr-gen)

RO nr.201: 24 fructidor IV (10 sep 1796)

- verwijzing naar, besluit volksrepresentanten en mission van 12 thermidor III ( 30 jul 1795); verklaring van de rechten en de plichten van de mens en de burger, onderdeel van de grondwet van 5 fructidor III (22 aug 1795); "arrêtés qui avaient assurểs la libre circulation des assignats"

- Code Merlin vermeldt als datum van een afkondigingsbesluit 23 fructidor IV (9 sep 1796 )

\section{IV fructidor 14 (1796 aug 31)}

BL Ile ser no.72 (669); LA IV fol 65ro; rH IX 284-285; P VII 385-386; cB IVe ser V 296-297

lol qui détermine la manière dont IL SERA Procédé dans le cas où les ADMINISTRATIONS DE DÉPARTEMENT REFUSERONT DE CONFIRMER DES NOMINATIONS DE PROFESSEURS AUX ÉCOLES CENTRALES

Wanneer een departementaal bestuur weigert de benoeming van een docent aan de école centrale, voorgedragen door de jury d'instruction (benoemingscommissie), te bevestigen, zendt hij de motivering van de weigering, vergezeld van de motiveringen van de jury d'instruction, aan het Directoire exécutif, dat ter zake uitspraak zal doen.

bo. Conseil des Cinq-cents s. Emm. Pastoret (pres); Ozun, Noaille (secr); Conseil des Anciens s. Muraire (pres); Johannot, Fourcade, Ferroux, Pecheur (secr)

RO nr.207(11): 2 wendémiaire V (23 sep 1796)

- afkondiging: besluit Directoire exécutif s. L.M. Revellière-Lépeaux (pres), Lagarde (secr-gen); 23 fructidor IV (9 sep 1796)

\section{IV fructidor 15 (1796 sep 1)}

BL Ile ser no.73 (673); LA IV fol 46ro-49ro; rH IX 171-176; P VII 387-389: cB IVe ser V 299-302

\section{LOI QUI SUPPRIME LES ÉTABLISSEMENS RELIGIEUX DANS LES NEUF DÉPARTEMENS RÉUNIS PAR LA LOI DU 9 VENDÉMIAIRE, AN IV}

In het algemeen zijn alle reguliere religieuze congregaties en instellingen, kloosters, abdijen, priorijen enzovoorts opgeheven, met uitzondering van instellingen van religieuze zusters die zich wijden aan openbaar onderricht of de ziekenzorg in huizen gelegen buiten de instelling zelf. Dadelijk na de bekendmaking van deze wet benoemt de directie der nationale domeinen commissarissen die, in aanwezigheid van de geestelijken, een staat van de inkomsten van de religieuze instellingen moeten opma- 
ken, alsmede een staat met een beknopte beschrijving van het zilverwerk wan de kerken en kapellen, van de sacristiegoederen, van het boekenbezit van bibliotheken enzovoorts. Ook dient er een staat te worden opgemaakt van de huidige staat van de huizen en de schulden betreffende roerende of onroerende goederen. Verder worden van alle geestelijken de namen genoteerd. Binen tien dagen na de bekendmaking dienen de door de directie der nationale domeinen opgemaakte processen-verbaal en de staten aan de minister van financiën te worden gezonden. Tot de ontruiming van de geestelijke instellingen blijven de religieuzen hun goederen, welke niet zijn verpacht, beheren en exploileren, onder toezicht van de directie der nationale domeinen en de municipale besturen, onder de last dat de opbrengsten ervan in de kas van de nationale domeinen worden gestort. Pacht- en huursommen van religieuze goederen verschuldigd voor de vruchten en inkomsten over het jaar IV dienen eveneens in de kas van de nationale domeinen te worden gestort. Een gedeelte van de inkomsten mogen de religieuze instellingen evenwel inhouden ten behoeve van het onderhoud van de gebouwen. Gerechtelijke procedures gericht tegen religieuze instellingen zijn opgeschort. De religieuzen - abten, priors, kanunniken, kanunnikessen, lekebroeders en -zusters, donaten - van de opgeheven instellingen ontvangen een zeker bedrag om in het levensonderhoud te voorzien in de vorm van bons, die evenwel alleen aangewend kunnen worden woor het verkrijgen van nationale goederen gelegen in België. Bij het verlaten van de communiteit mag men zijn persoonlijke spullen meenemen, maar men dient het habijt af te leggen. De ontruiming dient binnen twee decaden na de uitreiking van de bons te geschieden.

bo. Conseil des Cinq-cents s. Emm. Pastoret (pres); Bourdon, Noaille, Peyre (secr); Conseil des Anciens s. Muraire (pres); Ferroux, Pecheur (secr)

ao. commissie uit de Conseil des Cinq-cents inzake een message van het Directoire exéctuif

RO nr.203: 28 fructidor IV (14 sep 1796)

RE nr. 184: $3 / 4$ vendémiaire V (24/25 sep 1796)

- verwijzing naar: wet var 23,28 okt * 5 november 1790 "et autres lois relatives"; "lois relatives à la suppression des ordres et congrégations monastiques"; grondwet van 5 fructidor III (22 aug 1795)

- wetten betreffende het beheer, verpachtingen en de verkoop van nationale domeinen en schulddelgingen zullen in de Verenigde Departementen, voor zover nog niet gebeurd, worden bekendgemaakt - afkondiging: lformule Directoire exécutif s. L.M. Revellière-Lépeaux (pres), Lagarde (secr); 16 fructidor IV (2 sep 1796)]

\section{IV fructidor 16 (1796 sep 2)}

BL lle ser no.73 (674); LA IV fol 65vo-69ro; rH IX 286-292; P VII 389-391; MAP I 345-349

\section{ARRÊTÉ CONTENANT RÉGLemENT POUR LA POLICE dES PAPETERIES}

Het is werkers in de papiernijverheid verboden zich te organiseren, teneinde verbetering van de bezoldiging en de werkomstandigheden te bewerkstelligen, door middel van het uitoefenen van druk op de papierfabrikanten, zoals werkstakingen en dergelijke. Vergaderingen en andere samenkomsten te dien einde worden als een aanslag op de openbare orde en de vrijheid beschouwd. Werknemers hebben niet het recht om vrijelijk van de ene fabrikant bij de andere in dienst te treden. Evenmin is het geoorloofd om nieuw aangeworven arbeidskrachten of leerlingen te verhinderen hun werk 
uit te oefenen. Ten verzoeke van de commissaris van het Direcroire exéculif dienen de gerechtelijke instanties hier tegen op te treden. Werkers, maar ook de fabrikanten, in de papierindustrie die zich aan dergelijke activiteiten schuldigmaken, worden beboet of riskeren een vrijheidstraf.

\section{bo. Directoire exécutif}

s. L.M. Revellière-Lépeaux (pres); Lagarde (secr-gen)

RO nu. 207(12): 2 vendémiaire $\mathrm{V}$ (23 sep 1796)

- verwijzing naar: réglement van 29 jan 1739 concernant les ouvriers papetiers; wetten van 16 * 24 aug 1790; $14 * 17$ jun 1791; 23 nivôse II (12 jan 1794); decreet Convention nationale van 21 sep 1792; grondwet van 5 fructidor III (22 aug 1795); code des délits et des peines van 3 brumaire IV (25 okt 1795)

- het arrêté is goeddeels een compilatie van (deels opnieuw geredigeerde) artikelen van het réglement van 1739 (artt.47-51, 53, 59); van de wetten van $16 * 22$ aug 1790 (tit.III art.32); 14

* 17 jun 1791 (artt.4, 6, 8); 23 nivôse II (12 jan 1794) (artt.5-9)

- met spoed doen de commissarissen van het Directoire exécutif bij de departementale besturen in elke gemeente waar zich een papierfabriek bevindt en, vooral in de werkplaats zelf, het onderhavige besluit aanplakken, alsmede lezen in de openbare zitting van de kantonsmunicipaliteit

- afkondiging: besluit Directoire exécutif s. L.M. Revellière-Lépeaux (pres), Lagarde (secr-gen); 23 fructidor IV (9 sep 1796)

\section{IV fructidor 17 (1796 sep 3)}

BL The ser no.73 (678); LA IV fol 49vo-50ro; rH. IX 316-317; P VII 391; cB IVe ser V 308-309

LOI CONTENANT DES MOYENS POUR ACCÉLÉRER LA VENTE DES DOMAINES NATIONAUX ET L'EXÉCUTION DE LA LOI SUR LA SUPPRESSION DES MAISONS RELIGIEUSES DANS LES NEUF DÉPARTEMENS RÉUNIS LE 9 VENDÉMIAIRE, AN IV

De wet belast het Directoire exécutif met het op de kortst mogelijke termijn treffen van maatregelen ter instandhouding van de inkomsten, zowel de achterstallige als die van het lopende jaar, van de goederen behorende tot de religieuze instellingen in de départements réunis. Het Directoire exécutiff is gemachtigd om deze goederen te doen beheren, over te dragen, te vervreemden of te verpanden. Het Directoire kan voorts overgaan tot het verpanden of hypothekeren, zelfs verkopen, van het nationale domeingoed tot een beloop van 100 miljoen aan geldswaarde. De opbrengst van de verkochte goederen dient in de schatkist te worden gestort.

bo. Conseil des Cinq-cents s. Emm. Pastoret (pres); Ozun, Bourdon, Peyre, Noaille (secr); Conseil des Anciens s. Muraire (pres); Fourcade, Ferroux, Pecheur (secr)

RO nr.204: 28 fructidor IV (14 sep 1796)

- verwijzing naar; de wet "sur la suppression des maisons religieuses" [van 15 fructidor IV (1 sep 1796)]

- afkondiging: [formule Directoire exë́cutif s. L.M. Revellière-Lépeaux (pres), Lagarde (secr-gen); 17 fructidor IV ( 3 sep 1796)]

\section{IV fructidor $18(1796$ sep 4$)$}

BL IIe ser no.74 (682); LA V 8ro-9ro; rH X 325-327; P VII 393; cB IVe ser V 312-313 
Het tribunal de cassation is gemachtigd om één van de criminele rechtbanken aan te wijzen waar niet-verschenen beschuldigden, die door de Engelsen uit de Franse koloniën gedeporteerd zijn, zich kunnen zuiveren van het verstek. Eveneens is dit van toepassing op niet-verschenen beschuldigden, voor wie het onmogelijk was voor de rechtbank te verschijnen, die het verstek heeft onderzocht en geoordeeld.

bo. Conseil des Cinq-cients s. Emm. Pastoret (pres); Bourdon, Noaille, Peyre (secr); Conseil des Anciens s. Muraire (pres); Ferroux, Fourcade, Pecheur (secr)

ao. bijzondere commissie uit de Consell des Cinq-cents

RO nr.215(2): 7 brumaire V (28 okt 1796)

- verwijzing naar: code des délits et des peines van 3 brumaire IV (25 okt 1795)

- wet uitgevaardigd n.a.v. het verzoekschrift van Millet, door de Engelsen van het eiland Sainte-Lucie [Saint Lucia] gedeporteerd

- afkondiging: besluit Directoire exécutif s. L.M. Revellière-Lépeaux (pres), Lagarde (secr-gen); 24 vendémiaire $V(15$ okt 1796)

\section{IV fructidor 18 (1796 sep 4)}

BL lle ser no.74 (683); LA V foll 9; rH X 327-328; P VII 393; cB IVe ser V 313-314

\section{LOI QUI DETERMINE LES CAS DANS LESQUELS IL Y A LIEU À LA RÉVISION DES JUGEMENS MILITAIRES}

De revisie van militaire vonnissen, als bepaald in art.3 van de wet van 17 germinal IV (6 apr 1796), kan uitsluitend plaatsvinden, wanneer er sprake is van de schending van vormvereisten, of als de opgelegde straf zwaarder is dan door de wet op het misdrijf gesteld.

bo. Conseil des Cinqucents s. Emm. Pastoret (pres); Peyre, Bourdon (secr); Conseil des Anciens s. Muraire (pres); Ferroux, Fourcade, Pecheur (secr)

ao. commissie uil de Conseil des Cinq-cents

$\mathrm{RO}$ m.215(3): 7 brumaire $\mathrm{V}$ (28 okt 1796)

- verwijzing naar: wet wan 17 germinal IV (6 apr 1796)

- atkondiging: besluit Directoire exécurif s. L.M. Revellière-Lépeaux (pres), Lagarde (secr-gen); 24 vendemiaire $\mathrm{V}$ (15 okt 1796)

\section{IV fructidor 19 (1796 sep 5)}

LA IV fol 58; FA nr.276 fol 153ro-154ro, FA nr.291; rH IX 301-302; P VII xcii; MAP I 352-353

ARRETE CONCERNANT LES DROITS DE CONSOMMATION DONT LA PERCEPTION SE FAIT' A L'ENTRÉ, SUR LES BOISSONS, DENRÉES ET MARCHANDISES, DANS LES NEUF DEPARTEMENS REUNIS LE 9 VENDEMIAIRE, AN IV

De verbruiksrechten geheven op dranken, etenswaar en andere waren bij binnenkomst in de Verenigde Departementen worden definitief geïn, ook in het geval deze waren 
niet geconsumeerd worden en de invorderingsplichtige gemeenten weer verlaten. De reeds geheven verbruiksrechten op deze waren die weer uitgevoerd zijn vóór de bekendmaking van het onderhavige besluit, zullen worden terugbetaald.

bo. Directoire exécutif

ao. minister van financiën Ramel

ii. minister wan financiën

RO nr.205: 2 jour complëmentaire IV (18 sep 1796)

- besluit uitgevaardigd n.a.v. een verzoekschrift van wijnhandelaren te Brussel inzake de terugbetaling van de ingevorderde verbruiksrechten

- MAP-intitulé: "arrêté qui détermine le mode de paiement des droits de consommation qui se perçoivent à l'entrée dans les départemens réunis, sur les boissons, denrées \& marchandises"

\section{IV fructidor 21 (1796 sep 7)}

BL Ile ser no.74 (692); LA V 7ro-8ro; rH X 323-325; P VII 395; MAP I 356-358

\section{ARRÉTÉ QUI ÉTABLIT UN NOUVEAU MODE DANS LA CORRESPONDANCE DES AUTO- RITÉS CONSTITUÉES}

Teneinde bij de administraties economischer te kunnen werken dienen aan autoriteiten gerichte memories, verzoekschriften en brieven vanaf 1 vendémiaire V (22 sep 1796) in tweevoud geschreven te zijn met een marge die even breed is als het geschrevene. Verder dienen de stukken te zijn geëtiketteerd en van één of twee trefwoorden aangaande de aard ervan te zijn voorzien. Het antwoord van de administratie wordt in de marge bijgeschreven en het tweede wordt als minuut bewaard. Indien men zich niet aan deze voorschriften houdt, of stukken inzendt die op meerdere zaken tegelijk betrekking hebben, worden deze zonder beantwoording geretourneerd. Deze maatregelen kunnen aanleiding geven tot een reorganisatie van het administratieve personeel.

\section{bo. Directoire exécutif}

s. L.M. Revellière-Lépeaux (pres); Lagarde (secr-gen)

RO nr.215(1): 7 brumaire V (28 okt 1796)

RE nr.201: $15 / 16$ brumaire $V(5 / 6$ nov 1796)

- "Il sera, à la diligence des commissaires du Directoire exécutif près les administrations départementales, imprimé \& affiché dans toutes les communes de la République"

- afkondiging: besluit Directoire exécutif s. L.M. Revellière-Lépeaux (pres), Lagarde (secr-gen); 24 vendémiaire V (15 okt 1796)

\section{IV fructidor $21(1796 \operatorname{sep} 7)$}

BL Ile ser no.74 (689); LA V 9vo-10ro; rH X 328-329; P VII 394; cB IVe ser V 324

\section{LOI PORTANT QUE LE RECOURS EN CASSATION CONTRE LE JUGEMENT DES COM- MISSIONS MILITAIRES, EST ADMISSIBLE POUR CAUSE D'INCOMPETENCE}

Het beroep in cassatie tegen vonnissen van militaire rechtbanken is toelaatbaar in het geval van kennelijke onbevoegdheid. 
bo. Consell des Cinq-cents s, Emm. Pastoret (pres); Bourdon, Noaille, Ozun, Peyre (secr); Conseil des Anciens, Muraire (pres); Pecheur, Fourcade, Ferroux (secr)

ao. bijzondere commissie uit de Conseil des Cinq-cents

RO nr.215(4): 7 brumaire $V(28$ okt 1796)

- wet uitgevaardigd na.v. het verzoekschrift van Jean Langevin

- afkondiging besluit Direcroure exécunif s. L.M. Revelliêre-Lépeaux (pres), Lagarde (secr-gen); 24 vendemiaire $\mathrm{V}(1.5 \mathrm{kt} 1796)$

\section{IV fructidor $21(1796 \operatorname{sep} 7)$}

BL. Ile ser no.74 (690); LA $V$ fol 10ro-1 I ro; $\mathrm{rH} \mathrm{X} \mathrm{330-331;} \mathrm{P} \mathrm{VII} \mathrm{394;} \mathrm{cB} \mathrm{IVe} \mathrm{ser} \mathrm{V} \mathrm{326-327}$

\section{LOI RELATIVE AUX VACANCES DES TRIBUNAUX}

De burgerlijke rechtbanken zijn jaarlijks twee maanden op reces, van 15 fructidor tot 15 brumaire. Niettemin blijft er een section des vacations bestaande uit vijf rechters en de commissaris van de pouvoir exécutif of één van diens plaatsvervangers beschikbaar, belast met de behandeling van spoedeisende zaken. Deze sectie wordt jaarlijks vernieuwd; de leden kunnen tijdelijk zo nodig de rechters van de criminele rechtbank aanvullen. De correctionele, criminele en handelsrechtbanken en het tribunal de cassation kennen geen reces.

bo. Conseil des Cimq-cents s. Emm. Pastoret (pres); Bourdon, Peyre, Noaille (secr); Conseil des Anciens s. Muraire (pres); Ferroux, Fourcade, Pecheur (secr)

RO nr.215(5): 7 brumaire V (28 okt 1796)

- rH vermeldt abusievelijk als datum van uitvaardiging 21 fructidor $V$ (7 sep 1797)

- cB-intitulé: "décret quj règle la durée des vacances des tribunaux civils"

- afkondiging: besluit Directoire exécurif s. L.M. Revellière-Lépeaux (pres), Lagarde (secr-gen); 24 vendémiaire $\mathrm{V}(15 \mathrm{okt} 1796)$

\section{IV fructidor 23 (1796 sep 9)}

BL Ile ser no.76 (701); LA IV fol 50vo-57vo; rH IX 303-315; P VII 396-400; MAP I 363-371

\section{ARRÊtÉ INTERPRETATIF DE CELUI DU 11 PLUVIOSE, AN IV, QUI DÉTERMINE UN MODE POUR LA VENTE DES DOMAINES NATIONAUX DANS LES NEUF DÉPARTEMENS RÉUNIS LE 9 VENDÉMIAIRE PRÉCÉDENT}

De generale staat van de goederen afkomstig van de opgeheven religieuze instellingen zal op last van de speciaal benoemde commissaris van het Directoire exécutif, belast met de verkoop van de nationale domeingoederen, worden gedrukt en aangeplakt in de negen départements réunis, de aangrenzende departementen en het departement Seine. Vanaf dat moment kan men inschrijven op deze domeingoederen, hetzij bij de speciale commissaris, hetzij bij het departement waarin het goed is gelegen. De verkopingen geschieden bij opbod door het departementaal bestuur. De laagste inzet bedraagt ten minste de door een deskundige gemaakte schatting van het goed, welke in ieder geval niet lager is dan achttien maal de jaarlijkse opbrengst van het goed. Het besluit behelst voorts bepalingen inzake de wijze van kwijting van de betalingstermij- 
nen door de verkrijgers; de vroegere geestelijken kunnen dit door middel van de hun uitgereikte bons doen. Verkrijgers kunnen geen enkel recht doen gelden op de vruchten en inkomsten van het lopende jaar, noch op de eventuele achterstallige termijnen.

bo. Directoire exécutif

s. L.M. Revellière-Lépeaux (pres); Lagarde (secr-gen)

RO nr.206: 2 vendémiaire V (23 sep 1796)

RE nr. 194: 4/5 brumaire V (26 okt 1796)

- verwijzing naar: wetten van $20 * 27$ sep 1790; 3 frimaire IV (24 now 1795); 4 pluviôse IV (24 jan 1796); 15 fructidor IV (1 sep 1796); 17 fructidor IV (3 sep 1796); "lois observées dans l'ancien territoire de la République, et qui ont été promulguées dans les neuf départemens"; "lois sur l'aliénation"; besluit van 11 pluviôse IV ( 31 jan 1796)

- het besluit dient tweetalig te worden gedrukt en aangeplakt in de départements réunis

\section{IV fructidor 24 (1796 sep 10)}

BL Ile ser no.75 (698); LA V fol 11; rH X 332-333; P VII 400; cB IVe ser V 335

\section{LOI RELATIVE À LA MANIÈRE DE JUGER LES REBELLES SAISIS DANS UN RASSEM- BLEMENT ARMÉ}

De wet van 22 messidor IV (10 jul 1796) inzake de bevoegdheid van militaire rechtbanken draagt geen enkele beperking noch afwijking van het bepaalde in art.598 van de code des délits et des peines in zich. Dit geldt evenmin voor de wetten die door dat artikel worden bevestigd betreffende de opstandelingen die tijdens een gewapende samenscholing zijn gearresteerd.

bo. Conseil des Cinq-cents s. Emm. Pastoret (pres); Bourdon, Ozun (secr); Conseil des Anciens s. Muraire (pres); Fourcade, Pecheur, Ferroux (secr)

ao. Dirertoire exécutif, commissie uit de Conseil des Cinq-cents

RO nr.215(6): 7 brumaire V (28 okt 1796)

- verwijzing naar: wetten van 30 prairial III (18 jun 1795); 1 vendémiaire IV (23 sep 1795); 22 messidor IV (10 jul 1796); code des délits et des peines wan 3 brumaire IV (25 okt 1795)

- afkondiging: besluit Direcroire exécutif s. L.M. Revellière-Lépeaux (pres), Lagarde (secr-gen); 24 vendémiaire $\mathrm{V}$ (15 okt 1796)

\section{IV fructidor 27 (1796 sep 13)}

BL Ile ser no. 77 (705); LA $V$ foll 12; rH X 333-334; P VII 408; cB IVe ser $V 351$

LOI PORTANT QUE LES PREVENUS DE DÉLITS MILITAIRES ONT LE DROIT DE SE CHOISIR DES DÉfENSEURS, DANS LE LIEU OÙ S'INSTRUIT LA PROCEDURE

Art.12 van de wet van 2 jour complémentaire III (18 sep 1795) inzake de instelling van militaire rechtbanken wordt herroepen. Verdachten van een militair delict hebben het recht om zich een verdediger uit te zoeken uit alle lagen van de burgerij, mits dit geschiedt in de plaats waar de rechtszaak wordt behandeld. 
bo. Consell des Cinq-cents s. Emm. Pastoret (pres): Ozun, Noaille (secr); Conseil des Anciens s. Muraire (pres); Fourcade, Ferroux; Pecheur (secr)

$\mathrm{RO}$ nr.215(7): 7 brumaire $\mathrm{V}(28$ okt 1796)

- verwijzing naar: wet van 2 jour complémentaire III (18 sep 1795) [zie RO nr.47(1)]

- afkondiging: besluit Directoire exếcutif $\mathrm{s}$. L.M. Revellière-Lépeaux (pres), Lagarde (secr-gen); 24 vendemiaire $\mathrm{V}(15$ okt 1796$)$

\section{IV fructidor 29 (1796 sep 15)}

LA $V$ fol 25wo-27ro; FA nr.276 fol 196ro-197ro

\section{ARRETE RELATIF AU PAYEMENT DES TRAITEMENTS, SALAIRES ET GAGES DES AGENS FORESTIERS}

De bezoldiging van houtvesters, boswachters en landmeters geschiedt uit het fonds dat gevormd wordt uit de opbrengst van de toewijzingen voor het kappen van hout. Voor de vorming van het fonds blijft er twee stuivers per livre in de kas van de ontvangers van de régie der registratie en van de nationale domeinen. De ontvangers gaan tot de uitbetaling over na machtiging van de departementale besturen.

bo. Directoine exécurif

s. L.M. Revellière-Lépeaux (pres); Lagarde (secr-gen)

ti. minister van financiên Ramel

RO nr.212: 27 vendémiaire V (18 okt 1796)

- verwijzing naar: wetten van 15 aug 1792; 14 ventôse IV (4 mrt 1796); 18 thermidor IV (5 aug 1796)

\section{IV jour complémentaire 1 (1796 sep 17)}

BL Ile ser no.77 (706); LA V fol 12vo-13vo; rH X 335-337; cB TVe ser V 362-364

\section{LOI QUI ORDONNE LA SUSPENSION DES VENTES OU ECHANGES DES LIVRES EXIS- TANS DANS LES DÉPÔTS LITTÉRAIRES}

Het Institut national neemt de huidige staat van de boekenbewaarplaatsen in de departementen Seine en Seine-et-Oise en te Versailles op, en rapporteert daarover aan het Corps législatif en het Directoire exécutif. De in de depots aanwezige boeken dienen op de voordeligste wijze benut te worden voor de inrichting van nationale bibliotheken in de departementen en voor de completering van de Bibliothèque nationale. Het Institut moet voorts aangeven welke boeken zonder bezwaar van de hand kunnen worden gedaan. Gedurende de bestandsopname zal er geen enkele verkoping of ruil van boeken uit de depots mogelijk zijn. Het Direcroire exécutif bepaalt welke boeken uiteindelijk verkocht kunnen worden. De geldelijke opbrengst dient te worden aangewend voor de inrichting van de departementale nationale bibliotheken en voor overige kosten betreffende het openbaar onderwijs.

bo. Conseil des Cinq-cents s. Emm. Pastoret (pres); Bourdon, Noaille, Ozun, Peyre (secr); Conseil des Anciens s. Muraire (pres); Fourcade, Ferroux, Pecheur (secr) 
ao. commissies uit de Conseil des Cinq-cents inzake de boodschap wan het Directoire exefutif motie van éên van zijin leden

RO nr. 215(8): 7 brumaire V (28 okt 1796)

- afkondiging: besluit Directoire exếcutif s. L.M. Revellière-Lêpeaux (pres), Lagarde (secr-gen); 24 vendémiaire $\mathrm{V}$ (15 okt 1796)

\section{IV jour complémentaire 3 (1796 sep 19)}

BL Ile ser no.77 (709); LA V fol 14ro; rH X 337-338; P VII 409-410; cB INe ser V 369

\section{LOI RELATIVE AUX hONNEURS À RENDRE AUX MILITAIRES BLESSÉS DANS LES COMBATS}

Aan in de strijd gewonde soldaten die op weg zijn naar hulpverleningsposten, wordt militaire eer bewezen, onder meer door het presenteren van het geweer. Schildwachten dienen aan voorbijkomende soldaten met verminkte ledematen de militaire groet te brengen. Bij publieke feestelijkheden zal er speciaal een plek bestemd worden voor gewonde militairen.

bo. Conseil des Cinq-cents s. Emm. Pastoret (pres); Ozun, Peyre, Bourdon (secr); Conseil des Anciens s. Muraire (pres); Fertoux, Fourcade, Pecheur (secr)

ao. bijzondere commissie uit de Conseil des Cinq-cents

RO nr.215(9): 7 brumaire V (28 okt 1796)

- afkondiging: besluit Directoire exécutif s. L.M. Revellière-Lépeaux (pres), Lagarde (secr-gen); 24 vendémiaire $\mathrm{V}$ (15 okt 1796)

\section{$V$ vendémiaire 3 (1796 sep 24)}

BL Ile ser no.79 (729); LA IV fol 69; P VII 411; MAP II 7

ARRETÉ QUI ORDONNE L'AFFICHE DES DEUX ARTICLES DE LA LOI DU 6 FRUCTIDOR, AN IV, PORTANT ÉTABLISSEMENT DU DROIT DE PATENTES POUR L'AN V

De artt.27 en 28 van de wet van 6 fructidor IV (23 aug 1796) inzake het patentrecht voor het jaar $\mathrm{V}$ dienen te worden aangeplakt in de rechtszaal van iedere burgerlijke rechtbank, handelsrechtbank en van het vredegerecht.

bo. Dinectoine exécutif

ao. minister van justitie

s. L.M. Revelière-Lépeaux (pres); Lagarde (secr-gen)

RO nr.208: 18 vendemiaire V (9 okt 1796)

- geen uitdrukkelijk afkondigingsbesluit

\section{V vendémiaire 3 (1796 sep 24)}

BL. IIe ser no.79 (727); LA V fol 14vo-15ro; rH X 339-340; P VII 411; cB IVe ser VI 6-7

LOI QUi détermine la MANIĖRe de PROCÉder de la PART DES PERSONNES DÉCHUES DE L'EFFET D'ARRÊTÉS RÉVOQUÉS PAR DES LOIS POSTÉRIEURES 
Partijen die door wijziging van de rechterlijke organisatie (ordre judiciaire) niet langer de werking genieten van de besluiten uitgevaardigd door de comités van de Convention nationale of de volksrepresentanten en mission ingevolge hun herroeping door een latere wet, worden in de volle uitoefening van hun rechtsvorderingen en excepties van destijds hersteld. De wet geeft de termijn aan van de opschorting van de excepties, beroepstermijnen en cassatieberoepen.

bo. Conseil des Cinq-cents s. Emm. Pastoret (pres); Ozun, Peyre, Noaille, Bourdon (secr); Conseil des Anciens s. Roger-Ducos (pres); Futuvre-la-Brunerie, Ligeret, Poullain-Grandprey, Marbot (secr) RO nr.215(10): 7 brumaire $V(28$ okt 1796)

- $\mathrm{B}$-intinkle: "loi relatíwe aux personnies déchues par l'effet des arrêtés des comités de la convention \& des représentans du peuple en mission, réwoquếs par les lois postérieures"

- afkondiging: besluilt Dirècfoine exécutif s. L.M. Revelliêre-Lépeaux (pres), Lagarde (secr-gen); 24 vendemiatre $V(15$ akt 1796)

\section{$\mathrm{V}$ vendémiaire 4 (1796 sep 25)}

BL lle ser no.79 (731); LA V fol 15vo-16ro; $r H$ X 341-342; cB IVe ser VI 11-12

LOI PORTANT QUE LES MINISTRES DE L"INTÉRIEUR ET DE LA JUSTICE ORDONNANCERONT, POUR LE PREMIER TRIMESTRE DE L'AN V, LES ETATS DES DÉPENSES MISES A LA CHARGE PAR LA LOI DU 28 MESSIDOR, AN IV

In verband met het feit dat de hoogte van de directe belastingen nog niet is vastgesteld, machtigen de ministers van binnenlandse zaken en van justitie tot betaling van alle kostenstaten voor het eerste kwartaal van het jaar $\mathrm{V}$, waarmee de wet van 28 messidor IV (16 jul 1796) de departementen belast. Het voorgeschoten bedrag dient tijdens de inning van de opcenten in de openbare schatkist te worden teruggestort.

bo. Conseil des Cinq-cents s. Chasset (pres); Bergoeing, Riou, Bailleul (secr); Conseil des Anciens s. Roger-Ducos (pres); Ligeret, Poullain $\backsim$ Grandprey (secr)

ao. commission des dépenses uit de Conseil des Cinq-cents

RO nr.215(11): 7 brumaire $V(28$ okt 1796)

- cB-intitulé: "loï portant que les ministres de la justice \& de l'intérieur ordonnanceront les dépenses A la charge des départemens"

- afkondiging: besluit Dircctoire exécutif s. L.M. Revellière-Lépeaux (pres), Lagarde (secr-gen); 24 vendémiaire $V(\mathbb{5}$ okt 1796$)$

\section{V vendémiaire 5 (1796 sep 26)}

BL Ile ser no.79 (735); LA V fol 16; rH X 342-343; P VII 412; MAP II 18-19; F I 294-295

\section{ARRETE PORTANT QU'IL SERA TENU DANS LES TRIBUNAUX DES REgISTRES POUR INVENTORIER LES LOIS ET LA CORRESPONDANCE OFFICIELLE}

De commissarissen van de pouvoir exécutif bij de rechtbanken dienen een register bij te houden, waarin de hun toegezonden Bulletins des Lois, circulaires en overige officiële stukken, alsmede de uitgaande brieven die zij uit hoofde van hun functie 
versturen, staan ingeschreven. De griffiers van de rechtbanken dienen eveneens een register te houden, op zodanige wijze dat beide registers wederzijs als controle kumnen dienen.

bo. Directoire exécutif

a. minister van justitie Merlin

s. L.M. Revellière-Lépeaux (pres); Lagarde (secr-gen)

RO nr.215(12): 7 brumaire $V(28$ okt 1796)

- verwijzing naar: besluit van 7 thermidor IV (25 jul 1796)

- afkondiging: besluit Directoire exécutif s. L.M. Revellière-Lépeaux (pres), Lagarde (secr-gen); 24 vendémiaire $\mathrm{V}$ (15 okt 1796)

\section{V vendémiaire 6 (1796 sep 27)}

BL Ile ser no.79 (736); LA V fol 17; rH X 344-345; P VII 416; MAP II 19

\section{ARRÊTẾ RELATIF AUX PASSE-PORTS DES FOURNISSEURS GÉNÉRAUX DES ARMÊES, ET DE LEURS AGENS}

De leveranciers-generaal van de legers, hun agenten en overigen die niet wezenlijk deel uitmaken van het leger mogen, zoals alle Franse onderdanen, alleen reizen in het binnenland en het Franse territoir verlaten of er terugkeren, wanneer zij in het bezit zijn van een paspoort. De autoriteiten en militaire commandanten dienen op de kortst mogelijke termijn de leveranciers en hun agenten paspoorten en visa te verstrekken en hun anderszins van dienst te zijn. De leveranciers-generaal zijn persoonlijk verantwoordelijk voor inbreuken op de wetten, waaraan hun agenten zich schuldig mochten maken.

bo. Directoire exécutif

s. L.M. Revellière-Lépeaux (pres); Lagarde (secr-gen)

RO nr.215(13): 7 brumaire V (28 okt 1796)

"verwijzing naar: "lois sur les passe-ports"

- afkondiging: besluit Directoire exécurif s. L.M. Revellière-Lépeaux (pres), Lagarde (secr-gen); 24 vendémiaire $\mathrm{V}$ (15 okt 1796)

\section{V vendémiaire 16 (1796 okt 7)}

BL Ile ser no.81 (753); LA $V$ fol 21vo-23ro; rH X 317-319; P VII 419; cB IVe ser VI 41-42

\section{LOI QUI CONSERVE LES HOSPICES CIVILS DANS LA JOUISSANCE DE LEURS BIENS, ET RÈGLE LA MANIËE DONT ILS SERONT ADMINISTRÉS}

De municipale besturen hebben het directe toezicht op de burgerlijke gasthuizen, waartoe zij een commissie van vijf personen benoemen. Een ontvanger buiten hun midden benoemd legt rekenschap af over het gevoerde financiële beheer. Bestaande instellingen voor blinden en doofstommen blijven ten laste van de nationale schatkist. De burgerlijke gasthuizen blijven voorts in het genot van hun goederen, alsmede van de pachtsommen die hun door de schatkist of door particulieren zijn verschuldigd. 
Goederen die ingevolge de wet van 23 messidor II (11 jul 1794) - de wet is wat betreft de burgerlijke gasthuizen herroepen - verkocht zijn, zullen worden vervangen door nationale domeingoederen met eenzelfde opbrengst. De departementale besturen zujn met de afwikkeling hiervan belast, maar hun werk is uitsluitend voorbereidend; eerst uit hoofde van een uitdrukkelijke wet kan én en ander zijn beslag krijgen. Pachtsommen die de gasthuizen uit verkochte domeinen genoten en die nu in de schatkist worden gestort, zullen door de schatkist aan de burgerlijke gasthuizen worden overgemaakt.

bo. Conseil des Cinqucents s. Emm. Pastoret (pres); Peyre, Noaille, Bourdon (secr); Conseil des Anciens s. Roger-Ducos (pres); Poullain-Grandprey, Ligeret, Fauvre-la-Brunerie, Marbot (secr)

ao. bijzondere commissie uit de Conseil des Cinq-cents

RO nr.215(15): 7 brumaire V (28 okt 1796)

- verwijzing naar: wet van 23 messidor II (II jul I794) [later afgekondigd]

- afkondiging: besluit Directoire exécutuif s. L.M. Revellière-Lépeaux (pres), Lagarde (secr-gen); 24 vendémiaire V (15 okt 1796)

- N.B.: i.v.m een fout in de datering wordt er een rectificatie aangebracht: Loi contenant rectification d'une erreur de date dans celle du 16 Vendémiaire, an IV [lees V], relative aux hospices civils [datum van uitvaardiging: 8 brumaire V (29 okt 1796); BL IIe ser no.86 (823); RO nr. 219: 21 brumaire $V(11$ nov 1796)]

\section{V vendémiaire 21 (1796 okt 12)}

BL Ile ser no.83 (770); LA V fol 29; rH X 136; P VII 422; MAP II 45-46

ARRÊté QUi Proroge le délai fiXé PAR CELUI dU 16 PRAIRIAL, AN IV, RELATIF AUX FORMALITÉS À REMPLIR PAR LES FRANÇAIS VOYAGEANT EN PAYS ÉTRANGERS

Fransen die in het buitenland reizen dienen zich te voorzien van een dubbel certificaat, waaruit blijkt dat ze niet vermeld staan op de lijst van uitgewekenen. Degenen die vóór de bekendmaking van het besluit van 16 prairial IV (4 jun 1796) vertrokken zijn, hebben twee maanden de tijd om zich aan het bepaalde ervan te conformeren. Zijn zij hierin nalatig, dan zullen zij niet in de registers, die geopend zijn bij de gezanten en consuls van de Republiek in het buitenland, worden ingeschreven.

bo. Directoire exécutif

ao. minister voor buitenlandse betrekkingen

5. L.M. Revellière-Lépeaux (pres); Lagarde (secragen)

RO nr.220(1): 27 brumaire $V(17$ nov 1796)

- afkondiging: besluit Directoire extcurif s. P. Barras (pres), Lagarde (secr-gen); 16 brumaire V (6 nov 1796)

V vendémiaire 23 (1796 okt 14)

BL Ile ser no.83 (773); LA V fol 3; rH X 168-169; cB IVe ser VI $81-82$

LOI QUI ÉTEND AUX NEUF DÉPARTEMENS RÉUNIS, LE MODE ÉTABLI POUR PROCÉDER DANS LES INSTANCES EN MATIĚRE DE DOUANES 
Rechtsgedingen inzake douane-aangelegenheden zullen in de negen Verenigde Departementen, zoals elders in Frankrijk, voor de vrederechter in de kantons worden gebracht. In hoger beroep wordt ter zake rechtgesproken door de departementale burgerlijke rechtbank.

bo. Conseil des Cinq-cents s. Chasset (pres); Bailleul, Favart (secr); Conseil des Anciens s. RogerDucos (pres); Poullain-Grandprey, Ligeret, Fauvre-la-Brunerie, Marbot (secr)

ao. commissie uit de Conseil des Cinq-cents

RO nr.213: 7 brumaire V (28 okt 1796)

- verwijzing naar: wet van 14 fructidor III (31 aug 1795); "lois sur les douanes"; grondwet van 5 fructidor III (22 aug 1795)

- afkondiging: formule Directoire exécutif s. L.M. Revellière-Lépeaux (pres), Lagarde (secr-gen); 23 vendémiaire V (14 okt 1796)

\section{$V$ vendémiaire 23 (1796 okt 14$)$}

LA V fol I13vo; FA nr.277 fol 98vo-99ro, FA nr.2419; MAP II 51

\section{ARRÊTÉ RELATIF À LA SOMME ACCORDÉ POUR ROUTE AUX MENDIANS MIS EN LIBERTÉ}

Degenen die wegens bedelarij of op verdenking van diefstal gedetineerd waren en wederom in vrijheid gesteld zijn, krijgen voortaan drie stuivers in muntgeld per klein uur gaans als vergoeding om zich naar hun woonplaats te begeven, aangezien de vergoeding van drie stuivers in mandats [territoriaux] volstrekt onvoldoende is. De kosten hiervan moeten door elk departement worden gedragen uit de opcenten, aldus het toegevoegde post scriptum.

bo. Directoire exécutif

s. L.M. Revellière-Lépeaux (pres); Lagarde (secr-gen)

ti. minister van binnenlandse zaken Bénézech

RO nr.236: 11 nivôse $V$ (31 dec 1796); N.B.: in indicateur général ingeschreven onder de datum van 23 brumaire $V(13$ now 1796)

- MAP-initule: "Artêté portant que les trois sous par lieue accordés aux accusés mis en liberté, leur seront payés en valeur métallique"; N.B.: het post scriptum ontbreekt

\section{V vendémiaire 25 (1796 okt 16)}

BL IIe ser no.83 (786); LA V fol 25; rH X 170-171; cB IVe ser VI 88-89

\section{LOI QUI PROROGE LE DELAI ACCORDÉ POUR L'OBTENTION DES PATENTES}

De termijn ter verkrijging van patent welke op 15 vendémiaire $V$ (6 okt 1796) verliep, is verlengd tot 15 brumaire $V$ ( 5 nov 1796).

bo. Conseil des Cimq-cents s. Casset (pres); Bailleul, Favart, Bergoeing (secr); Conseif des Anciens 8. Roger-Ducos (pres); Poullain-Grandprey, Fauvre-la-Brunerie, Marbot (secr)

RO nr.217: 17 brumaire $V(7$ nov 1796)

- verwijzing naar: wet wan 6 fructidor IV (23 aug 1796) 
- afkondiging: besluit Direcroire exécuif s. L.M. Revellière-Lépeaux (pres), Lagarde (sect-gen); 3 brumaire V (24 okt 1796$)$ [BL ] Je ser no.85 (806)]

\section{V vendémiaire 28 (1796 okt 19)}

BL Ile ser no.84 (794); LA V fol 30ro; $\mathrm{rH}$ X 137-138; P VII 425; cB IVe ser VI 91

\section{LOI PORTANT PROROGATION DU TERME CI-DEVANT FIXÉ POUR L'INTRODUCTION DU NOUVEAU REGIME HYPOTHÉCAIRE}

De invoeringsdatum van 1 brumaire V (22 okt. 1796) van het nieuwe hypothecaire regime wordt verschoven tot de datum van de bekendmaking van de wetswijziging ter zake. Mitsdien blijft de wet van 19 prairial IV (7 jun 1796) van kracht.

bo. Conseil des Cinq-cents s. Chasset (pres); Bailleul, Favart, Riou, Bergoeing (secr); Conseil des Anciens s. Roger-Ducos (pres); Poullain-Grandprey, Fauvre-la-Brunerie, Marbot (secr)

RO 220(2): 27 brumaire $V(17$ nov 1796)

- verwijzing naar: code hypothécoire van 9 messidor III (27 jun 1795); wetten van 19 prairial IV (7 jun 1796); 24 thermidor IV (11 aug 1796)

- $\mathrm{cB}$ vermeldt als datum van uitvaardiging 27 vendémiaire $\mathrm{V}$ (18 okt 1796)

- afkondiging: besluit Directoire exécutif s. P. Barras (pres), Lagarde (secr-gen); 16 brumaire V (6 nov 1796)

\section{$V$ vendémiaire 28 (1796 okt 19)}

BL Ile ser no.84 (795); LA V fol 30vo-31 ro; rH X 138-139; P VII 425-426; MAP II 67-68

\section{ARRETE QUI INTERDIT LA CHASSE DANS LES FORÊTS NATIONALES}

De jacht in de staatsbossen is zonder onderscheid voor alle particulieren verboden. Boswachters dienen tegen overtreders proces-verbaal op te maken; op overtreding staat een geldboete.

bo. Divectoire executif

ao. minister van financièn

s. L.M. Revelliere-Lépeaux (pres); Lagarde (secr-gen)

RO nr. 220(3): 27 brumaire $V(17$ mov 1796)

RE nr.229: 4/5 pluviôse V (23/24 jan 1797)

- verwijzing naar: ordonnance van aug 1669; wet van 28 * 30 apr 1790; code des délits et des peines van 3 brumaire IV (25 okt 1795)

- afkondiging: besluit Directoire exécmif s. P. Barras (pres), Lagarde (secr-gen); 16 brumaire V (6 nov 1796) 
ARRÊTÉ RELATIF À LA FIXATION DU NOMBRE ET DU TRATTEMENT DES EMPLOYÉS, ET DES FRAIS DE BUREAU DES ADMINISTRATIONS ET DES FONCTIONNAIRES PUBLICS TANT CIVILS QUE MILITAIRES

leder ministerie dient op de kortst mogelijke termijn aan het Directoire exécutif een voorstel te overleggen ter zake wan het aantal personeelsleden, hun bezoldiging en de bureaukosten, één en ander in overeenstemming met de beginselen van goed beheer. Alle bureaus van administratie en publieke functionarissen, zowel civiele als militaire, vallen onder de herschikking van de middelen. Overtollige personeelsleden ontvangen als schadeloosstelling maximaal één maand salaris, gerekend vanaf 1 frimaire $V(21$ nov 1796). Uitgaven die niet door het Directoire exécutif via de overzichtsstaten goedgekeurd zijn, kunnen voortaan niet meer plaatshebben.

bo. Directoire exécutif

s. L.M. Revellière-Lépeaux (pres); Lagarde (secr-gen)

RO nr.216: 13 brumaire V (3 nov 1796)

- art.5 bepaalt dat het onderhavige besluit ook van toepassing is in de "pays réunis"

\section{$V$ vendémiaire 29 (1796 okt 20)}

BL. Ile ser no.84 (796); LA V fol 31; rH X 140-141; P VII 426-428; cB IVe ser VI 100-101

\section{LOI QUI RËLE LA MANIËRE DE SUIVRE LES ACTIONS DANS LESQUELLES LES COM- MUNES SONT SEULES INTÉRESSÉS}

Het recht om vorderingen in te stellen welke alleen gemeenten aangaan, is toevertrouwd aan de vertegenwoordigers van die gemeenten. In gemeenten boven de 5000 inwoners is dit recht opgedragen aan een daartoe door het gemeentebestuur aangewezen ambtenaar. Zij kunnen een dergelijke vordering pas instellen na voorafgaande machtiging door het departementale bestuur en nadat het advies is ingewonnen van het gemeentebestuur.

bo. Conseil des Cinq-cents s. Chasset (pres); Bailleul, Bergoeing. Favart (secr); Conseil des Anciens s. Roger-Ducos (pres); Poullain-Grandprey, Ligeret, Fauvre-la-Brunerie, Marbot (secr)

ao. commissie uit de Conseil des Cinq-cents n.a.v. een boodschap van het Directoire exécutif RO nr.220(4): 27 brumaire V (17 nov 1796)

- afkondiging: besluit Directoire exécutif s. P. Barras (pres), Lagarde (secrmgen); 16 brumaire V (6 nov 1796 )

\section{V brumaire 2 (1796 okt 23$)$}

BL IIe ser no.85 (804); LA V fol 35ro-36vo; rH X 147-149; MAP II 80-81

ARRÊTE QUI ORDONNE LA FORMATION ET L'ENVOI D'ETATS NOMINATIY DES MEMBRES COMPOSANT LES TRIBUNAUX CIVILS ET CRIMINELS, DES JUGES DE PAIX, DE LEURS ASSESSEURS ET DES NOTAIRES 
Voor het verwerven wan een owerzicht van de huidige staat der verschillende jurisdicties, alsmede van de leden die de onderscheidene gerechten vormen, teneinde tot een completering ervan te komen, verlangt het Directoire exécutif dat de commissarissen van de pouvoir exécutif bij de departementale burgerlijke en criminele rechtbanken tien dagen na de bekendmaking van het onderhavige besluit een lijst met de (voor)namen van de leden van de rechtbanken met hun datum van benoeming opstellen en toesturen aan de minister van justitie. De vrederechters dienen een soortgelijke staat op te stellen voor de leden van het vredegerecht, welke zij zenden aan de commissaris van dé pouvoir exécutif bij de correctionele rechtbank. Eveneens dienen de vrederechters een lijst van de in hun kanton werkzame notarissen met de vermelding van hun standplaats op te stellen. De commissaris van de pouvoir exécutif bij de burgerlijke rechtbank deponeert de dubbelen van alle naamlijsten ter griffie van de rechtbank.

\section{bo. Directoire exécuif}

ao. minister van justitie

\$. L.M. Revellière-Lépeaux (pres); Lagarde (secr-gen)

RO nr.220(7): 27 brumaire V (17 now 1796)

" verwijzing naar" wet wan 16 floréal IV (5 mei 1796)

- afkondiging: besluit Directoire executif s. P. Barras (pres), Lagarde (secr-gen); 16 brumaire V (6 nov 1796)

\section{V brumaire 3 (1796 okt 24)}

BL. Ile ser no.84 (802); LA V fol 32ro-33vo; rH X 141-144; P VII 428-429; cB IVe ser VI 112-113

LOI QUI PRESCRIT UN MODE POUR RETIRER DE LA CIRCULATION LES PIECES EN METAL DE BRONZE FABRIQUÉES EN EXÉCUTION DE LA LOI DU 28 THERMIDOR, AN III

Titel III van het decreet van de Convention nationale van 28 thermidor III (15 aug 1795) ter zake van het slaan van bronzen muntstukken van één, twee en vijf centime(s) en van én en twee décime(s) is in verband met het te ver uiteenlopen van de nominale en intrinsieke waarde herroepen. Tot 1 nivôse V (21 dec 1796) kunnen de stukken van vijf centimes en één en twee décime(s) als betaalmiddel gebruikt worden voor de sommen gelds die men aan de staat verschuldigd is; omgekeerd kan de nationale schatkist deze munten niet meer als betaalmiddel aanwenden. De uit de circulatie genomen vijf-centimes-stukken worden omgesmolten; de décimes-stukken krijgen een nieuwe muntopdruk. Vór 1 frimaire $V(21$ nov 1796) zullen er in elk departement voldoende wisselkantoren voor particulieren worden geopend. Voor het aangeboden geld krijgt men het dubbele aan gewicht in kopergeld terug. Het Directoire exécutif dient alle noodzakelijke maatregelen te treffen, teneinde fraude bij de openbare wisselkantoren te vermijden.

bo. Conseil des Cinq-cents s. Chasset (ex-pres); Mathieu, Dubois (des Vosges), Fabre, T. Berlier (secr); Conseil des Ancrens s. J.G. Lacuée (pres); Kervelegan, Viennet, Lepaige (secr)

RO nr.220(5): 27 brumaire V (17 nov 1796) 
- afkondiging: besluit Directonte exécutif s. P. Barras (pres), Lagarde (secr-gen); 16 brumaire V (6 nov 1796)

\section{V brumaire 3 (1796 okt 24$)$}

BL Ile ser no.84 (803); LA V fol 33wo-34vo; rH X 145-147; P VII 429-430; cB IVe ser VI 110-112

\section{LOI QUI ORDONNE LA FABRICATION D'UNE NOUVELLE MONNAIE DE CUIVRE}

Ter vergemakkelijking van de uitbetaling van de soldij en van betalingen in kleingeld zal er tot een beloop van tien miljoen aan koperen muntstukken met de waarde van één en vijf centime(s) en één décime worden geslagen. Een tiende gedeelte bestaat uit stukken van één centime, viertiende uit stukken van vijf centimes en vijftiende uit stukken van één décime. In de wet worden de precieze verhoudingen naar het gewicht van de onderscheidene muntstukken aangegeven. Daarnaast vermeldt de wet de uitwendige kenmerken van de munten.

bo. Conseil des Cinq-cents s. Chasset (ex-pres); Mathieu, T. Berlier, Dubois (des Vosges), Fabre (secn); Conseil des Anciens s. J.G. Lacuée (pres); Kervelegan, Viennet, Lepaige (secr)

RO nr.220(6): 27 brumaire V (17 nov 1796)

- afkondiging: besluit Directoire exécutif s. P. Barras (pres), Lagarde (secr-gen); 16 brumaire V (6 nov 1796)

\section{V brumaire 3 (1796 okt 24)}

BL Ile ser no.92 (868); LA V fol 97ro-102ro; $r H$ X 292-298; P VII 430; cB IVe ser VI $1.14-120$

\section{LOI CONTENANT RATIFICATION DU TRAITÉ DE PAIX CONCLU ENTRE LA RÉPUBLI- QUE FRANCAISE ET LE ROI DES DEUX-SICILES}

De wet behelst de ratificatie van het vredes- en vriendschapsverdrag op 19 vendémiaire V (10 okt 1796) tussen de Franse Republiek en het Koninkrijk der Beide Siciliën gesloten. Met het verdrag zullen de oorlogshandelingen worden gestaakt en geen der beide verdragsluitende partijen zal de vijand van de ander op enigerlei wijze de helpende hand bieden. Spoedig zal er over een handelsverdrag tussen beide staten worden onderhandeld. Overeenkomstig art.6 van het Haagse Verdrag van 27 floréal III (16 mei 1795) gelden de verdragsbepalingen tevens tussen het Koninkrijk der Beide Sicilliën en de Bataafse Republiek.

bo. Conseil des Cinq-cents en comité général s. Chasset (pres); Bailleul, Bergoeing, Favart, Riou (secr); Conseil des Anciens s. J.G. Lacuée (pres); Kervelegan, Lepaige (secr)

RO nr.232(14): 1 nivôse V (21 dec 1796)

- verwijzing naar: Haags Verdrag van 27 floréal III (16 mei 1795); grondwet wan 5 fructidor III (22 aug 1795)

- afkondiging: besluit Directoire exécutif s. P. Barras (pres), Lagarde (secr-gen); 16 frimaire V (6 dec 1796) 


\section{LOI QUI ORDONNE LA RÉUNION DANS LES CHEFS-LIEUX DE DÉPARTEMENT, DE TOUS LES TITRES ET PAPIERS ACQUIS À LA RÉPUBLIQUE}

De centrale administraties van de departementen dienen in de hoofdplaats van het departement alle titels en papieren die zich in depots bevinden die tot de staat behoren samen te brengen. Het Directoire exécutif kan tot tijdelijke opslag in nationale gebouwen machtigen, maar de plaatsing dient uiteindelijk te geschieden in de gebouwen waar het departementaal bestuur zetelt. Het Directoire exécutif laat onmiddellijk de bestaande bewaarplaatsen in de départements réunis inventariseren, teneinde informatie te verzamelen over de hoedanigheid van de nationale domeingoederen; daartoe kunnen ambtenaren worden aangesteld. De uitvoering van de wet van 7 messidor II (25 jun 1794) blijft in de andere departementen dan het Seine-departement en de negen Verenigde Departementen opgeschort. Verder wordt er niet gederogeerd aan de bepalingen van de wetten van 12 brumaire II ( 2 nov 1793) en 7 messidor II wat betreft de archieven van de Republiek.

bo. Conseil des Cinqacents s. Chasset (pres); Riou, Bailleul (secr); Conseil des Anciens s. J.G. Lacuee (pres); Lepaige, Viennet (secr)

RO nr.220(8): 27 brumaire $V(17$ nov 1796)

- verwijzing naar: wetten van 12 brumaire II ( 2 now 1793); 7 messidor II (25 jun 1794)

- afkondiging: besluit Directoire exécurif s. P. Barras (pres), Lagarde (secr-gen); 16 brumaire V (6 now 1796)

\section{V brumaire $6(1796$ okt 27$)$}

BL Ile ser no.85 (811); LA V fol 37vo-39wo; rH X 152-154; P VII 432-434; cB IVe ser VI 132-133; F I 297-299

\section{loI CONTENANT des mesures pOUR la CONSERVATION DES PROPRIÉtÉS DES DÉFENSEURS DE LA PATRIE}

De departementale burgerlijke rechtbanken benoemen drie integere en ontwikkelde burgers die een officieuze raad vormen, belast met het consulteren en de kosteloze verdediging, ten verzoeke van gemachtigden, in juridische kwesties van de verdedigers van het vaderland en overige burgers die krijgsdienst verrichten. Verkrijging, verjaring, of het verval van de procesaanleg (peremption d'instance) kan niet plaatsvinden gedurende de afwezigheid uit hun woonplaats, wanneer dit na de oorlogsverklaring is geschied. Bij het ingaan van de vrede of bij het definitief verlaten van de krijgsdienst kan zulks pas na één maand. Deze termijn bedraagt drie maanden wanneer de burgers dienstdoen buiten het grondgebied van de Republiek, maar binnen Europa; acht maanden in de koloniën aan deze zijde en twee jaar aan gene zijde van de Kaap de Goede Hoop. Vonnissen uitgesproken tegen landsverdedigers kunnen binnen deze termijnen geen aanleiding vormen tot een decreet gericht tegen hen, noch tot een bezitsontzetting van een onroerend goed. De vervolgende partij dient voor de 
tenuitvoerlegging van een vonnis een voldoende borg (caution solvable) te stellen. Griffiers en deurwaarders mogen pas tot de tenuitvoerlegging overgaan als het bewijs van ontvangst van de borg (jugement de réception de la caution) bij het veroordelingsvonnis is gevoegd. De municipale besturen van de kantons deponeren een lijst van degenen die wegens krijgsdienst afwezig zijn bij de griffies van de burgerlijke en handelsrechtbank en het vredegerecht. De eigendommen van de landsverdedigers en van overige burgers afwezig ten behoeve van de publieke dienst zijn onder de hoede van gemeenteambtenaren geplaatst.

bo. Conseil des Cinq-cents s. Chasset (ex-pres); Dubois (des Vosges), Fabre, Berlier (secr); Conseil des Anciens s. J.G. Lacuée (pres); Lepaige, Viennet (secr)

RO nr.220(9): 27 brumaire $V$ ( 17 now 1796)

- afkondiging: besluit Directoire exécutif s. P. Barras (pres). Lagarde (secr-gen); 16 brumaire V (27 okt 1796)

\section{V brumaire 8 (1796 okt 29)}

BL Ile ser no.87 (829); LA IV fol 165vo-166ro; rH X 178; P VII 434; MAP II 100

\section{ARRÊTÉ PORTANT QU'IL NE SERA ALLOUÉ AUCUNE SOMME POUR L'IMPRESSION DES JUGEMENS DES TRIBUNAUX CRIMINELS}

Geen enkel bedrag zal uit de staatskas worden toegekend ter bestrijding van de drukkosten van de vonnissen die door de criminele rechtbanken zijn gewezen. De bestaande wetten kennen alleen een som gelds toe voor het drukken van vonnissen van het tribunal de cassation en van vonnissen door de correctionele rechtbanken, uitgesproken in geval van recidive.

bo. Directoire exécutif

ao. minister van justitie

S. L.M. Revellière-Lépeaux (pres); Lagarde (secr-gen)

RO mr. $222(1)$ : 3 frimaire $V(23$ nov 1796$)$

- verwijzing naar: wetten van 27 nov * $\|$ dec $1790 ; 19 * 22$ jul $179 \|$

- afkondiging: besluit Directoire exécutif s. P. Barras (pres), Lagarde (secr-gen); 21 brumaire V (11 nov 1796)

\section{V brumaire 10 (1796 okt 31)}

BL Ile ser no.86 (825); LA $V$ fol 39vo-43vo; rH X 155-161; P VII 434-437; cB IVe ser VI 143-147

\section{LOI QUI PROHIBE L'IMPORTATION ET LA VENTE DES MARCHANDISES ANGLAISES}

De invoer van waren door de Britse nijverheid vervaardigd of afkomstig uit de handel is zowel over land als over zee verboden. Dergelijke lading aan boord van schepen wordt in beslag genomen, behoudens de bepalingen in de wet van 23 brumaire III (13 nov 1794). Uitgezonderd zijn ook schepen van boven de 100 ton, die noodzakelijkerwijs een haven moeten aandoen. De kapitein is gehouden aangifte van de Engelse koopwaar te doen. Bij het lossen van het schip worden deze tijdelijk opgeslagen. 
Buitgemaakte Engelse handelswaar of waren afkomstig van schepen die schipbreuk hebben geleden, zijn onderworpen aan opslag en wederuitvoer. De wet vermeldt een aanzienlijk aantal producten en handelswaren, waarvan bekend is dat ze zonder meer van Britse origine zijn, variërend van katoenen en wollen stoffen tot leerproducten en glas- en aardewerk. Goederen die afkomstig zijn uit Indië mogen alleen in Frankrijk worden ingevoerd, wanneer zij vergezeld zijn van certificaten welke afgegeven zijn door de Hollandse of Deense handelscompagnieën. Vanaf de bekendmaking van de onderhavige wet is het een ieder verboden Engelse goederen ten verkoop aan te bieden of zulks aan te kondigen. Degene die dergelijke goederen onder zich heeft, moet deze bij de kantonsmunicipaliteil aangeven. Elke overtreding van het bepaalde in deze wet leidt tot arrestatie en voorgeleiding aan de rechtbank van correctionele politie. Een veroordeling brengt altijd de verbeurdverklaring van de goederen, handelswaar, schepen, paarden en overige transportmiddelen met zich mee.

bo. Conseil des Cinq-cents s. Cambacérès (pres); Mathieu, Dubois (des Vosges), Fabre (secr); Conseül des Anciens s. J.G. Lacuée (pres); Kervelegan, Viennet, Lepaige (secr)

ao. commissie uit de Conseil des Cinq-cents belast met het onderzoek wan de boodschap van het. Directoire execcutiff

RO nr.220(10): 27 brumaire $V(17$ nov 1796)

RE nr.209: $12 / 13$ frimaire $V(2 / 3$ dec 1796), tweetalig

- verwijzing naar: wetten van I mrt 1793; 15 aug 1793; 18 vendémiaire II (9 okt 1793); 28 brumaire III ( 13 nov 1794)

- de wet van 18 vendémiaire II (9 okt 1793) en alle overige voorgaande wetten die met de onderhawige niet overeensterrmen, zijn herroepen

- afkondiging: besluit Directoire exécutif s. P. Barras (pres), Lagarde (secr-gen); 16 brumaire V (27 okt 1796)

\section{V brumaire 11 (1796 nov 1)}

BL Ille ser no.86 (826); LA V foll 43vo-44vo; rH X 162-163; P VII 437; cB IVe ser VI 249

\section{LOI QUI DÉTERMINE UN MODE POUR LE REMPLACEMENT DES PRÉSIDENS DES TRIBUNAUX CORRECTIONNELS, EN CAS D'EMPECHEMENT OU D'ABSENCE}

De voorzitters van de rechtbanken van correctionele politie kunnen in geval van verhindering of afwezigheid in alle werkzaamheden door de oudste vrederechters die de correctionele rechtbank vormen of bij hun ontstentenis door een andere vrederechter of de eerste assessor worden vervangen. Dit is niet van toepassing voor de functies ten behoeve van de leiding van de jury d'accusation en van het onderzoek van processen die voor de criminele rechtbank gevoerd worden. Art.22 van de wet van 19 vendémiaire IV (11 okt 1795) is herroepen, voor zover het strijdig is met de onderhavige wet.

bo. Conseil des Cinq-cents s. Chasset (pres); Bailleul, Bergoeing, Favart, Riou (secr); Conseil des Anciens J.G. Lacuée (pres); Viennet, Kervelegan, Lepaige (secr)

ao. commission de la classificarion des lois uit de Conseil des Cinq-cents

RO nr.220(11): 27 brumaire $V(17$ nov 1796)

- verwijzing naar: wet van 19 vendémiaire IV ( $\mathbb{1} 1$ okt 1795) [zie RO nr.80] 
- afkondiging: besluit Direcroire exécutif s. P. Barras (pres), Lagarde (secr-gen); 16 brumaire V (27 okt 1796)

\section{V brumaire 13 (1796 nov 3$)$}

BL Ile ser no.88 (843); LA V fol 49vo-54ro; $\mathrm{rH} X 202-211$; P VII 438-442; cB IVe ser VI 152-158

\section{LOI QUi RÈGle la MANIÈRe DE PROCÉDER AU JUGEMENT DES DÉlits MILITAIRES}

Om insubordinatie en gebrek aan discipline tegen te gaan, wordt bij iedere legerdivisie een krijgsraad (conseil de guerre) ingesteld, bestaande uit zeven leden. Een kapitein vervult steeds de functie van commissaris van de pouvoir exécutif voor zowel de naleving van de vormvereisten als de toepassing en uitvoering van de wet. De leden van de krijgsraad worden door de divisiecommandant benoemd. Door een dergelijke krijgsraad kunnen - naast militairen - inwoners van vijandelijk gebied dat door de vijanden van de Republiek is bezet, en overige personen die aan het leger verbonden zijn, worden berecht. Een verdachte kan een vriend als verdediger kiezen. Zittingen van de krijgsraad zijn openbaar, het aantal toeschouwers mag echter niet het drievoudige van het getal der rechters overschrijden. Wanneer drie leden van de raad de verdachte niet-schuldig verklaren, wordt hij terstond op vrije voeten gesteld. Wanneer, met een meerderheid van vijf stemmen, de schuldigverklaring wordt uitgesproken, wordt door de officier die de functie van commissaris van de pouvoir exécutif uitoefent, de in de wet gestelde strafmaat geëist. Op het moment van de bekendmaking van de onderhavige wet zijn de raden en militaire commissies, ingesteld ingevolge de wet van 2 jour complémentaire III (18 sep 1795), opgeheven.

bo. Conseil des Cinq-cents s. Cambacérès (pres); T. Berlier, Mathieu (des Vosges), Fabre (secr); Conseil des Anciens s. J.G. Lacuée (pres); Kervelegan, Viennet, Lepaige (secr)

RO nr.227(1): 18 frimaire V (8 dec 1796)

- verwijzing naar: wet van 2 jour complémentaire III (18 sep 1795)

- afkondiging; besluit Directoire exécutif s. P. Barras (pres), Lagarde (secr-gen); 4 frimaire V (24 nov 1796)

\section{V brumaire 14 (1796 nov 4)}

BL Ile ser no.87 (838); LA IV 151vo-152vo; rH X 179-180; P VII 442; cB IVe ser VI 161-162

\section{LOI PORTANT QUE LES DEMANDES EN CASSATION SERONT TOUJOURS PRECEDÉES D'UNE CONSIGNATION D'AMENDE}

Teneinde een halt toe te roepen aan het overmatig instellen van beroep in cassatie tegen vonnissen van de correctionele en politierechtbanken, dient aan het règlement van 1738 (tit.IV le ged. art.5), welke eisers in cassatie verplicht vooraf een som van 150 of 75 livres te storten, strikt de hand te worden gehouden, zowel op het gebied van het civiele als het correctionele en municipale toezicht. Behoeftige burgers zijn vrijgesteld van deze formaliteit, op vertoon van een certificaat van de kantonsadministratie dat de onvermogendheid constateert, voorzien van de visa van en de goedkeu- 
ring door het departementaal bestuur, onder bijvoeging van een uittreksel van de hun opgelegde belastingen.

bo. Conseil des Cing-çents s. Cambacérès (pres); Fabre, Mathieu, Dubois (des Vosges), T. Berlier (sect); Conseil des Anciens 5. J.G. Lacuée (pres); Lepaige, Viennet, Kervelegan (secr)

ao. commissie uit de Conseil des Cinq-cents belast met het onderzoeken van de boodschap wan het Dinectoire exécutif

RO nr.222(2): 3 frimaite $V(23$ nov 1796)

- verwijzing naar: reglement wan 1738

- afkondiging: besluit Directoire exécutif s. P. Barras (pres), Lagarde (secr-gen); 21 brumaire V (11 now 1796)

\section{V brumaire 16 (1796 nov 6)}

BL lle ser no.87 (839); LA IV foll 152vo-157vo; rH X 185-192; P VIl 443-445; cB TVe ser VI 174179

\section{LOI RELATIVE AUX DEPENSES ORDINAIRES ET EXTRAORDINAIRES DE L'AN V}

De begroting voor het jaar $\mathrm{V}$ bedraagt 1000 miljoen francs (valeur métallique); 450 miljoen daarvan is bestemd voor de vaste uitgaven en 550 miljoen voor de buitengewone uitgaven betreffende de oorlogsvoering. De vaste uitgaven worden in haar geheel geput uit de belastingopbrengst van het jaar V. De buitengewone uitgaven worden bekostigd uit de achterstallige belastingafdracht, uit de opbrengsten van de nationale domeinen en de staatsbossen en uit de verkoop van een additioneel gedeelte der nationale domeingoederen. De hoofdsom van de grondbelasting voor het jaar $\mathrm{V}$ is vastgesteld op 250 miljoen, welke wordt omgeslagen over de 98 departementen in Europa. De personele en weeldebelasting - 50 miljoen francs - wordt van alle inwoners geheven. Tien dagen na de bekendmaking van deze wet zullen er in iedere gemeente voorlopige kohieren voor het jaar $\mathrm{V}$ worden aangelegd. De wet geeft voorts de modaliteiten inzake de belastingafdracht in baar geld en staatsobligaties, alsmede de verkoop van de nationale domeingoederen en de betalingsverplichtingen van de verkrijgers. In de negen départements réunis is deels een afwijkende betalingsregeling van kracht ten gevolge van de bons toegekend aan de vroegere religieuzen, welke hun pensioenen vervangt.

bo. Conseil des Cinq-cents s. Cambacérès (pres); Dubois (des Vosges), Fabre, T. Berlier, Mathieu (secr); Conseil des Anciens s. J.G. Lacuée (pres); Kervelegan, Viennet, Lepaige (secr)

ao. bijzondere commissie uit de Conseil des Cinq-cents voor onderzoek van de boodschap van het Direcroire exécutif

RO nr.222(3): 3 frimaire $V(23$ nov 1796)

RE nr.215: $24 / 25$ frimaire $V(14 / 15$ dec 1796)

- verwijzing naar: wetten van 28 nivôse IV (18 jan 1796); 17 fructidor IV (3 sep 1796); 3 vendémiaire $V(24$ sep 1796); niet nader aangeduide wetten

- afkondiging: besluit Directoire exécurif s. P. Bartas (pres), Lagarde (secr-gen); 21 brumaire V (11 nov 1796) 


\section{brumaire 16 (1796 nov 6)}

BL Ile ser no.90 (850); LA V fol 69vo-70ro; rH X 230-231; P VII 445-446; MAP II 121-123

ARRÊTE QUI DÉTERMINE LA FORME ET LE TYPE DU SCEAU POUR LE BULLETIN DES LoIS

Voor het Bulletin des Lois zal een achthoekig zegelstempel worden gegraveerd met als karakteristiek de wetstafels in een haard van licht rustend op een gevleugelde bliksemstraal, welke de bekendmaking en snelle uitvoering van wetten symboliseert. De verre bestemming van de Republiek en de stabiliteit van haar wetgeving wordt door een zich in de staart bijtende slang verbeeld.

bo. Directoire exécutif

ao. minister van justitie

s. P. Barras (pres); Lagarde (secr-gen)

RO nr.227(4): 18 frimaire V (8 dec 1796)

- verwijzing naar: wet van 12 vendémiaire IV (4 okt 1795)

- afkondiging: besluit Directoire execulf s. P. Barras (pres), Lagarde (secr-gen); 4 frimaire V (24 nov 1796)

\section{$\checkmark$ brumaire 17 (1796 nov 7)}

LA V fol 27; FA nr.254 fol 208ro

ARRÊTÉ QUI NOMME DES COMMISSAIRES DU DIRECTOIRE EXÉCUTIF PRÈS LES MUNICIPALITÉS DU CANTON DE TONGRES ET DE HEYTHUYSEN

L.G. Bartels - homme de loi - is benoemd tot commissaris van het Directoire exécutif bij de kantonsmunicipaliteit van Tongeren, ter vervanging van de afgezette Sermoise. Hanf - onderwijzer te Luik - is benoemd tot commissaris van het Directoire exécutif bij de municipaliteit van het kanton Heythuysen, ter vervanging van de ontslagen Van Velthoven. De commissaris van het Directoire exécutif bij het departementaal bestuur van het departement van de Nedermaas is belast met de uitvoering van het besluit.

bo. gouvemementscommissaris Bouteville

RO nr.218: 19 brumaire V (9 nov 1796); N.B.: in indicareu" général ingeschreven onder de datum van 14 brumaire V (4 nov 1796)

\section{V brumaire 17 (1796 nov 7$)$}

BL Ile ser no.87 (841); LA IV fol 157vo-161ro; rH X 193-198; P VII 446-447; cB IVe ser VI 180184

LOI RELATIVE À LA RÉPARTITION ET AU RECOUVREMENT DES CONTRIBUTIONS DIRECTES 
De wet behelst voorschriften voor een zo spoedlig en tijdig mogelijke invordering van de belastingen. Binnen vijftien dagen na de ontvangst van de wetten ter zake dienen de departementale besturen de omslag der directe belastingen te verrichten, die op hun beurt binnen eenzelfde termijn tot invordering dienen over te gaan. Bij nalatigheid worden door het Directoire exécutif speciaal benoemde commissarissen hiermede belast, wier salarissen ten laste komen van de trage administrateurs. De ontvangers in alle echelons zijn persoonlijk verantwoordelijk voor de afdracht van de belastingen en zij worden eventueel met de inbeslagneming en de verbeurdverklaring van hun goederen bedreigd. In geval van weigerachtigheid van de zijde der belastingplichtigen zullen zij bij wege van inkwartiering tot betaling gedwongen worden, in het uiterste geval door de inbeslagneming en de verkoop van hun onroerende goederen, inclusief de wortelvaste vruchten (fruits pendans par racine). Ook de inning van de belastingen van voorbije boekjaren wordt alsnog geëffectueerd. Op 15 frimaire V (5 dec 1796) dient alles te zijn voldaan. De wet vermeldt voorts de betalingswijzen en de te gebruiken geldsoorten. Pachters zijn gehouden de belastingen van de eigenaars voor te schieten, maar zij kunnen zich doen terugbetalen of een inhouding verrichten op de pacht. Ten slotte voorziet de wet in een versnelde afdracht van de belastingen met de bijbehorende administratieve verwerkingen en kennisgevingen aan hogere autoriteiten.

bo. Conseil des Cinq-cents s. Cambacérès (pres); T. Berlier, Dubois (des Vosges), Fabre, Mathieu (secr); Conseil des Anciens s. J.G. Lacuée (pres); Viennet, Lepaige, Kervelegan (secr)

ao. bijzondere commissie uit de Consell des Cinq-censs voor het onderzoek van de boodschap van het Directoire execurif

RO nr.222(4): 3 frimaire $V(23$ now 1796$)$

RE nr.211: $15 / 16$ frimaire V (5/6 dec 1796)

- afkondiging: besluit Directoire exécutif s. P. Barras (pres), Lagarde (secr-gen); 21 brumaire V (11 nov 1796)

\section{V brumaire 20 (1796 nov 10)}

BL Ile ser no.88 (846); LA V foll 54ro-55ro; rH X 211-212; P VII 447-448; MAP II 129

\section{ARRETE PORTANT QUE LES MARCHANDISES NATIONALES SERONT DISTINGUEES DES MARCHANDISES ANGLAISES PAR UN SIGNE INDICATIF DES FABRIQUES}

Teneinde Franse handelswaar van volstrekt overeenkomstige Engelse waren, die genoemd worden in art.5 van de wet 10 brumaire V (31 okt 1796), te kunnen onderscheiden, dient elke fabrikant zijn product van een merkteken te voorzien. Aan handelaren en dergelijke belast met de verkoop moet hij een ondertekende en gezegelde factuur inzake het fabrieksmerk meegeven, welke door het municipale bestuur van het kanton voor echt verklaard is.

bo. Directoire exécutif

s. P. Barras (pres); Lagarde (secr-gen)

RO nr.227(2): 18 frimaire $V(8$ dec 1796)

- verwijzing naar: wet van 10 brumaire V (31 okt 1796)

- afkondiging: besluit Divectoire exécutif s. P. Barras (pres), Lagarde (secr-gen); 4 frimaire V (24 nov 1796) 


\section{$\checkmark$ brumaire 21 (1796 nov 11)}

BL. Mle ser no.90 (852); LA V fol 44vo-45ro; FA nr. 277 fol 44vo-45ro, FA nr. 2522; rH X 407; P VII 454; MAP II $\| 40$

\section{ARRÊTÉ QUI RÉTABLIT LE DROIT DE TRANSIT PAR MAESTRICHT, DES MARCHANDI- SES EXPEDIEES DU BRABANT BATAVE POUR LE PAYS DE JULIERS}

Handelswaren die van Bataafs Brabant naar het Gulikse en vice versa worden geëxpedieerd, mogen via het grondgebied van Maastricht worden getransporteerd, onder de last een kwijting tot zekerheidstelling (acquit-à-caution) te doen als garantie van de bestemming, alsmede het betalen van een vijfde van de invoergelden, of twee procent van de waarde voor waren die alleen onderworpen zijn aan uitvoergelden dan wel verboden zijn om uit te voeren.

bo. Directoire exécutif

ao. minister van financiën Ramel

s. P. Barras (pres); Lagarde (secr-gen)

ti. minister van financiën

RO nr.223: 3 frimaire V (23 nov 1796); N.B.: in indicateur géméral ingeschreven onder de datum van 4 frimaire $V(24$ nov 1796)

\section{V brumaire 21 (1796 nov 11)}

BL Ile ser no. 89 (848); LA V fol 55ro-64vo; rH X 213-230; P VII 448-454; cB IVe ser VI 193-204;

F $1301-313$

\section{CODE DES DÉlITS ET DES PEINES POUR LES TROUPES DE LA REPUBLIQUE}

In de code worden de militaire strafbare feiten omschreven, zoals desertie (al dan niet naar de vijand), verraad, ronselen en spionage voor de vijand, plundering, verwoesting en brandstichting, beroven van de burgers in bezette gebieden, diefstal en wanbeheer ter zake van de bevoorrading van het leger en insubordinatie in verschillende gradaties. De strafmaat varieert doorgaans van de doodstraf voor de zwaardere vergrijpen tot enige jaren dwangarbeid in ketenen (fers) of eenzame opsluiting (gêne), meestal in combinatie met degradatie. De straffen kunnen in de eerste plaats aan militairen worden opgelegd, in de tweede plaats aan burgers die aan het leger verbonden zijn, en soms ook aan inwoners van bezette gebieden die met de vijand samenwerken. De code is uitgevaardigd in verband met onvoorziene uitwassen en het gebleken gebrek aan discipline.

bo. Conseil des Cinq-cents s. Cambacérès (pres); Fabre, T. Berlier, Mathieu, Dubois (des Vosges) (secr); Conseil des Anciens s. J.G. Lacuée (pres); Lepaige, Viennet, Kervellegan (secr)

RO nr.227(3): 18 frimaire $V(8 \mathrm{dec} 1796)$

- verwijzing naar: "les lois militaires"

- afkondiging: besluit Directoire exécturifs. P. Barras (pres), Lagarde (secr-gen); 4 frimaire V (24 now 1796) 


\section{ARRETE QUI PRESCRIT UN MODE POUR LA PERCEPTION ET L'EMPLOI DES REVENUS DES HOPTTAUX CIVILS SITUES DANS UNE MÊME COMMUNE}

De inkomsten van burgerlijke gasthuizen die in dezelfde gemeente gelegen zijn, zullen door één en dezelfde ontvanger worden geönd en zonder onderscheid voor deze instellingen worden aangewend. Desalniettemin zullen er wel afzonderlijke staten van de uitgaven worden bijgehouden.

bo. Directoire exécunif

s. P. Barras (pres); Lagarde (secr-gen)

RO nr.227(5): 18 frimaire $V(8 \mathrm{dec} 1796)$

- verwijzing naar: wet wan 16 vendémiaire $V(7$ okt 1796)

- afkondiging: besluit Directoire exécutif s. P. Barras (pres), Lagarde (secr-gen); 4 frimaire V (24 nov 1796)

\section{V brumaire 24 (1796 nov 14)}

BL Ile ser no.90 (86I); LA V fol 45vo-47ro; FA nr.277 fol 48vo-50ro; rH X 183-184; P VII 455; MAP II 149-150

ARRETE PORTANT SUPPRESSION DES ANCIENNES IMPOSITIONS, TANT DIRECTES QU'INDIRECTES, ÉTABLIES PAR LE GOUVERNEMENT AUTRICHIEN DANS LES DÉPARTEMENS RÉUNIS PAR LA LOI DU 9 YENDÉMIAIRE, AN IV

Vanaf 1 vendémiaire $V(22$ sep 1796) zullen de oude Oostenrijkse directe belastingen in het vroegere België, bekend onder de naam van aides, subsides, tailles, vingtièmes en overige directe belastingen van welke aard en onder welke benaming ook, niet langer in de negen Verenigde Departementen worden geheven. De departementale besturen dienen tot 15 frimaire $V(5$ dec 1796) de noodzakelijke maatregelen te treffen om de heffing ervan te beëindigen, zowel voor het lopende jaar 1796 als voorgaande jaren. De indirecte belastingen welke eveneens door de voormalige Oostenrijkse regering zijn ingesteld en die door de steden en de vroegere Staten geïnd werden, zijn ook per 1 vendémiaire $\mathrm{V}$ opgeheven. De departementale besturen zullen sedert die datum tot aan de bekendmaking van het onderhavige besluit de opbrengst ervan vaststellen, welke wordt aangewend, met machtiging van de minister van binnenlandse zaken, voor de bestrijding van de departementale, municipale en gemeentelijke uitgaven voor het jaar $\mathrm{V}$, onder gelijktijdige en evenredige vermindering van de opcenten geheven op de grond- en personele belasting.

bo. Directoire exécutif

s. P. Barras (pres); Lagarde (secr-gen)

ti. minister van financiën Ramel

RO nr.224: 7 frimaire $V(27$ nov 1796) 
RE nr.208: 9/10 frimaire V (29/30 now 1796); N.B.: in indicarew general ingeschreven onder de datum van 6 frimaire $V(26$ nov 1796 )

- verwijzing naar: wet van 16 brumaire V (6 nov 1796)

\section{V brumaire 24 (1796 nov 14)}

BL Ile ser no.90 (862); LA $V$ fol 45 ; FA nr.277 fol 48 ; $r H$ X 182; P VII xcix-c; MAP II 150

\section{ARRETTE RELATIF À L'EXÉCUTION DES LOIS DES 16 ET 17 BRUMAIRE, CONCERNANT LES CONTRIBUTIONS DE L'AN V ET LEUR RECOUVREMENT DANS LES DEPARTEMENS RÉUNIS PAR LA LOI DU 9 VENDEMIAIRE, AN IV}

Het Directoire exécutif verlangt de prompte uitvoering van de wetten van 16 en 17 brumaire $V$ ( 6 en 7 nov 1796) inzake de belastingen voor het jaar $V$ en de invordering ervan. Ingevolge zijn besluit van 21 brumaire V (1\ nov 1796) zijn alle bepalingen van de beide wetten in de départements réunis toepasbaar, behoudens die betreffende de bevoegdheid om de belastingschuld te voldoen, hetzij tegen de koers van de mandats [territoriaux], hetzij in assignaten onder de 100 livres.

bo. Directoire exëcurif

s. P. Barras (pres); Lagarde (secr-gen)

ti. minister van financièn Ramel

RO nr.225: 7 frimaire V (27 nov 1796); N.B.: in indicateur génếral ingeschreven onder de datum van 6 frimaire $V(26$ nov 1796)

- werwijzing naar: besluit van 21 brumaire V (11 nov 1796) [zie ook RO nr.222(3) en nr.222(4)]

\section{V brumaire 26 (1796 nov 16)}

BL Ile ser no.90 (865); LA V fol 71; rH X 232-233; P VII 455; cB IVe ser VI 215-216

\section{LOI ADDITIONNELLE À CELLE DU 10 BRUMAIRE QUI PROHIBE L'IMPORTATION ET LA VENTE DES MARCHANDISES ANGLAISES}

Goederen die ingevolge de wet van 10 brumaire $V(31$ okt 1796) per schip naar Frankrijk zijn verzonden en vóór 20 frimaire V (10 dec 1796) in een Franse haven arriveren, zijn niet onderworpen aan de inbeslagneming en verbeurdverklaring, als elders de voorgeschreven formaliteiten zijn vervuld. Burgers voor wie deze goederen bestemd zijn, dienen een aangifte ter zake aan het douanekantoor te doen toekomen, alsmede de vrachtbrief vóor de aankomst van het schip te deponeren. Er zal gebruik van worden gemaakt in het geval er sprake is van het gedwongen binnenlopen van een haven.

bo. Conseil des Cinq-cents s. Cambacérès (pres); Dubois (des Vosges), T. Berlier, Mathieu (secr); Conseil des Anciens s. J.G. Lacuée (pres); Lepaige, Viennet, Kervelegan (secr)

ao. bijzondere commissie uit de Conseil des Cinq-cents

RO nr.227(6): 18 frimaire $V(8$ dec 1796)

RE nr.216: 24/25 frimaire $V(14 / 15$ dec 1796)

- afkondiging: besluit Directoire exécutif s. P. Barras (pres), Lagarde (secr-gen); 4 frimaire V (24 nov 1796) 
ARRÉTE QUI DESTTUUE LES ADMINISTRATEURS MUNICIPAUX DU CANTON DE MAESEYCK QUI ONT CONCURRU À LA PROVOCATION ADRESSÉE À LEURS ADMINISTRÉS, \&C

De administrateurs van het kanton Maaseik zijn ontslagen, aangezien zij medewerking hebben verleend aan het adres van 5 brumaire V (26 okt 1796) gericht tot de inwoners van het kanton en aan het verzoekschrift van het municipale bestuur van 13 brumaire V ( 3 nov 1796), welke gericht zijn tegen de uitvoering van de wet van 15 fructidor IV (1 sep 1796), houdende de opheffing van de religieuze instellingen. Het adres en het verzoekschrift zijn beide vernietigd. De gouvernementscommissaris Bouteville dient zorg te dragen voor de volledige uitvoering van de wetten. Het Directoire exécutif behoudt zich het recht voor de kantonsadministrateurs aan de rechter over te dragen, zodra het nadere inlichtingen zal hebben ontvangen van het departementale bestuur.

\section{bo. Directoire exécutif}

ao. minister van binnenlandse zaken Bénézech

s. P. Barras (pres); Lagarde (secr-gen)

ti. gouvernementscommissaris Bouteville

RO nr.226: 9 frimaire V (29 nov 1796); N.B.:" in indicateur général ingeschreven onder de datum van 24 brumaire $V(14$ nov 1796$)$

- verwijzing naar: grondwet van 5 fructidor III (22 aug 1795); wet van 15 fructidor IV (1 sep 1796)

\section{V brumaire 27 (17 nov 1796)}

BL IIe ser no.92 (869); LA V fol 96; rH X 290-291; P VII 456; cB IVe ser VI 217-218

LOI RELATIVE AU PAIEMENT des VALEURS STIPULÉES DANS LES BAUX À FERME ANTÉRIEURS AU DÉCRET DU $1^{\text {KR }}$ BRUMAIRE, AN II, EN ÉQUIVALENT DE LA DIME ET D'AUTRES DROITS SUPPRIMÉS

Eigenaren die in hun pachtcontracten bepaald hebben dat hun een bedrag betaald zal worden naast dat van de pachtsom, hebben het recht dat bedrag op te eisen, zonder rente evenwel. Dit ondanks het bepaalde in art.1 van het decreet van 1 brumaire II ( 22 okt 1793), dat is herroepen voor wat betreft de afgesloten pachtovereenkomsten en toegestemde bepalingen, tot stand gekomen vóór de bekendmaking van het decreet.

bo. Conseil des Cinq-cents s. Cambacérès (pres); Dubois (des Vosges), T. Berlier, Mathieu (secr); Conseil des Anciens s. J.G. Lacuée (pres); Kervelegan, Lepaige, Viennet (secr)

RO nr.232(13): 1 nivôse V (21 dec 1796)

- verwijzing narar: wetten van $1 \rrbracket$ mrt * 10 apr 1791; 25 aug 1792; 1 brumaire II (22 okt 1793); "des lois prohibutives"

- afkondiging: besluit Directoire exëcutif s. P. Barras (pres), Lagarde (secr-gen); 16 frimaire V (6 dec 1796) 


\section{ARRÊTE RELATIF AUX PATENTES OU COMMISSIONS EN COURSE EXPÉDIÉES PAR LE GOUVERNEMENT ANGLAIS PENDANT L'INVASION DE LA CORSE}

Corsicanen, houders van een door vijandelijke regeringen uitgereikte kaperbrief (commission en course), en die ontwapend zijn en hun opdracht aan de burgerlijke of militaire autoriteiten hebben overhandigd, worden naar Corsica teruggestuurd en ter beschikking gesteld van de gouvernementscommissaris aldaar. Dit geldt eveneens voor alle Corsicaanse zeelieden en vrijwilligers die zich van te voren op een kaperschip hebben ingescheept en thans afzien van dit soort kaapvaart. Degenen die onder Engelse of Anglo-Corsicaanse vlag blijven varen, zullen worden gearresteerd en als piraten en bandieten worden behandeld.

bo. Directoire exéccurif

ao. minister van marine en koloniën

s. P. Barras (pres); Lagarde (secr)

RO nr.232(15): 1 nivôse V (21 dec 1796)

- afkondiging; besluit Directoire exécutif s. P. Barras (pres), Lagarde (secr-gen); 16 frimaire V (6 dee 1796)

V brumaire 29 (1796 nov 19)

LA V fol 114; FA nr.277 fol 100ro-101 ro, FA nr.2601

\section{ARRÊTÉ RELATIVEMENT AU NOUVEAU MODE D'ADMINISTRATION DES HOUILLÈRES DE ROLDUC}

De reguliere kanunniken van de abdij Kloosterrade (Rolduc) dienen de gebouwen binnen twee decades na de uitreiking van de bons te verlaten en over te dragen aan de directie der nationale domeinen. Het voorlopige militaire beheer over de steenkoolmijnen, ingesteld bij besluit van de commissaris-ordonnateur van 1 thermidor IV (19 jul 1796), eindigt op het moment dat de directie der nationale domeinen de gebouwen en terreinen overneemt. Het beheer en de exploitatie dient zodanig te geschieden, dat er voldoende brandstof voor het leger voorradig is.

bo. Directoire exécurif

ao. minister van financiën Ramel

s. P. Barras (pres); Lagarde (secr-gen)

ti. minister van financiën; l'administrateur de la Régie de l'Enregistrement et du Domaine National, commissaire spécial du Directoire exécutif dans les Départemens réunis Bochet

RO nr.237: 11 nivôse V (31 dec 1796); N.B.: in indicatew gếnéral ingeschreven onder de datum van 24 frimaire $V(14 \operatorname{dec} 1796)$

- verwijzing naar: besluit commissaire-ordonnateur en chef des armées de la République et commissaire du gouvernement près les armées du Nord et de Sambre et Meuse et pays environnans Alexandre van I thermidor IV (19 jul 1796); wet van 15 fructidor IV (1 sep 1796) 
BL Ile ser no.92 (873); LA V fol 103; rH X 300-301; P VII 459; MAP II 174

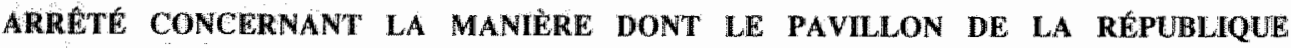 FRANÇAISE EN USERA ENVERS LES BÂTIMENS NEUTRES
}

Aan alle neutrale en geallieerde mogendheden wordt kennisgegeven, dat de Franse vlag op dezelfde manier jegens neutrale schepen wordt gehanteerd als neutrale schepen de de Engelse vlag eerbiedigen. Eén en ander geldt zowel voor confiscatie, als bij inspectie of inbeslagneming.

bo. Directoire exécutif

s. P. Barras (pres); Lagarde (secr-gen)

RO nr.232(16): I nivôse V' (2| dec 1796)

- afkondiging: besluit Divectoire exéc utif s. P. Barras (pres), Lagarde (secr-gen); 16 frimaire V (6 dec 1796)

\section{$\checkmark$ frimaire 2 (1796 nov 22)}

\author{
LA V fol 114vo-138ro; rH XVI 321-356
}

\section{INSTRUCTION SUR LE NOUVEAU MODE DE VENTE DES DOMAINES NATIONAUX AUX ENCHÈRES, ORDONNÉ PAR LA LOI DU 16 BRUMAIRE AN $V$}

Met behulp van de Instructie wordt een toelichting gegeven op de wijze van verkoop bij opbod van de nationale domeingoederen, zoals deze ingevolge de wet van 16 brumaire V (6 nov 1796) dient te geschieden. Alle nationale domeingoederen, daaronder die gelegen in de départements réunis, worden ten verkoop aangeboden, behalve de goederen die voor de openbare dienst gereserveerd zijn en de staatsbossen. De Instructie verwijst naar een veelheid van wetten ter zake van de modaliteiten met betrekking tot de verkoping van nationaal domeingoed. Een aparte paragraaf is gewijd aan bijzondere bepalingen betreffende de te verkopen goederen in de negen Verenigde Departementen.

bo. Directoire exécutif [Instructie goedgekeurd op 12 frimaire V (2 dec 1796)]

ao. minister van financièn Ramel

ii. minister van financiën

s. P. Barras (pres); Lagarde (secr-gen)

RO nr.238: 13 nivôse $V$ (2 jan 1797)

- verwijzing naar: decreten wan 22 dec 1789, 14 mei 1790; instructie van 31 mei 1790; wetten van 25 jul 1790, 16*24 aug 1790; decreten van 23 okt 1790, 3 nov 1790, 9 mrt 1791, $16 \mathrm{mrt} 1791$; instructie van 3 jul 1791; wet van 10 jul 1791; decreten van 19 jul 1791, 6 aug 1791, 13 sep 1791; wetten van $9 \mathrm{feb} 1792,13$ sep 1792, 1 \& 4 apr 1793; decreten van 24 apr 1793, 3 jun $\rrbracket 793,15$ frimaire II ( 5 dec 1793); wetten van 10 frimaire II ( 30 mov 1793), 17 frimaire II ( 7 dec 1793), 26 frimaire II (16 dec 1793), 11 ventôse II (1 mrt 1794), 28 germinal II (17 apr 1794), 21 floréal II (10 mei 1794); 2 prairial II (21 mei 1794), II prairial II (30 mei 1794), 21 prairial II ( 9 jun 1794), 1 messidor II (19 jun 1794), 2 messidor II (20 jun 1794), 23 messidor II ( 1 I jul 1794), 7 thermidor II (25 jul 1794), 19 vendémiaire III (10 okt 1794), 25 brumaire III (15 nov 1794), 22 frimaire III (12 dec 1794), 6 ventôse III (24 feb 1795), 21 ventôse III (11 mrt 1795), 15 germinal III (4 apr 1795$), 1$ 
floreal III (20 apr 1795); decreet van 3 floreal III (22 apr 1795); wetten van 9 floreal III (28 apr 1795), 21 prairial III (9 jun 1795); code hypothecaire wan 9 messidor III ( 27 jun 1795); wetten wan 3 vendémiaire IV (25 sep 1795), 7 vendémiaire IV $(29$ sep 1795), 2 brumaire IV (24 okt 1795), 30 brumaire IV (21 nov 1795), 19 nivôse IV (9 jan 1796), 28 ventôse IV (18 mrt 1796), 28 germinal IV (17 apr 1796), 6 floréal IV (25 apr 1796), 20 floréal IV $(9$ mei 1796), 30 thermidor IV (17 aug 1796), 15 fructidor IV (1 sep 1796), 17 fructidor IV (3 sep 1796), 20 fructidor IV (6 sep 1796); arrêté wan 23 fructidor IV (9 sep 1796); wet van 16 brumaire V ( 6 nov 1796); code d'aliénation du comité de l'Assemblée nationale

\section{V frimaire 3 (1796 nov 23)}

BL IIe ser no.92 (874); LA V fol 71vo-72vo; tH X 234-235; P VII 459; cB IVe ser VI 232-233

\section{LoI PORTant Rétablissement de droits d'entrée RÉdut PAR CRlle du 12 PLUVIÔSE, AN III}

De bepalingen in de wet van 12 pluviôse III ( 31 jan 1795), houdende de reductie van de invoerrechten op een veelheid aan producten, zijn herroepen. Deze rechten zullen voortaan als vóór de reductie worden geheven. Levensmiddelen en producten afkomstig uit de Franse koloniën in Amerika, van Franse eilanclen en Mozambique, die rechtstreeks naar Frankrijk worden getransporteerd, zijn vrij van alle heffingen. De douanerechten worden in muntgeld geheven.

bo. Conseil des Cinq-cents s. Cambacérès (pres); Dubois (des Vosges), T. Berlier, Fabre, Mathieu (secr); Conseil des Anciens s. Bréard (pres); Girod (de l'Ain), Fourcroy, Rousseau, Vigneron (secr) ao. bijzondere commissie uit de Consell des Cinq-cents

RO mr.227(7): 18 frimaire $V(8$ dec 1796)

- verwijzing naar: "lois existantes avant la dite réduction"; wetten van 11 sep 1793; 12 pluviôse III (31 jan 1795)

- afkondiging: besluit Directoire exécutif s. P. Barras (pres), Lagarde (secr-gen); 4 frimaire V (24 now 1796)

\section{V frimaire 3 (1796 nov 23)}

BL Ile ser no.93 (883); LA V fol 103vo-107ro; rH X 301-306; P VII 459-461; MAP II 179-182

\section{ARRETE QUI PRESCRIT DES MESURES DE SORETE POUR L'ADMISSION DES NAVIRES NEUTRALISES, ET DES INDIVIDUS VENANT D'ANGLETERRE, DANS LES PORTS DE LA REPUBLIQUE}

In het besluit worden nadere veiligheidsmaatregelen afgekondigd in de Franse havens ten aanzien van neutrale schepen en reizigers die uit Engeland komen. Het besluit beoogt de binnen- en buitenlandse vijanden van de Republiek de wind uit de zeilen te nemen. Op de neutrale schepen vindt inspectie plaats en de kapiteins dienen van de nodige documenten te zijn voorzien. Het municipale bestuur en de commissarissen van het Directoire exécutif hebben, naast de marine-administrateurs en de garnizoenscommandant, een toezichthoudende rol. Uit Engeland afkomstige schepen mogen een Franse haven alleen binnenlopen als de weersomstandigheden daartoe noodzaken. 
Franse en buitenlandse reizigers die uit Engeland komen, mogen zich alleen in de havens van Dieppe en Calais ontschepen. De besluiten van 20 germinal IV ( 9 apr 1796) en 19 floréal IV (8 mei 1796) zijn herroepen.

bo. Dinectoire executif

ao. minister van police générale

s. P. Barras (pres) . Lagarde (secr-gen)

RO nr.232(17): 1 niwóse V (21 dec 1796)

- verwijzing naar: wetten van 23 messidor III (11 jul 1795); 15 thermidor III ( 2 aug 1795); besluiten wan 20 germinal IV ( 9 apr 1796); 19 floréal IV ( 8 mei 1796)

- afkondiging: besluit Directoire exécutif s. P. Barras (pres), Lagarde (secr-gen); 16 frimaire V (6 dec 1796)

V frimaire 3 (1796 nov 23)

LA V fol 138; FA nr.277 fol 108vo-109vo

ARRÊTTÉ QUI APPROUVE L'ARRÊTÉ DE L'ADMINISTRATION DÉPARTEMENTALE DE LA MEUSE-INFÉRIEURE DU 8 BRUMAIRE DERNIER PORTANT SUSPENSION DE QUELQUES AGENS MUNICIPAUX DE CANTON DE TONGRES

Het Directoire exécutif bevestigt het besluit van het bestuur van het departement van de Nedermaas van 8 brumaire V (29 okt 1796), waarin de municipale agenten van de gemeenten Lauw, Rheeren ['s Heeren], Relderen [Elderen; thans 's Herenelderen], Morgeen [lees: Neerrepen] en Rutten, gelegen in het kanton Tongeren, worden geschorst, vanwege het feit dat zij hebben geweigerd mee te werken aan de repartitie in de gedwongen geldlening (emprunt forcé). Hun adjoints moeten terstond overgaan tot het aanleggen van de kohieren van de dwanglening. De kosten die weigering van de medewerking heeft veroorzaakt door het sturen van commissarissen en de gewapende macht, moeten persoonlijk door de municipale agenten worden gedragen. Het departement dient streng de hand te houden aan de uitvoering van het arrêté en daarvan rekenschap te geven aan de minister van financiën.

bo. Directoire exë̌urif

s. P. Barras (pres); Lagarde (secrogen)

ti. minister van financiën Ramel

RO nr.239: 17 niwôse $V$ (2 jan 1797); N.B.: in indicateur général ingeschreven onder de datum van 27 vendémiaire $\mathrm{V}(18$ okt 1796$)$

\section{$\checkmark$ frimaire 4 (1796 nov 24)}

BL IIe ser no.93 (884); LA V foll 75ro-78ro; rH X 236-240; P VII 461-462; MAP II 183-186

ARRÊTE QUI DÉTERMINE LES RAPPORTS EXISTANS ENTRE LES COMMISSAIRES DU GOUVERNEMENT PRÈS LES ADMINISTRATIONS ET PRÈS LES TRIBUNAUX, ET QUI PRESCRIT DES MESURES POUR LA POURSUITE DES DÉLITS 
Het besluit behelst de bevordering van een goede samenwerking tussen de onderscheidene commissarissen van het Directoire exécutif bij zowel de rechtbanken als de bestuursorganen, in het bijzonder ten aanzien van delicten en de tenuitvoerlegging van criminele, correctionele en politievonnissen. Wederzijds zijn de commissarissen gehouden elkaar te informeren over begane delicten die de openbare rust zouden kunnen verstoren, opdat de noodzakelijke politiemaatregelen kunnen worden genomen. Iedere décade (tien dagen) dient er een overzicht van gepleegde strafbare feiten en de ingestelde vervolgingen te worden opgezonden. De commissarissen van het Directoire exécutif bij de criminele rechtbanken zenden de eerste van elke maand aan de minister van justitie een overzicht van de namen van de commissarissen bij de municipale besturen en de correctionele rechtbanken met de vermelding wie van hen zich exact aan de voorschriften heeft gehouden en wie niet. De commissarissen bij de criminele rechtbanken sturen de minister een algemene opgave van gewezen vonnissen. Op de vijftiende van iedere maand worden door de minister van justitie de toegezonden naamlijsten en overzichten ter kennis gebracht van het Directoire exécutif, opdat het de commissarissen die het aan ijver en exactheid ontbreekt, kan ontslaan.

bo. Directoire exécutif

ao. minister van justitie

s. P. Barras (pres); Lagarde (secr-gen)

RO nr.228: 19 frimaire $V(9$ dec 1796)

- verwijzing naar: besluit van 20 plaviôse IV ( 9 feb 1796)

- "Il sera publié et exécuté dans les départemens réunis par la loi du 9 vendémiaire, an IV, comme dans les autres départemens de la République"

\section{V frimaire 7 (1796 nov 27)}

BL Ile ser no.94 (890); LA V foll 107ro-108ro; rH X 307-309; P VII 463-464; cB IVe ser VI 245246

\section{LOI QUI ORDONNE LA PERCEPTION PENDANT SIX MOIS, AU PROFIT DES INDIGENS, D'UNE DÉCIME PAR FRANC EN SUS DU PRIX DES BILLETS D'ENTRÉE DANS TOUS LES SPECTACLES}

Op de entreegelden voor alle openbare voorstellingen en voor besproken plaatsen zal gedurende zes maanden één décime per franc (=twee stuivers per livre) worden geheven. De opbrengst hiervan komt ten goede aan behoeftige burgers die zich niet in een gasthuis (hospice) bevinden. Zoveel mogelijk zal de onderstand aan huis in natura worden verleend. Eén maand na de bekendmaking van de onderhavige wet zullen er in de gemeenten bureaus van weldadigheid (bureaux de bienfaisance), gevormd door vijf personen, worden opgericht, die de zorg voor het beheer van de gelden hebben. De leden van een bureau van weldadigheid genieten geen bezoldiging. De wetten van 19 maart 1793 en 22 floréal III (11 mei 1795) zijn voor wat betreft de onderstand herroepen.

bo. Conseil des Cinq-cents s. Cambacérès (pres); T. Berlier, Mathieu, Dubois (des Vosges), Fabre (secr); Conseil des Anciens s. Bréard (pres); Vigneron, Girod (de l"Ain), Rousseau (secr)

ao. commission de lorganisation des secours uit de Conseil des Cinq-cents 
RO nr.232(18): I nivôse $V(21$ dec 1796)

- verwijxing naar: wetten van 19 maart $1793 ; 22$ floréal III (11 mei 1795)

- afkondiging: besluit Directoire execulf s. P. Barras (pres), Lagarde (secr-gen); 16 frimaire V (6 dec 1796)

\section{V frimaire 9 (1796 nov 29)}

BL Ile ser no.94 (891); LA V foll 108vo-110vo; $r H$ X 309-314; P VII 464-466; cB IVe ser VI 246250

\section{LOI ADDITIONNELLIE A CELLE DU 6 FRUCTIDOR, AN IV, SUR LES PATENTES}

Enige artikelen van de wet van 6 fructidor IV (23 aug 1796) die de patentbelasting instelt, dienen nader te worden gepreciseerd, teneinde de moeilijkheden die een volledige inning in de weg staan op te heffen. In deze aanvullende wet worden sommige burgers vrijgesteld van het patentrecht. Anderen daarentegen zijn patentplichtig geworden. Het gaat veelal om burgers die waren ten verkoop aanbieden. De municipale agent en zijn adjoint zijn gehouden binnen tien dagen na de ontvangst van de onderhavige wet aan het kantonnale bestuur een opgave van die burgers te doen, die vanwege hun handel en nijverheid onder het patentrecht vallen. Bij nalatigheid van burgers in het voldoen van de patentbelasting wordt er vervolging tegen hen ingesteld. Aan het slot van de wet zijn de tariefklassen van het patentrecht voor met name genoemde beroepsgroepen vermeld.

bo. Conseil des Cinq-cents s. Quinette (pres); Duhot, Hardy, G. Malès (secr); Conseil des Anciens s. Breard (pres); Fourcroy, Rousseau, Girod (de l'Aim) (secr)

RO nr.232(19): 1 nivôse V (21 dec 1796)

RE nr.221: $12 / 13$ nivôse V (1/2 jan 1797)

- in het cB-intinlé is abusievelijk sprake van $\mathbf{8}$ fructidor $\mathbb{V V}$ (25 aug 1796)

- afkondiging: besluit Directoire exécutif s. P. Barras (pres), Lagarde (secr-gen); 16 frimaire V (6 dec 1796)

\section{V frimaire 9 (1796 nov 29)}

BL IIe ser no.94 (892); LA $V$ fol 111; rH X 314-316; P VII 466; cB IVe ser VI 250-251

LOI QUI RAPPORTE LES DISPOSITIONS DE L'ART.XIX DE LA LOI DU 6 FRUCTIDOR AN IV PAR Lesquelles les MaNufacturiers SONT DISPENSÉS DU DROIT DE PATENTES

Het bepaalde in art.19 van de wet van 6 fructidor IV (23 aug 1796) dat fabrikanten voor het jaar $V$ dispensatie van het patentrecht verleent, is na klachten dienaangaande herroepen. Elke fabrikant moet zich van een patent voorzien dat aan een hoger tarief onderworpen is dan het patentrecht dat detailhandelaren moeten voldoen. Handwerkslieden die voor eigen rekening werken, zijn zij die geen personeel in dienst hebben, noch een winkel of een magazijn, noch een uithangbord hebben, en die verkopen naargelang het resultaat van hun arbeid, vallen onder de zesde tariefklasse. Alle andere tariefsomschrijvingen zijn slechts van toepassing op hen die in het groot of en 
detail de genoemde zaken verkopen. Degenen die de goederen fabriceren vallen in een hogere tariefklasse als hierboven vermeld.

bo. Conseil des Cinquents s. Cambacérès (pres); Dubois (des Vosges), Fabre (secr); Conseil des Anciens s. Bréard (pres); Rousseau. Girod (de l'Ain) (secr)

RO nr.232(20): 1 nivôse $V(21$ dec 1796)

- afkondiging: besluit Direcroire exécutif s. P. Barras (pres), Lagarde (secr-gen); 16 frimaire V (6 dec 1796)

V frimaire 15 (1796 dec 5 )

LA $V$ fol 73 vo; FA nr.257 fol 39vo, FA nr.4285

ARRÉTÉ QUI NOMME LE CITOYEN CHENARD À LA PLACE D'ADMINISTRATEUR DU DÉPARTEMENT DE LA MEUSE-INFERIEURE, EN REMPLAÇANT DU CITOYEN BELIN, DÉMISSIONNAIRE

Chenard - homme de loi te Mons [Bergen; departement Jemappes] - is als administrateur van het departement van de Nedermaas benoemd, ter vervanging van Belin (Bellin) die zijn aanstelling niet aanvaard heeft.

bo. gouvernementsconmissaris Bouteville

ti. Bouteville

RO nr.229: 21 frimaire V (11 dec 1796); N.B.: in indicateur général ingeschreven onder de datum wan 13 frimaire $V(3$ dec 1796$)$

- FA nr. 257: de naam Belin slecht leesbaar

\section{$V$ frimaire $15(1796$ dec 5)}

LA IV fol 223ro-229ro; FA nr.291; rH X 241-253; P VII ci-cwi

INSTRUCTION RELATIVE À LA LIQUIDATION DES CRÉANCES SUR LES MAISONS ET ETABLISSEMENS RELIGIEUX DE L'UN ET DE L'AUTRE SEXE, SUPPRIMEE PAR LA LOI DU 15 FRUCTIDOR, AN IV, DANS LES DÉPARTEMENS REUNIS EN CONFORMITE DE CELLE DU 9 VENDÉMIAIRE PRÉCEDENT

De Instructie behelst uitleg over de schuldvorderingen op de door de wet van 15 fructidor IV ( 1 sep 1796) opgeheven religieuze instellingen beider sexe en de snellere vereffening daarvan. Met name wordt nadere uitleg gegeven over de in de negen Verenigde Departementen ingevolge art. 19 van de wet bekendgemaakte wetten betreffende de liquidatie en terugbetalingen van de schulden van de opgeheven instellingen. Bijzondere aandacht wordt daarbij gegeven aan de onderscheidene schuldvorderingen aangaande hun authenticiteit, alsmede de te verrichten noodzakelijke formaliteiten, alvorens kan worden overgegaan tot vereffening dan wel inschrijving in het grootboek der openbare schuld. De Instructie is bedoeld om het werk van bestuurslichamen te vergemakkelijken, alsmede om nuttige informatie aan de schuldeisers te verschaffen. 
bo. Direksore exéculf

ao. minister van financièn

s. P. Barmas (pres); Lagarde (secr-gen)

RO nr.233: I nivôse V (21 dec 1796)

RE nr.228: 1/2 pluviôse V (20/21 jan 1797)

- verwijzing nalar: wetten van 23 okt 1790; 27 okt 1790; 24 aug 1793; 11 sep 1793; 21 frimaire III (11 dec 1793; 23 floréal II (12 mei 1794); 23 messidor II (11 jul 1794); 27 messidor II (15 jul 1794); 23 prairial III (1 I jun 1795); 23 messidor III (II jul 1795); 3 brumaire IV (25 okt 1795); 15 fructidor IV ( 1 sep 1796); 16 brumaire $V(6$ nov 1796$)$

- "Le Direcroire exécutif (...) arrête que ladite Instruction sera imprimée, publiée et affichée dans lesdits dếpartemens, pour y être exécutée selon sa forme et teneur"

\section{$V$ frimaire $16(1796$ dec 6$)$}

LA V fol 74ro-75ro; FA nr.291; rH XI 3-5; P VII cvi-cvii; MAP II 208-209

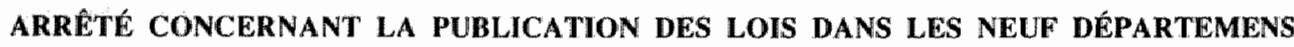 REUNIS PAR CELLE DU 9 VENDÉMIAIRE, AN IV}

Teneinde op een voortvarender wijze tot de uitvoering van wetgeving in de negen Verenigde Departementen te geraken, is bepaald dat de wetten en de besluiten van het Directoire exécutif geplaatst in het Bulletin des Lois die, gerekend van 16 frimaire V (6 dec 1796) aldaar arriveren, verbindend zijn voor de départements réunis, zoals in de andere departementen, vanaf de dag dat de cahiers van het Bulletin in de departementshoofdplaats verspreid worden, tenzij door middel van bijzondere besluiten wetgeving wordt uitgezonderd. Uitgezonderd zijn ook de wetten of wetsartikelen die de mandats territoriaux betreffen. De minister van justitie dient in voorkomende gevallen bij de wetten en besluiten die door hem in het Bulletin des Lois moeten worden geplaatst binnen 24 uur een ontwerp voor een arrêté aan het Directoire exécutif voor te stellen, houdende dat de départements réunis van de uitvoering uitgezonderd zijn. De overige ministers moeten zulks kenbaar maken via de minister van justitie. Voorts moet de minister van justitie binnen één maand aan het Directoire exécutif een overzichtsstaat doen toekomen van nog niet-bekendgemaakte Franse wetten, welke van nu af aan voor uitvoering vatbaar zijn. Binnen twee decades dienen de overige ministers daartoe een staat van dergelijke wetten die speciaal hun bevoegdheden betreffen aan de minister van justitie doen toekomen.

bo. Directoire exécutif

ao. minister van justitie

s. P. Barras (pres); Lagarde (secr-gen)

RO or. 230: 27 frimaire $V(17 \mathrm{dec} 1796)$

RE nr.219: 7/8 nivôse V (27/28 dec 1796)

- verwijzing naari: besluit comisé de salut public van 20 frimaire III (10 dec 1794); wet van 3 brumaire IV (25 okt 1795); besluiten Directoire exécurifif van 18 pluviôse IV (7 feb 1796); 20 germinal IV ( 9 apr 1796)

- MAP-imtinule: "arrêté prescrivant le mode d'envoi des lois aux départemens réunis par la loi du 9 vendémiaire, an IV, \& ordonnant la publication de plusieurs lois"

- "Le présent arrêtế sera imprimé, et ne sera envoyé qu'aux départemens réunis. Il en sera adressé expédition aux sept ministres" 


\section{ARRÊTÉ QUI RÉTABLIT LE MODE DES RÉQUISITIONS}

De bevoorrading van het Sambre-en-Maasleger en het Rijn-en-Moezelleger kan worden opgelegd aan de departementale, municipale en overige besturen in de veroverde gebieden en de départements réunis. De requisities kunnen alleen uitgaan van het opperbevel voerende generaals, gouvernementscommissarissen en commissarissenordonnateurs van oorlog. De requisitie dient steeds het tijdstip en de plaats van leverantie te bevatten en zal ter hand worden gesteld aan het bestuur dat de requisitie dient uit te voeren. Weigerachtigheid van de zijde der contribuabelen wordt met behulp van de gewapende macht gebroken. De leveranties die aan particulieren zijn opgelegd, vermelden de door het bestuur vastgestelde prijs, welke na visering van het reçu in de Verenigde Departementen in mindering wordt gebracht op de belastingen in geld.

bo. Directoire exécutif

ao. minister van oorlog

s. P. Barras (pres); Lagarde (secr-gen)

ti. commissaire-ordonnateur en chef de l'armée de Sambre et Meuse Luuyt

RO nr.247: 6 pluviôse V (25 jan 1797); N.B.: in indicateur gênéral ingeschreven onder de datum van 24 nivôse V (13 jan 1797)

$V$ frimaire 27 (1796 dec 17)

LA V fol 112; FA nr.257 fol 88vo-89vo, FA nr.4201

\section{ARRÊTÉ PORTANT QUE LA COMMUNE D'EIGELSHOVEN DEMEURERA RÉUNIE ET ATTACHÉE AU CANTON DE ROLDUC}

De gemeente Eygelshoven blijft deel uit maken van het kanton 's-Hertogenrade (Rolduc) gelegen in het departement van de Nedermaas, dat de gemeente geheel omsluit. In het besluit van het comité de salut public van 14 fructidor III (31 aug 1795 ) is deze gemeente bij vergissing vergeten. Het departementaal bestuur dient alle noodzakelijke maatregelen te nemen, teneinde alle afgekondigde wetten in de départements réunis in de gemeente Eygelshoven te doen bekendmaken en uitvoeren. Aan de gouvemementscommissaris moet het twee personen voordragen voor de vervulling van de functies van municipale agent en diens adjunct. De commissaris van het Directoire exécutif bij het departementaal bestuur is belast met de uitvoering van het onderhavige besluit.

bo. gouvernementscommissaris Bouteville

ti. Bouteville

RO nr.231: 29 frimaire V (19 dec 1796); N.B.: in indicateur général ingeschreven onder de datum van 12 frimaire $V(2 \mathrm{dec} 1796)$

- verwijzing naar: besluit comité de salu' public van 14 fructidor III (31 aug 1795) 
- besluit uitgewardigd na.v. briewen van de commissaris van het Directoire exécutif bij het kanton

"\$Hertogenrade, het municipale bestuur van het kanton en het departementaal bestuur van Nedermaas

\section{V frimaire 29 (1796 dec 19)}

LA $V$ fol 78; FA nr.258 fol 5, FA nr.896

\section{ARRÉTÉ QUI NOMME LE CTTOYEN POYCK À LA PLACE DE COMMISSAIRE DU DIREC- TOIRE EXÉCUTIF PRES LA MUNICIPALITÉ DU CANTON DE ROLDUC EN REMPLACE- MENT DU CITOYEN HENNEQUIN DEMISSIONNAIRE}

Poyck - voorzitter van de kantonsmunicipaliteit van 's-Hertogenrade (Rolduc) - - is benoemd tot commissaris van het Directoire exécutif bij hetzelfde kanton, ter vervanging van de aftredende Hennequin. De commissaris van het Directoire exécutif bij het departement van de Nedermaas is belast met de uitvoering van het onderhavige besluit.

bo. gouvernementscommissaris Bouteville

RO nr.234: 1 nivôse V (2I dec 1796); N.B.: in indicateur général ingeschreven onder de datum van 26 frimaire $\mathrm{V}(16 \mathrm{dec} 1796)$

\section{$V$ frimaire 29 (1796 dec 19)}

LA $V$ foll 145vo-146ro; FA nr.277 fol 121; MAP II 236-237

ARRÊTÉ QUI ORDONNE L'EXÉCUTION DE LA LOI DU 7 FRIMAIRE DERNIER PORTANT QU'IL SERA PERÇU PENDANT SIX MOIS AU PROFIT DES INDIGENS D'UN DÉCIME PAR FRANC EN SUS DU PRIX DES BILLETS D'ENTRÉE DANS TOUS LES SPECTACLES

De inning van één décime per franc bestemd voor behoeftige burgers gedurende zes maanden op de entreegelden voor alle openbare voorstellingen is vertraagd door de moeilijkheden, die door de directeuren en uitbaters van vermakelijkheden te Parijs zijn opgeworpen. Vanaf de dag van de kennisgeving van het onderhavige besluit zijn zij gehouden deze gelden te innen en de opbrengst ervan af te dragen aan het bureau central van het kanton Parijs.

bo. Directoine exécutif

s. P. Barras (pres); Lagarde (secr-gen)

ti. minister van binnenlandse zaken Bênézech

RO nr.244: 27 nivôse V (16 jan 1797)

- verwijzing naar: wet van 7 frimaire $V(27$ nov 1796)

- de geleidebrief van de minister van binnenlandse zaken van 16 nivôse $V(5$ jan 1797) stelt dat het bepaalde voor Parijs in het besluit mutatis mutamdis ook geldt voor het departement van de Nedermaas

$\checkmark$ nivôse 2 (1796 dec 22)

LA $V$ fol 113; FA nr.259 fol 1 ro-2ro, FA nr.896 


\title{
ARRETÉ PORTANT NOMINATION D'UNE NOUVELLE ADMINISTRATION MUNICIPALF. DU CANTON DE MAESEYCK, EN REMPLACEMENT DE LA COMMISSION ADMINISTRA * TIVE SUPPRIMÉE
}

In het kanton Maaseik worden in de gemeenten nieuwe municipale agenten en adjoints benoemd; te zamen vormen zij het nieuwe kantonnale bestuur, ter vervanging van het afgezette oude bestuur. Het betreft de gemeenten Maaseik, Dilsen, Ittervoort, Rotem, Elen, Neeroeteren, Opoeteren, Ophoven, Kessenich, Neeritter, Thorn en Wessem. De commissaris van het Directoire exécutif bij het departement van de Nedermaas is belast met de uitvoering van het onderhavige besluit.

bo. gouvernementscommisaris Bouteville

ti. commissaris van het Directoive exécutif bij het departement van de Nedermaas Girard

RO nr.235: 5 nivôse $V$ (25 dec 1796); N.B.: in indicateur général ingeschreven onder de datuman van

7 nivôse V (27 dec 1796)

- verwijzing naar: [besluit Directoire exécutif van 27 brumaire V (17 nov 1796)]

\section{V nivôse 4 (1796 dec 24)}

LA $V$ fol 139vo-141ro; FA mr.291

\begin{abstract}
ARRÊTÉ QUI ORDONNE L'EXÉCUTION DE CELUI RENDU LE $1^{\text {RR }}$ THERMIDOR, AN IV, PAR L'ADMINISTRATION CENTRALE DU DÉPARTEMENT DE JEMMAPPES, CONTRE LE CITOYEN CRESTAU, RECEVEUR DU CI-DEVANT CHAPITRE DE TOURNAY
\end{abstract}

Het Directoire exécutif beveelt dat het besluit van het bestuur van het departement Jemappes van 1 thermidor IV (19 jul 1796) - houdende het opleggen van een boete aan Crestau, ontvanger van het kapittel van Doornik waarvan de goederen gesequestreerd zijn, aangezien hij geweigerd heeft een register benodigd voor de inning der inkomsten aan de ontvanger der domeinen over te dragen - volgens inhoud en strekking dient te worden uitgevoerd, behoudens de mogelijkheid voor Crestau een zodanige administratieve weg te bewandelen, welke hij passend acht om tegen het departementale besluit in beroep te komen.

bo. Directoire exécutif

ao. minister van justitie

s. P. Barras (pres); Lagarde (secr-gen)

RO nr.240: 21 nivôse $V(10$ jan 1797)

- verwijzing naar: decreet van 17 jul 1793; besiuiten van 29 brumaire III (19 nov 1794); 9 frimaire III ( 29 nov 1794); 9 nivôse III (29 dec 1794); 6 ventôse III (24 feb 1795); besluit volksrepresentanten van 7 prairial III (26 mei 1795); grondwet van 5 fructidor III (22 aug 1795); wetten van 3 brumaire IV (25 okt 1795); 17 brumaire IV ( 8 nov 1795); 25 ventôse IV (15 mrt 1796); besluit van het departement Jemappes van I thermidor IV (19 jui 1796)

- besluit uitgevaardigd n.a.v. een schrijven van het departementaal bestuur van Jemappes van 11 frimaire $\mathrm{V}$ (1 dec 1796) aan de minister van justitie 
ARRETÉ QUI ORDONNE AUX MEMBRES DES CORPORATIONS RELIGIEUSES SUPPRIMEES DANS LES DÉPARTEMENS RÉUNIS, D'Y FAIRE LA DECLARATION PRESCRITE PAR L'ART.4 DU TTTRE 3 DE LA LOI DU 10 VENDÉMIAIRE AN IV, À PEINE d'ÊTRE CONSIDERES COMME VAGABONDS

De leden wan de opgeheven religieuze gemeenschappen dienen zich na het verlaten van hun gebouwen te melden bij de kantonsmunicipaliteit om hun woonplaats op te geven. Voorts moeten zij hun naam, leeftijd, de religieuze gemeenschap waarvan zij deel uitmaakten, welk beroep zij wensen uit te oefenen en hun middelen van bestaan opgeven. De municipale besturen geven hiervan kennis aan het departementaal bestuur. Bij verzuim worden de ex-religieuzen als vagebonden en landlopers beschouwd en als zodanig behandeld. Het besluit is speciaal bestemd voor de negen Verenigde Departementen en dient te worden gedrukt, bekendgemaakt en aangeplakt in alle gemeenten.

\section{bo. Directaire exécutif}

ao. minister van police générale

s. P. Barras (pres); Rewellière-Lépeaux (voor de secr-gen)

ti. minister van justitie

RO nr.245: 1 pluwiôse $V$ (20 jan 1797)

RE nr.231: $8 / 9$ pluwiôse $V(27 / 28$ jan 1797)

- verwijzing naar: wetten van 10 vendémiaire IV ( 2 okt 1795); 15 fructidor IV (1 sep 1796)

- besluit uitgevaardigd na kennisneming van de beraadslaging van het bestuur van het departement Sambre-en-Maas

- MAP-intitulex: "Arrêté qui enjoint aux membres des communautés religieuses supprimées par la loi du 15 fructidor demier de se présenter devant l'administration municipale du canton où ils se proposent de fixer leur rêsidence"

\section{V nivôse 17 (1797 jan 6)}

LA V fol 142ro-144ro; FA nr.257 fol 160ro-163ro, FA nr.648

ARRETÉ QUI FRAPPE SUR LE DÉPARTEMENT DE LA MEUSE-INFERIEURE UNE RÉQUISITION DE CENT CINQUANTE MILLE QUINTAUX DE FOIN ET CINQUANTE MILLE QUINTAUX D'AVOINE

Aan het departement van de Nedermaas wordt een requisitie van 150.000 centenaar (quintal; 50kg) hooi en 50.000 centenaar haver opgelegd. De repartitie ervan is opgedragen aan het departementaal bestuur: vijf dagen na ontvangst van het onderhavige besluit dienen de contribuabelen door middel van een proclamatie van deze requisitie in kennis te worden gesteld en drie dagen na de bekendmaking dienen de contribuabelen met de afdracht te beginnen. Door de magazijnmeester wordt aan iedere contribuabele een ontvangstbewijs van de geleverde fourage afgegeven. Het besluit behelst voorts de administratieve afwikkeling van de gedwongen leverantie. Weigerachtige 
contribuabelen zullen met militaire middelen tot leverantie worden gedwongen. Een bijzondere commissaris-ordonnateur is met het begeleiden van de requisitie belast.

bo. commissaire-ordoninateur en chef de l"armée de Sambre er Mewse Luyt

ti. commissaris-ordonnateur Luuyt

RO nr.241: 23 nivôse V (12 jan 1797); N.B.: in indicateur génuéral ingeschreven onder de datum van 24 nivôse V (13 jan 1797)

- verwijzing naar: besluit Directoire exécutif van 17 frimaire V (7 dec 1796)

V nivôse 21 (1797 jan 10)

LA V foll 144vo; FA nr.259 fol 113vo-114ro

ARRÊTÉ QUI NOMME LE CITOYEN GILLES VRANCKEN AGENT MUNICIPAL ET LE CITOYEN GERARD SILKEN ADJOINT DE LA COMMUNE DE BERGH, CANTON TONGRES, EN REMPLACEMENT LES CITOYENS DARDEN ET GERITEN, DÉMISSIONNAIRES

In de gemeente Berg, gelegen in het kanton Tongeren, worden Gillis Vrancken als municipaal agent en Gerard Silken als adjoint benoemd, ter vervanging van Darden en Geriten, die om hun ontslag verzocht hebben. De commissaris van het Directoire exécutif bij het departement van de Nedermaas is belast met de uitvoering van het onderhavige besluit.

bo. gouvernementscommissaris Bouteville

RO nr.242: 27 nivôse V (16 jan 1797); N.B.: in indicateur général ingeschreven onder de datum van 8 nívôse V (28 dec 1796)

V nivôse 22 (1797 jan 11)

LA V fol 144ko-145ro; FA nr.259 fol 114ro-115ro

ARRÊTÉ QUI SUPPRIME LE TRIBUNAL CORRECTIONNEL À ST. TROND, ET QUI RÉDUIT LES TRIBUNAUX CORRECTIONNELS DU DÉPARTEMENT DE LA MEUSE-INFERIEURE $A$ TROIS, SAVOIR À MAESTRICHT, HASSELT ET RUREMONDE

De bestaande indeling van het grondgebied van het departement van de Nedermaas in vier ressorten voor de correctionele rechtbanken wordt als gebrekkig ervaren. De correctionele rechtbank te Sint-Truiden ligt te excentrisch en wordt opgeheven. Voortaan zullen er drie correctionele rechtbanken functioneren te Maastricht, Hasselt en Roermond. De minister van justitie hecht zijn goedkeuring aan deze nieuwe indeling.

bo. gouvermementscommissaris Bouteville

RO nr.243: 27 nivôse V (16 jân 1797); N.B.: in indicateur général ingeschreven onder de daturn van 10 nivôse V ( 30 dec 1796$)$

- besluit uitgevaardigd n.a.\%. een schrijven van het bestuur van het departement Nedermaas 
ARRETTE QUI NOMME LE CTTOYEN ROSEN COMMISSAIRE DU DIRECTOIRE EXÉCUTIF PRESS LA MUNICIPALITÉ DU CANTON D'EYSDEN EN REMPLAÇANT DU CITOYEN BACHELIER DÉMISSIONAIRE

Ro[o]sen, woonachtig te Maarland, is benoemd tot commissaris van het Directoire exếcutif bij de municipaliteit van het kanton Eijsden in de plaats van Bachelier, die om zijn ontslag heeft verzocht.

bo. gouvernementscommissaris Bouteville

RO nr.246: 4 pluviôse V (23 jan 1797); N.B.: in indicateur général ingeschreven onder de datum van 24 frimaire $V(14$ dec 1796)

\section{V pluviôse 4 (1797 jan 23)}

Arch.Nat. AF III 429 doss.244I/70; Debidour IV 714

ARRÊTÉ PORTANT OUVERTURE D'UN CONCOURS EXTRAORDINAIRE POUR L'EXAMEN DES SUJETS QUI SE DESTINENT À SERVIR DANS L'ARME DE L'ARTILLERIE

Bij het wapen der artillerie zijn circa tachtig functies voor tweede luitenants vacant. Met het oog daarop wordt er in een dertiental plaatsen verspreid over Frankrijk gedurende vijftien dagen vanaf $\mathbb{\|}$ ventôse $V(19$ feb 1797) een vergelijkend examen afgenomen onder degenen die zichzelf voor de functie van tweede luitenant bij de artillerie geschikt achten. Het vergelijkende examen staat ook open voor leerlingen van de polytechnische school, officieren-kanonniers en vrijwillige kanonniers. Het vergelijkende examen beperkt zich vanwege de urgentie tot de rekenkunde, de meetkunde, de algebra tot en met de tweedegraads vergelijkingen en de vlakke driehoeksmeting, en eventueel tekenen. Het examen wordt afgenomen door de wiskunde- en tekenleraren aan de école centrale in de plaats waar het examen wordt gehouden. De uitslag wordt via het departementale bestuur naar de minister van oorlog gezonden. Voor de negen départements réunis wordt het vergelijkende examen afgenomen te Brussel.

bo. Directoire exécutif

s. Carnot, Reubell, L.M. Revellière-Lépeaux

$\mathbb{R O}$ nr.249: 23 pluviôse $V(11$ feb 1797)

- werwijzing naar: wetten van 18 floréal III (7 mei 1795); 30 vendemiaire IV (22 okt 1795)

- ondanks de inschrijving in het registre ouvert blijkt de afkondiging niet met zekerheid: er is geen afschrift; blijkens een schrijven van het bestuur van het Dijle-departement van 27 pluviôse $\mathrm{V}$ (15 feb 1797), met bijgevoegd eem vijftigtal gedrukte "avis au public", zal het vergelijkende examen op 11 ventôse $\mathrm{V}$ ( 1 mrt 1797) en volgende dagen worden afgenomen [FA $\mathrm{nr} .259$ fol 180wo-182ro]

\section{V pluviôse 13 (1797 feb 1)}

LA V fol 161ro-162ro; FA nr.277 fol 170vo-171 vo 
ARRETÉ QUI PRIVE D'UN MOIS DE TRAITEMENT LES COMMISSAIRES DU DIRECTOIRE EXECUTIF DE PLUSIEURS DÉPARTEMENS EN CAS DE RETARD DANS L'ENVOI DRS ETATS DÉCADAIRES DU RECOUVREMENT DES CONTRIBUTIONS DIRECTES

In een veertigtal departementen - daaronder bevinden zich geen van de negen départements réunis - krijgen de commissarissen van het Directoire exécutif of de administrateurs die hen vervangen over de maand nivôse geen salaris, wanneer zij niet gedurende de maand pluviôse nog de decadaire staten inzake de inning der directe belastingen over de maand frimaire overleggen. Zonodig vindt de salariskorting langer dan wel in daaropvolgende maanden plaats.

bo. Directoire exécutif

s. Reubell (pres); Lagarde (secr-gen)

ti. minister van financiën Ramel

RO nr.255: 15 ventôse V (5 mrt 1797); N.B.: in indicateur général ingeschreven onder de datum van 16 ventôse $V(6 \mathrm{mrt} 1797)$

- verwijzing naar: wet van 17 brumaire V (7 nov 1796)

\section{V pluviôse 17 (1797 feb 5)}

LA V fol 158vo-159ro; FA nr.291; rH XI 144-145; P VII clv-clvi; MAP II 346-347

ARRÊTÉ CONCERNANT LA PUBLICATION DANS LES NEUF DÉPARTEMENS RÉUNIS LE 9 Vendémiaire, an iv, de la loi dU 15 pluviôse, relative au paiement' des ARRÉRAGES DE RENTES ENTRE PARTICULIERS

Het Directoire exécutif beraadslaagt over de vraag of de wet van 15 pluviôse V ( 3 feb 1797) inzake de betalingen van zowel altijddurende als lijfrenten tussen particulieren wel of niet moet worden bekendgemaakt in de départements réunis. Het besluit dat bovengenoemde wet niet van de algemene regel, vastgelegd in het arrêté van 16 frimaire V (6 dec 1796), moet worden uitgezonderd en geacht moet worden te zijn bekendgemaakt in de negen Verenigde Departementen door het enkele feit van de binnenkomst van het Bulletin des Lois, waarin zij is geplaatst.

bo. Directoire exécutif

ao. minister van justitie

Si. Reubell (pres); Lagarde (secr-gen)

RO nr.250: 29 pluviôse V (17 reb 1797)

- verwijzing naar: besluit volkrepresentanten van 12 thermidor III (30 jul 1794); wet van 3 brumaite IV (25 okt 1795); besluit Direcroire exécutif van 16 frimaire V (6 dec 1796); wet wan 15 pluwiose W (3 feb 1797)

- MAP-intitulé: "arrêté, relatif à la publication de la loi du 15 pluviôse présent mois, dans les départemens réunis ${ }^{\text {*" }}$

- "Le présent arrêté sera imprimé pour les départemens réunis seulement"

\section{V pluviôse 18 (1797 feb 6)}

LA V fol 159; FA nr.291; rH XI 145; P VIl clvi 
De wet van 16 pluviôse V ( 4 feb 1797), welke art.13 van de wet van 10 maart 1793 herroept - houdende een verbod van het instellen van beroep in cassatie tegen vonnissen gewezen door de revolutionaire rechtbanken - , wordt geacht niet in de départements réunis te zijn bekendgemaakt, ofschoon zij is toegezonden door middel van de plaatsing in het Bulletin des Lois. Een en ander houdt verband met het feit dat de wet van 10 maart 1793 niet in de départements réunis is bekendgemaakt. Het niet-afkondigen van in het Bulletin des Lois geplaatste wetten is mogelijk ingevolge art.3 van het besluit van 16 frimaire $V(6 \mathrm{dec} 1796)$.

bo. Directoire exécutif

ao. minister van justitie

s. Reubell (pres); Lagarde (secr-gen)

RO nr.251: 29 pluviôse V (17 feb 1797)

- verwijzing naar: wetten van $10 \mathrm{mrt} 1793 ; 16$ pluwiôse V (4 feb 1797); besluit Directoire exểcutif van 16 frimaire V $(6$ dec 1796$)$

"Le présent arrêté sera imprimé pour les départemens réunis seulement"

\section{V pluviôse 19 (1797 feb 7)}

LA V foll 159vo-160ro; FA nr.277 fol 16lvo-162ro; rH XII 300

ARRETÉ PORTANT QU'IL SERA DÉLIVRÉ DES BONS DE RETRAITE AUX RELIGIEUX ET RELIGIEUSES SORTIS DE LEURS CLOÎTRES EN VERTU DES ARRÊTÉS DES REPRESENTANS DU PEUPLE ETC:

Aan ex-geestelijken in de negen Verenigde Departementen, die hun kloosters ingevolge de besluiten van de volksrepresentanten hebben verlaten, zullen bons de retraite op vertoon van hun pensioen worden uitgereikt. Dit geschiedt op dezelfde wijze als de uitreiking van de bons aan de geestelijken die bij de opheffing van de kloosters hun gebouwen verlieten.

bo. Direcroire exécutut

ao. minister van financièn

s. Reubell (pres); Lagarde (secr-gen)

RO nr.253: 5 ventôse V (23 feb 1797); N.B.: in indicuteur général ingeschreven onder de datum van 12 ventôse $\mathrm{V}(2 \mathrm{mrt} 1797)$

- verwijzing naar: besluiten volksrepresentanten van 19 germinal III ( 8 apr 1795); 6 prairial III (25 mei 1795); 15 brumaire IV (6 nov 1795); wet van 15 fructidor IV (1 sep 1796)

V pluviôse 23 (1797 feb 11 )

LA $V$ fol 160; FA nr.277 fol 163, FA nr.1145

ARRÊTÉ QUI MAINTIENT ET CONSERVE PROVISOIREMENT LES COMMUNAUTÉS CONNUES SOUS LE NOM DE SOEURS NOIRES DANS LES NEUF DÉPARTEMENS RÉUNIS 
De communiteiten van de zogenaamde zwarte zusters, die lijders aan een besmettelijke ziekte verplegen, mogen voorlopig voortbestaan. De opheffing van deze communiteiten is opgeschort, totdat er anders zal worden beslist. Wel moeten de zwarte zusters het habijt afleggen en gekleed gaan als de andere burgers.

bo. Directoire exécutif

ao. minister van financiën Ramel

s. Reubell (pres); Lagarde (secr-gen)

ti. minister van financiën

RO nr.254: 13 ventôse $V$ (3 mrt 1797)

- verwijzing naar: wet van $7 * 14$ okt 1790

\section{$V$ ventôse 5 (1797 feb 23)}

BL Ile ser no.114bis (1097bis); LA V fol 163vo-196ro; drukw FA nr.82; rH XI 258-303; P VII 518537; cB IVe ser VII 273-333

\section{LOI ET INSTRUCTION SUR LES ASSEMBLEES PRIMAIRES, COMMUNALES ET ELECTO- RALES}

De Instructie behelst een uiteenzetting aangaande het houden van de assemblees primaires, communales en électorales, zoals de grondwet voorschrijft. De assemblées communales worden gehouden in gemeenten beneden de 5000 inwoners voor het kiezen van de municipale agent en zijn adjoint. Assemblées primaires worden gehouden in ieder kanton om de kiezers te benoemen, welke de assemblée électorale vormen en verder voor het kiezen van de vrederechters en hun assessoren, en of de voorzitter van het municipale bestuur of de ambtenaren in gemeenten met meer dan 5000 inwoners. De assemblée électorale, in ieder departement gevormd uit de door de assemblées primaires gekozen kiezers, is belast met de verkiezing van de leden van het Wetgevend Lichaam, het tribunal de cassation, de hooggezworenen, de leden van de centrale administratie in het departement, welke voor vijf jaar benoemd zijn, en de rechters in het departement. De Instructie gaat verder in op de preliminaire werkzaamheden van de departementale en kantonnale besturen ter vorming van de diverse assemblées, op de stemgerechtigde burgers, op het aantal jaarlijks te verrichten benoemingen enzovoorts. Aan de orde komt eveneens het formeren van de assemblées en de inwendige politie van de zittingen (het benoemen van de voorzitter en de stemopnemers, de wijze van het uitbrengen van de stemmen en dergelijke). Aangaande de départements réunis wordt opgemerkt dat de assemblées électorales voor wat betreft de benoemingen voor de rechterlijke en de bestuurslichamen voor het jaar V zich dienen te conformeren aan het bepaalde in een bijzondere wet.

bo. Conseill des Cinq-cents s. P.A. Lalloy (pres); Collombel (de la Meurthe), Hourier-Eloy, Bachelot Conseil des Anciens s. Poullain-Grandprey (pres); P. Castilhon, Richou, Jevardat-Fombelle (secr)

RO nr.256: 23 ventôse $V(13 \mathrm{mrt} 1797)$

RE nr.251: $24 / 25$ ventôse $V(14 / 15$ mrt 1797)

- verwijzing naar: grondwet van 5 fructidor III (22 aug 1795); wetten van 21 fructidor III (7 sep 1795); 25 fructidor III (11 sep 1795); 19 vendémiaire IV (11 okt 1795); 25 frimaire IV (16 dec 1795); 22 ventose IV (12 mrt 1796); 14 frimaire $V(4$ dec 1796) 
- cB-initule: "Loi contenant une instruction sur les assemblées primaires \& electorale" " geeft ook de: formulieren van de proces-verbalen wan de zittingen van de assemblées primaires, communales en électorales, 19 ventôse $\mathrm{V}(9 \mathrm{mrt} 1797)$

- lafkondiging: formule Directoire exécutif s. Reubell (pres), Lagarde (secr-gen); 6 ventôse V (24 feb 1797); de gebruikelijke afkondigingsformulering; de Wet houdende Instructie eerder afzonderlijk toegezonden, gelet op de registratie in her departement van het BL Ile ser no.114bis op 15 germinal V (4 apr 1797); BL IIe ser no.108 (1038): loi qui adopte une instruction pour la tenue des assemblées primaires, communales é électorales, et en ordonne l'envoi aux administrations centrales et municipales, vermeld dat de wet en de instructie separaat worden gedrukt.]
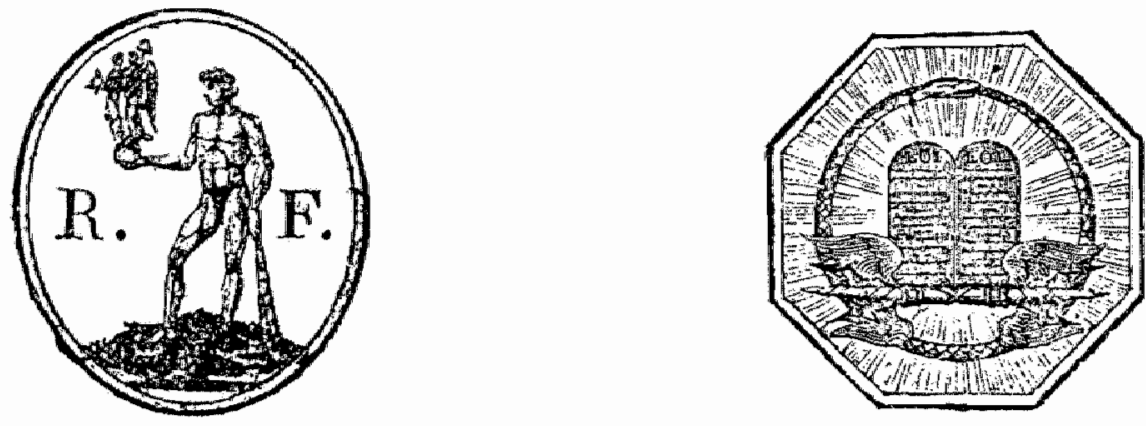

Afdruk van het oude (links) en het nieuwe zegelstempel (rechts), dat de authenticiteit van het Bulletin des Lois garandeert. 
(verwijst naar de inleidende hoofdstukken en de tekst van de regesten)

Aanbesteding $198,339,427$

Aanbrenger 318

Aangifte $116,293,447,455$

Aanhouding 304

Aanklacht $96,242,283,321,334$

Aanleg

eerste $321,371,391,403$

hoogste 321,403

Aanplakking 315

Aanslag 244, 313, 391

op openbare orde en vrijheid 430

Aansprakelijkheid 313

Aanstichter 194, 285, 287, 288, 291, 317, 429

Aantekening van verzet 398

Abdij 117, 326, 429

Abonnement 315

Accusé contumax 415

Achel, kanton 31, 404

Achterstalligheid 197, 200, 427

Activa en passiva 117, 186, 226, 267, 274

Activiteit

contrarevolutionaire 245

handels- 274

Adel 110, 115, 169, 251, 274

Administrateur 224, 362, 452, 456, 471

departements- 94, 348

kantons- 395

marine- 459

Administratie 433,443

kantons- 449

nationale domeinen 370

Advocaat 175

Afkondiging 33,315

besluit $401,407,385$

wetgeving 388

Afpersing 262

Afschrift

authentiek 261, 267

gecollationeerd 241

Afwezigheid 448

Afzet 412

Afzetting 299

Agent, municipale 22, 122, 130, 301, $317,401,460,462,465,467,473$ adjoint $87,90,122,460,462,465$, 467,473

Agent national $91,259,265,271,293$, $302,331,348,359$

Agitatie 428

Agrarische werkzaamheden 201

Aken $12-14,17,20,42,46,53,63,346$

arrondissement 19

kanton 21

Akte $73,122,124,201,230,235,244$, $263,352,357,361,390,392$

authentieke 20,182

buitengerechtelijke (acte extrajudiciaire) 188

burgerlijke stand 208

echtscheidings- 213

geboorte- $122,125,231,257,260,401$

huwelijks- $122,213,401$

minuut 101

onderhandse 182,411

openbare 287

overlijdens- $122,281,401$

proces- 250,263

van bekendheid 231

van beschuldiging $96,104,292,321$, $372,381,415$

van cessie 274

van eedsaflegging 412

van eigendomsoverdracht 411

van ruil 36.1

vennootschaps- 273

verkoop- 361

Alden Biesen, landscommanderij 29, 128

Alexandre, Charles-Alexis

commissaris Directoire exécutif

Noorderleger 389

commissaire-ordonnateur des guerres 389

Alimentatie 209

Ambacht

gezel 335

gilde $111,113,186,190,194,199$ * $260,335,337,338$

Ambassadeur 295, 31.5

Ambt 99, 406

aanvaarding 114 
Ambtenaar 443

opsporings- (officier de police) 97,386 . $387,391,414$

van gezondheid 395

Ambtenaren $125,130,164,230-232,299$ * $303,311,332,368,373,446,473$

departementale 349

der nationale domeinen 117,340

gemeente- $103,129,293,447$

gerechtelijke 97

municipale $221,336,343,424$

ontzetting uit functie 163

openbaar ministerie 321

rechterlijke 100

régie de l'enregistrement 293,412

Ambtsbediening $184,232,392$

Ambtskostuum 329

Amerika 459

Amnestie 334

Ampliatie 246

Ancien régime $16,67,81,102,106,110$. $111,114,126,337$

Andersdenkende 115

Annexatie $9,11,15,24$

Antwerpen 11, 73, 313, 315,400

departementshoofdplaats 12

Anze-sur-Geer, gemeente 16, 21, 22

Appel circulaire 94

Arbeiders $194,307,383,386,395,425$, 430

Arbeidswoorwaarde 113

Arbitrage 93,97

gedwongen 101

vrijwillige 101

Archieven 265, 302, 343

departementaal 361,401

Armenzorg 267

Arrest 109, 224, 233

Arrestatie 205, 259, 448, 457

mevell 321

Arreté 188, 244

departementaal 89

Directoire exécutif 87

Arrondissement $47,83,375,382$

administratie $13,315,316,319,320$, $324,325,328,339,341$

bestuur 12

grens 12

Artillerie 470

tweede luitenant 470

Ascendenten 283, 390

Assemblee 126,129

bestuurlijke 166,173 communale 85,473

electorale $85,94,96,310,329,406$, 473

municipale 166

primaire $10,26,85,94,310,316,317$, 329,473

revolutionaire $49,108,113,127$

wetgevende 93

Assemblée nationale $16,163,181,194$, 205

constituante $82,97,98,102,106,108$, $110,113,114,126$

législative 92, 107, 108, 111, 123, 124, 126

Assignaten $9,113,256,280,337-339$, $345,349,361,379,411,428,455$

omwisseling 393

Atelier 310

Altestatie $121,260,272,274,373,424$

de vita $260,338,396,413$

valse 395

Au nom du peuple français 244

Aube, departement 128

Auteur 183, 196, 225, 229, 387, 428

Authenticiteit 48, 70, 315, 392

Autoriteiten $40,44,58-60,62,68,104$, $116,117,227,237,238,259,269$, $274,277,283,296,299,303,315$, $316,319,329,331,339,363,373$, $377,380,429,433,439,452$

afkondigingsbevoegde 38,78

bestuurlijke $24,48,55,69,70,121$, 302

bevoegde 217

burgerlijke 40,457

Firanse 28,99

gerechtelijke $48,55,69,70,121,193$, 302

militaire 48,457

plaatselijke 55

Awerij 255

Bachelier, commissaris Directoine exécutif kanton Eijsden 470

Baden, tractaat 8

Bailli 212

Bailliage 167

Bailly, commissaris uitwoerende macht 403

Balije 211

Bankwezen 274

Bapaume, departement Pas-de-Calais 348

Barrière Tractaat, Derde 8 
Bartells, L.G., commissaris Directoire exécutif Tongeren 451

Bataafs Brabant 453

Batalse Republiek $31,37,312,380,409$, 419,445

Bataljon 376

Bedelarij 173, 441

Bediende 425

Bedrag 456

Bedreiging 194

Bedrijf 185,425

Beginselen 330

Begriffspromiskuität 38

Begroting 119

buitengewone uitgaven i.v.m. oorlogsvoering 450

vaste uitgaven 450

Beheer $274,430,431,443$

afleggen rekenschap 277

financieel 91,439

militair 457

militaire gebouwen 192

Behoeftige 405,449

Bekendmaking $34,315,397$

wetgeving $319,338,382,424,429$, 464,465

Belangengroepering 250

Belanghebbende 91, 183, 194, 281

Belasting 23, 42, 98, 127, 167, 339, 356, $391,403,450,465$

-aanslag 91

achterstallige afdracht 450

-afdracht 21, 200, 452

bezwaar 354

buitengewone 328

directe $88,89,164,165,176,202$,

$354,438,452,454,471$

-geschil 403

grond- $180,185,188,189,193,195$,

$200,202,224,400,412,450,454$

-heffing $180,382,416,454$

hoogstaangesllagene 287,349

indirecte $176,182,355,403,416,454$

-inning $173,200,316,328,340,345$, $354,452,462,471$

-invordering $180,400,452,455$

-kohier $23,262,354,400,450$

kwijting 239

-omslag 452

oorlogs- 349

Oostenrijkse (aides, subsides, tailles, vingtiemes) 454

op onroerend goed 201 op roerend goed $189,200,224$

-opbrengst 450

patent- 462

personele 450,454

-plichtige $176,180,262,354,452$

repartitie 91,354

-schuld 455

weelde- 450

Belening 235

Belgen 10,351

teruggekeerd 336

Belgiè $9,10,13,15,16,24,25,27,42$, $46,84,109,313,337,339,343$. $409,429,430,454$

territoriale indeling 342

Belgique 385

Belin (Bellin), weigeraar administrateur departement Nedermaas 463

Benadeling 299, 338

Bendevorming 106

Beneficie 173, 208

beneficiant 245

houder $163,170,212,361$

manoir 179

Bénezech, minister van binnenlandlse zaken $59,62,66$

Benoeming $100,127,348,359,360,371$, $378,417,418,429,444,473$

bisschop 114

pastoor 114

Beplanting 172,175

Berechting 317

Berg

gemeente 469

hertogdom 415

Bergen, departement Jemappes 313,463

departementshoofdplatits $\mathbb{1 2}$

Berlier, volksrepresentant 13

Berneau, bank van Sint-Servaas 14 gemeente 22,28

Beroep $113,130,274,425,467$

beoefening 113

groep $111, \mathbb{1 9} 4$

instantie 341

voorrecht 186

Beschadiging 269,271

Beschikking 89,344

Beschuldigde $203,220,237,249,289$, $321,381,414,415,432$

mede- 372

Beschuldiging 405

Beslaglegging 181, 199, 200, 228, 278

Besluit 315,316

afkondigings- 39,385 
Bestuwir $43,47,86,260,271,313,403$ arrondissements- 47

departementaal $19-21,29,43,46,50$, $53,54,55,58-61,65,68,75,78$, $88,89-91,94,95,98,99,129,130$, $172,175,176,179,183-186,188$, $189,190,195,207,211,217,219$. $221,222,236,268,277,301,304$, $305,306,313,315,317,331,333$, $344,346,347,349,350,353-355$, $357,358,360,362,367,372,374$, $379,382-384,392,394,396,397$, $400,405,407,410,415,421,429$, $434,436,440,443,446,450,451$, $452,454,456,460,465,468,470$, 473

departementaal; bevoegdheden 165

districts- $49,50,116,167,170,179$, $180,183,185,186,188,195,198$, $205,217,219,221,222,226,228$, $241,245,253,264,267,269,272$, $273,277,280,283,286,287,294$, $299,306,307,327,421$

gemeente- $58,65,87,122,396,443$

kantonnaal $129,357,362,462,467$, 473

municipaal $55,89,167,196,277,301$, $315,339,352,357,366,379,384$, $396,397,400,405,411,430,439$, $447,452,456,459,465,468,473$

municipaliteits- 317

provinciaal 339

verowerde gebieden 465

Bestururder 227

municipaal 329

Bestururlijke organisatie 318

Bestuursgeschil beslechting 89

Bestuurshandeling 300,310

Bestuurslichaam $178,179,193,194,207$, $217,267,277,285,300,302,310$, $319,343,357,461$

intermediair 87

lager 87

Bestuurszaak 344

Betaalmeester departementale 362 -generaal 350,400

Betaling 286, 328, 384, 402, 471 achterstallige 66

Betalingsmachtiging $268,353,360,379$, $410,436,438$

Betalingsopdracht 346,360 aflossing 364
Betalingsplichtige 107

Betichting van valsheid 223

Bevell

tot aanhouding 395

tot medebrenging (mandat d'amener) 395

Bevoegdheid 128, 245, 253, 255, 267, $275,299,332,333,341,398,435$, 455,464

civiele 192

departementale 88,91

district 91

geattribueerde 87

gemeentelijke 91

ontneming (évocation) 233

toekenning (attribution) 233

délibération 90

verordenende (pouvair rëglementaire) 89

Bevolking 83, 127, 428

dichtheid 317

statistiek 265

Bevoorrading 304, 325, 389, 408

leger en marine 310

van legerdivisies 332

Bewaarnemer 297

Bewaarplaats 446

kerkelijke 122, 401

Bewaker 242, 253, 264

Bewijs 234

betalings- 223

kwijtings- 349

ontvangst- 223,468

Bewijsstuk $21,224,267,280,307,338$, $370,421,424$

verbranding 109

Bewind, feodaal 92,251

Bezit 289

kerkelijk 127

Bezitsontzetting 446

Bezittingen $27,114,118,268,274,312$, 428

Bezoldiging: $100,104, \llbracket 14,176,192,208$, $221,269,302,333,340,345,349$, $350,353,358,368,369,396,408$, $410,430,436,443,452,461,471$

inhouding 397

scherprechter 106

soldij 445

van staatswege 425

wedde 405

Bezwaar 377,380

-schrift $373,380,421$ 
Bibliotheek 239, 269, 271, 320, 430, 436

Bibliotheque nationale 265,436

Bieder 195

Billon (koperen muntstuk) 422

Binnenland 439

Blanchard, ordonnateur des guerres 399

Blanco-wisselbrief 318

Bloed- en aanverwanten 104, 284, 372. 423

opgaande lijn 283

Bochet, bijzonder commissaris verkoping

Boedell nationaal domeingoed 362

-beschrijving $217,428,430$

-scheiding 390

Boeken $111,117,239,265,436$

-bezit 430

leer- 428

-ruil 436

-verkoping 436

Boekhouding 302

Boeren 333

Boerenkrijg 130

Boete $105,120,125,168,170,194,196$, $201,219,230,235,250,255,276$, $283,287,291,297,310,312,318$, $321,331,336,339,349,362,391$, $416,428,431,442,467$

Bons $118,290,430,435,450,457,472$ de retraite 472

Borg 307, 352, 400

bewijs van ontvangst (jugement de réception de la caution) 447

caution solvable 447

Bos

-stelling 311,420

-areaal $91,118,195,198,325,347$, 427

-behoud 198, 350

Forêt de Soignes (Zoniënbos) 335

hoogopgaand hout 347

houtkap $105,163,195,282,324,325$. $347,427,436$

-inspectie 350

nationaal 111

schade door vee of lastdieren 163

staats- $442,450,458$

verkoop areaal 324

-wachter 412

Bourbon-Capet, Franse koninklijke familie 285

Bourg-Felden [Burgfelden], departement Haut-Rhin 415
Bourg-Libre [Saint-Louis/Sankt Ludwig], departement Hawt-Rhin 415

Bouteville, gouvemementscommissaris 16 , $17,19-22,25,26,44,57,59,61-63$, $66,67,74,76,77,95,98,100,417$, 456

Brabant 10, 312

Breust, heerlijkheid 29

Briefgeheim, schending 130

Briez, volksrepresentant 13

Brugge 313,315 departementshoofdplaats 11

Brussel 12, 13, 15, 20, 21, 24, 46, 77, 84, $313,340,343,348,356,359,470$ departementshoofdplaats 11

Buiten-de-wet-geplaatste 115, 245, 252, 278,289

Buitenland $352,355,369,372,387,396$, 401,440

Buitenlander 116 bieden schuilplaats 295

uit neutrale of geallieerde landen 295 uit vijandige landen 295

Buitemlands vorst 252

Bulgembach [Bütgenbach], departement Ourthe 415

Bulletin de correspondance 49

Bulletin des Lois $37,39,48-51,53,55-57$, $59,62,65-67,68,73,75,76,79$, $101,116,117,269,315,363,382$, $438,451,464,47 i, 472$

Bureau voor registratie 182

Bureau de liquidation 267,391

Bureau de paix et de conciliation 93, 98, $174,255,377,403$

procedure 187

Bureau van weldadigheid (bureau de bienfaisance) 461

Burgers 92, 125, 129, 164, 283, 294, 363, $373,376,424,446,455,462,473$

behoeftige 461,466

Franse 312

gegoede 76,349

kiesgerechtigde 92

persoonlijke vrijheid 386

staats- 85

stemgerechtigde 473

welgestelde 367

"goede" 104

Burgeres 124, 257

Burgerij 110, 435

Burgerlijke partij 203, 321

Burgerlijke rechten $85,194,302$ 
opschorting 92,277

Burgerlijke staat $125,248,257$

Burgerlijke stand 122, 123

aangifte 208,213

akte 121

ambtenaar $90,122-124,208,209,230$, $257,317,401$

jaarlijkse tafel tienjaarlijkse taffel 208

register $122,123,281$

register houdende de huwelijksafkondigingen 213

register houdende de preliminaire echtscheidingsakten 213

register van geboorte, huwelijk, overlijden 208

Burgermilitie (arquebusiers, boogschutters) 203

Burtscheid, kanton 32

Cadier 1.4

gemeente 28

Calais, haven 460

Campo-Formio, verdrag 27

Carion, administrateur departement Nedermaas 348

Carnot, Lazare Nicolas Marguerite, lid Directoire exécutif 59

Cartils, heerlijkheid 29

Cassatie $71,73,97,181,233,254,292$, $373,433,438$

-beroep 449,472

eis tot 327

verzoek tot 327

Catalogus

boeken en manuscripten 320

Categorieèn

beroepsuitoefening 425

Cavalerist 405

Caventre deskundige 22

Census 94

Centime 444,445

Centrale Administratie 15

Landen tussen Maas en Rijn 12-14, 20, $42,46,63,82,340,346$

van België $12,13,46,316,319,344$

Certificaat $347,396,440,448$

geleide- 299

van herkomst 415

van onvermogendheid 449

van verblijfplaats 212,272

Certificat de propriété 330

Cessie 305

Challade, La, abdij 252 gemeente 252

Chapelier, Isaac René Guy le, afgevaardigde 113

Charante, departement 111

Charges politiques 396

Charter 269

Chatelet 176

Chenard, administrateur departement $\mathrm{Ne}$ dermaras 463

Chirurgijn 208

Chouans. opstandelingen $291,308,321$

Cijns $107,108,193,229,239$

altijddurende 164

censuels utiles 166

incidentele 109,224

-plichtige $166,215,248$

-recht 204

-register 186

vaste 109,224

Circulatie 444

Circumscriptie $10,13,28,44$

kerkelijke 114

Civiele zaak $298,321,327$

Civisme 408

Clairfayt, commissaris uitvoerende macht 403

Claon, gemeente 252

Coalitieoorlogen 27

Coalitieverbod 113

Cochon de Lapparent, minister van generale politive 60

Code civil 38, 103, 126

Code Napoléon 34, 37, 51

titre préliminaire $34,36,37,48,51$, 55,79

Cade des délits et des peines 95, 102, 126. $330,391,420,422,435$

Code des délits et des peines pour les troupes 453

Cade des émigrés 115,354

Code hypothêcuire $292,293,327,351$, 398,417

Code Merlin 55, 63, 67-70, 75-77, 79, 82, $87,92,97,100,101,105,111,116$, $120,121,125,128,129$

Code pếnal 102, 103, 105, 199, 203, 204, $206,259,262,292,334,399$

Code pénal militaire 306,355

Code rural 103

Codificatie 103

Coenegracht, administrateur departement Nedermaas 342,426 
Coenegracht, C., griffier criminele rechtbank Nedermaas 359

Coenegracht, commissaris 22

Collectie 265

College 219

Comité $127,303,373,380,438$

d'agriculture 251

d'instruction publique 271

de féodalité 108

de gouvernement 301

de législation $251,279,285,286,289$, 292, 294, 319

de liquidation 171,233

de salut public $9,10,15-17,19,20,22$, $31,35,40,41-43,47,57,60,63$, $85,86,272,304,319,328,340$, $342,346,363,465$

de sâreté gënërale $85,279,316,317$

des archives 265

des finances 251

regerings- $85,101,327$

Commandant 272

bataljons- 332

bevelvoerend 332

divisie- 449

eskadrons- 332,405

gamizoens- 459

militaire 439

plaatselijke 331

Commanderij 211,212

commandeur 212

Commies 210

Commissaris $21,22,219,228,281,305$ * $366,378,460$

bijzondere 452

-deskundige 221

gedelegeerd 321

gouvernements- $43,47,56,71,76,78$, $82,101,105,111,113-115,341$, $348,363,388,407,410,417,418$, $422,457,465$

-ordonnateur 457,469

-repartiteur 354

uitvoerende macht $69,95-97,165,174$ -

$176,313,314,343,358-360,365$, $372,384,394,396,426,434,438$, 444,449

van Directoire exécutiff $20,61,62,66$, $68,74,77,78,86,90,94-96,301$, $333,345,357,379,381,383,389$, $390,409,411,415,425,426,428$, $431,434,451,459,461,465-467$, 469,471 van oorlog $272,374,379$

van politie 213,317

Commissaris-ordonnateur van oorlog 465

Commissie 332,370

inzake lyypotheekregime 374

militaire 449

bevoorrading leger 299

Commission

d'approvisionnement 332

d'instruction publique 271

de l'organisation et du mouvement des armées de terre 332

des revenus nationaux 272,278

des travaux publics 272

Commissionair 310

Commitimus 233

Communiteit 117, 118, 164, 179, 190 , $191,245,248,430$

kerkelijke 324

leken- 264

opschorting opheffing 473

religieuze $219,264,287,391,468$

wereldlijke 219

zwarte zusters 473

Comparitie 178

Competentie, relatieve 97

Complexum feodale 106,107

Componist 225

Comptabiliteit 272

Concession primitive de fonds 166

Conciliatie 97, 101

Condominium 8

Congregatie 117,429

Consecratie $1,22,123$

Conseil

des Anciens $24,70,85,126$

des Cinq-cents $24,25,48,66,70,85$, $86,126,315,369,370,415$

d"état 51

de gouvernement $24,82,84,319,338$, $340-342,344,348,350$

de "administration 76

de préfecture 56

du Roi 233

Consignatiegelden 344,400

Constitutie

opgeheven kwalificaties 201

Constitution ciwile du clergé 114

Consul 55, 216, 396, 413

Consulaat 23,31

Consumptie, binnenlandse 387

Contrabande 127

Contract 283 
Contribuabele: $165,200,358,465,468$

Convention nationale $9-11,24,35,36,38$, $39,40,41,43,47-49,56,67,85$, $87,100,102,103,107,1094111$, $114,116,124-126,128-130,219$. $227,228,233,248,252,262,271$, $284,286,294,301,303,312,317$, $373,380,438,444$

Coopmans; J.P:A, rechtshistoricus 33,35 , 37

Corneli, departementaal administrateur 342 Corporatie 260

Corps

legislatif $16,23,25,38,48,58,85-89$, $104,117,118,129,165,182,190$, $228,265,302,315,330,352,363$, $365,370,373,377,380,382,392$, $406,414,436,473$

municipal 264

administratif 198

Correspondentie 433

Corsica 457

zeelieden en vrijwilligers 457

Corvee 166

Costumen 293

Couronne civique 384

Courtage 368

Cousturier, commissaris uitvoerende macht 403

Couturme 247

Cox, departementaal administrateur 342

Crestau, ontwanger kapittel wan Doomik 467

Curatele 254

Dader $130,287,288,317$

Dagloner 425

Dagloon 269

Dagvaarding $95,178,240,250,395,414$ verzoening 377

Dagwaarde 427

Dalhem, kanton 31

land $8,12,14$

Oostenrijks land 29

Staats land 28

Darden. municipaal agent gemeente Berg 469

Dassier, commissaris uitvoerende macht 404

Date de l'émission 55

Date de l'enregistrement 55

De Haynin, administrateur departement Nedermaas 348
Debiteur $173,193,197,215,228,280$, $287,307,322,348$

mede- 305

Decade $349,422,430$

Decharge 246

Décime 444, 445, 461, 466

Declaratie 287

Déclaration

des Droits de l"Homme et du Citoyen 110

des Droits et des Devoirs de l"Homme et du Citoyen 297

foncière, formulier 293

décret d'anmulation 128

défendeur coobligé solidaire 377

Delbee, Pierre, hoofdadministrateur steenkoolmijnen 408

Delecourt, Ch., auteur 69

Delfstoffen 395

Delict $95,102,120,196,200,220,292$, $306,321,330-332,355,386,391$, 461

bos- 104,416

economisch 106

gewelds- 313

militair 404,435

moord 218

plattelands- 201

uitlokking 218

velid- 104,416

Delinquent $102,105,287,334$

Denier 350, 422

Departement $7,10,11,15,16,21,31,47$, $87,89,130,173,175,182,205$, $215,232,239,265,281,302,308$, $312,316,317,321,332,341,347$, $350,351,352,355,361,365,379$, $392,405,406,413,436,438,441$, $444,450,471,473$

administrateur 342

centrale administratie 446,473

hoofdstad 259,268

opstandig 334

Départements réunis $15,16,19,22,23$, $25,29,43,44,47,56-63,66,67$, $69,70,71,73-75,78,79,83-85,87$, $88,98,99,102,104,107,109,111$, $114,116-121,123,127,128,131$, $185,249,318,326,328,337,340$. $342,351,355,361-364,366,369$, $379,381-383,385,388,391,395$, $403,405,407,408,412,417-419$, $422,423,427,428,431,432,434$, 
$441,446,454,455,458,463-$

$465,468,470-473$

betalingsregeling 450

Deportatie 432

Depositaris 211, 250

openbare $170,273,297$

particuliere 273

Depot $251,281,436,446$

centraal 265

openbaar 111

Derde-bezitter 309

Desertie 355,453

Deskundige $188,265,434$

-arbiter 274

Detachement 343

Deurwaarder 106, 171, 182, 184, 200, $232,250,404,428,447$

Devleeshouwer, $\mathrm{R}$, historicus 109

Diefstal 214

hout, houtvlotten 105

Dienst 365

fortificatiën, millitaire gebouwen 272

heerlijke 337

militaire 342

openbare instantie 310,458

overheids- 370

Dienst der registratie en het zegelrecht 192,202

Dienstbaarheid, persoonlijke 166

Dieppe, haven 460

Diest, departement Dijle 423

Diets-Heur (Heure-le-Tixhe), gemeente 31

Dijle, departement $11,59,60,62,71,74$, $75,77,94,106,313,341,400$

Dilsen, gemeente 467

Dîme 204, 208

Directeur 466

der domeinen 119,320

du jury $199,321,394,395,414,420$

du jury d'accusation $96,359,386,387$

(général) de la liquidation 241,267 , 291

Directoire exécutif $16,19,21,23,35,38$, $39,43,44,48,50,55-58,60,63$, $65,66,67,69,70,72,73,76-79$, $82,84,86,89,94,99,101,104$, $105,111,113,117-119,121,122$, $126,128-130,314,315,327,330$, $334,349,355,361,362,363,364$, $367,370,380,385,386,389,403$, $405,407,414,415,418,420,422$, $424,428,429,431,436,443$,
$444,446,452,455,456,460$, $461,464,467,471$

bevoegdheden 86

District $87,89,91,93,173,215,225$. 265,302

bestuurder 271

secretariaat 173,258

Docent 429

Documenten $273,281,446,459$

Domaine

directe 107

utile 107

Domicilie $130,272,306,313,347,352$, 377,397

Dominee 122

Doomik 10,312

kapittel inbeslagneming goederen 467

Douane $19,20,76,77,216,236,255$. $300,311,408,415,455$

-rechten $369,394,400,459$

-regime 364,369

-kwestie $383,391,441$

-stelsel 418

Doutrepont, lid Centrale Administratie van Belgié 15

Droit

persannel 108

réel 108

d" assistance (presentiegeld) 176, 396

de préemption 255

intermédiaire $38,110,12$ 1

Drukpers 387,428

verspreiding 386

Drukwerk 401

Dubbel 281

Duitse Keizer 27

Duitse Orde 29, 127, 211

grootmeester 29

Duitse Rijk 27, 419

Duiventil

recht 163

Dumoulin, notaris 73

Dwangbevel 197,200

Dwanglening (emprunt force) $21,76,349$, $351,358,367,374,375,391$

bezwaar tegen hoogte aansiag 361 .

inning 364

invordering 421

kohier 460

ontheffing 421

repartitie 460

vermindering aanslag 421

Dwangmaatregel 358 
Dwangmiddel 348

Echevinat 164

Echt, kanton 17, 29, 32

Echtgeno(o)t(e) $125,257,274,275,280$, 289

Echtscheiding 124, 125, 209, 248

erfrechtelijke positie 209

gronden woor echtscheiding 209

rechtsgevolg 209

École centrale 429

wiskunde- en tekenleraar 470

Edict 123,398

van 1771171

Eed 298, 412

aflegging 375

haat jegens koningschap $121,374,404$

herroepen 120

van haat jegens de anarchie 121

van trouw $114,120,121,358$

weigering 404

Eer, militaire 437

Eerste Consul 51

Eerstgeboorterecht 166

Egalité 238

Eigenaar $107,185,188,205,212,225$, $236,239,246,250,260,287,293$, $297,311,339,347,362,366,452$, 456

grond- 294

land 111

mede- 305

schadeloosstelling 190

Eigendom $118,180,208,228,274,282$, 313,447

beschadiging 218

grond- 107, 108, 168, 195, 204, 251, 293

ongedeelde 421

particuliere $277,313,314,386$

publieke $183,188,277,293,313,386$

Eijsden, gemeente 31,32

kanton 470

Eilanden 255

Franse 459

Eiser $184,377,449$

Elberfeld, stad 415

Elderen, gemeente 460

Election d"ami 195

Elen, gemeente 467

Elsloo, heerlijkheid 29

Embleem

van gelijkheid 239 van vrijheid 239

Enclave 28

Engeland 459

werboden goederen 216,236

Engelsen 252, 432

Ensiwal, departement Ourthe 73

Entreegelden 461 inning 466

Eredienst 120,224

bedienaar $120,121,301,312$

Erfdeel 283

Erfenis

Erf rechtsgevolg 211

-genaam $124,196,225,230,283,289$. $302,322,428$

-goed 283

-opvolger 248

-opvolging 247,338

Etre garant civilement 313

Europa 115, 446, 450

Examen, vergelijkend 470

Exceptie 438

Exclave 29,31

Executoriale kracht 392

Exploitant 466

Exploot 240

Eygelshoven, gemeente $16,19,20,29,61$, 465

Fabriek 274, 310, 419

staal- 389

wapen- 389

Fabrikant $400,425,452,462$

Faillissement 307

Faipoult, minister van financièn 76

Familie 278, 285, 298

-gerecht 101, 371

-lid $124,209,230,281,329,383,424$

-naam 169

-raad 124

-wapen 110

Federalisme 290

Feest, revolutionair 128, 129

Feestelijkheid, publieke 437

Feit

strafbaar $104,306,461$

strafbaar (militair) 453

Féodalité

contractante 108

dominante 108

Feodaliteit $82,107,110,170,266$ 
afschaffing $108,109,111,163,166$, $172,194,204,224,338$

Fête

de la fondation de la République 129. 420

de l'agriculture 129

de la jeunesse 129

de la liberté 129

de la reconnaissance 129

des époux 128, 384

des vieillards 129

Feudiste commissaire (zaakgelastigde van feodaal heer) 207

Feuilleton des résolutions et des projets de résolution 48,315

Financiën 88, 265, 461 administratie tussen Maas en Rijn 348

Financieringsmaatschappij

brandverzekering 283

caisse d'escompte 283

levenswerzekering 283

Flament, archivaris 28

Fleur-de-lys 111,236, 238

Fleurus, slag 7

Fonds $76,224,349,364,379,396,436$

Fontainebleau, verdrag $8,14,22,31$

Formulier bekendmakings- 39 madele 330

Fourage 384

Franc $369,412,461,466$ valeur métallique 450

Frankrijk $9-11,16,20,24,35,36,43-46$, $58,59,61,63,71,78,79,81-84$, $97,100,107,109-111,116,117$, $118,119,125,131,222,223,237$, $252,256,280,284,295,312,315$, $326,329,339,357,388,396,401$, $425,441,448,455,459,470$

Frans staatsburger 10, 197, 198, 201

Frans-Guyana 205, 237

Franse havens veiligheidsmaatregelen 459

Franse Keizerrijk 31, 55

Franse koloniền 432

Franse makelij 329

Franse natie 126

Franse onderdanen 439

Franse Republiek $9,27,49,51,70,84$, $94,118,212,216,227,231,232$, $236,241,244,265,272,274,280$, $284,287,290,291,301-303$,
$308,326,331,334,339,357$,

$376,396,403,404,409,419$,

423,445

viering vestiging 420

Franse Revolutie 106

Franse staat $375,382.407$

Franse taal 341

Franse volk 308

Fransman $396,413,440$

Fraude 418, 444

Frécine, volksrepresentant $\mathbb{1 2}$

Frédéric Eugène, hertog Württemberg en Teck 419

Functie 277 onverenigbaarheid 91

Functionaris $104,328,340,397$

bestuurs- 302,333

kerkelijke $114,122,237,302$

overheids- $54,91,119,206,215,262$, $264,271,333,363,383,410,425$, 443

rechterlijk 292, 406

toezichthoudende 90

Fysische gesteldheid 16

Gaboria, Armand, drukker te Brussel 78

Garantie civique 120

Garaud, M., rechtshistoricus 110, 119

Garnizoen 122

bevoorrading 407

commandant 192

Gasthuis 461

burgerlijk (hospice civil) 333, 439, 454

Gearresteerde 316

Geboorte 123, 208, 213

-aangifte 124,257

-akte 257,260

-plaats 331

Gebouw 111, 226, 236, 365, 446, 457, 468

nationaal 446

onderhoud 350,430

Gedaagde 377,414

Gedeporteerde $115,118,232,252,284$

Gedetineerde 246, 441

Geëndosseerde 318

Geestelijke $88,114,117,123,215,218$, $237,251,252,256,266,347,430$, $435,450,472$

eedsaflegging, 237

eedsweigeraar $205,302,321$

gedeporteerde $115,116,205,294,301$, $302,334,354,388,419$

herroeping eed 205,237 
in staat van afzondering $115,294,302$, 354

met gebrek of bejaard $115,205,237$. 259 .

teruggekeerde 301

weigering eed 302

zieke 237

Geestelijkheid $110,114,115,121,167$, $245,274,407$

regulliere 11.8

Geestesproduct exclusief recht 225

Gefailleerde 280

Gegadigde 274

Gehuwde 129,247

feest (fête des époux) 384

Geld 130, 333, 339

baar 379,450

papier- $113,401,425,427$

Gelder, arrondissement $14,47,89$

Gelders, president criminele rechtbank departement Nedermaas 359

Geldlening 164

Geldsoort 452

-klein 445

koper- 356,444

zillver- goud- 356

Geleidebrief 237

Gelijkheid 115

burgerlijke 111

Gemachtigde $95,240,246,250,293,305$, 423,446

eenvoudige (simple fondé de pouvoir) 100

fonde de pouvoir $32 \mathrm{r}$

Gemeente $10,16,20,43,45-49,87,89$, $92,95,102,104,116,122,130$, $200,211,213,219,226,231,236$, $249,254,260,270,281,287,296$, $301,304,308,312,313,317,336$, $340,345,346,350,354,357,359$. $366,393,397,400,401,412,420$, $443,450,454,461,467,468,473$ conseil genêral $200,222,225,272$. $293,294,295$

grens- 295

invorderingsplichtige 433

plattelands- 104, 294

-zegel 336

Gemene gronden 226

Gendarmerie mationale $63,104,201,416$ brigade 405

organisatie dienst 342
Generaal 465

Generaliteitsland 28

Génissieu, minister van justitie 60

Gens de main-morte 163, 164

Gent 313 departementshoofdplaats 11

Gerecht 254, 444

Gerechitigde deel- 246

Gerechtsbode 171

Gerechtsdeurwaarder 175

Gerechtsdienaar 184 heerlijk 404 koninklijk 404

Gerechtshof 233 provinciaal 123

Gerechtszaal verzegelling 343

Geriten, adjoint municipaal agent gemeente Berg 469

Geschiedenis 239

Geschil 125, 263, 266, 305, 323, 326, $335,338,355,371,377$ beslechting 101, 103 juridisch 73 justitieel 111

Geschrift 218

Getuige $96,272,298,372,373,395,414$ à charge 249 a decharge 249

Getuigenbewijs 287

Getuigenis $128,237,249,298$

Gevangene $242,253,289,419$

Gevangenis $103,173,196,259,291$

Gevangensethap 279

Gewapende bandieten 335

Gewassen 111, 416 schade 168

Geweldpleging 130, 194, 277

Gezagsondermijning 285

Gezegeld papier $213,223,352,381,411$

Gezin 384 hoofd 226

Gezworene 203, 338 -plaatsvervanger 414

Gilde

ambachts- $111, \mathbb{1} 3$

-meester 199

Girard, commissaris Directoire exécutif departement Nedermaas $54,62,68$, 122,425

Girondijnen 278,290

Giroust, volksrepresentant 43,130 
Glaswerk 387

Glons, kanton 23, 31

Godding, $\mathrm{Ph}_{\text {., }}$ rechttshistoricus 110

Gadechot, J., historicus 86, 113

Goed $71,125,127,199,238,243,245$, $255,268,271,273,285,309,355$, $392,424,431,439,448,452,458$, 463

cijns- 177

feodaal 177

in bewaring gegeven 297

kerkelijk 114, 118, 167, 173, 252, 258 , 320

ligging 421

onroerend $182,195,207,226,252$, $275,283,307,328,355,361,398$, $423,430,446,452$

onverdeeld 305

overdracht 280

overgang 298

publiek 214

roerend $171,182,211,217,226,232$, $252,275,283,307,324,361,375$, $377,428,430$

verbeurdwerklaard 245

verworven 357

Gordon, A., rechter te Maastricht 42,45 , $46,51,69$

Goud $349,351,401$

-geld 356

Graan $103,287,299,304,310,384,349$, 412

opbrengst 408

tarwe 333,369

zaaikoren 333

-leverantie (weigering) 276,399

Graatheide 32

Grammont, gemeente 10

Gratificatie 210

Gravenvoeren, "s-, gemeente 31

Grégoire le Jeune, commissaris uitvoerende macht 403

\section{Grens}

-kwestie 21

-scheiding $16,31,91,92,167$

-wijziging 32

Griffie $47,48,265,292,319,343,352$, $357,390,444,447$

griffier $94-96,102,171,175-177,182$, $187,232,251,298,321,336,426$. $428,439,447$

Groenendaels, commissaris uitvoerende macht 403
Grondwet $16,36-39,41,48,84,85,87$, $92,93,95,100,101,123,194$, $294,297,308,312,314,315,369$, $378,386,414,418,473$

Gronsveld, graafschap $9,13,27,29$

Grootboek 411

aanleg 251

inschrijving 330

der nationale schuld $228,280,330$, 463

van de lijfschuld (dette viagere) 283

Grosse $177,246,267$

Guadet; volksrepresentant 278

Guillotine 261

Gulik $17,19,20,28,29,394,395,402$, 453

hertogdom 9

landstreek 346

Gulpen, kanton 31

Haag, Den 14 verdrag $14,312,419,445$

Haardstedengeld 166

Haat jegens koningschap 358

Habijt 430,473

Halen, Brabants 29

Handel $318,362,369,419,425,462$

Handelaar $295,310,336,452$ detail- 462

Handeling contrarevolutionaire 429 oorlogs- 445

Handelscompagnie Deense 448

Hollandse 448

Handeliskamer (corps de commerce) 415 Handelswaar $199,216,236,255,300$, $369,387,453$ doorvoer 394,402 Engelse $447,452,455$ Franse 452

Handgeld (pot-de-win) 173

Handwerkslieden 274, 462

Hanf, commissaris Directoire exécutif kanton Heythuysen 451

Hardenberg, archivaris $12,19,22,23$

Hartmann, rechter 62

Hasselt $72,95,122,342,366,382,469$

Haussmann, volksrepresentant 12,13

Haven 255,455

Haynin, De, administrateur departement Nedermaas 426

Heeren, 's-, gemeente 460 
Heer $107,111,239$

Heerlen, kanton 17,98, 122, 404 lanid 12

Heers, kanton 393

Heerschappij

Oostenrijkse 312

Heiden, heerlijkheid 19,20

Heinsberg, kanton 32

Heks, gemeente 393

Helden, gemeente 32

Henegouwen $10,127,312$

Frans- 109

Hennequin, commissaris Directoire exécutif 's-Hertogenrade 19,466

Herstal, kanton 21, 23

Hertogenrade, 's- (Rolduc), kanton 19. $20,29,61,465,466$

land 8,14

Oostenrijks land 29

Staats land 28

Heythuysen, kanton 451

Hodimont, kanton 73

Hoger beroep 71, 93-95, 97, 222, 233 . $240,251,254,296,306,307,323$. $326,341,371,377,383,391,413$, 441

Holland $15,394,395,402$

Hommage 166

Homme de fief 392

Homme de loi $356,451,463$

Honorarium 196

Hoofdelijke medeschuldenaar (co-débiteur solidaire) 244

Hoofdplaats departements- $50,51,65,66,68,74$, $77,79,115,315,366,446,464$ districts- 252,397

kantons- $16,17,49,73,358,366,375$, 397

Hoofdsom 189

Hooggerechtshof (hawie-cour de justice) $92,406,413,414$

Hooggezworene (haut-jure) $414,415,473$

Hoogoven 389

Hoogstaangestelde 349

Horbach, gemeente 20

Horigheid 108

Horn, graafschap 8,29

Horst., kanton' 32

Hospitaal 173

Hôtel 232

Hôtel-de-ville 164

Houder $118,265,320,324,362,396,457$
Hout, gezaagd 413

Houtain-Saint-Siméon, gemeente 21

Houtvester 427,436

Huizen 111, 226, 324

Huur $173,282,339$

-overeenkomst 190

-som 430

huurder 245

Huwelijk $123-125,216,230,231,257$

afkondiging 208,231

contract 247

ontbinding 124

stuiting 208

Hypotheek 118, 127, 167, 309, 320, 351, 357,398

-bewaarder $293,327,357,398$

-kantoor 366

-overeenkomst 177

-regime $293,374,397,442$

-register 293

tarieflijst 293

tenietgaan 292

vestiging 292

Identiteitskaart 295

leper, gemeente 10

lerland 236

IJzergieterij 389

-mijnen en -smelterijen 190

Immatriculatie 184

Inbeslagneming $91,118,226,245,255$, $268,273,275,280,283,289,299$, $300,304,307,311,320,339,358$, $387,390,419,447,452,455,458$

Incivisme 237, 404

Indeling

kantonnale 302

municipale 302

territoriale 47

Indië 448

Ingezetene $25,27,47,60,66,79,84,85$, $99,185,337$

Inkomsten $118,286,430,454$

instandhouding 431

Inkwartiering 452

Inlijving 7,20

Inning 366,412

Inschrijving 276

Insolventie $287,293,308$

Inspectie 458,459

Instelling

geestelijke 113,120

kerkelijke $113,320,427$

klooster 117 
openbare 365

religieuze $117,118,260,429,431$. $434,456,463$

voor blinden en doofstommen 439

voor liefdadigheid 267

Institut national 436

Instructie $40,47,85,92,185,194,282$, 407,458

houden assemblées primaires, communales, électorales 473

vereffening schuldvorderingen opgeheven religieuze instellingen 463

verkoping nationaal domeingoed 119

Intitule 48, 67

Inventarisatie $211,265,357,446$

Invoer 413,447

Invoering financiële regime 346

Invordering 197, 348, 351

Invrijheidstelling 102

Inwoners $17,21,24,130,131,196,287$, $301,312,313,317,331,337,402$, $423,443,450,453,456,473$

Inzage 265

Ittervoort, gemeente 467

Jacht 111,168

-recht 163

-verbod 442

Jacobijnse dictatuur 48

Jacobijnse Republiek 85

Jeker, rivier 21

Jemappes, departement $12,69,127,313$, 467

Jenever 387

Jolivet, Henry-George le, inspecteur bruggen en wegen 379

Joubert, commissaris Directoire exécutif Sambre-en-Maasleger 389

volksrepresentant 12,13

Jozef II, Habsburgse keizer 8

Jurisdictie $14,103,346,444$

academische 326

heerlijke 108,164

kerkelijke 326

municipale ambtenaar 201

vrederechter 201

Jury $96,105,106,343,381$

d'accusation $96,270,395,448$

de jugement 96, 97

militaire 218

d'instruction (benoemingscommissie) 429

Jusrice civile 92

correctionnelle 92

criminelle 92

Justitiabele 98

Juwelen 401

Kaap de Goede Hoop 446

Kaapvaart 457

Kabinet 265 der gravures 225

Kalender, revolutionaire 352,407

Kanonnier 470

Kansspel 196

Kanton $10,13-17,20,68,87,89,95,99$, $130,173,175,182,328,366,377$. $428,441,444,447,452,473$

Kanunnik, reguliere 457

Kaperbrief (commission en caurse) 457

Kapitein 212, 255, 447, 459

Kapittel 195, 260

Onze-Lieve-Vrouw 117

seculier 117

Sint-Servaas 28,117

Kas 379

arrondissements- 341

-controle 422

departementale 360

der nationale domeinen $338,350,353$, 430

kassier 379

leger- 379

régie de l'enregistrement 427

staats- $105,447,360$

Katoen, (on)bedrukte 400

Kazernering 192, 272, 405

Kemexhe, kanton 23

Kempen, Luikse 12, 13

Kenteken

feodlaal 239

konünklijk 111, 231, 236, 239

Kerk $113,114,118,119,121,123,231$

Kessenich, gemeente 467 heerlijkheid 29

Ketelaar, F.C.J, auteur 108

Keulen $12,339,384$

Kiezer 94, 473

Kiezerscollege 114

Kinderen $129,209,243,245,257,273$, $274,275,280,283,384$

buitenechtelijke 125,288

klein- 283

Klacht 303

Kleding 275 
-voorschrift 329

Kooster $117,347,429,472$

Kloosterrade (Rolduc), abdij 407, 457

Koerier 315,316

Kohier $189,195,367,421$

vervallsing 262

Kokarde 103,234

Koloniën 446

Pranse 389,459

Koning 92

Koning der Fransen gerechte bestraffing 357

Koningschap 110,251 oproep tot herstel $277,284,386$

Koningshuis 245

Koninklijke familie goederen, rechten en vorderingen 289

Koninkrijk der Beide Siciliën 445

Koninkrijk Holland 31, 37

Koop 118,245

rouw- 402

Kooplieden 321

Koopovereenkomst vordering tot vernietiging 299

Koopprijs 398, 423.

Koper $119,186,195,223,230,286,310$, 325,402

Kortessem, kanton 403

Kortrijk 337

Kosten 263, 275, 436, 441

administratieve 353

bureau- $368,369,443$

commissie- 368,369

druk- 105,447

heffings- en inworderings- 189

huur- 369

porto- $365,394,406,410$

stants- 428

transport guillotine 261

transport veroordeelden 261

van inbewaringstelling 274

Krankzinnigheid 209

Krijgsdienst 446

Krijgsraad $237,272,306,308,317,332$, 335, 404 conseil de guerre 449

Kunst 239 -voorwerp 111

Kwestie

civiele 101,254

erfrechtelijke 71

juridische 446

Kwijting $193,333,358,361,374,375$, $381,392,395,410$ betalingstermijn 434

zekerheidstelling (acquit-ä-caution)

311,453

Kwijtingsbewijs $201,215,311$

Lacoste, volksrepresentant, 13

Lambert, commissaris uitvoerende macht 404

Lambrechts, commissaris Directoire exécuvif departement Dijle $59,60,77$

minister van justitie 74

Landarbeid 362

Landbouw $88,113,173,425$

Landbouwgereedschap 275

Landlloper 420,468

Landmeter 436

Landscommanderij 29

Landswerdediger 446

Landsverdediging 424

Laurensberg, gemeente 32

Lauw gemeente 460

Leeftijd 130

Lefebvre (de Nantes), volksrepresentant 43

Leger $28,49,299,306,308,332,337$, $339,357,362,366,374,376,386$, $389,404,449,457$

actieve dienst 424

bewoorrading 453,465

coalitie- 419

-divisie 449

gebrek aan discipline 449,453

insubordinatie 449,453

leveranciers-generaal 439

-magazijn 215, 399, 304

Noorder- 12, 13, 15, 41, 118, 389

-onderdeel 308

Rijn-en-Moezel- 465

Sambre-en-Maas- 12, 13, 41, 118, 339, $384,389,399,408,465$

Leges 411

Leie, departement $11,60,71,104,313$ 400,413

Lening 260

hypothecaire 391

Leoben, preliminair werdrag 27

LEsion d'outre-moitie 299,338

Lettre de ratification 398

Lettres patentes 233

Leut, heerlijkheid 29

Leuven 73

Levensmiddelen $287,384,432,459$

Levensonderhoud $118,310,324,405,430$ 
Leverantie $376,465,468$

Liberte 238

Lichaam

bestuurs- $27,48,91,463$

gerechtelijk 27

kerkelijk $173,361,362$

overheids- 374

Lijfsdwang (contrainte par corps) 201

Lijst 130,347

burgerpersoneel 374

houdende maam, leeftijd, beroep, woonadres 313

tarief- 361

van geboorten 281

van gezworenen 359

van huwelijken en echtscheidingen 281

van overlijiden 281

Limbourg 316

arrondissement 14,340

Limburg $10,11,26$

Belgisch- 7

Nederlands- 7

Linnengoed 275

Liquidateur 330

Liquidatie $190,274,283$

Liste civile 214

Livre $93,213,215,217,222,228,267$, $268,280,283,304,324,350,377$. $427,436,449,455,461$

Lodewijk. XIV 67, 100

Lodewijk XVI 1.10

Logementhouder $102,116,173,196,331$

Logne, graafschap $10,24,3 \Downarrow 2$

Lommel, gemeente 31

Loon, graafschap $8,12,28$ kanton 403

Louis, secretaris académie de chirurgie 204

Luik $12,13,15,21,22,53,312,313$, $380,409,451$

arrondissement $13,14,21$

prinsbisdom $7-10,12,14,15,24,27$. 28,29

Lummen, heerlijkheid 28,29

Lunéville, verdrag 27,28

Luxemburg $10,11,313$ departementshoofdplaats 12 vesting 389

Luyksgestel, gemeente 31

Lyon, witte terreur 285

Maarland, gemeente 470
Maas, rivier $79,11,14,15,17,22,31$, $89,380,389,408,409$

Maaseik 11,366

gemeente 467

kanton 456,467

land 12

Maastricht $7-9,12,13,15,17,19,21,24$, $26,28,29,47,53,56,62,73,75$, $76,95,99,115,117,122,313$,

$316,320,344,366,382,399,404$. $407,453,469$

arrondissement $12-14,20,21,42,46$, $63,82,89,339,340,342,359$

generaliteit 12,14

kanton 19,93

Wyck 19

Macht 108

ouderlijke 124,230

rechterlijke $91,92,97,100,270$

uitwoerende $34,38,85,86,207,208$, 212

wetgevende $42,85,101,189,371$

Machtenscheiding 92, 128

Machtiging 389

Machtsusurpatie 285

Magistratuur 92

Main-morte 204

mixte 108, 166

personnelle 108, 163, 166

réelle $108,163,166$

Mairie 164

Maison de correction 196

Makelaar 230

Malmédy 312

Malta 212

Maltezer Orde $127,207,219,222,223$

goederen $212,215,262,264$

kruis 208

pensioen 213

verzegeling goederen, eigendomstitels 211

Mandats territoriaux $82,393,411,441$, 455,464

promesse 379,393

Manuscript 269

Maria Theresia, keizerin 123

Marine 49, 357, 409

Markt 299, 325, 333

jaar- 310

openbare 310

-prijs 384,408

Marne, departement 128

Matrozen 380,409 
Maubeuge, departement Nord 348

Maxime, feodaal 108

Maximum

prijs levensmiddelen en waren 323

Medeplichtige $115,256,278,285,288$, 331

Medestander 317,335

Meerderjarige 299

Meijel, gemeente 32, 402, 415

Meinweg 32

Membrède, A.C., president criminele rechtbank Nedermaas 25, 359

agent national, commissaris uitvoerende macht 342

Memorie $240,409,423,433$

eenvoudige 100

Merlin (de Douai), Philippe-Antoine, minister van justitie $9,25,35$, $38,60,63,66,67,69,78,117$

Mesch, heerlijkheid 29

Meuse, departement 252

Meynard, volksrepresentant gouvernementscommissaris Landen tussen Maas en Rijn 364

Mheer, gemeente 29,31

Michiels aîné, openbaar aanklager

Mijn criminelle rechtbank 25,359

zout- 386

steenkool- 407,457

Mijnbouw 189

-concessie 190,386

-exploitatie 189,457

-exploratie 190

Militaire hospitalen

bevoorrading 407

Militair konwooi 385

Militairen $216,306,449,453$

gewonde 437

Millen, kanton 21

Milmort, kanton 21, 22

Minderjarige $124,230,254$

Minister $59,65,74,76,78,86,87,89$,

$217,302,360,379,400,414,464$

bevoegdheid 314

van binnenlandse zaken $25,59,62,66$, $122,188,205,314,358,400,407$, 438,454

van buitenlandse betrekkingen 314 , $372,380,396$

van financiën $76,77,314,330,400$, 430,460

van generale politie 35,60 van justitie $25,35,48,58-63,65,66$, $68,69,74,77,78,116,314,315$, $341,363,400,410,438,444,461$, 464,469

van marine en koloniền 314,380

van porlog $314,332,343,470$

van police générale 424

Ministerie $70,87,443$

Minnelijke schikking 187

Minuut 246, 261, 267, 352, 357, 433

Misbruik van vertrouwen 243

Misdrijf 102, 103, 106, 199, 277, 279* $381,386,432$

aanslag op binnenlandse veiligheid 310 anslag op de vrijheid, openbare veiligheid 321

ambts- 241

beroving burgers bezette gebieden 453 brandstichting $105,306,399,453$

contrarevolutionair 249

diefstal $105,306,313,321,399,441$, 453

doodslag 292,321

medeplichtigheid 405

moord 105, 291, 292, 306, 321, 386, 399

plundering 313

poging tot 105,399

politiek 106

vergiftiging 105,399

verkrachting 306

Mogendheid

buitenlandse $127,179,216$

geallieerde 458

neutrale $396,413,458$

wijandelijke 457

Molen 185

Molitor, $\mathrm{H}_{\text {., }}$ auteur 41

Montagne du Bon-Air "district 259

Montenaken, kanton 403

Montfort, ambt, land 8,28

Monument 231

Morgen (arpent) 427

Mort civile 302

Mozambique 459

Muillezel 362,366

Municipaliteit $47,89,90,115,123,129$, $164,168,173,175,176,183,186$ $188,189,190,194,195,198,202$, $205,208,219,225,236,251,252$. $285,287,295,296,299,310,315$, $316,319,324,325,331,333,339$, $343,346,353,372,384,400$ 
kantons- $17,65,68,87,89,90,95$, $98,99,130,301,313,354,360$. $403,425_{n} 448,451,466,468,470$

Muntcirculatie 337, 429

Muntgeld 93, 324, 325, 337-339, 343, $345,348,349,351,355,356,361$, $368,369,393,413,422,425,427$, $429,441,459$

waarde 375

Muntstuk

brons 444

koper $356,444,445$

Museum 239

Naam 130

achter- 125

voor- 125

Naamlijst 205, 252, 361

(onder)officieren, gendarmes 343

afwezigen i.v.m. krijgsdienst 447

leden rechtbanken en vredegerechten 444

van commissarissen bij correctionele rechtbanken 461

wan commissarissen bij municipale besturen 461

van notarissen 444

Nalatenschap $71,166,187,247,248$, $275,282,298,306,322,377,421$

Nalatigheid $130,339,452,462$

Namen $10,15,312,313$

departementshoofdplaats 12

Napoleon $27,31,32,35,79,84,100$, 104,126

Natie $114,120,226,306$

Nationaal domeingoed $118,127,167$, $168,170,173,179,180,186-188$, 197, 207, 214, 215, 217, 219 , $221-224,226,245,253,257,258$, $264,267,269,273,280,283,286$, $293,325,365,370,402,423,429$, $430,440,446$

beheer 118

biens de première origine 118

biens de seconde origine 118

directie 457

opschorting verkoop 294

toewijzing 276

verdeling en verkoop 242

verkoop 118, 119, 276, 361, 362, 411, $431,434,450,458$

verpachting 343

vervreemding 173,194

zwart goed 119
Nationale aanklager 415

Nationale bibliotheek 225

Nationale loterij 324

Nationale schatkist $297,300,302,400$. 422,431

Nationale schuld 187,260

altijddurende (non viager) 228

vereffening 330

Nationale veiligheid 314

Nationale Vergadering $115,265,277$, 363,386

belastering 284

Nationalisatie 114

Nedercruchten, kanton 99

Nederland(en) 11.9, 122

Nedermaas, departement $7,8,12,14-16$, $19-23,25-29,31,32,39,46-48,50$, $53,56,59,61,62,65,68,71$, $72-75,77-79,82-85,87,90,93,94$, $95,97-99,101,102,104,106,111$, $113,117,119,121,122,127,129$, $130,131,313,341,342,344,346$, $348,356,359,360,366,382,384$, $403,407,417,418,425,426,451$, $460,463,465-469$

Neeritter, gemeente 467

Neeroeteren, gemeente 467 heerlijkheid 29

Neerrepen, gemeente 460

Nerem, gemeente 22,23

Netto-opbrengst $180,185,189,228$

NeuB 339

Nietigheid $230,254,270,309,311,321$, $326,329,371,377,423$

Nieuwenhuysen, Constantin-Joseph Vanden, Mechelen (dep Twee Neten) 423

Nieuwstadt, gemeente 29

Nijmegen 12

Nijverheid $88,173,274,462$

Nivar, ontvanger directe belasting departement Nedermaas 368

Namination de command 195

Non obligat lex, nisi promulgata 35

Noorbeek, gemeente 29

Nord, departement 13

Notariaat $50,127,341$

Notaris $73,170,171,182,207,230,232$, $246,250,251,390,392,395,428$ ontzegging uitoefening functie 201 notaire public 390,392

standplaats 444

Nulle terre sans seigneur 108, 204 
Nypels, administrateur departement Nedermaas 426

Obbicht, gemeente 14,28

Obligatie, staats- 450

Officier 306,332

van de genie 272

opper- 332

Omkoping 265

Onbevoegdheid 433

Ondermijnende maatregel 329

Onderneming 275

handels $=273$

nijverheids- 273

Onderricht openbaar $88,117,429,436$

Onderscheid naar geboorte 110,197

Onderscheidingsteken $198,201,329$

Onderstand 461

Onderzoek 321

gerechtelijk 301

Onrust 429

Onteigening gerechtelijke 293

vrijwillige 293

Ontslag 339,359

Ontsnapping 242

Ontwanger $222,337,356,393,439,422$, 452,454

arrondissements- 215

belasting 354

belastingen en registratierechten 410

departementale $224,364,365,400$, 421

der domeinen $130,273,325,348,467$

der registratie en nationale domeinen 368,436

directe belasting 392

districts- $173,179,200,208,221,224$

gemeente- 200,421

insolventie 200

ontvangers 4.22

registratierechten 394

Ontvangstbewijis 215,321

Ontzetting wit functie 242

Onverenigbaarheid van functies 98,270 , $392,395,406$

Onvermogendheid 235

Oogst $195,200,245,263,282,294,326$, $332,348,425$

behoud 104

Oorlogsschip, bouw en onderhoud 118

Oorlogsverklaring 446

Oost, gemeente 14,28
Oostende 400

vrijhaven 76,369

Oostenrijk 27

Oosterrijks bewind 326

Oostenrijkse Nederlanden $7,8,15,29$, 123,337

Oostenrijjkse regering 454

Opbod 362

Opbrengst $239,268,324,402,427,436$, $440,461,466$

vruchten en inkomsten 434

van grond 202

Opcenten $189,441,454$

inning 438

Openbaar ministerie 94,174

Openbare aamklager $96,203,234,237$. $279,285,292,381,394,414,415$

Openbare functie 319,329

Openbare orde $102,192,196,461$

Openbare voorlezing 315

Openbare voorstelling 461,466

Openbare werken 88,89

Opgeld 189

Ophaven, gemeente 467

Oplichting 243

Opoeteren, gemeente 467

Opslag 448

Opstand 277

Opstandeling $103,227,231,237,246$, $261,291,308,321,352,355,435$

Opzet 270,422

Oranje, prins wan 423

Orde 198

Orderbiljet 318

Ordonmance civile van 1667100,184 , 191

Ordonnantie $67,100,116,331,337$

Organisatie

bestuurlijke 100

bestuurs- 40,50

rechterlijke 101

Originelen 281

Ouders $124,230,243,245,283,288$, $306,322,376,390$

groot- 283

Ourthe, departement $12,15,21-23,31$, $32,53,62,73,94,313,341,342$

Overdracht 235,305

eigendoms- 182

van grond 108

Overeenkamst 246

Overheid 121, 193

hogere 173

localle 173 
Owerheidsgezag 114

Overkwartier van Gelre 8

Oostenrijks 8, 10,14, 29

Pruisisch 8

Staats $8,14,28$

Overlevende 278

Overlijden $123,124,208,213,266,361$, $378,398,411$ voor- 104

Overmaas, Landen van $8,13,14$

Overmacht 255

Overtreder 95,311

Overtreding $103,168,234,294,304,324$, $387,411,428,442,448$

Overzicht goederen en inkornsten 320

Paard $75,362,366,376,385,389,405$, 448

Pacht $173,201,208,263,313,452$

-akte $212,219,264$

erf- 252,258

feodale 239

kerkelijke 239

-overeenkomst $186,188,193,215$, $221,223,239,245,252,258,264$, 311,456

-som $202,224,282,339,348,430$, 439,456

Pachter $111,168-170,173,181,188,202$, $205,215,239,245,248,258,262$, $263,273,311,313,452$

rechten en publieke geldmiddelen 345

Pacificatie 291

Paifve gemeente $16,21-23,28$

Pain d'abbaye (abtsbrood) 326

Paltsgraaf 19, 20, 27

Panhuys, van, griffier criminele rechtbank departement Nedermaas 359

Papenhoven, gemeente 14,28

Papier

-fabrikant 238,430

-handelaar 238

-nijwerheid 113,430

Parijs $9,24,25,32,43,51,58,60,61$, $70,79,82,89,95,96,101,124$, $130,131,232,257,265,278,290$, $296,304,310,316,317,466$

kanton, bureau central 466

Park 111, 226, 236, 423

Parlement 233 van Douai, arrest 175, 191 van Parijs 252

Parochiekerk 401
Partagetractaat 8

Particulier bezit 239

Particulieren $89,111,194,248,332,442$, 444,471

Partijen $254,263,298,303,326,414$, 438,445

belanghebbende 101

meest gerede 352

Pasinomie 76

Paspoort 116, 127, 130, 205, 237, 295, $313,331,372,373,380,389,409$, 439

visum $336,396,439$

Pastoor 122, 123, 324

Pastorie 401

Patent 187,425

dispensatie 462

-plichtig 462

tariefklassen beroepsgroepen 462

verkrijging 441

Pays de nantissement 177

Pays réunis 302

Peer 366

Pelerin, openbaar aanklager criminele rechtbank Nedermaas 359

Pensioen 205, 208, 209, 211, 222, 338, $379,450,472$

altijddurend, levenslang 322,326

Pérès, gouvernementscommissaris 20,25 , $47,81,83,97,107,403$

volksrepresentant $17,42,43,58$

Personeel $192,317,327,341,368,408$, $433,443,462$

huis- 113

militair 192

Petersheim, heerlijkheid 29

Petit, commissaris uitvoerende macht 404 departementaal administrateur 342

Picquery, administrateur departement $\mathrm{Ne}$ dermaas $59,348,382,418,426$

Piraten en bandieten 457

Pirenne, H., historicus $16,81,109$

Plaats

geboorte- 268

verblijf- $116,231,286,307,331,338$, 388

woon- $130,268,269,305,441,446$, 468

Plagiaat 225

Plattelandsbewoners 291, 310

Plechtigheid, religieuze 122,312

Pleidooi 98, 191

Plicht, dienst- 85 
Plichten, burgerlijke 85

Plundering $103,277,285,287,288,453$

Pointe, commissaris uitvoerende macht 404

Pol en Panheell, heerlijkheid 29

Police 129, 313

Politie 317 veld-en bos- 416

Politieke rechten 317

Pollitiemaatregel $102,196,461$

Polytechnische school 470

Portalis, Jean Etienne Marie, rechtsgeleerde 35

Portiez (de l'Oise), gouvernementscommissaris 13,17 , $20,25,43,47,81,83,97,107,403$ volksrepresentant 58

Posterijen 227, 365, 394, 410

directeur 340

paardenposterij 401

portvrijdom 206

postkantoor 406

postkoets 365,401

postmeester 365

tarieven 401

Postiljon 365

Pothier, Robert-Joseph, rechtsgeleerde

Traité de la procédure civile 185

Poullet, P., auteur 88

Poyck , commissaris Directoire exécutif kanton 's-Hertogenrade 466

Prefect 91

Préposé au triage 265

Prestatie 107, 109, 130, 193, 204, 224

Prior 212

Priorij 117, 211, 212, 429

Prise d partie 327

Prísse, administrateur departement Nedermaas 356

Privillege, koninklijk 239

Procedure 97, 100, 101, 106, 240, 261, $263,267,306,327,338,357,377$, 404,430

gerechtelijke 300,334

rechtbank 352

strafrechtelijke $102,103,105,115$

vorderings- 366

Proces 93, 199, 205, 207, 240, 241, 352, 448

Proces-werbaal $104,213,217,233,236$, $237,250,265,321,352,358,366$, $416,430,442$

van manhouding 316 van terechtstelling 281

van visitatie 212

Procesbescheiden 233

Proclamatie $25,39,81,83,84,244,308$, $315,337,338,414,428,468$

Procureur $100,191,211,240,250$

Procureur-(gếnérall)-syndic $91,165,176$, $179,188,286,299$

Producten 448, 459

categorieên 413

glas- en aardewerk 448

Franse 412

landbouw- 412

leer- 448

merkteken 452

nijverheids- 412,447

Propriété

directe 107

éminente 107

utile 107

Provinciale staten 260

Provinciegrenzen 16

Provocatie 386,387

Pruisen $8,28,29,402$

Pruneau, gouvernementscommissaris Landen tussen Maas en Rijn 20

Publiek belang 172,175

Putzeijs, ex-notaris 72

Raad, militaire 449 tucht- 332

Ramel de Nogaret, volksrepresentant 15 minister van financiën 77

Rantsoen 368

Rapport 251, 372

Rastatt, tractaat 8

Reces $199,407,434$

Recht

afgeschaft 108,109

afkoopbaar 108, 109

burger- 117

burgerlijke 126

cijns- $108,235,241,244$

domein- 192

eigendoms- $92,103,108,172$

erf- $71,126,127$

exclusief 428

feodaal 108, 109, 111, 166, 204, 208, $224,229,241,244$

gemene 103

gesupprimeerd 109

heerlijk $108,109,166,168,185,204$, $239,337,338$ 
hypotheek- 126,192

in- en uitvoer- $255,300,413,453,459$

jacht- 108, 111

kies- 24

kohier- 328

onlichamelijk 179,197

patent- $113,200,425,437,462$

personeel 108

personen- en familie- 122

privaat- 110

proces- 101

registratie- (droit d'enregistrement) 72 ,

$73,181,192,202,213,222,230$,

$328,355,361,366,411$

stem- 317

straf- $102,104,330$

strafproces- $102,104,330$

tol- 185,205

van de langstlevende (droit de survie)

260

van duiventil 1.08

van initiatief 86

van woorkoop (droit de préemption) 324,326

verbruiks- 432

verschuldigd 387

verworven 309

vis- 11.1

voor- 110,290

zakelijk 108

zegel- $72,73,182,192,193,355,411$

Rechtbank $48-50,55,68,86,94,97,99$. $128,175,193,199,240,244,255$, $265,268,272,300,303,314,315$, $317,326-328,333,341,343,345$, $359,365,381,383,394,403,407$, $409,432,438,461$

appel- 98,184

burgerlijke (tribumal civil) 19,61,69, $71-73,78,93,94,95,96,98,100$, $174,176,187,305,313,317,321$. $334,341,344,350,357,359,371$, $376-378,383,390,391,403,404$, $412,426,434,437,441,444,446$, 447

correctionele $95-97,100,105,317$, $344,378,391,395,434,444,447$, $449,461,469$

criminele (tribunal criminel) $25,61,78$, $95-97,105,106,128,203,206$, $214,220,227,234,243,253,256$, $265,270,277,279,284,285,291$, $292,341,344,350,373,376,381$,
$386,391,414,415,426,432$,

$434,444,447,448,461$

districts- $93,100,101,177,182,184$. $190,248,281,298,318,327,352$, 357,412

handels $93,94,100,174,317,434$, 437,447

hoger gerechtshof (tribunal supérieur) 99,343

militaire $289,291,308,355,433,435$

oppertribunaal 99

politie- 105,449

-procedure 95, 96, 100, 178, 185

revolutionair vonnissend 289

revolutionaire $243,289,472$

-sectie 334

van correctionele politie 243,448

volks- 289

voor koophandel en koopvaardij 321

voorzitter 334

Rechten 339

afgeschafte 107

afkoopbare 107

Rechter $86,94,100,101,174-176,187$, $191,241,303,321,326,327,333$, $335,344,345,353,371,376,396$, $414,426,434,449,456,473$

districts- 203

militaire 404

-plaatsvervanger $94,187,321,359$, 406

politie- 95

van correctionele politie 204

Rechterlijke organisatie (ordre judiciaire) $92,97,99,100,174,175,176$, $187,317,400,410,438$

Rechthebbende $199,202,290,421$

Rechtsgang 285

Rechtsgeding $248,299,303,383,419$, 441

Rechtsgevolg 124

Rechtshandeling 266

Rechtshandhaving 102,330

Rechtsmiddel 185

Rechtsopvolger 104, 398,423

Rechtspleging 102, 330

burgerlijke 92,187

heerlijke 184

straf- 92, 103

Rechtspraak 101

burgerlijke 93,97

correctionele 95

criminele 95

heerlijke 172 
jury- 96

straff- $95,97,106$

Rechispraktijk 337

Rechtsvervolging 357

Rechtsvoorsehrift 354,385

Rechtswordering $176,179,188,282,311$, $357,416,438$

burgerlijke 100,101

Rechtszaak 233, 239, 323, 352, 414, 435

burgerlijke 352

correctionele 327

criminele 327

politie 327

Rechitszaal 437

Rechtverkrijgende $196,225,428$

Recidive 105, 120, 261, 447

Reclamant 326

Reconnaissance de liquidation $\mathbf{3 3 0}$

Recueil Hayez 63

Redactie 416

Redemptiedorpen 8,28

Reder 321

ter kaapvaart 425

Redevoering 386

Référé 128

Regelgeving 172

Regensburg, Rijksdag. 28

Regering 277

Régie 182, 197, 411

Régie de l'enregistrement et des domaines nationaux $72,73,362$

ambtenaren 368

directeur 369

Régie des droits d'enregistrement et des domaines mationawx 355

rëgüsseurs 243

Register $62,68,90,267,280,315,357$.

$373,397,401,413,440$

circulaires, officièle bescheiden 438

gasten -331

geboorte 122,401

huwelijks- 122,401

inning inkomsten kapittel van Doornik 467

met opvoeringen 229

met verzoekschriften en adviezen 183 overlijdens- 122,401

parochie- 123

registre de pointe 176

registre d'immatricule 396

registre ouvert $43,45,53,55,56,58$,

$63,65,72,76-79,82,83,121$

van ovemachtingen $102,116,196$ van paspoorten 313

van verzoekschriften 91

Registratie $43,51,72,104,355,416,425$

Reglement 116,331

politie- 336

Reglement van $1738 \quad 449$

Reichsdeputationshauptschlug 29

Reintjes, J.M., secretaris departementaal bestuur 54

Reisroute 295

Reizigers

buitenlandse 460

Franse 460

Rekem, graafschap 29

Rekenschap 286

Relatieve competentie 327

Religiteuze 247

Religieuze corporatie 338

Rente 202, 246, 282

altijddurende $66,193,228,471$

gevestigde 179

grond-168, 179, 193

heerlijke 193,239

lijf- $66,193,217,260,283,326,338$, $379,411,471$

Rentmeester 273

Repartitie 468

Rêpertoire ou Mémorial chronologique ... 55

Repertorium $42,43,45,53,55,62,79$, $352,363,390$

Republiek $10,15,129,446,449,451$, 459

gezanten en consuls 440

Republiek der Verenigde Nederlanden 8 , 14,28

République Française 239, 411

une et indivisible 238

Request-civiel 184,185

Requisitie 311 wagens en paarden 276,339

Rescriptie (rescription) 364, 379

Resolutie 315

Restitutie $287,290,302,313$

Restrictie 309

Retrait

de mi-denier 171

lignager 171, 338

Reubell. lid comité de salut public 1.4

Revisie 432

Revolte 310

Revolutie 16, 103, 110, 115, 126, 278, 334 
Richterich, gemeente 20

Ridderorde 197, 211, 219 geestelijke 127

Rijckholt, heerlijkheid 29

Rijksdag 28

Rijn, rivier $7,9,12,27,89,312,419$

Rimburg, gemeente 342

Roberjot, volksrepresentant 14,43

Robespierre, lid comité de salut public $39,85,290$

Roclenge, gemeente 21,22

Roebruck, commissaris uitwoerende macht 404

Roemers, C.C., commissaris Directoire exécutif rechtbank 62

Roer, departement $29,31,32,53$ rivier 29

Roermond $8,9,31,32,47,77,95,320$, $342,366,382,469$

kanton 340

Roger-Ducos, volksrepresentant 13

Rogier, commissaris Directoire exécurif departement Nedermaas 19, 348, 417,425

departementaal administrateur 342

Rogier, historicus 28

Ronselaar 291, 355, 453

Rooillijn 178

Roosen, commissaris Directoire exécutif kanton Eijsden 470

Rotem, gemeente 467

Rurdorf, gemeente 29

Rutten, gemeente 460

Sagnac, Ph., historicus 126

Sambre-en-Maas, departement 12, 106, 313

Samenscholing $277,287,386$ gewapende $288,313,435$

Samenzweender 285,334

Samenzwering 290, 291, 321 royalisten en uitgewekenen 317

Sansculotide (jour complémentaire) 269

Schade 111, 130, 239, 244, 287

Schadeloosstelling $27,29,89,95,108$, $109,176,190,201,204,212,215$ $224,241,245,250,287,313,324$, $366,407,428,443$

Schatkist $86,222,224,260,318,361$, 364,379

nationale 439,444

openbare 438

Schatter (juré-priseur) 171
Schatting $221,362,428,434$ bedriegellijke 283

Schavot 105

Scheepwaartkanaal (oevers, jaagpadien, kunstwerken) 185

Scheidslieden $93,94,97,263,305$ arbitre forcé 371

Schelde, departement $11,71,74,313$, 400,413 rivier 408

Schenking 411 donation entre vifs 247

Schepen $380,409,447,455$

bewapende 49

buitenlandse 255

Franse 255

kaper- 457

neutrale 458,459

Schikking 93

Schilder 225

Schipbreuk 448

Scholen 284

Schorsing 460 bestuurshandeling 89

Schotland 236

Schuilplaats 256,278

Schuild 92, 283, 391

Schuldbedrag 287

Schulddelging 228

Schuldeiser $167,191,196,226,228,241$, $247,250,252,267,268,280,283$, $291,307,322,330,391,397,463$ hypothecaire 309

Schuldigverklaring 449

Schuldwereffening 463

Schuldvordering $191,228,230,252,267$, $274,280,291,304,305,339,463$

authenticiteit 463

vereffening 306,322

Secretaris 310

Section des vacations 434

Sedan, departement Ardennes 403

Seine, departement $434,436,446$

Seine-et-Oise, departement 436

Sênéchaussée 167

Sententie 250

Sermoise, commissaris Directoire exécutif kanton Tongeren 418,451

Serrurier, commissaris uitwoerende macht 404

Sieraad 275

Sieyès, lid comité de salut public 15 
Silken, Gerard, adjoint municipaal agent gemeente Berg 469

Sint-Pieter, heerlijkheid 29

Sint-Truiden $74,95,122,366,469$ heerlijkheid 29 kanton 404

Sittard 17.31

Slenaken, heerlijkheid 13,29

Soevereiniteit 27

Sol 350

Soldaat 306

Solventie 280,322

Som, hoofd- 450

Spa 316 arrondissement 12,340

Spaanse Nederlanden 109

Spanjaard 252

Spionage 295,453

Staat $10,120,123,254,255,267,269$, $274,275,283,297,305,322,324$, $325,348,349,367,374,444,446$

activa en passiva 117

Franse 115, 121

inkomsten en uitgaven $224,429,454$

inning directe belastingen 471

overzicht administratieve indeling départements réunis 16 overzicht nog niet-bekendgemaakte

Franse wetgeving 464

overzichts- 443,444

van boekenbewaarplaatsen 436

van goederen religieuze instellingen 434

werkzaamheden bestuurslichamen inzake uitgewekenen 424

Staat van afzondering 266

Stat van gebouwen en terreinen 370

Staat van vrede, van oorllog, van beleg 192

Staatkundige verbrokkeling 7 staatsbescheidlen 265

Staatscommissie, gewone uitgaven 365

Staatsgreep 121

Standen 194

derde stand 110

eerste stand 114

tweede stand 110

Standplaats 392

Staten 454

Staten-Generaal 29, 110

Stavelot-Malmédy, vorstendiom 10,24 , 312

Steden 260

Stein, heerlijkheid 29
Stemgerechtigdheid 301

Stemming 310

Stephens, commissaris untvoerende macht 403

Stevens, F., auteur $60,62,68,73,74$

Stevensweert, kanton 17

Stoffen, katoenen en wollen 448 doorvoer 415

Stokkem, district 11

Straf $120,219,262,276,292,308,332$, $375,391,432$

-bedreiging $90,105,122,399$

buiten-de-wet-geplaatst 115

burgerlijke degradatie 103, 199, 229

degradatie 453

deportatie $103,115,199,205,218$, $237,243,256,260,277,294,302$, 375,386

detentie $102,103,105,199,310$

dood- 102, 199, 204, 218, 237, 242, $249,272,279,288,291,306,317$, $334,355,386,398,453$

dwangarbeid in ketenen (fers) 102 , $105,199,206,210,218,225,236$, $249,265,311,317,453$

eenzame opsluiting (gêne) 102, 128, $199,206,453$

galei- 207,210

gevangenis- $196,213,234,242,288$, $296,355,373,395$

hechtenis $95,105,120,205,235,250$, $253,269,283,312,355,375,383$, $387,395,416$

invrijheidstelling 207

levenslang 207,302

lijf- $95-97,206,209,420$

-maat $102,200,386,420,449,453$

onterende $95-97,124,206,209,230$

onthoofiding 102,204

opsluiting 115,256

schandpaal (carcan) 103, 199

terechtstelling 116

tuchthuis (réclusion) 103, 199, 206

verbanning $117,120,272,329$

-vermindering 206

vrijheids- 289,431

Strafbaar feit $314,334,372$

Strens, commissaris uitvoerende macht 404

Substitutie (substitution fidéicommissaire) 211,338

Successieoorlog, Spaanse 8

Superioriteit 108 
Tabak 387

Tabellioen 392

Tableau civique 201

Tarieven $355,361,410,411,425$

Tarte, administrateur departement Nedermaas 348,356

Taxatie 232

Tegelen, gemeente 17

Tegenstander, politieke 115

Tekenaar 225

Tenlastelegging 391

Teraardebestelling 213

Terechtstelling $104,261,279,398$

Ter-inzage-legging 90

Termijn 247, 250, 258, 351, 441

achterstallige 435

beroeps- 438

betalings- 427

Territoir $8,9,12,14,15,17,28,29,50$, $51,73,79,84,119,127,216,218$, $236,284,302,313,315,343,369$, $376,392,394,407,419,446,453$ (semi)-soeverein $9,13,27,29$ bondgenootschappelijk 256

Frans $9,16,117,312,439$ neutraal 256

Oostenrijks 14,312

Spaans 8

Staats $8,15,22,312$

veroverd 272,304

vijandelijk 256

Territoriale indeling $317,319,346$

Terugbetaling $239,244,267,353,394$, $410,423,433,438,452$

Terugvordering $241,246,248,260,300$

Terugwerkende kracht 282, 309

Theater 183,284

-exploitant 183, 196, 229

-gezelschappen 183

-voorstelling 229

Thom, gemeente 467

vorstendom $9,27,29$

Tiendle $108,163,188,239,326,338$

gefeodaliseerde (dîme inféodée) 107 opbrengst 324

Tiendplichtige 107

Titel $110,208,228,230,235,246,250$, $273,305,330,446$

authentieke 217

bezits- 108, 166, 205

domein- 265

eigendoms- $108,109,166,205,223$,

$225,251,291,355,421$

feodale $235,251,265$ lijfrente- 260

onder bezwarende 309

oorspronkelijke $109,223,241$

schuldvorderings- $226,241,247,250$, $267,280,306,397$

titre primordial 108

Titularis 195,222

Toelage 247

uitbetaling 347

Toewijzing $253,282,286,323,343,427$

Toezicht $43,88,104,116,129,130,172$, $269,272,350,439$

bestuurlijk 167

civiel 449

contentieus 167

correctioneel 196, 235, 449

gerechtelijk (police judiciaire) 90

municipaal 449

plattelands- $103,201,294$

Tolgeld 166

Toneelwerk 229

Tongeren 366

kanton $22,23,31,393,418,451,460$, 469

Toulouse, colloquium 109

Transport 311, 400, 408, 453,459

graan en levensmiddelen 304

-middel 448

Tribunaat 48

Tribunal de cassation $72,73,92,95,96$, $101,105,128,181,199,220,222$, $251,373,406,413,414,432,434$, 447,473

secties 327

Tribunal de famille 174,230

Tribunal de police 95

Triel, kanton 259

Tuin $111,226,236$

Turfwinning 195

Twee Neten, departement $12,26,68,94$, $313,341,400,413$

Tweekamerstelsel 85

Ubachs, P.J.H., historicus 119

Uitgaven $353,360,369,410,443$

departementale 454

gemeentelijke 454

gerechtelijke 353

municipale 454

Uitgewekene $88,115,118,125,215,218$, $219,221,226,232,237,245,247$, $250,252,272,274,280,283-285$, $287,288,290,301,302,304,305$. 
$305,317,322,334,354,383$,

$388,402,419,424$

(on)roerend goed 217

goederen en bezitingen $116,215,272$, 390,421

lijst $116,117,129,272,286,289,290$, $296,319,329,367,370,396,397$, 424,440

rekenplichtig 391

wereffening schuld 330

verkoop roerend goed 214

Uitlokking 277

Uittrusting 405

Uittreksel, gewaarmerkt 267

Uitwoer $400,412,433$

eerste levensbehoeften 364

huiden 364

weder- 448

Universiteit 219

Utrecht, vrede van 8

Vaals, gemeente 31,32 land 12

Vacatiegeld 171,232

Vader 125,257

Vagebond $130,420,468$

Valenciennes, departement Nord 348

Valkenburg, kanton 17

land $8,12,14$

Oastenrijks land 29

Stats land 28

Valmy "slag 7

Valse naam 373,387

Valsemunter 285,334

Valsemunterij 238, 256

Van de Wardt. administrateur departement Nedermaas 348

Vanderhoven, commissaris uitvoerende macht 404

Vazal 166,248

Vee 275,425

Veeartsenijscholen 63

Veeteelt 201

Veiligheid, binmenlandse 386

Veiligheidsbeambte 321

Veiling $180,214,286,325$

Velden, gemeente 32

Veldwachter 201, 294

Velthoven, van, commissaris Direcroire exécutif Heythuysen 451

Venlo $7-9,15,28,32,47,320,402,415$

gemeente 394

kanton 29, 404

Vennoot 273,425 -schap 266

Verbanning 301

Verbeurdverklaring $110,125,168,196$, $199,216,226,228,236-238,252$, $255,268,273,285,287,289,300$, $302,304,310,318,324,336,347$, $348,355,362,448,452,455,458$

Verbintenis: 201, 337

Verblijfsperiode 336

Verbranding wan titels 111

Verdachte $95,96,105,106,115,270$, $285,287,291,306,308,317,321$, $332,355,399,404,405,422,435$, 449

mede- 104

opzet 105

Verdediger $95,306,308,435,449$

Verdeling 309

Verdrag 127, 265

bondgenootschappelijk 216

geheime conventie 27

Haags $14,419,445$

handels- $216,419,445$

ratificatie 419,445

vredes- en vriendschaps- $27,419,445$

Verdun, departement Meuse 404

Vereffening $280,283,291,307,309,391$

Vererving 355

Vereveningsfonds 330

Vergadering 301

Vergoeding $263,275,339,384,441$

Vergrijp 285, 420

krijgstuchtelijk 332

Vergunning 190,333

Verhaegen, . $_{\text {, historicus } 109}$

Verhindering 448

Verhouding

bezits- $106,108-110$

eigendoms- 106, 108-110

Verhuring $169,179,252,257$

Verificatie 379

Verjaring 446

Verkiezing 473

Verkiezingen 310

Verklaring 304

houdende hoedanigheid, ligging en opbrengst goederen 273

houdende personalia vreemdelingen 331

van voorkeur 283

Verkoop $167,195,225,264,275,280$, $355,423,425,448,452,462$

gerechtelijke 323,428

goederen en bezittingen 358 
modaliteiten 362

Verkoper 310

Verkoping $219,232,238,320,325,424$

bij opbod $169,180,214,219,434$, 458

publieke 428

weder- 402

Verkrijger $168,186,223,245,257,258$, $282,286,398,423,435,450$

Verkrijging 446

bezits- 186

Verkwister

openbare gelden 285,314

Vermogen 349

Vernietiging $72,101,271$

bestuurshandeling 89

Veroordeelde $95,96,104,105,118,128$, $210,268,275,279,280,285,332$, 375,398

teruggave goederen 302

Veroordeling $128,199,289,395,448$

Verordening politie-(règlement de police) 90

Verpachter 188

Verpachting $118,168,179,195,205$, $226,235,252,257,275,289,320$, 430

Verpanding 431

Verpleging 117

Verplichting $193,277,293,326$ betalings- $188,205,339,450$

cijns- 248

feodale $108,166,248$

Verraad 453

Versailles, departement Seine-et-Oise 436

Verspreiding 225

Verstek 415,432

Vertaler 99

Vertaling 319

Verval van procesaanleg (peremption d instance) 446

Vervallenwerklaring $241,246,258,260$ * $262,283,286,307,424$

Verviers, stad 15

Vervolging $96,214,260,277,290,317$, $355,357,375,461$

Vervreemding $118,119,177,307,309$, 320,431

Verweermiddel 409

Verwoesting 453

Verzegeling $219,238,246,250,275,379$

Verzending 319

aansluitingswet 315 wetten en besluiten 314

Verzet 233,310

Verzoekschrift $100,128,199,212,227$. $240,367,433,456$

Verzorger 362

Verzuim 286, 309

Vestingstad, militaire post 192,389

Veugen, administrateur departement Nedermaas 426

Vijand $103,227,231,234,237,246,261$, $272,278,355,424,445,449,453$

binnenlandse 459

buitenlandse 459

Vise, gemeente 14,32

Vlaanderen 10,312

Staats- (Flandre hollandaise) 15,408

Zeenws- 122

Vlag

Anglo-Corsicaanse 457

Engelse 457,458

Franse 458

Voedsel, uitwoer 364

Volksrepresentant $12,13,16,24,40,42$, $45,46,55,63,72,77,81,88,89$. $94,97-99,101,102,115,118,127$. $244,291,313,316,324,328,336$. $341,344,347,348,355,359,363$. $377,388,403,405,410,415,417$. $418,422,472$

belaging 277

en mission $10,39,40,41,43,60,78$, $82,101,116,130,285,300,319$, 377,438

Volmachthebber 283

Vondeling 208

Vonnis $79,94,95,97,98,100,101,105$, $109,124,128,178,185,207,220$, $224,227,230,233,239-241,251$, $253,254,261,263,268,279,290$, $292,294,298,300,306,311,323$. $341,352,371,373,375,381,383$. $413,433,446,447,449,461,472$ correctioneel 95

kracht van gewijsde 326

militair 432

opschortende werking 326

revisie 326

tenuitvoerlegging $105,383,447,461$

veroordelings- 447

Voorrecht van boedelbeschrijving 322

Voorwerp

kunstzinnige waarde 269,271

wetenschappelijke waarde 269,271 
Vordering $188,244,283,291,352,362$, $366,376,383-386,399,408,413$, $421,443,468$

rechts- 403

requisities 465

schuld - 39"

Vormvereiste $100,123,293,367,392$, 402,423

naleving 254,449

schending 254,432

Vorst 423

Vorstin-abdis 29

Vrancken, Gillis, municipaal agent gemeente Berg 469

Vrede $329,334,446$

Vredegerecht $19,55,93,97,100,174$, $178,193,225,317,341,352,437$, 447

procedure 300

Vrederechter $19,68,86,93,95,101-103$, $174,175,178,181,190,231,246$, $250,255,263,294,301,305,315$, $321,329,333,352,383,391,394$, $395,411,412,424,425,441,444$, 448

asssessor (prud" homme-assesseur) 344 bijzitter $93-95,104,174,177,270$, $377,378,416,448,473$

competentie 187,201

Vreemdelling $115,116,312$

verlenen van onderdak 331

Vreren, gemeente 31

Vrijheid 314

Vrijheidsboom 103,249

Vrijlating 279,283

op borgtocht 420

Vrijspraak 106

Vroedwrouw 208

Vroenhof, graafschap 28

Vrouwen $103,125,234,243,257,279$ gehuwde 254

Vruchten, wortelvaste (fruits pendans par racine) 452

Vruchtgebruik $182,207,211,236,266$

Vruchtgebruiker 273

Vruchtopbrengst 186,286

Waal, rivier 12

Waarde

intrinsieke 444

nominale 444

Waardepapier 130,318

Waardevermindering 328

Waardevol voorwerp 239
Wachter

bos- $104,416,436,442$

veld- 104,416

Waldfeucht, gemeente 32

Wankum, kanton 32

Wapen, slag-, steek- 336

Wapenbord 111,226

Wardt, Van de, administrateur departement Nedermaas 426

Waterlopen 293

Watermerk 238

Wederoverdracht (rétrocession) 214

Weduwe 273

Weert, gemeente 8 kanton 32

Wees 129

Wegen 201, 293 grote $91,177,178$

hoofd- 104,294

openbare 172

zij- 177

Wegneming, bedriegelijke 283

Wehrhahn, H., auteur $34,36,38,49,51$

Weigerachtigheid $439,452,465,468$

Weldadigheid 88

Welz, gemeente 29

Welzijn 173

Werknemer 113

Werkomstandigheden 430

Werkplaats 274

Werkstaking 430

Wessem, gemeente 467

Wetboek Napoleon ... 37

Wetgeving $54,63,67,73,97,107,109$, $113,126,127,131,451$

afkondiging $34-39,43,45-47,50,59$, $62,63,75,78,81,100$

bekendmaking $33,34,37,39,43,47$, $48,50,62,71$

burgerlijke 103,114

corpora 83

douane- 76-78

exécutoire 34

Franse $73,74,119$

gelegenheids- 100,103

in werking treden 78,328

invoering $50,58,355$

promulgatie $33-39,49,51,53,78,79$

promulgatio 33

Promulgationszuständigkeit 34

publicatio 33

Publikationszuständigkeit 34

reparatie- 126 
Republikeinse 116

revolutionaire 81

straf- 103

uitvauardiging $33,35,42$

verbindbaarheid 363

Wetgevingshandeling 377,380

Wettelijke schuld (dette légale) 167

Wettige verhindering 378

Wihogne, gemeente 31

Wijlre, heerlijkheid 9, 13, 29

land 12

Wijnandsrade, heerlijkheid 29

Wild 168

Wilmar, administrateur-landmeter 17

Wirion, brigadegeneraal gendarmerie nationale 342

Wisselagent 318

-brief 381

-kantoor 444

Wittem, graafschap 9, 13, 29

land 12

Wouden, departement $12,26,313,342$

Wraking $96,101,178,381,415$

récusation péremptoire 321

Zaakgelastigde 414

Zeehaven 295

Zegelstempel $182,411,451$.

Zekerheidstelling

kwijtingsbewijs (acquit-a-caution) 311, $394,408,415$

Ziekenzorg $117,267,429$

Ziekte

besmettelijke 473

Zilver $349,351,401$

-gell 356

-werk 117

Zitting 96,310

Zout 387

Zuidelijke Nederlanden $7,8,14,27,40$,

$99,110,343$

Zuster

religieuze 117

zwarte 117,473

Zwangerschap 279

Zwitserland 415 



\section{CURRICULUM VITAE}

Hendrik Albert Kamphuis werd op 22 september 1954 te Groningen geboren. Zijn middelbare schoolopleiding heeft hij gekregen aan de Openbare School voor U.L.O. te Loppersum, aan de Pedagogische Academie, Rijksopleiding voor Onderwijzer (H.A.V.O.-afdeling) en aan de Rijkscholengemeenschap (Atheneum-afdeling), beide te Appingedam. Na het vervullen van de militaire dienstplicht en een tijdelijke baan bij de ANWB heeft hij van 1976 tot 1984 geschiedenis gestudeerd aan de Rijksuniversiteit te Groningen. Gedurende de jaren 1988 tot 1992 was de auteur aangesteld als assistent in opleiding bij de vakgroep metajuridica van de Faculteit der Rechtsgeleerdheid van de Rijksuniversiteit Limburg te Maastricht. De schrijver heeft gepubliceerd over aspecten van de Groningse en Drentse geschiedenis uit de eerste helft van de negentiende eeuw. Voorts heeft hij een bijgedrage geleverd aan het samenstellen van een tweetal archiefinventarissen. 